\title{
BRITISH ASSOCIATION FOR THE
}

ADVANCEMENT OF SCIEMCE

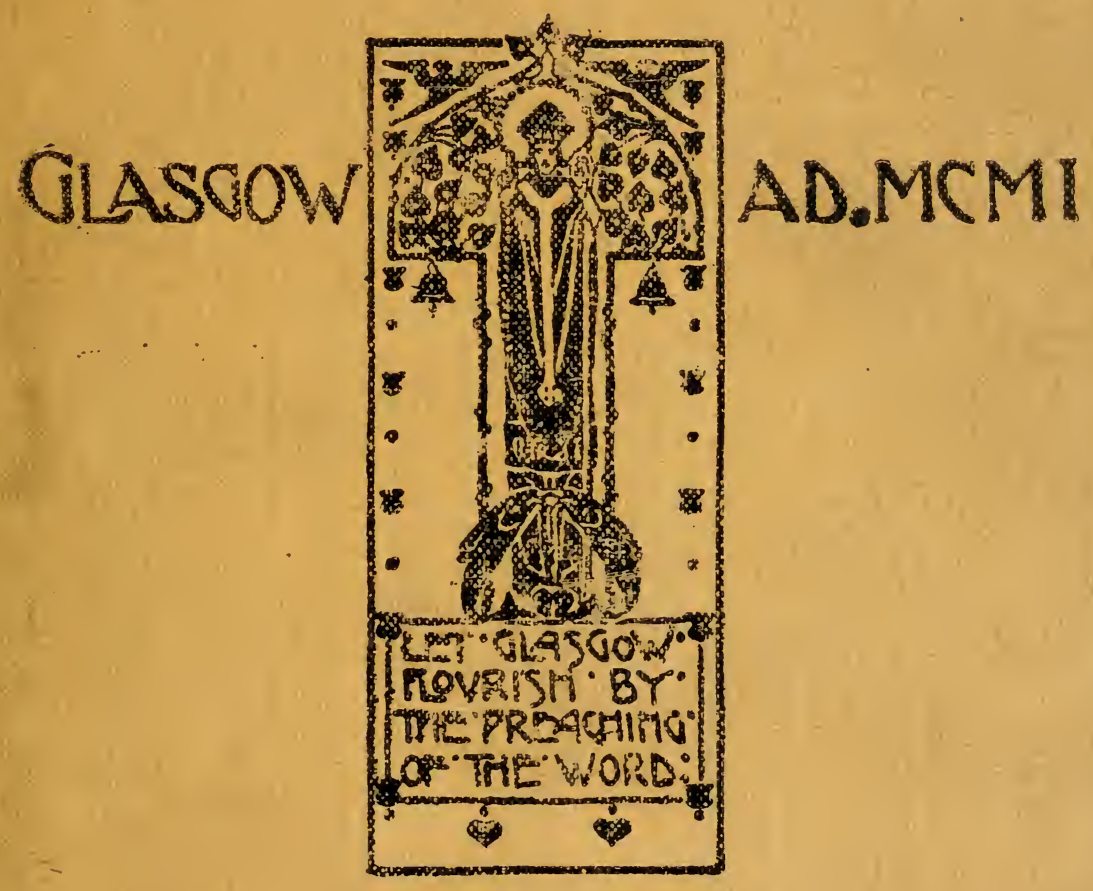

HAMBBOOK OM TIE

NATVRALHISTDRY

OF CIASOUWR THE

다미

WESTOFSCOTLAT

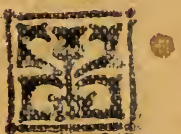


No
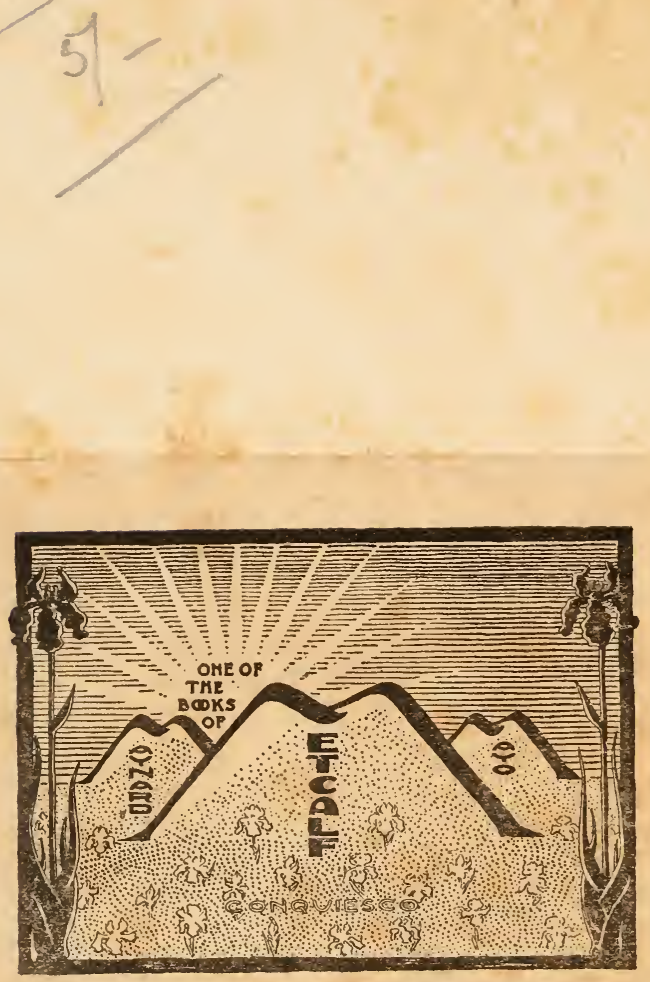

\section{DULAU $\&$ CO LII}




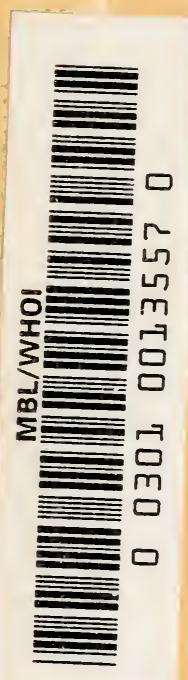





\section{British Association}

for the

Advancement of Science

GLASGOW 190I 
In connection with the Meeting of the British Association in

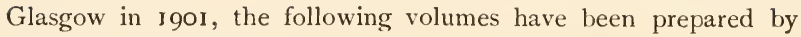
the Local Committee:

FAUNA, FLORA, AND GEOLOGY OF THE CLYDE AREA.

HANDBOOK OF LOCAL INDUSTRIES OF GLASGOW AND THE WEST OF SCOTLAND.

HANDBOOK OF ARCHAOLOGY, EDUCATION, MEDICAL AND CHARITABLE INSTITU'TIONS. 


\section{FAUNA, FLORA हٔ GEOLOGY}

\section{of the Clyde Area}

EDITED BY

G. F. SCOTT ELLIOT

MALCOLM LẢURIE

AND

J. BARCLAY MURDOCH

\section{Glasgow}

Published by the Local Committee for the Meeting of the British Association 
GI.ASGOW : PRINTED AT THE UNIVERSITY PRESS BY ROBERT MACLEHOSE AND CG. 


\section{PREFACE.}

Whex twenty-five years ago the British Association met in Glasgow a Natural History Handbook dealing with the Fauna, Flora, and Geology of the district was issued to the members. Owing to various circumstances-the chief of which were the paucity of workers and the short time available for the work-the lists were far from covering the whole ground, and by no means free from errors. It was felt by many Naturalists of the District that the present meeting of the British Association afforded an opportunity for repairing many of the errors and omissions of the former Handbook, and for bringing to a focus the very large amount of work which has been done of late years in the Clyde area. It is not to be supposed that the present volume professes either to be a coniplete record or to be free from errors. The size of the volume and the speed with which it had to be put through the press render it certain that nany errors have escaped correction, and a cursory inspection of the contents will reveal that many groups are not treated of, while others have only been studied during the last three years, i.e. since the idea of this Handbook was first mooted. It is to be hoped that the blanks will be as valuable for the future work in the district as the comparatively complete lists, inasmuch as they will show local workers on what groups they may most profitably concentrate their attention.

The Editors feel that this Handbook should not go out without an expression of its indebtedness to all concerned in its production. This number includes, in addition to the compilers, the great majority of the working Naturalists of the district and many eminent scientific men throughout the Kingdom, for each and all have freely placed the information in their possession at the service of those responsible for the various sections of the Handbook, and spared no pains to make the volume worthy of the meeting for which it has been prepared.

While those who have worked for this volume directly and indirectly are too numerous to thank individually, special mention of services done is due in two cases. The first is the Secretary of the original Committee, the Rev. G. A. Frank Knight, M.A., F.R.S.E., to whose enthusiasm and power of organisation a great part of the success of the volume is due. The second is the printers of the volume, Messrs. MacLehose, whose courtesy, care, and promptitude in carrying through a very difficult piece of work under trying circumstances none but the Editors can fully appreciate. 



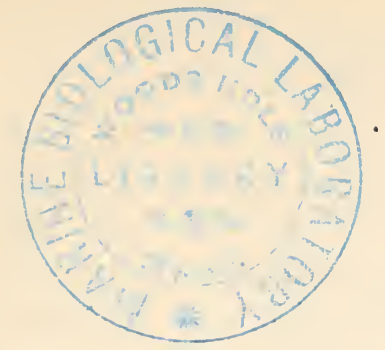

\section{CONTEN'TS.}

Botany. By G. F. Scott Elliot, - $\quad$ - $\quad$ - $\quad$ - $\quad$ - 1

History of Botany in Glasgow. By F. O. Bower, F.R.S., _ 3

The Phyto-Plankton of the Clyde Sea-Area. By G. Murray,

F.R.S., and V. H. Blackman, - $\quad$ - $\quad$ - $\quad$ - $\quad$ - 6

Freshwater Algae. By G. F. Scott Elliot, $\quad$ - $\quad-\quad-\quad-8$

Marine Algae. By E. A. L. Batters, - $\quad$ - $\quad$ - $\quad$ - 16

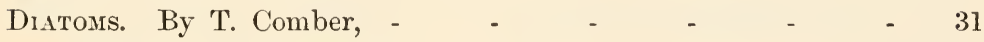

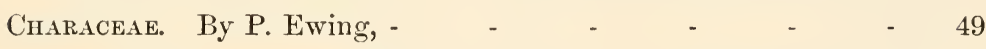

Lichens. By G. F. Scott Elliot, - $\quad$ - $\quad$ - . $\quad$ - $\quad$ - 50

Fongi (Microscopic). By D. A. Boyd, - $\quad$ - $\quad$ - $\quad$ - 61

Hymenomycetes and Gastromycetes. By William Stewart, - 78

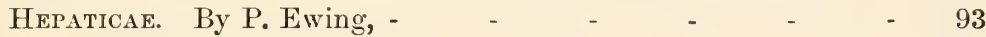

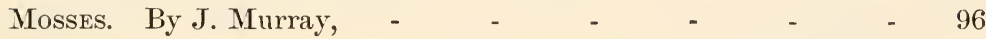

Ferns And their Allies. By W. Stewart, - - 106

Phanerogams. By P. Ewing, F.L.S., - $\quad$ - _ $\quad$ - 110

Measurements of Notable Trees. By John Renwick and

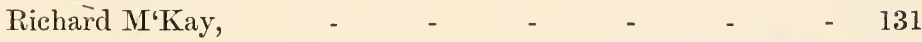

Anthropology of the Clyde Valley. By Ebenezer Duncan, M.D., 149

Mamalia. By Hugh Boyd Watt, - $\quad$ - $\quad$ - $\quad$ - $\quad$ - 155

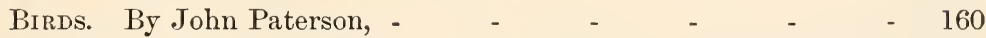

Reptilia and Amphibia. By Alfred Brown, _ $\quad$ - $\quad$ - 171

The Marine and Fresh-water Fishes. By Thomas Scott, F.L.S.,

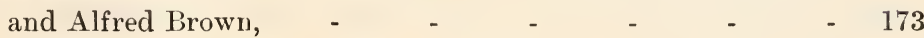

Tunicata. By James Rankin, B.Sc., M.B., C.M., - $\quad$ - $\quad$ - 181

The Land axd Fresh-water Moluusca. By Thomas Scott, F.L.S., 183

Marine Mollusca and Brachiopoda. By Rev. G. A. Frank

Knight, M.A., M.C.S., F.R.S.E., $\quad$ - $\quad$ - $\quad$ - $\quad$ - 189

Marine Polyzod. By Alexander Gray, - $\quad$ - $\quad$ - $\quad$ - 209 
Insecta-

Order Hymenoptera. Sub-Order Terebrantia. By Aud.

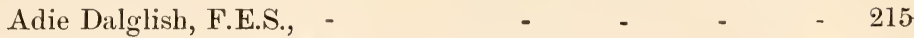

Sub-Order Aculeata. By J. Russell Malloch, - _ - $\quad$ - 219

Order Lepidoptera. Macro-Lepidoptera. By And. Adie

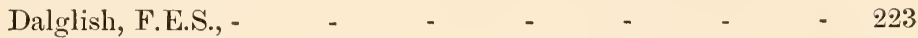

Microlepidoptera. By Prof. James J. F. X. King, F.E.S., - 246.

Order Diptera. (Except Tipulidae). By Percy H. Grimshaw, F.E.S., -

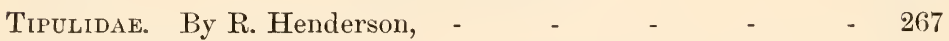

Order Coleoptera. By Anderson Fergusson, - _ - $\quad 272$

Order Trichoptera. By Prof. James J. F. X. King, F.E.S., - 302

Order Hemiptera. Sub-Order Heteroptera. By John Edward

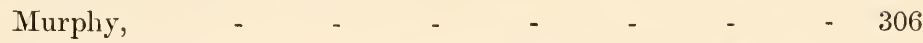

Sub-Order Homoptera. By J. M. B. Taylor, - _ - 310

Order Odonata. By James J. F. X. King, F.E.S., - $\quad-313$

Order Orthoptera. By James J. F. X. King, F.E.S., - - 314

Order Neuroptera-Planipennia. By James J. F. X. King,

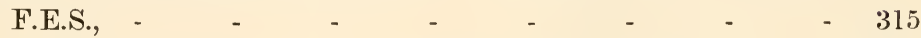

Orders Collembola and Thysanurá. By D. A. Boyd, - 316

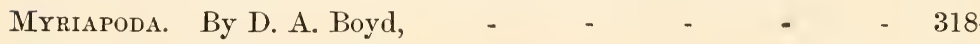

ArachnidA. By William Evans, F.R.S.E., - $\quad$ - $\quad$ - $\quad$ - 319

Land, Fresh-water and Marine Crustacea. By Thomas

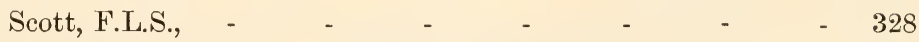

Marine Worms. By James F. Gemmil, M.A.; M.D., - $\quad$ - 359

Echinodermata. By George Bell Todd, M.B., C.M., _ - - 363

Coelentera. Actinozoa. By Malcolm Laurie, B.A., D.Sc., - 367

Hydroid. By James Rankin, B.Sc., M.B., $\quad$ - $\quad$ - $\quad$ - 369

Porifera. By James Rankin, B.Sc., M.B., - _ - $\quad$ - 372

\section{Protozoa-}

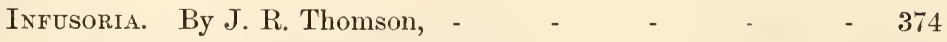

Foraminifera. By Mrs. Robertson, - - - - $\quad 376$

Physical Conditions of the Clyde Sea-Area. By Hugh Robert

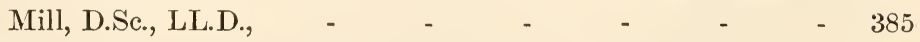

The Geology of the Clyde Territory. By John Horne, F.R.S., 40

The Crystalline Schists of the Highlands. By Peter Macnair, 414

The Silurian Rocks in the South of Scotland. By B. N.

Peach, F.R.S. ; J. Horne, F.R.S. ; and A. Macconochie, 
The Trilobites of the Silurian Rocks of Southwest Scot-

LAND. By B. N. Peach, F.R.S., - - - - 445

The Crustacea of the Silurian Rocks of Southwest Scotland.

By B. N. Peach, F.R.S.,

The Arthropoda froy the Silurian Rocks of Southwest Scot-

LAvd. By B. N. Peach, F.R.S.,

Graptolites. By Professor C. Lapworth, F.R.S., -

The Old Red Sandstone of the Clyde Area. By J. G. Goodchild, F.G.S.

The Carboniferous Rocks of the Clyde Drainage Area.

By John Smith, - $\quad-\quad$ - $\quad$ - $\quad$ 465

The Carboniferous Fossil Plants of the Clyde Basin. By

Robert Kidston, F.R.S.E., F.G.S.,

The Carboniferous Foraminifera of the Clyde Drainage

AreA. By (the late) John Young, LL.D., F.G.S.,

The Carboniferous Sponges of the Clyde Drainage Area:

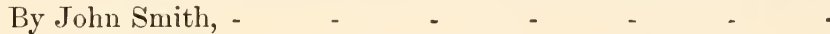

The Carboniferous Corals of the Clyde Drainage Area. By (the late) James Thomson, F.G.S., - - -

The Carboniferous Anselida of the Clyde Drainage Area.

By (the late) John Young, LLD., F.G.S.,

The Carboniferous Polyzoa of the Clyde Drainage Area. By (the late) John Young, LL.D., F.G.S.,

The Carboniferous Ostracoda of the Clyde Drainage Area.

By Prof. T. Rupert Jones, F.R.S., and (the late) James W.

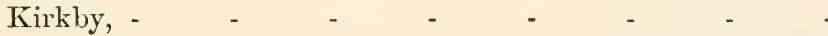

The Carboniferous Brachiopoda of the Clyde Drainage AreA. - By James Neilson,

The Carboniferous Lamellibranchiata of the Clyde DrainAge Area. By James Neilson,

Carboniferous Cephalopoda. By J. Neilsom, - $\quad$ - $\quad 502$

Carboniferous Gasteropoda. By J. G. Goodchild, F.G.S., - 505

The Conodonts of the Carboniferous Rocks of the Clyde

Drainage Area. By John Smith, - $\quad$ - $\quad$ - $\quad$ - 509

Ixcertae Sedis. By John Smith, - $\quad$ - $\quad$ - $\quad$ - $\quad 50$

The Carboniferous Echinodermata of the Clyde Drainage

Area. By John Smith,

The Carboniferous Fishes of the West of Scotland. By R.

H. Traquair, M.D., LL.D., F.R.S., F.G.S., 
The Amphibia of the Carboniferous Rocks of the Clyde Drainage Area. By (the late) John Young, LL.D., - -

e Permian Rocks of the Clyde Drainage Area. By John Smith,

The Drift or Glacial Formation of the Clyde Drainage Area. By John Smith, $\quad$ - $\quad$ - $\quad$ -

The Post-Drift Fossils of the Clyde Drainage Area at Low Levels. By John Smith, Thomas Scott, F.L.S., and

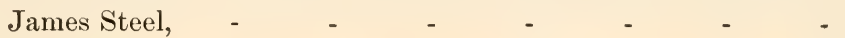

The Rocks of the Clyde Drainage Area. By Joseph Sommerville and G. R. Thompson, B.Sc., A.R.S.M., - $\quad$ - $\quad 546$

The Minerals of the Clyde Drainage Area. By Joseph Sommerville and G. R. Thompson, B.Sc., A.R.S.M., - - 548

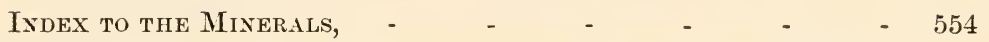

Localities for Old Red Sandstone and Carboniferous Fossils in the Clyde Drainage Area. By John Smith, - - - 557

Conrection.-P. 150, lines 15-22, Dr. Bryce's report should read:- "All the skulls were dolicho-cephalic the highest index being $75 \cdot 2$ the lowest $66 \cdot 6$. They possesed characters closely resembling those of the skulls found in the long Barrows in England--and two exactly realized the description of the Kumbecephalic skulls first described by Sir Daniel Wilson. In other respects the skeletons shewed primitive characters especially in the case of the Tibiae which in the majority of instances were platycnemic,

Thus in Neolithic times the inhabitants of the Clyde valley were of the same primitive race as that which built the long Barrows in England, and were characterised by long heads and short stature. They had not begun to use bronze. They still buried their dead in chambered cairns and were already skilful in the manufacture of pottery." 
FAUNA, FLORA, AND GEOLOGY OF THE CLYDE AREA 



\section{BOTANY.}

THE present Botanical handbook may be considered as a further development of that published for the British Association in 1876. Even at the earlier meetings in Glasgow, attempts were made by local botanists to give a special and satisfactory account of the Flora. For the present work an enormous amount of research has been required, and, as at previous meetings, the British Association may be considered as responsible for what is probably the most complete account of the Cryptogamic flora ever published for any particular district in Britain. The material is in fact so great that

- the introduction has been reduced to the very narrowest limits, and it is only possible to give a very brief account of the methods employed by the compilers, of past and present workers in the field, of the localities which may be recommended to botanical visitors, and of typical plant associations.

Most systematic work in Britain has been upon the old Watsonian lines of counties and vice-counties; we have; however, followed the method recommended by Mr. C. B. Clarke in his classical paper published by the Royal Society (Phil. Transactions, Vol. 183 (1892), B, pp. 3i1-387). The district has been divided by the lines of latitude and longitude, and the $30^{\prime}$ minute lines also of latitude and longitude. At first many of us had doubts upon the value of the system, but it has been found, as the writer suspected, particularly convenient in practice. The method has many advantages : thus it is exceedingly easy to map the distribution of a species, as it is only necessary to draw lines at right angles and enter the records ; it is not dependent on any theory as must be the case with a geological or river system, yet it is extremely easy to compare the rough map of any species' distribution with geological or physical maps; there is also the inmense advantage of economising space. One line of print will give an entire series of records in a manner easily followed by the reader. The lines are also as permanent and immutable as any lines upon the earth's surface can be, and lend themselves readily to sub-division or collation.

From an oecological point of view, the Flora of the Clyde may be considered as fairly representative of the whole of Scotland. It consists of four main divisions or formations, each with their special rock, loch, stream, and other plant associations, and there is also a very typical seaside flora.

The summits of Ben Lomond, Ben Oss, and the Cobbler possess most of the distinctive Scotch Alpines, such as Oxyria, Gnaphalium supinum, the Gyrophoras, and such mosses as the Andreaeas.

The lower slopes of these mountains and such places as Argyll's Bowling Green, Tinto moors, and the hills about Dalmellington, are good examples of the Scotch Grousemoors. They differ from similar formations in the Alps and Pyrenees very considerably, at least so far as the writer's own observations are concerned. 
Below these moors, which are not cultivated and abandoned to the blackfaced sheep, grouse, and black game, there appears to be two distinct formations which are, in practice, very difficult to distinguish from one another. The one, originally dominated by Pinus sylvestris, probably occupied a great many of the valleys and lower hills in both the extreme North and extreme South of the area. Unfortunately the Old Caledonian forest has long since vanished, though it is said to persist in the birch and Pinus sylvestris forests at Auchnacarry and the Black Wood of Rannoch. No observations of its limits in altitude or distribution have apparently been made in our district. In the North the writer believes that these very nearly coincided with the "Highland Line" or Roman Wall. There were also, doubtless at some time, Coniferous forests on the Dalmellington hills, and probably also on the Mistylaw and Tinto ranges, but no exact work has been done upon this subject, and the fact that the alpine flora, and no doubt also the Pinewoods, migrated at least once southwards and northwards over the British Isles, renders the problem an exceedingly difficult one to solve.

The last formation, that of the oak, can be traced to a certain extent, from historical documents. In Berghaus' Physikal Atlas, Nos. 47 and 48, the range of this tree is given as extending much farther North than is here suggested, but although the oak may flourish in favoured situations as far, or even farther North than is there represented, it is scarcely possible that it could form the dominant vegetation of the country beyond the Highland line. Practically all woods are artificial in the West of Scotland, and cultivation occupies a very large proportion of the whole area.

Everyone of these four dominant formations is interrupted by all sorts of rock, water, peat, and other associations. There is not space even to enumerate the whole of these modified floras, but the following list of typical localities may perhaps be useful to strangers visiting Glasgow with oecological views. Of the seaside vegetations, which are particularly well developed, the following are amongst the best localities :

(1) The sand-dunes at Monkton Links and thence to Ardrossan.

(2) Zostera meadows (Enaliden Vereins-Klasse) at Hunterston Point.

(3) Marine Algae (Nereiden, etc.), at Millport, Cumbrae (this is also one of the best places for flowering plants).

(4) Estuarine swamps and muddy foreshore from Dumbarton to Bowling, or at Langbank.

(5) Freshwater lochs and marshes abound in the neighbourhood of Glasgow. Perhaps St. Germains pond at Bearsden, and Possil Marsh (walking to Lambhill from Possilpark station) are amongst the best examples of "Röhrsumpfe" and "Sumpfemoore." Lochwinnoch valley and the plain about Renfrew have been so well drained that only an occasional willow tree or unhappy-looking Phragmites are left to show the character of the former flora.

(6) Deciduous woods are perhaps best developed at the classical locality of the Falls of Clyde (the best walk is from Tillietudlem to Lanark).

(7) The ascent of Ben Lomond from Rowardennan, or of the Cobbler from Arrochar, will give a good idea of the Scotch moors and of the Alpine flora.

(8) Calder Glen at Lochwinnoch may be visited as an example of a particular sort of lynn or mountain ravine which is difficult to place in any of Warming's categories.

(9) The Peat mosses or Sphagnummoore are not very interesting in the Glasgow district. Linwood moss or Garngad is perhaps one of the best.

(10) The blaes and blackband heaps (e.g. at Anniesland Toll, Great Western Road) are of great interest as they possess an artificial flora quite distinct from the natural vegetation surrounding it.

The map at the beginning of the handbook is divided by latitude and longitude lines; as explained above, each divison has its capital letter, A, B, 
C, etc., the capital letters following each species' name show that the plant occurs in that division. Localities and altitudes are mentioned in most cases. (See Introductions to Separate Lists.)

My greatest pleasure in this work has been to publish at anyrate part of the records derived from the enormous collections left by the late Roger Hennedy. These include valuable herbaria and microscopic slides of diatoms, algae of all kinds, lichens, and indeed every division of the vegetable kingdom. I must also heartily thank Professor B. G. Cornıck, M.A., B.Sc., for his invaluable co-operation and assistance.

G. F. Scott Elliot.

\section{HISTORY OF BOTANY IN GLASGOW.}

There is little evidence of interest in, or pursuit of, the Science of Botany in Glasgow prior to the end of the 18th century. It is true Botany was taught in the old College by the Professor of Anatomy ; but it was only at the period of rebound, after the long French wars, that the Science was taken up in earnest. Then, however, rapid advances were made, so that for a time Glasgow held a prominent position as a botanical centre.

The first Botanic Garden in Glasgow was in the precincts of the old College, in the High Street, where a piece of ground was set apart for the cultivation of plants for teaching; but no detailed account of it, or of its contents remains. We have, however, a record of early botanical activity in the Flora Glottiana (1813) of Mr. Hopkirk, who also conceived the idea of the first public Botanic Garden, and stocked it with his own collection. In April, 1817, the first meeting took place, at the instance of Mr. Hopkirk, which started the movement for founding the "Royal Botanic Institution" of Glasgow. Contributions from the Crown and the University, together with subscriptions, sufficed for the acquirement and laying out of some six and a-half acres of ground at Sandyford, then on the outskirts of the city. A Royal Charter was obtained in 1818. Dr. Robert Graham, the first occupant of the Regius Chair, endowed in 1818, also took an active part in the initial movement, and gave several courses of lectures in the new garden, but in 1821 he was succeeded by Sir William Hooker, a man whose name will be ever memorable in the annals of Botany, and one to whom the Glasgow garden was especially indebted for a great measure of its early success as a scientific institution. Partly as a result of his influence and initiative, and greatly no doubt owing to the zeal with which the movement was supported by individual citizens, and to the position of Glasgow as a great commercial centre, contributions began to come in from every quarter of the globe. Taking the number of species represented as a measure, the growth of the living collections was rapid beyond precedent. In 1821 the number of species living in the garden was about 9,000; in 1825 it is quoted at 12,000, while the increase in number from that period onwards was commonly 300 to 500 per annum. Of these a large number were new species, not previously described or figured: this work Hooker carried out, and the publication of his results widened still further the desire on the part of other gardens to effect exchanges with this, so that in 1828, after the garden had been but ten years in existence, the Glasgow Institution found itself not a mere beginner, living upon the scientific charity of the older establishments, but corresponding as an equal with 12 British and Irish, 21 European, and 5 Tropical gardens, while the number of private gardens in correspondence with it was upwards of 300 . The estimated market value of the plants in that year was $£ 7,500$, but a more correct estimate of their scientific value 
is provided for us in the list published in pamphlet form by Sir W. Hooker in 1825, in which a plan of the old garden is to be found. The years 1825 to 1840 were in fact the most notable period in the history of the Glasgow garden as a scientific iustitution compared with its contemporaries. It is noted in the minute books that at this time "scientific visitors to the garden almost invariably expressed the opinion that the garden would not suffer by comparison with any similar establishment in Europe" : it is to be remarked that this period coincides with the presence in Glasgow of the strongest occupant the Chair of Botany in the University has had, and it amply illustrates how great may be the personal influence of one individual upon the success of a public institution. It can hardly have come as a surprise to those who had witnessed his work here, that when a Director had to be appointed to the Royal Gardens at Kew, Sir William Hooker was offered, and accepted the post. In 1841 he left Glasgow, taking with him his private herbarium, library, and museum.

But before this event, owing to the extension of the town westwards, the garden was rapidly becoming engulfed in streets and houses, and was no longer a fit place for growing plants: it was found impossible to rear Coniferous trees, and many other plants were not grown with the same success as before; accordingly steps had already been taken to remove the garden from its position at Sandyford: the old ground having been advantageously sold, a new and more extensive site was selected further westwards, and the present garden was planned and laid out: from the point of view of scenery the choice was probably the best, but the cold unsympathetic clay soil, and exposed situation have ever since been a bar to the complete success of out-door gardening. This combined with the impurity of the atmosphere have made, and must always make the cultivation under glass a more prominent feature of the garden than out-door effects. Botanically speaking, the years 1842 to 1882 seem to have been monotonous, as compared with the more brilliant early years. As a centre of exchange and distribution of novelties the garden fell off, and the energies of the Institution appear to have been devoted to attempts to meet financial stress by means outside the first objects with which the garden was founded. In 1882 the main range of houses was rebuilt on an improved plan, and the collections largely increased; but as the money was borrowed, this only led to greater financial difficulties, which were finally overcome by the garden being taken over by the municipality, and it has since been under the control of the Town Council. The Professor of Botany in the University has a titular comnection with it, but has now no direct hand in the management.

The teaching of Botany in the University, which in the earlier days was conducted in the garden, has in later years been necessarily removed elsewhere : it is useless to regret the severance, which was a consequence on the one hand of increase in the number of students, and on the other of the municipal ownership of the garden. There was a lecture room in the old garden at Sandyford where Dr. Graham, Sir Wm. Hooker, and Prof. J. H. Balfour were heard. In the present garden also a lecture room was built, and used at times by successive Professors up to 1887 ; but it is now divided into dwelling rooms for the gardeners. For many years the University teaching has been carried on at Gilmorehill, and is aided by supplies of specimens from the Botanic garden, still contiuued under the Act for extension of the City Boundaries. In the present year a large range of rooms at the University, adapted to the modern requirements of the science, has been completed : this will provide suitable rooms for teaching and research, and allow of the proper arrangement of an extensive Museum and Herbarium. It is hoped that this building may become a centre of Botanical interest and reference, and materially help in the advancement of Botany in the West of Scotland. 
Teaching had also been carried on from an early date at the Mechanics' Institute, or the Andersonian University, and other Institutions which have been incorporated into the present Technical College. The most notable teacher in these was Roger Hennedy, well known as the author of the "Clydesdale Flora," of which a new edition was edited by one of his successors, Prof. Thomas King. Hennedy lectured from 1849 till his death in 1876. He was essentially an inspiring teacher, and much of the recent excellent field work of the district has been carried out by his pupils and successors. Its quality may be gauged by the lists contained in this volume, There is at present a scheme for New Buildings on an extensive scale for the Technical College, and doubtless suitable provision will be made in them for Botanical purposes.

Of local societies, the Natural History Society of Glasgow and the Andersonian Society are the most active, both as regards meetings and publications; the lists in this volume, Zoological and Botanical, are largely the work of their members. It is to be regretted that the Biological section of the Philosophical Society is at present in abeyance; if reorganised, it should serve the purpose of concentrating the best Biological work of the district. But even without this, it is believed that the output of Botanical work in Glasgow, whether in the field or in the laboratory, will be found to be creditable by those who care to look into it. It must be confessed that the palmy days of Botany in Glasgow were those of Sir William Hooker. Nevertheless the material facilities are as great now as ever they were; intercommunication is easier; the population is more numerous, and more wealthy. There seems therefore no reason why a high distinction in Botanical work should not be maintained in Glasgow at the present day also.

F. O. Bower, F. R. S. 


\section{THE PHYTO-PLANKTON OF THE CLYDE SEA-AREA.}

THE observations on this subject have been only few in number, and practically the whole of our knowledge is contained in the Report of Observation on Plant Plankton by George Murray, F.R.S., in the Fifteenth Annual Report of the Fishery Board for Scotland, 1897. There is still much work to be done before we shall have a thorough knowledge of the minute free-floating vegetation of this area.

The most striking character of this plankton, as of that of many other marine areas, is the great seasonal changes which occur, and the regular yearly alternation of Diatoms and Peridinieae. During the early months of the year the Diatoms are extraordinarily abundant in this district and in all the surrounding coastal waters. They continue in enormous numbers for some time and then, towards the end of March, or beginning of April, they begin to diminish in number; they appear to decrease steadily for some time and then their number remains about constant till the next yearly increase.

The Peridinieae, on the other hand, are very few while the Diatoms are in the ascendant, but as the Diatoms fall off in number they begin to increase, reaching their maximum about August and lingering on till December, as described in Mr. Murray's paper quoted above.

During the most active period of diatom life the predominant form in the Clyde Sea-Area is certainly Skeletonema costatum. This form exists in such enormous quantities at the surface that Mr. Murray describes how a bownet may, in a few minutes, be one-third filled with a sediment consisting principally of this species. In the layer beneath, at this time of year, species of Coscinodiscus, Biddulphia, Ditylum, Rhizosolenia, etc., abound, reaching their maximum at about 5 fathoms and extending down to 25 fathoms.

The Peridinieae of the later months show a much smaller variety of forms; those most frequently met with are species of Ceratium, namely: C. tripos, fusus, and furca, of which the first named seems to be most common in the Clyde Sea-Area. The genus Peridinium is also represented by certain forms, but the species have not yet been exactly determined.

In the summer, when the Peridinieae take the first place as far as actual quantity is concerued, the Diatoms, though much less in total amount than in the earlier months, show a considerable increase in the number of forms ; of which various species of Chaetoceros are the most noticeable. In late months, such as December, Coscinodiscus concinnus seems to be the most abundant form, and after it come Skeletonema costatum, Biddulphia mobiliensis, Chaetoceros decipiens, roughly in order of abundance, while Ceratium tripos and C. fusus are fairly plentiful.

At all seasons of the year, especially near the shore and at the top of loche and generally at the surface after heavy rain, a number of the Diatoms met with either possess only disorganised contents, or are mere skeletons. This is found particularly in the common species Skeletonema costatum, and is also especially noticeable in large forms like Coscinodiscus concinnus and Biddulphia mobiliensis, but it also occurs frequently in the case of many other Diatoms. This phenomenon is doubtless due to a decrease in the salinity brought about by the influx of fresh water through streams or by heavy rain, which produces a lighter fresh water layer at the surface.

Of forms other than the Diatoms and Peridinieae there is very little knowledge; small floating green algal cells, probably simple members of the Chlorophyceae, are fairly often met with, and present a quite unworked field.

A list, drawn up by Professor Cleve, is appended showing the forms met with in hauls from nine stations on the West Coast. The species obtained are very generally the same as those found in the Clyde Sea-Area. 


\section{EDITOR'S NOTE.}

It has been judged best to include the following list, as it gives the best account available of the marine plankton of the West of Scotland. Unfortunately, the localities given are almost all beyond the area under consideration. Never. theless, the marine free-floating vegetation is not likely to differ greatly in its character in the area from the Mull of Kintyre to the head of Loch Ryan.

Bacteriastrum varians, Laud.,

Cerataulina Bergonii, Per.

Chaetoceros borealis, Bail.

C. commutatus, $\mathrm{Cl}$.,

C. constrictus, Gran.

C. contortus, Schütt.

C. criophilus, Cast.,

C. curvisetus, $\mathrm{Cl}$.,

C. debilis, $\mathrm{Cl}$.,

C. decipiens, $C l$.

C. didymus, Ehr., -

C. diadema, Gran., -

C. septentrionalis, Oestr.,

C. scolopendra, $\mathrm{Cl}$., -

Coscinodiscus concinnus, $W . S m$. , .

C. excentricus, Ehr.,

C. radiatus, Ehr.,

Ditylum Brightwellii, Grun., -

Eucampia zodiacus, Ehr.,

E. groenlandica, $C l$,

Fragilaria striatula, Grev.

Guinardia flaccida, Per.,

Lauderia annulata, $C l$.,

Leptocylindrus danicus, $\mathrm{Cl}$.,

Navicula membranacea, $\mathrm{Cl}$.,

Rhizosolenia setigera, Brightw.

R. Shrubsolii, $C l$.,

R. Stolterfothii, Per.

R. pungens, $\mathrm{Cl}$.,

Roperia tessellata, Grun

Skeletonema costatum, $\mathrm{Cl}$.

Stephanopyxis Turris, Ralfs.

Thalassiosira Nordenskioldii, $\mathrm{Cl}$.,

T. gravida, $\mathrm{Cl}$.

Thalassiothrix longissima, $\mathrm{Cl}$. et Grun., $r r$

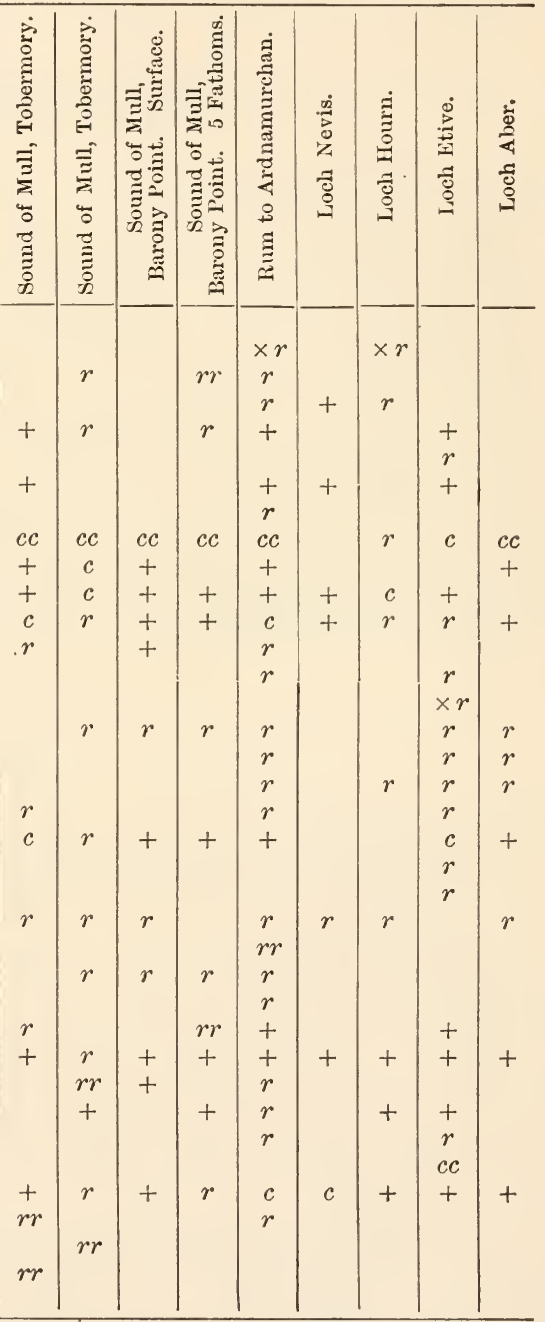

G. Murray, F.R.S., and V. H. Blackman.

$\times=$ dead fragments. $\quad r r=$ very rare. $\quad c c=$ very common. $\cdot r=$ rare $c=$ common. $\quad+=$ not rare. 


\section{FRESHWATER ALGAE.}

THE following list was originally entrusted to Mr. S. M. Wellwood, but unfortunately he was obliged to resign his position owing to continued illhealth; he has, however, with great kindness favoured me with a full list of his discoveries which are included under his name. On his resignation, Mr. J. M. B. Taylor and Mr. J. Paterson undertook the labours of compiling and collecting, and I have myself with their assistance, and that of Mr. J. A. Terras, collected and prepared the records from every source kuown to me. We have had the inestimable advantage of the assistance of Messrs. W. \& G. S. West. They have undertaken and completed the enormous labour of verifying the large collections made by the late Professor Hennedy (now at the Glasgow and West of Scotland Technical College). They have also most kindly inspected and named a very large number of fresh specimens sent to them from time to time. A sign ! means that the specimen so marked has been verified by Messrs. West. With regard to all other records, the responsibility for the occurrence of the species rests up botanist whose initials follow after the locality.

\section{G. F. Scott Elliot.}

\section{INDEX OF ABBREVIATIONS.}

E. M. H. =E. M. Holmes, F.L.S., Ruthven, Sevenoaks.

H. = The Hemnedy Herbarium in Glasgow and West of Scotland Technical College, also slides prepared by the late Professor R. Hennedy.

W. \& G. S. W.= Messrs. W. \& G. S. West, F.I.S., Referees for the group of Freshwater Algae.

S. M. W. =S. M. Wellwood, Esq., National Bank, Johnstone.

Hooker $=$ Wm. Hooker, "Flora Scotica," etc.

J. M. B. T. =J. M. B. Taylor, Esq., Museum, Paisley.

D. A. B. = D. A. Boyd, Esq., West Kilbride.

S. E. $=$ G. F. Scott Elliot, M.A., B.Sc., F.L.S., Scotstounhill.

J. P.=J. Paterson, Esq., 58 Glasgow Road, Rutherglen.

Bal. Exc. = The late Professor Balfour in MS. book of Excursions (Edinburgh University).

Dr. L. = Rev. Dr. Landsborough, D.D. MSS. supplied by his sil, the Rev.

Dr. Landsborough, D.D., of Kilmarnock.

W. A. = Walter Arnott, Herbarium in Glasgow University.

Major M. = Major Martin. See Hassal, "Freshwater Algae."

R. D. W. =R. D. Wilkie, Esq., Glasgow.

J.A.T. = J. A. Terras, M.A., B.Sc., 3 Teviot Row, Edinburgh.

Roy $=$ Roy and Bissett, Ann. Nat. Hist., vols. 3, 4, and 5.

Hop. = Hopkirk, "Flora," vide Hooker, l. c.

T. K. = The late Professor T. King, Glasgow. 
Chantransia chalybea, Lyngb.-F, Cumbrae, E. M. H. ; Saltcoats, H., W. \& G. S. W.!

C. violacea, Kutz.-F, Gleniffer, S. M. W.

Lemanea fluviatilis, Ag.-F G H, Milngavie, Hooker ; Port-Glasgow, J. M. B. T. ; Largs, D. A. B. ; Lamington, S. M. W.

L. torulosa, Roth.-F, Greenburn, J. M. B. T.

Batrachospermum moniliforme, Roth.-E F G, Rothesay, S. M. W. ; Bearsden, S. E. ; Beith, J. P. : both W. \& G. S. W.! Cumbrae, H.,

W. \& G.S. W. ! from $100-1000$ !

var. stagnalis. F, Cumbrae, S. M. W.

var. pulcherrimum. FG, Mistylaw, J. M. B. T. ; Possil, H., W. \& G. S. W. ! var. confusum. F, Cumbrae, H., W. \& G. S. W.!

var. proliferum? F, Gourock, H., W.\& G. S. W. !

B. vagum, Roth.-E F, Arran, Bal. Exc. \& H., W. \& G. S. W.! Gourock. H., W. \& G.S. W. !

B. atrum, Cooke.-F G, Possil, H., W. \& G. S. W. ! Stevenston, Dr. L.

var. setaceum. G, Possil, H., W. \& G. S. W. !

Coleochaete scutata, Breb.-F G, Cumbrae, Hogganfield, H., W. \& G. S. W.!

C. orbicularis, Pringsh.-F, Elderslie, S. M. W.

Bulbochaete setigera, Ag.-B F G, Beinn Buidhe, J. P. ; Cumbrae, Possil, H., all W. \& G. S. W. !

B. Nordstetii, Wittr.-F, Cumbrae, W. A., W. \& G. S. W. !

Oedogonium Landsboroughii, Kutz.-F, Stevenston, Dr. L. ; Cumbrae, H. W. \& G. S. W. !

O. crispum, Hass.-E, Ardrossan, Major M.

O. vesicatum, Lyngb.-G, Dalbeth, Hooker.

Rhizoclonium hieroglyphicum, $K u t z$. var. riparium. F, Cumbrae, H., W. \& G. S. W.!

Vaucheria sessilis, D. C.-F G, Cumbrae, S. M. W.; Clarkston, J. P., both W. \& G. S. W.!

Botrydium granulatum, L.-Hangingshaw, R. D. W.

Prasiola crispa, Ag.-F G, Cumbrae, S. M. W.; Hangingshaw, R. D. W.; Glasgow, H., W. \&. G. S. W. !

P. calophylla, spreng.-F G, Houston, S. M. W.; Thornliebank, H., W. \& G. S. IW.!

Hormidium parietinum, Kutz.-G, Clarkston, J. P., W. \& G. S. W. !

H. murale (Lyngb.), Kutz.-F G, Castlecary, Bridgeton, W. A. ; Cumbrae, H., W. \& G.S. W. !

Hormiscia subtilis, De Toni.-G, Dalmuir, J. P. \& W. W. ! var. variabilis. FG, Beith, J. P. ; Cumbrae, H., both W. \& G. S. W. !

var. tenerrina. B F, South Barr, J. M. B. T. ; Balloch, J. P., W. \& G. S. W. !

H. aequalis, Rabenh. var. cataeniformis. B F, Gleniffer, J. M. B. T. ; Ben Lomond, J. P., W.\& G. S. W. !

H. bicolor, Cooke.-F G, Largs, Cumbrae, Canal Glasgow, H., W. \& G. S. W.!

H. moniliformis, Rabenh.-F G, Beith, S. E. ; Harelaw, J. M. B. T.

H. zonata, Aresch.-F G, Crosbie, S.M.W.; Kilnalcolm, J. M. B.T. ; Bowling, Clarkston, J. P., W. \& G. S. W. !

H. tenuis, Kutz.-B F G, Milngavie, S. M. W.; Fereneze, J. M. B. T. ; Balloch, Clarkston, J. P., W. \& G. S. W.!

H. speciosa, Cooke.-F, Cumbrae, S. M. W.

Allogonium ramosum (Thur.) Hansg.-E, Arran, H., W. \& G. S. W. :

Trentepohlia aurea, L.-B F G, Loch Lomond, S. E., J. A. T.; Cumbrae, W.A.; Houston, S. M. W.

Herposteiron repens, Wittr.-G, St. Germains, S. E., W.\& G. S. W. !

Nordstedtia globosa, Borzi.-F, Cumbrae, W. A., W. \& G. S. W.!

Chaetophora pisiformis, Ag.-G, Possil, s. E., W. \& G. S. W. ! 
C. Cornu Damae, Ag.-G, Possil, H., W. \& G. S. W.! G, Carmunnock, J. P., W. \& G. S. W.!

C. elegans, Roth.-F G, Milngavie, S. M. W. ; Cumbrae, H., W. \& G. S. W. !

C. tuberculosa, Ag.-G, Frankfield Clyde Ironworks, Hooker.

Draparnaudia glomerata, Ag.-F G, Gourock; Possil, H., W. \& G. S. W. :

D. plumosa, Vauch.-F G, Inverkip, J. P., W. \& G. S. W. ; Cumbrae, Glasgow, H., W. \& G. S. W.!

Stigeoclonium tenue, Ag.-F G, Fereneze, J. M. B. T. ; Bardowie, S. M. W.; Ardrossan, Major M.

S. nanum, Dillu.-F G, Glasgow Canal, H., W. \& G. S. W.; Stevenston, Dr. L. ; Black Loch, J. M. B. 'T.

S. thermale, Braun.-F, Saltcoats, Dr. L.

Conferva bombycina, Ag.-F G, Cunibrae, S. M. W. ; Paisley, Clarkston, J. P., W. \& G. S. W. ! Largs, H., W. \& G. S. W. !

C. tenerrima. Cooke.-F, Beith, S. E., S. M. W.

C. fontinalis, Berk.-F, Cumbrae, S. M. W.

Microspora fugacissima, Cooke.-B, Ben Lomond. J. P., \& W. \& G. S. W. :

M. vulgaris, Cooke.-G, Clarkston, J. P., W. \& G. S. W. !

Cladophora crispata, Kutz.-G, St. Germains, S. E., W. \& G. S. W. !

C. glomerata, Kutz.-G, Cathcart, H., W. \& G.S. W.! J. A. T.

C. flavescens, Ag. $-\mathrm{F}$, Cumbrae, S. M. W.

C. fracta, Dillw.-F, Hanginshaw, R. D. W. ; Inverkip, J. M. B. T.

C. canalicularis, Roth.-F, Milton, J. M. B. T.

Mougeotia genuflexa, $A g .-F$, Cumbrae, H., W. \& G. S. W. !

M. nummuloides, Hass.-F, Cumbrae, S. M. W., H., W. \& G. S. W. !

Debarya glyptosperma, Wittr.-F, Fereneze, J. M. B. T.

D. laevis, West \& G. S. West.-F, Fereneze common, J. M. B. T.

D. scalaris, Hass.-F, Beith, J. P., W. \& G. S. W. !

D. gracillimum (Hass.) West.-F, Cumbrae, S. M. W.

Spirogyra crassa, Kutz.-G, Harelaw, J. M. B. T.

S. jugalis, Dillw.-F, Lochwinnoch, J. M. B. T.

S. porticalis, Vauch.-F, Inverkip, J. M. B. T.

Spirogyra tenuissima, Kutz.-F, Saltcoats, Maj. M. var. inflata. F, Stevenson, Maj. M.

S. flavescens, Hass.--F, Loch Thom, J. M. B. T.

S. gracilis, Kütz.-F, Cumbrae, H., W. \& G. S. W. !

S. calospora, Cleve.-F G, Bearsden, J. P.\& W. W.! Cumbrae, S. M. W.

S. condensata, Vauch.-FG, Ardrossan, Maj. M., Dr. L. ; Black Loch, J.M. B. T.

S. maxima, Wittr.-F G, Ardrossan, Maj. M. ; Harelaw, J. M. B. T.

S. longata, Vauch.-F G, Cumbrae, Bardowie, S. M. W. \& J. M. B. T. var. commune. F, Saltcoats, Maj. M.

S. Weberi, Kutz.-F, Stevenson, Maj. M., \& Dr. L. var. subventricosum. FG, Saltcoats, Maj. M. ; Possil, W.A.

Zygnema ericetorum, Hansg.-F, Gourock, H., W. \& G. S. W. ! Mistylaw, J. M. B. T.

Z. stellinum, Vauch.-var. Vancheriae. F, Cumbrae, H., W.\& G. S. W.! Durrochstone Dam, J. M. B. T.

Gonatozygon Ralfsii, De Bary.--F, Cumbrae, W. A., W. \& G. S. W. !

Mesotaenium Endlicherianum, Nag.-F, Renfrew, Roy.

M. chlamydosporum, De Bary.-E, Goatfell, W. A., W.\& G. S. W. !

M. macrococcum, Kirchn.-F, Renfrew, Roy.

var. micrococcum. F G, Gourock, Bardowie, H., W. \& G. S. W. !

M. De Greyii, W. B. Turn.-E, Kyles Bute, Roy.

M. mirificum, Arch.-E, Goatfell, H., W. \& G. S. W. !

Cylindrocystis Brebissonii, Menegh.-B F, Ben Lomond, J.P. \& W. W.! Cumbrae, H., W.\& G.S. W. ! 
C. crassa, De Bary.-E, Arran, H., W. \& G. S. W. !

Penium margaritaceum, Bréb.-E, Arran, Roy.

P. navicula, Breb.-B E, Arran, Roy ; Ben Lomond, J. P. \& W. W. !

P. oblongum, De Bary.-E, Arran, Roy.

P. polymorphum, Pertz.-E, Arran, Roy.

P. truncatum, Bréb.-E, Arran, Roy.

P. spirostriolatum, Barker.-E, Dumbarton, Roy.

P. libellula, Nordst. - var. intermedium. E, Arran, Roy.

P. Ralfsii, De Bary.-E, Arran, Roy.

P. spinospermium, Josh.-F, Renfrew, Roy.

P. crassiusculum, De Bary.-E, Kyles, Bute, Roy,

P. cruciferum, Wittr.-G, Clarkston, J. P., W. \& G. S. W. !

P. cucurbitinum, Bissett.-E F G, Bute, Clarkston, J. P., W. \& G. S W. ! Greenock, Roy.

f. minor. E, Tighnabruaigh, H., W. \& G. S. W. !

P. digitus, Bréb.-F, Gourock, H., W.\& G. S. W. !

P. lamellosum, Bréb.-E, Arran, Roy.

P. curtum, Bréb. - G, Anniesland, H., W. \& G. S. W.!

Closterium abruptum, West.-Forma brevior; G, Paisley, J. M. P. T., W.\&G. S. W.!

C. acerosum, Ehrenb.-F G, Beith, J. P. \& W. W.! Glasgow, W. A \& Hop.

C. Ehrenbergii, Menegh.-F, Salteoats, W. A.

C. Leibleinii, Kutz.-E, Arran, Roy.

C. pseudodianae, Roy.-Kingshouse, Roy.

C. Venus, Kutz.-E F, Bute, Dumbarton, Roy.

C. Jenneri, Ralfs.-E, Arran, Roy.

C. Cynthia, De Not.-F, Dumbarton, Roy.

C. Archerianum, Cleve.-Kingshouse, Roy.

C. regulare, Bréb.-Kingshouse, Roy.

C. intermedium, Ralfs.-E F, Arran, Dumbarton, Renfrew, Roy.

C. directum, Arch.-E, Arran, Roy.

C. angustatum, Kutz.-F, Renfrew, Roy.

C. Ralfsii, Bréb.-Kingshouse, Roy.

C. setaceum, Ehrenb.-Kingshouse, Roy.

C. incurvum, Bréb.--F, Dumbarton, Ruy.

C. acutum, Bréb.-F, Cumbrae, W. A., H., W. \& G. S. W. !

C. striolatum, Ehr.-F, Gourock, H., W.\& G. S. W. !

Pleurotaenium nobile, Richter.-Kingshouse, Roy.

P. clavatum, De Bary.-F, Gourock, H. Herb.

P. truncatum, De Bary-_var. granulatum; B F G, Ben Laoigh, W. W. : Dalmuir, J.P. \& W. W.! Gourock, H., W.\& G. S W.!

P. trabecula, Ehrenb.-E F, Arran, W. W.: Cumbrae, W. A., W. \& G. S. W. !

Tetmemorus, granulatus, Ralfs.-B, Ben Lomond, J. P. \& W. W.! Gourock, H., W.\& G. S. W. !

T. Brebissonii, Ralfs.-B, Ben Lomond, J.P., W. \& G. S. W. !

Euastrum oblongum, Ralfs._-(;, Clarkston, J. P., W. \& G. S. W. !

E. ventricosum, Lund.-E, Arran, Roy.

E. ampullaceum, Ralfs.-E, Arran, Roy.

E. insigne, Hass.-E, Arran, Roy.

E. didelta, Ralfs.-B, Beinn-an-Lochain, J. P., W. \& G. S. W. !

E. cuneatum, Jenner.-B E, Ben Lomond, J. P., W. \& G. S. W. ! Arran, Roy.

E. inerme, Lund.-E, Arran, Roy.

E. erosum, Lund.-E, Arran Roy.

E. binale, Ralfs.-B, Ben Lomond, J. P., W. \& G. S. W. !

E. lobulatum, Bréb.-F, Cumbrae, H., W. \& G. S. W. !

E. elegans, Bréb.-B, Ben Lomond, J. P., \& W. \& G. S. W. !

Micrasterias conferta, Lund.-E, Arran, Roy. 
M. crenata, Bréb.--E, Arran, Roy.

M. rotata, Ralfs.-F, Stevenson, Dr. L.

M. Jenneri, Ralfs.-E, Arran Roy.

Xanthidium aculeatum, Ehren.-F, Dumbarton, Roy ; Gourock, H., W. \& G. S. W.!

X. Brebissonii, Ralfs.-F, Gourock, H. Herb. ; Dumbarton, Roy,

Cosmarium quadratum, Ralfs.-G. Clarkston, J.P., W.\& G. S. W. !

C. sinuosum, Wille.-E, Arran, Roy.

C. Nymannianum, Grunov.-E, Arran, Roy.

C. variolatum, Lund.-E, Arran, Roy.

C. Cucumis, Corda.-E F, Cumbrae, H., W.\& G. S. W.! Tignabruaigh, H., W.\& G.S. W. !

C. Ralfsii, Bréb.-E, Arran, Roy.

C. pachydermum, Lund.-Kingshouse, Roy.

C. pseudopyramidatum, Lund.-B E F, Ben Lomond, J. P., \& W. W.! Arran, Dumbarton, Roy.

C. galeritum, Nord.-E, Arran, Roy.

C. rectangulare, Grun.-F, Cumbrae, W. A., W. \& G. S. W. !

C. pseudonitidulum, Nordst.-E, Arran, Roy.

C. phaseolus, Bréb.-E, Arran, Roy.

C. tetrachondrium, Lund.-Kingshouse, Roy.

C. pygmaeum, Archer.-E F, Arran, Dumbarton, Roy.

C. obliquum, Nordst.--E, Arran, Roy.

C. laeve, Rabh.-F G, Clarkston, J.P. \& W. W.! Cumbrae, H., W. \& G. S. W.!

var. septentrionale, J. P., W. \& G. S. W. !

C. Holmiense, Lund.-E, Arran, Roy.

C. undulatum, Corda.-F, Cumbrae, H.

C. margaritiferum, Menegh.-B F, Balloch, J.P.\& W. \& G.S. W. ! Cumbrae, $\mathrm{H}$.

C. Logiense, Bisset.-B F, Loch Long, Loch Lomond, Dumbarton, Roy.

C. orthostichum, Lund.-Kingshouse, Roy.

C. Botrytis, Menegh.-F G, Cumbrae, H., W. \& G. S. W! Paisley, Dalmuir, J. M. B. T., J. P., W. \& G. S. W.!

C. Turpini, Bréb.-Kingshouse, Roy.

C. Sportella, Bréb.-E, Arran, Roy.

C. coelatum, Ralfs.-B E G, Ben Lomond, Clarkston, J. P. ; Tighnabruaigh, H., W. \& G. S. W. !

C. quadrifarium, Lund.-E, Arran, Roy.

C. cyclicum, Lund.-F G, Renfrew, Roy.

C. speciosum, Lund.-E, Bute, Roy.

C. Blyttii, Wille.-F, Dumbarton, Roy.

C. parvulum, Bréb.-Kingshouse, Roy.

C. subcrenatum, Hantzsch.-B F, Balloch, J. P. \& W. W.! Cumbrae, H., W. \& G.S. W. !

C. subundulatum, Wille.--Kingshouse, Roy.

C nephroideum, (Wille), Roy.-E, Arran, Roy.

C. corriense, Bisset.-E, Arran, Roy.

C. praemorsum, Bréb.-G, Carmunnock, J. P., W. \& G. S. W. !

C. cylindricum, Ralfs.-E, Arran, Roy.

C. tuberculatum, Arch.-B, Lochs Long--Lomond, Roy.

C. Cucurbita, Bréb. f. minor. B, Ben Lomond, J. P. \& W. \& G. S. W. !

C. palangula, De Bary.-B, Lochs Long-Lomond, Roy.

C. granatum, Bréb.-F, Cumbrae, H., W. \& G.S. W. ! var. subgranatum. F, Largs, H., \& Cumbrae, W. A., W. \& G. S. W. !

. humile, Gay. var. substriatun, Nord. F, Cumbrae, H., W. \& G. S. W. ! difficile, Lutk.-F, Cumbrae, H., W. \& G. S. W. ! 
C. Reniforme, Arch.-F, Cumbrae, W. A., W. \& G.S. W. :

C. Scoticum, West.-B, Ben Laoigh, W. W. !

C. venustum, Rabh.-B, Ben Lomond, J. P., W. \& G.S. W. !

C. pyramidatum, Bréb.-F, Cumbrae, W. A., W. \& G.S. W. !

Staurastrum aristiferum, Ralfs.-F, Dumbarton, Roy.

S. O'Mearii, Archer-E, Arran, Roy.

S. laevispinum, Bisset.-E, Arran, Roy.

S. monticulosum, Bréb.-E, Arran, Roy.

S. muricatum, Ralfs.-E, Arran, Roy.

S. hystrix, Ralfs.-E, Arran, Roy.

S. orbiculare, Ralfs.-var. depressum. B G, Ben Laoigh, W. W. ! Carmunnock, J. P., W. \& G. S. W. !

S. punctulatum, Bréb.-B G, Beinn-an-Lochain, Clarkston, J.P., W. \& G. S. W. !

S. pygmaeum, Bréb.-G, Carmunnock, J. P., W.\& G. S. W. !

S. paradoxum, Meyen.-G, Carmunnock, J.P., W. \& G. S. W. !

S. crenulatum, Delp.-G, Carmunnock, J. P., W.\& G. S. W. !

S. capitulum, Bréb.-var. amoenum. E F, Bute, Dumbarton, Roy.

S. dispar, Bréb.-F, Dumbarton, Roy.

S. brachiatum, Ralfs.-E, Arran, Roy.

S. proboscideum, Archer.-E, Arran, Roy.

S. oxyacanthum, Archer.-E, Arran, Roy.

S. alternans, Bréb.-F, Cumbrae, H, W. \& G. S. W. !

S. sexcostatum, liréb.-subsp. productum. F G, Dumbarton, Renfrew, Roy.

S. hexacerum, Wittr.-F, Cumbrae, W. A., W. \& G.S. W.!

S. margaritaceum, Menegh.-B, Ben Lomond, J.P., W. \& G. S. W. !

S. scabrum, Bréb.-E, Arran, Roy.

S. gracile, Ralfs.-F, Cumbrae, H., W. \& G. S. W. :

Arthrodesmus incus, Hass.-F G, Cumbrae, W. A. ; Milngavie, H.

A. convergens, Ehr.-G, Milngavie, H.

Hyalotheca dissiliens, Bréb.-F G, Possil, Hooker ; Gourock, H., Cumbrae, W. A., both W. \& G. S. W.!

Volvox minor, Stein.-F, Springburn Quarry, T. K. ; Stanley, J. M. B. T.

V. globator, L.-G, Elderslie, Stanley, J. M. B.T.

Gonium pectorale, Mull.-G, Paisley, J. M. B. T.

Hydrodictyon utriculatum, Roth.-G, Glasgow, R. D. W.

Coelastrum microsporum, Nag.-G, Carmunnock, J. P. \& W. W. !

Pediastrum Boryanum, Turp.-F G, Cumbrae, H., Carmunnock, J. P., both

W. \& G.S. W. ! Prestwick, W. A.

var. granulatum. F, Cumbrae, $\mathrm{H}$.

P. Sturmii, Reinsch.-B, Ben Laoigh, W. \& G. S. W.

P. rotula, Ehr.-F, Cumbrae, H. (= P. Ehrenbergii Br.).

P. tetras, (Ehr.), Ralfs.-F, Cumbrae, H.

Ophiocytium cochleare, Braun.-G, Paisley, J. M. B. T.

Mischococcus confervicola, Nag.-G, South Barr, J. M. B. T.

Scenedesmus quadricauda, Cooke.-G, Glasgow, W. A. ; Carmunnock, J. P. \& W. W. !

S. denticulatus, Lagerh. var. linearis... F, Cumbrae, W. A., W. \& G. S. W. !

S. bijugatus, Kuetz.-F, Cumbrae, H., W. \& G. S. W. !

Rhaphidium aciculare, Braun.-F, Lochwinnoch, J. M. B. T.

R. falcatum, Corda.-F, Lochwinnoch, J. M. B. T.

Characium Pringsheimii, A. Br.-G, St. Germains, S. E. \& W. \& G. S. W. !

Apiocystis Brauniana, Naq.-F, Renfrew, J. M. B.T.

Tetraspora lubrica, Ag.-F G, Beith, Kilmalcolm, S. E. \& S. M. W. ; Hogganfield, H., W. \& G. S. W.! Bardowie, S. M. W.

T. gelatinosa, Desv.-G, Possil, H., W. \& G.S. W. !

Palmella hyalina, Bréb.-G, Carmunnock, J.P., W. \& G. S. W. : 
P. mucosa, Kutz.-B L, Garelochhead, S. M. W. ; Dalmellington, S. E. \& S. M. W.

P. cruenta, Ag.-G, Glasgow, Hooker.

Botrydina vulgaris, Bréb.-G, Paisley, J. M. B. T., W. \& G. S. W. !

Botryococcus Braunii, Kutz.-G, Linwood Moss, S. M. W. ; Fereneze, J. M. B. T.

Nephrocytium Naegelii, Grun.-F, Cumbrae, W. A., W. \& G. S. W.!

N. crassum, West.-G, Dalmuir, J.P. \& W. \& G. S. W.!

Oocystis solitaria, Wittr.-F, Cumbrae, H. \& W.A., W. \& G.S. W. !

Glaeocystis adnata, Huds.-F, Lochwinnoch, J. M. B. T.

G. Paroliniana, Menegh.-F G, Lochwinnoch, J. M. B. T. ; Dumgoyne Glen, J.P.\& W. \& G.S. W. !

G. gigas, Grun.-FG, Carmumnock, J. P., W. \& G. S. W.! Kilmalcolm, Johnstone, S. M. W.

Urococcus insignis, Kutz.-G, Paisley, J. M. B. T., W. \& G. S. W. !

U. Hookerianus, Hass.-G, Stonelaw, W. A. \& H.; Possil, H., W. \& G. S. W.!

Eremosphaera viridis, De Bary.-F, Inverkip, Garvock, J. M. B. T.

Pleurococcus mucosus, Rahb.-G, Dumbuck, J. M. B. T.

Trochiscia asperum, Hansg.-G, Dumgoyne Glen, J.P. \& W. W. !

Chlorococcum humicolum, Nag.-G, Crosslee, S. M. W.

Protococcus viridis, Ag.-G, Johnstone, S. M. W.

Gloiotrichia natans, Thur.-C, Fereneze, J. M. B. T.

G. pisum, Thur.-E, Arran, H., W. \& G.S. W.!

Stigonema mamillosum, Ag.-E, Arran, H., W. \& G. S. W. !

S. ocellatum, Thur.-E, Arran, H., W. \& G.S. W. !

S. hormoides, Born. and Flah.-E, Arran, H., W. \& G. S. W.!

Scytonema crispum, Born.-G, Campsie, H., W. \& G. S. W. !

S. mirabile, Dillw.-E, Arran, H., W. \& G.S. W. !

S. myochrous, Ag.-E F, Glengarnock, S. M. W.; Arran, H., W. \& G.S. W.!

S. alatum, Berk.-E, Arran, H.\& W. A., both W. \& G. S. W. :

Tolypothrix tenuis, Kutz.-FG, Clarkston, J.P.; Cumbrae, H., both W. \& G.S. W.!

T. lanata, Wartm.-G, Paisley, J.M. B.T.; Hogganfield, H., both W. \& G.S. W.!

'T. flaccida, Kutz.-F, Cumbrae, S. M. W.

Desmonema Wrangelii, Born. et Flah. (Tolypothrix Dillwynii)-F, Holy Loch, W. A.

Dichothrix Nordstetii, Born. and Flah.-E, Arran, H., W. \& G. S. W.!

D. gypsophila, Born. and Flah.-E, Arran, H., W. \& G.S. W.!

Nostoc verrucosum, Vauch.-.E G, Lamlash, Daldowie, H., W. \& G. S. W.!

N. microscopicum, Carm.-E F H, Coira Linn, J.P. ; Cumbrae, Tighnabruaigh, H., all W. \& G.S. W.!

N. Commune, Tauch.--F G, Campsie, H., W. \& G.S. W.! Cumbrae, W. A.

N. Linckia, Roth.-G, Harelaw, J. M. B. T.

N. muscorum, Ag.-E, Arran, H., W. \& G.S. W.!

N. pruniforme, Ag.-F, Cumbrae, W. A. \& H., W. \& G. S. W.!

Anabaena versicolor, Kutz.-F, Cumbrae, Wemyss Bay, H., W. \& G. S. W.!

Aphanizomenon flosaquae, Ralfs.-FG, South Barr, J.M.B.T.; Ayrshire, Dr. L.

Cylindrospermum stagnale, Kutz.-FG, Cumbrae, W. A.; Possil, H., both W. \& G.S. W.!

C. Majus, Kutz.-E. Arran, W.A., W. \& G.S. W.!

Nodularia spumigera var. litorea, Thur.-F, Cumbrae, H., W. \& G. S. W. !

(Schizothrix smithii, Kutz.-E, Goatfell, W. A. ; Species inquirenda, vide Gomont, "Monograph d. Oscillar.")

Dasygloea amorpha, Thwaites.-G, Paisley, J. M. B. T.

Lyngbya Menegheniana, Gomont.-F, Cumbrae, H., W. \& G. S. W. ! 
L. aerugineo-caerulea, Gomont.-E, Arran, H., W. \& G. S. W. :

L. majuscula, Harv._F, Gourock, H., W. \& G.S. W. !

L. aestuarii, Lieb.-E F, Brodick; Gourock, H., W. \& G.S. W. !

(I. Thomsonii, Hass.-J, Ballantrae. Hass Species inquirenda, see Gomont.)

Plectonema Thomasianum, Thur.-F, Cumbrae, H., W. \& G. S. W. !

Phormidium autumnale, Gomont.-B, Balloch, S. E. \& J.A.T.

P. corium, Gomont.-F G, Clyde, Cumbrae, H., W. \& G. S. W. !

P. fragile, Gomont.-K, Ayr. (v. Grevillea, vol. xxi.)

P. laminosum, Gomont.--F, Cumbrae, H., W. \& G. S. W. !

P. uncinatum, Gomont.-G, Carmyle, W.A.

Oscillatoria limosa, Ag.-F G, Beith, S. E. ; Glasgow Canal, H. ; Saltcoats, W. A., all W. \& G. S. W. ! Ben Laoigh, W. \& G. S. W. !

O. insignis, Cooke.-E, Arran, W. A.

O. nigroviridis, Cooke.-F, C'umbrae, W. A.

O. muscorum, Carm.-F H, Inverkip ; Douglas, H. Herb?

O. splendida, Grev.-G, Fereneze, J. M. B. T. ; Possil, H., W. \& G. S. W. !

O. mucosa, Hass.-F, Stevenston, Dr. L. (Species inquirenda Gomont.)

O. thermalis, Hass.-F, Stevenston, Dr. L. ; Glen. J. M. B. T.

O. antliaria, Jurgens.-F or G, Johnstone, S. M. W.

O. irrigua, Kutz.-F, Lochwinnoch, S. E., W. \& G. S. W. !

O. laetevirens, Crn.-F, Wemyss Bay, W. A., W. \& G.S. W. !

O. brevis, Kutz.-G, Paisley, J. M. B. T., W. \& G.S. W.!

O. acuminata, Gomont.-A, Inveraray, H., W. \& G.S. W. !

O. formosa, Bory.-F, Cumbrae, H., W. \& G. S. W. !

O. amphibia, Ag.-F. Cumbrae, H., W.\& G.S. W.! G, Fereneze, J. M. B. T.

O. tenuis, Ag.-FG, Milton, J.M. B. T. ; Wemyss Bay, Bardowie, H. ; Saltcoats, W. A., all W. \& G.S. W. !

O. chalybea, Mertens.-F, Gleniffer, J. M. B. T. ; Cumbrae, H., W. \& G. S. W. !

Microcoleus tenerrimus, Gom.-F, Cumbrae, H., W. \& G. S. W.!

M. vaginatus, Gom.-F, Hunterston, C'umbrae, H., W. \& G. S. W. !

M. paludosus, Gom.-F, Cumbrae, H., W. \& G. S. W. !

Spirulina tenuissima, Cooke.-F, Cumbrae, H., W. \& G. S. W. !

S. Menegheniana, Zanard.-F, Cumbrae, H., W. \& G. S. W. !

Aphanothece saxicola, Nag.-B, Ben Laoigh, W. \& G. S. W. !

A. microscopica, Nïg.-F G, Stonelaw, Cumbrae, H., W. \& G. S. WV. :

A. prasina, Br.-B? G, Gartcosh, H., W. \& G. S. W.! Gareloch, W. A. ?

Glaucocystis Nostochinearum, Itz.-B, Ben Lomond, J. P., W. \& G. S. W. !

Merismopaedia glauca, Nag.-B G, Ben Lomond, Carmunnock, J. P., W. \& G. S. W.

Caelosphaerium Kutzingianum, Nïg.-G, Bardowie, H., W. \& G. S. W. !

Microcystis protogenita, Bens.-G, South Barr, J. M. B.T.

Clathrocystis aeruginosa, Henf.-G, South Barr, J. M. B. T.

Aphanocapsa virescens, Hass.-G, Glengarnock, S. M. W.

Chroccoccus turgidus, Nag.-J F G, Ailsa Craig, Glengarnock, S. M. W. !

Glaeocapsa sanguinea, Kutz.-E, Arran, H., W. \& G. S. W. !

G. Ralfsiana, Harv.-E, Arran, W. \& G.S. WV. !

G. rupestris, Cooke.-G, Glengarnock, S. M. W.

G. aeruginosa (Carm.), Kutz.-F, Gourock, W. A.

G. livida, Carm.-G (E?), Fereneze, J.M. B.T. (Lamlash, W. A., sub Coccochloris.)

G. magma, Kutz.-E, Goatfell, Hooker.

Rivularia atra, Roth.-F, Cumbrae, Gourock, H., W. \& G. S. W.!

R. granulifera, Carm.-F, Cumbrae, W. A., S. M. W.

R. haematites, Ag.-F, Cumbrae, W. A., S. M. W.

R. nitida, Ag.-F, Cumbrae, Dr. L.

Arthrospira Jenneri, Stizen.-G, Old canal basin, W. A., W. \& G. S. W.! G, Old Canal, W. A. 


\section{MARINE ALGAE.}

ProbabLY 110 portion of the littoral of these Islands has been more thoroughly explored by competent algologists than the shores of the Firth of Clyde; yet, owing to the great extent of coast, which, following the indentations, extends for several hundred miles, much remains to be done. The more outlying portions of the great Lochs, the Western shores of Bute and Arran, and the Peninsula of Kintyre, are almost a terra incognita to the phycologist ; while hardly more than a beginning has been made with the exploration of the great Zoster beds at Fairlie, and the extensive banks of Lithothamnia, which are so plentiful in the districts around the Cumbraes and Arran.

The marine flora of the Firth of Clyde is Northern in its general characteristics, as is clearly indicated by the great number of Fucoidea which it contains; yet side by side with such typically Northern species as Monostioma Blyttii, Gobia baltica, Dictyosiphon hippuroides, D. Chordaria, D. Mesogloea, Stictyosiphon tortilis, Phaeosaccion Collinsii, Odonthalia dentata, Antithamnion floccosum, etc., we meet with Bifurcaria tuberculata, Cystoseira ericoides, C. granulata, Dasya arbuscula, Nemalion lubricum, Delesseria hypoglossum, Sphaerococcus coronopifolius, Naccaria Wigghii, Scinaia furcellata, Callyonema reniformis, Chondria tenuissima, Champia parvula, Monospora pedicellata, Halarachnion liqulatum, and others equally typical of a Southern flora.

With the exception of the Orkney Islands nowhere else on the British coasts can a similar mixture of Northern and Southern forms to the same extent be met with. As is well known, the temperature of the water is the most important factor regulating the distribution of marine algae, and "Gulf-stream influence" is usually considered responsible for this great influx of Southern forms into the algae-flora, of both the Clyde Sea-Area and the Orkney Isles.

The algae of the district have always presented peculiar attractions to botanists since the days of Lightfoot and Greville, Arnott and Hennedy, to those of Robertson and the workers of the present day, most of whom have at one time or other algologised in the district; but it is to the labours of the indefatigable Mrs. Robertson who, for many successive years, and at all seasons, continued her search for the sea-weeds of the neighbourhood, that we owe most of our knowledge of the marine algae of the Firth of Clyde.

Phaeosaccion Collinsii and Lithothamnion Battersii are to be niet with nowhere else in Europe, and Ectocarpus ovatus, Halicystis ovalis, Leptonema fasciculatum, and Lithothamnion orbiculatum, are hardly known to occur in Britain outside the Firth of Clyde, while Urospora collabens had not been found on our coasts since 1808 when, in March, 1894, it was rediscovered by the late Dr. Robertson growing on a wooden buoy in the harbour of Cumbrae. 
Excluding "waifs," etc., the species are distributed among the great groups in the following proportions: Myxophyceae, 34 ; Chlorophyceae, 74 ; F'ucoideae, 125 ; Rhodophyceae, 162.

The total number of species of British Marine Algae probably falls short of 750 , and ont of this the local flora contains 395 .

\author{
E. A. L. Batters.
}

\title{
REFERENCE KEY.
}

1. E. A. L. Batters: "Handlist of the Algae of the Clyde Sea-area." (Journal of Botany, 1891, pp. 209-214; 229-236: 272-283). N.B. This List was compiled from former records supplemented by a careful exanination of the Herbarium of Mrs. and the late Dr. Robertson, the National collections at Kew and the British Museum, the Herbarium of Glasgow University, etc. 2. Mrs. and the late Dr. David Robertson's Herbarium and collection of microscope slides. 3. E. A. L. Batters : "Some new British Marine Algae." (Journal of Botany, 1895, pp. 274-6 ; 1896, 6-11 ; 384-90 ; 1897, 433-400 ; 1900, 369-79). 4. E. A. L. Batters in lit. 5. E. A. L. Batters : "New or Critical British Marine Algae." (Grevillea, vol. xxi., pp. 13-23, 49-53, 97-100. Vol. xxii., pp. 20-24, 50-52, 90-92, 114-117. 6. Prof. R. Hennedy's Herbarium and microscope slides, Glasgow and West of Scotland Technical College. 7. E. M. Holmes in lit. 8. J. A. Mahoney : "List of the Marine Algae of Clydesdale." (Notes on the Flora and Fauna of the West of Scotland, 1876). 9. R. K. Greville: Scottish Eryptogamic Flora, 1823-1828. 10. Dr. Gregorsons : Proceedings Natural History Society of Glasgow, vols. i. and ii., pp. 65, 66, 78, etc. 11. Rev. D. Landsborough: A popular History of British Seaveeds, Ed. II., 185̃1. 12. J. Paterson, see 1. 13. E. M. Holmes: "New British Marine Algae." (Gievillea, vol. x., pp. 110-111. Vol. xi., pp. 140-142. 14. Dr. Thompson, see 11. 15. Mrs. Stark, see 11. 16. Major Martin, see 11. 17. MSS. of the late Prof. Balfour's Excursions to the Island of Arran. 18. Dr. W. H. Harvey : Phycologia Britannica, 1846-1851. 19. Geo. Brebner, see 3. 20. E. A. L. Butters: "Additional Notes on the Marive Algae of the Clyde Sea-area." (Journal of Botany, June, 1893, pp. 170-177). 21. Dr. P. R. Greville : Algae Britannicae, 1830. 22. J. Lightfoot : Flora Scotica, 1777. 23. S. M. Wellwood in lit. 24. Mrs. Ovens, see 11. 25. E. A. L. Batters: "On some new British Marine Algae." (Annals of Botany, vol. ix., pp. 307-321, June 1895). 26. Mrs. Gibb, see 11. 27. Miss M'Leish, see 11. 28. Rev. M. Lambie, see 11. 29. Mr. Gourlie, see 11. 30. Rev. Gilbert Laing, see 11. 31. W. G. Johnstone and A. Croall : The Nuture-painted British Seaveeds, 1859-1866. 32. W. H. Grattan : British Murine Algae, 1873.

\section{A. MYXOPHYCEAE.}

Merismopaedia glauca, Nag.-E, Kanıes Bay 1.

\section{Chamaesiphonaceate.}

Dermocarpa prasina, Born.-E F, Bute, Cumbrae 1 \& 2, Kilchattan, 20.

D. violacea, Crn.-B, Gareloch 20.

D. Schousboei, Born.-E F, Kames 20, Cumbrae 2.

Hyella caespitosa, Born et Flah.-E F, Bute 20, Saltcoats 1, Cumbrae 2.

\section{HoRMOGONEAE.}

1 Homocysteae.

Spirulina major, Kutz.-F, Millport 1.

S. subsalsa, Oersted.-E E, Corriegills, Wemyss Bay 1.

Oscillatoria subuliformis, Thw.-F, Largs 8 . 
O. margaritifera, $K u t z .=$ O. insignis, Thw.-F, Hunterston, Cumbrae 8 .

O. nigroviridis, Thw.-F, Millport 1 .

O. corallinae, Gom.-F, Hunterston 1.

Phormidium Ectocarpi, Gom.-F, Cumbrae 3.

P. papyraceum, Gom.-F, Cumbrae 20.

P. ambiguum, Gom.-F, Cumbrae 4.

Lyngbya aestuarii, Liebm.-E F, Brodick 1, Cumbrae 2.

L. majuscula, Harv.-F K, Hunterston 1, Girvan 2.

L. Rivulariarum, Gom.-F, Cumbrae 4.

L. lutea, Gom.-F, Cumbrae 5.

Plectonema Nostocorum, Born.-F, Cumbrae 2.

P. terebrans, Born. et Flah.-F, Cumbrae 5.

Symploca hydnoides, Kütz.

f. gennina, Gom.=-S. Harveyi Le Jol., Arran 1.

f. fasciculata, Gom.-F, Cumbrae 1.

Schizothrix vaginata, Gom.-F, Cumbrae 3.

Hydrocoleum lyngbyaceum, Kutz.

var. rupestris, Kutz.-E, Bute 7, Fintry Bay, Cumbrae 20.

Microcoleus chthonoplastes, Thur. - E F, Cumbrae, Gourock, Largs, Hunterston, Wemyss Bay, Brodick, Invercloy 1.

Heterocysteae.

Calothrix confervicola, C. Ag.-E F, Cumbrae 2, Arran, Ardrossan 1.

C. scopulorum, C. Ag.-E F, Holy Isle 8, Cumbrae 2.

C. pulvinata, C. Ag.-F, Cumbrae 2.

C. fasciculata, C. Ag.-E, Cumbrae $1 \& 2$.

Rivularia Biasolettiana, Menegh.--E, Arran.

R. atra, Rioth.-E F, Corriegills 8, Ardrossan 1, Cumbrae 2.

R. nitida, C. Ag.-F, Cumbrae, Hunterston Point, Gourock, etc., etc., 1.

Mastigocoleus testarum, Lagerh.-E F, Fintry, Lamlash, Saltcoats to Fairlie 26.

Nostocaceae.

Nostoc Linckia, Born.-F, Largs 8, Cumbrae 2.

N. entophytum, Born. et Flah.-F, Cumbrae 3.

Anabaena variabilis, Kütz.-F, Cumbrae 1.

Nodularia spumigena, Mert. B. litorea, Born. et Flah.-F, Cumbrae 1.

\section{B. CHLOROPHYCEAE.}

Protococcaceae.

Chlorochytrium inclusum, Kjellm.--F, Cumbrae, Kilcreggan 20.

C. dermatocolax, Rke.-B F, Gareloch, Cumbrae 20.

Codiolum Petrocelidis, Kuck. F, Cumbrae 4.

Blastosporaceae.

Prasiola stipitata, Suhr.-BF, Loch Goil, Dunoon 1, Cumbrae 2, Gareloch 20.

\section{Ulvaceae.}

Protoderma marinum, Rke.-F, Cumbrae 20.

Ulvella lens, Crn.-E F, Kames, Little Cumbrae 20.

Pringsheimia scutata, Rke.-F, Cumbrae 2, Ardrossan 1 \& 20.

Monostroma Blyttii, Wittr.-E F, Kames 1, Cumbrae 20.

M. fuscum, Wittr.-E F, Fintry 1, Cumbrae 20.

M. Grevillii, J. Ag. (Ulva lactucae, Phyc. Brit.)-E F K, Arran 1, Bute 9, Ardrossan, Portincross 1, Cumbrae 2, Gourock, etc., Saltcoats 1, Ayrheads 1. 
Capsosiphon aureolus, Gobi.-F, Cumbrae, Seamill 20.

Diplonema percursum, Kjellm.-E F, Bute, Gourock, etc., Ardrossan 20.

Enteromorpha clathrata, J. Ag.-E F, Arran 1, Bute 2, Cumbrae 2, Portincross, Fairlie Buoy, Hunterston Point 1.

E. Hopkirkii, McCalla.-E, Arran, Brodick, Corriegills 1.

E. erecta, J. Ag.-E F, Arran, Cumbrae, Ardrossan 1.

E. torta, Reinb. (=E. percursa, Phyc. Br.)-E F, Arran, Bute, Cumbrae 20.

E. crinita, J. Ag.-F, Fairlie 2.

E. ramulosa, Harv.-E F, Arran, Cumbrae 2, Wemyss Bay, Largs 1.

E. Linkiana, Grev.-E F, Arran Lamlash, Cumbrae 2.

E. compressa, Grev.-B E F, Gareloch, Arran, Bute, Cumbrae, Gourock, etc., Saltcoats 1 \& 2.

E. Linza, $J . A g$. f. lanceolata (Ulva linza)-J E F K, Kildonan, Kyles Bute 10, Cumbrae 2, Innellan, Gourock, etc. 1, Girvan 2, Rothesay, Ardrossan 20.

E. intestinalis, Link.-E F, Arran, Cumbrae 1, Innellan, Largs 1 \& 2.

var. cornucopiae, J. Ag.-E, Port Bannatyne 1.

E. micrococca, Kutz.-E F, Arran Cumbrae 20.

var. B. tortuosa. E F, Kames Farland 20.

E. minima, Naeq.-F, Cumbrae 20.

E. marginata, J. Ag.-E, Kames Bute 20.

Ulva latissima, L.-E F, Arran, Kyles Bute 1 \& 10, Cumbrae 2.

\section{ULOTHRICHACEAE.}

Ulothrix implexa, Kutz.-F, Cumbrae, Millport, 20 \& 2.

U. speciosa, Kutz.-E F, Arran, Gourock 1.

U. flacca, Thur. (=Lyngbya flacca \& L. Carmichaelii Phyc. Bn.)-B E F, Gareloch 20, Kilcreggan, Arran 1, Cumbrae 6, Saltcoats 1, Gourock 12, etc., Ardrossan 1.

\section{Chaetophoraceae.}

Acrochaete repens, Pringsh.-F, Cumbrae 20.

Bulbocoleon piliferum, Pringsh.-F, Cumbrae, West Kilbride 20.

Ochlochaete ferox, Huber.-Cumbrae 3.

Entoderma viride, Lagerh.-F, Tan Buoy (8-10 fathoms) 20.

E. Wittrockii, Wille.-Farland 20.

Tellamia contorta, Batt.-F, Cumbrae 3.

T. intricata, Batt.-F, Cumbrae 4.

\section{Cladophoraceae.}

Urospora collabens, Holm. et Batt.-F, Cumbrae 2 \& 5.

U. isogena, Batt.--E F K, Lamlash 2, Cumbrae 2, Greenock, etc., Ayrheads 20.

Chaetomorpha tortuosa, Kutz.-E F, Arran Cumbrae 2, Seamill 2, Saltcoats 11, Loch Ranza 20.

C. implexa, Kutz.-E F, Bute, Cumbrae 2.

C. litorea, Holm. et Batt.-E F, Arran 1, Cumbrae 6, Gourock 1.

C. linum, Kutz.-F. Cumbrae 1, Troon 1.

f. pulvinata, Batt. F, Cumbrae 20.

C aerea, Kutz.-J E F, Ailsa Craig 8, Lamlash 2, Cumbrae 2, Portincross 1.

C melagonium, Kutz.-I E F, Campbeltown 2, Arran 1, Cumbrae 2.

Rhizoclonium riparium (Roth.) Harv.-E F, Arran Bute 1, Cumbrae 2, Rothesay 20, Gourock, etc., Ardrossan 1.

f. Casparyi, Holm. et Batt. F, Cumbrae 6 .

R. tortuosum, Kutz.-E F, Arran, Bute 1, Cumbrae 2, Saltcoats 1, Kirn, Portincross 20.

R. Kochianum, Kutz.-F, Cumbrae 2. 
R. flavicans, Rab.-F, Wentyss Bay 1.

Cladophora pellucida, Kutz.-- F, Cumbrae 2.

C. hirta, Kutz.-F, Millport, Farland Point, Cumbrae 20.

C. Hutchinsiae, Harv.-F, Cumbrae 2, Saltcoats and Ardrossan 1.

f. diffusa, Holm. et Batt. F, Bute 2 .

C. utriculosa, Kutz.-E E, Arran 2, Cumbrae, Ardrossan 1.

f. laetevirens, Hauch.--B E F, Gareloch, Rothesay 20, Cumbrae 6, Ardrossanl 1.

C. rupestris, Kutz.-J E F K, Ailsa Craig 2, Bute 1, Cumbrae 2, Innellan, Ayrheads, etc., 1.

C. glaucescens, Griff.-F, Cumbrae 2.

C. Neesiorum, Kutz.-F, Cumbrae 7 .

C. rectangularis, Harv., f. subnuda, Kutz.-- F, Cumbrae 2.

C. fracta, Kutz.-E F, Arran, Cumbrae 1, Fairlie 2, Hangingshaw, R. D. W.

C. albida Kutz.-E F, Arran 8, Cumbrae 20.

f. refracta Holm. et Batt.-E F, Cumbrae 2, Saltcoats 11.

C. gracilis, Kutz.-F, Portincross, Ardrossan 1.

C. Balliana, Harv.-J F, Ailsa Craig 8, Fintry Bay Cumbrae 20, Little Cumbrae 2.

C. trichocoma, Kutz.-F, Cumbrae 7 .

Acrosiphonia arcta, Kjellm.-J E F, Kildonan 1, Lamlash 2, Cumbrae 6, Saltcoats 1.

A. lanosa, Kutz.-B E F, Loch Goil, Arran 1, Cumbrae 2, Ardrossan 1.

f. uncialis, Thur. E F, Arran 6, Cumbrae, Largs 2, Saltcoats 1.

A. pallida, Kjellm.-F, Cumbrae 3.

A. stolonifera, Kjellm.-F, Cumbrae 3.

Gomontiaceae.

Gomontia polyrhiza, Born. et Flah.-B F, Gareloch, Cumbrae, Fairlie to Saltcoats 20.

VAloniaceae.

Ostreobium Quekettii, Born. et Flah.-B E F, Gareloch, Loch Fyne, Cumbrae 20.

Halicystis ovalis, Aresch.-B E, Arran 2, Kyles 5, Loch Goil 15.

Blastophysa rhizopus, Reinke.-F, Cumbrae 3.

\section{BRYOPSIDACEAE.}

Bryopsis plumosa, C. 1g.-E F K, Arran 1, Cumbraes 2, Troon \& Saltcoats 1, etc., Girvan 2.

B. hypnoides, Lam.-F, Portincross, Seamill, Saltcoats 1.

\section{VAUChERIACEAE.}

Vaucheria sphaerospora, Nordst. f. dioica, Rosenv.-F, Seamill 20.

V. Thuretii, Woron.-E F, Arłan, Brodick, Langbank, etc., Largs, 1.

Codiaceae.

Codium tomentosum, Stackh.-J E F K, Arran 1 \& 10, Cumbraes 20 \& 2, Girvan 2, Ballantrae 14, Kildonan 1.

\section{FUCOIDEAE.}

\section{Desmarestiaceae.}

Desmarestia viridis, Lamx.-E F, Arran 2, Cumbraes 2 \& 20, Dunoon, Saltcoats 1.

D. aculeata, Lamx.-A B E F I J K, Upper Loch Fyne, Campbeltown, Gareloch, Kildonan 10, Cumbrae, Ayrheads, etc., 1 \& 2.

D. Ligulata, Lamx.-I J, Southend, Kintyre 11, Campbeltown 8, Ballantrae 15 
DiCTyOSIPHONACEAE.

Dictyosiphon foeniculaceus, Grev.-J E F, Kildonan, Arran, Bute 1, Cumbrae 2, Gourock, Wemyss Bay 1.

f. hispida, Kjellm.-F, Cumbrae, Fairlie 20.

D. hippuroides, Aresch.-E F, Arran 1, Cumbrae 20, Fairlie 1.

D. Chordaria, Aresch.-F, Fairlie, Portincross, Cumbrae 20.

D. Mesogloea, Aresch.--E F, Bute 20, Fairlie 2.

Gobia baltica, Rle.-F, Kilchattan, Bute 4.

\section{Punctariacean.}

Phaeostroma pustulosum, Kuck.-F, Cumbrae 3.

Phaeosaccion Collinsii, Furlow.-F, Cumbrae 3.

Litosiphon pusillus, Harv.-E F, Arran, Cumbrae 2, Saltcoats, Ardrossan 1. Pogotrichum filiforme, Rke.-B, Gareloch 5.

Phloeospora brachiata, Bornet. = Ect. brachiatus Phyc. Br. = Stictyosiphon Griffithsianus, Holm. et Batt. F, Wemyss Bay 2, Ardrossan 1, Seamill 11.

Stictyosiphon subarticulatus, Hauck.-J E F, Kildonan 13, Kames, Fintry 20.

S. tortilis, Rke.-J F, Kildonan 13, Cumbrae 2.

Desmotrichum undulatum, Rle.-E F, Bute 1, Cumbrae 2.

Punctaria plantaginea, Grev.-E F, Arran, Portincross, Cumbrae 2, Wemyss Bay 1, etc., Saltcoats 11.

f. torta. Holm. et Batt. F, Cumbrae 2 .

P. latifolia, Grev.-E, Arran 11.

f. zosterae. Le Jol. E F, Arran 1, Bute 1, Cumbrae 2, Wemyss Bay, etc., 1, between Largs and Fairlie 11, Ardrossan 16.

f. laminarioides. Holmes. et Batt. Cumbrae 20.

\section{Asperococcaceae.}

Myriotrichia clavaeformis, Harv.-E E J, Arran 1, Cumbrae 8, Ballantrae 14. M. filiformis, Harv. Farlou.-E E, Arran 11, Bute, Cumbrae 2.

M. densa, Batt.-E F, Arran, Cumbrae 3.

Asperococcus echinatus, Grev.-_J E F, Kildonan 10, Arran, Cumbrae 2, Portincross, Ardrossan 1.

A. bullosus, Lamx.-E F, Arran 16, 17, \& 1, Cumbrae 2, Bute 29, Loch Ranza, Brodick, etc., 1.

Striaria attenuata, Grev.--E F, Arran 1, Bute 21, Cumbrae 1.

Ectocarpaceae.

Ascocyclus orbicularis, Magn.-E F, Arran, Cumbrae, Portincross 1 \& 2.

Streblonema fasciculatum, Thur.-E E, Bute 1, Cumbrae 2, Fintry 20.

f. simplex, Rke.-F, Cumbrae 2.

S. aequale, Oltm.-F, Cumbrae 2.

S. sphaericum, Thur.-E E, Bute, Fairlie 20

? Ectocarpus helophorus, Rosenv._F, Cumbrae 19.

E. Zanardinii, Crn.-F, Cumbrae 2.

E. parasiticus, Sauv.-F, Cumbrae 2.

E. aecidioides, Rosenv.-F, Cumbrae 3 .

E. terminalis, Kutz.-E F, Arran, Cumbrae 2.

E. simplex, Crn.--E, Lamlash 2.

E. globifer, $K u t z$ (=E. insignis, Crno.). F, Seamill 2, Lamlash 20.

E. Crouani, Thur.-F, Cumbrae 2.

? E. Sandrianus, Zan.-E F, Lamlash, Cumbrae, Ardrossan 1.

E. longifructus, Harv.-F, Saltcoats 11, Cumbrae 2.

E. irregularis, $K u t z .-\mathrm{F}$, Seamill 20.

E. arctus, Kutz.-E F, Bute 1, Cumbrae 2, Saltcoats to Fairlie 1. 
E. confervoides, Le Jol.-B E F, Loch Goil, Arran, Bute, Cumbraes, Gourock, etc., Ardrossan 1 \& 2.

f. siliculosa, Kjellm. F, Cumbrae 2 .

f. penicillata, $C . A g$. F, Cumbrae 2 .

E. fasciculatus, Harv.-B F, Helensburgh, Cumbrae 2, Portincross, West Kilbride 1.

f. pygmaea, Batt. (= Ect. pygnaeus, Kjellm?) Cumbrae 2.

E. granulosus, C. Ag.--E F, Lamlash, Cumbrae 2, Gourock, Ardrossan 1.

f. refracta. F, Cumbrae, Irvine 2.

E. secundus, Kutz.-F Cumbrae, Fairlie 2.

E. ovatus, Kjellm.-E F, Lamlash, Cumbrae 2.

E. Hincksiae, Harv.-F, Ayrshire 11, Shoalsbuoy, Cumbrae 2.

E. tomentosus, Lyngb.-E F, Arran, Bute, Cumbraes, Kirn, etc., Saltcoats 1.

E. tomentosoides, Farlow. - F, Cumbrae 2.

E. Landsburgii, Harv.-E F, Arran 11, Kyles Bute 20, Cumbrae 2, Largs, Ardrossan 1.

E. distortus, Harv.-E F, Arran 1, Cumbrae, Ardrossan 2.

Sorocarpus uvaeformis, Pringsh.-F, Cumbrae 1, Gourock 2.

Isthmoplea sphaerophora, Kjellm.-E F, Arran 1, Cumbrae 2, Portincross 1.

Pylaiella litoralis, Kjellm.-B E F, Gareloch, Arran, Bute, Cumbrae, Gourock, etc., Ardrossan 1 and 2.

f. ferrugivea, Kjellm.-E F, Arran, Cumbrae 2.

f. compacta, Kjellm.-E, Seamill 1 .

P. varia, Kjellm.--E F, Bute, Cumbrae, Saltcoats 2.

Arthrocladiaceae.

Arthrocladia villosa, Duby.-E F, Lamlash 20, Cumbrae 16.

Elachistaceae.

Myriactis stellulata, Batt.-E F, Lamlash 16, Portincross 20, Cumbrae 8.

M. pulvinata, Kutz.-F, Cumbrae 20.

M. Areschougii, Batt.-F, Farland Point 20.

Elachistea Grevillii, Arn.-E F, Arran, Cumbrae 1, Largs, Seamill 1 and 7.

E. fucicola, Fries.-B E F K, Gareloch, Arran, Cumbraes 1 and 2, Wemyss Bay, etc., Ayrheads 2.

Leptonema fasciculatum, Rke.-F, Cumbrae 20.

f. subcylindrica, Rosenv.-Cumbrae 5 .

f. uncinata, Rke.-F, Gourock.

Halothrix lumbricalis, Rke._E F, Bute, Cumbrae, Fairlie 2 and 20.

\section{Sphacelariaceae.}

Sphacelaria radicans, Harv.-E F, Lamlash, Cumbrae 2.

S. olivacea, Pringsh.-E F, Arran 1, Cumbrae 2, Ardrossan 1.

S. racemosa, Grev.-E F, Arran 8, Cumbrae 6.

S. cirrhosa, C. Ag.-B E FJ K, Loch Goil 1, Corriegills Arran 1, Cumbrae 2, Fairlie, etc., Girvan 1, Ailsa Craig 2, Saltcoats, Ardrossan, etc., 1.

f. fusca, Holm. et Batt.-E F, Arran, Cumbrae 1.

var. aegagrophila, Ag.-E F K, Bute 9, Cumbrae 1, Fairlie, Ayrheads 1 and 2 .

var. patentissima, Grev.-E, Bute 9.

S. plumigera, Holm.-E F, Lamlash Arran 2, Cumbrae 6, Portincross, Ardrossan 11.

S. plumula, Zan.-E, Lamlash Arran 20.

Chaetopteris plumosa, Kutz.-E F K, Arran, Cumbrae 2, Portincross 20, Girvan 2, Ardrossan 1.

Cladostephus spongiosus $C$. Ag.-B E E J K, Loch Goil 1, Cumbrae 2, Ardrossan 1, Kildonan 10, Ayrheads 2. 
C. verticillatus, C. Ag.-F.J K, Cumbrae 2, Kildonan 1, Girvan 2, Arran 11. Stypocaulon scoparium, Kutz.-E F, Arrau 11, Cumbrae 2, Ayrshire 11, Rothesay 20.

Mrrionemaceae.

Hecatonema globosum Batt. (=Ascocyclus globosus, Rke.). F, Cumbrae 5. H. reptans, Saur. (=Ascocyclus reptans, Rke.). F, Cumbrae 5.

Myrionema strangulans, Grev.-E F, Corriegills Arran 11, Cumbrae 2.

f. baltica, Batt. (=Asc cyclus balticus, Batt. non Rke.). F, C'umbrae 20 .

f. Leclancherii, (=M. Lech., Phyc. Br.). Loch Striven 8, Brodick Bay 1.

M. Corunnae, Sauv. (=Ascocyclus foecundus, Batt. in Grevillea, Sept. 92). F, Cumbrae 3.

\section{Ralfsiaceae.}

Lithoderma fatiscens, Aresch.-F, Cumbrae 3.

Ralfsia clavata, Crn.-BE F, Loch Goil, Arrau, Bute, Fairlie to Saltcoats 20 and 2.

R. pusilla, Batt.-E, Kames Bute 20.

R. verrucosa, Aresch.-B E F, Loch Goil 1, Cumbrae, Ardrossan 20 and 2, Corriegills, Wemy-s Bay.

\section{Chordariaceae.}

Spermatochnus paradoxus, Rke.-E F, Arran 11, Lamlash 1 and 2, Ayrshire 11.

S. Lejolisii, Rke.-E F, Arran, Fairlie 20 and 2.

Stilophora rhizoides, $J$. Ag.-E F, Arran 16, Bute Rothesay 30, Cumbrae 1 and 2 .

S. tuberculosa, Rke.-F, Cumbrae 2 and 7 .

Chordaria divaricata, C. Ag.-F, Cumbrae, Fairlie 2 and 20.

C. fiagelliformis, C.Ag.-B E F I J, Gareloch, Arran 2, Bute 1, Cumbrae 8, Dunoon 1, Kildonan 10, Campbeltown 1.

Mesogloea vermiculata, Le. Jol.-E F J, Kildonan 10, Cumbrae 1, Dunoon 1, Ardrossan 11.

M. lanosa, Crn.--E F, Lamlash (8-10 fathoms) 20, Cumbrae 2.

Castagnea virescens, Thur.-EF, Arran, Cumbrae 2, Wemyss Bay, Saltcoats, Ardrossan 1.

f. gracilis, Berk.-F, Cumbrae 2 .

C. contorta, Thur.-F, Fairlie 20.

C. zosterae, Thur.-E F, Bute, Cumbrae, Seamill 20 and 2.

C. Griffithsiana, J. Ag.-E F, Arran 20, Cumbrae 2, Fairlie 20.

Leathesia difformis, Aresch.-E F, Arran 11, Cumbrae 1 and 2, Seamill 7, Saltcoats 2.

L. crispa, Harv.-F, Cumbrae 1 and 6.

\section{SporochNacea.}

Sporochnus pedunculatus, Ag.-E F, Arran 16, Cumbrae 2.

\section{Scrtosiphonacea.}

Phyllitis zosterifolia, Rke.-F, Portincross 20.

P. Fascia, Kutz.-E F, Arran 18, Bute 10, Cumbrae 2, Ardrossan 20. f. debilis, Grev.-F, Cumbrae 2.

Scytosiphon lomentarius, J.Ag.-E F J K, Arran, Bute, Cumbrae 1 \& 2, Kildonan, Ayrheads 1.

f. zostericola, Thur.-F, Cumbrae 2.

\section{Chordaceae.}

Chorda filum, Stackh.-E FJ, Arran, Bute 1, Cumbrae 2, Kildonan 10 etc. f. subtomentosa, Aresch.-F, Cumbrae 2. 
C. tomentosa, Lyngb.-F, Cumbrae 1, Saltcoats 2.

f. subfulva, Foslie.-F, Cumbrae 20.

Laminariaceae.

Laminaria saccharina, Lamx:-B E F, Gareloch 1, Arran, Bute 1, Cumbrae 2, Innellan 1.

f. phyllitis, Le Jol.-E F J, Arran, Cumbrae 2, Helensburgh, Kildonan 10.

L. digitata, Edm.-E F J, Arran 1, Cumbrae 2, Portincross, Ardrossan 1, Kildonan 10.

L. hyperborea, Foslie.--E F, Bute, Cumbrae 20.

Saccorhiza bulbosa, De la Pyl.-E F J, Cumbrae, Loch Fyne 1 \& 2, Kildonan 10, Ayrshire 1, Mull of Kintyre 11.

Alaria esculenta, Grev.-E F J, Cumbrae 2, Saltcoats 1, Kildonan 10, Southend, Kintyre 11.

\section{Cutleriaceaf.}

Cutleria multifida, Grev.-E F, Arran 16, Bute, Cumbrae 1 \& 2. (Sporophytic form = Aglanzonia reptans, Crn.-E F, Arran 20, Cumbrae 1 \& 2, Loch Fyne 2.)

\section{Fucaceate.}

Fucus ceranoides, L.-B E F.J, Bute 10, Cumbrae 2, Loch Long, Greenock 1, Kildonan 10, Loch Goil 20.

F. platycarpus, Thur-B E F, Gareloch, Cumbrae, Kilchattan, Farland 20.

F. vesiculosus, L.-B E F J, Gareloch, Arran 1, Cumbrae 2, Innellan 1, Kildonan 10.

f. laterifructa, Grev.-E, Bute $21 \& 1$.

f. baltica, J. Ag.-E E, Arran, Bute, Cumbrae, Gourock, Wemyss Bay 1 \& 2.

F. serratus, L.-B E F J, Gareloch, Bute 1, Cumbrae 2, Kildonan 10.

f. latifolia, Turn.-E, Bute 2.

f. laciniata, Grev.-E, Bute 21.

Ascophyllum nodosum, Le .Jol.-B E F J K, Gareloch 1, Cumbrae 1 \& 2, Kildonan 10, Ayrheads 1.

A. Mackaii, Holm. et Batt. f. Robertsoni, Batt. E, Loch Ranza 20.

Pelvetia canaliculata, Dcne et Thur. B E F J K, Gareloch 20, Bute 22 \& 1 , Cumbrae 2, Kildonan 10, Ayrheads 1.

Bifurcaria tuberculata, Stackh.-E, Arran 1.

Himanthalia lorea, Lyngb.-E F, Arran 1, Cumbrae 2.

Halidrys siliquosa, Lyngb.-B E F J, Loch Goil 20, Bute 1, Cumbrae 2, Toward, Ardrossan 20, Kildonan 10.

Cystoseira ericoides, C. Ag. - F K, Cumbrae 1, Ayrheads 2. (Also Machrihanish Bay 1.)

C. granulata $C . A g .-\mathrm{F}$, Stevenston 11 .

Tilopteridaceae.

Tilopteris Mertensii, Kutz.-F, Cumbrae, Toward $1 \& 2$, Saltcoats 4.

Haplospora globosa (Kjellm) Brebner (Scaphospora speciosa lijellm)._F, Lion Rock Cumbrae 5.

Achinetospora pusilla, Born. (Ect. pusillus Griff.).-E F, Arran, Cumbrae 2, Tan Buoy 8.

A. crinita, Batt. (Ect. crinitus Phyc. Brit.)-E F K, Arran, Cumbrae 2, Gourock 1, Girvan 2.

\section{Dictrotaceae.}

Dictyota dichotoma, Lamx.-E F J K, Cumbrae 1, Kildonan 10, Ayrheads 2, Mull of Kintyre 28.

f. implexa. F, Cloch 8. 


\section{RHODOPHYCEAE.}

I. Porphyraceat.

Bangia fuscopurpurea, Lyngb.-E F K, Arran 1, Portincross 19, Bute, Cumbrae 1 \& 2, Gourock, etc., 1, Girvan 2.

Erythrotrichia carnea, J. Ag.(=Bangia ceramicola, Phyc. Br.), J. Ag.-EF, Arran, Portincross 1, Cumbrae $1 \& 2$, Ardrossan, etc., Irvine 11.

f. investiens, Hauck (=Porphyra eiliaris 20). E, Arran 20, between Saltcoats and Fairlie 26.

Goniotrichum elegans, Zanard.-F, Cumbrae 1.

Conchocelis rosea, Batt.-F, Cumbrae 20.

Porphyra linearis, Grev.-E F, Arran, Cumbrae 1 \& 2, Helensburgh 10, Kirn 1.

P. leucosticta, Thur.-F, Cumbrae 1, Bute 20, Portincross 7.

P. coccinea, J. Ag.-F, Farland 20.

P. laciniata, C.Ag.-E F J, Arran, Bute, Skelmorlie, Cumbrae 1 \& 2, Helensburgh 10, etc., Ardrossan 1.

f. umbilicalis. B F, Loch Goil, Bute, Portincross, Ardrossan 1.

P. miniata, J. Ag.-F J, Arran, Kildonan 1, Cumbrae, Saltcoats, Irvine 2.

f. amplissima, Fostie.-Cumbrae 20.

f. abyssicola, Kjellm.-F, Cumbrae 2 .

f. tenuissima, Fostie.-F, Cumbrae 2.

f. typica, Foslie.-F, Cumbrae, Irvine 2 .

II. Florideae.

Helminthocladiaceae.

Acrochaetium virgatulum, J. Ag.-E F, Arran, Cumbrae, Hunterston 2, Largs 6, Skelmorlie 1.

A. Daviesii, Nüg.-E F, Arran, Cumbrae 2, Largs 1.

A. secundatum, Nïg.-F, Cumbrae, Saltcoats to Fairlie, Ardrossan 20.

A. chylocladiae, Batt. f. pulchra, Batt.-F, Cumbrae 2.

Nemalion multifidum, J. Ag.-E, Bute 1 (Machrihanish Bay 2).

N. lubricum, Duby.-F, Portincross 20.

Helminthora divaricata, J. 1 g.-E F, Arran 1 \& 2, Ardrossan, Saltcoats 11 .

\section{Chamtangiaceae.}

Scinaia furcellata, Bivona.-E F, Corriegills 11, Lamlash 16, Cumbrae 2. f. subcostata, J. Ag.--F, Cumbrae 1 \& 2.

\section{Gelidiaceae.}

Choreocolax Polysiphoniae, Reirsch.-F, Cumbrae, Fairlie to Saltcoats 20. C. tumidus, Reinsch.-F, Cumbrae 2.

Naccaria Wigghii, Endlich.-F I K, Cumbrae, Fairlie, Campbeltown, Ayrheads 1 (also Machrihanish Bay 11).

Harveyella mirabilis, Schmitz \& Rke.-F, Fairlie 20.

Gelidium corneum, Lamx.-J F K, Whiting Bay, Arran, Cumbrae, Girvan, Ayrheads 2.

f. clavifera, Grev. E, Port Bannatyne Bute 2.

G. crinale, J.Ag.-E F, Arran 2, Bute, Cumbrae, Fairlie to Saltcoats 20. f. polycladium, Hauch:-F, Cumbrae 2.

G. latifolium, Born. et Thur. (= G. corneum, f. latifolia 1).-E F, Bute, Cumbrae, Girvan 1.

\section{Gigartinacean.}

Chondrus crispus, Stackh.-B E F J K, Gareloch, Arran, Bute 1, Cumbrae, Ailsa Craig 2, Ayrheads, Portincross, etc. 1.

Gigartina mamillosa, J. Aq.-B E F J, Gareloch 20, Bute, Cumbrae 2, Kildonan 10, Gourock 11. 
Phyllophora rubens, Grev.-E F, Arran, Bute. 1, Cumbrae 2, Holy Isle, Ardrossan 1.

P. Brodiaei, J. Ag.--E F, Arran 1, Cumbrae, Holy Isle 2.

P. Traillii, Holm. et Batt.-E F, Bute 1, Cumbrae 2.

P. membranifolia, J. Ag.-B E F, Loch Goil, Arran, Bute 20, Cumbrae 2, Ardrossan 20.

Actinococcus subcutaneus, Rosenv.-F, Cumbrae 1.

Gymnogongrus norvegicus, J. Ag.-F or K, Ayrshire 11.

Ahnfeltia plicata, Fries. - B E F K, Gareloch 20, Arran 2, Bute 1, Cumbrae, Ayrheads 20.

Callocolax neglectus, Schmitz.-E, Arran, 24.

Callophyllis laciniata, Kutz.-I J F, Campbeltown 2, Kildonan 10, (Machrihanish 2).

(Callymenia reniformis, J. Ag.-Machrihanish Bay 11).

\section{RHODOPHyLLidaceae.}

Cystoclonium purpurascens, Kutz.-B E F I J K, Loch Goil, Arran, Bute 20, Cumbrae, Campbeltown 2, Kildonan 10, Ayrheads 1.

f. cirrhosa, J. Ag. F, Cumbrae $1 \& 2$.

Catenella opuntia, Grev.-F, Cumbrae 2, Ardrossan 11.

Rhodophyllis bifida, Kutz.-E F, Bute 11, Arran 1, Cumbrae 2, Kilbride, etc., Saltcoats 1.

R. appendiculata, $J$. Ag.-E F, Arran, Cumbrae $1 \& 2$.

\section{Sphaerococcaceae.}

Sphaerococcus coronopifolius, Grev.-E F, "Isle of Bute" 11, Arran, Cumbrae 1, Portincross 11, Ardrossan 16, West Kilbride 11, Heads of Ayr 20.

Gracilaria confervoides, Grev.-E F, Arran, "Nillport in the Isle of Cumbrae" $11 \& 2$.

Calliblepharis jubata, Kutz.-B E E J, Helensburgh 2, Arran 1, Cumbrae 2, Ballantrae 15.

C. ciliata, Kutz.-E F, Arran, Cumbrae 16.

\section{Rhodymeniaceae.}

Rhodymenia palmetta, Grev.-F, Saltcoats 26, Pladda Isle 11.

f. bifida, Turn.-F J, Cumbrae 2, Kildonan 10, Portincross 7.

R. palmata, Grev.-B E F J, Gareloch 1, Arran, Cumbrae 2, Kildonan 10, Ardrossan 20.

f. sobolifera. J. Ag. E, Arran, 1 \& 2.

f. laciniata. Holm. et Batt. F, Cumbrae 2.

Lomentaria articulata, Lyngb.-E F J, Arran, Cumbrae 2, Kildonan 10, Ardrossan 1.

L. clavellosa, Gaill.-B E F J, Helensburgh 10, Bute 1, Cumbrae 2, Kildonan 10, Ardrossan 1.

Champia parvula, Harv.-E F, Arran 1, Cumbrae 2, Saltcoats 15.

Chylocladia kaliformis, Grev.-E F J, Bute, Cumbrae 1 \& 2, 11, Kildonan 1, Ayrshire 11.

C. ovalis, Hook:-F, Dunoon 8.

Plocamium coccineum, Lyngb.--E F J K, Cumbrae 2, Ardrossan 11, Girvan 2, Ballantrae 11, Kildonan 1, Heads of Ayr 20.

f. uncinata, C. Ag. F, Cumbrae 2.

\section{Delesseriaceae.}

Nitophyllum Gmelini, Grev.-F, Cumbrae 2, Ardrossan 16.

N. laceratum, Grev.-B E F J, Helensburgh, Arran, Cumbrae 2, Kildonan 10.

N. reptans, Crn.-E F, Arran, Cumbrae 2. 
N. punctatum, Grev.-E F J, Kildonan 10, Bute, Cumbrae, Saltcoats, Ardrossan 1 \& 2.

f. ocellata, J. Ag.-E F, Aıran, Cumbrae 2 .

N. Bonnemaisonii, Grex:-E F J, Bute 1, Cumbra, Fairlie 2, Kildonan 10.

Delesseria alata, Lamx.-B E F K, Loch Goil, Arran, Bute, Cumbrae 1 \& 2 , Ardrossan 1, Girvan 2.

D. hypoglossum, Lamx.-E F J, Arran, Bute 1, Cumbrae 2, Kildonan 10, Innellan 1.

f. angustifolia, Kut:--F, Cumbrae ?.

D. ruscifolia, Lamx.-E F J, Arran 8, Saltcoats 27, Kildonan 10.

D. sinuosa, Lamx.-B E F.J, Arran, Cumbrae 2, Dunoon 1, Ailsa Craig 2, Ardrossan 1, Loch Goil, Gareloch 20.

f. lingulata, Ag.-Upper Loch Fyne 4.

D. sanguinea, Lamx.-B E EJ, Gareloch, Saltcoats Cumbrae, Kildonan, Ardrossan 1 \& 2.

BoNXEMAISONIACEAE.

Bonnemaisonia asparagoides, C. Ag.-A E FJ, Saltcoats 11, Southend, Argyleshire 28, Dredged off Skelmorlie 29, Loch Fyne (upper) 20, Cumbrae, Kildonan 1 \& 2 .

\section{Rhodomelaceae.}

Rhodomela subfusca, C. Ag.-B E F, Gareloch 29, Arran, Bute 29, Cumbrae 2, Wemyss Bay 1, Ardrossan 2.

R. lycopodioides, C. Ag.-B E F K, Helensburgh 10, Arran, Rothesay 20, Cumbrae, Ardrossan, Ayr 1 \& 2.

Odonthalia dentata, Lyngb.-E F J, Arran, Cumbrae 1, Kildonan, Kilbride, etc., Saltcoats 1.

Laurencia obtusa, Lamx.-E F I J K, Arran 1, Cumbrae 2, Portincross 11, etc., Girvan 2, Bute 11, Ardrossan 16, Ballantrae 14, Kintyre 11.

L. pinnatifida, Lamx.-E F J K, Arran 1, Cumbrae 2, Kildonan 1, Girvan 2. f. uncinata, Grev.-F, Cumbrae 1.

L. caespitosa, Lamour (=L. hybrida Lenorm).-E F J, Cumbrae 1, Krles of Bute 1(), Cumbrae, Seamill 2, Kildonan 10.

Chondria tenuissima, $C$. Ag.-E F ? Arran 1, Saltcoats 27.

C. dasyphylla, C. Ag.-E F, Arran \& Bute 11, Cumbrae 1, Ardrossan 16.

Polysiphonia macrocarpa, Harv. (= P. pulvinata, Harv. P. sertularioides. Auct. Angl.)-F.J, Cumbrae 1, Ailsa Craig 2, Saltcoats 11.

P. fibrata, Harv.-E F, Arran, Bute 1, Cumbrae 2, Saltcoats 11.

P. urceolata, Grev.-B E F J, Gareloch 20, Arran, Cumbrae 6 \& 2, Ailsa Craig 2, Kilchattan 20, Ardrossan 1, Loch Goil 20.

f. patens, J. Ag.-E F.J, Arran, Cumbrae 2, Kildonan 10.

f. formosa, J. Aq.-E F, Arran, Cumbrae 2, Bute 11, Portincross 29.

?P. spinulosa, Givev.-F, Cumbrae 2.

P. elongella, Harv._E F, Arran 1, Cumbrae 2, Kirn 1, Ardrossan 16, Seamill 20.

P. elongata, Grev.-BEFJ K, Loch Goil 20, Arran, Bute 1, Cumbrae 2, Ayrhearls 1.

P.violacea, Wyatt.-E F, Arran, Bute, Cumbrae 2, Holy Isle 1, Irvine 2.

P. fibrillosa, Grev.-B E F, Loch Goil 2, Arran 11, Bute 1, Cumbrae 2, Salteoats 1.

P. furcellata, Harv.?-F, Cumbrae 1.

P. fastigiata, Grev.-BEFJK, Loch Goil 20, Rothesay 20, Cumbrae 6, Kildonan, Ayrheads 20.

P. simulans, Harv.-E F, Arran, Cumbrae 2.

P. atrorubescens, Grev.-E F, Arran 1, Cumbrae 6, off Port Glasgow 1.

P. subulifera, Harv.-E, Lamlash 31. 
P. nigrescens, Grev.-B E F.J K, Loch Goil 1, Arran 2, Bute 1, Cumbrae 2, Kildınan 1, Gourock 6, Ayr 2, Ardrossan, etc. 20.

P. Brodiaei, Grev.-E F J K, Arran, Bute, Cumbrae 2, Portincross 20, Kildonan, Portineross 1, Girvan 2.

P. fruticulosa, Spreng.-E F, Arran 1, Cumbrae, Portincross 24, Ballantrae 14.

Pterosiphonia thuyoides, Schm.-E F, Arran 1, Portincross 11.

P. parasitica, Schm.-A E F.J, Loch Fyne 20, Ardrossan 16, Portincross 11, Cumbrae 6, Kildonan 10.

Brongniartella byssoides, Bory.-E F J, Bute 1, Cumbrae 2, Kildonan 10, Ayrshire 11.

Dasya arbuscula, C. Ag.-E F, Arran 1 Cumbrae 2, Ayrshire 27.

D. coccinea, C. Ag.-E F I.J K, Cumbrae 2, Kildonan 10, Ayr 2, Ardrossan, Southend Kintyre, Ballantrae, etc. 11.

f. tenuis, J. Ag.-A E F, Upper Loch Fyne 20, Arran, Cumbrae 2.

\section{Ceramiaceae.}

Sphondylothamnion multifidum, Naeg.-E F, Arran, Cumbrae 1 \& 2, Ardrossan 11.

Spermothamnion Turneri, Aresch.-E F, Arran, Bute 1, Cumbrae 2, Ardrossan 1.

f. repens, Le Jol.-E, Arran, Bute 1.

? S. Mesocarpum, Batt. = Callithamnion mesocarpum, Phyc. Bri.-E F, Lamlash 32, Cumbrae 2.

Griffithsia corallina, C. Ag.-E F I, Arran, Cumbrae 1, Ardrossan 11, Mull of Kintyre 11, (Machrihanish Bay 11).

G. setacea, C. Ag.-E F J, Cumbraes 2, Portincross 7, Kildonan 10.

Halurus equisetifolius, Kutz.-E K, Arran, Ayrheads 1.

Monospora pedicellata, Solier.-EF, Arran 11, Cumbrae 2, Saltcoats, Ardrossan 1.

Rhodochorton Rothii, Naeg.-E F, Arran, Cumbrae 2, Gourock 1, Saltcoats, etc. 11, Rothesay 20.

R. floridulum, Naeg.-E F, Arran 1, Cumbrae 6 \& 2.

R. membranaceum, Magn.--F, Cumbrae 2.

R. parasiticum, Batt. (=R. sparsum, hjellm.).-F, Cumbrae 1.

Callithamnion polyspermum, C. Ag.-B E F, Helensburgh, Arran, Cumbrae 2, Gourock, Ardrossan 2, Salteoats and Largs 11.

C. roseum, Harv.-E F, Arran, Bute, Cumbrae, Ardrossan 1 \& 2.

C. affine, Harv.-E F, Bute, Cumbrae 1 \& 2.

C. Hookerii, C. Ag.-E F, Arran 11, Cumbrae, Saltcoats 1 \& 2.

C. Brodiaei, Harv.-E F, Arran 1, Cumbrae 2, Saltcoats 11.

C. arbuscula, Lyngb.-E J, Arran 1 \& 2, Ballantrae 11.

C. tetragonum, C. Ag.-E F, Arran 11, Cumbrae 2, Ayrshire 11.

f. brachiata, J. Ag.-F, Cumbrae 2, Saltcoats 11, (Machrihanish 1).

C. corymbosum, Lyngb.-E F K, Arran, Cumbrae 2, Gourock etc. 1, Girvan 2.

C. granulatum, C. Ag.-E F J, Arran 2, Cumbrae 1, Kildonan 10, West Kilbride 16, Saltcoats 11.

C. byssoides, Arn.-E F, Arran, Cumbrae 2.

Seirospora Griffithsiana, Harv.-E, Arran 11, (Ayrshire 16).

Compsothamnion gracillimum, Schmitz.-E F, Arran 1, Cumbrae 2.

Plumaria elegans, Bonnem.-E F, Arran, Ardrossan, Cumbrae 1 and 2, Rothesay 20.

Ptilota plumosa, J. Ag.-E F I J K, Cumbrae 2, Campheltown 2, Kildonan 1, Ayrheads, etc.

Antithamnion cruciatum, Naeg.-E, Lamlash, Arran 2.

A. plumula, Thur.-E F, Arran 11, Cumbrae 2, Ayrshire 11. 
A. floccosum, Kleen.-F, Cumbrae 2, Saltcoats 1.

f. boreale, Kjellm.-E F, Lamlash (8-10 fathoms) 20, Cumbrae 2.

Ceramium tenuissimum, $J . A g .-\mathrm{E}$ E, Arran 1, Cumbrae 2, Saltcoats 11.

C. Deslongchampsii, Chauv.-E F. Arran 1, Bute, Cumbrae 2, Ardrossan 1.

C. strictum, Harv.-E F, Arran 6 and 2, Cumbrae 2.

f. divaricata, Holm. et Batt.--E F, Arran, Cumbrae, Fairlie 2.

C. diaphanum, Roth.-B E F, Loch Goil 20, Arran 1, Cumbrae 2, Ardrossan 1.

C. arborescens, J. Ag.-Cumbrae 4.

C. circinatum, J. Ag.-E F, Arran 6 and 1, C'nmbrae 2.

C. rubrum, C. Ag.-B E F J, Gareloch 1, Arran, Cumbrae 2, Gourock 1, Kildonan 10.

f. prolifera, J. Ag.-E F J, Arran 1, Cumbrae 2, Kirn 1, Salteoats 11, Kildonan 10, Ardrossan 11.

f. decurrens, J. Ag.-E J, Arran 1, Dunoon 1, Kildonan 10.

C. acanthonotum, Carm.-E F K, Arran, Portincross 11, Cumbrae 6 \& 2, Gourock, Ayrheads 21, Saltcoats 11.

C. echionotum, J. Ag.-F, Cumbrae 1, Saltcoats 11.

C. ciliatum, Ducluz.-E F, Arran, Salteoats 11.

C. flabelligerum, $J . A g .-\mathrm{F}$. , Cumbrae $6 \&$ 2, Largs 2, Ailsa Craig 1.

Gloeosiphoniaceae.

Gloeosiphonia capillaris, Carm.-E F J, Arran 11, Cumbrae 2, Ardrossan 11, Kildonan 10.

\section{Dumontiaceae.}

Dumontia filiformis, Grev.-B E F J, Gareloch, Loch Goil 20, Arran 1, Cumbrae 2, Kildonan 10.

f. crispata, $J . A g .-\mathrm{F}$, Cumbrae 2, Saltcoats 11.

Dudresnaia coccinea, Bonnem.--EF, Arran 11, Cumbrae, Holy Isle 2, Saltcoats 11.

Dilsea edulis, Stackh.-E F J, Arran 1, Cumbrae ?, Kildonan 10.

Nemastomaceiae.

Halarachnion ligulatum, $K u t z$ (= Halymenia ligulata, Ag.) -E F I K, Arran, Cumbrae 16, Portincross 11, Girvan 1, Southend, Kintyre 28.

Furcellaria fastigiata, Lamx.-E F. K, Cumbrae 6 \& 10, Kildonan 10, Ayrheads, Rothesay 20.

\section{RHizophyLLIDACEAE.}

Polyides rotundus, Grev.-B E F J, Loch Goil 20, ('mbrae 2, Larly Isle, Kildonan 1.

\section{Squamariaceae.}

Petrocelis cruenta, J. Ag.-B F, Loch Goil 20, ('umbrae 2, Gourock 6.

P. Hennedyi, Batt.-F, Cumbrae 6 \& 2 .

Cruoria pellita, Lyngb.-BE F, Lach Goil, Bute 20, Kilcreggan, Wemyss Bay, Cumbrae, Saltcoats 2.

Cruoriella Dubyi, Schmitz (= Peyssonnelia Dubyi, Crn.).-E, Lamlash 11, Bute 20, Cumbrae 2.

\section{HildexbraxdtiaceaE.}

Hildenbrandtia prototypus, $N a r d o$-BE F, Loch Goil 20, Arran 2, Bute 20, Cumbrae 2, Saltcoats 2.

f. rosea, Kutz.-E F, Arran 1, C'umbrae 2, Kirn, Ardrossan 1.

Corallinaceae.

Melobesia membranacea, Lam.x, F, C'umbrae 2, Largs 1.

M. pustulata, Lamx.-F, Cumbrae 2 .

M. confervicola, Holm. et Batt.-F, Cumbrae 1. 
M. corticiformis, Kutz.-F, Cumbrae, Fairlie-Saltcoats 20.

M. farinosa, Lam. $x$.-E F, Lamlash, Cumbrae 20.

M. Laminariae, $C r n$.-E F, Bute, Cumbrae, Fairlie to Saltcoats 20.

M. Corallinae, $C r n$.-F, Cumbrae. Between Saltcoats and Fairlie 20.

Lithophyllum lichenoides, Phil.-F, Cumbrae 2.

L. Lenormandi, Rosenv.-B E F, Loch Goil, Bute, Cumbrae 20.

L. Battersii, Foslie.-Cumbrae 3.

L. calcareum, Aresch.-F, Cumbrae 2, Imnellan 1.

L. flabellatum. f. Granii, Foslie.-E, Port Bannatyne, Bute 3.

L. polymorphum, Aresch.-E F, Arran 1, Cumbrae 10.

L. coralloides, Crn.-E E, Kyles Bute (8-10 fath.) 20, Cumbrae 2.

f. subsimplex, Batt.-E F, Arran 20, Cumbrae 2.

f. anstralis, Foslie.-F, Cumbrae 3.

L. colliculosum, Foslie.-B E F, Gareloch, Bute 20, Cumbrae 2.

f. roseum, Batt.-F, Cumbrae 5.

L. incrustans, Foslie.-E F J, Whiting Bay, Arran 2, Cumbrae 3.

f. Harveyi, Foslie.-F, ('mmbrae 3.

L. orbiculatum, Foslie.-E F, Kyles Bute 2, Arran, Seamill 3.

L. Sonderi, Hauck.-E F, Kyles Bute 2, Cumbrae 3.

Corallina officinalis, L.-E F J K, Cumbraes 2, Kildonan 10, Wemys: Bay, etc., 1.

C. rubens, Ellis et Sol.-E F J K, Arran, Cumbrae 2, and Salcoats 11, Girvan 1 , Ballantrae 11.

C. squamata, Ellis. - F .J, Portincross 1, Kildonan 10.

Species recorded on insufticient evidence, waifs, etc.

Lyngbya Meneghiniana, Gom.-F, Cumbrae 2.

Anabaena? Broomii, (Thw.).-E, Arran 8.

Schizothrix Cresswellii, Harv._-F, Cumbrae 2.

Asperococcus compressus, Griff.-E, Kildonan 10.

Striaria fragilis, $J .1 g .-\mathrm{F}$, Cumbrae 8.

Laminaria longicruris, De la Pyl.-F, Saltcoats 11.

Gigartina acicularis, Lamour.--E F, Arran (Lamlash), Ardrossan 2.

Nitophyllum versicolor, Harv.-E F, Lamlash, Cumbrae 2.

Seirospora (Callithamnion) interrupta, Schm.-E, Arran 11.

Grateloupia filicina, 4 g.-F, Cumbrae 2.

Lithothamnion fasciculatum, Aresch.-E, Lamlash, Arran 2. 


\section{DIATOMS.}

The following list has been drawn up by Mr. T. Comber from materials supplied by Dr. Thompson and others; from slides of Professor Walker Arnott, and others in his own collection; and from two nettings in the Firth of Clyde supplied by Dr. Murray. The works of Professor Gregory of Edinburgh, and the herbaria of Professors Walker Arnott, and R. Henuedy have also been consulted. Rev. Dr. Landsborough, of Kilmarnock, also supplied a MS. list of his own and the late Dr. Landsborough's collections. All the findings recorded since the list was begun have been verified by Mr. Comber, except a few which were named by $\mathrm{Mr}$. W. West, and which occurred in collections of Freshwater Algae.

\section{REFERENCE KEY.}

G.=Professor Gregory, Papers in Trans. and Proc. Roy. Soc., Edin., vols. 3,4 , and 5 .

M. =Dr. Murray, Trans. and Quart. Journ. Micro. Sc., vols. 3, 4, and 5.

W. A. = Walker Arnott Collection (Glasgow University).

H. $=$ Hennedy Collection (Technical College, Glasgow).

J. P. = John Paterson, Esq., Rutherglen.

J. C. T. = J. C. Thompson.

L. = Dr. Landsborough, MS.

Sm. = Professor Wm. Smith, Syn. Brit. Diat.

S. E. $=$ G. F. Scott Elliot.

T. =J. M. B. Taylor, Esq.

R.=Jobn Rattray, Esq.

V.H. = Van Heurcke, Textbook of Diatomaceue.

$\mathrm{D}$ * in localities = "Cantyre Peat" may be in D, E, or I districts.

Amphiprora paludosa, Sm.-A B F, Glenshira Sand, G. ; Gareloch, M. ; Cumbrae, W. A.

A. alata, Kutz. var. pulchra, Bail.-A F, Glenshira Sand, G. ; Cumbrae, W. A.

Auricula insecta, Cl.-F, Tarbert, J. C. T. ; Cumbrae, W. A.

A. decipiens, $C l$.-A E F, Loch Fyne, Glenshira Sand, G.; Arran, Cumbrae, W. A.

A. complexa, Cl.-A E, Loch Fyue, W.A.; Arran, G.

Tropidoneis lepidoptera, Cl.-A B F, Glenshira, G. ; Gareloch, M. ; Cunbrae, W. A. \& J.P.

var. pusilla, Greg.-A, Loch Fyne, G.

T. maxima, Cl.-A E F, Loch Fyne, Lamlash, G.; Cumbrae, W. A.

T. elegans, $C l$.-A, Loch Fyne, Glenshira Sand, G.

T. Van Heurckii, $C l$.-B, Loch Goil, M. 
T. vitrea, $C l$ - A B, Glenshira Sand, G.; Gareloch, M.

T. recta, $C l$.-A G, Glenshira Sand and Clyde, G.

Pleurosigma nubecula, Sm.-F, Cumbrae, H. \& W. A. var. intermedia, $S m$.-A F, Cumbrae, H. ; Glenshira, ( .

P. directum, Grun.-B, Loch Goil, M.

P. naviculaceum, Breb.-A E F, Loch Fyne, Lamlash, G.; Cumbrae, H.; Upper Loch Fyne, M.

P. lanceolatum, Donk.-A F, Loch Fyne, Cumbrae, W. A.

P. marinum, Donk.-F, Cumbrae, H. \& W. A.

P. delicatulum, Sm.-A B E, Loch Fyne, Lamlash, G.; Gareloch, M.

P. elongatum, Sm.-B F, Loch Goil, Gareloch, M.; Cumbrae, H.

P. rigidum, Sm.-A E F, Glenshira Sand, Lamlash, G. ; Cumbrae, W. A.

P. Normanni, Ralfs.-B F, Loch Goil, M. ; Cumbrae, H.

P. angulatum, Sm.-A, Glenshira Sand, G.

var. strigosa, Sm.-A B E F, Glenshira, G.; Loch Goil, Kyles Bute, M. ;

Cumbrae, W. A.

P. aestuarii, $S m .-$ B, Gareloch, M.

P. obscurum, Sm.-A ? E F, Loch Fyne, Lamlash, G. ; Cumbrae, W. A.

P. falcatum, Donk.-F, Cumbrae, $\dot{H}$.

P. decorum, Sm.-A F, Loch Fyne, Cumbrae, W. A.

P. formosum, Sm.-A E, Glenshira, G.; Upper Loch Fyne, M ; Tarbert, J.C.T.

Caloneis lepidula, $C l$.-G, Glasgow Botanic Gardens, Hamilton, W. A.

C. bacillaris, $C l$.-A, Crinan, W. A.

C. fasciata, $C l$.-E J, Tighnabruaigh Glen, W. A. ; Ailsa Craig, J. P.

C. silicula, $C l$. $-\mathrm{H}$, Falls of Clyde, W. A.

var. gibberula, Kutz.-A E D G, Glenshira Sand, G. ; Gourock, W. A. ; St.

Germains, J. P.; Cantyre Peat, Sm.

var. limosa, Kutz.-H, Falls of Clyde, W. A.

var. inflata, Grun.-B, Gareloch, M.

var. subinflata, Grun.-A G, Crinan, W. A. ; Cathkin, J. P.

C. Schumanniana, $C l$.- E, Kyles Bute, M.

C. obtusa, $C l$.- A, Glenshira, G.

C. liber, Cl.-A B E F, Loch Fyne, G. \& M. ; Gareloch, M. ; Arran, H. \& G. ;

Cumbrae, W. A. \& H.

var. bicumeata, Grun.-A F, Glenshira, G. ; Cumbrae, H.

var. linearis. A F G, Glenshira, G. ; Cumbrae, Hamilton, W. A.

C. formosa, $C l$. - A F, Glenshira and Clyde, G.

C. amphisbaena, Cl.-A E J G K, Glenshira, G. ; Arran, Prestwick, W. A. ;

Cambuslang, Ailsa Craig, J.P.

var. subsalina, $C l$.-B, Gareloch, M. (Powburn mouth, W. A.).

C. brevis, Cl.-A E F, Lamlash, Loch Fyne, G. ; Cumbrae, H.

C. blanda, $C l$.-A, Glenshira, G.

C. musca, $C l$. - F, Clyde, G.

Neidium iridis, $C l$.-A E F G, Glenshira, G. ; Gourock, Cumbrae, W. A. ; St. Germains, J. P. ; Arran, H.

var. amphigomphus Ehr.-F, Cumbrae, W. A.

N. affine, Cl.-A FG, Glenshira, G. ; Glasgow Gardens, W. A. ; Cambuslang, J. P. ; Gourock, W. A.

var. amphirhynchus, Ehr.-F, Castle Semple Loch, S. E.

N. dubium, $C l$.- G, Canbuslang, J.P.

Stenoneis inconspicua, $C l$. $-\mathrm{A}$ ? E, Loch Fyne, Lamlash $\mathrm{G}$.

Gyrosigma acuminatum, $\mathrm{Cl}$.- F G, Saltcoats, $\mathrm{H}$; Cambuslang, J. P.

G. attenuatum, $C l$.- A B D*, Glenshira, G. ; Gareloch, M. ; Cantyre Peat, Sm.

G. distortum, $C l$.-A, Glenshira, G.

G. fasciola, $C l$. var. (Pleurosigna arcuatum, Donk.).-F, Cumbrae, W. A. 
G. prolongatum, $C l$.-B F, Cumbrae, H. ; Gareloch, M.

G. Spenceri, Cl.-G H, Clyde Ironworks, H., W. A.; Glasgow Gardens, W. A. ; Rutherglen, Corra Linn, J. P.

G. balticum, Cl.-A, Glenshira Sand, G.

G. diminutum, Cl., var. reversa, Greg.-A, Loch Fyne, G.

G. rectum, $C l$.-B F, Gareloch, M. ; Cumbrae, W. A.

Frustulia vulgaris, $\mathrm{Cl}$.-F G, Perceton, Glasgow, W. A. ; Gourock, Cathkin, J. P.

F. rhomboides, Cl.-A B E G H, Glenshira, G. ; Ben Lomond, H. ; Kyles Bute, M. ; Castlecary, W. A. ; Corra Linn, J. P.

var. crassinervis, Bréb.-A EG H, Glenshira, G. ; Lamlash, H. ; Castlecary, W. A. ; Corra Linn, J. P.

var. viridula, Bréb.-F, Cumbrae, W. A.

var. saxonica. B, Ben Lomond, J. P. \& W. W.

Brebissonia Boeckii, Grun.-E, Brodick, W. A. \& H.

Amphipleura rutilans, $C l$.-E F, Arran, Bute, W. A. ; Cumbrae, H.

A. micans, $C l$. var. fragilis, $C l$.-F, Cumbrae, H., W. A.

A. pellucida, Kutz.-A E F H, Glenshira, G. ; Arran, Saltcoats, Falls of Clyde, W. A.

Anomoeoneis serians, Cl.-E, Goatfell, Brodick, W. A.

Pseudo-amphiprora stauroptera, $C l$.-A, Loch Fyne, G.

Trachyneis aspera, Cl.-A F, Cumbrae, Loch Fyne, W. A.

var. pulchella, Sm.-A BEFJ, Glenshira, G. ; Gareloch, M. ; Arran, W.A. ; Cumbrae, W. A. ; Ailsa Craig, J.P.

T. clepsydra, $C l$.-B, Gareloch, II.

Diploneis hyalina, Cl.-A B E F, Upper Loch Fyne, Gareloch, M. ; Arran, Cumbrae, W. A.

D. coffeaeformis, $C l$.-A B, Upper Loch Fyne, Loch Goil, M.

D. suborbicularis, Cl.-A E F, Loch Fyne, Lamlash, G ; Cumbrae, W. A.

D. constricta, $\mathrm{Cl}$.- F, Cumbrae, W. A.

D. incurvata, Cl.-A E F, Glenshira, Lamlash, G.; Cumbrae, H. \& W. A.

D. interrupta, Ehr.-A B, Loch Fyne, W.A.; Gareloch, M.

D. lineata, Cl.-A F, Upper Loch Fyne, M. ; Cumbrae, W. A.

D. splendida, $C l$.-A E, Glenshira, G. ; Upper Loch Fyne, M. ; Lamlash, G.

D. bomboides, $C l$.-F, Cumbrae, W. A.

D. didyma, Cl.-A B E F, Glenshira, G. ; Gareloch, M. ; Arran, H. ; Cumbrae, H. \& J.P.

var. costata. F, Clyde, G.

D. bombus, Ehr.-A E F, Loch Fyne, Lamlash G. ; Cumbrae, W. A.

D. chersonensis, Cl.-F, Cumbrae, H. \& W. A.

D. elliptica, $C l$.-A D* E F G, Crinan, W.A. ; Kyles Bute, M. ; Cumbrae, H. ; Cathkin, J.P. ; Cantyre Peat, Sm.

D. ovalis, Cl.-A EGH L, Crinan, W.A. ; Tighnabruaigh, M. ; Cathkin, J.P.; Falls Clyde, W.A. \& J.P. ; Dumfries House, W. A. var. oblongella. EG, Arran, W. A.; Cathkin, J.P.

D. Graeffii, Cl.--F, Cumbrae, W. A.

D. fusca, Cl.-A B E F, Loch Fyne, G. ; Gareloch, M. ; Lamlash, E. ; Cumbrae, W. A.

D. aestiva, $C l .-E$ F, Cumbrae, Loch Fyne, W. A.

D. litoralis, $C l$.-F, Cumbrae, W. A.

D. hyperborea, $C l$.-B, Gareloch, M.

D. Smithii, Cl.-A B F, Glenshira, G. ; Loch Goil, M. ; Cumbrae, H. \& J.P.

D. major, Cl.-A F, Upper Loch Fyne, M. ; Cumbrae, H.

D. nitescens, $C l$. - A E, Loch Fyne and Lamlash Bay, G.

D. crabro, Ehr.-A E F, Loch Fyne, W. A. ; Arran, H. \& W. A. ; Cumbrae, W. A. ; Firth of Clyde, H.

var. pandura, Breb.-A E, Glenshira Sand and Loch Fyne, Lamlash Bay, G. 
Pinnularia gracillima, Greg.-J G H, Ailsa Craig and Rutherglen, J. P. ; Castlecary, W. A.

P. leptosoma, Cl.-F G, Cumbrae, W. A. ; Cathkin, J.P.

P. appendiculata, $\mathrm{Cl}$.-B E F G, Gareloch and Kyles of Bute, M.; Cumbrae, W. A. ; Maryhill Bridge, $\mathrm{H}$.

P. subcapitata, Greg.-A J, Glenshira Sand, G. ; Ailsa Craig, J. P.

P. interrupta, Sm.-E J G, Kyles of Bute, M.; Ailsa Craig, Rutherglen, St. Germains Loch, J. P.

P. mesolepta, Ehr.-A D* F G, Glenshira Sand, G.; Cantyre Peat, Sm. ; Perceton Well, W. A.; Rutherglen, J.P.

P. globiceps, Greg.-A, Dubh Loch, Glenshira, G.

P. microstauron, $\mathrm{Cl}$. $-\mathrm{A}$ G H, Crinan, W.A. ; Cathkin, J.P. ; Castlecary, W. A.

P. hemiptera, Breb.-J, Ailsa Craig, J. P.

P. Brebissonii, Ktz.-A E G, Crinan, W. A. ; Kyles of Bute, M. ; Possil, J. P. var. stauroneiformis, $\mathrm{Cl}$.-G, Barrhead, W. A.

P. divergens, Sm._A B, Glenshira Sand, G. ; Ben Laoigh, W. W.

P. borealis, Ehr.-A J F G, Glenshira Sand, G. ; Ailsa Craig, J. P. ; Cumbrae, Saltcoats, W. A. ; Partick, H. ; St. Germains Loch, Cathkin, J. P. var. scalaris, Grun.-J, Ailsa Craig, J. P.

P. lata, Sm.-A J. Glenshira Sand, G. ; Upper Loch Fyne, M. : Ailsa Craig, J.P.

P. alpina, Sm.-F, Cumbrae, W. A.

P. gibba, Ehr.-A D*, Glenshira Sand, G. ; Cantyre Peat, Sn.

P. tabellaria, Ehr.-E F, Lamlash, Perceton Well, W. A.; Lochwinnoch, S. E. \& W. W.

P. parva, Greg.-H, Castlecary, W. A.

P. stauroptera, Rabh.-G, Rutherglen, J.P.

P. major, Rabh.-A B D* E J F G H, Glenshira Sand, G.; Gareloch, M. ; Lamlash, Saltcoats, W. A.; Cumbrae, H. ; Ailsa Craig, Cathkin, J.P.

P. viridis, Ehr.-A B D* E J F G H, Glenshira Sand, G. ; Crinan, Lamlash, Saltcoats, W. A.; Gareloch, M. ; Cantyre Peat, Sm. ; Ailsa Craig, St. Germains Loch, Corra Linn, J. P. ; Cumbrae, H., W. \& G.S. W. ; Lochwinnoch, S. E. \& W. W.

var. fallax, Grun.-B J G, Gareloch, M.; Ailsa Craig, Cathkin, St.

Germains Loch, J.P.

var. commutata, Grun.-E F G H L, Tighnabruaich Glen, Castlecary, Dumfries House, W. A. ; Castle Semple Loch, S. E. ; St. Germains Loch, J. P.

P. nobilis, Ehr.-D* F G, Cantyre Peat, Sm. ; Saltcoats, W. A. ; Clarkston, St. Germains Loch, J.P.

P. cardinalis, Sm.-D*, Cantyre Peat, Sm.

P. quadratarea, $C l$.-A, Glenshira Sand, G. ; Upper Loch Fyne, M. var. Theelii, Cl.-A, Upper Loch Fyne, M.

P. claviculus, Greg.-A F, Loch Fyne, G. \& H. ; Cumbrae, H.

P. trevelyana, $R b h$. - B, Gareloch, M.

P. rectangulata, Rbh.-E F, Lamlash Bay, G. ; Cumbrae, W. A. \& H.

Navicula gregaria, Donk.-F G, Saltcoats, Hunterston, Amniesland Toll, W. A.

N. cuspidata, Ktz.-D* G, Cantyre Peat, Sm. ; St. Germains Loch, Cambuslang, J. P.

N. crucigera, $C l .-F$, Cumbrae, W. A. \& H.

N. minima, Grun.-G, Glasgow Botanic Gardens, W. A. var. atomoides, Grun.-G, Cathkin, J.P.

N. seminulum, Grun.-E, Tighnabruaich Glen, W. A.

N. Rotoeana, Grun.-B E G, Gareloch, Kyles of Bute, M. ; Lanarkshire, G. var. oblongella, Grun.-B E, Gareloch, Kyles of Bute, M. 
N. mutica, Ktz. var. Goeppertiana, Grun.-A G, Crinan, W. A. ; Cathkin, J. P. var. Cohnii, Hilse.-G, Cathkin, J. P.

N. pupula, $K t z$-B E F G, Gareloch, M. ; Arran, Glasgow Botanic Gardens, W. A. ; Castle Semple Loch, S. E. ; Cambuslang, St. Germains Loch, J.P.

N. contenta, Grun. var. biceps, Grun.-F G, Gourock, H., W. \& G. S W. ; Maryhill, $\mathrm{H}$.

N. confervacea, Grun.-G, Glasgow Botanic Gardens, W. A.

N. inornata, Grun.-B F, Loch Goil, M. ; Cumbrae, H.

N. fusoides, Grun.-E, Kyles of Bute, M.

N. semen, Ehr.-A, Glenshira Sand, G.

N. crucicula, Donk.-A D* E, Glenshira Sand, G.; Cantyre Peat, Sm.; Arran, W. A.

N. integra, Rlfs.-E F G K, Arran, Cumbrae, W. A. ; Cambuslang, J. P ; Avr, $\mathrm{H}$.

N. rhombica, Greg.-A B F G, Glenshira Sand and Clyde, G. ; Gareloch, M. ; Perceton Well, Saltcoats, Cumbrae, W A. ; Auld Wives' Lift, H.

N. Grevillei, Donk.-B, Loch Goil, M.

N. libellus, Greg.-B E F, Gareloch, Kyles of Bute, M. ; Lamlash Bay, G. ; Cumbrae, IV. A. \& H.

N. complanata, Grun.-B, Loch Goil, M.

N. aponina, Ktz.-F, Cumbrae, W. A.

N. Bulnheimii, Grun.-A E, Crinan, Moneymore, W. A.

N. muralis, Grun. forma lanceolata.-B, Gareloch, M.

N. atomus, Grun.-F, Beith, H.

N. minuscula, Grun.-A E, Crinan, W. A. ; Kyles of Bute, M.

N. bacillum, Ehr. $\operatorname{var}(=\mathrm{N}$. lepida, Greg.)-E G, Arran, Hamilton H. ; St. Germains Loch, J.P.

N. pseudobacillum, Grın.-A, Upper Loch Fyne, M.

N. placenta, Ehr.-A E, Loch Fyne, Lamlash Bay, G.

N, cocconeiformis, Greg.-E, Cumbrae, W. A.

N. gottlandica, Grun.-F, Kilmalcolm, S. E.

N. cryptocephala, Ktz.-A E G H, Crinan, Corrygills, W. A. ; Botanic Gardens, W.A. \& H. ; Kyles of Bute, M. ; Cathkin, Tillietudlem, Corra Linn, J. P.

var. veneta, $K t z$ - - G H, Cathkin, Corra Linn, J. P.

N. rhynchocephala, Ktz.-E FG, Arran, W. A. ; Castle Semple Loch, S. E. ; Rutherglen, St. Germains Loch, J. P.

N. viridula, Ktz.-E FG, Arran, Kyles of Bute, W. A. ; Cumbrae, H. ; Castle Semple Loch, S. E. ; St. Germains Loch, J. P.

forma minor. G, Rutherglen, J.P.

var. slesvicensis, Grun.-E G, Arran, W. A. ; Rutherglen, Possil, J. P.

var. rostellata, $K t z$.-A F, Crinan, Cumbrae, W. A. ; Clyde, G.

N. hungarica, Grun. var. capitata, Grun.-B E, Gareloch, Arran, W. A. var. humilis, Donk.-G, St. Germains Loch, J.P.

N. cincta, Ktz.-FGH, Saltcoats, Barrhead Railway, Anniesland Toll, IV. A. ; Cambuslang, Corra Linn, J. P.

N. radiosa, Ktz.-A B D* E F GH, Glenshira Sand, G. ; Gareloch, Kyles of Bute, M. ; Cantyre Peat, Sm.; Largs, W. A.; St. Germains Loch, Corra Limn, J.P.

var. acuta, Sm.-A D*EGH, Glenshira Sand, G. ; Possil, W. A. \& H. ;

Kyles of Bute, M. ; St. Germains Loch, Corra Linn, J. P.

N. gracilis, Ehr.-A F G, Glenshira Sand, G. ; Perceton Well, Saltcoats, W. A. ; Cambuslang, H. ; Rutherglen, J. P.

var. schizonemoides, Cl.-A' B G, Glenshira Sand, G. ; Gareloch, M. ; Cambuslang, H. : Cathkin, J. P. 
N. peregrina, Ktz.-A FG, Glenshira Sand, G.; Upper Loch Fyne, M. ;

Millport, J. P. ; Paisley, T. \& W. W.

var. menisculus, Schum.-B, Gareloch, M.

var. upsaliensis, Grun.--E, Kyles of Bute, M.

N. maculosa, Donk:-A, Glenshira Sand, G.

N. tuscula, Ehr.-A D* F, Glenshira Sand, G. ; Cantyre Peat, Sm. ; Cumbrae, $\mathrm{H}$.

N. digito-radiata, Rlfs. var. cyprinus, $K t z$.-A BE, Glenshira Sand, G ; Loch Fyne, Arran, W. A. ; Loch Goil, Gareloch, M.

N. oblonga, Ktz.-A G, Glenshira Saud, G. ; St. Germains Loch, J. P.

N. capitata, Ehr.?-F, Cumbrae, W. A. \& H.

N. lanceolata, Ktz.-A E J F G, Glenshira Sand, G. ; Arran, W. A. ; Ailsa Craig, Millport, St. Germains Loch, J.P.

N. anglica, lilfs.-F, Gourock, W. A.

N. gastrum, $\dot{L} t z$.-A E, Glenshira Sand, G. ; Arran, W. A.

N. directa, Rlfs.-A BE F, Glenshira Sand, G.; Upper Loch Fyne, Gareloch, Loch Goil, M. ; Tarbert Bay, J. C. 'T. ; Millport, J. P.

var. remota, Cl.-A B E E, Glenshira Sand, Loch Fyne, Lamlash Bay, G. ; Gareloch, M.

var. subtilis, Cl.-A, Loch Fyne, W. A.

N. ramosissima, $C l$.-F, Millport, J.P.

N. jejuna, A. S.-B, Loch Goil, M.

N. cancellata, Donk.-A B F, Upper Loch Fyne, Loch Goil, Gareloch, M. ; Cumbrae, W. A.

var. Gregorii, Cl.-B F, Gareloch, M. ; Cumbrae, H.

var. retusa, Breb.-A B F, Glenshira Sand, G. ; Loch Goil, M. ; Saltcoats, W. A.

N. pectinalis, Breb.-E F, Arran, Saltcoats, W. A. ; Cumbrae, W. A. \& H.

N. inflexa, Rlfs.-A B E, Glenshira Sand, Loch Fyne, Lamlash Bay, G. ; Gareloch M.

N. Northumbrica, Donk.-A B E, Upper Loch Fyne, Gareloch, Kyles of Bute, M.

N. fortis, Rlfs.-A F, Glenshira Sand, Clyde, G.

var. (=Pinnularia curta, Sm.).-F, Cumbrae, W. A.

N. crucifera, Grun.-B F, Gareloch, M. ; Cumbrae, W. A.

N. solaris, Greg.-A, Glenshira Sand, G. ; Upper Loch Fyne, M.

N. distans, Rlfs.-A B F, Loch Fyne, W. A. ; Cumbrae, W. A. \& H. ; Gareloch, Loch Goil, M.

N. scutelloides, Sm.-D*, Cantyre Peat, Sm.

N. pusilla, Sm.-A F G, Glenshira Sand, G. ; Cumbrae, Maryhill, H.

N. humerosa, Breb.-A E F, Glenshira Sand, Loch Fyne, Lamlash Bay, G. ; Corrygill, Saltcoats, W. A. ; Cumbrae, H.

N. granulata, Breb.-A B E F, Glenshira Sand, Loch Fyne, Lamlash Bay, G. ; Gareloch, Loch Goil, M. ; Corrygill, Cumbrae, W. A.

latissima, Greg.-A E F, Glenshira Sand, Clyde, G. ; Lamlash, W. A. ; Arran, H.

N. lacustris, Greg.-A, Crinan, W.A.

N. marina, Rlfs.-F, Cumbrae, W. A.

var. Cluthensis, Greg.-E, Lamlash Bay, G.

N. Scandinavica, $C l .-E$, Tarbert Bay, J. C. T.

N. Baileyana, Grun.-? F, Cumbrae, W. A.

N. praetexta, Ehr.-A E F, Glenshira Sand, Lamlash Bay, G. \& W. A. ; Cumbrae, W. A. \& H.

N. Hennedyi, Sm.-A E F, Glenshira Sand, Lamlash Bay, G.; Upper Loch Fyne, M.; Holy Isle, W. A. ; Cumbrae, H. \& W.A.; Firth of clyde, H. var. nebulosa, Greg.-E, Lamlash Bay, G. \& W. A. ; Holy Isle, W. A.

N. spectabilis, G'reg.-EF, Lamlash Bay, G. \& W. A. : Cumbrae, W. A. \& H. 
N. abrupta, Donk.-A BE F, Loch Fyne, Lamlash Bay, G.; Gareloch, Loch Goil, M. ; Cumbrae, W. A.

N. clavata, Greg.-A E, Glenshira Sand, G. ; Lamlash, W. A.

N. lyra, Ehr.-A E F, Glenshira Sand, Losh Fyne, Lamlash Bay, G. ; Invercloy, W.A. ; Cumbrae, W.A. \& H.

N. pygmaea, Ktz.-A E G, Glenshira Sand, G. ; Corrygill, Anniesland Toll, W. A.

N. forcipata, Grev._E F, Lamlash Bay, Grev.; Cumbrae, W. A. \& H.

N. elegans, Sm.-A E K, Glenshira Sand, G. ; Corrygill, W. A. ; Ayr, H.

N. palpebralis, Breb.-F, Cumbrae, W. A. \& H.

var. angulosa, Greg.-A B F, Glenshira Sand, G. ; Loch Goil, M. ; Cumbrae, $\mathrm{H}$.

var. minor, Greg.-A, Loch Fyne, G.

var. Barclayana, Greq.-A BE, Loch Fyne, Lamlash Bay, G. ; Gareloch, M. var. semiplena, Donk.-B E, Loch Goil, M. ; Lamlash Bay, Grev.

N. exilis, Ktz-F, Cumbrae, H. W. \& G. S. W.

N. (Schizonema) Smithii, Sm.-E F, Arran, Cumbrae, Salteoats, W. A.

N. amphirhynchus, $K t z .-\mathrm{B}$, Ben Laoigh, W. W.

Scoliopleura latestriata, Grun.-F, Cumbrae, W. A.

S. Westii, Gmon.-A E E, Glenshira Sand, Clyde, G. ; Corrygill, W. A.

Stauroneis salina, Sm.-A, Glenshira Sand, G.

S. Gregorii, Rlfs.-A F, Glenshira Sand, G. ; Cumbrae, W. A.

S. Anceps, Ehr.-B F G K, Loch Goil, M.; Saltcoats, Clyrle Iron Works, Prestwick, W. A. ; Possil, H. ; St. Germains Loch, J. P.

S. phoenicenteron, Ehr.-A D* F G, Glenshira Sand, G.; Cantyre Peat, Sm. ; Lochwinnoch, S. E. \& W. W. ; St. Germains Loch, J. P.

var. gracilis, Ehr.-A D* F G, Crinan, Clyde Iron Works, W. A. ; Cantyre

Peat, Sn. ; Cumbrae, H. ; Possil, W. A. \& H. ; Gourock, Rutherglen, J. P.

S. Smithii, Grun.-G, Clyde Iron Works, W. A.

S. acuta, Sm.-D* G, Cantyre Peat, Sm.; St. Germains Loch, J. P.

Mastogloia splendida, Cl.-E, Lanlash Bay, G.

M. Smithii, Thu:-F H, Cumbrae, Castlecary, W. A. var. capitata, Grev.-F, Cumbrae, W. A.

M. Danseii, Thw.-A F, Glenshira Sand, G. : Cumbrae, W. A. \& H.

M. lanceolata, Sm.-E F, Arran, W. A. ; Cumbrae, W. A. \& H., \& J. P. forma elliptica, T. H.-A E, Glenshira Sand, G. ; Arran, W. A.

Gomphonema parvulum, $K$ ts.-A B F G, Glenshira Sand, G.; Gareloch, M. ;

Kilmalcolm, s. E. ; Cathkin, J. P.

var. micropus, $K t z .-\mathrm{G}$, Glasgow, V.H. var. tenella, Ltz.-B D*, Gareloch, M. ; Cantyre Peat, Sm.

G. angustatum, Ag.-B F G, Gareloch, M. ; Kilmalcolm, S. E. ; Rutherglen, J. P.

var. producta, Giun.-F G, Kilmalcolm, S. E. ; Cathkin, J.P. var. aequalis, Greg.-E G, Kyles of Bute, M. \& W. A. ; Lanarkshire, G. var. sarcophagus, Greg.-E G, Arran, W. A. ; Lanarkshire, G. var. angustissima, Grun.-F, Kilmalcolm, S. E.

G. intricatum, $K t z$ - A B E F G, Crinan, Tighnabruaich Glen, Moneymore,

W. A. ; Gareloch, M. ; Kilmalcolm, S. E.; St. Germains Loch, J. P. var. vibrio, Ehr.-E, Loch Ranza, W. A.

var. pumila, Grun.-G, Cathkin, J. P.

var. dichotoma, Ktz.-A B E, Glenshira Sand, G. ; Gareloch, M. ; Tighna-

bruaich Glen, W. A. \& H.

var. pulvinata, Br.-A, Upper Loch Fyne, M.

G. subtile, Ehr.-A, Glenshira Sand, G.

G. gracile, Ehr.-G, Glasgow Botanic Gardens, W. A. \& H.

var. aurita, Br.-H, Falls of Clyde, W. A.

var. hebridensis, Greg.-A. E, Crinan, W. A. ; Kyles of Bute, M. 
G. lanceolatum, Ehr.-A E, Glenshira Sand, G.; Kyles of Bute, W. A.

G. acuminatum, Ehr.-A C E F G, Glenshira Sand, G.; Gourock, St. Germains Loch, J. P.; Kyles of Bute, M. ; Carmyle, W. A. \& J. P.

var. coronata, Ehr.-A G, Glenshira Sand, G.; Robroyston, Rutherglen, J.P.

var. clavus, Breb.-G, St. Germains Loch, J. P.

G. mustela, Ehr.-H, Corra Limn, J.P.

G. subclavatum, Grun.-J G, Ailsa Craig, Cathkin, Cambuslang, J.P.

G. clavatum, Ehr.-G, Cathkin, J. P.

G. cristatum, Rlfs.-A, Glenshira Sand, G.

G. constrictum, Ehr.-A F G, Glenshira Sand, G.; Criuan, Cumbrae, Carmyle, W. A. ; Cumbrae, H., W. \& G. S. W.; Castle Semple Loch, S. E. ; Gourock, St. Germains Loch, J. P.

var. capitata, Ehr.-G, Glasgow Botanic Gardens, W.A.; St. Germains Loch, J.P.

G. geminatum, Ag.-A B E F G H, Glenshira Sand, G.; Gareloch, Kyles of Bute, M.; Falls of Clyde, W. A.; Bowling, H. ; Cambuslang, J. P.

G. olivaceum, Ehr.-E FG H, Kyles of Bute, M.; Cumbrae, Possil Marsh, H.; Robroyston, Corra Limn, J. P.

G. exiguum, Ktz. var. minutissima, $K t z .-\mathrm{B}$ E, Loch Goil, Kyles of Bute, $\mathrm{M}$.

Cymbella cesatii, Gmun.-A E, Crinan, Arran, W. A.; Kyles of Bute, M.

C. angustata, Cl.-B E G, Gareloch, Kyles of Bute, M. ; Cathkin, J. P.

C. delicatula, Ktz.-E G, Moneymore, W. A.; Cathkin, J. P.

C. laevis, Nag.--E, Arran, W. A.

C. rupicola, Grun.-A E, Crinan, Moneymore, W. A.

C. Ehrenbergii, Ktz.-A G, Glenshira Sand, G.; St. Germains Loch, J. P.

C. amphicephala, Nag.-EG, Arran, Clyde Iron Works, W. A. ; St. Germains Loch, J. P.

C. naviculaeformis, Auers.-A B D* E F, Glenshira Sand, G. ; Gareloch, M. ; Cantyre Peat, Sm.; Corrygill, W. A.; Castle Semple Loch, S. E.

C. prostrata, Cl.-AGH, Glenshira Sand, G.; Bowling, Falls of Clyde, W. A.; St. Germains Loch, S. E. \& J. P.; Carmyle, J. P.

C. turgida, Greg.--B E FG, Gareloch, M. ; Kyles of Bute, Cumbrae, W. A. ; Cathkin, J.P.

C. ventricosa, Ktz.-A BEFGH, Glenshira Sand, G.; Kyles of Bute, Loch Goil, M.; Gourock, Corra Limn, J. P.; A vou, G. \& W. A.

C. gracilis, $C l$. (=C. Scotica, Sm.)-A C E F, Glenshira Sand, G.; Unper Loch Fyne, M.; Crinan, Cumbrae, W.A. \& H.; Campsie Glen, Goat Fell, W. A.

C. lacustris, Cl.-H, Corra Lim, J. P.

C. aequalis, Greg.-A EG H, Crinan, Falls of Clyde, W. A.; Kyles of Bute, M. ; Lanarkshire, G. ; Cambuslang, J.P.

C. sinuata, Greg.-A, Glenshira Sand, G.

C. affinis, $K t z .-A . J$ G, Glenshira Sand, G.; Ailsa Craig, Cathkin, J. T'.

C. parva, Cl.-A E FGH, Crinan, W. A. ; Kyles of Bute, M. ; Castle Semple Loch, S. E. ; Cathkin, Corra Linn, J.P.

C. cymbiformis, V.H.-A B D* E.J F G H, Glenshira Sand, G. ; Hangingshaw, W. A. ; Cumbrae, W. A. \& H.; Gareloch, M. ; Ailsa Craig, Corra Linn, J.P.

C. cistula, V.H.-A J F G K, Glenshira Sand, G.; Ailsa Craig, St. Germains Loch, J. P. ; Cumbrae, W. A. ; Ayrheads, L.

var. maculata, V. H.-A D* E F G, Glenshira Sand, G. ; Cantyre Peat, Sm. ; Kyles of Bute, Saltcoats, Avon, W. A.; Gourock, St. Germaius Loch, J.P.

C. lanceolata, I. H.-A D*FG, Glenshira Sand, G.; Cantyre Peat, Sn.; Cumbrae, H., W. \& G. S. W. ; Ardrossan, W. A. ; St. Germains Loch, .J.P. 
C. helvetica, Ktz.-A, Glenshira Sand, G.

C. aspera, Cl.-A FGH, Glenshira Sand, G.; Largs, St. Germains Loch, Corra Limu, J. P.; Paisley, T. \& W. W.

C. arcus, Greg.--G, Hamilton, G. ; Cathkin, J.P.

Amphora dubia, Greg.-E, Lamlash Bay, G.

A. marina, Sm.-A B, Glenshira Sand, G.; Loch Goil, M.

var. pellucida, Greg.-A E, Loch Fyne, Lamlash Bay, G. var. nana, Greg.-A E, Loch Fyne, Lamlash Bay, G.

A. proteus, Greg.-A BE F, Loch Fyne, Lamlash Bay, G. ; Gareloch, M. ; Cumbrae, W. A.

var. contigua, $\mathrm{Cl}$.-A B, Loch Fyne, Glenshira Sand, G.; Gareloch, M.

A. robusta, Greg.-A B E F, Loch Fyne, Lamlash Bay, G.; Gareloch, M. ; Cumbrae, W. A. \& H.

A. ovalis, Ktz.-A B EG, Glenshira Sand, G. ; Gareloch, M. ; Corrygill, W. A. ; Cathkin, J. P.

var. pediculus, Ktz.-A G, Glenshira Sand, G. ; Cambuslang, H.

var. minutissima, Sm.-G H, Cambuslang Brig, H. ; Cathkin Corra Linn, J. P.

var. libyca, Ehr.-G, Rutherglen, J. P.

A. crassa, Greg.-A B E F, Loch Fyne, Lamlash Bay, G. ; Upper Loch Fyne, Gareloch, M. ; Cumbrae, W. A. \& H.

A. truncata, Greg.--Lamlash Bay, G.

A. sulcata, Greg.-A E, Loch Fyne, Lamlash Bay, G.

var. elongata, Greg.-A E, Loch Fyne, Lamlash Bay, G.

- A. proboscidea, Greg.-A, Loch Fyne, G.

A. milesiana, Greg.-A E, Loch Fyne, Lamlash Bay, G.

A. lyrata, Greg.-A E F, Loch Fyne, Lamlash Bay, G. ; Cumbrae, W. A.

A. Grevilleana, Greg.-A E F, Glenshira Sand, Lanılash Bay, G.; Upper Loch Fyne, M. ; Arran, W. A. ; Cumbrae, W. A. \& H.

var. quadrata, Greg.-A E F, Loch Fyne, Lamlash Bay, G. ; Cumbrae, W. A.

A. veneta, Ktz.-A G H, Glenshira Sand, G. ; Cathkin, Corra Linn, J. P.

A. Normanii, Rbh.-G, Cambuslang Brig, $\mathrm{H}$.

A. commutata, Grun.-A I, Glenshira Sand, G.; Dumfries House, W. A.

A. coffeaeformis, $K t z$. (incl. A. salina).-A B F, Glenshira Sand, Clyde, G. ; Loch Goil, M. ; Cumbrae, IV. A.

A. lineata, Greg.-A B E F, Loch Fyne, Lamlash Bay, G. ; Gareloch, Kyles of Bute, M. ; Cumbrae, W. A.

A. costata, $S m .-\mathrm{F}$, Cumbrae, H.

var.? monilifera, Greg.-E F, Lamlash Bay, G. ; Cumbrae, W. A.

A. macilenta, Greg. and var. Ergadensis, Greg.-A E, Loch Fyne, Lamlash Bay, G.

A. cymbifera, Greg.-A F, Loch Fyne, G. ; Cumbrae, W. A.

A. exigua, Greg.-A E, Loch Fyne, Lamlash Bay, G.

A. granulata, Greg.-A, Loch Fyne, G.

A. binodis, Greg.-A E, Loch Fyne, Lamlash Bay, G.

A. angularis, Greg.-Glenshira Sand, G.

A. turgida, Greg.- A E F, Loch Fyne, Lamlash Bay, G.; Cumbrae, W. A.

A. lineolata, Ehr.-A B E E, Glenshira Sand, G.; Loch Goil, M. ; Arran, Cumbrae, W. A.

var. plicata, Greg.-F, Cumbrae, W. A.\& H.

A. bacillaris, Greg.-A, Loch Fyne, G.

A. acuta, Greg.-A E F, Loch Fyne, Lamlash Bay, G.; Cumbrae, W. A.

A. nobilis, Greg.-A E, Loch Fyne, Lamlash Bay, G.

A. hyalina, Ktz.-A F, Glenshira Sand, G. ; Cumbrae, H.

A. arcus, Greg.-A E F G, Glenshira Sand, Lamlash Bay, G. ; Cumbrae, Maryhill, H. ; Avon, W. A. 
A. ostrearia, Breb.-A B F G, Glenshira Sand, Clyde, G. ; Loch Goil, M. ; Cumbrae, Avon, W. A.

A. laevis, Greg.-A B, Loch Fyne, G. ; Gareloch, M.

var. laevissima, Greg.-A E F, Loch Fyne, Lamlash Bay, G. ; Cumbrae, W. A.

A. excisa, Greg.-A E F, Loch Fyne, Lamlash Bay, G. ; Cumbrae, W. A.

A. obtusa, Greg.-A E F, Loch Fyne, Glenshira Sand, Lamlash Bay, G. ; Cumbrae, W. A.

A. spectabilis, Greg.-Loch Fyne, Lamlash Bay, G.

A. arenaria, Donk.-B, Loch Goil, M.

var. Donkinii, Rbh.-F, Cumbrae, W. A.

A. angusta, Greg.-A B E, Loch Fyne, Lamlash Bay, G. ; Loch Goil, M.

var. ventricosa, Greg.-A B E, Loch Fyne, Lamlash Bay, G. ; Gareloch M.

A. pusilla, Greg.-A E, Loch Fyne, Lamlash Bay, G.

A. rectangularis, Greg.-F, Cumbrae, W. A.

A. Scotica ?-E F, Corrygill, Cumbrae, $\mathrm{H}$.

Campyloneis Grevillei, Grun.-Glenshira Sand, G.

Cocconeis pediculus, Ehr.-A B F G H, Glenshira Sand, G. ; Gareloch, M. ; Gourock, Ardrossan, Falls of Clyde, W. A.; Cambuslang, Carmyle, J.P.

C. placentula, Ehr.-A D* E F G H, Glenshira Sand, G. ; Crinan, Cumbrae, Falls of Clyde, W. A. ; Cantyre Peat, Sm. ; Kyles of Bute, M. ; Carmyle, J.P.

C. scutellum, Ehr.-A B E J F, Glenshira Sand, G.; Upper Loch Fyne, Loch Goil, Gareloch, Kyles of Bute, M. ; Tarbert Bay, J. C. T. ; Ailsa Craig, J. P. ; Cumbrae, H. \& W. A.

var. ornata, Greg.-A E, Loch Fyne, Lamlash Bay, G.

var. stauroneiformis, Sm.-B E F, Loch Goil, Gareloch, M. ; Arran, W. A. ;

Millport, J.P.

var. parva, $C l$. - A, Glenshira Sand, G.

var. allmaniana, Greg.-A E, Loch Fyne, Lamlash Bay, G.

var. arraniensis, Grev.-B E, Gareloch, M. ; Lamlash Bay, G.

var. major, Greg.-E, Lamlash Bay, G. ; Kyles of Bute, M.

C. distans, Greg.-A E F, Glenshira Sand, Lamlash Bay, G. ; Holy Isle, W. A. ; Kyles of Bute, M. : Cumbrae, H.

Eucocconeis pseudomarginata, $C l$.-J, Ailsa Craig, J. P.

E. dirupta, Cl.-E F, Lamlash Bay, G.; Kyles of Bute, M. ; Saltcoats, W.A. ; Cumbrae, W. A. \& H.

E. flexella, $C l$.-A E G H, Crinan, W. A. ; Kyles of Bute, M. ; Cathkin, Cambuslang, J. P. ; Falls of Clyde, W. A. \& J.P.

Disconeis pinnata, Cl.-A E, Glenshira Sand, G. ; Lamlash Bay, G.

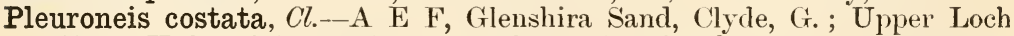
Fyne, Kyles of Bute, M. ; Lamlash, W. A. ; Cumbrae, H.

Heteroneis marginulata, $C l$.- E, Moneymore, W. A.

Actinoneis Lorenziana, $\mathrm{Cl}$.- $\mathrm{B}$, Gareloch, M.

Microneis minutissima, Cl.-E J G, Kyles of Bute, M. ; Ailsa Craig, Carmunnock, Cambuslang, J.P.

M. microcephala, $C l$.-A E G, Crinan, W. A. ; Kyles of Bute, M. ; Tighnabruaich Glen, Barrhead, W. A. \& H.

M. linearis, $C l$.-E G, Kyles of Bute, M. ; Rutherglen, J.P.

M. exilis, $C l$. - A E F G H, Glenshira Sand, G.; Crinan, Tighnabruaich, W. A. ; Saltcoats, Sm.; Hogganfield, H. ; Falls of Clyde, W. A. \& J. P.

M. trinodis, Cl.-E F, Moneymore, Cumbrae, W. A.

M. delicatula, $C l$.-Tighnabruaich, W. A.

M. hungarica, $\mathrm{Cl}$.-B, Gareloch, M.

Achnanthidium lanceolatum, Bréb.-A C F G, Glenshira Sand, G. ; Campsie, Gourock, Cathkin, J. P.; Cumbrae, W. A. ; Avon, H. ; Paisley, T. \& W. W. 
A. coarctatum, Bréb.-E G, Kyles of Bute, M. ; Aron, H. ; Cathkin, J. P.

A. brevipes, Grun.-A B E F, Glenshira Sand, G. ; Gareloch, Kyles of Bute, M. ; Cumbrae, W. A. var. intermedia, $\mathrm{Cl}$.-F, Gourock, $\mathrm{H}$.

var. parvula, $K t z$. - B E F, Loch Goil, M. ; Moneymore, W. A. ; Cumbrae, H. var. angustata, Grev.-A, Glenshira Sand, G.

A. Gregoriana, Grev.-E, Lamlash Bay. G.

Achnanthes longipes, Ag.-A B J F, Glenshira Sand, Ailsa Craig, G. ; Loch Goil, M. : Cumbrae, H.

Rhoicosphenia curvata, Grun.-A B E J F G, Glenshira Sand, G. ; Upper Loch Fyne, Kyles of Bute, M.; Ailsa Craig, Cumbrae, H. \& J. P. ; Bowling, W. A.

Epithemia Hyndmanni, Sm.-B G H, Gareloch, M. ; St. Germains Loch, J. P. ; Falls of Clyde, W. A.

E. turgida, $K t z$.-A B C D* J F G H L, Glenshira Sand, G. ; Gareloch, H. ; Ailsa Craig, J. P. ; Cantyre Peat, Sm. ; Dumfries House, W. A.; Falls of Clyde, W. A. \& J.P.

var. Westermanni, $K t z .-\mathrm{F}$ H, Largs, Corra Linu, J. P. var. granulata, Ktz.-G H, Cathkin, St. Germains Loch, Corra Linn, .J. P.

E. sorex, Ktz.-A D* E F G H L, Glenshira Sand, G. ; Cantyre Peat, sm. ; and Cumbrae, H. W. \& G.S. W.; Dumfries House, W. A. ; Falls of Clyde, W. A. \& .J. P. ; Gourock, J. P.

E. gibba, Ktz.-A E F G H L, Glenshira Sand, G.; C'rinan, C'umbrae, Dumfries House, W. A. ; Kyles of Bute, M. ; St. Germains Loch, J. P. ; Falls of Clyde, W. A. \& J. P.

var. ventricosa, $K t z .-\mathrm{F}$ G H L, Cumbrae, H. W. \& G.S. W. ; Hamilton, Dumfries House, W. A. ; Corra Linn, .J. P.

var. parallela, Grun.-G H, St. Germains Loch, Corra Linn, J.P.

E. zebra, $K t z$.-A G H J L, Glenshira Sand, G. ; Crinan, Dumfries House, W.A.; Falls of Clycle, W.A \& J.P.; Ailsa Craig, St. Germains Loch, .J. P.

var. proboscidea, $K t z_{\text {. }}$ - A G H, Glenshira Sand, G.; St. Germains Loch, Corra Linn, J. P.

E. argus, Ktz.-A B E E G H, Glenshira Sand, G. ; Arran, W. A. ; Gareloch, II.; Cumbrae, W. A. \& H. \& .J. P. : Cathkin, J. P.; Falls of Clyde, W. A. \& J.P.

var. amphicephala, Grun.-A F H, Glenshira Sand, G.; Cumbrae, H. ;

Corra Lim, J.P.

var. longicornis, Sm. (megafrustule)-E F H, Arran, Sm. \& W. A. ; Cumbrae, Castlecary, Falls of Clyde, W. A. var. ocellatà, Ktz.-D*, Cantyre Peat, Sm.

E. gibberula, Ktz.-A EFH, Glenshira Sand, G.; Upper Loch Fyne, Kyles of Bute, M.; Arran, W. A. ; Corra Linn, J. P. var. rupestris, $S m$.-E F H, Tighnabruaich, Cumbrae, Castlecary, W. A.

E. musculus, Ktz.-A E F, Glenshira Sand, G. ; Arran, Cumbrae, W. A. var. constricta, Sm.-A E, Glenshira Sand, G. ; Arran, W. A.

Eunotia exigua, Gmun.-CE.J GH, Fir Glen, Ailsa Craig, Cathkin, .J.P. ; Kyles of Bute, M.; Falls of Clyde, W. A. ; Castlecary, W. A. \& H.

E. monodon, Ehr.-A, Glenshira Sand, G.

E. diodon, Ehr.--A H, Glenshira Sand, G. ; Corra Linn, J. P.

E. triodon, Ehr.-A E, Glenshira Sand, G.; Goatfell, W. A.

E. robusta, Ralfs. var. tetraodon, Ehr.-A G, Glenshira Sand, G.; Upper Loch Fyne, M. ; St. Germains Loch, J.P. var. diadema, Ehr.-G, St. Germains Loch, J. P.

E. incisa, Greg.-A BCEG, Glenshira Sand, G.; Upper Loch Fyne, Gareloch, Kyles of Bute, M.; Campsie, Cathkin, J. P.: Arran, W. A.

E. bidentula, Sm.-BE, Loch Goil, M. ; Goatfell, W. A. 
E. arcus, Ehr.-A EFGH, Glenshira Sand, G.; Upper Loch Fyne, M. ; Crinan, Cumbrae, Corra Linn, IV. A. ; Arran, Tignabruaich, W. A. \& H.;

St. Germains Loch, J. P. var. diodon, Ehr.-E, Arran, W. A.

E. praerupta, Ehr.-E, Kyles of Bute, M. var. bidens, Ehr.-A, Glenshira Sand, G. var. bigibba, Ktz.-A, Glenshira Sand, G.

E. major, Rbh.-A E G, Glenshira Sand, G. ; Arran, W. A. ; Cathkin, J. P.

E. gracilis, Sm.-A B CJ FG, Glenshira Sand, G. ; Crinan, Gareloch, W. A. ; Fin Glen, Ailsa Craig, St. Germains Loch, J.P.; Castle Semple Loch, S. E. ; Carmyle, H.

E. pectinalis, Rbh.-A E FG, Glenshira Sand, G. ; Upper Loch Fyne, M. ; Arran, W. A. ; Castle Semple Loch, S. E. ; Cathkin, J. P.

Synedra hemicyclus, Ehr.-A, Glenshira Sand, G.

S. lunaris, Ehr.-A B E J FG, Glenshira Sand, G. ; Loch Goil, Gareloch, M. ; Fin Glen, Ailsa Craig, St. Germains Loch, J. P. ; Glen Sannox, Auld

Wives' Lift, H.; Kilmalcolm, S. E. ; Strathbungo, W. A. var. subarcuata. J, Ailsa Craig, J. P.

S. flexuosa, Breb. var. bicapitata. A, Glenshira Sand, G.

S. gibbosa, Ralfs.-A B EG, Upper Loch Fyne, Gareloch, Kyles of Bute, M. ; Arran, W. A. ; Carmyle, J. P.

S. pulchella, $K t z$.-A E FG, Glenshira Sand, G.; Arran, W. A. \& H. ; Bute, Bowling Canal, H. ; Dumbarton, T. \& W. W. ; Millport, Gourock, Carmvle, J.P.

var. Smithii, V.H.-A B E, Glenshira Sand, G.; Gareloch, Kyles of Bute, M.

var. lanceolata, V.H.-E F G, Kyles of Bute, Hunterston Point, Bowling

Canal, W. A. ; Possil Marsh, H.

var. minutissima, Sm.-BG, Gareloch, M. ; Possil Marsh, H.

var. vertebra, Greg.-A, Glenshira Sand, G.

S. Vaucheriae, $K t z$. var. truncata, I. $H .-\mathrm{B}$, Gareloch, M.

var. defornis, Sm.-B G, Gareloch, II. ; Bowling Canal, W. A.

S. capitata, Ehr.-G, St. Gerniains Loch, J. P.

S. splendens, $K t z$. A BCFGH, Upper Loch Fyne, Gareloch, M. ; Fin Glen, Gourock, Cathkin, Corra Limn, J. P, ; Cumbrae, Carmyle, H.

S. ulna, Ehr.-A CE FG, Glenshira Sand, G.; Campsie Glen, Largs, Clarkston, J. P.; Kyles of Bute, Cumbrae, W. A. \& H.; Monkland Canal, W. A. var. subaequalis. G, Rutherglen, Cambuslang, J.P.

var. lanceolata, $K t z$. A, Crinan, W. A.

var. danica, Kitz.-G, Cathkin, J.P.

var. obtusa, Sm.-A, Glenshira Sand, G.

S. amphicephala, $K t z$. - A, Upper Loch Fyne, M.

S. acus, Ktz.-B F G, Gareloch, M. ; Saltcoats, W. A. ; Cathkin, J. P. var. radians, Ktz.-A F G, Glenshira Sand, G. ; Saltcoats, Monkland, W.A. ;

Cumbrae, W. A. \& H. ; Carmyle, H. ; St. Germains Loch. J. P.

S. Gaillonii, Ehr.-B.J F, Loch Goil, M.; Ailsa Craig, J. P. ; Cumbrae, W. A. \& H. ; Saltcoats, W. A.

S. affinis, Ktz.-BE FG, Gareloch, Kyles of Bute, M. ; Cumbrae, H. \& J. P.; Saltcoats, Monkland Canal, W. A.

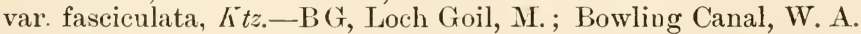

var. tabulata, Ktz.-F, Cumbrae, $\mathrm{H}$.

S. arcus, $K t z$.-F, Cumbrae, Saltcoats, H.

S. undulata, Greg.-E F, Lamlash Bay, G.; Cumbrae, W. A. \& H.

S. Hennedyana, Grea.-E E, Lamlash Bay, G. ; Cumbrae, IV. A. \& H.

S. superba, Ktz.-A E, Glenshira Sand, G.; Lamlash, W. A. var. robusta, Ralfs.-F, Cumbrae, W. A.

S. baculus, Greg.-A F, Glenshira Sand, G. ; Cumbrae, W. A. 
S. investiens, Sm.-F, Saltcoats, IV. A.

Asterionella formosa, Hass.-BG, Loch Goil, M. ; St. Germains Loch, Cathkin, J.P.

var. Bleakcleyi, Sm.-B, Loch Goil, M.

var. gracillima, Heib.-A, Upper Loch Fyne, M.

Thalassiothrix Frauenfeldii, Grun.-B, Loch Goil, M.

T. nitzschioides, Grun.-A B E, Upper Loch Fyne, Gareloch, Kyles of Bute, M.

Fragilaria virescens, Ralfs.-B.J FG, Ben Lomond, J. P. \& W. W.; Ailsa Craig, J.P. ; Kilnalcolm, ‥ E.

F. capucina, Desm.-FG, Kilmalcoln, S. E. ; St. Germains Loch, Carmumnock, J.P.

F. mutabilis, Grun.-A E FG, Glenshira Sand, G. ; Kyles of Bute, M. ; Arran, W. A. ; Cumbrae, W. A. \& J. P. ; Robroyston, J. P.

F. construens, Grun.-A, Crinan, W. A. \& H.

F. hyalina, Grun.-B E, Loch Goil, M. ; Tarbert Bay, J. C. T.

var. minima, Ralfs.-F, Cumbrae, $\mathrm{H}$.

var. (= Ralfsia tabellaria). B, Loch Goil, MI.

F. northumbrica, G'run.-F, Cumbrae, W. A.

F. pacifica, Grun. var. cuncata (= Meridion marinum, Gireg.).-Loch Fyne, Lamlash Bay, G. ; Loch Goil, M. ; Cumbrae, W. A.

Odontidium hiemale, $K t z-\mathrm{BCEJFG}$, Glen Fruin, s.E. ; Ailsa Craig, Inverkip, Cathkin, J.P. ; Arran, Sm.

var. mesodon, Ktz.-A CEFGH, Glenshira Sand, G. ; Campsie, Cathkin, Corra Linn, J.P. ; Arran, Sm.; Gourock, H.; Hunterston, W. A. ; Stevenston, L.

O. Harrisonii, Sm.-A E F, Glenshira Sand, G. ; Arran, W. A. ; Cumbrae, H.

Diatoma elongatum, Ag.-A FG, Glenshira Sand, G. ; Stevenston, L. ; Cumbrae, H. ; Galston, W. A. ; Cambuslang, J.P. ; St. Germains, s. E. \& W. A.

var. tenuis, Ag.-F, Gourock, H. ; Cumbrae, W. A. \& H.

D. vulgare, Bory.-A F G H, Glenshira Sand, G. ; Ardrossan, L. ; Cumbrae, W. A. \& H.; Monkland, W. A. ; Corra Linn, J. P.

D. pectinale, Ktz.-F, Gourock, J.P.

Denticula tenuis, Ktz.-A E FGH, Glenshira Sand, G. ; Loch Ranza, Cumbrae, Falls of Clyde, W. A.; Kelvindock, H. ; Cathkin, J. P.

var. inflata, Sm.-J, Ailsa Craig, J. P.

var. frigida, $K t z .-\mathrm{G}$, Cathkin, J.P.

D. crassula, Nïg.-A G, Upper Loch Fyne, M. ; Cathkin, J. P.

D. elegans, Ktz.-A H, Loch Fyne, W. A. ; Corra Linn, .J. P.

Meridion circulare, Ag.-A B E F G, Glenshira Sand, G. ; Crinan, Hunterston, Strathbungo, W. A. ; Glen Eruin, Castle Semple Loch, S. E. ; Kyles of Bute, Cumbrae, W. A. \& H. ; Cathkin, J. P.

var. constricta, Ralfs.-A G, Glenshira Sand, G. ; Hamilton, H.

Raphoneis nitida, Gmu._-A E, Loch Fyne, Lamlash Bay, G.

R. amphiceros, Ehr.-F, Cumbrae, H.

Sceptroneis caduceus, Ehr.-A, Loch Fyne, G.

Dimergramma marinum, Ralfs.-A BEF, Loch Fyne, Lamlash Bay, G. \& IV. A. ; Gareloch, M. ; Cumbrae, H.

D. fulvum, Ralfs.-A BE F, Loch Fyne, G. \& W. A. ; Gareloch, M. ; Lamlash Bay, G. ; Holy Isle, Cumbrae, W. A.

D. nanum, Ralfs.-A E F, Loch Fyne, Lamlash Bay, G.; Upper Loch Fyne, Gareloch, MI. ; Clyde, V.H. ; Cumbrae, W. A.

D. minus, Ralfs.-ABEF, Loch Fyne, Lamlash Bay, G.; Gareloch, II. ; Cumbrae, W. A.

D. distans, Palfs.-A E, Loch Fyne, Lamlash Bay, G.; Upper Loch Fyne, II. ; Arran, W. A. 
D. capitatum, Ralfs.-A, Loch Fyne, G.

Glyphodesmis Williamsonii, Grun.-A E F, Loch Fyne, G. \& W. A. ; Arran, Cumbrae, W. A. \& H.

Plagiogramma staurophorum, Herb.-A E F, Loch Fyne, Lamlash Bay, G. \& W. A.; Arran, H. ; Cumbrae, W. A. \& H.

P. laeve, Ralfs.-A E, Loch Fyne, Lamlash Bay, G.

P. ornatum, Ralfs.-A E, Loch Fyne, Lamlash Bay, (*.

P. interruptum, Ralfs.-E, Lamlash Bay, G. \& W. A.

Hantzschia amphioxys, Grun.-A B G, Glenshira Sand, G.; Loch Goil, M.; Hamilton, Partick, W. A. ; Cathkin, J. P.

var. vivax, Grun.-A, Glenshira Sand, G.

H. virgata, Grun.-F, Cumbrae, Saltcoats, W. A.

H. marina, Grun.-F, Cumbrae, W. A. \& H.

Nitzschia punctata, Grun.-A B, Glenshira Sand, G. ; Loch Fyne, W. A.; Gareloch, M.

N. debilis, Grun.-G, Maryhill Bridge, W. A.

N. tryblionella, Hantz-F, Cumbrae, W. A.

var. levidensis, Grun.-G, Hangingshaw, W. A.

N. angustata, Grun.-A E, Glenshira Sand, G. ; Arran, W. A.

N. delicatissima, $C l$.-B, Loch Goil, M.

N. panduriformis, Greg.-A, Loch Fyne, G. \& W. A.

N. contricta, Gvun.-A E, Glenshira Sand, G. ; Kyles of Bute, M.

N. marginulata, Gren. var. subconstricta, Grun.-B, Gareloch, M.

N. apiculata, Grun.-A E F G, Glenshira Sand, Loch Fyne, G. ; Cumbrae, H. ; Barrhead, W. A.

N. acuminata, Grun.-A F, Glenshira Sand, G.; Upper Loch Fyne, M.; Cumbrae, $\mathrm{H}$.

N. socialis, Greg.-F, Cumbrae, W. A. \& H.

N. paradoxa, Grun.-A B F, Glenshira Sand, G.; Upper Loch Fyne, Loch Goil, M. ; Stevenston, L. ; Cumbrae, H.

N. distans, Greg.-A BE, Glenshira Sand, Loch Fyne, Lamlash Bay, G.; Loch Goil, M.

N. angularis, Sm.-A B F, Glenshira Sand, G.; Upper Loch Fyne, Loch Goil, M. ; Cumbrae, W. A. \& H.

N. spathulata, Bréb.-F, Cumbrae, W. A.

var. hyalina, Greg.-A, Loch Fyne, (*.

N. dissipata, Grun.-A G, Glenshira Sand, G. ; Glasgow, Barrhead, W. A.

N. filiformis, I. H.-F G, Ardrossan, W. A.; Monkland Canal, H.

N. macilenta, Greg.-A E, Loch Fyne, W. A.; Lamlash Bay, Grev.

N. Clausii, Hantz.-G, Glasgow, W. A.

N. linearis, Sm.-G H, Carmyle, Cathkin, J. P. ; Falls of Clyde, W. A.\& J. P.

N. sigmoidea, Sm.-FG, Saltcoats, H. ; St. Germains Loch, Cambuslang, J. P.

var. armoricans, Grun. (=N. Brebissonii).-F, Saltcoats, H.

N. sigma, Sm._-A B F, Upper Loch Fyne, Gareloch, M. ; Cumbrae, H. var. sigmatella, Greg.-B, Gareloch, M.

N. obtusa, Sm.-A, Upper Loch Fyne, M.

N. dubia, Sm.-G, Barrhead, Hangingshaw, Glasgow Botanic Gardens, W. A. var. B., Sm.-G, Barrhead, H.

N. thermalis, Aners.-G, Glasgow Botanic Gardens, W. A.

var. litorea, Grun.-B, Loch Goil, M.

N. hybrida, Givn.-A F, Upper Loch Fyne, M. ; Cumbrae, W. A.

N. parvula, Sm.-B G, Loch Goil, M. ; Paisley, T. \& W. W.

N. latestriata, Grun.-A F, Glenshira Sand, G.; Upper Loch Fyne, M. ; Cumbrae, H.

N. sinuata, Gren.-A J F G H, Glenshira Sand, G. ; Maryhill, W. A. \& H. ; Falls of Clyde, W. A.\&J. P. ; Ailsa Craig, J. P.; Cumbrae, Sm. 
N. denticula, Grun.-J, Ailsa Craig, J.P.

N. insignis, Greg.-A G, Glenshira Sand, G. ; Loch Fyne, W. A. ; Crinan, Kelvindock, $\mathrm{H}$.

var. apiculata, Sm.-F G, Gourock, Rutherglen, J.P.

N. tenuis, Sm.-FG, Lochwinnoch, S. E. \& W. W. ; Inverkip, Cathkin, Carmyle, J.P.

N. lanceolata, Sm.-B, Gareloch, II.

N. arcuata, Grev.-A E, Loch Fyne, Lamlash Bay, Brodick Bay, Grev.

N. frustulum, Grun.-G, Cathkin, J. P. ;

var. Hantzschiana, Grun.-G, Cathkin, J.P.

N. Heufleriana, Grun.-G, Cathkin, J.P.

N. closterium, Sm.-B, Loch Goil, M.

var. acicularis, Sm.-EG, Arran, W. A. ; Carmyle, H.

N. longissima, Grun.-A B E, Upper Loch Fyne, Loch Goil, M. ; Tarbert Bay, J.C.T.

N. palea, Ktz.-G, Paisley, T. \& W. W.

Cylindrotheca gracilis, Grun.-G, Glasgow Botanic Gardens, W. A.

Streptotheca Thamesis.-E, Tarbert Bay, J. C. T.

Surirella Smithii, Ralfs._A B E, Glenshira Sand, G. ; Gareloch, M. ; Arran, W. A.

S. linearis, Sm.-BD*EJG, Gareloch, M. ; Ailsa Craig, Clarkston, J.P. ; Kyles of Bute, W. A. ; Clyde Iron Works, H.

S. tenera, Greg.-F K, Saltcoats, Prestwick, W. A.

S. splendida, Ehr.-BD*G, Gareloch, M.; Cantyre Peat, Sm.; St. Germains Loch, J.P.

S. bifrons, Ehr.-BEG, Gareloch, Kyles of Bute, M. ; Clyde Iron Works, H. ; St Germains Loch, J.P.

S. elegans, Ehr.-F, Cumbrae, H.

S. angusta, Ktz.-G, St. Germains Loch, J. P.

S. fastuosa, Ehr.-A BE F, Glenshira Sand, G. ; Upper Loch Fyne, Gareloch, M. ; Arran, G. \& W. A. \& H. ; Cumbrae, W. A. \& H.

S. lata, Sm.-A E F, Loch Fyne, Lamlash Bay, G. ; Cumbrae, W. A.

S. gemma, Ehr.-B, Gareloch, M.

S. striatula, Turp.-F, Cumbrae, H.

S. spiralis, Ktz.-F G, Cumbrae, W. A. ; Cathkin, J. P.

S. limosa, Bail.-B, Gareloch, M.

S. pinnata, Sm.-A G, Glenshira Sand, G. ; Glasgow Botanic Gardens, Clyde Iron Works, W. A.

var. panduriformis, Sm.-G, Glasgow Botanic Gardens, W. A.

S. ovalis, Bréb.-G, Barrhead, IV. A.\&H.

var. ovata, Ktz.-A E F GH, Glenshira Sand, G.; Kyles of Bute, Hunterston, Falls of Clyde, W. A. ; Cathkin, J. P.

val. crumena, Bréb.-A G K, Glenshira Sand, G. ; River Avon, W. A. ; Ayr, H.

var. minuta, Bréb.-A GH, Glenshira Sand, G. ; Barrhead, W. A. ; Clyde Iron Works, H. ; Tillietudlem, J.P.

var. angusta, Ktz.-G, Glasgow Botanic Gardens, W. A.

Cymatopleura solea, Sm.-A B G, Glenshira Sand, G. ; Gareloch, M. ; St. Germains, Robroyston, J. P.

C. elliptica, Sm.-B E F G, Gareloch, M. ; Arran, W. A. ; Cumbrae, H. ; Cambsulang, J.P.

Campylodiscus Hodgsonii, Sm. var. marginata, Johns.-A, Loch Fyne, W. A. var. eximia, Greg.-Loch Fyne, G.\& W. A.

C. Ralfsii, Sm.-A E F, Glenshira Sand, Loch Fyne, Lamlash Bay, G.; Cumbrae, H.

var. decora, Breb.-A F, Loch Fyne, Cumbrae, W. A. 
C. Echeneis, Ehr.-F, Cumbrae, W. A.

C. angularis, Greg.-A, Loch Fyne, G. \& W. A.

C. Horologium, Will.-A E, Loch Fyne, G.\& W. A. ; Lamlash Bay, G.

C. bicostatus, Sm.-A, Glenshira Sand, G.

C. Thuretii, Bréb.-A E F, Loch Fyne, Arran, W. A. ; Cumbrae, H. var. parvula, Sm.-A E, Loch Fyne, Arran, W. A.

C. latus, Shadb.-A B, Loch Fyne, G. ; Gareloch, M.

C. noricus, Ehr. var. hibernica, Ehr.-G, Cathkin, J. P. var. costata, Sm.-A D* E F G H, Glenshira Sand, G. ; Arran, Cumbrae,

W. A. ; St. Germains Loch, Corra Linı, J. P.

C. limbatus, Greg.-A, Glenshira Sand, G. ; Loch Fyne, G. \& W. A.

Rhabdonema arcuatum, $K t z$.-A B J F, Glenshira Sand, G. ; Upper Loch Fyne, Loch Goil, M. ; Ailsa Craig, Gourock, J. P. ; Cumbrae, W. A.\& H.

R. minutum, $K t z .-\mathrm{A}$ B E F, Glenshira Sand, G. ; Loch Goil, Kyles of Bute, M. ; Tarbert Bay, J. C. T. ; Hunterston, Cumbrae, W. A. \& H.

R. adriaticum, Ktz.-A J F, Upper Loch Fyne, M. ; Ailsa Craig, J. P. ; Cumbrae, W. A. \& H.

Striatella unipunctata, Ag.-A E F, Upper Loch Fyne, M. ; Tarbert Bay, J. C.T.; Cumbrae W. A.

Tabellaria fenestrata $K t z$.-A E F G, Glenshira Sand, G. ; Arran, W. A. \& H. ; Stevenston, L. ; St. Germains Loch, Robroyston, J. P.

T. flocculosa, Ktz.-A B E F G, Glenshira Sand, G.; Gareloch, Kyles of Bute, M. ; Ben Lomond, Carmyle, J. P. ; Cumbrae, H. W. \& G. S. W.

Diatomella Balfouriana, Grev.-A F, Glenshira Sand, Clyde, G.; Crinan, W.A.

Tetracyclus lacustris, Ralfr.-G, St. Germains Loch, J.P. var. emarginata, Sm.-G, St. Germains Loch, J.P.

Grammatophora stricta, Ehr.-A, Loch Fyne, W. A. \& M.

G. macilenta, Sm.-A E F, Loch Fyne, Lamlash Bay, G. ; Tarbert, J.C. T. ; Cumbrae, W. A.

G. minima.-E, Tarbert Bay, J.C.T.

G. marina, Ktz.-A B E J F, Glenshira Sand, G. ; Gareloch, Kyles of Bute, M. ; Tarbert Bay, J. C.T. ; Ailsa Craig, J.P.; Cumbrae, W. A. \& H.

G. islandica, Ehr.-A, Upper Loch Fyne, M.

G. serpentina, thr.-A J F, Glenshira Sand, G.; Upper Loch Fyne, M.; Ailsa Craig, J. P. ; Cumbrae, Saltcoats, W. A.

Licmophora flabellata, Ag.-F, Portincross, L. ; Cumbrae, W. A.

L. splendida, Grev.-F, Saltcoats, L.

L. paradoxa, Grun.--F, Cumbrae, Toward, W. A. \& H.

L. Lyngbyei, Grun.- B E F, Loch Goil, M. ; Tarbert Bay, J.C.T. ; Toward Point, W. A.

L. tenuis, Grun.-F, Toward, W. A. \& H.

Cyclotella antiqua, Sm.-D*, Cantyre Peat, Sm.

C. comta, $K t z$. var. radissa, Grun.-G, St. Germains Loch, J. P.

C. operculata, $K t z$.-A D*G, Glenshira Sand, Glasgow Botanic Gardens, W. A. ; Clyde Canal, H. ; Cathkin, J.P.

C. Kutzingiana, Thw.-E.J F G, Arran, Wemyss Bay, W. A. ; Largs, H. W. \& G.S. W. ; Ailsa Craig, Cambuslang, .J. P.

C. Meneghiniana, Ktz.-G, Glasgow Botanic Gardens, W. A. ; St. Germains Loch, J.P.

C. striata, Grun.-B J, Loch Goil, M. ; Ailsa Craig, J.P.

Hyalodiscus scoticus, Grun.-A F, Upper Loch Fyne, M. ; Cumbrae, W.A.

H. stelliger, Bail.-A BEF, Glenshira Sand, G.; Upper Loch Fyne, Loch Goil, Kyles of Bute, M. ; Cumbrae, W. A.

H. radiatus. B, Loch Goil, $M$.

Podosira Montagnei, $K t z$.-A E F, Loch Fyne, Lamlash Bay, G.; Cumbrae, H. \& W. A. 
P. hormoides, Ktz.-A F, Upper Loch Fyne, M. ; Cumbrae, H.

P. maxima, Grun.-A E, Upper Loch Fyne, M. ; Arran.

P. laevis, Greg.-E, Lamlash Bay, Grev.

Thalassiosira Nordenskioldii, $C l$.-BE, Loch Goil, Gareloch, Kyles of Bute, M. ; Tarbert Bay, J. C. T.

T. gravida, $C l$.-B, Loch Goil, Gareloch, M.

Skeletonema costatum, Cl.-B, Loch Goil, Gareloch, M.

Melosira. Westii, Sm.-A, Loch Fyne, W. A.

M. nummuloides, Ag.-A, Glenshira Sand, G.

M. Borreri, Gmun.-A B F, Glenshira Sand, G. ; Gareloch, M. ; Firth of Clyde, Cumbrae, W. A.

M. varians, Ag.-A F G H, Glenshira Sand, G. ; Hunterston, Bowling, W. A. ; St. Germains Loch, Corra Linn, J.P. ; Paisley, T. \& W. W.

M. subflexilis, $K t z$.-F, Largs, W. A.

M. Dickiei, $k t z$.-B E, Glen Fruin, S. E. ; Tighnabruaich Glen, W. A. \& H. forma mirabilis. J G, Ailsa Craig, J.P. ; Partick, H.

M. Roeseana, Rbh.-AGH, Glenshira Sand, Cr.; Loch Fyne, Falls of Clyde, W. A. ; Partick, H. ; Paisley, T. \& W. W. !

IM. distans, $K t z .-\mathrm{G}$, St. Germains Loch, J.P.; Paisley, T. \& W.

M. crenulata, $K t z$.-B D* E F G, Loch Goil, M. ; Lamlash, Saltcoats, W. A. ; Stevenston, L. ; St. Germains Loch, J. P.

M. nivalis, Sm.-A E, Glenshira Sand, G. ; Arran, H.

M. arenaria, Moore.-A FG H, Glenshira Sand, G. ; Cumbrae, W. A. \& H. ; Cathkin, J.P.; Falls of Clyde, W. A. \& J.P.

Paralia sulcata, $C l$.-General in Marine Gatherings.

Stephanopyxis Turris, Ralfs.-F, Cumbrae, Grev. \& H. ; Clyde, G.

S. cruciata. E, Lamlash Bay, G.

Actinocyclus Ralfsii, Pritch.-A B E F, Glenshira Sand, Lamlash Bay, G. ; Loch Goil, Kyles of Bute, M. ; Cumbrae, H.

A. sparsus, Rtr.-A B F, Glenshira Sand, G.; Gareloch, Loch Goil, M. ; Cumbrae, W. A.

A. moniliformis, Ralfs.-A E, Upper Loch Fyne, Kyles of Bute, M.

A. subcrassus, Rtr.-A BEF, Upper Loch Fyne, Gareloch, Kyles of Bute, M. ; Cumbrae, H.

A. crassus, Ralfs.-A E F, Glenshira Sand, Loch Fyne, Lamlash Bay, G. ; Cumbrae, Saltcoats, W. A.

A. subtilis, Ralfs.-A E F, Loch Fyne, Lamlash Bay, G. ; Arran, Cumbrae, W. A. \& H.

Coscinodiscus excentricus, Ehr.-A BEF, Glenshira Sand, G.; Loch Fyne, W. A. \& M. ; Gareloch, Kyles of Bute, M. ; Cumbrae, H.

C. decipiens, Grun.-A B EJ,Glenshira Sand, G.; Loch Goil, Kyles of Bute, M. ; Ailsa Craig, J.P. ; Tarbert Bay, J. C. T. ; Cumbrae, W. A. \& H.

C. concavus, Greg.-A E, Loch Fyne, Lamlash Bay, G.

C. lineatus, Ehr.-B, Gareloch, M.

C. nitidus, Greg.-E F, Lamlash Bay, G. ; Cumbrae, W. A. \& H.

C. curvatulus, Grun.-A B E, Upper Loch Fyne, Gareloch, Kyles of Bute, M.

C. stellaris, Roper.-A B E, Upper Loch Fyne, Gareloch, Kyles of Bute, M.

C. subtilis, Ehr.-B, Loch Goil, M.

C. Normanni, Greg.-B, Loch Goil, Gareloch, M.

C. Rothii, Grun.-B F, Loch Goil, M. ; Cumbrae, H.

C. umbonatus, Greg.-E, Lamlash Bay, G.

C. radiatus, Ehr.-A B E F, Glenshira, G. ; Upper Loch Fyne, Loch Goil, Kyles of Bute, M. ; Cumbrae, W. A.

C. argus, Ehr.-E, Kyles of Bute, M.

C. concinnus, Sm.-A BEF, Upper Loch Fyne, Gareloch, M. ; Lamlash Bay, G. ; Cumbrae, W. A. \& H. 
C. centralis, Ehr.-A B E, Upper Loch Fyne, Gareloch, Kyles of Bute, M. ; Lamlash Bay, G.

C. oculus Iridis, Ehr.-A, Upper Loch Fyne, M.

C. apiculatus, Ehr.-E F', Kyles of Bute, M. ; Cumbrae, H.

C. punctulatus, Greg.-A E, Loch Fyne, Lamlash Bay, G.

Auliscus sculptus, Ralfs.-A E F, Loch Fyne, Lamlash Bay, G. ; Kyles of Bute, M. ; Cumbrae, W. A.

A. coelatus, Bail. var. strigillata, Schmidt.-E, Arran, R.

Roperia tesselata, V. H.-B E, Gareloch, M. ; Arran, H.

Actinoptychus undulatus, Ehr.-A B F, Glenshira Sand, G. ; Gareloch, M. ; Cumbrae, $\mathrm{H}$.

forma triradiata, Roper.-A B, Upper Loch Fyne, Gareloch, M.

A. splendens, Ralfs-A, Glenshira Sand, G.

Triceratium antediluvianum, V. H.-A E F, Glenshira Sand, G.; Arran, Saltcoats, W. A.

Biddulphia aurita, Bréb.-A B F, Glenshira Sand, G. ; Gareloch, M. ; Saltcoats, W. A.

B. mobiliensis, Grun.-A BE, Loch Fyne, Lamlash Bay, G.; Gareloch, Kyles of Bute, M.

Cerataulus Smithii, Ralfs.-A, Glenshira Sand, G.

C. turgidus, Ehr:-A B E, Loch Fyne, Lamlash Bay, G.; Gareloch, M.

Isthmia nervosa, $K t z$.- E, Arran, W. A.

I. enervis, Ehr.-F, Cumbrae, W.A.

Ditylum Brightwellii, Grun.-A B E, Upper Loch Fyne, Gareloch, Kyles of Bute, M.

Chaetoceros boreale, Bail.-A B E, Upper Loch Fyne, Gareloch, Kyles of Bute, M.; 'Tarbert Bay, J. C. T.

C. laciniosum. E, Tarbert Bay, J. C. T.

C. protuberans, Laud.-A E, Upper Loch Fyne, Gareloch, M.

C. mamillanum. E, Tarbert Bay, J. C.T.

C. scolopendria, Cl.-B E, Gareloch, M.; Tarbert Bay, J. C. T.

C. sociale, Laud.-B E, Gareloch, M.; Tarbert Bay, J. C. T.

C. pelagicum. E, Tarbert Bay, J.C.T.

C. Greenlandicum, $C l$. - A B, Upper Loch Fyne, Loch Goil, M.

C. curvisetum, Cl.-B E, Gareloch, M. ; 'Tarbert Bay, J. C. T.

C. decipiens, Cl.-A B E, Upper Loch Fyne, Gareloch, Kyles of Bute, M. ;

Tarbert Bay, J. C. 'T.

C. Wighamii, Bitw.-E, Tarbert Bay, J. C. T.

C. didyma, Ehr.-A B, Upper Loch Fyne, Loch Goil, M.

C. danicum, $C l$.-A, Upper Loch Fyne, M.

C. (Syndendrium) diadema, Ehr.-E F, Tarbert Bay, J. C. T. ; Clyde, G.

Rhizosolenia imbricata, Brtw.-F, Cumbrae, H.

R. alata. E, Tarbert Bay, J. C. T.

var. gracillima. E, Tarbert Bay, J. C. T.

R. styliformis, Brtw.-B E F, Gareloch, M. ; Tarbert Bay, J. C. T. ; Arran, Cumbrae, $H$.

R. setigera, Brtw.-A B E, Upper Loch Fyne, Gareloch, M.; Tarbert Bay, J. C.T.

R. pusilla? F, Cumbrae, H. 


\section{CHARACEAE.}

Тнат this order of plants is very abundant in the West of Scotland is a well-known fact to all who have taken any interest in aquatic plants. Yet although there are 27 species and 23 varieties given in the ninth edition of the Lond. Cat. of British Plants, the following are all that are recorded in the Clyde area. The Messrs. H. \& J. Groves have always proved willing and ready to help in the identification of either fresh or dried specimens :

Chara fragilis, Desv.

var. barbata, Gant.-F G, Milngavie ; Millport.

var. capillacea, Coss. and G.-C, Drymen.

var. delicatula, Braun.-E, Tarbert.

C. contraria, Keutz.-F, Millport.

C. hispida, L.-E, Tarbert.

C. vulgaris, L.-F, Millport.

var. longibracteata, Kutz.-A, Lochgilphead.

var. papillata, Wallr.-E F, Innellan; Arran.

var. melanopyrena, $H$. and $J$. G.-F, Millport.

Nitella flexilis, Agardh.-Dumbarton.

N. opaca, Agardh.-F, Stevenston, Renfrew, Lanark.

P. Ewing. 


\section{LICHENS.}

The classification, which has been adopted in the following list, was suggested by Dr. O. V. Darbishire, and is based upon that proposed by Dr. Reinke (Pringsheim's Jahrbuch. 1894-1896). It has not, however, been thought advisable to subdivide the genera Lecanora and Lecidea. A thorough and critical revision of all the species described in Crombie's and Leighton's works would be certainly necessary if they are to be included in such a system, and of course any such revision was quite impossible in the time at our disposal. Dr. O. V. Darbishire has with the greatest kindness examined a very great number of specimens, and his help has been invaluable in the preparation of the list. Many others, especially Lecideas and Graphideae, have been critically examined by the Rev. W. Johnson, whose assistance has also been of the greatest value. 'The compiler must also express his gratitude to the authorities of the British Museum, and to Professor Bayley Balfour, for permission to consult the herbaria in London and Edinburgh respectively, and to Messrs. L. Watt, J. Murray, D. A. Boyd, and J. Paterson for many interesting specimens and notes.

It is unfortunately only too evident that the district has been insufficiently explored, yet every attempt has been made to include all trustworthy records. Many species, which occur in the list submitted to the British Association in 1876, are not mentioned in the following one ; these consist of forms found on Ben Lawers, or in other places beyond our boundaries.

The committee hoped to obtain the valuable assistance of Dr. Stirton, the compiler of the previous list, but to their great regret we found that he was unable to undertake the work. The very short time available has been a great obstacle, and a great many species collected by myself are not mentioned at all, in default of proper verification by the referees. The authority of Leighton, Crombie, or Dr. Stirton, and the opinion of Dr. Darbishire, or the Rev. W. Johnson has been considered as decisive. Very few records have been permitted to appear if not confirmed by one or other of these lichenologists.

There is a distinct similarity in the distribution of the lichens as compared with that of the flowering plants. Certain species are found on mountain summits, and again on rocks by the seashore, though they are apparently absent from the cultivated ground, low hills, and other less exposed places. A large number are almost contined to the Inveraray and Loch Lomond districts (A and B), though some reappear about Loch Doon (L), where there is probably another sub-alpine region. But whilst Glen Falloch, for instance, has been explored by almost every British lichenologist of note, very few seem to have visited any part of the Lowlands except the Falls of Clyde. It is probable that a large number may have escaped notice, especially in such places as Ballantrae, which have been but rarely visited by botanists.

G. F. Scott Elliot. 


\section{KEY TO ABBREVIATIONS.}

Cr.=Crombie, British Lichens, Part I. ; British Museum Nat. Hist., 1894; Ann. Scot. Nat. Hist., 1899 ; Grevillea, Vols. $2,3$.

St. =Dr. Stirton, F.L.S., British Association List, 1876.

Lg. = Leighton, Lichen Flora of Great Britain, 1876.

O V. D. =Dr. O. V. Darbishire, Ph.D., etc., Owen's College, Manchester.

W. J.=Rev. W. Johnson, M.A., Hornsea House, Hartlepool.

S. E. = G. F. Scott Elliot, M.A., B.Sc., F.L.S.

M'M = Rev. J. H. MacMillan, D.D. (Trans. Bot. Soc. Edin., various papers, and Edinburgh Herbarium).

L. W. = L. Watt, Esq., Clydebank.

J.M. = J. Murray, Esq., East Kilbride.

Cr. Ms. = Rev. J. Crombie, M.A., F.L.S., specimens in Herb. Brit. Mus.

H. Herb. = The late Professor Hennedy's Herbarium, Teclınical College.

H. Fl. Sc. = Hooker, Flora Scotica, 1821.

Green. Herb. = Greenock Herbarium, collected by Dr. Calder, communicated by Mr. W. Niven.

Lind.= Lindsay, Popular History of British Lichens, 1856.

J. P. =.J. Paterson, Esq., Rutherglen.

Lightf. = Lightfoot, Flora Scotica, 1777.

J. A. = Miss J. Auld, Queen Margaret College, Glasgow.

Sm. = Smith, see Sowerby, Engl. Bot., Vols. 5, 13, etc., etc.

Borrer. See Notes in Crombie and Leighton's Floras.

Grev. =Dr. Greville, Scottish Cryptogamic Flora.

Mass.=Dr. G. Massee, Kew, Grevillea, Vol. 21, p. 28.

Calicium trichiale, Ach.-G, Hamilton, St.

C. chrysocephalum, Ach.-H, Falls of Clyde, Cr.

C. hyperellum, Ach. - G H, Hamilton, St.; Falls of Clyde, Cr., J. M. \&

C. quercinum, Pers.-H, Falls of Clyde, Cr.

C. curtum, Turn. et Borr.--B, Glen Falloch, Cr.

Coniocybe furfuracea, Ach.-G, Calderbank, St.

Sphaerophorus coralloides, Pers.-A B E E, Inveraray, Cr. ; Loch Lomond, Ben Oss, Ben Chroinn, Kilmalcolm, S. E., O. V. D. ; Arran, Lg. \& M'M.

S. fragilis, Ach.-B G K, $1000-3000 \mathrm{ft}$. Ben Lomond, L. W., O. V. D. ; Cobbler, J. M. ; Old Kilpatrick, L. W., O.V.D. ; Girvan, S. E. \& O.V. D.

? (Melaspilea Patersoni, Stirt.--B, Ben Brecht (Beinn Bhreac ?) St., Lg.)

Arthnnia astroidea, Ach.- "Common," St.

A. epipasta, $-A c h .-B$, Loch Lomond, St.

A. cinnabarina, Wall $:-\mathrm{H}$, Falls of Clyde, Cr. Ms.

A. Swartziana, Ach.-G, Campsie, St. ; Old Cumnock, S. E. \& W. J.

Lecanactis (Lecidea Oederi, Web.) Oederi, Darb.-B, Ben Voirlich, St.

L. melaena ( $\left.V_{y} l.\right)$ Darb.-E, Ormidale, St.:

L. sphaeroides (Dick.) Darb.-G, Milngavie, St.

L. milliaria ( $F r$.) Darb.-G, Milngavie, St. (Ayrshire, Lg.).

Opegrapha lentiginosula, $N y l$.-B, Glen Falloch, Lg., Cr. Ms.

O. constrictella, Stivt._- "Ben Brecht" (Beimn Bhreac?), St., Lg.

O. herpetica, Ach. var. rubella. B, Cobbler, St.

O. atra, Pers.-L, Dalmellington, S. E.

var. parallela. G, Campsie, $\mathrm{St}$.

var. denigrata. B, Loch Lomond, St.

O. atricolor, Stirt.-F, Dunoon, St.

? O. vulgata, Ach.-F, Inverkip, H. Herb. \& S. E.

O. saxicola, Ach.-B, Tarbert, St.

var. Chevallieri, Leight.--G, Bothwell Castle, St.

? O. Turneri, Leight.-J L, Ballantrae, Dalmellington, S. E. 
O. varia, Pers. var. tigrina. F, Dunoon, St.

O. rufescens, Pers.-F, Dunoon, St.

O. amphotera, $N y l$.-K L, Ayr River, S. E. ; Old Cumnock, S. E., W.J.

O. mirifica, Stirt.-F, Cumbrae, Lg.

Graphis elegans, Sm.-A BGK, Inveraray, Lg.; Ben Lomond, Cr.; Glasgow, Cr. ; Auchincruive, S. E.

Graphis scripta, Ach.-B E F H K L, Ardlui, Gourock, H. Herb., S. E.

var. divaricata. $\mathrm{K}$, Knockdolyan, $\mathrm{Lg}$.

var. recta. F, Dunoon, St.

var. varia. F, Kilmalcolm, S. E. \& W. J.

var. serpentina. B H, Tarbet, S. E. ; Falls Clyde, Lg.

var. eutypa. "Common," Lg.

var. pulverulenta. H, Falls Clyde, Lg.

var. stellulata. L, Auchinleck, S. E. \& W.J.

G. dendritica, Ach.--E, Rothesay, St.

Roccella phycopsis, Ach.-F, Millport, Cumbrae, Cr.

Xylographa parallela, Ach.-B, Cobbler, St. ; Glen Falloch, Lg. var. pallens. F, Dunoon, St.

Gyalecta (Lecidea cupularis, Ehr.) cupularis, Ach.-G, Campsie Glen, St.

Lecidea decipiens, Ehr._- "Common," Lg.

L. lugubris, Sommrf.-B, Cobbler, St.

L. botryiza, $N y l$ - - B, Ben Voirlich, Loch Lomond, St.

L. lucida, Ach.-B F, Ben Voirlich, Dumoon, St.

L. ochrococca, Nyl.-B, Inverarnan, Glen Falloch, Lg., Cr.

L. decolorans, Flke.-G, Campsie, St.

L. flexuosa, Fr.-L, Muck Burn, Dalmellington, S. E., W. J.

L. sylvicola, Flot. var. infidula, $N y l$.-E, Ormidale, St.

L. turgidula, Fr.--B, Glen Falloch, Cr.

L. enteroleuca, Ach.-E, Arran, St.

L. sanguineoatra, Ach.-B, Glen Falloch, Lg.

L. parasema, Ach.-B F, Tarbet, J. M., W. J. ; Gourock, H. Herb. var. elaeochroma, Ach.-F, Kilmalcolm, S. E. \& W.J.

L. enterochlora, Tayl.-F, Cumbrae, S.E., W. J.

L. arctica, Smrf.-B, Ben Voirlich, St.

L. aglaea, Smrf.-B, Ben Voirlich, St. ; Ben Chroinn, S. E. \& W. J.

L. mesotropa, Syl.-B, Ben Lomond, Lg.

L. coarctata, Sm. f. elacista, Ach.-B, Ben Lomond, St.

L. pammicta, Stirt.-B, Ben Arthur, St.

L. panaeola, Ach.-B, Ben Voirlich, St.; Glen Falloch, Cr. Ms.

L. Bruyeriana, Schaer.-E, Ormidale, St.

L. polycarpa, Flk.-B, Ben Voirlich, St. ; Ben Chroinn, S. E. \& W. J.

L. Kochiana, Hepp., and var. lygaea. E, Ormidale, St.

L. lapicida, Fr.-B H, Ben Oss, Douglas, S. E. \& W.J.

L. lithophila, Ach.--B, Ben Lomond, Cr.

L. plana, Lahm.-B, Tarbet, S. E. \& W.J.

L. rivulosa, Ach.-B, Alt Andorran, Glen Falloch, S. E. \& W. J.

L. interludens, $N y l$. - E, Tighnabruaich, St.

L. fuscoatra, Ach.-BE, Ben Lomond, H. Fl. Sc.; Glen Falloch, Cumbrae, S.E. var. fumosa, Ach.-F G, Paisley, St. ; Kilmalcolm, s. E.

L. lactea, Flk.-B, Ben Voirlich, St.

L. subkochiana, $N y l$.-E, Ormidale, St.

L. Taylori, Salw.-B, Ben Lomond, St.

L. contigua, Fr.-B L, Loch Lomond, Ben Chroinn to $3000 \mathrm{ft}$. , S. E. ; Lugar,

S. E. \& W. J.

f. limitata, Leight-E, Kilmalcolm, S. E. \& W. J.

f. nobilis, $F r$. - B, Ben Oss, S. E. \& W. J.

(Also forms platycarpa, $F r$., and flavicunda, Ach., without locality, St.). 
L. albocaerulescens, Wulf.-B L, Ben Arthur, St.; Dalmellington, S. E. \& W. J.

L. confluens, Webr:-B G, Ben Lomond, Cathkin Braes, H. Fl.Sc.

f. complicata, Leight.-B, Tarbet, S. E. \& W. J.

f. laevigata, Leight.-B, Ben Oss, S. E. \& W.J.

L. phaeops, Nyl.-B, Ben Voirlich, St.

I. gelatinosa, Flk.-B, Glen Falloch, Cr. Ms.

L. sarcogyniza, Nyl.-B, Ben Voirlich, St.; Ben Chroinn to $3000 \mathrm{ft}$., S. E.

L. canescens, Dick.--F G, Strone Glen, Green. Herb.; Hamilton, St.

L. verruculosa, Borr.-E, Ormidale, St.

L. flavovirescens, Dick.-F, Helensburgh, $\mathrm{Cr}$.

L. stellulata, Tayl.-E, Ormidale, St.

L. disciformis, Fr.-B, Rossdhu, J. M., W. J.; Loch Lomond, Cr. Ms.

L. coniops, Wahl.-E, Ormidale, St.

L. badioatra, Flke.-B, Ben Oss, S. E. \& W. J.

L. atrobadia, Nyl.-B F, Alt Andorran, Cumbrae, S. E. \& W.J.

L. myriocarpa, D.C.-B F G L, Loch Lomond, Cr. Ms. ; Kilmalcolm, S. E. ; Hamilton, St.; Dalmellington, S. E.

L. applanata, Fr:-BG, Ben Lomond, Ben Voirlich, St.; Clyde, J. M. \& W. J.

L. grossa, Pers._-"Crummach," Lg.

L. Lightfootii, Sm.-BE F, Gourock, H. Herb. ; Dunoon, Ormidale, St.

L. globulosa, Flke.-B, Ben Lomond, St.

L. pulverea, Borr.-B, Inverarnan, Loch Lomond, Lg., Cr. Ms.

L. anomala, $\mathrm{Fr}$. - G, Cadder, St.

L. tricolor, Wittr.-B G, Glen Falloch, Lg., Cr. Ms.; Calder Bridge, J. M. \& W. J.

L. lutea, Dick.-A B, Inveraray, Cr.; Tarbert, St.

L. cyrtella, Ach.-G, Hamilton, St.

L. pineti, Ach.-B, Glen Falloch, St., Cr. Ms.

L. caradocensis, Leight.--H, Douglas, S. E. \& W. J.

L. alboatra, Hoffm.-K, South Girvan, S. E. \& W.J.

L. melaena, Nyl.-E, Ornidale, St.

L. Oederi, Web.-B, Ben Voirlich, St.

L. sphaeroides, Dick.-G, Milngavie, St.

L. milliaria, Fr.-G, Milngavie, St. ; Ayrshire, Lg.

L. sabuletorum, Flke.-G, Campsie, St.

L. premnea, Ach.-B, Glen Falloch, S. E.

L. citrinella, Ach.-B, Glen Falloch, Cr.; Ayrshire, Lg.

L. geographica, L.-B M, Ardlui, Abington, S. E. var. sulphurea. E, Arran, M'M.

L. soreumidea, St.-B, Ben Brecht (Beinn Bhreac), Lg.

L. petrea, Wulf.-B F L, Ben Lomond, St. ; to $3000 \mathrm{ft}$., Ben Chroinn, Cumbrae, S. E. ; Dalmellington, S. E. \& W. J.

L. lavata, Fr.-B E F, Ormidale, St. ; Tarbet, Kilmalcolm, S. E. \& W. J.

L. concentrica, Dav.-B H, Falls of Clyde, S. E. \& W. J. ; Ormidale, St.

L. excentrica, Ach.-E F, Dunoon, Ormidale, St.

L. rimosa, Dick.-B, Ben Lomond, St.

I. morio, Ran.-E, Arran, St.

L. Parmeliarum, Sommrf.-A, Inveraray, Cr. Ms. ; Crinan, Lind.

Umbilicaria pustulata, Hoffm.-E, Arran, H. Herb. \& O. V. D.

Gyrophora cylindrica, Ach.-B E H, 2-3000 ft., Ben Oss, S. E. \& W. J. ; Cobbler, J. M.; Goatfell, Lg. ; Tinto, J. M. \& O. V. D.

var. denudata.-B, Ben Chroinn, S. E. \& W.J.

var. denticulata.-B, Ben Voirlich, St.

G. torrefacta, Cromb.-B E, Alt Andorran, Glen Falloch, S. E. \& W.J. ; Goatfell, Lg. 
? G. erosa, Ach.-B, Cobbler, J. M.

G. polyphylla, Turn. et Borr.-B E L, Ben Lomond, Cr. ; Goatfell, H. Herb., Dalmellington, S. E. \& O. V. D.

G. flocculosa, Turn. et Borr.-B, Ben Arthur, St. ; Ben Oss, S. E.

? G. polyrhiza, $K r b$. - B, Glen Croe, M'M.

Pilophorus cereolus, $N y l$.-BE, Ben Lomond, Lg: ; Ormidale, Ben Arthur, St.

Stereocaulon coralloides, Fr.-A F K L M, Inveraray, Cr.; Dumbarton,

S. E., L. W. ; Girvan, Loch Doon, S. E. \& O. V. D. ; Leadhills, Cr.

S. paschale, Fr.-A, Inveraray, M'M. ; "Common," St.

S. evolutum, Graewe.-K, Girvan, S. E. \& O. V. D.

S. tomentosum, $F r$.-(Without locality) St.

S. denudatum, Flke.-B F G K L, Glen Falloch, 3000 ft., S. E. \& O. V. D. ; Beinn Buidhe, J. P. ; Ben Oss, S. E., W..J. ; Kilmalcolm, S. E. \& O. V. D. ;

Cathkin, J.P. \& S. E. ; Girvan, S. E. ; Loch Doon, S. E. \& O. V. D.

var. pulvinatum, Flot.-B F, Ben Oss, Kilmalcolm, S. E. \& O. V. D.

S. pileatum, Ach.-B, Rock, Loch Lomond, S. E. \& O. V. D.

Baeomyces rufus, DC.-A B E F G H L M, Inveraray, M'M. ; Glen Falloch,

Cr.; Glasgow, Sm. ; Dalmellington, S. E., O. V.D. ; Leadhills, Cr.

B. roseus, Pers.-A B L M, Inveraray, M'M. ; Cobbler, J. M., S. E. ; Leadhills, Cr. ; Dalmellington, S. E., O. V. D.

B. aeruginosus, DC.-A B, Inveraray, M'M. ; Ben Arthur, St.; Ben Oss, S. E., O. V.D.

Cladonia endiviaefolia, $F r$ - F, Dumoon, St.

C. pyxidata, Fr.-B E F G H K L M, Ben Lonıond to 2000 ft., L. W., S. E. ; Dalmellington, S. E., O. V. D. ; Abington, S. E.

var. pocillum. B, Ben Arthur, St.

var. chlorophea. B H K L, Tarbet, S. E. \& W.J. ; Dalmellington, S. E.

\& O. V. D. ; etc., etc. f. myriocarpa. B, Tarbet, S. E. \& W.J.

C. cariosa, Spreng.-H, Douglas, S. E. \& O. V.D.

C. fimbriata, Fr.-B F G H L M, Ben Oss, Kilmalcolm, Abington, S. E. \& O. V.D., etc., etc. ; Milngavie, H. Fl. Sc.

subsp. fibula, f. tortuosa. L, Dalmellington, S. E. \& W. J.

C. gracilis, Hoffm.-F L, Largs, Cr.; Dalmellington, S. E., O. V. D.

C. ochrochlora, Flke.-B F H K L, Beu Oss, Kilmalcolm, Douglas, Girvan, Dalmellington, S. E. \& O. V. D.

var. ceratodes. F, Cumbrae, S. E. \& W. J.

C. cervicornis, Schaer.-B E F K L, to $3000 \mathrm{ft}$., Ben Lomond, L. W. \& O.V.D. ; Arran, Lightf. ; Greenock, St. ; Dalmellington, S. E. \& O.V.D.

C. degenerans, Flke.-B F, Kilmalcolm, S. E. \& O. V.D.; Ross, L. W., O. V. D.

C. furcata, Hoffm.-B E F G H J L, Beinn Buidhe, 3000 ft., J. P. \& O. V. D. ; Arran, Lightf.; Cumnock, Douglas, Glasgow, Ballantrae, S. E. \& O. V. D.

var. cornucopioides. L, Cumnock, S. E., O. V. D.

C. pungens, Flke.-B, Tarbet, S. E. \& O. V. D.

C. crispata, Nyl.-B J, Arrochar, Ballantrae, S. E., O. V. D. var. spinosa. F, Kilmalcolm, S. E. \& W. J. var. furcatiformis. H, Douglas, S. E. \& W. J.

C. squamosa, Hoffm.-B L, Alt Andorran, S. E. \& W.J. ; Dalmellington, S. E. \& O. V. D.

C. coccifera, Schaer.-B F H K, Beinn Buidhe, 3000 ft., J. P., S. E. ; Kilmalcolm, Douglas, Girvan, S. E. \& O. V. D.

f. cornucopioides. B K, Ben Oss, Girvan, S. E. \& O. V. D.

C. bellidiflora, Flke.-B E, Ben Lomond, Lightf.; Ben Arthur, St. ; Arran, Lg.

C. digitata, Hoffm.-E L, Arran, Lightf. ; Dalmellington, S. E. \& O. V. D.

var. cerucha. B F L, Loch Lomond, S. E. ; Clynder, Dalmellington, S. E. \& W.J. 
C. macilenta, Hoffm.-F G L, Kilmạlcolm, S. E. ; Old Kilpatrick, L. W. \& W. J.; Dalmellington, S. E. \& W.J.

var. coronata. Old Kilpatrick, S.E. \& W. J.; Dalmellington, S. E. \& O. V.D.

C. bacillaris, Nyl.-B(F ?) L J, Ben Oss, J.A. \& W. J. ; Cumnock, Ballantrae, S. E. \& O. V. D. ; (Gourock, ? H. Herb., O. V. D.).

? C. Floerkeana, $\mathrm{Fr}$.-B, Arrochar, S. E.

Cladina rangiferina, Nyl.-B E F G H L, Beinn-an-Lochan, J. P., S. E., 3000 ft. ; Arran, Lightf., Greenock, Green. Herb., Tinto, J. M. ; Dalmellington, S. E. \& O. V.D., etc., etc.

C. sylvatica, Nyl.-B H K L, Loch Lomond side, Douglas, Carleton, Cumnock, S. E, \& O. V. D.

C. uncialis, $N y l$.-B E F G L, Ben Lomond, 2000 ft., L. W., S. E., W. J. ; Old Kilpatrick, L. W., S. E. ; Cumnock, S. E. \& O. V. D.

Thelotrema lepadinum, Ach.-BGK, Ben Lomond, Cr.; East Kilbride, St. ; Ayr, S. E. \& O. V. D.

Megalospora (Lecidea) sanguinaria, Rke.-A B G Inveraray, M'M. ; Glen Falloch, Lightf. ; Roseneath, Cr. ; Paisley, St.

Ochroleckia (Lecanora) tartarea, (L.), Mass.-A B F H L, Inveraray, Lg. ; Kilmun, Cr. ; Falls of Clyde, S. E. ; Loch Doon, S. E. \& O. V. D. var. frigida. F H, Gourock, H. Herb., \& W. J. ; Falls of Clyde, S. E.

0. parella (L.), Mass._B C E F H L MI, Helensburgh, H. Fl. Sc. ; Buchanan Ho., S. E. ; Dalmellington, Abington, S. E.

0. pallescens (L.), Mass.-F, Greenock, St., \& Dr. Calder.

Variolaria globulifera, Turn.-A B, Inveraray, Helensburgh, Cr. var. opthalmiza, $N y$ l. -B, Glen Falloch, Cr. \& St.

V. lactea, (L.), Ach.-B GL, Campsie, Cathkin, H. Fl. Sc. ; Tarbet, Dalmellington, S. E. \& O. V. D.

V. dealbata, Ach.-B F G H, Glen Falloch, St. ; Kilmalcolm, Douglas, S. E. ; Auchentibber, J. Mall \& O. V. D.

V. amara, Ach.-F G, Glasgow, Cr.; Kilmalcolm, S. E. \& O. V.D.

Pertusaria communis, DC.-BFGH L, Gourock, H. Herb., S. E. ; Glasgow, Cr. ; Luss, J. M. ; Douglas, Cumnock, S. E. \& O. V. D.

P. Wulfenii, DC.-B K L, Glen Falloch, Ayr, Auchenleck, S. E. \& O. V. D.

Lecanora hypnorum, Ach.-B E, Ben Voirlich, St. ; Kyles Bute, Cr.

L. crassa, Ach.-E, Urmidale, St.

L. saxicola, Ach.-E, Kyles Bute, Cr.

L. gelidaa, Ach.-B, Ben Lomond, H. Fl. Sc. ; Lochgoilhead, St.

L. elegans, Ach.-F G, Helensburgh, Cathkin, H. Fl. Sc.

L.(Placodium bracteatum $H o f m$.). E, Ormidale, St.

L. murorum, Ach.--E, Ormidale, St.

L. (Placodium albescens, Hoffm.).-F, Cumbrae, S. E. \& O. V. D.

L. callopisma, Ach.-G, Milugavie, St.

L. citrina, Ach.-F, Gourock, Cr.

L. vitellina, Ach.-F K L, Kilmalcolm, Girvan, Cumnock, S. E.

L. aurantiaca, $N y l .-F G H$ L, Largs, Cr. ; Hamilton, St.; Falls Clyde, Dalmellington, S. E.

L. ochracea, iyl.-E, Ormidale, St.

L. ferruginea, $N y l$. - F, Largs, Cr.

var. festiva. BFGH K L, Ardlui, S. E. ; Glasgow, Lg. ; W. Kilbride, D. A. B.

L. concilians, Nyl.-E K, Arran, St. ; Girvan, S. E.

L. cerina, Ach.-F, Largs, Cr.

L. pyracea, Nyl._-Conmon," St. ; J, Ballantrae, S. E.

L. subexigua, St.-E, Ormidale, St.

L. roboris, Nyl._-"Frequent," St.

L. exigua, St.-E, Ormidale, St. 
L. circinata, Ach.-G, Cathkin, Lg., St.

L. galactina, Ach.-F K, Dunoon, St. ; Girvan, S. E.

L. livida, Ach.-F, Troon, St.

L. expallens, $A c h$. var. lutescens, $N_{y} l$.--B L M, Tarbet, S. E. \& W. J. ; Dalmellington, Abington, S. E.

L. symmicta, Ach. var. saepincola, $N y l$.-K, Girvan, S. E. \& W.J.

L. subfusca, Nyl.-St., B G L M, Abington, etc., S. E.

var. distaus. K L M, Cumnock, S. E. ; Abington, J. M.

L. allophana, Nyl.-A B F G H J K L, Inveraray, Cr. \& S. E.

L. rugosa, $N y l$. - G, Glasgow, Cr. subsp. chlarona. G, Glasgow, Cr.

L. atrynea, $N y l .-F$, Dunoon, St.

L. gangaleoides, $N y l .-\mathrm{E}$, Arran, St.

L. angulosa, Ach.-E, Ormidale, St.

L. glaucoma, Ach.-E F G, Kyles Bute, Cr.; Troon, St. ; Campsie, H. Fl. Sc.

L. umbrina, Nyl.-F H, Cumbrae, Lg.; Lanark, S. E., W. J.

L. Hageni, Ach.-A E, Inverarav, Cr.; Ormidale, St.

L. sulphurea, Ach.-B F, Ben Lomond, H. Fl. Sc.; Kilbride, D. A. B.

L. varia, Ach.-B F L, Loch Lomond, Helensburgh, St., S. E.

L. conizaea, $N y l$. - G, Old Kilpatrick, L. W. \& W. J.

L. polytropa, Ehr.-B, Ben Lomond, H. Fl. Sc.

L. sarcopis, Ach.-E, Ormidale, St.

L. atra, Ich.-E F G H K L, Glasgow, Cr. ; Cumbrae, S. E. \& O. V. D. ; Arran (corticola), St. \& S. E.

L. coccinea, Cromb.-F or G, Bowling, Cr.

L. haematomma, Ach.--F, Cumbrae, S. E.

L. ventosa, Ach.-B F, Ben Lomond, Sm. ; Cobbler, J. M. ; Ben Chroinn$2000 \mathrm{ft}$., S. E.

L. rubra, Ach.-B L, Cumnock, S. E.

L. calcarea, Sommrf.-B, Cobbler, St.

L. Dicksonii, Nyl.-B L, Ben Oss, Alt Andoarran, Loch Doon, S. E.

L. lacustris, Fr:-B, Glen Falloch, Glen Croe, Cr.

L. fuscata, Nyl.-B G, Ben Lomond, H. Fl. Sc.; Glasgow, St.

L. smaragdula, $N y l$. f. sinopica. B, Ben Voirlich, Cobbler, St.

Parmelia perlata, Ach.-A B CEJ, Inveraray, Cr.; Tarbet, J. M. ; Buchanan, Ho.; Ballantrae, S. E. \& O. V.D.

subsp. ciliata, Nyl.-A B, Lochgilphearl, St. ; Helensburgh, Cr.

P. cetrarioides, $N y l$.-A B, Carsaig, St.; Loch Lomond, Lightf.

P. tiliacea, Ach.-E F, Fairlie, J. M. \& O. V. D. ; Brodick, M'M. var. scortea, Ach.-F, Dunoon, St.

P. saxatilis, Ach.-BEFGHKLM, Arran, Lightf. ; Abington, S. E., O. V.D., etc.

var. furfuracea, Schaer.-B, Helensburgh, Cr.

P. sulcata, Tayl.-B F K L, to $3000 \mathrm{ft}$. Ben Lomond, L. W., S. E. ; Kilmalcolm, Ayr, Cumnock, S. E. \& O. V.D.

P. omphalodes, Ach.-B L, Ben Oss, Loch Lomond, Loch Doon, S.E., O.V.D. var. panniformis. B, Glen Falloch, S. E. \& W.J.

P. caperata, Ach.-A BEF K, Inveraray, M'M. ; Cumbrae, H. Herl. ; Auchincruive, S. E. \& O. V. D., etc.

P. sinuosa, Ach.-A BEG, Inveraray, Cobbler, M'M.; Brodick, Green. Herb. ; Cathkin, H. Fl. Sc.

P. conspersa, Ach.-A B, Inveraray, Cr.; Lochgoilhead, St., etc., etc. var. stenophylla, Ach.-A, Inveraray, $\mathrm{Cr}$.

var. isidiata, Leight._B F, Lochgoilhead, St.; W. Kilbride, D. A. B.

P. olivacea, Ach.-F H, Kilmalcolm, Douglas, S. E. \& O. V. D,

P. exasperata, $N y l$.-B F H L, Largs, Cr.; Ardlui, Falls Clyde, Cumnock, S. E. \& O. V. D. 
P. fuliginosa, Nyl.-B F J, Greenock, Ballantrae, S. E. \& O. V. D. ; Tarbet, J. M. \& O. V.D.

var. laetevirens. J, Ballantrae, S. E. \& O. V. D.

P. lanata, Wallr. var. reticulata, Crombie.-B, Ben Lomond, Sm.

P. tristis, Nyl.-B H, Cobbler, St.; Ben Lomond, Lightf.; to $3000 \mathrm{ft} ., \mathrm{S}$. E. \& W.J.; Tinto, J. M. \& O. V.D.

P. physodes, Ach.-A B E F G H L M, Abington, S. E. \& O. V. D, etc.

P. pertusa, Schaer.-A B, Carsaig, St. ; Ardgarten, M'M.

In addition the following species have been recorded by the Rev. H. Macmillan, D.D., for the districts mentioned below :

P. perforata, Ach.-B, Glencroe; P. laevigata, Ach.-A B, Inveralay, Larick; P. xanthomyela, Nyl.-B, Larick; P. mougeotii, Schaer.-B, Ardgarten.

Cetraria islandica, Ach.-B F, Beinn Buidhe-3000 ft., J. P., S. E. ; Ben Lomond, Sm., S. E. ; Dunoon, St.

C. aculeata, $F r$--B FGH L, Ben Oss, Dalmellington, S. E. \& O. V.J). ; Dumoon, St. ; Edenbarnet, L. W., S. E. ; Tinto, J. M., S. E. var. hispida, Cromb.-F, Kilmalcolm, S. E. \& W.J.

Platysma saepincola, Nyl._-"Frequent," St.

P. ulophyllum, $N y l$.-B F H, Glen Falloch, Cr. ; Cumbrae, Douglas, S. E. \& O. V.D.

P. diffusum, $N y l$.-B, Inverarnan, Cr.

P. commixtum, Nyl.-B, Cobbler, J. M., S. E.

P. glaucum, Nyl.-A B E FGH L, Inveraray, Cr. ; Dalmellington, S. E. \& O. V.D., etc., etc.

var. fallax. A B L, Inveraray, Cr. ; Ardlui, Auchinleck, S. E. \& O. V. D.

P. lacunosum, $N y l$.-B, Glen Falloch, Cr.

Evernia prunastri, Ach.-FGH K L, Cumbrae, S. E. \& O. V. D. ; Lanark, H. Herb., Dalmellington, S. E. \& O. V.D.

E. furfuracea, $F r$.-BFG H L, Duncombe-1000 ft., L. W. ; Glen Falloch, Cr. ; Cumnock, S. E. \& O. V. D., etc., etc.

var. uuda Cromb. BH M, Glen Falloch, S. E. ; Douglas, S. E. \& O. V. D. ;

Crawfordjohn, J. M., S. E.

var. ceratea, $N y l$.-B H, Glen Falloch, Cr. ; Falls Clyde, S. E. \& O. V. D.

Usnea florida, Ach.-A B, Inveraray, Cr. ; Loch Lomond, St.

U. hirta, Hoffm.-A F H K L M, Inveraray, Cr.; Greenock, Green Herb., Abington, S.E. \& O. V.D., etc., etc.

U. dasypoga, Nyl.-BH L, Glen Falloch, Falls Clyde, Dalmellington, S. E. \& O. V. D.-

Alectoria sarmentosa, $A c h$. var. cincinnata, $N_{y} l-B$, Ben Voirlich, St.

A. jubata, Ach.-B H L, Glen Falloch, Cr. ; Lanark, H. Herb., Dalmellington, S. E. \& O. V.D.

var. chalybeiformis, $N y l$.-B H L, Ben Voirlich, St. ; Douglas, Dalmellington, S. E. \& O. V.D.

var. lanestris, Ach.-B H, Gleu Falloch, Douglas, S. E. \& O. V. D.

var. subcana, Nyl.-M, Abington, S. E. \& O. V. D.

Ramalina calicaris, $N y l .-\mathrm{K}, \mathrm{Ayr}$, S. E. \& O. V. D.

R. fraxinea, Ach.-H, Douglas, S. E. \& O. V.D.

var. ampliata. F, Dunoon, St.

R. fastigiata, Ach.-F H, Millport, Green. Herb., Douglas, S. E. \& O. V. D.

R. farinacea, Ach.-F H J K L, Gryfe, Douglas, Ayr, Cumnock, Ballantrae, S. E. \& O. V. D.

R. scopulorum, Ach.-BE F J, Tarbet, St. ; Arran, Lg. ; Cumbrae, Green. Herb., Ailsa Craig, Cr.

R. polymorpha, Ach.-K, Girvan, S. E. \& O. V.D. 
R. cuspidata, $N y$ l.-F K, Inverkip, Cr. ; Girvan, S. E. \& O. V. D.

var. minor. F, Cumbrae, S. E. \& O. V. D.

var. breviuscula. K, Girvan, S. E. \& O. V. D.

Physcia obscura, Nyl.-“Common," St.

P. erosa, Leight.-F, Gourock, St.

P. aipolia, Nyl.-K, Knockdolyan, S. E. \& O. V. D.

var. cercidia. A, Inveraray, Ch.

P. stellaris, Nyl.-B F J, Dunoon, St. ; Fairlie, J. M. ; Gourock, H. Herb., Balloch, S. E. \& O. V. D. ; Ballantrae, S. E. \& O. V.D.

Subsp. tenella. B F H L, Kilmalcolm, Falls Clyde, Girvan, Cumnock, S. E. \& O. V. D. ; Tarbet, St.

P. aquila, Nyl.-A B F K, Inveraray, Glencroe, M'M. ; Cumbrae, H. Herb. \& O. V.D. ; Girvan, S. E.

P. pulverulenta, $N y l$.-F J H, Largs, Cr. ; Ballantrae, S. E. ; Biggar, J. M., both O. V. D.

f. pityrea. G, Glasgow, Lg.

f. argyrophaea. H, Donglas, S. E. \& W. J.

P. speciosa, Nyl.-B, Glen Falloch, St.

var. hypoleuca. B, Glencroe, M'M.

P. caesia. f. teretiuscula. K, Girvan, S. E., O. V. D.

Anaptychia ciliaris. - "Not unfrequent," St.

Xanthoria polycarpa, Lamy.-M, Abington, S. E. \& W.J.

X. parietina.-B E F K K L, Roseneath, .J. P. ; Arran, Lg. ; Cumbrae, Green.

Herb., Cumnock, Ballantrae, etc., S. E., O. V. D.

X. chrysopthalma.-B, Loch Fyne, Ben Brecht, St.

X. flavicans.-J, Ailsa Craig, Lightf.

Lichina confinis, Ach.-B F, Ormidale, St. ; West Kilbride, D. A. B.

L. pygmaea, Ach.-F, West Kilbride, D. A. B.

Ephebe pubescens, Nyl.-B, Rock, Loch Lomond, J. M. \& O. V. D.

Coccocarpia plumbea, Nyl.-A B E, Inveraray, Lind.; Glen Falloch, Cr.; Glencroe, M'M. ; Goatfell, H. Herb. \& O. V. D.

var. nyyriocarpa. G, Campsie, Cr.

Pannaria rubiginosa, Del.- A B, Inveraray, Glen Falloch, Cr.

P. brunnea, Nyl.-E F, Goatfell, Arran, H. Herb. \& W. J.; Bowling Bay, Cr.

P. caeruleobadia, Mudd.-B, Luss, J. M. \& O. V. D.

Pannularia triptophylla, $N y l$.-A, Inveraray, Cr.

Stictina intricata, $\mathbf{I} y l$.-A, Inveraray, $\mathrm{Cr}$.

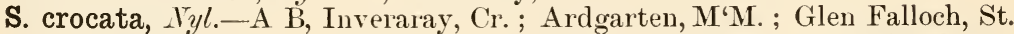

S. fuliginosa, $N y l$.-A B F H, Inveraray, Cr.; Glencroe, M'M. ; Largs, J. M. ; Falls Clyde, S. E.

S. limbata, $N y l$.-A B H, Inveraray, Cr. ; Tarbet, J. M. \& O. V. D. ; Falls Clyde, Cr.

S. sylvatica, $N^{\top} y l_{\text {. }}$ - A B F H, Inveraray, Cr.; Glencroe, M'M. ; Falls Clyde, Cr.; Fairlie, J. M. \& O. V. D.

Ricasolia amplissima, Leight.-A B F G, Inveraray, Loch Long, Roseneath, Mugdock, Cr.

R. laetevirens, Leight.-A E F, Inveraray, Largs, Cr. ; Ormidale, St.

Lobarina scrobiculata, $N y l$.-A B E F L, Inveraray, Cr. ; Rothesay, H. Herb.; Bowling, St.; Glen Falloch, Loch Doon, S. E., O. V. D.

Lobaria pulmonaria, Hofm.-A B E G H, Inveraray, Cr. ; Glencroe, M'M. ; Rothesay, H. Herb. ; Barncluith, Lg. ; Douglas, S. E. \& O. V. D. vars. hypomela and aggregata. A, Inveraray, Cr.

Peltidea apthosa, Ach.-A H L, Inveraray, Cr. ; Falls Clyde, St. ; Dalmellingtol, S. E. \& O. V. D. ; Stroine Dhu, H. Herb., O. V. D. var. leucophlebia. A, Inveraray, Cr.

Peltigera malacea, Fr.-A L, Inveraray, Cr. ; Dalmellington, S. E. \& O. V. D. 
P. canina, Hoffm.-B E F G H L, Arran, Lg. ; Ross, L. W. \& O. V. D. ; Inverkip Green, Herb., Campsie, St.; Cumnock, Falls Clyde, S. E. \& O.V.D.

var. membranacea.-B F H L, Garelochhead, L. W. \& W. .J. ; Bowling, St. ;

Falls Clyde, Dalmellington, S. E. \& O. V. D.

P. rufescens, Hoffm._ "Common," St. ; F H, Falls Clyde, Kilmalcolm, S. E. \& O. V. D.

var. praetexta.-B, Garelochhead, L. W. \& W. J.

P. polydactyla, Hoffm.-A B E F G, Inveraray, Lind.; Arran, Lg. ; Kilmalcolm, S. E., O. V. D. ; Tarbet, Blantyre, J. M., O. V. D.

var. hymenina.-A G, Inveraray, Kenmure, $\mathrm{Cr}$.

P. scutata, Leight.-A B, Inveraray, Cr. ; Glencroe, M'M. ; Luss, J. M. \& O. V.D.

P. horizontalis, Hoffm.-E F, Arran, Lg. ; Dunoon, C'r.

Nephromium lusitanicum, Schaer.-A B F, Inveraray, Cr. ; Luss, J. M. ; Dumbarton Castle, Sm.

N. laevigatum, Ach.--B L, Ross Dhu, J.M. ; Dalmellington, S. E., both O. V.J.

N. parile, $N_{y} l .-G$, Campsie, J. M. \& O. V.D.

Solorina crocea, Ach.-B, Ben Lomond, $\mathrm{Cr}$.

(S. saccata, 1 ch.-Loch Awe, Cr.)

Collema auriculatum, Hoffm.-A, Inveraray, Lg.

C. furvum, Ach.-E, Ormidlale, St.

C. flaccidum, Ach.-F H, Kilmalcolm, Falls Clyde, S. E. \& W. J.

C. pulposum, Ach.-F J, Cumbrae, H. Herb., Ballantrae, S. E. \& W.J.

C. tenax, Ach.-G, Campsie, Cr.

C. cheileum, 1ch.-G, Glasgow, $\mathrm{Cr}$.

C. melaenum, Ach.-B, Ben Arthur, st.

C. fasciculare, Ach.-B, Arrochar, Edin., Herb.

Leptogium lacerum, Gray.-G, Campsie, J. M.

var. fimbriatum.-A, Inveraray, $\mathrm{Cr}$.

var. lophaeun.-Without locality, St.

L. scotinum, B F, Ben Arthur, St.; Ben Toirlich, J. M. ; Cumbrae, H. Herb., S. E.

var. sinuatum.-B F, Gareloch, Lightf. ; Bowling, Cr.

L. tremelloides, Gray.-A B F, Inveraray, Borrer, Loch Lomond, G. ; Dumbarton, Sm.

L. saturninum, $\mathrm{N} y \mathrm{l}$.-A, Inveraray, $\mathrm{Cr}$.

L. Rurgessii, Mont.-A B, Inveraray, C'r. ; Glencroe, M'M.

Collemodium fluviatile, Nyl.-H, Bonnington Fall, Cr.

Pyrenopsis grumulifera, $\hat{N}_{y l} l-\mathrm{B}, \mathrm{Ben}$ Arthur, St.

Collemopsis furfurella, $N y i$.-Without locality, St.

Verrucaria mucosa, Wahi.-A F, Ardrishaig, Ardrossan, Cr.

V. epigaea, Pers.-F, Bowling, St.

V. margacea, Wahl. var. acrotella. F, Gourock, St.

V. nigrescens, Pers.-B, Cobbler, St.

V. plumbea, Ach.-E, Ormidale, St.

V. gemmata, Ach.-F, Bowling, St.

V. epidermidis, Ach.- "Common," St.

V. fallax, Nyl.-E, Ormidale, St.

V. antecellens, Nyl.-B, Arrochar, St.

V. litoralis, Tayl.-E, Ormidale, St.

V. nitescens, Salw.-E, Arran, St.

V. punctiformis, Ach.-B, Arrochar, st. var. deminitula, $N y l$ - E, Ormidale, Arran, St.

V. lectissima, $F r .-B$, Ben Arthur, st.

V. nitida, Weig.-F, Dunoon, St. 
V. rupifraga, Mass.-B, Ben Arthur, st.

V. Henscheliana, Körb.-B, Ben Voirlich, St.

V. ventosicala, Mudd.-B, Cobbler, St

V. laetevirens, Mass.-B F, Gareloch, Cumbrae, Mass.

Endocarpon miniatum, L.-F H K, Cumbrae, H Herb. ; Falls Clyde, Cr. ; Girvan, S. E.

var. complicatum. B F H, Tarbet, S.E. \& W.J.; Bowling, Cr. ; Stonebyres, J. M. \& W.J.

var. leptophyllum. B, Ben Lomond, Sm., St.

E. fluviatile, D. C.-B F, Tarbet, J. M. ; Loch Lomond, Cr., St., Kilmalcolm, S. E.

Normandina laetevirens, Turn.-B, Glencroe, M'M.

N. pulchella, Borr.-B, (Flen Falloch, Cr.

Thamnolia vermicularis, Schaér.-B, Ben Voirlich, St. 


\section{FUNGI (MICROSCOPIC).}

Is the preparation of this list, the chief works used have been Saccardo's Sylloge Fungorum, Karsten's Revisio Monographica atque Synopsis Asconycetum in Fennia hucusque detectorum, Phillips's Manual of the British Discomycetes, and Plowright's Monograph of the British Uredineae and Ustilagineae, besides the various books and papers mentioned below, and several others which have been consulted for minor details.

The usual mark of authentication (!) is placerl after localities from which specimens have been submitted to one or more of the referees. The numerals placed after this sign correspond with those in the appended lists of referees and published works.

When compared with the published results of mycological research in the East of Scotland, the list now submitted contrasts very unfavourably as regards the number of genera and species which it contains. This defect, however, must not be attributed to climatic or other physical causes. The genial climate of the West Coast, and the natural configuration of the shores and islands of the Firth of Clyde, with their luxuriant vegetation and moist shady glens, afford the very best conditions for the development of microfungi.

In view of the manifest incompleteness of the present list, it may be hoped that its publication will stimulate local research, and so enable the Mycological Flora of the West of Scotland to be ere long as fully and carefully investigated as that of the Eastern counties has already been.

D. A. Boyd, Local Secy. Crypt. Soc. Scot.

I.-Referees by whom Specimens have beex Identified.

1. Mr. V. H. Blackman, M.A., F.L.S., British Museum (Natural History).

2. Dr. M. C. Cooke, A.L.S., Kew.

3. Rev. James Keith, LL.D., Forres.

4. Mr. Arthur Lister, F.R.S., F.L.S.

5. Mr. George Massee, F.L.S., Kew.

6. Mr. William Phillips, F.L.S., Shrewsbury.

7. Dr. C. B. Plowright, F.L.S., King's Lynn.

8. Miss A. Lorrain Smith, British Museum (Natural History).

9. Prof. James W. H. Trail, M.D., F.L.S., Aberdeen.

\section{II.-Works CITEd FOR Localities for SPECIES.}

10. R. K. Greville-Scottish Cryptogamic Flora.

11. Dr. M. C. Cooke and G. Massee, F.L.S.--Papers on New British Fungi in later volumes of Grevillea.

12. T. Hopkirk-Flora Glottiana.

13. William Phillips, F.L.S.-Manual of the British Discomycetes.

14. Rev. John Stevenson, LL.D.-Mycologia Scotica.

15. Scottish Naturalist, vol. vi., p. 32. 
16. Prof. J. W. H. Trail, M.D.--Report on Fungi of Inveraray District, in Scottish Naturalist, vol. iv. (New Series), pp. 57-68.

17. Prof. J. W. H. Trail, M.D.-Revision of the Scottish Discomycetes, in Scot. Nat., vol. iv. (New Series).

18. Prof. J. W. H. Trail, M.D.-New Records for Clyde, in Scot. Nat., vol. iv. (New Series), pp. 224-225.

19. Prof. J. W. H. Trail, M.D.-Revision of the Uredineae and Ustilagineae of Scotland, in Scot. Nat., vol. iv. (New Series).

20. Prof. J. W. H. Trail, M.D.-Revision of the Scottish Perisporiaceae, in Trans. Nat. Hist. Soc. of Glasgow, vol. iii.

21. Annals of the Glasgow Indersonian Naturalists' Society, vol. ii.

22. Transactions of the British Mycological Society, 1897-98, pp. 73-74.

23.

$1898-99$, p. 11
0, pp. $423-424$.

25. Dr. M. C. Cooke--Handbook of British Fungi.

26. " " " Papers in later volumes of Grevillea.

27. Dr. C. B. Plowright-Monograph of the British Uredineae and Ustilagineae.

\section{Myxomycetes.}

Badhamia utricularis, Bull.-G, Cadder, Prof. T. King ; Craigton, near Milngavie, Prof. T. King.

B. capsulifera, Bull.-F, Seamill, !2.

Physarum citrinum, Schum. (= Ph. Schumacheri, Spr.)-A, Inveraray, Rev. C. Smith, 14.

Ph. cinereum, Batsch._- "Clyde," 14.

Fuligo septica, $\operatorname{Link}$ (=F. varians, Sommerf.).-F G K L, Common.

Craterium pedunculatum, Trent.-A B, Essachossan, Trail, 16 ; Blairmore, Prof. G. F. Scott Elliot, :4.

C. minutum, Leers. - A F, Duniquoich, Trail, 16; W. Kilbride, !3.

Leocarpus fragilis, Dicks.-A F, Inveraray, Rev. Dr. Stevenson, 16 ; W. Kilbride.

Tilmadoche nutans, Pers._F G, W. Kilbride, Prof. T. King ; Cadder, Mr. R. B. Johuston, 21 ; Darnley, Prof. Scott Elliot, ! 4.

T. mutabilis, Rostf.-_Clyde," 15.

Chondrioderma difforme, Pers.- "Clyde," 14.

Didymium physaroides, Pers._F, West Kilbride, ! 3.

Spumaria alba, Bull.-A FG, Essachossan, Trail, 16 ; Cumbrae, Hennedy Herbarium ; Lambhill, Hemedy Herbarium.

Comatricha Friesiana, De Bary.-F, Seamill, $! 2$.

Stemonitis fusca, Roth.-FG, Duchal, Lochwinnoch; W. Kilbride, :3 ; Cathkin, Prof. Scott Elliot; Cadder, Hennedy Herbarium.

S. ferruginea, Ehrh.-F, W. Kilbride, !3.

Tubulina cylindrica, Bull.-F G L, W. Kilbride, Sorn, Barskimming.

Clathroptychium rugulosum, Wallr.-F, Ardneil Bank Wood, !3.

Dictydium cernuum, Pers._-"Clyde," 14.

Reticularia lycoperdon, Bull.-F G L, Lochwinnoch, Prof. T. King;

W. Kilbride, Carm yle Wood, T. Hopkirk, 12 ; St. Germains, Prof. G. F.

Scott Elliot, ! 4 ; Dalmellington, Mr. R. B. Johnstone, 21.

Perichaena corticalis, Batsch.-F, West Kilbride, !3.

Arcyria punicea, Pers.--F, Kilmalcolm, Prof. G. F. Scott Elliot, !4.

A. pomiformis, Roth.- "Clyde," 14.

A. cinerea, Bull.--"Clyde," 14 .

[T. King.

A. incarnata, Pers.-F, Lochwinnoch, Prof. T. King; W. Kilbride, Prof.

Lycogala epidendrum, Bux.-F G H K, Frequent.

Trichia fallax, Pers. - "Clyde," 14.

T. botrytis, Pers.-F G, Kilmalcolm, Prof. G. F. Scott Elliot; Darnley, Prof. G. F. Scott Elliot, ! 4 . 
T. varia, Pers.-A, Inveraray, Rev. Dr. Stevenson, $! 6$. [T. King.

T. chrysosperma, Bull.-F, Finlaystone, Prof. T. King ; W. Kilbride, Prof. T. affinis, De Bary.-H, Falls of Clyde, Prof. G. F. Scott Elliot, ! 4.

\section{Monadinaceae.}

Plasmodiophora brassicae, Wor.-F, Seamill.

P. alni, Möller (=Schinzia alni, Wor:). -F, Kilmalcolm, Scott Elliot; Largs ; W. Kilbride.

Tetramyxa parasitica, Gobel.-F, W. Kilbride, !2 ; Horse Isle.

Phytomyxa leguminosarum, Schröt. (= Schinzia leguminosarum, Frank.) -F, Seamill, etc.

\section{Phycomycetes.}

\section{Mucorineae.}

Pilobolus crystallinus, Wigg.--F, W. Kilbride.

Hydrophora stercorea, Tode.-F, Cumbrae, Hennedy Herbarium, ! 7.

Mucor mucedo, Linn.-FG, common.

var. caninus, Pers.-A F, Inveraray, Trail, 16; W. Kilbride.

M. ramosus, Bull.-G, Glasgow, Hennedy Herbarium, ! 7.

Spinellus fusiger, Link.-A F G, Essachossan, Trail, 16 ; Kilmahew, W. Kilbride, ! 7 ; Cadder.

Rhizopus nigricans, Ehrenb. (=Ascophora mudeco, Tode.)-"Clyde," 14.

\section{Peronosporeae.}

Cystopus candidus, Pers.-A F G K L, Common.

C. spinulosus, De Bary.-F G, W. Kilbride, 3 ; Cadder, Sorn.

C. lepigoni, De Bary.-F, W. Kilbride, ! 8 ; Horse Isle.

Phytophthora infestans, Mont.-Very common.

[Failford.

Bremia lactucae, Regel.-B F L, Tarbet, Trail, 16 ; Largs, W. Kilbride,

Peronospora pygmaea, Unger.-K, Barr.

P. nivea, Unger.-F G K L, frequent.

P. densa, Per's.-F K L, frequent.

P. calotheca, De Bary.-F K, Largs, W. Kilbride, Barr.

P. myosotidis, De Bary.-F, Ardneil Bay (only once found).

P. viciae, Berk.-F, W. Kilbride.

P. alsinearum, Casp.-F K, Kilmalcolm, Prof. G. F. Scott Elliot, ! 7 ; W. Kilbride, Ayr.

P. arenariae, Berk.-F, Largs, W. Kilbride, Ardrossan.

P. parasitica, Pers.-F G, W. Kilbride, Kilmarnock,

P. ficariae, Tul.-F, Largs, W. Kilbride.

P. violae, De-Bary.-F, W. Kilbride.

P. obovata, Bon.-F, Lochwinnoch, W. Kilbride.

P. trifoliorum, De Bary.-F K L, Largs, W. Kilbride, Ayr, Barr, Tarbolton.

P. grisea, Ung.-F, Kilmalcolm, Prof. G. F. Scott Elliot, ! 7 ; W. Kilbride.

P. effusa, Grev.-F K, W. Kilbride, Barr.

P. urticae, Lib.-F K, Kilmalcolm, Prof. G. F. Scott Elliot, !7; W. Kilbride, Troon, Ayr.

P. candida, Fckl. - F L, W. Kilbride, Dalmellington, Prof. G. F. Scott Elliot.

P. rumicis, Corda.-F, W. Kilbride.

P. alta, Fckl.-A F K, Inveraray, Trail, 16 ; W. Kilbride, Barr.

P. sordida, Berk.-F K, W. Kilbride, !8 ; Barr.

\section{Entomophthoreae.}

Empusa muscae, Fr.-F, W. Kilbride.

\section{Chytridieae.}

Synchitrium stellariae, $F c k l$.-F, Seamill.

S. taraxaci, De Bary and Wor.-FG L, Frequent. 
S. succisae, De Bary and Wor.-F, W. Kilbride.

S. mercurialis, Lib.-F K, W. Kilbride, Barr.

\section{Ustilagineae.}

Ustilago longissima, Sow._FGK, Lochwinnoch, W. Kilbride, Cadder, Barr. U. segetum, Bull.-F G, common.

U. caricis, Pers.-F K, Bridge of Weir, Mr. R. Turner; W. Kilbride, !8; Barr. U. utriculosa, Nees.-F K, W. Kilbride, Ayr.

U. violacea, Pers.-B F K, Hell's Glen, Trail, 16 ; W. Kilbride, Barr.

Tilletia tritici, Bjerk.-F, W. Kilbride.

[Gailes, ! 8.

T. decipiens, Pers.-A F, Glen Aray, Trail, 16 ; Lochwinnoch, W. Kilbride, T. striaeformis, West.-F G K, W. Kilbride, ! 8 ; Kilmarnock, Barr.

Urocystis anemones, Pers.-A F G K, Essachossan, Trail, 16; Largs, W. Kilbride, Loudoun, Barr.

U. violae, Sow.-K, Barr.

Entyloma Fergussoni, B. and Br.-F, W. Kilbride.

E. ranunculi, Bon.-E, Largs, W. Kilbride.

E. matricariae, Trail.-F, W. Kilbride, Irvine.

E. microsporum, Ung.-A F G L, frequent.

E. calendulae, Oud.-F, Noddsdale, W. Kilbride.

Graphiola phoenicis, Moug.-G, Glasgow Botanic Gardens, ! 2, 19.

\section{Protomyceteae.}

Protomyces macrosporus, Unger.-F G K L, common.

P. bellidis, Krieger.-F, Seamill, ! 8, 23.

P. pachydermus, Thüm. - F GL, W. Kilbride, ! 8 ; Ardrossan, Dalry, Kilmarnock, Tarbolton.

\section{UREDINEAE.}

Uromyces fabae, Pers.-A F K L, Glen Aray, Trail, 16 ; Largs, W. Kilbride, Barr, Tarbolton, Auchinleck.

U. limonii, DC.-F, Kelburne, Portincross, Chapelton Point, Ardrossan ; Kilwinning, Mr. John Smith, ! 2.

[ford.

U. polygoni, Pers.-F K L, Lochwinnoch, W. Kilbride, Ardrossan, Ayr, Fail-

U. trifolii, A. and S.-F K, W. Kilbride, Ardeer, Ayr.

U. geranii, DC.-F G, Kilwinning, Mr. John Smith; Blantyre Priory, Mr. R. Turner.

U. valerianae, Schum.-F, Ardneil.

U. parnassiae, DC. (As Aecidium parnassiae, Grev.)-G, "Near Glasgow," Greville, 27.

U. poae, Rabh. (As Aecidium ficariae, Pers.)-F G, common. (Teleutospores)-B F, Ardlui, Prof. G. F. Scott Elliot; Kilmalcolm, Prof. Scott Elliot; W. Kilbride.

U. rumicis, Schum.-F L, Lochwinnoch, Largs, W. Kilbride, Ardrossan ; Muck Glen, Dalmellington, Prof. Scott Elliot.

U. alchemillae, Pers.-A F G K, common.

U. behenis, $D C .-\mathrm{F}$, Portincross, 19.

U. ervi, Wallr. (As Aecidium ervi, Wallr.) - G, Cathkin, Hennedy Herbarium, ! 7 .

U. ficariae, Schum.-F G, W. Kilbride, ! 8 ; Ardrossan, Neilston.

U. scillarum, Grev.-F K, W. Kilbride, ! 1 ; Greenan Castle, Mr. John Smith; Newark, near Ayr.

Puccinia galii, Pers.-F, W. Kilbride, Ardrossan, Ardeer.

P. calthae, Link.-F K, Lochwinnoch, Largs, Cumbrae, Mr. R. Turner ; Ardneil Bank Wood, Ardrossan, Barr.

P. porri, Sow.-F, Portincross.

P. lapsanae, Schultz.-F G K L, common.

P. variabilis, Grev.-A E L, common. 
P. pulverulenta, Grev.-A F, Inveraray, Trail, 16; Largs, W. Kilbride, Blair.

P. violae, Schum.-A F G H K L, very common.

P. albescens, Grev.-F, W. Kilbride.

P. pimpinellae, Strauss.-FG, Gourock, W. Kilbride, Ardrossan, Beith, Campsie.

P. menthae, Pers.-B F L, common.

P. aegra, Grove.-F, Seamill, Ardeer.

P. primulae, $D C$.- A F G, Inveraray, Trail, 16; Gourock, Kelly Glen, Mr. R. Turner; Kelburne, W. Kilbride, ! 3 ; Sorn.

P. soldanellae, $D C$. (As Aecidium soldanellae, Hornsch.)-G, Glasgow Botanic Gardens, Sir W. J. Hooker, Hooker Herbarium, 14.

P. saniculae, Grev._F G K, Largs, West Kilbride, :3 ; Torrance, Mr. R. Turner; Newark, near Ayr.

P. graminis, Pers. (As Aecidium berberidis, Pers.)-F, Gourock. (Teleutospores)- "Clyde," 14.

P. festucae, Plow. (As Aecidium periclymeni, Schum.)-F K, Largs, W. Kilbride, Barr. (Teleutospores)-F, W. Kilbride.

P. sessilis, Schneider.-F, Largs, $19 ;$ W. Kilbride.

P. rubigo-vera, $D C$. - F G K L, very common.

P. poarum, Vielsen.-A EGK L, very common.

P. Schoeleriana, Plow. and Mag. (As Aecidium compositarum, Mart., var. jacobaeae, Grev.)-F, Gourock, Hemnedy Herbarium.

P. caricis, Schum.-F K, Cumbrae, Largs, W. Kilbride, Ardrossan, Barr.

P. paludosa, Plow. (As Aecidium pedicularis, Lib.)-F K, Ardrossan, Barr.

P. obscura, Schröt. (As Aecidium compositarum, Hart., var. bellidis, $D C$.) $-\mathrm{F}$, Seamill.

P. moliniae, Tul.-A, Glen Aray, Trail, 16.

P. suaveolens, I'ers.-A F K L, common.

P. bullata, Pers. (=P. umbelliferarum, DC., p.p.) - "Clyde," 14.

P. hieracii, Schum.-A B FGK L, common.

P. centaureae, Mart.-B F G K L, common.

P. taraxaci, Plow.-_Clyde," 19.

P. polygoni, Pers.-F L, W. Kilbride, Ardrossan, Tarbolton.

P. oblongata, Link.-A F G K L, common.

P. Baryi, B. and Br.-F G L, Cumbrae, W. Kilbride, Kilmarnock, Sorn, Barr.

P. pruni, Pers.-F, Seamill, !9.

P. anthoxanthi, Fckl.-F K, W. Kilbride, Barr.

P. sonchi, Rob.-F, W. Kilbride.

P. lychnidearum, Link.-A E, Inveraray, Trail, 16 ; W. Kilbride, ! 3.

P. campanulae, Carm.-F, W. Kilbride, ! 8.

P. aegopodii, Schum.-FG, W. Kilbride, ! 3 ; Campsie, Smidlycroft, Mr. R. Turner.

P. epilobii, $D C$ - - A F, Glen Aray, Trail, 16 ; Largs, W. Kilbride.

P. umbilici, Guép.-E, Tighnabruaich, Dr. F. B. White, 14.

P. fusca, Relh.-G, Bothwell, Mr. R. Turner.

P. bunii, $D C$.-F, Lochwinnoch, W. Kilbride, ! 1 .

P. Fergussoni, B. and Br.-A E, Duniquoich, Trail, 16 ; Stonefield, Mr. R. Turner.

P. adoxae, DC.-F G, W. Kilbride, Garscube.

P. senecionis, Lib.-F, W. Kilbride.

P. glomerata, Grev.-F, W. Kilbride, 18 ; Ardrossan.

P. arenariae, Schum.-F, Noddsdale, Kelburne, Mr. R. Turner.

P. chrysosplenii, Grev.-FG, "Clyde," 15 ; W. Kilbride. Near Glasgow, Prof. Scott Elliot.

P. veronicae, Schum._- Clyde," 19.

P. valantiae, Pers.-B F G K, Hell's Glen, Trail, 16 ; Lochwinnoch, W. Kilbride, Ashgrove, Neilston, Barr. 
P. malvacearum, Mont.-F J K L, Seamill, Dippen, Mr. Wm. Stewart; Barr, Failford.

P. circaeae, Pers.-A, "Clyde," 15 ; Inveraray, Trail, 16.

P. veronicarum, DC.- "Clyde," 14.

P. annularis, Strauss.-A F, Inveraray, Trail, 16 ; W. Kilbride, !9.

Triphragmium ulmariae, Schum:-E F G K, common.

Phragmidium fragariastri, DC.- $\mathrm{F} \mathrm{G} \mathrm{K}$, common.

Ph. tormentillae, Fckl.-F, W. Kilbride, 19 ; Ardrossan.

Ph. violaceum, Schultz.-A F L, frequent.

Ph. rubi, Pers.-K, Anchendrane, Mr. Auderson Fergusson.

Ph. subcorticatum, Schrank.-A F G K L, common.

Ph. rubi-idaei, Pers.-F K, W. Kilbride, Barr.

Gymnosporangium sabinae, Dicks. (As Podisoma sabinae, Fr.)-G, Dalbeth, Hopkirk, 12.

G. juniperinum, Linn.-G, Milngavie, Mr. P. Cameron.

Melampsora lini, Pers.-BFK, Hell's Glen, Trail, 16 ; Gourock, W. Kilbride, Ardrossan, Barrassie, Barr.

M. farinosa, Pers.-B F G K L, common.

M. vitellinae, $D C$. $-\mathrm{F} \mathrm{G}$, Seamill, Mains.

M. tremulae, Tul.-A B, Duniquoich, Trail, 16 ; Hell's Glen, Trail, 16.

M. populina, Jacq.-B F, Hell's Glen, Trail, 16; W. Kilbride, Ardrossan, Blair.

M. hypericorum, $D C$.-F, Millport, Mr. R. Turner; West Kilbride, ! 1

M. betulina, Pers.-A FG L, Inveraray, Trail, 16; Largs, W. Kilbride, Ardrossan, Mains ; Sorn, !9; Auchinleck.

M. circaeae, Schum.-A FGK, Dumiquoich, Trail, 16; Essachossan, Trail, 16 ; Largs, W. Kilbride, Calderwood, Mr. R. Turner; Barr.

M. vacciniorum, Link.-A F G L, frequent.

M. pyrolae, Gmelin.-G, St. Germains, Bearsden, Prof. Scott Elliot, ! 7.

M. cerastii, Pers.-F L, Largs, W. Kilbride, Tarbolton.

Coleosporium senecionis, Pers.--FGK, Fairlie, Mr. R. Turner; W. Kilbride, Sor'n, Ayr.

C. sonchi, Pers.-A F G K L, common.

C. campanulae, Pers.-A B F K, Inveraray, Trail, 16 ; Ardlui, Prof. Scott Elliot; Cumbrae, Largs, W. Kilbride, Barr.

C. euphrasiae, Schum.-A B F G L, common.

Uredo symphyti, DC.-FG, Kelly Glen, Mr. R. Turner ; Lochwinnoch, Stevenston, Scotstounhill, Prof. Scott Elliot, ! 7.

U. polypodii, Pers.-F, Gourock, Hennedy Herbarium.

U. scolopendri, Fcll. (=Milesia polypodii, B. White)-A F L, Essachossan, Trail, 16; Gourock, Prof. Scott Elliot; Noddsdale, W. Kilbride, Dalmellington, Prof. Scott Elliot, $! 7$.

U. Mulleri, Schröt.-F, W. Kilbride, ! 8.

U. Lynchii, B. and $\mathrm{Br}$.-G, Kelvinside, ! 2 .

[Cumbernauld.

Caeoma mercurialis, Pers.-FG, Duchal, Mr. R. Turner; Ardneil Bank, C. alliorum, Link.-F, Seamill.

Aecidium thalictri, Grev.-B, "Ben Voirlich, near Loch Lomond,"Greville, 10. Ae. grossulariae, Gmel.-F GH, frequent.

Ae. strobilinum, A. and $S$. (=Phelonitis strobilina, Pers.)-A, "Clyde" 14 ; Inveraray, Duke of Argyll, : Sir W. J. Hooker.

Ae. leucospermum, DC.-F, Gourock.

\section{Discomycetes.}

Helvellaceae.

Morchella conica, Pers.-H, Airdrie, Prof. T. King, ! 6. [T. King, ! 6.

M. hybrida, Pers. (=M. semilibera, DC.)-FG, Seamill, !6 ; Darnley, Prof. Helvella crispa, Scop.-F G, Kilmahew, Prof. King; Blair, Prof. King ; 'Torrance, Prof. King. 
H. lacunosa, Afz.-F, W. Kilbride.

H. infula, Schaeff-G, Thoruliebank, !6 ; Yoker, Mr. iV. Stewart. [King.

H. elastica, Bull.-A E, Essachossan, Phillips, 16; Mount Stewart, Prof. Leotia lubrica, Scop.-A F G K L, frequent.

Mitrula phalloides, Bull.-E F, Kames Castle, Greville, 10 ; Gourock, Hennedy Herbarium, ! 7 ; Inmellan, Prof. King.

M. viridis, Pers.-B F G, Loch Lomond, Dickson ; IV. Kilbride, Sorn.

Geoglossum difforme, Fr.-F, W. Kilbride, ! 3.

G. hirsutum, Pers.-F, W. Kilbride, Prof. King.

G. glabrum, Pers.-F, Gourock, Hennedy Herbarium, ! 7.

Spathularia clavata, Schaeff. (=S. flavida, Pers.)-G, Cadder, Prof. King ; Dougalston, Hopkirk, 12 ; Torrance, Prof. King.

\section{Pezizaceae.}

Rhizina inflata, Schaeff.-EF, Hafton, ! Rev. Dr. Stevenson ; W. Kilbride, !3. Peziza (Otidea) onotica, Pers.-A, Essachossan, Trail, 16.

P. (Cochlearia) aurantia, Oeder.-A B G, Inveraray, Stevenson, 16 ; Tarbet, Trail, 16 ; Clydebank, Prof. King; Glasgow, Loudoun.

P. (C.) badia, Pers.-A, Inveraray, Stevenson, 16.

P. (C.) cochleata, Bull.- "Clyde," 14.

P. (C.) Adae, Sadler:-G, Whiteinch, Mr. W. Stewart, : 6.

P. (Pustularia) vesiculosa, Bull.-F G, Seamill, Cadder, Prof. King.

P. (P.) bufonia, Pers.-G, Cadder, Mr. W. Stewart, ! 6.

P. (Humaria) granulata, Bull.-F G K, Firlaystone, W. Kilbride, ! 6 ; Blair, Stevenston, Mains, Torrance, Mauchline.

P. (Pyronema) domestica, Sow.-G, Crosshill, Mr. W. Stewart, ! 9, 17.

Hymenoscypha (Sclerotinia) sclerotiorum, Lib.-F, W. Kilbride, : 6.

H. (S.) tuberosa, Bull.-F, Cumbrae, Hennedy Herbarium, ! 7.

H. (S.) Curreyana, Berk.-F K, W. Kilbride, !6 ; Barr, !8. (As Sclerotium roseum, Kneiff.) - A F, Inveraray, Trail, !6; Ardrossan. [F, W. Kilbride.

H. (S.) baccarum, Schröt. (As sclerotium in berries of Vaccinium Nyrtillus) -

H. (Ciboria) luteo-virescens, Rob.-F, W. Kilbride.

H. (C.) firma, Pers.-F, W. Kilbride, ! 2 .

H. (Trichoscypha) coronata, Bull.-F, W. Kilbride, ! 6.

H. (Cyathoidea) petiolorum, Rob.-F, W. Kilbride, Blair.

H. (C.) virgultorum, Tahl.-F, W. Kilbride.

H. (C.) fructigena, Bull.-F L, W. Kilbride, Barskimming.

H. (C.) scutula, Pers.-F, W. Kilbride, ! 6 ; Ardrossan.

H. (C.) albida, Rob.-F, W. Kilbride.

H. (C.) cyathoidea, Bull.-A F, Glen Aray, Trail, 16 ; W. Kilbride. var solani, Pers._- "Clyde," Trail, 17.

H. (C.) urticae, Pers.-F K, W. Kilbride, Barr.

Chlorosplenium aeruginosum, Fl. Dan.-FGL, W. Kilbride; Craigton, near Nilngavie, Prof. King; Barskimming.

[bride, ! 2 .

Helotium citrinum, Hedw.-A F, Inveraray, Stevenson, 16 ; Largs, W. Kil-

H. salicellum, $F r$.-F, W. Kilbride, ! 6 .

H. epiphyllum, Fr.-F, IV. Kilbride.

H. marchantiae, Berk.-F, W. Kilbride.

H. pruinosum, Jerd.-F G, Largs, W. Kilbride, !6 ; Torrance, Loudoun.

H. herbarum, Pers.-A, Inveraray, Trail, 16.

H. humuli, Lasch.-F, Seamill, ! 8.

Mollisia (Niptera) cinerea, Batsch.-F G, common.

M. (N.) benesuada, Tul.-F, W. Kilbride.

$[: 6$; Cadder, Barr.

M. (Pyrenopeziza) atrata, Pers.-AFGK, Glen Aray, Trail, 16; W. Kilbride, var. oenanthes, Phil.-F, W. Kilbride.

var. ulmariae, Lasch.-F K, W. Kilbride, !6 ; Barr.

var. mercurialis, Fckl.--F, W. Kilbride, !6. 
M. (P.) digitalina, Phil.-F, W. Kilbride, ! 6.

M. (P.) carduorum, Rehm.-F, W. Kilbride, !6.

M. (P.) plantaginis, Fckl.-F, W. Kilbride.

M. (P.) arenevaga, Desm.-F, W. Kilbride, !6 ; Ardrossan, Ardeer.

M. (P.) sphaerioides, Desm.-F, W. Kilbride, ! 6.

M. (P.) rubi, $F r$. - F, W. Kilbride, ! 6.

M. (Dilutella) filicum, Phil.-F, W. Kilbride.

M. (Mollisiella) versicolor, Desm.-F, W. Kilbride.

Lachnea (Sarcoscypha) coccinea, Jacq.-F G, Finlaystone, Prof. King; Innellan, Prof. King; Largs, W. Kilbride, Hamilton Wood, Hopkirk, 12.

Forma aurea.-F, Ardneil Bank Wood.

L. (S.) macropus, Pers.-E, Blair, Prof King.

L. (Sepultaria) fimbriata, Quel.-G, Whiteinch, Mr. W. Stewart, : 6.

L. (Scutellinia) trechispora, B. and $B r$.-F, W. Kilbride, !6 ; Ardeer.

L. (S.) miniata, Fckl.-G, Whiteinch, Mr. W. Stewart, !6.

L. (S.) scutellata, Linn.-FG, W. Kilbride, Kerelaw, !6; Glasgow, Dr. Cooke, also Hennedy, ! 7 .

[Hennedy Herbarium.

L. (S.) stercorea, Pers.-FG, Largs, W. Kilbride, Ardrossan ; Tollcross,

Dasyscypha cerina, Pers.-F, W. Kilbride.

D. lanariceps, Cke. and Phil.-G, Glasgow Botanic Garden, Mr. W. Stewart, !6

D. clandestina, Bull.-F, W. Kilbride.

D. palearum, Desm.-F, W. Kilbride, ! 6 .

D. calycina, Schum.- "Clyde," 14.

var. Trevelyani, Cke.-FG, Kilmahew, W. Kilbride, !17; Mains.

var. Willkommii, Hartig.-A, Glen Aray, Trail, 16.

D. nivea, $\mathrm{Hedw}$.-F G, W. Kilbride, Prof. King ; Mains.

D. virginea, Batsch.-A FG, Inveraray, Stevenson, !16; W. Kilbride, !6 ;

D. bicolor, Bull.-K, Barr.

D. echinulata, Awd.-A, Glen Aray, Trail, 16 ; Essachossan, Trail, 16.

D. crucifera, Phil.-A, Glen Aray, Trail, 16.

D. acutipila, Karst., var. laetior, Karst.-F K, W. Kilbride, Barr.

D. apala, $B$. and $B r$.-A FG K, Inveraray, Trail, 16 ; Lar'gs, W. Kilbride, : 6 ; Ardrossan, Cadder, Newark, near Ayr.

Lachnella escharodes, $B$. and $B r$.-F, W. Kilbride.

L. sulphurea, Pers.-F K, W. Kilbride, !3 ; Ardrossan, Barr.

Tapesia rosae, Pers.-F K, W. Kilbride, !6 ; Barr.

T. prunicola, Fckl.-K, Barr.

T. fusca, Pers.-F, W. Kilbride, !1.

\section{Ascobolaceae.}

Ascobolus vinosus, Berk.-F G, W. Kilbride, !6 ; Ardrossan, Blair, Sorn.

A. glaber, Pers.-F, Fairlie, W. Kilbride.

A. furfuraceus, Pers.-A FG, Inveraray, Stevenson, 16; W. Kilbride, Stevenston, Mains, Torrance, Sorn.

A. immersus, Pers.-F, W. Kilbride.

Saccobobus Kerverni, Crouan.-F, Seamill, :6.

S. violascens, Boud.-F, W. Kilbride, ! 6.

Ascophanus pilosus, Fr., var. ciliatus, Berk.-F, W. Kilbride.

\section{Bulgariaceue.}

Bulgarieae,

Bulgaria inquinans, Pers.-A F G, Inveraray, Stevenson, 16 ; W. Kilbride, Mains, Prof. King ; Cadzow, Prof. King.

Ombrophileae.

Stamnaria equiseti, Hoffm.-F, W. Kilbride, !6, 8 .

Coryne sarcoides, Jacq.-F G, common.

C. urnalis, Nyl.-F G, W. Kilbride, !6 ; Mains, Torrance, Loudoun. 
Calloria fusarioides, Berk.-F K, Cumbrae, Largs, W. Kilbride, !6 ; Ardrossan, Irvine, Barr.

Orbilia xanthostigma, Fr.-F, Largs, W. Kilbride, !3.

O. leucostigma, Fr.-F, Largs, W. Kilbrirle, ! 3.

O. vinosa, A. and S.-A F, Glen Aray, Trail, 16 ; Largs; W. Kilbride, ! 6.

O. marina, Phil.-F, W. Kilbride, !6; Ardrossan.

Agyrium rufum, Fr.-F, Noddsdale, !6.

\section{Dermateaceae.}

Cenangium furfuraceum, Pers.-F, W. Kilbride.

Dermatea ulicis, Cooke.-F, W. Kilbride, !6.

D. livida, B. and $B r$.-F, Dunoon, Plowright, 17.

D. abietina, Auersu.-F, Kilmalcoln, Prof. Scott Elliot, ! 6.

D. rhabarbarina, Berk.-A F, St. Catherine's, Trail, 16; W. Kilbride, ! 6.

\section{Patellariaceae.}

Karschia lignyota, Fr.-F, Dunoon, Plowright, 14.

Patellaria atrata, Hedw.-F, W. Kilbride, :3.

\section{Phacidiaceae. \\ Triblidieae.}

Pseudophacidium callunae, Karst.-F, W. Kilbride, ! 8, 22.

Heterosphaeria patella, Tode.-A F K, Inveraray, Trail, 16; W. Kilbricle, !6; Barr.

Triblidium caliciiforme, Reb.-G, Hamilton, Klotzsch, 14.

Phacidieae.

Coccomyces pini, A. and S.-F, W. Kilbride.

C. dentatus, schmidt.-A, Essachossan, Trail, 16.

Rhytisma acerinum, Pers.-A B F G H, Common.

var. punctatum, Pers.-Common.

Rh. salicinum, Pers.-F G, Seanill, Ardeer, Cambuslang.

Rh. empetri, $B$. White.-F, Noddsdale, : 1 .

Rh. urticae, $\mathrm{Fr}$.-F, W. Kilbride.

Schizothyrium ptarmicae, Desm.-F, W. Kilbride.

Ephelina rhinanthi, Phil.-A B F, Glen Aray, Trail, 16; Hell's Glen, Trail, 16 ; W. Kilbride, Ardrossan.

E. prunellae, Phil.-F, Largs, W. Kilbride, ! 6.

Pseudopeziza divergens, Desm.-F, W. Kilbride, !6.

Ps. trifolii, Bern.-A F K L, Glen Aray, Trail, 16 ; W. Kilbride, Ayr, Barr, Auchinleck.

Ps. cerastiorum, Wallr.-F, W. Kilbride, !6.

Ps. calthae, Hassee (= Phacidium calthae, Phit.)-FG, W. Kilbride, Cadder.

Ps. ranunculi, Wallr.-A F, Glen Aray, Trail, 16 ; W. Kilbride.

Ps. repanda, $F r$. - F, W. Kilbride.

Phacidium ilicis, Lib.- "Clyde," 14 ; common in the stylospore stage known as Ceuthospora phacidioides, lirev., but rarely produces asci.

Trochila craterium, Fr.-F G K, Kilmahew, Largs, W. Kilbride, :6, 8; Kilmarnock, Barr.

T. buxi, Capron.-F, Largs, Seamill, : 6 .

T. lauro-cerasi, Desm.-F K L, common.

Stegia ilicis, $F r$. - B F L, common.

Celidium varians, Dav. (=Arthonia varians, $I_{y}$ l.)-F, W. Kilbride.

Stictideae.

Stictis radiata, Linn.-K, Newark, near Ayr.

S. stellata, Wallr.-F, W. Kilbride, ! 8, 22.

Nemacyclus niveus, Pers._F, W. Kilbride. 
Propolis faginea, $S c h r a d$. (=P. versicolor, $F r$.) -F, Largs, W. Kilbride, !6 ; Ardrossan, Blair.

Ocellaria aurea, Tul. (=Peziza lecanora, Schm. and Kze.)-F K, Lochwinnoch, Dalry, W. Kilbride, Barr.

\section{Hysteriaceae.}

Lophodermium arundinaceum, Schrad.-F, W. Kilbride, !9, 18.

L. hysterioides, Pers.-A, Inveraray, Trail, 16.

L. maculare, Fr:-B, "Clyde," 14 ; Loch Lomond, Greville, 10.

L. herbarum, Fr. - F, W. Kilbride.

L. cladophilum, Lev.-FL, W. Kilbride, !9, 18 ; Barskimming.

L. juniperinum, $F r$. - F, Ardneil Bank.

L. pinastri, Schrad.-F, Gourock, W. Kilbride, Aritrossan.

Acrospermum compressum, Tode.-A, Duniquoich, Trail, 16.

Hypoderma conigenum, Pers.-."Clyde," 14.

H. virgultorum, DC. - F, "Clyde," 14; W. Kilbride, ! 3.

Hysterographium fraxini, Pers.-F, "Clyde," 14 ; W. Kilbride.

Dichaena quercina, Pers.-A, Inveraray, Trail, 16.

D. faginea, Pers.-A, Inveraray, Trail, 16.

D. strobilina, $F r$ - - Clyde," 14.

D. rugosa, Fr.-CClyde," 14.

Colpoma quercinum, Wallr.-F, W. Kilbride.

Hysterium pulicare, Pers.-F, W. Kilbride.

Actidium hysterioides, Fr.-F, W. Kilbride, !9.

\section{Gymnoascean.}

Ascomyces deformans, Berk:-G, near Glasgow.

A. potentillae, Farlow.-A F G, Inveraray, Trail, 16 ; W. Kilbride, Cadder.

A. Tosquinetii, West.-B, Hell's Glen, Trail, 16.

A. Sadebeckii, Johans.-A B, Glen Aray, Trail, 16 ; Hell's Glen, Trail, 16.

A. alni, $B$. and $B r$. - F, W. Kilbride.

A. turgidus, Sadeb.-A F G, conmon.

\section{Perisporiaceae.}

Erysipheae.

Sphaerotheca pannosa, Wallr.-A F, St. Catherines, Trail, 16; W. Kilbride.

S. Castagnei, Lév.-A F G K, common.

S. epilobii, Link:-F, Loch winnoch, Noddsdale.

Podosphaera oxyacanthae, $D C$.--F G L, common.

Phyllactinia corylea, Pers.-."Clyde," 14.

Erysiphe Linkii, Lév.-F, W. Kilbride.

E. Martii, Lév:-F G L, W. Kilbride, Stevenston, Mains, Mauchline, Tarbolton, Auchinleck.

E. umbelliferarum, De Bary.-_"Clyde," 20.

E. graminis, DC.-"Clyde," 20 ; common as Oidium monilioides, Link.

E. communis, Wallr.- "Clyde," 14.

E. galeopsidis, $D C .-\mathrm{F}$, Largs, W. Kilbride.

E. cichoracearum, DC.-F G L, Largs, W. Kilbride, Kilmarnock, Loudoun, Failford.

Uncinula aceris, DC.-A B, Inveraray, Trail, 16 ; Tarbet, Trail, 16 ; Blairmore. Microsphaera berberidis, DC.-"Clyde," !4.

M. grossulariae, Wallr.-"Clyde," 14.

\section{Perisporieae.}

Eurotium herbariorum, Wigg.-F G, common.

Penicillium crustaceum, Linn.--"Clyde," 20.

Capnodium salicinum, $A$. and S-"Clyde," 20.

Asterina veronicae, Lib._A, Glen Aray, Trail 16. 


\section{Pyrenomycetes.}

\section{Hypocreaceae.}

Claviceps purpurea, Fr. (As Sclerotium clavus, DC.) - E F G, Arran, Prof. King ; W. Kilbride, Ardrossan, Ardeer, Sorm.

Cordyceps militaris, Linn.--F G, W. Kilbride, ! 3 ; Cadder.

C. ophioglossoides, Ehrh.-F, Crosbie, near West Kilbride.

C. capitata, Holmsk.-F, Inveraray, Stevenson, 16.

Epichloe typhina, Pers._F G K, Lochwinnoch, Fairlie Glen, W. Kilbride, !8 ; "About Glasgow," Hopkirk, 12 ; Barr.

Calonectria Plowrightiana, Sacc.-F, W. Kilbride, ! 5, 8.

Gibberella pulicaris, $F r$.-F, W. Kilbride.

G. cyanogena, Desm.-F, Seamill, !5.

Hypocrea rufa, Pers.-F G, "Clyde," 15 ; W. Kilbride, ! 3 ; Loudoun, ! 9.

H. moriformis, Cke. and Massee.-F, Ardrossan, ! 8.

Hypomyces aurantius, Pers._-"Clyde," 14.

Nectria cinnabarina, Tode.-FG, common.

N. ribis, Tode.-F K, Seamill, ! 2 ; Barr.

N. sinopica, Fr.-F, W. Kilbride.

N. coccinea, Pers.-F G, W. Kilbride, Ardrossan, Cadder, Loudoun, ! 9.

N. aquifolii, $F r$.-F, W. Kilbride.

N. sanguinea, Sibth.-F, W. Kilbride, !2 ; Ardrossan.

Eleutheromyces subulatus, Fckl. (=Sphaeronema subulatum, Tode.)-B,

Tarbet, Greville, 10.

\section{Dothidiaceae.}

Rhopographus filicinus, $F r$.-F, Cumbrae, W. Kilbride, !5.

Plowrightia ribesia, Pers._F K, "Clyde," 14 ; Seamill, ! 5 ; Barr.

Scirrhia rimosa, A. and S.-F, W. Kilbrirle.

Dothidea tetraspora, $B$. and $B r .-F$, W. Kilbride.

Phyllachora ulmi, Duv._- F, "Clyde," 14 ; Largs, W. Kilbride, Ardrossan.

Ph. heraclei, Fr.-F L, W. Kilbride, Tarbolton.

Ph. graminis, Pers.-F, Largs, W. Kilbride.

Ph. junci, Fr.-A F G K, common.

Ph. trifolii, Pers.-F K, W. Kilbride, Ayr.

Ph. angelicae, Fr.-F G L, Largs, W. Kilbride, Dalry, Ardrossan, Londoun, Mauchline, Tarbolton.

Ph. podagrariae, Roth.-FG L, frequent.

\section{Sphaeriaceae.}

\section{Sphaerieae.}

Cryptospora suffusa, Fr.-F K, W. Kilbride, Ardrossan, Barı.

C. corylina, Tul.-F, W. Kilbride.

Sillia ferruginea, Pers.-F K, Largs, W. Kilbride, Barr.

Ophiobolus porphyrogonus, Tode.-F, W. Kilbride.

O. acuminatus, Sov.-F, W. Kilbride.

O. immersus, Trail.-B, Tarbet, Trail, 16.

Pleomassaria siparia, B. and Br.-F, W. Kilbride.

Cucurbitaria berberidis, Pers.-F, Seamill.

C. laburni, Pers.-F, Seamill, Aritrossan.

C. spartii, De Not.--F K, Lochwinnoch, W. Kilbride, Barr.

Pleospora herbarum, Pers.-F G, common.

Ceratosphaeria crinigera, Cke.-F, Dmoon, Plowright, 14.

Massarina eburnea, T'ul.-F, W. Kilbride, ! 1 ; Dalry.

Chaetosphaeria callimorpha, Mont._-"Clyde," 14.

Hypospila bifrons, Fr._- Clyde," 14. 
Metaphaeria persistens, $B$. and $B r .-\mathrm{F}$, W. Kilbride.

M. dumetorum, Niessl.-F, Seamill, ! 8.

Pseudovalsa lanciformis, Fr.-F, W. Kilbride.

Melanomma pulvis-pyrius, Pers.-F, "Clyde," Stevenson, 14 ; W. Kilbride.

M. Aspegrenii, Fr.-F, W. Kilbride, !5.

Leptosphaeria doliolum, Pers.-B F, Tarbet, Trail, 16 ; Largs, W. Kilbride, !3.

L. conoidea, De Not.-B, Tarbet, Trail, 16.

L. agnita, Desm.-F, W. Kilbride, ! 8.

L. acuta, Moug.-F K, Cumbrae, Largs, W. Kilbride, Ardrossan, Ardeer, Irvine, Barr.

L. pellita, Rabh.- "Clyde," 14.

L. rusci, Wallr.-F, Largs, W. Kilbride, ! 3 ; Blair.

Clypeosphaeria Notarisii, Fckl.-B F, Loch Lomond, Cumbrae, W. Kilbride.

Massaria foedans, Fr.-F, W. Kilbride! 1.

M. inquinans, Tode.-F, W. Kilbride! 1 ; Ardrossan.

Diaporthe pulla, Ntke.-F, Largs, W. Kilbride! 8 ; Perceton.

D. occulta, Fckl.-F, W. Kilbride, !5.

D. inaequalis, Curr.-F, W. Kilbride, : 5 .

D. Ryckholtii, West.-F, Seamill.

D. Landeghemiae, West.-F, Seamill.

D. lirella, Moug. and Nestl.-F, W. Kilbride.

Melanconis stilbostoma, Fr.-F G, W. Kilbride, Sorn.

Gibbera vaccinii, Sow.-F, Noddsdale, !9, 18.

Venturia alchemillae, Grev._B G, Hell's Glen, Trail, 16 ; Sorn, ! 9.

V. exosporioides, Desm.-A, Duniquoich, Trail, 16.

Bertia moriformis, Tode.- "Clyde," 14.

Stigmatea Robertiani, Fr.-B E K, Loch Lomond, Prof. Scott Elliot; Loch winnoch, Cumbrae, W. Kilbride, !1 ; Ardrossan, Barr.

S. ostruthii, $\mathrm{Fr}$.-F, Dalry.

Sphaerella maculaeformis, Pers._-"Clyde," 14.

S. vaccinii, Cke.-A, Glen Aray, Trail, 16.

S. microspila, B. and Br.-A, Essachossan, Trail, 16.

S. cerastii, Rabh.-A, Glen Aray, Trail, 16.

S. rumicis, Desm.-F K L, common.

Didymosphaeria conoidea, Niessl.-F, W. Kilbride.

Botryosphaeria dothidea, Moug. and Fr.-F G, W. Kilbride, Kilmarnock.

B. advena, Ces, and De Not.--F, W. Kilbride.

Ditopella fusispora, De Not.-F, W. Kilbride, !8 ; Ardrossan.

Laestadia faginea, A uersw.-A F G, common.

Xylaria Hypoxylon, Linn.-A F G L, common.

X. carpophila, Pers.-F, W. Kilbride.

Ustulina vulgaris, Tul.-F, W. Kilbride, ! 8 ; Blair.

Hypoxylon coccineum, Bull.-FG, Largs, W. Kilbride, ! 2 ; Loudoun.

H. fuscum, Pers.-F K, Cumbrae, Largs, W. Kilbride, !3 ; Barr.

H. multiforme, $F r$.-F L, W. Kilbride, ! 3 ; Barskimming.

H. rubiginosum, Pers._F, Largs, W. Kilbride.

Daldinia concentrica, Bolt.-F, W. Kilbride.

Anthostomella phaeosticta, Berk.-F, W. Kilbride, ! 8.

Anthostoma turgidum, Fr:- EG, W. Kilbride, ! 1 ; Torrance, Loudoun, ! 8.

Sordaria coprophila, Fr.-F, W. Kilbride.

Chaetomium comatum, Tode.-G, Glasgow, Dr. Scoular, 10 ; "Clyde," 14.

Diatrypella verruciformis, Ehi.h.-G, Loudoun, : 9 .

D. favacea, Fr._F L, W. Kilbride, Barskimming.

Diatrype stigma, Hoffm.-F G L, common.

D. disciformis, Hoffm.-F G L, frequent.

Eutypa flavo-virescens, Ehrh.-FG, Largs, W. Kilbride, Loudoun, !9. 
Cryptosphaeria millepunctata, Grev.-F, W. Kilbride.

Valsa lauro-cerasi, Tul.-F, W. Kilbride.

V. ambiens, Pers.-F K, Largs, W. Kilbride, Barr.

V. salicina, Pers.-F, W. Kilbride.

V. Curreyi, Ntke.-F, W. Kilbride.

Microthyrieae.

Microthyrium microscopicum, Desm.-A F, Glen Aray, Trail 16; W. Kilbride.

\section{Tuberaceae.}

Elaphomyces granulatus, Fr.-A, Inveraray, Stevenson, 16.

E. variegatus, Titt.-F, Crosbie, near W. Kilbride.

\section{FUNGI INCOMPLETI.}

\section{SPHAEROPSIDEAE.}

Sphaerioideae.

Phyllosticta ribicola, $F r$.- F, Seamill.

$\mathrm{Ph}$. garryae, Cke and Harkness.-F, Largs, West Kilbride.

Ph. lonicerae, West.-A F G L, Glen Aray, Trail, 16; W. Kilbride, Loudoun, Barskimming.

Ph. sambuci, Desm.-A F, St. Catherines, Trail, 16 ; Noddsdale.

Ph. ligustri, Sacc.-B F, Tarbet, Trail, 16 ; Seamill, : 9, 18.

Ph. maculiformis, Sacc.-A, Essachossan, Trail, 16.

Ph. tiliae, Sacc. and Speg.-F, W. Kilbride.

Ph. trollii, Trail.-B, Hell's Glen, Trail, 16.

Ph. argentinae, Desm.-A, St. C'atherines, Trail, 16.

$\mathrm{Ph}$. ulmariae, Thïm.-A, Inveraray, Trail, 16.

Ph. teucrii, Sacc. and Speg.-F L, Cumbrae, Largs, W. Kilbride, $: 9$; Dalry, Failford.

Phoma Ryckholtii, Sacc.-F, Seamill.

Ph. Landeghemiae, Ntke.-F, Seamill, :9, 18.

Ph. Mulleri, Cke.-F, Seamill, !9.

Ph. callunae, Karst.-F, W. Kilbride.

Ph. pulla, Sacc.-F, W. Kilbride.

Ph. cylindrospora, Desm.-F, Seamill, :9.

$\mathrm{Ph}$. nepenthes, Cke. and Massee.-G, Kelvinside, ! 2, 11.

Ph. herbarum, West.-F, West Kilbiide.

Ph. acuta, Fi:-B F, Tarbet, Trail, 16 ; Cumbrae, Largs, W. Kilbride.

Ph. malorum, Berk.-F, Seamill.

Ph. laminariae, Cke. and Massee.-F, West Kilbride, ! 2, 11.

Asteroma pyri, Rob. and Desm.-F, Seamill.

A. salicis, Rob. and Desm.-F, W. Kilbride.

A. ulmi, Klotzsch.-A, Inveraray, Trail, 16.

A. prunellae, Purt.--F, Largs, W. Kilbride.

A. juncaginearum, Rabh.-F, W. Kilbride, !5.

Vermicularia trichella, Fr.-F, W. Kilbride.

V. dematium, Pers.-F, W. Kilbride.

V. atramentaria, $B$. and $B r .-F$, W. Kilbride.

Cytospora chrysosperma, Pers.- "Clyde," 14.

C. Curreyi, Sacc.-F, W. Kilbride, !5.

C. lauro-cerasi, Fckl.-F, W. Kilbride.

var. ramulorum, Sacc.-F G, W. Kilbride, Kilmarnock.

Ceuthospora phacidioides, Grev.-FGL, Largs, W. Kilbride, !3 ; Torrance, Loudoun, Barskimming.

Coniothyrium Fuckelii, Sacc.-F, Seamill, !9, 18. 
C. hederae, Desm.-F, Largs, W. Kilbride.

C. kerriae, Le Bret.-F, Seamill, ! 8, 23.

C. Boydeanum, A. L. Smith.-F, Seamill, !8, 24 .

C. conoideum, Sacc.-F, W. Kilbride.

C. concentricum, Desm.-F, Halkshill, Hunterston.

Diplodia pruni, Fckl.-F, Seamill, ! 8.

D. crataegi, West.-F, W. Kilbride.

Ascochyta pallor, B. and Br.-F, Seamill, :9, 18.

A. pisi, Lib.-F, Seamill.

A. potentillarum, Sacc.-A, St. Catherines, Trail, 16.

[leck.

Actinonema rosae, Lib.-FGL, Skelmorlie, IV. Kilbride, Sorn, !9; Auchin-

Darluca filum, Biv.-.A F G, Glen Aray, Trail, 16 ; Cumbrae, W. Kilbride, Sorn, ! 9 .

Diplodina ammophilae, Trail.-F, W. Kilbride, ! 9.

Hendersonia sarmentorum, West., var. berberidis, Trail.--F, Seamill,

H. rubi, West.-F K, W. Kilbride, Ardrossan, Barr.

Prosthemium betulinum, Kunze.-F, W. Kilbride.

Stagonospora, subseriata, Desm., var. moliniae, Trail.-A, Glen Aray, Trail,

Camarosporium laburni, West.-F, Seamill.

C. spartii, Trail.--F, W. Kilbride.

C. macrosporum, B. and $B r$.-F, Seamill.

C. metableticum, Trail.--F, W. Kilbride, Ardeer.

Septoria rosae, Desm.-A, St. Catherines, Trail, 16.

S. hederae, Desm.--"Clyde," 14.

S. ribis, Desm.-A, Duniquoich, Trail, 16.

S. viburni, West.-F, W. Kilbride.

S. unedinis, Desm.-G, Glasgow. Cooke, 26.

S. avellanae, B. and Br.-A B, Inveraray, Trail, 16 ; Hell's Glen, Trail, 16.

S. myricae, Trail.-A, Glen Aray, Trail, 16.

S. gei, Rob. and Desm.-B FG K, Hell's Glen, Trail, 16; W. Kilbride, Ardrossan, Dalry, Kilmarnock, Barr.

S. tormentillae, Desm. and Rob.--A, Inveraray, Trail, 16.

S. hyperici, Desm.-A, Duniquoich, Trail, 16.

S. lychnidis, Desm.-.F, W. Kilbride.

S. stellariae, Rob. and Desm.-B F K L, Hell's Glen, Trail, 16; W. Kilbride, Ayr, Failford, !9.

S. lepidii, Desm.-F G, W. Kilbride. Near Glasgow, Cooke, 26

S. anemones, Desm.-K, Barr.

S. ficariae, Desm.- "Clyde," 14.

S. heraclei, Desm.-A F L, St. Catherines, Trail, 16; W. Kilbride, Ardrossan, Tarbolton.

S. podagrariae, Lasch.-F G L, common.

S. petroselini, Lib.-F, Seamill, ! 8.

S. hydrocotyles, Desm.-F, Cumbrae, W. Kilbrile.

S. lysimachiae, West.-B, Hell's Glen, Trail, 16.

S. prunellae, Trait.-B F, Tarbet, Trail, 16; Hell's Glen, Trail, 16: W. Kilbride.

S. stachydis, Rob. and Desm.-F G K L, common.

S. scabiosicola, Desm.-A FG, Glen Aray, Trail, 16; W. Kilbride, Glasgow, Cooke, 26.

S. obscura, Trail.-B, Hell's Glen, Trail, 16.

S. polygonorum, Desm., var. persicariae, Trail.-A F, St. Catherines, Trail, 16; W. Kilbride.

S. urticae, Desm. and Rob.-B F L, Tarbet, Trail, 16; W. Kilbride, Failford.

S. graminum, Desm., var. moliniae, Trail.-A, Glen Aray, Trail, 16.

Phleospora ulmi, Fr.-A F, Inveraray, Trail, 16 ; Largs, W. Kilbride.

Dilophospora graminis, Desm.-F K, W. Kilbride, ! 8 ; Barr. 
Leptostromeae.

Leptothyrium periclymeni, Desm.-F, W. Kilbride.

L. alneum, Lév.-B F, Hell's Glen, Trail, 16 ; W. Kilbride.

L. rubi, Duby.-F, W. Kilbride, !9, 18.

L. litigiosum, Desm.-F, W. Kilbride.

Melasmia acerina, Lév.-FGK L, common; early stage of Rhytisma acerinum.

M. punctata, Sacc. and Roum.-Common.

Leptostroma virgultorum, Sacc.-F, W. Kilbride.

L. herbarum, Fr.-A, Glen Aray, Trail, 16.

L. filicinum, Fr.-G, Glas»ow, Cooke, 26 .

Discosia artocreas, Tode.-F, W. Kilbride : 5 .

\section{Excipuleae.}

Discella carbonacea, Fr.-F K, W. Kilbride, : 1, 8; Ardrossan, Barr.

\section{Melaxconieae.}

Gloeosporium tiliae, Oud.-F G, W. Kilbride, Blair, Mains, Loudoun, !9.

G. ribis, Lib.-A F, St. Catherines, Trail, 16 ; Largs, Seamill.

G. paradoxum, De Not.-F K, Cumbrae, W. Kilbride, ! 8 ; Barr.

G. affine, Sacc.-G, Kelvinside, !2.

G. elasticum, Cke. and Massee.-G, Glasgow Botanic Garden, ! 11.

G. fagi, Desm. and Rob.-A F, Essachossan, Trail, !16; W. Kilbride, Blair.

G. umbrinellum, B. and Br.-A, Essachossan, Trail, 16.

G. betulae, Lib.-A F, Glen Aray, Trail, 16 ; W. Kilbride.

G. cinctum, $B$. and $C .-\mathrm{G}$, Kelvinside, ! 2 .

Myxosporium griseum, Pers.-F, W. Kilbride.

Cylindrosporium ficariae, Berk.-F, W. Kilbride.

Cryptosporium Neesii, Corda.-F, W. Kilbride, Ardrossan. var. betulinum, Sacc.-F, W. Kilbride.

Libertella rosae, Desm.-F, Seamill.

L. blepharis, A. L. Smith.-F, Seamill, !24.

L. corticola, A. L. Smith.-F, Seamill, :24.

L. ribis, A. L. Smith.-F, Seamill, :24.

I. faginea, Desm.-F L, W. Kilbride, ! 1 ; Barskimming, !9.

L. salicis, A. L. Simith.-F, W. Kilbride, ! 24.

Melanconium sphaeroideum, Link.-F, W. Kilbride.

Barr.

M. bicolor, Nees.-B F G K, Hell's Glen, Trail, 16 ; Largs, W. Kilbride, Sorn,

Thyrsidium hedericolum, De Not.-F, Largs, W. Kilbride, ! 1, 5. var. carpini, Sacc.-F, W. Kilbride, : 8,22 .

Th. botryosporum, Mont.-F, Largs, W. Kilbride, ! 5.

[Trail, 16.

Marsonia potentillae, Desm., var. anserinae, Trail.-A, Essachossan,

Stilbospora macrosperma, Pers.--F, W. Kilbride, : 5.

Coryneum disciforme, Kunze and schm.-F, W. Kilbride.

Scolecosporium fagi, Lib.-F, W. Kilbride, : 5.

Asterosporium Hoffmannii, Kunze.-FG L, Largs, W. Kilbride, ! 5 ; Dalry, Torrance, Barskimming.

Steganosporium piriforme, Hoffm.-F, W. Kilbride, ! 5, 8 .

\section{Hyphoyrcetes.}

\section{Mrecedineae.}

Oospora ovalispora, Sace. and Vogl. (=Torula ovalispora, Berk.)-F, W.

Kilbride, ! 3 .

O. epilobii, Corda.-A, Duniquoich, Trail, 16.

Cylindrium flavovirens, Bon.-F, W. Kilbride.

Oidium erysiphoides, Fr-B F, Tarbet, Trail, 16 ; Lochwinuoch, Largs.

O. leucoconium, Desm.-F G, Skelmorlie, W. Kilbride, Cadder, etc.; comnon. 
0. monilioides, Link.--F G L, Largs, W. Kilbride, Mains, Cadder, Glasgow, Kilmarnock, Failford, Auchinleck.

Botryosporium diffusum, Grev.-F, W. Kilbride.

Trichoderma lignorum, Tode. (= T. viride, Pers.)-F G, W. Kilbride, Glasgow, Cooke, 26 ; Loudoun.

Aspergillus glaucus, Link.-F G, common.

Penicillium glaucum Link.-G, Glasgow, Cooke, 26.

Sporotrichum chlorinum, Link:-G, Glasgow, Cooke, 26.

Botrytis (Polyactis) vulgaris, Link.-"Clyde," 14.

B. (P.) cana, Kunze.-G, Glasgow, Cooke, 26.

B. (P.) cinerea, Pers.-F G, Kilmalcolm, W. Kilbride; Glasgow, Cooke, 26. var sclerotiophila, Kunze.-F, W. Kilbride.

Ovularia sphaeroidea, Sacc.-A F L, Inveraray, Trail, 16; W. Kilbride, Mauchline, Tarbolton.

O. veronicae, Fckl.-B F G L, Tarbet, Trail, 16 ; Noddsdale, Knightswood, Sorn, Barskimming.

O. primulana, Thïm.-B F, Hell's Glen, Trail, 16 ; W. Kilbride, :9.

O. bistortae, Fckl.-A F G, Inveraray, Trail, 16 ; W. Kilbride, Assloss Glen.

0. obliqua, Cke.-A F G, common.

Sepedonium chrysospermum, Bull.-A F G L, common.

Acrostalagmus cinnabarinus, Corda.-F, Seamill, ! 8 .

Trichothecium roseum, Link.-FG, W. Kilbride, :1 ; Glasgow, Cooke, 26 ;

Lambhill Wood, Hennedy Herbarium.

Didymaria Ungeri, Corda.-B F G L, common.

Ramularia violae, Trail.-A, Inveraray, Trail, 16.

R. ulmariae, Cke.-B F, Hell's Glen, Trail, 16; W. Kilbride, Ardrossan.

R. epilobii, Schn.-A BG, Glen Aray, Trail, 16; Hell's Glen, Trail, 16 ; Loudoun, !9.

R. valerianae, Speg.-F G, W. Kilbride, Loudoun, !9.

R. lampsanae, Desm.-B K, Hell's Glen, Trail, 16; Barr.

R. pruinosa, Fckl.-A, Essachossan, Trail, 16.

R. variabilis, Fckl.-A, Inveraray, Trail, 16.

R. calcea, Desm.--A F G, Inveraray, Trail, 16; W. Kilbride, Mains, Loudoun.

R. plantaginis, E. and M.-A B, Inveraray, Trail, 16 ; Tarbet, Trail, 16.

R. pratensis, Sacc.-A B, Inveraray, Trail, 16; Hell's Glen, Trail, 16; 'Tarbet, Trail, 16.

R. urticae, Ces.-A B L L, Essachossan, Trail, 16 ; Tarbet, Trail, 16 ; W. Kilbride, Auchinleck.

R. rufibasis, B. and Br.-A E, Glen Aray, Trail, 16 ; Tighnabruaich, Dr. B. White, 14.

Helicomyces roseus, Link:-F, W. Kilbride, : 8 .

\section{Dematieae.}

Hormiscium pithyophilum, Nees.-B G, Roseneath, Mr. J. Paterson, : 7, 21 ; Glasgow, Cooke, 26.

Periconia byssoides, Pers.-F, W. Kilbride.

P. nigrella, Berk.-F, W. Kilbride.

Camptoum curvatum, Kunze and Schm.-E, Portincross.

Goniosporium puccinioides, Kunze and Schm.-F, W. Kilbride.

Zygodesmus fuscus, Corda.-FG, West Kilbride, !1.; Blair, Mains, Loudoun, !9.

Graphiopsis chlorocephala, Fres.-A, Essachossau, Trail, 16.

Dematium hispidulum, I'ers.-G, Glasgow, Cooke, 26.

Clasterosporium fungorum, Fr.-FG, W. Kilbride, Glasgow, Cooke, 26.

Fusicladium dendriticum, Fckl.-F, Seamill.

Polythrincium trifolii, Kunze and Schm.-FKL, W. Kilbride, Ayr, Auchinleck. 
Cladosporium fulvum, Cke.-G, near Glasgow.

C. herbarum, Link.-F, W. Kilbride.

Cercospora ii, Trail.-A, Essachossan, Trail, 16.

C. microsora, Sacc.-A, Inveraray, Trail, 16.

C. mercurialis, Fckl.-A, Inveraray, Trail, 16 ; St. Catherine's, Trail, 16.

Heterosporium algarum, Cke. and Massee.-F, W. Kilbride, !2.

Dendryphium comosum, Wallr.-F, W. Kilbride.

Coniothecium amentacearum, Corda.-F K, W. Kilbride, Barr.

C. betulinum, Corda.--F, W. Kilbride.

Speira toruloides, Corda.-F, Seamill.

Tetraploa aristata, B. and Br.-F, W. Kilbricle.

Macrosporium cheiranthi, Fr.-F, Seamill.

Fumago vagans, Pers.-F, W. Kilbride.

\section{Stilbeae.}

Isaria farinosa, Dicks.-F, W. Kilbride, !3.

I. arachnophila, Ditm.-A, Essachossan, Trail, 16.

I. citrina, Pers.-G, Cadder, Heunedy Herbarium, !7.

Isariopsis carnea, Oud.-A F, Inveraray, Trail, 16; W. Kilbride.

I. albo-rosella, Desm.-F L, W. Kilbride, Ardrossan, Auchinleck.

Ceratium hydnoides, A. and S.-"Clyde," 15.

\section{Tubercularieae.}

Tubercularia vulgaris, Tode.-F G, conmon.

T. nigricans, Bull.-F, W. Kilbride.

T. confluens, Pers.-F, W. Kilbride, Ardrossan.

T. sarmentorum, Fr.-F, W. Kilbride.

T. herbarum, $F r$.-F, W. Kilbride.

Hymenula vulgaris, Fr.-F, Seamill.

Illosporium roseum, Schreb.-F G, "Clyde," 15 ; West Kilbride, Ardrossan, Sorn.

Volutella citrina, Cke. and Massee.-F, Seamill, ! 11.

Bactridium flavum, Kunze and Schm.-F, Ardneil Bank Wood, : 3.

Fusarium roseum, Link.-F, W. Kilbride.

\section{Sclerotia.}

Sclerotium roseum, Kneiff.-A F K, Inveraray, Trail, 16; W. Kilbride, Ardrossan, Barr.

S. durum, Pers.-A E, very abundant.

S. nervale, Fr.-A F, Essachossan, Trail, 16 ; W. Kilbride.

S. semen, Tode.-F, Seamill, : 2.

S. hyacinthi, Guép.-A, Duniquoich, Trail, 16.

S. clavus, $D C$.-E F G, Arran, Prof. T. King; W. Kilbride, Ardrossan, Ardeer, Sorn. 


\section{HYMENOMYCETES AND GASTROMYCETES.}

STUDY of Fungi in the West of Scotland may be said to date from the visit of the Cryptogamic Society to Glasgow in 1880. Hennedy, it is true, had taken it up to some extent, and has left a considerable number of specimens of the Polypori, correctly named, in the Technical College Museum, but he seems to have had no helpers or successors, until the late Professor Thomas King, with one or two other members of the Natural History Society, entered upon it at the date named. It is due to the visits of the Cryptogamic Society, of which Mr. King afterwards became Local Secretary and Treasurer, and greatly to his enthusiasm, that there is any material for a record of this section of the Cryptogams of this district.

The list has been drawn up, as to arrangement and nomenclature, according to the Rev. Dr. Stevenson's Hymenomycetes Britannici, and, for the Gastromycetes, that in Mr. George Massee's British Fungus Flora.

In these two families, as given in the works named, there are 1749 species of which 538 have been recorded for the Clyde area. The district, however, has not been very thoroughly examined, except in those sections easily accessible ; indeed for two of them, D-I (Kintyre, south of Ardrishaig), and $\mathrm{K}$ (South Ayrshire), there is not a single record, while in others the number is comparatively few, as shown in the following statement for the various sections: A, 172 species ; B, 178; C, 82 ; D-I, 0 ; E-J, 61 ; F, 278, $\mathrm{G}, 356 ; \mathrm{H}, 87$; K, 0 ; L-M, 128.

The following species, not in Hymenomycetes Britannici, are in the list: Ag. (Psilocybe) sarcocephalus, Fr. Craigends, (F.) R. B. Johnston ; Bolbitius bulbillosus, Fr. Largs, (F.) W. S. ; Russula azurea, Bres., and R. caerulea, Pers., Rossdhu, (B.) Dr. Plowright; var. nivea, Pers. of R. fragilis, and var. niveus of Boletus scaber, Buchanan Castle, (C.) Dr. Plowright; Polyporus sanguineus, Fr., P. pergamenus, Fr., and Stereum lobatum, Kunze, Botanic Gardens, (G.) R. Paterson, certified by Dr. M. C. Cooke ; Cyphella capula, Fr., var. cernua, Schum., West Kilbride, (F.) D. A. Boyd ; and three Clavariae, certified by Dr. Cooke as C. fragilis, C. helvola, and C. candida, Botanic Gardens, (G.) W. S.

The records of the Cryptogamic Society of Scotland, the lists of the late Professor Thomas King, Mr. D. A. Boyd, West Kilbride, and the local secretary, and the collections made during the course of the work by willing assistants of the Natural History and Andersonian Societies, are the main sources from which the material has been drawn. The list was submitted to and approved by the Society at Boat-of-Garten, 18th September, 1900. The Society's referees for rare, uncommon, and critical species were: the Rev. John Stevenson, LL.D., F.R.S.E., Glamis ; Rev. James Keith, LL.D., Forres ; Rev. David Paul, LL.D., Edinburgh; and Dr. C. B. Plowright, Kings Lynn, of the British Mycological Society ; to all of whom thanks are due. Thanks are also due to Mr. Lymburn and Mr. Barrett for facilities for research in the University and Mitchell Libraries; and to Mr. G. F. Scott Elliot, M.A., B.Sc., F.L.S., F.R.G.S., for access to records and aid in 
collecting; to Mr. R. B. Johnston, Honorary Secretary of the Andersonian Naturalists' Society, who collated the material for the Gastromycetes; and to him and others for researches in various districts.

William Stewart,

Local Secy. Crypt. Soc. Scot.

\section{FUNGI (HYMENOMYCETES).}

Order I. Agaricini.

Genus. I. AgArices.

Series I. Leucospori.

Sub-genus I., Amanita, Fr.-A. virosus, Fr.-G, Cadder Wilderness.

A. phalloides, $F r$-A B F G.

A. mappa, Fr.-A B C, Inveraray, Rossdhu, Drymen.

A. muscarius, Linn.-A B E \& I F G L \& M.

A. pantherinus, $D C$. - F G, Hafton, Loudon Castle, Cadder WV.

A. excelsus, Fr.-G, Cadder W.

A. rubescens, l'ers.-A B C E \& I F G H L \& M.

A. spissus, Fr.-F G H, West Kilbride, Cadder W., Craigton Wood, London Castle, Synington.

A. nitidus, $F r$. - B, Rossthu.

A. vaginatus, Bull.-A B C E \& I F G H L\& M.

var. fulvus, Schaeff.-FG, Cadder W., Craigton W., Loudon Castle.

Sub-genus II., Lepiota, Fr.-A. procerus, Scop.-E\& I, Mountstuart.

A. acutesquamosus, Weinm.-G, Kelvingrove Park, Paisley.

A. clypeolarius, Bull.-G, Bothwell (Hook. Fl. Scot.).

A. cristatus, A. and S.-B F G H L \& M.

A. cepaestipes, Sow.-F G, Greenock, Innellan, Botanic Gardens.

A. carcharias, Pers.-F G, W. Kilbride, Gleniffer, Cathkin Park.

A. granulosus, Batsch.-A B F G L\& M.

Sub-genus III., Armillaria, Fr.-A. melleus, $F l$. Dan.-A B E\& I F G H $\mathrm{L} \& \mathrm{M}$.

A. robustus, A. and S.-G, Cathkin Park.

A. mucidus, Schrad.-A E\& I G, Inveraray, Bute, Cadder W.

Sub-genus IV., Tricholoma, Fr.-A. portentosus, Fr:-G, Cadzow Forest, East Kilbride.

A. resplendens, $F r$.-B C F G L \& M.

A. spermaticus, $\mathrm{Fr}$.-H, Lanark.

A. fulvellus, $F r$.-F, Kelburne, W. Kilbride.

A. flavobrunneus, $F r$.-B F, Roseneath, Kelburne, W. Kilbride.

A. albobrunneus, Pers.-B G, Rossdhu, Craigton, W.

A. ustalis, Fr.-B F G, Ardlui, Kelburne, Rouken Glen.

A. rutilans, Schaeff.-A B E \& I F G.

A. variegatus, Scop.-G, Cadder, W.

A. columbetta, Fr.-G, Kennishead, Rouken, Craigton W.; Cadder W. ; Cathkin Pk.

A. imbricatus, Fr.--F H, Inuellan, Kilmalcolm, Douglas Support.

A. vaccinus, Pers.-L \& M, Ballochmyle.

A. terreus, Schaeff.-A B E \& I F G L \& M.

A. saponaceus, $\ddot{F r}$.-A B C F G.

A. murinaceus, B.-G, Hawkhead.

A. virgatus, Fr.-B F G H L \& M.

A. gambosus, Fr.-F G, Langbank, Kelvingrove, Pk.

A. albus, Schcueff-A, Inveraray.

A. personatus, Fr.-G, Bishøpbriggs, Capelrig. 
A. nudus, Bull.-G, Cathkin Pk.

A. cinerascens, Bull.-G, Bothwell Park, Cadder W.

A. panaeolus, $F r$. - G, Kelvingrove Pk.

A. grammopodius, Bull.-B, Roseneath.

A. subpulverulentus, Pers.-G, Kelvingrove Pk.

A. sordidus, Fr.-G, Bot. Gardens, Cadder W.

Sub-genus V., Clitocybe, Fr.-A. nebularis, Butsch.-A C E \& I F G.

A. clavipes, Pers.--B, Rossdhu.

A. odorus, Bull.-CG, Drymen, Cadder W

A. cerussatus, Fr.-G, Clyde Shipyards.

A. phyllophilus, Fr.-A, Inveraray.

A. pithyophilus, Secr.-G, E. Kilbride.

A. dealbatus, Sow.-G, Clyde Shipyards, Craigton W. ; Cadder W.

A. gallinaceus, Scop.-A E \& I G, Inveraray, Arran, Hamilton Pk.

A. aggregatus, Schaeff.-G, Clyde Shipyards.

A. fumosus, Pers.-F G L \& M, Craigends, Craigton W.; Paisley, Ballochmyle.

A. tumulosus, Kalchbr.-G, Clyde Shipyards.

A. maximus, Fl. Wett.-F G, Loch wimnoch, Cadzow For.

A. infundibuliformis, Schaeff.-A B F G.

var. membranaceus, Fr.-. E G H, Innellan, Cadzow For., Milton-Lockhart.

A. spinulosus, Stev. and Sm.-G, Bothwell Pk.

A. geotropus, Bull.-T, Dalry.

A. flaccidus, Sow.-A, Inveraray.

A. cyathiformis, Fi:-A F G, Inveraray, Cathkin, Bothwell Pk.

A. brumalis, $F r$. - G, Cadder W.

A. metachrous, $F$ :--B, Blairmore.

A. fragrans, Sow.--A B C F G.

A. laccatus, Scop.-A B CE \& I F G H L \& M.

var. amethystinus, Bolt.-B CG H L \& M.

Sub-genus VI., Collybia, Fr-A. radicatus, Rehl.--A B F G H L \& M.

A. platyphyllus, Fr.-B G, Rossdhu, Cadder W. ; Loudon Castle.

A. fusipes, Bull.-G, Craigton W.

A. maculatus, $A$. and $S-A$ E \& I F G H L \& M.

A. butyraceus, Bull.-A B E \& I F G L \& M.

A. velutipes, Curt.-A F G H L \& M.

A. vertirugis, Cke-- G, Bot. Gardens.

A. confluens, Pers-A B F G.

A. conigenus, Pers.-A F, Inveraray, W. Kilbride.

A. cirrhatus, Schum.-G, Bot. Gardens.

A. tuberosus, Bull.- B F L \& M, Roseneath, Bridge of Weir, Ballochmyle.

A. dryophilus, Bull.-A B CF G L \& M.

A. rancidus, Fr:-C, Drymen.

A. ambustus, $F_{i}$ :-C, Drymen. Sub-genus VII., Mycena, Fr.-A. rubro-marginatus, Fr:-G, Cadder W.

A. purus, Pers.-A F GL \& M.

A. luteo-albus, Bolt.-C, Drymen.

A. flavo-albus, $F r$ - A C, Inveraray, Drymen.

A. rugosus, $F r$.-A B FG.

A. galericulatus, Scop.-A B C F G H L \& M.

A. polygrammus, Bull.-A C F G.

A. dissiliens, Fr.-G, Clyde Shipyards.

A. alkalinus, $F r-A$ B E G L \& M.

A. ammoniacus, $F r$. C F G L \& M.

A. filopes, Bull.-A, Inveraray.

A. amictus, Fr.-G, Craigton, W. 
A. acicula, Schaeff-B, Rossdhu, Blairmore.

A. haematopus, Pers.-G, Loudon Castle.

A. sanguinolentus, $A$. and S.-A B F G L \& M.

A. galopus, Pers.-A B C F G L \& M.

A. leucogalus, Cke.-B, Rossdhu.

A. epipterygius, Scop.-A B F G.

A. vulgaris, Pers.-A G, Inveraray, Hamilton Pk.

A. stylobates, Pers.-A, Inveraray.

A. tenerrimus, Berk:-B, Blairmore.

A. sacchariferus, $B$. and $B r$. var. electicus, Buck-F, Seamill.

A. pterygenus, $\mathrm{Fr}$.-F G, W. Kilbride, Hamilton Pk.

A. corticola, Schum.-B, Rossdhu.

Sub-genus VIII., Omphalia, Fr.-A. pyxidatus, Bull.-F, Innellan.

A. muralis, Sou:-F, Finlay stone.

A. umbelliferus, Limn.-A B C F G H.

A. fibula, Bull.-CG, Drymen, Hamilton Pk. ; Loudon Castle. var. Schwartzii, $F$ :-C, Drymen.

A. gracillimus, Weinm.-B G, Blairmore, Nitshill.

Sub-genus IX., Pleurotus, Fr.-A. corticatus, $F \%$-F, Johnstone Castle,

Finlaystone.

A. ulmarius, Bull.-G, Clyde shipyards.

A. ostreatus, Jacq.-G L \& M, Kelvinside, Dalmellington.

A. salignus, $A b b$. d. Schw.-F L \& M, Largs, Dalmellington.

A. serotinus, Schrad.-FG, W. Kilbride, Cadder W. ; Nitshill, Craigton W.

A. mitis, Pers.-A B F G.

A. porrigens, Pers.-A B F, Inveraray, Ardentinny, Rossdhu, Duchal.

A. atro-caeruleus, $F r$-C, Drymen.

A. applicatus, Batsch.-B F, Rossdhu, W. Kilbride.

Series II-Hyporhodii.

S'ub-genus X., Volvaria, Fr.-A. speciosus, Fr.--G, Garnkirk.

Sub-genus XII., Pluteus, Fr.-A. cervinus, Schaeff---A B C F G L\& M.

A. umbrosus, Pers.-G, Bishopbriggs.

Sub-genus XIII., Entoloma, Fr.-A. sinuatus, Fr.-C, Drymen.

A. jubatus, $F$. - A BCFG.

A. sericellus, Fr.-BL\& M, Roseneath, Sorn.

A. clypeatus, Limn.-F G H, Dalry, W. Kilbride, Neilston, Gleniffer, Monkland glen.

A. rhodopolius, Fr.-B F G L \& M.

A. costatus, Fi:-G, Cathkin Pk.

A. nidorosus, $F \%$-A B E\& I F.

Sub-genus XIV., Clitopilus, Fr-A. prunulus, Scop.-A B F G H L\& M. Sub-genus XV., Leptonia, Fr.-A. lampropus, Fr.-A C, Inveraray,

Drymen.

Sub-genus XVI., Nolanea, $F_{r}$-A. Aascuus, Pers.-A B E \& I F G L \& M.

A. pisciodorus, Ces.-B E\& I F G L\& M.

Sub-genus XVIII., Claudopus, Worth. Smith.-A. variabilis, Pers.-B F, Rossdhu, Dalry, W. Kilbride.

\section{Series III. Dermini.}

Sub-genus XIX., Pholiota, Fi--A. aureus, Matt.-G, Kelvingrove Pk.

Kelvinside.

A. caperatus, Pers.-H, Maudslie Castle.

A. terrigenus, Fr.-G, Clyde Shipyards, Kelvingrove Pk.

A. erebius, Fr.-. G, Hamilton Pk., Cathkin Pk. 
A. togularis, Bull.-G, Kelvingrove $\mathrm{Pk}$.

A. durus, Bolt.-F G, W. Kilbride, Rutherglen.

A. praecox, Pers.-(i, Kelvinside.

A. radicosus, Bull.- F, Hafton.

A. heteroclitus, $F r$ :-G, Cadder W.

A. aurivellus, Batsch.-A, Inveraray.

A. squarrosus, Miill.-A F G H L\& M.

A. spectabilis, Fr:-F G, W. Kilbride, Finlaystone, Cadzow For., Cadder W., Craigton W., Kelvingrove Pk., Bot. ( Gardens.

A. adiposus, $F r$ - F, Hafton.

A. flammans, $F$ :-A F G L \& M.

A. mutabilis, Schaeff.--A B F GH L\& M.

A. marginatus, Britsch.-FG, W. Kilbride, Bothwell Pk., Clyde shipyards.

Sub-genus XX., Inocybe, $F r$-A. hystrix, $F r$ - B CF G H.

A. hirsutus, Lasch.--A, Inveraray.

A. lacerus, Fi:-L\& M, Barskimming.

A. obscurus, Pers.-F, Finlaystone.

A. haemactus, Berk. and Cke.-G, Loudon Castle.

A. rimosus, Bull.-A CFGH L\& M.

A. eutheles, B. and Br.-B, Rossdhu.

A. geophyllus, Sow.-A B F $($.

A. trechisporus, Berk.-F G H, W. Kilbride, Cadder W., Craigton, W., E. Kilbride, Douglas Sup.

Sub-genus XXI., Hebeloma, Fr-A. fastibilis, Fr-C F, Drymen, Kelburne.

A. glutinosus, Lind.-A GH, Inveraray Cadder W., Fiddler's Gill.

A. mesophaeus, $F \%$ :-BCGL\& M.

A. subcollariatus, $B$. and $B r$ - $:$, Cadzow For.

A. crustuliniformis, Bull.-F G L\& M, Largs, Kilmahew, Kelvingrove Pk., Bot. Gardens, Cadder W., Craigton W., Loudon Castle, Barskimming.

A. longicaudus, Pers.-G, Craigton W., Yoker.

Sub-genus XXII., Flammula, $F r-$ A. floccifer, $B$. and $B r .-F, W$. Kilbride.

A. lentus, Peis.-C, Drymen.

A. gummosus Lasch.-G, Cadder WV.

A. spumosus, $F r$ - G Clyde Shipyards.

A. carbonarius, $F r$. G, Clyde Shipyards, Cadder W.

A. astragalinus, $F_{r}$ :-G, Cadder W.

A. alnicola, $F r$. - G, Craigton W., Cadder W., Kelvingrove Pk.

A. flavidus, Schaeff.--A BG H L\& M.

A. inopus, $F i$-C CG, Drynen, Cadder W., Hamilton Pk.

A. sapineus, $F r$.-CGL\& M.

A. scambus, Fr.-A FG L \& M.

Sub-genus XXIII., Naucoria, Fr.-A. cucumis, Pers.-G, Hamilton Pk.

A. semi-orbicularis, Bull.-F G, Loch Libo, W. Kilbride, Kilmalcolm, Kelvinside, Cadder W., Craigton W.

A. erinaceus, $F r$ :-B, Roseneath.

A. escharoides, $F$ r.-B, Rossdhu.

Sub-genus XXV., Galera, $F r$-A. tener, Schaeff.-A B F G.

A. ovalis, $F r$ - G, Hamilton Pk.

A. hypnorum, Batsch.-A B CFGH L\& M.

Sub-genus XXVII. Crepidotus, Fr.--A. alveolus, Lasch.-H, Biggar.

A. mollis, Schaeff.-A B FG L \& M.

A. calolepis, Fr:-B F, Camis Eskan, Largs, W. Kilbride, Dumlop. 
Series IT: Piatelli.

Sub-genus XXIX., Psaliota, Fr.-A. arvensis, Schaeff.-C E \& I F G.

A. campestris, Linn.-E \& I FG.

A. haemorrhoidarius, Kalch.-E \& I, Blackwaterfoot.

Sub-genus XXX., Stropharia, $F \%$-A. aeruginosus, Cu,t.-A B F G H.

A. stercorarius, $F i$ - F G H, Imellan, Largs, Kilmalcolm, Craigton W. Kelvinside, Hamilton Pk., Douglas Sup., Dullatur.

A. semiglobatus, Batsch.-A E\& I F G L\& II.

A. scobinaceus, Fr.-F ( ${ }^{4}$, Castle Semple, Cadder W., Craigton W.

sub-genus XXXI., Hypholoma, Fr.-A. sublateritius, S'chaeff.--B F G L \& M.

A. capnoides, Fr.-B F G H.

A. epixanthus, Fr-BFG, Luss, W. Kilbride, Kilmalcolm, Dalry, Cadder W., Craigton W.

A. storea, $F r$ :- ( $\div$, Cadder W.

A. lachrymabundus, Fr.-G, Bothwell, (Hook. Fl. Scot.), Hamilton Pk., Calderwood.

A. pyrotrichus, Holmsk.-CGL\& II, Drymen, Loudon Castle, Ballochmyle.

A. velutinus, Peis.-B C F $\&$ H L\& M.

A. appendiculatus, Bull.-BFGL\& M.

Sub-genus XXXII., Psilocybe, F\%-A. areolatus, Klotsch.-G, Bot. Gardens, (Stev. Birt. Fun., v. i., p. 326).

A. semilanceatus, Fr.-A B CE\& I F G H L \& M.

A. spadiceus, Fi:-FG, W. Kilbride, Cadzow For.

A. cernuus, Fl. Dan.-FG, Innellan, Kelvinside, Kelvingrove Pk., Cadder W.

A. foenisecii, Pers.-A ( 4 , Inverarav, Hamilton Pk.

A. sarcocephalus, Fr.-F, Craigends.

\section{Series I. Coprinurii.}

Sub-genus XXXIV., Panaeolus, Fr.-A. separatus, Linn.-A FG, Inveraray, Strone, Craigton W., Cadder W.

A. leucophanes, $B$. and $B r$.- B, Ardlui.

A. fimiputris, Bull.-A, Inveraray.

A. retirugis, $F r$. - F, W. Kilbride,

A. campanulatus, Linn.--BCF G L \& M.

A. papilionaceus, Fr.-B G, Camis Eskan, Hamilton Pk., Cadder W.

Sub-genus XXXV., Psathyrella, Fi-A. gracilis, $F$ :-A G, Inveraray, Loudon Castle.

A. disseminatus, Pers._F G, Ardgowan, Kilmalcolm, Kelvingrove Pk.

\section{Genus III. Coprinus, Pers.}

C. comatus, Fr.-BFG, Roseneath, Ardgowan, Paisley, Hamilton Pk., Craigton W., Kelvingrove Pk., Loudon Castle.

C. atramentarius, $F r$ - A B F G L \& M.

C. fimitarius, $F r$. - G, Cadder W.

C. niveus, $\mathrm{Fr}$. - G, Hamilton Pk.

C. micaceus, Fr.-A F G H L \& M.

C. deliquescens, Fr.-B, Rossdhu,

C. lagopus, $F r$-G, Cadder W.

C. plicatilis, Fr.-A E\& I F G H L\& M.

Genus IV. Bolbitius, Fr.

B. hydrophilus, $F r$--BG, Roseneath, Craigton W.

B. titubans, Fr.-G, Bearsden. 
B. bulbillosus, Fr:-FG, Largs, Kelvingrove Park. New to Britain. It appeared on Largs Green in 1895, 1896 and 1897, in considerable numbers, and sparingly in Kelvingrove Park, in 1897 and 1898. It is distinguished by a strikingly margined bulb, and the entire absence of striae on the pileus.

\section{Genus V. Cortinarius, $F$ r. \\ Tribe I. Phlegmacium, Fr.}

C. triumphans, $F_{i}$.- F, Kilmalcolm.

C. varius, $F r$.-E\& I, Arran.

C. cyanopus, Fr.-FG L\& M, Ardgowan, Cadder W., E. Kilbride, Loudon Castle, Barskimming.

C. largus, $F r$ - A, Inveraray.

C. multiformis, $F$, - C, Drymen.

C. caerulescens, $F$ r-B F G, Luss, Kelburne, Cadder W.

C. purpurascens, $F r$ - A BCG.

Tribe II. Myracium, Fr.

C. collinitus, $F r$.--F, Ardeer.

C. elatior, $F r$.-A C F G L \& M.

C. pluvius, $F$ r:-B, Rossdhu.

Tribe II: Dermocybe, $\mathrm{Fr}$.

C. ochroleucus, $F r$.-C, Drymen.

C. tabularis, $F$ :-G, Kelvingrove $\mathrm{Pk}$.

C. caninus, $F r:-\lambda$, Inveraray

C. anomalus, Fr:-BCG, Luss, Drymen, Craigton W.

C. sanguineus, Fr:-A BG, Inveraray, Blairmore, Craigton W.

C. cinnamomeus, $F r$.-A B C FGH L \& M.

\section{Tribe V. Telamoniu, $F r$.}

C. torvus, Fr.--A B G, Inveraray, Rossdhu, E. Kilbride, Loudon Castle.

C. armillatus, $F r$.-L\& M, Barskimming.

C. hinnuleus, Fr.-A B C, Inveraray, Luss, Roseneath, Rossdhu, Drymen

C. psammocephalus, $F r$. - A, Inveraray.

C. incisus. Fr.-G, Kelvinside.

C. iliopodius, $F r$. - A F, Inveraray, Kilmahew.

C. hemitrichus, Fr:-GL\& M, Caider W., Barskimming.

C. paleaceus, $F i$.-BC, Rossdhu, Drymen.

C. leucopus, $F r$.-C, Drymen.

Tribe VI. Hygrocybe, Fr.

C. decipiens, $F r$. G G Craigton $\mathrm{W}$.

C. acutus, Fr.-B, Rossdhu.

Genus VI. Gomphidius, $F r$.

G. glutinosus, Fr.-F L\&M, Kelburne, Lochwinnoch, Innellan, Barskimming, Ballochmyle.

G. viscidus, Fr.-Fi, Largs, Innellan.

Gexus VII. Paxillus, $F r$.

P. giganteus, $F r$-C L \& M, Drymen, Barskimming.

P. lepista, $F$ : - G, Kelvingrove Pk.

P. involutus, $F r$.-A B C E \& F G H L \& M.

Genus VIII. Hygrophorus, $F r$.

Section I. Limacium, Fr.

H. hypothejus, $F r$ - - A P FG L \& M.

H. cerasinus, Berk.-L\& M, Barskimming, Ballochmyle. 
Section II. C'emarophyllus, Fr.

H. leporinus, $F$,--B, Luss.

H. pratensis, $F r$.-AB CE\& I F $\&$ L\& M.

H. virgineus, $F r-A$ B C F G H L\&M.

H. fornicatus, $F r$. C , Drymen.

H. Clarkii, $B$. and $B r--B$ G, Luss, Kelvingrove Pk.

H. lacmus, Fr.-.-B, Rossdhu.

Section III. Hygrocybe, Fi.

H. laetus, $F r$.--BG, Rossdhu, E. Kilbride.

H. vitellinus, $F r$ :-B, Roseneath, Rossdhu.

H. ceraceus, $F r$-C, Drymen.

H. coccineus, $F r$ - A B F G H.

H. miniatus, $F r$ - C E \& I F G.

H. puniceus, $F r-$ A B F G H.

H. conicus, $F r$ - A B F G L\& M.

$\mathrm{H}$. calyptraeformis, $B$. and $B r$.-A B C F G.

H. chlorophanus, $F \%-$ A B F G H L\& M.

H. psittacinus, Fr.-A B CE\& I F $\&$ H L \& M.

H. nitratus, Fr.-A, Inveraray.

\section{Geves IX. Lactarius, $F \%$.}

Tribe I. Piperites.

L. torminosus, Fr.-A BCE\&IF $\&$ H L\& M.

L. turpis, Fr.-A C FGH L\& M.

L. insulsus, Fr.-F G, Kilmalcolm, Craigton W., E. Kilbride, Lennox Castle.

L. blennius, Fr.-A B F G H L\& M.

L. hysginus, $F r$ - - B, Camis Eskan.

L. circellatus, Fr.-C, Drymen.

L. pyrogalus, Fr-C F G, Drymen, Innellan, cailder W.

L. chrysorheus, Fr.-E\& J Colintraive.

L. piperatus, $F$ - A E \& I F G.

L. vellereus, Fr--A B F G L\& M.

L. exsuccus. Smith.-E\& I, Colintraive.

L. deliciosus, Fr.-B F G H L\& M.

Tribe II. Dapetes.

Tribe III. Russulares.

L. pallidus, $F r$.--A BCG.

L. quietus, Fr.-A BE\& I FGH L\& M.

L. theiogalus, Fr.-G, Fiddler's Gill.

L. vietus, Fr-C L \& M, Drymen, Barskimming.

I. rufus, Fr.-A B E\& I F G H L\& M.

L. helvus, Fr.-C C, Carlder W.

L. glyciosmus, Fr.-A B F G L\&M.

L. fuliginosus, $F r$ GH, Craigton W., Loudon ('astle, Fiddler's Gill, Dullatur.

L. picinus, Fr. - G, Lennox Castle.

L. lilacinus, Lasch.- (', E. Kilbride.

L. volemus, Fr.-E \& I F, Colintraive, Innellan, Sandbank.

L. serifluus, $F r$ - C E \& I G L \& M.

L. mitissimus, $F r$. A B F G L \& M.

L. subdulcis, Fr:-A B F G L \& M.

L. camphoratus, Fr.-FG H, Tullichewan, Craigton W., Cadder W., E. Kilbride, Dullatur. 
Gevus X. Russula, Pers.

Section I. Compactae.

R. nigricans, $F \%$ - A BCE\& I F G H L \& I.

R. adusta, $F_{i}$ :-A F G H L \& M.

R. delica, $F r$. A BCE\&I FG.

R. rosacea, $F_{r}$.-.-F, Largs.

Section II. Furcatae.

R. sardonia, $F$; - G, Cadder W.

R. depallens, $F r$ - B C F G H.

\section{Section III. Rigidue.}

R. virescens, $F r$ - A G, Inveraray, Loudon Castle.

R. lepida, $F \%$ - G, Craigton W.

R. rubra, Fr:-G H. Cadder W., Cathkin Pk., Symington.

R. cutefracta, Cke.-G, Cadder W., Cathkin Pk.

\section{Section IT. Heterophyllae.}

R. vesca, $F$ :- A C G, Inveraray, Drymen, Cadder W.

R. cyanoxantha, $F r$. - A B F G H L \& M.

R. azurea, Bres.- B G, Rossdhu, Cadder W.

R. heterophylla, $F r$. A F G H.

R. caerulea, Per:s.-B, Rossdhu.

R. foetens, Fr.-A B CE\& I F G H L\& M.

R. fellea, $F r$ - A B E\& I F G H L\& M.

R. Queletii, Fr.-FG, Largs, Cadder W., Rouken Glen.

\section{Section I. Fragiles.}

R. emetica, $F$ :-A B E\& I E GH L\& M.

R. ochroleuca, Fr.-A B E\& I F G H L\& M.

R. fragilis, $F r$.-A B F G L \& M.

var. nivea, Pers.-C, Drymen.

R. integra, $F$ :-G L \& M, Calderwood Glen, Cadzow Fol., Barskimming.

R. decolorans, $F r$. F G, Kilmalcolm, Kelvinside.

R. alutacea, $F r$. - A F G H.

R. Iutea, $F r$.-B F, Ardlui, Innellan.

R. vitellina, $F r$.-F, Innellan.

Genus XI. Cantharelles, idams.

Section I. Mesopus.

C. cibarius, $F r$ - A B CE\&I FGH L\& M.

C. aurantiacus, $F r$. A B C F G H.

C. tubaeformis, $F r$.-A G H L\& M.

C. infundibuliformis, Fr.--E \& I F G, Colintraive, Milliken, E. Kilbride, Capelrig.

C. cinerea, $F r:-G$, Cadder W.

Section III. Pleuropus.

C. muscigenus, Fr.-G, Paisley.

Gexus XIII. Nyctalis, Fi.

Section II. Parasitae.

N. asterophora, $F r$ r-F G, Innellan, Craigton W.

N. parasitica, Fr:-B F G L \& M, Innellan, Largs, Tullichewan, Cadder W., Craigton W., Loudon Castle, Ballochmyle. 


\section{Gexus XIV. Marasmius, Fr.}

Section I. Collybia.

M. urens, Fr.-A G, Inveraray, Cathkin Pk.

M. peronatus, $F r$.-A B F G.

M. porreus, $F r$.-B F, Camis Eskan, Tullichewan.

M. oreades, Fr.-A F, Inveraray, Innellan, Bute, Barassie. Troon, W.

Kilbride.

M. impudicus, Fr.-B, Blairmore.

M. amadelphus, Fr.-C, Drymen.

\section{Section II. Mycenae.}

M. rotula, Fr.-A F H, Inveraray, Innellan, Kelburne, Douglas Sup.

M. androsaceus, Fr.-G L\& M, Craigton W., Ballochmyle.

\section{Genus XV. Lentinus, Fr.}

Section I. Mesopodes.

L. lepideus, $F r$ - - G H, Paisley, Symington.

L. cochleatus, Fr.-A F G, Inveraray, Innellan, Craigton W., Cadder W., Loudon Castle.

\section{Section II. Pleuroti.}

L. scoticus, B. and Br.-G, Clyde shipyards.

\section{Gexus XVI. Paxus, Fr.}

P. conchatus, Fr.-F, W. Kilbride.

P. stipticus, $F$ r--F G, W. Kilbride, Yoker, Cadder W.

Genus XIX. Schizophyllum, $F r$.

S. commune, Fr.-F G, W. Kilbride, Bot. Gardens, (Grev. vol. v., p. 112).

Genus XX. Lexzites, $F r$.

I. abietina, Fr.-G, Glasgow, (Stev. Brit. Fun., v. ii., p. 165).

L. saepiaria, Fr.-F G, Kilmalcolm, Clyde Shipyards, W. Kilbride.

\section{Order II. Polyporei.}

\section{Genus XXI. Boletus, Dill.}

B. luteus, Linn.-A F G L \& M.

B. elegañs, Schum.-A F, Inveraray, Ardgowan.

B. flavus, With,-A B C G.

B. granulatus, Linn.-F, Kelburne.

B. bovinus, Linn.-A GL\& M, Inveraray, Milngavie, Carmyle, Bothwell Pk., Dougalston, (Hook. Fl. Scot.), Barskimming.

B. badius, Fr.-A B C F G H.

B. piperatus, Bull.-A B F G H.

B. variegatus, S'w.-A B F, Inveraray, Ardentinny, Kilmalcolm.

B. chrysenteron, $F \%$ - A B F G H L \& M.

B. subtomentosus, Linn.-A B C F G H L\& M.

B. radicans, Pers.-B, Rossdhu.

B. olivaceus, Schaeff.-A F, Inveraray, Tullichewan.

B. pachypus, Fr.-A G, Inveraray, Kelvingrove $\mathrm{Pk}$.

B. edules, Bull.--A B C E\& I FG H L \& M.

B. satanas, Lenz.-A, Inveraray.

B. luridus, Schaeff.-A B E \& I F G L \& M.

B. erythropus, Pers.-F, Largs.

B. laricinus, Berk.-H, Milton-Lockhart.

B. versipellis, Fr.-A G, Inveraray, Cadder W., E. Kilbide. 
B. scaber, $F r$ - - A B C E\& I F G L\& M.

var. niveas, $F r$-C, Drymen.

B. cyanescens, Bull.-B E\& I, Loch Eck, Colintraive.

\section{Genus XXIII. Fistulina, Bull.}

F. hepatica, Fr.-F(x, Kilmahew, Hamilton Pk., Cadzow For., Kelvinside, Loudon Castle, Bot. Garden. Reported by Mr. Campbell, Assistant Curator, to have beeu identified by member's of the British Association in 1876 in Kelvingrove Park.

\section{Genus XXIV. Polyporus, $F r$.}

Section I. Mesopus.

P. brumalis, $F r$ - F, Innellan, W. Kilbride, Carrloss.

P. perennis, Fr.-B E\& I F, Rossdhu, Tighnabruaich, Innellan, W. Kilbride.

\section{Section II. Pleuropus.}

P. squamosus, $F r$.-A E\& I F G H.

P. melanopus, Fr.-G H, E. Kilbride, Craigton W., symington.

P. picipes, Fr.-F G, Kilmalcolm, Milngavie, Cathkin Pk., Loudon Castle.

P. varius, Fr.-G H, Cathkin Pk., Symington.

P. lucidus, Fr.-G, Bothwell, (Grev. vol. v., p. 245).

P. sanguineus, Fr.-G, Botanic Gardens, (Grev. vol. v., p. 112).

\section{Section III. Merisma.}

P. frondosus, $F r$.-F, Aldgowall.

P. intybaceus, Fi:-CFG, Drymen, Finlaystone, Hamilton Pk., Craigton W., Cadzow For.

P. giganteus, Fr.-CFG, Drymen, Dalry, Hamilton Pk., Loudon Castle, Craigton W., Cadder W., Lemnox Castle, Greenock, Kelvingrove Pk.

P. sulphureus, Fr:-CG, Drymen, Hamilton Pk., Cadzow For.

P. lacteus, $F r$ - - F, W. Kilbride.

$$
\text { Section IV. Apus. }
$$

P. fragilis, $F r$. - G, Yoker, Craigton.

P. mollis, $F r$. F, Ardgowan.

P. caesius, Fr.-FG, W. Kilbride, Loudon Castle.

P. destructor, $F \%$. A, Inveraray.

P. fumosus, $F r$.-F G H L \& M.

P. adustus, Fr:-A F G, Inveraray, Innellan, Largs, Kelvingrove Pk., Clyde Shipyards, Craigton W., Cadder W., Cadzow For.

P. amorphus, $F r$. - H, symington.

P. hispidus, $F r$.-G, Cadder $\mathrm{W}$.

P. dryadeus, $F r$ - G, Cadzow For., Barneluith, Cadder W.

P. betulinus, Fr.-A F G, Inveraray, W. Kilbride, Cadder W., Kelvinside, E. Kilbride, Milngavie.

P. fomentarius, $F\rangle$.-A G, Inveraray, Hanilton Pk.

P. igniarius, $F \%-\mathrm{A} \mathrm{B} \mathrm{F} \mathrm{G.}$

P. roseus, $F r$. - G, Thornliebank.

P. annosus, $F r$. A B F $\div$ L \& M.

P. radiatus, Fr.-F G H, W. Kilbride, Kilmalcolm, Finlaystone, Kelvinside, Cadder W., Yoker, Craigton W., Dullatur, Cadzow For:

P. hirsutus, $F$ r:-B, Roseneath.

P. velutinus, $F$ r.-BG, Loch Lomond, Clyde Shipyards, Cadder W.

P. versicolor, $F r$ - A B E \& FG H L II.

P. pergamenus, $F r$-G, Botanic Gardens (Grev. vol. v., p. 112). 


\section{Section 1: Resupinuti.}

P. ferruginosus, Fr.-G, Loudon Castle.

P. subfusco-flavidus, Rostk.-B, Blairmore.

P. terrestris, $F r$-B G, Rossdhu, Cadder W.

P. obducens, Peis.-G, Cadder W.

P. callosus, $F r$ - G G, Clyde Shipyards.

P. vulgaris, Fr.-BG, Blairmore, Kelvingrove Pk.

P. sanguinolentus, $F \%$ - $:$ L \& M, Cadder W., Milngavie, Barskimming.

P. vaporarius, Fr-FG, W. Kilbride, Finlaystone, Cadder W., Clyde Shipyards, Nitshill.

Gends XXV. Tranetes, Fr.

T. mollis, $F r$ - A B FG.

Gexus XXVI. Daedalea, Pers.

D. quercina, Pers.-H, Cartland Crags.

Gexus XXIX. Merulius, Fr.

M. tremellosus, Schrad.-F, W. Kilbride.

M. corium, $F i$ - A B EG.

M. molluscus, Fr:-G, Clyde s'hipyards.

M. lachrymans, Fr.-A G, Inveraray, Kelvingrove Pk., Clyde Shipyards.

Gexus XXXI. Solenia, Hoffm.

S. ochracea, Hoffm.-F G, W. Kilbride, Dalry, Loudon Castle.

S. anomala, $F r$ - F, W. Kilbride.

Order III. Hydnei, Linn.

Genus XXXII. Hyduen, Linn.

H. repandum, Linir.--A B E\& I F G H L \& M.

H. rufescens, Pers.-A F, Inveraray, Finlaystone, Kilmahew.

H. auriscalpium, Linn.-F, Largs, W. Kilbride.

H. coralloides, Scop... G, Clyde shipyards.

H. ochraceum, Pers.-A F, Inveraray, W. Kilbride.

H. resupinatum, $F r$ r $-\mathrm{F}$, West Kilbride.

Gevus XIXVI. Irpex, Fr.

I. pendulus, Fr:-F, Castle Semple, (Stev. Brit. Fun. vol. ii., p. 249).

I. obliquus, $F r$-G, Cathkin, Carlder W.

Genus XXXVil. Radulum, $F$;

R. orbiculare, Fr:- F, W. Kilbride.

R. quercinum, Fr.-C;, Cathkin Pk.

Gexus XXxvili. Phlebia, Fr.

P. merismoides, $F,--$ B, Rossdhu.

P. contorta, $F$ i:- F, W. Kilbride.

P. vaga, $F_{r}$. - F, W. Kilbride.

\section{Genus Xxxix. Grandixia, $F$.}

G. granulosa, Fr--A F G, Inveraray, W. Kilbride, Finlaystone, Kilmahew,

E. Kilbride, Milngavie, Loudon Castle.

G. mucida, Fr.-F, W. Kilbride.

(ienus Xl. Odontia, $F$.

O. fimbriata, Peis.-F, W. Kilbride, Finlaystone.

Gevus Xli. Kneiffia, $\mathrm{Fr}$.

K. setigera, $F r$ :-F, W. Kilbride. 
Order IV. Thelephorei, $F r$.

C. sinuosus, $F r$ : - G, Loudon ('astle.

C. crispus, $F \%$ ( 4 , Cadder W.

\section{Genus Xliv. Thelerhora, EKr\%.}

T. multizonata, B. and Bi:-L\& M, Ballochmyle.

T. palmata, $F \%-\mathrm{F}$, W. Kilbride.

T. laciniata, Pers--F, W. Kilbride.

T. fastidiosa, $F r$--G, Cadder W.

\section{Genus XlVi. Stereum, Pers.}

S. lobatum, Kunze.-(i, Botanic Gardens (Grev., vol. v., p. 112).

S. purpureum, Pers.-B F \& H.

S. hirsutum, Fr.-A B C E \& I F G H L\& M.

S. sanguinolentum, $F r$ - A B C F C.

S. rugosum, $F r$ - A E \& I FG.

Genus Xlivil. Corticiula, $F i$.

Section II. Himantiae.

C. lacteum $F r$. - F, W. Kilbride.

C. laeve, Pers. - G, Cadder W.

C. sanguineum, Fi,-B F, Rossdhu, W. Kilbride.

C. caeruleum, $F r$ r-F G, W. Kilbride, Ibrox Pk.

Section III. Leiostroma.

C. calceum, $F r$ :-G, Cadder W.

C. lividum, Pers.-F, Finlaystone.

C. quercinum, $F$; - A G, Inveraray, Paisley.

C. cinereum, $F^{\prime}:-\mathrm{F}, \mathrm{W}$. Kilbride.

C. incarnatum, Fr.-A F, Inveraray, W. Kilbride.

C. nudum, Fr.-F, W. Kilbride.

C. comedens, $F r$ :- F, W. Kilbride.

Sub-genus I., Coniophora, Pers.-C. puteanum, Fr.-G, Clyde Shipyards. Sub-genus II., Hypochnus, $F r$-C. sambuci, $F r$-F, W. Kilbride.

Genus Xlix. Cyphella, $F$.

C. muscigena, Fr.-F, W. Kilbride.

C. muscicola, $F \%$ - F, W. Kilbride.

C. capula, $F r$ r.- F, W. Kilbride. var. cernua, Schum.-F, W. Kilbride.

C. dochmiospora, $B$. and $B r$ :- F, W. Kilbride.

Order V. Clavariei, $F r$.

Genus Li. Clavaria, tim.

Section I. Ramaria.

C. botrytes, Pers-A, Inveraray.

C. amethystina, Bull.-C, Drymen.

C. fastigiata, Linn.-F ; , Dundonald, Dalry, Kelvingrove Pk., Cadder W.

C. muscoides, Linn.-F, W. Kilbride.

C. coralloides, Linn.-F G, Imnellan, Craigton.

c. cinerea, Bull.-B FG H.

C. cristata, Pers.-CF G L \& M.

C. rugosa, Bull-A B CE\& I F G L \& M.

C. Kunzei, $F r$ :- (', Bot. Gardens. 


\section{Section II. Syncoryne.}

C. fusiformis, Sow.-FG, Innellan, Cadzow For., Loudon Castle.

C. inaequalis, $\mathrm{Fl}$. Dan.-A B F G. var. helvola, Cke.-G, Bot. Gardens.

C. argillacea, $F r$.-G, Bot. Gardens.

C. vermicularis, Scop.-L\& M G, Ballochmyle, Possil (Hennedy).

C. fragilis, Holmesk--F G, Imnellau, Bot. Gardens.

\section{Section III. Holocoryne.}

C. pistillaris, Linn.-G, Dougalstone (Hook., Fl. Scot.).

C. tenuipes, $B$. and $B r$ :- $\mathrm{G}$, Bot. Gardens.

C. candida, Cke.-G, Bot. Gardens.

C. uncialis, Grev.-FG, W. Kilbride, Bot. Gardens.

C. abietina, Pers.-E, Arran (Hennedy).

\section{Genus LII. Calocera, $F$;}

C. viscosa, Fr. A B E\& I F GL\& M.

C. cornea, $F r$ - A B F G.

Gexus LIV. Trphula, Berk.

T. erythropus, Fi.-F G, W. Kilbride, Finlaystone, Lambhill (Hennedy).

Gexus LT. Pistillaria, Berk.

P. quisquiliaris, $F$;.-A B, Inveraray, Roseneath.

P. puberula, Berk.-F, Finlaystone.

\section{Order VI. Tremellinei.}

Gevus LVII. Tremella, Dill.

Section I. Mesenteriformes.

T. frondosa, $F i$-A, Inveraray.

T. foliacea, Pers.-A FG L\& II.

T. lutescens, Pers.-G, Carkow For.

\section{Section II. Cerebinae.}

T. mesenterica, Retz.-B F G, Rossdhu, Innellan, W. Kilbride, Finlaystone, Capelrig, Loudon Castle.

T. intumescens, Eng. Bot.-G, Cadzow For., Carmyle, (Hook. Fl. Scot.).

T. albida, Huds.-B FG, Roseneath, W. Kilbride, Finlaystone, Loudon Castle, Dalbeath, (Hook. Fl. Scot.).

T. sarcoides, Sm.-F G, Cumbrae (Hennerly).

\section{Section III. Cirustaceae.}

T. tubercularia, Berk:-F, Kilmahew.

T. versicolor, Berk.--F, W. Kilbride.

$$
\text { Gexus LVIII. Exidia, } F i \text {. }
$$

E. glandulosa, $F r$ - A B F G.

\section{Genus LiX. Hirneola, $F r$.}

H. auricula-Judae, Berk.-E\& I F G, Bute, W. Kilbride, Crookston Castle.

\section{Genus LXI. Naematelia, $F r$.}

N. encephala, $F$ r:-F, W. Kilbride.

N. nucleata, Fr.-F L\& M, W. Kilbride, Kilmahew, Abington, Dalmellington.

N. virescens, Corde.-F, W. Kilbride. 
(imxus LXIII. DAcryayces, Nees.

D. deliquescens, Dub.-A F, Inveraray, W. Kilbride, Fiulaystone, Kilmahew, E. Kilbride.

D. stillatus, Vees-F(i, W. Kilbride, Dalry, Finlaystone, Kilmahew, Cadder W., Craigton W.

\section{(GASTROMYCETES.}

I. Hymenogastreae. Hydnangium, Wall:

H. carotaecolor, B. and Br.-C (, Botanic (iardens (I)r. Dickson, Lat. Hist. Trans., vol. iii., p. 194).

Hymenogaster, Tul. H. Klotzschii, Tul.-G, Botanic Gardens (Berkeley's Out. Brit. Fung., p. 295).

\section{Sclerodermeae. Scleroderma, Peis.}

S. vulgare, $F r$,-B FG L\& M.

III. Nidularieae. Cyathus, Haller.

C. vernicosus, DC.-FG, West Kilbride (D. A. Boyd) ; Carmyle (HennedyTech. Col. Mus.).

Crucibulum, Tul. C. vulgare, Tul.-BF(t, Fruin Bridge (G. F. Scott Elliot); Cumbrae (Hennedy-Tech. Col. Mus.); W. Kilbride (D. A. Boyd); Yoker (W. S.) ; Torrance (T. King and W. S.); Kelvingrove Park (W. S.); Cadder Wilderness (T. King and W.S.).

Sphaerobolus, Tode.

S. stellatus, Tode.--F ( , W. Kilbride (T. King); Whiteinch (T. King and W.S.); Loudon Castle, C. C., 1897 ; Yoker (W.S.).

IV. Lycoperdeae. Lycoperdon, Tournef. (emended).

L. gemmatum, Batsch.-A FGL\& II.

L. pyriforme, Sohaeff-_FGL\& M, Cumbrae (Hemnedy-Tech. ('ol. Mus.) ; Barrassie (T. King); W. Kilbride (D. A. Boyd); Greenock, C.C., 1887 : Craigton (T. King and W. S.); Whiteinch (W. S.) ; Hamilton, Loudon Castle, Ballochmyle, C. C., 1897.

L. bovista, Lim.-- F, W. Kilbride (D. A. Boyd).

Geaster, Micheli. G. rufescens, Pers-F, W. Kilbride (D. A. Boyd).

G. fimbriatus, Fi:- F, W. Kilbride (Hennedy-Tech. Col. Mus.); Cumbrae.

V. Phalloideae. Ithyphallus, Fischer.

I. impudicus, Fisch.-FG L\& M, W. Kilbride, Finlaystone, Greenock, C. C., 1887 ; Haylie (D. A. Boyd); ('raigton, Cadder Wilderness, Kelvingrove Park (T. King and W. S.); Loudon Castle, C. C.., 1897 ; Calderwood Glen, C. C., 1880 ; Barskimming, Ballochmyle, C. C., 1897.

Mutinus, $F r$. M. caninus, $F r-F$, W. Kilbride (T. King); Craigends (R. B. Johnston). 


\section{HEPATICAE.}

Is comparing the present and former lists, several important differences will be apparent. Some plants iucluded in the former have been left ont, whilst on the other hand a great many additions have been made, though the greatest care has been exercised both with regard to the proscribed limits and the exclusion of doubtful records. It would be rash to say that all these plants do not occur in the Clyde area, but as the plants camnot be produced, it is perhaps safer to exclude them. The nomenclature followed may be said to be that of D1. Spruce, than whom England has not produced a more ardent or critical enthusiast on this order of plants, and whose nomenclature is in general use among British collectors at the present time.

P. EWING.

\section{EDITOR:S NOTE.}

The district letters and additional records obtained by Mr. Lee and myself (mostly verified by Her. K. Muller of Freiburg) have been added by myself.

$$
\text { G. F. Scott Elliot. }
$$

Frullania Tamarisci, L.-B G, Loch Long, Lee ; B F L, Scott Elliot.

F. fragilifolia, Tayl.-Ben Lomond, Campbeltown, A B.

F. dilatata, L.-Common on trees, B F L H, Scott Elliot.

Lejeunea serpyllifolia, Dicks.-Common.

L. cavifolia, Lindb.-Common.

L. flava, $S_{x}$-Hamilton, Kyles of Bute, Campbeltown, A EG.

Radula voluta, Tayl.-Dalmellington, L.

R. Lindbergii, Gottsche.-Ben Lomond, B.

R. germana, . Jack.-Ben Lomond, B.

R. aquilegia, Tayl.--Blantyre, $\mathrm{G}$.

R. complanata, L.-Common, B L, Scott Elliot.

Porella laevigata, Schrod.--Ben Laoigh, Loch Tom, Greenock, B F.

P. platyphylla, L.-Common, G, Lee ; F, scott Elliot.

P. rivularis, Nees.-Killin, Ben Laoigh, B.

Pleurozia cochleariformis, Weiss.-Common on the Western Hills.

Anthelia julacea, Lightft.-Common from $500 \mathrm{ft}$. upwards ; B, $3000 \mathrm{ft}$., Lee.

A. Juratzkana, Limpr.-Ben Laoigh, B.

Herberta adunca, Dicks.-Common above $1000 \mathrm{ft}$.

Blepharozia ciliaris, L.-Common in Peaty bogs.

B. pulcherrima, Hoffm.- Head of Loch Lomond, B.

Trichocolea tomentella, Ehr.-Common in shady places ; $G$, Lee.

Blepharostoma trichophyllum, Dill.-Common. 
Lepidozia reptans, L.-C'ommon, li, Lee.

L. setacea, II $c b$.-Campbeltown, I.

Bazzania trilobata, L.- B, Loch Long, Lee.

B. triangularis, Schleich.-Ben Lomond, B.

Kantia trichomanis, L.-( $\mathrm{G}$, Lee ; H L, s'cott Elliot.

K. arguta, Hart.-Helensburgh, F.

Cephalozia bicuspidata, L.-Common everywhere, H, scott Elliot.

C. Lammersiana, Huben.-Helensburgh, Campleeltown, B I.

C. connivens, Dicks.-Falls of Clyde, H.

C. curvifolia, Dicks.-Lanark, Hamilton, \& H.

C. Sphagni, Dicks.-Loch Thom, F.

C. divaricata, Sm.-Common, G, Lee ; F H, scott Flliot.

C. leucantha, Spruce-Largs, F.

Pleuroclada albescens, Hook.--Ben Laoigh, B.

Hygrobiella laxifolia, Hook:- (ommon above 1000) ft.

Scapania compacta, Lindenb. - Ben Laoigh, Largs, Cimpbeltown, I I F.

S. resupinata, Ium.-Common.

S. subalpina, Nees.-Largs, Falls of Clyde, Darvel, F H.

S. nimbosa, Ttuyl.-Ben Laoigh, B.

S. aequiloba, Schwaege.-Ben Laoigh, Largs, Campbeltown, I B F.

S. nemorosa, L.-Largs, Darvel, Carradale, F G D or E.

S. undulata, L.-Common, G, Balldernock, Lee ; B F, Soott Elliot.

S. purpurea, Dill.-Carr, B F, Scott Elliot.

S. purpurascens, Hook.-Sandbank.

S. uliginosa, Sw.-Ben Laoigh, Carradale, B D or 1.

S. curta, Mart.-Killin, Trossachs, Campbeltown, I.

Diplophyllum albicans, L.-Common, BG, Lee ; B F L, scott Elliot.

D. ovatum, Dicks.-Ben Lomond, Ben Laoigh, B.

Lophocolea bidentata, L.-Common, (- Lee; B F H L M, scott Elliot.

L. cuspidata, Limpi.-Common.

L. heterophylla, Schiad.-Bothwell, Kilmarnock, G.

Chiloscyphus polyanthus, L.-Common, G, Lee; H, scott Elliot.

Mylia Taylori, Hook:-Common in bogs, B, scott Elliot.

M. anomala, Hook.-Common in sub-alpine bogs.

Plagiochila asplenioides, L.-Common, G, Lee; B H L, scott Elliot.

P. Dillenii, Tayl.-Common.

P. spinulosa, Dicks.-Common.

P. punctata, Tayl.-Bowling, G.

P. tridenticulata, Tayl.-Dalmellington, Lochwimnoch, F L.

Jungermania cordifolia, Hook:-Common in subalpine wells and streams.

J. riparia, Tayl.-Ben Lomond, Loch Thom, Falls of Clycle, B F H.

J. inflata, Hiels.-Ben Lomond, B.

J. turbinata, Raddi.-. Johnstone, F or G.

J. sphaerocarpa, Hook:-Common.

J. exsecta, Schmid.-Killin, Ben Lomond, B.

J. lycopodioides, Tayl.-Ben Laoigh, Killin, B.

J. Floerkii, Web. and Wohr.-Ben Lomond, Killin, Kyles of Bute, B E.

J. barbata, Schmid.-Common, G, Lee ; F, Scott Elliot.

J. Lyoni, Tuyl.-Killin, Tarbert, Campbeltown, I B.

J. gracilis, Schleich.-Ben Lomond, Killin, Lanark, B H.

J. incisa, Schrad.-Common, F, Scott Elliot.

J. bicrenata, Schmid.-Campsie, Kyles of Bute, Arran, EG.

J. alpestris, Schleich.-Ben Lomond, Killin, B.

J. ventricosa, Dicks.-Common, G, Bearsden, Lee.

J. saxicola, Schrad.-Creag Mohr.

J. minuta, Crantz.-Ben Laoigh, B.

J. crenulata, $S m$.-Common, $\mathrm{A}$, Lee. 
J. gracillima, Sm.-Common.

Eucalyx hyalina, Lyell.-Common.

E. obovata, Nees.-Common.

Nardia compressa, Hook.-Ben Laoigh, Killin, Largs, B F.

N. scalaris, Schrad.-Common.

Marsupella emarginata, Ehr h-Common, B, Tarbet, Lee.

M. Funckii, Web. and Mohr.--Common.

Acolea corallioides, Nees.-Ben Lomond, Ben Laoigh, B.

A. concinnata, Corda.-Ben Lomond, Ben Laoigh, B.

A. crassifolia, Carr--Ben Lomond, Ben Laoigh, B.

A. adusta, Nees, p.p.-Ben Lomond, Ben Laoigh, B.

Saccogyna viticulosa, Wich.-Common, B, Lee.

Fossombronia caespitiformis, De Not.-Uddingston, Largs, Maybole, FGK.

F. pusilla, L.-Lanark, $\mathrm{H}$.

Blasia pusilla, L.-Common, F, Scott Elliot.

Pellia epiphylla, L.-Common, G, Lee; B F H, Scott Elliot.

P. Neesiana, Gottsche and Limpr.-Killin, Campsie, Largs, Arran, E F G.

Aneura palmata, Heder.-Killin, Ben Lomond, Largs, Campbeltown, B C F I.

A. multifida, L.-Campsie, Lochwimnoch, G.

A. sinuata, Dicks.-Conmon.

A. pinguis, L.-Ben Lomond, Campbeltown, I B.

Metzgeria pubescens, Schrank.-Ben Lomond, Arran, Largs, B E F.

M. furcata, $L$.-Common, B, Lee (1600 ft.); F H, Scott Elliot.

M. conjugata, Lindb.-Common, F, Scott Elliot.

Marchantia polymorpha, L.-Common, G, Lee.

Conocephalus conicus, L.-Common, G, Lee ; B H, scott Elliot.

Reboulia hemisphaerica, L.-Largs, Campbeltown, A F.

Chomiocarpon quadratus, Scop.-Common, H, Lee.

Lunularia cruciata, L.-Common near Gardens, B, Lee.

Riccia glauca, L.-Lochwimnoch, F.

R. bifurca, Hoffm.-Common everywhere.

R. crystallina, L.-Campbeltown, I.

Anthoceros punctatus, L.--Fields near Ayr, K. 


\section{MOSSES.}

Material included in this list has been contributed, or access to herbaria permitted by Mrs. Fingland, Miss E. R. Burden, Dr. Braithwaite, the late Col. Stirling of Gargunnock, Prof. G. F. Scott Elliot, Messrs. D. A. Boyd, W. Campbell, H. N. Dixon, P. Ewing, G. Herriott, R. Kidston, J. R. Lee, R. M'Kay, D. Nimmo and R. D. Wilkie.

Explanations: The arrangement and nomenclature are those used by $\mathrm{Mr}$. H. N. Dixon in the Students Handbook of British Iosses, the only exception being that I have not followed him in the use of sub-species.

No contractions are used which are not self-explanatory or in general use. except (Henn. herb.) = in the Hennedy Herbarium in (Anderson's) Glasgow Technical College. Proper names in brackets are the collectors' names, except in the case of (Stirton) which usually means quoted from Dr. Stirton's list of 1876 .

I am indebted to Mr. H. N. Dixon, M.A., F.L.S., for examining and confirming the naming of several species about which I was in doubt, viz., Tortula ambigua, Tortula intermedia, Camptothecium lutescens, Amblystegium irriguum, and Hypuum riparium.

J. Murray.

\section{MUSCI.}

Order Sphagnaceat.

Sphagnum cymbifolium, Ehr.-A BE E G H.J L.

S. medium, Limpr.-B, Dubh Lochan (Stirling and Kidston); G, Chapelton Moss ; M, Crawfordjohn.

S. papillosum, Lindl.-A B E E G H L M.

S. Austini, Sull.-Dubh Lochan, near Loch Lonınd (Stirling and Kidston).

S. rigidum, Schp.-A B F G L.

S. tenellum, Ehi. B F G H J L M.

S. subsecundum, Nees.-A B E F G H J L.

S. laricinum, spruce.-B F G.

S. teres, ingsti:-F H.

S. squarrosum, Pers.-FG.

S. acutifolium, Ehr.-A B D E F G H J L M.

S. Girgensohnii, Russ.-B F L.

S. fimbriatum, Wils.-G, Frankfield, L. and Possil, frequent.

S. intermedium, Hofm.-B E F G H L M.

S. cuspidatum, $\mathrm{E}_{\mathrm{N}} \mathrm{h}$.- A F G H M.

Order Andreabaceae.

Andreaea petrophila, Ekit.-BC EGH M.

A. alpina, smith.-A B E F.

A. Rothii, W. and I/.-A B E F.

A crassinervia, Bruch.-B, Succoth Hill ; G, Kilpatrick Hills. 
Order Tetraphidaceae.

Tetraphis pellucida, Hedw.-F G H, C. fr., Devol's G.

T. Browniana, Grev.-A C F G.

Order Polytrichaceae.

Catharinea undulata, $\Pi$. and $M$.-A B C E F G H J L M.

Oligotrichum incurvum, Lindb.-B E F G M.

Polytrichum nanum, Neck.-E, Arran, (Landsborough); F, W. Kilbride (Boyd); G, Barrhead (Stirton), Campsie (Farquhar). Frequently recorded, commonly in error. I have seen no local specimen so named that had not the columella winged.

P. aloides, Hedv.-A B C E F G H L M.

P. urnigerum, L.-A B C E F G J L M.

P. alpinum, L.- B E E G K.

P. sexangulare, Ehrh.--B, Ben Lomond (Hook. Flor. Scot.).

P. piliferum, Schreb.--A B CE F G H J M.

P. juniperinum, Willd.-A B F G H J L M.

P. strictum, Banks.-F G.

P. gracile, Dicks.--A B E F G H L.

P. formosum, Hedw.-A B E E E H.J.

P. commune, L.-A BCE FG H.J L M.

Order Buxbauniaceae.

Buxbaumia aphylla, L.-B, Rowardeman (Paterson) ; E. Kilfinan (B. M. E.); G, Bowling and Campsie (Stirton).

B. indusiata, Brid.-B, Loch Lomond (Stirton).

Diphyscium foliosum, Wohr:-A B E E G H,

\section{Order Dicraxaceae.}

Archidium alternifolium, Schp.-G, Possil (Stirton); L, Loch Doon.

Pleuridium axillare, Lindb.-G, Hamilton, frequent.

P. subulatum, Rabenh.-FG H.

P. alternifolium, Rabenh.-G, Canniesburn (Stirton).

Ditrichum homomallum, Hampe.-A B F G L.

D. flexicaule, Hampe.--B F G H K.

Swartzia montana, Lindb.-B, Arrochar ; H, Stonebrres.

S. inclinata, Ehrh.-F, Stevenston (Stirton).

Seligeria Doniana, C.IY.-A, Glen Shira (Rev. C. Smith); F, Kelly Glen, 1887.

S. recurvata, $B$. and $S .--\mathrm{F} \mathrm{GH}$, frequent.

Brachyodus trichodes, Fiirmr.-F G, frequent.

Ceratodoñ purpureus, Brid.-CE FG H K L M.

Rhabdoweisia fugax, $B$. and $S$--B, Cobbler; F, Lochwinnoch (Boyd).

R. denticulata, B. and S.-BCFG.

R. crenulata, .Jameson.-B, Lochgoilhead and Cobbler; F, Glengarnock.

Cynodontium Bruntoni, B. and S.-F, Gourock, 1867 (Stirton).

C. polycarpum, Schp._F, West Kilbride, 1887 (Boyd).

Dichodontium pellucidum, Schp._A B CE F G H. K L M.

D. flavescens, Lindb.-E E G H L.

Dicranella heteromalla, Schp.-A B E F G H J L M.

D. cerviculata, $S c h p .-F$ G.

D. crispa, schp.-A B F G.

D. secunda, Lindb.-B E E.

D. curvata, Schp.--F, Hills of Dunoon, Greenock (Drummond).

D. rufescens, Schp.-C F G L M.

D. varia, $S c h p$.-B E F G L M.

D. Schreberi, Schp.-F, Dalry ; G, Lennoxtown (Stirton).

D. squarrosa, Schp.-A B CE F G H. L II. 
Blindia caespiticia, Lindb.--B, Ben Lomond (Stirton).

B. acuta, B. and S.-A B C E F G H L.

Dicranoweisia cirrata, Lindb.-F G H M, common.

D. crispula, Lindb.-B, Ben Vorlich.

Campylopus subulatus, Schp.-B, Succoth Hill, 1865 (M'Kinlay).

C. Schimperi, Mitde.-B, Ben Lomond (Stirton).

C. Schwarzii, Schp.-A, Ben More, Cowal; B, Cobbler and Ben Vorlich ; F, Dumoon.

C. flexuosus, Brid.-A B E F G H L.

C. pyriformis, Biid.-A E F G.

C. fragilis, $B$. and $S$.-B E F G H J L M.

C. atrovirens, De Not.-A B E F G L.

C. brevipilus, B. and S.-F, Cumbrae (Wilkie).

Dicranodontium longirostre, $B$. and S.-B F G. var. alpinum. Succoth Hill, c. fr. (M'Kinlay).

Dicranum fulvellum, Smith.-B, Cobbler.

D. falcatum, Hedwo.-B E.

D. Starkei, W. and M.-A, Ben More, Cowal.

D. bonjeani, De Not.-E F G H J L.

D. scoparium, Hedw.-A B C D E F G H J K L M.

D. majus, Turn.-B E F G H J L.

D. fuscescens, Turn.-A B F G H L.

D. Scottianum, Turn.-B, Loch Lomond ; E, Tighnabruaich ; F, Dunoon.

D. uncinatum, C.M.-B, Ben Vorlich by Loch Lomond 1825 (Greville).

D. asperulum, Mitt.-B, Cobbler and Ben Vorlich ; G, Lennoxtown, 1861 (M'Kinlay), Milngavie, 1864 (Stirton).

Leucobryum glaucum, Schp.-ABEFGHLM, Ben Lonınd, c. fr. (Stirton).

Order Fissidentaceae.

Fissidens exilis, Hedw.-G, Possil (Stirton), Frankfield Loch.

F. viridulus, Wahl.-G, Mains, (Wilkie).

F. pusillus, Wils.--F G H K.

F. incurvus, Starke.-F, Seamill and West Kilbride; G, Possil (Stirton).

F. tamarindifolius, Wils.-G, Possil (Stirton).

F. bryoides, Hedw.-B C E F G H J K L M.

F. crassipes, Wils.-G, Possil (Stirton), Hamilton, Blantyre Mills.

F. osmundoides, Hedrw.-A B C E F G H L.

F. adiantoides, Hedw.-A B C E F G H J K L M.

F. decipiens, De. Not.-A B E F G H J K L.

F. taxifolius, Hedw.-A C E F G H J K L M.

Order Grimmiaceae.

Grimmia apocarpa, Hedw.-A B C E F G H J K L M.

G. conferta, Funck:-G, Bowling (Stirton); H, Falls of Clyde (Wilkie).

G. maritima, Turn.-E F J K.

G. funalis, Schp.-B, Cobbler.

G. torquata, Hornsch.-B, Cobbler.

G. pulvinata, Smith.-B E F G H K L.

G. orbicularis, Bruch.-G, Bowling (Stirton).

G. trichophylla, Grev.-B F G H K M.

G. Muhlenbeckii, Schp.-G, Bothwell (Stirton).

G. subsquarrosa, Wils.-B, Loch Lomond (Dixon); F, Dumbuck, e. fr. (Stirton).

G. Stirtoni, Schp.-G, Near Glasgow (Stirton).

G. decipiens, Lindb.-F, Cardross and Dumbuck (Stirton).

G. robusta, Ferg.-B, Garelochhead (Hunt.); F, Cardross (Stirton).

G. Hartmani, Schp.-B, Loch Lomond; F, Cardross ; G, Campsie. 
G. patens, B. and S.-B, Cobbler ; C', Drymen ; F, Glengarnock.

G. Doniana, $S m$.-G H K M.

G. leucophaea, Grev.-E, Dumbuck (Stirton).

G. elongata, Kaul.-G, frequent near Glasgow (Stirton).

Rhacomitrium ellipticum, $B$. and S.-B, Cobbler.

R. aciculare, Bird.-A B C E F G H J K L M.

R. protensum, Biaun.-A B E F G H L.

R. fasciculare, Brid.-A B C E F G H K L M.

$\mathrm{R}$ heterostichum, Brid.-A B CE F G H J K L M.

R. sudeticum, $B$. and S.-B F H.

R. lanuginosum, Brid.-A B C D E F G H L M.

R. canescens, Brid.-A BCE F G H K L M.

Ptychomitrium polyphyllum, Fürn:-A B CE FG H J K L M.

Glyphomitrium Daviesii, Brid.-C, Dungoyne ; G, Bowling 1863 (Galt and II'Cartney), etc.

Hedwigia ciliata, Ehil.-A B CE E G H K L.

\section{Order Tortulaceae.}

Acaulon muticum, C.M.-G, Shawlands (Henn. herb.); I, Campbeltown (Ewing).

A. triquetrum, C.IY.-G, Near Glasgow (Stirton).

Phascum cuspidatum, Schieb.-G, Carmyle, Hamilton, common.

Pottia recta, Witt.-Bowling (Stirton).

P. Heimii, Fïrni.-E E G.

P. truncatula, Linab.-F G H.

P. intermedia, Fürni:-F, West Kilbride (Boyd).

P. crinita, Wil.-G, Maryhill (Stirton).

P. minutula, Fïrnr.-F, West Kilbride (Boyd).

P. lanceolata, C.IK.-G, Bowling (Stirton).

Tortula pusilla, Mitt.-F, Dumbarton ; G, Glasgow, frequent (Stirton).

T. rigida, Schrad.-G, Paisley Canal (M'Kinlay), Possil Rd. (Stirton).

T. ambigua, Angstr.-G, Cathkin Quarry, Calderwood Glen, frequent near Hamilton.

T. aloides, De Not.-F, Largs (Boyd); common (Stirton). This species and $\mathrm{T}$. ambigua confused in local records.

T. atrovirens, Lindb.-F, Cardross (Stirton).

T. marginata, Spruce.-F, Dumbarton (Stirton).

T. muralis, Hedw.-A B C E F G H J K L M.

T. subulata, Hedu.-F G H K L.

T. mutica, Lindb.-G, Glasgow (Drummond); K, Dailly, c. fr. (Shaw).

T. laevipila, Schwogr.-B F G H J K.

T. intermedia, Berk:-G, Bowling (Stirton) ; H, Walston.

T. ruralis, Ehrh.-E F H.

T. ruraliformis, Dixon.-F, West Kilbride.

T. princeps, De Not.-G, Bowling (Stirton); H, frequent near Lanark, Falls of Clyde, etc.; abundant at Hazelbank.

T. papillosa, Wils.-BFH K.

Barbula rubella, Witt.-A B CE F G H L M.

B. tophacea, Mitt.-B F G H.

B. fallax, Hedw. - B F G H K L M.

B. spadicea, Witt.-G, Cathkin ; H, Fiddler Gill, and Walston.

B. rigidula, Witt.-A B F GH K L.

B. cylindrica, Schp.-CF GH J K, c. fr. Falls of Clyde.

B. gracilis, Schwgr.-G, Bowling (Stirton).

B. Hornschuchiana, Schultz--H, Lesnahagow ; K, Dailly (Shaw).

B. revoluta, Bird.-A B E F G K. 
B. convoluta, Hedw.- F G.

B. unguiculata, Hedu.-B F G H .J K M.

Leptodontium flexifolium, Hpe.-B F H .J L, c. fi'. Tinto.

L. recurvifolium, Lindb.-B, Ben Lomond aud Ben Vorlich (M Kinlay).

Weisia microstoma, C.II.-G, (ampsie Glen (Wilkie).

W. viridula, Hedw.-BCFG H L.

W. mucronata, B. and $S .-(\mathrm{G}$, Dowanhill, c. fr. (Stirton).

W. tenuis, C.II.-C E G K.

W. rupestris, C.U. - B C E F \& H K L.

W. curvirostris, C.II.-B FG H.

W. verticillata, Brid.-B F G H.

Trichostomum crispulum, Binch.-FGH K.

T. mutabile, Bruch.-B E F.J L.

T. flavovirens, Bruch.-E, Tighnabruaich (Stirton).

T. tenuirostre, Lindb.-A B E F G L, c. fr. Campsie (Stirton).

T. tortuosum, Diron.-B CE F G H K L.

Cinclidotus fontinaloides, P. Beuuv.-B E $: \mathrm{H}$.

\section{Order Encalyptaceae.}

Encalypta vulgaris, Hedw.-( , Mugdock (King); H, Falls of Clyde (Wilkie).

E. ciliata, Hoffm.-F, Largs (Boyd); G, Ballagan.

E. streptocarpa, Hedw.-A B E F GH L M.

\section{Order Orthotrichaceae.}

Anaectangium compactum, Schwgr.-A B E E H L.

Zygodon lapponicus, B. and S.-G, Kittochside (Wilkie).

Z. Mougeotii, B. and S.-BCD E F GH J K L, c. fr. Campsie (Stirton).

Z. viridissimus, Brown.-A BG H.J K L.

Z. Stirtoni, Schp.-B F G H, Falls of Clyde, c. fr. (Wilkie).

Z. conoideus, H. and T.-A, Inveraray (Dickson); K. Dailly (Shaw).

Ulota Ludwigii, Brid.-B, Glen Falloch (Hunt), Rowardennan (Woorl).

U. Drummondii, Brid.-G, Campsie Glen (Hemn. herb.) ; K, Dailly (Shaw);

B, Glen Falloch (Grev.).

U. Bruchii, Hornsch.-A BD E FG H J K L M.

U. crispa, Brid.-A B D E F GH K M.

U. calvescens, Schp.-B, Rowardennan (Bury); K, Dailly (Shaw); L, Loch Doon (Shaw).

U. phyllantha, Brid.-A B E F G.J K.

U. Hutchinsiae, Hamm.-A, Ardrishaig (Stirton); B, Loch Lomond.

Orthotrichum rupestre, Schleich.-A B E F G H.

o. anomalum, Hedw.-F G K.

O. cupulatum, Hoffm.-B GH K L.

O. Shawii, Wils.-K, Kilkerran, 1862 (Shaw).

O. leiocarpum, $B$. and $S .-\mathrm{BGH}$ J K.

O. Lyellii, $H$. and $L$.-B E F G H.J K L M.

0. affine, Schrad.-B F G H K M.

O. rivulare, Tu*n.--G H K, frequent.

O. Sprucei, Mont.-G, By Clyde, 1824 (Drummond); K, Dailly (Shaw).

O. Schimperi, Hamm.-B, Rowardennan (Wood) ; K, Dailly (Shaw).

O. stramineum, Hornsch.-B F H J K.

o. tenellum, Bruch.-B F H K.

O. pulchellum, Smith.-E F G H K M.

O. diaphanum, Schrad.-A F GH K.

Order Schistostegaceae.

Schistostega osmundacea, Mohr.-G, Kilsyth Glen, 1884 (Dr. Calder). 


\section{Order Splachiaceae.}

Oedipodium Griffithianun, Schugr.-B, Cobbler and Ben Lomond.

Splachnum ampullaceum, L._A, Glen Massan (Herriot) ; E, Arran (Landsborough); G, Garnkirk (Henn. Herb.).

S. sphaericum, $\operatorname{Lin} n$ fil.-B F G H L.

S. vasculosum, L.- $\mathrm{B}$, Ben Lomond (Lightfoot).

Tetraplodon mnioides, $B$. and S.-B E K L.

T. angustatus, $B$. and S.-B, Hell's Glen (Stirton).

Tayloria lingulata, Lindb.-B, Ben Lomond (D. Don).

\section{Order Funariaceae.}

Discelium nudum, Brid.-G, Gartnavel (Stirton).

Ephemerum serratum, Hampe.-G, Near Glasgow (Stirton).

Physcomitrella patens, $B$. and $S .-G$, Hamilton (Stirton).

Physcomitrium pyriforme, Brid.-F, Devol's Glen (Stirton); G, Blythswood (Wilkie).

Funaria fascicularis, Schp._F, Devol's Glen (Stirton); W. Kilbride (Boyd).

F. ericetorum, Dixon.-B E H.

F. Templetoni, Sm.-A B E F.

F. hygrometrica, Sibth.-BCE F G H M.

F. calcarea, Wahl.-E, Arran (Landsborough).

\section{Order Meesiaceae.}

Amblyodon dealbatus, P. Beauv.-G, Fin Glen (M·Kay).

Meesia trichoides, Spruce.-F, Largs (Boyd).

Aulacomnium palustre, Schwgi.-A BC E F G H J L M.

A. androgynum, Schwgr.-G, Cadder Wood (Wilkie); H, Falls of Clyde (Wilkie).

\section{Order Bartraniaceae.}

Conostomum boreale, Suartz.-B, Ben Lomond ; E, Arran.

Bartramia Oederi, Sw.-FG.

B. ithyphylla, Brid.-BC E F G H K M.

B. pomiformis, Hedw.-A B CE E G H L M.

B. Halleriana, Hedw.-F, Largs ; G, Campsie ; L, Loch Doon.

Bartramidula tenella, Stirton.-B, Cobbler (Stirton).

Philonotis fontana, Brid.-A B C E F G H K L M.

P. calcarea, Schp.-G, Campsie, c. fr. (Stirton).

P. capillaris, Lindb.-B, Cobbler (Stirton); G, Campsie Glen.

Breutelia arcuata, Schp.-A BCEFGH.JKL M, c. fr. Largs, Campsie Glen, and Dailly.

\section{Order Bryaceae.}

Orthodontium gracile, Schwgr.--F, West Kilbride, 1887 (Boyd); G, Lennox Cas. 1865 (Stirton).

Leptobryum pyriforme, Wils.-F, West Kilbride; G, Possil, Hamilton, frequent.

Webera polymorpha, Schp.-B, Cobbler.

W. acuminata, Schp.-B, Cobbler.

W. elongata, Schwgr.-A, Ben More, Cowal ; B, Cobbler.

W. cruda, Schugr.-BCFG H L M.

W. nutans, Hedw.--A BCE F GH.J L M.

W. annotina, Schugr:-BCFGH, c. fr. Ardeer, Some doubt attaches to all the records of this species. It is not understood. Bulbils like those relied on in naming this occur also in other species.

W. Ludwigii, Schp.-B, Ben Lomond, Cobbler.

W. commutata, Schp.-B, Ben Lornond (Stirton); G, Campsie (Hunt).

W. gracilis, De Yot.-B, Ben Lomond (Stirton). 
W. carnea, Schp.-A E G H J L.

W. albicans, Schp.-E E G H, c. fr., Arran (Campbell), Largs (Boyd), Calderwood Glen, Campsie.

Plagiobryum Zierii, Lindb.-A B C D E F G H L.

Bryum filiforme, Dicks.-A B E E G L.

B. pendulum, Schp.-H, Tinto. Fornerly regarded as conmon and perhaps frequent enough, but since the elucidation of this species by the character of the peristome no other specimen has been seen.

B. Warneum, Bland.-F, Stevenston (Stirton).

B. Marratii, Wils.--F, Stevenston (Stirton).

B. inclinatum, Bland.-B F G.

B. uliginosum, B. and S.-B, Inverarnan (Hunt) ; G, Possil (Stirton).

B. pallens, $S w$. - A B CE F G H L.

B. turbinatum, Schugr.--E, Arran (Landsborough); H, Fiddler Gill, c. fr.

B. bimum, Schreb.--F, Stevenston (Stirton).

B. pseudo-triquetrum, Schugr.-A B CEFGH J L M.

B. caespiticium, L.-B E F G H L M.

B. capillare, L.-A B C F G H J K L M.

B. erythrocarpum, Schwgr.-F, Cumbrae (Henn. herb.).

B. atropurpureum, W. and $M$.- H, Lesmahagow.

B. Donianum, Grev.-B, Inversuaid (Burchard).

B. murale, Wils.-F, Skelmorlie (Fingland); K, Girvan (Shaw).

B. alpinum, Huds - A B C E F G J L, c. fr., Tighnabruaich (Fingland).

B. Mildeanum, Jur.-B, Ben Narnain 1899 (Dixon).

B. argenteum, L.- C F G H L M.

B. roseum, Schreb.-F, Cumbrae c. fr. 1861 (Levack), Largs ; H, Falls of Clyde.

B. Dixoni, Cardot in litt.-B, Ben Narnain 1899 (Dixon). Placed here, meanwhile, as I am unaware of its affinities.

Mnium affine, Bland.-F G H K.

M. cuspidatum, Hedw.-F H.

M. rostratum, Schrad.-C E F G H .J K.

M. undulatum, L.-A B C E F G J K L M, c. fr., Largs (Boyd).

M. hornum, L.-A B C D E F G H J K L M.

M. serratum, Schrad.-C F GH K.

M. stellare, Reich.-F G H.

M. cinclidioides, Hübn.-B, Balloch (Wilkie); F, Kilmalcolm (Wilkie).

M. punctatum, L.-A BCD E F G H K L M.

M. subglobosum, B. and S.-F, Devol's Glen (Boyd); G, Possil (Stirton).

\section{Order Fontinalaceae.}

Fontinalis antipyretica, L.-A B C F G H.

F. squamosa, $L$.-A B C F G M.

Order Crypilaeaceae.

Cryphaea heteromalla,.Mohr.-B, Lochgoilhead ; F, Largs ; K, Dailly ; M, Crawfordjohn.

Order Necheraceat.

Neckera crispa, Hedw.-A E F G H L.

N. pumila. Hedw.-A B F G K.

N. complanata, Hïbn.-F G H.J L.

Homalia trichomanoides, Brid.-A E F G H K.

Order Hookeriacea.

Pterygophyllum lucens, Brid.-B C E F G H L. 
Order Leucodontaceae.

Pterogonium gracile, Sw.-B, Loch Lomond ; F, Cumbrae, Largs.

Habrodon Notarisii, Schp.-B, Rossdhu, 1898 (Wilkie).

Myrinia pulvinata, Schp.-H, Falls of Clyde (Stirton); K, Girvan Val., c. fr., 1865 (Shaw).

Antitrichia curtipendula, Brid.-F G H.

Porotrichum alopecurum, Witt.-B C E F G H J K L.

Order Leskeaceae.

Leskea polycarpa, Ehrh.-B F G H.

Anomodon viticulosus, $H$. and T.-F G H, c. fr., Campsie Glen.

Pterigynandrum filiforme, Hedw.-Frequent Western Hills (Stirton).

Heterocladium heteropterum, $B$. and $S$.-BC F G H L M.

var. fallax. $\mathrm{FGH}$.

Pseudoleskea atrovirens, B. and S.-G, Blantyre Priory (D. Don).

Thuidium abietinum, $B$. and S.-F, Stevenston (Stirton).

T. tamariscinum, $B$. and $S .-\mathrm{A}$ BCE FG H J K L M, c. fi., Innellan and Falls of Clyde.

T. delicatulum, Nitt.-K, Dailly, 1865 (Shaw).

T. recognitum, Lindb.-A B C F GH L.

\section{Order Hypyaceae.}

Climacium dendroides, $W$. and $M$.- B C E F G H L M, c. fr., Lochwinnoch (King) ; Craigallion (Boyd).

Pylaisia polyantha, B. and S.-K. Dailly (Stirton.)

Orthothecium rufescens, $B$. and $S$.-B, Ben Narnain, Glen Douglas.

O. intricatum, B. and S.-F, Largs ; G, Campsie Glen ; H, Falls of Clyde.

Isothecium myurum, Brid.-A B F G H.J K L.

Pleuropus sericeus, Dixon.-B C F G H J K L M.

Camptothecium lutescens, $B$. and S.-G, East Kilbride; H, Falls of Clyde.

C. nitens, Schp.-H, Tinto, 1900.

Brachythecium glareosum, B. and S.-F, Largs (Boyd); G, Hamilton ; H, Stonehouse.

B. albicans, B. and S.-FGH K L, c. fr., West Kilbride (Boyd).

B. salebrosum, B. and S.-Frequent (Stirton).

var. palustre, Schp.-F, West Kilbride (Boyd).

B. rutabulum, $B$. and $S$.- A B C E F G H J K L M.

B. rivuiare, $B$. and $S$.-A B C E F G H K L M.

B. velutinum, $B$. and $S$.-B F G H M.

B. populeum, $B$. and $S$.-BCE F G H K L M.

B. plumosum, B. and S.-A B CE F G H J L M.

B. purum, Dixon.-A B C E F G H J K L I, c. fr., Innellan (King); Troon, Milngavie (Stirton).

Hyocomium flagellare, $B$. and $S$.-A B E F.

Eurhynchium piliferum, $B$. and S.-A C F GHKLM, c. fr., Barrhead (Stirton).

E. crassinervium, B. and S.-F, Largs; G, Cadzow ; H, Falls of Clyde, c. fr.

E. praelongum, $B$. and $S$.-A B C D E F G H J K L M.

E. Swartzii, Hobkirk:--A C F G H K.

E. pumilum, Schp.-F, Cumbrae (Henn. herb.); Cardross (Stirton); G, Hamilton; K, Bennane Hd.

E. Teesdalei, Schp.-F, Gourock and Cardross (Stirton); G, Campsie Glen, c. fr. ; K, Dailly (Shaw).

E. tenellum, Milde.-F, Millport; G, Cadzow. 
E. myosuroides, $S c h p .-\mathrm{A}$ BCE F G H J K L M.

E. striatum, $B$. and S.-B E E G H J K L.

E. striatulum, B. and S._- E, Tighnabruaich (Stir.ton).

E. rusciforme, Wilde.-A BCF G H J K M.

E. murale, Nilde-A G H K.

E. confertum, Nitde.-A B F G H J K.

Plagiothecium depressum, Dixon.-F, Portincross (Boyd); G, Hamilton (Stirton), Campsie Glen ; K, Dailly (Shaw).

P. Borrerianum, spruce.-BCD E F G H L.

P. Mullerianum, Schp.-B, Ben Narnain, 1896.

P. pulchellum, $B$. and S.-BCDE F G L.

P. striatellum, Lindb.-B, Cobbler.

P. denticulatum, $B$. and S.-A B C E F G H J K L M.

var. sylvaticum. F, Largs (Boyd), Cumbrae (Henn. herb.) ; H, Fiddler Gill.

P. undulatum, $B$. and S.-A B E E G H J K L M.

Amblystegium serpens, $B$. and $S$.- C E F G H K.

A. irriguum, B. and S.-F, West Kilbride (Boyd); G, East Kilbride ; H, near Douglas; K, Girvan Val. (Shaw).

A. fluviatile, $B$. and $S$. $-\mathrm{CFGH}$ M.

A. filicinum, De Not.-B C F G H J K L M.

Hypnum riparium, L.-F, Lochwinnoch; G, Blantyre, c. fr., Possil; Loch End.

H. polygamum, Schp.-F, West Kilbride (Boyd); G, Possil (Stirton).

H. stellatum, Schreb.-A B C E F G H J K L M, c. fr., Milngavie.

H. chrysophyllum, Brid.-F G H.

H. Sommerfeltii, Myr.-G, Campsie Glen ; K, Dailly.

H. aduncum, Hedw.-E F G.

H. Wilsoni, Schp.-F, Cumbrae (Boyd); G, Garteosh (Stirton).

H. lycopodioides, Schwgr.-G, Campsie Hills (G. and D. Don).

H. fluitans, L.-B F G H.

H. exanulatum, Gümb.--A B E F G H J.

H. uncinatum, Hedw.-A B CFG H L M.

H. vernicosum, Lindb._- F, West Kilbride (Boyd).

H. revolvens, $S w .-A$ B C E F G H L M.

H. commutatum, Hedw.-A B E F G H.J K L M.

H. falcatum, Brid.-A C E F G H M.

H. incurvatum, Schrad.-K, Dailly.

H. cupressiforme, L.-A B CD E F G H.J K L M.

H. Patientiae, Lindb.--A E F G H L.

H. callichroum, Brid.--B, Ben Narnain ; E, Goat Fell (Campbell).

H. molluscum, Hedw.-A B CE E G H J K L M.

H. palustre, L.-A B C E F G H .J K L M.

H. eugyrium, Schp.-A, Glen Massan ; B, Loch Lomond ; G, Campsie Glen (Shaw).

H. ochraceum, Turn.-A B CE F G H L M.

H. scorpioides, L.-A B EFG.J M, c.fr., near Kilmun (Stirton); Loch Humphray Burn (Wilkie).

H. micans, Wils.-B, Succoth Hill, Arrochar, June 1866 (M'Kinlay). Dr. Braithwaite noticed the specimen in Wilson's Herbarium in British Museum.

H. stramineum, Dicks.-B F G H L, c. fr., West Kilbride (Boyd).

H. trifarium, W. and N.-B, Ben Lomond (Stirton).

H. cordifolium, Hedw.-E F G, c. fr., West Kilbride (Boyd).

H. giganteum, $S c h p .-\mathrm{B} \mathrm{F} \mathrm{G} \mathrm{H.}$

H. sarmentosum, Wahl.-A B E F G.

H. cuspidatum, L.-A B C E F G H J K L M. 
H. Schreberi, Willd.-A B C E F G H J K L M, c. fr., Innellan (King); Barrhead (Stirton).

Hylocomium splendens, B. and S.-A B C E F G H.J K L M.

H. umbratum, $B$. and S.-B, Cobbler.

H. brevirostre, B. and S.-A E F G H K L.

H. loreum, $B$. and $S-A$ B E F G H K L M.

H. squarrosum, $B$. and S.-A BCE F G H.J K L M.

H. triquetrum, $B$. and S.-BC'E F G H.J K L M. 


\section{FERNS AND THEIR ALLIES.}

This list is based, as to arrangement and nomenclature, on Sir J. D. Hooker's Students' Flora of the British Islands. Of the 19 genera and subgenera in that work, there are representatives of 17 in the Clyde areaAdiantum and Gymnogramme only being absent; while of the 48 species and sub-species, 40 have been recorded: Capillus Veneris, Asplenium germanicum, A. septentrionale, Woodsia Ilvensis, Cystopteris alpina, Nephrodium Thelypteris, Gymmogramme leptophylla, and Ophioglossum Lusitanicum being the absentees. The distribution of the genera and sub-genera, species and sub-species, and varieties, as at present recorded, is as follows: Section A, 6 genera and sub-genera, 8 species and sub-species, and 5 varieties; B, 17 genera, 26 species, and 10 varieties; C, 14, 20, and 5 ; D-I, 13, 18, 0 ; E-I, 17, 29, 26 ; F, 17, 31, 14; G, 16, 25, 4; H, 8, 12, 2 ; $\mathrm{K}, 14,21,4$; and L-M, $13,20,6$.

The only records in Scotland of Trichomanes radicans, Asplenium lanceolatum, Nephrodium cristatum, and N. rigidum are for the Clyde area, while there are several new and striking, and a considerable number of rare, varieties of Nephrodium dilatatum and of Athyrium Filix-foemina peculiar to it. Hymenophyllum tumbridgense is recorded for 4, and $H$. unilaterale, for 8 sections; while Woodsia hyperborea, Cystopteris montana, Aspidium lonchitis, and Ceterach officinarum (now rare in Scotland) are recorded. A few, only, of the sections have been thoroughly examined-even common species having no record in fully half the number. It is to be hoped that more attention will be devoted in future to those sections which have been hitherto comparatively neglected.

Thanks are due to Professor G. F. Scott Elliot for access to the Herbaria in the West of Scotland Technical College, and other records; to Mrs. G. J. Combe, Glasgow, and Messrs. A. Laing, Troon, and T. Wise, Hamilton, for access to private collections; and to Messrs. R. Kidston, F.R.S.E., Stirling ; D. A. Boyd, West Kilbride ; the Rev. D. Landsborough, Kilmarnock ; I. M'Tnnes, Campbeltown ; J. R. Lee, Glasgow ; and P. Ewing, Uddingston ; and others for information and assistance in drawing up the list.

\section{Order I. Filices (Fervs).}

\section{Hymenophylléae.}

1 Hymenophyllum, $S m .-$ H. tunbridgense, $S m .-B$ E \& I F G. H. unilaterale, Willd.-A B C D \& I E \& I F G L \& M.

2 Trichomanes, L.-T. radicans, L.-E \& I, Corrie, G. J. Combe, 1863 ! nr. Mauchrie Bay, R. Kidston, 1876! Northend, Miss M'Bean, 1877 ! Loch Fyne, Cook and Young, 1863 ! 


\section{Polypodieae.}

4 Pteris, L.-P. aquilina, L.-B C D \& I E \& I F G H K L \& M. var. integerrima, Noore.-B, Tarbet; Lowe, vol. ii. p. 413.

5 Cryptogramme, B.-C. crispa, Br.-B C E \& I F G K L \& M.

6 Lomaria, Willd.-I. spicant, Desv.-BCD\& I E\& I FG K L \& M.

7 Asplenium, L. (Sub-gen. 1).-A. Ruta-muraria, L.- A C D \& I E \& I F G H K.

A. Trichomanes, L.-BCD\& I E\& I F G H K L\& M.

A. viride, Huds.-A B CE\& I F G H L \& M.

A. marinum, L.-D \& I E \& I F K.

A. lanceolatum, Huds.-A, Lochgilphead, Link, (Moore's British Ferns 1857, p. 169).

A. Adiantum-nigrum, L.-A C D \& I E \& I F G H K L \& M. var. obtusatum, Woore.-A, Ardrishaig; Lowe, vol. ii. p. 175. var. oxyphyllum, Moore.-F, Dunoon ; Lowe, vol. ii., p. 176.

Athyrium, Koth. (Sub-gen. 2).-A. Filix-foemina, Bernh.-B C I \& I E\& I F G H K L\& M.

var. rhaeticum, Roth.-A BCE\& IFG.

var. molle, Roth.-E \& I, Bute, Arran, Hen. 5th Ed.; Kingscross,

Balfour's MSS.; F, Cumbrae, Hen. 5th Ed.; G, Hamilton, Hen. 5th Ed.

var. marinum, Moore.-E \& I, Bute, Arran, Hen. õth Ed. ; F, Inverkip, Cumbrae, Hen. 5th Ed.

var. incisum, Hoff.-E \& I, Bute, Arran, Hen. 5th Ed. ; F, Gourock,

Cumbrae, Hen.5th Ed.; G, Cadder Wilderness, Garscube, Hen. 5th Ed. var. laxum, Schu.-A B E\&IGK.

var. odontomanes, Hoore.-A B E\& I F G K.

var. Ewingii, Ewing.-C, Campsie Glen, P. Ewing, 1872 :

var. digitata, Lowe.-E\& I, Kilmory, Arran, 1880, W. S.

var. distans, Hoore.-E\& I, Sannox, 1879, W.S.

var. hymenophyllum, Moore.--E\& I, Corrie, 1879, W.S.

var. pendens, Hoore.-E\& I, Corrie, 1879, W.S.

var. pannosum, Moore.-E\& I. Corrie, 1878, W.S.

var. Arranense, Lowe.-E \& I, Arran, 1863, P. N. Fraser ; Corrie,

1879 ; Dipping, 1899, W. S. ; F, Dundonald, A. Laing !

var. Victoriae, Moore.-C, Buchanan Castle, 1861 ; J, Cosh.

var. refractum-multifidum, Moore.-E \& I, Corrie, 1879, W. King :

"New and good," Moore.

var. laciniatum, Hoore.-G, Craigmaddie, G. J. Combe!

var. pruinosum, Moore.-B, Tarbet, Lowe, vol. ii., p. 81.

var. grandidens, Woore.-K, Heads of Ayr, A. Laing !

var. plumosum-Landsboroughi, Laing.-F, Dundonald, A. Laing !

A. Ceterach, Willd.-(Sub-gen. 3). C. officinarum, Desv.-B, Roseneath, 1895, Miss Henderson, Ex. Nat. Hist. Soc. ; F, near Largs, 1896, IT.S.; (r, near Paisley, Hen. 5th Ed.; Galt's Herb.; W.S., 1880; K, near Ayr, Bot. of Aysshire, 1882 ; J. Hendry, Paisley; Berry, Lendalfoot ; L\& M, Loch Doon, Bot. of Ayrshire, 1882.

8 Scolopendrium, $S w .-$ S. vulgare, $S m$.-B C D \& I E \& I F G H K L \& II.

9 Woodsia, Br.-W. hyperborea, Br.-B, Glen Falloch, Flora of Perthshire, 1898.

10 Cystopteris, Bernh.-C. fragilis, Bernh.-A B C I \& I E \& I F G H K L\& M.

var. dentata, Hook.-B, Loch Lomond, Balfour's MSS. ; Tarbet, Hills above Holy Loch, Hev. 5th Ed.; E\& I, Blue Rock, Arran, T. King ;

Corrie, W.S.; G, Mauchline, A. Laing :

var. angustata, Moore.-E \& I, Corrie, W.S. 
C. montana, Link.-B, Ben Lui, Druce, P. Ewing, J. R. Lee ; Ben Lonond, A. Somerville, 1894.

11 Aspidium, Sw.-A. lonchitis, Sw.-B, Ben Lomond, J, Ramsay, Balfour's MSS., Flora of Perthshive, Ben Lui ; J. R. L. ; Ben Voirlich, R. Mackay.

A. aculeatum, $S w$.-B C E\& I F G H K.

A. lobatum, Sw.-CD\& I E \& FGH K L\& M.

A. angulare, Willd.-B D\& I E\& I F G K.

12 Nephrodium, Rich.-N. Filix-mas, Rich.-BCD\& I E \& I F G K L \& I. var. incisum, Woore.-F, Craigie, A. Laing! G, Woods around Glasgow, Hen. 5th Ed., Mauchline, A Laing!

var. productum, Hoore.-E \& I, Bute, Arran, Hen. 5th Ed.; F, Gourock, Hen. 5th Ed.; Craigie, A. Laing ! G, Garscube, Cadder Wilderness, Hen. 5th Ed.; Mauchline, A. Laing!

var. paleaceum, Hoore.-CE\& I FG L\& M.

var. pumilum, Moore.-L\& M, New Cumnock, A. Laing !

var. abbreviatum, Moore.-L\& I, New Cumnock, A. Laing !

N. cristatum, Rich.-F, near Crofthead, G. J. Conıe, Hen. 5th Ed.; Renfrew, Hook. Stud. Flora.

N. rigidum, Desv.-E\& I, Corrie, R. B. Stewart! F, Dundonald, 1896, A. Laing! L \& M, New Cumnock, 1899, A. Laing! Only one plant was found in each instance, the Corrie one was verified by the late T. Moore, and the others by W.S.

N. spinulosum, Desv.-(Sub-sp.). B C D \& I E \& I F G. var. nanum, Sim.-E\&I, Corrie, W. S.

N. dilatatum, Desv.-(Sub-sp.). BC D \& I E I F G H K L\& M. var. nanum, Newm.-F\& I, Bute, Arran, Hen. 5th Ed.; G, Cadder

Wilderness, Hen. 5th Ed.

var. dumetorum, Noore.-E\& T, Colintraive, Bute, Arran, Hen. 5th

Ed. ; Colintraive, Corrie, W. S. ; G, Cadder Wilderness, Hen. 5th

Ed. ; L\& M, N. Cumnock, A. Laing !

var. collinum, Moore.-H, Ardrishaig, T. Moore; B, Tarbet, T. Moore;

E\& I, Arran, T. Moore ; Bute, Colintraive, Arran, Hen. 5th Ed.

var. alpinum, Moore.-B, Ben Lomond, L. Watt; E\& I, Lamlash, Hen.

Herb. ; Corrie, (in three very distinct forms,) W. S. ; L \& II,

N. Cummock, A. Laing !

var. glandulosum, Woore.-E \& I, Bute, Arran, Hen. 5th Ed.; G, Cadder Wilderness, Hen. 5th Ed.

var. pumilum, Voore.-E \& I, Bute, Arran, Hen. 5th Ed., Lowe, vol. i.,

p. 305 ; Colintraire, Hen. 5th Er. ; F, Dumbarton, Lowe, vol. i., p. 305 .

var. micromerum, Moore.-B, Glencroe, Lowe, vol. i., p. 315 ; G, Stoney

Brae, Paisley, W. S.

var. laceratum, Moore.-B, Ben Lomond, 1878, W. S.

var. grandidens, Moore.--E \& I, Corrie, W. S.

var. cuspidens, Moore.-B, Ben Lomond, W.S.; E \& I, Corrie, W.

King, W.S. A new and striking form, named for compiler by

Mr. Moore.

var. gracile, Lowe.-E \& I, Arran, Lowe, vol. i., p. 316.

var. rugosum, Tait.-H, Monkland Glen, Lowe, vol. i., p. 320.

var. validum-erectum, Moore-H, Monkland Glen, Lowe, vol. i., p. 291 ; L \& M, New Cumnock, A. Laing !

N. remotum, Braun. (sub-sp.).-F, Dundonald, 1899, A. Laing !

N. aemulum, Baker.-D I E \& I, Corrie, Lamlash, Hen. 5th Ed.; Bute, Arran, Balfour's MSS. ; Lamlash, G. J. Combe ! Holy Isle, Kingscross, Corrie, Lochranza, W.S.; F, Wemyss Bay, Fairlie, W. S.; West Kilbride, D. A. Boyd ; Dundonald, A. Laing! 
N. Oreopteris, Desv.-B C D \& I E \& I FG K L \& M.

13 Polypodium, L.-P. vulgare, L.-A BC D \& I E \& I F G H K L \& M.

var. serratum, Willd.-F, Largs, West Kilbride; J. Smith, (Bot. of Ayrshire, 1896).

var. semilacerun, Link:-F, West Kilbride, D. A. Boyd :

P. phegopteris, L.-BD \& I E \& I F G H K L \& M.

P. Dryopteris, L.-BC E \& I FG H K L \& M.

P. alpestre, Hoppe.-B, Ben Lomond, Flora of Perthshire, 1898 ; Ben Voirlich, R. Mackay ; L \& M, New Cumnock, A. Laing !

15 Osmunda, L.-O. regalis, L.-BD \& I E \& IF. Rooted out at most stations, but still growing in all sections but last.

16 Ophioglossum, L.- O. vulgatum, L.-D \& I E \& I F G H.

17. Botrychium, Su-B. lunaria, Sw-BCD\& I E \& I G K.

\section{Order II. Equisetaceae.}

Equisetum, L.-E. arvense, L.-B C F G.

E. pratense, Ehr.-C, Campsie, Hen. 5th Ed.; G, Clyde near Newton, Hen. 5th Ed.; Cambuslang to Uddingston, Amn. Anders. Nat., p. 15 ; H, Bonnington, Hen. sth Ed.

E. maximum, Lamk.-E \& I F G H K.

E. sylvaticum, L.-B F G H.

E. palustre, L.-B, Loch Lomond, Flora of Perthshire, 1898; G, Frankfield Loch, Hen. 5th Ed. ; Possil, Paisley Canal, Galt's Herb.

var. polystachyum, Auct.-F, Kilbirnie, Beith, Dalry, Kilwinning, Stevenston, J. Smith, (Botany of Ayrshire, 1896).

E. limosum, L.-F, Iriverkip Glen, Dr. Calıler ; G, Possil, Hogganfield, Hen. 5th Ed. ; Possil, Paisley Canal, Galt's Herb.

E. hyemale, L.-F G H L \& M.

E. variegatum, Schleich._E \& I, Clyde Isles, Sow., Eng. Bot.; Hook. Stud. Flora ; G, Frankfield Loch, Hen. 5th Ed.

\section{Order III. LYCopodiaceae.}

1 Lycopodium, L.- L. clavatum, L.-B E \& I F G H K L \& M.

L. annotinum, L.-B, Ben Toirlich, R. Mackay; Ben Lomond, J. R. Lee ; E \& I, Goatfell, Sow. Eng. Bot. ; F, Gryfe Farm, A. O. Leitch; "The Clyde," Hook., Stud. Flora.

L. alpinum, L.-B E \& I FG L \& M.

I. inundatum, L.-B, Inverarnan, Sow., Eng. Bot. ; F, Stevenston, D. A. Boyd; near Kilwinning, J. R. Lee.

L. selago, L.-B E \& I F G.

\section{Order IV. Selaginellaceae.}

1 Selaginella, Beauv.-S. selaginoides, Gray.-B E \& I E G K L \& M.

2 Isoetes, L.- I. lacustris, L.-B E \& I G L \& M.

I. Hystrix, Durieu.-B, Ben Voirlich, Prof. Babington (Sow., Eng. Bot.).

\section{Order $\mathrm{T}$. Marsileaceae.}

1 Pilularia, L.-P. globulifera, L.--B F G K. 


\section{PHANEROGAMS.}

THE neighbourhood of the City of Glasgow with its concomitants of steel, iron and chemical works, coal mines, manufactories and miles of dwelling houses, does not appear a very promising tract of country for the growth of plants, yet as we become better acquainted with the open spaces even within the smoke-begrimed area of the city proper we shall be surprised by the great variety of flowering plants found within a radius of only a few miles of Glasgow Royal Exchange. Possil Marsh, for instance, now included within the city boundary, is still the happy hunting ground of the city botanist, and has been for loug known as the haunt of many rare plants. Butomus umbellatus, L., and Sagittaria sagittifolia, L., were supposed to be fully established there twenty years ago, and though these and many others are now plants of the past, there still remain many interesting and beautiful forms in this and other such places within easy distance of the city.

For the purposes of this catalogue it was thought advisable to limit the boundaries of research to the land draining into the River and Firth of Clyde only, not as on the occasion of the former meeting of this Association, in 1876, when the area involved was the entire West of Scotland, and although the time at our disposal has been too limited to overtake systematically the sections into which it was proposed to divide this tract of country, a glance at the following lists will make it evident that a very fair knowledge of its flora has been gained.

Nearly all the information contained in these pages was collected for the Glasgow Catalogue of Native and Established Plants, in which list the names of all those who assisted with the work appear. We nevertheless feel it to be our duty again to thank those specialists who so kindly certified critical species, and thereby made the records valuable. Nearly every plant of any consequence here given has been seen either by Mr. A. Bennett, F.L.S., Croydon, Rev. E. F. Linton, M.A., Rev. E. S. Marshall, M.A., F.L.S., who have either named the plants themselves or obtained an opinion on them from some other well known expert.

We have not thought it advisable to compare in detail the present list with that made in 1876 . This one is much more extensive, although it does not embrace anything like the same amount of country, many of the plants there given as rare, will be found common here, many there given as common will be found rare here, and a good number do not appear here at all.

It may be mentioned that the names of towns or villages given are those of the nearest railway station to the point at which the plant was noted, and that it was found within a few miles of that place.

Although there is in the area with which we have had to deal a very large amount of sea margin, there are also, as has been already remarked, numerous hills overlooking it. Certainly few of these reach the alpine or even the 
sub-alpine limit, the majority of them being under $1500 \mathrm{ft}$., but deep glens and rocky summits lend them the requisites of an extensive and varied flora.

Exposure: Natural protection is admittedly one of the most important factors in plant life. Light, heat, and moisture plants must certainly have, but these, without the proper shelter, both during summer and winter, to the majority of our native plants, would avail but little. Had space permitted, many notable examples might have been given in illustration of this observation. For instance, in the case of ballast heap plants, we have forms imported from colder climates than our own which yet are unable to pass through our winter. Many Canadian plants do not pass through the winter with us, yet the Rhododendron, which flowers with us while snow is on the ground, cannot pass through the Canadian winter. Similar instances are to be found in our own native flora. Doubtless it is for some such reason that we find Erophila inflata, Hook. fil., Juncus castaneus, Sm., Woodsia hyperborea, R. Br., and alpine ferus generally on eastern, and most luxuriant on north-eastern exposures, and Arabis petraea, Lam., Juncus biglumis, L., principally on western, and most luxuriantly on south-western exposures. These are one or two notable eases, but a very large list might be made up from our own Scottish flora. What effect the mild winters of recent years is having on our flora generally, it does not come within the scope of our present purpose to enquire, however interesting and important the subject may be.

Temperature: The present mean temperature at different points of former agrarian levels, during the growing season shows the cause of failure in attempting to grow cereals now, where in comparatively recent times very good crops of corn were cultivated. In consequence of this failure, plants associated with arable lands in these districts have suffered, and will ultimately become extinct.

The classification followed is that of the London catalogue, 9th edition.

P. Ewing, F.L.S.

\section{EDITOR'S NOTE.}

The capital letters showing records in the districts and the altitudes have been added by the editor from the following well-known authorities, Light. foot, Bryce, Balfour, Hooker, Hennedy, and Buchanan White. Great injustice would also have been done to such well known workers as John Smith, Flora Ayrshire, L. Watt, D. A. Boyd, T. Wise, Dr. Fullarton and A. Somerville, by the absence of their records, and so far as possible their work has been included also. The short time available has made this very difficult, and their contributions are only distinguished by the commas between the letters.

\section{G. F. Scott Elliot.}

Clematis Vitalba, L.-Uddingston, Innellan, Bowling. No doubt introduced. FG.

Thalictrum alpinum, L.-Ben Lomond, Cobbler, Arran, B E L, over $1000 \mathrm{ft}$. -2500 ft., Buchanan White.

T. minus, L.-Ayr, Falls of Clyde, Ben Laoigh, Arran, Campbeltown, B D E H K L, J. Bryce.

T. majus, Crantz.-Ayr, Rutherglen, Dunoon, Arran, Tarbert, B E F G K.

T. flavum, L.-Paisley, Rutherglen, Bowling, Arran. Garden escape. E E G, J. Bryce.

Anemone nemorosa, L.-Common. B, F G J K L, D or I, Somerville.

Ranunculus fluitans, Lam.-Crossford, G, Hennedy. F.

R. pseudo-fluitans, "Bab." Hiern.-Lanark, Dumbarton, F G, B, Balloch, Watt. 
R. trichophyllus, Chaix.-Ayr, Lanark, Dumbarton, Arran, B E F K, G. var. demersus, Hiern.-G, Burn, Loch Fin, $800 \mathrm{ft}$., Watt.

R. Drouetii, Godr.-East Kilbride, Milngavie, Dumbarton, F G.

R. Godronii, Gren.-Milngavie, G.

R. peltatus, Schrank.-Neilston, Uddingston, Gartmore, Bowling, Arran, B E F, G, Hennedy,

R. floribundus, Bab.-Kilwinning, Dumbarton, F G, $800 \mathrm{ft}$., Watt.

R. Baudotii, Godr.-Ardrossan, Cambuslang, Arran, E F G.

R. confusus, Godr.-Dumbarton, F.

R. Lenormandi, F. Schultz.-FG, Cumbrae, Possil (Hennedy), J.

R. hederaceus, L.-Common, G (Hooker), E E K to $700 \mathrm{ft}$., D or I.

R. sceleratus, L.-Common, F G K, E.

R. Flammula, L.-Common, F G.J K L, B, D or I, to $900 \mathrm{ft}$. (var. pseudo reptans. F, Somerville, Editor.)

R. Lingua, L.-Possil, Milngavie, Renfrew, Stevenston, Maybole, F G K, E (Hooker), L, Smith.

R. auricomus, L.-Milngavie, Falls of Clyde, Renfrew, Maybole, F G H K. J Fullarton.

R. acris, L.-E, F G J K L, B to $1800 \mathrm{ft}$., D or I.

R. repens, L.-FG J K L, B to $1100 \mathrm{ft}$., D or I.

R. bulbosus, L.-F K J L, G, Glasgow Green, Hennedy, D or I.

R. Sardous, Crantz.-Campsie, Lauark, Renfrew, Ayr, FGH K.

R. arvensis, L.-G (Hooker).

R. Ficaria, L.-FGK L, to $400 \mathrm{ft}$. Watt, J, D or I.

Caltha palustris, L.-FGJ K L, B, D or I.

C. minor, Syme.-Ben Lomond, B and G? Watt, to $800 \mathrm{ft}$., D or I.

Trollius europaeus, L.-GH (Hooker), F L, B to $600 \mathrm{ft}$., Loch Humphry, Watt, E.

Helleborus viridis, L.-Bothwell, Barrhear, Newmilns. Garden outcast. FG.

H. foetidus, L.-Bothwell. Garden outcast. G (Hooker), F \& K ? Smith. Aquilegia vulgaris, L.-Common. Garden escape. G H (Hooker), F J K L. Aconitum Napellus, L.-Common. Garden escape. FGK, B, Balmaha, Galt.

Berberis vulgaris, L.-Common. Introduced. GH, F K.

Nymphaea lutea, L.-Common, G, F K L, B, J, Fullarton.

N. intermedia, Ledeb.-Dumbarton, F, G, Lily Loch, $800 \mathrm{ft}$., Watt.

N. pumila, Hoffm.-Carstairs, Dumoon, F H, G, Mugdock, etc., Hennedy.

Castalia speciosa, Salisb.-Common, G (Hooker), F K L, B E, Hennedy, J.

C. minor, DC.-Carstairs, Carradale, H, F, G D or E.

Chelidonium majus, L.-Campsie, Falls of Clyde, Bowling, Arran. Garden escape. EFGH, K.

C. laciniatum, Stokes.-Campsie. Garden escape. G.

Papaver Rhoeas, L.-Common, F J K, G, Hennedy.

P. dubium, L.-Common, F ( . J K L.

P. Argemone, L.-Common, F K, G.

Meconopsis cambrica, Tig.-From different stations, but not native in any of them. FG.

Glaucium flavum, Crantz.-Millport, Ballantrae where it may be a native. F.J, E (Hooker), K.

Neckeria lutea, Scop.-Lanark, Campsie, Bowling. Garden escape. FG H.

N. claviculata, N.E.Br.-G, B, E F, Hennedy, J.

Fumaria Boraei, .Jord.-F, Watt.

F. confusa, Jord.-Arran, Campbeltown, D E, F.

F. densifiora, $D C$.-Dumbarton, $\mathrm{F}$.

F. pallidiflora, Jord.-Dumbarton, F, Watt.

F. officinalis, L.-Common, FG K. 
Cheiranthus Cheiri, L.-No doubt introduced in the districts recorded. FG K.

Nasturtium officinale, R.Br.-Common, F G J K L, D or I.

N. sylvestre, R.Br.-G, Watt.

N. palustre, DC.-Common, G (Hooker) F K, B.

N. amphibium, R.Br.-Stonehouse, Beith, FG.

Barbarea vulgaris, R.Br.-Common, G, F.J K, Smith.

B. stricta, Andrz.-Falls of Clyde, Dumbarton, F H.

Arabis hirsuta, Scop.--Commin, H (Hooker), E F G, B to $1600 \mathrm{ft}$., Watt, J.

Cardamine amara, L.-Cunımo», G (Hooker), F, Hennedy, J.

C. pratensis, L.-Common, F G K L, B to 90 ( $\mathrm{ft}$., J, D or I.

C. hirsuta, L.-Common, F G J K L to $800 \mathrm{ft}$., D or I.

C. flexuosa, With.-B G, D or I.

C. impatiens, L.-Falls of Clyde, H (Hooke'), K.

Draba muralis, L.-Elvanfoot, Dunoon, Arran, F E, M, Johnstone, G (Balfour, Ex).

D. incana, L.-Ben Lomond, B, Balfour.

Erophila vulgaris, $D C$ :-Conmon, F G.

Cochlearia officinalis, L.-Common, F J K, Smith ; E, Auld ; B, Balfour ; $\mathrm{D}$ or $\mathrm{I}$.

C. alpina, H. C. Wats.-Ben Lomond, B, Balfour, F.

C. danica, L.-Ayr Harbour, Bowling, Arran, E F K (Hooker).

C. anglica, L.-Dumliarton, F.

Hesperis matronalis, L.-Common garden escape. G (Hooker), F H, Smith.

Sisymbrium Thalianum, .J. Gay.-Common, F G, J.

S. officinale, Scop.-C nmmon, F G J K, D or I.

S. Sophia, L.-Falls of Clyde, Dumbarton. Introduced. FH E.

S. Alliaria, Scop.-Common, FG.

Erysimum cheiranthoides, L.-Ayr, Renfrew, Dumbarton. Introduced. F K, G.

Camelina sativa, Crantz.-Giffnock, Uddingston, Dumbarton. Introduced. FG.

Subularia aquatica, L.-Loch Lomond,* Loch Doon, B* L (*Hooker).

Brassica monensis, Huds.-Irvine, Girvau, Arrau, Carradale, B E* F* $\mathrm{K}^{*}$ (*Hookeı), J, Ailsa Craig, Smith.

B. Sinapistrum, Boiss.-Conımon, F G J K L, D or I.

B. alba, Boiss.-Common, E, Balfour, (*.

Diplotaxis tenuifolia, $D C$.-Ayr Harbour, Dumbarton, F K, G.

D. muralis, $D C$. - F, Boyd.

Bursa Bursa pastoris, Weber.-F G K L, Smith, to $600 \mathrm{ft} ., \mathrm{D}$ or I.

Coronopus didymus, Sm.-Ayr Harbour, Renfrew. Introduced in these cases. FK.

C. Ruellii, All.-Troon, Arran. No doubt introduced. E F, J.

Lepidium sativum, L.-Paisley, Dınoon, Dumbarton. Introduced. FG, .J K.

L. campestre, R.Br.-Uddingston, Milngavie, Tarlert, B G* (*Hooker), E.

L. hirtum, Sm.-Conmon, G (Hooker), E F, Hennedy.

Thlaspi arvense, L.-Troon, Giffnock, Lanark, Milugavie, Millpoıt. Introduced. $\mathrm{FG} \mathrm{H}, \mathrm{J}$.

Iberis amara, L.-Irvine, Crossmyloof, Uddingston, Dumbartou. Introduced. F, G (Lightfoot).

Teesdalia nudicaulis, R.Br.-Tollcross, Dumbarton, Stevenston, Monkton, F, G (Hooker), K.

Crambe maritima, L.-Arran, E, F.

Cakile maritima, Scop.-Toward Point, Stevenston, Ballantrae, Arran, Carraclale, B E F J, K.

Raphanus Raphanistrum, L.-Common, E (Don), F G J K L, Smith, D or I. 
R. maritimus, Sm.-Renfrew, Arran, Dumbarton, Innellan, Tarbert, B E F J K.

Reseda alba, L.-Kilwinning, Bowling. Introduced. F B.

R. lutea, L.-Paisley. Introduced. G.

R. Luteola, L.-Uddingston, Dumbarton, Kilwinning. Introduced. F, G (Hooker), K L, Smith, B, J.

Helianthemum Chamaecistus, Mill.-Carstairs, Arran, Girvan, E H K, G (Hooker), J K.

Viola palustris, L.-Cimmon, B E F G J K L to $2700 \mathrm{ft}$., D or I.

V. odorata, L.-Largs, Bothwell, Dumbarton. Garden escape. FG.

V. Riviniana, Reich.-G (Hooker), F J K L M to $900 \mathrm{ft}$., D or I.

V. ericetorum, Schrader.-Common.

V. tricolor, L.-F G.J K L, E to $1000 \mathrm{ft}$., D or I.

V. arvensis, Murr.-F G J K L, E, D or I.

V. Curtisii, Forster.-Prestwick, Innellan, Arran, Tarbert, BE F.

V. lutea, Huds. - G, Hooker; F K L, Smith.

V. amoena, Symons.-E F, Hennelly.

Polygala vulgaris, L.-F G K L M, E, B. (var. depressa, E G, J, Editor.)

P. serpyllacea, Weihe.-B F G, D or I.

Silene Cucubalus, Wibel.-F K L, G, J, H.

S. maritima, With.-J, Ailsa Craig (Lightfoot) ; E F K, Smith, D or I.

S. acaulis, L.-Ben Lomond, Ben Laoigh, B (Lightfoot) to $3100 \mathrm{ft}$.

Lychnis alba, Mill.-F K, G, C, E, J.

L. dioica, L.-J (Lightfoot, Ailsa Craig), E F G K L, B, D or I.

L. Flos-cuculi, L.-F G J K L, D or I.

L. Githago, Scop.-F, Greenock, Scott ; G, Watt, E.

Cerastium tetrandrum, Curtis.-F K, E G H, J, D or I.

C. semidecandrum L.-F K L, G.

C. glomeratum, Thuill.-F G J K L, D or I.

C. apetalum, Dum.-Innellau, F.

C. triviale, Link.-F G.J K L. B to $1000 \mathrm{ft}$., D or I.

C. alpinum, L.-Ben Lomond,* B (*Livhtfoot) to $20110 \mathrm{ft}$.

C. arvense, L.-Gourock, Crossford. Not reported for some years. F G, H.

(Saponaria officinalis, L.-K, Ayr, Nat. Hist. Soc., \& Editor.)

Stellaria nemorum, L.-Largs, Bothwell, Campsie, Dumbarton, F G (Hooker), H, B, .J.

S. media, $C y r$. - E F G J K L, B, D or I.

S. Holostea, L.-FG J K L, B to $900 \mathrm{ft}$., D or I.

S. palustris, Retz.-G, F.

S. graminea, L.-F G J K L, D or J.

S. uliginosa, Murr.-F G J K L, B, D or I.

Arenaria trinervia, L.-G, F J K L, B.

A. serpyllifolia, L.-F J K, E G, D or I.

A. peploides, L.-Common on the shores F J K, E, D or I.

Sagina maritima, Don.-Gourock, Innellan, Bowling, Arran, Carradale, Largs, Ballantrae, B E F J, G K, Smith, etc.

S. apetala, L.-Dumbarton, F, E, Arran, Balfour, G.

S. procumbens, L.-F G J K L, B.

S. Linnaei, Presl.-Ben Lomond, B.

S. subulata, Presl.-G, Muıdock, Hooker; B, Balfour, F J K, E.

S. nodosa, Fenzl.-F G, E K L to $400 \mathrm{ft}$.

Spergula arvensis, L.-F G J K L, B to $400 \mathrm{ft}$., D or I.

S. sativa, Boenn.-Arran, E.

Buda rubra, Dum.-E F J, Ailsa Craig, Smith ; F, Hennedy.

B. marina, Dum.-F, E.

var. media, $F r$.-Stevenston, Gourock, F.

var. neglecta, Kindb.-Largs, Innellan, F, J, Ballantrae, Smith, G. 
B. media, Dum.-Gourock, Innellan, Dumbarton, Arran, Largs, E F.

B. rupestris, Lond. Cat.-Ballantrae, Carradale, . I I.

Claytonia sibirica, L.-Gourock, Arran. Introduced, but well established. $\mathrm{E} \mathrm{F} \mathrm{G,H.}$

Montia repens, Pers., or M. erecta, Pers.-F G J K L, E, B to. $700 \mathrm{ft}$., D or I.

Hypericum Androsaemum, L.-Common. No doubt introduced in all cases. A E, Lightfoot, B F J K, D or I.

H. calycinum, L.-Dumbarton, Whiting Bay. No doubt introduced. EF.

H. perforatum, L.-FG.J K L, E, D or I.

H. dubium, Leers.-G $\mathrm{G}$ (Hooker), F.J, E.

H. quadratum, stokes.-E F G.J K L, D or I.

H. humifusum, L.-G, B E F, J K, I or I, H.

H. pulchrum, L.-E G, F.J K L, B to $1(00 \mathrm{ft}$., D or I.

H. hirsutum, L.-Falls of Clyde, Clydebank, Inverkip, Manchline, Arran, E FGH K.

H. elodes, Huds.-Loch Doon, Arran, Dumbarton, Dunoon, Tarbert, BEFL.JK.

(Lavatera arborea, L.-J, Ailsa Craig and outcast, E F, Editor.)

Althaea officinalis, L.-Arran, Tarbert. Due to cultivation. B E, G, Hooker.

Malva moschata, L.-Crossford, Inmellan, Kilwinning, Arran, Garden escape, E FGK J.

M. sylvestris, L.-F G J K, E, H.

M. rotundifolia, L.-No doubt introduced. F.J K, G.

Tilia vulgaris, Hayne.-Introduced. A, Inveraray, Lightfoot ; F G J K L, D or I.

Radiola linoides, Roth.-E F G, Hooker ; K, Smith, D or I.

Linum catharticum, L.-F G.J K L, B to $1000 \mathrm{ft} ., \mathrm{D}$ or I.

L. usitatissimum, L.-Not persistent. E, Balfour ; G, Hennedy.

Geranium sanguineum, L.-Falls of Clyrle, West Kilbride, Colmonell, Arran, E F H K.J.

G. phaeum, L.-Bothwell, Barrhead, Kilwinning. Introduced. F, G, Hooker ; E, Balfour.

G. sylvaticum, L.-F G K L M, B to $600 \mathrm{ft}$.

G. pratense, L.-B E F G J K L, D or I.

G. molle, L.-FG.J K L, D or I.

G. pusillum, L.-G, Hooker ; F J K, E.

G. dissectum, L.-F G, E, D or I.

G. Columbinum, L.-F J, Ballantrae, Smith; Glasgow to Dumbarton, Lightfoot.

G. lucidum, L.-F G H, Hooker ; E to $400 \mathrm{ft}$.

G. Robertianum, L.-F G.J K L, B, D or I.

Erodium cicutarium, L'Hérit.-F J K, E G.

Oxalis Acetosella, L.-F G J K L, B to $2500 \mathrm{ft}$., D) or I.

Impatiens Noli-tangere, L.-Castlemilk, Gourock. Introduced. F, G.

Ilex Aquifolium, L.-Introduced. H, F G K L, B.

(Euonymus europaeus, L.-G, Londoun, Smith (planted), Editor.)

Acer Pseudo-platanus, L.-Commonly planted. F G J K L to $500 \mathrm{ft}$., D or I.

A. campestre, L.-Commonly planted. F K, G.

Genista anglica, L.-Falls of Clycle, Campsie (Hooker), G H.

Ulex europaeus, L.-F G J K L, B to $900 \mathrm{ft}$., I or I.

U. Gallii, Planch.-Kilnaurs, F E; Bute, Hennedy.

U. nanus, Forster.---Innellan, F.

Cytisus scoparius, Link.-Common, F G.J K L, B to $500 \mathrm{ft}$.

Ononis repens, L.-Common, E F K, G, J.

Medicago sativa,.L.-Uddingston, Paisley, G.

M. sylvestris, $F r$--Heads of Ayr. Introduced. K.

M. falcata, $L$. Ayr, Ballast heaps, K, F, Smith. 
M. Iupulina, L.-Common. F, K, Smith.

M. denticulata, Irilld.-Ayr, Crossmyloof. On waste heaps. G K.

M. indica, All.-Crossmyloof. On waste heaps. G.

Melilotus officinalis, Lam.-Ayr Harbour, Giffnock, Bowling, F ( $\mathrm{K}$. Introduced.

M. alba, Desr:-Paisley, Ayr Harbour. Introduced. K, G.

M. arvensis, Wullr.-F.

Trifolium pratense, L.-Common. F GJ K L, B to $600 \mathrm{ft}$., D or I.

T. medium, L.-F G J K L to $600 \mathrm{ft}$.

T. arvense, L.-F.J K, E G.

T. striatum, L.-Ayr Harbour. Introduced. K, F G.

T. hybridum, $L$-C Commonly sown in hay fields. $\mathrm{FGJ}$ K L, D or I.

T. repens, L.-F G J K L, B, D or I.

T. agrarium, L.-F G J K L, E.

T. dubium, sibth.-J, Ballantrae, D or I, F K L.

Anthyllis Vulneraria, L.-FG.J K L, E, D or I.

Lotus corniculatus, L.-B G, F K L, E, J, D or I.

L. uliginosus, Schkuhr.-F, B to $500 \mathrm{ft}$., D or I.

Astragalus danicus, Retz.-Maybole, K.

Ornithopus perpusillus, L.-Tollcross, Dumbarton, Hooker, Maybole, FG K.

Vicia hirsuta, Gray.-F.J K, E G.

V. gemella, C'rantz.-Bothwell, Gourock, Largs, FG.

V. Cracca, L.-F G J K L, B to $400 \mathrm{ft}$., E, D or I.

V. Orobus, $D C$.-Falls of Clyde. Introduced. H.

V. sylvatica, L.-G H, Hooker ; F E K L M J.

V. sepium, L.-FG.J K, B to $2500 \mathrm{ft}$., E, D or I.

V. sativa, $L$.-F GJ K.

V. angustifolia, L.-F J K, E G.

V. lathyroides, L.-W est Kilbride, Girvan, Dumbarton, Arran, E F K, J.

Lathyrus Aphaca, L.-Kilwinuing, Giffnock. Introduced. F G.

L. pratensis, L.-F G J K L to $400 \mathrm{ft}$., D or I.

L. sylvestris, L.-Ayr, Lanark, Arran, E H K.

L. montanus, Bernh.-F G, B to $900 \mathrm{ft}$., E.

Prunus spinosa, L.-F G.J K L, D or I.

P. insititia, Huds.-H, Lanark, Hooker ; G K, Smith, F, J.

P. Avium, L. G F J K, D or I.

P. Cerasus, L.-G, Glasgow, Hooker.

P. Padus, L.-G, F K L, E H, B to $400 \mathrm{ft}$.

Spiraea salicifolia, L.-H, Ho ker, F G K L, J.

S. ulmaria, L.-FG J K L, B to $700 \mathrm{ft}$., D or I.

Rubus idaeus, L.-E, Lightfoot; F G J K L, B to $900 \mathrm{ft}$., D or I.

R. fissus, Lindl.-Lanark, Innellan, Dumbarton, F H.

R. suberectus, Anders. - Stevenston, Imnellan, Dumbarton, 'Tarbert, B F, A G, Hooker, E, K.

R. sulcatus, Vest.--Tarbert, B.

$\mathrm{R}$-affinis, $\mathrm{I}$. and $\mathrm{N}$.-Dumbarton, Innellan, F, E G, Hennedy, B.

R. carpinifolius, $W$. and $\mathrm{N}$.-Innellan, E F G.

R. Lindleianus, Lees.-Dumbarton, Tarbert, B F, A Roger's, E G, Hennedy.

R. rhamnifolius, $W$. and N.-Dumbarton, Innellan, Tarbert, B F, E, Hennedy.

R. pulcherrimus, Neum.-Dumbarton, Arran, Tarbert, B E F, A, Salmon.

R. Scheutzii, Lindeb.-Dumbarton, F.

R. dumnoniensis, Bab.--Tarbert, B, A, Rogers.

R. villicaulis, Koehl.-Dumbarton, Arran, Carradale, E F, B.

R. Selmeri, Lindeb.-Dumbart n, Tarbert, B F, A, Salmon.

R. hirtifolius, Muell. and Wirtg.-Lanark, H.

R. mucronatus, Blox.-Dumbarton, F, A, Rogers. 
R. radula, Weihe.-Stevenston, Dumbarton, F, E G, Hemnedy.

R. anglicanus, Rogers.-Dumbarton, A F.

R. corylifolius, Sm.-E, Balfour ; G, Watt, F K.

$\mathrm{R}$ caesius, $L_{0}-\mathrm{G}$, Watt.

R. saxatilis, L.-F H, Hooker ; B G K L M, E to $1000 \mathrm{ft}$.

R. Chamaemorus, L.-Wilsontown Dunoon, Ben Lomond, Glenfalloch, B F, G H, Hooker; M 1900- $2000 \mathrm{ft}$.

Geum urbanum, L.-F G J K L, B, E, D or I.

G. rivale, $L$.-F G.J K L, B to $500 \mathrm{ft}$., E.

G. intermedium, Ehrh.-F, G, E.

Fragaria vesca, L.-FG J K L, D or I.

F. elatior. Ehrh.-Common garden escape, FG.

Potentilla Fragariastrum, Ehrh.--Common, F G J K L.

(P. norvegica, L.-G, Clydebank, Watt, Editor.)

P. sylvestris, Neck.-F G.J K L, B, D or I.

P. procumbens, Sibth.-GE F.JK L.

P. reptans, L.-G, Hooker; F K L.

(P. rubens, Vill.-B, Ben Lomond, Buchanan White, Editor.)

P. Anserina, L.-F G J K L, B D or I.

P. palustris, Scop.-EG.J K L, E, B D or I.

P. Sibbaldi, Hall. fil.-B, Ben Lomond, Lightfoot, $2700 \mathrm{ft}$. or $3000 \mathrm{ft}$.

Alchemilla arvensis, Srop.-F G.J K L, E D or I.

A. vulgaris, L. - G E, E, B, J.

A. pratensis, Schmidt.-F.

A. alpestris, Schmidt.-B E, E to $600 \mathrm{ft}$.

A. filicaulis, Buser.-C'omm 'nn.

A. alpina, L.-Ben Lomond, Arran, Carradale, B E to $2700 \mathrm{ft}$.

Agrimonia Eupatoria, L.-E F G J K L.

A. odorata, Mill.-Falls of Clycle, Arran, Tarbert, B E H.

(Poterium sanguisorba, L.-G, Daldowie, Hooker, Editor.)

Rosa spinosissima, L.-F J K, E.

R. involuta, Sm.-Ayr, K ; E, Arran, Hooker.

R. Sabina, Woods.-Arran, EG.

R. mollis, Sm.-F G J K L.

R. coerulea, Wood:-_Lanark, H.

R. tomentosa, Sm.-F, Murrick, Watt; J.G.

R. subglobosa, Sm.-F, Murrick, Watt.

R. scabriuscula, Sm.-Barrhear, G.

R. rubiginosa, L.-F G, Hemedy.

R. obtusifolia, /lesv.-Arran, E.

R. canina, L.-F G J K L, D or I.

R. lutetiana, Lemın.-G, Lanark.

R. dumetorum. Thuill.-Arran, E.

$\mathrm{R}$ arvatica, Balier.-Barrhead, $\mathrm{G}$.

R. glauca, Till.-Lanark, Avr, H K.

R. subcristata, Lond. Cat.-E, Baker, F.

R. coriifolia, Fr.-Innellan, F.

R. Watsoni, Buker.-Barrhead, Dumbarton, F G, E.

(R. arvensis, Huds.-F ( $*$, Bogleshole, Hooker ; F, Hennerly, K L, Editor.)

Pyrus Aria, Ehrh.-Planted. F G K, E, Hennerly.

P. Aucuparia, Ehrh.-F( . . K L, E, B to $900 \mathrm{ft}$., D or I.

P. Malus, L.-Not native in the Clyde Area. B E G J K L to $400 \mathrm{ft}$.

Crataegus Oxyacantha, L.-F ( $\mathrm{J}$ K L, B to $500 \mathrm{ft}$., D or I.

Saxifraga oppositifolia. L.-Falls of Cly de, Ben Lomond, B H, Lightfoot, Hooker; E to $2500 \mathrm{ft}$.

S. nivalis, L.-Ben Lomond. B, Hooker, to $3000 \mathrm{ft}$., L. W:

S. stellaris, L.-B E F G L M to $3000 \mathrm{ft}$. 
S. aizoides, L.-B F K L, E to $1800 \mathrm{ft}$.

S. granulata, L.--Carmyle, Barrhead, Largs, Ballantrae, F G J, H Lightfoot, $K$.

S. hypnoides, L.-B F K L, E G to $2500 \mathrm{ft}$.

Chrysosplenium oppositifolium, L.-F G J K L, B to $2700 \mathrm{ft}$., I of I.

C. alternifolium, L.-F, Lightfoot; G, Hooker, J.

Parnassia palustris, L.-E E J K L M, G, B to $2000 \mathrm{ft}$., D) or I.

(Ribes Grossularia, L.-F ( .J K L, Editor.)

Cotyledon Umbilicus, L.-Gourock, Colmonell, Arran, Carrarale, B I) or I E F, A J, Ailsa Craig, K.

Sedum roseum, Scop.-B F, Lightfoot, E to $25010 \mathrm{ft}$., L, K, J.

S. Telephium, L.-A garden escape. F G, K L, D or I.

S. villosum, L.-G, Hooker, F K L M, E to $700 \mathrm{ft}$.

S. anglicum, Huds.-F, Dumbarton, Hooker, B E.J K, G, D or I.

S. acre, L.- E, Arran, Lightfout ; F G J K D or I.

S. reflexum, L.-Lanark. Garden escape. H, Craignethan, Hooker ; F, Dalry, Smith.

Sempervivum tectorum, L.-Darvel, Lanark. Introduced. H, F, ${ }^{G}$, Hennedy.

Drosera rotundifolia, L.-E F J K L M, G, B to $800 \mathrm{ft}$., D or I.

D. anglica, Huds.-E, Arran, Hooker, B F ( $)$ to $600 \mathrm{ft}$.

(D. intermedia, Hayne.-B, Loch Lomoud, Hentedy ; G, K, Suith, Editor.),

Hippuris vulgaris, L.-F, Hooker ; K, Straiton Smith, G to $800 \mathrm{ft}$.

Myriophyllum spicatum, L,-E F K L, G D or I.

M. alterniflorum, DC.-Dumbarton, Dunoon, Arran, Carradale, BE F G to $900 \mathrm{ft}$.

Callitriche verna, L.-F G J K L.

C. stagnalis, Scop.-B, D or I.

C. hamulata, Keutz.-F G, B to $2000 \mathrm{ft}$.

Peplis Portula, L.-G, Hooker, B E F K L to $400 \mathrm{ft} .$, D or I, J.

Lythrum Salicaria, L.-B E FJ K L, G, D or I.

Epilobium angustifolium, L.-G F J K L M, E.

E. hirsutum, L.-E F G K to $400 \mathrm{ft}$.

E. parviflorum, Schreb.-F G J K L to $400 \mathrm{ft}$.

E. montanum, L.-FG J K L, B, to $400 \mathrm{ft}$., D or I.

E. adnatum, Grisebach.-F G K L.

E. obscurum, Schreb.-Dumbarton, Arran, Innellan, Tarbert, B E F G, 1 or I.

E. palustre, L.-F G J K L, B to $400 \mathrm{ft}$., D or I.

(E. anagallidifolium, Lam.-B, Ben Lomond, Buchanan White, Editor.)

Circaea lutetiana, L.-FG J K L.

C. intermedia, Lond. Cat.-Lanark, Arran, Cantyre, B.

C. alpina, L.-Dumbarton, Arran, E, B F G.

Hydrocotyle vulgaris, L.-F J K L, G to $400 \mathrm{ft}$., E, D or I.

Fryngium maritimum, L.-Inverkip, West Kilbride, Arran, E F J K.

Astrantia major, L.-Common near gardens, FG.

Sanicula europaea, L.-F G J K L, E, D or I.

Conium maculatum, L.-F G, Hooker, J K, E, D or I.

Smyrnium Olusatrum, L.-Renflew, Maybole, Dumbarton, Arran, E F K J.

Apium graveolens, L.-Ayr, Carradale, E, Arran, Balfour.

A. nodiflorum, Reichb. fil.-D or I, E, Arian, Balfour, F J G.

A. inundatum, Reichb. fil.-E F G K L, J.

Cicuta virosa, L.-G, Hooker, F.

Carum verticillatum, Koch.-B E F, Lightfoot and Hooker, K L to $600 \mathrm{ft}$.

Sium erectum, Huds.-Renfrew, West Kilbride, Campbeltown, F I.

Aegopodium Podagraria, L.-F G J K L.

Pimpinella Saxifraga, L.-F G J K L, E.

Conopodium denudatum, Koch.-F G.J K L, B, E, D or I. 
Myrrhis odorata, Scop.-F G J K L, E to $400 \mathrm{ft}$.

Chaerophyllum temulum, L.-F G K.

Scandix Pecten-Veneris, L.-F, Irvine Smith, G, Hennedy, E.

Anthriscus vulgaris, Bernh.-F J K, G.

A. sylvestris, Hoffm.-F G J K L, D or I.

Crithmum maritimum, L.-Ayr Harbour, K, Hooker.

Oenanthe fistulosa, L.-Gourock, F, Hıoker, G.

Oe. Lachenalii, C. Gmel.-Gourock, Ballantrae, Innellan, Bowling, Arran, Cantyre, E F J G, D or I.

Oe. crocata, L.-E FGJ K to $400 \mathrm{ft}$., D or I.

Aethusa Cynapium, L.-FGJ K, E.

Meum athamanticum, .Jacq.--B F G M, Hooker, Lightfoot, L.

Ligusticum scoticum, L.-Largs, Ballantrae, Arran, Carradale, E F J K.

Angelica sylvestris, L.-F G J K L, B to $1100 \mathrm{ft}$. D or I.

Heracleum Sphondylium, L.-FG.J K L, B, D or I.

(Peucedanum Ostruthium, Koch.-E F G K, Editor.)

Daucus Carota, L.-F G J K L, E, D or I.

Caucalis Anthriscus, Huds.--E FG.J K L, D or I.

C. nodosa, Scop.-Renfrew, G.

Hedera Helix, L.- F G.J K L, B to $700 \mathrm{ft}$., D or I.

(Cornus suecica, L.-B, Loch Long, Balfour Ex., Editor.)

Adoxa Moschatellina, L.-G, Hooker, F K to $300 \mathrm{ft}$.

Sambucus nigra, L.-FG J K to $400 \mathrm{ft}$. D or I.

S. Ebulus, L.-G, Hooker, F K.

Viburnum Opulus, L.-FG K L.

Lonicera Periclymenum, L.-G, Hooker, F J K L, B to $1200 \mathrm{ft}$., D or I.

Galium boreale, L.-E F G H K L M, B to $700 \mathrm{ft}$. J.

G. Cruciata, Scop.-F G to $600 \mathrm{ft}$.

G. verum, L.-E, Lightfoot, F G.J K L to $1000 \mathrm{ft}$., D or I.

G. Mollugo, L.-G H F.

G. saxatile, L.-G, F J K L, B to $2600 \mathrm{ft}$., D or I.

(G. palustre, L.-B, Lomond, Buchanan White, D or I, Editor.)

G. Witheringii, Sm.-F G J K .

G. uliginosum, L.-G, F L, E.

G. Aparine, L.-F G J K L, B, D or I.

Asperula odorata, L.-F G.J K L to $600 \mathrm{ft}$., E.

Sherardia arvensis, L.--G F J K L.

Valeriana Mikanii, Syme.-F G J K L M, E.

V. sambucifolia, Willd.-E F G, B, D or I.

V. pyrenaica, L.-Introduced. Daldowie, G, Hooker, F.

Valerianella olitoria, Poll.-F K, E G.

Dipsacus sylvestris, Huds.-Introduction. F, Scott, G, Hennedy.

Scabiosa succisa, L.-F G.J K L, E, B to $1300 \mathrm{ft}$., D or I.

S. arvensis, L.-G, Hooker, F, K, E G.

Eupatorium cannabinum, L.-G, Carmyle, Hooker, E F K J.

Solidago Virgaurea, L.-F G J K L M, E, B to $1500 \mathrm{ft.,} \mathrm{D} \mathrm{or} \mathrm{I.}$

S. cambrica, Huds.-Ben Lomond, B to $2500 \mathrm{ft}$.

Bellis perennis, L.-F G.J K L, B to $600 \mathrm{ft}$., D or I.

Aster Tripolium, L.-B E K, E.

Filago germanica, L.-Uddingston, Stevenston, Arran, EG, F.J.

F. minima, Fr.-Tollcross, Innellan, Stevenston, Arran, E F G, K.

Antennaria dioica, R.Br.--G, F K L M, E, B to $2400 \mathrm{ft}$.

Gnaphalium uliginosum, L.-F G.J K L, E to $400 \mathrm{ft}$., D or I.

G. sylvaticum, L.-G, Possil, Hooker, E K L, E, B to $600 \mathrm{ft}$, , D or I.

G. supinum, L.-B, $2800 \mathrm{ft}$, Ben Lomond, L, Watt, and F, Innellan, Ewing.

Inula Helenium, L.-Uiddingston, Arran, Tarbert, Garden outcast, $\mathrm{BEG}, \mathrm{K}$. 
Bidens cernua, L.-Lanark, Renfrew, Dumbarton, Arran, Cantyre, E, FG.

B. tripartita, L.-Milngavie, St. Quivox, Arran, Cantyre, E G K, F.

Achillea Millefolium, L.-F G J K L, B, D or I.

A. Ptarmica, L.-F G.J K L, B, D or I.

Anthemis Cotula, L.-Lanark, Renfrew, Dumbarton, G, Hennedy.

A. arvensis, L.-Ayr. Introduced. F K, G.

A. nobilis, L.-Kilwinning, Arran. Introduced. E F J.

Chrysanthemum segetum, L.-F G.J K L, B to $400 \mathrm{ft}$., D or I.

C. Leucanthemum, L.-F G K L to $300 \mathrm{ft}$., D or I.

C. Parthenium, Pers.-Garden escape. F, Inverkip, Fergusson ; E G, Hennedy.

Matricaria inodora, L.-F F J K L.

M. salina, Bab.-Carradale, F, D or I.

M. maritima, L.-E, Bute, Lightfoot, F, Watt.

Tanacetum vulgare, L.-Introduced. G, Hooker, F J K, E, D or I.

Artemisia vulgaris, L.-F G J K, E, D or I.

Tussilago Farfara, L.-FG J K L, B to $600 \mathrm{ft}$., D or I.

Petasites officinalis, Moench.-F G J K L, D or I.

Doronicum Pardalianches, L.-Bothwell, Largs, Maybole, Garden escape, FGK.

Senecio vulgaris, L.-F G J K L, B to $400 \mathrm{ft}$., D or I.

S. sylvaticus, L.-G, Tollcross, Hooker, F K, E, D or I.

S. viscosus, L.-Uddingston, Barrhead, Campsie, Bowling, Dalry, FG, Hooker, B.

S. Jacobaea, L.--F G J K L to $600 \mathrm{ft} ., \mathrm{D}$ or I.

S. aquaticus, $H u d s$. - F G J K L, E, B, D or I.

S. saracenicus, L.-Bothwell, Renfrew, Kilwinning, Innellan, F G.

Carlina vulgaris, L.-Biggar, Arran, Ballantrae, EJ H.

Arctium majus, Bernh.-F GJ.

A. minus, Bernh.-F G J K L, E, D or I.

A. intermedium, Lange.-Dumbarton, Arran, E, Baker, G.

Carduus pycnocephalus, L.-G F, J.

C. nutans, L.-Lanark, $H$.

C. crispus, L.-F K, J.

Cnicus lanceolatus, Willd.-F G.J K L, B to $700 \mathrm{ft}$., D or I.

C. palustris, Willd.-FGJ K L, B, D or I.

C. heterophyllus, Willd.-G F K L M, E, B to $2000 \mathrm{ft}$.

C. arvensis, Hoffm.-F G J K L, D or I.

(Saussurea alpina, DC.-B, Ben Arthur, Hooker; Ben Buidhe, J. Paterson, to $2500 \mathrm{ft}$., Editor.)

Centaurea nigra, L.-F G.J K L, B to $1000 \mathrm{ft}$., D or I.

C. Scabiosa, L.-G, Hopkirk.

C. Cyanus, L.-Introduced. F K, G.

Cichorium Intybus, L.-Uddingston, Kilwinning, Bowling, C'antyre. Introduced. F G, E.

Lapsana communis, L.-F G J K L to $700 \mathrm{ft}$.

Crepis virens, L.-FG.J K L to $600 \mathrm{ft}$., D or I.

C. paludosa, Hoench.-F G J K L, E, B to $900 \mathrm{ft}$., D or I.

Hieracium Pilosella, L.-FGJ K L, D or I.

H. aurantiacum, L.-Bothwell, Innellan, Bowling. Garden escape. FG.

(H. holosericeum, Backh.-B to $2500 \mathrm{ft}$., Buchanan White, Editor.)

H. lingulatum, Backh.-Campsie, Dumbarton, G B to $1900 \mathrm{ft}$.

H. senescens, Backh.-Dumbarton, B to $2000 \mathrm{ft}$.

(H. sinuans, F. .J. Hanb.-Glen Falloch, Buchanan White, Editor.)

H. anglicum, Fr.-Campsie, Dumbarton, B to $2000 \mathrm{ft}$.

(var. cerinthiforme. Ben Laoigh, Buchanan White, Editor.)

H. cerinthiforme, Backh, in litt.-B to $1800 \mathrm{ft}$. 
H. Schmidtii, Tausch.-Imnellan, Arran, E F.

H. rubicundum, $F$. J. H.-B.

(H. iricum, Fr.--B, Ben Laoigh, Buchanan White, Editor.)

H. buglossoides, Arv. Touv.-G.

H stenolepis, Lindeb.-B, Ben Voirlich, $2000 \mathrm{ft}$. , Watt.

H. rivale, $F$. J. Hanb.-Arran, E B, Ben Laoigh, White.

H. murorum, L. pt.-Botlıwell, Innellan, Bowling, A rran, Carradale, E G F to $1100 \mathrm{ft}$., J. L.

H. micracladium, Dahlst.-M, Johnstone.

H. caesium, Fr.-Falls of Clyde, H E, Baker, F.

H. Orarium, Lindeb. $-\mathrm{B}$ to $2000 \mathrm{ft}$.

H. duriceps, $F$. J. Hanb.-B.

H. vulgatum, $F r$. B to $1100 \mathrm{ft}$. \& $\mathrm{G}, \mathrm{D}$ or I.

(H. caesiomurorum, Lindeb.-B, Buchanan White.

H. praelongum, Lindeb.-G, Campsie, Buchanan White.

H. reticulatum, Lindeb. - G, Campsie, Buchanan White.

H. Dewari, Bosw.-B. Inverarnan, Buchanan White.

H. subanfractum, Marsh.-B, Buchanan White. All these in Perth Flora,

H. ravusculum, Dahlst.-Arran, E, Somerville.

H. maculatum, Sm.? or A uct. Angl.?-F G, Hennedy.

H. stenophyes, Wr. Li. Linton.-G.

H. angustatum, Lindeb.-M.

H. gothicum, (Fr. pt.) Back.-M, Johnstone ; E F G, Hennedy, L.

H. sparsifolium, Lindeb.-Campsie, G B.

H. prenanthoides, Till.-Falls of Clyde, H, M, Johnstone.

H. strictum, Fries.-F M.

H. auratum, $F r$-Campsie, G, B, Watt.

H. crocatum, Fr.-B, Loch Long, Watt.

H. boreale, Fr.--G, Hennedy, J.

H. umbellatum, L.-Udılingston, Arran, E G K L, J.

(H. argenteum, $\mathrm{Fr}$.-G, Campsie, White.

H. pictorum, Linton.-B, Glen Falloch, White.

H. subhirtum, F. J. Hanb.-B, Glen Falloch, White. These three Perth Fl., Editor.)

Hypochoeris radicata, L.-F G J K L, B to $1200 \mathrm{ft}$., D or I.

Leontodon hirtus, L.-Lanark, Dumbarton, Innellan, F G, Hooker.

L. hispidus, L.-F G K L, J.

L. autumnalis, $L$. B F G K L to $2700 \mathrm{ft}$.

L. pratensis, Koch.--Wilsontown, Ben Lomond, BE, Arran, Balfour, to $2300 \mathrm{ft}$.

Taraxacum officinale, Web.-F G J K L, B to $2500 \mathrm{ft}$., D or I.

T. palustre, DC.-G, Glasgow, Hooker; F K, E to $600 \mathrm{ft} ., \mathrm{G}, \mathrm{D}$ or I.

Lactuca muralis, Fresen.--Innellan, Kilwiuning, Cantyre, F.

Sonchus oleraceus, L.-F G .J K L.

S. asper, Hoffm.-F G J K L, D or I.

S. arvensis, L.-F G K L, D or I, J.

Tragopogon pratense, L.--Introduced. G, Daldowie, Hooker, E F.

Lobelia Dortmanna, L.-G, Hooker, B E F, D or I, K, L.

Jasione montana, L.-E G, Lightfoot, F K L, D or I J.

Wahlenbergia hederacea, Reichb.-Gourock, Innellan, Ayr, F K, Hooker.

Campanula Trachelium, L.-Lanark, Ayr. Garden escape. G, Mugdock, Hooker, F.

C. latifolia, L.-G H, Lightfoot, Hooker, F J K L, D or I.

C. rapunculoides, L.-Lanark, Ayr. Introduced. F K.

C. rotundifolia, L.-E G F J K L, B to $1200 \mathrm{ft}$.

C. lancifolia, Mert. and Koch.-Arran, EG to $1100 \mathrm{ft}$.

Vaccinium Vitis-Idaea, L.-B E F G H J K L M to $1000 \mathrm{ft}$., D or I. 
V. uliginosum, L.-Cantyre, A, Inveraray, Lightfoot ; B, Ren Lomond to $2000 \mathrm{ft}$.

V. Myrtillus, L.-B F G J K L, H to $2500 \mathrm{ft}$., E, D or I.

Schollera Occycoccus, Roth.-FG M to $900 \mathrm{ft}$., K.

Arctostaphylos alpina Spreng.-Arran, E.

Andromeda polifolia, L.-Gartcosh. Possibly introduced. G F.

Calluna Erica, DC.- E F G J K L, B to $2000 \mathrm{ft}$., I) or I.

Erica Tetralix, L.-E F G J K L B to $2000 \mathrm{ft}$., D) or I.

E. cinerea, L. E F G J K L B D or I to $2000 \mathrm{ft}$.

(Pyrola rotundifolia, L.- - H, Hooker, G, Editor.)

P. media, Sw.-Lanark, Ayr, GK.

P. minor, L.-Lanark, Renfrew, Stewarton, Arran, E F, H, Hooker ; G L, Smith, K.

var. arenaria. F, Smitl.

P. secunda, L.-G H, Hennedy, $500 \mathrm{ft}$. to $2000 \mathrm{ft}$., Watt.

Armeria maritima, Willd.-B E F J K L to $2700 \mathrm{ft}$., I or I.

Primula acaulis, L.-F G J K L, B to $1000 \mathrm{ft}$., D or I.

P. veris, L.-Bothwell, Ibrox, Dalry, Arran. Introduced in these stations. E F G.

Lysimachia thyrsiflora, Ait.--Lanark, Renfrew, Ayr, Dumbarton, G, Possil, Hooker ; F, Ardrossan, Duncan.

L. vulgaris, L.--F G, B E L.

L. Nummularia, L.-G, F.

L. nemorum, L.-F G J K L, B, D or I.

Trientalis europaea, L.-B, Ben Lomond, Lightfoot, E, K, Smith.

Glaux maritima, L.-F J K, E, J or I.

Anagallis arvensis, L.- E F.J K L, G.

A. caerulea, Schreb.-Troon. On ballast. F H, Hooker.

A. tenella, L.-E F, J K, D or I.

Centunculus minimus, L.-Ayr, Arran, EG, Hooker ; K, Maybole, Smith, FJ.

Samolus Valerandi, L.-E F, J K, D or I.

Fraxinus excelsior, L.-F G J K L, B to $400 \mathrm{ft}$., E, I) or I.

Ligustrum vulgare, L.-G, E F K L, D or I.

(Vinca major, L.-G F, Largs, Smith.

V. minor, L.-FG K, Smith, Editor.)

Erythraea Centaurium, Pers. - E F J K, G, D or I.

E. littoralis, Fr.-Ayr, Imnellan, Arran, Carradale, E F, D or I.

Gentiana campestris, L.-E G, Hooker, F K I, D or I J.

Menyanthes trifoliata, L.-F G K L, E, B to $900 \mathrm{ft}$., D or I.

Polemonium caeruleum, L.-Garden escape. H, Falls Clyde, Balfour, G F.

Symphytum officinale, L.-E F G J.

S. tuberosum, L.-G, Hooker ; F, Kelly, J.

Borago officinalis, L.- F G.

Anchusa officinalis, L.--Dumbarton, G, Glasgow, Hooker. Garden escape. K, Maybole, Smith.

A. sempervirens, L.-Lanark, Renfrew, Dalry, Saddell. Garden escape.

E FG K, H, J.

Lycopsis arvensis, L.-F K, E G.

Pneumaria maritima, Hill.-Ballantrae, Arran, Lightfoot, E J, K, F.

Myosotis caespitosa, F. Schultz.-FG J K L, E, B to $600 \mathrm{ft}$., D or I.

M. strigulosa, Wert. and Koch.-F.

M. repens, $G$. Don.-F G J K L, E, B to $700 \mathrm{ft}$., D or I.

M. sylvatica, Hoffm.-Barrhead, Bothwell, G.

M. arvensis, Lam.-F G.J K L, D or I.

M. umbrosa, Bab.-Common.

M. versicolor, Reichb.-FG J K, B, D or I, L. 
Lithospermum officinale, L.-Lanark, Renfrew, Arran, EG, Mugdock, Hooker.

L. arvense, L.-Bothwell, Renfrew, Maybole, Campbeltown, G I K, F.

Echium vulgare, L.-F J, E G, Hooker.

Volvulus sepium, Junger.-Introduced. E FGJ K, D or I.

V. Soldanella, Junger.-Ayr Harbour, Arran, Carradale. Often introduced. E F K J.

Convolvulus arvensis, L.-F K, G, Hooker, E.

Cuscuta Epithymum, Hurr.-Ayr, G, Hooker ; K, Duncan.

Solanum Dulcamara, L.-E F J K, G, Hooker.

S. nigrum, L.-Bowling, Ayr Harbour, F K, B, Hennedy, G.

Hyoscyamus niger, L.- Bowling, Renfrew, Ayr. Introduced. F, G, Hooker.

Verbascum Thapsus, L.-Garden escape. E F G K.

V. nigrum, L.-Bowling. On ballast. F.

Linaria Cymbalaria, Mili.-E F G, B.

L. Elatina, Mill.-Bowling. On waste heaps. GF.

L. purpurea, L.-Bowling. On waste heaps. G.

L. repens, Mill.-Lanark, Ayr. Introduced. G, K.

L. vulgaris, Nill.-F, G E, J.

L. viscida, Moench.-Lanark, Paisley, Ayr. Introduced. FM.

Scrophularia umbrosa, Dum.-Lanark, Renfrew, FG, H.

S. nodosa, L.-F G.J K L, E, B to $400 \mathrm{ft}$., J or I.

S. vernalis, L.-Bothwell, Renfrew. Near gardens. FG.

Mimulus luteus, L.-F H K L, E.

(Limosella aquatica, L.-F, Largs, Smith, Editor.)

Digitalis purpurea, L.-F G J K L, E, B to $1100 \mathrm{ft}$., D or I.

Veronica hederaefolia, L.-F, M, Johnstone, G, Hemnedy.

V. polita, Fr.-Lanark, Dumbiarton, Arran, Carradale, E, D or I.

V. agrestis, L.-FG J K L, D or I.

V. Tournefortii, C. Gimel.-F G K.

V. arvensis, L.-F K L, G, B, D or I, J.

V. serpyllifolia, L.-FG.J K L, B, Hooker to $2200 \mathrm{ft}$., D or I.

V. officinalis, L.-E F G J K L B to $1100 \mathrm{ft}$., D or I.

V. Chamaedrys, L.-F G J K L, B, D or I.

V. montana, L.-F G K, H, Hooker, E, D or I.

V. scutellata, L.--F G K, E to $700 \mathrm{ft}$., D or I, J.

V. Anagallis-aquatica, L.- F K, EG, J.

V. Beccabunga, L.-FG J K L to $700 \mathrm{ft}$.

Euphrasia officinalis, L.-FG J K L, B.

E. gracilis, $F r$. - B to $2000 \mathrm{ft}$.

Bartsia Odontites, Hud.s.-FG.J K L to $400 \mathrm{ft}$., D or I.

B. viscosa, L.- Renfrew, Dumbarton, Arran, Cantyre, E F, B, Loch Goil, Lightfoot.

Pedicularis palustris, L.-F G J K L, E, B to $800 \mathrm{ft}$., D or I.

P. sylvatica, L.-FG J K L E, B to 80 () ft., J or I.

Rhinanthus Crista-galli, L.-B F G J K L to $2400 \mathrm{ft}$., D or I.

Melampyrum pratense, L.-F G L M, E, B to $400 \mathrm{ft}$., D or I, J.

M. montanum, Johnst.-Ben Lomoud, B.

M. sylvaticum, L.-Lanarkshire, K L.

Lathraea Squamaria, L.-Cambuslang, Ayr, Catheart, Hooker, G K ; H Lanark, Hemmerly ; F, Dundonald, Smith.

Utricularia vulgaris, L.-Pai-ley, Dumbarton, Ayr, Arran, E F G K, B.

U. neglecta, Lehm.-Ben Lomoni, B G to $700 \mathrm{ft}$.

U. minor. L. - G, Kilpatrick, Hooker; F, Ardrossan, Smith, to $400 \mathrm{ft}$., E, D or I, K.

U. intermedia, Hayne.-Ben Lomond, Arran, Carradale, BE, G, Possil, Hooker, to $700 \mathrm{ft}$. 
Pinguicula vulgaris, L.-E F G J K L M, B to $2500 \mathrm{ft}$., D or I.

P. lusitanica, L.-Ayr, Millport, Carradale, F, K, Lightfoot ; E, Hooker ; B, Tarbert, Scott, D or I.

Mentha rotundifolia, Huds.-Dumbartoushire. Garden outcast. E.

M. alopecuroides, Hull.-Drymen, Arran, Tarbert. Garden outeast. B C E, D or I.

M. longifolia, Huds.-Barrhead. Garden outcast. G.

M. piperita, L.-Garden outcast. G.

M. viridis, L.-Dumbarton, Kilwinning. Garden outcast. E FG.

M. hirsuta, Huds.-B, D or I.

M. sativa, L.-F G J K L, E (var. paludosa, G, Campsie, White, Editor.)

M. arvensis, L.-FG J K L, D or I.

M. Pulegium, L.-Dundonald. Garden outcast. F.

Lycopus europaeus, L.--E, Arran, Hooker, B F, G, D or I.

Origanum vulgare, L.-Campsie, Falls of Clyde, Paisley, Newton, G H, K, smith.

Thymus Serpyllum, Fr.-F G J K L, B to $1000 \mathrm{ft}$., D or I.

Calamintha Clinopodium, Spenn.-Barrhead, Ballantrae, G J.

Salvia officinalis, $L$.-Ayr, K.

Nepeta Glechoma, Benth.-F G J K L, E, D or I.

Scutellaria galericulata, L.-B E F K, D or I.

S. minor, Huds.-Dumbarton, Arran, Cantyre, E F G.

Prunella vulgaris, L.-F G J K L, B to $400 \mathrm{ft}$., D or I.

Marrubium vulgare, L.-Dumbarton, Ayr. On waste heaps. K, F.

Stachys Betonica. Benth.-Ayr Harbour, K, G, Cambuslang, Hooker ; J, Ballantrae, F, Smith.

S. palustris, L.-F G J K L, B, D or I.

(S. ambigua, Sm.-A, Inveraray, Hooker ; F, Cardross, Watt, E, Editor.)

S. sylvatica, L.-F G J K L, B, D or I.

S. arvensis, $L$.--E F J K L, G.

Galeopsis Ladanum, L.-Helensburgh, Ayr, F K G.

G. versicolor, Curt.-G, Hooker, F LE.

G. Tetrahit, L.-F G J K L, B, D or I.

G. bifida, Boenn.--Innellan, F.

Lamium amplexicaule, L.-F K, G E.

L. intermedium, Fr.-Common, F K, E G, D or I.

L. hybridum, Vill.-Lanark, Innellan, F.

L. purpureum, L.-F G.J K L, D or I.

L. maculatum, L.-F K.

L. album, L.--Introduced. F G K.

L. Galeobdolon, Crantz.-Helensburgh, Pollock, Darvel. Introduced. FG,J. Ballota nigra, L.-Lanark, Ayr Harbour. On waste heaps. K, G, Hooker, F. Teucrium Scorodonia, L.-FG J K L, B to $1200 \mathrm{ft}$., D or I.

Ajuga reptans, L.-FG L K, B, D or I.

A. pyramidalis, L.-Innellan, F.

Plantago major, L.-F G.J K L, B to $400 \mathrm{ft}$., D or I.

P. intermedia, Gilib.-F, Craigendoran, Watt.

P. media, L.-Tanark, Renfrew, Ayr, G, F, Walker, D or I J.

P. lanceolata, L.-F G J K L, B, D or I.

P. maritima, L.-F, B E G J K L to $2500 \mathrm{ft}$., D or I.

P. Coronopus, L.-F J K E, D or I.

Littorella juncea, Berg.-B F K I, E G to $900 \mathrm{ft}$., E.

Herniaria glabra, L.- - Paisley, G, Ewing.

Scleranthus annuus, L.-F J K, F, E, D or I.

Chenopodium album, $L$.-F G J K.

C. viride, Syme.-Lanark, Dumbarton, F K L.

C. rubrum, L.-Lanark, Ayr, Renfrew, Dumbarton, F J K G. 
C. Bonus-Henricus, L.-Lanark. Garden escape. F, G.

Beta maritima, L.-Dumbarton. Introduced. F, Wemyss Bay, Balfour, G, J.

Atriplex patula, L.-F G J K L, D or I.

A. erecta, Huds.-Common. Overlooked in Ayrshire. E G, Balfour.

A. angustifolia, Sm.--E, Balfour.

A. hastata, L.--Lanarkshire.

A Babingtonii, Woods.-E F J K, D or I.

A. virescens, Lange.-Arran.

A. laciniata, L.-E F, D or I.

Salicornia herbacea, L.-Bowling, West Kilbride, Arran, E F K, B.

Suaeda maritima, Dum.-E F.

Salsola Kali. L.-Troon, Arran, Campbeltown, E F I J K.

Polygonum Convolvulus, L.-F G J K L, B, E, D or I.

P. aviculare, $L$. - E F G J K L, D or I,

P. arenastrum, Bor.- trran, E, Boyd.

P. Raii, Bub.-E F'J K, D or I.

P. Hydropiper, L.-B E F G J K L to $400 \mathrm{ft}$., D or I.

P. minus, Huds.-Brother Lochs, Mearns, G. (I have seen no plants forsome years, P. Ewing.)

P. Persicaria, L.-F i J K L, B, D or I.

P. elatum, Gren. and Godr.-Lanarkshire.

P. lapathifolium, L.-E F.J K, G, D or I.

P. amphibium, L.-F K, E G, D or I, H.

P. terrestre, Leers.- G, D or I, F.

P. Bistorta, L.-Garden outcast. A E F G, Lightfoot and Hooker.

P. viviparum, L.-Falls of Clyde, Ayr, B H K M to $2500 \mathrm{ft}$.

Oxyria digyna, Hill.-Ben Lomond, Arran, B E L.

Rumex conglomeratus, Nurr.-F G K L, E.

R. sanguineus, L.-F, (, $\mathrm{H}$.

R. viridis, Sibth.-F, E G.

R. obtusifolius, L.-E F G J K L, B, D or I.

R. crispus, L.-F G J K L, D or I.

R. Acetosa, L.-F G.J K L, B to $410 \mathrm{ft}$., D or I.

R. Acetosella, L.-FG J K L, B to $7110 \mathrm{ft}$., D or I.

Asarum europaeum, L.-Only near gardens. F, H.

Hippophae rhamnoides, L.-F G K, D or I.

Euphorbia Helioscopia, L.-F G J K L, D or I.

E. Peplus, $L .--\mathrm{F}, \mathrm{E} \mathrm{G}, 1)$ or I.

Mercurialis perennis, L.-F G.J K L, B to $400 \mathrm{ft}$., D or I.

M. annua, L.-Ayr Harbour, F' K.

Ulmus montana, Stokes.-F G J K L to $600 \mathrm{ft}$., E, D or I.

U. surculosa, Stokes.-F G K L.

Humulus Lupulus, L.-Introduced. G H, Hooker, F, Smith, K.

Urtica dioica, L.-F G J K, B to $500 \mathrm{ft}$., D or I.

U. urens, L.-FG.J K L, D or I.

Parietaria officinalis, L.-G, Bothwell, Hooker ; F, Greenock, Scott, B H, E.

Myrica Gale, L.-F J K L, E, B to $800 \mathrm{ft}$., D or I.

Betula verrucosa, Ehrh.-F G J K L, B to $600 \mathrm{ft}$., E, D or I.

B. pubescens, Ehrh.-B to $2000 \mathrm{ft}$., (and var. p rviflora, White, Editor.)

Alnus glutinosa, Medic.-F G J K L, B to $500 \mathrm{ft}$., D or I.

Carpinus Betulus, L.-F G K.

Corylus Avellana, L.-F G J K L, B to $600 \mathrm{ft}$., E, D or I.

Quercus Robur, L.-F G.J K L, B to $400 \mathrm{ft}$., D or I.

Castanea sativa, Mill.-F G K L, D or I.

Fagus sylvatica, L.-F G.J K to $600 \mathrm{ft}$., D or I.

Salix pentandra, L.-A, Inveraray, Lightfoot, F G K L, E, D or I. 
S. undulata, Ehrh.-Falls of Clyde, H, Ewing.

S. fragilis, L.-F $\mathrm{F}$ K L, D or I.

S. alba, L.-FG J K L, D or I.

S. purpurea, L.-F K, G, D or I.

S. rubra, Huds.-Carmyle, Dumbarton, Tarbert, B F G.

S. viminalis, L.-F G J K L, E, D or I.

S. Caprea, L.-F G J K L, E, B.

S. aurita, L.-FGK L, E, B to $800 \mathrm{ft}$., D or I.

S. ambigua, Ehrh.--Tarbert, B, Ewing.

S. cinerea, L.-F G J K L, I) or I.

S. aquatica, Sm.-Dumbarton, F.

S. laurina, Sm.-Lanark, Dunoon, Tarbert, B F.

S. nigricans, Sm.-Ben Lomond, B.

S. phylicifolia, L.-Falls of Clyde, Ben Lomond, Possil, BG H.

S. repens, L.-F K L.J, D or I.

(S. reticulata, L.-B, Buchanan White, Flora Perthshive, Editor.)

S. herbacea, L.-Ayr, Cantyre, BEL, Ben Lomond, Arran, Lightfoot, to $2900 \mathrm{ft}$.

(S. Wahlenbergii, And.--B, Buchanan White, Editor.)

Populus alba, L.-Largs, Lanark, Arran. Planted. E F, G L K.

P. tremula, L.-Planted in most cases. F G J K, E, B. var. glabra, D or I.

P. nigra, L.-Lanark, Ayr, Dumbarton. Introduced, but seeds freely. FG.J K L.

Empetrum nigrum, L.-B F G J K L to $1300 \mathrm{ft}$., E, D or I.

Juniperus communis, L.-B E, F G, J.

J. nana, Willd.-Ayr, Dumbarton, Arran, Cantyre, B E K.

Taxus baccata, L.-Planted, FG K L.

Pinus sylvestris, L.-F G J K L, B.

Elodea canadensis, Wich.--E, G.

Malaxis paludosa, $S w$.-Ayr, Dumbarton, Clyde Isles. But not recently. Ben Voirlich, B, K, E.J.

Neottia Nidus-avis, Rich.-Kilwinning, Paisley, Lanark, Dumbarton, F G, $\mathrm{K}, \mathrm{H}$.

Listera cordata, R.Br.-B E, Hooker, F K, G to $900 \mathrm{ft}$., J, D or I.

L. ovata, R.Br.- E FGK.

Goodyera repens, R.Br:-F, Dundonald.

Cephalanthera ensifolia, Rich.-Prestwick, Whiting Bay, Cantyre, E F.

Epipactis latifolia, All.-G, Hooker, F K L.

Orchis mascula, L.-F G J K to $400 \mathrm{ft}$., E.

O. incarnata, L.-Tarbert, B, H, Balfour ; M, Johnstone, D or I.

O. latifolia, L.-G, Lightfoot, E F K to $600 \mathrm{ft}$., D or I.

O. maculata, L.-E F G J K L B to $10(10 \mathrm{ft}$., D or I.

Habenaria conopsea, Benth.-B E F H K, G, D or I.

H. albida, R.Br:- - F, G E, B.

H. viridis, R.Br.-BE, Lightfoot; G, Hooker; F K, Smith.

H. bifolia, R.Br.-E F K G to $400 \mathrm{ft}$., D or I.

H. chloroleuca, Ridley.-B E G, F to $400 \mathrm{ft}$., D or I.

Iris Pseudacorus, L.-F G.J K L, B, D ır I.

Narcissus Pseudo-narcissus, L.--Bothwell, Barrhead, Largs. Introduced. F G.

Galanthus nivalis, L.-Introduced. G, F.

Convallaria majalis, L.-Buthwell, Giffnock, Largs, Dumbarton. Introduced. F G, H.

Allium vineale, L.-Common. Doubtful native, unless in Arran. E, G, Hooker; F, K Smith, J. var. compactum, F, Somerville.

A. ursinum, L.-E, Arran, Lightfoot; F K L, G to $600 \mathrm{ft}$; J, Ailsa Craig, D or I. 
Scilla verna, Hud.s.-Carradale, K J, J K.

S. festalis, Salisb.-G, F.J K L, B to $1100 \mathrm{ft}$., E.

Ornithogalum umbellatum, L.-Bothwell Woods, Renfrew. Introduced.

G, F.

Narthecium Ossifragum, Huds.-F GJ K L, B to $900 \mathrm{ft.,} \mathrm{E.}$

Tofieldia palustris, Huds.-Ben Lomond, B, $2300 \mathrm{ft}$. to $3500 \mathrm{ft}$.

Gagea fascicularis, Salisb.-Milngavie. Introduced. G.

Paris quadrifolia, L.-Cartland Craigs, Barrhead, Galston, G H, F.

Juncus bufonius, L.-F G J K L, B to $400 \mathrm{ft}$., D or I.

J. trifidus, Koch.-Ben Lomond, Arran, B E to $2500 \mathrm{ft}$.

J. squarrosus, L.-FG J K L, B to $2700 \mathrm{ft}$., D or I.

J. compressus, Jacq.-Dumbarton, F G, J.

J. Gerardi, Loisel.-E E.J K, D or I.

J. tenuis, Willd.-Bridge of Weir, Dumbarton, F.

J. glaucus, Lees.-Lanark, Renfrew, Arran, E F G.

J. effusus, L.-F J K L, B, D or I.

J. conglomeratus, L.-F G J K L, B to $600 \mathrm{ft}$., D or I.

J. maritimus, Lam.-E F K, D or I.

J. supinus, Woench.-G, Glasgow, Don; E F.J K L, B to $900 \mathrm{ft}$., $\mathrm{D}$ or I.

J. lamprocarpus, Ehrh.-F GJ K L E, B to $900 \mathrm{ft}$., D or I.

J. acutiflorus, Ehrh.-E F G.J K L, B to $900 \mathrm{ft}$., D or I.

J. triglumis, L.-Ben Lomond, Lightfoot; Arran, Carradale, B E to $2500 \mathrm{ft}$.

Luzula vernalis, DC.-J L C, B to $1000 \mathrm{ft}$., D or I.

L. maxima, $D C$.- F G.J K L, B to $1200 \mathrm{ft}$., D or I.

L. spicata, $D C$.- Ben Lomond, B, Balfour to $2700 \mathrm{ft}$.

L. campestris, $D C$.- F G J K L M B to $600 \mathrm{ft}$.

L. erecta, Desv.-B to $600 \mathrm{ft}$., D or I.

L. congesta, Lejeune.-G, to $900 \mathrm{ft}$.

Typha latifolia, L.-Uddingston, Loch Semple, Symington, Tarbert, B FG H, E.

T. angustifolia, L.-Carstairs, Ayrshire, H.

Sparganium ramosum, Huds.-EFGJKL. (var. microcarpum, D or I, Edit.)

S. simplex, Huds.--E G, Hooker, F K.

S. affine, Schnizl.-Drymen, Arran, Carradale, C E, B to $2000 \mathrm{ft}$., D or I.

S. minimum, $F r-F \mathrm{~K} \mathrm{~L}, \mathrm{G}$ E.

Arum maculatum, L.-Garden outcast, G, Hooker, F, H, E, J.

Lemna trisulca, L.-Possil, Bowling, Troon. Iutroduced. F G to $300 \mathrm{ft}$.

L. minor, L.-FG $\mathrm{K}$ to $300 \mathrm{ft}$.

L. gibba, L.--Possil, Ayr. Introduced. G.

L. polyrhiza, L.-Possil. Introduced? G H, Lanark, Hooker.

Alisma Plantago aquatica, L.-E F G.J K L, B.

A. ranunculoides, L.-Blantyre, Renfrew, West Kilbride, Dumbarton, Arran, E F G.

Triglochin palustre, L.-F G J K L, E to $900 \mathrm{ft}$., D or I.

T. maritimum, L.-F, Hooker, E.J K, G, D or I.

Potamogeton natans, L.-F G K L E, D or I.

P. polygonifolius, Pour.-B G to $900 \mathrm{ft}$., D or $\mathrm{I}$.

P. pseudo-fluitans, Syme.-B.

P. coloratus, Hornem.-Arran, E.

P. alpinus, Balb.-G to $600 \mathrm{ft}$.

P. heterophyllus, Schreb.-G, Hooker, FJ K L (and var. gramineus. B, Watt, Editor).

P. nitens, Web.-Arran, Tarbert, B E.

P. lucens, L.-Lanark, Barrhead, Kilwinning, Dunoon, F G.

(P. decipiens, Nolte.-B, Watt, Editor.)

P. angustifolius, Presl.-Lanark, B.

P. perfoliatus, L.-F, G. 
P. crispus, L.--F K, G.

P. densus, L.-G, Barlowie, Hooker.

P. obtusifolius, Mert. and Koch.-Lanark, K.

P. pusillus, L.-F K K.

P. pectinatus, L.-Dumbarton, Ayr, Cantyre, F, Watt.

P. interruptus, lit. - A yrshire, G.

Butomus umbellatus, L.-Possil, Paisley. Introduced. G.

Ruppia rostellata, Koch.-West Kilbride, Dumbarton, Cantyre, F, J.

Zannichellia palustris, L._Cambuslang, Neilston, Dumbarton. Introduced. G F.

Zostera marina, L.-Gourock, West Kilbride, Dumbarton, Millport, Cantyre. F, E K.

Z. nana, Roth.-West Kilbride, Dumbarton, Arran, Tarbert, B E, F K.

Eleocharis acicularis, R. Br.-G E B.

E. palustris, R. Br.-E FG J K L, B to $900 \mathrm{ft}$., D or I.

E. uniglumis, Reichb.-Arran, Carradale, E.

E. multicaulis, Sm.-FGK L, E, B, D or I.

Scirpus pauciflorus, Lightf.-G, Mugdock, Hooker, E F, B, D or I.

S. caespitosus, L.- E G J K L, B to $900 \mathrm{ft}$., D or I.

S. fluitans, L.-F, E G.

S. cernuus, Vahl.-West Kilbride, Ballantrae, Millport, Cantyre, F J

S. setaceus, L.-F G J K L, E, G to $700 \mathrm{ft}$., D or I.

S. lacustris, L.-F K L G.

S. tabernaemontani, Gmel.-Renfrew, West Kilbride, F.

S. maritimus, L.--E F J K G, D or I.

S. sylvaticus, L.-G H, F J K L, B.

S. Caricis, Retz.-Wemyss Bay, West Kilbride, Arran, E F.

S. rufus, Schrad.-E, Hooker, F K, G, B, D or I.

Eriophorum vaginatum, L.-FG J K L, B to $900 \mathrm{ft}$., E, D or I.

E. angustifolium, Roth.-F G J K L, B to $900 \mathrm{ft}$., E, D or I.

E. latifolium, Hoppe.-Falls of Clyde, Carradale, H.

Rhynchospora alba, Vahl.-B E F.

Schoenus nigricans, L.-E FJ K, D or I.

Cladium jamaicense, Crantz.-Bute, EJ.

Carex dioica, L.-F K L M, E, B to $900 \mathrm{ft}$., D or I.

C. pulicaris, L.-F G K L E, B to $800 \mathrm{ft}$., D or I.

C. pauciflora, Lightf.-E, Arran, Lighfoot, BG K, Smith, D or I.

C. disticha, Huds.- F, Dalmuir, Watt to $500 \mathrm{ft}$.

C. arenaria, L.-E, Lightfoot, F J K, D or I.

C. teretiuscula, Good.-F K G E.

C. paniculata, L.-G, H, Balfour, E.

C. vulpina, L.-E F K G D or I.

C. muricata, L.-G, E F.J K.

C. echinata, Murr.-F G J K L M, B to $900 \mathrm{ft}$., D or I.

C. remota, L.-F K G E J, H, D or I.

C. Boenninghausiana, Weihe.-Ayrshire, K, Culzean, Watt.

C. curta, Good.--F L M, G to 700 it., E.

C. ovalis, Good.-F G J K L M to $900 \mathrm{ft}$., E, D or I.

C. atrata, L.-Ben Lomond, B.

C. Hudsonii, Ar. Benn.-Lanarkshire, Renfrewshire, Dumbartonshire.

C. acuta, L.-G F E, K.

C. rigida, Good.-Ben Lomond, Arran, Carradale, B E to $2900 \mathrm{ft}$.

C. aquatilis, Wahlenb.-- $\mathrm{FH}, \mathrm{G} \cdot \mathrm{J}$.

C. elatior, Bab.-Milngavie, Luch Semple, F G.

C. Goodenowii, J. Gay.-F G J K L, B, D or I.

C. flacca, Schreb.-FG J K L to $9(\%) \mathrm{ft}$., b) or I.

C. magellanica, Lam.-G to $800 \mathrm{ft}$. 
C. limosa, L.-F G to $700 \mathrm{ft}$., J, K.

C. pilulifera, L.-E, Arran, Lightfoot, F G J K L M, B to $2500 \mathrm{ft}$., D or I.

C. verna, Chaix.-F, G E.

C. pallescens, L.-B E F K L, G, D or I.

C panicea, L.-F G J K L, B to $2500 \mathrm{ft}$., D or I.

(C. vaginata, Tausch.-B. White.

C. capillaris, L.-B. White. Both Perth. Flora, Editor.)

C. pendula, Huds.-Crossford, Castle Semple, West Kilbride, Ballantrae, F J, G, F K L.

C. sylvatica, Huds.-F G K L, E, J.

C. laevigata, $S m .-\mathrm{G}$, Hooker, E, E, D or I.

C. binervis, Sm.-F G J K L, E, B to $2500 \mathrm{ft}$., D or I.

C. distans, L.-Kilwinning, Arran, Carradale, E F, K, D or I.

C. fulva, Good.-E F.J K L, B to $400 \mathrm{ft}$., D or I.

C. extensa, Good.-E F J, D or I.

C. pumila, Anders.-Arran, E.

C. flava, L.-F G J K L M, E, B to $2500 \mathrm{ft}$., and D or I.

C. Oederi, Retz.-Ben Lomond, Carradale, B G, E.

C. cyperoides, Marsson.--Ben Lomond, Carradale, B F, Somerville.

C. filiformis, L.-Lochwinnoch, Carradale, F, K, Lightfoot, J.

C. hirta, L.-F G J K L, E, D or I.

C. acutiformis, Ehrh.-G K E.

C. riparia, Curtis.-Falls of Clyde, Renfrew, Kilwinning, Bowling, F H, G K L.

C. rostrata, Stokes.-F J K L G to $900 \mathrm{ft}$., D or I.

C. elatior, Blytt.-Loch Semple, F.

C. vesicaria, L.-F G K, B.

C. pulla, Good.-Ben Lomond, B.

(C. obtusangula, Ehr.-B. White, Perth. Flora, Editor.)

Phalaris canariensis, L.-Introduced. G, Hooker, F.

P. arundinacea, L.-F G J K L, B, D or I.

Anthoxanthum odoratum, L.-F G J K L, B to $2500 \mathrm{ft}$., D or I.

A. Puellii, Lecoq. and Lamotte.--Renfrewshire. Recent introduction.

Alopecurus myosuroides, Huds.-Uddingston, Crossmyloof, Ayr Harbour, Innellan. Introduced. F G K.

A. geniculatus, L.-F G J K L to $400 \mathrm{ft}$., D or I.

A. pratensis, L.-F G K L.

Milium effusum, L.-G, Hooker, F, H, D or I.

Phleum pratense, L.-F G J K L, D or I.

Agrostis canina, L.-F G.J K L to $1000 \mathrm{ft}$., D or I.

A. palustris, Huds.-F G J K L, D or I.

A. maritima, Mey.-Arran, Tarbert, B E, F, D or I.

A. vulgaris, With.-F J K L, E, B, D or I.

A. pumila, L. - Prestwick, Carradale, F J, D or I.

Apera Spica-venti, Beauv.-Renfrew, Milngavie. Recent introduction. G.

Ammophila arundinacea, Host.-E E J K.

Aira caryophyllea, L.-FG.J K L, D or I.

A. praecox, L.-FG.J K L, D or I.

(Weingaertneria canescens, Bernh.-K, Smith and Beeby, Editor.)

Deschampsia caespitosa, Beauv.-B F G J K I. to $2000 \mathrm{ft}$., D or I.

D. alpina, Gaud.-Ben Lomond, B.

D. pseudo-alpina, Syme.--Ben Lomond, B.

D. alpina, Roem. and Schult.-Ben Lomond, B.

D. flexuosa, Trim.-F G J K L, B, D or I.

D. montana, Hook. fil.-Tarbert, B, D or I.

Holcus mollis, L.-G, F K L, E, B, D or I.

H. lanatus, L.-F G.J K L, B, D or I. 
Trisetum pratense, l'ers.- G, F.

Avena pubescens, Huds.-G, F K, D or I.

A. pratense, L.-Milngavie, Dumbarton, Innellan, Ayr, G F K, J L, E, B to $2400 \mathrm{ft}$.

Arrhenatherum avenaceum, Beauv.-F G J K L, D or I.

A. nodosum, Reichb.-Bothwell, G.

Sieglingia decumbens, Bernh.-FG J K L, E, B to $2000 \mathrm{ft}$., D or I.

Phragmites communis, Trin.-E F J K L G, D or I.

Cynosurus cristatus, L.-F G J K L, B, D or I.

Koeleria cristata, Pers.-F.J K.

Molinia varia, Schrank.-F G.J K L, E, B to $900 \mathrm{ft}$., D or I.

Catabrosa aquatica, Beauv.-E, Arran, Balfour, F, G, K.

C. littoralis, Parn.-Prestwick, Carradale, F, D or I.

Melica nutans, L.-H K L, G to $600 \mathrm{ft}$.

M. uniflora, Retz.-G, F J K L, E, G to $500 \mathrm{ft}$.

Dactylis glomerata, L.-F G J K L, B to 400 f.t., D or I.

Briza media, L.-H, Hooker, F G K L.

Poa annua, L.-F G J K L, B, D or I.

P. alpina, L.--Ben Lomond, B, Balfour, E to $2400 \mathrm{ft}$.

P. glauca, $S m$. $\rightarrow$ Ben Lomond, B.

P. Balfourii, Parn.-Ben Lomond, B, Balfour to $2000 \mathrm{ft}$

P. nemoralis, L.-F G K, B, H.

P. compressa, L.-Lanark, Renfrew. Recent introduction. G.

P. pratensis, L.-F G J K L, D or I.

P. trivialis, $L$.-F G J K L, D or I.

Glyceria fluitans, $R$. $B r$.-F J K L to $700 \mathrm{ft}$., D or I.

G. plicata, Fr.-Arran, Carradale, E.

G. aquatica, $S m$.-F G B.

G. maritima, Nert. and Koch.-F J K, G, D or I.

G. distans, Wahlenb.-Renfrewshire.

Festuca rottboellioides, Kunth.- Troon, Arran, Campbeltown, E F.J.

F. sciuroides, Roth.-F K K L, B, D or I.

F. ovina, L.-F G J K L to $1300 \mathrm{ft}$.

F. rubra, L.-F to $1000 \mathrm{ft}$., D or I, and var. arenaria. D or I.

F. sylvatica, Iill.-K.

F. elatior, L.-F G J K.

F. pratense, Huds.-B G.

Bromus giganteus, L.-F G J K L, E, D or I.

B. ramosus, Huds.-F G J K L, D or I.

B. sterilis, L.-F K G. Recent introduction.

B. secalinus, L.--Introduced with ballast. G.

B. racemosus, L.-Renfrew, Dumbarton, Ayr, G, Hooker, F K, E.

B. commutatus, Schrad.-F K, G.

B. mollis, L.-F G J K L, B, D or I.

Brachypodium gracile, Beauv.-F G J K L, E.

Lolium perenne, L.—F G.J K L, B, D or I.

Agropyron caninum, Beauv.-FG J K L.

A. repens, Beauv.-FG.J K L, D or I.

A. acutum, Roem. and Schult.-Troon, F.

A. junceum, Beauv.-Largs, Ballantrae. Arran, Millport, Carradale, E F.J K.

Lepturus filiformis, Trin.-West Kilbride, Milporr, F.

Nardus stricta, L.-F J K L, G E, B to $1200 \mathrm{ft}$. , D or I.

Hordeum murinum, L.-Ayr Harbour, K, F, Smith.

Elymus arenarius, L.-Stevenston, Arran, Carradale, E F.

P Ewing, F.L.S. 


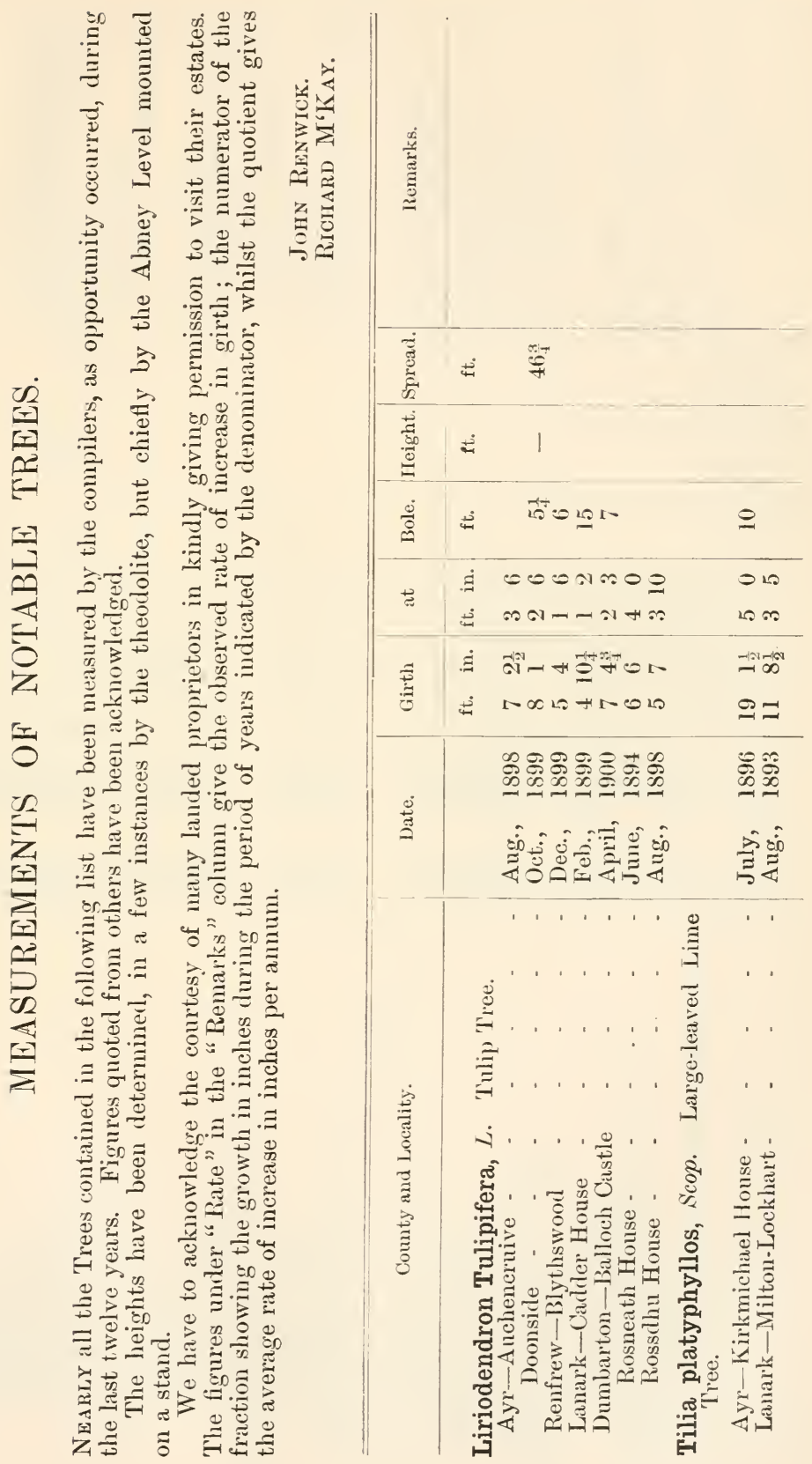




\begin{tabular}{|c|c|c|c|c|c|c|c|}
\hline 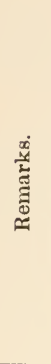 & 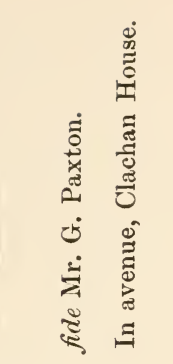 & 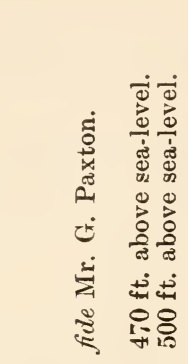 & 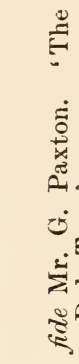 & 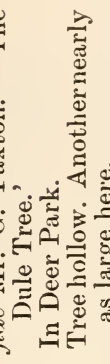 & 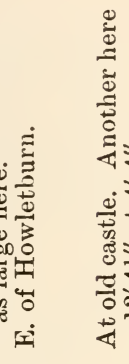 & 焉 & 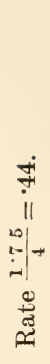 \\
\hline 芭 & \pm 1 & 11 & i & 11 & 1 & 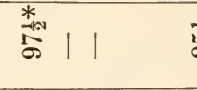 & है \\
\hline 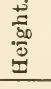 & \pm 1 | & 11 & $!$ & 11 & 1 & ஓ & $\infty$ \\
\hline$\stackrel{0}{\circ}$ & \pm 10. & o & 10 & $0.10^{-10}$ & مิ & \pm 8 & 10 \\
\hline$\stackrel{+}{\approx}$ & $\begin{array}{l}\doteq \oiint_{0} \infty \infty \\
\stackrel{\Xi}{=}++\infty\end{array}$ & $\begin{array}{l}000020 \\
-420-01\end{array}$ & $\begin{array}{l}0 \\
10\end{array}$ & $\begin{array}{l}0.0 \\
1000\end{array}$ & $\begin{array}{l}0000 \\
007-1\end{array}$ & $\begin{array}{l}n+100000 \\
110+012 n\end{array}$ & $\infty$ \\
\hline t: & 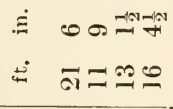 & 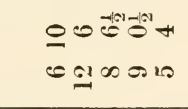 & $\stackrel{\infty}{\infty}$ & 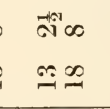 & 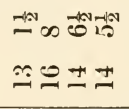 & 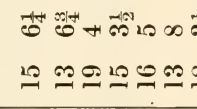 & \\
\hline 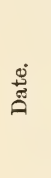 & 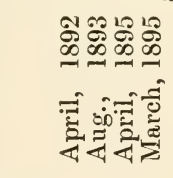 & 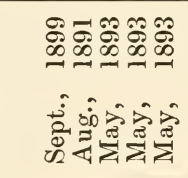 & 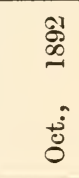 & 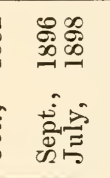 & 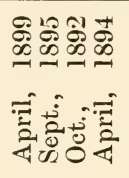 & 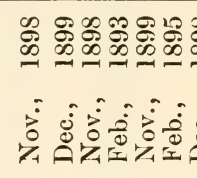 & 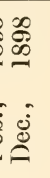 \\
\hline 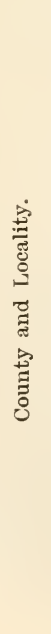 & 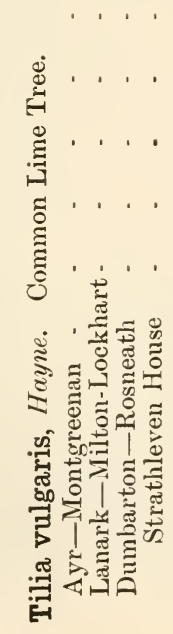 & 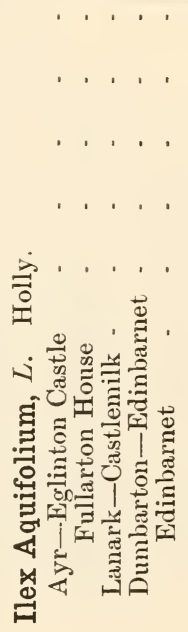 & 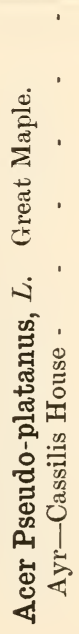 & 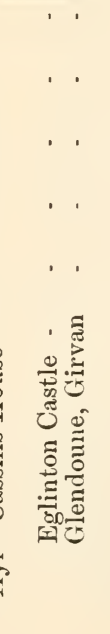 & 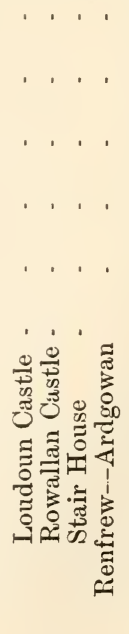 & 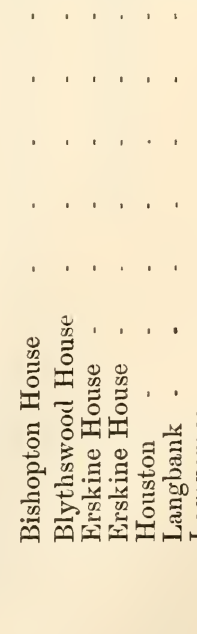 & 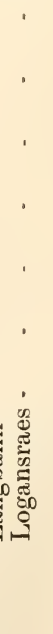 \\
\hline
\end{tabular}




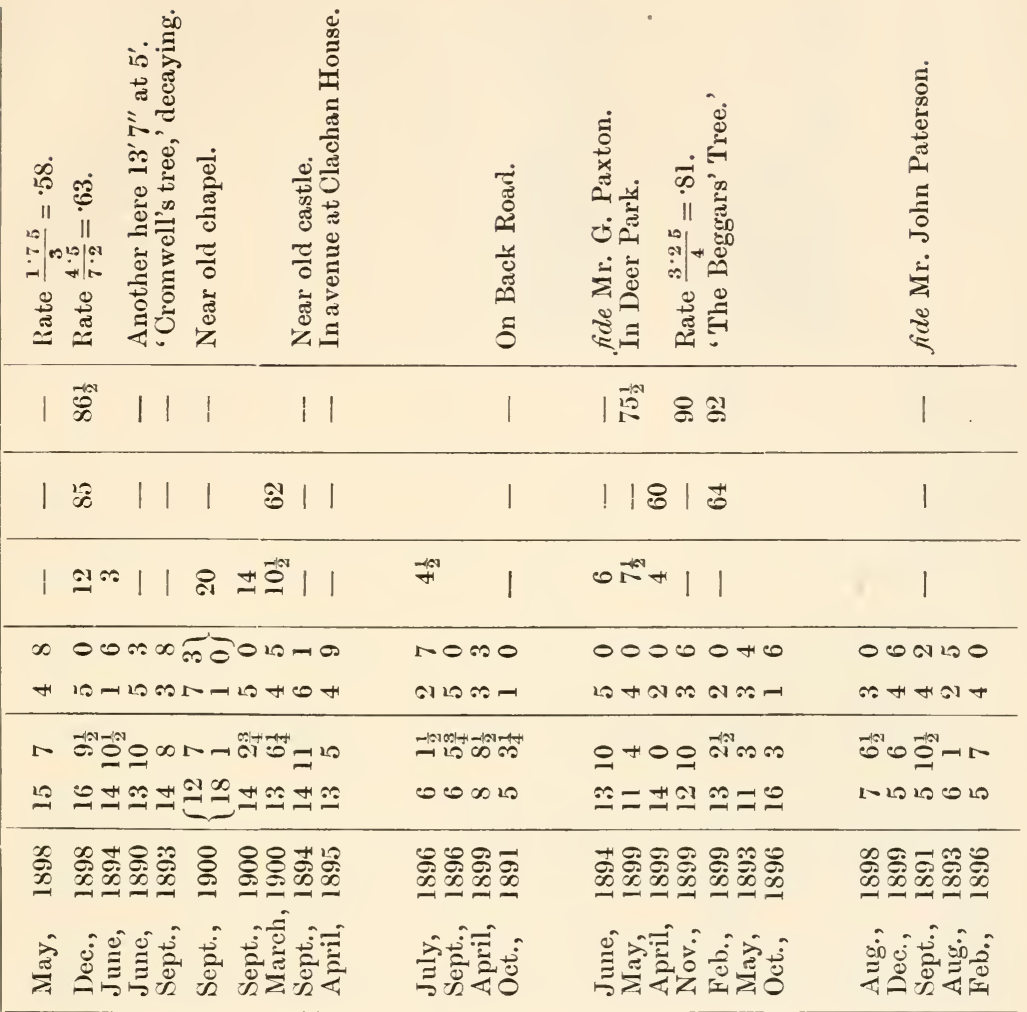




\begin{tabular}{|c|c|c|c|c|c|c|}
\hline 离 & & 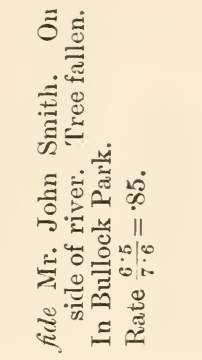 & 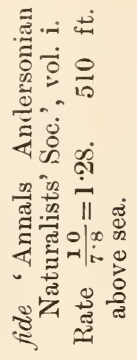 & 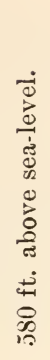 & 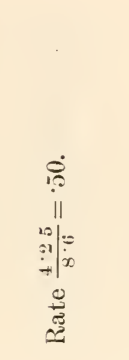 & 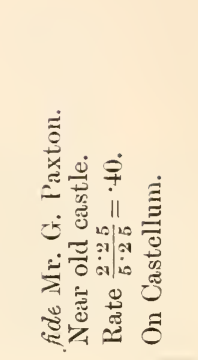 \\
\hline 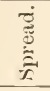 & $\dot{4}$ & $1 \quad 1 \stackrel{-\infty}{3} \Re$ & 1 & $\stackrel{\infty}{+}$ & 1 & \\
\hline 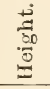 & $\dot{\ddagger}$ & $1 \mid \begin{array}{ll}\mid & 1\end{array}$ & 1 & 1 & 18 & 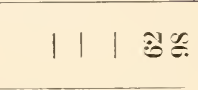 \\
\hline$\stackrel{\infty}{\circ}$ & ثُ & a $110+01$ & $\begin{array}{l}0 \\
\cdots\end{array}$ & 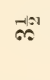 & 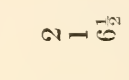 & $1 \mid 1201$ \\
\hline$\vec{己}$ & $\begin{array}{l}\dot{\Xi} \\
\dot{\leftrightarrow}\end{array}$ & 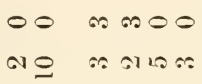 & $\begin{array}{ll}0 & 0 \\
r & 0\end{array}$ & $\begin{array}{l}\varrho \\
-\end{array}$ & $\begin{array}{l}000+ \\
\therefore--+\end{array}$ & $\begin{array}{l}00+1000 \\
02001+\text { an }\end{array}$ \\
\hline 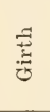 & 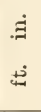 & 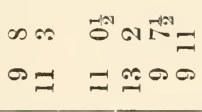 & $\begin{array}{l}+ \\
=\end{array}$ & r & 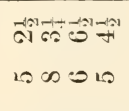 & $\begin{array}{l}0-0 \rightarrow 00 \\
00901\end{array}$ \\
\hline 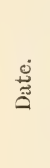 & & 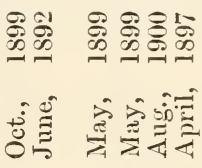 & 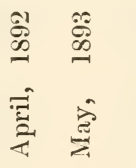 & 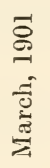 & 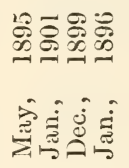 & 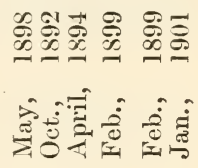 \\
\hline
\end{tabular}

宛

产. .

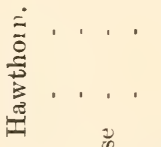

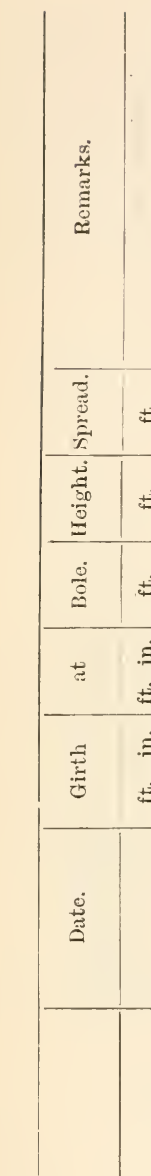
年苟 产

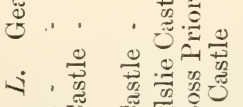
हี่

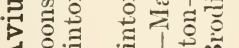
40.700000

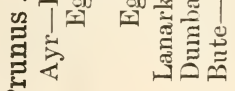
告

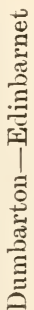
مr

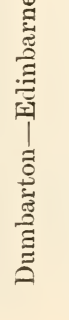

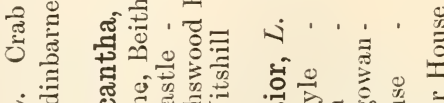

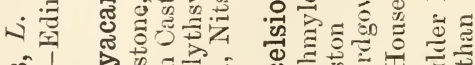
थ! 宊 设 थ है क्षे 记 pr मि 


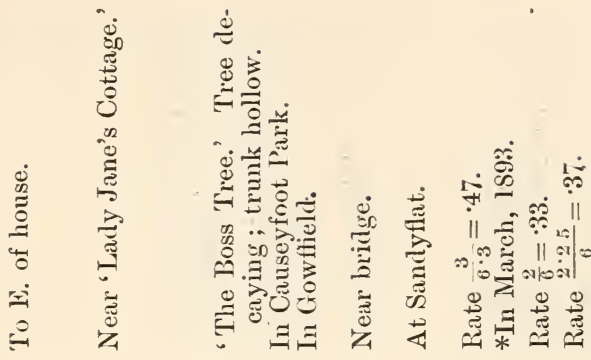

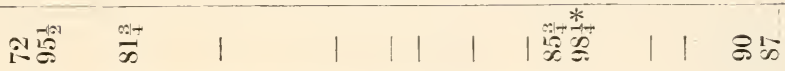

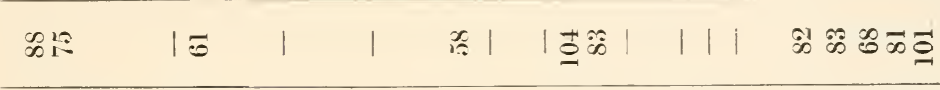

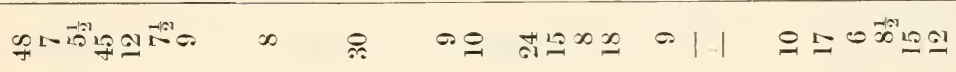

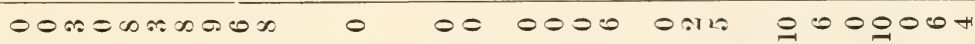

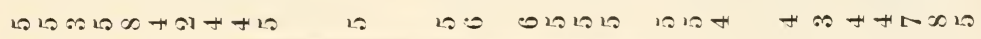

N

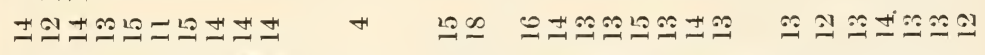

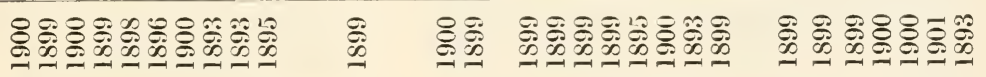

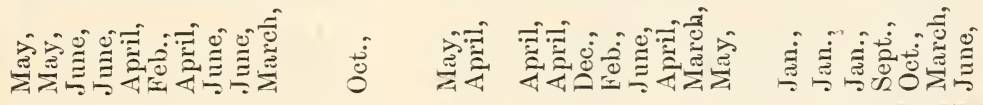

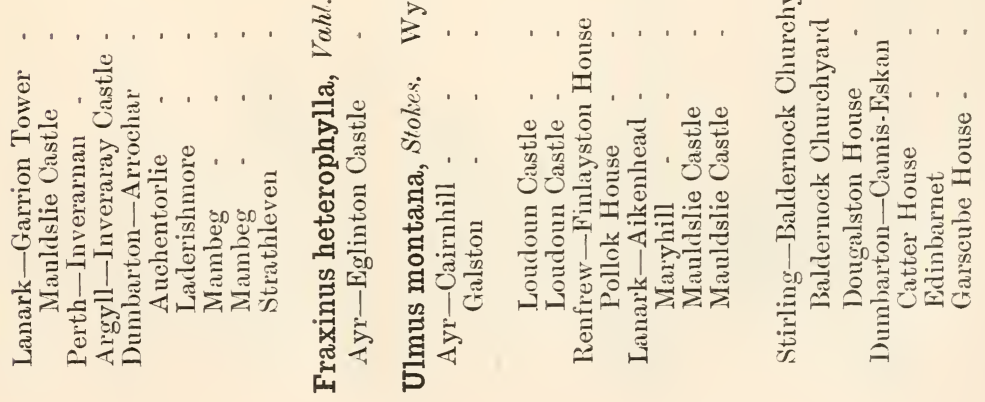




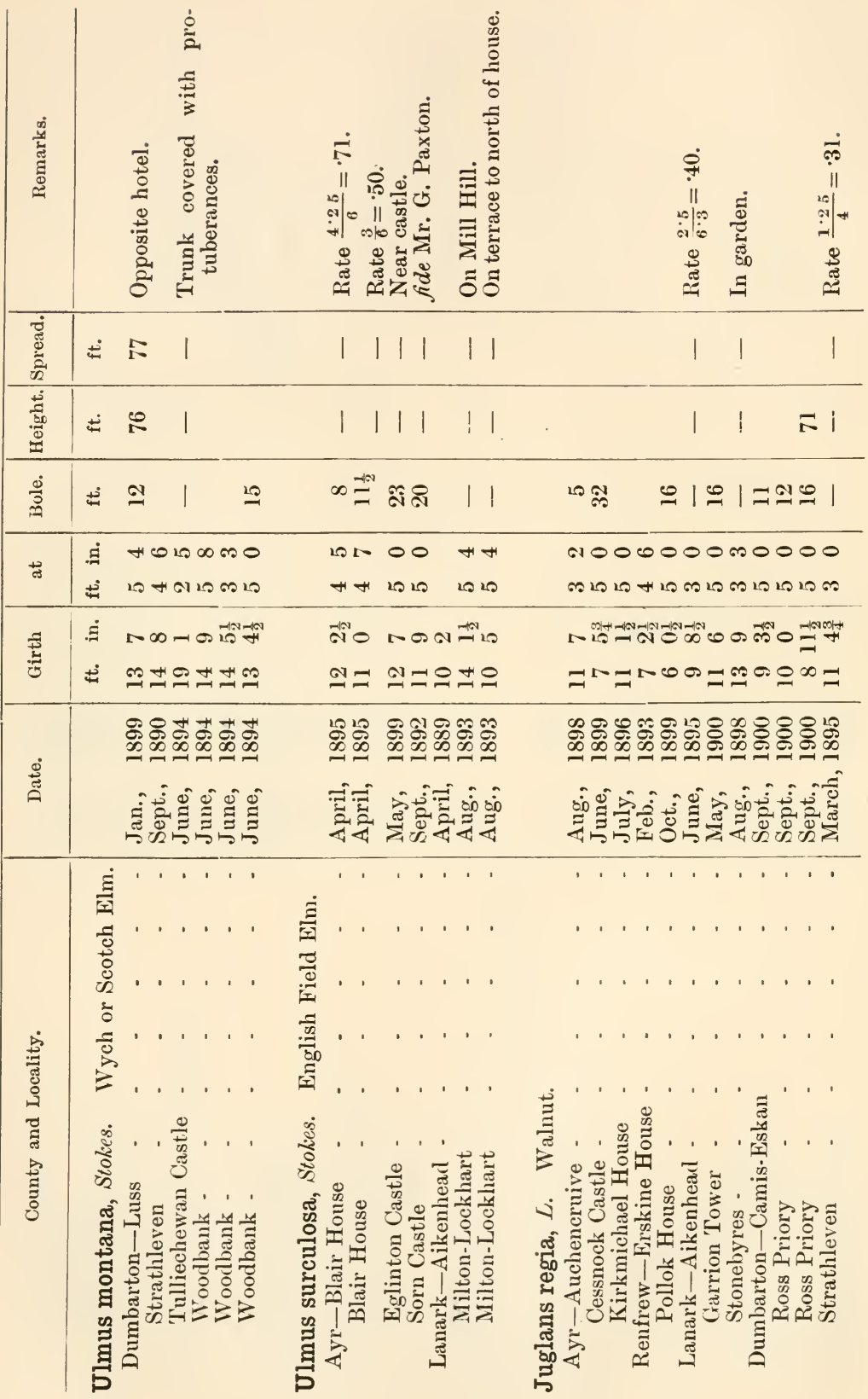




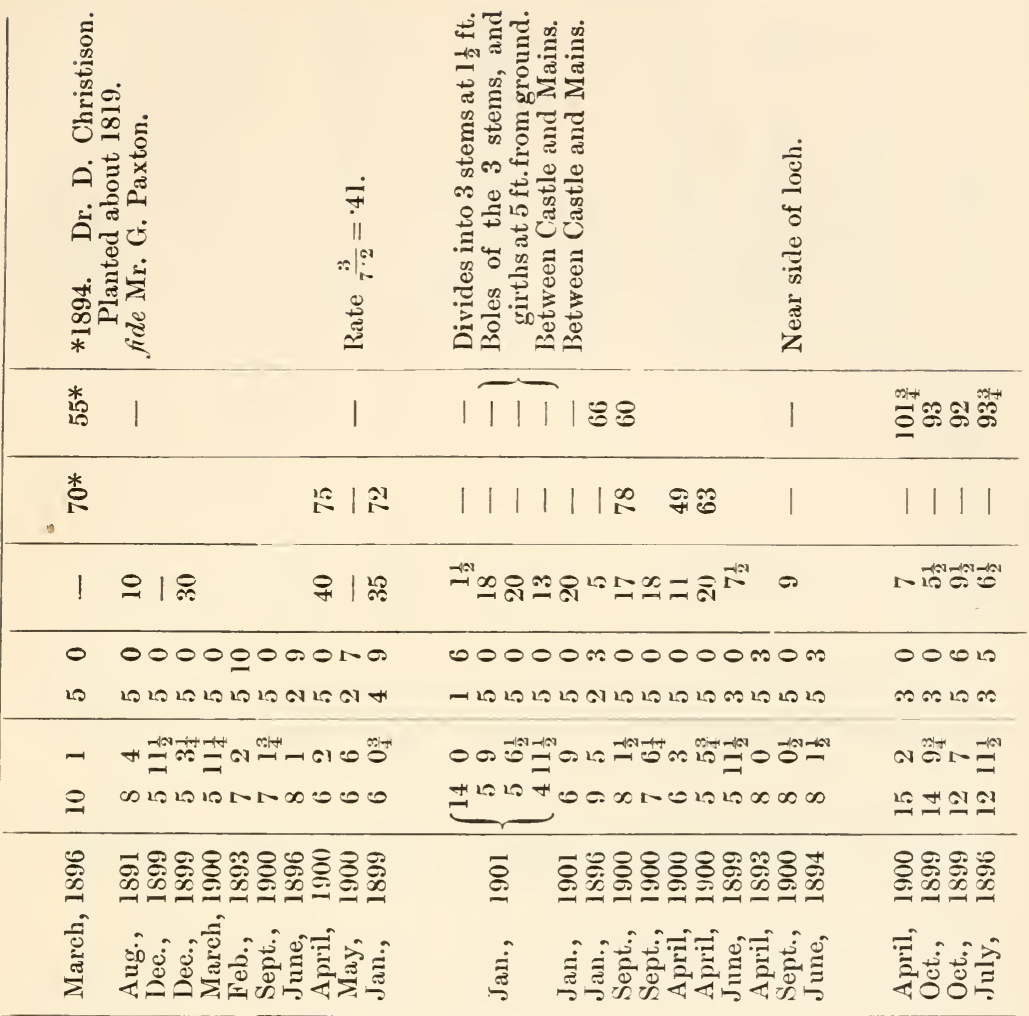
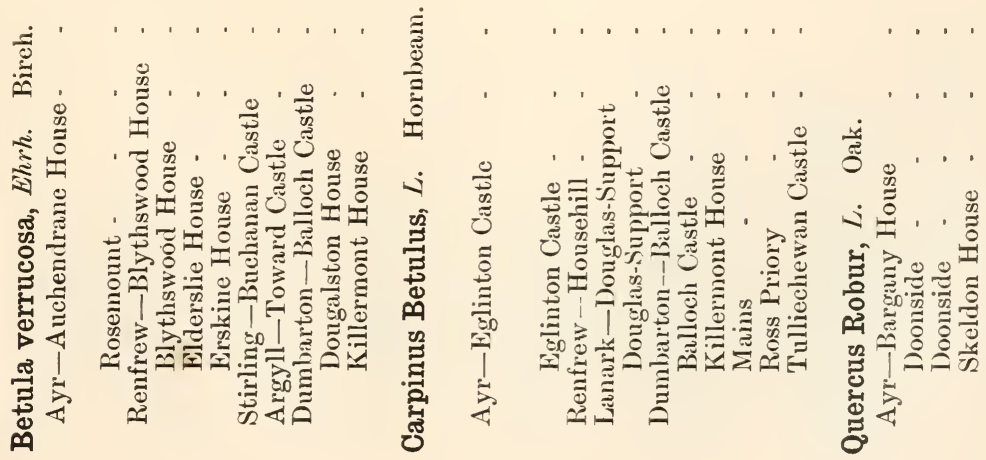


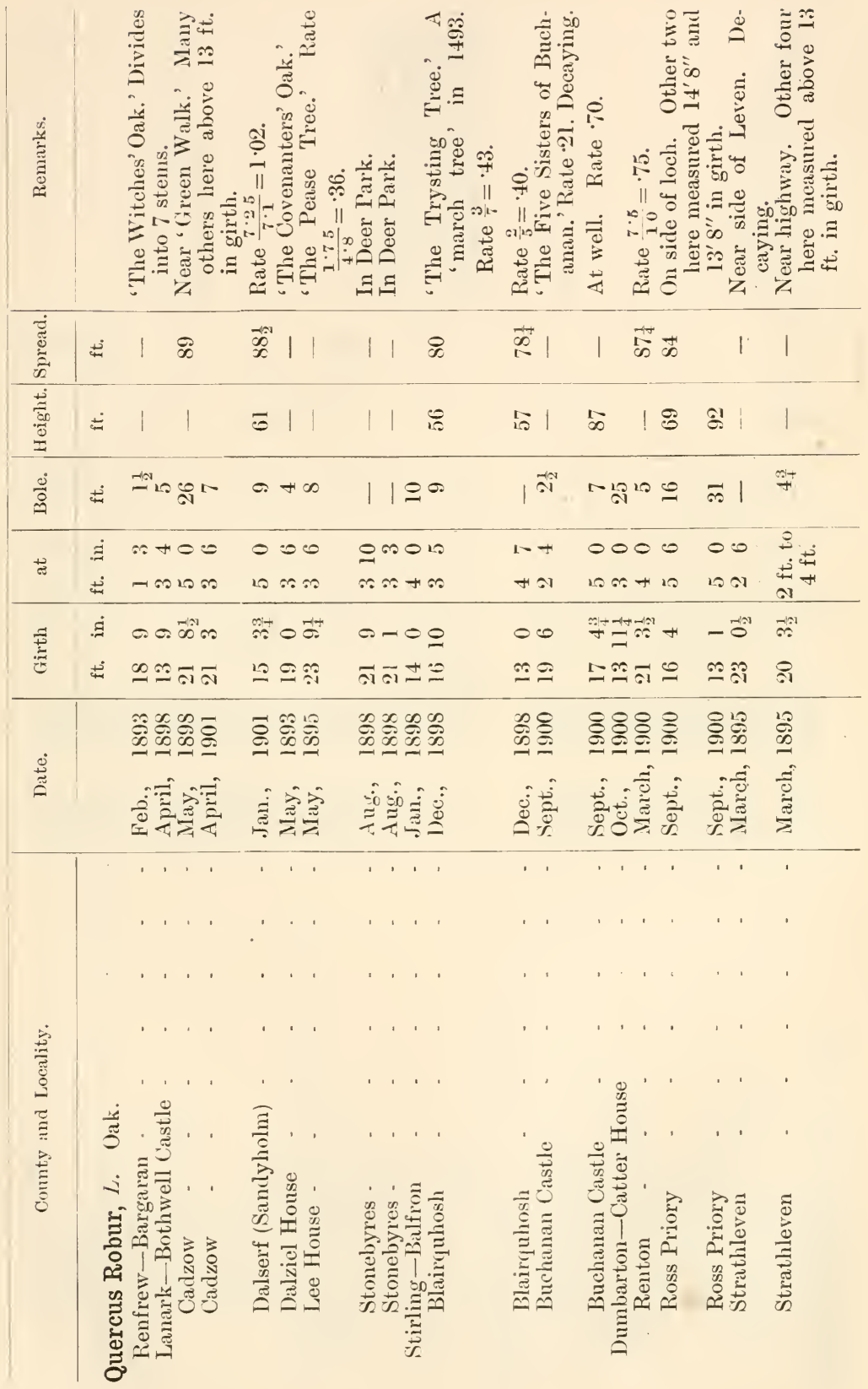




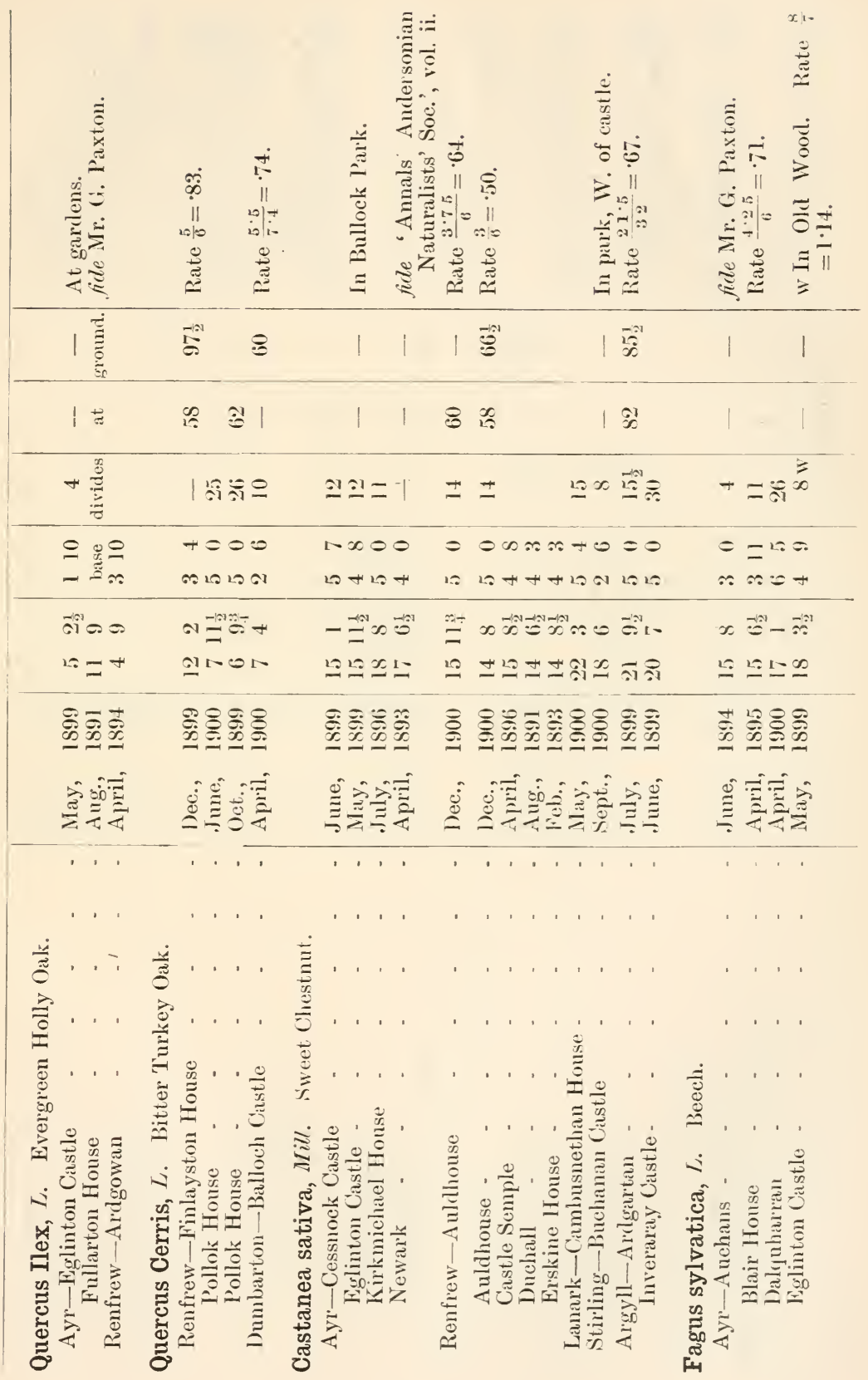




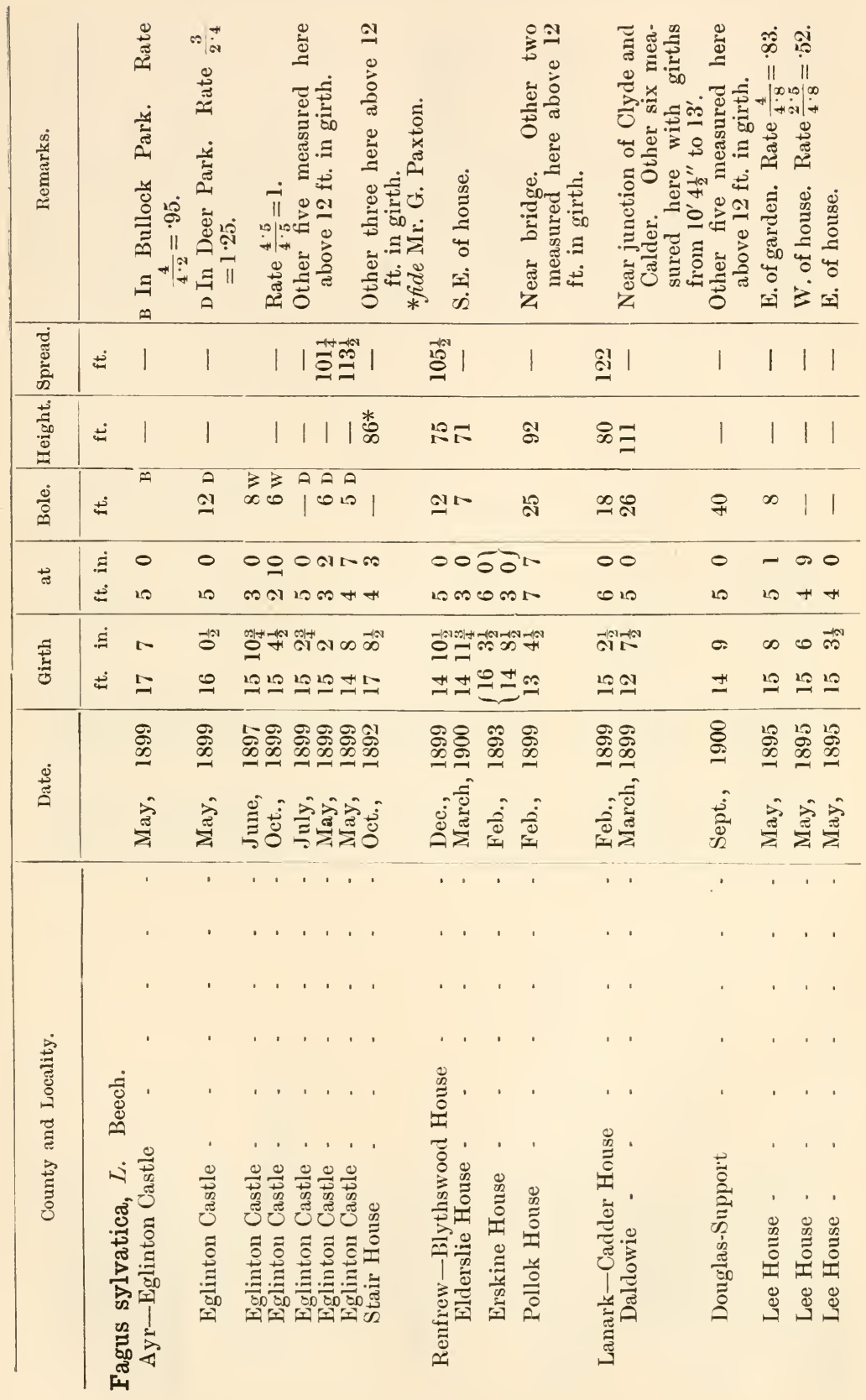




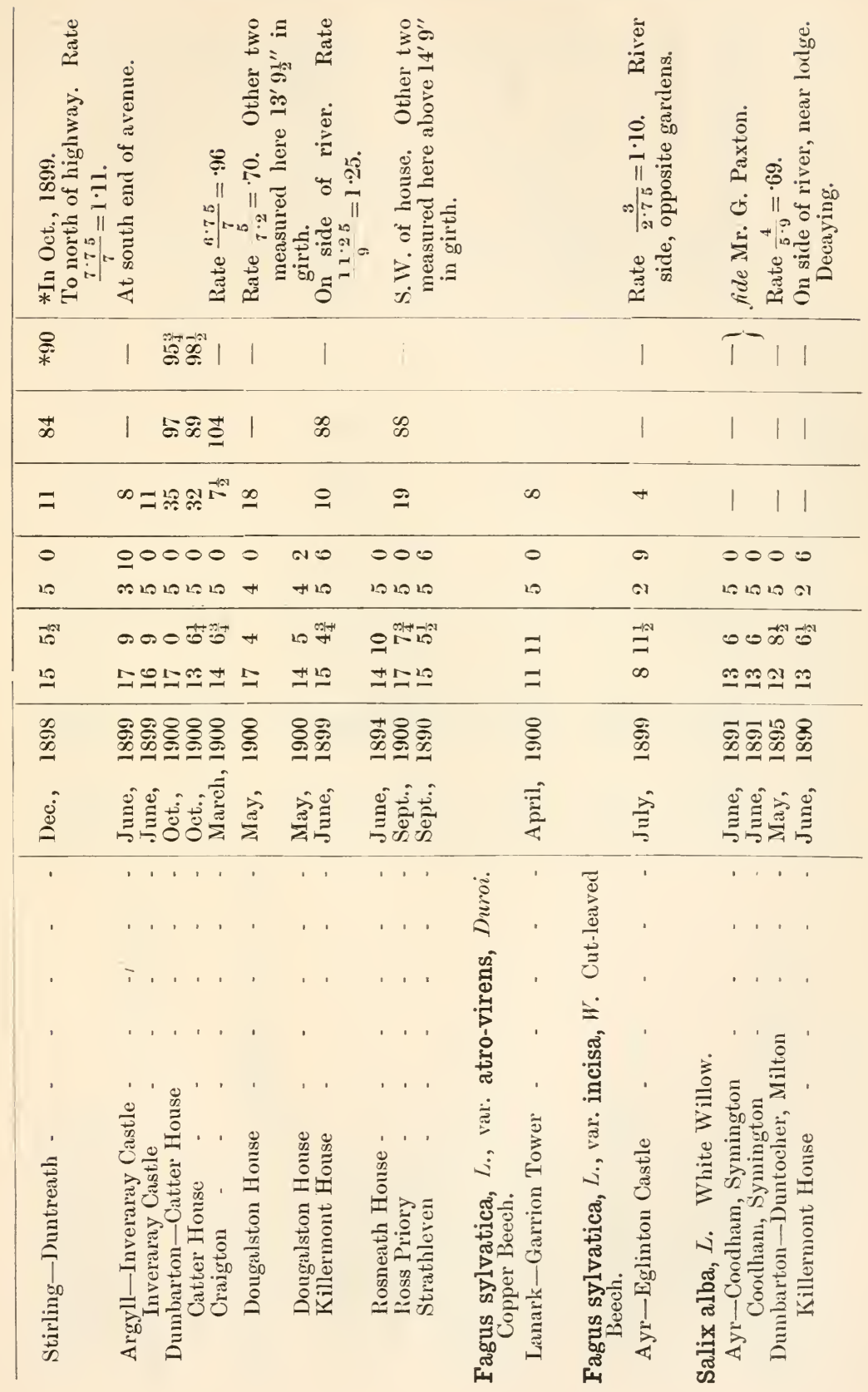




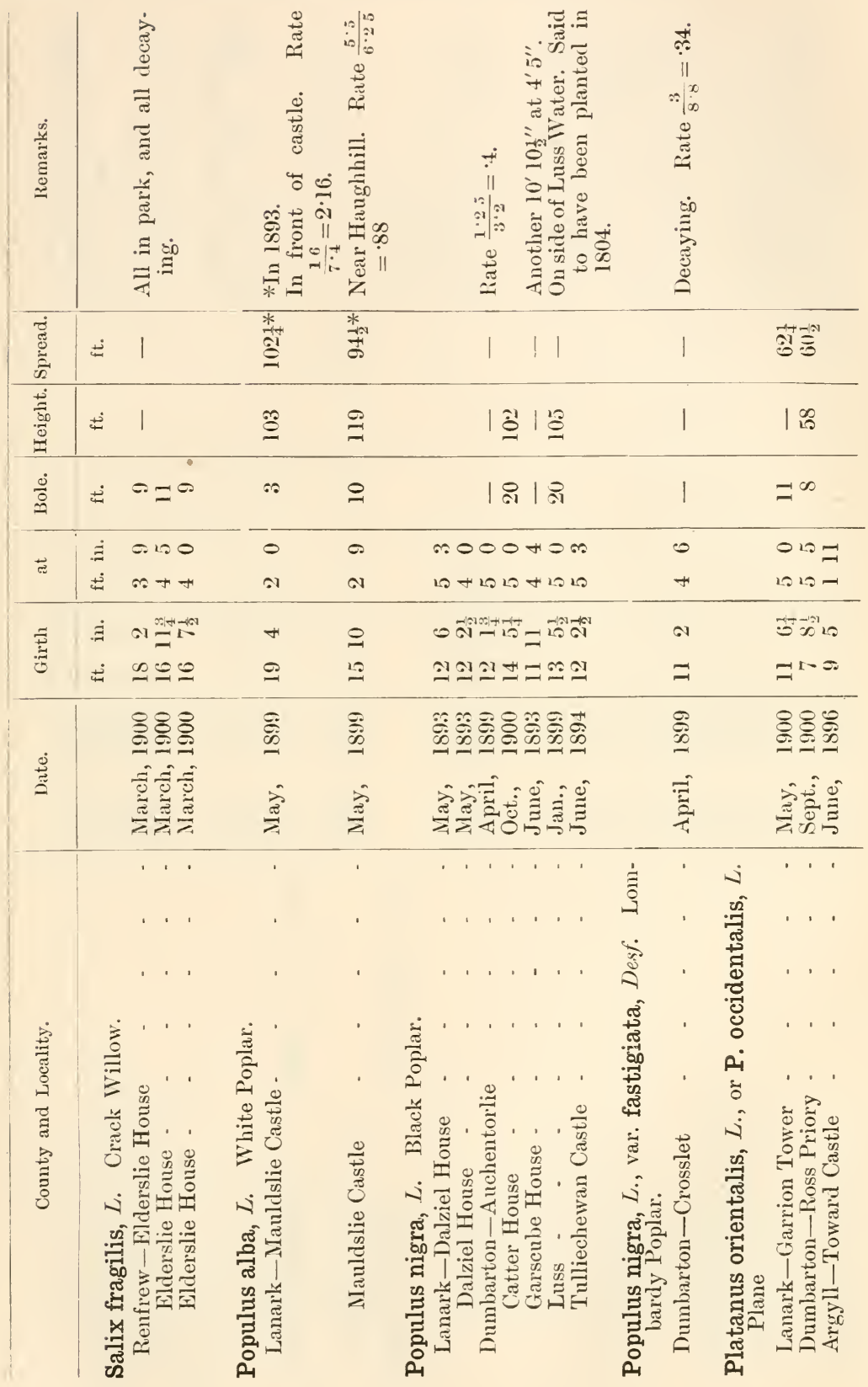




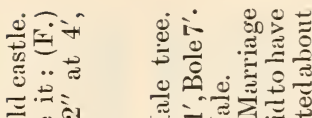

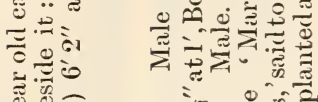

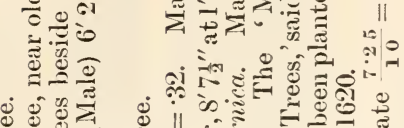

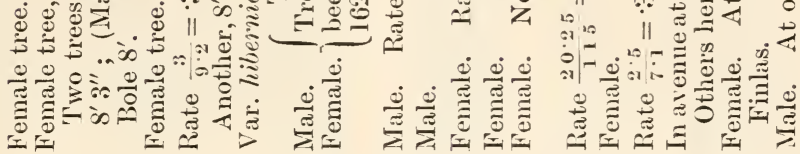

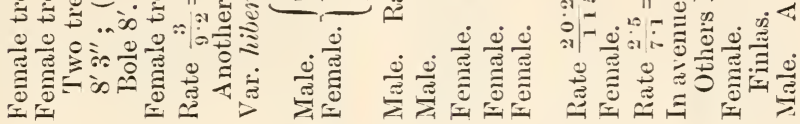

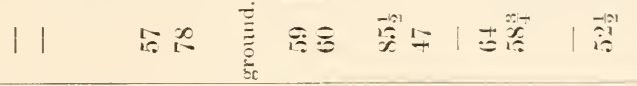

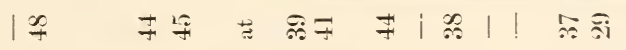

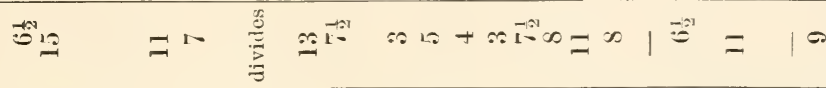

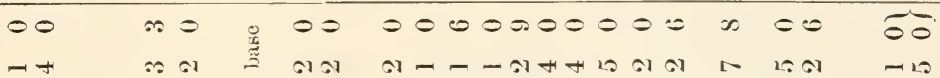

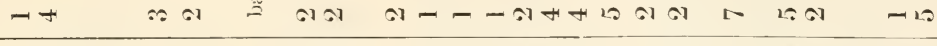

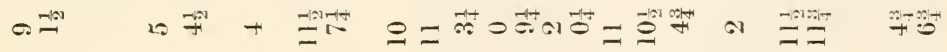

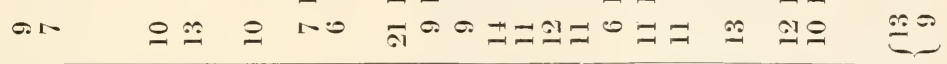

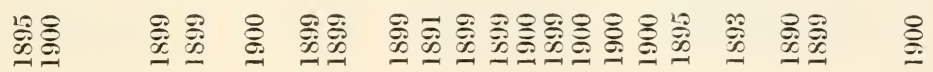

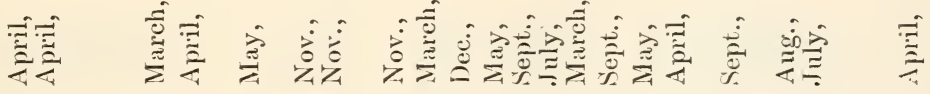
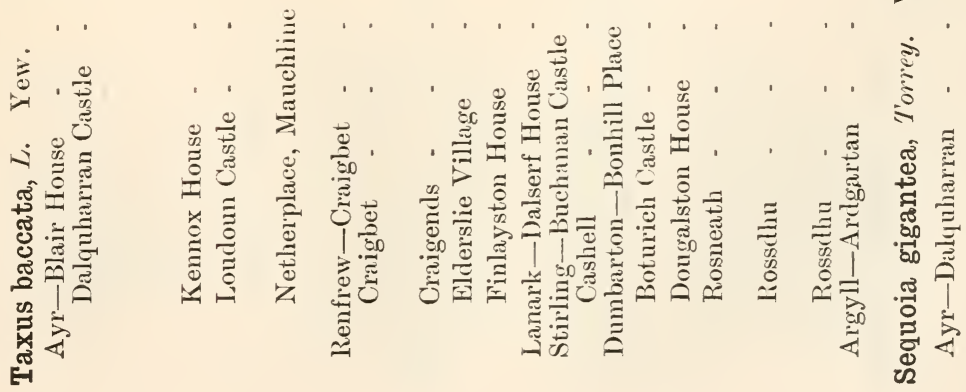


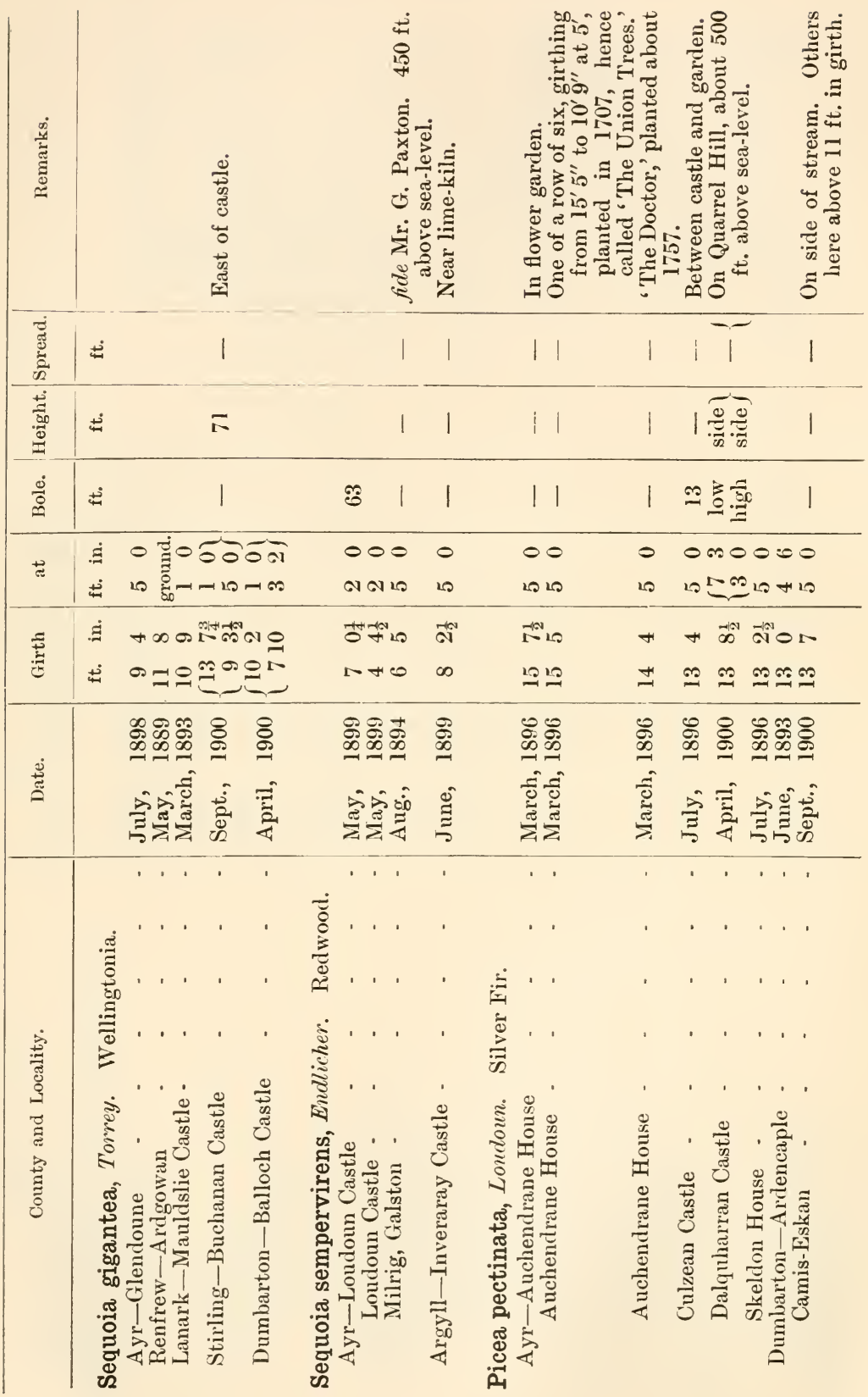




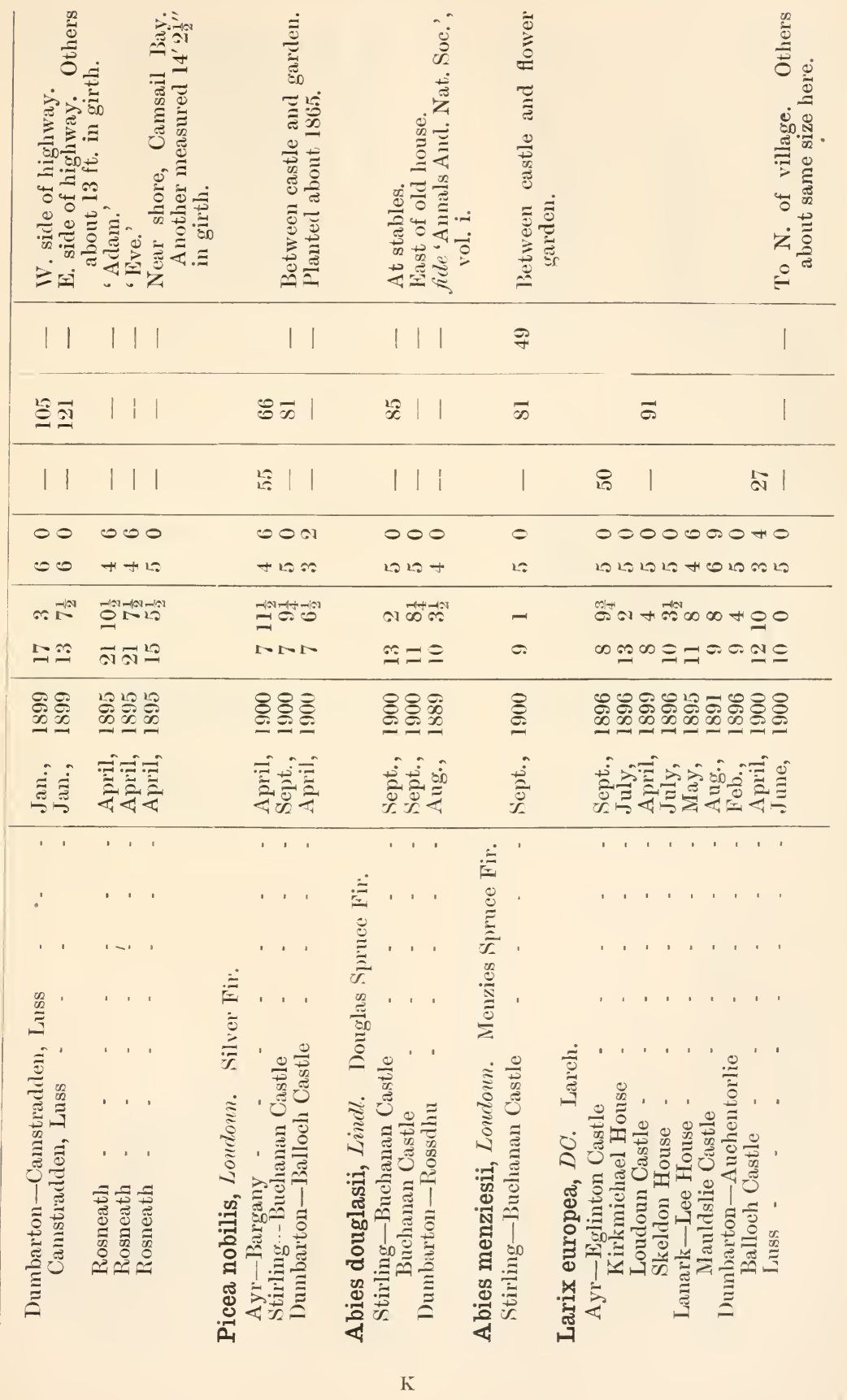




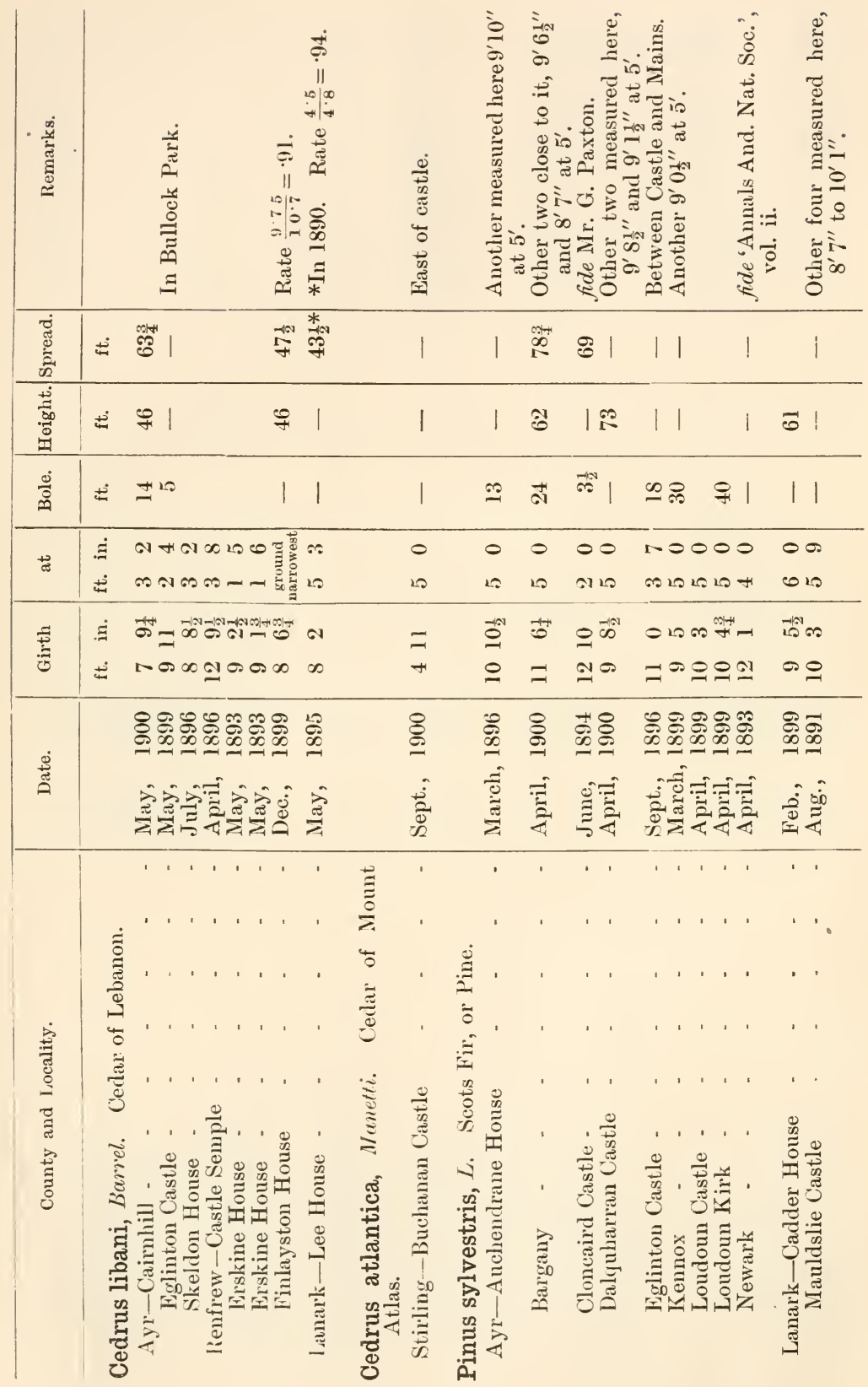




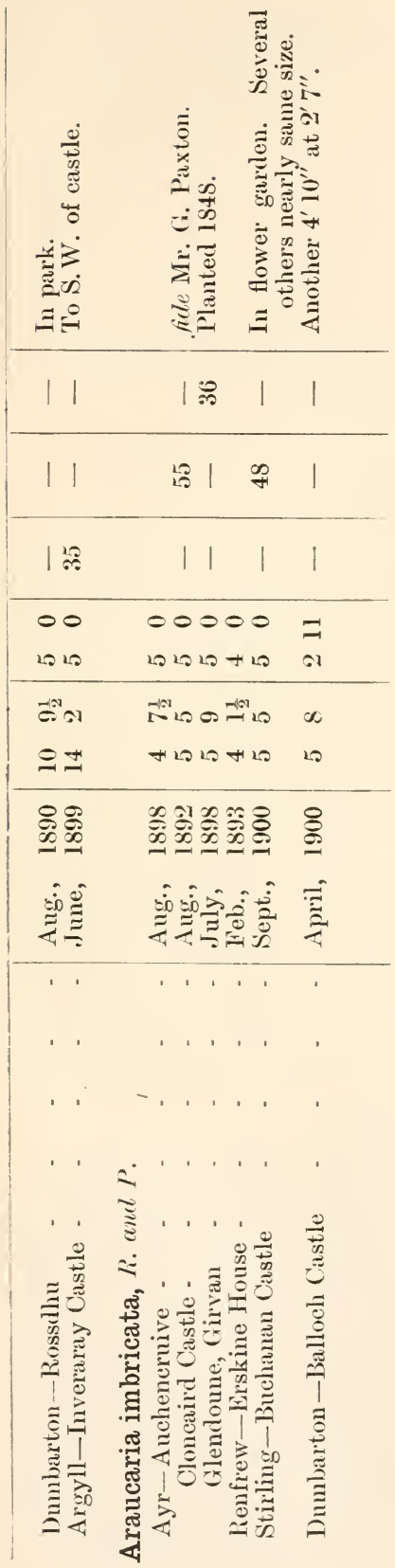





\title{
ANTHROPOLOGY OF THE CLYDE VALLEY.
}

\author{
By Ebenezer Duncan, M.D.
}

\section{PREHISTORIC.}

THE only evidence of existence of man in the Clyde Valley during the palaeolithic period is that adduced by the Rev. Frederick Snith in a paper entitled "Palaeolithic Remains in Scotland" published in 1898. He figures there certain water-worn stones obtained on the shores of the Clyde Estuary which have a striking resemblance to palaeolithic weapons, and are similiar to those found in the Somme Valley and in England. He believes that the floor of the Clyde Estuary formed the hunting ground of palaeolithic man during the period of the great upheaval in Scotland, when the ground now covered by the waters of the Clyde Estuary was covered by forest trees, among which the Mammalian Fauna of the Pleistocene age were abundantly found. He alleges that stone weapons, formed by human agency in that remote age, have been floated up from the bed of the Estuary by sea-weed during storms and cast upon the shore at Ayr and Prestwick, where he found them lying. Unfortunately we have no means of ascertaining the physical characters of the race of men who fashioned these weapons, if weapons they be. The remains of the Mammoth, the Reindeer, The Irish Elk, the Urus, and the horse have been found in the interglacial beds of Scotland, but no bones of palaeolithic man have hitherto been found either in the Clyde Valley or elsewhere in Scotland.

\section{PRIMITIVE RACE.}

Archaeological investigation has proved that in the neolithic age the primitive race inhabiting Scotland was Iberian in type, i.e. short statured and long headed people who buried their dead in chambered graves of the long barrow type. The first evidence of the existence of this race in the Clyde valley was found by the writer a few years ago in the Island of Arran, where he discovered a tumulus containing chambered graves. Several human skeletons were found by him in one of these chambers. From the construction of the graves, the condition of the bones and the physical character's of the skeletons, he formed the opinion that they were the remains of a preAryan Iberian race, ${ }^{2}$ short in stature, dark in complexion, and with Dolichocephalic skulls. These bones were examined by Professor John Young, and may now be found in the Hunterian Museum of the University of Glasgow.

I Proceedings of the Philos. Soc. Glasgow, vol. xxx., page 35.

2 "The Scottish Races," Proceedings of Glasgow Philosophical Soc., vol. 28. 
More extensive explorations of these Arran graves were made last year by the writer in conjunction with Dr. Thomas Bryce of Glasgow. In an adjoining compartment of the same tumulus more human bones were unearthed and associated with them a chipped flint implement and some fragments of rude undecorated pottery which fixed the age of the graves in the neolithic period.

Another tumulus in the same vicinity yielded even more interesting results. The graves were chambered graves built in series under a cairn of stones. A number of complete skulls were obtained associated with rude undecorated fragnents of pottery and polished stone implements. One complete clay bowl was found near the bottom of the grave which was decorated with a geometrical pattern; it did not contain any human remains. No trace of cremated remains and no bronze articles were discovered. The objects found under this cairn fixed its age in the later neolithic period. The bones were carefully examined by Dr. Bryce who reported as follows: "All the skulls were dolicho-cephalic two exaggeratedly so. In other respects the skeletons showed primitive characters especially in the case of the shinbones which in the majority were platyeuemic.

"Thus in later neolithic times the inhabitants of the Clyde valley were still of the Iberian race, characterised by long head, short stature, and probably dark complexion, mingled with the earliest Celtic immigrants. They had not begun to use bronze. They still burned their dead, and were already skilful in the manufacture of pottery. These earlier inhabitants may well have been driven over to the outlying islands by the pressure from the east, and it is probable that in these outlying inaccessible regions the stage of neolithic culture may have overlapped the succeeding bronze culture established on the mainland."

The Celts are supposed to have arrived in Britain about 1200 B.c. Skeletons having Brachy-cephalic crania and all the other osseous characteristics of the Celt have been found in various parts of the Clyde district, in short cists, stone coffins, and, as cremated fragments, in cinerary urns. In their first interments their osseous remains have been associated with polished stone implements, marking the date of their first appearance in the neolithic age. At a later period of the archaeological record bronze weapons were found in these graves, and as we approach the historical period, articles of gold and of iron.

In the Clyde district a skull of this Celtic type was found in Kilsyth Moss, and was afterwards figured in the Crania Britannica. Another specimen was found by the late Dr. James Bryce at Tormore, Arran. It was associated with stone implements and with a bronze pin. This latter skull was examined and measured by the late Dr. Allen Thomson, and is now to be seen in the Museum of the Scottish Antiquarian Society. Unfortunately most of the Celtic graves which have been opened in the Clyde district have been examined by persons who placed no value on the osteological remains they contained. Stone and bronze weapons, implements, and ornaments have been carefully gathered, described, and preserved, but unfortunately for the anthropologist, the bones have generally been thrown aside as of no value.

\section{HISTORICAL.}

In the first historical accounts of the races found in the Clyde valley, Strathclyde was said to be in the possession of a powerful Celtic tribe called the Damnii, who spoke the Cornish dialect and who are supposed to have come from the same stock as the Celts of Cornwall. Archaeological investigation proves that long before the historical period the Celts had almost entirely displaced the aboriginal Iberian race from the Clyde valley 
and had driven them into the remoter parts of the country. On the withdrawal of the Roman legions at the end of the 4th century the Damnii were subjected to an invasion by the Scots and Picts, who colonised the northern districts of Strathclyde, driving the Damnii into the southern parts of Lanarkshire and into Galloway. The Scots and Picts, being themselves Celts, introduced no new racial element. They differed from their predecessors only in the dialect they spoke.

About the beginning of the fifth century the Teutonic race began to make its appearance in Scotland. Scandinavians, Frisians, and Saxons found their way along the valley of the Forth, and a few of them made themselves a home in the neighbouring Clyde valley. Like the Celts, these people were a tall, muscular, fair-headed race, but, unlike the Celts, they were long-headed, resembling in this respect the Iberian aboriginals, but differing from the Iberians not only in their larger stature but in having a somewhat prognathous face. They were followed in the middle of the sixth century by hordes of Angles of the same Teutonic type, who invaded Northumbria, and, marching northwards, drove out the Celtic inhabitants from the southeastern counties of Scotland, and founded there the kingdom of Bernicia. The Fentonising of the western lowlands followed in the seventh century, when the Angles of Bernicia conquered and partially colonised the most fertile parts of the Clyde valley. From this date onwards until the twelfth century bands of Teutons (Angles, Saxons, and Normans) swarmed into Scotland, where by conquest, by intermarriage with the daughters of the Celtic chiefs, and by grants of land from the Scottish kings, they overran the whole of the lowlands of Strathclyde, driving the Celtic tribes into the wilds of Galloway and into the mountainous regions of the northern highlands. The last racial element was added to the people of the valley in the twelfth century, when, in consequence of their expulsion from England by Henry II., a numerous body of Flemings found refuge in Scotland. Several colonies of these people, who were mostly of Teutonic origin, are known to have settled in Strathclyde.

Table of Racial Elemexts in the Clyde Valley.

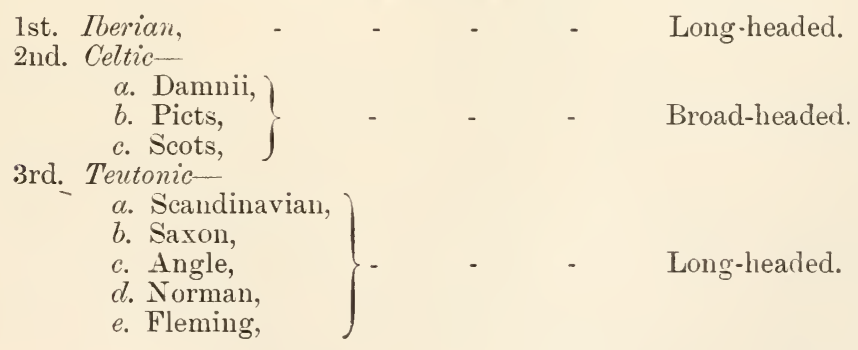

\section{LANGUAGE.}

No trace remains in any part of Britain of the speech of the Iberian aboriginals. The remnants of this race in the Hebrides of Scotland, in Wales, and in the West of Ireland, look upon themselves as pure Celts, and cling tenaciously to the Celtic language.

In early historical times three British dialects of the Celtic language were spoken in Strathclyde. The bulk of the population in the districts now known as Lanarkshire, Renfrewshire, Ayrshire, and Dumbartonshire, spoke the Cornish dialect. On the shores of Argyllshire the Gaelic dialect was spoken, and in the southern half of Lanarkshire Welsh was the dialect in 
common use. Many of the old place names in various parts of Strathclyde retain the Celtic form, but the Celtic speech is rapidly becoming extinct. Two of its dialects, Cornish and Welsh, became extinct at an early period, and Gaelic only survives as a spoken language in a small percentage of the population. Since the thirteenth century a dialect known as lowland Scotch, the old Anglian dialect of Bernicia, has been spoken by the Scottish lowlander in Strathclyde.

The number of people who still speak Gaelic in the three most populous counties of the Clydesdale valley is stated in the Census for 1891, as follows :

\begin{tabular}{lrccc} 
& $\begin{array}{c}\text { Total } \\
\text { Population. }\end{array}$ & $\begin{array}{c}\text { Number of Persons } \\
\text { who speak } \\
\text { Gaelic only. }\end{array}$ & $\begin{array}{c}\text { Number of Persons } \\
\text { who speak } \\
\text { English and Gaelic. }\end{array}$ & $\begin{array}{c}\text { Per- } \\
\text { centage. }\end{array}$ \\
Lanarkshire, & $1,046,040$ & 84 & 22,887 & $2 \cdot 19$ \\
Renfrewshire, & 290,798 & 63 & 8,425 & $2 \cdot 90$ \\
Ayrshire, & 226,283 & $\underline{14}$ & $\underline{1,827}$ & $\cdot 8$ \\
\multicolumn{1}{c}{ Total, } & $1,563,121$ & $\overline{161}$ & 33,139 & $2 \cdot 1$
\end{tabular}

\section{POPULATION.}

At the census of 1801 the population in the drainage area of the Clyde and its estuary, amounted in round numbers to about 350,000 . During the nineteenth century, not only has the native population increased with great rapidity, but, owing to the rapid growth of the iron and coal industries, a large number of people have been attracted from all parts of Gieat Britain and Ireland. The population has changed in character from a people, the majority of whom were engaged in rural and agricultural pursuits, to a community of town dwellers. From data furnished by the Registrar-General I calculate that the population of Strathclyde now (1901) numbers about 2,000,000. One half of this number live in Glasgow and its adjacent suburbs. The larger part of the remainder lives in the other manufacturing centres of the Clyde valley. Some idea of the extent to which the racial type is being modified by this fresh invasion of new comers, may be arrived at by a consideration of the figures disclosed by the Census tables of 1891. Taking Glasgow as an example, within its Municipal boundaries the population at that date amounted to 658,198 , and of these only 349,597 were born in the city. 308,601 were born in other parts of Great Britain and Ireland. Of the latter, 134,000 were recruited from the adjacent counties of Scotland south of the Clyde and Forth, and 84,796 from the northern counties of Scotland. 66,071 were born in Ireland, and 23,557 were English born. The number of foreigners was comparatively insignificant. These figures show that although no new racial element has been added by the influx of strangers, the tendency is to an increase of the Celtic strain and to a gradual approximation of the dwellers in the Clyde valley to the Teuto-Celtic type, which is the most prevalent type of man found in England, and erroneously named Anglo-Saxon.

\section{CRANIOLOGY.}

It is an axiom that the shape of the skull is one of the least variable characteristics of race. As it is quite certain that no trace of the aboriginal Iberian has been found in Strathclyde during the historical period, the shape of the crania of the present inhabitants is a very conclusive test of the amount of Teutonic blood, as compared with Celtic blood, which they now possess. The cephalic index is the test most readily applicable. In any part of Britain where the Iberian is excluded the long-headed people are mostly Teutonic in ancestry, and the broad-headed mostly Celtic. Four 
years ago in a paper on the Scottish Races, ${ }^{1}$ I published a table of the sizes and shapes of hats supplied to Glasgow and London respectively by one of the largest London firms of hat makers. The figures seemed to show that the heads of the people of Glasgow were on the average larger and longer than the heads of the people of London, and, therefore, approached more nearly to the dolicho-cephalic type of the Teuton.

Since the publication of that paper, three firms of wholesale hatters doing a large business both in Glasgow and London have, through the kindness of Mr. Stewart, Hatter, Glasgow, furnished me with their experience of the hat shapes and sizes commonly sold by them in these towns. The figures are approximately the same as those previously published, but the average cephalic index is slightly higher. This may be accounted for by these firms providing to a greater extent hats for the working classes among whom, in Glasgow, Irish and Highland round-headed Celts are numerous.

Average.

\section{Authorities.}

Thos. Towend \& Co., Size, $6 \frac{1}{2}$ London,

Walker \& Ienney, D

Pritchard \& Co., London, 3

Average number sold of each size in 9 doz. hats, 9

\section{English Sizes and Ovals} Doz. Hats.

$\begin{array}{rrrrrrrr}6 \frac{5}{8} & 6 \frac{3}{4} & 6 \frac{7}{8} & 7 & 7 \frac{1}{8} & 7 \frac{1}{4} & 7 \frac{3}{8} & \text { Ovals } \\ 4 & 7 & 8 & 7 & 4 & 3 & 1 & 1 \frac{1}{2} \\ 8 & 10 & 8 & 3 & 2 & 1 & 0 & 1 \frac{1}{2} \\ 7 & 8 & 8 & 6 & 3 & 1 & 0 & 1 \frac{1}{2} \\ \frac{1}{19} & -\frac{25}{24} & \frac{1}{16} & -9 & 5 & - & 1\end{array}$

Average.

Authorities.

Scottish Sizes and Ovals

Thos. Towend \& Co., Size, $6 \frac{1}{2}$ London, No. sold, 2

Walker \& Lenny, Denton, 2

Pritchard \& Co., London, 2

Average number sold of each size in 9 doz. hats, 6

$\begin{array}{ccc}6 \frac{5}{8} & 6 \frac{3}{4} & 6 \frac{7}{8} \\ 4 & 8 & 10 \\ 4 & 8 & 10 \\ 4 & 8 & 8 \\ -- & - & - \\ 12 & 24 & 28\end{array}$

\section{7}

6

6

5

6

$7 \frac{1}{8}$
3
4
4
-

3 Doz. Hats

$\begin{array}{ccc}7 \frac{1}{4} & 7 \frac{3}{8} & \text { Ovals. } \\ 2 & 1 & 1 \frac{5}{8} \\ 2 & 1 & 1 \frac{9}{16} \\ 3 & 1 & 1 \frac{5}{8} \\ -7 & -3 & \end{array}$

With reference to the foregoing table Mr. Stewart informs me that the oval named above for Scotland $1 \frac{5}{8}$ th is the ordinary stock oval kept by him and that he often finds it necessary to elongate such hats as his Glasgow customers have frequently rather longer and narrower heads, i.e., more inclined to be dolicho-cephalic.

Through the kindness of Mr. Kirsop, Hatter, Glasgow, I have had an opportunity of ascertaining the size of head of 265 of his customers, who are of the middle and upper classes. The size and shape of the head was measured very accurately by a hatter's instrument called the Conformateur. I estimated the cephalic index of these persons with the following results: 139 were found to have cephalic index varying from 70 to 78 inclusive, and 126 had a cephalic index of 79 to 89 inclusive. The average size of hat for these people was $7 \frac{1}{8}$. Comparing 10 of the most typical dolicho-cephalic heads with 10 of the most typical brachy-cephalic heads, I found that the former were larger on the average than the latter in the proportion of $7 \frac{1}{8}$ th to $6 \frac{5}{8}$ th.

The high average hat size of $7 \frac{1}{8}$ th in these 265 persons suggested to me the possibility of some selection of the persons measured by Mr. Kirsop. On enquiry I found that for trade reasons the small sizes of head were not so regularly measured and thus the average is higher than it ought to be, and does not correspond with the average hat size $6 \frac{7}{8}$ calculated from the

${ }_{1}^{1}$ Proceedings of the Philos. Soc. Glasgow, vol. 28, page 11. 
tables furvished by the London hat manufacturers. The following table sub-divides the 265 hearls measured into the classes usually named by craniologists :

\begin{tabular}{|c|c|c|c|}
\hline & nde & below 75 dolicho-cephalic, & \\
\hline " & " & 75 to 77 sub-dolicho cephalic, & - \\
\hline " & , & 78 and 79 ortho-cephalic, - & - \\
\hline ", & " & 80 to 82 sub-brachy cephalic, & - \\
\hline " & $"$ & 83 to 89 brachy-cephalic, & - \\
\hline
\end{tabular}

265

It is evident from the above tables that the majority of the dwellers in the Clyde valley are still more Teutonic than Celtic in blood. Nevertheless during the nineteenth century a modification has taken place in the strongly Teutonic character of the people. From the continual influx of recruits from all parts of Britain and Ireland an approximation to the ortho-ceplatic index so common in London is becoming more marked in Glasgorv. In a few generations the mixing of the different racial elements in the Clyde valley will certainly lead to a more uniform type and to the elimination of the extreme examples of the long-hearled and broad-headed people, which the above tables show to exist among the population of Strathclyde at the present time. 


\section{MAMMALIA.}

By Hugh Boyd Watt, 3 Victoria Drive, Glasgow.

THE authorities followed for classification and nomenclature are, for the Cetacea the late Sir Wm. H. Flower's List of the Specimens of Cetacea in the British Museum, (1885), and for the other orders Mr. Richard Lydekker's Handbook of the British Mammalia, (1896), with a few exceptions.

When a locality is named the species has actually been taken there. References are only given for very rare or unusual records. Square brackets indicate that confirmation is required for the occurrence of the species. An * indicates an extinct species in the area and t one that has been introduced.

\section{Order Chiroptera.}

Fam. Rhinolophidae.

[Rhinolophus hipposiderus, (Bechst.)-Lesser Horse-Shoe Bat. Crookston, Renfrewshire. New Statistical Account, 1845, viii., p. 162.]

\section{Fam. Vespertilionidae.}

Plecotus auritus, (L.)-Long-eared Bat, c.

Vesperugo pipistrellus, (Schreber.)-Com. Bat or Pipistrelle, c.

Vespertilio daubentoni, Leisl.-Daubenton's Bat. Glasgow Green, 1864 ; Kelvingrove, 1879; Craigenfeoch, Renfrewshire, numbers, Jauy. 1885. Probably more frequent than is supposed.

V. nattereri, Kuhl.-Reddish-grey Bat. Inveraray, 1858, one. Dobson's Cat. of the Chiroptera in the Brit. Wuseum, 1878, p. 307-8.

\section{Order Insectivora.}

\section{Fam. Erinaceidae.}

Erinaceus europoeus, L.-Hedgehog, c., no Arran records ; in Bute.

\section{Fam. Talpidae.}

Talpa europoea, L.-Mole, c., occurs up to nearly $2000 \mathrm{ft}$., not reached some districts, e. g. Southend, Kintyre, nor islands, except Bute.

\section{Fam. Soricidae.}

Sorex vulgaris, L.-Com. Shrew, c., also in Arran and Bute.

S. minutus, L.-Lesser Shrew. Lesmahagow ; Paisley ; Sanda ; Cumbrae ; Ailsa Craig, (?). Probably more freq. than these occurrences indicate.

Crossopus fodiens, (Pall.)-Water Shrew. Widely distributed, including Arran; no Argyllshire records. 
Order Carnivora.

Fam. Felidae.

Felis catus, L.-Wild Cat. Practically extinct now ; Gleniffer, Renfrewshire, 1895. Ann. Scot. Nat. Hist., 1895, p. 121.

Fam. Canidae.

* Canis lupus, L.-Wolf. Known from history and legend. Bones found Ardrossan Shell-mound (?).

Canis vulpes, L.-Fox, c.; not in islands. Eglinton Hounds (Ayrshire) have killed 82 brace in one season; on Benmore estate, Cowal, 149 were killed between 1891-7.

Fam. Mustelidae.

Mustela martes, L.-Pine Marten. Very r. now ; Maybole, 1876; Minnoch Water, 1878-9 ; Tarbet, 1882 ; Glenloin, Arrochar, 1882; Kilmory, Ardrishaig, 1896.

M. putorius, L.-Polecat. Apparently extinct now ; last record Craigenfeoch, Renfrewshire, about 1868.

M. erminea, $L$.-Stoat, c. ; in Bute, not Arran.

M. vulgaris, Erxl.-Weasel, c. ; in Bute, not Arran.

Meles taxus, L.-Badger, r.; Dolphinton, 1890 ; Renfrewshire, 1893 and 1896 ; Loudon, Ayrshire, 1894; Arran, 1895 (introduced); Carluke and Jock's Gill, Lanarkshire, 1896 ; Milton Lockhart, Lanarkshire, 1897; Murroch Glen, Dumbartonshire, 1899 ; Benmore, Cowal (now); Glengarnock, 1901.

Lutra vulgaris, Erxl.-Otter. Widely and gen. dist. in suitable waters and on coast. Numerous recent records, including Glasgow (Clyde), 1899.

\section{Fam. Ursidae.}

* Ursus arctos, L.-Brown Bear. Long extinct. Marked in Roy. Scot. Geograph. Socy's. Atlas, Plate VII., on Inchmurrin.

\section{Fam. Phocidae.}

Halichoerus grypus, (Fabr.) - Grey Seal. Kitchen-midden, Campbeltown ; Sanda, about 1874 ; L. Cumbrae, 1900. Ann. Scot. Nat. Hist., 1900, p. 243.

Phoca vitulina, L.-Com. Seal. Freq.; numerous recent records, e.g. herd of over 30 off Troon, June, 1900.

[P. groenlandica, Fabr.-Harp-Seal? Between Pladda and Ayrshire coast, 1899 ; shot but lost, F. G. Pearey].

Order Rodentia.

Fam. Sciuridae.

Sciurus vulgaris, L.-Squirrel ; c., absent in some localities, e.g. the islands.

Fam. Castoridae.

* Castor fiber, L.-Beaver. Remains in Ardrossan Shell-mound and Cleaves Cove, Dalry. Introduced at Mount Stuart, Bute, 1874; died out by 1890.

Fam. Muridae.

Mus minutus, Pall.-Harvest-Mouse. Unknown; nest taken Kilbarchan, 1895 (Paisley Museum); also $\mathrm{mr}$. Paisley. Ann. Scot. Nat. Hist., 1898, p. 112.

M. sylvaticus, L.-Wood or Long-tailed Field-Mouse, c. ; also in islands.

M. musculus, $L$.- - House-Mouse, c.

+ M. rattus, L.-Black Rat. Practically extinct; recent specimens from Glasgow, Greenock aud Paisley almost certainly introductions. 
† M. decumanus, Pall.--Brown Rat. Probably our commonest species, finding a living on even the smaller islands, e.g. Glunimore, Kintyre.

Microtus agrestis, (L.)-Com. Field-Vole, c. ; also in islands.

M. glareolus, (Schreber.)-Bank-Vole. Little known ; Lesmahagow, 1866 ; Paisley, 1891; Luss (1'ecent). Guide to N ${ }^{2}$ at. Hist. of Loch Lomond, 1895, p. 17.

M. amphibius, (L.)-Water-Vole, e.; both brown and black vars. On islands L. Lomond.

Fam. Leporidae.

Lepus europoeus, Pall.-Com. Hare. Fairly c.; also in Bute and G. Cumbrae ; introduced into Arran; decreasing generally.

L. timidus, L.-Mountain Hare. On the hills in every country in the area, and c. in many places; 300 killed in one season on Misty Law Hills, Renfrewshire.

† L. cuniculus, L.-Rabbit. Shares with Brown Rat in being our commonest species; on the smaller islands also, e.g. Lady Island (Troon), and Sheep Island (Kintyre). Not on Sanda.

\section{Order Uygulata.}

Fam. Bovidae.

†? Bos taurus, L.-White or Park-Cattle. Semi-domesticated; the carefully preserved herd at Cadzow, now numbering about 50 head, is the sole representative of this species in Scotland.

* B. primigenius, Bojanus.-Fossil Ox or Urus. Doubtfully historical ; remains found in Glasgow; Partick; Jordanhill; Carluke ; Paisley ; Neilston ; Rothesay Bay; Ardeer and Maybole within recent years.

* B. longifrons, Owen.-Celtic Shorthorn. Remains found in Glasgow ; Gorbals; Pollokshaws; Dumbuck, Dumbartonshire; Cleaves Cove ; Ardrossan Shell-mound, Lochlee; Crannog, and Kirkoswald, Ayrshire, within recent years.

\section{Fam. Cervidae.}

Cervus elaphus, L--Red Deer. Maintained in some of the Highland parts of our area aud in Arran, where fresh blood has been introduced.

+C. dama, L.-Fallow Deer. Semi-domesticated; herds in many parks, sometimes rumning wild.

Capreolus caprea, Gray.-Roe Deer. Not unc. in woodlands; in Bute : extinct in Airan.

* Rangifer tarandus, (L.)-Reindeer. Doubtfully historical ; remains found, Glasgow, Partick, Carluke, Drymen, Kilmaurs, and Lochlee Crannog.

\section{Fam. Suidae.}

* Sus scrofa, L.-Wild Boar. Remains found Dumbuck Crannog, Dumbartonshire.

\section{Order Cetacea.}

The want of authentic records for this order in indicated by what follows, but reports of "whales" in Clyde waters are frequent. "Balcena mysticetus, the Greenland Whale," and "Physeter microps, the Bluntheaded Whale" are named for the Clyde in the new "Statistical Account of Scot. (1845), vol. vii., but these are not included in this list.

\section{Fam. Balaenidae.}

[Balaenoptera musculus, L.-Com. Rorqual or Fin-Whale. Reported from Loch Fyne and Kilbrannan Sd., by Walker, (1808), and new Stat. Acct., (1845); no capture known.

Remains from Tertiary deposits, Irvine Water, where they have been found from 1790 onwards are thought by Sir Wm. Turner to belong to a Balaenoptera, but the species is not named.] 
B. rostrata, Fabr.-Lesser Rorqual or Pike Whale. One captured off Largs, Augt., 1897. Ann. Scot. Nat. Hist., 1899, p. 236.

\section{Fam. Physeteridae.}

Hyperoodon rostratus, Mïller.-Bottlenose Whale. Apparently not unc.; frequently reported. Captured, Row, 1792 (old Stat. Acct.); Gareloch, 1863 ; Loch Ranza, 1883 ; Port-Glasgow, 1896 ; Loch Long, 1898; and Ayr, 1899.

\section{Fam. Delphinidae.}

Phocaena communis, Lesson.-Com. Porpoise, c. ; all the year round.

[Orca gladiator, Gray.-Killer or Grampus. Reported but not captured, Stat. Accts., 1793 and 1845, and Ann. Scot. Nat. Hist., 1898, p. 237.]

Lagenorhynchus albirostris, Gray.-White-beaked Dolphin. A pparently not unc.; frequently reported particularly in Autumn. Captured, Kilbrannan Sd., 1874 (first Scottish record), 1894 and 1895 ; Bute, 1899.

L. acutus, Gray. - White-sided Dolphin. One captured, Loch Fyne ; HarvieBrown and Buckley's Vertebrate Fauna of Argyll and Inner Hebrides, 1892, p. 29.

[Delphinus delphis, L.-Com. Dolphin. Skull, apparently of this species in Rothesay Museun.]

Tursiops tursio, Fabr:--Com. Tursio. One captured, Loch Long, 1879 ; skull, etc., in Anatomical Museum, Edinburgh University.

\section{PRE-HISTORIC SPECIES.}

Order Proboscidea.

Elephas primigenius, Blumenbach.-Fossil Elephant or Mammoth. Bishopbriggs; Airdrie; Cliftonhall; Ballieston ; Kilmaurs; and Dreghorn, Ayrshire.

\section{Order Ungulata.}

Equus caballus, L.-Fossil Horse. Bowling; Irvine; Neilston ; W. Kilbride; Ardrossan and Paisley ; species not always certain.

Cervus giganteus, Blumenbach.-Gigantic Irish Deer or Elk. Paisley; Neilston, and Maybole. 


\section{BIRDS.}

By John Paterson, 82 Cumming Drive, Glasgow.

\section{Nomenclature Followed.}

List of British Birds, revised to March, 1899, by Howard

saunders, F.L.S., F.Z.S., etc.

$($ Gray $)=$ Birds of the West of Scotland, or Birds of Ayrshire.

The records for Dumbarton and Argyll, especially the latter, are very incomplete.

\section{Order Passeres.}

\section{Fam. Turdidae.}

Turdus viscivorus, Linnaeus.-Mistle-Thrush. C.

T. musicus, Linnaeus.-Song-Thrush. C. Much scarcer in many localities in winter.

T. iliacus, Linnaeus.-Redwing. C. in winter, appearing in Oct.

T. pilaris, Linnaeus.-Fieldfare. C. in winter, appearing after the preceding.

T. merula, Linnaeus.-Blackbird. Abundant.

T. torquatus, Linnaeus.-Ring-Ouzel. Gen. dist. Scarce in some places though locally $\mathrm{c}$.

Saxicola oenanthe (Linnaeus).-Wheatear, C. End of March till Oct.

Pratincola rubetra (Linnaeus).--Whinchat. Gen. dist. and locally c. summer. Appears second half of April.

P. rubicola (Linnaeus). - Stonechat. Very scarce or r. inland. C. in bramblepatches and whins on Ayr coast. Not so c. in Buteshire. A resident.

Ruticilla phoenicurus (Linnaeus).--Redstart. Summer visitor appearing second half April. R. unless on migration in Renfrew and Ayr. Wellknown as nesting in Lanark and northern half of "Clyde."

Erithacus rubecula (Linnaeus).--Redbreast. C.

Sylvia cinerea (Bechstein).--Whitethroat. C. summer visitor, usually appearing end of April.

S. curruca (Linnaeus).-Lesser Whitethroat. Very little positive evidence of occurrence in "Clyde." V. Ann. Scot. Nat. Hist., 1899, pp. 210-214.

S. atricapilla (Linnaeus).-Blackcap. Summer over whole area, scarcer than S. hortensis.

S. hortensis (Bechstein).-Garden-Warbler. C. in summer.

Regulus cristatus, $K$. L. Koch.-Golden-crested wren. C.

Phylloscopus rufus (Bechstein).-Chiffchaff. C. in summer in Ayr, freq. in W. Renfrew (Castle-Semple), infreq. E. Renfrew, r. Lanark, freq. L. Lomond and Gareloch, occurs in Argyll, e.g. Benmore and Castle Toward; Bute and Arran. 
P. trochilus (Linnaeus).-Willow-Wren. Abund. in summer, appearing in third week of April.

P. sibilatrix (Bechstein).--Wood-Wren. Gen. dist. summer woods and glens, locally abund. e.g. oak-woods in Dumbarton and Argyll.

Acrocephalus phragmitis (Bechstein).- - Sedge-Warbler. C. in summer, appearing end of April or first days of May.

Locustella naevia (Boddaert).--Grasshopper-Warbler. Thinly distributed over "Clyde" in summer, appearing with great regularity 30th April or 1st May. Freq. in some places as at Beith, Ayrshire, where Messrs. M. Barr and J. Craig found 4 nests in 1899.

Accentor modularis (Linnaeus).-Hedge-Sparrow. C.

\section{Fam. Cinclidae.}

Cinclus aquaticus, Bechstein.-Dipper. C., streams and rivers, all seasons.

\section{Fam. Paridae.}

Acredula rosea (Blytl $)$.- - British Long-tailed Titmouse. Freq.

Parus major, Linnaeus.-Great Titmouse. C.

P. britannicus, Sharpe and Dresser.--British Coal-Titmouse. Not r. in mixed woods, c. in pine woods.

P. dresseri, Stejneger-_British Marsh-Titmouse. Ayr. pretty c. Lendalfont (Ch. Berry), where nest has been taken ; "seldom seen Beith" (Barr and Craig), occurs in winter W. Kilbride. Renfrewshire " $r$. nr. Paisley" (Paisley Nat. Vs.), occasional in E. of county. Well known in orchard country of Lanark at all seasons. "Rather r." L. Lomond (Lumsden). " $\dot{I}$ lave never seen it in Argyll" (the late Duke of Argyll in Gould's Birds of Great Britain.)

P. caeruleus, Limnaeus.-Blue Titmouse. C.

P. cristatus, Linnaeus.--Crested Titmouse. Records for Argyll, Dumbarton, and Lanark refer to first half of nineteenth century.

Fam. Troglodytidae.

Troglodytes parvulus, Koch.-Wren. C.

\section{Fam. Certhiidae.}

Certhia familiaris, Limnaeus.--Tree-Creeper. Gelı. dist. but nowhere numerous.

\section{Fam. Motacillidae.}

Motacilla lugubris, Temminck:--Pied Wagtail. C.

M. alba, Linnaeus.-White Wagtail. A fairly c. bird of passage.

M. melanope, Pallas.-Grey Wagtail. C.

M. flava, Linnaeus.--Blue-headed Yellow Wagtail. Seen 4/98 at Cambuslang, Lanark.

M. raii (Bonaparte)--Yellow Wagtail. A summer visitor appearing about 21st April. C. in parts of Ayr, Renfrew, and Lanark. R. or absent in northern half of "Clyde" and Bute.

Anthus trivialis, Linnaeus.-Tree-Pipit. Summer visitor appearing second half April. C.

A. pratensis (Limnaeus).-Meadow-Pipit. C.

A. obscurus (Latham).-Rock-Pipit. C. by the shore.

\section{Fam. Oriolidae.}

Oriolus galbula, Linnaeus.-Golden Oriole. One killed, Arran, 1807. (Fleming, History of British Animals).

\section{Fam. Laniidae.}

Lanius excubitor, Linnaeus.-Great Grey Shrike. Many occurrences are recorded or known to the writer, but scarcely a regular winter visitor. 
[L. collurio, Linnaeus.-Red-Backed Shrike. Recorded by the writer as having nested in Lanark. (Ann. Scot. Nat. Hist. '93, p. 183), but I fear deception somewhere].

\section{Fam. Ampelidae.}

Ampelis garrulus, Linnueus.-Waxwing. Scarce and irregular winter visitor. A vast flock appeared in the haughs of Hamilton, winter 1782 (Stat. Acc. Lanarkshire, 1841, p. 262).

\section{Fam. Muscicapidae.}

Muscicapa atricapilla, Linnaeus.-Pied Flycatcher. One obtained 22/4/95, Muirkirk, Ayrshire (Ann. Scot. Nat. Hist., 1897, p. 152): At Ardpeaton, L. Long, 24/8/1900, Mr. Wm. Evans's son and daughter saw a male.

M. grisola, Linnaeus.-Spotted Flycatcher. A c. summer visitor appearing usually in first half of May. Reaches remote and barren places, e.g. head of L. Doon.

Fam. Hirundinidae.

Hirundo rustica, Linnaeus.--Swallow. C.

Chelidon urbica (Linnaeus).--House-Martin. C. locally.

Cotile riparia (Linnaeus).-Sand-Martin. C. locally.

\section{Fam. Fringillidae.}

Ligurinus chloris (Limnaeus).-Greenfinch. C.

Carduelis elegans, Stephens.-Goldfinch. In the beginning of last century not unc. Judging from reports I conclude that a few pairs presently nest in all counties in "Clyde," except Buteshire.

C. spinus (Linnaeus).- Siskin. Little known in "Clyde," and reports generally speak of its rarity or scarcity. I have seen it in summer at Luss, L. Lomond, where it will doubtless nest.

Passer domesticus (Linnaeus).-House-Sparrow. C.

P. montanus (Linnaeus). - Tree-Sparrow. Reported to Gray (Birds West Scot., p. 140) to have occurred at Arrochar, L. Long. Has bred at Ardrossan, Ayrshire (loc. cit., p. 512). "Nest in the hole of a cottage at Annbank [Ayrshire], 3 eggs, 10/5/90" (W. C. S. Fergusson). Seen Jan. 1897, and Dec. 1898, in Carmichael Parish, Lanark (Rev. J. D. W. Gibson, Ann. Scot. Nat. Hist., 1897, 1899).

Fringilla coelebs, Linnaeus.-Chaffinch. C.

F. montifringilla, Linnaeus.-Brambling. A r. or unc. winter visitor; appears in large numbers occasionally ; e.g. Ayrshire 1864 (Zoologist, 1865, pp. 9439, 42); Lanarkshire 1898-1899 (Annals Scot. Nat. Hist., 1899 , p. 109).

Linota cannabina (Linnaeus).--Limnet. Not r. but apparently scarcer than formerly in many localities. Still quite characteristic of rough ground on the shores of the Firth.

L. linaria (Linnaeus).-Mealy Redpoll. R. and uncertain; winter ; Ayr (Gray and Anderson); Renfrew (Morris Young); outskirts of Glasgow (Gray); Lanark (Rev. J. D. W. Gibson).

L. rufescens (Vieillot).-Lesser Redpoll. Gen. dist. but not c. unless locally.

L. flavirostris (Linnaeus).- Twite. Absent from large tracts of moorland which might be supposed suitable to its tastes. A few here and there throughout "Clyde" in nesting season. Not r. in flocks in the lowlands in winter.

Pyrrhula europaea, Vieillot.--Bullfinch. Freq. in South half of area, commoner in North half.

Loxia curvirostra, Linnueus.-Crossbill.

L. pityopsittacus, Bechstein.-Parrot-Crossbill. The Crossbill nested in Girvan valley 1864 (Gray), flocks in Glenapp 1883-4, and may have 
nested there next year (Rev.J.D. W. Gibson). In "many" parts of Lanark in "considerable" numbers in breeding season (Gray, Birds West of Scot., p. 153). May nest in small numbers at present in Arran, Argyll, and L. Lomond. A Parrot-Crossbill, "one of a flock," killed at Wemyss B. 1862 (Gray).

Emberiza miliaria, Linnaeus.-Corn-Bunting. Not infreq. in inland localities. C. in sandy fields on the shores of the Firth.

E. citrinella, Linnaeus.-Yellow Bunting. C.

E. schoeniclus, Linnceus.--Reed-Bunting. Freq.

Plectrophenax nivalis (Limnaeus).-Snow-Bunting. Winter visitor; has been seen on Corscrine bet. Ayr and Kirkcudbright summer (Robt. Service) ; caught in rabbit-trap on Tinto, 16/9/97 (Rev. J. D. W. Gibson).

\section{Fam. Sturninae.}

Sturnus vulgaris, Linnaeus.-Starling. Rare as a breeding species in the begimning of the nineteenth century, but now abundant almost everywhere and at all seasons.

Pastor roseus (Linnaeus).-- Rose-coloured Starling. Two shot nr. Glasgow, 1853 (Gray), one in Cumbrae, 5th Aug. 1854 (Zoologist), one nr. Glasgow, 7th Aug. 1868 (Proc. Nat. Hist. Soc. Glasgow, i., p. 229).

\section{Fam. Corvidae.}

Pyrrhocorax graculus (Linnaeus).-Chough. Formerly nesting inland and sea-cliffs, now never inland, but freq. obtained diring past decade in S. Ayrshire nr. the sea. A skin of an adult Alpine Chough (P. alpinus, Koch.) shot at Ballanhoe [Ballantrae?], Scotland, in the Bree coll. in possession of Yorkshire Phil. Soc.

Garrulus glandarius (Linnaeus).--Jay. Formerly not r. in parts of Ayr, Renfrew, and Lanark. Probably a pair or two survive in Ayr.; quite extinct I believe in Renfrew and Lanark. Still well known about L. Lomond and Benmore, Holy L.

Pica rustica (Scopoli).-Magpie. Freq. throughout Ayr., less so in Renfrew, c. nr. Glasgow. Formerly c. in Bute (Colquhomn), now unknown. Seldom in L. Lomond district (Lumsden).

Corvus monedula, Linnaeus.- Jackdaw. C.

C. corax, Linnaers.-Raven. Freq. in mountainous districts and precipitous cliffs by the sea.

C. corone, Linnaeus.-Carrion-Crow. Fairly c.exceptRenfrew and nr. Glasgow.

C. cornix, Linnaeus.--Hooded Crow. Has nested recently in extreme S. of Ayr. (Rev. J. D. W. Gibson), Darvel (Robt. IVilson) and probably in Clyde Isles where it is not $r$. R. in Renfrew and Lanark. Well known in L. Lomond district.

C. frugilegus, Linnaeus.-Rook. Abund. most cultivated and some pastoral districts.

Fam. Alaudidae.

Alauda arvensis, Linnaeus.--Sky-lark. C. Abund. in fields nr. Glasgow.

[A. arborea, Linnaeus.-.Wood-lark. Almost certainly the records of this species in Statistical Account of Scotland, etc., refer to Tree Pipit, which is known as "Wood-Lark" in many places.]

\section{Order Picariae.}

\section{Fam. Cypselidae.}

Cypselus apus (Linnceus).- - Swift. C. in summer, arriving about 1st May. C. melba (Linnaeus). - Alpine Swift. One caught 25/8/1892 at Muirkirk, Ayr. (Ann. Scot. Nat. Hist., 1897, p. 152). Rev. J. D. W. Gibson has no doubt as to his identification of one he saw bet. Cronberry and Muirkirk, 28/7/1900. 


\section{Fam. Caprimulgidae.}

Caprimulgus europaeus, Linnaeus.-Nightjar. Pretty c. Ayr; r. Renfrew and Lanark; c. Arran; occurs in Bute; c. at Kyles of Bute (Eagle Clarke); often on moors at L. Lomond (Lumsden).

\section{Fam. Picidae.}

Iÿnx torquilla, Linnaeus.-Wryneck. One "was lately shot" Stat. Account, Hamilton Parish, Lanark. 1841. Another shot nr. Garnkirk in first week of Oct. (1871 ?) (Proc. Nat. Hist. Soc. Glasgow, ii., p. 179).

Dendrocopus major (Linnaeus).--Great Spotted Woodpecker. An occasional winter visitor.

Fam. Alcedinidae.

Alcedo ispida, Limnaeus.-Kingfisher. Not unc. in Ayr, Renfrew, and Lanark. Has nested at Brodick (Dr. Neil Fullarton). Comparatively r. L. Lomond (Lumsden); somewhat r. Inveraray (Vert. Fauna of Argyll, etc.).

\section{Fam. Coraciidae.}

Coracias garrulus, Linnaeus.-Roller. ". . has been seen in this parish" (Stevenston, Stat. Account of Ayrshire, 1837). One from Greenock Harbour, 27/6/1847, in Mus. of Science and Art, Edinburgh. One shot Biggar, Oct. 1866 (Gray), and another observed by late Duke of Argyll, at Inveraray, Feby. 188s.

\section{Fam. Meropidae.}

Merops apiaster, Linnaeus.-Bee-eater. One nr. Paisley, 8/1869 (Gray); one Paisley Moss, about 1872 (A. Stevenson, Paisley Nat. MS. List).

\section{Fam. Upupidae.}

Upupa epops, Linnaeus.-Hoopoe. One shot Coylton, Ayr. 10/1836 (Mag. of Geol. and Botany, i., p. 491); one at Dean Castle, Ayr., shot "some years ago" (Kitmarnock Standard, 12/3/98). One shot Renfrew (W. Small, Paisley Nat. MS. List). One 5/77, Arran (Pr. Nat. Hist. Soc. Glas., iii., p. 225). One Cardross, Dumbarton, 1/11/-? (Op. cit., iv., p. 12). One nr. Campbeltown, 1887 (Op. cit., ii. (n. s.), p. xlv.).

\section{Fam. Cuculidae.}

Cuculus canorus, Linnaeus.-Cuckoo. Common.

\section{Order Striges.}

\section{Fam. Strigidae.}

Strix flammea, Linnaeus.-White or Barn-Owl. Freq., apparently c. formerly.

Asio otus (Linnaeus).-Long-eared Owl. C.

A. acciptrinus (Pallas).-Short-eared Owl. Freq. autumn and winter. R. as a breeding species.

Syrnium aluco (Linnaeus).- Tawny Owl. C.

Nyctea scandiaca (Linnaeus).- Snowy Owl. R. winter visitor, Ayr, 1; Renfrew, 3; Dumbarton, 1; (Gray); one recently in Dumbarton, (Mr. W. A. Donnelly).

Surnia funerea (Linnaeus).-American Hawk-Owl;

S. ulula (Linnaeus).-European Hawk-Owl. Two seen in parish of Kilmichael-Glassary about 1858 (Vert. Fauna Argyll, p. 101); one shot, Maryhill, nr. Glasgow, 12/1863; one taken in the flesh to a Greenock bird-stuffer, 10/1868 (Gray). The Maryhill spec. was "recognizable at a glance as the American bird" (Dresser, Birds of Europe, v. v., pp. 310, 311). 
Bubo ignavus T. Forster.-Eagle-Owl. One trapped at Poltalloch, Argyll, on our borders, 3/1882 (Pr. Nat. Hist. Soc. Glas., v. p. 224).

\section{Order Accipitres.}

\section{Fam. Falconidae.}

Circus aeruginosus (Linnaeus).-Marsh-Harrier. Recorded for Luss Parish, Dumbarton. (Rev. John Stewart, Stat. Account Scot., 1796.) One trapped, Caldarvan, Dumbarton., 2/7/83 (Lumsden, Nat. Hist. of L. Lomond, etc., p. 41).

C. cyaneus (Linnaeus).-Hen-Harrier. Formerly c. in wild tracts (351 killed on Craiglure and Culzean estates, Ayr., from 1850 to 1854); now very r. Arran is the only recent nesting locality reported to me.

C. cineraceus (Montagu).-Montagu's Harrier. Male shot ur. Ballantrae, 1836 (Thompson, Birds of Ireland, 1, p. 83); one shot, 6/1895, in Avondale parish, Lanark. (Ann. Scot. Nat. Hist., 1895, p. 252).

Buteo vulgaris, Leach.-Buzzard. Still not r. in wild tracts, e.g. S. Ayrshire, about L. Lomond and Cowal district of Argyll.

B. lagopus (Gmelin).--Rough-legged Buzzard. An irregular winter visitor. Aquila chrysaëtus (Linnaeus).-Golden Eagle. Formerly bred in S. Ayrshire, but not for about the past half-century. Nests in Arran at present and probably on confines of Argyll and Dumbarton.

Haliaëtus albicilla (Linnaeus).-White-tailed Eagle. Formerly bred in Galloway and on Ailsa Craig. Now quite unknown in "Clyde."

Accipiter nisus, Linnaeus.-Sparrow-Hawk. Not r. in wooded districts.

Milvus ictinus, Savigny.-Kite. Formerly bred in Ayr, Arran, Argyll, and Dumbarton; was still c. in the last two in first half of nineteenth century. Not known to breed anywhere in the area now. Two stragglers reported from S. Ayrshire within the last dozen years; one shot and preserved.

Pernis apivorus (Linnaeus).--Honey-Buzzard. Four reported (1) Lanark., autumn, 1831 (Stat. Account, 1841) ; (2 and 3) Ayr., one trapped, 9/1863, one shot, 9/1864 (Gray); (4) Renfrew., 1874 (Paisley Nat. Hist. Socy. MS. List).

Falco candicans, Gmelin.-Greenland Falcon. One shot, Lanarkshire, 1835 (Gray).

F. islandus, Gmelin.-Iceland Falcon. One trapped, Glendaruel, Argyll, 1866 (Gray).

F. peregrinus, Tunstall.-Peregrine Falcon. Not yet very r.; five or six eyries in Ayr and several in Argyll and Dumbarton.

F. subbuteo, Linnaeus.-Hobby. There are old records of its occurrence in Dumbarton and Arran, which should not be hastily dismissed, as it is known to have nested in Perth. in 1887. I have only seen one Clyde example, from Fintry, 6/1894.

F. aesalon, Tunstall.-Merlin. Very unc. at present owing to unremitting persecution.

F. timnunculus, Linnaeus.-Kestrel. Fairly e.

Pandion haliaëtus (Linnaeus).-Osprey. Formerly nested at L. Enoch (Robert Service); L. Doon (Gray); Inchgalbraith, L. Lomond ; no recent authentic evidence of this species in "Clyde."

\section{Order Steganopodes.}

\section{Fam. Pelecanidae.}

Phalacrocorax carbo (Linnaeus).-Cormorant. C. at all seasons all over F. of Clyde; has long been reported to nest on Ayrshire coast S. of Ballantrae; no recent information of it nesting on Ailsa Craig ; appears frequently on inland lochs. 
P. graculus (Linnaeus).--Shag. Not r. in Firth. Nests in S. Ayr. and on Glunimore I., off Mull of Cantyre.

Sula bassana (Linnaeus).-Gannet. Thousands breed on Ailsa Craig.

\section{Order Herodiones.}

Fam. Ardeidae.

Ardea cinerea, Limaeus.--Common Heron. A bout ten heronries distributed over "Clyde" with 8 nests or more (H. B. Watt, Trans. Nat. Hist. Soc. Glas., iii. (N.S.), pp. 378-398).

Nycticorax griseus (Linnaeus).--Night-Heron. One shot "many years ago" nr. Kilmarmock (Gray); one shot nr. the same town in 1888 (The Field, $21 / 11 / 1896)$.

[Ardetta minuta (Linnaeus). - Little Bittern. One reported shot nr. Eglinton . Castle recently, but not yet properly authenticated.]

Botaurus stellaris (Linnaeus).-Bittern. Probably a pair or two nested in Clyde over a century ago; since then only an irregular winter visitor.

\section{Order Axseres.}

\section{Fam. Anatidae.}

Anser cinereus, Meyer.-Grey Lag-Goose.

A. albifrons (Scopoli).-White-fronted Goose.

A. segetum (Gmelin).-Bean-Goose.

A. brachyrhynchus, Baillon.-Pink-footed Goose. Examples of the above four species of "Grey" geese have been obtained or recorded at rar. intervals. Unfortunately owing to the absence of information regarding the specific identity of the flocks of "Grey" geese seen from time to time, and the extreme rareness of examples reaching bird-stuffers, there are no data for a satisfactory comparison of the numbers of the various species which visit "Clyde."

Bernicla leucopsis (Bechstein).-Barnacle-Goose.

B. brenta (Pallas).-Brent Goose. Gray stated that the former species greatly outnumbered the latter in this region. The writer from observation and data communicated by correspondents has been led to a contrary opinion. Both occur in the estuary, and the Brent Goose is seen regularly in large flocks in the muddy bays S. of Fairlie.

Cygnus musicus, Bechstein.-Whooper Swan. An occasional winter visitor to L. Lomond, the Clyde estuary, and Lochwinnoch.

C. bewicki, Yarrell.-Bewick's Swan. A winter visitor of uncertain appearance ; recorded from Argyll, L. Lomond (several times) ; Hogganfield L. ; Lochwinnoch.

C. olor (Gmelin).-Mute Swan. Fairly c. in ponds and lochs.

Tadorna cornuta (S.G.Gmelin).-Common Sheld-Duck. C. in estuary and Firth. Seems to have increased in numbers in the past decade and extended its breeding range, which now includes L. Lomond (Lumsden).

Anas boscas, Linnaeus.-Mallard or Wild Duck. Common.

A. strepera, Linnaeus.-Gadwall. Very r., only two occurences known; one shot Tarbolton (Gray); one shot on L. Lomond recently, now in Sir Geo. H. Leith Buchanan's collection.

Spatula clypeata (Limnaeus).--Shoveler. Appears regularly on spring migration on lochs nr. Glasgow. Has bred at L. Lomond; two or three pairs, I am informed, nest at Lochwinnoch.

Dafila acuta (Limnaeus).-Pintail. Scarce in winter, absent in summer. A pair observed 2/5/1898 in E. Renfrew (Robert Wilson). Another pair seen 5/1901 by writer in E. Renfrew.

Nettion crecca (Linnaeus).-Teal. C. 
Mareca penelope (Linnaeus).-Wigeon. Abund. autumn to spring. Observed in Renfrew and Lanark in midsummer, but not known to nest.

Fuligula ferina (Linnaeus).-Pochard. Fairly c. in winter and observed in summer in Renfrew and Lanark, but not known to nest.

F. cristata (Leach).--Tufted Duck. C. in winter and nests in Renfrew, Lanark, Dumbarton, and probably Ayr (at Kilbirnie).

F. marila (Limnaeus).- Scaup Duck. Great numbers in winter in estuary and Firth of Clyde and freq. on lochs inland. Observed in Renfrew in summer but not known to nest.

Clangula glaucion (Linnaeus).-Goldeneye. C. in winter. No occurrence in the height of summer is known.

Harelda glacialis (Linnaeus).-Long-tailed Duck. In winter ; on L. Lomond (Lumsden), and in the Firth at Bute in small parties (Evans).

Somateria mollissima (Linnaeus).-Common Eider Duck. Occurs in the Firtl but only rarely as far as is known.

Oedemia nigra (Linnaeus).--Common Scoter. Occurs in winter in estuary and Firth but not c.

Oe. fusca (Linnaers).---Velvet Scoter. Has occurred at Ardrishaig and the Gareloch (Gray).

Mergus merganser, Linnaeus.-Goosander. In small parties on inland lochs and in the estuary in winter.

M. serrator, Linnaeus.-Red-breasted Merganser. R. inland except on L. Lomond where it breeds. C. in nesting season breeding in Bute and Argyll and possibly in Ayrshire. C. in estuary in winter.

M. albellus, Linnaeus.--Smew. R., only positively reported from L. Lomond.

Order Columbae.

Fam. Columbidae.

Columba palumbus, Linnaeus.-Ring-Dove or Wood-Pigeon. C.

C. oenas, Linnaeus.-Stock-Dove. Observed in recent years in Ayr, Bute, and Lanark, in all of which it probably nests. Eggs taken in Lanark, 1901 (Robert Wilson.)

C. livia, Gmelin.-Rock-Dove. On coasts of Ayr, Bute, and Argyll.

Turtur communis, Selby.-Turtle-Dove. A few have occurred during the past seventy years in Ayr and Dumbarton.

Order Pterocletes.

Fam. Pteroclidae.

Syrrhaptes paradoxus (Pallas).-Callas's Sand-Grouse. This vagrant visited "Clyde" 1863 (Renfrew), 1872 (Ayr), 1888 (Ayr, Bute, Argyll).

\section{Order Gallinae.}

Fam. Tetraonidae.

Tetrao urogallus, Linnaeus.-Capercaillie. Introduced unsuccessfully in Ayr and Argyll. Established in Arran. Has extended to Argyll, Dumbarton, Stirling, and Lanark (Quarter). A straggler in Renfrew.

T. tetrix, Linnaeus.-Black Grouse. C.

Lagopus scoticus, Latham.-Red Grouse. C.

L. mutus (Montin).--Ptarmigan. Formerly in the south and in Arran.

Not unc. in Dumbarton (and Argyll?).

\section{Fam. Phasianidae.}

Phasianus colchicus, Linnaeus.-Pheasant. C.

Perdix cinerea, Latham.--Partridge. C.

Coturnix communis, Bonnaterre--Quail. Formerly not r. in Ayr. Has bred in Lanark (Gray), and occurred in Argyll, Bute, and Renfrew. 


\section{Order Fulicariae.}

\section{Fam. Rallidae.}

Crex pratensis, Bechstein.--Corn-Crake or Land-Rail. C. in summer.

Porzana maruetta (Leach).--Spotted Crake. Recorded from Ayr (twice), Renfrew (Gray), Bute (on Pladda), Dumbarton (L. Lomond, several), Argyll (marshes by the R. Add), on our borders.

P. bailloni (Vieillot).-Baillon's Crake. One Lochwinuoch, May, 1893.

Rallus aquaticus, Linnaers.-Water-Rail. Frequently included in the

Statistical Account, 60 yrs. since ; still probably not r. Its habits rarely bring it under notice.

Gallinula chloropus (Linnaeus).-Moor-heu. C.

Fulica atra, Linnaeus.-Common Coot. C.

\section{Order Alectorides.}

\section{Fam. Otididae.}

Otis tarda, Linnaeus.-Great Bustard. Mentioned in the Statistical Account of the parish of Maybole (1837). One found in the sea at Irvive, 6/1895 (Ann. Scot. Nat. Hist., 1895, p. 253).

\section{Order Limicolae.}

\section{Fam. Oedicnemidae.}

Oedicnemus scolopax (S. G. Gmelin).-Stone-Curlew. One shot at Muirhouse, Stirling, Aug. 1895 (Annals Scot. Nat. Hist., 1897, p. 225).

\section{Fam. Glareolidae.}

Cursorius gallicus (Gmelin).-Cream-coloured Courser. One shot near Lanark, 7/10/1868 (Gray).

\section{Fam. Charadriidae.}

Eudromias morinellus (Linnceus).-Dotterel. "Frequents the Kells Range" betw. Kirkcudbright and Ayr (R. Service); shot nr. Glasgow (Gray); Carluke parish, Lanark (D. Pringle) ; observed L. Ranza (MacGillivray); Luss, Dumbarton (Stat. Account Scot., 1796).

Aegialitis hiaticola (Linnceus).-Ringed Plover. C. by the sea, infreq. by inland lakes, but observed there on passage.

Charadrius pluvialis, Limnaeus.-Golden Plover. C.

Squatarola helvetica (Linnaeus).-Grey Plover. Very r. Mr. Chas. Berry, Lendalfoot, Ayr, has seen it twice or thrice, and has one which he shot. Mr. John Robertson has recorded one recently from E. Renfrew.

Vanellus vulgaris, Bechstein.-Lapwing. Abundant.

Strepsilas interpres (Linnaeus).-Turnstone. Middle of August till first week in June on shores of Clyde. Abund. in some locs., as N. of Girvan, in autumu ; nowhere r.

Haematopus ostralegus, Linnaeus._Oyster-catcher. C. by the sea. Occasional on inlaud lochs, breeds at L. Lomond.

Himantopus candidus, Bonnaterre.-Black-winged Stilt. One killed PortGlasgow, 1850; one seen Possil Marsh, 1867 (Gray).

Phalaropus fulicarius (Linnaeus).-Grey Phalarope. Occasionally in winter.

Scolopax rusticula, Linnaers. - Woodcock. Frequent, nests sporadically throughout the area.

Gallinago major (Gmelin).-Great Snipe. Ayr (several), Argyll (two), E. Renfrew (two), Dumbarton (two).

G. coelestis (Frenzel).-Comnon Snipe. C.

G. gallinula (Linnaers).-J Jack Snipe. C. in winter.

Tringa maculata, Tieillot.-Pectoral Saudpiper. A female shot on L. Lomond, 11/1882. 
T. alpina, Linnaeus.-Dunlin. C.

T. minuta, Leisler.-Little Stint. Has occurred in Ayr, Bute, and Dumbarton.

T. subarquata (Güldenstiidt).-Curlew-Sandpiper. Has occurred in Ayr and E. Renfrew in small numbers.

T. striata, Linnaeus.-Purple Sandpiper. A c. winter visitor to the British coasts, but not so in Clyde ; regularly seen in some parts as S. Ayrshire (Ch. Berry).

T. canutus, Linnaeus.-Knot. Usually in estuary and Firth of Clyde in small numbers.

Calidris arenaria(Linnaeus).--Sanderling. A regular bird of passage, but I have never seen more than twenty-five in a flock.

Machetes pugnax (Linnaeus).-Ruff. Rather r., only about ten occurrences known to the writer.

Totanus hypoleucus (Linnaeus).-Common Sandpiper. C. in summer.

T. glareola (Gmelin).-Wood-Sandpiper. One in autumn 1853, Renfrew (Gray). One from Campbeltown sent to Small, Edinburgh, for preservation Aug. 1856 (Vert. Fauna Argyll, etc.). Two shot on L. Lomond $8 / 1872$ and $10 / 1878$ by Sir George H. Leith Buchanan.

T. ochropus (Linnaeus).-Green Sandpiper. One shot 10/11/1868 in E. Renfrew, and another seen in its company (Gray). One shot Milngavie, $8 / 12 / 1894$.

T. calidris (Linnaeus).-Redshank. C.

T. fuscus (Linnaeus).- - Spotted Redshank. Observed in antumn 1898 and 1899, Balgray Dam, E. Renfrew.

T. canescens (Gmelin).-Greenshank. A tolerably regular bird of passage in autumn at least.

Macrorhampus griseus (Gmelin).-Red-breasted Snipe. One shot Lanark (Gray); one nearer Crinan than Poltalloch, Argyll (1891), (Annals Scot. Nat. Hist. 1893 , p. 45).

Limosa lapponica (Linnaeus).--Bar-tailed Godwit. Generally a regular bird of passage; a few may usually be seen at midsummer and mid-winter in Bute.

L. belgica (Gmelin).-Black-tailed Godwit. One shot spring of 1851 on L. Lomond. Dumbarton 11/1867, one (Gray); Castle Semple (Renfrew), 8/1869, one (Gray). Two in Renfrew 9/1899, one seen at Balgray (John Robertson), and the other shot at Caldwell.

Numenius arquata (Linnaeus).-Common Curlew. C.

N. phaeopus (Linnaeus).-Whimbrel. A regular bird of passage.

\section{Order Gaviae.}

\section{Fam. Laridae.}

Hydrochelidon nigra (Linnaeus).-Black Tern. Ayr, L. Lomond and L. Fyne (Gray).

Sterna cantiaca, Gmelin.-Sandwich Tern. Formerly nested on Inch Moan, L. Lomond. Seems r. in Clyde estuary at present.

S. dougalli, Montagu.--Roseate Tern. Originally described in 1812 from a colony on the "Allans," Millport B., a haunt long since deserted. Later there were colonies in Kilbrannan Sd., and on Inch Moan, L. Lomond (Gray). Not now known in "Clyde."

S. fluviatilis, Naumann.-Common Tern.

S. macrura, Naumann.-Arctic Tern. These two said to have nested formerly on Inch Moan, L. Lomond. At present a few pairs of "terus" are resident there in summer. ? Whether both species are represented. The former nesting on islets in Kyles of Bute within last two or three years (Eagle Clarke). Both nest in considerable numbers on rocky islets in L. Fyne and one or both probably on Barmore peninsula. The Common Tern is decidedly the more c. of the two in Clyde generally I believe. 
S. minuta, Linnaeus.--Little Tern. Formerly nested on Inch Moan, L. Lomond in small numbers (Gray). Occasionally seen and obtained in autumn on Ayrshire coast.

Xema sabinii (J. Sabine).--Sabine's Gull. The late Duke of Argyll believed he saw this species nr. Campbeltown 8/1894. One from Sliddery, Arran, reached me in the flesh 24/9/1897.

Larus philadelphia, Ord.--Bonaparte's Gull. One shot 4/1850, L. Lomond, Sir Geo. H. Leith Buchanan.

L. minutus, Pallas.-Little Gull. Once obtained in Firth of Clyde (Selby, $v$. Gray); once seen L. Lomond (Gray).

L. ridibundus, Linnaeus.-Black-headed Gull. Many "gulleries" in inland localities. The large colony formerly occupying Inch Moan, L. Lomond, was broken up about 1889.

L. canus, Linnaeus.-Common Gull. Nests at L. Doon (Eagle Clarke), Bute and Inchmarnock (Robertson), and several rocky islets in L. Fyne. Fairly c.

L. argentatus, Gmelin.-Herring-Gull. A few pairs nest on Ailsa Craig, Large colonies on Glunimore I., and Sheep I. off Mull of Cantyre. Considerable flocks sometimes appear inland in winter.

L. fuscus, Linnaeus.-Lesser Black-backed Gull. Colonies on Ailsa Craig and Inch Moan, L. Lomond. C. Glasgow Harbour, estuary and Firth in summer. $R$. in winter.

L. marinus, Linnaeus.-Great Black-backed Gull. Nests on Glunimore I. off Mull of Cantyre, and possibly Ailsa Craig. Not c.

L. glaucus, Fabricius.-Glaucous Gull.

L. leucopterus, Faber.--Iceland Gull. These two occasionally visit the Firth in winter.

Rissa tridactyla (Linnaeus). - Kittiwake Gull. A very large nesting colony on Ailsa Craig.

Pagophila eburnea (Phipps).-Ivory Gull. A r. winter visitor to the Firtl. Stercorarius pomatorhinus (Temminck).-Pomatorhine Skua.

S. crepidatus (G'melin).--Arctic or Richardson's Skua. These two occur occasionally in passage in the Firth in about equal numbers.

S. parasiticus (Linnaeus).--Long-tailed or Buffou's Skua. An occasional straggler. Shot, Dalserf parish, Lanarkshire, forty yeårs since ; now in Mr. Drummond Pringle's collection.

\section{Order Alcae.}

Fam. Alcidae.

Alca torda, Linnaeus.-Razorbill. C. in estuary and firth, nesting on Ailsa Craig.

[A. impennis, Linnaeus.-Great Auk. The claim of this extinct species rests upon the bird which regained its liberty off the S. of Arran in 1821 , and the tradition of one having been washed ashore nr. Gourock about the same time, which may have been the same individual (Gray).]

Uria troile (Linnaeus).-Guillemot. C., many nesting on Ailsa Craig.

U. grylle (Linnaeus).-Black Guillemot. Two pairs at least nest on Glunimore I. off the Mull of Cantyre; a few pairs almost certainly on the cliffs in the S. of Ayr.

Mergulus alle (Linnaeus).-Little Auk. Occasionally in winter under stress of weather.

Fratercula arctica (Linnaeus).--Puffin. C. in the Firth in sunımer, many nesting on Ailsa Craig.

Order Pygopodes.

Fam. Colymbidae.

Colymbus glacialis, Linnaeus.-Great Northern Diver. Probably not r. from autumn to spring in the Firth. 
C. adamsi, G. R. Gray.-White-billed Northern Diver. One shot at Achaglachach, L. Fyne, autumn, 1893, identified by Dr. Bowdler Sharpe (A Handbook to the Birds of Great Britain, iv., p. 304).

C. arcticus, Linnceens.-Black-throated Diver. Probably not $r$. in the Firth from autumn to spring.

C. septentrionalis, Linnceus.-Red-throated Diver. Very c. in estuary and Firth from autumn to spring. Has nested in Arran.

\section{Fam. Podicipedidae.}

Podicipes cristatus (Linnaeus).--Great-Crested Grebe. A few pairs have nested for the past twelve years on lochs in $\mathrm{E}$. Renfrew where the bird is well-known. Still r. in other parts of Clyde.

P. griseigena (Boddaert).--Red-necked Grebe. R.; has occurred in Lanark, Renfrew and Ayr.

P. auritus (Linnaeus).-Slavonian Grebe. Unc., but a few have occurred all over "Clyde."

P. fluviatilis (Tunstall).-Little Grebe. C.

\section{Order Tubinares.}

\section{Fam. Procellariidae.}

Procellaria pelagica, Linnaeus.-Storm-Petrel. Occasionally after storms. Has nested on Ailsa Craig.

Oceanodroma leucorrhoa (Vieillot).--Leach's Fork-tailed Petrel. A few have been found after storms.

Fam. Puffinidae.|

Puffinus anglorum (Temminck).--Manx Shearwater. Occasionally in the Firth. 


\title{
REPTILIA AND AMPHIBIA.
}

By Alfred Brown, Luss.

\author{
REPTILIA.
}

Order SaURia.

\section{Fam. Lacertidae.}

Lacerta vivipara, Jacquin.-The Lizard or Ask. Gen. dist. throughont district, in dry heathy places, stone heaps, walls, and ruined buildings.

\section{Order Saurophidia.}

\section{Fam. Anguidae.}

Anguis fragilis, Lin.-The Blindworm or Slowworm. Very c. amongst dead wood and decayed leaves, quarry refuse, and stone heaps; preferring dry situations.

\section{Order Ophidia.}

\section{Fam. Colubridae.}

[Tropidonatus natrix, Lin.-The Smooth or Ringed Snake. Several examples have been taken nr. Paisley, and seen in woods nr. Carluke, Lanarkshire. These were probably all escapes.]

\section{Fam. Viperidae.}

Pelius berus, Lin.-The Adder or Viper. Not unc. in dry heathy places, amongst old ruins, under fallen trees, and on dry sunny banks.

\section{AMPHIBIA.}

Order Anoura.

\section{Fam. Ranidae.}

Rana temporaria, Lin.--The Frog; c. everywhere in ditches, etc., frequenting also high ground amongst heath and bog.

\section{Fam. Bufonidae.}

Bufo vulgaris, Laurenti.--The Toad or Paddock. Very c. everywhere; frequenting chiefly gardens, woods and hedgerows.

Bufo calamita, Laurenti.- The Natterjack Toad. Lately found near Inverkip by J. M. B. Taylor, Paisley. The only previous Scots record is from Solway. 


\section{Order Urodela.}

\section{Fam. Salamandridae.}

Molge cristata, Laurenti.-The crested or warty Newt. Very scarce and local ; Campsie, in a deep well hole, somewhat numerous ; Fintry, in a swamp; Balfron, in a backwater of the Endrick; Helensburgh, in a quarry hole; Anniesland, in a clayhole behind Gartnavel ; Carradale Glen, Kintyre, in ditches ; Lendalfoot, Ayrshire ; Abbey Parish, Paisley.

M. vulgaris, Lin.-The Common Newt. Abounds in ditches, ponds, marshes, and quarry holes everywhere.

M. palmata, Schneider.-The Palmated Newt. Equally common with the preceding species, and having a similar habitat. 


\section{THE MARINE AND FRESH-WATER FISHES.}

By Thomas Scott, F.L.S., Fishery Board Laboratory, Aberdeen, and Alfred Brown, Luss.

\section{Nomenclature Followed.}

A History of Scandinavian Fishes by B. Fries, C. U. Ekström, and C. Sundevall, 2nd edit., revised by Prof. F. A. Smitt (1893-95).

\section{Arrangement Followed.}

Dr. Francis Day, The Fishes of Gt. Britain and Ireland, 2 vols. 1880-84.

\section{Authorities with their Abbreviated References.}

B. \& S. = "A list of L. Fyne fishes," by Geo. Brook, F.L.S., and Thos. Scott, F.L.S. (Fourth Ann. Rep. Fishery Bd. for Scot., 1886).

H. B. = J. A. Harvie-Brown, F.R.S.E., H.Z.S., and T. E. Buckley, B.A., F.Z.S., Vertebrate fauna of Argyll and the Inner Hebrides, 1892 (separate reprint).

G. $=$ Dr. A. C. L. G. Günther, F.R.S., "Rep. on fishes obtained by Sir John Murray on N. W. coast of Scotland" (Proc. Roy. Soc. Edin., vol. xv., 1888).

F. S. G. = Fishery Statistics of the Scottish Fishery Bd. S. S. 'Garland.'

M. = Records of the S. Y. 'Medusa,' obtained by Sir John Murray.

R. = Fishery-records of the late David Robertson, LL.D., F. G. S., Millport.

S. $=$ Thos. Scott, F.L.S., (a) "Fishes of L. Fyne" (Fifteenth Ann. Rep. Fishery Bd. for Scot., Pt. iii., 1897).

(b) "Fishes of the F. of Clyde" (Eighteenth Ann. Rep. Fishery Bd. for Scot., 1900).

\section{SUB-CLASS TELEOSTEI.}

\section{ORDER ACANTHOPTERYGi.}

Fam. Percidae.

Perca fluviatilis, Lin.-Perch; c. low-lying lakes, ponds, and sluggish streams ; usually absent from high-lying waters.

Polyprion americanum (Bloch.). - Stone Basse. One taken years ago at mouth of Clyde (Aflalo), off L. Cumbrae 1870 (H.B., p. 184).

\section{Fam. Mulliảae.}

Mullus barbatus, Lin.-Surmullet, Red Mullet. One L. Fyne (CaptCampbell of Inverneil, H. B., p. 185). 


\section{Fam. Sparidae.}

Sparus centrodontus, De la lioche.-Common Sea-bream. Cumbrae, one (M. P. Bell R. in Proc. N. H. S. Glasg., vol. i., p. 119), E. L. Tarbert, 1886 one (S.).

\section{Fam. Cottidae.}

Cottus gobio, Lin.-Miller's Thumb. Upper Kelvin and tributaries; Carmel Water, Ayrshire (H. A. Woodburn); Dobbs Burn, nr. Paisley (J.M. B. Taylor).

C. scorpius, Lin.--Sea Scorpion. Gen. dist., esp. inshore.

var. groenlandica. Occasionally obtained.

C. bubalis, Euphr.-Father Lasher. Mull of Kintyre, 60 f. ; Sd. of Sanda, 20 f. (G.) ; Little Harbour ; off Inveraray, L. Fyne (F. S. G.).

C. lilljeborgii, Coll.-Norway Bullhead. Off Ardrossan, 15-30 f. ; Sd. of Sanda, 20 f. (G.).

Trigla lineata, Gmel.-Streaked Gurnard. E. L. Tarbert, not c. (B. \& S.); r. (F. S. G.).

T. pini, Bloch.--Red Gurnard. Occasionally, trawl (F. S. G.) lower estuary.

T. lucerna, Lin.-Sapphirine Gurnard. Ballantrae, in Salmon nets (Thompson) (Day, vol. i., p. 62).

T. gurnardus, Lin.-Grey Gurnard ; c., and gen. dist., esp. during summer.

Triglops murrayi, Günther-Murray's Triglops. Mull of Kintyre, 64 f.; off Sanda I., 35 f. (G.) ; nr. Sanda, one in Shrimp-trawl (F. S. G., 11/96).

\section{Fam. Cataphracti.}

Agonus cataphractus (Lin.).--Pogge. Ardrishaig (Dr. Scouler); L. Fyne and Clyde estuary occasionally (F.S. G.).

\section{Fam. Pediculati.}

Lophius piscatorius, Lin.-Angler-fish. Freq. (F.S.G.), esp. in deep water; sometimes 45 in. long.

\section{Fam. Trachinidae.}

[Trachinus vipera, Cuv.-Lesser Weaver. Arran, Landsborough's Nat. Hist. Arran (1875), p. 318.]

\section{Fam. Scombridae.}

Scomber scombrus, Lin.-Mackerel. L. Fyne; Clyde estuary ; sometimes in L. Long and L. Goil.

Orcynus thynnus (Lin.).- Tunny. One, $9 \mathrm{ft}$. long, in Gareloch nearly opposite Greenock, 7/31, (Day). One weighing 460 lbs., at Inveraray in 1769, (Pennant, Zool., vol. iii., p. 268).

[Euthynnus pelamis, Lin.-Bonito. One in Clyde, July, 1832, (Scouler).]

Sarda pelamis (Brïn.).--Belted Bonito. One, 1859, now in Hunterian Museum.

\section{Fam. Coryphaenidae.}

Brama raii (Bloch.).-Ray's Sea-bream. Specimen in Hunterian Museum, said to have been taken nr. Ayr, (H. B., p. 188).

Lampris pelagicus (Gunn.).-Opah or King-fish. One taken in Clyde in 1833, (Scouler). One in 1864, in Hunterian Museum. One in L. Fyne early in 1899, (Late Duke of Argyll, in letter to Rev. G. A. Frank Knight).

\section{Fam. Cyttidae.}

Zeus faber, Lin.-John Dory. Off Rothesay, (H. B., p. 187); L. Fyne, (B. \& S.) ; Kilbrannan Sd., in Shrimp-trawl, (F. S. G.).

\section{Fam. Gobiidae.}

Gobius flavescens, Fabr.-Two-spotted Goby. L, Fyne (Scouler); amongst zostera, E. L. Tarbert, (B.\& S.); Clyde; L. Fyne various parts (F.S.G.). 
G. niger, Lin.-Black Goby. Freq. (F. S. G.).

G. minutus, Gmel.--Speckled Goby ; c. and gen. dist.

G. jeffreysii, Gïnther.-Jeffrey's Goby. Kilbrannan Sd., 6-18 f. ; off Whiting B., $20 \mathrm{f}$.; off Cumbrae, 56 f. (G.).

Fam. Callionymidae.

Callionymus lyra, Lin.-Dragonet. Not unc. (F. S. G.).

C. maculatus, Bonap.-Spotted Dragonet. Kilbrannan Sd., rather abund., 26 f.; Sd. of Sanda, $24-28$ f., (H. B., p. 194) ; occasionally in shrimptrawl (F. S. G.).

Fam. Discoboli.

Cyclopterus lumpus, Lin.-Lumpsucker. Occasionally in trawl (F. S. G.); young sometimes in tow-net.

Cyclogaster liparis (Lin.).--Sea-snail. Not unc., Clyde ; L. Fyne ; usually in shall. inshore $\mathrm{w}$.

C. montagui (Donov).--Montagu's Sucker. Not so c. as last; habitat somewhat similar.

Fam. Gobiesocidae.

Lepadogaster gouanii (Lacep.).-Cornish-sucker. "Millport, Clyde," (H.B.).

L. bimaculatus, (Donov).-Doubly spotted sucker; c. everywhere except in mud.

Anarrhichus lupus, Lin.-Cat or Wolf-fish. Not unc., Clyde; L. Fyne, (F. S. G.).

\section{Fam. Blenniidae.}

Blennius pholis, Lin.-Shanny. Clyde area (H. B., p. 185); nr. Millport (Gray.).

Chirolophis galerita (Lin.).-Yarrell's Blenuy. E. L. Tarbert, one (B. \& S.) ; Ballantrae Bank, one, 1/99 (F. S. G.).

Pholis gunnellus (Lin.).-Butter-fish; c. and gen. dist. esp. inshore amongst weed and stones.

Enchelyopus viviparus (Lin.).-Viviparous Blenny. One near Row (R.).

Lumpenus lampretiformis ( $\mathrm{W} a l b$.).- Sharp-tailed Lumpenus. Bet. Cumbrae and Skelmorlie, 20 f.; off Cumbrae L. H., 60 f. (G.). Occasionally offshore in shrimp trawl (F. S. G.); a dozen have been taken in one haul.

Fam. Cepolidae.

[Cepola rubescens, Lin.-Red Band-fish. 7 mls. S. of Ayr (Harvie) ; beach at Ballantrae after a storm (Thomp.). See $H$. B., p. 195.]

\section{Fam. Atherinidae.}

Atherina presbyter, Cuv.-Sand Smelt or Atherine. Freq. amongst zostera, E. L. Tarbert, in spring 1885, but not later (B. \& S.); Campbeltown L. twice (Gray).

\section{Fam. Mugilidae.}

[Mugil capito, Cuv.-Grey Mullet. The "earstones" of one captured off Fairlie are in the Robertson Museum, Millport.]

M. chelo, Cuv.-Thick-lipped Grey Mullet. Gregarious in estuaries of Clyde, Leven, and some Ayrshire rivers; advancing with tide to top of flood.

\section{Fam. Gasterosteidae.}

Gasterosteus aculeatus, Lin.-Three-spined Stickleback. Fairly freq. round shores of Clyde estuary, also in F. W.lakes, ponds, etc., throughout district. var. spinulosa. L. Lomond with the other, $r$.

G. pungitius, Lin.-Ten-spined Stickleback. Mod. c. L. Lomond, Possil Marsh, etc.

Gastraea spinachia (Lin.).-Fifteen-spined Stickleback. Mod.c.round shores, but more purely marine. 
Fam. Labridae.

Labrus bergylta, Ascan.-Ballan Wrasse. Ayrshire (Thomp.); Clyde area (H. B., p. 199); L. Fywe, freq. in autumn (B. \& S.).

L. mixtus, Lin.-Striped Wrasse. E. L. Tarbert (B. \& S.); Clyde area (H. B., p. 199) ; Two, $\delta$ and \&, in Ayr Bay, 30/1/1900 (R. Duthie, Fishery Officer)!

L. (Crenilabrus) melops, Lin.-Goldsinny. Nr. Cairndow, 8/99 (F. S. G.) ; Lamlash B., 6-18 f. (G.).

L. (Ctenolabrus) rupestris, Lin.-Jago's Goldsinny. c., esp. nr. Skate I., L. Fyne (B. \& S.); Lamlash B., 6-18 f. ; bet. Cumbrae and Skelmorlie Buoy, 20 f. (G.).

L. (Centrolabrus) exoletus, Lin.-Small-mouthed Wrasse. L. Fyne, occasionally (B. \& S.).

Coris julis (Lin.).-Rainbow Wrasse. Clyde area (H. B., p. 200).

\section{Order Anacanthini.}

\section{Fam. Gadidae.}

Gadus callarius, Lin.-Cod-fish ; c. and gen. dist., esp. in seaward portion.

G. aeglefinus, Lin.-Haddock. More or less freq. and gen. dist.

G. luscus, Lin.-Bib, or Brassie. Fairly c. and gen. dist., esp. in seaward part.

G. minutus, Lin.-Poor, or Power-cod. Not unc. in seaward part of estuary (F. S. G.); Kyles of Bute, Arran, etc.

G. esmarkii, Nils.-Norway Pout. Kilbrannan Sd. to Lo. L. Fyne, not unfreq. (G.) ; sometimes in shrimp-trawl (F. S. G.).

G. merlangus, Lin.-Whiting. Mod. c. and gen. dist., esp. in seaward portion of estuary.

G. poutassou (Risso.).-Couch's Whiting. Three in shrimp-trawl at mouth of estuary, 54 f., 22/9/97! (F. S. G.).

G. virens, Lin.--Saithe, or Coal-fish. Mod. c. and gen. dist.

G. pollachius, Lin.-Lythe, or Pollack. Fairly freq. and gen. dist.

Merlucius merluccius (Lin.).--Hake. Freq. at all the "stations" in the Clyde (F.S. G.).

Phycis blennoides (Brün.).-Greater Fork-beard. Nr. Cumbrae, 4/90 (R.).

Molua molva (Lin.).- - Ling. Not unc., sometimes in trawl-net (F. S. G.).

Onos mustela (Lin.).--Five-bearded Rockling. E. L. Tarbert, bet. tide-marks; not c. (B. \& S.).

O. cimbrius (Lin.).-Four-bearded Rockling. Very c. and gen. dist. (G.).

0. tricirratus (Brïn.).-Three-bearded Rockling. Rothesay B.; Up. L. Fyne (F.S. G.), etc. ; r.

[0. maculatus, Risso.-Spotted Rockling. L. Fyne, 40 f.; Mull of Kintyre, $65 \mathrm{f}$. (G.). "If this and 0 . tricirratus be really distinct, the Clyde specimens should perhaps be all included under the latter name" (S. b.)].

Raniceps raninus (Lin.).-Lesser Fork-beard. L. Fyne (Scouler).

\section{Fam. Ophidiidae.}

Ammodytes lanceolatus, Le Savvage.-Greater Sand-launce. Occasionally nr. E. L. Tarbert (B. \& S.), nr. Sanda I. (G.), abund. at Lamlash.

\section{Fam. Pleuronectidae.}

Hippoglossus vulgaris, Flem.-Halibut. L. Fyne (B.\& S.), occasionally ; mod. freq. in sea-ward part of the estuary.

Drepanopsetta platessoides (Fabr.)._-Long Rough Dab; c. and gen. dist. esp. in deep water.

Bothus maximus ( $\operatorname{Lin}$.).-Turbot. A regular fishery is carried on off Girvan. Sometimes in Clyde and L. Fyne (F.S. G.). 
B. rhombus (Lin.).-Brill. Dist. and freq. somewhat similar to turbot.

Zeugopterus punctatus (Bl.).-Miiller's Topknot. Clyde area, 60 f. (G.); U. L. Fyne 10-25, f. (M.); Kilbrannan Sd., Ailsa Craig (E.S. G.).

Scophthalmus unimaculatus (Risso.).-One-spotted Topknot. One off Ardrossan, 10 f., 4/88 (G.). Several in a shallow sandy B. at Barmore, L. Fyne, 1885 (B. \& S.).

S. norvegicus (Günther).-Ekström's Topnot. Off Cloch L. H., 43 f. ; Lamlash B., 6-18 f. ; Kilbrannan Sd. (G.) ; trawl-net (F. S. G.), r.

Lepidorhombus whiff (Walb.).-Sail-fluke or Whiff. Clyde area (G.) ; fairly freq., esp. in seaward portion of estuary (F. S. G.).

Platophrys laterna (Walb.).--Scald-fish. Clyde area (G.) ; sometimes Kilbranuan Sd., etc. (F. S. G.).

Pleuronectes platessa, Lin.-Plaice. Mod. c. and gen. dist., esp. on sandy bottom; ascends most tidal rivers, and is occasionally obtained in L. Lomond.

P. microcephalus, Donovan.-Lemon or Smooth Dab. Fairly freq. and gen. dist.

P. cynoglossus, Lin.-Witch-sole, or Pole Dab. Very c. in deeper parts of estuary.

P. limanda, Lin.-Common Dab. c. and gen. dist.

P. flesus, Lin.-Flounder or Fluke; c. and gen. dist. ; ascends most tidal rivers, and frequents some lakes as L. Lomond, where it is not unc.

Solea vulgaris, Guensel.-Black-aole. Occasionally ; esp. in sea-ward portion (F.S.G.).

S. variegata, Donov.-Variegaterl-sole, or Thickback. Mull of Kintyre, 65 f., (G.) ; nr. Sanda I., 15/6/99 (F.S. G.) ; r.

S. lutea, Risso.-Solenette. Nr. mouth of estuary, r. (F.S.G.).

\section{Order Physostomi, Müller.}

Fam. Salmonidae.

Salmo salar, Lin.-Salmon; c. in estuary, and all larger rivers ; also Lochs Eck, Lomond, Doon, Dhub, and Iorsa.

S. trutta, Lin.-Sea Trout. Very c. Distribution same as S. Salar, but penetrating into higher and smaller waters.

S. eriox, Gmel.-Grey Salmon or Bull Trout. Scarce. Occasionally in L. Lomond and the Ayrshire rivers.

S. levenensis, Walker. - Loch Leven Trout. Introduced in many smaller lakes, e.g. Cochno, Craigallian, Castle Senple, etc. ; in most of which it thrives.

S. fario, Lin.-Brown Trout. Very abuud. in almost every stream and lake.

[S. ferox, Jardine.-The Ferox, or Great Lake Trout (doubtless a var. of fario) said to inhabit L. Lomond. No satisfactory authority for this.]

S. Iemanus, Moreau.-Geneva Lake Trout. Introduced many years ago in L. Lomond; now very $r$.

S. estuarius, Knox.-Estuary Trout. Not unc. in tidal waters at mouths of streams. Merely a var. of fario.

S. umbla, Lin.-Char. Scarce. Only record, L. Doon, Ayrshire, where it is now.

S. fontinalis, Mitchell.-American Brook Trout. Introduced in many small lakes throughout district, also in $\mathrm{L}$. Lomoud where it still maintains its identity, but has not thriven. Has been distributed throughout Renfrewshire and Ayrshire, and is thriving in Rivers Ayr and Irvine, and the Waters of Borland, Kilmarnock, Cessnock, Carmel, and Alnwick (H. A. Woodburn).

Osmerus eperlanus (Lin.).-Smelt. One taken with mussel-bait, Brodick, 1088 ; not unc. (H. B., p. 218). 
Coregonus levaretes (Lin.).-Powan or Fresh-water Herring. Very c. L. Eck; exceedingly c. L. Lomond, attaining over 3 lbs. weight.

Thymallus vulgaris, Nils.-Greyling; c. in upper reaches of Clyde, introduced many years ago ; frequents also Rivers Ayr, Lugar (H. A. Woodburn); Gryffe, and Greenburn (J. M. B. Taylor).

Argentina sphyraena, Lin.-Hebridean Smelt. Not unc., esp. in deep water (G., F. S. G.).

\section{Fam. Esocidae.}

Esox lucius, Lin.-Pike ; c. most lakes, ponds, canals, and sluggish streams.

\section{Fam. Scombresocidae.}

Rhamphistoma belone (Lin.).-Garpike. One 28 in. long, off Dunoon, 25/5/77 (Dr. R. P. Fleming); occasionally in shoals (H. B., p. 212).

* Scombresox saurus (Walb.).--Saury Pike. Clyde (H.B., p. 212).

\section{Fam. Cyprinidae.}

Cyprinus carpio, Lin.-Carp. Various ponds doubtless introduced.

C. auratus, Lin.-Goldfish. Semi-domesticated; waste ponds nr. Paisley and elsewhere in that district, where it breeds freely.

Leuciscus rutilus (Lin.).--Roach or Braise; c. gregarious ; low-lying lakes and ponds; some streams, e.g. Clyde (above Glasgow), Kelvin, Endrick, Leven, and their tributaries ; and in all canals.

Phoxinus aphya (Lin.).-Minnow.--Very c. and gregarious in most clear streams and lakes in Lanark, Renfrew, Ayr, and Dumbarton; gen. absent from Argylishire and Arran, except where introduced.

Tinca vulgaris, Flem.-Tench. Scarce and local. L. Lomond and R. Endrick; probably nowhere else.

Cobitis barbatula, Lin.-Loach or Beardie. Shallows of streams and lakes throughout district; fairly $\mathrm{c}$.

\section{Fam. Clupeidae.}

Clupea harengus, L.-Herring. Abund., F. of Clyde ; L. Fyne.

C. sprattus, Lin.-Sprat. Not unc. in Clyde; frequently mistaken for young herrings, so their numbers and distribution are somewhat uncertain.

C. alosa, Lin.-Allis Shad. Large specimens in L. Fyne 1888, (H. B., p. 221). A fine specimen in seine-net off Ross, winter 1894 (Gray).

Fam. Muraenidae.

Anguilla vulgaris, Leach.-Eel. Very c., all lakes, ponds, canals and streams ; occasionally in "Shrimp-trawl," inshore L. Fyne, (F. S. G.).

A. latirostris, Risso.-Yellow broad-nosed Eel. Is now generally considered a form of the Common Eel. Both are about equally abund.

Conger niger (Risso).--Conger. Occasionally in trawl-net in various parts of the Clyde (F. S. G.) ; Lunderston B. bet. tide-mark.

\section{ORDER LOPHOBRANCHII.}

\section{Fam. Syngnathidae.}

Syngnathus typhle, Lin.-Broad-nosed Pipe-fish. E. L. Tarbert (B. \& S.); r. S. acus, Lin.-Great Pipe-fish. Not unc. in Clyde and L. Fyne.

Nerophis aequoreus (Lin.).-Straight-nosed Pipe-fish. E. L. Tarbert, (B. \& S.); Cumbrae (R.) ; r.

N. lumbriciformis, (Will.).-Worm Pipe-fish. E. L. Tarbert (B. \& S.); Lunderston B. (S.) ; Campbeltown L. (F. S. G.).

Hippocampus antiquorum, Leach.-Sea-horse. Kilbrannan Sd.; Fairlie Sands, (Gray, v. S. b., p. 289). 
Order Plectognathi.

Fam. Gymnodontes.

Orthagoriscus mola, (Lin.).- Short Sun-fish. One off Greenock Esplanade, 10/9/81, $7 \mathrm{ft} .9 \mathrm{in}$. long, and $3 \mathrm{ft} .9 \mathrm{in}$. high, and weighed about a ton (J. M. Campbell.).

\section{SUB-CLASS CHONDROPTERYGII.}

Order Gavoidei.

Fam. Acipenseridae.

Acipenser sturio, Lin.-Sturgeon. Often noticed in L. Fyne during herring fishery, seldom captured (B. \& S.) ; Carradale; Penimore B. (Gray, v. S. b., p. 289).

\section{Order Elasmobranchit.}

Fam. Carchariidae.

Carcharias glaucus (Lin.).-Blue Shark. L. Fyne (H. B., p. 177). One stranded Ayr Bay, 9/99 (H. B. Watt).

Galeorhinus galeus (Lin.).-Tope. Several landed at Girvan, 12/99 (S.b., p. 290).

\section{Fam. Lamnidae.}

[Alopias vulpes (Gmel.).-Thraser or Fox-Shark. L. Fyne, bet. Crarae and Cas. Lachlan (Capt. Campbell, F. S. G., S. b., p. 290.)]

Cetorhinus maximus (Gunn.).--Basking-Shark. Young specimen, $8 \mathrm{ft}$. long. Captured in Maidens B., nr. Turnberry (Scotsman, Sept. 26th, 1898 ; confirmed by Fishery Ofticer, Girvan). Tide also Landsborough, Nat. Hist. of Arran, pp. 95, 96.

\section{Fam. Scylliidae.}

Scylliorhinus canicula (Lin.).-Lesser-spotted Dog-fish, or Rough-Hound. Sd. of Sanda (G.). Occasionally, esp. in seaward part of estuary (F.S. G.).

Pristiurus catulus (Gunn.).-Black-mouthed Dog-fish. U. L. Fyne, $37 \mathrm{f}$. (G.). Occasionally in deep water, bet. Arran and Turnberry (F. S. G.).

\section{Fam. Spinacidae.}

Squalus acanthias, Lin.-Picked Dog-fish. Sometimes in Clyde and L. Fyne, esp. during herring fishing.

\section{Fam. Rhinidae.}

Rhina squatina (Lin.).-Angel-fish. F. of Clycle. Not unc., freq. after gales (Norman, Zool., v. xv., p. 5366. Occasionally trawled on Ballantrae Bank (Wright of Barrow in Furness).

Raia batis, Lin.-Grey Skate. Mod. c., and gen. dist., esp. off shore.

R. intermedia, Parnell.-Flapper Skate. Bet. Sanda and Ailsa Craig (G.). deep water E. of Arran; nr. Ailsa Craig (F. S. G.).

R. oxyrhynchus, Lin.-Long or Sharp-nosed Skate. Two small specimens in deep water E. of Arran (F. S. G.). One, 51 in. long, captured in Clyde, was brought to Girvan, 1/2/1900 (Duthie, Fishery Officer).

R. fullonica, Lin.--Shagreen or Fuller's-ray. L. Fyne, off Skate I., 100 f.; Kilbrannan Sd., 20 f. (G.). Occasionally (F.S. G.).

R. clavata, Lin.-Thornback-ray. Fairly c. and gen. dis.

R. maculata, Mont.-Spotted, or Homelyn-ray. Bet. Cumbrae and Wemyss Pt., 30-40 f. ; Sd. of Sanda, 20 f. ; off Ardrossan ; Whiting B. (G.), occasionally (F. S. G.).

R. circularis, Couch.-Cuckoo or Sandy-ray. Sd. of Sanda, 20 f. (G.) ; not very $r$. in seaward portion (F. S. G.). 


\section{SUB-CLASS CYCLOSTOMATA.}

Fam. Petromyzontidae.

Petromyzon marinus, Lin.--Sea Lamprey. Very r. Occasionally frequents R. Leven, and tributaries of L. Lomond; ascending from sea in pairs to spawn.

P. fluviatilis, Lin.-River Lamprey; c. in most streams and lakes. Not migratory, and does not spawn in pairs, but promiscuously in groups of from 10 to 30 individuals.

\section{Fam. Myxinidae.}

Myxine glutinosa, Lin.-Hag-fish, Rothesay; said to be numerous off Girvan, and destructive to line-fishes ( $H . B$., p. 225).

$$
\text { SUB-CLASS LEPTOCARDII. }
$$

Fam. Cirrhostomi.

Branchiostoma lanceolatum (Pallas).-Lancelet, or Amphioxus; nr. L. Cumbrae (R.); bet. L. Cumbrae and Hunterston (Gray). (v. H. B. p. 225, Landsborough, etc.) 
TUNICATA.

By James Rankin, B.Sc., M.B., C.M., Zoological Laboratory, The University, Glasgow.

Classification.

Herdman, Prof. W. A., F. R. S., Journ. Linn. Soc., vol. xxiii.

$$
\begin{aligned}
& \text { Abbreviations. } \\
& \text { H.= Herdman. } \\
& \text { R.=Rankin. } \\
& \text { M.='Medusa' records of Sir John Murray. } \\
& \text { c.=common. l. w.= low water mark, etc. }
\end{aligned}
$$

Order I. Ascidiacea.

Sub-order I. Ascidiae Simplices.

\section{Fam. I. Molgulidae.}

Eugyra glutinans, Möll.-Dunoon Basin, Centre, 10-15 f. (M.) ; Lamlash B. ; I. Ranza, (H.).

Molgula oculata, Forb.-Lamlash B.; L. Ranza, (H.).

M. Holtiana, Herdm.-Cumbrae, littoral, (R.).

M. citrina, Ald. and Han.--Lamlash ; Bute, etc. (H.).

\section{Fam. II. Cynthiidae.}

Cynthia echinata, L.-Sanda to Achahoan, 22 f. (M.); off Skate I., 80-100 f. (M.) ; Castle B., L. Cumbrae (Gemmill); L. Fyne ; Lamlash, (H.).

Pelonaia glabra, Forb. and Goods.-Rothesay B., 7 f. (Forb. and Goods. Br. Mollusca, vol. i.)

Styela rustica, $L$.- Sanda to Achahoan, 19-22 f. ; off Skate I., 80-100 f.; L. Goil, 24-40 f. ; L. Striven, Centre, W. and E. sides, 10-40 f. ; Upper L. Fyne, 10-70 f. (all M.).

Styelopsis grossularia, Van Ben.-Abund.

Polycarpa pomaria, Sav.-Dunoon Basin, 40 f. (Hoyle); L. Goil, 35 f. (Hoyle); Lamlash B. ; Tarbert (H.) ; off Sheep I., 25 f. (R.).

P. comata, Alder.-Lamlash B. ; Tarbert, (H.).

P. quadrangularis, Forbes.-L. Fyne, 80 f., bet. Tarbert and Ardrishaig, (H. J. L. S., vol. xxiv.); L. Fyne, 30 f. (Forb. and M'Andrew) (Br. Mollusca, vol i.).

Fam. III. Ascidiidae.

Corella parallelogramma, O.F.M.-Gen. dist., 15-65 f. Very c. in Millport waters.

A. venosa, O.F. M.-Tarbert, (H.).

A. triangularis, Herdm.-Lamlash B., 10-20 f. (H. J. L.S., vol. xv.). 
Ascidiella virginea, $O . F . M$.-Abund., gen. dist.

A. aspersa, O.F.M.-L. Ranza ; off Tarbert (H.); L. Long (H. J. L. S., vol. xv.) ; aculeata form, Lamlash B., 5-15 f. (H. J. L. S., vol. xxiv.).

A. scabra, O. F.M.-Tarbert; Lamlash (H.) ; Millport, l. w. (R.) ; Inchmarnock Basin, 45-104 f. (Hoyle); not unc.

Ascidia conchilega, O.F.M.-Off Skelmorlie, 20 f. (Maclaren); Kildalloig B., S. of Davaar, 14-16 f. (R.).

A. mentula, O.F. M.-Abund., gen. dist.

A. plebeia, Ald.-Off Skate I., 80-100 f. (M.); off Lion Rock, Millport, 12-15 f. (R.) ; The Eileans, l. w. (R.) ; bet. Davaar and Sanda, 21-26 f. (R.) ; Kilchattan B. ; off Tarbert, (H.).

A. fumigata, Grube.-Millport, l. w. (R.).

A. producta, Hanc.-E. L. Tarbert, on stones below extreme 1. w. (H. J. L. S., vol. xxiv.).

A. lata, Herdm.-Upper end of L. Long, 5-10 f. (H. J. L. S., vol. xv.).

A. fusiformis, Herdm.- - Jpper end of L. Long, 5-10 f. (H. J. L. S., vol. xv.).

A. Patoni, Herdm.-Upper end of L. Long, 5 f. (H. J.L.S., vol. xv.).

A. truncata, Herdm.- Upper end of L. Long, 5. 10 f. (H. J. L. S., vol. xv.).

A. muricata, Heller.-Lamlash B., 15 f. (H. J. L. S., vol. xv.).

A. obliqua, Alder.-Lamlash B., 20 f. (H. J. L. S., vol. xv.).

A. depressa, Alder.-Extreme l.w. nr. King's Cross P., Lamlash B. (H. J.L.S., vol. xv.) ; off Kilchattan B. (H.).

A. exigua, Herdm.-Lamlash B. 10 f. (H. J. L. S., vol. xv.).

A. arachnoidea, Forbes.-Lamlash B. (Alder. Br. Mollusca, vol. i.).

A. Normani, Ald. and Han.-F. of Clyde (Robertson, Ann. Nat. Hist., vol. vi., 1870).

Ciona intestinalis, L.-Mod. c.

\section{Fam. IV. Clavelinidae.}

Clavelina lepadiformis, U.F.M.-Lamlash and Rothesay B. (Alder. Br. Mollusca, vol. i.) ; Lamlash B. ; L. Ranza ; Tarbert, (H.).

C. Savigniana, M.-Edw.-Castle B., L. Cumbrae, 12 f. (Gemnill).

\section{Sub-order II. Ascidiae Compositae.}

\section{Fam. I. Botryllidae.}

Botryllus Schlosseri (Pallas) Sav.-Millport, shore, (R.) ; Lamlash B. (H.).

B. smaragdus, M.-Edw.-Lamlash B., etc. (H.).

B. violaceus, H. M.-Edw.-Lamlash B., etc. (H.).

Botrylloides rubrum, H.M.-Edw.-Castle B., L. Cumbrae, extreme 1.w. (Gray); Lamlash ; Tarbert, etc. (H.).

\section{Fam. III. Polyclinidae.}

Glossophorum variabile, Rankin.-Millport, l. w. (R.).

Psammaplidium molle, Rankin.-Millport, l. w. (R.).

Amaroucium punctum, Giard.-(?) L. Cumbrae, 12 f. (Gemmill).

A. proliferum, M.-Edw.--Lamlash ; Tarbert, (H.).

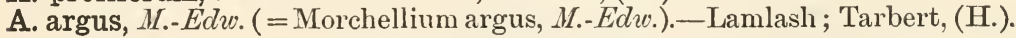

Fam. IV. Didemnidae.

Didemnum niveum, Giard.-Millport, shore, (R.).

D. inarmatum, v. Dr.-(?) Millport, shore, (R.).

Pseudo-didemnum gelatinosum, M.-Edw.-Lamlash ; Tarbert, etc. (H.).

Leptoclinum. Several sp. Lamlash, etc. (H.).

Order III. Larvacea.

Fam. Appendiculariidae.

Oikopleura dioica, Fol.-Millport (R.) ; Lamlash, (H.).

O. flabellum, J Miill.- Upper and Lower L. Fyne, (Scott, F. B. Report, 1896).

Fritillaria.-Sp. ? Millport (R.); off Pladda (Maclaren); Lamlash B. (H.). 


\title{
THE LAND AND FRESH-WATER MOLLUSCA.
}

\author{
Br Thomas ScotT, F.L.S., Aberdeen.
}

\section{Arrangement and Nomexclature.}

List of British Land and Fresh-water Mollusca, prepared by a Committee of the Conchological Society of Gt. Britain and Ireland (.I. of Conch. vol. vii., p. 49-66, 1892.).

\section{Authorities ANd References.}

(B.)=Binnie, F. G., "List of the L. and F. W. Mollusca of Clydesdale." (Fauna and Flora of the West of Scotland, 1876).

(C.) = "Census of Scottish L. and F. W. Mollusca," by W. Denison Roebuck, (Roy. Phys. Soc. Edin. Proc., vol. x., (1891), p. 437-503).

(D.) = Dougall, John, "The L. and F. W. Mollusca found within ten miles of Glasgow," (N. H. Soc. Glasg. Trans., vol. i., p. 188, 1867).

(E.)= Evans, Wm., F.R.S.E., MS. List of Clydesdale Mollusca.

(G.) = Scott, Thos., F.L.S., "On the L. and F. W. Mollusca of Greenock," (N. H. Soc. Glasg. Trans., 1886, vol. i., (N. S.), p. 279).

(H.)= Haddin, Wm., "On the distribution of the Helicidae in Bute, and in the vicinity of Largs," (N. H. Soc. Glasg. Trans., vol. i., p. 247, 1869).

(K.)= Knight, Rev. G. A. F., MS. List of Clydesdale Mollusca.

$(\mathrm{N})=$. "Supplementary Lists of L. and F. W. Mollusca," by W. D. Roebuck, (Ann. of Scot. Nat. Hist.).

(S.) = Scott, Thos., F.L.S., "The L. and F. W. Mollusca of Bute," (N. H. Soc. Glasg. Trans., 1881, vol. ii. (N.S.), p. 125, vol. iii., 1891, p. 170).

$(\mathrm{T})=$. Scott. Thos., F.L.S., "Preliminary notes on the L. and F. W. Mollusca about Tarbert, L. Fyne," (J. of Conch., vol. v., 1886, p. 72).

(W.) = Watt, Hugh Boyd, MS. List of Clydesdale Mollusca.

M.=Marsh; Cnl.=Canal; Gl.=Glen; Wd.=Wood ; C.=Common ; R. = rare, etc.

\section{Class Cephala.}

Sub-order Pulmonata.

\section{Fam. Arionidae.}

Arion ater (Lin.).-C. and gen. dist.

var. succinea. Garscadden; nr. Skelmorlie ; Maybole (C.).

var. nigrescens. Garscadden; Bute; E. Tarbert (C.). (Neither of these var. names occur in Conch. Soc. list).

A. subfuscus, Drap.-Dunoon; Bute; E. Tarbert (C.), bet. Elvanfoot and Leadhills (E.). 
A. hortensis, Fér.-Possil M. ; Sheilhill Gl.; nr. Greenock, Hunters' Quay ; Bute ; Girvan (C.).

A. minimus, Simroth.-Hunters' Quay; nr. Skelmorlie; Greenan L., Bute (C.); bet. Elvanfoot and Leadhills (E.).

A. circumscriptus, Johnst.-Possil M. ; Dumbarton Rock; Sheilhill Gl. ; Dunoon ; Bute ; W. Kilbride ; Girvan (C.) ; Arran (N., 1895) ; Faslane B., Gareloch (K.).

\section{Fam. Limacidae.}

Amalia gagates (Drap.).-C. nr. Aquarium at Rothesay (C.).

A. sowerbyi (Fér.).-Greenock ; Rothesay (C.), Eilean Aoidh, Minard (IV.), (vide .J. of Conchol., 1892, p. 68).

Limax maximus, Lin.-Nr. Forth and Clyde Cnl. by Maryhill; Greenock (C.). var. cellaria, J'Arg.-Greenock ; Gl. App., nr. Ballantrae (C.).

var. cinerea, Moq.-Greenock ; Dunoon (C.).

var. fasciata, Moq.-Greenock; Dunoon ; Rothesay ; Maybole (C.).

L. cinereo-niger, Wolf.--Nr. Brodick (N., 1895).

L. marginatus (Müll.). (=L. arborum, B.-Ch.)-C. (B.); Cloch, etc. (G.): On beech trees nr. Rothesay, freq. (S.) ; Tarbert (T.) ; Arran (N., 1895); bet. Elvanfoot and Leadhills (E.).

L. flavus, Lin.--R. Greenock, etc. (G.); c. Sugar Refinery, Baker St. (C.). var. griseasea. Greenock, in same locality with type (C.).

Agriolimax agrestis, Lin.-C. and gen. dist.

A. laevis, Muiller.--Locally freq.

\section{Fam. Vitrinidae.}

Vitrina pellucida (Müll.).-Widely dist., more or less freq., Lanark; Greenock ; Largs ; Bute ; Arran (C.).

\section{Fam. Zonitidae.}

[Hyalinia draparnaldi (Beck).-Rothesay, prob. this species (C.).]

H. cellaria (Miill.).-Mod. c. and gen. dist.

var. albina (Moq.).-Port-Bannatyne (C.) ; near Tarbert (T.).

H. alliaria (Mill.).-Mod. c. and gen. dist.

var. viridula (Jeff.).- Shore of L. Fad, Bute (C.); nr. Cloch L.-H. (G.); Glas Eilean (W.).

H. glabra (Studer).-Maryhill, Glasgow ; Port-Bannatyne ; Largs (C.).

H. nitidula (Drap.).-Gen. dist.

H. pura (Alder).-Skelmorlie; Tarbert; Bute ; Arran (C.); Sheilhill Gl. (G.) ; c. (B.).

var. margaritacea (Jeff.).-Nr. Cloch L.-H.; Largs ; E. Tarbert; nr. Rothesay (C.).

H. radiatula (Alder).-C. (B.) ; Kenmuir Bank, nr. Greenock ; Bute (C.) ; Arran (N., 1895); E. Tarbert (T.).

var. viridescenti-alba (.Jeff.).-E. Tarbert, the only locality recorded.

H. crystallina (Müll.).-Gen. dist.

H. fulva (Mïll.).-Gen. dist., more or less freq.

H. nitida (Miill.).-Bute (B.); shores of L. Fad (C.).

H. excavata (Bean.).-Cumbernauld Gl. ; Bute (B.); Sheilhill Gl. ; nr. Cloch L.-H. ; Cumbrae (C.).

\section{Fam. Helicidae.}

Helix rotundata, Mïll.-C. and gen. dist.

var. alba, Moq.-Crosslet nr. Dumbarton ; nr. Cloch L.-H. ; E. Tarbert (C.). var. minor, Jeff.-Nr. Rothesay (C.).

var. pyramidalis, Jeff.-Sheilhill Gl. ; nr. Greenock (C.).

H. pygmea, Drap.-Nr. Baldernock ; Girvan (R.) ; L. Lomond (B.) ; Skelmorlie; nr. Port-Bannatyne ; L. Ranza (C.). 
H. lamellata, Jeff.-Calderwood and Auchentorlie Gls. (B.) ; nr. Cloch L.-H. (G.) ; Inveraray ; Skeoch Wds. Bute ; Skelmorlie (C.).

H. aculeata, Mïller:-Calderwood and Auchentorlie Gls., Bute (B.); nr. Cloch L.-H. (G.) ; E. Tarbert ; Skelmorlie ; Largs ; Blantyre (C.).

H. pulchella, Mïller.-Lime quarries, North Hill, Campsie; Bute (B.) ; nr. Port-Bannatyne ; Ettrick B., Bute (C.); Hairmyres (S.).

H. aspersa, Mïller.-C. and gen. dist.

var. conoidea, Picard.-E. Tarbert (T.) ; Port-Bannatyne (S.).

var. depressa, T. S.-E. Tarbert (T.); Rothesay nr. the Aquarium (S.).

var. undulata, Moq.--Rothesay Castle (C.).

var. zonata, Moq.-E. Tarbert (C.).

monst. scalariforme, Toylor-Crawford St., Greenock (C.).

H. nemoralis, Lin.-C. and gen. dist.

var. castanea, Moq.-E. Tarbert (C.).

var. libellula (Risso).-E. Tarbert (T.) ; Lanark ; Greenock ; Skelmorlie ;

Bute (C.) ; Eilean Aoidh, Minard (W.).

var. rubella, Moq.--Lanark ; Greenock ; Innellan ; E. Tarbert ; Maybole, etc. (C.) ; Glas Eilean (W.).

var. roseolabeata, Taylor.-Liath Eilean, Kilmory (W.).

var. albolabiata, Ion Martin.-Glas Eilean (W.).

$\mathrm{H}$. hortensis, Müller.-Lanarkshire and Ayrshire.

var. incarnata, Moq.-Nr. Glasgow (C.).

var. lutea, Moq.-Greenock ; Largs ; Ardrossan ; Maybole (C.).

H. arbustorum, Lin.-Nr. Glasgow; Greenock ; Rothesay ; Largs ; E. Tarbert ;

Campbeltown, etc., (C.).

var. alpestris, Ziegl.-Nr. Sunmerston, Lanarkshire; Sheilhill Gl., nr.

Greenock (C.).

var. cincta, Taylor.-Nr. Sunımerston ; nr. Greenock ; Tarbert (C.).

var. flavescens, Moq.-Kilkerran B., Kintyre (C.).

var. fuscescens, $D$. and $M$. (=var. Marmorata, Taylor.).-E. Tarbert (C.). var. conoidea, Westerl.-Nr. Shandon; E. Tarbert (C.).

H. rufescens, Penn.--Greenock ; Inveraray ; Campbeltown (C.) ; Bowling ;

Largs ; Bute ; Arran, (Introluced ?) (B.).

var. alba, Moq.-Greenock, Hunters' Quay (C.).

var. minor, Jeff.-Greenock (C.).

var. rubens, IIoq.-Hunters' Quay (C.).

H. hispida, Lin. (=H. concinna, Jeff.).-Rothesay nr. the Aquarium (S.);

Glasgow ; Dumbarton ; Dunoon ; Largs, etc. (C.).

var. albida, Jeff.-Dumoon (C.) ; Port Bannatyne (R.).

var. depilata, Alder.-Duntocher (C.).

var. subglobosa, Jeff.-Garscadden, Dumbartonshire (C.).

var. subrufa, IIoq. - Greenock; Gl. Morag nr. Dunoon; E. Kilbride (C.).

"Var. fusca" is recorded from Campbeltown in the "Census," but the name does not occur in the Conch. Soc. list.

H. granulata, Alder. ( $=\mathrm{H}$. sericea, Jeff.).-Gourock; Skelmorlie; Largs ;

Port Bannatyne; Campbeltown (B. \& C.). var. cornea, Jeff.-E. Tarbert, about the Old Castle (C.).

H. fusca, ILont.-Falls of Clyde ; nr. Greenock ; Skelmorlie ; Largs ; Inveraray; Bute ; Arran (B. \& C.).

H. itala, Lin. (= H. ericetorum, Müll.).-St. Ninian's B., Bute (H. B. C.).

H. caperata, Mant.-E. Kilbride ; Dumbarton; W. Kilbride; Maybole ;

Bute; Campleltown, etc. (C.). var. fulva, Moq.-Ayr (C.).

var. ornata, Picard. - Campluetown (C.).

H. virgata, Da Costa.-Troon (C.).

var. alba, Taylor.-Troon (C.).

var. albicans, Grat.-Troon (C.). 
var. lineata, Otivi. (= var. maritima, Jeff.).-Troon (C.). The "var. subdeleta" (recorded in the "Census" from Troon) is not included in the Conch. Soc. list of names.

H. acuta, Miill.- Sand hills at Troon (B.).

var. strigata, Wenke.-In same locality as the type (C.).

\section{Fam. Pupidae.}

Buliminus obscurus (Mïll.).-Bothwell Old Castle; Kenmuir Bank ; Auchentorlie Gl. (B.); Falls of Clyde nr. Lanark (C.).

Pupa anglica (Fér.). (=P. ringens, Jeff.).-Largs (B.); Sheilhill Gl. nr. Greenock; Skelmorlie (C.).

var. pallida, Jeff.-Sheilhill Gl. nr. Cloch L. H. (C.).

P. cylindracea (Da Costa). (= P. umbilicata, Drap.)-C. and gen. dist. var. albina, Moq.--Sheilhill Gl. (C.).

var. edentula, IJoq.-Houston nr. Paisley (C.) ; Shielhill Gl. (G.).

P. muscorum (Lin.). (=P. marginata, Drap.). var. albina, Menke.-Millport (C.).

Vertigo antivertigo (Drap.).-Bute;Arran (B.); L. Fad ; L. Ascog, on shore (C.).

V. pygmaea (Drap.).-Hairmyres ; E. Kilbride ; Largs ; Bute (B.) ; Shielhill Gl. ; Skelmorlie ; L. Fad, etc. (C.).

var. pallida, Jeff.-Rottenburn Gl. by Greenock (G.).

V. substriata (.Jeff.).-Shore of L. Fad (C.) ; Rottenburn G1. (G.).

V. pusilla, Müll. - Nr. the Clyde about Lanark (J. Steel) ; Largs (C.).

V. edentula (Drap.).-Nr. Milngavie ; Bute (B.) ; nr. Cloch L.-H. ; Largs ; Cumbrae ; E. Tarbert (C.).

Balea perversa (Lin.).--Skelmorlie; Largs; Kilmun; Inveraray; Bute ; Campbeltown, etc. (B. C.).

Clausilia perversa (Pult.). (= C. rugosa, Drap.)-Freq. and gen. dist.

var. parvula, Turt.--High Mains nr. Dumbarton (C.).

var. tumidula, Jeff.-Largs; Ettrick B. Bute ; Campbeltown (C.).

\section{Fam. Stenogyridae.}

Cochlicopa lubrica (Miill.).-Freq. and gen. dist.

var. lubricoides, Fer.-W. Kilbride ; nr. Rothesay ; L. Fad (C.). The "var. viridula" (recorded in the Census from Dunoon) is not in Conch. Soc. List.

\section{Fam. Succineidae.}

Succinea putris (Lin.).-Arran (B.); Possil M.; Cloch below Gourock; Largs ; Bute (C.); nr. Arrochar; Cumbrae (H.).

S. elegans, Risso. var. pfeifferi.-Arran (C.).

S. oblonga, Drap.-Quarry nr. Dalry (J. Steel) (C.); Auchinskeoch nr. Dalry (R.).

\section{Order Inoperculata.}

Sub.Order Pulmonobranchiata.

Fam. Auriculidae.

Carychium minimum, Mïll.-C. (B.); Greenock ; Cloch ; Skelmorlie; Largs; Blantyre; Bute, etc. (C.).

\section{Fam. Limnaeidae.}

Planorbis fontanus (Lightfoot). (=P. nitidus, Jeff.)-Forth and Clyde Cnl. at Firhill (B.); Paisley Cnl. (C.).

P. nautileus (Lin.).-Arran (B.); Hogganfield; L. Cumbrae ; Shores of L. Ascog (C.) not unc. in district.

var. crista $($ Lin.).- - Nr. Elderslie, Renfrewshire (C.).

P. albus (Lin.)._C. (B.); Paisley Cnl.; L. Fad (C.). 
P. parvus, Say. (= P. glaber, Jeff.)-L. Greenan nr. Rothesay (S.).

P. spirorbis, Miill.-Small M. on Rutherglen Rd. ; Bishop L. ; Pool nr. Inverkip; Arran (B.); nr. Paisley ; Port-Glasgow (C.); Pond above Kerrycroy, Bute (R.).

P. contortus (Lin.).--Pond nr. Robroyston ; Frankfield L. ; Arran (B.); L. Greenan and L. Fad (C.).

Physa fontinalis (Lin.).-C. (B.); Possil M., Paisley Cnl., Ditch at Greenock, L. Fad, etc. (C.).

Limnaea peregra (Mïll.).-C. and gen. dist.

var. lacustris (Leach).-R. Clyde above Rutherglen (C.).

var. ovata, Drap.-C. with the type (B.); Blantyre; Greenock; L. Greellan (C.).

L. auricularia (Lin.).--Paisley Cnl. (C.); formerly c., now probably extinct as the canal bed has been utilized largely by a railway.

L. stagnalis (Lin.).-Possil M., introduced (B.) ; Old Quarry at Possil, introduced and now extinct (C.) ; dam at Greenock introduced, 1882 (S.).

L. palustris (Miill.).--Possil M. ; Bardowie and Frankfield Ls.; Arran (B.); Pools nr. Port-Glasgow on side of Kilmalcolm Road (G.); L. Greenan (S.).

L. truncatula (Kïll.).-C. (B.); R. Clyde above Rutherglen; Greenock; Largs ; E. Tarbert; Bute (C.).

var. minor, Iloq.-Holy I. (C.).

L. glabra (Miill.).-Frankfield L., prob. introduced (B.).

Ancylus fluviatilis, Wüll.-C. in running streams (B.); Coatbridge ; Greenock; Dunoon; Largs ; E. Tarbert ; Bute (C.).

Velletia lacustris (Lin.).-Possil M.; Bishop L. ; Forth and Clyde Cnl. at Old Kilpatrick (B.).

Order Operculata.

Sub-Order Pulmonata.

Fam. Aciculidae.

Acicula lineata (Drap.).-Lanarkshire (Jeff.); nr. Cloch L. H.; Skelmorlie (C.).

Order Operculata.

Sub-Order Pectinibranchiata.

Fam. Paludinidae.

Bythinia tentaculata (Lin.).-Possil M.; St. Germains' L. ; Forth and Clyde Cnl.; Paisley Cnl. (B.).

var. producta, Menke.-Glasgow and Paisley Cnl. (C.).

Fam. Valvatidae.

Valvata piscinalis (Mïll.).-Possil M. ; Forth and Clyde Cnl. at Dalmuir ; Paisley Cnl. (B.).

V. cristata, Miill.-Possil M. ; Forth and Clyde Cnl. at Firhill (B.).

ACEPHALA.

Order Pelecypoda.

Sub-Order Isomya.

Fam. Unionidae.

Unio margaritifer (Lin.).-R. Clyde at Cambuslang (B.) ; R. Gryfe nr. Kilmalcolnı (C.).

Anodonta cygnea (Lin.).-Paisley Cnl. ; empty shells in Bardowie L. ; R. Cart at Cardonald Mills; R. Clyde above Cambuslang (B.).

var. incrassata (Shepp.).-Paisley Cnl. (C.).

var. radiata (Nüll.).-Paisley Cnl. (C.) 


\section{Fam. Sphaeriidae.}

Sphaerium corneum (Lin.).--Possil M.; Forth and Clyde Cnl. (D.); Paisley Cnl. (C.). Locally though not gen. c.

S. lacustre (Müll.).--Possil M. ; Forth and Clyde Cnl. at Firhill, possibly introduced (B. D.).

Pisidium amnicum (Müll.).-Glasgow and Paisley Cnl. (C.); R. Clyde above Rutherglen Bridge (B.).

P. fontinale (Drap.).-Possil M.; ditch between Frankfield and Hogganfield (B.) ; E. Tarbert ('T.).

var. henslowana (Shepp.).-Glasgow and Paisley Cnl. (Mihi.).

P. pusillum (Gmelin).-Possil M. ; nr. Cloch L. H. (B.) ; Tarbert (C.); L. Fad and L. A scog (R.).

P. nitidum, Jenyns.-Frankfield L. (B.); pools by side of road bet. PortGlasgow and Kilmalcolm (fide J. G. Jeffreys) (G.); L. Fad (R.).

\section{Sub-Order Heteromya.}

\section{Fam. Mytilidae.}

Dreissena polymorpha (Pallas).-Forth and Clyde Cnl. ; c., not native (B.); Paisley Cnl. (C.). 


\title{
MARINE MOLLUSCA AND BRACHIOPODA.
}

\author{
By Rev. G. A. Frank Knight, M.A., M.C.S., F.R.S.E., \\ Auchterarder.
}

\section{Classification and Nomenclature Followed.}

"List of Brit. Marine Mollusca and Brachiopoda," prepared by a Committee of the Conchological Society. (Journ. of Conch., vol. x., p. 9, 1901.) [This List differs considerably in both classification and nomenclature from the standard hitherto recoguized, viz. Jeffreys' Brit. Conch.; for convenience of reference, therefore, wherever the nomenclature of that work is departed from, the change is notified by the inclusion of the old name within square brackets.]

\section{Authorities and References.}

(A.) = Alder, J., and Hancock, A., "Monograph of the Brit. Nudibranch. Mollusca" (Ray Soc.), 1845-55.

(B.) = Brown, Alfred, "The Mollusca of the Firth of Clyde," 1878.

(Bar.) = Barlee, referred to very frequently by Jeffreys (Brit. Conch.).

(C.) = Coulson, Frank, Esq., Fimnartmore, Kilmun; MS. Dredging Records.

(F.) = Forbes, Prof. E., "Rep. on the investigation of Brit. Marine Zoology by means of the dredge," Pt. I. (Brit. Assoc. Rep., 1850, p. 192).

(F. \& H.) = Forbes, Prof. E., and Hanley, Syl., Hist. of Brit. Mollusca, 4 vols., $1852-53$.

(G.) = Records made by S.S. 'Garland' (Fish. Bd. for Scot. Rep., 1897, Pt. III., p. 83 ; 1898, Pt. III., p. 63).

(G. \& M.) $=$ Greville, Dr., and Miles, Rev. C. P., M.D., "Dredging Rep. Firth of Clyde" (Brit. Assoc. Rep., 1856).

(H.) = Herdman, Prof. W. A., F.R.S., "The Invertebrate Fauna of Lamlash Bay" (Roy. Phys. Soc. Edin. Trans., vols. v., vi., 1880).

(Henderson)=Henderson, Prof. J. R., "A Dredging Trip to Arran" (Scott. Nat., vol. ii. (N.S.), p. 5, 1885-86).

(Hennedy) $=$ Hennedy, Roger, "Contrib. to Nat. Hist. of Clydesdale from Fauna of Greenock" (Naturalist, vol. ii., p. 88, 1852.)

$($ Hoy. $=$ Hoyle, W. E., M.A., F.R.S.E., "The Deep-water Fauna of the Clyde Sea-Area" (.Journ. Linn. Soc. (Zool.), vol. xx., p. 442, 1890).

$\left(\mathrm{Hy}_{\mathrm{r}}\right)=$ Hyndman, G. C., "Species obtained by deep dredging near Sanda I., off Mull of Kintyre" (Brit. Assoc. Rep., 1842, p. 70).

(J.) = Jeffreys, J. Gwyn (1) British Conchology, 5 vols., 1863-69.

(2) "Descriptions and Notices of Brit. Shells, mostly obtained by Geo. Barlee off W. coast of Scotland" (Ann. and Mag. N.H., xix. 1847, p. 309).

(3) "Additional Notices of British Shells" (Annals, xx., 1847, p. 16).

(4) "On Recent Species of Odostomia" (Annals, vol. ii. (2 Ser.), 1848, p. 330). 
(5) "Gleanings in Brit. Conchology" (Annals (3 Ser.), vol. i., 1858, p. 39 ; vol. ii., 1858, p. 117 ; vol. iii., 1859, pp. 30, 106 ; vol. iv., 1859, p. 189.)

(K.) = Knight, Rev. G. A. F. (1) "A Day with the Dredge at Machrie Bay" N. H. Soc. Glas. Trans. (2 Ser.), vol. iv., 1897, p. 169).

(2) "Mollusca obtained on S.S. 'Garland" (Millport Marine Biolog. Station Communications, i., 1900).

(3) Cabinet collection.

(L.) Landsborough, Rev. David, and his son, Excursions to Arran, 1847, 1851, 1852, and new edit., 1875.

(2) "Account of a Dredging Excursion in the Clyde" (Ann. and Mag. N. H., vol. xv., 1845, p. 251 ).

(3) Nudibranchiate Mollusca found in Ayrshire (MS. list).

(M) = Dredging records of Sir John Murray, on S.Y. 'Medusa.'

(M'A.) = M'Andrew, Robert, F.R.S. (see Journ. of C'onch., vol. iii., 1882, p. 310).

(Mar.) = Marshall, J. T. (1) "Additions to British Conchology" ( J. of Conch., vol. vii., 1893 , p. 241 ; 1894 , p. 379 ; vol. viii., 1896, pp. 338,385 ; vol. ix., pp. 61, 120, 165, 222).

(2) "Alterations in British Conchology" J. of Conch., vol. viii., p. 24, 1894, p. 385, 1896 ; vol. ix., pp. 61,120 , 165, 222, 284, 332, 1898-1900.

(N.)= Norman, Rev. Canon A. M., D.C.L., F.R.S. (1) "The Mollusca of the Firth of Clyde" (Zoologist, 1857-60).

(2) "Revision of British Mollusca" Ann. and Mag. N. H. (6 Ser.), vol v., 1890 , p. 452 ; vol. vi., 1890 , p. 60 ).

(P.)= Pearcey, Fred. G., Naturalist on the Scot. Fishery Bd.'s S.Y. 'Garland.'

(R.) = Robertson, David, LL.D., F.G.S. (1) "The Nudibranchiate Mollusca of the Shores of the Cumbraes" (N. H.S. Glas. Trans., vol. i., p. 204, 1868.)

(2) "On Some Marine Mollusca" (Ibid. (2 Ser.), vol. ii., p. 150, 1890).

(3) "On Isocardia cor" (Ibid., p. 215, 1890).

(4) Pleurobranchus plumula and membranaceus (Ibid., vol. iii., p. 268, 1897).

(5) "Recent Marine Mollusca of the W. of Scotland (Fauna and Flora, Brit. Assoc. Handbook, 1876).

(S.) = Scott, Thos., F.L.S. (1) "Marine Mollusca at Tarbert" (Scot. Fish. Bd. Rep., 1886, app. 234).

(2) "Marine Invertebrates of Loch Fyne" (Ibid., 1897, Pt. III., p. 107).

(3) "Nat. Hist. Notes from Tarbert" (N. H. S. Glas. Trans. (2 Ser.), vol. i., p. 377,1887$)$.

(Som.) = Somerville, A., B.Sc., F.L.S. (1) "Dredging off Portincross" (Ibid., vol. ii., p. 189, 1890).

(2) "Isocardia cor in the W. of Scotland" (Ibid., vol. iii., p. 42, 1892).

(3) Cabinet collection.

$($ Sv. $)=$ Somerville, Rev. James E., Crieff, Cabinet collection.

(Sm.) = Smith, Jas., of Jordanhill, "Recent Shells in Basin of the Clyde" (Mem. Wern. Soc., vol. viii., 1838).

$($ Sth.) = Smith, John, Kilwinning, "Shells Observed on the Ardeer and Irvine Beaches" (N. H. S. Glas. Trans., vol. iii. (N.S.), 1889-92, p. 243).

\section{ABBREVIATIONS.}

Abund.=abundant ; $\mathrm{B}=$ Bay ; bet.=between ; c. = common ; $(d)=$. dead ; d. w.=deep water ; esp.=especially; f.=fathoms ; freq.=frequent ; gen. dist.=generally distributed ; h. w.=high water; L. =Loch or Lower or Little ; $(l)=$. living ; l. w. m. =low water mark ; mod. c. = moderately common; $\mathrm{nr} .=$ near ; not unc. $=$ not uncommon ; prob. $=$ probably ; $\mathrm{r} .=$ rare ; $\mathrm{Sd} .=$ Sound ; shall. w. = shallow water ; t. m.= tide marks ; U. =Upper.

[Doubtful and insufficiently attested species are placed within square brackets.] 


\title{
MOLLUSCA.
}

\author{
Amphineura.
}

Fam. Chaetodermatidae.

Chaetoderma nitidulum, Lov.-Dredged 9 mls. S. W. of Corsewall Pt. $50 \mathrm{f}$. (Gemmill), identified by W. K. Hutton, M.A., M.B.

Fam. Chitonidae.

Lepidopleurus [= Chiton] cancellatus (G. B. Sow.).-('Iyde (M'A.).

Hanleya [= Chiton] hanleyi (Bean.).-Lamlash (H.): Clyde $18 \mathrm{f}$. (Som.).

Tonicella [=Chiton] marmorea $(F a b r$.$) . -Gen. dist., some specimens 2 \frac{1}{2}$ ' in length (P.).

T. ruber (Lowe).-Gen. dist.

Callochiton [= Chiton] laevis (Mont.).-Scarce; L. Long (Bar.): Cumbrae (R.) : Holy I. 15 f. (H.) : Cowal 5-15 f. (C.).

Craspedochilus [= Chiton] onyx (Speng.) [= cinereus]-c. var. rissoi, Jeff.-Not unc. (B.)

C. cinereus $(L$.$) [ =marginatus ]-$ Very c. on all shores.

C. albus (L.).-L. Fyne (N.): Cumbrae (R.).

Acanthochites $[=$ Chiton] fascicularis $(L) ..-G e n$. dist.

\section{Pelecypoda.}

\section{Fam. Nuculidae.}

Nucula sulcata, Bronn.-Sparsely dist. (abund. in 33 f. bet. Pladda and Turnberry (K.)).

N. nucleus, $(L$.$) . - c.$

var. radiata, $-F$. and H.-Lamlash (A.) : Cumbrae: L. Fyne (R.): E. of Bute, scarce (B.): Kyles 5-28 f. (C.).

N. nitida, G. B. Sow.-Widely dist. (abund. in Gareloch (K.)).

N. tenuis (Mont.). - - c.

var. inflata, Han.-deepest part of L. Fyne (J.): L. Long 24 f. (K.).

Nuculana [=Leda] minuta (1/ïll.)._Freq. in all depths.

var. brevirostris, Jeff.-Dunoon $40 \mathrm{f}$. (Hoy.): nr. Carradale 20 f. (M.).

$[\mathrm{N}$. tenuis $($ Phil.) [= pygmaea]-Very r.; Lamlash $15 \mathrm{f}$. (Som.): valves in Rothesay B. and d. w. outside Cumbrae (B.)].

[N. pernula (Müll.).-Ayr (d.) (Sm.): E. of Sanda 40 f. (d.) (Hy.)].

\section{Fam. Anomiidae.}

Anomia ephippium, $L$.- On all coasts and down to $65 \mathrm{f}$.

var. squamula, L.-Freq.

var. aculeata, Müll.-Bute (Sm.): Cumbrae : Lamlash (L. N. B.): Tarbert 20 f. (Som.): Gareloch 5-21 f. (M.).

var. cylindrica, Gm.-Clyde freq. (B.): Brodick (Som.): Strachur 2-7 f. (K.).

A. patelliformis, L.-Not plentiful but gen. dist.; Bogany: Toward (B.): Lamlash (L.): Kilbrennan Sd. 40-49 f.: U. L. Fyne 75 f. (Hoy.): Cumbrae (R.): Gareloch 5-21 f. (M.): Kyles 5-28 f. (C.). var. striata, Lov.-Not unc.

Fam. Arcidae.

Glycymeris [= Pectunculus $]$ glycymeris $(L$.$) . - Widely dist. but not \mathrm{c}$. var. pilosa, L.-Arran: Ayr (Sm.): E. of Sanda 40 f., 300 specimens, mostly dear ( $\mathrm{Hy}$.).

[Barbatia [=Arca] lactea (L.).-Very r., 2 or 3 near Corriegills (Martin \& L.).] 


\section{Fam. Mytilidae.}

Mytilus edulis, L.-Everywhere abund.

var. pellucida, Penn.-Campbeltown : Rothesay : Helensburgh(B.): bottom of 'Ark' Cumbrae (R.).

var. incurvata, Penn.-c., Kenmore, L. Fyne (K.).

Modiolus [= Mytilus] modiolus, L.-Very c.

var. umbilicata, Penn.-Gareloch (K.).

M. barbatus (L.).-Scarce; U. L. Fyne 75 f. (Hoy.): Rothesay l. w. (Wotton): Dunoon basin 20 f. (M.): Machrie B. : off Pirnmill (G.).

M. phaseolinus (Phil.)._-Not c.; Lamlash(L.Som.): King's Cross(H.): Tarbert (Som: M'A.): bet. Sanda and Mull of Kintyre 19 f. (K.).

Modiolaria marmorata (Forb.).-c. (in tests of Ascidia mentula).

M. discors (L.).-Plentiful among Corallina officinalis.

var. semilaevis, Jeff.-Cumbrae: Brodick in corallines (Som.).

[M. discrepans (Leach) [= nigra].-Very r.; Dunoon basin 20 f. (M.) : off Mull of Kintyre $9 \mathrm{mls} .55 \mathrm{f}$. (K.).]

Crenella decussata (Mont.).-r.; Lamlash (Sm. L.): bet. Sanda and Mull of Kintyre 19-25 f. : inside Sanda 25 f. (K.).

Fam. Pteriidae.

Pinna fragilis, Penn. [= rudis].-Very r.; only once at Arran (L.) : once dredged by Major Martin off Largs, given by him to Rev. Dr. C. P. Miles, F.L.S., by him to (Sv.), and is now in cabinet of (K.).

\section{Fam. Ostreidae.}

Ostrea edulis, L.-Not c.

var. parasitica, Turt.-Widely dist.

var. hippopus, Lmk.--Rothesay B. (B.)

var. deformis, $L m k$. - Not c.

\section{Fam. Pectinidae.}

Pecten maximus (L.).-Gen. dist. and fairly c.

P. (Hinnites) pusio (L.).-Gen. dist., but scarce.

P. (Chlamys) varius $(L$.$) . - Valves freq., not c. living.$

var. purpurea, Jeff.-Cumbrae (R.): Kyles (C.). A white form of varius (not nivea) occurs in Kyles (Som.), and below Carrick, L. Goil (fide P.). [var. nivea, Macg. - Cumbrae (Snı.).]

P. (Aequipecten) opercularis (L.).-c. var. lineata, $d a c$.- Off Craigmore (B.). var. elongata, Jeff.-Kilbrennan Sd. 55 f. (Mar.)

P. (Peplum) clavatus var. septemradiatus, Mïll.-Locally abund., most c. in d. w.

var. alba, Jeff.-Occasional, L. Fyne 36-70 f. : L. Goil 24-40 f. (M.): Cumbrae (R.): L. Fyne (Som.).

var. dumasi, Payr. [= septemradiatus, var.]--Toward: L. Fyne16 f. (Som.): Cumbrae (R.): L. Goil 35-40 f. (M.): Dumoon basin 5-30 f. (C.)

P. (Palliolum) tigerinus, Müll. [=tigrinus].-Widely dist. and c. var. costata, Jeff.-c. with the type.

P. (Palliolum) incomparabilis (Risso). [=testae].-Very r., L. Fyne (M'A. $\mathrm{N}$.): one recent valve, Lamlash $10 \mathrm{f}$. (Henderson).

P. (Palliolum) striatus (Müll.).-Gen. dist., but not plentiful.

P. (Palliolum) similis (Lask.).-Gen. dist. but scarce living.

\section{Fam. Limidae.}

Lima elliptica, Jeff.-Scarce, fairly freq. in L. Fyne.

L. subauriculata (Mont.).-Not c. living; L. Fyne (M'A.), Tarbert 40 f. (d.) 
(S.): off Callum's Hole, Bute(R.) : off Craigmore : Tan Spit : off Silvereraigs 10 f. (B.): Inveraray 10-40 f. : skipness (C.).

L. loscombi, G. B. Sorv.-Widely dist., but rather r.; Holy I. 10-15 f. (G. \& M.): Cumbrae (R.): off Shellbole B. very fine, but not in nests (B.): Skelmorlie: L. Fyne 100 f.: Kilbreunan Sd. 10-20 f. (M.): off Sanda I. 19 f. (K.): Lamlash 15 f. (Som.)

L. hians $(G m$.).-abund. locally, esp. in Lamlash B. (L. N. H. G. \& M.) : Sanda 19-25 f. (K.): Tan (R.): Ardbeg, Bute (B.).

[var. tenera, Turt.-Arran (Sm.): E. of Sanda, 160 specimens, dead, $40 \mathrm{f}$. (Hy.)?]

\section{Fam. Kelliellidae.}

Turtonia [=Cyamium] minuta $(F a b r$.$) - - Allans, Cumbrae : Clachland Pt.,$ plentiful (N. B.) : Tarbert (J.) : Brodick (L. Som.).

\section{Fam. Astartidae.}

Astarte sulcata, $d \alpha$ C.-c.

var. scotica (Maton and Rack.).-Scarce; Ayr : Bute(Sm.): Cumbrae(R.B.):

Kyles: Skelmorlie 8 f. (Som.): Tighnabruaich (C.).

var. multicostata, Jeff.-Cumbrae (R.).

A. elliptica (Bro.).-Widely but sparingly dist.

A. compressa (Mont.).--Not unc. var. globosa, Möll.-L. Fyne (M‘A.): Clyde 18 f. (Mar.)

var. striata (Leach.).-More c. than the type; Wemyss Bay 10-15 f.: L.

Fyne (Som.): Tarbert (S.): Dunoon 5-15 f. (M.): Toward (C).

Goodallia [= Astarte] triangularis (Mont.).-Usually dead; Lamlash (N.):

Clycle 40 f. (d.) (F.): near Sanda 40 f. (d.) (Hy.): Sanda 25 f. (l.)(K.): off

Silvercraigs 12 f. (d.) (B.).

\section{Fam. Isocardiidae.}

Isocardia humana (L.) [= cor].-In d. w. bet. the Cumbraes, a few valves (N.): 2 connected vv. off Holy I. 60 f. (Hend.): bet. Cumbrae and Brodick 9098 f.(R.): Portavadie 20 f. umbos (Som.): Brodick 50-60 f. (Hoy.): Dunoon basin 30-40 f.: off Holy I. 90 f. (M.): off Ailsa Craig 2 full-grown specimens: bet. Pladda and Ayr 28-33 f. 5 very fine (P.): off Machrie Bay (d.) (G.).

\section{Fam. Arcticidae.}

Arctica [=Cyprina] islandica $(L$.$) . - Young very c., large adult (l$.$) scarce.$

Fam. Lucinidae.

Lucina spinifera (Mont.).-Scarce; Lamlash (L. C.): W. of Cumbrae 12 f. : Otter: Moll Dhu, not full grown (B.): Kyles 15 f. (Som.): U. L. Fyne $60 \mathrm{f}$. (M. C.): Brodick (Sv.).

L. borealis (L.).-Freq. on sandy coasts. var. gibba, Jeff.-Moll Dhu, L. Fyne (B.)

Cryptodon [= Axinus] flexuosus (Mont.).-Widely dist. and abund. esp. in Rothesay B. 15-20 f. (B.) and Gareloch very fine, 16-23 f. (K.).

C. croulinensis (Jeff.).-Now found to be widely dist.; Lamlash B. 15 f.: L. Ranza 50 f.: Bute: Kilbrennan Sd. 70 f.: off Tarbert 20-50 f.: Skelmorlie 7-18 f. : Millport $40 \mathrm{f}$. : Pt. of Ayr $20 \mathrm{f}$. : Kyles 12-23 f. : Brodick 23-40 f. (Som.): Machrie B. 20-29 f. : Strachur 12-56 f. (K.).

C. ferruginosus (Forb.).-Widely dist. from 10 to $100 \mathrm{f}$. ; remarkably plentiful in L. Fyne (B. N. R. Som. M. K. C.).

Montacuta substriata (Mont.).- - c. but not often recorded, (on the ventral spines of Spatangus purpureus); N. of Holy I. (G. \& M.): Lamlash (L.): W. of Cumbrae: Tan Spit 8-25 f.: $\operatorname{Otter}($ N. R. B.): Davaar 21 f.: inside Sanda I. 25 f. (K.): L. Fyne (C.). 
M. bidentata (Mont.).-Gen. dist. but usually dead.

M. tumidula, Jeff.-r.; Tarbert 25 f.: L. Ranza 55 f. : Skelmorlie 18 f. : Arran 25 f. (Som.): L. Fyne 25-56 f. (S. K.).

Tellimya [= Montacuta] ferruginosa (Mont.).-Widely dist. but scarce and rarely perfect; Millport (N. R.): Lamlash B. (A.L.): Inveraray (Bar.): Ardrishaig 6 f.: Garroch Hd. (B.): Kyles 5-20 (Som. C. K.): Pirnmill 21 f.: bet. Ailsa and Corsewall 60 f.: Campbeltown 23 f.: Strachur 25 f.: Arrochar 12 f. (K.).

var. ovata, Mar.--Kyles of Bute 18 f. (K.).

Diplodonta rotundata (Mont.).-Very r. ; Horse I., Ardrossan, 2 valves (C.).

\section{Fam. Leptonidae.}

Kellia suborbicularis (Mont.).-Gen. dist. but rather scarce.

Lasaea rubra (Mont.)-c., but somewhat local ; among corallines. var. pallida, Jeff.-Clachland Pt. (N.): Millport (Som. C.): E. L. Tarbert (Som. S. B.).

[Lepton squamosum (Mont.).-Clyde 15 f. (d.) (F.).]

L. nitidum, Turt.-Not c., local ; Lamlash Bay 10-20 f. (N. H. Som.): off Silvercraigs : Otter Spit : Cumbrae $(d$.$) : Craigmore (d).(B$.$) : Sunidale B. :$ Tarbert (S.): L. Ranza 18 f.: Skelmorlie $7-18$ f. (Som.): bet. Sanda and Mull of Kintyre $19 \mathrm{f}$. : off Mull of Kintyre $9 \mathrm{mls}$. $55 \mathrm{f}$. (K.). var. convexa, Ald.-Lamlash (L.). var. lineolata, Jeff.-L. Fyne (M'Nab).

L. clarkiae, $C l$. - Sanda I. 19-25 f. valves (K.)

\section{Fam. Scrobiculariidae.}

Syndosmya [=Scrobicularia] prismatica (Mont.).-Very scarce; Lamlash B. 25 f. (L. H. Som. K.): Cumbrae (R.): Machrie B. 20-29 f. (K.): Ardrishaig $6 \mathrm{f}$. rather c.: L. Goilhead: Rothesay $($ d.) (B.): Brodick (Som): Kyles 5-28 f. : Skipness (C.).

S. nitida (Müll.).-Widely dist., but local ; L. Fyne 50 f. (F. N. Som. (75 f.) M. (80-90 f.) R.): Portincross abundant juv. 30-44 f.: Brodick 40 f.: Skelmorlie 10 f.: Cumbrae 25 f.: Kilbrennan Sd. 70 f. (Som.): Machrie B. 20-29 f.: 6 mls. off Davaar 23 f.: Ailsa 27 f. : inside Sanda 25 f. : Strachur 25-36 f. : Arrochar 8-24 f. (K.): Inchmarnock 50-80 f. (Hoy. K.)

S. alba (Wood.).-A Aund. locally, esp. in Gareloch (K.) and L. Gilp. (B.). var. oblonga, Mar.-Arran 30 f. (Mar.): Arrochar $\left(1 \frac{1}{8}^{\prime \prime} \times \frac{3^{\prime \prime}}{4}\right)($ K.).

S. tenuis (Mont.).-Very r.; Clyde (Sm.): L. Goil (Hoy.): Kyles (C.).

Scrobicularia plana (da C.) $[=$ piperata $]-r$.; Ayr (Sm.): Ardeer to Irvine (Sth.): Corriegills (L.): Bute (N.): Fairlie : Cumbrae (R.).

\section{Fam. Tellinidae.}

Tellina crassa $(G m$.$) .- Scarce; Ayr (Sm.): Ardeer to Irvine, (d.) (Sth.):$ Clyde 40 f. (d.) (F.) : Cumbrae (N.R.): Lamlash B. (L.): nr. Sanda I. 12 valves, 40 f. (Hy.): Machrie B. (d.) (K.): Sunidale B. (d.) (S.): one on Tan Spit: one off Silvercraigs (B.): Campbeltown L. 8-22 f.: Dunoon basin 10-20 f. (M.).

T. squalida, Pult.-r. ; Ayr: Bute (Sm.): Lamlash B. (A. L. N. H.): Brodick: L. Fyne (d.) (Som.): Cumbrae (R.): Scalpsie B. 10 f. (d.) (C.).

T. donacina, L.-Gen. dist., but not c.

T. pusilla, Phil.-Very r.; Clyde 5-20 f. (d.) (F.): off Sanda I. 26 f. (K.).

T. tenuis, da. C.-Very c.

T. fabula, Gron.-c., but somewhat local.

Iacoma [=Tellina] balthica $(L).[=$ var. attenuata $]$-Campbeltown: L. Gilphead: Cumbrae (B.).

var. carnaria, Penn. [=balthica]-c., but somewhat local, seems to be decreasing in abundance. 


\section{Fam. Donacidae.}

Donax vittatus $(d \alpha C$.).--Scarce, Clyde (Sm. L.): Ardeer to Irvine freq. (Sth.): Kames B., Cumbrae, one living, one dead (M. R.): Saltcoats (Som.): Ardrossan to Ayr (C.).

\section{Fam. Mactridae.}

Mactra stultorum, L.-Not c.; Ayr (Sm.): Ardrossan : Saltcoats : Irvine(C.), bet. Ardeer and Irvine freq. (Sth.): Lamlash B. (L.) : Machrie B., fresh but $(d$.$) (som.).$

var. cinerea, Mont.-Ayr (Sm.) : Lamlash (L.).

Spisula [= Mactra] solida (L.).-By no means c.; Bute (Sm. N. B.): Lamlash B. : off Holy I. (G. \& M., H., Sv.) : Cumbrae (N.).

var. truncata, Mont.-c. in Bute and Cumbrae.

S. elliptica (Brown).-c., and widely dist.

S. subtruncata $(d a C$. $)$.- - Very abund. on certain sandy shores, e.g. Ettrick and St. Ninian's Bs., Bute: Kames and Fintry Bs., Cumbrae: Troon: Kilbride B. Ardlamont: Lamlash.

var. striata, Brown.-Lamlash 2-5 f. (H.) : Troon (K.).

Iutraria elliptica, Lmk.-c.

\section{Fam. Veneridae.}

Lucinopsis undata $(P e n n)$.-Gen. dist., but not c. var. aequalis, Jeff.-L. Fyne: Kyles (d.) (C.).

Dosinia $[=$ Venus $]$ exoleta (L.).-Abund., and widely dist.

D. lupina (L.) [=lincta]-Less c. than the preceding. var. compta, Lov.-Cumbrae (R.).

Venus (Clausinella) fasciata ( $d a C$.).-Freq. var. radiata, Jeff.-Ettrick B., Bute (C.).

V. (Ventricola) casina, L.-Widely dist., but not c.

V. (Ventricola) verrucosa, L.-r.; Lamlash (L.): one living off Garroch Hd. from fisherman's lines (R.): single and much worn valves (B.): Ardeer to Irvine (Sth.).

V. (Timoclea) ovata, Penn.--Very c., and gen. dist.

var. trigona, Jeff.-Tarbert 25 f. (Mar.).

V. (Chamelaea) gallina, L.-Very c. var. laminosa, Mont.-Clyde c. (B.): Nachrie B. 20-29 f.: Lamlash B. 22 f. : Kyles 20 f. (K.).

var. gibba, Jeff.-Clyde c. (B.): Scalpsie B. 10 f. : Kyles 5-28 f. (C.). var. alba.-St. Bride's B. (Som.).

[Tapes aureus (Gm.).-Very r.; Ayr (Sm.): Ardeer to Irvine (Sth.): Arran (L.).]

T. virgineus (L.).-Freq. and widely dist. var. sarniensis (Turt.).-Not c.; Balloch B., Cumbrae (R.) : Kyles (C.).

T. pullastra (Nont.).-Abund.

var. perforans Mont.-Freq.; Lamlash B. (N.): Campbeltown (B.) :

Corriegills (Som.): Kyles (C.). var. plagia, Jeff.-L. Fyne (Bar.).

T. decussatus (L.).-Scarce and local: Holy I. (G. \& M.): Campbeltown, large and abund. (R.): Rothesay, scarce (B.): off Sanda 19 f.: L. Goil (M.) : Irvine (C., Sth.).

Gouldia [ = Circe] minima (Mont.).-Widely dist., not unc.

[Irus [= Venerupis] irus (L.).-Very r., Brodick (Sv.).]

Fam. Cardiidae.

Cardium aculeatum, L.-Very r., N. says Sm. is wrong in saying that it is "common"; Kilbrennan Sd. 22 f. (Ḧoy.): nr. Carradale 18-28 f. (M.). 
C. echinatum, L.-Mod. c. var. ovata, Jeff.-Inveraray (M'Nab).

C. tuberculatum, L.-Bute (Sm.): Ballantrae (d.) (K.).

C. exiguum, Gm.-Scarce : Ayr: Bute (Sm.): Clyde 6 f. (d.) (F.) : Lamlash 3-10 f. (L. H.): Cumbrae: outside Tan: Bogany Pt. : Otter (B.) : E. L. Tarbert (S.): Cumbrae (R.).

C. fasciatum, Mont.-c. and widely dist. var. globosa, Jeff.-Clyde district (B.).

C. nodosum, Turt.-Locally dist. over all the Firth. var. ovata, Jeff.-Lamlash $15 \mathrm{f}$. (Som.).

C. edule, L.-A hund.

C. minimum, Phil.-Widely dist., but scarce.

Laevicardium [ = Cardium] norvegicum (Speng.).-Not unc. locally.

\section{Fam. Psammobiidae.}

Psammobia tellinella, $L m k$.-Widely dist., but scarce.

P. costulata, Turt.--Very r.; Ayr (Sm.): off Carradale 28 f. (M.).

P. ferroensis (Chem.).-Mod. c., rather scarce (l.).

Psammocola [=Psammobia] depressa, Penn [=vespertina]-Very r., L. Ranza (L.) : Lamlash 15-25 f. (H.).

\section{Fam. Myidae.}

Mya arenaria, L.-c.

var. lata (J. Sow.).-Cumbrae (R.): L. Goil 24-40 f. (M.).

M. truncata, L.-c.

Sphenia [=Mya] binghami, Turt.-r. ; Clyde (M'A.) : Arran (L.) : Millport (Som.).

Corbula gibba (Olivi.).--Locally abund.

var. rosea, Bro.-Gareloch 10-22 f. (K.).

\section{Fam. Solenidae.}

Solecurtus scopula (T'urt.) [=candidus].-Very scarce : Lamlash (d.) (H.) : Tan Spit: off L. Cumbrae 8-15 f. (d.) (B.): Cumbrae, alive (R.): Sanda 19 f. (M.).

S. antiquatus $\left(P u l t\right.$.).-Scarce (l.): Lamlash $\left(d_{\text {. }}\right)\left(\mathrm{H}_{\text {. }}\right)$ : Brodick $23 \mathrm{f}$. (Henderson. Som.): Kilbrennan Sd. 50 f. (d.) (Som. C.): Machrie B. 20-29 f. (d.): Sanda to Carradale 18-21 f. $(d$.$) : Kyles (K.): Campbeltown L. 8$ f. (Gray): L. Cumbrae 15-20 f. (B. R.): L. Fyne (C.).

Cultellus [= Solen] pellucidus (Penn.).-Gen. dist., and not unc.

Ensis [= Solen] ensis (L.).-c. locally.

E. siliqua $(L) .$.- c. on all sandy coasts.

var. arcuata, Jeff. - Not so c. as preceding: E. L. Tarbert (S.) : Cumbrae (R. B.) : L. Goil : Strachur (M.): Kyles (K.).

[Solen vagina, L.-Bute (Sm.) : Innellan (Mrs. Brockbank) : in Millport (R.), and Campbeltown Museums as "S. siliqua var. marginatus".]

\section{Fam. Saxicavidae.}

Saxicavella [= Panopea] plicata (Mont.).-r.; L. Fyne (l.) (Bar.): Largs 20 f. $(\mathrm{R})$ : Portincross $(d$.$) : off Dunoon: L. Ridden (Som.): L. Gilphead, one$ (l.) (B.), L. Long 24 f. : Kyles: Gareloch, 6 perfect: Lamlash B. 22 f. (K.): Tighnabruaich : 6 (l.) Kirn to Skelmorlie 5-30 f. (C.).

Saxicava rugosa $\left(L_{0}\right)$.- c.

S. $\operatorname{arctica}\left(L_{\text {. }}\right) .-\mathrm{c}$.

var. praecisa, Mont.-Cumbrae: L. Fyne (R.): Lamlash (H.): Tarbert

16 f. : Skipness (Som.).

var. cylindrica, S. Wood.-Lamlash (Mar.). 


\section{Fam. Pholadidae.}

Pholas dactylus, L.- - r.; Clyde (Sm.) : Ardrossan : Hearls of Ayr (d.) (C.).

Barnea [= Pholas] candida (L.).-r.; Rothesay (Fraser): Ardrossan to Ayr (d.) (C.).

Zirfaea [=Pholas] $\operatorname{crispata}(L$.$) .- mod. c. locally.$

Xylophaga dorsalis (Turt.). - freq. in drift wood.

\section{Fam. Teredinidae.}

Teredo norvegica, Speng.-Holy I. wreck of old pier (G. \& M. H.) : Arrau ; Ayr (Som.): Ardrossan pier (Martin): Cumbrae (R.).

T. navalis, L.-Carrick pier (Kirsop): Fairlie (Bryce).

T. megotara, Han.-Arran (L. J.) : L. Goil (M.).

\section{Fam. Pandoridae.}

Pandora inaequivalvis var. pinna, Mont. [=obtusa].-L. Fyne (Bar.), very r., not since corroborated.

\section{Fam. Lyonsiidae.}

Lyonsia norvegica (Chem.).--Sparingly dist.

var. elongata, Gray.-Clyde 18 f. (M̀ar.).

\section{Fam. Anatinidae.}

Cochlodesma [=Thracia] praetenue $(P u l t$.$) . - Scarce throughout the$ district.

Thracia fragilis, Penn. [= papyracea].-Not unc.

var. gracilis, Jeff.-Off Tarbert, L. Fyne 16 f. (Som.).

var. villosiuscula, Macg. - Widely diffused, with the type.

[T. pubescens $(P u l t$.$) - - Arran (Sm. \& L.), not since corroborated.]$

T. convexa (W. Wood.).-Very r. (l.) : Ayr (Sm.): single valves Arran (A.): Lamlash (L.): Campbeltown L. valve (R.) and 8 f. (Gray) : L. Fyne $20 \mathrm{f}$. (Mar.): Brodick 40 f. (d.) (Som.) : L. Goil 24-40 f. (M.): Kyles 15-20 f.: Strachur 25 f. : $3(l$. juv., bet. Sanda and Bennan Hd. 25 -30 f., one full grown $\left(l_{\text {. }}\right)(\mathrm{P}$.$) .$

T. distorta (Mont.). - mod. c., but local.

\section{Fam. Cuspidariidae.}

Cuspidaria [= Neaera] abbreviata $\left(F_{0} r b\right.$.).-r.; L. Fyne (M‘A. Bar. S. N.) : St. Catharines: Kilbrenuan Sd. 60 f.: Brodick 40 f. (Som.): Inchmarnock 30 f. (Hoy.): Minard 15-70 f. (M.): Cumbrae 80 f. (R.): Kyles 18 f. : Strachur 35-56 f (K.) : Inveraray 10-40 f. : Skipness 29 f. (C.).

C. costellata (Desh.).-r.; L. Fyne 40-70 f. (M'A. Bar. N. R.): Cumbrae (R.):

Lamlash 20 f. : Brodick 40 f. : Tarbert 19 f. (Som.): Battle I. 40 f. (S.):

Minard: Furnace 10-25 f. (M.): off Skate I. 105 f. (Hend.): Tarbert 20-60 f., Otter $5(l$.) : Skipness 29 f. (C.).

C. cuspidata (Olivi.).-Widely dist., but very scarce.

\section{ScAPHOPODA.}

Fam. Dentalidae.

Pulsellum [=Siphonodentalium] lofotense (M. Sars.).-r.; L. Fyne 100 f. (M.): Cumbrae (R.) : Strachur 22-56 f. (K.): Skate I. 107 f. (S.): Tarbert 75 f. (Som.).

var. affine, M. Sars.-Off Skate I. 90-100 f. (M.): Strachur, 56 f. (K.): very $r$.

Dentalium entalis, $L .-$ Gen. dist. aud c. 
Gastropoda.

PROSOBRANCHIA.

\section{Fam. Patellidae.}

Patella vulgata, L.-Very c.

var. elevata, Jeff.-Cumbrae, (R.).

var. intermedia, Knapp.--L. Striven (M.).

var. depressa, Penn.-c.

var. caerulea, $L$.-mod. c.

Patina [= Helcion] pellucida (L.). - c.

var. laevis, Penn.--c.

Fam. Acmaeidae.

Acmaea [ = Tectura] testudinalis $(M / i l l$.$) . - c.$

A. virginea (Müll.).-Gen. dist.

Fam. Lepetidae.

Lepeta caeca (Müll.)._Very r.; L. Fyne (M`A.) : Kyles (d.) 18 f. (K.).

L. [=Tectura] fulva (Müll.).-Widely dist., but scarce. var. albula, Jeff.-L. Fyne (M‘A.).

\section{Fam. Pleurotomariidae.}

Scissurella crispata, Flem.-Very r.; L. Fyne (Bar.): Clyde 18 f. (Som.): bet. Sanda and the Mull $19 \mathrm{f}$. : off Mull of Kintyre 9 mls. 55 f. (K.).

\section{Fam. Fissurellidae.}

Puncturella noachina (L.).-Not unc., widely dist.

Emarginula fissura (L.).-Mod. c. over all the firth. var. subdepressa, Jeff.-Lamlash 7-13 f. (H.) : L. Fyne 25 f. (K.) var. elata, Jeff.-Clyde $18 \mathrm{f}$. (Mar.). var. incurva, Jeff.-Lamlash 18 f. (Som.).

[E. conica, Schum. [= rosea].-Very r.: only record Whiting B. (F. B. R., 1898, Part III., p. 66).]

E.crassa, J. Sow.-Very scarce: L. Fyne 20 f. (d.) (F.) : L. Long (Bar.): Lamlash 15 f.: off Tarbert 75 f. (d.) (Som.): Battle I. (d.) (S.): one L. Gilphead 12-14 f. (B.): Inchmarnock 104 f. (d.) (Hoy.): Inveraray (R.): Tighnabruiach (Sv.): Minard 10-20 f. : L. Striven 15-35 f.: L. Goil 24-40 f. (M.) : L. Long : L. Fyne: Kyles (C.).

Fissurella graeca (L.).-Very r.: Bute (Sm.): N. of Holy I. 10-30 f. (G. \& M.): L. Fyne (Bar.): Lamlash (L.): L. Goil 35-40 f.: Dunoon basin 6-8 f. (M.). Propilidium ancyloide (Forb.).-r.; Ballantrae (Getty): Lamlash 20 f. (Sm., F. L. Som.): S. E. of Ailsa 27 f.: off Mull of Kintyre 9 mls. 55 f. (K.).

\section{Fam. Trochidae.}

[Moelleria costulata, Möll.--Off Silvercraigs 12 f. (B.): Lamlash 10 f., all (d.), prob. post-tertiary.]

Eumargarita [= Trochus] helicina ( $F a b r$.$) --Locally plentiful.$

E. groenlandica (Chem.).-Very r.; Lamlash (L.) : Cumbrae (R.).

Gibbula [ $=$ Trochus] magus $(L$. $)-c$. var. alba, Jeff.-Lamlash 10-20 f. (H.).

G. tumida (Mont.).-c.

G. cineraria (L.).-Very abund.

G. umbilicata (Mont.).-Much less c. than preceding.

[Monodonta [= Trochus] crassa (Montf.) [= lineatus].-Prob. not recent ; Cumbrae (Sm.): dead shells off Battery, Cumbrae (B. R.).]

Calliostoma [= Trochus] montagui, $W$. Wood.-Not c. ; one off Cumbrae (N.): Lamlash (L. A. H.): Tan : Otter (d.) (B.) : Brodick (Sv.) : L. Goil (M.) : 7 from L. Striven 10-20 f. (C.). 
[C. exasperatum (Penn.).-A solitary doubtful record; Ayr and F. of Clyde (Sm.).]

C. miliare (Broc.), [=millegranus $]$.-Locally c.

C. granulatum (Born.).-Nr. Sanda (Hy. B. A.R., 1842, p. 75): one (l.) off Sanda (S.), very r.

C. zizyphinus $(L$.$) .-Freq.$ var. lyonsi, Leach.-Inside Sanda I. 25 f. (K.). var. humilior, Jeff.-Cumbrae (R.).

Fam. Cyclostrematidae.

Delphinoidea $[=$ Cyclostrema $]$ nitens (Phil.). -Not unc., generally (d.); Lamlash 1()-17 f. (L. N. Som.): Tan : Silvercraigs 10-30 f. (B.): S. E. of Ailsa $27 \mathrm{f}$.: off Mull of Kintyre $9 \mathrm{mls} .55 \mathrm{f}$. (K.).

D. serpuloides (Hont.).-Lamlash 17 f. (M'A. L. N. Som.): not unc.; Shellbole B. $($ d. $)($ B.): bet. Sanda and the Mull 19 f.: off Mull of Kintyre $9 \mathrm{mls}$. 55 f.: inside Sanda 25 f. (K.).

Fam. Turbinidae.

Phasianella pullus (L.).-Very r.; Clyde 15 f. (F.): Arran (Sv.): bet. Sanda and the Mull $19 \mathrm{f}$. (K.).

\section{Fam. Littorinidae.}

Lacuna divaricata $(F a b r \cdot)$.- c. var. canalis, Mont.-Cumbrae (R.): E. L. Tarbert (S.). var. quadrifasciata, Mont.-Sanda to Carradale 18-21 f. (K.).

L. parva $\left(\begin{array}{lll}d a & C\end{array}\right),[=$ pticeolus $]$. - Outer Allans plentiful (N.): Farland Pt., Cumbrae, very scarce (B.): L. Gair to Minard (G.).

L. pallidula ( $d a$ C.).-Mod. r.; Cumbrae (N. B.): Ayr (Sm. L.): Lamlash (Sm. L. H.): Brodick: Whiting B.: Helensburgh (Som.): Tarbert (S.): Ardeer to Irvine (Sth.): Silvercraigs (B.). var. patula, Thorpe.-L. Goil 24-40 f. (M.). var. albescens, Jeff.-E. L. Tarbert (S.).

Littorina obtusata (L.).-Abund. var. ornata, Jeff.-c.; Cumbrae (R. N.): E. L. Tarbert (S.): nr. head of L. Eyne 10-20 f. (M.).

L. neritoides (L.).-Very iocal ; Holy I. (G. \& M.): Lamlash (L.): Outer Allans (N.): Cumbrae (R. Hend. Cook).

L. rudis (Maton.).-Abund. var. saxatilis, Johnst.-Outer Allans : Clachland Pt. (N. B.). var. jugosa, Mont. - Clyde (B.). var. patula, Thorpe.-LLocal : rocks at Callum's Hole, Bute : and Corriegills (N.). var. tenebrosa, Mont.-Salt marshes, Brodick (N.): Clyde (B.): Skipness corallines (Som.).

L. littorea (L.).-Very abund.

\section{Fam. Rissoidae.}

Rissoa parva ( $d a$ C.).- - Very abund. var. interrupta, $A d .-c$.

R. inconspicua, Ald.--Widely dist., but mostly (d.). var. variegata, $v$. Kohr.-Cumbrae (M'A.), Easlane B. 16-23 f.: Kyles $11 \mathrm{f}$. (K).

R. albella, Lor.-Rothesay (A.). var. sarsi, Lov.-Tarbert: Inveraray : Cumbrae (Som.).

R. violacea, Desm.-Not unc., widely dist. var. ecostata, Jeff.-Tarbert : Brodick: Lamlash (Som.).

R. guerini var. costulata, Ald. $[=\mathrm{R}$. costulata $]$ - "L. gives Lamlash, but prob. it was $R$. violacea" (J.). 
Alvania [= Rissoa] cancellata $(d \alpha$ C.).-Very r.; Lamlash(L.): L. Fyne(Bar.): Ayr (Sm.).

A. reticulata (Mont.).-Very abund. (d.), scarce (l.).

var. calathus $(F . \& H),.[=$ R. calathus $]$. -Cumbrae (Sm.): Lamlash (L.): Kyles 20 f. (Som.): r.

var. cimicoides, Forb, [=R. cimicoides].-r.; L. Fyne (N.): Tan Spit, 7-10 f. (Som.).

A. punctura (Mont.).-Locally plentiful.

A. subsoluta var. abyssicola, Forb. $-[=\mathrm{R}$. abyssicola $]$.-Scarce, local : L. Fyne 100 f.: L. Kanza 60 f. (M'A. \& F. N. Som. R.) : Cumbrae (L.): Portincross 30 f.: Kyles: Kilbrennan Sd. 55-70 f.: Catacol 25 f.: Cumbrae 15-65 f.: Tarbert 50-75 f. (Som.): Machrie B. 20-29 f.: Kyles 23 f.: Pimmill 73 f.: Campbeltown 23 f.: 6 mls. off Davaar 23 f.: Ailsa Craig 27 f.: Strachur 8-36 f. (K.): Tarbert 50 f. (S.).

Manzonia [=Rissoa] zetlandica (Mont.).-Scarce : Lamlash : Bute (L.): L. Fyne (N.): Tan 15-30 f. (d.): Silvercraigs 20 f. (d.) (B.): Tarbert Bank (S.): Cumbrae 20 f. (Mar.): Tan 7-10 f.: Skelmorlie 7-18 f.: Lamlash: L. Cumbrae $40 \mathrm{f}$. (Som.): off Mull of Kintyre $9 \mathrm{mls} .55 \mathrm{f}$.: inside Sanda $25 \mathrm{f}$. (K.).

M. costata (J. $A d$.). - r. and geu. (d.); Ayr: Bute (Sm.): Lamlash (L. N. B.). Zippora [= Rissoa] membranacea (J. Ad.), [=membranacea, var. elata].Cumbrae (R. Son.): E. L. Tarbert (S.): Lamlash (N.).

var. labiosa, Mont. [= membranacea]. - Not unc. and widely dist.

Onoba $[=$ Rissoa] striata $(. J . A d$.$) . - Very abund.$

var. candida, Broun.-Skipuess (Som.).

var. aculeus, Gould [=arctica].-(d.) c., rarer (l.); Arran (Som.): Kyles 20 f. (K.).

var. distorta, Mar.-Bet. Sanda and the Mull 19 f.: inside Sanda 25 f. (K.).

Ceratia [= Rissoa] proxima, Ald.-Very r.; Machrie B. 20-29 f.: off Mull of Kintyre $9 \mathrm{mls} .55$ f.: inside Sanda 25 f. (K.): Lamlash $12-15$ f. (H. Som.): Brodick $40 \mathrm{f}$. (Som.).

Hyala [= Rissoa] vitrea (Mont.).-Local and r.; Lamlash (L.): Ayr (Sm.): Largs 20-25 f. (R.): Portincross 30-44 f.: L. Cumbrae, 15-65 f.: Millport 7 f.: Kilbrennan Sd. 55 f. (Som.): Machrie B., $20-29$ f.: bet. Ailsa and Corsewall $60 \mathrm{f}$. (K.).

Setia [=Rissoa] fulgida (J. Ad.).-Scarce : Kames Bay: Lamlash (N. L.): Cumbrae (B.): Skipness (Som.).

S. obtusa (Cant.), [=soluta].-Local, but not $\mathrm{r}$.

Cingula [=Rissoa] semistriata (Mont.) - - r.; Lamlash (L.): Cumbrae (R.): bet. Sanda and the Mull $19 \mathrm{f}$.: off Mull of Kintyre 9 mls. 55 f.: inside Sanda 25 f.: Gareloch 16-23 f. (K.).

C. trifasciata, J. $A d$. [= cingillus].-Not unc. throughout the district.

Galeodina [= Rissoa] carinata, da C. [= striatula].-r.: Cumbrae: Arran (Sm. L.): Lamlash (N. Som.): Ayr (Sm.): Girvan: St. Ninian's Bay (R.): Silvercraigs 12 f. (d.) (B.).

[Barleeia rubra (Mont.).-Lamlash B.: Bute (L.): "requires confirmation" (J.).]

\section{Fam. Assimineidae.}

Paludestrina [= Hydrobia] stagnalis (Bast.). [= ulvae].-Widely dist. on mud flats; pools on Burnt Islands, Kyles of Bute : Horse I. Ardrossan (K.). var. barleei, Jeff._L. Fyne 70 f., r. (M'A.): Faslane B. Gareloch 16-23 f. (K.).

\section{Fam. Jeffreysiidae.}

Jeffreysia diaphana (Ald.).-Abund. on Outer Allans (N.): Brodick (Som.): Battery Pt., Cumbrae, scarce (B.).

J. opalina, Jeff.-Somewhat c. off Shellbole B., Cumbrae : and Battery Pt. (B.): Outer Allans abund. (N.). 
Fam. Adeorbidae.

Adeorbis subcarinatus (Mont.).-Lamlash B. (L. N.): Cumbrae : Bute (R.): a few $\left(\vec{d}\right.$.) off Silvereraigs $\left(B_{\text {. }}\right)$.

\section{Fam. Skeneidae.}

Skenea planorbis (Fabr.).-A bund. and widely dist. var. trochiformis, Jeff.-Arran (Mar. Som.).

Fam. Homalogyridae.

Homalogyra atomus (Phil.).--Mod. c. var. vitrea, Jeff.-L. Fyne (Bar.).

H. $\operatorname{rota}(F$. and H.).-r.; Arran (L. N.): L. Cumbrae (R.): Ayr B.: Campbeltown L. (S.).

Fam. Capulidae.

Capulus hungaricus (L.).-Fairly c.

Fam. Cypraeidae.

Trivia [=Cypraea] europaea (Mont.).-Very c. $\left(d_{0}\right)$; rather scarce (l.).

[Erato [= Marginella] laevis (Don.).-Ayr (Sm.), the only record.]

Fam. Naticidae.

Natica (Lunatia) sordida, Phil.-Mod. r. ; Kilbremnan Sd. 25 f. (M'A. Hoy. M.): L. Fyne (Bar. N. M.): Bute (R.): Bogany (d.) (B.): Brodick 90 f..:

Inchmarnock 37-104 (d.): Cumbrae 60 f.: L. Goil 45 f. (Hoy.): Sanda : Campbeltown 8-22 f.: L. Striven 10-20 f.: Saddell (M.): Ailsa Craig (G.): Irvine (d.) (Sth.).

N. (Lunatia) catena ( $d a C$. $)$.-Not une.

N. (Lunatia) alderi, Forb.--Very c.

N. (Lunatia) montagui, Forb.-Abund.

Fam. Lamellariidae.

Lamellaria perspicua (L.).-Scarce and local : Holy I. (G. \& M.): Lamlash (L.): Gourock (Hennedy): Allans (N.): Cumbrae (R. B.): E. L. Tarbert shore (S. Som.).

Velutina laevigata (Penn.).-c.

Velutella [=Velutina] flexilis (Mont.), [=plicatilis]-Very r., Clyde 20 f. (F.): L. Fyne one in 25 f. (M'A. Bar.): one at Bogany Pt. 12-15 f. (B.): Kilbremnan Sd. (C.).

\section{Fam. Cerithiidae.}

Bittium [ = Cerithium] reticulatum ( $d a C$. $)$.-Not unc.

Triforis [= Cerithium] perversa (L.).-Mod. r. (l.); Cumbrae (Sm. N. B.) : Lamlash (L.): Tarbert Bank (d.) (S.): off Mull of Kintyre 9 mls. 55 f.: inside Sanda 25 f. (K.).

Cerithiopsis tubercularis (Mont.).--Rather r., (l.); L. Fyne (Bar.): E. L. Tarbert (S.): Lamlash (L. N.): L. Ranza 18 f. (Som.): Sanda 19 f. : off Mull of Kintyre 9 mls. 55 f. (K.): off Dunoon 6-28 f. (C.): Cumbrae (N. B.).

\section{Fam. Scalidae.}

Scala [=Scalaria] turtonis (Turt.).-Scarce; Cumbrae 2(l.)(R.): Lamlash (L.): Bogany: Ascog: W. coast of Cumbrae ( l. $_{0}\left(\mathrm{~B}_{\mathrm{o}}\right)$ : Corriegills (N.): Saltcoats (Som.): Irvine (Sth.): Dunoon basin 10-15 f. (M.): Inchmarnock (C.).

S. clathrus $(L$.$) [= communis]-Very r.: Lamlash (L. N.): Gourock(Hennedy):$ Irvine : Ardeer (d.) (Sth.).

[Cioniscus [=Aclis] albidus, $G$. Adams. [=unicus]-The only records are Lamlash (Sm. L.), a waiting confirmation.]

Aclis ascaris (Turt.).--Very r.: Kilchattan B.(R.): Campbeltown L. 23 f.(K.). 
A. minor, Brown. [=supranitida]-Very r.; 2 (d.) outside Tan 18 f. (B.): Tarbert Bank (S.): off Pirnmill 73 f.: 6 mls. off Davaar 23 f. (K.).

Pherusina [ = Aclis] gulsonae, var, tenuicula, Jeff.-Lamlash B. (Bean.).

\section{Fam. Pyramidellidae.}

Odostomia lukisi, Jeff.-r.; off Tarbert 25 f.: Lamlash B. 20 f.: Clyde 18 f. (Som.).

0. conoidea, (Broc.).-c.

var. australis, . Teff. $-6 \mathrm{mls}$. off Davaar $23 \mathrm{f}$. (K.).

O. umbilicaris (Malm.).-Rather scarce; one (d.) outside Tan 15 f. (B.): Tan

10 f.: Lamlash 17 f.: Skelmorlie 15 f. (Som.): L. Fyue (Bar.). var. elongata, .Jeff.-Skelmorlie $15 \mathrm{f}$.: Lamlash $17 \mathrm{f}$. (Som.).

O. acuta, Jeff.-One (l.) outside Tan 15-18 f. (B.): L. Fyne (M'A. Bar.): Lamlash 12-15 f.: Skelmorlie 7-18 f. (Som.): Campbeltown L. 10 f.: bet. Ailsa and Corsewall $60 \mathrm{f}$.: S.E. of Ailsa 27 f.: off Mull of Kintyre $9 \mathrm{mls}$. 55 f. (K.). var. attenuata, Mar.-Clyde district (Mar.).

O. conspicua, Ald.-L. Fyne (M'Nab. S.): Lamlash B. 17 f.: L. Fyne 20 f. (Som.).

O. unidentata, $F$. and $H$.-c.

O. turrita, Han.--Not minc. throughout the district. var. nana, Mar.-Millport (Mar.).

O. plicata (Mont.).-r.; Clyde 7 f. (F.): Bute (Sm.): Lamlash (L.).

Jordanula $[=$ Odostomia $]$ nivosa (Mont.).-Cumbrae one (l.)(R.): Lamlash B. (L. N. M'A.).

Liostomia [=Odostomia] clayula (Lov.).-L. Fyne 27 f. (Bar. Som.): Brodick 40 f. : Clyde 18 f. (Som.).

Brachystomia [= Odostomia] albella (Lov.).-Not unc., but local.

B. rissoides (Han.).- Not unc. var. exilis, Jeff.-Cumbrae : Arran (Mar.).

B. ambigua, (Mat. and Rack.) [=pallida].-c. var. crassa, Thomp.-Clyde district (Mar.). var. angusta, Jeff.-Lamlash (Som.).

Ondina $[=$ Odostomia $]$ divisa (J. Adams.) [=insculpta].-Plentiful (d.) rather scarce $(l$.$) .$

O. diaphana (Jeff.).- Very r. ; Clyde 18 f. (Som.).

O. obliqua (Ald.).-Scarce; Bute (R.): Cumbrae: $A \operatorname{scog}(d$.$) (B.): Tarbert(S.).$

Pyrgulina [= Odostomia] decussata (Mont.). -Scarce ; Lamlash (L. N.): off Ascog 15 f. (B.): Tan 7-10 f. (Som.).

P. indistincta (Mont.).-Not unc. throughout the district.

P. interstincta (Mont.) [ = var. suturalis]. $-\mathrm{c}$. var. intermixta, Ntros.-Pirnmill $21 \mathrm{f}$. (K.).

P. eximia (Jeff.).-Very r. ; S.E. of Ailsa 1 mile 27 f. (K.).

P. fenestrata (Forb.).-One off Kilchattan B. : two from St. Ninian's B., Bute (R.) ; very $r$.

Spiralinella [=Odostomia] spiralis (Nont.).-Gen. dist. var. coarctata, Mar.-Off Mull of Kintyre $60 \mathrm{f}$. (K.).

Miralda [=Odostomia $]$ excavata (Phil.).--Lamlash B. (L. Bean. N.): Tan 7-10 f. (Som.): Skelnorlie: Dumoon (Mar.).

Pyrgostelis [=Odostomia] scalaris var. rufescens, Forb.--Scarce, but widely dist.

P. interrupta (Totten.) [ = rufa var. fulvocincta].-Not unc. var. rufa, Phil. $[=0$. rufa].-Less c., but widely dist.

[Turbonilla [= Odostomia] lactea (L.)-Tan $15 \mathrm{f}$. (d.) (B.).]

Eulimella [= Odostomia] scillae (Scac.). - Not unc., widely dist., but gen. (d.).

E. commutata (Mort.) [=acicula]. - Scarce; L. Fyne (F. \& H. Bar. R.) : Strachur $42-56 \mathrm{f}$. : off Mull of Kintyre $9 \mathrm{mls}$. $55 \mathrm{f}$.: Campbeltown $\mathrm{L}_{\text {. }}$. 
10-23 f.: bet. Ailsa and Corsewall 27-60 f.: off Davaar 26 f.: Carradale 23 f. (K.): Lamlash (Som.): L. Cumbrae 20 f. (B.).

E. ventricosa (Forb.).-r.; L. Fyne (Bar.): bet. Ailsa and Corsewall 60 f. (K.).

E. nitidissima (Kont.).-r.; off Horse I.: Cumbrae (R.): Arran (M'A.): Lamlash (L.): Millport (N.); one specimen in each locality.

\section{Fam. Eulimidae.}

Eulima polita (L.).-Not unc.

E. ephamilla, Wats.-Arran 31 f. (Mar.); r.

E. intermedia, Cantr.-r.; Lamlash (N.): L. Cumbrae 20 f. (B.): off Mull of Kintyre, 9 mls. 55 f.: Sanda to Carradale 18-21 f. (K.): Inveraray 10-40 f.: Otter (C.).

var. rubrotincta (Jeff.).-L. Fyne (J.): Tan 7-10 f. (Som.).

E. incurva (Renier.) [ = distorta].--Gen. dist.

E. gracilis, Forb. [= distorta var. gracilis]. - Not unc. in the district.

E. (Leiostraca) bilineata $(A l d$.).-Locally dist., but scarce.

\section{Fam. Caecidae.}

Caecum imperforatum (G. Adams.) $[=$ trachea].-Local and gen. (d.).

C. glabrum (Mont.).- Not nne. throughout the district.

\section{Fam. Turritellidae.}

Turritella communis, $L m k$. [ = terebra].-Abund. var. nivea, Jeff.-Much less freq. than the type.

\section{Fam. Trichotropidae.}

Trichotropis borealis, Brod. and Sow.-Not unc., and widely dist.

Fam. Aporrhaidae.

Aporrhais pes-pelecani (L.).-c. var. albida, Jeff.-O Off Campbeltown 22 f. (R.).

[A. serresianus, var. macandreae, Jeff.-Lamlash (L.), awaits confirmation.]

Fam. Buccinidae.

Buccinum undatum, L.-Very c.

var. littoralis, King.-Fintry B. (B.).

var. striata, Penn.-Ayrshire (M'A.).

[Donovania [=Lachesis] minima (Mont.).-N. of Sanda 19 f. (M.) ? : 5 on tablet in Millport Marine Station Museum marked 'shore Cumbrae' (R.), donbtful.]

Neptunea $[=$ Fusus $]$ antiqua (L.).-c.

[Volutopsis $[=$ Fusus] norvegicus $($ Chem.).-Bute $(\mathrm{Sm})$, probably from postglacial beds.]

Tritonofusus [=Fusus] gracilis, da Costa.-c.

T. (Siphonorbis) propinquus ( $A l d$.$) .-Near Kirn? (Mrs. Brockbank, J. of$ Conch. vi. p. 386): Carradale B. (d.): bet. Ailsa and Sanda (G.).

Fam. Muricidae.

Ocinebra [= Murex] erinacea (L.).--Bute: Ayr (Sm.): Clyde 15 f. (d.) (F.): Ardrossan (Som.): very r.

Trophon muricatus (Mont.).-r. ; Upper L. Fyne 12-25 f. (M.): Tarbert Bank (S.).

var. barvicensis, Johnst. $[=\mathrm{T}$. barvicensis].-Scarce: Lamlash (L. S.): L. Fyne (Bar.): Skelmorlie: Tarbert 25-50 f.: Cumbrae 40 f. (Som.): off Holy I. 20 f. (Hend.): bet. Sanda and the Mull 19 f. : off Mull of Kintyre 9 mls. 55 f.: iuside Sanda 25 f. (K.): Kyles $7-15$ f.: Inveraray $10-40$ f. $(d$.$) : Kilbrenman Sd. (d.) (C.).$

T. clathratus var. truncata, Ström. [=T. truncatus].-Scarce, but widely dist. 
Purpura lapillus (L.).-Very abund.

var. major, Jeff.-Kenmore, L. Fyne (K.).

\section{Fam. Nassidae.}

Nassa reticulata (L.).-c. throughout the district.

N. incrassata (Ström.).-Locally abund. var. minor, Jeff.-Brodick (Som.).

N. pygmaea $(\operatorname{Lmk}$.).-Rather r.: Minard 7-20 f.: N. of Sanda 19 f.: L. Goil 9-20 f.: Dunoon basin 6-20 f.: off Carradale 16-20 f. (M.): Cumbrae (R.): Sanda to the Mull $19 \mathrm{f}$. (K.).

\section{Fam. Pleurotomidae.}

Bela [ = Pleurotoma $]$ turricula (IVont.). - c. var. rosea, M. Sars. - Clyde district (B.): Ardentinny 10-30 f. (C.).

B. trevelyana (Turt.)._Ayr (Sm.): U. L. Fyne 11-20 f. (M.).

B. rufa (Iont.).-Scarce; L. Fyne (Bar.): Lamlash (d.) (L. G. \& M.). var ulideana, Thomp.-Clyde district (Eyton): one off King's Cross (G. \& M.).

[Spirotropis [= Pleurotoma] modiola (Crist. and.Jan.) [= carinata].-Dunoon basin $20 \mathrm{f}$. (M.), very doubtful.]

Haedropleura [=Pleurotoma] ecostata $(d a$ Costa $)$ [=septangularis].-Ayr: Bute (Sm.): Lamlash (N.): Cumbrae (R.); r.

Mangilia [=Pleurotoma] striolata (Scac.).-Scarce: L. Cumbrae 15-20 f. (N. B.): Otter $(d).($ B. C.) : Lamlash (L.): Tighnabruaich (Sv.): N. of Sanda 19 f.: Dunoon basin 10-20 f. (M.) : gen. (d.).

M. attenuata (Mont.)-Clyde 15-20 f. (d.) (F.): Lamlash (L.): Minard 12-20 f.: Sanda 19 f. (M.); very r.

M. costata (Don.).-Abund., but usually (d.).

var. coarctata, F. and $H$.-Carradale 23 f.: Davaar 21 f. (K.).

M. brachystoma (Phil.).--Not unc.: Portincross 30-44 f.: Catacol 25 f.: Kilbremuan Sd. 55 f.: Cumbrae 40 f. (Som.): Machrie B. 20-29 f.: off Davaar $6 \mathrm{mls} .23 \mathrm{f}$. (K.): Rothesay (d.) (B.).

M. nebula (Mont.).-Scarce ; Bute (Sm.): Lamlash (L.): Cumbrae (R. B.): Moll Dhu 10-25 f. (B.): L. Ranza 18 f. 7-10 f. (Som.).

var. vittata, Norm. [= P. laevigata].-Minard 15-20 f.: Dunoon basin 20 f.: off Carradale 16-20 f. (M.).

var. elongata, .Teff--Sanda to Carradale 18-21 f. (K.).

Teres $[=$ Defrancia $]$ anceps (Eichw.) $[=$ teres].--Very sparingly over the district.

Bellardiella [= Defrancia] gracilis (Mont.).-Scarce, but generally dist.

Clathurella [= Defrancia] leufroyi var. boothi, Broun. [=D. leufroyi].Sparsely dist. throughout the district.

C. linearis (Mont.).-Not unc. aud widely dist. var. intermedia, $F$. and $H$. [=aequalis].-Off Silvereraigs, L. Fyne (B.).

C. reticulata, Ren.--r.; Upper L. Fyne 12-15 f.: off Carradale 18 f. (M.): Garroch Hd. (R.): Lamlash 15 f. (Som.): off Inchmarnock 8-15 f.: Skipness 29 f. (d.) (C.).

var. asperrima, $F$. and $H$. [=formosa].-Lamlash $15 \mathrm{f}$. (Som.).

C. purpurea (Nont.). - Very sparingly, Clyde 15-20 f. (d.) (F.): off Clachland Pt. (N.): Ayr : Arran (Sn.): Cumbrae (R.): Lamlash (H.): Tan 10-20 f.: off Otter $(d$.$) (B.) : Upper L. Fyne 10-20 f. : N. of Sanda 19$ f. : Farland Pt. 2 f. (M.).

var. philberti, Mich.-Outer Allans, Cumbrae (N.).

\section{() PISTHOBR.I NCHIA.}

Fam. Actaeonidae.

Actaeon tornatilis (L.). - Sparsely, but widely dist. var. bullaeformis, Jeff:--L. Fyne 40-45 f. (M'Nab). 


\section{Fam. Tornatinidae.}

Tornatina [=Utriculus] mammillata (Phil.).-Scarce (l.): Lamlash B. $17 \mathrm{f}$.

(Bar. N. Som.) : Cumbrae (R.): Tan : Ascog : Bogany : off Silvercraigs

8-12 f. (B.): Skelmorlie 7-15 f. (Som.): Machrie B. 25 f. (K.).

T. truncatula (Brug.).-Rather c. throughout the district.

T. obtusa (Mont.).-Not c. ; L. Fyne (J.R.) : Lamlash (L.) : Tan : off Silvercraigs 8 f. (B.): Ardeer to Irvine, freq. (d.) (Sth.).

T. [= Cylichna $]$ nitidula (Lov.).--Widely, but locally dist., not c.

T. [= Cylichna] umbilicata (Mont.).-Locally dist. throughout the district. var. strigella (Lov.).-U. L. Fyne 20 f. : L. Goil 24-40 f. (M.).

Diaphana [= Utriculus] hyalina ('Turt.).-Not unc.

Scaphander lignarius (L.).-c

Fam. Scaphandridae.

Volvulella [ = Cylichna] acuminata (Brug.).-Rather r.; Tan 10 f. (B.) : L. Fyne (Bar. A. J. M'A. R. Som.) : Strachur 25 f. (K.): Lamlash (A. L.).

Bullinella $[=$ Cylichna $]$ cylindracea $($ Penn.).-Very c. var. linearis, Jeff.-L. Fyne (J.).

\section{Fam. Bullidae.}

[Haminaea [= Bulla] hydatis, L.-d.w. of U. L. Fyne (M.)-awaits confirmation.]

Roxania [= Bulla] utriculus, Broc.-Widely dist., but scarce. var. oblonga, Jeff.-one from L. Fyne (J.).

Acera bullata, Mïll.-Very scarce ; Ayr: Arran : Bute (Sm.) : Lamlash B. (L. N.): Tarbert (Som.S.) : Farland Pt. (B.): Cumbrae (R.).

Fam. Philinidae.

Philine scabra (Mïll.).-Not une. over all the district.

P. catena (Mont.). - Scarce ; Lamlash 10-15 (L. H. Som.): Bute (L.): Ascog 8-10 f. (B.): U. L. Fyne 35 f. (M.) : Dunderave to Cairndow (G.).

P. punctata (Clark).-Scarce; Cumbrae (L. R.) : Tan 10 f. (B.) : Lamlash 15 f. (L. Som.) : L. Ranza 18 f. : off Portincross 30-44 f. (d.) (Som.) : U. L. Fyne 70 f. (M.): Campbeltown L. 10 f. (K.).

P. pruinosa (Clark).-Very r.; L. Fyne (Bar.): Tan 3-15 f. : two living (B.). P. aperta (L.). - Not unc. throughout the district.

Fam. Limacinidae.

Limacina $[=$ Spirialis $]$ retroversa $($ Flem.). -Lamlash (Sm. L.) : L. Fyne (S.) : Strachur 56 f. (K.); r.

Fam. Aplysiidae.

Aplysia punctata, Cuv.-Fairly freq.

A. depilans (L.).-Gourock (Hennedy): Ardrossan r. (L).

Fam. Pleurobranchidae.

Pleurobranchus plumula (1/ont.).-Scarce; Maybole (Sm.): Cumbrae, l. w. m. and fishermen's lines 15 f. (R.): Farland Pt., Cumbrae (B.): E. L. Tarbert (S.): 3 bet. Pladda and Ayr (G.).

Oscanius [= Pleurobranchus] membranaceus (Mont.).-Off Garnock Beacon 25 f. (R.): Cumbrae (N.): freq. taken in S.Y. "Medusa."

\section{Fam. Runcinidae.}

Runcina coronata Quatr. [=hancocki].-r.; Cumbrae (N.); E. L. Tarbert (S). NUDIBRA NCHIA.

\section{Fam. Hermaeidae.}

Hermaea bifida (Mont.).-Cumbrae, dredged on Grifithsia corallina, mod. c. (R.): E. L. Tarbert (S.); r. 
H. dendritica (A. and H.).-Farland Pt., Cumbrae (R.).

Alderia modesta, Lov.-Among zostera nr. head of E. L. Tarbert (S.).

Elysia viridis (Mont.).-c.

\section{Fam. Elysiidae.}

Fam. Limapontiidae.

Limapontia capitata (Miill.) [=nigra].-Farland Pt., rock pools, abund. (N.).

\section{Fam. Eolididae.}

Eolis papillosa (L.).-c.

Aeolidella [=Eolis] glauca $(A$. and $H$.).-Kilchattan B. l. w. : Port Bannatyne l. w. (R.).

Ae. alderi (Cocks.).-Under stones; Cumbrae (R.).

Cuthona [=Eolis] nana, $A$. and $H$.-Cumbrae, once dredged on shell with Pagurus bernhardus (R.): Gourock B. in similar habitat (Grieve).

C. aurantia, A. and H.-Under stones near l. w. m. ; Ardrossan, r. (A.\& H.): Lamlash (L.): Cumbrae, mod. r. 25 f. (R.): Kyles 7 f. (B.).

Cratena [ = Eolis] amoena (A. and H.).-Cumbrae, r., on Sertularia polyzonia 10 f. (R.): Holy I. 20 f. (A.): Kyles 7 f. (B.).

C. viridis (Forb.).-Saltcoats : Portincross l.w.m. (L.) : Cumbrae, mod. c. (R.): Holy I. 20 f. (H.): Bute (B.).

var. glottensis (A. and H.).-Scarce: Lamlash B. on $P$. operculairs (A.): Cumbrae on zoophytes 10 f. (R.): Holy I. W. side 15-20 f. (?) (H.): Lamlash (L.).

C. olivacea (A. and H.).-Bet. t. m., Rothesay (A. \& H.) : Ardrossan : Saltcoats : Lamlash (A.L.) : Cumbrae once (R.).

C. concinna (A. and H.).- Saltcoats (L.): Cumbrae once at l.w. m. (R.) : Kyles (B.).

C. peachi (A. and H.).-One dredged at Cumbrae (R.).

Tergipes [=Eolis] despectus (Johnst.).-c. at S. W. entrance to Lamlash : Tarbert: L. Ranza (H.).

Embletonia pulchra (A. and H.).-At l. w. m., Rothesay (A.): Saltcoats: Lamlash (L.).

Amphorina molios, Herd.-Two off Port Lewis, Lamlash 10 f. (H.).

Galvina [ = Eolis] cingulata, $A$. and $H$.-Cumbrae once at l. w. m. (R.).

G. picta, A. and H.-r.; Cumbrae on Tubularia indivisa (R.): Port Lewis to the Cordon 10-20 f. (H.): Lamlash (L.): Kyles: Ascog 6-8 f. (B.): E. L. Tarbert (S.).

G. tricolor (Forb.).-Lamlash 10 f. (L. H.) : Cumbrae (R.) : E. L. Tarbert as E. farrani (S.).

G. exigua (A. and H.).-Mod. r. : Cumbrae, l. w. m. and dredged on Laminaria saccharina (R.).

Coryphella [= Eolis] rufibranchialis (Johnst.) [including E. smaragdina, $A$. and $H$. and E. pellucida, A. and $H$.]-Clyde district at 1 . w. m. (A.\& H.): Lamlash B. 5-15 f. (L. H.): Cumbrae: Kilchattan Bay as E. gracilis (R.).

C. lineata (Lov.).-Very r.; Saltcoats (L.): Cumbrae 25 f. (R.): Bute S. end (B.).

C. landsburgi (A. and H.).-Very r. ; Saltcoats (L.): Cumbrae (N.).

Favorinus [= Eolis] albus (A. and H.).-c.; Rothesay l.w. m. (A. \& H.) : Ardrossan (L.) : Lamlash B. (A. L.) : Cumbrae (N. R.) : E. L. Tarbert (S) : Ascog (B.): Kilchattan B. (R.).

Facelina [=Eolis] coronata, $F$. and Goods.-Mod. c. : Rothesay B. (A. \& H.): Cumbrae : Arran (N. R.) : Lamlash 3-21 f. (H. L.) : Bute (B.) : Saltcoats (L.) : L. Ranza (H.).

F. drummondi, Thomps.-c.

Proctonotus mucroniferus (A. and $H$.).-S. E. of Holy I. 15 f. (H.).

Hero formosa (Lov.).- -Very r.: Cumbrae (R.): Lamlash 10-20 f. (H.). 


\section{Fam. Lomanotidae.}

Lomanotus genei, Vér. [=flavidus]-Lamlash B. 4 f., one specimen (A.).

Fam. Dotonidae.

Doto fragilis (Forb.).-Mod. r.: Lamlash B. (A. L.N.): Port Lewis to the Cordon 10-20 f.: Holy I. 15 f.: L. Ranza (H.): Cumbrae (N. R.): Kyles 8 f. (B.).

D. coronata (Gmel.).-Mod. c.

\section{Fam. Dendronotidae.}

Dendronotus frondosus (Ascan.) [=arborescens]-Locally c.

\section{Fam. Scyllaeidae.}

[Scyllaea pelagica, L.-One specimen taken in tow-net by Gray off Biol. Station, Millport, accidentally destroyed before verified absolutely, but prob. correct.]

Fam. Pleurophyllidiidae.

Pleurophyllidia loveni, Bergh.-Several times in L. Striven 37-40 f. (M.).

Fam. Tritoniidae.

Tritonia hombergi, Cuv.-Not unc.; Cumbrae (R.): Minard 11-25 f.: Gareloch: L. Striven 12-20 f.: L. Goil 14 f. and shore: Pladda 30-35 f. (M.): nr. Ailsa Craig (G.).

T. (Candiella) plebeia, Johnst.-c.

T. (Candiella) lineata, A, and H.-On Plumularia pinnata S. W. off Holy I. 20 f. (H.).

\section{Fam. Dorididae.}

Archidoris [= Doris] tuberculata (Cuv.).-c.

A. flammea $(A$. and $H$.).-Dredged on $P$. opercularis in shall. w. Rothesay B. (A. \& H.): Lamlash (L.) : Cumbrae d. w. (N.).

Cadlina $[=$ Doris $]$ obvelata $($ Miill.$)$ [= repanda $]$-Rather local; Cumbrae once (R.): E. L. Tarbert r. (S.) : Ardmaleish Pt. Bute (B.).

Jorunna $[=$ Doris $]$ johnstoni $(A$. and $H$.).-Mod. c.

Platydoris [= Doris] testudinaria (Risso).-Lanılash B. 14-16 f. (A. \& H.) : nr. Cumbrae (R.).

Fam. Polyceridae.

Aegires punctilucens ( $\left.d^{\prime} O r b.\right)$. -Mod. c. : Ardrossan (A.) : Lamlash (A. L.) : L. Ranza (H.) : Davaar I. (F.) : Cumbrae (R.): E. L. Tarbert (S.).

Trjopa clavigera (Miill.). - c. in large rock pools.

Thecacera pennigera (Mont.). $-\mathrm{R}$. believed he took one at Cumbrae but it died in transmission (N.H.S. Glasg. Trans., vol. i., p. 205), since certified by Collingwood (Mrs. R.).

Palio [= Polycera] lessoni ( $d^{\prime} \mathrm{r}^{\prime}$. $)$.).-Off Holy I. S.W. 20 f. (H.).

var. ocellata, A. and H.-Lamlash: Saltcoats (L.): Cumbrae mod. c. (R.): E. L. Tarbert (S.).

Polycera quadrilineata (Mïll.).-c. at low tide and in lam. zone.

Acanthodoris [= Doris] pilosa (Müll.).-Mod c.

[Adalaria [= Doris] proxima (A. and H.).-Cumbrae (?) (R.).]

Lamellidoris $[=$ Doris $]$ aspera, $A$. and $H$.-Rather local: Ardrossan : Rothesay (A.): Cumbrae bet. t. m. and on $L$. saccharina (R. B.).

L. bilamellata $(L$.$) . - c.$

L. diaphana, $A$. and $H$.-Cumbrae (R.).

L. depressa, $A$. and H.-Two at Farland Pt. Cumbrae (B.).

L. inconspicua, A. and H.-Cumbrae at l. w., Farland Pt. (R.).

Goniodoris nodosa (Mont.).-Holy I. one l. w. (G. \& M.): Clachland Pt. (H.): Ardrossan (A.): Salteoats (L.): Cumbrae (R.) : E. coast of Bute (B.): E. L. Tarbert (S.). 
G. castanea, $A$. and H.-Under stones near l. w. m. Saltcoats (L.): off Whiting B. $25 \mathrm{f}$. (H.).

Idalina $[=$ Idalia] leachi (A. and H.).--Off Skate I., L. Fyne 105 f. (Hend.). I. (Idaliella) aspersa ( $A$. and $H$.).-Fintry B. (R.).

Ancula cristata ( $A l d$.).-Mod. c.; Lamlash 10 f. (L. H. Birm. N. H. Soc.): Cumbrae at l. w. (R.): Kyles (B.): Portincross (L.).

$$
\text { PULMONATA. }
$$

Fam. Otinidae.

Otina otis (Turt.).-Arran (N.): Clachland Pt. from washed weed : Cumbrae (R.).

\section{Fam. Auriculidae.}

Leuconia [= Melampus] bidentata (Mont.).-Mod. c. but local : Lamlash B. (N.): Bute (Sm.): Millport (Som. B. R.): Farland Pt. 20 or $30(l$.$) (B.): E.$ L. Tarbert (Steel. Som. S.).

Oncidiella [= Oncidium] celtica ( $C u v$.).-Shore U. L. Fyne (M.).

\section{Cephalopoda.}

\section{Fam. Loliginidae.}

Loligo forbesi, Steens.-Machrie B.: off Pirnmill : 7 mls. S. W. of Ailsa Craig (G.).

L. media (L.).-Maybole (Sm.): Lamlash B. (N.)

\section{Fam. Sepiidae.}

Sepia officinalis, L.-Ayr (Sm.): Ardeer to Irvine r., interual bone only (Sth.).

\section{Fam. Sepiolidae.}

Sepiola scandica, Steens. [= rondeleti].-Freq., esp. in trawlings (G.).

Rossia macrosoma (delle Ch.), [including R. oweni, Ball.].-L. Fyne: N. of Sanda 22 f.: Dunoon basin 30-40 f.: Brodick 28-90 f.: Kilbrennan Sd. 22-49 f.: L. Goil 35-40 f.: Gareloch (M.): Machrie B.: off Pirnmill: L. Gair to Minard : bet. Pladda and Ayr (G.), freq.

Fam. Octopodidae.

Polypus [=Octopus] vulgaris, Lmk.-Lamlash B. (Wyville Thomson): Arran (L.): in herring nets, Laggan B. (S.): scarce, one (d.) Toward : one Rothesay: one Millport (B.): Whiting B.: Ayr B.: very r. (G.). [N. and Hoy. consider Clyde records very doubtful.]

Moschites [=Eledone] cirrosa, Lmk.--Freq.: Lamlash (L.): King's Cross (H): Laggan B. (S.): off Shellbole, Cumbrae 12 f.: Rothesay (B.): Kilbreman Sd. 22 f. (Hoy.): U. L. Fyne 30 f.: Gareloch 8 f.: N. of Sanda 22 f.: L. Striven 15-25 f.: L. Goil, 10-40 f.: off L. Cumbrae 20 f.: Dunoon basin (M.): Carradale B.: Ailsa Craig: Ayr B.: bet. Pladda and Ayr (G.).

\section{BRACHIOPODA.}

\section{Fam. Craniidae.}

Crania anomala, Müll.-Mod. c. and widely dist.

Fam. Terebratulidae.

Macandrevia [= Terebratula] cranium, Müll.-Very r.; Tarbert, L. Fyne $30 \mathrm{f}$. (F.).

Terebratulina [=Terebratula] caput-serpentis (L.).-Gen. dist., esp. in L. Fyne, where it is $c$. 


\section{MARINE POLYZOA.}

By Alexander Gray, Marine Biological Station, Millport, Cumbrae.

Classificatios axd Nomenclature: Hincks, "Biitish Marine Polyzoa."

Abbreviations.

B. $=$ Jas. Bryce, LL.D., Arran and other Clyde Islands.

A. $\mathrm{G}=$ = Alexander Gray.

J. F. G. =James F. Gemmill, M.A., M.D., The University, Glasgow.

H. =Geo. C. Hyndman, "Dredging records from near Sanda I., off Mull of Kintyre," (Brit. Assoc. Rep., 1842, p. 70).

J. R. H. = Prof. J. R. Henderson, "A dredging trip to Arran," (Scott. Naturalist, vol. ii., N. S., 1885-86, p. 5).

W. A. H. = Prof. W. A. Herdman, F.R.S., "Invertebrate Fauna of Lamlash Bay" (Roy. Phys. Soc. Edin. Trans., vols. v. vi., 1880.

W. E. H. =W. E. Hoyle, M.A., F.R.S.E., "Deeper water Fauna of Clyde SeaArea," (Journ. Linn. Soc. (Zool.), vol. xx., p. 244, 1890).

T. H. $=$ Thomas Hincks.

H. P. = When placed after initials or name of an authority, implies that the record is to be found in Hincks' Brit. Mar. Polyzoa, 1880.

L. $=$ Rev. David Landsborough and his son, Arran, its Topography, Natural History, etc., 1875.

M. = MS. records of S. Y. "Medusa," published by Thos. Scott, F.L.S. in 15th Ann. Rep. Fishery Bd. for Scotland, pt. iii, p. 156, 1896.

A. M. N. $=$ Rev. Canon A. M. Norman, D.C.L., F.R.S.

R. $=$ The late David Robertson, LL.D., F.G.S.

M. B. S. = Marine Biological Station, Millport, Cumbrae.

W. T. $=$ William Thompson, Belfast.

C. $=$ common, r. =rare, litt.=littoral, l.w. m. =low water mark, t. m. = tide marks.

\section{GROUP A. ECTOPROCTA.}

Order Gymiolaemata.

Sub-order I. Cheilostomata.

\section{Fam. Aeteidae.}

Aetea anguina, Linn.-Ayrshire (L.), H. P.

A. recta, Hincks.-Rather r. ; Lamlash (T. H.), H. P. ; off M. B. S., Cumbrae $15 \mathrm{f}$. (A. G.).

A. truncata, Landsb.-Lamlash B. 10-20 f. (W. A. H.), H.P. 


\section{Fam. Eucratiidae.}

Eucratea chelata, Linn.-C. ; off Blind Man's Rock, Campbeltown ; Keppel pier (R.) ; Ayrshire (L.), H. P. ; Arran (L.) ; off Lion Rock, Cumbrae 10 f. (A. G.).

Gemellaria loricata, Linn.-C.; Cumbrae; L. Fyne 15 f. (R., M.); Lamlash B. (W. A. H.); Keppel, Cumbrae 12 f. (A. G.).

Scruparia clavata, Hincks._Lamlash B. (T. H.), H. P.

S. chelata, Linn.-Lamlash B. 8-13 f. (W. A. H.); not in Hincks, probably = preceding sp. (?).

\section{Fam. Cellulariidae.}

Scrupocellaria scruposa, Linn.-C. everywhere ; Cumbrae, litt. (R); Lamlash B. 5-25 f. (W. A. H.) ; off M. B. S., Cumbrae 15 f. (A. G.).

S. scrupea, Busk.-Cumbrae, on seaweeds (R.).

S. reptans, Linn.-C. everywhere on seaweeds ; Cumbrae (R.) ; Kilbrennan basin 64 f. (W. E. H.) ; off Lion Rock, Cumbrae 10 f. (A. G.).

Fam. Bicellariidae.

Bicellaria ciliata, Linn.-Rather r.; Ayrshire (L.), H. P.; Lamlash B. 14-20 f. (W. A. H).

Bugula avicularia, Linn.-R. ; Lamlash B. (W.A. H.); Kilbremnan Sd. 35 f. (J. F. G.), on Flustra secufrons.

B. turbinata, Alder.--Kilbrennan basin 30-50 f.(W.E. H); L. Fyne, E. Side 10-20 f.; Mull of Kintyre 30-50 f. (M.).

B. purpurotincta, Norman.-Kilbremnan Sd. 17-20 f. (R.).

B. Murrayana, Johnston.-Lamlash B. (T. H.), H.P.

Beania mirabilis, Johnston.-Lamlash (T. H.), H. P.

\section{Fam. Cellariidae.}

Cellaria fistulosa, Linn.-Lamlash 20 f. (W. A. H., L.), H. P. ; Kilbrennan basin 25-64 f. (W. E. H.) ; Cumbrae 10-15 f. (R., A. G.).

C. sinuosa, Hassall.-Mod. c.; Tan buoy, Cumbrae 10 f. (A. G.); Arran (L.).

C. Johnsoni, Busk.-Very r.; Kilbrennan S. 30 f. (A.G.); a few sniall branches on Cellepora ranulosa.

\section{Fam. Flustridae.}

Flustra foliacea, Linn.-Mull of Kintyre, 50 f.; Campbeltown (R.); Kilbrennan basin 25-49 f. (W.E. H.) ; Arran 14-21 f. (B., W. A.H.); Kilbrennan Sd. 35 f. (J. F. G.).

F. papyracea, Ell. and Sol.-Lamlash B. 3-10 f. (W. A. H.).

F. secufrons, Pallas.--Mod c.; Campbeltown (R.); 2 miles E. of Sanda I. 40 f. (H.), H.P.; Kilbrennan basin 65 f. (W.E. H.) ; Kilbrennan Sd. 35 f. (J. F. G.).

F. carbasea, Ell. and Sol.-Lamlash B. 3-10 f. (W. A. H.).

\section{Fam. Membraniporidae.}

Membranipora catenularia, Jameson.-Mod. c.; Mull of Kintyre $40 \mathrm{f}$. (H.), H. P. ; Cumbraes (R., A. G.) ; Kilbrennan basin 50 f. (W. E. H.); Arran 20 f. (W. A. H., D. L.).

M. pilosa, Linn.-C.; Cumbrae (R. \& A. G.) ; Kilbrennan basin 50 f.; Inchmarnock basin 104 f. (W. E. H.) ; U. L. Fyne 10-20 f. (M.).

M. membranacea, Linn.-C. everywhere on Laminaria, etc.

M. lineata, Linn.-Very c.; Cumbraes (R., A. G.); Arran (W. A. H., L.).

M. craticula, Alder.-K. ; Tan buoy, Cumbrae 10 f. (A. G.).

M. spinifera, Johnston.-R. ; Tan buoy, Cumbrae 10 f. (A.G.).

D. unicornis, Fleming.-R. ; off Farland Pt., Cumbrae 10 f. (A. G.).

M. Mumerilii, Audouin.-Rather r. ; off Farland Pt., Cumbrae 10 f. (A. G); Arran (T. H.), H. P. 
M. imbellis, Hincks.-R. ; off M. B. S., Cumbrae 15 f. (A. G.).

M. Flemingii, Busk.-Kilbrennan basin 65 f. (W. E. H.) ; Minard, U. L. Fyne 10-15 f. (M.); Cumbrae (R.); Arran (L.).

\section{Fam. Microporidae.}

Micropora coriacea, Esper:--Off Sanda I. (H.), H. P.

\section{Fam. Cribrilinidae.}

Cribrilina radiata, Moll.-Lamlash (W. A. H.).

C. punctata, Hassal.-C. ; Port Loy, Cumbrae, litt. (R., A. G.) ; Arran (IV. A. H.).

C. annulata, Fabi:-Mod. c. ; Ayrshire; Arran; Cumbrae (L.), H. P.; Cumbrae 3-5 f. (R.) ; Sanda I. (H.), H. P. ; Tan buoy 10 f. (A. G.).

C. figularis, Johnston.-R.; Cumbrae (R.), on Laminaria.

Membraniporella nitida, Johnston.-R. ; Ayrshire (L.), H.P. ; Port Loy, Cumbrae, litt. (A. G.).

\section{Fam. Microporellidae.}

Microporella ciliata, Pallas.--Mod. c.; Kilbrennan basin 50 f. (W. E. H.); Arran (D. L.) ; off Lion Rock, Cumbrae 10 f. (A. G.).

M. Malusii, Audouin.-C. ; Ayrshire (L.), H. P. ; off M. B. S., Cumbrae $15-20$ f. (A. G.).

M. impressa, Audouin.-Mod. c. ; Ayrshire (L.), H. P. ; Kilbremnan basin 50 f. (W. E. H.) ; Arran (L.) ; Minard, U. L. Fyne, 10-20 f. (M.); off Lion Rock, Cumbrae 10 f. (A. G.).

Chorizopora Brongniartii, Audouin.-Nod. c. ; Ayrshire (L.), H. P. ; Lamlash B. 3-8 f. (W. A. H.) ; Sanda I. (H.), H. P. ; off M. B. S., Cumbrae, 10-15 f. (A. G.).

\section{Fam. Myriozoidae.}

Schizoporella unicornis, Johnston.-Ayrshire (L.), H.P.; Cumbrae (R.) ; Kilbrennan basin 25 f. (W. E. H.); Minard, U. L. Fyne, E. side 10-30 f. (M.).

S. spinifera, Johnston.-Lamlash (T. H.), H. P.

S. simplex, Johnston.-Off Sauda I. 40 f. (H.), H.P.

S. linearis, Hassall.-Off M. B. S., Cumbrae, l.w.m. to 12 f. (A. G.).

S. sinuosa, Busk.-Off M. B. S., Cumbrae 12 f. (A. G.). var. armata. Off Lion Rock, Cumbrae 10 f. (A. G.).

S. cruenta, Norman.-F. of Clyde 90 f. (A. M. N.) ; off Farland Pt., Cumbrae (R.) ; off M. B.S., Cumbrae 12 f. (A. G.) ; Arran (B.); Minard, U. L. Fyne (M.).

S. hyalina, Linn.-E. of Castle, L. Cumbrae (R.); Lamlash B. 5-15 f. (W. A. H.) ; Tan buoy 10 f. (A. G).

Mastigophora Hyndmanni, Johnston.-Off Sanda I. ; S.E. of Mull of Kintyre 40 f. (H.), H. P.

Hippothoa divaricata, Lam.-Mod. c.; Lamlash B. 10-20 f. (W. A. H.) ; off M. B. S., Cumbrae 15 f. (A. G.).

var. carinata, Norman.-Kilbrennan basin 50 f. (W.E. H..)

H. flagellum, Manzoni.-Minard, U. L. Fyne 15 f. (M.).

\section{Fam. Escharidae.}

Lepralia Pallasiana, Moll.-C. ; Ayrshire (L.), H.P. ; Minard, U. L. Fyne (MI.) ; Arran (L.) ; Port Loy, Cumbrae, litt. (A. G.).

L. foliacea, Ell. and Sol.-Lamlash B. 3-20 f. (W. A. H.).

L. pertusa, Esper.-Not c. ; off Sanda I. (H.), H. P.; Arran (L.), H. P. ; off Keppel Point, Cumbrae 15 f. (A. G). 
Umbonella verrucosa, Esper.-R. ; off Lion Rock, Cumbrae 6 f. (A. G.)

Porella concinna, Busk.-Mod. c. ; off M. B. S., Cumbrae 15 f. (A. G.).

P. compressa, Sowerby.-Cumbrae (R.); Kilbreman basin 25 f. (W. E. H.) ; U. L. Fyne, E. Side 10-20 f. (M.).

P. laevis, Fleming. - Rothesay (R.).

Escharoides rosacea, Busk.-Very c. ; L. Fyne (A. M. N.), H. P. ; Minard, L. Fyne (M.); off M. B. S., Cumbrae 15 f. (A.G.).

Smittia Landsborovii, Johnston.-Mod. c. ; Arran (L.); Lamlash B. (W. A. H.) ; off M. B.S., Cumbrae 15 f. (A. G.).

S. reticulata, J. Macgillivray.-L. Fyne (Lady Emma Campbell), H.P. ; Kilbremnan basin 25 f. (W. E. H.) ; U. L. Fyne (M.).

S. trispinosa, Johnston.-Cumbrae (R.); Lamlash B, 15-25 f. (W. A. H.).

S. producta, (Packard) Hincks.-Nr. Lamlash; new to Britain; vide A.M.N. (Ann. and Mag. Nat. Hist., Ser. 6., vol. iii., p. 430, pl. xxi., fig. 2).

Mucronella Peachii, Johnston.-Veryc.; Kilbrennan basin 25-64 f.(W.E.H.); Lamlash B. 10-20 f. (W. A. H.); off M. B. S., Cumbrae 15 f. (A.G.).

M. ventricosa, Hassall.-Mod. c. ; Sanda I. (H.), H. P. ; Kilbrennan basin 50 f. (W. E. H.) ; Lamlash B. (W.A.H.); off M. B.S., Cumbrae 12 f. (A. G).

M. variolosa, Johnston.-Sanda I. 40 f. (H.), H. P.

M. coccinea, Hincks.-Fairly c.; Ayrshire (L.), H.P.; Lamlash B. 10-20 f. (W. A.H).

var. mamillata. Off Lion Rock, Cumbrae 15 f. (A. G.) ; fairly c.

Palmicellaria elegans, Alder.-L. Fyne (A. M. N.), H. P.

P. Skenei, Ell. and Sol.-Lamlash B. 5-15 f. (W. A. H.).

\section{Fam. Celleporidae.}

Cellepora pumicosa, Linn.-Cumbrae (R., A. G.); Kilbrennan basin $60 \mathrm{f}$. (W. E. H.) ; Arran (B., L., W. A. H.), Minard, U. L. Fyne, E. Side, 15-20 f. (H.).

C. ramulosa, Limn.-C. on fishermen's lines; Campbeltown (R.); off Sanda I. 40 f. (H.), H. P. ; Kilbrennan basin 25-64 f. (W. E. H.); Arran (B.) ; U. L. Fyne, E. Side 15-20 f. (M.) ; Kilbremman Sd. 30 f. (A. G.)

C. avicularis, Hincks.-Kilbrennan basin 50-65 f. (W. E. H.) ; U. L. Fyne, E. Side 15-20 f. (M.).

C. tubigera, Busk.-Lamlash B. (G. West.), H. P.

C. armata, Hincks.-R. ; off M. B. S., Cumbrae 10 f. (A. G).

C. costazii, Audouin.-Mod. c. ; Pt. of Ayr (T.H.), H.P.; Ayrshire, on Patella cerulea (L.), H.P. ; off Lion rock, Cumbrae 8 f. (A.G.).

\section{Sub-Order II. Cyclostomata.}

\section{Fam. Crisiidae.}

Crisia cornuta, Lınn.-Lamlash B. 5-8 f. (W. A. H.) ; Arran (D. L.). var. geniculata. Tan buoy, 10 f. (A. G.)

C. eburnia, Linn.-Ayrshire (R. \& W.T.), H. P.; Lamlash B. 15-55 f. (W. A.H.) ; Minard, U. L. Fyne, E. side 15-20 f. (M.); off Lion rock, Cumbrae 15 f. (A. G.).

var. aculeata. 50 f. ; Kilbrennan basin 25 f. (W. E. H.) var. producta. 25 f.; Kilbrennan basin (W. E. H.). var. Geniculata, M. Edw.-Off Lion rock, Cumbrae 15 f. (A. G.).

C. denticulata, Lamk.-L. Goil (R.); off Keppel rock, Cumbrae (R.); Kilbrennan basin 64 f. (W.E. H.); Minard, U. L. Fyne, E side 15-20 f. (M.) ; Lamlash B. 2-20 f. (W. A. H.). 


\section{Fam. Tubuliporidae.}

Sotmatopora granulata, M.-Edwards.-Kilbrennan basin 65 f. (W. E. H.); Minard, U. L. Fyne (M.) ; off M. B. S., Cumbrae 15 f. (A. G.).

S. major, Johnston.--Sanda I. (W.T.) H.P.; Arran (J.R.H.) ; S.E. of Holy I. 20-25 f. (W. A. H.) ; off Farland Pt., Cumbrae 15 f. (A. G.).

S. dilatans, Johnston.-Off Sanda I. (H.) H.P. ; Arran (J. R. H.).

S. expansa, Hincks.-R. ; off Lion rock, Cumbrae 12 f. (A. G.).

S. incrassata, Smitt.-Off M. B. S., Cumbrae 15 f. (A. G.).

Tubulipora flabellaris, Fabr.-Off Lion rock, Cumbrae 15 f. (A. G.).

T. fimbria, Lamk.--Lamlash B. 5-15 f. (W. A. H.).

Idmonea serpens, Linn.-Very c. ; Cumbrae (R.); Kilbrennan basin 65 f. (W.E.H.) ; Lamlash B. 3-8 f. (W.A.H.); off Lion rock, Cumbrae 12 f. (A. G.).

Diastopora patina, Lamk. - Lamlash B. 4-20 f. (W. A. H.); Arran (J. R. H. \& L.).

D. obelia, .Johnston.-Cumbrae (R.) ; Kilbrennan basin 50-64 f. (W.E. H.); U. L. Fyne, E. side 15-20 f. (M.).

D. suborbicularis, Hincks.--R.; off M. B. S., Cumbrae 12 f. (A. G.).

\section{Fam. Lichenoporidae.}

Lichenopora hispida, Fleming.-Rothesay B. ('T. H.), H.P.; Cumbrae (R., A. G.) ; Kilbrennan basin 25-64 f. (W. E. H.) ; Lamlash B. 10-20 f. (W. A. H., L.) ; Minard, U. L. Fyne 15-20 f. (M.).

var. meandrina, Peach.-Kilbrennan basin 65 f. (W. E. H.).

L. verrucaria, Fabr. --Arran (Busk.), H. P.; Kilbrennan basin 50 f. (W.E. H.); off M. B. S. ; Tan buoy, Cumbrae 10-12 f. (A. G.).

\section{Sub-Order III. Ctenostomata.}

Fam. Alcyonidae.

Alcyonidium gelatinosum, Linn.-Cumbrae (R., A. G.); c. from l. w. m. to mod. depths ; v. c. off Keppel and Farland Pts. 8-15 f.

A. hirsutum, Fleming.-Lamlash B. 12-25 f. (IV. A. H.).

\section{Fam. Flustrellidae.}

Flustrella hispida, Fabr.-C. everywhere bet. t. m. on Fucus serratus, etc. ; Lamlash B. 10 f. (W. A. H.) ; Cumbrae (R., A. G.).

\section{Fam. Vesiculariidae.}

Vesicularia spinosa, Linn.-Kilbrennan basin 50 f. (W. E. H.) ; U. L. Fyne, E. side 15 f. (M.).

Bowerbankia imbricata, Adams.-Lamlash B. 14-21 f. (W. A. H.).

\section{Fam. Buskiidae.}

Buskia nitens, Alder.--Lamlash B., on Zoophytes (W. A. H.).

\section{Fam. Cylindroeciidae.}

Cylindroecium dilatatum, Hincks.-Kilbrennan basin 65 f. (W. E. H.).

Fam. Valkeriidae.

Valkeria uva, Limn.-var. cuscuta. Ayrshire (L.), H.P. 


\section{GROUP B. ENTOPROCTA.}

\section{Fam. Pedicellinidae.}

Pedicellina cernua, Pallas.-Lamlash B. 2-25 f. (W. A. H.) ; off Keppel Pt., Cumbrae 12 f., on Gemellaria loricata; Old Castle B., L. Cumbrae 15 f. (A. G.).

P. gracilis, Sars.-Lamlash (T. H.), H. P.

\section{FRESH-WATER POLYZOA. \\ By M. Laurie. \\ Order Phylactolaemata.}

Cristatella mucedo, Cuv.-Not unc. (T. Scott).

Lophopus crystallinus (Pall.).-Bute; Kintyre, etc. (T. Scott).

Alcyonella fungosa (Pall.).-St. Germain's L. Maryhill (Nat. Hist. Soc. Glasgow, vol. 2). 


\section{INSECTA.}

\section{Order HyMenoptera.}

\section{Sub-Order Terebrantia.}

\section{Fam. Tenthredinidae.}

By And. Adie Dalglish, F.E.S., 21 Princes St., Pollokshields.

Authority Followed : Pastor F. W. Konow, "Tenthredinidae Europae," Deut. Ent. Zeitschr., 1890, with a few subsequent alterations.

Almost all the specimens have been examined by the Rev. F. D. Morice, F.E.S., or Pastor Konow.

Authorities for Localities Abereviated : (A.F.), Anderson Fergusson; (T. G.), Thomas Grant ; (R. H.), Robert Henderson ; (J. M.), John R. Malloch ; (G. W. O.), the late Geo. W. Ord.

The records only extend over the last two years.

$\mathrm{m} .=$ male $; \mathrm{f} .=$ female $; \mathrm{c}_{.}=$common ; $\mathrm{r} .=$ rare.

\section{Lydini.}

Lyda stellata, Christ.-One f. Cadder Wilderness, June, 1899 (T. G.).

Pamphilius silvaticus, $L$.-One f. Luss $4 / 6 / 00$.

P. balteatus, Fall.-One f. Bonhill, June 1900 (J. M.).

\section{Cephini.}

Cephus pallipes, $K l g .-O n e$ m. nr. Cambuslang 29/6/99.

\section{Siricini.}

Sirex juvencus, L.-Several taken lately, but all doubtlessly importations.

S. gigas, L.-Imported specimens freq. all over district. Seems permanently established in wds. of Bute, Arran, and L. Riddon (J. Ballantyne, Trans. G. N. H. S., V., N.S., 187-9) mm. scarce, ff. very c.

\section{Cimbicini.}

Trichiosoma lucorum, L.-Larvae c., birch, July and Aug., one m. bred Mch. 1899 from Giffinock.

T. tibialis, Ste.-Larvae c., hawthorn, nr. Glasgow, etc., July and Aug.

Two mm. bred Apl. 1900, Cadder (T. G.), one m. Crookston May 1899.

Abia sericea, L.-Freq.; m. Eaglesham 12/6/99 (Mr. Ross), fff. Gl. Falloch 6/99 ; Bonhill 6/7/00 ; King's Cross, Arran 7/8/00.

\section{Argini.}

Arge cyanella, Klg.-One m. Barr, Ayrshire 6/00 (A. F.).

A. ustulata, L.-One f. Cadder Wilderness 10/6/00.

\section{Lophyrini.}

Lophyrus pini, L.-One f. Blairskaith Moor 29/6/99 (G. W. O.). 


\section{Tenthredinini.}

Trichiocampus viminalis, Fall.-One f. Inveruglas 12/9/96.

T. ulmi, L.-One f. West Kilbride 29/8/99.

Priophorus Padi, $L$.-f. Bonhill (J.M.); f. Giffnock 4/6/99; f. Crookston 6/6/99.

Dineura nigricans, Christ.-m. Bonhill 15/6/00 (J.M.); f. Pirnmill, Arran $6 / 00$ (A. F.) ; f. Irvine 26/5/00.

D. testaceipes, $K l g$. - One f. Brother L., Renfrewshire 16/6/00.

Cryptocampus medullarius, Htg.--Several ff. Lamington 24/6/99.

C. saliceti, Fall.-f. Luss 4/6/00; f. Cambuslang 22/5/00.

Pontania leucosticta, Htg.--m. Luss, 4/6/00; f. Crookston 28/6/00; m. Johnstone $14 / 6 / 00$; f. Dundonald 14/7/00.

P. nigrolineata, Cam.-One f. Lamington 24/6/99.

P. pedunculi, Htg.-f. Cambuslang 22/5/00.

P. salicis, Christ. -m. Bonhill 7/5/00 (J. M.).

P. vesicator, Bremi- -f. Brother Loch, 16/6/00.

Pteronus miliaris, Pz.-f. Cadder Wilderness 24/8/99.

P. microcercus, Thms.-f. Crookston $7 / 6 / 99$; f. Irvine $26 / 5 / 00$.

P. oligospilus, Zadd.-f. Cambuslang 29/6/00.

P, salicivorus, Cam.-f. Carmyle 13/6/99 (G. W. O.).

P. myosotidis, Fab.-C., Lamington 24/6/99; Irvine 26/5/00; Barr 15/7/99. Sexes about equal.

P. ribesii, Scop.-Very c. everywhere, destructive to red currant and gooseberry bushes.

Amauronematus viduatus, Zett.-One m. Irvine Moor 21/4/00.

Croesus septentrionalis, $L$.-One f. Milngavie 11/8/99; ff. Irvine 1/9/00.

Holcocneme lucida, $P z$.-One m. Bonhill 1899 (J. M.).

Nematus acuminatus, Thms.-One f. Luss 4/6/00.

Pachynematus brachyotus, Först. - m. Brother L. 16/6/00; m. Possil 8/99; f. Ravenscraig $17 / 6 / 99$; f. Dundonald 14/7/00.

P. capreae, $P z$. - Abund. every where from May till Aug. mm. not so c. as ff.

P. rumicis, Fall.-f. Cambuslang 24/6/99.

P. einersbergensis, Htg.-f. Bowling 6/6/99 ; f. Crookston 7/7/99; f. Irvine $8 / 7 / 99$.

P. xanthocarpus, Htg.-f. Giffnock 13/6/99; m. Crookston 29/5/99; m. W. Kilbride 19/8/99; m. Dundonald 14/7/00.

P. clitellatus, Lep.-One f. King's Cross, Arran 9/8/00.

P. vagus, Fab.-Pirnmill, Arran 6/00 (A.F.); Barr 14/7/99; Johnstone $14 / 6 / 00$; only ff.

P. obductus, Htg.-Two ff. Giffnock 4/6/99. var. conductus, Ruthe.-f. Johnstone $14 / 6 / 00$; f. Irvine 26/5/00.

P. albipennis, Htg.- One f. Crookston 9/6/99.

Lygaeonematus laricis, Htg.-One f. Bonhill 6/7/00 (J. M.).

L. moestus, Zadd.-One f. Bishopton 4/5/00.

Pristiphora pallidiventris, Fall.-f. Barr 6/00 (A. F.); ff. Milngavie 11/6/99; f. King's Cross $7 / 8 / 00$.

P. fulvipes, Fall.-One f. Irvine Moor 12/8/99.

P. crassicornis, Htg.-f. Crookston 1/6/99; m. Johnstone 14/6/99.

P. Wustnei, de Stein.-f. Irvine 26/5/00 ; f. Luss $4 / 6 / 00$.

Eriocampoides aethiops, Fab.-One f. Luss $4 / 6 / 00$.

Hoplocampa crataegi, Klg.-Not c. by sweeping hawthorn. f. Pirnmill $6 / 00$ (A. F.) ; m. Crookston 7/6/99; f. Arrochar 10/6/99.

Tomostethus fuliginosus, Schrnk.--Marshy ground; one f. Barr, Ayrshire $16 / 7 / 99$.

T. fuscipennis, Fall.-C. marshy ground; Milngavie (G.W.O.); Crookston 7/6/99; Bishopton 3/7/99; A rrochar 10/6/99; Irvine 26/5/00; Colintraive 24/5/00 ; Ayr 19/5/00. Only ff. 
Blennocampa subcana, Zadd.-One f. Milngavie 21/5/99.

B. tenuicornis, $K l g$., var. humeralis, Voll.-f. Pirmmill 6/00 (A. F.); f. Busby 30/6/00 ; m. Crookston 9/6/99.

Scolioneura betuleti, $K l g$.-One f. Bishopton 3/7/99.

Monophadnus geniculatus, Htg.--Two ff. Bonhill 6/00 (J. M.) ; three mm. Crookston 29/6/99.

M. albipes, Gmel.-f. Bonhill 6/00 (J. M.) ; f. Milngavie 6/99 (G. W. O.).

Kaliosysphinga ulmi, Sundev.-Two ff. Cambuslang 22/5/00; swept in marshy ground.

K. Dohrni, Tischb.-Marshy ground, one f. Irvine 14/7/00.

Athalia lineolata, Lep.-A bund. all over district, June to Aug. Sexes about equal.

A. lugens, Klg.-Not c. ; m. Strathblane $17 / 7 / 99$ (G. W. O.) ; m. and f. Barr Barr 14/7/99; f. Dundonald 14/7/00.

Selandria flavens, $K l g$. -Not unc. ; m. and f. Possil Marsh 6/99 (G. W. O.) ; $\mathrm{m}$. Ravenscraig $17 / 6 / 99$; m. and two ff. Brother L. 16/6/00.

S. serva, Fab.-Very c. marshy ground all over district June and July Sexes about equal.

S. Furstenbergensis, $K n w$.-One f. Arrochar 10/6/99.

S. stramineipes, Klg.-Not unc. ; Pirnmill (A.F.); Arrochar 10/6/99 ; Luss $4 / 6 / 00$. Only ff.

S. morio, Fab.-Not unc. ; Strathblane 17/7/99 (G. W. O.); Lamington 24/6/99 ; Luss 4/6/00 ; Barr 14/7/99. Only ff.

Stromboceros delicatulus, Fall.-Not c.; Finnich Glen (R. H.); Bonhill (J. M.) ; Pirnmill June 1900 (A. F.) ; Cadder 24/8/99 and 10/6/00. Only ff.

Strongylogaster cingulatus, Fab.-Freq.; Bonhill (J. M.) ; Ailsa Craig 24/5/00 (R. H.) ; Luss 4/6/00. Only ff.

Poecilosoma liturata, Gmel.-R.; f. Eaglesham 12/6/99(G. W.O.); f. Pirnmill $6 / 00$ (A. F.) ; f. Milngavie 6/6/99.

P. longicornis, Thms.-One f. Bonhill 6/00 (J.M.).

P. tridens, Knw.-One f. Giffnock $8 / 6 / 00$.

P. excisa, Thms.-One m. Luss 4/6/00.

Emphytus cinctus, L.-f. Crookston $9 / 6 / 99$; m. King's Cross 8/8/00.

E. serotinus, $K l g .-$ m. Bonhill $17 / 10 / 00$ (J. M.) ; two ff. Johnstone 21/10/00.

E. grossulariae, $K l g$.- One f. bred from cocoon obtained under bark, Strathaven $14 / 4 / 00$.

Taxonus glabratus, Fall.-C. ; Bonhill (J.M.) ; Pirnmill (A. F.) ; Crookston 9/6/99; 29/5/00 ; Brother L. 19/6/00. Sexes about equal.

T. equiseti, Fall.-Not unc. ; m. Bonhill (J.M.) ; f. Eaglesham 12/6/99 (G. W. O.) ; m. and ff. Crookston 9/6/99.

Dolerus pratensis, Full.-C. and widely dist. May till Aug. Sexes about equal.

D. aericeps, Thms.-m. Barr 6/00 (A. F.); m. Giffnock 12/7/00; nm. Irvine $14 / 7 / 00$; f. King's Cross 13/8/00.

D. palustris, Klg.-Marshy ground ; Bishops L. 5/99 (G. W. O.) ; Cambuslang 22/5/00; Crookston 28/5/00. Sexes about equal.

D. madidus, $K l g$. - - m. Bonhill (J. M.) ; f. Bishopton $3 / 7 / 99$; m. Milngavie 26/5/99.

D. Thomsoni, Knw.-One f. Bowling 6/6/99 ; m. and f. same loc. 14/5/00, marshy ground.

D. dubius, Klg.-One f. Lunderston (R. H.); two mm. and f. Irvine 26/5/00, marshy ground.

D. gonager, Fab.-Widely dist. and abund. May and June. mnı. not so c. as ff.

D. picipes Klg.-Freq. ; Crookston 29/5/99; Milngavie 31/5/99; Bowling $6 / 6 / 99$. Sexes about equal. 
D. nigratus, Miill.-Not unc. ; Cambuslang 22/5/00 ; Giffnock 8/5/00; Bishopton 4/5/00 ; Irvine 26/5/00. Sexes about equal.

D. fumosus, Zadd.-Two mm. Bonhill 24/4/00 and 5/5/00 (J. M.).

D. rugosulus, $v$. Dalla Torre.-f. Luss 4/6/00; m. Irvine 21/4/00.

D. coruscans, Knv.-R.; Crookston 14/5/00 ; Irvine 21/4/00 ; Ayr 19/5/00. two mm. and one f.

D. haematodes, Schrnk.-Not unc. ; Possil 15/6/99; Giffnock 8/6/00 ; Cambuslang 225/00; Bowling 14/5/00; Bishopton 4/5/00; Ayr 19/5/00. Sexes about equal.

D. aeneus, Htg.--Aluund. everywhere May till end of July. mm. commoner than ff.

Loderus palmatus, $K l g .-$ One f. Cambuslang $296 / 99$.

Rhogogastera viridis, L.-C. wds.; Bonhill (J. M.) ; Glenfalloch (G. W. O.) ; Pirnmill and Barr 6/00 (A. F.) ; Glennallan 9/7/98; Johnstone 14/6/00. Sexes about equal.

R. punctulata, Klg.-C.; Lamington 24/6/00; Cambuslang 29/6/00; one m. several ff.

R. fulvipes, Scop.-Two mm., one f. Crookston 7/6/99 and 28/5/00.

R. aucupariae, Klg.-f. Bonhill 6/00 (J. M.) ; f. Crookston 29/6/99.

Tenthredopsis litterata, Geoff.-m. Bonhill 6/00 (J. M.); f. Blairskaith Moor 6:99 (G. W. O.); f. Pirmill (A. F.); mm. and f. Cambuslang 29/6/99. var. cerasi, L.-f. Blairskaith Moor 6/99 (G. W. O.).

T. tiliae, $F a b$.-Railway embankments, etc., c.; Lamington 24/6/99 ; Cambuslang 22/5/00 ; Crookston 13/6/99 ; Dundonald 14/7/00. Only ff. var. inornata, Knw.-f. Barr 6/00 (A. F.) ; ff. Dundonald 14/7/00.

T. dorsalis, Lep.-m. Cadder 10/6/00 ; m. Luss 4/6/00 ; tf. Gl. Falloch 6/99.

T. campestris, L.-Abund. wds. June, widely dist. Sexes about equal.

T. spreta, Lep.-Cadder 10/6/00 ; Irvine 26/5/00. One m. and two ff.

T. gibberosa, Kn w. - Cambuslang 14/5/00; Dundonald 14/7/00. Three ff.

T. fenestrata, Kn $u$.-Barr 6/00 (A. F.) ; Cadder 10/6/00 ; Newton Mearns, $14 / 6 / 00$. Three mm. and three $\mathrm{ff}$.

T. Coqueberti, Klg.-Not c.; Milngavie 26/6/00; Crookston 7/7/99. Only $\mathrm{mm}$.

T. tristis, Ste? Cam.-Not unc.; Lamington 24/699 ; Ravenscraig 17/6/99 ; Crookston 13/6/99. Two mm. and several tr.

T. Thornleyi, Knw.-Not unc.; Milngavie 26/5/99; Cambuslang 22/5/00. Two mm., five ff.

Perineura rubi, Pz.-Very 1. ; One n. Cadder 10/6/00.

Pachyprotasis rapae, L.-Abund. everywhere, June and July. Sexes about equal.

Allantus temulus, Scop.-One f. Bonhill 16/6/00 (J. M.).

A. scrophulariae, L.-One m. Bouhill, June 1900 (J. M.).

A. arcuatus, Forst.-A bund. every where, May till Aug. mm. not so c. as ff.

Tenthredo ferruginea, Schrnk.-One m. Shewalton $7 / 7 / 00$ (A.F.); one f. Barr 14/7/99.

T. balteata, Klg.-m. Bonhill $7 / 00$ (J. M.) ; f. Dundonald 14/7/00.

T. velox, Fab.-Not c.; f. Strathblane 699 (G. W. O.); m. Lamington 24/6/99 ; m. Irvine 30/6/00 ; m. Dundonald 16/7/00; m. Barr 14/7/99.

T. atra, L.-One m. Cadder 10/6/00.

var. dispar, Klg.-f. Blairskaith Moor 6/99 (G. W. O.); f. Arrochar $10 / 6 / 99$; f. Barr 14/7/99.

T. livida, L.-C.; m. Pirnmill ; f. Barr 6/00 (A.F.) ; m. Blairskaith Moor $6 / 99$ (G. W. O.) ; ff. Cambuslang 29/6/99.

T. mesomelaena, L.-Abund. and widely dist., June and July. Sexes about equal.

T. olivacea, Htg.-C. ; ff. Barr 6/00 (A. F.) ; m. Bonhill (J. M.) ; m. Strathblane 6/99 (G. W. O.) ; f. Fairlie, 26/8/00 ; f. King's Cross 9/8/00. 


\section{Sub-Order Aculeata.}

By J. Russell Malloch, Bonhill.

\section{ARRANGEMENT.}

Hymenoptera Aculeata, Edward Saunders, 1895.

Mr. Saunders has kindly identified many species in the list. Records have also been received from Messrs. A. Adie Dalglish (A.A.D.), Wm. Evans, Jn. E. Murphy (J.E. M.), Anderson Fergusson, and the late G. W. Ord.

\section{HeTEROGYNa.}

\section{Fam. Formicidae.}

Formica rufa, Linn.-Not unc. ; pine woods ; Tignabruaich ; Rowardennan (J. R. II.); Colintraive, etc. (A. A. D.).

F. fusca, Latr:--Very c. and gen. dist. under stones, etc. ; sometimes nesting under same stoue as M. rubra.

Lasius flavus, De Geer.-Not so c. as preceding ; under stones, etc. ; Gallangad, Campsie (J.R. M.) ; Irvine Moor, Kirkintilloch, Bishopton (A.A.D.).

L. niger, Linn.-Very c.; in the ground and under stones, etc.; well dist. throughout district.

Prenolepis vividula.-Introduced. Queen's Park hot-houses and Botanic Gardens, Glasgow (A.A.D.) (J. R. M.).

\section{Fam. Myrmicidae.}

Myrmica rubra, Linn.--Everywhere c.

race sulcinodis, $N y l$.-Irvine Moor (A. A. D.).

race ruginodis, 1 y $y$. - Very c.

race laevinodis, Iyl.-Barr, Ayrshire (A. A. D.).

race scabrinodis, I'yl.-Gourock Hills (A.A.D.); Bonhill (J.R. M.).

Stenamma westwoodi, Westw.-R., Misty Law, Renfrewshire (Taylor).

Leptothorax acervorum, Fab.-Not unc., under stones and in rotten wood. Bonhill; Whistlefield; Gallangad (J.R.MI.); Irvine Moor; Bishopton (A.A.D.).

\section{Fossores.}

\section{Fam. Pompilidae.}

\section{Pompilus plumbeus, Fabr:-Irvine Moor c. (A. A. D.).}

P. niger, F'ab.-Not unc.; Bonhill; Levenside Moor (J.R. M.) ; one Irvine Moor (A.A.D.).

P. spissus, Schiödte.-Dundonald (A. A.D.).

P. unguicularis, Thoms.--King's Cross, Arran (A. A. D.).

Salius fuscus, Linn.-One taken and others seen Arrochar 25/5/99 (J. R. M.).

S. pusillus, Schiödte.-Two Jamestown (J. R. M.). 
S. parvulus, Dahlb.-Not unc. Levenside Moor. Nesting in paths (J.R.M.). Ceropales maculata, Fabr.--Scarce; Bonhill (J.R. M.); c. ; Irvine Moor; King's Cross (A. A. D.).

\section{Fam. Sphegida.}

Pemphredon Shuckardi, Moraw.-Scarce ; Bonhill (J. R. M.); Cambuslang ; Irvine (A. A. D.).

Mimesa bicolor, Fab.-Abund. at Irvine (A. A. D.).

Gorytes mystaceus, Linn.-Scarce; Bonhill (J.R. M.); Strathblane (A.A.D.). Mellinus arvensis, Linn.-C. ; Bonhill (J.R.M.); Irvine ; King's Cross (A. A. D.).

Oxybelus uniglumis, Linn.-Not unc. ; Irvine Moor (A. A. D.).

O. mandibularis, Dahlb.-Scarce at Irvine (A. A. D.).

Crabro tibialis, Fabr.-R. ; Dundonald (A. A. D.).

C. clavipes, Linn.-Irvine (A. A. D.).

C. leucostomus, Linn.--Nesting in an old fencepost at Balloch (J. R. M.).

C. palmipes, Linn.-The most abund. species of the genus. Gen. dist.

C. varius, Lep.-Levenside Moor (J. R. M.); Irvine (A. A. D.); c.

C. elongatulus, V. de L.-Bonhill (J.R.M.). Nests in walls. Strathblane (G. W. O.); Luss (A. A. D.).

C. dimidiatus, Fab.-Scarce; Blairskaith Moor (G.W. O.); Bonhill (J. R. M.); Irvine (A. A. D.).

C. chrysostomus, Lep.-C., Irvine (A. A. D.).

C. cribrarius, Linn.-Very c.; Levenside Moor (J.R.M.) ; Irvine (A. A. D.).

C. peltarius, Schr.-Irvine Moor (A. A. D.).

\section{Fam. Vespidae.}

Vespa vulgaris, Linn.-Very c. everywhere. A male with colouring of Germanica but genital armature of Vulgaris at Bonhill (J. R. M.)

V. germanica, Fab.-C. at Bonhill (J. R. M.); Irvine (A. A. D.).

V. rufa, Linn.-Barr (A. F.); Irvine etc. (A. A. D.); Bonhill c. (J. R. M.).

V. austriaca, Panz.-R.; Bonhill (J. R. M.); Dargavel (J. E. M.); Irvine (A. A. D.).

V. sylvestris, Scop.-Very c. in the district.

V. norvegica, Fab.-Bonhill (J. R. M.); Milngavie ; Irvine (A. A. D.).

\section{Fam. Eumenidae.}

Odynerus spinipes, Linn.-Irvine (A. A. D.); Barr (A. F.).

O. parietum, Linn.--Bonhill (J. R. M.); Cambuslang (A. A. D.).

O. pictus, Curt.-Glenmallon (A. A. D.); L. Long (W. Evans.).

O. trimarginatus, Zutt.-Bonhill (J.R. M.); Fairlie; Barr; Dundonald (A. A.D.).

0. paretinus, Linn.-Ardpeaton, L. Long (W. Evans).

\section{Antrophila.}

\section{Fam. Colletidae.}

Colletes succincta, Linn.-C. : Bonhill (J. R. M.) ; Campbeltown (Smith.); Irvine (A. A. D.).

C. montanus, Mortz.-C. Irvine Moor (A.A.D.). Taken for the first time in Britain by Mr. Dalglish 8/7/99.

Prosopis brevicornis, Nyl.-Irvine (A. A. D.).

\section{Fam. Andrenidae.}

Sphecodes subquadratus, Smith.-Very c. ; Bonhill ; Jamestown (J. R. M.).

S. Pilifrons, Thoms.-Tollcross (P. Cameron), Trans. Glas. Soc. Field Nat. 1872-73.

S. hyalinatus, Schm.-Bonhill ; Jamestown (J. R. M.).

S. variegatus, $v$. Hag.- Scarce Levenside Moor (J. R. M.). 
S. dimidiatus, v. Hag.-Scarce Levenside Moor (J. R. M.).

S. affinis, v. Hag.-Not unc. ; Bonhill (J. R. M.) ; Irvine (A. A. D.).

Halictus rubicundus, Chr.--Very c. and gen. dist.

H. albipes, Kirb.-C. throughout the district.

H. cylindricus, Fab.-Very c. on flowers of ragwort. Gen. dist.

H. subfasciatus, $N_{y} l$.-Bonhill (J.R.M.) ; Luss ; Dundonald ; W. Kilbride (A. A. D.).

H. villosulus, Kirb.-R., King's Cross, Arran (A. A. D.).

H. tumulorum, Linn.-C., King's Cross (A. A. D.).

H. smeathmanellus, Kirb.-Not unc. ; Bonhill (J.R.M. ; A.A.D.); Cardross (J. R. M.).

H. morio, Fab.-Not c. Bonhill (J. R. M.).

H. leucopus, Kirb.-Bonhill (J. R. M.) ; King's Cross (A. A. D.).

Andrena albicans, Kirb.-The commonest species of the genus. Occurring at sallow bloom in spring. Gen. dist.

A. rosae, Panz. race trimmerana, Kirb.-Gen. dist. and c.

A. cineraria, Linn.-Pirnmill, Arran (A. F.); Strathblane (G. W. Ord).

A. clarkella, Kirb.-Arrochar; Bonhill (J.R.M.); Brodick (W. Evans); Giffnock; Irvine (A. A. D.).

A. gwynana, Kirb.-Spring and summer broods both occur. Bonhill (J. R. M.) ; Kings Cross ; Irvine (A. A. D.).

A. fucata, Smith.--C. ; Bonhill (J. R. M.); Barr ; Ayrshire ; Cadder (A. A. D.); Garelochhead (J. E. M.).

A. fuscipes, Kirby.-Not unc. ; Levenside Moor (J.R.M.); Holy I. (A.A.D.); visits flowers of common heath.

A. cetii, Sch.-R., King's Cross, Arran (A. A. D.).

A. albicrus, Kirb.-Bonhill (J. R. M.); c. Irvine Moor (A. A. D.).

A. coitana, Kirb.-C. ; Bonhill (J. R. M.); King's Cross (A. A. D.).

A. analis, Panz.-C. ; Levenside Moor, burrows in paths (J. R. M.) ; Arrochar (A. A. D.); Glenfalloch (G. W. O.).

A. minutula, Kirb.-C. ; Arrochar ; Bonhill ; Gallangad (J.R. M.) ; Glenfalloch (G. W. O.) ; Johnstone ; Luss (A. A. D.).

A. nana, Kirb.-King's Cross, Arran (A. A. D.); not unc. at Bonhill (J. R. M.).

A. wilkella, Kirb.-Arrochar (A. A. D.) ; very c. Bonhill; Jamestown (J. R. M.).

Nomada obtusifrons, Tyl.-Not unc. ; Bonhill (J.R.M.) ; King's Cross, Arran (A. A. D.); near Glasgow (J. E. M.).

N. solidaginis, Panz.-Scarce, Irvine (A. A. D.).

N. alternata, Kirby.-C. ; Arrochar ; Bonhill ; Jamestown, etc. (J.R. M.) ; Giffnock (A. A. D.); Kilbowie (R. Henderson).

N. ruficornis, Linn.-Lamington (A. A. D.); Barr (A. F.); Bonhill (J.R. M.).

N. bifida, Thoms.-C. ; Arrochar ; Bonhill (J. R. M.).

N. borealis, Nett.-Scarce, Bonhill (J.R. M.).

N. lateralis, Panz.--One recorded by P. Cameron, Trans. Nat. Hist. Soc. Glas., vol. ii., 1869-74, as N. Xanthosticta.

N. ochrostoma, Kirby.-Barr, Ayrshire (A. F.).

N. fabriciana, Linn.-Scarce, King's Cross (A. A. D.).

N. flavoguttata, Kirb.-C. ; Bonhill, (J.R.M.); Pirnmill, Arran (A. F.); Luss ; Johnstone (A. A. D.).

Fam. Apidae.

Epcolus productus, Thoms.-Scarce, Irvine Moor (A. A. D.).

Caelioxys elongata, Lep.-Troon (J. E. M.); Irvine Moor (A. A. D.).

Megachile willughbiella, Kirby.-Barr, Ayrshire (A. A. D.).

M. circumcincta, Lep.-Irvine Moor (A. A. D.). 
Psithyrus vestalis, Foure--Very c. and gen. dist.

var. distinctus, Per.-C., but so far as I have seen the var. is in $\mathrm{m}$.

P. barbutellus, Kirb.-Not so c. as foregoing, Bonhill (J. R. M.); Barr, Milngavie (A. A. D.).

P. quadricolor, Lep.-Scarce; Bonhill (J.R. M.); Elvanfoot (W. E.); Possil Marsh (J. E. M.).

Bombus Smithianus. A light var. occurs in the district, which has I believe been confounded with Venustus. All the ofs examined have been declared to be Smithianus.

B. venustus, Smith.-Recorded for several localities but no specimens are in existence so far as has been ascertained. The records seem to point to the foregoing sp. Until an authentic male is discovered the following localities must be looked upon as applying to Smithianus: Paisley (J. Dunsmore); Barrassie ; Kilsyth etc. (Ä.A.D.); Bonhill (J.R. M.).

B. agrorum, $F a b$.-Very c. everywhere.

B. hortorum, Linn.-Paisley (J. D.); Bonhill (J.R. M.) ; Irvine ; W. Kilbride (A. A. D); Strone (R. Henderson); Possil Marsh (J. E. M.).

B. latreillellus, Kirb.-Trans. Glas. Fld. Nat. Hist. Soc., 1872-73, p. T (P. Cameron). Possil Marsh.

B. lapidarius, Linn.-W. Kilbride ; Kilkerran ; King's Cross ; Irvine (A. A. D.) ; Cardross; Bonhill ; Dumbarton (J.R. M.).

B. jouellus, Ki irb.-Elvanfoot (W.E.) ; King's Cross ; Irvine Moor; Luss (A. A.D.).

B. lapponicus, Fabr.-Argyllshire (Hym. Aculeata. E. S.).

B. pratorum, Linn.-C. and gen. dist.

B. soroensis, Fabr.-Barr (A.F.) ; Elvansfoot (W. E.) ; Bonhill (J.R. M.); Kilkerran ; Kilsyth ; Dundonald ; Barr (A.A.D.).

B. terrestris, Linn.-Very c. everywhere. race. lucorum, $S m$. $-\hat{\alpha}$ common. race. virginalis, $\operatorname{kir} b$.-Much rarer than the other forms. Both of and $\mathcal{Q}$; Bonhill (J. R. M.); Carmyle ; Crookston ; King's Cross, etc. (A. A. D.).

Apis mellifica, Linn.-Not native in wild state; generally cultivated and often crossed with other continental species. Sometimes wild as escape. 


\section{ORder Lepidoptera.}

MACRO-LEPIDOPTERA.

By Axd. Adie Dalglish, F.E.S., 21 Princes St., Pollokshields, and the late GEO. W. ORD.

Classification and Nomexclature: Handbook of Bitish Lepidoptera, Ed. Meyrick, B.A., F.Z.S., 1895.

Dr. T. A. Chapman, F.Z.S., has kindly placed in our hands the valuable MS. list compiled by his father, the late Thomas Chapman, and the following gentlemen have kindly provided us with lists of their captures : A. H. Begg, (A. H. B.) ; Thomas Chapman (T.C.) ; Dr. T. Algernon Chapman, M.D., E.Z.S. (T. A. C.) ; Dr. Hugh Colquhoun (H.C.), Chapman MS. ; C. B. Cross (C. B. C.) ; Wm. M. Christy, M.A., F.E.S. (W. M. C.) ; Miss M. L. Cottingham (M. L. C.) ; Entomologist, xxvii. 223, and xxviii. 21; Andrew Adie Dalglish (A.A.D.) ; John Dunsmore (J. D.) ; J. P. Duncan (J.P. D.), Chapman MS.; Edward C. Eggleton (E.C.E.); Andrew Erskine (A.E.) ; William Evans, F.R.S.E. (W. E.); W. C. S. Fergusson (TV. F.); J. G. M'Haffie Gordon, F. E.S. (J. G. G.) ; J. Gray (J. G.), Chapman MS.; Robert Henderson (R. H.) ; Thomas J. Henderson (T.J.H.) ; J. J. F. X. King, F.E.S. (J.J.K.); R. F. Logan, Chapman MS.; Henry Lupton (H.L.); A. M'Corkle (A. M'C.) ; Rev. J. A. Mackonochie, F.E.S. (J. A. M.); John Mackay, Young Naturalist series; Andrew Mackieson (A. M.); John R. Malloch (J. M.) ; John A. Nix (J. A. N.) ; George W. Ord (G. W. O.) ; George Rose (G.R.); John Scott (J.S.), Chapman IIS.; John Smith (J.Sm.); William Smith (W.S.) ; Alexander M. Stewart (A. M. S.) ; Alexander Somerville, B.Sc., F.L.S. (A.S.) ; J. W. Tutt, F.E.S., etc., Entomologists Record, iv. 285; Howard Vaughan (H. V.), Entomologist, xviii. 239 ; Rev. A. B. Walker (A.B. W.), Entomologist xxvi. 52 ; William Watson (W. W.); J. Jenner Weir, F.E.S. (J.J.W.), Entomologist, xv. 250; Richard Weaver (R. W.), Zoologist, iii. 846 ; Dr. F. Buchanan White, F.E.S. (F.B.W.), Scottish Naturalist series; Thomas Wilson (T. W.); and Morris Young (M. Y.), Chapman MS.

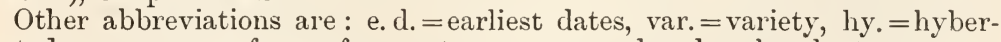
nated, c. = common, freq. = frequent, nr.= near ; abund.=abundant.

Some of the Kintyre records are from the W. side.

\section{CARADRININA.}

\section{Fam. Arctiadae.}

Oeonistis quadra, L.-Kilberry, Argyllshire (M. L. C.).

Lithosia lurideola, Zk._ "Clyde" (F. B. W.); Tayvallich (J. Mackay, A. M. S.). 
Gnophria rubricollis, L.--Not unfreq. nr. Inveraray (J. G. Nat. (1) 1/85).

Cybosia mesomella, L.— "Clyde" (F. B. W.). One, Tarbert, L. Fyne, $12 / 7 / 86$ (A. A. D.).

Setina irrorella, L.- "Clyde" (F. B. W.) Probably Western Kintyre, as this sp. is not unc. nr. Oban.

Nudaria mundana, L.-Locally c.; Arrochar, 14/7/91 (A. A.D.); Dunoon (T. C.) ; Bonhill (J. M.); Newton Mearns, 21/7/92 (A. A. D.); Ardrossan (H. C.) ; Carradale (G. W. O.).

Roeselia confuscalis, H.S.-Local and r. ; Lochgoilhead, 2 on paling, 1/6/94 (A. A.D.); $\operatorname{Ayr}$ (J.A. M., W. F.).

Nola cucullatella, L.-Rosemount, Ayrshire (J.P. D.).

Sarrothripus undulana, Hb.-Very r.; Dunoon and Ardentinny (T.C.); Lochgoilhead 7/7/88 (A. A.D); Ben Lomond (J.S.); Wemyss B. (A. S.).

Halias prasinana, L.-Freq.; larvae c. on oak. L. Riddon (W. M. C.); Lochgoilhead 17/6/92 (A.A.D.) ; Garelochhead (T.J.H.); Johnstone (W. W.) ; Corrie, Arran 7/7/87 (A.A. D.).

Tyria jacobaeae, $L$.-Singly or in small numbers all over district. C. on Turnberry Sands, Ayrshire (W.F., G. W. O.).

Phragmatobia fuliginosa, L.-C. and widely dist., larvae abund. Sept. on various plants; e.d. $6 / 6 / 91 ; 29 / 5 / 97$.

Diacrisia urticae, Esp.-One, banks of Kelvin nr. Glasgow (H. C.).

D. menthastri, Esp.-Abund. everywhere. Depth of ground colour varies greatly ; e.d. $23 / 5 / 95 ; 15 / 6 / 96 ; 28 / 5 / 98$. Mr. A. M. Stewart has one deep buff coloured with the spots obsolete.

D. lubricipeda, L.--Searce nr. Glasgow. Abund. Ayrshire, Cumbrae, Bute, Argyll ; larvae on lettuce, etc.

D. russula, L.-Freq.; Gl. Falloch 4/6/95 ; Lochgoilhead 30/6/88 (A. A. D.) ; Garelochhead (T.J.H.) ; Luss (A. M'C.); Baljaffray (A.H. B.); Arran (W.S.).

Arctia plantaginis, L.-Lochgoilhead 30/6/88 (A. A. D.); Garelochhead (T. J. H.) ; Bonhill (J.M.) ; Milngavie 17/6/99 (G. W. O.) ; Kilmalcolm (J. D.) ; Shewalton (G.R.) ; Ailsa Craig (A. M. S.).

var. hospita, Schiff.-R. Bridge of Weir (W.W.); Greenock Hills (Mr. Watt).

A. caja, L.-Abund. and widely dist., especially in Ayrshire ; e. d. 26/6/85; $4 / 7 / 93$.

Fam. Caradrinidae.

Cucullia chamomillae, Schiff.-One, Ardrossan, end of May 1857 (H. C.).

C. umbratica, L.-Freq.; L. Riddon 12/7/95 (A. A. D.) ; Dunoon (H. C.); Fintry (E. C. E.) ; Milngavie (G. W. O.); Giffnock 10/7/95 (A. A. D.); Johnstone (W. W.) ; Ayr 9/7/94 (W. F.); Kilberry (M. L. C.).

Polia exoleta, L.-C. at sugar. L. Riddon $9 / 10 / 93$; Inveruglas, abund. 20/9/95 (A. A. D.) ; Garelochhead (T. J. H.) ; Paisley (W. S., A. M. S.) ; Kilwinning (J. Sm.) ; Arran (A. B. W.); hy. 27/3/92; 16/4/94; 20/3/95.

P. vetusta, Hb.-Abund. at sugar. Inveruglas 9/9/95 (A. A. D.); Garelochhead (T.J.H.); L. Riddon 9/10/93 ; Catheart 28/9/93 (A. A. D.); Gleniffer (J.D.); Dundonald (J.Sm.); Arran (A. B. W.); hy. 20/3/95.

P. solidaginis, Hb.-Dunoon 7/9/57 (T.C.); Inveraray (E. B. teste T. C., J. A. N.); Inveruglas 3/9/95 (A. A. D.); L. Riddon (W. M. C.); Craigmaddie 6/9/91 (G. W. O.).

P. areola, Esp.-Scarce nr. Monkton, Ayrshire (J. P. D.).

P. viminalis, Fb.-Never c.; Dunoon (T. C.); Garelochhead (T. J. H.) ; L. Riddon (W. M. C.) ; Luss 12/9/91 ; Inveruglas 9/9/95 (A.A.D.); Kilberry (M. L. C.).

var. intermedia, Tutt.-Dark suffused grey, distinct markings, freq.

P. lichenea, Hb.-Very r.; One very dark sp. Barrochan Moss, Renfrewshire 1895 (J. D.) ; nr. Adamton and Fullerton, Ayrshire (J.P. D.). 
P. protea, Bkh.-Locally abund., very variable. Inveruglas 8/9/95 ; L. Riddon 20/8/8. (A. A. D.) ; Bonhill (J. M.) ; Cadder (G. W.O.) ; Fintry (E. C. E.) ; Douglas (J. A. M.) ; Paisley (J. D.); Adamton (J.Sm.).

var. variegata, Tutt.-Very dark, black and reddish; distinct stigmata and pale inner margin, freq.

P. aprilina, L.-At sugar and at rest on oaks, local. Dunoon (T. C.) ; Garelochhead (T. J. H.) ; Inveruglas $9 / 9 / 95$, Milngavie 23/9/93 (A.A. D.); Fintry (E. C. E.) ; Douglas (J. A. M.) ; Paisley (J. D.) ; Ayr, (W. F.).

P. chi, L.-Abun. on walls everywhere, e.d. $20 / 8 / 92 ; 17 / 8 / 93 ; 10 / 8 / 97$. var. olivacea, St.-R. One Kilsyth Hills 9/9/99 (A. A. D.).

Dasypolia templi, Thnb.-Freq. Newton Steel Wks., Lanarkshire, at electric light (Harkness); 5 on lamp, Paisley (A.M.S.); Ayr (W.F.); Carluke (K. J. Morton).

Miselia oxyacanthae, L.-C. at sugar. Ardlui 26/9/96 ; L. Riddon 9/9/91 (A. A. D.) ; Fintry (E. C. E.) ; Cádder (G. W. O.) ; Paisley (W.S., J. D.) ; Kilmarnock (G. R.).

Diloba caeruleocephala, L.-R.; nr Glasgow (Mr. Hislop teste T. C.); Fintry (E.C. E.) ; Paisley Woods, r. (J. D.); Ayrshire (J.P. D.); Arran (D. Landsborough).

Aporophyla lutulenta, Bkh. var. luneburgensis, Frr.--One L. Riddon (W. M. C. Ent. xxix. 273).

A. nigra, Haw.-Local. Inveruglas 8-20/9/95; Lochgoilhead, c. 2/9/92 (A. A. D.) ; L. Riddon (W. M. C.) ; Dunoon (T. C.) ; one from Inveruglas has black reniforn.

A. lunosa, Haw.-Local, very variable. Kilmarnock (G. R.); Troon (J. P. D.) ; Ayr, c. 31/8/94 (W. F.) ; Ballantrae 21/8/97 (A. A. D ).

var. agrotoides, Gn.-Dark grey, pale nervures ; perhaps our commonest.

Orthosia xerampelina, Hb.-Very r. L. Riddon Aug. 92 (A.A.D., W. M. C.) ; Ayr one bred 4th Aug., one sugar $9 / 8 / 94$ (W. F.).

O. flavago, Fb.-C. and widely rist., variable ; e.d. $29 / 8 / 87 ; 12 / 9 / 91 ; 2 / 9 / 92$. var. ochreaga, Bork.-Central band complete, and red, r.

O. fulvago, $L$.-Abund. everywhere, variable, e.d. $24 / 8 / 86 ; 29 / 8 / 87 ; 25 / 8 / 97$. var. flavescens, Esp.-Occurs everywhere, not c.

O. circellaris, Hufn.-Abund. at sugar, variable, e.d. $25 / 9 / 92 ; 28 / 9 / 93 ; 18 / 9 / 95$.

O. helvola, $L$. (rufina, L.)-Locally c. at sugar. Inveruglas $9 / 9 / 95$; Luss $17 / 9,91$; Lochgoilhead 2/9/92 (A.A.D.); Fintry (E.C.E.); Dunoon (T. C.).

var. punica, Bkh. and ochrea, Tutt.-Lochgoilhead.

O. litura, L.-C., very variable. Bonhill (J.M.) ; Fintry (E. C. E.) ; Cadder (G. W.O.) ; Giffnock 30/8/87, 26/8/89, 15/8/95 (A.A.D.) ; Paisley (J. D., A.M. S.) ; Ayrshire (J. P. D., W. F.) ; Arran (A.B.W.).

var. ornatrix, Hb.-Gey.-Purplish grey, and var. borealis, Sp.-Schn.Purplish grey, with pale base, occasionally.

O. macilenta, Hb.-Locally abund., variable. Inveruglas $9 / 9 / 95$; Luss $12 / 9.91$ (A. A. D.) ; L. Riddon (W. M. C.) ; Fintry (E. C.E.) ; Paisley (J. D., A. M. S.) ; Arran (A. B. W.).

O. lota, Cl.-Not c. ; Inveruglas 19/9/95 ; Luss 12/9/91 (A. A. D.) ; L. Riddon (W. M. C.) ; Giftinock 30/8/87 (A.A.D.) ; Paisley (M. Y., J. D.) ; Ayr bred $24 / 8 / 94$ (W. F.).

O. suspecta, $H b$. - R. ; Inveruglas $1 / 9 / 95$; Luss 30/7/93 (A. A. D.) ; L. Riddon (W. M. C.) ; Paisley (J. D., A. M. S.) ; Johnstone (W. W.) ; Arran (A. E.); Tayvallich (A. M. S.).

var. rufa, Tutt.-Bright red almost unicolorous, few lines; distiuct stigmata, Arran.

var. congener, Hb.-Gey.-Pale reddish grey, outer area paler, Luss.

O. satellitia, L.-C. and widely dist., variable, e. d. $14 / 10 / 93 ; 7 / 10 / 95 ;$ by. 20/3/95. 
Conistra vaccinii, L.-A A bund. at sugar, very variable. Inveruglas 13/9/95 (A. A. D.); Bonhill (J. M.) ; L. Riddon (W. M. C.); Langside 7/9/85 (A. A. D.) ; Paisley (J. D.); Dundonald (J. Sm.); hy. 20/3/95, 21/2/97.

Leucania turca, L.-Very r. Newfield, Ayrshire (J.P.D.).

L. lithargyrea, Esp.-Not c. Fintry (E. C. E.) ; Giffnock, one $27 / 7 / 86$ (A.A.D.); Linwood (J.D.); Ayr ; Maybole 6/8/94 (W.F.); Girvan (G. W. O.).

L. littoralis, Curt.-Local, r. Freq. Prestwick (J.P. D.) ; one on ragwort Arran (A. B. W.).

L. conigera, Fb.-Locally c. Giffnock 21/7/88, 22/7/93; Barr 20/7/99 (A.A.D.); Paisley (J. D., A. M. S.) ; Elderslie (W. W.) ; Kilwinning (J.Sm.);

L. comma, L.-R. in Clydesdale. "Clyde"(F. B. W.); L. Riddon (W. M. C.); Kilberry (M. L. C.) ; Stranraer (A. A. D.).

L. impura, Hb.-Abund. everywhere. e. d. 20/6/93, 5/7/95, 23/6/96.

L. pallens, L.- Some years c., varies from pale ochreous to deep reddish ochreous, dark spots sometimes obsolete, e. d. 27/7/94, 5/7/95.

Monima incerta, Hufn.-Abund. at sallows, and sugar, exceedingly variable, e. d. $4 / 4 / 94,22 / 4 / 95$.

M. gracilis, Fb.--Very r. ; Portincaple (T. C.) ; Cadder (E. C. E., D. Gourley, one each); Brodick 30/4/95 (W.E.).

M. stabilis, View._Abund. at sallows and sugar, very variable, e.d. 14/4/94, $22 / 4 / 95,23 / 4 / 96$.

M. populeti, Tr.-Larvae c. on aspen. Gareloch ; Loch Goil (T. A. C.); one Kelvingrove Pk. (E. C. E.).

M. pulverulenta, Esp._- "Clyde" (F. B. W.).

M. gothica, $L$.-Abund. at sallows, comes freely at sugar, variable, e.d. $14 / 4 / 94,29 / 4 / 95,23 / 4 / 96$.

Charaeas graminis, L.-Widely dist., some years very abund. on ragwort and thistles, e.d. 19/7/90, 11/7/95 till sept.

Neuronia popularis, Fb.-Local in Ayrshire. Kilwinning; Dundonald (J. Sm.); Prestwick 6/8/93 (A. M`C.); Stranraer 8/00 (A. A. D.).

Panolis piniperda, Panz.--Not unc. Garelochhead (T. J. H.); Round Paisley (W.S., J.D.) ; Kilbarchan (A. M.S.) ; A yr 5/4/94, 31/395 (IV. F.) ; Shewalton (G. R.).

Harmodia nana, Rott.-Freq. on coast. Ardentimny (A. M. S.) ; Dunoon, Ardrossan (H. C.) ; Girvan (J. J. K.) ; Arran (R. Weaver, J. J. W.).

H. carpophaga, Bkh.-Taken by Birchall in Argyll (F. B. W., Scot. Nat.).

H. capsincola, Hb.-Local and r. Crawfordjohn, Lanark (H.C.); Paisley (A.M.S., W.S.) ; Bonhill (J. M.) ; Kilwinning (J. Sm.); Monkton (J. P. D.).

H. cucubali, Fuesl.-Locally c. Lanark (J. G.) ; Giffnock 23/6/89; 20/693 (A. A. D.) ; Paisley (A. M. S., W. S.) ; Bonhill (J. M.) ; Monkton (J. P. D.)

Melanchra dentina, Esp._Locally c. Lochgoilhead 5/6/91 (A.A.D.); Garelochhead (T.J.H.); Paisley (W.S., A. M. S.) ; Gourock, 19/6/97 (A.A.D.); Milngavie (G. W. O.) ; Ardrossan (H.C.) ; $\operatorname{Arran}$ (J. J. W.).

M. glauca, Hb.-On rocks on hills, not unc. Lochgoilhead 5/6/91 (A. A. D.); Dunoon (T. C.) ; Garnkirk (A. M'C.) ; Paisley (J. D.); Kilbarchan (A.M. S.); Arran (J.J. W.).

M. contigua, Vill.-Very r. Argyll ; Bute (T. C.) ; Loch Riddon (W. M. C.); nr. Lanark (J.G.); Linwood (W. W.) ; Kilmarnock (G. R.) ; Arran (H. L.).

M. genistae, Bkh.-Once nr. Paisley (M. Y.) ; scarce Monkton, Ayrshire (J. P. D.).

M. thalassina, Rott.-C. every where, freely to sugar, variable, e.d. 28/5/96, $26 / 5 / 97$.

M. dissimilis, Knoch.-R. in Ayrshire (J.P. D.). 
M. oleracea, L.-Very gen. dist., often c., e.d. $156 / 93,21 / 6 / 94,17 / 6 / 95$.

M. pisi, $L$. -Widely dist., c., very variable., larvae abund. on heather, etc. Sept, e.d. $10 / 6 / 95,295 / 97$.

M. tincta, Bkh.-Singly or r. ; Dumoon (T.C.) ; Garelochhead (T. J.H.); Coulport 27/7/90; L. Riddon $7 / 92$ (A.A.D.); Strachur (A. M.) ; Tayvallich (A. M. S.).

M. advena, Fb.-Occasionally nr. Paisley (J. D.) ; r. Ayrshire (J. P. D.).

M. nebulosa, Hufn.-Widely dist., sometimes locally c., e.d. $6 / 7 / 89,15 / / 92$, $15 / 794$.

M. brassicae, L.-Larvae abund., gardens everywhere, e.d. 1/6/93, 4/6/95, $12 / 6 / 96$.

M. persicariae, L.-One, Glasgow (E. C. E.) ; Monkton, Ayrshire (J.P. D. teste J. Sm.).

M. albicolon, Hb.-Very r. "Clyde" (F. B. W.) ; one Ayr 3/7/94 (W. F.).

M. myrtilli, L.-Widely dist. moors all over district, larvae abund. heather, e.d. $6 / 6 / 94,28 / 6 / 96,26 / 6 / 97$.

M. melanopa, Thnb. - "Clyde" reported from Argyllshire (F. B. W.).

Agrotis vestigialis, Rott.-On coast locally c., variable. Ardrossan (H.C.) ; Troon (G. W. O.) ; Avr 23794 (W. F.) ; Corrie (H. L.).

A. corticea, Hb.-Local, r. Fintry (E. C. E.) ; Bonhill (J. M.) ; Ayr 14/6 94 (W. F.) ; Monkton (J. P. D.) ; Kilberry (M. L. C.).

A. segetum, Schiff.-Very uncertain. Garelochhead (T. J. H.) ; L. Riddon (W. M.C.) ; Stepps (G. W. O.); Giffnock $11 / 8 / 93$ (A. A. D.) ; Paisley (J. D., A. M. S.) ; Kilmarnock (G. R.) ; Mauchline 16/7/92 (A. A.D.) ; Arran (A. B. W.).

A. ypsilon, Rott. (=Suffusa, Hb.)-Freq. Iuveruglas 16/9/95 (A. A. D.); Ardentinny (T.C.); L. Riddon (W.M.C.); Clarkston, c. 30/9/95 (A.A.D.);

Paisley (J.D., A. M.S.) ; scarce in Ayrshire (J.P. D.) ; Arran (A.B.W.).

A. exclamationis, L.-Locally abund., variable. Fintry (E. C. E.); Stepps (G. W. O.) ; Giffnock 21/6/95, 23/6/96 (A. A.D.); Paisley (J.D., A.M.S.); Dumoon (T. C.) ; Arrshire (J.P. D.) ; Arran (J..J. W., H. L.).

A. nigricans, $L$.-Not c. at ragwort, and sugar. Giffnock 7/8/92 (A. A.D.); Ardrossan (H.C.) ; Monkton (J.P.D.); Ballantrae 11/8 97 (A.A.D.); Arran (A. B. W.).

var. fuliginea, Godart.-Unicolorous smoky-black, stigmata paler. Our specimens nearly all referable to this.

A. saucia, Hb.-Very r. Clarkston at sugar, 1 sp. 30/9/93 (A.A.D.); Paisley few (J. D., A. M. S.) ; at Ivy Troon (J. P. D.).

A. praecox, L.-Freq. Ayrshire coast (R. Wearer, J. P. D.).

A. cursoria, Hufn. - R. Ayrshire Sand Hills (R. Weaver, J. P. D.) ; Ardrossan (H. C.).

A. ripae, $H b .-$ K., Troon (J.P. D.) ; Ayr several (W. F.).

A. plecta, L.-Universally dist. and abund., e.c. 30/5 95, 17 6 97, 3/6/00.

A. strigula, Thnb. - Abund. moor's all over district, e.d. 10/7/97, 9/7/9\&, $7 / 7 / 00$.

A. agathina, Dup.-Bred singly, larva on heath. Dargavel, Renfrew (W.S): one caught same loc. (A. M. S.).

A. tritici, L.-Local, not unc. Kilmalcolm (J.D.); $\operatorname{Ardrossan}($ H.C.) ; Monkton (J.P.D.) ; Ayr 23/7/94 (W. F.) ; Corrie 13/7/87 (A.A.D.); Inveraray (J. A. N.).

A. augur, $F b$. - Widely dist., not unc., variable, e.d. 6/7/93, 17/6/95, 3/7/97.

A. occulta, L.-Decidedly scarce. Cadder once (C.B.C.); Paisley (2) (J.D.); L. Riddon (W. M. C.) ; Monkton (J.P.D.).

A. lucernea, L.-Local, not unc. Fintry (E. C. E.) ; Campsie (J. G.) ; Luss Quarries 16/7/93 (A. A. D.) ; Dunoon ; Cumbraes (H. C.) ; Arran (J. G.).

A. simulans, Hufn.-R. nr. Monkton (J.P. D.).

A. obscura, Brh.-R. ur. Monkton (J. P. D.). 
A. putris, L.-R. ; Paisley, several bred 1900 (J. D.); Linwood (W.S ) ; Ayr 26/7/94 (W. E.); Girvan (G. W. O.) ; Whiting B. 6/1856 (A. S.) ; Lamlash (W.S.).

A. c-nigrum, L.-C. at sugar. Lochgoilhead 18/6/92 ; Luss 5/7/93 (A.A.D.); Cadder (E.C. E.); Paisley (A.M.S.); Girvan (G.W. O.); Arran (J. J.W.); second brood Clarkston 14/10/93 (A. A. D.).

A. triangulum, Hufn.-R. ; Loch Goil (T. C.) ; Gareloch 13/7/99 (R. H.) ; Giffnock 3/7/91 (A. A.D.); Ayr 7/8/94 (W.F.); Mauchline 31/7/92 (A. A. D.) ; Kilberry (M. L. C.).

A. pronuba, $L$.- Universally dist., c., very variable, e.d. 29/6/91, 17/6/95, 1/7/36.

A. comes, $H b$. - Widely dist., c. on ragwort, variable, e.d. 19/7/92, 21/7/95, $1 / 8 / 96$.

var. nigrescens, Tutt.-Black, with transverse lines, stigmata outlined pale ochreous. One Millport, one Tayvallich (A. M. Stewart).

A. brunnea, $F b$. C C but local, variable. Lochgoilhead $7 / 7 / 88$; Glenmallan 9/7/98 (A. A. D.) ; Dunoon (H. C.) ; Fintry (E. C. E.) ; Paisley (.J. D.) ; Ayrshire scarce (J. P. D.) ; Corrie (H. L.) ; Tayvallich (A. M. S.).

A. xanthographa, $F b$. - C. everywhere, on ragwort etc., exceedingly variable, e.d. 3/8/92, 19/7/93, 8/8/94.

A. castanea, Esp.-Very r.; Strachur 10/8/91 (R. H.); L. Riddon (W.M.C.); Luss 31/7/93 (A. A. D.) ; Bonhill (J. M.) ; Douglas (J. A. M.).

var. neglecta, $H b$. and laevis, Haw.-The grey and reddish-grey forms, all the local specimens we have seen are referable to these.

A. umbrosa, Hb.-Freq. ; Giffnock 27/7/93 ; 13/7/96 (A. A. D.) ; Elderslie (J. D.) ; Ardrossan (H. C.) ; Girvan ; Carradale (G. W. O.).

A. rubi, Yiew. - Never c. ; Douglas (J.A. M.) ; Giffnock 14/7/97, 7/7/98 (A.A.D.) ; Stepps (G. W. O.); Kilcreggan; Garelochhead (T. J. H.) ; Corrie 10/7/87 (A. A.D.) ; Ayr 25/6/94 (W. F.).

A. Dahlii, Hb. - Sometimes locally c., variable. Tayvallich (A. M.S.) ; Inveruglas 7/9/95, Lochgoilhead 27/8/92 (A.A.D.); Helensburgh (A.S.); Paisley r. (J. D.); Arran (R. Weaver.).

A. festiva, Hb. - Not. c., very variable. Douglas (J.A. M.); Cadder (G.W. O.); Fintry (E.C.E.) ; Luss 18/7/93 (A.A.D.) ; Paisley (J. D., A. M. S.) ; Gourock 17/7/97 (A. A. D.) ; Ayrshire (J.P.D.) ; Arran (J. J.W., H. L.).

A. stigmatica, Hb.-Very r., occasionally nr. Paisley (A.M.S.) ; Linwood (W. W.).

A. glareosa, Esp.-Not c. ; Inveruglas 1/9/95 ; Luss 12/9/91 (A. A. D.) ; Dunoon 20/9 (H.T. Stainton); Milngavie (G. W. O.); Paisley (J. D.,

A. M. S.) ; Arran (A. B. W.) ; Elvanfoot (W. E.).

var. rosea, Tutt.-Has been taken in Paisley district.

A. depuncta, L.-One Fintry (E. C. E.).

A. typica, L.-Generally dist., very c., e. d. 1/8/92, 7/8/94, 10/7/97.

Triphaena fimbria, L.-Not c.; nr. Glasgow (T. C.) ; Renfrew (J. S.) ; Garelochhead (T. J. H.); Lochgoilhead 15/8/92, c. (A. A. D.) ; L. Riddon (W. M. C.); Troon (G. W. O.); Bute (J.G.).

T. ianthina, Esp.-Freq. ; Inveruglas (A. A. D.); Dunoon (H. C.); L. Riddon (W.M.C.); Giffnock 27/7/87, 17/8/93 (A.A. D.) ; Paisley (A. M.S.); Ayr 29/8/94 (W. F.).

T. baja, $F b$.-Widely dist., not c., variable, e. d. 13/7/87, 23/7/92, 21/7/95.

T. rubricosa, $F b$.-Freq. at sallows. Tarbet (J.S.); Bonhill (J.M.); Fintry (E. C. E.); Giffnock 14/4/94 (A.A.D.) ; Kilbarchan (A.M.S.) ; Dundonald (J.Sm.); Arran (J.J. W.).

var. mucida, Esp.-Dark purplish, slatey grey suffusion, perhaps commonest form.

T. prasina, Fb.-Not c.; Ardentinny (T. C.) ; Lochgoilhead 10/7/88 (A. A. D.); Kilmun (A. S., W. W.) ; Fairfield (J. P. D.); Barr 6/1900 (A. Fergusson); Tayvallich (A. M. S.). 
Heliothis peltigera, Schiff--Monkton, Ayrshire (J. P. Duncan).

Ochria ochracea, $H b$. -R. Gourock (J. D.).

Luperina testacea, Hb.-Giffnock 28/8/87 (A. A.D.) ; Elderslie r. (J. D.) ; Monkton (J.P. D.) ; Ayr c. 24/8/94 (W.F.) ; Ballantrae 8/8/97 ; Arran $14 / 8 / 00$ (A. A. D.).

var. nigrescens, Tutt.-Blackish-grey melanic. Occasionally nr. Glasgow and Paisley.

L. Dumerilii, Dup.-One in Arran (Stainton).

Rusina tenebrosa, $H b$.-Widely dist., locally abund., e. d. 18/6/92, 20/6/94, $17 ; 6 / 95$.

Amphipyra tragopogonis, L.-Abund. almost everywhere, at sugar, e.d. $24 / 8 / 94,15 / 8 / 95,20 / 8 / 97$,

Caradrina trapezina, L.-Almost every loc., very variable, e. d. 30/7/95, $12 / 8 / 96,25 / 7 / 97$.

C. subtusa, Fb.-R. Titwood, Glasgow 9/66 (T. J. H.); Sandbank (W. W.); one bred Ardentinny (T. C.) ; Ayr (J.G.).

C. umbra, Hufn.-Very r. Douglas (J. A. M.) ; Ayr once (W. F.).

C. micacea, Esp. - Widely dist., c. at sugar and ragwort, 29/7/87, 31/7/93, $12 / 8 / 94$.

C. petasitis, Dbld.-R. and local. Nr. Paisley (J. D.); Monkton (J.P. D.).

C. fulva, Hb.-Abund. marshy ground all over district, e.d. 3/9/98, 29/7/99, $8 / 9 / 00$. Great range of variation. The type I think does not occur, but all the other vars. in Tutt's "British Noctuae" may be taken, including var. concolor, Tutt.

C. arcuosa, Haw.-Widely dist., sometimes locally abund., e.d. 25/6/96, $10 / 7 / 97,3 / 7 / 98$.

C. quadripunctata, $F b$.-Abund. everywhere, e.d. 5/6/87, 12/6/89 ; latest $14 / 9 / 93,18 / 9 / 95$.

C. morpheus, Hufn.-Very r., singly. Fintry (E. C. E.) ; Cadder (C. B. C.) ; Ardrossan (H. C.) ; Ayr 6/7/94 (W. F.).

C. alsines, Brh.-Douglas, Lanarkshire (J. A. M.).

C. taraxaci, $H b$.-Local and r. Fintry (E. C. E.) ; Giffnock 30/6/94, 5/7/95 (A. A. D.) ; Paisley r. (J. D., A. M. S.) ; a melanic specimen Giffnock 1895.

C. exulis, Lef.-One Arran at rest on rock; R. W. 1847, (Stainton, Ent. Ann.).

C. trigrammica, Hufn.-Local and r. Kilwinning (J.Sm.); Ayr (W. E.) ; Arran (J. J. W.).

Stilbia anomala, Haw.-Local, sometimes c. Holy L. (W. W.) ; L. Riddon 27/7/89 (A. A. D., W. M. C.) ; Rothesay (M. Y.) ; Cumbrae c. (A. M.S., J. D.) ; Arran (W. S., A. E.).

Hadena meticulosa, $L$.- Scarce in June, c. on ragwort and sugar in autumn, e.d. $2 / 7 / 87,19 / 6 / 94,5 / 9 / 93,10 / 9 / 94$.

H. lucipara, L.-Widely dist., c., but locally inclined, e.d. 18/6/92, 21/5/93 ; second brood scarce $23 / 9 / 90,19 / 9 / 95$.

H. maura, L.-Not c., richly coloured. Glasgow (T. C.) ; Paisley (J. D., R. Aden); Hamilton (W. Forsyth); Kilbarchan (A. M. S.) ; Ayr 24/8/94 (W. F.) ; Ballantrae several 19-21/8/97 (A. A. D.) ; Arran (T. C.). Ballantrae specimens intermediate betw. vars. rosea and striata, Tutt.

H. rectilinea, Esp.-Two Lochgoilhearl 17/6/92 (A.A.D.); Shandon (T. Grant).

H. adusta, Esp.-Freq., variable. Lochgoilhead 19/6/92 (A. A. D.); Garelochhead (T..T.H.); Douglas (J.A.M.); Giffnock 21/6/94, 20/5/95 (A. A. D.) ; Kilwinning (J. Sm.) ; Arran (A. B. W.).

H. gemina, $H b$. - Widely dist., c. and very variable, e. d. 5/7/93, 13/6/95, 23/6/96. var. remissa, $H b$.-Occurs with type everywhere.

H. polyodon, L.-Abund. everywhere, very variable, e. d. 13/7/92, 5/7/93, $15 / 7 / 96$.

var. infuscata, White, and aethiops, Stdgr. have been showing a tendency to displace the type in many localities. 
H. lithoxylea, Fb.-C. and widely dist., e. d. 15/7/92, 10/7/93, 5/7/94.

H. sublustris, Esp._Occasional specimen nr. Paisley (J. D.): Bonhill (J. M.).

H. rurea, Fb.-Abund. everywhere, very variable, e.d. 15/6/94, 30/5/95, $23 / 6 / 96$.

var. combusta, $H b$. ?-As c. as type, depth of colour varies greatly.

H. hepatica, $H b$.- Single specimen nr. Stepps 1898 (E. C. E.).

H. furva, $H b$.- Freq. Giffnock July 1888 two (A. A. D.) ; Gleniffer c. (J. D., A. M. S., W. S.) ; Ardrossan (H. C.) ; Girvau (A. H. B.) ; Arran (J. J. W.).

H. sordida, Blh.-Paisley woods not recently (J.D.); Fintry, once (E. C. E.) ; Ardrossan (H. C.).

H. basilinea, $F b$. - Universally dist. and abund., e. d. 15/6/94, 4/6/95, 17/6/97.

H. pabulatricula, Brh. (=connexa, Bkh.)-One Holy L. 8/1885 (W. W.).

$\mathrm{H}$. leucostigma, $H b$.- One. var. lunina, Haw., or as reniform is ochreous probably var. flavo-lunina, Tutt., Luss, L. Lomond 29/7/93 (A. A. D.).

H. unanimis, Tr.--Freq. Bonhills (J.M.) ; Fintry (E. C. E.) ; Giffnock several at sugar 5/7/95 (A. A.D.); Kilbarchan (A.M.S.); Monkton (J.P. D.).

H. didyma, Esp.-Abund., excessively variable, e. d. 19/7/93, 29/7/94, 8/8/95, $27 / 7 / 96$.

vars. rava, furca, and lugens, Haw., all c., with many intermediate forms.

H. nictitans, Bkh.-Hills, moors, etc. Some years very abund., exceedingly variable, e. d. 12/9/91, 2/9/92, 16/7/93.

var. lucens, Frr.-Our specimens almost entirely referable to this. Type rarely met with.

H. Haworthii, Curt.-C., very variable. Lochgoilhead 2/9/92 (A. A. D.) ; Garelochhead (T. J. H.) ; Fintry (E. C. E.) ; Douglas (J. A. M.) ; Stepps (G. W. O.) ; Gleniffer (A. M. S.) ; Arran 12/7/87 (A. A. D.).

H. literosa, Haw.-Locally c. Garelochhead (T.J.H.); Giffnock 1/8/92, 20/7/93; Arran 4/8/00 (A. A. D.) ; Paisley (J. D.) ; Ayr 9/8/94 (W. F.).

H. bicoloria, Iill.-Locally c., variable. Luss 15/7/93; Giffnock 20/7/87, 19/7/88 (A. A.D.) ; Paisley (A. M. S.) ; Troon (G. W. O.) ; Kings Cross $4 / 8 / 00$ (A. A. D.).

var. rufuncula, Haw., is perhaps our commonest on Ayrshire coast.

H. strigilis, $C l$.-Garelochhead (T.J. H.) ; Giffnock $4 / 7 / 93,23 / 6 / 94$ (A. A. D.); Elderslie (J. D.) ; Greenock (A.S.); Ayr 14/6/95 (W.F.).

var. aethiops, Haw.-Freq. in all localities.

H. fasciuncula, Hax.-Abund., very variable. Typical red and clay coloured. var. cana, Stdgr., equally c., e. d. 21/6/94, 17/6/95, 23/6/96.

var. rubencula, Freyer.-Almost unicolorous light red markings and central band not developed. One Giffnock (A. A. D.) ; probably.

Metachrostis perla, Fb.-Locally c. Barrochan on walls (W. W.); Adamton (J. Sm.) ; Girvan (G. R., A. M. S.).

Acronycta leporina, L.-Very r.; Dumoon (T.C.); Kilmun (J.S.) ; Auldton, Ayrshire (J.P.D.).

A. psi. L.-C., varies greatly in ground colour, e.d. 5/6/91, 6/6/94, 4/6/95.

A. ligustri, $F b$. - Once Lochgoilhead 17/6/92; one Gl. Mallan 9/7/98(A.A.D.); Larvae pleutiful Inveraray 1897 (J. A. N.) ; Kilberry (M. L. C.).

A. rumicis, L.-C., L. Riddon (W. M. C.) ; Lochgoilhead 21/5/93 ; Arrochar 28/5/98 (A. A. D.) ; Garelochhead (T.J. H.) ; Paisley (J.D.) ; Shewalton (G. R.) ; Girvan (G. W. O.).

A. euphorbiae, $F$ b.-var. myricae, Gn.-Larva Dunoon (T. C.) ; Shewalton (J. Sm.).

A. menyanthidis, Viev.-Hills and moors, not unc. Dunoon (T. C.); Lochgoilhead 21/5/93 (A. A. D.) ; Garelochlead (T. J.H.) ; Houston (W.S.) ; Shewalton (G. R.) ; Arran (H. L.). 


\section{Fam. Plusiadae.}

Aethia tarsipennalis, Tr.-.Very local but c., nr. Ayr (J. P. D., T. W.).

Hypenodes costistrigalis, Stph.-Locally c. L. Fyne ; Lochgoilhead (T. C.); L. Riddon 14/7/89 ; Coulport 17/7/00 (A. A. D.) ; Millport (J. D.).

Hypena proboscidalis L.-Abund. everywhere amongst nettles, variable, e.d. 21/6/92, 1/7/93, 25/6/95.

Scoliopteryx libatrix, L.-Not unc. Lochgoilhead 4/92, hy.; Ardlui 10/10/00 (A.A. D.); L. Riddon (W. M. C.) ; Johnstone (W.W.); Monkton (J. P. D.).

Plusia chrysitis, L.-C. and widely dist. e.d. 9/7/89, $7 / 7 / 94,7 / 7 / 98$.

P. bractea, Fb.-Scarce, at flowers. Dunoon (T.C.); L. Riddon 12/7/89 (A. A. D.) ; Portincaple (A. M.) ; Fintry several (E. C. E.) ; Bonhill (S. M.) ; Shandon (T. Grant) ; Lanark (J.G.) ; Paisley (M. Y.); Newton Woods 1882 and 84 (A. M.S.) ; Ayr (W. F.).

P. festucae, L.-Widely dist., locally abund. at Lychnis, etc., e.d. 20/6/93, 29/6/95, 7/7/98.

P. iota, L.-Almost everywhere, sometimes abund. on Sweet William, e.d. 5/7/93, 29/6/95, 9/7/98.

P. pulchrina, Haw.-Widely dist., c. at flowers, flies on moors in sunshine, e.d. $13 / 7 / 92,20 / 6 / 93,25 / 6 / 95$.

P. gamma, L.-C. June and July, abund. Sept., e.d. 4/7/85, 1/6/95̃-12/9/95, $7 / 9 / 97$; once bred $7 / 12 / 95$.

P. interrogationis, L. - Freq. moors. Iuveraray (J.A. N.) ; L. Riddon 15/7/89, Glemmallan c. 18/7/97 (A. A. D.) ; Douglas (J. A. M.) ; Greenock Hills (W.W.) ; Kilmun (H.T.Stainton); Arran (W. S., J. J.W.) ; Tayvallich (A. M. S.).

P. tripartita, Hufn.-Almost everywhere, never c. ; at nettles, e.d. 23/6/87. $5 / 7 / 89,7 / 7 / 98$.

P. triplasia, L.--Singly or scarce. Ayr 3/6/95 (W. F.) ; Monkton (J.P. D.), Euclidia mi, $\mathrm{Cl}$.- Widely dist. moors all over district, c. in Argyll, e.d. $1 / 6 / 94,23 / 5 / 95,21 / 5 / 96$.

E. glyphica, L.-Very local, sometimes c., Lanark, Ardentinny (T.C.) ; Shewalton (T. W.); Monkton (J.P. D.); Ayr 9/5/94, 25/5/95 (iW. F.).

Eustrotia uncula, Cl.--Locally c., Glen Falloch 4/6/95, 21/5/96, 19/5/98 (A. A. D.).

E. viridaria, $C l$.—Widely dist., moors, often locally abund., e.d. 5/6/91, 1/6/94, $23 / 5 / 95$.

Panemeria tenebrata, Sc.-Robroyston many years since (Mr. Ross teste T.C.).

Eublemma ostrina, Hb. - Once nr. Monkton, by Mrs. Duncan (J. P. D.).

Rivula sericealis, Sc.-Local and r. Loch Goil (T. C.); Lochgoilhead several 30/6/88 (A. A. D) ; Arran (T. C.) ; Tayvallich (A. M.S.).

\section{Fam. Ocneriadae.}

Orgyia antiqua, L.-Moors all over district, larvae some years abund, e.d. $12 / 9 / 91,2 / 9 / 92,1 / 9 / 95$.

Dasychira fascelina, L.-Larvae plentiful L. Long (T. C.) ; Bishopton once 28/6/96 (A.A. D.) ; Barochan ; Port-Glasgow (J. D.) ; Barrassie (J. Sm.).

Colocasia coryli, L.-Not unc. on birch (T. C.); L. Riddon (W. M. C.); Cadder (C. B.C.) ; Rosemount, Ayrshire (J.P. D.); Inveraray (J. A. N.).

Porthesia similis, Fuesl.-R., Monkton, Ayrshire (J.P. D.).

Stilpnotia salicis, L.-R. in Ayrshire (J. P. D.).

$$
\text { NOTODONTINA. }
$$

\section{Fam. Hydriomenidae.}

Trichopteryx viretata, Hb.-R. Rosemount, Ayrshire (J. P. D.).

T. carpinata, Bkh.-Freq. Ardentinny (T.C.); Dunoon (H.C.); Gareloch- 
head 28/4/00 (A. A. D.); Strathblane (J.A. M.); Monkton (J.P. D.) Arran (W.S., J. J. W.).

T. polycommata, Hb.-Arran (J. J. W., Ent. xv. 250).

Chloroclystis rectangulata, L.-Gardens. Luss c. 5/7/93 (A. A. D.) ; Garelochhead (T.J.H.) ; Greenoock (A.S.); Monkton (J.P.D.) ; Girvan (G. W. O.).

var. nigrosericeata, Hav.-Black or nearly so. Gourock 17/6/96 (A. A. D.). Gymnoscelis pumilata, $H b$.-Locally c. on heaths. Ardentinny (T. C.); Tarbert 5/7/86 (A. A. D.) ; Garelochhead (T. J. H.) ; Cadder (C. B. C.); Lamlash (W.S.).

Tephroclystis venosata, Fb.-Local, on coast. Arran (J.J.W.); Ailsa Craig (A. M. S., R. H.) ; Ballantrae, larvae on Silene, 8/97 (A. A. D.).

T. expallidata, Gn.-R. and local, nr. Glenmallan. L. Long two 11/7/97 (A. A. D.); Millport (A. M. S.).

T. minutata, Gn.-Locally c., moors. Tarbert 8/7/86 (A. A. D.) ; Garelochhead (T. J. H.) ; Fintry (E. C. E.) ; Bishopton (W.S., J. D.); Monkton (J. P. D.) ; Arran (W.S.).

T. absinthiata, $C l$.-Freq. Uddingston 8/6/92; Giffnock 11/6/87 (A. A. D.); Paisley (J. D.) ; Garelochead (T. J. H.).

T. assimilata, $G n$. - Not unc. gardens. Pollokshields, bred 28/6/95(A. A.D.); Paisley (J.D.) ; Garelochhead (T.J.H.) ; Glenmallan 11/7/97; Kilbarchan (A. M.S.).

T. vulgata, Haw.-Abund. hedges round Glasgow and Paisley ; widely dist., e.d. $21 / 5 / 93,31 / 5 / 94,25 / 5 / 95$.

T. oblongata, Thnb.-Freq. Tarbert 13/7/86 (A. A. D.); Fintry (E. C. E.); Garelochhead (T.J.H.) ; Govanhill (C. B. C.) ; Giffnock 22/6/92 (A. A. D.); Paisley (W.S.); Ardrossan (H. C.).

T. subfulvata, Haw.-Scarce. Glenmallan 9/7/98 (A. A. D.) ; Garelochhead (T. J. H.) ; Greenock (A. S.) ; Inveraray (J. A. N.).

var. oxydata, $T r$. - A single specimen Glenmallan.

T. satyrata, $H b$.-Abund. moors, very variable, mostly var. callunaria, Std.-Banded vars., verging on var. Curzoni, Greg.-occasionally, e.d. 1/6/94, 23/5/95, 16/5/96 ; larvae on scabiosa Sept.

T. pulchellata, Stph.-Freq. Larvae abund. on Digitalis flowers, July. Glenmallan 3/7/97 (A. A. D.) ; Garelochhead (T. J. H.) ; Gourock hills, bred, 12-14/5/96, 18-26/5/97 (A. A. D.) ; L. Riddon (W. M. C.) ; Arran (J.J. W.).

T. succenturiata, L.-R. $\operatorname{Ardrossan}($ H. C.). var. disparata, $H b$.- One, Millport 7/97 (A. M. S.).

T. castigata, $H b$. - C. Garelochhead (T. J. H.); Giffnock 27/6/89, 16/6/90 (A. A. D.) ; Paisley (A. M. S., W.S.) ; Arran (J. J. W.); Kilmartin (H. V.). Melanic var.="Paisley Pug," Linwood (J. D., A. M. S., W. S.); Johnston 14/6/90 (A. A. D) ; Arran (W. S.).

T. lariciata, Frr.-Abund. fir woods, widely dist., e.d. 5/6/91, 21/5/93, $1 / 6 / 94,23 / 5 / 95$.

T. plumbeolata, Haw.-Very local, sometimes c. Garelochhead (T. J. H.) ; Crookston $7 / 7 / 99,21 / 6 / 00$ (A. A. D.) ; Gleniffer ; Donald's Wood, Paisley (J.D.) ; Kilbarchan (A. M. S.).

T. pygmaeata, Hb.-Scarce. Garelochhead (T.J.H.); Giffnock 13/6/87 (A. A. D.) ; Paisley district (W.S., A. M. S.) ; Johnstone (W. W.); Ardrossan (H. C.) ; Girvan (G. W. O.).

T. tenuiata, $H b$.-Local. Larvae in willow catkins. Luss 5/7/98 (A.A.D.) ; Garelochhead (T. J. H.); Bonhill (J. M.).

T. indigata, $H b$.-C. pine woods. Milngavie 16/5/96 (A. A. D.) ; Cadder (T. J. H.) ; Linwood (J. D., A. M. S.) ; Bishopton 8/6/95, 26/6/97 (W. S., W. W., etc.) ; Bonhill (J. M.).

T. constrictata, Gn.-R. Ardrossan, at rest on trap rocks (H. C.). 
T. abbreviata, Stph.-Scarce. Garelochhead (T. J. H.) ; Bonhill (J. M.).

T. exiguata, $H b$.- Once at Bothwell (H. C.).

T. fraxinata, Creve.-R. on ash. Hillhead, Glasgow (T. J. H.) ; Dunoon (H. T. Stainton); L. Riddon, two, 7/89 (A. A. D).

T. sobrinata, $H b$-Amougst juniper, local. Strathblane (F. G. Binnie); Milngavie several 8/94 (A. A. D.) ; Paisley (J. D.) ; Arran (R. Weaver); Tayvallich (A. M. S.).

T. helveticaria, $B d v$.-Amongst juniper, very variable. Milngavie (T.J.H., A. A. D.); dates bred, $7 / 4-29 / 5 / 94,25 / 4-19 / 5 / 95 ;$ Tayvallich (A. M. S.).

var. arceuthata, $\mathrm{Fr}$.-Commoner than type.

T. nanata, $H b$. - Abund., moors all over district. Larvae on heath Sept., e. d. 12/6/97, 11/6/98, 17/6/99.

Eucymatoge scabiosata, Bkh.-R.; Arrochar 10/6/99 (A. A. D.) ; Garelochhead (T. J. H.).

E. togata, $H b$-One Possil Marsh (J. J. K.) ; Inveraray, one (J. A. N.).

Eucestia spartiata, Fuesl.-Abund. among broom. Fintry (E. C. E.); Luss 25/9/91 (A. A. D.) ; Gareloch hear (T.J.H.) ; Milngavie (A. M.) ; Bridgeof-Weir 22/9/97 (A. A. D., A. M. S.) ; Dundonald (J. S.).

E. rufata, Fb.-R. ; Irvine (J. Sm.); Monkton (J.P. D. ; Giffnock 18/5/01 (A. A. D.).

E. plagiata, L.-Not unc. on walls and rocks all over district, e.d. 18/7/93, $17 / 7 / 96,10 / 7 / 98$.

Carsia paludata, Thnb.-Very local, but c. on moors. Douglas (J. A. M.) ; Helensburgh (A. M'C.); Gourock 21/7/95, 16/7/96, 23/7/97 (A. A. D.); Dumoon (T. C.) ; Tarbert (G. W. O.).

Eustroma prunata, L.-In gardeus, c. L. Riddon (W. M. C.) ; Luss 16/7/93 (A. A. D.) ; Bothwell (H. C.) ; Fintry (E. C. E.) ; Kilbarchan (A. M. S.) ; W. Kilbride (W.S.) ; Corrie 10/7/87 (A. A. D.).

E. associata, Bkh.-Nr. Paisley (Morris Young).

E. populata, L.-C. amongst Vaccinium, and widely dist., e.d. 6/7/89, 12/7/95, $17 / 7 / 96$.

E. testata, L.-Abund. everywhere, and variable, e.d. 16/7/91, 28/7/93, $29 / 7 / 96$.

Plemyria bicolorata, Hufn.-Abund. amongst alders, widely dist., variable, e.d. $12 / 7 / 89,16 / 7 / 93,24 / 7 / 97$.

var. plumbata, Curt.-Occurs with type everywhere, very variable.

P. hastata, L.-Local. Dunoon (T. C.); Luss (R. F. Logan) ; Garelochhead $31 / 5 / 58$ (A.S.) ; Shewalton (G. R.) ; N. Cumnock (R. M'Gill) ; Corrie 2/7/87 (A. A. D.) ; Lamlash (W.S.) ; Kilberry (M. L. C.).

P. tristata, L.-Locally c. Ardlui 21/5/96; Lochgoilhead 23/5/95; Gourock 19/6/97 (A. A. D.); Mugdock (G. W. O.); Cadder (E. C. E.) ; Arran (J.S.).

P. rivata, Hb.-R. ; Douglas (J. A. M.) ; Kilwinning (J.Sm.) ; Ayr (W. F.) ; Arran (J. J. W.) ; Kilberry (M. L. C.).

P. sociata, Bkh.-A bund. everywhere, e.d. 5/6/91, 21/5/93, 1/6/95.

P. galiata, Hb.--Local and scarce, variable. Bishopton (W. W.); W. Kilbride (J.Sm.); Cumbraes (H.C.) ; Arran (J. J. W.).

Hydriomena ocellata, L.-Universally dist., and very c., e.d. 23/6/90, $17 / 6 / 92,1 / 6 / 93,1 / 6 / 95$.

H. simulata, Hb.-Local and r. Craigmaddie 6/9/9l (R. H.); nr. Glasgow (T. C.); Arran (R. Weaver); Tayvallich 8/1900, c. (A. M.S.).

H. variata, Schiff.-Abund. pine woods Renfrew, not so c. elsewhere, variable, e. d. $21 / 5 / 93,8 / 6 / 90$; latest 16/9/91, $12 / 9 / 95$.

var. obliterata, White-Commonest form, almost black.

H. juniperata, L.-Local and r. on juniper. Nr. Glasgow (J.S.); Kirn several 10/92 (E. C. E.) ; Arran (R. Weaver) ; Kilberry (M. L. C.). 
H. fulvata, For'st. - C. amongst rose bushes everywhere, e. d. 31/7/92, 16/7/93, $5 / 7 / 95$.

H. dotata, L.-Widely dist., often locally abund., e.d. 16/7/91, 31/7/92, 11/7/96.

H. miata, L.-Local, unc., variable. Inveruglas 18/9/95; Luss 23/9/92 (A.A.D.) ; Garelochhead ; Kilcreggan (T. J. H.) ; Dunoon ; nr. Glasgow (T. C.) ; Douglas (J. A. M.) ; Ayr 20/9/94 (W. F.).

H. siterata, Hufn.-Local and une. Ardlui ; Inveruglas 20/9/95 (A. A. D.); Dunoon 20 Sept. (H. T. Stainton); Immellan (T. C.) ; Paisley (J. D.); Fullerton (J.P. D.) ; Ayr 20/9/94 (W. F.) ; Kilberry (M. L. C.).

H. sordidata, Fb. - Abund. everywhere, extremely variable, e. d. 29/7/93, 6/8/95, 20/7/96. Red heath-feeding form on Gourock, Arran, and S. Ayrshire hills.

var. infuscata, Std.-Black form, c. in woods. Nr. Glasgow; Renfrew.

H. trifasciata, Bkh.-Widely dist., abund. amongst alders, extremely variable, e. d. 1/6/89, 22/5/90, 19/5/98.

H. ruberata, Frr.-Local and r. Lochgoilhead 21/5/93 (A. A. D.) ; Garelochhead (T. J. H.) ; Eaglesham (J.J.K.) ; Kilberry (M. L. C.).

H. truncata, Hufn.-Local, but widely dist., very variable, e.d. 16/7/91, $5 / 7 / 93,5 / 6 / 95$, till middle of Augt.

var. comma-notatum, Haw.-Giffinock (A. A. D.); Ayr (W. F.) ; Arran.

H. immanata, Hav.-C. almost everywhere, very variable, e.d. 24/7/91, 24/7/92, 29/7/93 ; latest 19/9/91, 23/9/94, 20/9/95.

var. unicolorata, Std.-One almost black, Inveruglas.

H. silaceata, Hb.--Not unc. ; Dunoon (T. C.) ; Lochgoilhead 21/5/93, 1/6/94 ; Ardlui 21/5/96 (A. A. D.) ; Garelochhead (T. J. H.) ; Port Glasgow (J.D.) ; Cadder (C. B. C.) ; Girvan (G. W. O.) ; Corrie 2/7/87 (A.A.D.); Howwood (A. M. S.).

H. corylata, Thnb.-Freq. ; Dunoon (T. C.) ; Lochgoilhead 5/6/91, 21/5/93 (A. A. D.) ; Garelochhead (T. J. H.) ; Cadder (G. W. O.) ; Fullerton (J. Sm.) ; Corrie (A. A. D.).

H. suffumata, $H b$.-Widely dist., locally inclined, variable, e.d. 10/5/90, 2/5/95, 22/4/96.

var. piceata, Steph.--Freq. in Renfrew woods, etc.

H. caesiata, Lang.-Abund. and widely dist., on rocks on hillsides, e.d. 15/7/93, 1/7/95, 17/7/96. Exceedingly variable, Renfrew and Arran specimens darkest.

H. flavicinctata, Hb.-Local but not unc. Lochgoilhead 8/92 (A.A.D., J. W. Tutt.); Water-courses above Ardentinny (T. C.).

H. dubitata, L.-R., Sept. Douglas (J. A. M.).

H. badiata, $H b$.-Locally c., variable. Garelochhead (T. J. H.) ; Giffnock 4/4/93, 9/5/95, 22/4/96 (A. A. D.) ; Linwood (W.S.) ; Monkton (J. P. D.).

H. nigrofasciaria, Gz.-Local and r. Ardentinny (T.C.) ; Lochgoilhead 17/6/92 (A.A.D.) ; Garelochhead (T.J.H.) ; Port-Bannatyne (W.S.) ; Dundonald (J. Sm.).

H. rubidata, Fb.-Arran (J. J. W., Ent. xv. 250).

H. albicillata, L.-R., Monkton (J. P. D.); Kilwinning (J. Sm.).

H. adaequata, Bkh.-Locally c. Lochgoilhead (T. C.); Arrochar 17/7/91; Ardlui 27/5/96; Glenmallan 9/7/98 (A.A.D.); Garelochhead ; nr. Glasgow (T. J. H.).

H. minorata, Tr.-Local, sometimes abund. Blairmore (A.S.) ; Coulport 14/7/97 ; Luss 12/7/93 (A. A. D.) ; Garelochhead (T. J. H) ; Fintry (E. C. E.) ; Innellan 13/7/88 (A. A. D.) ; Carradale (G. W. O.).

H. unifasciata, Haw.-Very local, unc. Giffnock Quarries 4/8/92, 4/8/93 (A. A. D.) ; Paisley (J. D.) ; Johnstone (W.W.) ; Ardrossan 1857 and 74 (H. C.) ; Arran (R. Weaver).

H. alchemillata, L.-Widely dist., sometimes locally abund, e.d. 20/6/93, $14 / 6 / 94,23 / 6 / 95$. 
H. affinitata, Stph.-Generally scarce. Tarbert 18/7/86; L. Riddon 21/7/92; Ballantrae c. 7/8/97 (A. A. D.) ; Possil (E. C. E.) ; Ayr (W. C.S. F.); Girvan (G. W. O.) ; Arran (W.S., J.J. W.) ; Tayvallich (A. M.S.).

H. decolorata, Hb. - Sometimes c. Fintry (E. C. E.); Cadder (G. W. O.); Camıuslang 17/6/88 ; Giffnock 19/6/91, 6/6/95 (A.A. D.) ; Milliken Park (A. M. S.) ; Linwood (W. S.) ; Girvan (G. W. O.) ; Lochgoil (T. C.).

H. albulata, Schiff.-Widely dist., abund., varies slightly, e.d. 22/6/92, $20 / 6 / 93 ; 30 / 6 / 94 ; 31 / 5 / 95$.

H. bilineata, L.-Universally dist., abund. banded forms c., e.d. 30/6/90, $5 / 7 / 93,21 / 6 / 94$.

H. lapidata, Hb.-Widely dist. moors, abund. 1894, scarce since. Dunoon 13/9/57 (T. C.) ; L. Riddon (J. D., IV. M. C.) ; Kilberry (M. L. C.) ; GI. Messan (J.J.K.) ; Fintry (E. C. E.) ; Kilsyth Hills (A. A. D.) ; Lanark Hills (K.J. Morton) ; Carrick Hill 20/9/9+ (W. F.); e.d. 12/9/96, 7/9/97, 9/9/98.

Pelurga comitata, L.-Not c. Pollokshields 25/7/88 (A. A. D.) ; Paisley (J.D., W.S., A.E.) ; Monkton (J. P. D.); Ayr (W. F., T. W.); Corrie $8 / 7 / 87$ (A. A. D., H. L.).

Operophtera brumata, L.-Abund. on hedges everywhere, dark, and banded vars., freq.; e.d. 6/11/97, 31/10/98, 18/10/00.

o. boreata, Hb.-Freq., becoming commoner lately. Milngavie 6/11/97 (A. A. D.) ; W. end Paisley; Kilbarchan (A. M. S.) ; Bonhill (J.R. M.) ; Kilmarnock (G R.).

Euchoeca luteata, Schiff.-Local and r. Ardentinny (T. C.) ; Lochgoilhead several 18/6/92, 21/5/93, Glenmallan 1 sp. 2/7/93 (A. A. D.).

Asthena candidata, Schiff-Locally c. Ardentinny (T. C.) ; Lochgoilhead 18/6/92, 21/5/93 (A. A. D.) ; Garelochhead (T. J. H.) ; Arran (J. J. W.).

A. dilutata, Bkh.-Oak woods, abund. pale and dark banded vars. freq., e.d. $24 / 9 / 87,10 / 10 / 89,27 / 9 / 96$.

var. obscurata, Std.-Dark unicolorous, freq. Paisley woods.

A. filigrammaria, H. S-High on Goatfell (R. Weaver, Zool. 3496); L Ridrlon (IV. M. C.) ; Bonhill (J. M.) ; Douglas (J. A. M.).

A. autumnaria, Gn.-Local and r. Among birches Ardentinny (T.C.); Gl. Falloch several 27/9/96 (A. A. D.).

Venusia cambrica, Curt.-Local. Ardentinny (T. C.); Glenmallan 3/7/97; Luss 5/7/93 (A. A. D.) ; Garelochhead (T. J. H.) ; Dargavel, Renfrew (A. II. S.); Girvan (G. W. O.) ; Corrie abund. 2-18/7/87 (A.A.D.); Tayvallich c. (A. M. S.).

Xanthorhoe vittata, Bkh.-Lncal, sometimes abund. Giffnock 1/7/93 (A.A.D.) ; nr. Paisley (J.D., A. M.S.) ; Linwood (W.S.) ; L. Riddon $12 / 7 / 89$; Tarbert $10 / 7 / 86$ (A. A. D.).

X. cervinata, Schiff.-R. Ardrossan (H. C.); Arran (A. B. W.).

X. limitata, $S c .-$ Widely dist., locally abund., very variable, e. d. 3/8/90, $1 / 8 / 92,28 / 7 / 93$.

X. plumbaria, $F$ b.--Local. Tarbert $5 / 7 / 86$ abund. (A. A. D.) ; Garelochhead (T.J.H.); Greenock (A.S.); Paisley (W.S.); Ayr 12/6/94 (W. F.); Corrie 2/7/87 (A. A. D., H. L.).

X. bipunctaria, Schiff.-Arran (J.J. W., Ent. xv. 250).

X. multistrigaria, Huv.-Locally c. Dunoon 6th Apl. (T. C.) ; Fintry (E. C. E.); Cadder (C. B. C.); Giffnock 31/3/90, 29/3/93 (A. A. D.); Paisley (A. M. S., W. S.).

X. didymata, L.-Universally abund., variable, e.d. 16/7/92, 21/7/93, $23 / 7 / 94$.

X. spadicearia, Bkh. (=ferrugaria, Haw.)-. Widely dist. moors, sometimes locally abund., e. d. $23 / 5 / 95,19 / 6 / 97,11 / 6 / 98$; latest $3 / 9 / 98$.

X. ferrugata, L. (=unidentaria, Haw.) -Widely dist., never c., e. d. 17/6/92, $31 / 5 / 95,19 / 5 / 00$. 
X. designata, Rott.-Universally dist., c. May till Augt., e.d. 23/5/89; $5 / 6 / 91 ; 21 / 5 / 92$.

X. munitata, Hb.--Locally abund. in all counties, e.d. 21/7/92; 8/7/93; 12/7/95.

X. firmata, $H b$.-Freq. ; Inveruglas 1/9/95 (A. A.D.) ; Bonhill (J. M.) ; Craigmaddie (G.W. O.); Clarkston 23/8/99 (A.A.D.); Paisley Moss (M. Y.) ; Dargavel (A. M. S.); Troon (W.S.).

X. montanata, Bkh.-Very abund. everywhere, variable, e.d 5/6/91; $17 / 6 / 92 ; 21 / 5 / 93$. The late T. J. Henderson took two with median band only reaching from costa to middle. In one from Giffuock it is entirely awanting.

X. fluctuata, L-Abund. gardens, etc., very lark, e.d. 16/5/93; 27/5/94; $13 / 5 / 95$; latest $12 / 9 / 91$.

X. salicata, $H b$. - Local, sometimes abund. rocks on hillsides. Lochgoilhead $1 / 6 / 94$ (T. C., A. A. D.) ; Tarbert (G. W. O.) ; L. Riddon (W. M. C.) ; Milliken Park 12/6/97 (A.M.S.); Gourock Hills 17/6/99 (A. A.D.); occasionally at end of July and beginning of 'Aug.

X. olivata, Bkh.-Widely dist., often locally abund., e.d. 24/7/97; 9/7/98; $18 / 7 / 99$.

$\mathrm{X}$. viridaria, $\mathrm{Fb}$.-Abund. woods and moorlands, large and brightly coloured, e.d. $20 / 6 / 93 ; 7 / 6 / 94 ; 1 / 6 / 9$.

\section{Fam. Sterrhidae.}

Eois virgularia, $H b .-$ C. Renfrew (J. S.).

E. dilutaria, $H b$.-Local and r.; Garelochhead (T. J. H.) ; Tarbert, L. Fyne, 3, July 1886 (A. A. D.).

E. aversata, L.-Widely dist., sometinies locally c., especially in gardens, e. d. $24 / 7 / 92 ; 10 / 7 / 93 ; 29 / 6 / 94$.

E. dimidiata, Hufn.-Local and une. Crookston 27/6/95; 28/6/98 (A. A. D.). Freq. in Ayrshire (J.Sm.); Dundonald 14/7/00 (A. A. D.).

E. trigeminata, Haw.-Scarce, Renfrew (J.S.).

E. bisetata, Hufn.-Locally c., Tarbert $11 / 7 / 86$; L. Riddon $8 / 7 / 89$ (A.A.D.); Garelochhead (T.J.H.) ; Gourock (J.D.); Monkton (J.P.D.) ; Barr 16/7/99 (A. A. U.).

Leptomeris remutaria, Hb.-Locally c. Ardentimny (T. C.) ; Lochgoilhead 5/6/91 ; 1/6/94 (A. A. D.) ; Garelochhead (T.J.H.); Incheonnachan, L. Lomond (G. W. O.).

L. immutata, L.-Arran (J. J. W., Ent. xv. 250).

L. marginepunctata, Gz.--Ardrossan, middle June to end July rocks in dry pastures (H. C.) ; very dark.

Pylarge fumata, Stph.-Moorlands all over district, locally c., e.d. 10/7/97; $9 / 7 / 98 ; 14 / 7 / 00$.

Leucophthalmia orbicularia, Hb.-One Blackstone Woods, Renfrew (M. Y.).

L. pendularia, Cl.-Very r. ; Argyle (T. C.) ; Luss (R. F. Logan) ; Garelochhead (T.J.H.) ; Innellan (H.C.) ; Corrie 2/7/87 (A.A.D.); Tayvallich (A. M.S.).

L. porata, Fb.-Singly and r. Lochgoilhead (A.S.) ; Kilmum (J.S.) ; Garelochhead (T. J. H.) ; Arran (J. J. W.).

L. punctaria, L.-Local. Ardentinny c. (T. C.) ; Lochgoilhead, several, $17 / 6 / 92 ; 21 / 5 / 93$ (A. A. D.); Garelochhead (T. J. H.); Whiteinch (C. B.C.) ; Linwood (A.M.S.); Monkton (J.Sin.).

Calothysanis amata, L.-One Linwood, Renfrew (W.S.); Arran (J.J. W.).

\section{Fam. Geometridae.}

Euchloris lactearia, L.-Locally c. ; Ardentinny (T. C.) ; Tarbert 5/7/86 ; Lochgoilhead 21/5/93 ; 1/6/94 (A. A. D.) ; Is. L. Lomond (G.W.O ) ; L. Riddon (W. M. C.) ; Ayr (W. F.). 
Geometra papilionaria, L.-Freq.; Ardlui (T. C.); Luss c. 5-31/7/93 (A. A.D.); Garelochhead (T. J.H., A.M.) ; Renfrewshire (J.G.) ; L. Riddon 10/7/89 (A. A. D) ; Arran (W.S., J.J. W.).

Pseudoterpna pruinata, Hufn.-Local and r. ; Luss (R. F. Logan) ; Prestwick 30/7/94 (J. P. D., A. M'C., W.S.).

\section{Fam. Monocteniadae.}

Baptria atrata, L.-Widely dist., and locally abund., e.d. 24/5/88 ; 17/6/92 ; $17 / 6 / 95$.

Erannis aescularia, Schiff.-Not c. ; Renfrew (J. S.) ; Johnstone 20/2/97 (A. A. D.) ; Gourock (T. C.) ; L. Riddon (W. M. C.) ; Ayr 20/3/95 (W. F.).

\section{Fam. Selidosemidae.}

Opisthograptis liturata, Cl.-Scarce; Ardentinny (T. C.) ; Lochgoilhead 19/6/92 (A. A. D.) ; Cadder (C. B. C.) ; Bishopton several (W. S., A. E.) ; Kilmarnock (G. R.) ; Dailly (G. W. O.) ; Arran (R. Weaver).

O. clathrata, L.-C., Railway embankment S. of Ayr 9/5/94; 25/5/95; 19/5/00 (W. F.) ; Shewalton (T. W.).

O. luteolata, L.-Abund., in hawthorn hedges all over district, e.d. 23/5/93 ; $3 / 6 / 95 ; 24 / 5 / 98$ occasionally in Augt.

Diastictis wauaria, L.--Widely dist., sometimes abund., in gardens, e.d. $13 / 7 / 87 ; 3 / 8 / 92 ; 21 / 7 / 93$.

Ectropis biundularia, Bkh.-Locally c., larch woods ; Ardlui 18/5/99; Lochgoilhead 21/5/93 (A.A. D.); Ardentinny (T.C.); Inchconnachan (A. M'C.); Kirn (E. C. E) ; Arran (W. E.).

Deileptenia abietaria, $H b .-\mathrm{Nr}$. Dumbarton (M. Y.).

Cleora lichenaria, Hufn.-R. ; Glasgow (T. C.) ; Monkton (J. P. D.) ; Ayr 26/7/94 (W. F.) ; Girvan (G. W. O.) ; Barr 21/7/99 (A. A. D.) ; Kilberry (M. L. C.).

Selidosema ericetaria, Vill.-Arran (J. J. W., Ent. xv. 250).

S. repandata, L.-Abund., variable, widely dist., e.d. 27/6 89 ; 13/7/92; $5 / 7 / 93$.

var. conversaria, Hb.-Broad dark banded Arran ; Argyll.

var. sodorensium, Weir.-Leaden grey; commonest form, Arran sp. generally darker.

S. glabraria, $H b$.- Reported for Clyde (F. B. W.); several in woods nr. Inveraray during last 4 years (J.A. N.).

S. gemmaria, Brh._Local and r.; Garelochhead (T. J. H.) ; Cumbraes (H. C.); Ayr 7/7/94 (W. F.) ; Girvan (G. W. O.).

Bupalus piniarius, L.-Widely dist., pine woods, often abund., e.d. 14/6/90; $6 / 6 / 94 ; 8 / 6 / 95$.

B. atomarius, L.-Abund., moors everywhere, variable several dark brown unicolorous sp. from Renfrewshire, e.d. $23 / 5 / 94 ; 16 / 5 / 96 ; 19 / 5 / 98$.

Abraxas grossulariata, L.-Abund. gardens, e.d. $24 / 6 / 87 ; 16 / 7 / 92 ; 1 / 7 / 95$. Larvae on Cotyledon umbilicus? Ailsa Craig (Thos. Chapman).

A. sylvata, Sc.-Local in Ayrshire, Prestwick once (J. P. D.); PinwhappleGl., Girvan abund. (G. W. O.).

A. adustata, Schiff.-Arran (J.J. W., Ent. xv. 250).

A. marginata, L.-Locally c., markings very variable. Lochgoilhead 30/6/88; 21/5/93. Gl. Falloch 21/5/96 (A.A.D.) ; Garelochhead (T.J. H.); Monkton (J.P.D.) ; Girvan (G. W. O.) ; Arran (J.J. W.).

Pseudopanthera macularia, L.-Local and r. Yoker (M. Y.) ; Mugdock 18/5/90 (G. W. O.) ; and 26/5/95 (R. H.) ; Milngavie 2/6/92 (A. A. D.) ; Girvan (J. Sm.) ; Arran (J. J. W.).

P. obscuraria, Hb.-Local and unc. Cumbrae (W.S., A. M. S.) ; Ardrossan. (H. C.) ; Tayvallich (A. M. S.). 
P. obfuscaria, Hb.-Locally c., variable. Dumoon (T. C.) ; Garelochhead (T. J. H.); Gourock 19/7/96 ; 10/7/97 (A. A. D.); Arran c. (J.J.W., W. S., etc.).

P. petraria, Hb.-C. Ardentinny (T. C.) ; Arrochar 19/5/98; Gl. Falloch 11/5/95 (A. A. D.) ; Garelochhead (T. J. H.) ; Inchmoan (G. W. O.).

Crocota belgaria, Hb.-Freq. moors. Dumoon; L. Long (T. C.) ; Tarbert 5/7/86 (A. A. D.) ; Garelochhead (T. J. H.) ; Garnkirk (G. W. O.) ; Greenock 12/6/58 (A.S.) ; Irvine 22/7/00 (A. A. D.) ; Arran (W. S.).

C. strigillaria. Hb.-Very local but c. Linwood; Bishopton ; Renfrew (J.D., A. M.S., W.S., etc.).

Theria rupicapraria, Hb.-Locally c. Renfrew 8/2/51 (J.S., Zool. 3061); Johnstone (W. W.) ; Killarchan $4 / 3 / 00$ (A. M. S.) ; Kilmarnock (G. R.); Ayr at light 20/3/95 (W. F.).

Hybernia leucophaearia, Schiff.-Not unc. (J.S.) probably Renfrew. No recent records.

H. marginaria, Bkl.-Abund. everywhere, variable, e.d. 20/2/97; 5/3/98; 25/2/99. Very dark unicolorous specintens in Renfrew.

H. aurantiaria, Esp._Local and unc. Cadder (C. B. C., T. J. H.) ; Garelochhead (T. J. H.); Paisley Woods (M. Y.).

H. defoliaria, Cl.- Oak woods, very variable, larvae abund. Inveruglas 20/9/95 (A. A.D.) ; Garelochhead (T.J.H.) ; Fintry (E. C. E.) ; Milngavie (G. W. O.) ; Cadder 13/10/96 (E. C. E., C. B. C.) ; nr. Paisley (J. D.) ; Argyll (T. C.) ; freq. Ayrshire (J. Sm.).

Apocheima pedaria, $F b$.C.C. and widely dist., variable, e.d. 15/2/96;20/2/97; $17 / 3 / 00$.

Biston hirtarius, Cl.-Pupa in Renfrew (M. Y.) : nr. Paisley (J. D.).

B. betularius, L.-Not unc.; Kilmartin (H. V.); L. Riddon (W. M. C.) ; Garelochhead (T. J. H.) ; Luss, larvae (A. A. D.) ; Inchmoan (G. W. O.) ; Paisley (J. D.) ; Gourock 25/6/97 (A.A.D.) ; Arr bred 22/5/95 (W. F.); Rothesay (T. Grant).

var. Doubledayaria, Mill.-Bred from larvae, nr. Paisley (J. Dunsmore).

Deilinia pursaria, L.-Abund. evervwhere, ed. 25/5/95; 26/6/97; 19/5/00.

D. exanthemata, Sc.-Gen. dist., e.d. 5/6/91; $17 / 6 / 92 ; 1 / 6 / 93$.

Ourapteryx sambucaria, L.-Local and r. ; nr. Glasgow (T. C.) ; Milngavie 22/7/85 (A. A. D.) ; Ayr 26/7/91 (A. Mumro, W. F.) ; Dundonald (J. Sm.).

Metrocampa prosapiaria, L.-Never c. ; Lochgoilhead 19/692 (A. A. D.); Garelochhead (T.J.H.) ; Fintry (E.C. E.) ; Cadder (C.B. C.) ; Douglas (J. A. M.) ; Bishopton (W.S., A. M. S.) ; Arran 3/7/87 (A. A. D., H. L.).

M. margaritaria, L.-Scarce nr. Glasgow, abund. elsewhere all over district, e.d. $30 / 6 / 88 ; 27 / 6 / 89 ; 10 / 7 / 93$.

M. pulveraria, L.-Freq. ; Dunoon ; Ardentimny (T.C.) ; Lochgoilhead $17 / 6 / 92$; $1 / 6 / 94$; Ardlui 14/6/95 (A. A.D.) ; Garelochhead (T. J. H.).

Euchlaena prunaria, L.-Arran (J. J. W. Ent. xv. 250).

E. apiciaria, Schiff.-Dumoon (T. C.); Lochgoilhead not unc. 27/8/89 (A. A. D., J. W. Tutt); Renfrew (J. S.).

Selenia bilunaria, Esp.--Widely dist., seldom c.; Lochgoilhead (A.M.); Dumbarton (R.H.) ; Cadder (C.B.C.) ; Lanark (J.G.) ; Giffnock 6/5/87; 13/5/93 (A. A. D.) ; Paisley (W. S.) ; Kilmarnock (G. R.) ; Arran (J. J. W).

S. Iunaria, Schiff.-Very r. c ; Monkton (J.P.D.) ; 2 at light Ayr 25/5/94 (W.F.) ; Inveraray (J. A. N.).

Colotois pennaria, L.-Freq.; L. Riddon (W. M. C.); Dunoon (H.C.) ; Bonhill (J. M.); Milngavie bred 3/10/94 (A. A. D.) ; nr. Glasgow (T. C.); Paisley (J. D.) ; Ayr 10/10/94 (W. F.) ; Kilberry (M. L. C.).

Ennomos erosaria, Bkh.-R. ; Inveruglas 8/9/95 (A. A. D.); Drymen 9/1895 (G. W. O.). 
E. alniaria, L.-Freq. ; Ardentinny (T. C.); Dumoou (H. C.); L. Riddon (W. M. C.); Luss $13 / 9 / 91$ (A. A.D.) ; Ayr 4/9 94(W. F., J. G.) ; Arran (W.S., A. E.).

E. quercinaria, L.-Dunoon from oak (T. C.).

Gonodontis bidentata, $\mathrm{Cl}$.-C., widely dist., dark and variable, e.d. 18/6/92 ; $235 / 94 ; 23 / 597$.

G. elinguaria, L.-Widely dist., sometimes locally c., variable, e.d. 13/7/89 ; $27 / 7 / 93 ; 29 / 7 / 94$.

\section{Fam. Polyplocidae.}

Habrosyne derasa, L.-Very r. ; Southbar ; Gourock (J. D.).

Thyatira batis, L.-C. at sugar; Dunoon (T.C.) ; Lochgoilhead 18/6/92 ; $21 / 593$ (A.A.D.) ; Linwood (W.S.) ; Avr 25694 (W. F.) ; Girvan (G. W. O.) ; Arran (T. C.) ; Carradale (G. W. O.).

Palimpsestis duplaris, L.-Freq.; Ardentinny 10/7/08 (A.S.); Glenmallan 3797 ; $9 / 7 / 98$ (A.A.D.) ; Lanark (J.G.); Paisley (J.D.) ; Tarbert 8/7/86; Corrie $7 / 7 / 87$ (A. A. D.).

var obscura, Tutt.-Nr. Paisley ; L. Long.

P. or, $F b$.-Larvae on aspen L. Long ; L. Goil (T. A. C.) ; L. Lomond (T. C.) ; nr. Glasgow (J. G.).

Polyploca diluta, Fb.-One bred from pupa Paisley woods (M. Y.).

P. flavicornis, L.-Ereq., larvae c. on hirch. Dunoon (T.C.); Bonhill (.J.M.) ; nr. Glasgow (H.C.) ; Renfrew (J.S.) ; Johnstone 8/3/97 ; Inverkip 3/4/97 (A. A. D.) ; Kilberry (M. L. C.).

\section{Fam. Sphingidae.}

Hemaris bombyliformis, Esp.-Larvae occasionally on Scabiosa. Dunoon 27th May (T. C.) ; L. Riddon (W. M. C.) ; Garelochhear 31/5/58 (A. S.) ; Ayrshire (J. P. D., Mr. Tainsh teste T.C.) ; nr. Paisley (J. D.).

H. fuciformis, L.-Scarce nr. Paisley (J.S.); 1 . in Ayrshire (J.Sm.).

Macroglossa stellatarum, L.-Uncertain, abund. in 1899. Inveraray (J. A. N.) ; Fintry ; Glasgow (E. C. E.) ; Thankerton (Rev. J. D. Gibson); Kilbarchan 6/1899 (A. II.S.); Monkton freq. 1851 (J. D. P.) ; Arrau (J. J. IV.).

Deilephila porcellus, L.-C. Ayrshire, Irvine; larva full fed $3 / 9 / 00$ (A. A. D.); Monkton (J. P. D.) ; Ayr 24/6/99 (T. W.) ; Girran (G. R.); Lendalfoot (Berry); Troon (W. E.).

D. elpenor, L.-Clyde (B. F. W. Scot. Nat.) ; Lendalfoot, Ayr (R. Dunlop).

D. celerio, L.-Scarce immigrant. One in greenhouse Hamilton, scarce in Ayrshire (J. P. D.).

D. nerii, L.-Immigrant. One Glasgow 10/9/86 (J.E. Wilson); one nr. Barrhead end of Sept. 1900 (T. Grant).

D. lineata, $F b$.-One nr. Glasgow about 1845 (J. G.).

D. euphorbiae, L.-Monkton, Ayrshire (R. Dunlop).

D. galii, Rott.-Very r.; Glasgow 9/1888 (E.C.E.) ; Larvae Monkton (J.P.D.) ; one caught and several seen $\mathrm{mr}$. Kilmarnock by Miss Stewart (IV. D. Robinson).

Sphinx ligustri, L.-R. ; nr. Glasgow about 1846 (J. G.) ; Banks of Kelviu 1897 (J. Brand) ; Possil Marsh (C. B. C.) ; nr. Kilmarnock (R. Dunlop).

S. convolvuli, L.-R. ; Row $9 / 1875$ (J. H. Pearson); Glasgow (J..J.K.); Paisley (J.S.) ; Kilbarchan 9/97 (A. M.S.) ; Ayr 9/94 (IT. F.) ; Lamlash $3 / 9 / 47$ (IW. T. C. Thomson).

Acherontia atropos, L.-Kirn (A. M'C. ); Vale of Leven (J. M.) ; Campsie (C. B. C.) ; Glasgow 20/9/00 (A. A. D., J.J. K.) ; Giffnock (G. W. O.) ; Renfrew (J. S.) ; Paisley 12/6/97; larvae Port Glasgow (Taylor) ; Bishoptın (P. H. Grimshaw); Milliken Park (W. W.); Greenock (J. G.); Kilmarnock 10/7/00 (G. R.); Lendalfoot; larva and pupa 8/1900 (T. W.); Stranraer (J. G. G.). 
Smerinthus populi, L.-Larvae abund. ; poplar, willow all over district. Dilina tiliae, L.-Very r., nr. Hamilton 1859 (Mr. Lang teste T. C.) ; once nr. Houston (J. D.) ; nr. Kilmarnock (R. Dunlop).

\section{Fam. Notodontidae.}

Pygaera pigra, Hufn.-Dunoon, larvae plentiful (T. C.); Garelochhead (T.J. H.) ; Paisley (M. Y.) ; Kilberry (M. L. C.).

Notodonta ziczac, L.-Larvae c. on poplar and willow. Dunoon (T. C.) ; Inveraray (.J. A. N.) ; Garelochhead (T. J. H.) ; Lanark (J. G.) ; Crookston (A. A. D.) ; Ayrshire (J.S. M.) ; Arran (H. L.).

N. dromedarius, L.-Iarvae c. on birch. Kippen (G. W. O.) ; L. Lomond ; Dunoon (T. C.) ; Lanark (J. G.) ; Dargavel (W. S., A. M. S.) ; Kilmarnock (G. R.) ; Ayr (W. F.) ; Corrie 5/7/87 (A.A.D., H.L.).

N. tritophus, Esp.-One in Renfrewshire (M. Y.) second British capture.

Drymonia dictaeoides, Esp.-Not c., larvaeon birch. Ardentinny ; Gareloch ; L. Lomond (T. C.) ; Inveraray (J. A. N.) ; Kilwinning (J. S.) ; Corrie $15 / 7 / 87$ (A. A. D., H. L.) ; Kilberry (M. L. C.).

D. tremula, $C l$ (=dictaea, Esp.).-Larvae c., on willow and alder. Ardentinny (T. C.) ; Luss (A. A. D.) ; Garelochhead (T. J. H.) ; Lanark (J. G.) ; Dargavel (J. D.) ; Monkton (J. P. D.) ; Ayr (T. W.).

D. trepida, Esp.-Larva at Arrochar (T. C.).

D. trimacula, Esp.-Very r. ; Ardentinny, 1858 (T. C.) ; Luss (R. F. Logan).

D. chaonia, $H b$.-Once nr. Johnstone (W. W.) ; once L. Riddon (W. M. C.).

Pterostoma palpina, L.-Once nr. Monkton (J. P. D.).

Odontosia camelina, L.--Larvae abund. on beech, etc., e.d. 5/6/91 ; 3/6/92 ; $1 / 6 / 95$.

O. carmelita, Esp.-Larvae at Ardentinny, L. Long 1858 (T. C.).

Cerura vinula, L.-Widely dist., larvae c. on willow, full fed end of July, bred $26 / 5 / 91 ; 20 / 5 / 95$.

C. furcula, L.-Local, but not unc. Lanark (J. G.) ; nr. Glasgow (T. C.) ; Paisley (M. Y.) ; Loch Riddon (W. M. C.) ; Monkton (J. P. D.).

Phalera bucephala, L.-Larvae Abund., Augt. \& Sept. on oak, willow, alder, etc., bred, $12 / 5 / 97 ; 19 / 5 / 98 ; 23 / 4 / 00$.

\section{Fam. Saturniadae.}

Saturnia pavonia, L.—C., moors all over district, e.d., 12/5/97; 19/5/98 ; $23 / 4 / 00$.

\section{LASIOCA MPINA.}

\section{Fam. Drepanidae.}

Cilix glaucata, Sc.-Locally c. ; Paisley (J. D.) ; Renfrew (J.S.) ; Rothesay 6/1889 (A. A. D.) ; Ayr 6/6/95 (W. F.) ; Whiting Bay 6/1856 (A. S.).

Falcaria lacertinaria, L.-Freq. ; Dunoon ; Ardentinny (T. C.) ; Lochgoilhead 5/6/91 ; 18/6/92 (A. A. D.) ; Inchmoan (G. W. O.) ; L. Riddon (W. M. C.) ; Paisley (J. D.) ; Corrie (H. L.) ; Lamlash (W.S.).

F. falcataria, L.-Freq.; Dunoon (T. C.) ; Lochgoilhead 5/6/91 ; 18/6/92 ; Ardlui; larva on alder, bred 23/5/97 (A. A. D.); Garelochhead (T.J.H.); Milngavie 14/6/91 (R. H.) ; Arran (H. L.).

\section{Fam. Lasiocampidae.}

Lasiocampa quercus, L.-A bund. moors, widely dist., but somewhat local. Our specimens all var. callunae, Palmer, e.d. 6/7/86;10/7/97;12/7/99.

Eriogaster populi, L.-Freq. at light. Lochgoilhead 11/96 (A. A. D.) ; Kilmun (A. S.) ; Dunoon (H. C.) ; Garelochlead (T. J. H.) ; Shandon 10/98 (T. Grant) ; Barr 11/94 (W. F.).

E. lanestris, L.-Various places on Firth of Clyde (J. G.). 
E. rubi, L.-Larvae abund. hills and moors, everywhere, e.d. $1 / 6 / 95 ; 13 / 6 / 97$.

E. crataegi, L.-Very r. in Ayr (J. P. D.) ; one Lamlash (W. S.).

Odonestis potatoria, L.-Locally abund. Inveraray (J.A. N.) ; Arrochar 6/7/91 ; Glenmallan 10/7/97 (A. A. D.) ; Inchmoan (G. W. O.) ; Rower. dennan (J. A. M.) ; Fintry (E. C. E.); L. Riddon (W. M. C.) ; Bute (T. C.) ; Kilmarnock (G. R.) ; Monkton (T. W.).

$$
\text { PAPILIONINA. }
$$

\section{Fam. Nymphalidae.}

Argynnis paphia, L.--One nr. Arrochar (M. Y.) ; Newman gives specimen by Birchall same locality. Perhaps the same record.

A. aglaia, L.-All over Dumbarton and Argyll hills ; Bute ; Arran ; locally abund. in several localities in Ayr, e.d. 4/7/87, 17/7/97, 7/7/00.

A. euphrosyne, L.-No recent records. Argyll, not unc. (T. C.) ; Garelochhead 31/5/88 (A. S., T. J. H.) ; Dundonald ; Castle hill, Ayr (J. P. D.) ; Arran (D. Landsborough).

A. selene, Schiff.-Universally dist., locally c., e.d. 5/6/91;18/6/92;1/6/95.

Melitaea aurinia, Rott.--Pupa Gl. Messan ; imagines abund. Dunoon (T. C.); Farm of Jangholm and nr. Dundonald, Ayrshire (J. P. D.) ; Kilmartin (H. V.) ; Kilberry (M. L. C.).

Vanessa urticae, L.-Abund. everywhere. Large and richly coloured. Hy. Apl. and May, e.d. 13/7/89, 1/7/93, 4/8/00.

V. polychloros, L.-One Castle Sweyne, South Napdale 20/7/87 (J. Mackay); one seen Cairn Ryan (J. G. G.).

V. io, L.-Very r ; Hamilton once (W. Forsyth); Bonhill (J. M.) ; W. Kilbride (D. A. Boyd); Stevenston (Marshall, teste J.Sm.); Monkton larvae 1857; Symington (J. P. D.) ; Arran (T. C., A. Noble) ; in Glasgow (teste E. C. E.).

V. antiopa, L.-Two nr. Paisley by Mr. Strang 1852 (teste T. C.) (note J. S. Zool. xvi. 6065); Mr. J. Smith reports another nr. Beith.

V. atalanta, L.-C. some years. Abund. in 1894, 1899 and $1900 . \mathrm{Hy}$. May and June, e.d. 16/8/98;19/8/99;17/8/00.

V. cardui, L.-Uncertain and migratory. Campsie (T. C.) ; Garelochhead ; Kilcreggan (T.J.H.) ; Baldernock 7/98 (G. W. O.) ; Barrhead 25/6/88 (A. A. D.) ; Paisley (W.S.) ; Ayr 9/94 (W. F.); Arran (A. B. W., A. Noble).

\section{Fam. Satyridae.}

Pararge àegeria, L.-R; Inveraray (T. C.) ; Cadzow (H. C.) ; Ballochmyle, 4th May (J. P. D.) ; Arran (H.C.) ; Tayvallich 8/1900 (A. M. S.).

P. megaera, L.-R ; Ardrossan (H. C.) ; every parish in Ayr (J.P.D.) ; Whiting B. $6 / 1856$ (A.S.).

Satyrus semele, L.-Locally abund. ; Argyll (T. C.) ; Erskine Ferry (J.S.); all along coast Saltcoats to Ballantrae; locally abund. Arran, e.d. $7 / 7 / 87 ; 87 / 99 ; 14 / 7 / 00$.

Epinephele tithonus, L.-A few in Dundonald parish Ayr (J. P. D.).

E. janira, L._A A bund., variable, ff. large and brightly coloured, e.d. 16/7/92 ; $5 / 7 / 93 ; 7 / 7 / 00$.

E. hyperanthus, L.-Locally c. ; Lochgoilhead 30/6/88 (A.A.D.) ; Kilmalcolm (J.D.) ; Falls of Clyde 22/6/89 (R. H.) ; Shewalton 30/6/94 (G. R.) ; Girvan (G. W. O.) ; Arran (D. Landsborough).

Erebia aethiops, Esp.-Locally abund. in Dumbarton, Argyll, Bute, and Ayrshire. Variable. Added to British list from specimens taken in Arran in 1804 by Sir Patrick Walker, e.d. $12 / 7 / 87 ; 13 / 7 / 89 ; 10 / 7 / 93$.

E. epiphron, Knock.-Ben Lomond, first week in 8/1856 (M. Y. Ent. Wk. Int. i. 166). 
Coenonympha tiphon, Rott.-C. moors and widely dist., e.d. 20/6/94; $13 / 6 / 96 ; 27 / 6 / 97$.

var. laidion, Bkh.-Our commonest form.

var. philoxenus, $E s p$.- Specimens from Kintyre often approach this.

C. pamphilus, $L$.-Widely dist., abund., variable, e.d. $5 / 6 / 91 ; 1 / 6 / 93$; $21 / 5 / 94 ; 25 / 5 / 95$.

\section{Fam. Lycaenidae.}

Thecla rubi, L.-Locally abund. L. Long, end of April (T. C.); Lochgoilhead 5/6/94 (A. A. D.) ; Milngavie (G. W. O.); Auchincruive (J.P. D.); Rothesay 24/5/91 (A. A. D.) ; Arran (W.S.).

T. quercus, L.--Local and r. Kilmun 2 sp. about 1881 (W.W.); Luss (R. F. Logan); Helensburgh (J. S.); Monument Plantation, Monkton (J. P. D.); Tayvallich (A. M. S.).

Chrysophanus minimus, Fuesl.-Local. Dumbarton (J.G.); Ardrossan (H. C.); Troon (J.P.D.) ; Girvan (G. W. O.) ; Arran (A. S.).

C. astrarche, Bgstr. var. artaxerxes $F^{\prime} a b$.-Ayrshire coast locally c. Troon to Ballantrae (J. P. D., G. W. O., A. A. D., etc.), e.d. 5/7/94, nr. Stranraer, 6/6/96 (J. G. G.).

C. phlaeas, L.--Widely dist., often locally abund., three broods, May till Oct., e.d. $15 / 5 / 94 ; 19 / 5 / 00$; latest 3/10/96. var. radiata, Tutt.-One Inveruglas 13/9/95 (A. A. D.).

Lycaena aegon, Schiff.-One m. near Gourock 3/8/94 (A. M.).

L. icarus, Rott.-Widely dist., abund., ff. very variable, e.d. 12/6/94; 14/6/96 ; 30/6/00 ; occasionally in Aug. var. icarinus, Scriba.-Occasionally occurs.

\section{Fam. Pieridae.}

Colias hyale, L.--Immigrant. One Bonhill, Dumbarton, 5/8/96 (J. M.).

C. edusa, Fb.-Immigrant, irregular. Tarbert, 24/8/92 (A. M'C. R. H., W. W.); Inveraray (J. A. N.); Dunoon 7th Sept. (Mr. Manners teste T. C.); Whistlefield, L. Long (Hughes); Row (Woodford Ent. xxv. 313) ; Gourock (J. D.) ; five on Ayrshire Coast 1852 (T. C. Ent. Wk. Int. 5/43) ; several in Ayrshire (J. Sn. Proc. G.N.H.S. iv. n-s, 35 and J. P. D. Scot. Nat. i. 75) ; Lamlash 3/9/47 (Thomson, Zool. vol. vi. p. 1985); several Arran (A. B. W., J. A. M. Ent. xxvi, and A. Noble Trans. G. S. of F. N. 107) ; Stranraer $29 / 8 / 98$ (A. A. D.).

Euchloe cardamines, $L .-$ No recent records. Lanarkshire (T. C.) ; Renfrew (J.S) ; Paisley (M. Y.) ; Gourock (J. E. S. teste T. C.) ; Ayrshire, gen. dist. and rather c. (J. P. D.).

Pieris napi, $L$ - -Abund. everywhere. Strongly marked seasonal variation, e.d. first brood $9 / 5 / 96 ; 19 / 5 / 98 ; 3 / 5 / 00 ;$ second $31 / 7 / 96 ; 14 / 7 / 99$; $14 / 7 / 00$.

P. rapae, L.-Very c. and gen. dist., decided seasonal varieties, e.d. first brood $16 / 4 / 99 ; 19 / 4 / 00$; second $15 / 7 / 99 ; 26 / 7 / 00$.

P. brassicae, $L$.-C. and widely dist., e.d. first brood, $6 / 6 / 91 ; 5 / 6 / 94 ; 26 / 5 / 00$; second 20/8/97; 28/8/99; i3/8/00.

var. chariclea, St.--Freq. and with both broods.

\section{Fam. Hesperiadae.}

Hesperia malvae, L.-No recent records. Heathy places nr. Glasgow (J. G.) ; Cairn Ryan 6/6/96 (J. G. G.).

H. tages, L.-Locally c. ; near Glasgow (T. C.) ; Troon (J. P. D.) ; Shewalton (T. W.) ; nr. Ayr 7/5/94, 25/5/95, 19/5/00 (W. F.) ; nr. Stranraer 6/6/97 (J. G. G.).

Pamphila sylvanus, Esp.-One Cairn Ryan, Wigton 5/6/97 (J. G. G.). 


\section{PYRALIDINA.}

Fam. Phycitidae.

Anerastia lotella, $H b$. - One Irvine sand hills 8/7/99 (A. A. D.).

Pempelia dilutella, $H b_{0}-\mathrm{R}$; Ardrossan (H. C.).

Salebria fusca, Haw.-C. moors. Frequen ting burnt heather. Luss 16/7/93 (A.A.D.) ; Bonhill (J.M.) ; Dunoon (T. C.) ; Bishopton 30/6/96 ; 26/6/97 (A. A. D., W.S.) ; Arran (W. S.); Shewalton 14/7/00 (A. A. D.).

Dioryctria abietella, Fb.-Very r.; nr. Rutherglen 30 June (H. C.); one beat from pine, Linwood (W. W.) ; once Dargavel (J. D.).

Ephestia elutella, Hb.-One in Maderia Court, Glasgow 8/94 (A. A. D.).

E. calidella, Gn.-Fruit shops in Glasgow (T. C.).

E. kuehniella, Z.-Occasionally in Paisley (J. D.).

Homoeosoma binaevella, $H b$.--One in Glasgow (T. J. H.).

\section{Fam. Galleriadae.}

Meliphora grisella; $F b$.-Paisley, bred in abundance from old bee-skep (J. D.) ; Monkton (J. P. D.).

Aphomia sociella, L.-Freq.; Tarbert 7/7/86 (A. A. D.); Garelochhead (T. J. H.) ; Catacole, Arran (A.S., J. D.) ; Corrie 18/7/87 (A. A.D.); Holy Isle (H. C.) ; Lamlash (W. S.).

\section{Fam. Crambidae.}

Crambus hamellus, Thnb.-Donald's Wood nr. Paisley, several (J. D.).

C. pascuellus, L._-Locally c. ; Dunoon (H. C.) ; Lochgoilhead 3/6/94 ; Glenmallan 2/7/98 (A. A. D.) ; Bonhill (J. M.) ; Johnstone 15/6/95 (A. A. D.); Lamlash (W. S.) ; Ardrossan (H. C.).

C. dumetellus, Hb.-Locally c. on Gleniffer Braes (J. D.).

C. pratellus, L.-Very abund. all over district, e.d. $21 / 5 / 96 ; 28 / 5 / 98 ; 3 / 6 / 00$.

C. culmellus, L.-Most abund. occurring everywhere, e.d. 10/7/92; 28/6/93 ; $25 / 6 / 95 ; 1 / 7 / 96$.

C. hortuellus, Hb.-Locally c. ; Garelochhead (T. J. H.) ; Cathcart 4/6/95 ; Crookston 25/6/96; Corrie 3/7/87 (A.A. D.); Kilbarchan (A. M.S.).

C. pinellus, L.-Freq. ; Lochgoil (T. C.) ; Tarbert 13/7/86 ; Luss c. 17/7/93 (A. A. D.) ; Garelochhead (T.J. H.) ; Cadder (G. W. O.); Dundonald $14 / 7 / 00$; Corrie 5/7/87 (A. A. D.) ; Tayvallich (A.M. S.).

C. nargaritellus, $H b$.-Locally c.; Dunoon (T.C.); Glenmallan 9/7/98 (A. A. D.) ; Garelochhead (T. J. H.) ; Bishopton (J. D.) ; Cadder Moss $7 / 89$; Corrie $2 / 7 / 87$ (A. A. D.) ; Tayvallich (A. M. S.).

C. latistrius, Haw.-Irvine Moor, c. 12/8/99 (A.A.D.); Arran (F. B.W. Scot. Nat. i. 169).

C. perlellus, Scop.-C. Troon (J. D., W. S.) ; several Corrie 8/7/87 (A. A. D.). var. Warringtonellus, Zell. - Several Troon (J. D.).

C. geniculeus, Haw.-Locally abund.; Ardrossan (H.C.); Saltcoats (R. Weaver): Ballantrae 7/8/97; Little Cumbrae 10/8/95; King's Cross, Arran 7/8/00 (A. A. D.).

C. tristellus, Fb.-Abund. everywhere, e.d. $16 / 7 / 92 ; 13 / 6 / 93 ; 30 / 6 / 94$; till Sept.

\section{Fam. Pyraiustidae.}

Donacaula mucronella, Schiff.-Nr. Glasgow 28th July (J. S. Zool. 8. 2885); Possil Marsh. one, 1/9/94 (A. A. D.).

Cataclysta lemnata, L.-Very abund. Possil Marsh, e.d. 6/8/95 ; 10/8/96; $30 / 7 / 97$.

Nymphula stagnata, Don.-Locally c. ; Possil Marsh (T. J. H.) ; Crookston 22/6/97 (A, A. D.); near Paisley (J. D., A. M. S.); Troon (J. P. D.); Tayvallich (A. M. S.), 
Hydrocampa nymphaeata, L.--Locally abund. ; extremely variable. Possil Marsh (T.J.H.); Crookston 22/6/95; 29/6/96 ; 28/6/98 (A. A. D.) ; nr. Paisley (J. J., W.S.) ; Ardrossan (H.C.) ; Monkton (J.P. D.) ; Tayvallich (A. M. S.)

Eurrhypara urticata, L.-Once Monkton (J.P. D.) ; one Dundonald 22/7/00 (A. A. D.).

Phlyctaenia crocealis, Hb.-R.; Once Rothesay (M. Y.) ; Ormadale, two (J.D.).

P. lutealis, $H b$.-Abund. and widely dist., e.d. $6 / 7 / 95 ; 13 / 7 / 96 ; 14 / 7 / 99$.

P. ferrugalis, $H b$.-Singly or scarce, Cathcart 22/5/87 ; Crookston 25/6/95 ; 15/6/96 ; Cadder 24/8/99 (A. A. D.) ; Ardrossan once 10/6/57 (H. C.).

P. prunalis, Schiff.-C. on hedgerows all over district, e.d. $6 / 8 / 92 ; 31 / 7 / 93$; $18 / 7 / 95$.

P. terrealis, Tr.-Once at Dunoon (T. C.).

P. fuscalis, Schiff.-Abund. and widely dist., e.d. $1 / 6 / 94 ; 23 / 5 / 95 ; 21 / 5 / 96$.

Nomophila noctuella, Schiff.-Local, sometimes c. Lochgoilhead plentiful (T. C.) ; Dunoon (Mr. Manners teste T. C.) ; Luss (R. F. Logan) ; Cadder (C. B. C.) ; Paisley (J. D.) ; Ardrossan (H. C.) ; Lamlash (W. S.).

Pyrausta octomaculata, Fl.-Two Ormadale, Argyll (J.D.).

P. cingulata, L.-Locally c. ; Grassy slopes Dumbartonshire (J. G.) ; Little Cumbrae 10/8/95 (A.A. D.) ; bet. Girvan and Ballantrae (W. W.).

P. sanguinalis, L.-Very local, but c. ; Monkton (J. P. D.) ; Troon (W. S., J.J. K.).

P. purpuralis, L.-Locally c. moors ; Arrochar 23/5/95 ; Luss 16/7/93 (A. A. D.); Garelochlead (T. J. H.); Gleniffer (J. D.) ; Brodick (W. S.) ; Barr 14/7/99 (A. A. D.).

P. aurata, Sc.-R. in Arran (T. C.).

P. cespitalis, Schiff.--Locally abund. moors and hillsides, widely dist., e.d. $13 / 7 / 95 ; 10 / 7 / 97 ; 19 / 6 / 99$.

P. alpinalis, Schiff.-Local, but not unc. ; Ardentinny (T. C.) ; Glenmallan 15/7/97 (A. A. D.) ; Luss (R. F. Logan) ; Ben Lonond (T. A. C.) ; Garelochhead (T. J. H.).

P. decrepitalis, H.-S.-Local, sometimes plentiful; Ardentinny (T.C.); Lochgoilhead 5/6/91; Arrochar 23/5/95; Inveruglas 23/5/97; Gl. Falloch 21/5/96 (A. A. D.) ; may be taken at sea level.

P. olivalis, Schiff.-Local and r.; Glenmallan several 3/7/97; 7/7/98 (A. A.D.); Garelochhead (T. J. H.) ; Kenmuir, Lanark (J. J. K.).

Scoparia lineola, Curt.-Local and r. ; Ardrossan (H.C.) ; Little Cumbrae several 10/8/95 (A. A. D.).

S. angustea, Stph.-Local but not unc. ; Ardrossan (H. C.) ; Little Cumbrae 10/8/95; Ballantrae 22/8/97 (A. A. D.).

S. murana, Curt.-Abund. on walls all over district, e.d. $3 / 6 / 95 ; 19 / 6 / 95$; latest $10 / 8 / 90 ; 4 / 9 / 96$.

S. frequentella, Stt.-Locally c. on walls. Luss 15/7/93 (A.A.D.); Garelochhead (T. J.H.) ; Cumbrae (J.D.) ; Dundonald 14/7/00; King's Cross 5/8/00 (A. A. D.).

S. crataegella, $/ / b$. - On walls, locally c. Garelochhead (T. J. H.) ; Bonhill (J. M.) ; Milngavie (J. J. K.) ; Ardrossan (H. C.) ; Dundonald 14/7/00 (A. A. D.) ; Tayvallich (A. M. S.).

S. truncicolella, Stt.-Local and r. ; Cumbrae (J.D.) ; Irvine Moor 14/ $/ 00$ (A. A. D.).

S. cembrae, Haw.-Abund. amongst Tussilago. Very variable. Giffnock $11 / 7 / 91$; shop windows in suburbs Glasgow 5/8/95 (A.A.D.); round Paisley (J. D., A. M. S., W. S.) ; Coulport 19/7/00; Luss 29/7/93 (A. A. D.).

S. dubitalis, $H b$.-Abund. and widely dist., variable, e.d. 9/7/93; 15/6/96 ; $10 / 6 / 97$. 
S. ambigualis, $T r$.-Abund. everywhere, especially on moorlands, variable, e.d. $1 / 6 / 94 ; 25 / 5 / 95 ; 24 / 6 / 00$.

Mesographe forficalis, L.-C. in gardens, etc., widely dist., e.d. $27 / 6 / 88$; $15 / 6 / 94 ; 9 / 7 / 97$.

\section{Fam. Pyralididae.}

Pyralis farinalis, L.-Abund. in stables and stores all over district, date $27 / 6 / 99$.

Aglossa pinguinalis, L.-Out-houses Glasgow (J. G.) ; Paisley (J.D.) ; Johnstone (IV. W.) ; Ardrossan ; Arran (H. C.).

\section{Fam. Pterophoridae.}

Platyptilia cosmodactyla, Hb.-Very r. Dunoon (T. C.).

P. acanthodactyla, $H b$.-Local, seldom c. ; Lochgoilhead (J. W. Tutt) ; Luss 2:3/9/91 (A. A. D.) ; Garelochhead (T. J. H.) ; Gourock (J. D.) ; Cathcart 5/6/92 (A. A. D.); Arran (W. S., A. Sharpin).

P. gonodactyla, Schiff.-Abund. amongst Tussilago everywhere, e.d. 13/5/93; $13 / 6 / 94$; latest $27 / 8 / 86 ; 17 / 8 / 93$.

P. Bertrami, Rsl.-Local, sometimes abund. Giffnock 26/6/93 ; Crookston 30/6/95 (A. A. D.) ; nr. Paisley (W.S., J. D.) ; Mauchline abund. 15/7/92 ; Corrie 12/7/87 (A. A. D.).

Pterophorus tetradactylus, L.-R., Renfrewshire (Mr. Riddell teste T. C.).

Alucita osteodactyla, Z.--R. ; Garlens Fintry (E. C. E.) ; Garelochhead (T. J. H.).

A. tephradactyla, Hb.-One Coulport L. Long 18/7/90 (A. A. D.).

Stenoptilia pterodactyla, L.-Locally c. Luss 13/7/93 (A. A. D.) ; Garelochhead (T. J. H.) ; Crookston 256/96 (A. A. D.); Paisley (J. D.) ; Ardrossan (H. C.) ; Barr 15/7/99 (A. A. D.).

S. bipunctidactyla, Haw.-Local, sometimes abund. Garelochhead ; Possil (T.J.H.) ; Milngavie 4/7/96; Crookston 29/6/00 (A. A. D.); Paisley (W. S., J. D.) ; Mauchline $15 / 7 / 92$; Corrie $13 / 7 / 87$ (A. A. D.).

\section{Fam. Orneodidae.}

Orneodes hexadactyla, L.-Local and unc. Lochgoilhead (J. W. Tutt); Dunoon; Glasgow ; Bothwell (H. C.) ; Bishopton (J. D.) ; Little Cumbrae $10 / 8 / 95$ (A. A.D.).

\section{PSYCHINA.}

\section{Fam. Zygaenidae.}

Zygaena filipendulae, L.-Locally abund. Cumbrae (Prof. Rennie, J. D.); Shewalton 14 ; 00 (A. A. D.) ; Troon (W. S.) ; Monkton (J.P. D., T. W.); Girvan (G. W. O) ; Bennan Hear, Arran (D. Landsborough). 
MICROLEPIDOPTERA.

\section{By Prof. James J. F. X. King, F.E.S.}

Nomenclature : Edward Meyrick's Handbook of British Lepidoptera, 1895.

Messrs. the late T. Chapman (T.C.) ; the late Hugh Colquhoun (H.C.); A. A. Dalglish (D.) ; the late J. P. Duncan (J. P. D.) ; John Dumsmore (J.D.); the late J. Gray (J.G.) ; the late T. J. Henderson (H.); the late R. F. Logan (L) ; J. R. Malloch (J. M.) ; K. J. Morton (M.) ; Archdale Sharpin (S.) ; A. \& J. Somerville (Som.) ; William Watson (W.) ; and the late Morris Young (M. Y.) are the authorities for the various localities, their initials being placed after the localities given.

\section{TORTRICINA.}

\section{Fam. Epiblemidae.}

Lobesia permixtana, Hïbner.--Dunoon ; Ardentimny (T. C.) : Gourock ; Arran (J. D.) : Mugdock Wood (K.): Garelochhead (H.)

Bactra lanceolana, $H b$.-Common.

B. furfurana, Haworth.-Kilmun (K.) : Gourock ; Arran (J. D.).

Eucosma corticana, Hb.-Bonhill (J. M.) : Johnstone (D.) : Dargavel (J. D.).

E. betuletana, Hw.-Possil (K.) : Bonhill (J. M.) : Carluke (M.) : Dargavel (J.D.) : Gallangad (J. M.) : Bishopton ; Glen Mallon (D.).

E. sororculana, Zetterstedt.-Milngavie (K.) : Bonhill (J. M.) : Carluke (M.) : Dargavel (J. D.) : Garelochhead (I.).

E. variegana, $H b .-$ Dunoon (H.C.) : nr. Glasgow (T. C.) : Bonhill (J.M.) : Gourock ; Arran (J. D.).

E. pruniana, Hb.-Bonhill (J.M.) : Johnstone; Dundonald (D.): Carluke (M.) : Newton Woods (J.D.).

E. oblongana, Hw.-Dunoon (T. C.) : Gourock ; Arran (J. D.) : nr. Glasgow (T. C.).

E. dimidiana, Sodoffsky.-Rowardemnan (M.): Garelochhead (H.) : Conlport ; Arrochar (D.).

E. schulziana, Fabricius.-Ardentinny (K) : Luss (Logan) : Gleniffer (J. D.) : Tinto (M.): Kilpatrick Hills; Milngavie (K): Bonhill (J.M.): Gourock ; Ravenscraig ; Imnellan ; Corrie (D.).

E. palustrana, Zeller.--Ardentinny; Milngavie (K.): Cleghorn (M.): Gleniffer (J.D.) : Bonhill (J. M.).

E. rivulana, Scopoli.-Luss (L.): Kilbarchan ; Gourock ; Arran (J. D.).

E. micana, Frölich.-Carmichael nr. Lanark (J. Gray): Clober (K.) : Port Glasgow (J. D.).

E. urticana, Hb.-Luss (L) : Bonhill (J. M.) : Garelochhead (H) : Gourock ; Arran (J. D.) : Jamestown (J. M.) : Johnstone ; Dundonald (D.).

E. lacunana, Duponchel.-Abundant.

E. cespitana, $H b$.--Nr. Glasgow (K.) : Bonhill (J.M.) : Gourock : Arran (J.D.). 
E. striana Schiffermiller.-Nr. Glasgow (K.): nr. Paisley (J. D.).

E. antiquana, Hb.-Dunoon (T. C.): Ardrossan; nr. Glasgow (H. C.) : Carluke (M.): nr. Paisley (J.D.): Bonhill (J. M.) : L. Riddon ; Giffnock ; Crookston ; Ravenscraig ; Straiton (D.).

Pamplusia mercuriana, Hb.-Dunoon (T. C.): Milngavie; Ardentinny (K.) : Bonhill (J.M.) : Tinto (M.) : Waes Hills (J. D.) : Brodick (S). : Corrie ; Gourock (D.).

Evetria pinivorana, Z.-Bonhill (J. M.) : Bishopton (D.) : Carluke (M.).

E. turionana, Hb.-Linwood (W.).

E. resinella, Linné.-Linwood ; Bishopton; Johnstone(W.) : Bonhill (J.M.).

E. duplana, $H b$.-Newton Woods, Paisley (J. D.).

Enarmonia cruciana, L.-Nr. Paisley (K.): Dunoon (T. C.) : Luss (L.) ; Bonhill (J. M.) : Irvine ; L. Riddon (D.).

E. rubiginosana, Herrich-Schüffer-CBridge of Weir ; Johnstone ; Bishopton (K): Bonhill (J. M.).

E. nanana, Treitschke.-Bonhill (J. M.) : Bishopton (D.).

E. pinicolana, Z.-Renfrew (J.S.) : Ardentinny (T. C.) : Newton Woods, Paisley (J. D.) : Cadder Wilderness ; Langside (K.) : Bonhill (J. M.) : Carluke ; Tinto (M.).

E. vacciniana, Z.-Bonhill (J. M.): Ravenscraig (D.).

E. corticana, Hb.-Cadder Wilderness ; Langside (K.) : Carluke (M.) : nr. Paisley (J. D.) : Bonhill (J. M.) : Luss (D.).

E. woeberiana, Schiff.-Bothwell (H. C.).

Eudemis naevana, "Hb.-Cadder (K.); Luss ; P'shields ; Johnstone (D.) : Carluke (M.): Waes Hills (J. D.) : Dumbarton ; Bonhill (J. M.).

Ancylis derasana, $H b$.- "In bogs" (T. C.).

A. lundana, F.-Portincross (H. C.) : Possil (K.) : Carluke (M.) : Gleniffer (J. D.) : Bonhill ; Jamestown (J. M.).

A. myrtillana, Tr.-Bishopton (K.): Cleghorn (M.) : Gleniffer (J. D.) : Bonhill (J. M.) : .Johnstone; Ravenscraig (D.).

A. unguicella, L.-Bishopton; Milngavie (K.): Carluke (M.): Bonhill ; Alexandria (J. M.) : Donald's Wood, Paisley (J. D.) : Garelochhead (H) : Luss ; Arrochar ; Gourock (D.).

A. uncana, Hb.--Arrochar ; Ardlui (D.): Donald's Wood, Paisley (J. D.).

A. biarcuana, Stephens.-Blairmore (Som.): Clober (K.).

A. mitterbacheriana, Schiff.-Nr. Glasgow (K.): Bonhill (J. M.): Newton Woods, Paisley (J. D.): Garelochhead (H.): Arrochar (D.).

Gypsonoma dealbana, Fröl.-Gallangad (J.M.).

G. neglectana, Dup.-Hillhead (T. C.): P'shields ; Crookston (D.): Gleniffer (J. D.).

Cydia trimaculana, Donovan.-Bonhill (J. M.) : Carluke (M.) : Nr. Paisley (J.D.) : Crookston; Glen Mallon ; P'shields (D.).

C. ramella, L.-Dunoon (T. C.) : Cadder Wilderness (K.) : Carluke (M.): Newton Woods, Paisley (J.D.): Bonhill ; Jamestown (J.M.) : Brodick (S.) : Glen Mallon ; Luss (D.).

C. signatana, Douglas.-Carluke (M.).

C. strobilella, L.--Ardrossan (H. C.): Gourock ; Arran (J. D.).

C. nigromaculana, $H w$.-Cadder Wilderness (K.): Argyll (T. C.): Ardrossan (H. C.) : Bonhill (J.M.) : Giffnock; Ravenscraig ; Dundonald (D.): Gourock ; Arran (J. D.).

C. aemulana, Schlïger.-Luss (L.): Johnstone (D.): Gourock; Arran ; Dumoon (J. D.).

Notocelia uddmanniana, L.-Ardrossan (H. C.) : Gourock ; Arran (J.D.).

N. rosaecolana, Doubleday.-Botanic Gardens.

N. trimaculana, $H w$.-Luss (L.): nr. Glasgow (T. C.): Bishopton (K.): Bonhill (J. M.): Mauchline ; Dundonald (D.).

N. roborana, Tr.-Ardrossan (H. C.) : Gourock ; Arran (J. D.). 
N. tetragonana, Stph.-Luss (L.).

Epiblema tripunctana, F.-Possil ; Langside (K.): Carluke (M.): nr. Paisley (J. D.) : Bonhill (J. M.) : Giffnock ; Ardlui ; Arrochar (D.).

E. suboceliana, Don.-Dunoon (H.C.): Possil ; Bishopton (K.) : Carluke(M.): Bonhill ; Arrochar (J.M.): Lochgoilhead ; Linwood ; Crookston (D.).

E. penkleriana, Fischer von Röslerstamm.-C.

E. nisella, Clerck.-Dunoon (T.C.): Bonhill (J. M.): Carluke (M.): Gourock ; Arran (.J. D.).

E. immundana, F.R.-Nr. Paisley (J.D.) : Bonhill ; Gallangad (J.M.) : Crookston ; Irvine (D.): Brodick (M.).

E. tetreaquetrana, $H w$.-Argyll ('T. C.): Cadder Wilderness; Milngavie (K): Bonhill ; Gallangad (J.M.): Carluke; Brodick (M.): nr. Paisley (J.D.).

E. tedella, Cl.-C. ; Cadder Wilderness ; Ardentinny (K.): Carluke (M.): nr. Paisley (J. D.): Bonhill (J. M.).

E. similana, Hb.-Argyll (T. C.): Ardrossan (H. C.) : Gourock; Milngavie ; Cadder Wilderness (K.): Carluke (M.): Bonhill (J.M.): Giffnock ; L. Riddon (D.) : nr. Paisley (J. D.).

E. pflugiana, Hw.-Dunoon (T. C.) : Ardrossan (H. C.): Bonlill ; Gallangad (J. M.): L'goilhead; Arrochar; Luss (D.); Carluke (M.): Newton Woods, Paisley (J. D.).

E. trigeminana, Stph.-Dunoon ; nr. Glasgow ; Ardrossan (T. C.): Newton Woods, Paisley (J. D.) : Bonhill (J. M.) : Busby ; Crookston (D).

E. brunnichiana, Fröl.-Carluke (M.): Possil ; Sighthill ; Kirklee (K.): Bonhill (J. M.): Dumoon (T.C.) : Ruchill (H.): Newton Woods, Paisley (J. D.).

E. turbidana, Tr.-Crookston (D.).

E. bilunana, $H w$. -Nr. Glasgow (J. G.) : Bonhill (J. M.) : nr. Paisley (J. D.) : Glen Mallon; Bishopton (D.).

E. ophthalmicana, $H b$.--Paisley ; Stanley Wood (J. D.) : Bridge of Weir ; nr. Milngavie (K.) : Bonhill (J. M.) : Johnstone (D.).

E. solandriana, $L .-$ C.

E. semifuscana, Stph.-Langside; Cadder Wilderness (K.): Gourock; Arran (J. D.).

E. sordidana, Hb.-Allander (K.): Bonlill (J.M.) : Gourock ; Arran (J.D.): Irvine (D.).

E. scopoliana, $H w .-$ Kirklee (K.) : Carluke (M.) : Gleniffer (J.D.).

E. cana, Hw.-Kirklee (K.) : Ardrossan ; Dunoon (H. C.) : Bonhill (J. M.) : Carluke (M.) : nr. Paisley (J. D.).

Hemimene petiverella, L.-Nr. Glasgow (T. C.): Jamestown (J.M.): Renfrew (J. D.).

H. acuminatana, Z.-Ardrossan (H. C.) : Gourock ; Arran ; Dunoon (J. D.).

H. tanaceti, Stainton.-Possil Marsh ; Langside (K.) : Carluke (M.) : Newton Woods, Paisley (J. D.) ; Garelochhead (H.): Bonhill (J. M.) : Crookston; Giffnock; Dundonald ; Ravenscraig (D.).

H. plumbagana, Tr.-Carmichael (J.G.) : nr. Glasgow (K.): Bonhill (J. M.) : Gleniffer (J. D.).

Lipoptycha plumbana, Sc.-Possil Marsh; Milngavie (K.): Gleniffer (J. D.).

Pammene nitidana, F.-? Near Haggs Castle ('T. C.).

P. germarana, $H b$.-Dunoon (T. C.).

P. rhediella, Cl.-Nr. Glasgow (T. C.) : Paisley (J. D.) : Bonliill (J. M.).

P. splendidulana, Gn.-Luss (L.) : Bonhill (J. M.) : Gleniffer (J. D.).

P. fimbriana, $H w$. - Nr. Glasgow (J.G.) : nr. Paisley (J.D.).

P. argyrana, Hb.-Kenmuir Bank; Milngavie ; Cadder Wilderness ; Ardentinny (K.): Bonhill (J.M.): Crookston (D.): Newton Woods, Paisley (J. D.).

Laspeyresia roseticolona, Z.-Bonhill (J. M.). 
I. rufillana, Wilkinson.-Renfrew (J. D.) : Barr ; King's Cross (D.).

L. perlepidana, Hw.-Nr. Glasgow (T. C.): nr. Paisley (K.): Jamestown (J. M.) : Kilmalcolm (J. D.) : Crookston ; Ayr (D.).

I. nigricana, Stph.-Paisley Moss (M. Y.).

L. cosmophorana, Tr.-Bishopton (W.).

L. coniferana, Ratzeburg.-Milngavie; Ardentinny (K.) : Bonlill (J.M.) : Bishopton (D.).

L. ulicetana, $H w$.-Common.

Carpocapsa pomonella, L.-Glasgow (T.C.): Bonhill (J.M.): Newton Woods, Paisley (J. D.).

C. splendana, Hb.--Bonhill (J.M.) : Dargavel (J.D.).

Epinotia aurana, F.-Renfrewshire (I. Y.): Botanic Gardens (T. C.): Possil Marsh; Milngavie (K.): Bonhill; Carluke (M.): nr. Paisley (J.D.) : Crookston; Giffnock ; Ballantrae (D.).

E. funebrana, Tr._"Bred from plums" (T. C.): nr. Paisley (.T. D.).

\section{Fam. Tortricidae.}

Rhacodia caudana, $F$.-C.

Acalla hastiana, L.-Argyll (T. C.) : Allander (K.) : Carluke (M.).

A. rufana, Schiff.-Bute Shore; Linwood (W.) : L. Riddon (D.).

A. sponsana, $\ddot{F}$.-Cadder Wilderness ; Allander (K.): Bonhill (J. M.) : Car. luke (M.) : Clarkston ; Luss ; Jolnnstone ; Straiton (D.).

A. literana, L.-Renfrew (J.D.): $\operatorname{Brodick}$ (S.).

A. mixtana, Hb.-Garelochhead (T. C.): Allander (K.): Carluke (M.): Renfrew (J. D.) : Bonlill (J. M.).

A. lipsiana, Schiff.-Gourock; Arran (J. D.).

A. logiana, Schiff.-Argyll (T. C.) : Milngavie (K.) : nr. Paisley (J.D.) : Bonhill (J. M.) : Luss (D.).

A. variegana, Schiff.-C.

A. perplexana, Barrett.-Cadder Wilderness; Mugdock Woors ; Cleghorn (K.) : Bonhill (J. M.) : Carluke (M.) : Dargavel (J. D.).

A. schalleriana, L.-Nr. Glasgow (H.C.) : Milngavie; Langside ; Allander ; Cadder Wilderness (K.): Carluke (M.): Dargavel (J.D.): Bonhill (J.MI.) : Luss ; Giffnock ; Straiton (D.): Brodick (S.).

A. comariana, Z.-Allander ; Cadder Wilderness (K.): Dargavel (J.D.): Bonhill (J. M.).

A. contaminana, $H b .-\mathrm{C}$.

A. ferrugana, $T r$.-Langside; Cadder Wilderness; Milngavie (K.): Bonlill (J. M.) : Inverglas (D): Carluke; Cleghorn (M.): nr. Paisley (J. D.) : Johnstene (D.).

A. caledoniana, Stph.-Dunoon (T. C.): Milngavie (K.): Carluke (M.): Newton Wood, Paisley (J.D.): Bonhill (J.MI.): Ravenscraig ; King's Cross ; Straiton (D.).

A. aspersana, Hb.-Dunoon (H. C.): Carmichael nr. Lanark (J.Gray) : Milngavie (K.): Carluke (M.): nr. Paisley (J.D.): Bonhill (J. MÍ.) : Inverglas; Glen Mallon ; Ravenscraig (D.).

A. holmiana, L.-Milngavie ; Cadder Wilderness (K.): Bonhill (J. M.): nr. Paisley (J. D.) : Johnstone (D.).

Philedone prodromana, Hb.-Bonhill (J. M.): Linwood (W.).

P. gerningana, Schiff.-Clober Moor (K.): Carluke (M.): Gourock; Arran (J. D.): Bonhill (J. M.) : Irvine ; Ravenscraig (D.).

Capua angustiorana, Hw.-Nr. Glasgow (H.C.): Bonhill (J.M.): $\mathrm{nr}$. Paisley (J. D.).

C. favillaceana, Hb.-Ardentinny ; Milngavie (K.) : Bonhill (J. M.) : Garelochhead (H.) : Arrochar (D.).

Cacoecia, podana, $S c .-$ Ardrossan (H. C.) : Carluke (M.) : Gourock ; Arrau (J. D.). 
C. xylosteana, L.-Possil ; Langside ; Callander (K.): Bonhill (J.M.) : Johnstone ; Straiton (D.): Paisley (J. D.).

C. rosana, L.-Possil ; Langside (K.): Bonhill (J. M.) : $11 \mathrm{r}$. Paisley (J. D.) : Giffnock ; Johnstone ; King's Cross ; Straiton (D.) : Carluke (M.).

C. costana, Fb.-Renfrew (J. D.) : Possil ; Langside (K.).

C. semialbana, Guenée.-? Ardrossan (H. C.): Lochgoilhead (T. C.): Gourock ; Arran (J. D.).

C. unifasciana, Dup.-Bonhill (J. M.): Pollokshields (D.): nr. Paisley (J. D.).

C. lecheana, L.-Langside; Bishopton (K.): Newton Woods (J. D.): Bothwell ('T. C.) : Bonhill (J. M.) : Cambuslang ; Corrie (D.).

C. musculana, Hb.-Argyll (T.C.): nr. Cadder House (K.): Carluke ; Bonhill (J.M.)': nr. Paisley (J.D.): Johnstone; L'goilhead ; Arrochar(D.).

Pandemis corylana, $F$.-Nr. Glasgow (K.): nr. Paisley (J. D.).

P. ribeana, $H b$.- Possil ; Langside ; Milngavie (K.) : Carluke (M.) : Bonhill (J. M.): Paisley (J. D.): Giffnock ; P'shields ; Barr ; Dundonald (D.).

P. heparana, Schiff.-Possil ; Langside ; Milngavie (K.): Carluke (M.): Paisley (J. D.): Bonhill (J. M.): P'shields; Arran ; Barr ; Giffnock (D.).

Tortrix bergmanniana, L.-C.

T. ministrana, L.-Cadder Wilderness ; Allander ; Loch Long (K): Carluke (M) : nr. Paisley (J. D.) : Bonhill; Luss (J. M.) : L'goilhead ; Ardlui ; Arrochar (D.).

T. conwayana, F.-Dunoon (H. C.) : Milngavie ; Cadder Wilderness (K.); Carluke (M.): Gourock; Arran (J. D.): Bonhill (J. M.) : Johnstone ; Newton Mearns ; Cathcart ; Dundonald (D.).

T. loeflingiana, L.-Monkton (J.P. D.) : Dunoon (H.C.) : Milngavie (K.) : Carluke (M.) : Gourock; Arran (J. D.): Bonhill (J. M.): Luss ; L. Rirldon (D.).

T. viridana, L.-C. everywhere.

T. paleana, Hb.-Ardrossan (H. C.) : Langside ; Kirklee (K.) : Jamestown (J. M.) : Carluke (M.) : near Paisley (J. D.) : Giffnock ; Crookston ; Dundonald (D.).

T. viburniana, F.-Clober moor (K.) : Paisley (J.D.) : Carluke (M.) : Bonhill (J. MI.) : Ravenscraig ; L. Riddon ; Glen Mallon ; Gourock (D.).

T. rusticana, Tr.-C. ; Bonhill (J. M.) : Carluke (M.) : Waas Hill (J. D.) : Garelochhead (H.): Arrochar ; Johnstone (D).

T. fosterana, F.-Ardrossan; Cumbrae (H. C.): Bonhill (J. M.) : Strone (D.) : Gourock ; Arran (J. D.).

T. politana, Hw.-Garelochhead (T. C.) : Craigmaddie (K.) : Gourock ; Arran (J. D.) : Bonhill (J. M.) : Ravenscraig ; Currie (D.).

T. virgaureana, Tr.-Possil ; Langside (K.): Carluke (M.): nr. Paisley (J. D.) : Bonhill (J. M.) : Ruchill (H).

T. incertana, Tr.-Nr. Glasgow (T. C.) : Ardrossan (H. C.) : Cadder Wilderness ; Langside (K.) : nr. Paisley (J. D.) : Carluke (M.).

T. pascuana, fib.-Bonhill (.J. M.) : Carluke (M.).

T. bellana, Curtis.-Sandbank (W.): Millport (J. D.).

T. octomaculana, $/ / w$. - Nr. Glasgow (T. C.) : Ardrossan (H. C.) : Cadder Wilderness; Langside (K.): Carluke (M.): Jamestown (J. M.) ; nr. Paisley (J. D.) : Giffnock ; P'shields ; Troon (D.).

T. osseana, Sc.-Dunoon ('T. C.) : Ardros*an (H. C.) : Barrachan Moss ; Milngavie (K.) : Paisley (.J. D.) : Bonhill (J.M.) : Tinto ; Ben Lomond (M.) : L'goilhead; Coulport ; Corrie; Barr (D.).

Isotrias hybridana, Hb.-Ardrossan (H. C.): Gourock ; Arran (J. D.).

Exapate congelatella, Cl.-Bonhill (J. M.) : Milngavie (D.) : n. Paisley (J. D.).

Cheimatophila tortricella, $H b$.-Garelochhead (T. C.) : Cadder Wílderness ; Mugdock (K.): Carluke (M.) : Renfrew (J. D.) : Alexandria (J. M.) : Johnstone (D.) 
Fam. Phaloniadae.

Phalonia smeathmanniana, F.-Ardrossan (H. C.): Possil Marsh (K.) : Carluke (M.): Bonhill (J. M.): Gourock (D.).

P. badiana, Hb.-Nr. Glasgow (T. C.) : Dunoon (H. C.): Gleniffer (J. D.) : Bonhill (J. M.): Cathcart ; Giffnock; Johnstone (D.).

P. cnicana, Dbld.--Milngavie (K.): Bonhill (J.M.): Carluke (M.): Gleniffer (J. D.) : Cathcart ; Giffnock ; Crookston (D.).

P. tesserana, Tr.-Dunoon (T. C.) : Gourock ; Arran (J. D.).

P. ciliella, Hb.-Milngavie (K.): Jamestown (J. M.): Carluke (M.) : Gleniffer (J.D.) : Ardlui ; Inverglas ; Arrochar ; Johnstone (D.).

P. nana, $H w$.-Luss (L.): Arran (J.S.): Bonhill (J. M.): Gleniffer (J. D.) : Garelochhead (H.): Linwood (D.).

P. atricapitana, Stph.-Bonhill (J. M.).

P. pallidana, Z.-Ardrossan (H. C.) : Possil (K.).

P. dubitana, Hp.-Nr. Glasgow (T. C.) : Paisley; Possil (K.).

Chlidonia baumanniana, Schiff.-Dunoon (T. C.): Bonhill (J. M.) : Carluke (M.): Waes Hills (J. D.) : Giffnock (D.).

Eupoecilia maculosana, Hw.-Mugdock Wood (K.): Bonhill (J.M.) : nr. Paisley (J. D.).

Anisotaenia ulmana, Hb.-Ardentinny (K.): Gleniffer (J.D.).

Euxanthis angustana, Tr.-Garelochhead; Clober (K.): Brodick (S.): Dunoon (T. C.) : Lamlash (H. C.) : Bonhill (J.MI.): Carluke (M.) : nr. Paisley (J. D.).

E. straminea, Hw.-Nr. Glasgow ; Ardrossan (T. C.): Dunoon (H. C.) : Ruchill ; Possil Marsh (K.): Carluke (M.): Gleniffer (J. D.) : Bonhill (J. M.) : Giffnock; Crookston (D.).

E. hamana, L.-Dunoon (T. C.) : Ardrossan (H. C.) : Bonhill (J. M.) : Gourock ; Arran (J. D.); Giffnock (D.).

Hysterosia inopiana, Hu.-Crookston (D.): Donald's Wood, Paisley (J. D.).

Fam. Trypanidae.

Trypanus cossus, L. - Nr. Troon (D.).

\section{TINEINA.}

Fam. Aegeriadae.

Aegeria apiformis, $C l$.-Ayrshire (D.).

A. crabroniformis, Lewin.-West End Park (E. E.): St. Germains L. ; Possil Marsh (K.) : Ayrshire (J. P. D.) : Carluke (M.) : Giffnock; Crookston ; Houston (D.).

Trochilium tipuliforme, Cl.-Bonhill (J. M.) : Bearsden (D.).

T. culiciforme, L.-Nr. Garelochhead (Som.).

Fam. Gelechiadae.

Sitotroga cerealella, Olivier.-Nr. Glasgow (Stn. Man.).

Aristotelia stipella, $H b$. - Cadder (D.).

A. tenebrella, Hb.-Durrochston Dam (K.): Bonhill (J.M.): Dargavel (J. D.) : Crookston; Bishopton (D.).

A. pulveratella, H.S.-Bonhill (J. M.).

Xenolechia aethiops, Westriood.-Carluke (M.) : Bonhill (J.M.).

X. humeralis, Z.-Giffnock (D.).

Gelechia umbrosella, Z.-Troon (K.).

G. affinis, Dgl.-Bonhill (J.M.) : Bishopton (D.).

G. similis, Stt.-Bonhill (J. M.): Bishopton (D.).

G. politella, Stt.--Possil (K.) : Bonhill (J. MI.): Glen Mallon (D.).

G. terrella, Hb.-C. 
G. acuminatella, Sircom.-Mugdock Wood; Barrachan Moss (K.) : Bonhill (J.M.): Newton Woods (J.D.).

G. proximella, Hb.--Langside ; Cadder Wilderness ; Mugdock Wood (K.): Garelochhead (H.) : Bonhill (J. M.).

G. notatella, Hb.-Possil ; Mugdock Wood (K.): Bonhill (J.M.) : nr. Paisley (J. D.).

G. triparella, Z.-Bonhill (J. M.): Glen Falloch (D.).

G. dodecella, L.-Possil (K.): Bonhill (J. M.): Johnstone (D.): Dargavel (J. D.).

G. sequax, $H w$.-Giffnock (D.).

G. sororculella, $H b$._Luss (D.).

G. diffinis, $H w .-$ Bonhill (J. M.) : Bishopton (D.) : Linwood (J. D.).

G. boreella, Dgl.-Glen Mallon (D.).

G. mulinella, Z.-Newton Woods, Paisley (J.D.): Forth and Clyde Canal nr. Anniesland (K.) : Bonhill (J. M.).

G. ericetella, $H b$. - C.

G. longicornis, Curtis.-Carluke ; Brodick (M.).

Recurvaria cinerella, Cl.-Glen Mallon; Irvine (D.).

Chelaria huebnerella, Don.-Mugdock ; Cadder Wilderness (K.) : Bonhill (J. M.) : Carluke (M.) ; Mauchline ; Luss (D.) : Brodick (S.).

\section{Fam. Oecophoridae.}

Pleurota bicostella, Cl.-Barrachan Moss (K.): Carluke (M.): Bonhill (J. M.) : Gourock (D.) : nr. Paisley (J.D.).

Chimabache phryganella, Hb.-Bonhill (J.M.): Johnstone ; L. Riddon (D.) : nr. Paisley (J. D.).

C. fagella, F.-C. Carluke (M.) : nr. Paisley (J. D.) : Bonhill (J. M.).

Semioscopis avellanella, $H b$.-Carluke (M.).

Depressaria costosa, Hw.-Milngavie (K.): Bonhill (J. M.) : Carluke (M.) :

Newton Woods, Paisley (J.D.) : Ravenscraig ; Luss ; Arrochar (D.).

D. umbellana, Stph.-Brodick (S.).

D. assimilella, Tr.-C. Gourock; Arran (J. D.) : Bonhill (J.M.).

D. liturella, Schiff.-Carluke (M.): Newton Woods, Paisley (J. D.).

D. arenella, Schiff.-Mugdock Wool (K.) : Bonhill(J. M.) ; Newton Woods, Paisley (J. D.) : Inverglas ; Luss ; Arrochar (D.).

D. hypericella, Tr.-Giffnock ; Crookston ; Ballantrae (D.).

D. ocellana, F.-Catheart ; Giffnock ; Crookston (D.).

D. conterminella, Z.-Luss; Johnstone (D.): Gourock; Arran ; Dunoon (J. D.).

D. angelicella, Hb.-Mugdock Wood ; Possil (K.) ; Linwood (D.).

D. ciliella, Stt.-C.

D. applana, F.-- Cadder Wilderness ; Langside (K.) : Bonhill (J. M.) : Carluke; Brodick (M.) : Newton Woods (J. D.): Inverglas ; Luss ; Giffnock (D.).

D. douglasella, Stt.-Giffnock ; Ravenscraig ; King's Cross (D.).

D. albipunctella, $H b$.-Cadder Wilderness (K.) : Gleniffer (J. D.).

D. pimpinellae, Z.-Possil (K.) : Dargavel (J. D.).

D. pulcherrimella, Stt.-Mugdock Wood (K.).

D. heracliana, De Geer.-C.; Douglaston (K.): Uddingston (M.) : Bonhill (J. M.).

D. nervosa, Hw.-Millport; Gourock ; Arran (J. D.).

Oecophora sulphurella, F.-West End Park ; Possil (K.) : Gourock ; Arran (J.D.) ; Bonhill ; Balloch (J. M.).

Acompsia similella, $H b$.-Carluke (M.).

A. flavifrontella, $H b$. - Linwood (J.D.).

A. pseudo-spretella, Stt.-C.

A. fuscescens, $H w$.-Cambuslang (K.) : Bonhill (J. M.) : Dargavel (J. D.). 
Fam. Elachistidae.

Coleophora fabriciella, Villers.-Bonhill (J. M.).

C. alcyonipennella, Kollar.-Giffnock (D.): Carluke (M.).

C. nigricella, Stph.-Nr. Glasgow (K.): Bonhill (J. M.) : nr. Paisley (J. D.).

C. siccifolia, Stt.-Bonhill (J. M.) : Giffnock : Crookston; Johnstone (D.).

C. gryphipennella, Bouché.-Cadder Wilderness (K.).

C. vitisella, Gregson.-Bonhill (J. M.) : Gourock ; Arran (J. D.).

C. viminetella, Z.-Bonhill (J. M.) : Gourock; Arran (J. D.).

C. fuscedinella, Z.-Kirklee (K.).

C. lutipennella, Z.-Bonhill (J. M.) : Johnstone (D.): Gourock ; Arran (J. D.).

C. limosipennella, Dup.-Bonhill (J. MI.).

C. laricella, Hb.-Barrachan Moss (K.).

C. juncicolella, Stt.-Bonhill (J. M.).

C. pyrrhulipennella, Z.-Bonhill (J.M.).

C. discordella, Z.-Bonhill (J. M.) : nr. Paisley (J. D.).

C. albicosta, Hw.-Cadder Wilderness (K.) : Bonhill (J.M.) : wr. Paisley (J.D.) : Garelochhearl (H.) : Giffnock ; Crookston ; Johnstone (D.).

C. tripoliella, Hodgkinson.-Busby (D.).

C. laripennella, Zett.-Cadder Wilderness (K.).

C. artemisiella, Scott.-Bonhill (J.MI.).

C. murinipenella, Dup.-Bonhill ; Jamestown (J.M.); Ravenscraig (D.).

C. caespititiella, Z.-Mugdock Wood ; Barrachan Moss (K.); nr. Paisley (J. D.) ; Bonhill (J. M.) ; Garelochhead (H.).

Elachista apicipunctella, Stt._Langside (K.); Bonhill (J.M.); nr. Paisley (J.D.).

E. albifrontella, $H b$. - C.

E. luticomella, Z.-Bonhill (J. M.); Glenmallon (D.). var. flavicomella, Stt.-Has occurred nr. Milngavie (K.).

E. atricomella, Stt.-Bonhill (J.M.); Newton Wood, Paisley (J. D.).

E. kilmunella, Stt.-C. Bonhill (J.M.); Gourock; Arran (J.D.); Glen Mallon; Ravenscraig (D.).

E. nigrella, $H w$.-Kenmuir Bank (K.); Bonhill (J. M.) ; nr. Paisley (J. D.).

E. obscurella, Stt.-N1. Glasgow (K.) ; Bonhill (J. M.) ; Giffnock ; Ravenscraig (D.); nr. Paisley (J. D.).

E. zonariella, Tengstrom.-Nr. Glasgow (K.); Renfrew (Stn. Man); Bonhill (J.M.).

E. megerlella, Stt.-Bonhill (J. M.).

E. serricornis Stt.-Bonhill (J. M.); Ravenseraig (D.).

E. biatomella, Stt.-Barrachan Moss (K.).

E. eleochariella, Stt.-Bonhill (J.M.): Ravenscraig (D.).

E. rhyncosporella, Stt.-Bishopton Moss (K.) : Bonhill (J.M.): Ravenseraig; Gourock (D.).

E. triatomea, $H w$.-Nr. Glasgow (K.).

E rufocinerea, $H w$.-Bonhill (J. MI.); Giffnock ; Crookston (D.); Newton Woods (J. D.).

E. cygnipennella, Hb.-C. ; Arrochar ; Bonhill (J.M.); Carluke (M.) ; nr. Paisley (J.D.).

E. subalbidella, Schl.-Mugdock Wood (K.); Bonhill (J.M.); Arrochar (D.); Dargavel (J. D.).

Chrysoclista aurifrontella, Hb.-Ruchill ; Mugdock Wood (K.): Bonhill (J. M.) : Dargavel (J. D.) : Crookston (D.).

C. atra, Hw.--Clober Moor (K.): Bonhill ; Jamestown (J. M.): Crookston (D.).

Mompha schrankella, Hb.-Bonhill (J. M.): Glenmallon (D.).

M. propinquella, Stt.-Langside (K.) : Crookston (D.). 
M. lacteella, Stph.-Bonhill (J. M.).

Heliozela sericiella, Hw.--Bonhill (J. M.).

H. resplendella, Stt.-Troon (K.): Bonhill (J. M.).

Endrosis lacteella, Schiff.-C.

Cataplectica fulviguttella, Z.-Bonhill (J. M.).

Schreckensteinia festaliella, $H b$.-Cadder Wilderness (K.): Bonhill (J. M.):

Carluke (M.) : nr. Paisley (J. D.) : Lochgoilhead ; Johnstone (D.).

Epermenia chaerophyllella, Göze.-Bonhill (J. M.) : Carluke (M.).

\section{Fam. Plutellidae.}

Atemelia torquatella, Z.-Darrochston Dam; Bishopton Moss; Mugdock Wood ; Kilmun (K.): Bonhill (J. M.): Dargavel (J. D.).

Prays curtisellus, Don.--Kirklee; Kenmuir Bank; Rutherglen (K.) : Bonhill (J. M.) : Cathcart ; Johnstone ; Dundonald (D.) : Carluke (M.) : nr. Paisley (J. D.).

Cerostoma xylostella, L.-Cadder Wilderness; Mugdock Wood (K.) : Carluke (M.): Bonhill (J.M.): Luss ; Clarkston ; Dundonald (D.): Brodick (S.).

C. costella, F.-Nr. Glasgow (K.) : Bonhill (J. M.) : Carluke (M.): Johnstone (D.): Dargavel (J. D.).

C. radiatella, Don.-Cadder Wilderness ; Mugdock Wood ; Langside (K.) ; Bonhill (J. M.): Luss; Clarkston; Johnstone (D.): Carluke (M.);

Newton Woods (J. D.).

C. vittella, L.--Nr. Glasgow (K.): Barrachan Moss (K.): Carluke (M.) : Bonhill (J. M.) : Ballantrae (D.).

Plutella porrectella, L.-Nr. Johnstone (K.) : Giffnock ; Crookston (D.).

P. cruciferarum, Z.-C.

P. annuletella, Curt.-Nr. Glasgow (K.).

P. dalella, Stt.-Mugdock Woods (K.): Bonhill (J. M.) : Carluke (M.).

Glyphipteryx thrasonella, Sc.-C.

G. haworthana, Stph.-Craigmaddie (K.): Bonhill (J.M.): Gourock ; Arran ; Dunoon (J. D.).

G. fischeriella, Z.-Langside; Cambuslang; Troon (K.): Jamestown (J. M.): Giffnock ; Crookston (D.) : Gourock ; Arran ; Dunoon (J. D.).

Choreutis myllerana, F.-Luss (L.): Mugdock Wood (K.): W. Kilbride (D.): Gourock; Arran; Dunoon (J. D.).

Simaethis fabriciana, L.-C.

\section{Fam. Tineidae.}

Nepticula atricapitella, $H w$.-Bonhill (J. M.) : Dargavel (J. D.).

N. fletcheri, Tutt.--Bonhill (J.M.).

N. gratiosella, Stt.-Nr. Glasgow (K.) : Bonhill (J. M.) : Dargavel (J. D.).

N. plagicolella, Stt.-Bonhill (J. M.).

N. argentipedella, Z.-Cadder Wilderness; Langside; Mugdock Wood

(K.): nr. Paisley (J. D.): Bonhill (J.M.).

N. tityrella, Stt._-Cadder Wilderness; Mugdock Wood (K.).

N. angulifasciella, Stt.-Bishopton Moss (K.).

N. salicis, Stt.-Nr. Glasgow (K.).

N. floslactella, Haw.—C.; Langside; Kenmuir Bank (K.): Bonhill (J. M.).

N. pulverosella, Stt.-Bonhill (J. M.).

N. cryptella, Stt.-Langside (K.): Dargavel (J.D.).

Trifurcula immundella, Z.-Bonhill (J.M.).

Opostega crespusculella, Z.-Barrachan Moss (K.): Bonhill (J.M.) : Giffnock (D.).

Bucculatrix nigricomella, Z.-Var. Bonhill (J. M.): Crookston (D.).

B. crataegi, Z.-Barrachan Moss (K.): Glen Mallon(D.). 
Lithocolletis cramerella, F.-C.; Langside; Mugdock Wood: Bonhill (J. M.): Dargavel (J. D.) : Johnstone ; Glemmallon (D.).

L. heegeriella, Z.-Cadder Wilderness (K.): Bonhill (J.M.): Gourock ; Arran (J. D.) : Johnstone (D.).

L. alnifoliella, Dup.-Nr. Glasgow ; Cadder Wilderness (K.): Gourock ; Arran (J. D.) : Bonhill ; Jamestown (J.M.) : Glen Falloch ; Crookston ; Johnstone (D.).

L. lautella, Z.-Cadder Wilderness (K.): Renfrew (Stn. Man.): Bonhill (J.M.).

L. ulmifoliella, Hb.-Possil ; Mugdock Wood; Barrachan Moss (K.): Bonhill (J. M.) : Johnstone (D.) : nr. Paisley (J. D.).

L. spinolella, Dup.-Cadder Wilderness ; Barrachan Moss ; Mugdock Woorl (K.): Bonhill ; Arrochar (J.M.) : ur. Paisley (J. D.): Kilsyth ; Giffnock (D.).

L. oxycanthella, Z.-Paisley ; Bonhill (J. M.).

L. pomifoliella, Z.-C.

L. sorbi, Frey.-Bonhill (.J. MI.).

L. cerasicolella, Hs.-Bonhill (J. M.) : nr. Paisley (J. D.).

L. spinicolella, Stt.-Bonhill (J. M.): nr. Paisley (J. D.).

L. faginella, Z.-C. ; Cadder Wilderness ; Langside (K.): Bonhill (J. M.) : Giffnock ; Johnstone (D.) : nr. Paisley (J. D.).

L. coryli, Nicelli.-Bonhill (J.M.).

L. junoniella, Z.-Cadder Wilderness (K.) : Gleniffer (J. D.).

L. quercifoliella, Z.-Cadder Wilderness ; Langside ; Kenmuir Bank ; Mugdock Wood (K.) : nr. Paisley (J. D.): Bonhill (J. M.).

L. messaniella, Z.-Bonhill (J. M.).

L. corylifoliella, Hw.-Nr. Glasgow (K.): Bonhill (J.M.) : Garelochhead (H.): Linwood (J. D.).

L. nicellii, Stt.-Bunhill (J. M.) : Glen Mallon (D.).

L. froelichiella, Z.-Bonhill (J. M.).

L. stettinensis, Nic.-Bonhill (J.M.).

L. klemannella, F.-Mugdock Wood (K.): Bonhill (J.M.): Glen Mallon(D.).

L. emberizipennella, Bch.-Langside (K.): Bonhill (J. M.) : Gourock; Arran (J. D.).

Ornix loganella, Stt.-Luss (Stn. Man.): Bonhill (J. M.).

O. betulae, Stt.-C. Mugdock Wood (K.): Bonhill (J. M.) : Linwood (J. D.).

O. scoticella, Stt.-Cadder Wilderness (K.): Bonhill (J.MI.): Dargavel (J.D.).

O. torquillella, Z.-Bonhill (J. MI.).

O. anglicella, Stt.-Bonhill (J. M.).

Gracilaria alchimiella, Sc.-C.

G. elongella, L.--Mugdock Wood ; Gourock (K.) : Bonhill (J. M.) : Arrochar (D.) : nr. Paisley (J. D.).

G. tringipennella, Z.-Jamestown (J.M.) : Carluke (M.) : Mearns ; Giffnock; Mauchline (D.).

G. syringella, F.-Langside (K.): Bonhill (J.M.): Carluke (M.): nr. Paisley (J. D.) : Crookston ; Dundonald ; Busby (D.).

G. auroguttella, Stph.-Bonhill (J. M.) : Gourock ; Arran (J. D.).

Leucoptera iaburnella, Stt.-Bonhill (J. M.) : mr. Paisley (J. D.).

L. spartifoliella, Hb.-Bonhill (J.M.) : Giffnock ; Ravenscraig (D.) : Carluke (M.) : mr. Paisley (J. D.).

Lyonetia clerkella, L.-Gourock (K.) : Bonhill (J. M.) : Arran (J. D.).

Ticheria complanella, Hb.-Bonhill (J. M.) : nr. Paisley (J. D.).

Ocnerostoma pinariella, Zell.-Possil ; Kirklee ; Bishopton (K.): Bonhill (J. M.) : Dargavel (J. D.).

Cedestis farinatella, Dup.-Barrachan Moss (K.): Bonhill (J. M.) : Carluke M.) : nr. Paisley (J. D.): Dundonald ; Mauchline (D.). 
C. gysseleniella, Dup.-Bonhill (J. M.) : Gourock ; Arran (J. D.).

Argyresthia arceuthina, Z.-Clober Moor (K.).

A. brockeella, $H b$. - C.

A. gaedartella, L.-C. ; Bonhill (J. M.) : Carluke (M.) : Giffnock ; Dundonald ; Bishopton (D.).

A. pygmaeella, Hb.-Giffnock ; Bishopton (D.): Carluke (M.) : nr. Paisley (J.D.).

A. cornella, F.-C. ; Bonhill (J. M.) : nr. Paisley (J. D.).

A. retinella, Z.-C. ; Bonhill (J.M.) : Carluke (M.): nr. Paisley (J. D.) : Johnstone ; Glen Mallon ; Dundonald (D.).

A. conjugella, Z.-Bonhill (J.M.): Giffnock; Gourock (D); Gleniffer (J. D.).

A. spiniella, Z.-C. Langside ; Cadder Wilderness (K.) : Bonhill (J. M.) : Linwood (J. D.).

A. ephippella, F.-Bouhill (J. M.) : Dundonald (D.).

A. nitidella, F.-Langside (K.) : Bonhill (J. M.) : Gleniffer (J. D.).

A. albistria, Hw._Possil Marsh ; Mugdock Wood (K.) : Bonhill (J. M.) : Carluke (M.) : Dargavel (J. D.).

A. semitestacella, Curt.-Nr. Glasgow ; Cadder Wilderness (K.): Bonhill (J. M.): Gleniffer (J. D.).

Swammerdamia combinella, Hb.-Garelochhead (H.) : Carluke (M.) : Bonhill (J. M.): Arrochar (D.).

S. heroldella, $H b$.-C.

S. lutaria, Hw.-Gourock ; $\operatorname{Arran}$ (J. D.).

S. caesiella, $H b .-\mathrm{C}$.

Diplodoma marginepunctella, Stph.-Bonhill (J. M.).

Ochsenheimeria bisontella, Z.-Mugdock Wood ; Cadder Wilderness (K.) : Bonhill ; Jamestown (J. M.) : Gleniffer (J.D.): Ravenscraig; Glen Mallon (D.).

Incurvaria pectinea, Hw.-Cleghorn ; Brodick (M.).

I. muscalella, F.-Kenmuir Bank; Cadder Wilderness (K.) ; Carluke (M.) : Bonhill; Jamestown (J. M.) : Cathcart ; Johnstone ; Rothesay (D.).

Lampronia quadripunctella, Stph.-Nr. Glasgow (K.): Bonhill (J. M.) ; Crookston (D.): Gleniffer (J.D.).

L. praelatella, Schiff.-Milngavie (K.): Garelochhead (H.): Dargavel (J. D.) : Glen Maillon (D.).

L. rubiella, Bjerkander.-Cadder Wilderness; Bishopton Moss; Allander (K.): Bonhill (J. M.) : Carluke (M.) : Dargavel (J. D.) : Garelochhead (H.) : Johnstone ; Dundonald (D.).

Myrmecozela ochraceella, Tgst.-Ruchill (K.).

Tineola biselliella, Hiimmel.-C. in houses.

Phylloporia bistrigella, Hw.-Dargavel ; Langside ; Clober (K.) : Gleniffer (J.D.) : Bonhill (J. M.) : Johnstone (D.).

Monopis imella, Hb.-Bonhill (.J. M.).

M. fenestratella, Heyden.-Carluke (M.).

M. rusticella, Hb.-Cadder Wilderness; Barrachan Moss (K.): Bonhill (J. M.) : Carluke (M.) : ır. Paisley (J. D.).

Trichophaga tapetiella, L.-Bonhill (J.M.): Garelochhead (H.) : Paisley (J.D.).

Tinea arcella, F.-Carluke (M.).

T. cloacella, $H w$.-C.

T. fuscipunctella, $H u$.-Bonhill (J.M.) : Uddingston (M.): nr. Paisley (J. D.).

T. pellionella, L.-Bonhill (J. M.) : nr. Paisley (J. D.).

T. pallescentella, Stt.-C.

T. lapella, Hb.--Barrachan Moss (K.) : Bonhill (J. M.) : nr. Paisley (J. D.) : Catheart; Crookston; Johnstone (D.). 
T. semifulvella, $H w .-$ Bonhill (J. M.) : Arrochar ; Shewalton (D.).

Nemophora swammerdamella, L.-Cadder Wilderness ; Milngavie ; Langside (K.): Renfrew (J. D.) : Carluke (M.).

N. schwarziella, Z.-Cadder Wilderness (K) : Bonhill (J. M.) : Carluke (M.) : Renfrew (J.D.) : L'goilhead (D.).

N. pilella, $F$.-Bonhill (J. M.).

Adela rufimitrella, Sc.-Possil Marsh (K.) : Crookston (D.) : Dargavel (J.D.).

A. cuprella, Thunberg.-Rowardennan (M.).

Nemotois cupriacellus, $H b$.-Barr (D.).

N. minimellus, Z.-Carluke (M.) : Straiton (D.).

\section{MICROPTER YGINA.}

Fam. Hepialidae.

Hepialus hectus, L.-Cadder Wilderness; Langside; Ruchill ; Mugdock Wood (K.): Dunoon (H.C.) : Renfrew (J.S.) : Bonhill (J.M.) : Johnstone ; L. Riddon ; L'goilhead ; Barr ; Luss (D.).

H. lupulinus, L.-Cambuslang; Langside ; Ruckhill ; Cadder Wilderness (K.) ; Renfrew (J. S.) : Carluke (M.): Ardrossan (H.C.) : Giffnock ; Cathcart ; Tarbert (D.).

H. sylvinus, L.-Ruchill ; Possil ; Gourock (K.) : Dunoon (T. C.) : Loch Goil : Bonhill (J. M.) : Ayrshire ; Carmunnock ; Corrie (D.).

H. velleda, $H b$.-Ruchill ; Langside ; Cadder Wilderness (K.) : Bonhill (J. M.).

H. humuli, L.-C.

\section{Fam. Micropterygidae.}

Micropteryx sparmanella, Bosc.-Mugdock (K.).

M. purpurella, Hw.-Mugdock (K.).

M. semipurpurella, Stph.-Bonhill (J. M.).

M. unimaculella, Zett._Langside (K.): Bonhill (J. M.) : Gourock ; Arran (J. D.).

M. subpurpurella, Haw.-Langside (K.) : Mugdock (K.) : Bonhill (J. M.) : Garelochhead (H.) : Gourock ; Arran ; Dunoon (J. D.).

Eriocephala aureatella, Sc.-Cadder Wilderness (K.) : Clober (K.): Bonhill (J. M.) : nr. Paisley (J. D.) : Crookston ; Johnstone ; Luss (D.).

E. aruncella, Sc.-Langside (K.): Arrochar (J.M.): Bonhill (J.M.) : Gleniffer (J. D.) : Crookston ; Giffnock ; Johnstone (D.).

E. calthella, L.-Langside ; Possil ; Troon; Milngavie ; Strathblane (K.): Bonhill (J. M.) : Colintraive (D.) : Newton Woods, Paisley (J. D.). 


\section{ORder Diptera.}

\section{(Except Tipulidae).}

\section{By Percy H. Grimshaw, F.E.S., Museum of Science and Art, Edinburgh.}

Classification and Arrangement : Verrall, List of Biritish Diptera, 1888 (with a few exceptions).

Contractions: c. $=$ common, $\mathrm{r}_{.}=$rare, gen. dist. $=$generally distributed etc.

$(\mathrm{V})=$. Verrall (in most cases in Ent. Monthly Mag., vol. xix., 1883) ; (B. $)=$ Binnie ; $($ D. $)=$ A. Adie Dalglish, F.E.S. ; $($ F. $)=$ Anderson Fergusson ; (G.) $=$ P. H. Grimshaw, F.E.S.

The compiler is much indebted to the labours of the four gentlemen named above, and others whose names appear in brackets below, without whose aid the list must have been much abbreviated.

\section{Fam. Cecidomyidae.}

Asphondylia pimpinellae, F. Lw.-Galls on Angelica sylvestris, Mugdock Wds., Glasgow (B.).

A. sarothamni, Lw.-Galls on Cytisus scoparius, Glasgow; Milngavie (B.).

A. ulicis, Traill.-Galls on Ulex europaeus, Milngavie ; Kilpatrick Hills ; Kilsyth Gl. (B.).

Cecidomyia betulae, Winn.-Galls on Betula alba, Glasgow ; Mugdock Wds. ; Bishopton (B.).

C. bursaria, Bremi.-Galls on Nepeta glechoma, Glasgow (B.).

C. campanulae, Mïll.--Galls on Campanula rotundifolia nr. Glasgow (B.)

C. cerastii, Bimie.-Galls on Cerastium viscosum, c. Possil district (B.)

C. crataegi, Winn.-Gall on Crataegus oxyacantha, near Glasgow (B.).

C. galii, Lw.-Galls Possil Marsh and nr. Glasgow (B.).

C. marginemtorquens, Bremi.-Galls on Salix viminalis nr. Glasgow (B.).

C. persicariae, L.--Galls on Polygonum persicaria, Glasgow (B.).

C. pilosellae, Binnie.-Galls on Hieracium pilosella, nr. Glasgow; Kilsyth Glen ; Milngavie (B.).

C. pruni, Kltb.-Galls on Prunus spinosa, Mugdock Wd. ; nr. Glasgow (B.).

C. pteridis, Müll.-Galls at Glasgow (B.).

C. quercus, Binnie.-Galls on Quercus robur, nr. Cambuslang; banks of Clyde, nr. Newton (Cameron) : Mugdock Wd.; Cadder Wilderness (B.)

C. rosaria, Lw.-Galls on Salix, Glasgow (B.).

C. rosarum, Hardy.-Galls nr. Glasgow (B.).

C. salicis, Schrk.-Galls on Salix, Glasgow (B.).

C. tornatella, Bremi.-Galls on Fagus sylvatica, nr. Glasgow (B.).

C. trifolii, F. Lw.-Galls on Trifolium repens, Glasgow (B.).

Diplosis dryobia, F. Lw.--Galls, Mugdock Wood; Cadder Wilderness (B.)

D. loti, Deg.-Galls on Lotus corniculatus, nr. Glasgow (B.).

Hormomyia capreae, Winn.-Galls on Salix, Glasgow (B.). 
H. juniperina, L.-Galls on Juniperus communis, nr. Glasgow (B.).

H. millefolii, Lw.-Galls on Achillea millefolium, Glasgow (B.).

H. piligera, Lw.-Galls on Fagus sylvatica, nr. Glasgow (B.).

H. ptarmicae, Vallot.-Galls on Achillea ptarmica, nr. Glasgow (B.).

\section{Fam. Mycetophilidae.}

Mycetophila bimaculata, Fab.-Arran (V.).

Macrocera lutea, $\mathbf{M g}$.-Arran (V.).

Fam. Bibionidae.

Scatopse inermis, Ruthé.-Arran (V.).

S. notata, L.-Arran (V.).

Dilophus albipennis, Mg.-Blairskaith Muir, Campsie (Ord.).

D. febrilis, L.-Generally distributed.

D. femoratus, $1 \mathrm{Mg}$.-Troon (Ord.) : Barr (F.).

Bibio johannis, L.-Bishopton (D.).

B. lacteipennis, Ztt.-Monkland Canal, Lanarkshire (Ord.): Banks of Allander ; Milngavie (Ord.) : Cronkston (D.): Arran (V.).

B. laniger, Mg.-Bishop Loch, nr. Coatbridge (Ord.): Milngavie (Ord.): Ailsa Craig (Henderson).

B. leucopterus, $M g$. - Giffnock (D.).

B. marci, L.-Bowling; Ayr (D.).

B. pomonae, Fab.-Inverglas; W. Kilbride (D.) : Elvanfoot (Evans).

Fam. Simuliidae.

Simulium latipes, $M g$.-Lagg, $\operatorname{Arran}(\mathrm{V}$.$) .$

\section{Fam. Psychodidae.}

Pericoma fallax, Eaton.-L. Lomond (King).

P. trivialis, Eaton.-L. Lomond (King).

Fam. Rhyphidae.

Rhyphus fenestralis, Scop.-Generally distributed.

R. punctatus, Fab.-Crookston (D.) : Arran (V.).

Fam. Stratiomyidae.

Nemotelus notatus, Ztt.-Arran (V.).

Oxycera trilineata, Fab.-Crookston (D.).

Odontomyia viridula, Fab.-Barr (D.).

Sargus nubeculosus, Ztt.-Crookston (D.).

Chloromyia formosa, Scop.-Strathblane (Ord.).

Microchrysa flavicornis, 1 Ig.-Milngavie (Ord.) : Busby (D.): Arran (V.).

M. polita, L.-Crookston (D.): Arran (V.).

Beris chalybeata, Först.-Arran (F. ; V.): L. Loskin, Dunoon (G.).

B. fuscipes, $M$ g. - Strathblane (Ord.).

B. vallata, Först._Cambuslang ; Irvine Moor (D.) : Arran (F. ; V.).

Fam. Tabanidae.

Haematopota crassicornis, Whlbq.-Ravenscraig (D.) : Arran (V.).

H. pluvialis, $L$. - Generally distributed.

Tabanus sudeticus, Zeller.-Bonhill (Malloch): Glenmallan (D.).

Chrysops relictus, $M g$. - Gl. Falloch, L. Lomond (Ord; D.).

Fam. Leptidae.

Leptis notata, Mg.-Arran (F. ; V.).

L. scolopacea, L.-C. and gen. dist.

L. tringaria, L.-Barr (D.).

Chrysopilus auratus, Fab.-Gen. dist. 
Atherix ibis, Fab.-Barr (Fergusson).

Symphoromyia crassicornis, Panz. - Surathblane (Ord): Lamington ; Barr (D.).

Fam. Asilidae.

Dioctria reinhardi, Wied.-Barr (D.).

Isopogon brevirostris, $M g$.-Gl, Falloch (Ord.): Arrochar (D.): Arran (F.; V.).

Pamponerus germanicus, L.-Irvine Moor (D.).

Philonicus albiceps, $M g$.-Irvine Moor (D.).

Dysmachus trigonus, Mg.-Irvine Moor (D.): Troon (Ord).

Fam. Bombyliidae.

Bombylius major, L.-L. Riddon (D.).

Fam. Therevidae.

Thereva annulata, Fab.-Irvine Moor (D.).

Fam. Empidae.

Hybos culiciformis, Fab.-Gl. Falloch (Ord): Ardpeaton, L. Long (Evans).

H. grossipes, L.-King's Cross, Arran (D.).

Cyrtoma spuria, Fln.-Dundonald (D.).

Rhamphomyia albosegmentata, Ztt.--Arran (V.).

R. flava, Fln.--Arran (D.; V.).

R. geniculata, Mg.-Arran (V.).

R. nigripes, Fab.-Banks of Allander, Milngavie (Ord) : L. Loskin, Dunoon (G.) : Arran (V.).

R. sulcata, Fln.--Tollcross (Ord) : Monkland Canal, Lanarkshire (Ord) : Crookston (D.).

R. tarsata, Mg.-Arran (V.).

R. umbripennis, $M /$. - Arran (V.).

Empis bilineata, Lw.-Eaglesham (Ord) : Barr (F.).

E. livida, $L .-C$. and gen. dist.

E. opaca, Fab.--Eaglesham (Ord).

E. punctata, $M g$.-Lamington (D.).

E. scutellata, Curtis.-A male of this very rare species taken at Arrochar, 10/6/99 by Mr. A. Adie Dalglish.

E. stercorea, $L$.-Gen. dist.

E. tessellata, Fab.-C. and gen. dist.

E. trigramma, $\mathbf{M g}$. - Gen. dist.

E. vernalis, $M g$. - Arran (V.).

Hilara interstincta, Fln.-Gl. Falloch (Ord): Ardpeaton, L. Long (Evans): Arran (V.).

H. maura, Fab.-Arran (V.) : L. Loskin, Dunoon (G.).

H. pruinosa, $\mathrm{Mg}$. - Arran (V.).

H. squalens, Ztt. - Arran (V.).

Hemerodromia melanocephala, Hal.-Arran (V.)

H. precatoria, Fln.-L. Loskin, Dunoon (G.).

Gloma fuscipennis, $\mathrm{Mg}$.-Arran (V.).

Tachypeza nubila, Mg.-Arran (V.).

Tachista annulimana, $1 / g$.-Arran (V.): Giffnock (D.) : Elvanfoot (Evans).

Fam. Dolichopodidae.

Psilopus platypterus, Fab.-Arran (V.): Ardpeaton, L. Long (Evans).

Hygroceleuthus diadema, Hal.-Arran (V.).

Dolichopus aeneus, Deg. - C. and gen. dist.

D. atratus, Mg.-Arran (V.).

D. atripes, Mg.-Arran (V.). 
D. discifer, Stan.-Gl. Falloch (Ord): Arran (V.).

D. lepidus, Staeg.-Arran (V.).

D. nubilus, Mg.-Arran (V.).

D. pennatus, Mg.-Arran (V.).

D. plumipes, Scop.-Strathblane ; Troon ; Blairskaith Muir, Campsie (Ord): L. Loskin, Dunoon (G.).

D. popularis, Wied.-Arran (V.): Barr (F.): L. Loskin, Dunoon (G.) : Ravenscraig (D.).

D. simplex, Mg.-Arran (V.).

D. trivialis, Hal.-Ardpeaton, L. Long (Evans).

D. urbanus, Mg.-Arran (V.): Banks of Allander, Milngavie (Ord.): L. Loskin, Dunoon (G.).

D. vitripennis, $M g$. - Arran (V.).

Tachytrechus notatus, Stan.-Arran (V.)

Gymnopternus aerosus, $F l_{n}$.-Arran (V.).

G. cupreus, Fln.-Arran (V.).

Argyra argentina, M.q.-Arran (V.).

A. argyria, Mg.-Milngavie; Blairskaith Muir, Campsie (Ord).

A. diaphana, $F a b$. - Arran (V.).

A. leucocephala, $M g$. - A rran (V.).

Rhaphium longicorne, $F^{\prime} l n$. - A Arran (V.).

Porphyrops praerosus, $L w$.-Arran (V.).

Synarthrus pallipes, Fab.-Arran (V.).

Syntormon sulcipes, $M / g$. - Arran (V.).

Machaerium maritimae, Hal.-Arran (V.).

Xiphandrium appendiculatum, Ztt.--Arran (V.).

$\mathrm{X}$. fissum, $L w$. - A rran (V.).

X. monotrichum, Lw.-Arran (V.) : L. Loskin, Dunoon (G.).

Medeterus apicalis, Ztt.? - Arran (V.).

Hydrophorus bipunctatus, Lelem.-Elvanfoot (Evans).

Campsicnemus armatus, Ztt.-Arran (V.).

C. curvipes, Fln.-Arran (V.).

Sympycnus annulipes, $M / g$.-Arran (V.).

Fam. Pipunculidae.

Pipunculus furcatus, Schin.-Strathblane (Ord): Barr (D.).

Fam. Syrphidae.

Pipizella biguttata, Curt.-Barr(F.): Gl. Falloch, L. Lomond ; Strathblane; Blairskaith Muir, Campsie ; L. Loskin, Dunoon (Ord).

Pipiza carbonaria, $\mathbf{M g}$. ?-Gl. Falloch, L. Lomond (Ord).

Chrysogaster hirtella, Lw.-Gen. dist.

C. metallina, Fab.-Arran (V.) : Possil Marsh ; Troon ; L. Loskin, Dunoon (Ord) : Ravenscraig (D.).

Chilosia albitarsis, $M g$.-Arran (V.).

C. antiqua, $M g$.-Arran (V.) : Barr (D.).

C. chloris, Mg.-Arran (V.; D.) : Irvine (D.).

C. flavimana, $\mathrm{Mg}$.-Arran (V.): Barr (F.): Crookston (D.).

C. intonsa, $L w$-Crookston (D.).

C. oestracea, L.-Bonhill (Malloch): Dundonald (D.).

C. sparsa, Lw.-Arran (V.).

C. variabilis, Panz.-Arran (V.): Barr (E. ; D.).

Leucozona lucorum, $L$.-C. and gen. dist.

Melanostoma mellinum, L.-C. and gen. dist.

M. scalare, Fab.-Arran (V.).

Pyrophaena ocymi, Fab.-Inverkip (Ord): West Kilbride ; Busby ; King's Cross, Arran (I).). 
P. rosarum, Fab.-King's Cross, Arran (D.).

Platychirus albimanus, $F a b$. - C. and gen. dist.

P. angustatus, Ztt.-Barr (F.).

P. clypeatus, $M g$. - C. and gen. dist.

P. manicatus, $\mathrm{VI}$. - C. and gen. dist.

P. peltatus, $\mathrm{Mg}$. - C. and gen. dist.

P. scambus, Staeg.--C. and gen. dist.

Syrphus annulatus, Zett._Arran (V.).

S. arcticus, Zett.-Arran (V.).

S. balteatus, Deg.-C. and gen. dist.

S. barbifrons, $F^{\prime} l n$.-Arran (V.).

S. cinctellus, Zett.-Irvine Moor (D.).

S. cinctus, Fln.-Arran (V.).

S. compositarum, Ver.-Arran (V.).

S. grossulariae, $\mathrm{Mg}$. - Arran (V.).

S. laternarius, Miül.-Dundonald ; Barr (D.).

S. latifasciatus, Mcq.-Milngavie ; Gourock ; Ravenscraig (D.).

S. luniger, $\mathrm{I} / \mathrm{g}$.-Barr (F.).

S. nigritarsis, Ztt. ? Arran (V.).

S. punctulatus, Ver.-Arran (V.).

S. quadrilunulatus, Schum.-Arran (V.).

S. ribesii, L.-C. and gen. dist.

Catabomba pyrastri, L.-Possil Marsh; Irvine Moor (D.); Elvanfoot (Evans).

Sphaerophoria menthastri, L.-Arran (V.; D.) : L. Loskin, Dunoon (G.).

S. picta, $M g$. C. and gen. dist.

Sphegina clunipes, Fln.-Strathblane (Ord).

Ascia floralis, $\mathrm{Mg}$.--Arran (V.).

A. podagrica, Fab.-Strathblane (Ord): Arran (V.; F.).

Rhingia rostrata, $L$. C. and gen. dist.

Volucella bombylans, L., var. bombylans, Mg.--Barr (D.).

var. plumata, $1 /$ g. - Barr ; King's Cross, Arran (D.).

V. pellucens, L.-Bonhill (Malloch).

Sericomyia borealis, Fln.-Barr; Ravenscraig; King's Cross, Arran (D.).

S. lappona, L.-Arran (V.) : Barr (F.) : Dunoon (G.): Strathblane (Ord) : Colintraive (D.).

Arctophila mussitans, Fab.-Barr (D.) : Bonbill (Malloch).

Eristalis arbustorum, L.-C. and gen. dist.

E. horticola, Deg.-Gell. dist.

E. intricarius, L.-Bishopton (D.) : Bonhill (Malloch) : Bishop L., nr. Coatbridge (Ord) : Elvanfoot (Evans).

E. nemorum, L.-Arran (V.).

E. pertinax, Scop.-C. and gen. dist.

E. rupium, Fab.-Barr (F. ; D.): Elvanfoot (Evans).

E. sepulchralis, L.-Possil Marsh (Ord).

E. tenax, L.-C. and gen. dist.

Myiatropa florea, L.-Bonhill (Malloch) : L. Loskin, Dunoon (Ord).

Helophilus hybridus, Lw.-Possil Marsh (D.).

H. lineatus, Fab.-Possil Marsh (Ord ; D.).

H. pendulus, L.-C. and gen. dist.

Criorrhina oxyacanthae, Mg.-Barr (D.).

Xylota segnis, L.-Arran (V.) : Inverkip (Ord) : Barr (D.)

Syritta pipiens, L.-C. and gen. dist.

Chrysotoxum arcuatum, L.-Inverkip (Ord).

C. bicinctum, L.- Dundonald (D.).

Microdon mutabilis, L.- Nr. Glasgow (Cameron). 
Fam. Conopidae.

Sicus ferrugineus, L.--Dundonald (D.).

Myopa buccata, L.-Irvine Moor (D.).

Fam. Tachinidae.

Siphona geniculata, Deg.-Blairskaith Muir, Campsie ; Eaglesham (Ord).

Olivieria rufomaculata, Deg.-Barr (D.).

Sisyropa lota, $M g$. - Gl. Falloch, L. Lomond (Ord).

Miltogramma punctata, M.g.-Arran (Curtis).

Metopia amabilis, $\mathrm{Mg}$.--Strathblane (Ord).

Degeeria blanda, Fln.-Colintraive (D.).

Fam. Dexiidae.

Dexia vacua, Fln.-Barr; King's Cross, Arran (D.).

\section{Fam. Sarcophagidae.}

Sarcophaga albiceps, $M g$.-Inverglas (D.).

S. atropos, $M g .-\operatorname{Arran}(\mathrm{V}$.$) .$

S. carnaria, L.-Arran (V.); Barr ; Lamington (D.); Strathblane (Ord).

S. melanura, $\mathrm{Mg}$.-C'rookston (D.).

Cynomyia alpina, Ztt.-Barr (E.).

C. mortuorum, L.-Arran (V.): Elvanfoot (Evans) : Troon (Ord).

\section{Fam. Muscidae.}

Lucilia caesar, L.-C. and gen. dist.

L. cornicina, Fab.--C. and gen. dist.

L. sericata, 1 g. - Strathblane (Ord).

Calliphora erythrocephala, $M g$.-C. and gen. dist.

C. groenlandica, Ztt.-Dunoon (G.).

C. vomitoria, L.-Arran (V.).

C. sepulchralis, $M g .-\mathrm{C}$. and gen. dist.

Pollenia rudis, Fab.-Inverglas (D.): Strathblane ; Gl. Falloch ; L. Lomond (Ord).

Mesembrina meridiana, L.-Arran (V.): Inverglas ; Barr (D.).

Graphomyia maculata, Scop.-Arran (V.): L. Loskin, Dunoon ; Possil Marsh (Ord) : Barr (F.).

Morellia hortorum, Fln.-Arran (V.).

M. simplex, Lw.-Arran (V.): Milngavie (Ord).

Cyrtoneura stabulans, Fln.-Arran (V.).

Myiospila-meditabunda, Fab.-Arran (V.): Blairskaith Muir, Campsie; Monkland Canal, Janarkshire (Ord).

Haematobia stimulans, $1 . \mathrm{g}$.-Arran (V.).

Fam. Anthomyiidae.

Polietes albolineata, Fln.-Arran (V.).

P. hirticrura, Meade.-Kilmarnock (V.).

P. lardaria, $F a b .-C$. and gen. dist.

Hyetodesia aculeipes, $Z$ tt.- Strathblane (Ord). New to Britain.

H. basalis, Ztt.--Barr (F.): Strathblane (Ord).

H. boleticola, Rnd.-Arran (V.).

H. cunctans, $M g$.-Arran (V.).

H. errans, $I I g$.-Tollcross (Ord) : Arran (V.).

H. hirsutula, Ztt.-Arran (V.).

H. incana, Wied.-C. and gen. dist.

H. innocua, Ztt.-Arran (V.).

H. lasiophthalma, Mcq.-Arran (V.).

H. longipes, Ztt.-Arran (V.; F.): Strathblane; Blairskaith Muir, Campsie ;

Gl. Falloch (Ord). 
H. lucorum, Fln.-Arran (V.): Blairskaith Muir, Campsie; Strathblane; Milngavie (Ord).

H. marmorata, Ztt. - Arran (V.).

H. obscurata, Mg.-Blairskaith Muir, Campsie (Ord).

H. scutellaris, $F l n .-A$ rran (V.).

H. semicinerea, Wied.-Arran (V.).

H. signata, Mg.-Arran (V.).

H. umbratica, $M g$.--Arran (V.).

H. variabilis, Fln.-Arran (V.): L. Loskin, Dunoon (Ord).

Mydaea impuncta, $F \eta_{n}$. - C. and gen. dist.

M. pagana, $F a b$.-Gen. dist.

M. urbana, Mg.-Arran (V.) : Milngavie (Ord).

Spilogaster communis, Dsv.-Arran (V.)': Dunoon (G.).

S. compuncta, Wied.-Arran (V.).

S. consimilis, $F_{l n}$.-Arran (V.).

S. contractifrons, $Z t t$.-Arran (V.).

S. maculosa, Mg.-Arran (V.).

S. nigrinervis, $Z t t$.-Gen. dist.

S. solitaria, Ztt.-L. Loskin, Dunoon (G.).

S. sororcula, Ztt.-Arran (V.).

S. trianguligera, $Z t t$. - Inverglas (D.).

Hydrotaea ciliata, Fab.-Arran (V.).

H. dentipes, Fab.-Arran (V.): Eaglesham (Ord).

H. fasciculata, Meade.-Arran (V.).

H. irritans, Fln.-Arran (V.): Banks of Clyde, Carmyle ; Troon (Ord).

H. meteorica, L.-Arran (V.).

H. occulta, Mg.-Arran (V.).

H. palaestrica, $M g$.-Arran (V.).

H. rondanii, Meade.-Arran (V.).

Drymeia hamata, Fln.-King's Cross, Arran (D.).

Hydrophoria conica, Wied.-Arran (V.): Strathblane (Ord).

Hylemyia cardui, Mg.-Eagleshan ; Gl. Falloch (Ord).

H. lasciva, Ztt.-Barr (F.).

H. nigrimana, $M g$.-Arran (V.).

H. praepotens, Ii ied.-Ardpeaton, L. Long (Evans).

H. strigosa, $F a b$. - C. and gen. dist.

H. variata, Fln.-Gen. dist.

Lasiops ctenocnema, Kow.-Arran (V.).

L. roederi, Kow.-Arran (V.).

An`homyia pluvialis, L.-Airran (V.).

A. radicum, L.-Arran (V.).

Phorbia floccosa, $M / c q$.- Arran (V.).

P. trichodactyla, Rond.-Arran (V.).

Pegomyia bicolor, Wied.-Ailsa Craig (Henderson).

Homalomyia aeria, Ztt.-Arran (V.).

H. armata, Mg.-Arran (V.).

H. manicata, Mg.-Arran (V.).

H. polychaeta, Lw.-Arran (V.).

H. serena, Fln.-Arran (V.).

Azelia cilipes, Hal.-Arran (V.) : Inverglas (D.).

A. gibbera, $M g$. - Arran (V.).

A. macquartii, Staeg.-Arran (V.).

A. zetterstedtii, Rond.-Arran (V.).

Macrorchis intermedia, Fln. - Ardpeaton, L. Long (Evans): Strathblane;

Blairskaith Muir, Campsie (Ord).

Coenosia sexnotata, Mg.-Gl. Falloch (Ord).

Hoplogaster mollicula, Fln._Ardpeaton, L. Long (Evans). 


\section{Fam. Scatomyzidae.}

Parallelomma albipes, Fln.--Irvine Moor (D.).

Amaurosoma tibiella, Ztt.--Steps Moor, nr. Glasgow (Ord).

Norellia spinimana, Fln.-Pirn Mill, Arran (F.).

N. striolata, Mg.-Monkland Canal, Lanarkshire (Ord).

Spathiophora hydromyzina, Fln.-Crookston (Ord).

Scatophaga inquinata, Mg.-Arran (V.).

S. litorea, Fln.-Arran (V.): Crookston (Ord).

S. lutaria, Fab.-Gourock (D.).

S. maculipes, Ztt.-L. Loskin, Dunoon (G.).

S. squalida, Mg.-Goatfell, Arran (V.): L. Loskin, Dunoon (Ord ; G.): Crookston; Eaglesham ; Giffnock (Ord).

S. suilla, Fab.-Gen. dist.

S. stercoraria, L.--Abundant every where.

Clidogastra nigrita, Fln.-Banks of Allander, Milngavie (Ord).

Gimnomera tarsea, Fln.-Barr (F.): Arran (V.).

Fam. Helomyzidae.

Helomyza laevifrons, Lw.-Strathblane; Gl. Falloch ; Milngavie (Ord).

Blepharoptera serrata, L.-Steps Moor, nr. Glasgow (Ord).

\section{Fam. Sciomyzidae.}

Dryomyza anilis, Fln.-Strathblane ; Milngavie (Ord.)

D. decrepita, Ztt.-Gl. Falloch, L. Lomond (Ord).

D. flaveola, Fab.-Tollcross ; Milngavie ; Carmyle (Ord): Giffnock (D.).

Sciomyza albocostata, Fln.-Giffnock (D.).

S. pallida, Fln.-Gl. Falloch, L. Lomond (Ord).

Phaeomyia fuscipennis, Mg.-Blairskaith Muir, Campsie (Ord).

Tetanocera elata, Fab.-Banks of Clyde, Carmyle (Ord).

T. ferruginea, Fln.-Crookston; Strathblane ; Monkland Canal, Lanarkshire (Ord).

T. laevifrons, Lw.-Eaglesham ; Strathblane (Ord) : L. Loskin, Dunoon (G.).

T. reticulata, Fab.-L. Loskin, Dunoon (G.).

T. robusta, Lw._-Crookston; Gourock ; Colintraive (D.).

T. sylvatica, $\mathrm{Mg}$.-Milngavie (Ord).

T. umbrarum, L.-GI. Falloch (Ord): Ravenscraig (D.).

Limnia unguicornis, Scop.-. Strathblane (Ord).

Elgiva albiseta, Scop.-Blairskaith Muir, Campsie; Giffnock (Ord).

E. dorsalis, Fab.-Colintraive (D.).

\section{Fam. Psilidae.}

Psila atra, Mq.-Ardpeaton, L. Long (Erans).

P. fimetaria, L.-Arran (V.): Strathblane; Milugavie (Ord); Crookston (1).).

P. nigra, Fln.-Arran (V.).

P. pallida, Fln.-Barr (F.).

P. rosae, Fab.-Ailsa Craig (Henderson).

P. rufa, Mg.-Lamington (D.).

Loxocera aristata, Pz.-Barr (F.) : Blairskaith Muir, Campsie ; Milngavie

(Ord): Irvine; Ravenscraig ; Lamington (D.).

\section{Fam. Micropezidae.}

Calobata petronella, L.-Strathblane (Ord).

\section{Fam. Ortalidae.}

Pteropaectria frondescentiae, L.-Gen. dist.

Ceroxys crassipennis, Fab.-Lamington (D.).

Rivellia syngenesiae, Fab.-Strathblane (Ord): Dundonald (D.).

Seoptera vibrans, L.-Cumbuslang (D.). 
Fam. Trypetidae.

Acidia heraclei, L.-Busby (D.).

Trypeta onotrophes, Lw.--Busby (D.).

Urophora solstitialis, L.-Gl. Falloch, L. Lomond (Ord).

U. stylata, Fab.-Barr (D.).

Carphotricha pupillata, Fln.-Giffnock (D.).

Tephritis leontodontis, Deg.-Barr (F.): Elvanfoot (Evans).

Fam. Lonchaeidae.

Palloptera arcuata, Fln.-Gourock (D.): Strathblane ; Carmyle (Ord).

P. umbellatarum, Fab.-Arran (V.).

Fam. Sapromyzidae.

Sapromyza longipennis, Fab.-Strathblane (Ord).

S. obsoleta, Fln.-Blairskaith Muir, Campsie (Ord).

S. praeusta, Fln.-Strathblane (Ord).

S. rorida, Fln.-Blairskaith Muir, Campsie ; Carmyle ; Strathblane (Ord).

Fam. Opomyzidae.

Opomyza germinationis, L.-Lamington (D.).

\section{Fam. Sepsidae.}

Sepsis cynipsea, L.-Barr ; Johnstone (D.).

Nemopoda cylindrica, Fab._Ailsa Craig (Henderson) : Giffnock (D.) : L. Loskin, Dunoon (G.).

Cheligaster putris, L.-Ardpeaton, L. Long (Evans).

\section{Fam. Ephydridae.}

Notiphila nigricornis, Stenh.-L. Loskin, Dunoon (G.).

Hydrellia griseola, Fln.-L. Loskin, Dunoon (G.).

Fam. Chloropidae.

Chlorops didyma, Zett.-Dundonald (D.).

Fam. Agromyzidae.

Agromyza nigripes, $M g$. - Crookston (D.).

Fam. Milichidae.

Phyllomyza securicornis, Fln.--Ardpeaton, L. Long (Evans).

Fam. Borboridae.

Borborus equinus, Fln.-Tollcross, nr. Glasgow (Ord).

B. geniculatus, Mcq.-L. Loskin, Dunoon (G.).

Fam. Nycteribiidae.

Nycteribia hermanni, Leach.-On bats, Nethercraigs, Renfrewshire (J. Paterson). 
By R. Henderson, 12 Armadale Street, Glasgow.

\section{Nomexclature.}

Verrall, List of British Diptera, 1888 [5 species recorded are not in Verrall's List].

I am much indebted to Mr. A. Ross, who joined me after the death of my friend and colleague, Mr. G. W. Ord, and to Mr. A. Adie Dalglish, who sent me a large number of specimens. Mr. Verrall and Mr. E. E. Austen, of the Brit. Mus., have inspected the specimens marked $\$$ and + respectively.

For the most part the list covers only 1899, 1900, and part of the present year.

\section{AbBreviations :}

R., Freq., C.= Rare, Frequent, Common.

Baldernock=Linn of Baldernock, and Blairskaith Muir; Bardowie = Old Strathblane Rd., nr. Bardowie Loch ; Cadd. Wild.=Cadder Wilderness ; Cadd. Wd.=Cadder Wood, adjoining bank of Forth and Clyde Canal; Cambuslang $=\mathrm{S}$. bank of Clyde between Cambuslang and Newton ; Carmyle $=\mathrm{N}$. bank of Clyde from Carmyle to Kenmuir Bank ; Eaglesham=Moor at Eaglesham, nr. Ballageich; Lunderstone=Wood at Lunderstone, on shore, below Cloch Lighthouse ; Milngavie=Clober Dam and left bank of Allander, at Mugdock; Monkd. Cl.=S. bank of Monkland Canal, nr. Cardowan; Possil M. = Possil Marsh.

(G. W. O.) = The late G. W. Ord ; (A. A. D. $)=$ A. Adie Dalglish.

\section{Fam. Dixidae.}

Dixa maculata, $\mathbf{M g}$-CC. April-Oct. Cadd. Wild.; Craigton Wd. ; \&c.

D. nebulosa, Mg.-Freq. May, and July-Oct. Cleghorn Woods; Finnich Glen ; \&c.

\section{Fam. Ptychopteridae.}

Ptychoptèra contaminata, L.-Freq. May\&Aug. Bishopton ; Cambuslang; Giffnock; Colintraive.

P. paludosa, Mg.-R. May-Aug. Cambuslang; Cadd. Wd. ; Strathblane; Lunderstone.

P. lacustris, Mg.-Freq. June-Aug. Loch Thom; Strathblane; W. Kilbride; Lunderstone ; Millport; Cadd. Wild.

P. albimana, F.-Freq. May-Sep. Milngarie; Crookston ; \&c.

P.scutellaris, Mg.-R. May-June. Eaglesham; Ravenscraig; Frankfield L.

\section{Fam. Limnobidae.}

\section{Limnobince.}

Limnobia bifasciata, Schrk.-Freq. July-Aug. Milngavie ; Largs ; Lunderstone ; Troon; Colintraive; L'goilhead.

L. quadrinotata, Mg.-R. June, and Aug.-Sept. Gl. Falloch; Troon; Colintraive; Waulkmill Gl.

L. nubeculosa, IVg.-C. May-Oct.

L. flavipes, F.-Freq. May-Aug. Mains Wood, nr. Giffuock ; Cambuslang ; Inverkip ; Gourock ; Milngavie ; Nurroch Gl. ; Ormidale. 
L. tripunctata, F.-Freq. May-July. Mains Wd. ; Cadd. Wild.; Strathblane; Inveraray; Murroch Gl.

L. trivittata, Schum.-Freq. July-Aug. Millport; Milngavie; \&c. ; Largs and Skelmorlie districts.

L. macrostigma, Schum.-Freq. May-June and Sept.-Oct. Milngavie; Cambuslang ; Ardmore Pt. ; Cadzow F. ; \&c.

Dicranomyia aquosa, Ver.-Two, Inverkip, 24/6/99 (G. W. Ord).

D. pilipennis, Egg.-Freq. May-Aug. Kiru ; Wemyss Bay ; W. Kilbride ; Ormidale ; Blairmore.

D. modesta, Mg.-C. June-Oct. Cadd. Wild. ; Milngavie ; Crookston ; \&c.

D. chorea, $\mathbf{I g} .-\mathrm{C}$. April-Oct. Cambuslang; Cadd. Wild.; Lusterstone; \&c.

D. sp. ?-R. Sept. Ardmore Point; Arden; Steps Wd. An ochreous species with very different genitalia from the two preceding.

D. sp. ?-R. May-July. Crookston ; Milngavie; Gl. Falloch ; \&c. A dark species, probably a var. of D. sericata, Mg.

D. stigmatica, $M g$.--R. Aug. Lochgoilhead ; Colintraive.

D. didyma, Mg.-Freq. June-July. Baldernock; Strathblane ; Murroch Gl.; Inverkip ; Millport ; Gallangad Gl.

D. dumetorum, IIg.-Freq. June-Sep. C. in Cadd. Wild.

D. morio, F.-Freq. May-Sept. Giffnock; Millport; Waulkmill Gl. : Bishopton ; Milngavie ; Largs ; itc.

D. ornata, $\mathrm{Mg}$. - One male, 4/6/99, Crookston (A. A. D.) : 3 m., 25/5/01, Gorge of Avon (Ross).

Rhipidia maculata, M $\mathrm{M}$-CC. May-Oct. Cadder Wild. ; Ardmore Pt. ; \&c. Geranomyia unicolor, Hal.-One, 11/7/97, probably at Holy L., althongh L. Eck was visited same day. Recorded hitherto only from S. of England and from Ireland.

\section{Rhamphidinae.}

Rhamphidia longirostris, Mg.-R. May-July. Possil M. ; Cadd. Wd.; Frankfield L. ; Ormidale.

Orimarga sp.?-Single specimens Murroch Gl.; Loch Eck, 8/7/99 and $15 / 7 / 00$.

Antocha opalizans, O-Sack:-Freq. May-July, and Sept. Milngavie : Kenmuir ; Murroch Gl. ; \&c. C. at Cambuslang.

\section{Eriopterinae.}

Empeda flava, Schum.-R. June-July. Murroch Gl.; Clober Dam ; Cambuslang ; Cadd. Wild. ; Gallangad Gl.

E. nubila, Schum.-C. April-Oct. Gartloch; Crookston ; Cadd. Wild. ; \&c. Goniomyia connexa, Lw.-One male, 8/7/99, Murroch Gl. I have not seen any record of this species in Britain.

G. tenella, Mg.-Freq. May-Ang. Troon ; Kirn ; Strone; Milngavie : nr. Largs ; \&c.

G. sp. ?-Freq. May-Sept. Milngavie; Lunderston ; Ardmore Pt. ; \&c. A dark species, which I have not been able to identify.

Chilotrichia imbuta, $1 / g$. - One male, 22/7/00, nr. Largs (Ross).

Acyphona maculata, Mg.-Freq. May-Sept. Clober Dam ; Cadd. Wild. ; Lunderstone; Waulkmill Gl.; \&c.

\$cyphona sp ?-May-June. C. at Cambuslang. An unspotted species; unknown to Mr. Verrall.

Molophilus appendiculatus, Staeg.—C. May-Oct. Cadd. Wild.; Lunderstone ; Eaglesham.

M. propinquus, Egg.-C. May-Sep. Possil M. ; Milngavie; \&c.

M. bifilatus, Ver-C. May-Sep. Crookston ; Strone; Gartloch; \&c.

M. obscurus, $M / g$ - -R. May-July. Clober Dam ; Strathblane ; Cambuslang.

M. murinus, Mgg.-R. May-.July. Strathblane ; Gorge of Avon ; Inveraray. 
Rhypholophus lineatus, Mg.-Freq. May-July, and Sept. Monkd. Cl. ; Cadd. Wild. ; Mains Wd.

R. nodulosus, Mcq.-C. May-Sep. Gartloch; Cadd. Wild.; Lunderstone ; \&c.

R. pentagonalis, $L w .-\mathrm{R}$. June-July. Milngavie; Strathblane.

R. similis, Staeg.--R. June-July. Cadd. Wild. ; Gallangad Gl.

R. varius, $M$ g. - Freq. Aug.-Oct. Cadd. Wild. ; Ardmore Pt. ; \&c:

R. haemorrhoidalis, Ztt.-C. Sept.-Oct. Baldernock; Cadzow F. ; \&c:

Erioptera flavescens, $\mathrm{Mg}$.-Freq. June-Aug. Possil M.; Clober Dam ; \&c:

E. taenionota, Mg.-C. May-Oct. Carmyle ; Gartloch ; Eaglesham ; \&c.

E. fuscipennis, Mg.-Freq. June-Oct. Cumbrae; Ardmore Pt.; Cadd. Wild. ; \&c.

E. trivialis, Mg.-Freq. May-Sept. Eaglesham; Milngavie; Possil M.

Symplecta punctipennis, $\mathrm{Mg}$.-R. July and Sept. Monkd. Cl.; nr. Kilmun.

S. stictica, Mg.-Freq. May-July, and Sept. Monkd. Cl. ; Ardmore Pt.; nr. Kilmun.

Lipsothrix errans, Wlk.-Freq. May-June. Milngavie ; Kenmuir Bank; Cambuslang; Ormidale.

\section{Limnophilinae.}

Idioptera fasciata, L.-R. May-June. Milngavie; Frankfield L.

I. pulchella, Mg.-May-Jume. Both sexes fairly c. at Frankfield Loch; Milngavie.

I. trimaculata, Ztt.-R. May-June. Drymen Road; Milngavie.

Ephelia miliaria, Egg.-R. May. Gorge of Avon.

E. apicata, Lw.-R. July-Aug. Lunderstone; Lock Eck ; Blairmore.

E. submarmorata, Ver.-Freq. May-Aug. Strathblane; West Kilbride ; Lunderstone; Cambuslang ; \&c.

E. marmorata, Mg.-Freq. May-Aug. Monkd. Cl.; Cadder Wd.; Arrochar ; Cambuslang; \&c.

Dactylolabis sp. ?-1 m., 27/4/01, Gorge of Avon (Ross).

D. Frauenfeldi, Egg.--One pair, 15/5/98, Fiddler Gill.

Poecilostola punctata, Schrk.-Freq. May-June. Eaglesham ; Cambuslang; Monkd. Cl. ; Castle Semple.

Limnophila Meigenii, Ver.-Freq. May-Sept. Cadd. Wild.; Milngavie ; Colintraive ; Irvine ; \&c.

L. dispar, Mg.-R. May-June. Carmyle; Mains Wood, nr. Giffnock; Strathblane.

L. lineola, Mg.-R. May-Sept. Gartloch Est.; Millport; Ormidale.

L. lineolella, Ver.-C. May-Aug. Cadd. Wild.; Milngavie; Ravenscraig; Strone.

L. aperta, Ver.-Freq. June-Aug. Clober Dam ; Colintraive; W. Kilbride ; Cadd. Wd. ; Kilmun ; Blairmore.

L. ferruginea, $\mathbf{M g}$.-Freq. May-June, and Sep. Monkd. Cl. ; Milngavie ; Eaglesham ; Arrochar ; \&c.

L. ochracea, Mg.-C. May-Sep. Cadd. Wild. ; Murroch Gl. ; Cambuslang; \&c.

L. bicolor, Mg.--Freq. May-July. Milngavie; Arrochar; Strone; Busby; Ormidale; Kilmun.

L. punctum, Mg.-R. June-Aug. Lochgoilhead ; Gl. Falloch ; Kilmun.

L. discicollis, Mg.-Freq. June-Sep. Clober Dam ; Cambuslang; Cadd. Wd. ; Strone ; Waulkmill Gl. ; \&c.

L. lucorum, Mg.-R. May-July. Strone ; Inveraray ; Ormidale.

L. nemoralis, Mg.-C. May-Sept. Monkd. Cl. ; Lunderstone ; Crookston; \&c.

L. filata, $W l k .-$ R. June-July. Clober Dam ; Blairmore.

L. senilis, Hal.-Freq. July-Sept. Cadd. Wild.; Lunderstone ; Millport; W. Kilbride ; \&c. 
Trichocera annulata, $M g$.-C. July-Oct. Carmyle; Gartloch ; \&c.

T. hiemalis, Deg.-C. April-Jany. Cadd. Wild.; Milngavie ; Cadzow ; \&c.

T. fuscata, $\mathrm{Mg}$.-Freq. June-Oct. Monkd. Cl. ; Clober Dam ; Cadd. Wild. ; Ardmore Pt. ; \&c.

T. regelationis, L.-Occurs in almost every month of the year, gen. dist.

\section{Anisomerinae.}

Anisomera vittata, Mg.-Freq. May-June. L. Thom; Cambuslang; Cadd. Wd. ; Gorge of Avon.

Peronecera fuscipennis, Curt.-One pair, 22/5/99, Cambuslang (A. A. D.). Amalopinae.

Ula pilosa, Schum. Freq. May-July and Sep.-Oct. Mains Wd.; Cadd. Wild.; Milngavie ; \&c.

Dicranota pavida, Hal.-R. July-Aug. Lunderstone; Blairmore.

D. bimaculata, Schum.-Freq. April-Sep. Eaglesham ; Strathblane; Cadd. Wild.; Steps Wood ; \&c.

Amalopis immaculata, Mg.-C. May-Sept. Frankfield; Eaglesham ; Ardmore Pt.; Colintraive.

A. unicolor, Schum.-Freq. April-Aug. I. Eck; Colintraive ; Largs ; Gorge of Avon ; Millport ; Blairmore.

A. claripennis, Ver.-R. May and Aug. Lunderstone ; Inverkip ; Colintraive; Millport.

A. occulta, Mg.-2 m., 25/5/01. Blairmore (Ross).

$\$$ A. sp. ?-Very local. Aug.-Oct. Lunderstone; Cadzow F.; Baldernock ; Fiddler Gill, \&c. I submitted this as A. geniculata, Mg., to Mr. Verrall, who says that it stands in his collection as the probable A. straminea of Walker.

A. littoralis, Mg.-Very local. June-Sep. Strathblane; Baldernock; Murroch Gl. ; Largs ; \&c.

Pedicia rivosa, L.-Freq. May-Aug. Milngavie; Lunderstone; Arrochar ; Cambuslang; Crookston; \&c.

\section{Cylindrotominae.}

Cylindrotoma distincțissima, $M g$.-One female, 16/6/00, Cleghorn Wd. (Mr. Ross).

Liogma glabrata, Mg.-One pair, 23/7/99, Cadd. Wild.

Phalacrocera replicata, L.-May. Milngavie; c. at Frankfield L.

\section{Fam. Tipulidae.}

Dolichopeza sylvicola, Curt.-C. June-July. Cadd. Wild.; Cambuslang ; Milngavie; Ardentinny ; Inveraray ; Murroch Gl. ; Blairmore.

Nephrotoma dorsalis, F.-R. July. L. Eck; Blairmore.

+ Pachyrrhina sp. ?-Resembles $P$. imperialis, Mg., but with black streak on scutellum. Freq. June-Aug. Cadd. Wild. ; Lunderstone ; L'goilhead; Strone; Cambuslang; Troon ; \&e.

P. scurra, Mg.-R. July-Aug. Troon; Irvine; W. Kilbride ; \&c.

P. histrio, F.--Freq. June-July. Monkd. Gl. ; Murroch Gl. ; Strathblane ; Cadd. Wild. ; Crookston ; \&c.

P. maculosa, Mg.-Freq. June-July. Cadd. Wild. ; Crookston; Lenzie ; Frankfield L.

§. lunulicornis, Schum.-R. May-July. Cambuslang; Kenmuir Bank; L. Eek. Not recorded as British. Mr. Verrall thinks my identification may be right.

P. sp. ?-Resembles $P$. analis, $M g$., but with black markings on pleurae. $\mathrm{R}$. June-July. Clober Dam; Cambuslang; Irvine ; Inverkip ; \&c.

P. guestfalica, Westh.-One male, 16/7/99, Strathblane (G. W. O.).

P. quadrifaria, Mg.--Freq. May-July. Strone; L. Eck; W. Kilbride ; Cadd. Wd. ; Murroch Gl.; Gorge of Avon. 
P. annulicornis, Mg.-Freq. May-July. Cadd. Wild.; Cambuslang; Clober Dam ; Glen Massan ; Inverkip ; Ormidale ; Rowardemnan.

Tipula pagana, Mg.-Freq. Sept-Oct. Cathkin Park; Cadder Wild.; Ardmore Pt. ; \&c. ; 8 females at Clober Dam, 21/10/00.

+ T. obsoleta, Mg.-Freq. May-Sep. Cadd. Wild.; Carmyle ; Murroch Gl.; Gourock; \&c.

† T. signata, Staeg.-R. Sep.-Oct. Ardmore Pt. ; Cadzow Forest; Cadd. Wild.; Steps Wood ; \&c.

+ T. confusa, V. d. Wulp.-Freq. Aug.-Sept. Cadd. Wild.; Finnich Gl.; Colintraive, Ardmore Pt. ; Waulkmill Gl. ; \&c.

† T. marmorata, $M g$.-R. Sep.-Oct. Fiddler Gill ; Mains Wood ; Finlaystone Park ; Cadd. Wild.; Ardmore Pt.

T. rufina, Mg.-Freq. May-Aug. Gourock ; Mt. Florida ; Strone ; Cadder Wild. ; Frankfield L.

T. longicornis, Schum.-C. May-July. Possil M. ; Milngavie ; Cambuslang; Strone.

+T. winnertzii, Egg.-Two males, Strone, 3/7/00. Apparently new to British list.

T. hortulana, Mg.-Freq. May-June. Gorge of Avon ; Ormidale ; Inveraray ; Cambuslang; Cadd. Wd. ; Blairmore.

T. varipennis, Mg.-C. May-July. Cadder Wild.; Eaglesham; Arrochar; Frankfield L.; Cambuslang ; \&c.

T. nubeculosa, Mg.-One female, Luss, 30/6/00 (Mr. W. Adam).

T. scripta, 1 gg.-C. June-Sept. Cadder Wild.; Murroch Gl. ; Strone ; Waulkmill Gl.

T. plumbea, F.-Freq. April-June. Frankfield L. ; Eaglesham. C. at Clober Dam, 14/5/99.

T. pruinosa, W.-Freq. May-June. Milngavie ; Gl. Falloch ; Inverkip ; Ormidale: Kilmun.

T. luteipennis, $M g$. -R. Sep. Ardmore Pt. ; Cadd. Wild.

T. flavolineata, Mg.-R. May-July. Kirn; Ormidale.

T. lunata, L.-C. May-June. Arrochar; Possil M.; Colintraive ; Milngavie; Murroch Gl. ; Inveraray ; Ormidale.

T. Diana, Mg.-R. May-June, and Aug. Eaglesham ; Milngavie ; Frankfield L. ; freq. Possil M.

T. lateralis, Mg.-Freq. May-Aug. Milngavie ; Cambuslang ; Frankfield L.; Ormidale ; Gt. Cumbrae ; Largs.

+T. montium, Egg.-May-Aug. C. and more widely dist. than the preceding, but I have not seen any record for Britain.

T. vernalis, Mg.-Freq. May-June. Eaglesham; Crookston; Barassie ; Baldernock; Milngavie ; Cambuslang.

T. vittata, Mg.-Freq. May-July. Tollcross ; Eaglesham; Cadd. Wild. ; Finn Glen ; Steps Wd. ; Cambuslang.

T. gigantea, Schrk.-Freq. May-July. Eaglesham; Arrochar ; Cambuslang; Strone; Ravenscraig; \&c.

T. lutescens, F.-C. June-Sep. Clober Dam ; Cadder Wild. ; Lunderstone ; Troon ; Strone ; Crookston ; \&c.

T. oleracea, L.-C. May-July, and r. in Sep. Not so c. nor so widely dist. as the next.

T. paludosa, $M g$. - Very c. everywhere. July-Sep., occasionally in latter part of June.

T. fascipennis $M g .-$ R. July-Aug. Cadd. Wild.

T. peliostigma, Schum.-R. June-July. Cadd. Wild. ; Troon ; Strone ; Baldernock ; Bishopton:

T. ochracea, Mg.-Freq. May-July. Crookston; Cambuslang; Carmyle : Possil M. ; Irvine; Cadd. Wd. ; Blairmore. 


\section{Order Coleoptera.}

\section{By Anderson Fergusson, Sandyhills Cottage, Shettleston.}

Arrangement Followed : Sharp \& Fowler's Catalogue, 1893.

Authorities for Localities: Thomas G. Bishop (T. G. B.); D. A. Boyd (D. A. B.); Andrew Adie Dalglish, F.E.S. (A. A. D.) ; John Dunsmore (J. D.); Robert Eden (R. E.) ; William Evans, F.R.S.E. (W. E.) ; William Gilmour (W. G.) ; Robert Henderson ; J. S. R. Malloch (J. M.) ; the late G. W. Ord ; Alexander Ross; Thomas Scott, F.L.S. (T.S.) ; Rev. J. E. Somerville, B.D., F.S.A.Scot. (J. E. S.) ; A. M. Stewart (A. M. S.) ; and Thomas Wilson.

The Rev. Alfred Thornley, M.A., F.L.S., F.E.S., of South Leverton, Lincoln, has very kindly verified or identified nearly all the species standing in the names of A. A. Dalglish, J. Dunsmore, W. Evans, J. S. R. Malloch, Thomas Scott, and myself. The Rev. H. S. Gorham, F.Z.S., has also given his opinion on several critical species.

Doubtful records are enclosed in square brackets.

\section{Abbreviations Used in the List.}

A. S. N. H. = The Annals of Scottish Natural History.

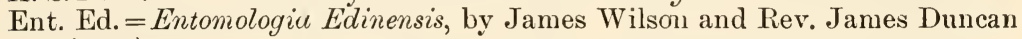
(1834).

Ent. Wkly. Int. = The Entomologists Weekly Intelligencer.

Ent. Ann.= The Entomologist's Annual.

E. M. M. = The Entomologist's Monthly Magazine.

Ent. = The Entomologist .

F. F. W.S.= The Fauna and Flora of the West of Scotland (1876).

M. Cat. = Catalogue of the Coleoptera of Scotland, by Andrew Murray (1853).

Sharp $=$ "The Coleoptera of Scotland," by D. Sharp, M. B. (Scottish Naturalist, 1871-81).

Zool. = The Zoologist.

T. R. B. = "Coleoptera collected by Mr. A. B. Watson of Edinburgh in the South of Arran," by 'T. R. Billups (Entomologist, xxvi., 654).

J. J. K.=J. J. F. X. King in Trans. Nat. Hist. Soc. Glasgow, Ir., p. 217 or 254. J.S. = "Coleoptera, etc., from moss during the spring months (presumably from the Renfrew District)," by John Scott, Renfrew (Zoologist, Vol. x., 1852, p. 3462).

J.J.W.= "Coleoptera at Campbeltown, N.B.," by J. J. Walker, F.E.S. (Entomologist's Monthly Magazine, vir., N.S., 110).

M. Y. = The late Morris Young in Ent. Wkly. Int., I., p. 166, or v., p. 68, except where otherwise indicated.

\section{Fam. Cicindelidae.}

Cicindela campestris, L.-C. sandy localities.

var. funebris, Sturm.-Oct. 1858, Gl. Finart, W. side L. Long, Dr. A. Chapman (T. Chapman, E. M. M., III., 251). 


\section{Fam. Carabidae.}

Cychrus rostratus, L.-Occasional; Tarbert (T. S.): Campbeltown (J. J. W.): Ardlui ; Lamington (A. A. D.) : Bonhill (J.M.) : Glasgow (J. E. S.) : Ayr ; Barr ; Arran (A. F.).

Carabus catenulatus, Scop.-C. and widely dist.

C. nemoralis, Müll.-Gardens, Tarbert (T.S.): Innellan, Arran (J. E. S.) : Glasgow (A.A.D. ; A. F.): W. Kilbride (D. A. B.) : Ayr (Thos. Wilson).

C. glabratus, Payk.-Scarce, on higher hills 500 to $2000 \mathrm{ft}$., Ben Lomond (Ent. Ed., 71): Glenmallan (A. A. D.): Craigmaddie, G. W. Ord (A.S. N. H. 1899, 183): Greenock (T. S.; J. E. S.): W. Kilbride (D. A. B.): Arran, Goatfell, 1858 (J.E.S.): Ben Bharrain (Mrs. Blaikie, Port Glasgow ; A. F.).

C. violaceus, L.-C. and widely dist.

C. clathratus, L.-Very local and r., four in a field, Blairmore, 1857 (J. E. S.): Ayrshire Coast (F. F. W. S.).

C. nitens, L._Local ; Arrochar (J.E. S.): Bonhill (J. M.): nr. Paisley (J. D.): Greenock (T.S.): Stewarton (W.G.): Hareshaw (Mr. Cuthbert): Dunoon (P. Cameron, Trans. N.H.S.Glasg. I., N.S., xxx.).

C. granulatus, L.-Freq. and widely dist.

C. monilis, F.-Very r., Paisley, J. D., (A.S.N.H., 1900, 53) : Arran (T. R. B.).

C. arvensis, F.-Scarce, Arrochar ; Blairmore ; L. Eck (J. E. S.) : Greenock (T. S.): W. Kilbride (D. A. B.) : Arran (Ent. Ed.).

Notiophilus biguttatus, F.-C. and gen. dist.

N. substriatus, Wat.-R., Ayr (A. F.): Arran (T. R. B.).

N. aquaticus, L.-Gen. dist.

N. palustris, Duft.-Scarce, Eaglesham Moor ; Irvine (J. J. K.): Shewalton ; $\operatorname{Ayr}($ A. F.).

Leistus spinibarbis, F.-R., under loose bark nr. Paisley (J. D., R. E.).

L. fulvibarbis, Dej.-Scarce, damp places; Milngavie (J.E.S.): Bowling (A. F.): Possil (J.E.S.): Ayr ; Barr (A.F.) : Arran (T. R. B.).

L. ferrugineus, L.--One in Mrr. J. Dunsmore's collection from Paisley district.

L. rufescens, F.-Freq., Tarbert (T.S.): Bonhill (J.M.): Robroyston (J.E. S.): Ayr ; Barr (A. F.) : Arran (T. R. B.).

Nebria brevicollis, $F$.-Abund. throughout the district.

N. gyllenhali, Sch.-C. throughout the district.

Pelophila borealis, Payk.-Three at Clober (J. J. K.). Mr. King's specimens, 1 understand, were named by Mr. G. C. Champion, F.Z.S.

Blethisa multipunctata, L.-Local and r., Bowling (A. F.): Hogganfield, 1859 (J. E. S.) : L. Fad, Bute (T. S.) : Brodick (W. E.).

Elaphrus riparius, L.-Freq., wet places; Rowardennan; nr. Glasgow (J.E.S.): Barassie (A. A. D. ; A. F.).

E. cupreus, Duft.-Margins of ponds, gen. dist.

E. uliginosus, F.-One on top of a wall, Greenock, 1858 (J. E. S.).

Loricera pilicornis, $F$.-C. and gen. dist.

Clivina fossor, L.-C. and gen. dist.

C. collaris, Herbst.-Local, muddy river banks, Kelvin (T.G. B.) : Cart (J. D.): Irvine (A. A. D. ; A. F.).

Dyschirius thoracicus, Rossi.- Very local and scarce, sandy places on coast in burrows of Bledius arenarius, Barassie (A. A. D.; A. F.).

D. impunctipennis, Daws.-Very local and scarce, with the preceding species, Barassie (J. D. ; A. A. D. ; A. F.) : Macrihanish, on the beach r. (J. J. W.).

D. salinus, Schaum.-Macrihanish r. on the beach (J.J. W.): Arran (T. R. B.).

D. globosus, Herbst.-Occasional, sandy banks of streams; Barassie (A. A. D. ; A. F.): Prestwick ; Ayr (A. F.): $\operatorname{Brodick}$ (W. E.). 
Miscodera arctica, Payk.-Mountains; local; Ben Lomond (Ent. Ed. ; J.E. S.) : Ben Nuis, Arran (J. E. S.).

Broscus cephalotes, $L$.-C. on sandy coasts.

Badister bipustulatus, F.--Occasional ; Row (J. E. S.) : Campsie (A. A. D). : Glasgow (J. E. S.) : Ayr ; Barr (A. F.).

B. sodalis, Duft.-Very r., one by shaking moss, Barr 4/1900 (A. A. D.).

Chlaenius nigricornis, $F$.-Lanarkshire (M. Cat.).

Stenolophus plagiatus, Gorham.-Two under stones above high water mark, nr. Gourock (J.D.). This species was described from the above specimens by Rev. H. S. Gorham (A. S. N. H., 1901, 24).

Acupalpus dorsalis, F.-Nr. Paisley M. Y., (M. Cat.).

A. brunnipes, Sturm.-Nr. Paisley M. Y., (M. Cat.).

Bradycellus placidus, Gyll.-Macrihanish, singly at roots of bent grass $11 / 1895$ (J. J. W.).

B. cognatus, Gyll.-Lennoxtown, under stones 3/1900 (A. A. D.).

B. verbasci, Duft.-Not unc., Lambhill (J. E. S.): Ayr (A. F.).

B. harpalinus, Dej.-Eaglesham Moor (J.J.K.): Douglas ; Peaton, L. Long, 1900 (W. E.).

B. collaris, Payk.-Cadder Wilderness (J.J.K.).

B. similis, Dej.-Freq. Whistlefield (A. F.): Bonhill (J.M.): Giffnock ; Irvine (A. A. D.).

Harpalus ruficornis, F.-C. under stones.

H. aeneus, $F$. - Abund. and gen. dist.

H. rubripes, Duft.-Arran (T. R. B.).

H. latus, $L$. - C. and gen. dist.

H. tardus, Panz.-R., one by shaking a tuft of grass on the shore, Ayr (A F.).

Dichirotrichus pubescens, Payk.-Local, on the shore, Bowling (A. A. D. ; A. F.) : Ardrossan (A. F.).

Anisodactylus binotatus, F.-Rowardennan (J. E. S.) ; occasional nr. Paisley and Glasgow (M. Cat.): Bishopton (J. E. S.).

Stomis pumicatus, Panz.-Scarce Giffnock (A. A. D. ; A.F.) : Ayr (A. F.).

Pterostichus cupreus, L.-Occasional, Glasgow ; Helensburgh ; Innellan (J. E. S.) : Ayr (A. F.) : Arran (T. R. B.).

P. versicolor, Sturm.-C. and gen. dist.

P. lepidus, F.-Apparently very local and r. Tolleross (M. Cat.; F. F. W. S. ; J.E.S., etc.): Arran (T. R. B.). Has not been taken at Tollcross for a number of years.

P. madidus, $F$.-Very abund. and gen. dist.

P. aethiops, Panz.-Mountains ; not c., W. of Scotland (M. Cat.) : Ben Lomond (F. F. W. S.).

P. vitreus, Dej.-Scarce; on hills, Ben Lomond (Ent. Ed.) : Whistlefield (A. F.) : Kilsyth (A. A. D.) : Elvanfoot(W. E.) : Campbeltown (J. J. W.) : Arran; Holy I. (J. E. S.).

P. niger, Schall.-C. and gen. dist.

P. vulgaris, $L_{0}-\mathrm{C}$. and gen. dist.

P. nigrita, F.-Abund. and gen. dist.; a curious form with clear red femora occurring rarely at Campbeltown (J.J. W.).

P. minor, Gyll.-Clyde (A. Buchan Hepburn Scot. Nat. iv. 248) : Brodick 4/1895 (W. E.).

P. strenuus, Panz.-Not unc.; Ben Lomond (J. E. S.): Cambuslang (A. A. D.) : Lanark (W. E.) : nr. Paisley M. Y., (M. Cat.) : Irvine ; Barr (A. F.).

P. diligens, Sturm.-Not unc.; Ardlui ; Whistlefield (A. F.): Arrochar ; Lamington (A. A. D.) : Brodick (W. E.).

P. vernalis, Gyll.-R., under stones, Ayr (A. F.).

P. striola, F.-C. and gen. dist. 
Amara fulva, Dej.-Sandy places on coast and inland, local, Tollcross (J.E.S.) : Stevenston ; Hurlford ; Ayr (A. F.) : Brodick (W.E.) : S. of Arran (T. R. B.).

A. apricaria, Sturm.--Scarce, nr. Glasgow (J. E. S.) : W. Kilbride (A. A. D.): Ayr (A. F.).

A. consularis, Duft.-Very local, Ayr (A. F.).

A. spinipes, Auct.-Freq., nr. Glasgow (J.E.S.) : Crookston (A.A.D.) : Shewalton; Ayr (A. F.) : Immellan (J. E. S.): Arran (T. R. B.).

A. rufocincta, Dej-Cllyde, very r. (Sharp).

A. bifrons, Gyll.-Nr. Glasgow (J.E.S.; T.G.B.) : Arran (J.E.S. ; T.P.B.).

A. ovata, F.-Occasional, Bowling (A. A. D.) : Ayr (A.F.).

A. acuminata, Payk.-Occasional, Glasgow; Greenock; Helensburgh; Innellan (J. E. S.): Kilmaurs (W.G.): Arran (T. R. B.).

A. tibialis, Payk.-R., Paisley district (J. I). ; R. E.).

A. lunicollis, Schiödte.-Scarce, Possil (J.J.K.): Greenock (J.E.S.) : $\operatorname{Ayr}($ A. F.).

A. familiaris, Duft.-C., Ayr (A. F.) : and probably other localities.

A. trivialis, Gyll.--Lambhill (J. E.S.) : Brodick (W. E.).

A. communis, Panz.-Freq., Bonhill (J. M.) : Bowling; Irvine (A. A. D.) : $\operatorname{Ayr}($ A. F.).

A. plebeia, Gyll.-Not unc., Bowling; Tolleross ; Ayr (A. F.).

Calathus cisteloides, Panz.-C. and gen. dist.

C. flavipes, Fourc.-Local, sandy places; Stevenston; Ayr (A.F.) : Irvine (A. A. D.).

C. mollis, Marsh.-Local, sandy places ; Fairlie ; Stevenston ; Ayr (A. F.) : Arrau (T. R. B.).

C. melanocephalus, L.-Abuud. and gen. dist. var. nubigena, Hal.--Ayr (A. F.).

C. micropterus, Duft.-Summit of Ben Bharrain, Arran (2330 ft.) (A. F.).

C. piceus, Marsh.- Rather scarce, woods; Ardlui in numbers (A. A. D.): nr. Glasgow (J.E.S.): Johnstone (A.F.): Arran, Pirnmill (A.F.) : Brodick (W. E.).

Taphria nivalis, Panz.-R. ; nr. Govan (W. G.): Possil (T.G. B.) : Arran (J. E. S.).

Pristonychus terricola, Herbst.--R., in outhouses, etc. ; Stevenston ; Ayr (A. F.): King's Cross, Arran (A.A. D.).

Anchomenus angusticollis, $F$.-Gen. dist. and locally c.

A. dorsalis, Mïll.-C. and gen. dist.

A. albipes, F.-Abund., margins of streams.

A. marginatus, L.-Local, nr. Glasgow (J. E. S.) : Paisley (J. D.) : Bishopton; Irvine (A. A. D.): Stevenston (A. F.) : Brodick (W. E.).

A. ericeti, Panz.-R., nr. Paisley M. Y., (M. Cat.): Elvanfoot (W. E.).

A. sahlbergi, Chaud.-Banks of Clyde below Glasgow by Messrs. Henderson and Bishop of Glasgow (W.W. Fowler, E.M.M., XII., 264). Now appears to be extinct in original locality.

A. parumpunctatus, $F$.-Abund.

A. viduus, Panz.-Brodick 4/1895 (W. E.).

var. moestus, Duft.-Scarce, Bowling (A. A. D.) : Hurlford; Ayr (A. F.).

A. micans, Nic.-Under bark of trees, Possil (T. G. B.).

A. fuliginosus, Panz.-C., margins of pools, etc.

A. gracilis, Gyll.-Eaglesham IIoor (J.J.K.): sparingly nr. Paisley (M.Cat.): Campbeltown (J. J. W.).

A. piceus, L.-Local, margins of pools; Bowling (A.A.D.; A.F.) : 11 r. Glasgow (J. E.S.).

Olisthopus rotundatus, Payk.-Occasional, Ben Lomond (J. E. S.) : Whistlefield; Giffnock (A. A. D.): Stevenston; Ayr ; Barr (A. F.). 
Cillenus lateralis, Sam.-Local ; below high tide mark, shore nr. Dumbarton (E. F. W.S.): Bowling (A. A. D. ; A. F.) : Kilpatrick (M. Cat.) : W. Kilbride (D. A. B.).

Bembidium rufescens, Guér-_Local, under bark, Cambuslang (A. A. D. ; A.F.): nr. Paisley; Bothwell (M.Cat.): Greenock (J.E.S.): Ayr (A.F.): Macrihanish (J. J. W.) : Arran (T. R. B.) : Brodick (W. E.).

B. quinquestriatum, Gyll.-R. Ben Lomond; Lambhill (J.E.S.) : Barr (A.F.).

B. guttula, $F$.-Abund̆., banks of rivers and ponds.

B. mannerheimi, Sahl.-Scarce ; wet places, Bowling (A.A.D.) : Ayr (A. F.).

B. biguttatum, F.-nr. Glasgow (J. E. S.) : Arran (T. R. B.).

B. aeneum, Germ.-Local, banks of rivers and on the coast, Bowling (A. A. D.; A. F.): $\operatorname{Avr}($ A. F.) : Macrihanish (J.J. W.).

[B. articulatum, Panz.-Ben Lomond, Dr. Leach, 'Steph. Illust.' (M. Cat.).]

B. doris, Panz.-Very local, about the margin of a pond, Ayr (A.A.D.; A.F.).

B. lampros, Herbst.-C. and gen. dist.

var. velox, Er.-Nr. Glasgow (A. and M. Soloman, Ent. Wkly. Int. ix. 52).

B. tibiale, Duft.-C., gravelly banks of streams.

B. atrocaeruleum, Steph.-C. ; with the preceding.

B. decorum, Panz.-Local; gravelly banks of rivers, Carfin (Ent. Ed.) : Irvine (A. A. D.) : Strathaven; Barr (A.F.).

B. nitidulum, Marsh.-Local and scarce ; nr. Glasgow (J. E.S.) : Renfrewshire (M. Cat.) : Ravenscraig (A.A.D.) : Barr (A.F.).

B. affine, Steph.-Very local and r.; nr. Glasgow (J. E. S. ; A. and M. Soloman, Ent. Wkly. Int. ix. 52) : Giffnock (A. A. D.) : Paisley (J. D.).

B. monticola, Sturm.-Occasioval on high grounds in Renfrewshire (M. Cat.): banks of Clyde, nr. Glasgow (A. A.D.; A. F.).

B. stomoides, Dej.-Very local and r., muddy banks of rivers, Clyde (A.A.D.; A. F.) : Avon (A. F.).

B. lunatum, Duft.-Ayrshire (M. Cat.).

B. testaceum, Duft.-Very r. ; amongst gravel on bank of Irvine (A. A. D. ; A. F.), teste Rev. H. S. Gorham.

B. concinnum, Steph.-Very local; banks of tidal rivers ; Clyde (A. A. D.) : Garnock (A. F.).

B. femoratum, Sturm.-Local, Tollcross (A. A.D.; A. F.) : nr. Paisley (M. Cat.): Stevenston (A. F.) : Irvine (A. A. D.).

B. bruxellense, Wesm.-Nr. Glasgow (J. E. S.): Arran (J. E. S.) : Macrihanish (J.J. W.).

B. littorale, Ol.-Abund.; banks of streams.

B. pallidipenne, Ill.-Local and r., maritime ; Barassie (J. D. ; A. A. D.) : Ayr (A. F.) : Macrihanish (J.J. W.): Arran (T. R. B.).

B. bipunctatum, L.-Scarce. Helensburgh (J.E. S.): Bowling (A. F.) : $n \mathrm{r}$. Glasgow (J.E. S.) : Barassie (A. A.D.).

B. punctulatum, Drap.-C. Gravelly banks of rivers.

B. prasinum, Duft.-L. Lomond; Lanarkshire (M. Cat.).

B. flammulatum, Clairv.-Arran (T. R. B.).

B. paludosum, Panz.-Nr. Glasgow (Peter Cameron, Jun., Scottish Naturalist, i., 177).

Tachypus pallipes, Duft.-Clyde, r. (Sharp).

T. flavipes, L.-Local and scarce ; nr. Paisley (M. Cat.) : Renfrew district (J.S.) : $\operatorname{Ayr}($ W. C. S. Fergusson): Arran (T. R. B.).

Aëpus marinus, Ström.-Local, below stones submerged at high tide ; Gareloch (F. F. W. S.) : Bowling (A. A. D. ; A. F.) : Gourock (J.D.).

Trechus micros, Herbst.-Nr. Paisley; Glasgow (M. Cat.): Cambuslang; Giffnock (A.A.D.) : Macrihanish, rarely, in flood rubbish (J.J. W.).

T. lapidosus, Daws.-Lambhill (J. E.S.) : on shore Row (J.E. S.).

T. rubens, F.-Occasional, nr. Paisley (M. Cat., under paludosus), Arran (J. E. S.). 
T. minutus, $F$.-A bund. and gen. dist.

var. obtusus, Er.--Ben Lomond (J.E.S.): Macrihanish, r. in flood rubbish (J.J. W.) : Tollcross ; Cartside (J. J. K.).

Patrobus excavatus, Payk.-Not c.; Ben Lomond (J. E.S.): Ardlui (A.A.D.): Bonhill (J.M.): Govan (W.G.): Ravenscraig (A.A.D); Stevenston (A. F.): Brodick (W. E.).

P. assimilis, Chaud.-Clyde, c. (Sharp).

P. septentrionis, Dej.-Inveraray (Ent. Ed.): sparingly, Ben Lomond (M. Cat.): Holy I. (J. E. S.).

Cymindis vaporariorum, L.-Paisley (Fowler, Brit. Coleopt., I. 135) : Arran ; Holv I. (J. E. S.).

Lebia chlorocephala, Hoff.-Very r., about broom, ur. Paisley (M. Cat.) : Ayr, one (W.C.S. Fergusson).

L. crux-minor, L.-A Apparently very r. Beaten off a sallow nr. Luss. Mr. R. Logan. (M. Cat.).

Dromius linearis, Ol.-Local, sandy localities, Irvine (A.A. D.): Ayr (A. F.).

D. agilis, F.-Not c., under bark, Johnstone (A.A.D.) : $\operatorname{Ayr}$ (A. F.) : Campleltown (J.J. W.).

D. meridionalis, Dej.-One, Brodick, 4/1895 (W. E., A. S. N. H., 1900, 92).

D. quadrimaculatus, L.-C. and gen. dist., under bark.

D. quadrinotatus, Panz.-Not c., under bark, Possil (J. E. S.) : Hogganfield ; Ayr (A. F.).

D. nigriventris, Thoms.-Scarce, in tidal refuse, Ayr (A. F.).

Metabletus foveola, Gyll.-R., sandy places, Irvine (A. F.).

\section{Fam. Haliplidae.}

Brychius elevatus, Panz.-Kelvin (M. Cat.).

Haliplus confinis, Steph.-Scarce, in pools, Stevenston ; Ayr (A. F.).

H. flavicollis, Sturm.-Local and scarce in stagnant water clinging to sticks, Bishopton (A. A. D. ; A. F.).

H. fulvus, F.-Not unc. ponds, Possil ; Arran (J.E. S.) : Paisley (M. Cat.) : Stevenston; Ayr (A.F.) : Aucha Lochy, Campbeltown (J.J. W.).

H. ruficollis, De G.-C., ponds.

H. lineatocollis, Marsh.-C., ponds.

Cnemidotus impressus, F.-Ayrshire. R. Hislop. (Sharp).

\section{Fam. Dytiscidae.}

Laccophilus obscurus, Panz.-Ponds; c. nr. Glasgow (M. Cat.): Ayr-(A. F.).

Hyphydrus ovatus, L.-South of Arran (T. R. B.).

Coelambus inaequalis., F.-Ponds, Lanarkshire (M. Cat.) : Port Glasgow ; Ayr (A. F.).

C. confluens, F.-Nr. Paisley (M. Cat.).

C. novemlineatus, Steph.-Local; lochs; Tarbert (T.S.): L. Lomond; Bute (M. Cat.): Gareloch (F.F.W.S.): Aucha Lochy, Campbeltown (J.J. W.).

Deronectes assimilis, Payk.-Ponds ; Hogganfield, c., 1859 (J. E. S.) : Port Glasgow, 7/1900 (A.F.): Bute, in profusion, 1854 (Rev. Hamlet Clark, Zool. xii. 4529) : Arran (T. R. B.).

D. depressus, F.-Rumning water; Gartnavel (J. E. S.) : Irvine (A. A. D. ; A. F.) : a dark var. c. in Bute, 9/1854 (Rev. Hamlet Clark, l.c.).

D. duodecimpustulatus, F.-Not unc.; pools.

Hydroporus pictus, F.-Gartnavel (J.E.S.) : c. nr. Paisley (M. Cat.).

H. lepidus, Ol.-Local; pools; Lanarkshire (II. Cat.): Giffnock ; Stevenston (A. F.) : Campbeltown (J.J. W.).

H. rivalis, Gyll.-Running water; Possil (J. E. S.) : Ayr (A. F.). 
H. septentrionalis, Gyll.-Running water ; Possil (J. E. S.) : Irvine (A. A. D. ; A. F.).

H. davisii, Curt.-Streams ; Possil (J. E. S.) : Barr (A. F.) : Allander (T.G. B.).

H. tristis, Payk.-Brodick 4/1895 (W. E.).

H. umbrosus, Gyll.-Sparingly ur. Paisley, M. Y., (M. Cat.).

H. gyllenhali, Schiödte.-Nr. Greenock (T.S.): Campbeltown, peaty pools on high ground (J. J. W.): Brodick (W. E.).

H. vittula, Er.-Paisley (M. Cat.).

H. palustris, $L$.-C. ponds.

H. incognitus, Sharp. -One in flood refuse Macrihanish (J. J. W.).

H. erythrocephalus, L.-Ponds; Ayr (A.F.) : Campbeltown, peaty pools on high ground (J.J.W.).

H. rufifrons, Duft.-Occasional nr. Paisley (M. Cat.).

H. memnonius, Nic.-By sweeping marshy ground Ravenscraig (A. A. D.) : in a pond, Bishopton (A. F.).

H. obscurus, Sturm.-Campbeltown, peaty pools on high ground (J.J.W.).

H. nigrita, F.-Ponds and streams ; nr. Paisley (M. Cat.)? Tarbert (T. S.): Strathaven ; Ayr (A. F.).

H. pubescens, Gyll.-Nr. Paisley (M. Cat.): Tarbert (T. S.).

H. planus, $F$ - C. ; ponds.

H. lituratus, F.-Brodick 4/1895 (W. E.).

H. ferrugineus, Steph._- "I detected a specimen in Mr. Young's collection of Renfrewshire Coleoptera" (R. Hislop, Zool. XV. 5856).

H. obsoletus, Aubé.-Two in flood rubbish Macrihanish (J. J. W.).

Agabus guttatus, Payk.-C. ; running water.

A. biguttatus, Ol.-Renfrewshire, local (M. Y., I., under fontinalis).

A. paludosus, F.-Renfrewshire, abund. (M. Y., I.). Fowler (British Coleoptera, I., 191) states that this species apparently does not occur in the western districts of Scotland. He seems to have overlooked this record.

A. affinis, Payk.-Nr. Glasgow (M. Cat.): Renfrew, local but very abuud. (M. Y., I.). A. unguicularis has usually been mistaken for this (Sharp).

A. unguicularis, Thoms.-Clyde, not c. (Sharp).

A. congener, Payk--One Robroyston Bog nr. Glasgow (Robert Hislop Zool. XIV., 4956).

A. nebulosus, Forst.-C., ponds.

A. femoralis, Payk--Nr. Paisley (M. Cat.).

A. arcticus, Payk:-Renfrewshire, local, but very abund. (M. Y., I.).

A. sturmii, Gyll.-Nr. Glasgow, c. (J.E.S.) : abund. in stagnant water, Campbeltown (J.J. W.) : Renfrewshire, very c. (M. Y., I.).

A. chalconotus, Panz.-Renfrewshire, not very abund. (M. Y., I.).

A. bipustulatus, L.-C., ponds.

Platambus maculatus, L.-Runıing water; Strathaven ; Irvine (A. F.).

Ilybius fuliginosus, F.-C. ; streams.

I. ater, De G.-Glasgow (M. Cat.): Possil (J.E. S.): Renfrewshire, c. (M. Y., I.).

I. obscurus, Marsh.-Clyde, rare (Sharp).

[I. guttiger, Gyll.-Freq. nr. Paisley, M. Y. (M. Cat.): Renfrewshire, local but very abund. (M. Y., I.).]

I. aenescens, Thoms.-R., Brodick 4/1895 (W. E.).

Rhantus exoletus, Forst.-L. Arklet, 6/1898 (T.S.) : "Glasgow ; abund. but local nr. Paisley" (M. Cat.) : Possil Marsh (J.E. S.) : Renfrewshire c. (M. Y., I.).

R bistriatus, Berg.-Nr. Glasgow and Paisley (M.Cat.): Possil Marsh (J. E. S.): Renfrewshire, not very abund. (M. Y., I.).

Colymbetes fuscus, L.-Not unc.; ponds ; Tollcross (G. W. Ord) : Hamilton (J. E. S.) : Renfrewshire (M. Y., I.) : Kilmaurs (W. G.) : Ayr (A. F.). 
Dytiscus punctulatus, F.-Not c. ; ponds ; Helensburgh ; Possil (J. E. S.): Renfrewshire (M. Y., I.) : Kilmaurs (W. G.) : Ayr (A. F.).

D. marginalis, L.-Not unc. and widely dist. ; ponds.

D. lapponicus, Gyll._- Clyde, very local. In highland lakes" (Sharp).

Acilius sulcatus, L. var. scoticus, Curt.--Not unc. ; ponds ; Helensburgh (J.E.S.) : c., Possil Marsh (F.F.W.S.): Tollcross (G. W. Ord) : Renfrewshire (M. Y., I.) : Kilmaurs (W. G.): Stevenston (A. F.).

A fasciatus, De G.-Possil Marsh, not r. (J.E.S.): Renfrewshire, local but abund. (M. Y., I.).

Fam. Gyrinidae.

Gyrinus minutus, F.-Small loch on Dungoin ; nr. Glasgow (J.E. S.): nr. Paisley (M. Cat.).

G. natator, Scop.-C. and gen. dist.

G. marinus, Gyll.-Three nr. Balmaha, L. Lomond, 6/1898 (T. S.).

G. opacus, Sahl.-Not c. Tarbert (T. S.): Glasgow (D. Sharp, E. M. M., V. 59). Canal nr. Glasgow and Paisley (M. Cat. under G. marinus, Gyll.) probably refers to this species.

Orectochilus villosus, Mïll.-Local, under stones nr. margins of streams, L. Lomond; Kelvin (M. Cat.): Barr (A.F.).

\section{Fam. Hydrophilidae.}

Hydrobius fuscipes, L.-C. stagnant and rumning water.

H. picicrus, Thoms.-Tarbert (T. S.).

Anacaena globulus, Payk.-Clinging to sticks in ponds and in flood refuse ; Tarbert (T.S.): Bonhill (J. M.): Bowling; Bishopton; Ayr (A. F.).

Philhydrus melanocephalus, Ol.-Nr. Paisley (M. Cat.): Brodick (W.E.) : Ailsa Craig (Thomas Scott, Trans. N. H.S. Glas., V., s.s., 158).

P. minutus, F.-Nr. Paisley, r. M. Y., (M. Cat.): Brodick (W. E.),

Laccobius sinuatus, Mots. - In flood refuse; Strathaven 8/1900 (A. F.).

L. minutus, L.-Not c.; stagnant water, Tarbert (T.S.): Bishopton (A. A. D. ; A. F.).

L. bipunctatus, F.-Not unc. ; stagnant water, Bishopton (A. A. D. ; A. F.): Port Glasgow (A. F.).

Limnebius truncatellus, Thoms.-In flood refuse, and clinging to submerged sticks, Strathaven 8/1900 (A. F.).

Helophorus rugosus, Ol.-Clyde, scarce (Sharp).

H. nubilis, F.-Clay pits, Botanic Gardens, Glasgow, 1859 (J. E. S.).

H. aquaticus, L.-C. running and stagnant water.

H. aeneipennis, Thoms.-Very c. ; running and stagnant water.

H. brevicollis, Thoms.-C. in similar localities.

H. arvernicus, Muls.-Local ; sandy banks of the Irvine (A. A. D. ; A. F.).

Hydrochus brevis, Herbst.-C. in Cart nr. Paisley (M. Cat.).

H. angustatus, Germ.-Nr. Glasgow (M. Cat.).

Henicocerus exsculptus, Germ.-Flood refuse, Strathaven (A.F.): Cart (M. Cat.).

Octhebius bicolon, Germ.-Flood rubbish, Machrihanish, r. (J.J. W.).

Hydraena riparia, Kug.-Flood rubbish, Strathaven, 8/1900 (A. F.).

H. nigrita, Germ.-Clinging to stones in streams, local, Ayr (A. F.).

H. angustata, Sturm.-Glasgow (W. W. Fowler, Ent. xvii., 162).

Cyclonotum orbiculare, $F$.- Local, in moss, margins of ponds ; nr. Paisley ; Kilmun (M. Cat.) : Possil (T. G. B.) : Ayr (A. F.).

Sphaeridium scarabaeoides, $F$.-Abund., in dung.

S. bipustulatum, F.-Not unc. ; in dung; nr. Glasgow ; Blairmore (J. E. S.) : Ayr (A. F.).

Cercyon littoralis, Gyll.-C., under decaying seaweed on the coast. Three of a striking var. having elytra pale testaceous with a black spot towards the posterior of each were taken on the shore at Ayr in 1894 (A. F.). 
C. depressus, Steph.--Very r., one on shore at Barassie 6/1899 (A. A. D.).

C. haemorrhoidalis, $F$. $-C$., in dung.

C. obseletus, Gyll.-R., one in dung, Ayr (A. F.).

C. flavipes, $F$.-C., in dung.

C. lateralis, Marsh.-C., in dung.

C. melanocephalus, L.-Abund. and gen. dist.

C. unipunctatus, $L$-Possil (J. E. S.): by sweeping, Ayr (A. F.).

C. pygmaeus, L.-Clyde, c. (Sharp).

C. analis, Payk.-In vegetable refuse, Cambuslang (A. A. D.): Paisley (M. Cat.).

Megasternum boletophagum, Marsh.--In dung, probably c., Strathaven (A. F.) : Lanark district (W. E.) : $\operatorname{Barr}$ (A. A. D.).

Cryptopleurum atomarium, F.-C. in dung.

\section{Fam. Staphylinidae.}

Aleochara ruficornis, Grav.-Nr. Glasgow (A. and M. Soloman, Ent. Wkly. Int., IX., 53).

A. fuscipes, F.-Paisley (J.D.).

A. brevipennis, Grav.-Very c. in moss and damp tufts of grass Nov. and Dec.; sparingly by sweeping June, Campbeltown (J. J. IV.).

var. fumata, Grav.-Clyde (Sharp).

A. lanuginosa, Grav.-C., in vegetable refuse etc.

A. moesta, Grav.-On shore, Ardrossan and Barassie (A. F.).

A. nitida, Grav.-Vegetable refuse; Ardrossan (A.A.D.): Bishopton ; Irvine; $\operatorname{Ayr}$ (A. F.).

A. grisea, $K r$. - On the coast under seaweed, Ayr (A. F.).

A. obscurella, Er.-Not c., under seaweed, Ardrossan ; Ayr (A. F.): Barassie (A. A. D.).

Microglossa nidicola, Fairm.--Very r., six by sweeping flowers at Barr 7/1899 (A. A. D.).

Oxypoda spectabilis, Mark.-Clyde, rare (Sharp).

O. lividipennis, Mann.-Bonhill (J.M.).

O. opaca, Grav.-C. in refuse, moss, etc.

O. alternans, Grav.-In fungi, Drymen 9/1900 (A. F.).

O. lentula, Er._- By Mr. Morris Young at Paisley," (Ent. Ann. 1864, 38).

0. umbrata, Grav.-Glasgow (M. Cat.).

O. nigrina, Wat.-Found by M. Y. nr. Paisley (Ent. Ann. 1859, 126).

O. longiuscula, Er.-Not unc., Bowling (A.F.): Glasgow (M. Cat.): Giffnock ; Strathaven (A. A. D.) : Ayr (A. F.).

O. rupicola, Rye.-Clyde, rare (Sharp).

O. recondita, $K r$.-Clyde district (Paisley). (Fowler, Brit. Coleopt., II., 35).

Ocyusa incrassata, $K r$._- "Taken by Mr. M. Young nr. Paisley." (Ent. Ann. 1859, 126, under Oxypoda aterrima, Wat.).

Phloeopora reptans, Grav.-Glasgow (M. Cat.). This is the corticalis, Grav. of Murray's catalogue.

Ocalea castanea, Er.-Clyde, c. in damp moss (Sharp).

Ilyobates nigricollis, Payk.--Renfrew district, in moss (J. S.).

Calodera riparia, Er.-Clyde, rare (Sharp).

C. aethiops, Grav.-One by shaking tufts of grass, Ayr (A. A. D.).

Chilopora rubicunda, Er.-Clyde district, Paisley M. Y., (Fowler, Brit. Coleopt. II., 51).

Myrmedonia humeralis, Grav.--Renfrew district, in moss (J.S. under Pella humeralis).

Astilbus canaliculatus, F.-Occasional, by shaking moss; Whistlefield (A. A. D.) : Renfrew district (J.S.): Elvanfoot (W. E.): Garelochhead ; Ayr ; Barr (A. F.).

Callicerus rigidicornis, Er.-Clyde, very rare (Sharp). 
Homalota currax, $K r$.-One, bank of Garnock, Stevenston (A. F.).

H. gregaria, Er.-Clyde, abund. in varied situations (Sharp).

H. tibialis, Heer.-Clyde, c., Alpine (Sharp).

H. vestita, Grav.-On the coast, Bowling; Barassie (A. A. D.) : Ardrossan ; $\operatorname{Ayr}($ A. F.).

H. nitidula, Kr.-Arran (Fowler, Brit. Coleopt. II., 80).

H. oblongiuscula, Sharp.-Clyde, rare (Sharp).

H. puncticeps, Thoms.-Clyde, local, maritime (Sharp).

H. excellens, $K r$.-Arran (Fowler, Brit. Coleopt. II., 86).

H. subglabra, Sharp.-Arran (Fowler, Brit. Coleopt. II., 87).

H. circellaris, Grav.-In moss, Milngavie; Strathaven; Giffnock (A. A. D.) ; Lennoxtown; Johnstone; Ayr (A. F.).

H. eremita, Rye.-In moss, Bowling (A. F.): Johnstone (A. A. D.).

H. analis, Grav.-A bund. and gen. dist.

H. depressa, Gyll.-In fungi on a birch stump, Giffnock (A. A. D.).

H. euryptera, Steph.--In vegetable refuse; Lennoxtown; Ayr (A.A.D.) : Cambuslang; Irvine (A. F.).

H. subterranea, Muls._- "The only specimen I possess is from Paisley and was given me by Morris Young." (Waterhouse, Zool. XV., 8219).

H. atramentaria, Gyll.-Abund. and gen. dist.

H. longicornis, Grav.-In moss, vegetable refuse etc., Cathkin (A.A.D.): Lemnoxtown ; Ardrossan ; Irvine ; Ayr (A. F.).

H. sordida, Warsh.-Abund. throughout the area.

H. muscorum, Bris.-Clyde, abund. (Sharp).

H. fungi, Grav.--In moss, abund.

Tachyusa flavitarsis, Sahl.-Banks of streams, Ardrossan; Barassie (A. A. D.).

Xenusa sulcata, Kies.--Under seaweed nr. Corrie (Sharp).

Falagria sulcata, Payk.-Glasgow (M. Cat., under sulcatula, Gravenh.): in refuse, Barassie (A. F.).

F. obscura, Grav.-In vegetable refuse, Cambuslang; Ayr (A. F.): nr. Paisley M. Y., (M. Cat.).

Autalia impressa, Ol.-In decaying fungi, Drymen; Strathaven (A. F.).

A. rivularis, Grav._-"C. ; low ground, Gareloch" (W. Henderson, E.M.M., II., 88) : Glasgow (M. Cat.).

A. puncticollis, Sharp.-Hills round Gareloch (W. Henderson, E. M. M., II. 88).

Encephalus complicans, Westw.--R., in moss, Renfrew district(J. S.) : Ayr (A. F.) : Campbeltown (J. J. W.).

Gyrophaena pulchella, Heer.-Very r., about 12 in decaying fungi, Drymen, $9 / 1900$ (A. F.).

Placusa pumilio, Grav.-Nr. Paisley, M. Y., (Ent. Ann. 1859, 127).

P. complanata, Ei:-Specimens from Paisley in Mr. Rye's Collection (Fowler, Brit. Coleopt., II. 161).

P. infima, Er.-Under the bark of felled trees, Cadder (J. J. K.).

Leptusa fumida, Er.-_"Renfrewshire freely" (M. Y., V.).

Sipalia ruficollis, Er.-Under bark, "Renfrewshire freely" (M. Y., V.) : Bonhill (J. M.): Milngavie ; Giffnock; Johnstone (A. A. D.).

Bolitochara lucida, Grav.-Very r., "Glasgow, R. Hislop" (Fowler, Brit. Coleopt. II. 168) : Renfrewshire (M. Y., V.).

B. lunulata, Payk.-R. ; Glasgow (M. Cat.): Paisley (Fowler, Brit. Coleopt. II. 168).

B. obliqua, Er.-Glasgow (M. Cat.) : Renfrewshire (M. Y., V.) : in fungi on old stump, Giffnock (A. A. D.).

Phytosus balticus, $K r .-\mathrm{R}$., on the coast, $\operatorname{Arr}(\mathrm{A} . \mathrm{F}$.$) .$

Diglossa mersa, Hal.-Clyde, very local. Maritime (Sharp).

Myllaena brevicornis, Watthw.-Clyde, in damp places (Sharp). 
Gymnusa variegata, Kies.-R., one by shaking moss Bowling (A. F.).

Conosoma pubescens, Grav.-Dumbarton, Mr. Hislop (M. Cat.).

C. lividum, Er.-Cleghorn Gl., Lanark 10/1900 (W. E.).

Tachyporus obtusus, L.-Abund. in moss.

T. formosus, Matth.-Very r., one in tidal refuse Ayr, 1894 (A. F.): teste

H. S. Gorham : one at Lag, Arran 4/1895 (W. E.).

T. solutus, Er.-Clyde, not c. (Sharp).

T. chrysomelinus, L.-C. in moss.

T. humerosus, Er.-Not unc.; in moss, Bowling ; Strathaven; Giffnock (A. A. D.): Ayr (A.F.).

T. tersus, Er.-Clyde, local (Sharp).

T. hypnorum, $F$.-Abund. and widely dist.

T. brunneus, F.-In refuse, moss, etc., Cambuslang ; Ayr (A. F.).

Cilea silphoides, L.-Renfrew district, in moss, (J.S. under Tachinus silphoides).

Tachinus humeralis, Grav.-In fungi, etc. Paisley (J. D.).

T. proximus, $K r$.-Sheep's dung Ben Lomond, D. Sharp (Ent. Ann., 1865, 51) : Gareloch, summit of the hills (W. Henderson, E. M. M., II. 88).

T. rufipes, $L$.- In moss, abundant.

T. subterraneus, $L$.-In vegetable refuse, Helensburgh (J.E.S.) : Cambuslang (A. A.D.): Renfrew district (J.S.): Ayr (A.F.).

T. marginellus, $F$.-C. and widely dist.

T. collaris, Grav.-In moss, Ayr (A. F.).

T. elongatus, Gyll.-Glasgow (M. Cat.): Tollcross (J. J. X. K.).

Megacronus cingulatus, Mann.--Glasgow (M. Cat.).

M. analis, F.-Scarce; in moss, Glasgow, (M. Cat.): Renfrew district (J.S.): Paisley (J.D.) : Ayr (A. F.).

M. inclinans, Grav.-Very r., one amongst dead leaves, nr. Paisley (J. D.).

Bolitobius lunulatus, L.-In moss, Renfrew district (J. S.) : in fungi, Ayr (W. C.S. Fergusson).

B. trinotatus, Er.-In decaving fungi, Glasgow (M. Cat.): Renfrew district (J.S.) : Drymen (̇̈. F.).

Mycetoporus punctus, Gyll.-Clyde, rare (Sharp).

M. lepidus, Grav.-In moss, Ayr (A. F.).

M. nanus, Er.-Paisley M. Y., (Ent. Ann., 1865, 41).

M. clavicornis, Steph.-Renfrew district, in moss (J. S., under pronus).

M. splendidus, Grav.-Scarce by shaking tufts of grass, Ayr 2/1894 (A. F.).

M. longicornis, $K r$-Clyde, rare (Sharp).

Heterothops binotata, Er.--Shore, Brodick B. 4/1895 (W. E.).

Quedius longicornis, $K r$.-Recorded doubtfully from Clyde by Sharp.

Q. lateralis, Grav.-Glasgow (M. Cat.).

Q. mesomelinus, Marsh.-Vevetable refuse, Cambuslang (A. A. D. ; A. F.).

Q. fulgidus, F.-R., one at Lennoxtown under a stone, 2/1900 (A. A.D.), teste Rev. H. S. Gorham.

Q. puncticollis, Thoms.-Arran (Fowler, Brit. Coleopt., II. 233).

Q. cinctus, Payk.--In moss and tufts of grass; Ardrossan; Ayr (A. F.).

Q. fuliginosus, Grav.-C. and widely dist. in moss.

Q. tristis, Grav.-Not unc., in moss; Ben Lomond (J. E. S., Ent. Wkly. Int. VI., 60 under frontalis): Ardlui ; Arrochar ; Campsie, Barr (A. A. D.) : Bonhill (J. M.) : Paisley (J. D.): Tollcross ; Ardrossan (A. F.).

Q. molochinus, Grav.-Not unc. and widely dist. in moss etc.

Q. picipes, Mann.-Glasgow (M. Cat.).

Q. nigriceps, $K r$.--Glasgow (M. Cat., under ruficollis, Steph.): Arran (T. R. B.).

Q. maurorufus, Grav.-R., Ayr, one by shaking tufts of grass, 10/1895 ; one in moss, 3/1900 (A. F.). 
Q. umbrinus, Er.-Glasgow (M. Cat.): Renfrew district, in moss (J.S., under semiobscurus).

Q. suturalis, Kies.-R., two in tidal refuse, Ayr, 3/1894 (A. F.).

Q. scintillans, Grav.-R., three amongst rubbish on the banks of a burn, Barassie 5/1899 (A. F.).

Q. auricomus, Kies.-in damp moss nr. streams, local; nr. Hamilton (M. Cat.) : nr. Paisley M. Y., (Edward Newman, Zool. XVII., 6792) : Bardowie L. (T. G. B).

Q. rufipes, Grav.-Scarce, in moss and vegetable refuse, Bowling; Artrossan ; Ayr (A. F.): Fairlie (A. A. D.).

Q. attenuatus, Gyll.-C. and widely dist. in moss.

Q. semiaeneus, Steph.-S. end of Arran (T. R. B.).

Creophilus maxillosus, L.-C. in carcases.

var. ciliaris, Steph.-Shores of Arran (F.F. W. S.).

Leistotrophus nebulosus, F.-Scarce, Dungoin (J.E.S.) : Barr (A. A. D.) : Ascog, Bute (T. S.).

Staphylinus pubescens, De G.-Not unc., nr. Glasgow (M. Cat.): Aỵr (W. C. S. Fergusson).

S. fulvipes, Scop.-Paisley Moss (F. F. W. S.).

S. stercorarius, Ol.-Local and scarce, nr. shore, Ayr 7/1895 (A. F.) : Arran (M. Cat.): Ailsa Craig (Ann. And. Nat's. Soc. II., 147).

S. erythropterus, L.-C. and gen. dist.

S. caesareus, Ceder.-R., one, shore of L. Lomond 5/1899 (A. A. D.).

Ocypus olens, Müll.-Not unc.; gardens under stones, nr. Glasgow (J.E.S.): Tarbert; Greenock (T.S.) : Ayr (A. F.) : Arran (D. Landsborough Zool., I., 31).

O. brunnipes, F.-Scarce; Glasgow (M. Cat.): one from Paisley district (J. D.): Brodick 4/1895 (W.E.).

O. fuscatus, Grav.-Tolleross (M. C'at.).

O. cupreus, Rossi.-C. and gen. dist.

O. ater, Grav.-C. under stones on turf walls etc., Campbeltown (.J.J. W.).

0. morio, Grav.-Under stones. Tarbert (T.S.): Milngavie (J.E.S.) : Giffnock (A.A. D.) : Paisley (J. D.) : Ayr (A. F.).

O. compressus, Marsh.-Arran, one "taken by myself" 8/1879 (Fowler, Brit. Coleopt. II., 258).

Philonthus splendens, F.-R., one from Bonhill (J. M.).

P. laminatus, Creutz.--In moss, dung, etc., Ardlui ; Tolleross (A. A. D.) : Paisley (J. D.) : Campbeltown (J.J. W.) : Arran (T.R. B.).

P. aeneus, Rossi.-Abundant in moss.

P. proximus, $K r$.-Paisley (J.D.) : and probably other localities.

P. carbonarius, Gyll.-Scarce; Ardlui; Arrochar; Giffnock (A. A. D.): teste Rev. H. S. Gorham.

P. scutatus, Er.-Scarce ; in moss, Bonhill (J.M.) : Glasgow district, 1863 (J. E. S.) : Paisley M. Y., (Fowler, Brit. Coleopt. II., 265) : Johnstone; Irvine (A. F.) : Campbeltown, r. (J.J. W.).

P. decorus, Grav.-In moss and flood refuse, Ardlui (A.A. D.) : Bonhill (J.M.) : Cambuslang (A.F.) : Paisley (J. D.) : Greenock (T.S.) : Campbeltown (J.J. W.).

P. politus, F.-In moss and under stones, Lennoxtown (A.F.): Ayr (A.A.D.).

P. Iucens, Er.-Clyde, very rare (Sharp).

P. varius, Gyll.-Very c. in moss.

P. marginatus, $F$.-In vegetable refuse and moss, Ben Lomond (J.E. S.): Ardrossan (A. A. D.) : Irvine ; Ayr (A. F.).

P. cephalotes, Grav.-Not unc.; various situations, Bowling ; Tolleross ; Cambuslang (A. A. D. ; A. F.).

P. fimetarius, Grav.-Not unc.; in vegetable refuse, Ardlui ; Ardrossan ; Ayr (A. F.) : Tolleross ; Bishopton (A. A. D.). 
P. sordidus, Grav.-In dung, etc. Tollcross; Cambuslang; Ardrossan (A.A.D. ; A.F.) : Irvine ; Ayr (A. F.).

P. ebeninus, Grav.--Three from Ayr district are referred to this species by the Rev. H. S. Gorham.

P. fumigatus, Er.-R. One by shaking tufts of grass, Ayr 3/1894 (A. F.).

P. debilis, Grav.-Clyde (Sharp).

P. cruentatus, Gmel.-Renfrew district, in moss (J.S.).

P. longicornis, Steph.-Clyde, in refuse (Sharp).

P. varians, Payk.-In refuse and moss ; Arrochar; Irvine (A.A.D.): Bonhill

(J.M.): Tolleross (A. F.) : Paisley (J. D.): Ardrossan ; Ayr (A. F.).

P. vernalis, Grav.-R. One amongst refuse on banks of stream, Barassie 5/1899 (A. A. D.).

P. micans, Grav.-R. In flood refuse, Barassie 5/1899 (A. F.) : in moss, Ayr 3/1900 (A. A. D. ; A. F.), teste Rev. H. S. Gorham.

P. trossulus, Nord.-In moss etc., Bowling (A. F.) : Giffnock (A. A. D.): Lanark (W.E.) : Ayrshire coast (A.A.D.; A. F.) : teste Rev. H. S. Gorham.

P. puella, Nord.-R., one from Arrochar (A. A. D.): Hamilton (M. Cat., under parumpunctatus, Er.) : one from Paisley district (J.D.).

Cafius fucicola, Curt.-R., under decaying seaweed Macrihanish beach 11/1895 (J.J. W.).

C. xantholoma, Grav.-Under decaying seaweed, Ardrossan ; Barassie ; Ayr (A. A.D. ; A. F.) : Brodick (W.E.).

C. sericeus, Holme.- "Very local. Found by Prof. M'Nab nr. Ayr" (Sharp).

Actobius cinerascens, Grav.-Scarce in flood refuse, Ardrossan (A. F.): in damp moss, Ayr 3/1900 (A. A. D. ; A. F.).

Xantholinus fulgidus, $F$.-Very r., one amongst rubbish, Tolleross 4/1899 (A. F. ; A. S. N. H., 1900, 53).

X. glabratus, Grav.-Scarce ; under stones, Kilsyth (A.A.D.) : Paisley (J.D.) : Ayr (A.F.).

X. punctulatus, Payk.-Very c. and gent. dist.

$\mathrm{X}$. linearis, $O l$.-Abund. in vegetable refuse etc.

Baptolinus alternans, Grav.-C. under loose bark.

Othius fulvipennis, $F .-C$. in moss.

O. laeviusculus, Steph.-Clyde, scarce (Sharp).

O. melanocephalus, Grav.-Scarce in moss, and under stones, Bonhill (J. M.) : Lennoxtown; $\operatorname{Ayr}($ A. F.) : Lanark (W. E.) : $\operatorname{Barr}$ (A. A. D.).

O. myrmecophilus, Kies.-R., one Lennoxtown 3/1900 (A. A. D.).

Lathrobium elongatum, L.-Gen. dist. ; in marshy places.

L. fulvipenne, Grav.-C. in various situations.

L. brunnipes, $F$. - C. in damp moss and tufts of grass.

L. quadratum, Payk.-R.; wet moss on the margins of a pond nr. Ayr 3/1900 (A.A.D. ; A.F.).

L. multipunctum, Grav.-R., two in moss, Lennoxtown 4/1899 (A. F.).

Stilicus rufipes, Germ.--Renfrew district, in moss (J.S.).

S. orbiculatus, Er.-Renfrew district, in moss (J.S.).

S. affinis, Er.-Not unc. ; moss and refuse, Tollcross ; Cambuslang ; Bishopton; $\operatorname{Ayr}$ (A. F.) ; Lanark (W. E. ; A. S. N. H., 1900, 96).

Evaesthetus scaber, Thoms.-R. ; flood refuse, Bishopton 2/1900 (A. A. D.); Renfrew district, moss (J. S.).

Dianous coerulescens, Gyll.-R. ; damp moss by side of streams, nr. Glasgow (M. Cat.) : Barr, one 6/1900 (A. F.): below Gl. Ashdale waterfall, Whiting Bay 1856 (J. E. S.) : Bardowie L. (T. G. B.).

Stenus bimaculatus, Gyll.-Renfrew district, in moss (J.S.).

S. juno, F.-In damp moss, Bowling (A. F.): Milngavie; Giffnock; Ayr (A. A. D.). 
S. guynemeri, Duv.--In some numbers nr. Paisley by Mr. M. Young (Ent. Ann., 1859, 134) : Bardowie L. (T. G. B.).

S. speculator, Er.-In moss and grass, Milngavie; Giffnock (A.A.D.) : Bowling; Strathaven; Ayr (A. F.).

S. bupthalmus, Grav.-In wet places, Bowling (A. F.).

S. canaliculatus, Gyll.-R., one in flood refuse, Bishopton 2/1900 (A. A. D.).

S. pusillus, Er.-Lanark district (W.E.).

S. declaratus, Er:-In moss, Johnstone; Ayr (A. F.).

S. brunnipes, Steph.-Gen. dist. in moss, flood refuse, etc.

S. ossium, Steph.-Damp places and moss, Milngavie (A. A. D.) : Bowling ; Ayr (A. F.).

S. geniculatus, Grav.-Gareloch, summit of hills (W. Henderson, E. M. M., II., 88).

S. impressus, Germ.-Freq. in moss, Bonhill (J. M.) : Milngavie ; Crookston (A. A. D.) : Cambuslang; Johnstone (A. F.).

S. pubescens, Steph.- Scarce in wet places, Milngavie (A.A.D., A. F.): Bowling (A. F.).

S. pallitarsis, Steph.-R., four, banks of Irvine 5/1899 (A. A. D.).

S. bifoveolatus, Gyll.-In damp moss by side of a pond nr. Ayr 3/1900 (A. A.D., A. F.).

S. nitidiusculus, Steph.-Flood refuse, Barassie 5/1899 (A. A. D.).

S. foveicollis, $K r$..."Sharp and Henderson, Gareloch" (Ent. Ann., 1866, 49, under bievicollis).

S. similis, Herbst.--In moss and flood refuse, Strathaven; Ayr (A. F.); Lamington ; Giffnock (A. A. D.).

S. tarsalis, Ljun.-By shaking moss, Giffnock (A. A. D.) : Ayr, c. (A. F.).

S. paganus, Er.-R.; moss, Milngavie(A.A.D.): flood refuse, Ayr $3 / 94$ (A. F.).

Bledius arenarius, Payk.-Local but abund. on shore at Barassie (J.D., A. A. D., A. F.).

B. subterraneus, Er.-Banks of streams; Clyde (M. Cat.).

Platystethus arenarius, Fourc.-In dung, Bonhill (J.M.): Giffinock (A. A. D.): Colintraive (A. F.).

Oxytelus rugosus, Grav.-Abund. in various situations.

var. terrestris, Lac.-Renfrew district, in moss (J. S.).

O. laqueatus, Marsh.-In vegetable refuse, Bonhill (J.MI.): Lamington (A. A.D.): Ardrossan ; Ayr (A. F.).

O. sculpturatus, Grav.-In vegetable refuse, Cambuslang (A. F.).

O. maritimus, Thoms.-Lncal and scarce, on the coast, Barassie (A.A.D., A. F.): Ayr (A.F.). One or two of the var. with testaceous elytra have occurred with the type at Ayr.

O. nitidulus, Grav.-Irvine, 1899 (A.A.D.).

O. complanatus, Er.-R., one example Irvine Sandhills 1899 (A. A. D.).

O. tetracarinatus, Block.-Abund. in vegetable refuse etc.

Ancyrophorus aureus, Fauv.-Taken by Mr. Waterhouse and Mr. Morris Young, both at Paisley (Ent. Ann., 1863, 87).

Trogophloeus elongatulus, Er:- - R., in damp moss, Giffnock 4/1900 (A. A. D.) : Ayr 3/1900 (A. A. D., A. F.).

Coprophilus striatulus, F.-Scarce; vegetable refuse ; Bonhill (J.M.); Tollcross (A.A.D.) : Cambuslang (A. F.) : Renfrew district (J. S.).

Deleaster dichrous, Grav.-Very r., West End Park, Glasgow (J.E.S., E. M. M., V., 142) ; nr. Glasgow (A. and M. Soloman, Ent. Wkly. Int., IX., 53).

var. leachii, Curt.-Very r., one from nr. Paisley (Mr. J. Dunsmore).

Anthophagus testaceus, Grav.-Not unc., Bonhill (J. M.) : Cadder(A. A. D.) : Barr (A. F.).

A. alpinus, Payk.-Glasgow ; Ben Lomond (Fowler, Brit. Coleopt., II., 399) : below Gl. Ashdale Waterfall, Whiting Bay, Arran, 1856 (J. E. S.). 
Geodromicus nigrita, Müll.-In damp moss by ponds and rivers, one, Bowling, 1899 (A. F.) : two Irvine, 1899 (A. A. D.).

G. globulicollis, Mann.-Ben Lomond (Fowler, Brit. Coleopt., II., 400).

Lesteva longelytrata, Goeze.-In damp moss; Bowling; Irvine (A. A. D.).

L. Sharpi, Rye.-Taken by Dr. Sharp with Mr. Henderson in numbers at Garelochhead (E. C. Rye, E. M. M., III., 124) : Arran, Mr. Sharp (Ent. Ann., 1865, 61, under monticola, Kies.).

L. pubescens, Mann.-Nr. Paisley M. Y., (Ent. Ann., 1859, 137).

L. punctata, Er.--In flood refuse, Barassie 5/1899; Bowling (A. F.), teste Rev. H. S. Gorham.

Acidota crenata, F.-Renfrewshire (M. Y., V.) : Campbeltown "one only, under a stone at a low elevation, 9/1894" (J.J. W.).

A. cruentata, Mann.-Taken by Mr. R. Henderson crawling on a stone wall at Glasgow about Nov. 1865 (E. C. Rye, E. M. M., III., 163).

Olophrum piceum, Gyll.--In moss, Garelochhead; Gourock (A. A. D.); Helensburgh ; Glasgow (J.E. S.); Ayr (A. F.): Brodick (W. E.).

0. fuscum, Grav.-Sparingly in tufts and flood rubbish, Campbeltown (J.J. W.) : Elvanfoot, 1910 (W. E.).

Lathrimaeum unicolor, Steph.-In flood rubbish and moss, Bonhill (J. M.) : Ayr ; Barr (A. F.).

Deliphrum tectum, Payk.-Ben Lomond (J. E. S., Ent. Wkly. Int. VI., 60) : Renfrewshire (M. Y., V.) : r. on hill tops, Campbeltown (J. J. W.).

Arpedium brachypterum, Grav.-One, nr. top of Green Lowther 10/1900 (W.E.).

Micralymma brevipenne, Gyll.-Clyde, very local, maritime (Sharp).

Coryphium angusticolle, Steph.-Glasgow ; Paisley (F. F. W.S.): Renfrewshire (M. Y., V.).

Omalium rivulare, Payk.-Under a dead bird, Bishopton (A. A. D. ; A. F.) : Inverkip (A. A. D.): Ayr (A. F.).

0. rugilipenne, Rye.-Very r., two in tidal refuse, Ayr 3/1894 (W.C.S. Fergusson).

0. laeviusculum, Gyll.-R., in refuse on shore at Barassie, two, 5/1899 (A. A. D. ; A. F.).

0. septentrionis, Thoms.-Gareloch (F. F.W. S.): one, Arran 8/1864 (W. Henderson, E.M.M., II., 205), its first occurrence in Britain.

0. riparium, Thoms.-Freq. under decaying seaweed, Ardrossan (A. A. D.) : Barassie ; Ayr (A. F.) : teste Rev. H. S. Gorham.

O. allardi, Fairm.-Taken somewhat plentifully by Mr. Morris Young at Paisley. (Ent. Ann., 1863, 88).

0. excavatum, Steph.-Clyde, common (Sharp).

O. nigriceps, Kies.-Taken by Mr. Morris Young and Mr. Waterhouse (presumably at Paisley). (Ent. Anu., 1863, 89).

O. vile, Er:-Under bark, Lennoxtown; Cambuslang; Giffnock; Johnstone (A. A. D.).

0. concinnum, Marsh.-Elvanfoot, 9/1900 (W. E.).

O. deplanatum, Gyll. - Clyde in vegetable refuse, local (Sharp).

Anthobium ophthalmicum, Payk.-In flowers, and hybernating in moss, Ayr (A. F.) : Barr (A. A. D.).

A. torquatum, Marsh.-In flowers, Bonhill (J.M.): Ravenscraig (A. A. D.).

Proteinus ovalis, Steph.-In some numbers under a dead bird Bishopton, 3/1900 (A. A.D. ; A. F.) : under decaying seaweed, Ardrossan (A. F,) : Cleghorn Gl., Lanark, 10/1900 (W.E.).

Megarthrus depressus, Lac.--In dung, Ardlui (A. A. D.).

Phloeocharis subtilissima, Mann.-Under bark, Bonhill (J. M.) : teste Rev. H. S. Gorham. 


\section{Fam. Pselaphidae.}

Pselaphus heisii, Herbst.-R., in moss, Ayr (A. F.): in some numbers, Barr 4/1900 (A. A. D. ; A. F.) : two at Elvanfoot 9/1900 (W. E.).

Tychus niger, Payk.-R., four nr. Paisley by Mr. Morris Young, and at Ayr by myself (A. Fergusson, A. S. N. H., 1896, 61).

Bythinus puncticollis, Denny.-Occasional, in moss, Garelochhead; Giff$\operatorname{nock}$ (A. A. D.) : $\operatorname{Barr}($ A. F.).

B. bulbifer, Reich.--Occasional in moss, Giffnock (A. A. D.) : Barr (A. F.).

B. curtisi, Denny.-R., one male in moss, Barr 4/1900 (A. A. D.).

B. burrelli, Denny.-Paisley, M. Y. (M.Cat.).

Bryaxis fossulata, Reich.-Clyde, local in marshes (Sharp).

B. haematica, Reich,-Renfrew district, in moss (J.S.).

B. juncorum, Leach.-R., three in damp moss on the margins of a pond $\mathrm{nr}$. Ayr 3/1900 (A. A.D. ; A. F.).

\section{Fam. Scydmaenidae.}

Scydmaenus collaris, Müll.-Elvanfoot 9/1900 (W. E.).

S. exilis Er.-Paisley, M. Y. (Ent. Ann., 1859, 42).

Eumicrus tarsatus, Müll.-R., in moss, Garelochhead; Giffnock 4/1900 (A. A. D.).

Eutheia schaumi, Kies._- "Has been taken nr. Glasgow" (Fowler, Brit. Coleopt., III., 81).

\section{Fam. Leptinidae.}

Leptinus testaceus, Miill.-Clyde, very r. about the nests of Bombi (Sharp): Paisley (F. F. W.S.).

\section{Fam. Silphidae.}

Calyptomerus dubius, Marsh.-Renfrew district, in moss (J.S.).

Agathidium nigripenne, Kug.- "Local but plentiful nr. Paisley" (Mi. Cat.) : Arran (T. R.B.).

A. atrum, Payk.-Not r. near Paisley (MI. Cat.).

A. varians, Beck.-R., one in flood refuse Ayr 3/1894 (A. F.).

A. rotundatum, Gyll.-Noticed amongst some Agathidia sent to Mr. E. C. Rye by Mr. M. Young of Paisley (Ent. Ann., 1863, 92).

Amphicyllis globus, F.-Banks of Kelvin (M. Cat.; F. F. W.S.), but Dr. Sharp does not include it in his list of Scottish Coleoptera.

Liodes humeralis, Kug.- In fungi on trees, not unc., L. Lomond (J. E. S.): Cambuslang (A. A D.): Paisley (M. Cat.): Ayr (A. F.).

Anisotoma picea, Ill.- "Luss in Scotland beneath a stone. Dr. Leach, Steph. Illust." (Ent. Ed., 146): Paisley (M. Cat.).

A. dubia, Kug._- A few on sandhills, Macrihanish 9/1894" (J.J.W.): Peaton, L. Long (W. E.): Ardrossan and Ayr (A. F.), teste Mr. G. C. Champion.

A. calcarata, Er.-Shewalton ; Ayr (A. F.) : teste Mr. G. C. Champion.

A. ovalis, Schmidt.-One by evening sweeping, Campleitown (J. J. W.).

Colensis dentipes, Gyll.-Hamilton; Paisley (M. Cat.).

Hydnobius, spec. incog.-One taken ur. Leadhills 10/1900 (W. E.).

Necrophorus humator, $F$.-C., in carcases.

N. mortuorum, $F$.-Widely dist., in carcases.

N. ruspator, Er.-Probably c. ; in carcases ; Paisley (R. E.): Campbeltown (J.J. W.).

N. vespillo, L.-In carcases ; Luss (A. A.D.): Paisley (R. E.): Bishopton (J.E. S.).

Necrodes littoralis, L.-Scarce; in a spider's web at Inveruglas (A. A. D.): Arran, Glen Cloy (J. E. S.) : Brodick (IV. E., A. S. N. H., 1900, 97).

Silpha nigrita, Creutz.-Nr. Glasgow ; Helensburgh; Innellan ; Whiting Bay Arran (J. E. S.). 
S. opaca, L.-Scarce; Peaton, L. Long (W.E.): Bowling (A. A. D.) : Lanarkshire (M. Cat.): Ayr (J. E. S., A. F.): Macrihanish (J.J. W.) : Brodick (W. E.).

S. thoracica, L.-Not unc. ; in carcases, Ben Lomond (J. W. Douglas, Ent. I., 105): Greenock (T. S.): Ayr (A. F.): L. Ridden (A. A. D.): Arran (T. R. B.) : Ailsa Craig (T.S., Trans. N. H. S. of Glasgow, V. x. S., 158).

S. rugosa, L.-Abundant, in carcases.

S. dispar, Herbst.- "Paisley" (Fowler, Brit. Coleopt., III. 52).

S. atrata, L.-C. ; under loose bark and in moss.

Choleva angustata, F.-R., in flood rubbish, Canpbeltown (J.J.W.): under stones, Giffnock 4/1900 (A. A. D.).

C. spadicea, Sturm.-R. in moss, Campbeltown (J. J. W.).

C. agilis, Ill.-R. Clyde district and Arran (Fowler, Brit. Coleopt., III. 57 ).

C. velox, Spence.-Renfrewshire (M. Cat.).

C. fusca, Panz.-In vegetable refuse, Cambuslang (A.F.): rather c. in moss, Campbeltown (J. J. W.) : nr. Paisley (M. Cat.).

C. nigricans, Spence.-Scarce in moss, Ayr (A. F.).

C. morio, F.-R., one male in moss, Barr 4/1900 (A. A. D.).

C. grandicollis, Er.-Nr. Paisley (M. Cat.).

C. nigrita, Er.-R., one in vegetable refuse Cambuslang, 1899 (A. A. D.).

C. tristris, Panz.-In various situations, Milngavie; Bishopton (A. F.) : Bonhill (J. M.): Giffnock; Inverkip (A. A. D.) : nr. Paisley (M. Cat.).

C. kirbyi, Spence.-Paisley (M. Cat., under festinans, Spence).

C. chrysomeloides, Panz.-Scarce, in carcases; Strathblane (G. W. Ord) : Lennoxtown (A. A. D.): Ayr (A. F.): Campbeltown (J.J. W.): Brodick (W. E.).

C. fumata, Spence.-Nr. Paisley (M. Cat.).

Ptomaphagus sericeus, F.-In moss, Bowling (A. A. D.) : Ayr; Barr (A. F.).

Colon serripes, Sahl.-Paisley, Young (Ent. Ann., 1866, 50).

C. brunneum, Latr.-In moss nr. Paisley (M. Cat.).

C. latum, $K r$.-Paisley (F. F. W.S.).

\section{Fam. Histeridae.}

Hister cadaverinus, Hoff.-Hamilton ; Ayr (J.E.S.): Brodick (W.E., A. S. N. H., 1900, 97).

H. succicola, Thoms.-In carcases; Arrochar (A.A. D.) : Bonhill (J. M.) : Ayr ; Colintraive (A. F.).

H. purpurascens, Herbst.-Clyde, r., in sandy places (Sharp).

H. neglectus, Germ.-One, under a stone Bowling (A. A. D.).

H. bimaculatus, L.-Glasgow (M. Cat.).

Gnathoncus nannetensis, Mars.-Glasgow (M. Cat.).

Saprinus nitidulus, Payk.-Two from Kilbarchan district (A. M. S.).

S. aeneus, F.-Scarce, Irvine (A. A. D.): Ayr (J. E. S.).

S. quadristriatus, Hoff.-Paisley (Fowler, Brit. Coleopt., III., 212).

S. maritimus, Steph.-R., in sandy places on the coast, Ayr 3/1894 (A. F.): Barassie 5/1899 (A. A. D.).

Onthophilus striatus, F.--Ben Lomond (J. E. S., Ent. Wkly. Int., VI., 60): Paisley (J.D.) : Colintraive, in dung (A. A. D.).

\section{Fam. Trichopterygidae.}

Trichopteryx fascicularis, Herbst.-Clyde (Sharp).

T. sericans, Heer.-Clyde (Sharp).

Ptenidium punctatum, Gyll.-Clyde, maritime (Sharp).

P. evanescens, Marsh.-Clyde (Sharp). 
Fam. Coccinellidae.

Subcoccinella 24-punctata, L.-R., Ardpeaton ; L. Long 6/1900 (W. E.) : Ailsa Craig (Ann. And, x. s., II., 147).

Adalia obliterata, L.-Not unc. by beating fir trees, Johnstone (A. A. D.) : A yr (A. F.).

A. bipunctata, L.-Abund., and widely dist.

Mysia oblongoguttata, L.-C. on firs.

Coccinella 10-punctata, L.-C. and widely dist.

C. hieroglyphica, L.-Two at Milngavie9 1898 (A. A. D.) : Douglas, Lanarkshire 10/1900 (W. E.) : Campbeltown, r. (J. J. W.).

C. 11-punctata, L.-C., by sweeping.

C. 7-punctata, L.-C., by sweeping.

Halyzia 16-guttata, L.-Luss (J. E. S., E. M. M., VII., 108).

H. 14-guttata, L.--By sweeping and beating, Johnstone (A. A. D.) : Shewalton ; Barr (A. F.) : Arran (T. R. B.).

H. 18-guttata, $L-$ R., Bonhill (J. M.) : .Johnstone (A. A. D.) : Bishopton (A.A. D.).

H. conglobata, L.-Very r., two by sweeping at Luss 6/1900 (A. A.D.),

Hyperaspis reppensis, Herbst.-One by sweeping, Campbeltown (J. J. W.). Rhizobius litura, F.--Very scarce, Ayr (A. F.).

Coccidula rufa, Herbst.- Not unc., by sweeping and in flood refuse, Ayr; Barr (A.A. D. ; A. F.) : Brodick 4/1895 (W.E.).

Fam. Micropeplidae.

Micropeplus tesserula, Curt.-Very r., Paisley, M. Y., (Ent. Ann., 1865, 42).

\section{Fam. Nitidulidae.}

Brachypterus urticae, F.--Br sweeping nettles, Barr (A. F.).

Epuraea aestiva, L.-By beating hawthorn, Luss; ('rookston; Bonhill (A.A.D.): Irvine ; Ayr (A. F.).

E. obselata, F.-Paisley (II. (at.).

Soronia grisea, L.-Nr. Glasgow (J. E. S.).

Omosita depressa, L.-R., one clinging to an old sack on shore, Ardlui, L. Lomond, 51899 (A. F.).

0. colon, L.--Irvine (A. A. U.).

O. discoidea, F.-One flying in a street, Ayr 51895 (A. F.).

Meligethes rufipes, Giyll, $-S$. end of Arran (T. R. B.).

M. aeneus, $F .-$ C., in flowers.

M. viridescens, F.-C. in flowers.

M. picipes, Sturm.-Bonhill (J. M.).

M. erythropus, (iyll.--Clyde (Sharp).

Cychramus luteus, F.-Ayrshire (M. Cat.).

Ips quadripunctata, Herbst.-R., Glasgow (M. Cat.) : Johnstone (A. A. D.): Ayr (A.F.).

I. quadripustulata, L.-Renfrewshire (M. Cat.).

Fam. Trogositidae.

Tenebrioides mauritanicus, L.-In Egyptian wheat, Glasgow (J. E. S.).

Fam. Cucujidae.

Rhizophagus cribratus, Gyll.-Very r., one by sweeping, Ayr, 8/1895 (A. F.): two under bark, Cumbuslang 1899 (A. A. D.).

R. parallelocollis, Er.-Very r. One from Bonhill (J. M.).

R. aispar, Gyll.-Under bark, Johnstone; Bishopton (A.A.D.): Brodick (W. E.).

R. bipustulatus, F.-Possil (J. E. S.).

Silvanus unidentatus, Fab.--One, Paisley district (M. Y., V.). 
S. bidentatus, $F$.-One under fir bark, Paisley, M. Y., (Fowler, Brit. Coleopt., III., 304).

\section{Fam. Monotomidae.}

[Monotoma quadricollis, Aubé.-Nr. Glasgow. Mr. R. Hislop (M. Cat.).]

\section{Fam. Lathridiidae.}

Lathridius lardarius, De Geer.-By sweeping, not unc. : Crookston (A.A.D.): $\operatorname{Ayr}($ A. F.).

Enicmus minutus, L.-In regetable refuse etc., Bishopton (A. F.): King's Cross, Arran (A. A. D.).

Cartodere filiformis, Gyll._- "Devouring an old Greek anthor in Paisley," M. Y., (M. Cat.).

Corticaria denticulata, Gyll.-Three in tidal refuse, Ayr, 3/1894 (A. F.).

C. elongata, Humm.-One, in moss Giffnock, 4/1900 (A. A. D.).

Melanopthalma fuscula, Humm.-Ayr (A. F.).

\section{Fam. Cryptophagidae.}

Antherophagus nigricornis, F.-Clyde, r., in flowers (Sharp).

A. pallens, Gyll.-One by sweeping, Campbeltown (J.J. W.).

Cryptophagus setulosus, Sturm.-Not unc. in vegetable refuse and by sweeping, Pollokshields ; Giffnock (A. A. D.) : Ayr (A. F.).

C. saginatus, Sturm.-R. ; one from Lanark (W. E.) doubtfully referred to this by the Rev. A. Thornley.

C. scanicus, L.-In moss, Giffnock (A. A. D.).

C. dentatus, Herbst.-In vegetable refuse, Cambuslang; Ayr (A.F.) : Johnstone (A. A. D.).

C. distinguendus, Sturm.-Very r., one in flood refuse, Bishopton, 3/1900 (A. F.).

C. cellaris, Scop.-Clyde, rare (Sharp).

Micrambe vini, Panz.-In flood refuse, Barassie (A.A. D.): Ayr (A. F.): Cleghorn Gl., Lanark (W. E.).

Paramecosoma melanocephalum, Herbst.-In flood refuse Strathaven (A. F.): nr. Paisley, M. Y., (M. Cat.).

Atomaria umbrina, Er.-Paisley (M. Cat.).

A. elongatula, Er-Clyde, very rare (Sharp).

A. longicornis, Thoms.-Paisley (Fowler, Brit. Coleopt., III., 334).

A. fuscipes, Gyll.-Clyde, common (Sharp).

A. peltata, Kr.-Very r., Clyde district, Paisley, M. Y., (Fowler, Brit. Coleopt., III., 336).

A. fuscata, Schön.-In moss, Giffnock (A. A. D.).

A. berolinensis, $K r$.-Clyde, local (Sharp).

A. gibbula, Er:-Low ground, Garelochhead (W. Henderson, E. M. M., II., 88).

A. analis, Er.-Clyde, local (Sharp).

A. ruficornis, Marsh.-Clyde, rare (Sharp).

A. versicolor, Er.-Clyde, rare in dung (Sharp).

Ephistemus globosus, Waltl._Clyde, rare in dung (Sharp).

E. gyrinoides, Marsh. var. dimidatus, Sturm.--Renfrew district, in moss (J.S. under confinis).

\section{Fam. Mycetophagidae.}

Typhaea fumata, L.-Clyde, local (Sharp).

Fam. Byturidae.

Byturus tomentosus, F.-Greenock (J. E. S.). 


\section{Fam. Dermestidae.}

Dermestes lardarius, L.-Clyde, rare (Sharp).

\section{Fam. Byrrhidae.}

Byrrhus pilula, L.-In moss ; Ben Lomond (J.E.S., Ent. Wkly. Int., VI., 60): Bonhill (A.A.D.): Greenock; Whiting Bay, Arran (J.E.S.): Ailsa Craig, W. C. S. Fergusson (Trans. N. H. S. of Glasg., V., x. s., 158).

B. fasciatus, F.-Scarce, Ben Lomond (J. E. S., Ent. Wkly. Int., VI., 60) : Hamilton (J. E. S.): Irvine (A. A. D.) : Ayr (A. F.).

B. dorsalis, F.-R., sandy localities, one Irvine (A. A. D.) : one Ayr (A. F.). Cytilus varius, $F$.-C., in moss.

Morychus aeneus, F.--Scarce, sandy localities, Stevenston (A. F.): Irvine (A. A. D. ; A. F.).

Simplocaria semistriata, F.-Not unc., Ben Lomond (J. E. S., Ent. Wkly. Int., VI., 60) : ur. Glasgow (J. E. S) : Lanark (W. E.): Ayr (A.A. D.).

\section{Fam. Parnidae.}

Elmis aeneus, Miill.-Clinging to stones immersed in streams, local but c. where it occurs, Ayr (A. F.).

E. volkmari, Panz-LLocal and scarce in similar situations, nr. Glasgow (J. E. S.) : Cart. (M. Cat.) : Ayr (A. F.).

E. parallelopipedus, Müll.-Clyde in streams, not unc. (Sharp).

Parnus prolifericornis, F.-Margins of strearns and ponds, Bonhill (J. M.) : Port Glasgow (A. F.) : Arran; Glen Cloy (J. E. S.) ; Pirnmill (A. F.).

P. auriculatus, Panz.--In similar situations, Elvanfoot (W. E.): Stevenston; Ayr ; Barr (A. F.).

\section{Fam. Heteroceridae.}

Heterocerus marginatus, $F$.-Nr. Cambuslang (M. Cat.).

\section{Fam. Scarabaeidae.}

Onthophagus nuchicornis, L.-Ayrshire, Mr. J. P. Duncan (M. Cat.). Aphodius erraticus, L. - S. end of Arran (T. R. B.).

A. fossor, L.-Scarce, in dung ; Gareloch head (J.E.S.) : Dundonald (A.A.D.; A. F.) : Whiting Bay, Arran (J. E. S.).

A. foetens. F.-In sheep's dung, Macrihanish $7 / 1895$ (J. .J. W.).

A. fimetarius, L.-Abund. and widely dist.

A. ater, De. G.-A A bund. and widely dist.

A. nitidulus, F.-In sheep's dung, Macrihanish $7 / 1895$ (J. J. W.).

A. sordidus, F.-In sheep's dung, Macrihanish $7 / 1895$ (J. J. W.).

A. rufescens, F.- Ayr (A.F.) : in sheep's dung, Macrihanish 7/1895 (J.J. W.): Arran (T. R. B.).

A. lapponum, Gyll.-Ben Lomond (J. E.S., Ent. Wkly. Int., VI., 60) : on the hills behind Greenock (J. E.S.) : plentiful on high ground, Campbeltown (J. J. W.).

A. foetidus, $F$ - - Plentiful on high ground, Campbeltown (J. J. W.).

A. putridus, Sturm.-Plentiful on high ground, Campbeltown (J.J. W.)

A. merdarius, F.--Not c., Irvine (A.A. D.): Ayr (A. F.).

A. tessulatus, Payk.-S. end of Arran (T. R. B.).

A. punctato-sulcatus, Stm.-C. and widely dist.

A. prodromus, Brahim.-C. and widely dist.

A. contaminatus, Herbst.-Nr. Glasgow (J.E.S.): Kilsyth (A.A.D.) : Whiting Bay, Arran (J. E. S.): probably c.

A. luridus, F.-Scarce; Irvine (A. A.D.): Ayr (A. F.) : on high ground, Campbeltown (J.J. W.) : Arran (T. R. B.).

A. rufipes, L.-Abund. and widely dist.

A. depressus, Kug.-Abund. and widely dist. 
Aegalia sabuleti, Payk.-Not c., Cambuslang (A. F.) : Irvine (A. A. D., A. F.). Ae. arenaria, F.-Sandy places on the coast, Irvine (A. A. D.) : Ayr (A. F.). Geotrupes typhoeus, L.- Very local; on a mor by the side of the road from Brodick to Lamlash (W.E., A.S. N.H., 1895, 198): S. end of Arran (T.R. B.): Irvine Moor by Mr. Thos. Wilson (A.S. N.H., 1897, 47) : since taken in the latter locality by (A. A. D. \& A. F.).

G. stercorarius, L.-C. and widely dist.

G. sylvaticus, Panz.-Dubh Lochan mr. L. Lomond (J.E.S.) : Ardlui (A. F.) : Glenmallan (A. A. D.) : Kilbarchan (A. M.S.) : Greenock (T.S.) : Arran (J.E.S. ; T. R. B.).

G. vernalis, L.--Ben Lomond (II. Cat.): Elvanfoot (W. E.) : Brodick several 4/1895 (W. E.) : Holy I. (J. E. S.).

Hoplia philanthus, Fïss.-Very r., three at Catacol, Arran 7/1855 (J. E. S.).

Serica brunnea, L.-Freq.; Greenock (J. E. S.) : Skelmorlie (T.S.) : W. Kilbride (D. A. B.): Ayr (A. F.): Elvanfoot (W. E.): Macrihanish (J. J. W.).

Melolontha vulgaris, F.-Lanark ; Sorn (M. Cat.) : Paisley one (J. D.).

M. hippocastani, F.-Hamilton (M. Cat.) : Cadzow Forest ; Ayrshire (Robert Hislop, Zool., XIII., 4924) : c. spring 1895, Ayr (Thos. Wilson; A. F.).

Phyllopertha horticola, L.-C. ; L. Eck (J. E.S.): Ardlui ; Arrochar (A. A. D.) : W. Kilbride (D. A. B.) : Troon (Mr. Ross).

Anomala frischii, F.-R.; on bushes, Ayrshire (M. Cat.) : Stewarton (W. G.) : Irvine 7/1900 (A. A. D.; A. F.).

Cetonia aurata, L.-P. ; on ragwort L. Ridien (A.A. D.): Ayrshire (M. Cat.).

C. floricola, Herbst.-R., one at Tarbert 8/1896 (G. W. Ord): Ormidale, one (T. S.).

\section{Fam. Throscidae.}

Throscus dermestoides, L.--Paisley and Glasgow (M. (at.).

\section{Fam. Elateridae.}

Lacon murinus, L.-Scarce, by sweeping, Prestwick (A. F.): Whiting Bay, Arran (J. E. S.).

Cryptohypnus riparius, $F \cdot-\mathrm{C}$. and widely dist.

C. dermestoides, Herbst.-Not unc. ; gravelly banks of streams Strathaven (A. F.): $\operatorname{Barr}$ (A. A. D. ; A. F.).

var. quadriguttatus, Lap.-With the type, Barr (A.A.D.; A. F.).

Elater balteatus, L.-Local but not unc., by sweejing, L. Eck; Robroyston (J.E.S.) : Renfrew. and Lanark. (M. Cat.) : Irvine (A. A. I).) : Shewalton ; Barr (A. F.).

Melanotus rufipes, Herbst.--R.; one by sweeping at Luss 6/1900 (A. A. D.). Athous niger, L.-Not unc., by sweeping in sumner; Ardlui (A. A. D.): Bonhill (J. M.) ; Ayr (A. F.) : Greenock ; Whiting Bay, Arran (J. E. S.).

A. haemorrhoidalis, $F$.-Very c., by sweeping, May to Aug.

A. vittatus, F.-By sweeping, L. Eck (J. E. S.): Pirnmill, Arran (A. F.).

Limonius cylindricus, Payk:-Local and scarce, in sandy localities, Irvine (A. A. D. ; A. F.).

Sericosomus brunneus, L.-Local and scarce, Bishopton (J. D. ; A. A. D.) : L. Eck (J. E. S.) : r. on summit of Bengullion, Campbeltown (J. J. W.).

Adrastus limbatus, F.-R. ; one by sweeping at Shewalton T/1900 (A. F.).

Agriotes sputator, L.-R. ; one mr. Greenock (T. S.).

A. obscurus, L.-Abund. under stones.

A. lineatus, L.-R. One in moss, Ayr, 12/1895 (A. F.).

A. pallidulus, $I l l$.-By sweeping under trees, freq., Luss (A. A. D.): Peaton, L. Long (W. F.) : Bonhill (J.M.) : Crookston (A. A. D.) : Ayr ; Barr (A. F.): Colintraive (A. A. D.). 
Dolopius marginatus, L.-C: by sweeping.

Corymbetes cupreus, F.-Freq. by sweeping hilly ground, Luss; Colintraive (A.A.D.): Kilbarchan (A.MI.S.): Garelochhead; Greenock; sparingly, slopes of Bengullion, Campbeltown; Whiting Bay (J.E. S.): Barr ; Pirnmill (A. F.).

var. aeruginosus, F.-With the type, Luss (A.A.D.): Paisley (J.D.) : Kilharchan (A. M. S.): Pirmmill, Arran (A. F.).

C. tessellatus, F.--Scarce, by sweeping, Ardlui ; Irvine (A. A. D.) : Garelochhead; Greenock ; Whiting B. (J. E.S.): Dunoon (M. Cat.): Brodick (W. E.)

C. quercus, Gyll.-By beating and sweeping, c.

var. ochropterus, Steph.-With the type, c.

C. aeneus, L.-P., one nr. Greenock (T.S.).

Campylus linearis, L.-By beating, scarce, Cambuslang; Johnstone (A. A. D.): Ayr; Barr (A.F.). Colour very variable.

\section{Fam. Dascillidae.}

Dascillus cervinus, $L .-\mathrm{By}$ sweeping hilly pasture, nr. Ben Lomond (Ent. Ed.): Glenmallan (A. A. D.): Greenock (J.E.S.) : Kilbarchan (A.M.S.): Arr; Barr (A. F.) : scalce, Campbeltown (J.J. W.) : Holy I. (J. E. S.).

Helodes minuta, L.-By sweeping; Arrochar ; Cambuslang ; Ravenscraig (A.A.D.): Avr ; Barr (A. F.).

H. marginata, $F$.-By sweeping; Milngavie; Cambuslang (A.A.D.) : ('ampbeltown (J. J. W.) : Colintraive; Pirmmill, Arran (A.F.).

Microcara livida, $F$.-By sweeping, Bishopton (A.A. D.).

Cyphon coarctatus, Payk.-C'lyde, c. (Sharp).

C. nitidulus, Thoms.-By sweeping; Bonhill (J. M.): Bishopton (A. A.D.) : Ayr (A. F.).

C. variabilis, Thunb.-By sweepin๕; Bonhill (J. M.): Whistlefield; Ravenscraig (A.A.D.) : Ayr ; Barr (A. F.).

C. pallidulus, Boh.-R., two, Pavenscraig, 6/1899 (A. A. D.).

Hydrocyphon deflexicollis, Müll.-Scarce by sweeping herbage beside streams, Irvine; Barr (A. F.).

\section{Fam. Malacodermidae.}

Lampyris noctiluca, L.--Local and scarce, Tarbert (T.S.): Kilmalcolm (A. F.) : Girvan district (G. W. Ord, A.S. N. H., 1892, 240) : Barr (A.F.).

Podabrus alpinus, Puyk.-Hamilton (M. C'at.).

Telephorus rusticus, Fall.-Nr. (Hlasgow (J. E. S.) : Renfrew district in. cop. with T.lividus (J. S., Zool. XI., 3919): Greenock (J. E. S.).

T. lividus, L.-Occasional, by sweeping, Arrochar (A.A.D.) : nr. Glasgow ; Greenock (J.E.S.) : Renfrew district (J.S., Zool., XI., 3919): Irvine ; $\operatorname{Ayr}($ A. F.).

T. pellucidus, F.-Occasional, Bonhill (.J.M.): Crookston (A.A.D.) : Greenock (J. E. S.) : Barr (A. F.).

T. nigricans, Müll-C., by sweeping. var. discoideus, Steph.-With the type, c.

T. lituratus, F.-Two specimens, Bonhill (J. M.).

T. darwinianus, Sharp.-S. end of Arran (T. R. B.).

T. figuratus, Mann.-Clyde, local (Sharp).

T. bicolor, F.-C., by sweeping.

T. paludosus, Fall.-Local and scarce, Ravensciaig, 61899 (A. A. D.) : Barr by sweeping, 61896 (A.F.) : Campbeltown, r. on flowers of Mountain Asl, .June (J.J. W.).

T. flavilabris, Fall.-Locally c., Ayr ; $\operatorname{Barr}$ (A. F.).

Rhagonycha fulva, Scop.-A A bund., by sweeping.

R. testacea, L.-Greenock (.J. E.S.). 
R. limbata, Thoms.-C. and widely dist.

R. pallida, $F$.-Not so c. as preceding; (Glasgow ; Greenock (J. E. S.): Johnstone (A. A. D.) : Ayr (A.F.) : Arran (T.R. B.).

Malthinus punctatus, Fourc.-Clyde, not rare (Sharp).

Malthodes marginatus, Latr.-Not unc., by sweeping, Cambuslang (A. A. D.): Ayr ; Barr (A. F.).

M. guttifer, Kies.-R., Garelochhead (D. Sharp, E.M.M., V., 19).

M. dispar, Germ.-Campbeltown, c. by sweeping (J.J. W.) : specimens from Crookston (A. A. D.), and Pirnmill, Arran (A. F.) doubtfully referred to this by Rev. A. Thoruley.

M. minimus, L.-By sweeping, Ayr (A. F.).

\section{Fam. Ptinidae.}

Niptus hololeucus, Fald.-In presses in old houses, Bonhill (J. M.): Greenock (J. E. S.) : Ayr (A. F.) : in Egyptian wheat, Glasgow (J. E. S.). Anobium domesticum, Fourc.-In old wood in houses, Ayr (A. F.).

Ernobius mollis, L.-In numbers in palings, Glasgow 1866 (J. E. S.).

\section{Fam. Cissidae.}

Cis boleti, Scop.--In fungi on trunks of trees, palings, etc., Bonhill (.J.M.) : Possil (J. E.S.) : Giffnock (A. A. D.) : Barr (A. F.).

C. bidentatus, Ol.--Glasgow (M. Cat.).

C. nitidus, Herbst.-Possil (J. E. S.).

C. fuscatus, Mell.--An immature example, Brodick 4/1895 (W. E.).

Octotemnus glabriculus, Gyll.-Scarce in fungi on trunks of trees, Giffnock (A. A. D.): $\operatorname{Barr}$ (A. A. D. ; A. F.).

\section{Fam. Cerambycidae.}

Aromia moschata, L. - One in a florist's shop in Glasgow, imported (A. A. D.). Asemum striatum, L.-Palings and old posts at Renfrew (.J.S., Zool., VIII., 2885).

Clytus arietis, L.-Lanarkshire; Hamilton, Mr. J. Blyth ; nr. Carnwath, Mr. A. Hepburn, (M. Cat.).

Rhagium inquisitor, F.-Tarbert (T.S.): L. Eck (J. E.S.) : Douglas, Lanarkshire, many in rotten birch $11 / 1900$ (J. E.S.).

R. bifasciatum, $F$.-C. in decaying trees.

Strangalia quadrifasciata, L.-R.; one on a flower in a garden, L. Ridden (A. A. D.): $\operatorname{Arran}($ F. F.W.S).

S. armata, Herbst.-Extremely r., Gl. Cloy, Arran 865 (J. E. S.).

Acanthocinus aedilis, L.-Introducerl. In a pit, Coatbrilge (Thos. Chapman, E.M.M., VI., 89) : in railway carriage on Greenock line (Trans. N.H.S. of Glasgow, II., 1): on a wall, Ayr (A. F., Trans. N. H.S. of Glasgow, V., s.s., 136) : Kilbarchan, in wood yard (A. M. S.).

\section{Fam. Bruchidae.}

Bruchus pisi, L.-In pease, imported, Bonhill (J. M.): Glasgow, Mr. Hislop (M. Cat.).

R. rufimanus, Boh.-Local and scarce, by sweeping vetches nr. Ayr (A. F.).

\section{Fam. Chrysomelidae.}

Orsodacna lineola, Panz.-Paisley specimens sent to Mr. G. C. Chapman, F.Z.S., by Mr. J. Dunsmore in 1877 (E.M.M., IX., s.S., 175).

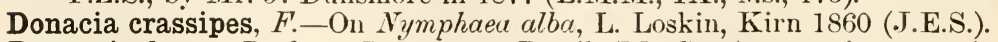

D. versicolorea, Brahm.--R., one at Possil (Mr. Ross) : one in moss, Ayr $12 / 1895$ (A.F.).

D. dentipes, F.-Glasgow (M. Cat.).

D. bicolora, Zsch.-Nr. Milngavie; nr. Glasgow (M. Cat.). 
D. impressa, Payk.-Ayrshire, Mr. Hardy (M. Cat.). Dr. Sharp states that he has some doubts whether this is properly recorded as $D$. impressa.

D. simplex, $F$.-Not unc. by sweeping in wet places, Garscube (J. E. S.) : Crookston (A. A. D.): $\operatorname{Ayr}($ A. F.).

D. vulgaris, Zsch.-Nr. Glasgow, Mr. R. Hislop (M. Cat.).

D. clavipes, $F$.-R., amongst reeds, Ardlui 6/1900 (A. A. D.).

D. sericea, L.-Not unc., on bog bean and grasses in wet places.

D. discolor, Panz.-Nr. Glasgow; Greenock; L. Eck (J. E. S.) : Brodick (W. E., A. S. N. H., 1900, 99).

Lema lichenis, Voet.-C. and gen. dist.

L. melanopa, L.-Occasional, by sweeping, L. Eck (J. E. S.): Irvine (A. A. D.): Ayr ; Barr (A.F.).

Cryptocephalus moraei, L.-R., two females by sweeping at Shewalton 7/1895 (A. F., A. S. N. H., 1896, 61).

C. labiatus, L.-Nr. Paisley (M. Cat.).

Timarcha violaceonigra, De G.-Very r., one from Stewarton district (W. G.).

Chrysomela banksi, F.-Ayrshire, Dr. G. M'Nab (M. Cat.).

C. staphylea, L.-C., by sweeping.

C. polita, L.-C., by sweeping.

C. haemoptera, L.-R., Stewarton, by Mr. W. Gilmour (A. S. N. H., 1899, 115). There is probably a mistake as to the locality in this record as the species occurs near the coast.

C. varians, Schall.-Scarce, Bonhill (J. M.) : L. Eck (J. E. S.) : Gl. Cloy, Arran (J. E. S.) : S. end of Arran (T. R. B.).

[C. menthrasti, Suffr.-Arran (M. Cat., under fulgida). Dr. Sharp states in his catalogue that the records of $C$. fulgida and Graminis in Murray's Catalogue perhaps refer to this species].

C. hyperici, Forst.-R., Rothesay (M. Cat.): King's Cross, Arran, by sweeping $7 / 1900$ (A. A. D.).

Melasoma aeneum, L.-Scarce, two by shaking moss, Johnstone (A. A. D.).

Phytodecta olivacea, Forst. - Not unc. on broom, Ayr (A. F.). var. litura, $F$.-Barr (A. A. D.).

Gastroidea viridula, De G.-Paisley (R. E.) : Glasgow ; Greenock ; Blairmore (J.E. S.).

G. polygoni, L.-Not unc., by sweeping in summer and in moss in winter, Irvine (A. A. D.) : Ayr (A. F.) : Pirmmill, Arran (A. F.).

Phaedon tumidulus, Germ.- Very c. and widely dist.

P. armoraciae, L.-Local and scarce, Helensburgh (J. E. S.) : on Iris pseudacorus, Shewalton $7 / 1895$ (A. F.).

P. cochleariae, $F$.-Local, on plants on muddy flats, below high tide mark, Bowling (A. A. D. ; A. F.).

P. concinnus, Steph.-Clyde, local (Sharp).

Phyllodecta vitellinae, L.-Very c. on willows.

Hydrothassa aucta, $F$.-By sweeping in summer and in moss in winter, Glasgow (M. Cat.) : Strathaven (A. A. D.) : Ayr ; Barr (A. F.) : Blackwaterfoot, Arran 4/1895 (W. E.).

H. marginella, L.-Nr. Glasgow (J. E. S.) : Lamington (A. A. D.) : Paisley (J. D.).

Prasocuris phelandrii, L.-Locally c. Milngavie (A.A.D.): Possil (J.E.S.): Renfrew district (.J. S.) : Ayr, in moss (A. F.).

Phyllobrotica quadrimaculata, L.-Has more than once been found $\mathrm{nr}$. Glasgow (Sharp).

Luperus rufipes, Scop.-Scarce, Blairmore (J. E. S.) : Strone (R. H.).

L. flavipes, L.-Scarce, L. Eck (J. E. S.) : Barr by sweeping (A. F.).

Lochmaea capreae, L.-Robroyston; Greenock; Helensburgh; L. Eck (J. E. S.). 
L. suturalis, Thoms.-C. on heather. A fine black var. occurred commonly at Irvine 4/1900 (A. A. D. ; A. F.).

Galerucella nymphaeae, L.-Scarce, Milngavie (A. A. D.): Possil, three examples of a fine black var. (A. A. D.).

G. tenella, L.-Scarce; by beating birches etc. Luss (A. A. D.) : Colintraive (A. F.) : Elvanfoot (W. E.) : Barr (A. F.).

Adimonia tanaceti, L.-Kilbarchan district (A. M. S.).

Longitarsus holsaticus, L.-Dumoon (M. Cat.).

L. luridus, Scop.-Scarce ; by sweeping in summer, in moss in winter, type, Luss; Barrhead (A.A.D.): pale form, Ayr (A.F.): melanic form, Bishopton ; Barr (A. F.) : Cleghorn Gl., Lanark (W. E.).

L. suturellus, Duft.-In flood refuse, Strathaven 3/1900 (A. F.).

var. fuscicollis, Steph.-By sweeping in autumn and in moss in winter, Bonhill (J. M.): Giffnock (A.A.D.) : Cleghorn G1., Lanark (W.E.) : Ayr (A. F.): King's Cross, Arran (A. A. D.).

L. melanocephalus, $A l l$. - C. by sweeping and in flood refuse, Strathaven ; Ayr ; Pirnmill, Arran (A. F.) : Crookston ; King's Cross (A. A. D.).

L. jacobaeae, Wat.-On ragwort (Senecio jacobaea), c., Bonhill (J.M.) : Strathaven; Ayr (A. F.): King's Cross, Arran (A. A. D.).

L. laevis, Duft.-One in flood refuse, Strathaven 8/1900 (A. F.).

Haltica oleracea, L. (?).-Shewalton, by sweeping $7 \& 9 / 1895$ (A. F.).

H. pusilla, Duft.-Not unc., by sweeping, May to July, Whistlefield ; Bonhill (A.A.D.) : Ayr ; Barr ; Pirnmill, Arran (A. F.).

Phyllotreta undulata, Kuts.-Freq.; by sweeping in summer, in moss in winter, Bonhill ; Milngavie; Giffnock; Strathaven (A. A. D.): Lanark (W.E.): Shewalton ; Barassie ; Ayr ; Barr ; Pirnmill (A. F.).

P. nemorum, L.-Nr. Glasgow ; Greenock (J. E.S.).

P. flexuosa, Ill.--Nr. Glasgow (M. Cat.).

P. sinuata, Steph.-R., by sweeping, Luss 6/1900 (A. A. D.).

P. exclamationis, Thunb.-Local and scarce, in moss, Feb. \& March, Ayr (A. A. D. ; A. F.).

Apthona nonstriata, Goeze-On Iris pseudacorus, May-July, W. Kilbride (D. A. B., Trans. N. H.S., Glasgow, II., N. s., XXXIV.): Ayr (A. F.) : Colintraive (A.A. D.): Pirmmill, Arran (A. F.): Brodick (W.E.).

Sphaeroderma testaceum, F.-C. on thistles. A melanic form occurs on the shore at Ayr along with the type (A. F.).

S. cardui, Gyll.-Not mnc. on thistles, Shewalton (A. F.): Dundonald (A. A. D. ; A. F.).

Apteropoda orbiculata, Marsh.-Nr. Glasgow ; Dumbarton (M. Cat.) : two, Cleghorn Gl., Lanark 10/1900 (W. E.).

Mniophila muscorum, Koch.-Plentiful nr. Bothwell (M. Cat.): scarce by sweeping, Shewalton and Ayr, July : in moss; Barr, April (A. F.).

Mantura rustica, $L$. var. suturalis, Weise.-Scarce by sweepiog May and June, Irvine; Ayr (A. F.).

Crepidodera transversa, Marsh.-C. by sweeping rushes, June to Aug.

C. ferruginea, Scop.-By sweeping rushes, June and July, Barr (A. A. D. ; A. F.).

C. rufipes, L.-Local, by sweeping in June, Crookston (A.A.D.): Barr (A. F.).

[C. helxines, L.-Glasgow (M. Cat.)].

C. aurata, Marsh.--Very r., one by sweeping at.Bouhill 7/1900 (A. A. D.).

Hippuriphila modeeri, L.-Very scarce, by sweeping, Barr 7/1899 ; flood refuse Bishopton 2/1900 (A. A. D.).

Chaetocnema hortensis, Fourc.-R., two by sweeping, King's Cross, Arrau 8/1900 (A. A. D.).

Plectroselis concinna, Marsh.-In moss in winter, by sweeping in summer, Bonhill (J. M.) : Crookston ; Bishopton (A. A.D.) : Ayr ; Barr (A. F.). 
Psylloides chrysocephala, L.-Not c., by sweeping, Paisley (J. D.) : Irvine (A. A. D.): Shewalton : Arr (A.F.).

P. marcida, Ill.-R., one by sweeping, Ayr (A. F.).

P. chalcomera, Ill.-P., one by sweeping, Luss 6/1900 (A. A. D.).

P. picina, Marsh.-Scarce, by sweeping, Bonhill (J. M.): Ayr, Jume (A. F.).

Cassida flaveola, Thunb.-Xot unc., by sweeping, Campsie (J. E. S.): Glasgow (M. Cat.) : Ayr ; Colintraive (A. F.).

C. viridis, F.--On thistles, Troon (A.R.): Ayr ; Barr (A.F.): Arran, Whiting Bay (J. E. S.) ; King's Cross (A. A. I.).

C. hemisphaerica, Herbst.--Very r., one crawling on a sandhill, Irvine $6 / 1900$ (A. F.).

Fam. Tenebrionidae.

Blaps mucronata, Latr.-_scarce, in cellars and outhouses, Bonhill (J.M.) : Paisley (R. E.) : Greenock (T.S.).

Heliopathes gibbus, $F$.-Very local, in sandy places nr. coast, Arrshire, Mr. J. P. Duncan (M. Cat.): Irvine; Prestwick (A.F., Trans. N. H.S., Glasg., V. x. s., 136).

Alphitobius diaperinus, Panz.-Clycle (Sharp).

A. piceus, ()l. - In a loaf in Glasgow, M. Hislop (M. Cat.).

Gnathocerus cornutus, F.-Paisley, in grain store (R. E.).

Tribolium ferrugineum, F.-In Egrptian wheat, Glasgow (.J. E. S.) : one, in bread, Elvanfoot, I900 (W. E.).

Helops striatus, Fourc.-Tarbert (T.S.): on the very summit of Holy I., beneath the cairn, 1859 (W.E.): two nr. Brodick +1895 (W. E., A. S. N. H., 1900, 99).

\section{Fam. Melandryidae.}

Tetratoma ancora, F.-Paisley (M. Cat.).

\section{Fam. Pythidae.}

Salpingus castaneus, Panz-Scarce, Cambuslang (A.A.D.) : by sweeping in fir wood, Shewalton (A. F.).

S. ater, Payk:-Glasgow (M. Cat.) : one, apparently this species, br sweeping nr. Campbeltown 6/1895 (.J. J. W.).

Rhinosimus ruficollis, L.-Local and scarce, under loose bark, Paisley, M. Y., (M. Cat.): Johnstone (A. A. D.) : $\operatorname{Arr}($ A. F.).

R. viridipennis, Steph.-Renfrewshire (M. Y., V.).

R. planirostris, F.-Under bark, and by sweeping, Glasgow district (J.E.S.): Johnstone (A. A. D.): Avr (A.F.) : a remarkably large form rarely under beech bark, Campbeltown (J.J. W.).

\section{Fam. Mordellidae.}

Anaspis frontalis, L.-Not unc., by sweeping, Luss (A.A. D.): Greenock (J. E. S.) : $\operatorname{Barr}($ A. F.).

A. rufilabris, Gyll.-Scarce, Cadder (A. A. D.).

A. maculata, Fourc.-Scarce, by sweeping flowers, Dundonald (A. A. D.).

\section{Fam. Rhipidophoridae.}

Metoecus paradoxus, L.-Apparently very r.; "Bothwell Castle" (M. Cat.).

\section{Fam. Anthicidae.}

Anthicus floralis, L.-R., Bonhill (J. M.).

A. scoticus, Rye.-Local and r., Paisley by M. Young (E. C. Rye, E. M. M., IX. 10): in flood refuse, Barassie (A. A. D.) : Ayr (A. F.).

\section{Fam. Meloidae.}

Meloe proscarabaeus, L.-Locally abund.; in sandy places, Tollcross (J. E. S.): Irvine (Thos. Wilson; A. F.) : 1 r. Brodick (W. E.). 


\section{Fam. Curculionidae.}

Rhynchites aeneovirens, Harsh.-R., one by beating oak, Ayr (A. F.).

R. minutus, Herbst. - Clyde, scarce (Sharp).

R. nanus, Payk.-R., by beating birches, Linwood, Paisley (R. E.): Bishopton (A. A. D.).

Deporauis megacephalus, Germ.--Scarce, by beating birches, Greenock (J. E. S.): Bishopton (A. A. D.).

D. betulae, L.-Freq., by beating birches, Bonhill; Cadder (A. A. D.): Shewalton (A. F.).

Apion subulatum, Kirby.-R., by sweeping retches, May and June, Ayr (A. F.).

A. ulicis, Forst.-On broom, not unc., Lanark (W. E.) : Ayr (A. F.).

A. cruentatum, Walt.-Local, but not une.; by sweeping, June-Sept., Shewalton ; Barr (A. F.) : one shaken ont of moss, Barr 4/1900.

A. haematodes, Kirby.-One by sweeping at Shewalton 8/1895 (A. F.): Cleghorn Gl., Lanark 10/1900 (W. E.).

A. viciae, Payk.-On Vicia, three, Ayr 6/1895 (A. F.).

A. apricans, Herbst.-C., in moss and by sweeping, March-July.

A. dichroum, Bedel.-Very c., in moss and by sweeping, Feb.--July.

A. onopordi, Kirby.-One, King's Cross, Arran 8/1900 (A. A. D.).

A. carduorum, Kirby.-On thistles, c., May-Aug.

A. virens, Herbst.-In moss, banks of pond, Ayr 3/1900 (A. F.).

A. aethiops, Herbst.-Scarce, Giffnock (A.A. D.) : in moss, Ayr 3/1900 (A. F.) : by sweeping, Barr, 6/1900 (A. A. D. ; A. F.).

A. striatum, Kirby.-One, Ayr (A. F.): Cleghorn Gl., Lanark, 10/1900(W. E.).

A. spencei, Kirby-_By sweeping, June and July, Shewalton (A. F.) : Ayr (A. A. D. ; A. F.).

A. ervi, Kirby.-In moss and by sweeping, Feb.-June, Milngavie (A. F.): Giffnock; Bishopton (A. A. D.): Ayr ; Barr (A. F.).

A. vorax, Herbst.-By sweeping, Bishopton, 6/1900 (A. A. D.): Ayr (A. F.).

A. gyllenhali, Kirby.-R.; one in moss, Ayr, 4/1900; one by sweeping, Shewalton $7 / 1900$ (A. F.).

A. loti, Kirby.-One, Bonhill (J. M.) : two in moss, Barr 4/1900 (A. A. D.).

A. violaceum, Kirby.-C. ; in moss and by sweeping.

A. hydrolapathi, Kirby.-One by sweeping, A yr 5 1900 (A. F.).

A. humile, Germ.-By sweeping, May-July, Milngavie (A. F.): Crookston (A. A.D.) : Lanark (W.E.): Irvine ; Ayr ; Barr ; Pirnmill, Arran (A. F.).

Otiorrhynchus atroapterus, De. G.-On the coast, Ardrossan (A.A.D.) : Ayr ; Turnberry (A. F.): Macrihanish beach (J.J. W.).

O. blandus, Gyll.-OOn the higher hills, Castle Ayle, L. Fyne (T. S.) : Campbeltown (J.J. W.) : Arran, Whiting Bay (J. E. S.); Ben Bharrain (A. F.): Ailsa Craig, W. C. S. Fergusson (Trans. N. H. S. Glasgow, V., s. s., 158).

0. maurus, Gyll.-Ben Lomond (J.E.S., Ent. Wkly. Int., VI., 60) : Dunoon (II.' Cat.).

0. ligneus, Ol.-In moss and by sweeping, Luss (A. A. D.) : Bonhill (.J. M.): Tollcross; Shewalton (A.F.): Barr (A.A.D.): Macrihanish beach (J. J. W.) : Gl. Cloy, Arran (J. E. S.).

O. septentrionis, Herbst.-Arran (T. R. B.).

O. picipes, $F$.-Abund., by sweeping and beating.

O. sulcatus, $F$.-In moss etc., Garelochhead; Bowling; Giffnock (A.A. D.) : Greenock (J. E. S.) : Kilbarchan (A. M. S.) : Ayr (A. F.) : Arran, Whiting Bay (J. E. S.) ; Brodick (W. E.).

O. rugifrons, Gyll.-C Scarce; in moss and under stones, Castle Ayle, L. Fyne (T.S.) : Giffnock (A. A. D.) : Stevenston (A. F.) : Ailsa Craig, W. C. S. Fergusson (Trans. N. H. S. Glasg., V., N. s., 158). 
O. ovatus, L.-Freq. by sweeping and under stones, Stevenston ; Irvine ; Ayr (A. F.) : Macrihanish beach (J.J. W.).

Strophosomus coryli, $F$.-C. by beating hazels.

S. lateralis, Payk:-Nr. Paisley (R. E.).

Exomias araneiformis, Schr.-R., in moss, Paisley district (M. Young) : Ayr ; Barr (A.F. ; A. S. N. H., 1897, 48).

Sciaphilus muricatus, F.-Freq. by sweeping, Bonhill (A.A.1).) : Ayr ; Barr (A. F.).

Tropiphorus tomentosus, Marsh.-C . in moss and by sweeping.

Liophloeus nubilis, $F$.- Scarce, by sweeping herbage on banks of streams, Giffnock (A. A. D.) : Kilbarchan (A. M.S.): Ayr; Barr (A. F.).

Polydrusus micans, F.-Lanarkshire, nr. Hamilton (M.Cat.): Dr. Sharp states with regard to the inclusion of this species in Murray's catalogue that he is inclined to suspect an error of identification.

P. tereticollis, De G.-Not unc. by beatiug hazels etc., Luss (A.A.D.): Bonhill (J. M.) : Avr (A. F.).

P. pterygomalis, Boh.--Not unc. by beating young trees, Ayr; Pirmmill, Arran (A.F.).

P. cervinus, L.-Not unc. by beating firs, Bishopton (A. A. D.) : Ayr (A. F.).

Phyllobius oblongus, L.--Local ; by sweeping, Crookston (A.A. D.) : Ayr ; Barr (A. F.).

P. calcaratus, F.-Bonhill (J. M.) ; Glasgow ; Greenock (J. E. S.) : Campbeltown (J. J. W.).

P. urticae, F.-On nettles, c.

P. pyri, L.-C. by beating and sweeping.

P. argentatus, $L .-C$., by sweeping.

P. maculicornis, Germ.-C., by sweeping.

P. viridiaeris, Laich.-Very c., and widely dist.

P. viridicollis, F.-Not unc. locally. Crookston (A. A. D.) : Irvine ; Ayr (A. F.).

Philopedon geminatus, $F$.-C. on the coast.

Barynotus obscurus, $F$.- Scarce in moss, and by sweeping. Bonhill (J. M.): Greenock (J. E.S.): Irvine (A. A. D.) : Shewalton (A.F.).

B. schonherri Zett.-In moss and under stones. Bouhill (J. M.) : (rookston (A. A.D.): Elvanfoot (W.E.) : Ayr ; Barr (A.F.) : scarce Camplueltown (J. J. W.).

B. elevatus, Marsh.-In moss and by sweeping, occasional. Tarbert (T.S.): Giffnock (A.A.D.): Campbeltown (J.J.W.): Ayr; Barr; Pirnmill, Arran (A. F.).

Alophus triguttatus, $F$.-In flood refuse and moss, and by sweeping, Crookston ; Ayr ; Barr (A.F.): Arran, GI. Cloy (J. E. S.) ; Brodick (W. E.).

Sitones griseus, $F$.--Very local and rather scarce, amongst bent grass, Irvine (J. D.; A. A. D.; R. E.).

S. cambricus, Steph.-R. ; one, Giffnock, 1899 (A. A. D.).

S. regensteinensis, Herbst.-Freq. on broom.

S. lineellus, Gyll.-In plenty by shaking out roots of bent grass on the sandhills Macrihanish (J. J. W.).

S. tibialis, Herbst.-Not unc.; by sweeping ; Irvine (P. E. ; A. A. D.) : Ayr (A. F.).

S. hispidulus, F.-Occasional by sweeping 8/1895, Ayr (A. F.).

S. puncticollis, Steph.-C. in moss, April, by sweeping, June-Aug.

S. suturalis, Steph.-Occasional, in moss Feb. and March ; by sweeping June ; Giffnock ; Crookston (A. A. D.): Bishopton (A. F.).

S. lineatus, L.-Very c. in moss and by sweeping.

Limobius dissimilis, Herbst.-Renfrew district, in moss (J. S., under fulvipes.). 
Hypera punctata, F.-Occasional, by sweeping, Bishopton ; Ayr ; Barr (A. F.).

H. fasciculata, Heibst.-Clyde, extremely local, maritime (Sharp).

H. rumicis, L.-Occasional, on docks, Ayr (A. E.) : Barr (A. A. D.).

H. polygoni, L.-Freq., in moss and flood refuse and by sweeping; Bonhill (J.M.): Renfrew district (J.S.) : Shewalton ; Ayr (A. F.).

H. suspiciosa, Herbst.-R., one, Paisley district (J. D.).

H. murina, F.-Very r., one, Paisley district (J.D.).

H. plantaginis, De (i.-Rather r.; in moss and tufts of grass, Renfrew district (J.S.): Paisley (J.D.): Irvine (A. A. D.) : Ayr (A. F.).

H. trilineata, Marsh.--Very r., one Paisley district (J.D.).

H. nigrirostris, $F$.-C. in moss and by sweeping.

Liosoma ovatulum, clairv.-C. in mo-s.

var. collaris, Rye.-R. in company with type, Macrihanish (J. J. W.).

Hylobius abietis, L.-C. on firs.

Pissodes pini, L.-Inveraray (Ent. Ed.) : Robroyston (J.E. S.) : Greenock (T.S.).

Orchestes quercus, L.--Several by beating oaks in autumn 1900 (A. A. D.).

O. fagi, L.-C. on beeches, Irvine; Ayr (A. F.).

O. rusci, Herbst.-Two, by beating birches Milngavie, 6/1900 (A. A. D).

O. stigma, Germ.-Glasgow (M. Cat.): on sallows, Bengullion, Campbeltown (J.J. W.).

Grypidius equiseti, F.-Freq. by sweeping, Crookston (A.A.D.): Ayr ; Barr (A. F.).

Erirhinus bimaculatus, F.-R., one by sweeping on shore, Portincross $5 / 1900$ (A. A. D.).

E. acridulus, L.-Freq. by sweeping marshy places, May-Aug., Possil (J.E.S.): Cadder; Crookston ; Johnstone (A.A.D.) : Ayr ; Barr (A.F.).

E. aethiops, $F$._- "I found it among some beetles sent to me for names from Paisley by Mr. Morris Yomng." (E. C. Rye, Ent. Ann., 1868, 56).

Dorytomus vorax, F.-Glasgow (M. Cat.).

D. maculatus, Marsh.-On sallows, Paisley (J.D.): Bishopton (A. A. D.) : Bonhill (J. M.) : Ayr (A. F.).

D. melanopthalmus, $\dot{P}$ ayki. var. agnathus, Boh.-Greenock (J. E. S.).

D. pectoralis, Gyll.-Dumoon, Mr. R. Hislop (M. Cat.).

Bagous alismatis, Marsh.-Scarce; on aquatic plants, clay pits, Glasgow, 1857 (J.E.S.) : flood refuse Bishopton, 3/1900 (A. E.): by sweeping banks of Irvine, 5/1900 (A. A. D.).

B. frit, Bit. Coll.-One, 11/1894, clinging to a piece of wood in Aucha Lochy nr. Campbeltown (.J. .J. W.).

Anoplus plantaris, Vaez.-Glasgow (M. Cat.): Bishopton (A. A. D.).

Elleschus bipunctatus, L.-By beating sallows, scarce. Colintraive, May ; Pirnmill, Arran, Jume 1900 (A. F.).

Gymnetron labilis, Herbst.- Scarce, by sweeping, Glasgow (M. Cat.) : Renfrew district (J.S.): Giffnock (A. A.D.) : Ayr (A. F.).

Mecinus pyraster, Herbst.-In moss, Barr, 4/1900 (A. F.).

Anthonomus ulmi, De (i.-Arran (T. R. B.).

A. rosinae, Des Gozis.-R. ; one example, Ayr (A. F.).

A. pedicularis, L.-Occasional by beating hawthorn and sweeping, Ayr ; Barr (A. F.).

A. rubi, Herbst.-Local by general sweeping, Shewaltrn (A. F.).

A. comari, Crotch.--R., on sallows, Bengullion, Campbeltown (J.J. W.).

Nanophyes lythri, F.-Argyleshire, Rev. Geo. Little (M. Cat.).

Cionus scrophulariae, L.-C. ; on Scrophularia nodosu, Kirkintilloch (W.E., A. S. N. H., 1900, 100): C'rookston (A. A. D.) : Barr (A. F.).

C. blattariae, F.-. Very local and scarce on S. nodosa, Barr 6/1896 (A. F.): Luss 6/1900 (A. A. D.). 
C. pulchellus, Herbst.-Very local and r. on S. nodosa nr. Ayr $7 / 1895$ (A.F.). Orobites cyaneus, L._- Scarce; by sweeping, Ayr 7/1895 ; in moss, Barr, $4 / 1900$ (A. F.).

Coeliodes rubicundus, Herbst.-Xr. Inveraray (Ent. Ed. under Inthorynchus. melanocephalus): Bishopton, 51900 (A. A. D.).

C. quadrimaculatus, L.-Very c. and gent dist.

Ceuthorrynchus assimilis, Payk:-By sweeping, Ayr (A. F.).

C. ericae, Gyll.-Clyde on heather (sharp).

C. erysimi, F.-Lanark (W. E.).

C. contractus, Marsh.-C., by sweeping.

C. quadridens, Panz.-Bonhill (.J. M.).

C. pollinarius, Forst.-C., on nettles.

C. viduatus, Gyll.-Tollcross (F. F. W.s.).

C. pleurostigma, Larsh.-By sweeping, Bonhill (J. M.) : Irvine (A. A. D.).

C. rugulosus, Herbst.--By shaking out roots of bent grass, Macrihanish (J.J. W.).

C. litura, F.-Scarce, thistles; Paisley (J.J.): King's Cross, 7/1900. (A. A. D.)

Ceuthorrynchidius troglodytes, F.-Freq., by sweeping, Crookston (A. A.D.): Shewalton; Ayr (A.F.).

Rhinoncus pericarpius, L.-C., Crookston (A.A.D.): Shewalton ; Barr (A.F.). R. castor, $F$.-Glasgow (M. Cat.) : Irvine (A. A. D.).

Phytobius quadrituberculatus, $F$.-In moss and by sweeping Irvine. (A.A.D.): Ayr (A.F.): Barr (A.A.D.): Campbeltown (J.J. W.).

P. canaliculatus, Fahi.-In great profusion, Aucha Lochy nr. Campbeltown clinging to weeds and small pieces of wood (J.J. W.).

Limnobaris T-album, L.-By sweeping, Barr (A. A. D.).

Balaninus villosus, $F$.-Very r., one on N. side of Holy L., 1860 (J. E. S.).

B. salcivorus, Payk.-Not unc. by sweeping, May and Jume; Renfrew district (J.S.): Garelochhead; Cambıslang; Giffnock ; Crookston ; Irvine (.A. A. D).

Calandra granariae, L.-In Egyptian wheat, Glasgow (J. E. S.): Paisley (R. E.).

Rhopalomesites tardyi, Curt.-Very r., number of remains in a rotten stump, Gourock 3/1900 (A. A. D.): under bark, W. Kilbride 5/1900 (A. A.D.; A. F.) : Kilnum, Mr. .T. M‘Call (M. Cat.) : Dunoon (.J. E. S.) : Arran (T. R. B.).

Hylastes opacus, Er.-Glasgow (M. Cat.).

H. palliatus, Gyll.-Tarbert (T. S.).

Myelophilus piniperda, L.-Not unc. nr. Glasgow (.J.E. S.) : Bishopton (A. A. D.).

Pityogenes chalcographus, L.-Glasgow (Fowler, Brit. (oleopt.).

P. bidentatus, Herbst.- Glasgow (M. Cat.).

Introduced Species.

Monochammus dentator, Fab.-Taken alive in Glasgow (a North American species), Mr. R. Hislop (M. Cat.).

Arhopalus speciosus, Say.-Taken in the district (A. F., Trans. N.H.S., Glasg., V., s.s., 469), teste G.C.Champion, F.Z.S. A North American species.

Bupestris (ancylochira) haemorrhoidalis, Herbst.-In a house in Ayr(A. F., Trans. N. H.S., Glasg., V., x.s., 469), teste G. C. Champion. A south European species. Both this and the preceding species would probably be brought to this country, in the larval state, in timber.

Species doubtful as British.

Cardiophorus rufipes, Fourc.-Corkendale Law, Paisley, by Mr. Johw Dunsmore, summer 1875 (G. C. Champion, E. M. M., XIII., 227). 


\section{Order Trichoptera.}

\section{By Prof. James J. F. X. King, F.E.S.}

Nomenclature: M'Lachlan's revised list of British Trichoptera, Trans. Ent. Soc., part II., 1882.

Recorders and Contractions: (M.) =K. J. Morton; (B.)=F. G. Binnie; $(\mathrm{D})=$. A. Adie Dalglish ; (H.) $=$ the late T. J. Henderson; (L.)=the late Frank Jex Long.

\section{INAEQUIPALPIA.}

\section{Fam. Phryganeidae.}

Neuronia ruficrus, Scopoli--Carluke (M.).

Phryganea grandis, Linné.-Hogganfield (K.).

P. striata, L.-Hogganfield ; Possil M. ; Milngavie (K.): Lily L.; Kilpatrick Hills (B.): Carluke (MI.): Bowling (D.).

P. varia, Fabricius.-Possil M. (K.): Carluke (M.).

P. obsoleta, M'Lachlan.-Lily L. (B.): Carluke (MI.): Ravenscraig (D.). Agrypnia pagetana, Curtis.-Knightswood; Hogganfield (K.).

\section{Fam. Limnophilidae.}

Colpotaulius incisus, Curt.-Possil M. (K.): Carluke (M.).

Grammotaulius atomarius, $F$.-Carluke (M.).

Glyphotaelius pellucidus, Retzius.-Cadder Wild. (K.).

Limnophilus rhombicus, L.-Bishopton Moss (K.): Carluke (M.).

L. flavicornis, F.-Possil M. (K.) : St. Germain's L. (B.) : Bishop's L. (M.) : Crookston ; Pollokshields ; Catheart (D.)

L. marmoratus, Curt.-St. Germain's L. (B.): Cadder Wild. ; Possil M. ; Clober Moor ; Campsie Gl. ; Garelochlead (K.): Carluke (M.).

L. stigma, Curt.-Leadhills (K.): Carluke (M.).

L. zanthodes, M'Lach.-Possil M. ; Clober Moor ; Cadder Wild. ; Ruchill (K.) : Pollokshields (D.).

L. lunatus, Curt.-Possil M. ; Cadder Wild.; Clober Moor; Mugdock W. (K.): Carluke (M.): Inverglas ; Dundonald (D.).

L. politus, M'Lach.-Bishop's L. (M.).

L. ignavus, $M I^{\circ}$ Lach.-Leadhills (MI.).

L. nigriceps, Zetterstedt.-Mugdock (K.): Carnwath (M.).

L. centralis, Curt.-Cadder Wild. ; Clober Moor ; Bridge of Weir ; Kilmun ; Hogganfield (K.) : Strathblane (B.): Carluke (M.): Ravenscraig ; Giffnock (D.).

L. vittatus, F.-Strathblane (B.): Possil MI. ; Ruchill ; nr. Paisley ; Hogganfield ; Gleniffer ; Bishopton Moss ; nr. Greenock ; L. Fad, Bute (K.) : Carluke (M.).

L. affinis, Curt.-Bute (M.): Kilmun ; nr. Greenock (K.): Crookston (D.). 
L. auricula, Curt.-Kilmun (K.) : Carluke ; Cleghorn (M.).

L. griseus, L.-Carluke (M.).

L. extricatus, $M \cdot$ Lach.-Bridge of Weir (K.): Paisley Can. (B.) : Carluke (M.) : Giffnock (D.).

L. luridus, Curt.-W. Kilpatrick Hills ; Coplaw Dam (B.) : Garelochhead (H.): Carluke (M.): Devol Glen; Bishopton Moss: Cleghorn ; Cadder Wild. ; Allender ; L'goilhead (K.).

L. sparsus, Curt.-Possil M. ; Cadder Wild.; Mugdock Wd. ; Bishopton Moss; Kilmun ; Derol Glen; Bridge of Weir (K.): Carluke (M.): Garelochhead (H.) : Giffnock ; Ardlui ; Arrochar (D.).

L. fuscicornis, Rambur.-Uddingston; Carluke (M.).

Anabolia nervosa, Curt.-St. Germain's L. (B.): Mugdock Wd. (K.): Uddingston ; Carluke (M.): Inverglas (D.).

Asynarchus coenosus, Curt.-Bishopton Moss (B.) : nr. Carluke (K.).

Stenophylax infumatus, $Y \cdot$ Lach.-Carluke (MI.).

S. rotundipennis, Brauer.-Carluke (M.).

S. stellatus, Curt-Carmyle (K.): Carluke (M.) : Ballantrae (D.).

S. latipennis, Curt.-Allander (K.) : Carluke (M.).

S. permistus, $M^{\prime} L$.-Carluke (M.).

S. vibex, Curt.-Carluke (M.).

Micropterna sequax, $W \cdot$ Lach.-Garelochhead (K.): Carluke (M.): Greenock (L.).

M. lateralis, Stephens.-Carluke (M.): Garelochhead (H.): Mugdock Wd. ; Deil's Craig Dam (K.) : Ravenscraig ; Crookston (D.).

Halesus radiatus, Curt.-Carmyle; Allander; Mugdock Wd. (K.): Bridge of Weir (D.): Gourock nr. Cloch (B.): Carluke (M.).

H. digitatus, Schrank.-Carmyle ; Allander (K.): Carluke ; Cleghorn (M.).

H. auricollis, Pictet.-Carluke (M.): Cleghorn (K.).

Drusus annulatus, Stph.-Spout of Ballagan (B.): Clober Moor ; Dalry ; Leadhills ; W. Kilbride ; Cleghorn ; nr. Johnstone (K.) : Carluke (M.).

Ecclisopteryx guttulata, Pict.-Mugdock Wd. ; Dalry (K.): Carluke (M.). Chaetopteryx villosa, F.-Leadhills; Dalry (K.): Carluke; Cleghorn (M.).

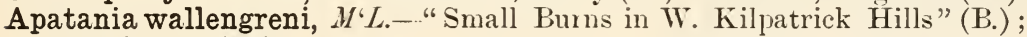
Symington (M.).

\section{Fam. Sericostomatidae.}

Sericostoma personatum, Spence-Kenmuir Bank; Mugdock Wd. (K.): Carluke; Cleghorn (MI.).

Goera pilosa, F.-Carluke (M.): Mrugdock (K.) : Irvine (D.).

Silo pallipes, F.-Carmyle; Mugdock Wd. ; L'goilhead (K.): Carluke (M.): Ravenscraig (D.).

Brachycentrus subnubilus, Curt.-Cambuslang (K.) : Carluke (M.).

Crunoecia irrorata, ('urt.--Kilmun(K.) : Spout of Ballagan (B.) : Cleghorn; Carluke (M.).

Lepidostoma hirta, F.-Carmyle; Mugdock Wd. (K.): Carluke (M.).

\section{A EQUIPALPIA.}

\section{Fam. Leptoceridae.}

Beraea pullata, C'urt.-Possil M. (K.): Paisley Can. (B.): Carluke (M.).

B. maurus, Curt.-Carluke ; Cleghorn (M.).

Beraeodes minuta, L.-Bridge of Weir (K.) : Carluke (M.).

Odontocerum albicorne, Scop.-Allander ; Cleghorn (K.) : Carluke (M.).

Leptocerus nigro-nervosus, Retz.-Uddingston (M.).

L. fulvus, Ramb.-Possil M. (K.) : Paisley Can. (B.).

L. annulicornis, Stph.-Uddingston; Carluke (II.). 
L. aterrimus, Stph.-Dalmuir ; Possil M. ; Clober (K.): Maryhill ; Frank. field L. ; Paisley Can. (B.) : Carluke (M.): Ravenscraig (D.).

L. cinereus, Curt.-Kenmuir Bank; Clober; nr. Paisley (K.): Cleghorn ; Uddingston (M.): Ballagan Burn (B.).

L. albifrons, L.-Clyde above Cambuslang (K.) : Carluke (M.).

L. commutatus, W'Lach.-Carluke ; Cleghorn (M.) : Flemington (D.).

L. bilineatus, L.-Carmrle ; Allander (K.) : Carluke (M.).

L. dissimilis, Stph.-Carluke (M.).

Mystacides nigra, L.-Lambhill ; Paisley Can. ; Clyde above Cambuslang (B.): Dalmuir ; Anniesland (K.) : Carluke (M.).

M. azurea, L.-Kenmuir Bank (K.): Carluke (M.).

M. longicornis, L.-Durrochston Dam ; Bardowie (K.) : Bishop's L. ; Law (M.) : Pollokshields (D.).

Triaenodes bicolor, Curt.-Possil M. (K.).

Adicella filicornis, Pict.-Cleghorn (K.).

Oecetis ochracea, Curt.-Pollokshields (D.).

O. lacustris, Pict.-Bishop's L. ; Bute (M.): Raveuscraig (D.).

O. testacea, Curt.-Recorded in 1875 list from Allander but probably in error.

Fam. Hydropsychidae.

Hydropsyche pellucidula, Curt.-Clober (K.): Carluke; Uddingston (M.). H. instabilis, Curt.-Above Cambuslang ; Lily L. (B.): Allander ; Baldernock (K.): Carluke (M.).

H. angustipennis, Curt.-Dougleston (K.): Humphrey Burn Kilpatrick Hills (B.).

H. guttata, Pict.-Carluke ; Uddingston (M.).

H. lepida, Pict.-Carluke ; Uddingston (M.).

Diplectrona felix, $/$ 'Lach.-Arrochar (K.): Cleghorn (M.).

Philopotamus montanus, Donovan.-W. Kilpatrick Hills (B.): Allander ; Ballagau Burn (K.): Cleghorn ; Tintock (M.).

Wormaldia occipitalis, Pict.-Carluke ; Cleghorn (M.).

W. subnigra, M'Lach.-Carluke ; Cleghorn (M.).

Plectrocnemia conspersa, Curt.-Clober ; Bishopton Moss (K.): Ballagan burn (B.) : Carluke (M.) : Giffnock ; Glen Mallon (D.).

P. geniculata, M'Lach.-Carluke (M.).

Polycentropus flavomaculatus, Pict.-Mugdock Wd.; Kenmuir Bank (K.) : Lily L. (B.): Carluke ; Cleghorn (M.).

P. multiguttatus, Curt.-Carluke (M.).

Holocentropus dubius, Ramb.-Carnwath (M.) : nr. Glasgow (Gardner).

H. picicornis, Stph.-Possil M. (K.): Carluke (M.) : Ravenscraig (D.).

Cyrnus trimaculatus, Curt.-Lily L. ; Paisley Can. (B.) : Kenmuir Bank; Lambhill (K.): Carluke ; Cleghorn (M.).

C. flavidus, M/Lach.-Bishop's L. (M.) : Hogganfield (K.) : Irvine Moor (D.). Tinodes waeneri, L.-C. Paisley Can. (B.): Ballagan Burn (K.) : Carluke; Cleghoru (M.).

T. aureola, Zett.-Spout of Ballagan (B.) : Cleghorn (M.).

Lype phaeopa, Stph.-Carluke (II.).

\section{Fam. Rhyacophilidae.}

Psychomyia pusilla, F.-Above Cambuslang (B.): Allander (K.): Carluke; Cleghorn (M.).

Rhyacophila dorsalis, Curt.-C. everywhere.

R. septentrionis, $I^{\prime}$ Lach.-Carluke (K.).

R. obliterata, $I^{\prime}$ Lach.-Carluke (K.): Cleghorn (M.).

Glossosoma boltoni, Curt.-A bove Cambuslang (B.): Kilmun (K.).

G. vernale, Pict.-Kenmuir Bank (K.): Carluke (M.). 
Agapetus fuscipes, Curt.-Mugdock Wd.; Ballagan Burn; Troon (K.): Giffinock (D.) : Strathblane (B.) : Carluke (M.).

A. comatus, Pict.-Kenmuir Bank (K.): Carluke (M.).

A. delicatulus, M'Lach.-Arran (M.).

Fam. Hydroptilidae.

Agraylea multipunctata, Curt.-Gartcosh (M.).

Allotrichia pallicornis, Eaton.-Uddingston (M.).

Hydroptila femoralis, Eaton.-Devol Glen (K.).

H. forcipata, Eaton.-Port Glasgow (K.): Carluke ; Uddingston (M.).

H. maclachlani, Klapalik.-Carluke (M.).

Ithytrichia lamellaris, Eaton.-Carluke (MI.).

Oxyethira costalis, Curt.-Clydesdale (K.).

O. falcata, Morton.-Carluke (MI.). 


\section{Order Hemiptera.}

\section{Sub-Order Heteroptera.}

\section{By John Edward Murphy, 52 Rose St., Garnethill.}

Arrangement and Nomenclature: Hemiptera Heteroptera of the British Isles, by Ed. Saunders, 1892. Mr. Saunders has kindly identified most of the species.

Authorities and Contractions: (A. A. D.) A. Adie Dalglish ; (J.R. M.) James Russell Malloch; (J.T.) J. M. B. Taylor; (K.) J. J. F. X. King; (W. E.) W. Evans ; (J. W. D.) J. W. Douglas, in Ent. Month. Mag., Oct. 1874; (E. S.) E. Saunders, Hemipt. Brit. Isles ; (M. Y.) the late Morris Young.

\section{Fam. Pentatomidae.}

Sehirus biguttatus, L.-One, in Moss, Garelochhead (A. A. D.).

Tropicoris rufipes, L.-Not unc. on Birch, Dargavel ; Ardrossan; Garelochhead (J. E. M.) : Bonhill (J. R. M.) : L. Long (W. Evans).

Picromerus bidens, L.-Not c. Dargavel Aug. 1899 (J. E. M.).

Acanthosoma dentatum, $D e$ G.-C. on Birch, etc., Luss ; L. Eck (J. E. M.); Glen Mallon (A.A. D.).

A. interstinctum. L.-C. Luss. This and last species beaten from same tree.

\section{Fam. Lygaeidae.}

Nysius thymi, Wolff.-Bonhill (J. R. M.).

Henestaris laticeps, Curt.-Renfrew (J.T.).

Rhyparochromus chiragra, Fab.-Renfrew (M. Y.).

R. antennatus, Schill.-Renfrew (M. Y.)

Ischnocoris angustulus, Boh.-Renfrew (M. Y.)

Macrodema micropterum, Curt.-Renfrew (M. Y.).

Lasiosomus enervis, $H$. Schff.-Renfrew (M. Y.).

Stygnus rusticus, Fall.-Meikleriggs 27/7/1894 (J.T.).

S. pedestris, Fall.-C. and gen. dist. ; by sweeping grasses.

Peritrechus luniger, Schill.-Irvine (A. A. D.).

Scolopostethus decoratus, Hahn.-Not c. Gartcosh (J.E. M.): Bonhill (J. R. M.).

Drymus sylvaticus, Fab.-Not unc. in Moss, etc. ; gen. dist.

D. brunneus, Sahlb.-Renfrew (M. Y.).

\section{Fam. Hydrometridae.}

Velia currens, Fab.-C. (undeveloped) and gen. dist. Developed form rare, one Allander (J. E. M.) : Cambuslang (K.).

Gerris costae, H. Schff.-C. Luss ; Lochgoilhead (J. E. M.): Arrochar (A. A. D.): nr. Brodick (W. E.).

G. thoracica, Schum.-C. and gen. dist.

G. aspera, Fieb.-Not unc. (developed) Kilmarnock ; Lanark (J. E. M.).

G. lacustris, L.-C. and gen. dist. 
Fam. Reduviidae.

Nabis brevipennis, Hahn.-Langbank (M. Y.).

N. lativentris, Boh.-Langbank (M. Y.).

N. major, Cost.-Blackstone (J. T.): Langbank (M. Y.).

N. flavomarginatus, Scholtz.-C. (undeveloped) and gen. dist.; one developed f. Ardrossan (J. E. M.).

N. limbatus, Dahlb.-C. (undeveloped) Possil Marsh; Troon; Lanark (J. E. M.).

N. lineatus, Dahlb.-R. Blackstone (J. T.).

N. ferus, $L$. - Not unc., Milngavie ; Gartcosh (J. E. M.) : Bowling (A.A. D.).

N. rugosus, $L$. - Renfrew (M. Y.).

N. ericetorum, Schltz.-C. (developed) Cadder Wilderness; Lochgoilhead (J.E. M.): Irvine ; Arrochar (A. A.D.).

\section{Fam. Saldidae.}

Salda lateralis, Fall.-C. nr. Paisley (J. T.).

S. riparia, Fall.-Nr. L. Winnoch (J.T.).

S. orthochila, Fieb.-Bonhill (J. R. M.).

S. scotica, Curtis.-Bute; Cartland Craigs (Curtis, in E. S.): not unc. Baldernock (J. E. M.): Lochwinnoch (J. T.) : Barr (A. A. D.).

S. littoralis, L.- Not unc.; Gl. Rosa (J.W.D.) : Ardlui (A.A.D.) ; Cardross (R. W.) : Gleniffer (J. T.).

S. c-album, Fieb.-C. Saltcoats (J. W. D. in E. S.) : Gl. Rosa (J. W. D.) : Ardrossan (J.E. M.) : Strathaven (A. A. D.).

S. saltatoria, L.-Lochgoilhead (J. E. M.) : Mugdock Wood (K.) : Gleniffer (J.T.) : Gl. Rosa (J. W. D.).

S. pilosella, Thoms.-Nr. Paisley (J.T.).

S. arenicola, Schltz.-Gleniffer (M. Y.).

S. elegantula, Fall.-Not c. Langbank, 9/1894 (M. Y.).

S. cincta, $H$. Schff.-Generally distributed.

\section{Fam. Cimicidae.}

Cimex lectularius, L.-C. in many houses.

Anthocoris confusus, Reut.-C. and gen. dist.

A. nemoralis, Fabr.-Gleniffer (J.T.).

A. sylvestris, L.-C. and gen. dist.

Acompocoris pygmaeus, Fall.-C. on Fir trees, Milngavie; Gartcosh; Troon (J. E. M.) : Bonhill (J. R. M.).

\section{Fam. Capsidae.}

Pithanus maerkeli, H. S.--C. (undeveloped) on Grasses, etc., Cadder Wilderness; Dargavel ; Ardrossan (J.E. M.).

Miris holsatus, Fab.-C. on Grasses etc., and gen. dist.

M. laevigatus, $L$.-South Barr (J. T.).

M. calcaratus, Fall.-C. on Grasses, Troon (J. E. M.) : Jamestown (J.R.M.). Megaloceraea ruficornis, Fall.-C. on Grasses and gen. dist.

Leptopterna ferrugata, Fall.—C. on Grasses, Troon ; Gareloch head (J.E.M.) : Giffnock (A.A.D.) : Jamestown (J.R. M.).

Bryocoris pteridis, Fall.-C. on Ferns, Ardrossan; Lanark; Milngavie; Carmunnock (J. E. M.).

Monalocoris filicis, L.-C. on Ferns, Cadder Wilderness ; Luss ; Ardrossan (J.E. M.).

Phytocoris populi, L.--C. on various trees, Luss; Cadder Wilderness; Ardrossan (J.E. M.) : Bonhill (J.R. M.).

P. tiliae, Fab.-Not unc. on limes etc., Milngavie; Glasgow Botanic Gardens ; Cambuslang (J. E. M.) : Bonhill (J.R.M.).

P. longipennis, Flor:-Not unc., Jamestown (J. R. M.) : Ardrossan (J. E. M.). 
P. reuteri, Saund.-Jamestown (J. R. M.).

P. pini, Kbm.-C. on fir trees, Garelochhead; Dargavel ; Milngavie (J.E.M).

P. ulmi, L.-C. on Elms, Allander; Troon (J. E. M.) : Bonhill (J.R. M.)

Calocoris striatellus, Fab.-C. on Oaks, Lanark; Troon (J. E. M.) : GlenMallon (A. A. D.) : Jamestown (J. R. M.).

C. sexguttatus, Fab.-Abund. on Nettles and gen. dist.

C. roseomaculatus, $D e$ G.-C. on Linaria vulgaris, Auchenbathie (J.T.) :

Giffnock (A. A. D.) : Caldwell (J. E. M.).

C. chenopodii, Fall.-Ruchill Wood (K.).

C. bipunctatus, $F a b$.-Abund. on shrubs everywhere.

C. striatus, L.-Not. unc., Helensburgh (J. E. M.) : Glen Mallon (A. A. D.).

Plesiocoris rugicollis, Fall.-C. on Sallows, Possil Marsh ; Milngavie (J. E. M.) : Jamestown (J. R. M.).

Lygus pabulinus, L.-Abund. on Nettles etc., and gen. dist.

L. contaminatus, Fall.-C. on Birch, Luss ; Caldwell ; Gartcosh (J. E. M.).

L. viridis, Fall.-C. on Oak and Birch, Luss (J. E. M.).

L. pratensis, $F a b .-C$. on shrubs and gen. dist.

L. pastinacae, Fall.-Allander (K.).

L. kalmii, L. -Not unc., Jamestown (J. R. M.) : Dargavel (J. E. M.).

L. cervinus, H. Schf.-Bonhill (J.R.M.): Blackstone (J.T.): Ettrick bay (K.).

L. rubricatus, Fall.-Not unc., Luss (J. E. M.) : Bonhill (J. R. M.).

Liocoris tripustulatus, $F a b$.-Blackstone on Nettles (J.T.).

Rhopalotomus ater, L.-C. on Shrubs, and gen. dist.

Bothynotus pilosus, Boh.-Very r. on Hills betw. L. Long and L. Lomond, four taken by Sharp (E. S.).

Macrolophus nubilus, H. Sch.-Not c. on Stachys sylvatica (J.T.).

Dicyphus pallidicornis, Fieb.-Gleniffer (J.T.).

Campyloneura virgula, H. Schf.-Scarce. Luss (J.E.M.) : Peaton, L. Long (W. E.).

Cyllocoris histrionicus, L.-Allander (K.) : abund. Newton Woods (J.T.).

Aetorhinus angulatus, Fall.-C. on Salix, Gartcosh ; Milngavie (J. E. M.): Bonhill (J. R. M.).

Mecomma ambulans, Fall.-C., m's. ouly developed, Ardrossan (J. E. M.).

Orthotylus marginalis, Reut.-C. on Salix, Luss; Milngavie (J.E. M.) : Bonhill (J. R. M.).

O. ericetorum, Fall.-C. on Heather, Garelochhead (J. E. M.): Bonhill (J. R. M.).

Heterocordylus tibialis Hahn.-Scarce, Ardrossan (J. E. M.).

Macrocoleus molliculus, Fall.-Nr. Paisley (J.T.).

M. hortulanus, Mey.-R., Renfrewshire (M. Y.).

Harpocera thoracica, Fall.-Troon (K.): Luss (A. A. D.).

Phylus melanocephalus, L.-C. on Oaks, Cadder Wilderness (J. E. M.) : Bonhill (J. R. M.).

Psallus betuleti, Fall.-C. on Birch, gen. dist.

P. ambiguus, Fall.-C., Bonhill (J.R. M.).

P. variabilis, Fall.-C. on various trees, gen. dist.

P. fallenii, Reut.-C. on Sallows, gen. dist.

P. lepidus, Fieb.-Allander (K.).

P. varians, H.Schf.-C. on Birch and Oak, Shandon ; Luss (J. E. M.) : Bonhill (J.R. M.): Mugdock Wood (K.).

P. sanguineus, Fab.-Abund. on Salix, Luss ; Colintraive (J. E. M.).

Plagiognathus arbustorum, $F a b$.-Abund. on Nettles, gen. dist.

P. viridulus, Fall.-Abuud. on Grasses, gen. dist.

Fam. Naucoridae.

Naucoris cimicoides, L.-Clyde at Cambuslang (K.). 


\section{Fam. Nepidae.}

Nepa cinerea, L.-C. Ponds and Ditches, gen. dist.

Fam. Notonectidae.

Notonecta glauca, L.-C. and gen, dist.

\section{Fam. Corixidae.}

Corixa geoffroyi, Leach.-C. and gen. dist.

C. linnaei, Fieb.-Not unc. Lanark; Allander (J.E. M.) : Ayr (A. A. D.).

C. sahlbergi, Fieb.-C. and gen. dist.

C. striata, Fieb.-Not unc., Milngavie (J. E. M.).

C. distincta, Fieb.-C. Gleniffer ; Possil Marsh (J.E. M.).

C. fallenii, Fieb.-Not unc., Kirkiutilloch ; St. Germain's L. (J.E.M.) : Bishopton (A. A. D.).

C. moesta, Fieb.-Bishopton (A. A. D.).

C. venusta, $D$. \& S.-Rothesay (J. W. D. in E. S.).

C. fabricii, Fieb.-C. and genl. dist.

C. fossarum, Leach.-C. Gleniffer (J. E. M.).

C. scotti, Fieb. - Loch nr. Kirn, Douglas \& Scott (E. S.).

C. cognata, D. \& S.-L. Grienan, Rothesay ; Douglas (E. S.). 


\section{Sub-order Homoptera.}

By J. M. B. Taylor, Curator, Free Museum, Paisley.

Arrangement Followed: Catalogue of British Hemiptera: T. M M'Gregor, Perth, 1890 ; (The Homoptera by James Edwards, F.E.S.).

The records are all recent and cover only a small part of the Clyde basin.

Authorities and contractions: (Cic. Ed.)-The Hemiptera-Homoptera of the British Isles, by Janies Edwards, F.E.S., 1896 : (J.E. M.) John E. Murphy; (M. Y.) The late Morris Young; Wm. Evans, F.R.S.E., and Jno. K. Malloch have also assisted.

Issus coleptratus, Geoff.-Gouk Quarry, Kilmalcolm, Aug.-Sept.

Cixius cunicularis, Lin.-Not c. Paisley (J. E. M.): Thornley on broom, whin and young birch.

C. nervosus, Lin.--Paisley (J. E. M.): Thornley wd., Aug. and Sept.

Liburnea notula, Germ.-Renfrewshire (M. Y.) : marshy places Langbank ; Ashton.

L. lineola, Germ.---On Holcus mollis Stanley Wd. ; Old Patrick burn.

L. vittipennis, J. Sahl.-Neilston Pad, Gleniffer, on short grass and thyme. Flies in rain.

L. pallidula, Boh.-On Holcus mollis, etc., Thornley ; Staneley.

L. smaragdula, S'tal.-On Phalaris arundinacea. Local, Staneley; White Cart.

L. elegantula, Boh. (aemulatrix, $S \operatorname{cott}$ ).-By sweeping grass Blackstone Wd.

L. pellucida, Fab.-Among Holcus mollis Blackstone Wd.

L. limbata, Fab.-Not c., among rushes glen dam.

Dicranotropis hamata, Boh.-Paisley (Cic. Ed.): brachypterous form c., macropterous not c., latter at foot of Gleniffer.

Stiroma pteridis, Boh.-On Pteris, Alt-Patrick; Auchenbathie.

Triecphora vulnerata, Illig.-Paisley (Cic. ed.). Not c. Dusky Gl.

Aphrophora alni, Fall.-Renfrewshire (M. Y.): Garelochhead (J.E. M.) : Staneley Wd.

Philaenus spumarius, Lin.-Abund. many parts Renfrew. ; appears July ; Ardrossan ; Carluke (J. E. M.).

P. exclamationis, Thumb.-Langbank ; Clydeside (M. Y.): scarce.

P. lineatus, Lin.-Paisley (Cic. Ed.): Wilderness (J. E. M.).

Ledra aurita, Lin.-Paisley (M. Y.): not c., on oak Staneley.

Ulopa reticulata, Fab.-Paisley (Cic. Ed.).

Megophthalmus scanicus, Fall.-Paisley (Cic. Ed.).

Macropsis microcephala, H.S.-Ashton, Renfrew. (M. Y.).

M. lanio, Lin.-Paisley (Cic. Ed.); Luss (J. E. M.) : c. birch June.

Bythoscopus alni, Schr.-Ashton, Renfrew. (M. Y.).

B. rufusculus, Fieb.-Ashton (M. Y.): Carluke (J. E. M.).

B. flavicollis, Lin.--Paisley (Cic. Ed.) : Luss (J. E. M.) : on birch, Staneley. Pediopsis cereus, Germ.-Luss (J. E. M.).

Idiocerus varius, Fab.-Cathcart 10/6/00 (J. E. M.) ; appears early.

I. laminatus, Flor.-Renfrew. (Cic. Ed.); Staneley on Populus tremula. 
I. lituratus, Fall.-Renfrew. (Ashton?) (M. Y.) : on willows.

I. populi, Lin.-Renfrew. (Cic. Ed.) ; Garelochhead (J.E. M.) ; Staneley on Populus tremula.

I. confusus, Flor.-On low willows Thornley.

I. albicans, $K b m$.-Staneley on poplars.

Agallia puncticeps, Germ.--Paisley (Cic. Ed.).

A. venosa, Fall.-Paisley (Cic. Ed.).

A. brachiptera, Boh.-Paisley (Cic. Ed.).

Evacanthus interruptus, Lin.-Paisley (Cic. Ed.): Troon (J. E. M.).

E. acuminatus, Fab.-Renfrew. (M. Y.).

Tettigonia viridus, Lin.-_Paisley (Cic. Ed.): Garelochhead ; Luss (J.E.M.).

Strongylocephalus megerli, Scott.-Renfrew. (M. Y.).

Acocephalus nervosus, Schr. (= rusticus, Fab.).-Paisley (Cic. Ed.).

A. bifasciatus, Lin. - Paisley (Cic. Ed.) : Garelochhead (J. E. M.).

A. albifrons, Lin. (=interruptus, Scott ;=polystolus, Scott): Renfrew. (Cic. Ed.).

A. brunneo-bifasciatus, Lin.-Linwood, Renfrew. (J. E. M.).

A. flavostriatus, Don.-Paisley (Cic. Ed.): Thornley; Staneley.

Eupelix cuspidata (= producta, Germ.: =spathulata, Germ.)Penfrew.(M.Y.).

Doratura stylata, Bon.-Renfrew. (M. Y.).

Paramesus nervosus, Fall.-Renfrew. (M. Y.).

P. phragmitis, Boh.-Renfrew. (Ashton ?) (M. Y.).

Glyptocephalus proceps, $K b m .(=$ Athysanus canescens, $D . \& S$.$) , Renfrew.$ (M. Y.).

Athysanus russeolus, Fall.-On heath Houston, Renfrew.

A. brevipennis, $K b m$.-Renfrew. (M. Y.).

A. sordidus, Zett.-Renfrew. (M. Y.).

A. sahlbergi, Reut.-Paisley (Cic. Ed.) : not c. marshy ground Durrockston, Renfrew.

A. communis, J. Sahl (=plebejus, D.\& S.). Not c. or overlooked? Damp grass Renfrew.

A. obscurellus, $K b m$.-Renfrew. (M. Y.): Dumbarton ; Carluke (J.E. M.).

A. obsoletus, $K b m$.-Renfrew. (Cic. Ed.).

Deltocephalus abdominalis, Fab.-Renfrew. (Cic. Ed.).

D. pascuellus, Fall. (=minki, Fleb.)-Among Holcus mollis in damp woods Thornley; Blackstone.

D. ocellaris, Fall.-Renfrew. (M. Y.).

D. striatus, Lin.-Paisley (Cic. Ed.). On Hieracium pilosella and Draba verna beginning of June Jenny's Well, Renfrew.

D. punctum, Flor.-Renfrew. (M. Y.).

Allygus commutatus, Fieb.-Renfrew. (M. Y.).

A. mixtus, Fab.-Renfrew. (M. Y.).

Thamnotettix prasina, Fall.-Paisley (Cic. Ed.) : Luss ; Ardrossan (J.E.M.).

T. cyanae-Renfrew. (M. Y.).

T. subfusus, Fall.-Paisley (Cic. Ed.).

T. variegata, $K b m$. [=irrovatus, Scott].-Railway banks Houston, Renfrew.

T. striatola, Fall.-Renfrew. (M. Y.).

T. cruentata, Pans.-Renfrew. (M. Y.). One on heather, Gl. Rosa (Cic. Ed.) Luss (J. E. M.) : r. on heather, Houston.

Limotettix striola, Fall.-Gl. Rosa (Cic. Ed.) : Garelochhead (J. E. M.).

L. quadrinotata, Fab.-Renfrew. (M.Y.): Carluke (J. E. M.).

L. nigricornis, J. Sahl.-Renfrew. (M. Y.).

L. suphurella, Zett.-Paisley (Cic. Ed.), on barren fronds of Equisetum sylvaticum Blackstone, Renfrew., Sept.

Cicadula septemnotata, Fall.-Renfrew (M. Y.).

C. sexnotata, Fall.-Paisley (Cic. Ed.); on Meum athamanticum Gouk quarry, Renfrew. 
Alebra albostriella, Fall.-Renfrew. (Cic. Ed.): Staneley (various trees and vars.).

Dicraneura flavipennis, Zett.-Renfrew. (M.Y.); on Carex ampullacea Durrockston, etc.

D. variata, Hardy.-Renfrew. (Cic. Ed.).

Kybos smaragdulus, Fall.-Paisley (Cic. Ed.): Thornley ; Staneley, on willows and poplars.

Chlorita flavescens, Fab.-Autumn, winter, and spring on trees, Houston ; Blackstone.

C. viridula, Fall.-Along with C. flavescens.

Eupteryx vittatus, Lin.-Paisley (Cic. Ed.) : among Mentha, Ashton.

E. urticae, Fab.-Sept. and Oct. on nettles, Thornley ; Auchenbathie.

E. stachydearum, Hardy.-Paisley (Cic. Ed.): Cleghorn (W. Evans): on Teucrium scorodonia, The Linn, Gleniffer.

E. auratus, Lin.-Paisley (Cic. Ed.): Ardrossan (J.E. M.): Thornley ; Auchenbathie, Sept. Uct.

E. atropunctata, Goeze [= pictus, Fub.]-Paisley (Cic. Ed.): Staneley reservoir on Spiraea ulmaria.

E. signatipennis, Boh.-Renfrew. (M. Y.).

F. germari, Zett.-Fir trees, Houston, Renfrew.

E. pulchellus, Fall.-Arran ; Paisley; Renfrew. (Cic. Ed.): very pale at Staneley on oak.

E. concinna, Germ.-Paisley (Cic. Ed.) : on oak, Staneley, sept.

Typhlocyba sexpunctata, Fall. [=decumpunctata, Fall.].-Renfrew. (M. Y.).

T. debilis, Dougl.-R., Kilmalcolm.

T. ulmi, Linn.-Renfrew. (M. Y.).

T. gratiosa, Boh.-Renfrew. (M.Y.).

T. lethierryi, Edw.-Paisley (Cic. Ed.) : Gl. Killock.

T. rosae, Lin. (=lactea Dougl.).-Renfrew. (M. Y.).

T. salicicola, Edw.-Newton Wds., Renfrew., on willows.

T. quercus, Fab.-Renfrew. (Cic. Ed.) : on oak, W. of Staneley, Sept.

T. nitidula, Fab.-Firs and Wych Elm, Mavisbank, Renfrew.

T. geometrica, Schr.-Paisley (Cic. Ed.): Newton Wds.

Zygina tiliae, Geoffr.-Renfrew. (M. Y.): Braidland, Renfrew., on lime 7/95.

Livia juncorum, Latr._Elvanfoot 9/1900 (W. Evans).

Aphalara picta, Zett.-Paisley (Cic. Ed.).

A. exilis, Web. \& Mohr.-Paisley (Cic. Ed.) : on Sheep's Sorrel, Thornley; Houston.

A. nervosa, Forst.-Renfrew. (M. Y.) : Cathcart (J. E. M.).

Psyllopsis fraxinicola, Forst.-Renfrew. (M. Y.).

P. fraxini, Lin.-Renfrew. (M. Y.).

Psylla crataegi, Schr. (=ferruginea, Forst. = costatopunctata, Forst.).Renfrew (M. Y.).

P. peregrina, Forst. (=crataegicola, Scott).-Renfrew. (M. Y.) : Stevenston, Ayr, 5/95.

P. pineti, Flor.-Renfrew. (M. Y.).

P. salicicola, Forst.-On Salix capraea, end of May. Blacklandmill Heath, Renfrew.

P. betulae, Lin.-Newton Wds., on great spear thistle, not birch 7/94.

P. forsteri, Flor.-Renfrew. (M. Y.).

P. alni, Lin.-Renfrew. (M. Y.) : Langbank 10/94.

P. buxi, Lin.-Various garden plants but certainly not on Box, 6/94.

Livilla ulicis, Curt.-Renfrew. (M. Y.).

Arytaena genistae, Latr.--On broom, Oct., Thornley ; Lanark (W. Evans).

Trioza urticae, Lin.-On nettles, Blackstone ; Thornley. 


\section{Order OdONATA. \\ By JAMES J. F. X. King, F.E.S.}

Nomevclature, W. J. Lucas, British Diragonfies, 1900.

Records of localities are by the following: K. J. Morton (M.); J. P. Taylor (T.); John Murphy (Mur.); A. A. Dalglish (D.); and myself (K.).

\section{Fam. Libellulidae.}

Sympetrum sanguineum, Mïll.-Wouston (T.).

S. scoticum, Don.-Brodick (Mur.): Houston (T.): Cumbrae ; Ballantrae ; King's Cross (D.).

Libellula quadrimaculata, L.-Newton Woods ; Kilmalcolm (T.) : L'Goilhead (Mur.): Ardlui (D.).

\section{Fam. Gomphidae.}

Cordulegaster annulatus, Latr.-Ardentinny ; Bute (K.) : Glen Cro ; Loch Eck; Millport; Cove (Mur.): Newton Woods (T.): Glen Mallon (D.).

\section{Fam. Aeschnidae.}

Aeschna juncea, L.-Carluke (K) : Strachur; Arran (Mur.): Glen Mallon (D.). Often caught in the streets of Glasgow.

\section{Fam. Agrionidae.}

Pyrrhosoma nymphula.-Clober; Bridge of Weir ; Arrochar; Luss (K.): Kilmarnock (Mur.): Glen Mallon; Giffuock; Ardlui (D.).

Ischnura elegans, Lind.-Crookston ; Pollokshields (D.).

Enallagma cyathigerum, Charp.-Possil; Dougleston; Bridge of Weir ; Mugdock (K.): Ravenscraig; Crookston (D.). 


\section{ORDER ORTHOPTERA. \\ By James J. F. X. King, F.E.S.}

Nomenclature: Malcolm Burr, F.Z.S., British Orthoptera, 1897.

Records of localities are by the following: The late Morris Young (M.Y.); John Murphy (Mur.) ; A. A. Dalglish (D.); Wm. Evans ; J. P. Taylor (T.); and myself $(\mathrm{K}$.$) .$

\section{Sub-Order Forficularia.}

Forficula auricularia, Linné.-C. everywhere.

Labia minor, Linné.-Inchinnan (K.).

\section{Sub-Order Blattodea.}

Fam. Phyllodromidae.

Phyllodromia germanica, L.-All quarters of the city; also in Paisley.

\section{Fam. Blattidae.}

Blatta orientalis, $L$.-The common cockroach is found almost everywhere. Periplaneta americana, L.-Glasgow Botanic Gardens (K.): Woodside Conservatory, Paisley (M. Y.).

P. australasiae, Fabricius.-Kilnside Conservatory, Paisley (M. Y.).

I have seen two species of Blattodea taken at the Bromielaw, probably Lucophaea Surinamensis, L., and Blabera gigantea, L., which were no doubt imported.

\section{Sub-Order Acridiodea.}

\section{Fam. Tryxalidae.}

Stenobothrus viridulus, L.-Elvanfoot (Evans): Millport; Garelochhead (Mur.): Barr (D.) : Kilbarchan (A. M. Stewart).

S. bicolor, Charpentier.-Ardlui (D.).

S. parallelus, Zetterstedt.-Elvanfoot (Evans).

Gomphocerus maculatus, Thunb.-Irvine Moor (D.) : Luss ; Garelochhead ; Arrochar ; Troon (Mur.).

\section{Fam. Tettigidae.}

Tettix bipunctatus, L.-Arrochar (K.) : Peaton, L. Long (Evans): Irvine ; Barr; Glen Mallon (D.).

\section{Sub-order Gryllodea.}

Fam. Gryllidae.

Gryllus domesticus, L.-House Cricket. Not unc. in various parts of city, chiefly bakehouses. Also in Paisley and at Kilbarchan.

Fam. Gryllotalpidae.

Gryllotalpa gryllotalpa, Linné.-Kilmalcolm (T.). 


\section{Order Neuroptera-Planipennia.}

By JAMES J. F. X. King, F.E.S.

Nomenclature : Catalogue of British Neuroptera, by Robert M'Lachlan 1870, ex. genus Hemerobius in which it is Mr. M'Lachlan's revision of the genus, Entom. Mon. Mag., April, June, July and August, 1899.

Localities have been recorded by K. J. Morton (M.); John Murphy (Mur.) ; A. A. Dalglish (D.); Wm. Evans and myself (K.).

\section{Sub-order Sialina.}

Fam. Sialidae.

Sialis lutaria, Linné.-Kelvinbridge (K.): Carluke (M.): Kilnıarnock (Mur.) : Crookston (D.).

S. fuliginosa, Pictet.-Kilmarnock; Paisley (Mur.).

Fam. Hemerobiidae.

Sisyra fuscata, Fabricius.-Ardentinny (K.).

Micromus paganus, Linné--Possil (K.): Carluke (M.): Paisley (Mur.): Crookston; Giffnock (D.).

Hemerobius nervosus, F.-Possil ; Ardentinny (K.): Carluke(M.): Ayr(D.).

H. subnebulosus, Stph.-Carluke (M.).

H. marginatus, Stph.-Cleghorn (M.): Glen Mallon (D.).

H. lutescens, F.-Ardentinny (K.): Carluke (M.).

H. humuli, L.-Carluke (M.).

H. orotypus, Wall.-Tinto (M.).

H. stigma, Stph._Ardentinny(K.): Carluke(M.): Bishopton ; Johnstone(D.).

H. pini, Stph.-Carluke (M.).

H. micans, Olivier.-Carluke (M.) : Loch Lomond (Mur.).

H. inconspicuus, $M^{\prime}$ Lach.-Carluke (M.).

H. concinnus, Stph. var. quadrifasciatus, Reuter-Ardentinny (K.).

Drepanepteryx phalaenoides, Linné-Cleghorn (K.): Carluke (M.).

\section{Fam. Chrysopidae.}

Chrysopa flava, Scopoli, Possil (K.): Carluke (M.) : Cadder Wildnerness (Mur.): Glen Mallon (D.).

C. vittata, Wesmael.-Carluke (M.): Dundonald ; Craigenfeoch (D.).

C. alba, L.-Carluke (M.): Glen Mallon (D.).

C. vulgaris, Schneider.-Carluke (M.): Giffnock in a house, 1/1900 (D.):

Loch Lomond (Mur.).

C. septempunctata, Wesmael.-Carluke (M.).

Fam. Coniopterygidae.

Coniopteryx tineiformis, Curtis.-Ardentinny (K.).

Sub-order Panorpina.

Fam. Panorpidae.

Panorpa communis, Linné.-Dargavel (Mur.).

P. germanica, L.-Ardentinny (K.): Carluke (M.): Linwood (Mur.) : Bonhill ; Cambuslang; Colintraive (D.).

\section{Fam. Boreidae.}

Boreus hyemalis, Linné.-New Town Paisley (M. Y.): Braidwood Gl. (Evans). 


\section{Orders Collembola axd Thysanura.}

By D. A. Boyd, Esq., Seamill, W. Kilbride.

The chief works consulted have been Tullberg's Sveriges Podurider and Lubbock's Monograph of the British Collembola and Thysanura.

Arrangement Followed: G. H. Carpenter and W. Evans, "Collembola and Thysanura of the Edinburgh District," Pro. Roy. Physical Soc. Edin., vol. xiv.

\section{Collembola.}

\section{Fam. Sminthuridae.}

Sminthurus fuscus (Linn.).-On walls and stones in shady places: freq. : Ayrshire.

S. viridis (Linn.).-On grass and herbs : freq. : Lanarkshire; Renfrewshire ; Ayrshire; Buteshire.

S. hortensis, Fitch.-On bare ground, esp. sandy or peaty soil : immense numbers in summer, in gardens. Seamill.

S. luteus, Lubbock.-On living stems and leaves: c.: Lanarkshire ; Avrshire; Buteshire.

S. violaceus, Keuter.-On flower-pots in conservatories, \&c. : Seamill.

S. niger, Lubb.-Under boards, and on flower-pots : W. Kilbride.

S. igniceps, Reuter.-On flower-pots in conservatories, \&c. : Seamill.

S. Malmgrenii, Tullberg, var. elegantulus, Reuter.-On surface of stagnant pools and ditches: Cumbrae ; W. Kilbride ; Ardrossan ; Barr.

S. aquaticus, Bourlet.-Stagnant pools: Kilmalcolm ; Cumbrae; Ardrossan ; Barr.

Papirius ornatus (Nicolet). - Under fallen branches, leaves, \&c.: c. : Ayrshire.

P. minutus (O. Fabr.).-Under wood, \&c. : freq. : Ayrshire.

\section{Fam. Entomobryidae.}

Tomocerus plumbeus (Linn.) (=Podura longicornis, Hïller).-Under wood, \&c. : not unc.: Ayrshire.

T. niger (Bourlet).- Under wood, \&c. : not unc. : Ayrshire.

T. tridentiferus (Tullb.).--Under wood, leaves, \&c. : abund. and gen. dist. throughout the year.

Lepidocyrtus lanuginosus (Gmelin)._-Under wood, stones, \&c. : abund. and gen. dist.

L. cyaneus, Tullb.-Under stones, \&c.: freq.: Ayrshire.

Beckia argentea, $L u b b$. - In a conservatory, on earth in flower-pots: Seamill. Entomobrya albocinta (Templeton) (=Degeeria cincta, Lubb.).-Beneath dry bark, under loose stones, and on walls : c.: Lanarkshire ; Ayrshire ; Buteshire.

E. nivalis (Linn.) (=D. annulata, Lubb.).-Amongst furze and herbage : c.: Lanarkshire ; Ayrshire.

E. muscorum (Nic.) (D. Nicoletii, Lubb.).-Under stones, amongst herbage, and at roots of grass: c.: Lanarkshire; Ayrshire ; Buteshire. 
E. multifasciata (Tullb.) (=D. nivalis, Nic.-Under stones, \&c. : Lanarkshire; Ayrshire.

Orchesella cincta (Linn.).--Under sțones, wood, \&c. : abund. throughout the year.

Templetonia nitida (Templ.).-Under boards, \&c., on the ground: Seamill. Isotoma viridis Bourl.-On bare earth, and under stones, \&c.: abund. throughout year.

I. palustris (Müller).-On the edges of pools and ditches : c.

I. arborea (De Geer).--Under fallen branches, \&c. : W. Kilbride.

\section{Fam. Poduridae.}

Podura aquatica, Linn.--On surface of pools and quarry-holes: W. Kilbride. Achorutes armatus (Nic.).-On water: W. Kilbride.

A. viaticus (Linn.).-On stones, \&c., in damp places: W. Kilbride.

A. purpurascens, Lubb.-W. Kilbride.

Anurophorus laricis, Nic. (=Lipura corticina, Lubb.).-Under bark: c. at W. Kilbride.

Lipura armata, Tullb.-Under wood, decaying vegetables, \&c. : W. Kilbride.

L. ambulans (Linn.).-Under wood, decaying vegetables, \&c.: W. Kilbride.

L. fimetaria ( $N i c$.) (=L. inermis, Tullb.).-Under wood, decaying roots, \&c.: Seamill.

Anurida maritima (Guer.).-On maritime rocks and pools: Ayrshire; Buteshire.

Anura muscorum (Templ.).-Under rotten wood, \&c.: freq.: IV Kilbride.

\section{Thysayura.}

Campodea staphylinus, Westwood.-Under stones: not c. : W. Kilbride.

Machilis maritima (Leach).-Under loose stones, and in dry walls: c. at sea-coast: Renfrewshire; Ayrshire ; Buteshire. 


\section{MYRIAPODA. \\ By D. A. Boyd, Esq.}

Is the compilation of this list reference has been made to Latzel's great work, Die Myriopoden der österrisch-ungarischen Monarchie; also to papers by Leach and Newport in the Transactions of the Linnean Society, vols. xi. and xix. ; and to Sir T. D. Gibson-Carmichael's "Preliminary List of the Scottish Myriopoda," in the Proceedings of the Royal Physical Society of Edinburgh vol. vii.

\section{Chilognatha.}

Iulus pusillus, Leach.-Under decaying bark, and in rotten trunks of trees : c.

I. sabulosus, Linn.-Under stones and wood : c. and gen. dist.

I. punctatus, Leach.--Under stones, etc. : c.

I. terrestris, Linn.-Under stones, etc. : c. and gen. dist.

Blaniulus guttulatus, Fabr.-Under stones and bark: W. Kilbride.

Polydesmus complanatus, Latr.-Under bark, wood, etc. : abund. and gen. dist.

Craspedosoma Rawlinsii, Leach.-Under stones and amongst moss : Cartland Crags (Wm. Evans).

C. polydesmoides, Leach.-Under wood: Seamill.

Glomeris limbata, Latr.-Under stones, etc.: Brodick (Wm. Evans): W. Kilbride ; Kilwinning.

\section{Chilopoda.}

Lithobius forficatus, Linn.-Under bark and stones : c. and gen. dist.

L. variegatus, Leach.-Under stones; Bowling; Inveraray (Sir T. D. Gibson-Carmichael).

Himantarium subterraneum, Leach.-Amongst earth in gardens : Seamill. Geophilus longicormis, Leach.-Under stones: W. Kilbride. 


\title{
ARACHNIDA. \\ By William Evans, F.R.S.E.
}

\section{Order Araneidea.}

\begin{abstract}
Arrangement and Nomenclature: Rev. O. P. Cambridge's List of British and Irish Spiders, 1900.
\end{abstract}

"Clyde" on account of its position and the diversity of country will, when thoroughly investigated, probably be found to occupy a high place among the 'drainage areas' of Scotland. This should act as a stimulus to resirlent naturalists to take up the work begun by the late Morris Young and $H$. C. Young. Their records have been of the greatest service in compiling this list. Help has also been received from many local naturalists to all of whom I here tender my best than's. I have personally only 'sampled' the Clyde spiders at various points but my captures include 5 new to the Scottish list, two (Tapinocyba pallens and Cornicularia karpinskii) being first records for Britain.

The number of species in this list is 201-out of 290 recorded from Scotland-and as against 215 in the adjoining "Forth" area. A good many are rarities, but space does not allow me to particularise.

Reliability in the identification being of the first importance, it is satisfactory that the high authority of the Rev. O. Pickard-Cambridge, F.R.S., can be cited for nearly every species on the list. My personal obligations to him in this matter are very great, and he has my hearty acknowledgment and thanks. I have also to thank Mr. G. H. Carpenter, B.Sc., for verifying the determinations of some of my Arran specimens.

Contractions for Authorities for localities, etc., are :

W. R. B. =W. R. Baxter, Glasgow : short list of spiders taken by himself some years ago.

Dr. C.=late Dr. H. Colquhoun, Bothwell : small coll. chiefly at Dunoon, 1843-6 ; given to H. C. Y. and entered in his Journal.

O. P. C. = Rev. O. Pickard-Cambridge, Bloxworth, Dorset: list of Scottish Spiders, Entomologist, 1877 ; also numerous records in Trans. Linn. Soc. xxvii. (1869-71); Ann. and Mag. N. H., 5th ser., I. iv. (1878, 1879); Spiders of Dorset (1881), and suppts. in Proc. Dors. N.H. Field Club $(1882-1900)$.

A. W. P. C. = A. W. Pickard-Cambridge : small coll. at Crawford, Lanark., $9 / 1898$; list sent me by O.P. C.

M'D.=G. M'Dougall, Campsie : specimens from Kirkintilloch, and Campsie Gl. W. E. $=$ Wm. Evans, Edinburgh (Compiler): collections made at Arran (4/1895) ; Bute ; Peaton ; Lanark ; Douglas ; Elvanfoot (9/1900) ; etc.

Ferg. = Anderson Fergusson, Glasgow : specimens from several localities.

For. = Adrian Forrester, Glenmiln : specimens from Kilmalcolm (recorded by Carpenter, Ann. Scot N.H., 1893), and Helensburgh. 
F. L. G.=Frank L. Grant, Glasgow : list of records, Ann. Scot. L.H., 1894 and Trans. N.H.S. Glasg., iv. (n.s.), pp. 153, 282.

J. R. M. =J. R. Malloch : specimens from Bonhill.

T. W. = Thomas Wilson, Ayr : local collection.

H. C. Y.= late Henry C. Young, Sale, Cheshire : collected 20-30 years ago, in the district for a list for the Glasg. N.H. Soc., which never appeared. many of his records were published by O.P.C., who named most of his specimens, and a few by himself, Proc. N.H.S. Glasg., III., pp 170, 351, and Iv. p. 79. From his Journals-now in the possession of Mr. M'Naught Campbell who has kindly given me the use of them-I have also got many records of specimens marked as named by O.P. C.

M. Y.= late Morris Young, Paisley : furnished O.P.C. with many valuable local records ; a list by himself of the rarer spiders of Renfrew. appeared in Ann. Scot. N.H., 1894, p. 185. For the exact localities in a number of these I am indebted to Mr. J. M. B. Taylor, Paisley Museum.

\section{Fam. Dysderidae.}

Dysdera crocota, C. L. K.-Ad. f., Ayr, $7 / 1897$ (T. W.) : ad. m., Kirkintilloch, 1899 (M'D.).

Harpactes hombergii (Scop.).-Local and scarce: Cadder; Baldernock; Prestwick (H.C. Y.) : Ayr (T. W.).

Segestria senoculata (L.).-Gen. dist. and c. : Bute and Arran; to Milngavie (H. C. Y.) ; Lanark ; \&c.

Oönops pulcher, Templ._-Not unc. locally : Paisley district (M. Y.): Bute (W. E.) : Campsie (M'D.).

\section{Fam. Drassidae.}

Drassus cupreus, $B l$.-Gen. dist. and abund. : Bute, and Arran ; to Campsie and Elvanfoot ( $=D$. lapidicolens of Messrs. Young and others).

D. pubescens, Thor:-Nr. Paisley (M. Y.) : Auldmurroch (H.C. Y.) : Arran (W. E.).

D. troglodytes, C.L.K.-Widely dist. : Bute, and Peaton (W. E.): Dunoon (Dr. C.): Paisley (M. Y.): Ėlvanfoot (W.E.).

D. mysticus, $C b$.-Described by O.P.C. from specimens got under bark of fallen firs nr. Paisley, by M. Y. (Proc. Dors. N.H. Club, xv. (1894), p. 104).

Prosthesima nigrita (Fab.).-Ad. m., Prestwick 7/1879 (H. C. Y.).

P. latreillii, C. L.K.-Ad. m., nr. Ayr 7/1897, T. W. Only previous Scottish record-Balmoral 6/1879 (O.P.C. in Ann. and Mag. of Nat. Hist., 5th ser., iv. 209).

P. lutetiana, L. K.-The Rev. O. P. C. in 1878 received from Mr. H. C. Young, an ad. f. "found at Dunmore in Scotland" (Ann. and Mag. of Nat. Hist. 9/1879, p. 210), but in "Spid. Dors." the locality is altered to "Dunnon." I can find no reference to the species in any of Mr. Young's notes or journals. On 30th June, 1900, females-both adult and immature-were found by myself in some numbers among shingle at Peaton, L. Long.

Macaria pulicaria (Sund.).-Paisley district (M. Y.): Cadder ; Baldernock; Prestwick (H. C. Y.).

Clubiona terrestris, Westr.-C. : Bute, and Arran; to Campsie and Lanark district.

C. reclusa, Cb.-Mod. c. : Glasgow dist.(H. C. Y.) : Paisley (M. Y.) : Bonhill (J. R. M.): Bute ; Lanark (W. E.).

C. lutescens, Westr.-Paisley district (M. Y.).

C. holosericea, De G., Cb.--Cadder ; Prestwick (H. C. Y.): Paisley (M. Y.) : Ayr (T. W.): Peaton: Bute ; and Arran, fairly c.

C. pallidula, Clk.-Inversnaid (O.P. C., Entom., 1877): Milngavie (H.C. Y.): Peaton (W. E.). 
C. diversa, $C b$. (=C. pallens, Cb., Spid. Dors.).-Not unc. : Paisley district (M. Y.): Crawford (A. W.P.C.): Campsie (M'D.): Bute ; Elvanfoot (W. E.).

C. trivialis, L.K.-Rather c., moorland districts : Arran: Peaton: Campsie.

C. brevipes, $B l$.-Glasgow district (H. C. Y.).

C. comta, C.L.K.-C.: Paisley (M. Y.): Ayr (T. W.) : Arran : Campsie : Cleghorn (W.E.).

Chiracanthium carnifex (F.).-C., moors: Craigmaddie (H. C. Y.) : Mugdock (W. R. B.): Arran; Dunoon; Peaton (W. E.).

C. lapidicolens, Sim. (=C. nutrix, Cb., Spid. Dors.).-R.: Milngavie, one ; Arran, one (H. C. Y.) : Monkton, 8/1899, f. (T. W.).

Zora maculata ( $B l$.$) .-Campsie Glen (M'D.).$

Anyphaena accentuata (IVlk.).-Haugh Glen, 8/1879, abund. (H. C. Y.).

Agroeca proxima, Cb.-Kilmalcolm (H.C. Y.) : Bute (W. E.).

A. gracilipes, $(B l$.$) -Douglas, 11/1900, f. not quite mature-named for me$ by O.P. C.

\section{Fam. Dictynidae.}

Dictyna arundinacea (L.).-Abund. in moorland districts: Craigmaddie (H. C. Y.): Campsie (M`D.): Irvine (T. W.) : Peaton; Dunoon ; Arran; Elvanfoot: \&e.

Amaurobius similis ( $\mathrm{Bl}$.).-C. and general, usually about outhouses: Ardpeaton: Douglas : \&c.

A. fenestralis (Sir.)-Geu. dist., and very c.

\section{Fam. Agelenidae.}

Cryphoeca silvicola (C.L.K.).-Widely dist.; c.: Arran : Erskine Ferry (H. C. Y.) : Campsie : Elvanfoot : \&c.

Argyroneta aquatica, Latr.-Possil Marsh, 1868-69, and in old quarry-hole, nr. Partick (J. M. Campbell, Scot. Nat., vol. v., p. 311): Possil Marsh, 1877 (H. C. Y., Proc. N. H. S. Glas., iii., p. 351).

Tegenaria atrica, C.L. K.-In a warehouse Forth Street, Port Dundas, Glasgow, 2/1878 (H. C. Y.).

T. derhamii (Scop.).-C. houses throughout the area.

Textrix denticulata (Oliv.) (= T. lycosina, Bl.).-Gen. dist. and abund. : Ailsa Craig (F. L. G.) : Arran, \&c., to Elvanfoot.

\section{Fam. Hahniidae.}

Hahnia helveola, Sim.-Ad. m. in moss on bank of Mouse Water above Cartland Craigs 27/10/1900 (W.E.), named by O. P. C. First record for Scotland.

H. montana $(B l$.$) .-Widespread and not unc. : Goatfell ; Cartland Craigs ;$ \&c. (W. E.).

\section{Fam. Theridiidae.}

Theridion sisyphium $(C l k$.).--A bund. all over the area.

T. denticulatum (Wlk.).-Clarkfield (H. C. Y.): Bonhill (J. R. M.): Rothesay (W. E.).

T. varians, Hahn.-Glasgow (H. C. Y.): Ayr 6/1898, f. (T. W.).

T. pictum, Hahn.-Glasgow (H. C. Y.).

T. tepidariorum, C.L.K.-C. in greenhouses: Hamilton Palace, \&c., (H. C. Y.) : Glasgow (W. R. B.) : Arran ; Ardpeaton (W. E.).

T. bimaculatum (L.).-Auchinloch, 1879, one f. (H. C. Y.)-named by O. P. C. I think this is the first record for Scotland.

T. pallens, $B l$.-Paisley (M. Y.): Allander (H. C. Y.) : Bonhill (J. R. M.) : Lanark ; Cleghorn Gl. (W. E.).

Pholcomma gibbum (Westr.).-Paisley (M. Y.) : Bute ; Elvanfoot (W. E.). 
Nesticus cellulanus ( $C l k$.).-Paisley district (M. Y.): Possil ; Haugh Gl. ; Prestwick; \&c. (H.C. Y.): Campsie (M'D.) : Cleghorn Gl. ; Arran (W. E.).

Phyllonethis lineata $(C l k$.).-C. : Ayr : Bute : Dunoon : Lanark : \&c.

Steatoda bipunctata (L.).-M. in window of cellar Port Dundas, Glasgow, $6 / 1878$; f. $7 / 1879$ (H. C. Y.) : Ayr, imm. m., 5/1900 (T. W.).

Euryopis flavomaculata, (C. L. K.).-Nr. Paisley (M. Y.).

Asagena phalerata, Panz.-Nr. Troon (W.R. B.).

Pedanostethus arundinetus $(C b$.) (=Neriene clarkii, $C b$.).-Ad. m. nr. Paisley (M. Y.), and sent to O. P. C. 1866 (v. Trans. Linn. Soc., xxvii., p. 443).

P. lividus $(B l$.$) - Gen. dist., and abund. especially in upland districts.$

P. neglectus $(C b$.).-Nr. Paisley, a m. (M. Y.).

Tapinopa longidens (Wid.) (=T. unicolor, Cb.).-Nr. Paisley (M. Y.) : Erskine Ferry ; Milngavie (H. C. Y.).

Bolyphantes bucculentus (Clk.) (=Linyphia frenata, Cb. Spid. Dors.).Nr. Glasgow (H. C. Y.).

B. alticeps (Sund.).-Cadder; Erskine F.; Wishaw (H. C.Y.): Campsie $\left(\mathrm{M}^{\circ} \mathrm{D}.\right)$ : Douglas (W. E.).

B. luteolus $(B l$.$) .- Gen. dist., and c.$

B. expunctus (Cb.).-Nr. Glasgow (H. C. Y., v. Spid. Dors.).

Drapetisca socialis (Sund.).-Cadder; Loup of Fintry (H.C. Y.) : Elvanfoot (W. E.).

Stemonyphantes lineata $(L).(=\mathrm{L}$. bucculenta, Cb. Spid. Dors.)-Arran : Ayr (T. W.): Prestwick ; Wishaw (H.C. Y.).

Linyphia insignis, $B l$.-Glasgow distriet (H.C. Y.): Lanark ; Douglas (W. E.).

L. montana (Clk.).-Ayr ; Irvine (T. W.): Dunoon (Dr. C.): Glasgow district (H. C. Y.) : Helensburgh (For.): Bonhill (J.R.M.) : Paisley (M. Y.).

L. triangularis $(C l k$.).-Abund. throughout: Bute ; to Campsie, and Crawfordjohn (W. E.).

L. peltata, Wid.-Fairly c. : Cumbernauld ; Cadder (H. C. Y.) : Ayr (T. W.): Arran ; Cleghorn Gl.

L. pusilla, Sund..-C. locally: Blairmore; Bonhill ; Gl. Kinglas (H.C.Y.): Paisley (M. Y.): Ayr (T. W.) : Arran ; Bute ; Cleghorn ; Elvanfoot.

L. hortensis, Sund.-Paisley (M. Y.): Ayr, 5/1900, m. (T. W.).

L. clathrata, Sund.-Widely dist. and c. : Bute; Arran : Glasgow district (H. C. Y.) : Cleghorn ; \&c.

Labulla thoracica (Wid.).-Arran; Peaton; Carluke: Glasgow district ; Campsie ; etc.

Leptyphantes minutus ( $B l$.).-Widespread, but not very c.: Glasgow district (H. C. Y.) : Campsie (M'D.) : Douglas ; Elvanfoot ; Bute.

L. nebulosus (Sund.).-Warehouse in Port Dundas, Glasgow, plentiful (H. C. Y.).

L. leprosus $(O h l$.).—Glasgow district (H. C. Y.) : Kilmalcolm (For.): Arran (W.E.).

L. terricola $(C . L . K).(=\mathbf{L}$. alacris $(B l)$.$) .--Rather c. : Glasgow district$ (H.C. Y.): Paisley (M. Y.) : Bute ; Peaton ; Lanark ; etc.

L. blackwallii, Kulcz. (=Linyphia zebrina, Cb. Spid. Dors.).-Gen. dist., and usually abund.

L. cristatus, Menge.-Allander (H. C. Y.) : Cleghorn Gl., ad. m., 10/1900 (W. E.).

L. obscurus ( $B l$.).-Rather scarce: Paisley (M. Y.): Glasgow district (H. C. Y.) : Bonhill (J.R. M.) : Arran ; Peaton (W. E.).

L. pallidus (Cb.).-Hamilton, 8/1878 (H. C. Y.).

L. tenuis $(B l$.$) (=Linyphia tenebricola, Cb. Spid. Dors.).-Gen. dist. and$ very $\mathrm{c}$. 
L. ericaeus (Bl.).-C. among heather: Paisley (M. Y.) : Arran ; Elvanfoot ; Leadhills (W. E.).

Bathyphantes variegatus ( $B l$.$) .-C., upland districts: Arran ; to Campsie,$ Kilsyth, and Leadhills.

B. concolor (Wid.).-Gen. dist., but much more c. in some districts than others.

B. approximatus (Cb.).-Haugh Glen (H.C. Y.): m. and f., Strathaven, Lanarkshire (Ferg.).

B. nigrinus (Westr.).-Castlecary Gl. (H. C. Y.) : Arran ; Douglas (W. E.).

B. gracilis (Bl.).-Widespread: Arran; Bute: Paisley (M. Y.): Cleghorn ; etc.

B. dorsalis (Wid.).-C. : Paisley (M. Y.): Allander; Gl. Kinglas, etc. (H. C. Y.): Cleghorn; Elvanfoot.

Porrhomma pygmaeum (Bl.).-Paisley (M. Y.): Bute; Cleghorn Glen (W. E.) : nr. Glasgow (H. C. Y.) ; (recorded as Neriene barbata, Thor., by O.P.C. Ann. and Mag. of N. H., 1879).

P. adipatum (L.K.) (=Linyphia reticulata, Cb. Spid. Dors.).-Cairndow, head of L. Fyne ; summit of Ben Ime, 7/1878 (H. C. Y.).

Hilaira excisa $(C b$.$) (=Nierene excisa, Cb. Trans. Linn. Soc., xxvii., p.$ 440).--The type specimen (an ad. m.) captured nr. Paisley by M. Y. in 1866.

Tmeticus rufus ( Wid.).--Cadder Wilderness (H.C. Y.): Braidwood Gl. (W. E.).

T. hardii (Bl.).-A m. nr. Elvanfoot, 9/1900 (W. E.).

T. scopiger (Grube.) (=Linyphia rufa, Cb. Spid. Dors.).-Glasgow district (H. C. Y. ; see Spid. Dors., p. 521): one, f., between Elvanfoot and Leadhills, 9/1900 (IV. E.).

T. abnormis (Bl.).-Bute; Arran (W.E.): Paisley (M. Y.): Cumbernauld Gl. (H. C. Y.). This last was recorded as Neriene (Erigone) Douglasii, Cb., and in H. C. Y.'s journal it is also entered as Linyphia linguata, Cb., from Cadder; Craigton; and Ben Ime.

T. montigena (L. K.) (=Neriene rudis, Cb. Spid. Dors.)-_"Nr. Glasgow" (H. C. Y. fide O.P. C.). Doubtless the "Neriene sp. n." in Mr. Young's journal, found under stones on summit of Ben Ime, 13/7/1878. Several (both sexes), nr. Leadhills, 1/10/1900 (W. E.).

T. bicolor ( $\mathrm{Bl}$.).-Kilmalcolm (For.): Bute : c. in Lanarkshire (W. E.).

T. concinnus (Thor.).-Ad. m. taken by me at Carstairs, 10/1899.

T. sylvaticus (Bl.).-Arran ; Douglas, m. and f. (W. E.): Campsie (M'D.).

T. prudens (Cb.).-Ad. m. Crawford, Lanarkshire, 9/1898 (A. W. P. C.).

Microneta subtilis (Cb.).- In 11/1900, I got a f. nr. Douglas, Lanarkshire, which O.P.C. refers to this form. It is new to the Scottish list.

M. viaria (Bl.).-Paisley district (M. Y.): Cadder; Clarkfield (H. C. Y.) : Arran ; Douglas.

M. rurestris (C.L. K.) (= M. (Neriene) fuscipalpis, Cb. Spid. Dors.).-C. : Paisley (M. Y.) : Craigenglen (H. C. Y.): Peaton; Cleghorn; Elvanfoot. Specimens from all these localities were named fuscipalpis by O.P.C.

M. sublimis $(C b$. $)$.-Adults, both sexes, under stones nr. Elvanfoot end of 9/1900 (W. E.).

M. saxatilis $(B l$.$) - - Nr. Paisley (M. Y.). Recorded under Erigone and Veriene$ by O. P. C. (Entom. 1877, and Spid. Dors.).

Sintula diluta ( $C b$.).-Arran, 4/1895, one (IV. E.).

Maso sundevallii (Westr.).-Cartland Crags, 10/1900, one (W. E.).

Gongylidium rufipes (Sund.).-Glasgow district (H.C.Y.): Lanark, f. (W. E.).

G. fuscum ( $B l$.).-Renfrew. (M. Y.) : Bowling (Ferg.) : Elvanfoot (W. E.).

G. agreste $(B l$.).-Brodick, 4/1895 (W. E.).

G. retusum (Westr.).-Nr. Paisley (M. Y.). 
G. apicatum ( $B l$.$) - - Nr. Paisley (M. Y.).$

G. dentatum (Wid.).-Arran ; Cleghorn Gl. (W. E.).

Gongylidiellum latebricolum $(C b$.).- $\mathrm{Nr}$. Paisley (M. Y.).

Tiso vagans $(B l$.$) (=Neriene longimana, C b$. Spid. Dors.).-Renfrewshire (M. Y.) : Bowling (Ferg.) : Arran (W. E.).

Erigone longipalpis (Sund.).-Renfrew. (M. Y.) : Bute ; Arran (W.E.).

E. promiscua (Cb.).-Brodick, m. (W. E.) : Prestwick (H. C. Y.).

E. dentipalpis (Wid.).-C. : Corrie (F. L.G.): Port Dundas (H.C.Y.) : Cambuslang (Ferg.) : Lanark ; Peaton ; Bute (W.E.).

E. $\operatorname{atra}(B l$.$) .-Widespread: Corrie (F. L. G.): Renfrew. (M. Y.) : Lanark$ (W. E.).

Lophomma punctatum (Bl.).-Nr. Paisley (M. Y.).

Dicymbium nigrum ( $B l$.).-Not r. ; Bowling (Ferg.) : nr. Paisley (M. Y.) : Crawford (A. W. P. C.) : Bute ; Lanark ; Carstairs ; Elvanfoot (W.E.).

Neriene rubens, $B l$.-Gen. dist. and c.

N. rubella, $B l$. - Campsie, one (M'D.).

Dicyphus (Gonatium) bituberculatus (Wid.).-Locally c. : Paisley (M. Y.) : Bowling (Ferg.): Cleghorn Gl. ; Bute ; Arran.

Dismodicus bifrons (Bl.).-Paisley (M. Y.) : Arran ; Peaton (W. E.).

Diplocephalus cristatus (Bl.).-Paisley (M. Y.): Carluke; Elvanfoot (W. E.).

D. latifrons (Cb.).-S. Barr, nr. Paisley (M. Y.).

D. alpinus (Cb.).-Cambuslang (Ferg.): Peaton ; Cartland (W. E.).

D. picinus (Bl.).-Glen and Blackstone, Renfrew. (M. Y.).

D. fuscipes (Bl.).-Widespread, and c.: Bute and Arran, to Douglas.

Entelecara flavipes (Bl.).-Craigielea, Renfrew. (M. Y.).

Savignia frontata, Bl.-C. and general; Bute; Arran and Ayr; to Campsie and Lanark.

Lophocarenum nemorale (Bl.).-Paisley Moss (M. Y.) : nr. Lanark, m., Dec. (W. E.).

Peponocranium ludicrum (Cb.).-Paisley (M. Y.): Bonhill (J.R. M.): Campsie (M'T.) : Elvanfoot; Arran (W. E.).

Minyriolus pusillus ( Wid.).-Glen, Renfrew. (M. Y. fide Mr. Taylor).

Araeoncus humilis ( $B l$.).- Nr. Lanark, ad. m. (W. E.).

A. crassiceps (Westr.).-Ad. m's. c. among sand on beach, Brodick B., 4/1895, (W. E.).

Pocadicnemis pumilus ( $B l$.).--Renfrew., several localities (M. Y.).

Troxochrus hiemalis (Bl.).-S. Barr, Renfrew. (M. Y.).

Cnephalocotes obscurus ( $B l$. $)$.- - Nr. Paisley (M. Y.).

C. curtus, Sim.-Both sexes in considerable numbers on upper part of beach at Brodick B., 4/1895 (W. E.). : C.fuscus, $C b$., described in 1899 was from Banff not Crawford.

Tapinocyba pallens $(C b$.).-Ad. m. among withered leaves in Braidwood Gl., 2/12/99 (new to British list); another m. at Cartland Crags, 27/10/1900 (W. E.).

Caledonia evansii, $C b$.-Mm. and ff. on Lowther Hills, nr. Leadhills, 1/10/1900 (W.E.). The only other loc. known is Pentland Hills, nr. Edinburgh, where I found the type specimen, 9/1893.

Wideria antica (Wid.).-Nr. Paisley (M. Y.): Lanark ; Douglas (W.E.).

Walckenaëra acuminata, Bl.-Paisley Moss, \&c. (M. Y.): Bowling (Ferg.): Cumbernauld Gl., \&c. (H.C. Y.): Bonhill (J.R.M.): Arran; Bute; Carluke ; Douglas ; Elvanfoot.

W. obtusa, Bl._Craigielea, nr. Paisley (M. Y.).

W. nudipalpis (Westr.)-Blackstone, nr. Paisley (M. Y.).

W. capito (Westr.).-R. : ad. m. nr. Paisley ; 9/1893 (M. Y) (O. P. C. Proc. Dors. $F$. C., vol. xv., p. 113).

Cornicularia karpinskii (Cb.).-Ad. m. Cornicularia from summit of Green 
Lowther, 1/10/1900, (W.E.) is, O. P. C. says, referable to this. The type was sent from Siberia. First record for British Isles.

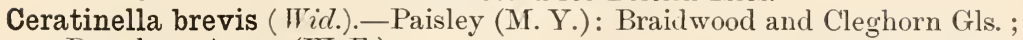
Douglas ; Arran (W. E.).

C. brevipes (Westr.).-Craigielea nr. Paisley (M. Y.): Arran; Lanark (W. E.).

\section{Fam. Mimetidae.}

Ero thoracica (Wid.)-Greenan Castle, Ayrshire (H. C. Y.) : Arran ; Bute ; Cartland Craigs (W. E.).

\section{Fam. Epeiridae.}

Tetragnatha extensa (L.)-C.: Arran; Leadhills (W. E.) : Dunoon ; Gl. Kinglas; Lochgoilhead ; Allander, \&c. (H. C. Y.): Ayr (T. W.).

Pachygnatha degeerii, Sund.-Gen. dist. and c.

P. clerckii, Sund.-Not r. : Glasgow district; Kilmalcolm (H. C. Y.) : Bute ; Arran ; Campsie ; Elvanfoot.

Meta segmentata ( $C l k$.).-Abund. everywhere: Arran and Bute; to Crawfordjohm and Elvanfoot.

M. merianae, Scop.-Widespread and fairly c.: numerous localities from Arran ; Troon ; and Dunoon ; to Campsie ; Kilsyth ; and Cleghorn.

M. menardi (Latr.).-Vaults under Craignethan Castle (W. R. B., Proc. N.H.S., Glasgow, vol. ii. (x. s.) p. xix.): Cairndow ; Ben Ime (H. C. Y.): Dalry (T. W.) : reported as c. in caves Ailsa Craig; specimens twice sent me for identification (see Annals S. $V . H ., 1898$, p. 239).

Singa hamata $(C l k$.)._Craigmaddie Moor, c., $9 / 77$ and $7 / 79$ (H. C. Y.).

Zilla x-notata (Clk.).-C. in Glasgow district (H. C. Y.) : Rothesay ; Corrie ; and Lanark (W. E.) : Dalry (F. L. G.) : Helensburgh (For.).

Z. atrica $(C . L . K$. $)$.-Gen. dist. and abund.

Epeira diademata $(C l k$.).--Abund. all over area : specimens from rocks and walls at Elvanfoot and other upland localities, are of the dark variety.

E. cucurbitina (Clk.).-Not r. : Paisley district (M. Y.) : several places $n$. Glasgow (H. C. Y.) : Arran ; Lanark (W. E.).

E. triguttata $(F a b$.$) (=E. agalena, Spid. Dors.)-Paisley district (M. Y.).$

E. umbratica (Clk.).-Bothwell (Dr. C.) : Barr (Ferg.).

E. quadrata (Clk.)-Locally c. on heather, \&c. ; Craigmaddie, \&c. (H. C. Y.) ; Ayr (T. W.): Arran; Bute; Dunoon; L. Long; Elvanfoot.

E. cornuta $(C l k$.$) .-C. locally on rushes, \&c. : Paisley district (M. Y.) :$ Allander, \&c. (H. C. Y.): Helensburgh (For.): Dunoon (Dr. C.) : Ayr, \&c. (T. W.): Arran: Cleghorn: Elvanfoot.

\section{Fam. Thomisidae.}

Xysticus cristatus $(C l k$.).-Abund. all over the area.

X. pini, Hahn.-A f. Xysticus taken on Ailsa Craig a few years ago by Mr. F. L. Grant, referred by O. P. C. to this.

X. ulmi, Hahn.-In H. C. Y.'s journal, a f. of this form, determined by O.P. C., is marked "Glasgow district."

Oxyptila atomaria (Panz.) (= = horticola (C. L. K.), Spid. Dors.).-Cadder Wilderness, 6/1878, f. (H. C. Y.).

O. trux (Bl.).-Glasgow district (H. C. Y.) : Ayr (T. W.) : Kirkintilloch (M'D.) : Cleghorn ; Douglas (W. E.).

Philodromus aureolus (Clk.).--Plentiful: Glasgow district; Prestwick; \&c. (H. C. Y.): Dunoon (Dr. C.): Bute; Arran ; \&c.

Tibellus oblongus ( $W l k$.).-Abund. on Ayrshire Coast (H.C. Y.) : Troon (W. R. B.).

\section{Fam. Pisauridae.}

Pisaura mirabilis (Clk.).-Inchtavanach, 6/1879 (H.C. Y.): Brodick, (W.E.). 


\section{Fam. Lycosidae.}

Pirata piraticus $(C l k$.).-In marshy places : Cairndow (H.C.Y.): Bishopton (Ferg.) : Bute ; Arran; L. Long; Elvanfoot.

P. hygrophilus, Thor.-f., Peaton, L. Long, 8/1900 (W. E.).

P. knorrii (Scop.)._-Arran ; (recd. by Dr. L. Koch from Mr. Kyle). This is the only British Record (v. O.P. C., Ann. \& Mag. Nat. Hist., 1878, p. 124).

Trochosa ruricola ( $D e$ G.).-C., especially on coast: Glasgow district (H. C. Y.): Paisley district (M. Y.) : Ayr (T. W.) : Dunoon : Arran.

T. terricola, Thor.-Gen. dist., and usually fairly c.

T. leopardus (Sund.).-Decidedly local : Paisley district (M. Y.): Arran (H. C. Y.) : Brodick (W. E.).

T. picta (Hahn).-C. on sandhills, Ayrshire; Arran (W.E.): Sandpits at Tolleross (H. C. Y.).

Tarentula andrenivora ( $W l k$.)._-Sparsely but widely dist. : Loup of Fintry ; Allander ; Prestwick (H.C. Y.) : Lendalfoot (T. W.): Arran ; Elvanfoot (W. E.).

T. pulverulenta $(C l k$.).-Abund. in hilly districts : Arran ; Dunoon ; Kilpatrick; Campsie Hills ; Crawford ; Elvanfoot.

T. aculeata (Clk.).-Arran ; recd. by Dr. L. Koch (O. P. C., Entom.: 1877).

T. miniata, C. L. K.-One, f., Prestwick 7/1878 (H.C. Y.).

Lycosa amentata $(C l k$.).-Abund. all over area.

L. agricola, Thor.-C. among shingle on the beach, Peaton, 6/1900 (W. E.).

L. annulata, Thor.-O. P. C. referred to this a poor specimen from Corrie sent him by F. L. G.

L. nigriceps, Thor--Widespread, and not unc. : Haugh Gl.(H.C. Y.) : Bonhill (J.R. M.) : Arran ; Bute ; Cleghorn.

L. pullata $(C l k$.).-Very c. everywhere.

L. prativaga, C. L.K. (=L. prativaga + L. riparia, Cb. Spid. Dors.).-A Lycosa from Corrie (Mr. Grant) was named riparia by O. P. C. This and $L$. annulata seem to me to need confirmation.

L. lugubris, Wlk.-C. in oak coppices nr. L. Lomond (W. E.).

L. palustris $(L$.).-C. in hilly districts : Arran ; Bute ; Elvanfoot ; Lowther Hills (W. E.).

L. monticola (C. L. K.).-Prestwick ; Innellan ; Cadder (H. C. Y.) : Arran; Bute (W. E.). In Scotland usually nr. the sea.

\section{Fam. Salticidae.}

Epiblemum scenicum $(C l k$.). - C.: Cadder (H. C. Y.) : Dunoon (Dr. C.) : Ayr (T. W. : Lanark; Elvanf ot.

E. cingulatum (Panz.).-Glasgow district in 1879 and 1880 (H. C. Y. fide O. P. C.).

Heliophanus flavipes, C. L. K.-Nr. Glasgow, 2 ff., 6/1878 (H. C. Y.).

Neon reticulatus ( $B l$.).-Paisley district (M. Y.) : Cartland Craigs, several, $10 / 1900$ (W. E.).

Euophrys frontalis ( $W l k$.).-2 ff., among shingle on beach, Peaton, 6/1900 (W. E.).

E. erraticus ( $W l k$.).-Nr. Paisley (M. Y.) : nr. Brodick (W. E.).

E. aequipes $(C b$.).-Described by Mr. Cambridge (Trans. Linn. Soc., vol. xxvii., p. 401), from a m. and f. captured by Morris Young, nr. Paisley, in 1866.

Hasarius falcatus (Clk.).-Cleghorn, Lanarkshire (W. R. B.).

$\mathrm{H}$. arcuatus $(C l k$.).-Paisley district (M. Y.).

H. adansonii (Sav.).- Adults of both sexes taken by M. Y. in exotic planthouses at Paisley in 1893 (O. P. C., Proc. Dors. F. C., xv., p. 115). 


\section{Order Phalangidea.}

Classification and Nomenclature : Rev. O. P. Cambridge, Monograph of the British Phalangidea, or Harvest-men, 1890.

The present list is based almost entirely on specimens collected by myself. A few records have been got from the late H. C. Young's note-books; and Mr. G. M'Dougall has sent me a few specimens from Campsie.

\section{Fam. Phalangiidae.}

Liobunum rotundum (Latr.).-C. in most districts during summer and autumn: Prestwick (H.C. Y.) : Arran : Lanark : \&c.

Phalangium opilio, Linn.-Abund. and general: Saltcoats and Arran; to Peaton, Campsie and Elvanfoot.

Platybunus corniger (Herm.).-Much less c. than either of the above, and occurs chiefly in spring: Arran ; Peaton : Campsie (M'D.).

P. triangularis (Herbst.).-Fairly c., no doubt: Cleghorn ; Douglas : Campsie (MrD.).

Megabunus insignis, Meade.-C. and widespread: Ardrossan; Glasgow district (H.C.Y.): Campsie (M'D.): Peaton: Cartland: Douglas : Elvanfoot.

Oligolophus morio (Fabr.).-Gen. dist. and abund.

O. cinerascens (C.L.K.).--Examples, from the Glasgow district, were received by Mr. Cambridge from H. C. Young.

O. agrestis (Meade.).-Abund. and general: Bute; to Kirkintilloch, and Leadhills.

0. hansenii (Kraep.).-Elvanfoot, 9/1900, fairly c. on spruce firs-determination verified by $O$. P.C. A recently described species, which seems as yet to have been taken in Britain only by myself ( $c f$. Proc. Roy. Phys. Soc., xiv., 178).

O. tridens (C.L.K.).-Doubtless c. and widespread: Campsie (M'D.): Douglas : Elvanfoot.

\section{Fam. Nemastomatidae.}

Nemastoma lugubre (O.F. Mïll.).-C. throughout the area.

N. chrysomelas (Herm.).--Rather scarce: between Elvanfoot and Leadhills (W. E.) : Campsie (M'D.).

\section{Order Chernetidea.}

Classifieation and Nomenclature : Rev. O. P. Cambridge, Monograph of the British Chernetidea, or False-Scorpions, 1892.

\section{Fam. Cheliferidae.}

Obisium muscorum, Leach.-Seems to be c. all over the area: Kilpatrick Hills (H. C. Y.): Campsie (M'D.): Paisley (J. M. B. Taylor): Milngavie; Giffnock (A.A.Dalglish): Brodick; Carluke ; Douglas ; Elvanfoot (W. E.).

Chelifer (sp. ?).-Mr. Macnaught Campbell writes me that he has a note of "Chelifer museorum" found in a press in the Glasgow Museum. He is not positive, however, about the identification. 


\section{LAND, FRESH-WATER, AND MARINE CRUSTACEA.}

By Thomas Scott, F.L.S., Mem. Soc. Zool. de France, F.R.Ph.S.E., Corr. Mem. Geol. and Nat. Hist. Socs. of Glasgow, etc.

\section{Order Podophthalma.}

Authorities and References.

(F. S. G.) = The Statistics of the work of the Fishery Board, S.S. "Garland."

$(H)=$. Prof. J. R. Henderson "The Higher Crustacea of the Clyde" $(N . H$. Soc. Glasg. Trans., vol. i. (N. S.) p. 315.

(M.)=MS. records of Sir John Murray's S.Y. "Medusa."

(A. M. N.) = Rev. Canon A. M. Norman, F.R.S., "A Revision of the British species of Schizopoda" (Ann. and Mag. N. H., 1892).

(R.) $=$ Records of the late Dr. Robertson, Millport.

(C.) =Dr. W. Y. Calman, Dundee, "On the genus Pandalıs."

(S.) = Thomas Scott, F.L.S.

Nomenclature and Classification Followed.

Rev. T. R. R. Stebbing, "History of the Crustacea," 1893 (Intern. Scient. Ser.).

Shall. w. = shallow water ; l. nı. w. =low water of ordinary or spring tides ; d. w. =deep water ; bet. t. m. = between tide marks; b. w. = high water.

[Insufficiently attested or doubtful species are enclosed within square brackets.]

\section{Sub-Order Brachyura.}

\section{Fam. Cancridae.}

Cancer pagurus, Lin.-C. on rocky shores (H.).

Xantho hydrophilus (Herbst.).-One captured at mouth of estuary 15/6/1899 (F.S. G.). Fishery Board's Coll., Aberdeen.

Pilumnus hirtellus, (Lin.).--Portloy, Cumbrae, under stones at l. w. (R.). Apparently $r$.

\section{Fam. Portunidae.}

Carcinus maenas (Penn.).-C. bet. t. m., and in shall. w. inshore ; sometimes in 10-20 f. upwards.

Portunus puber (Lin.).-Cumbrae; Lamlash B. ; L. Fyne (H.): Shallow Bays, Barmore (S.).

P. depurator (Lin.).-The most c. Portunus in the Clyde (H.).

P. corrugatus (Penn.).--One off Tan Buoy, 8 f. (H.).

P. arcuatus, Leach.-F. of Clyde, not r.

P. pusillus, Leach.-Mod. c.; hard ground, down to 30 f. (H.) : nr. Fort Matilda, Greenock (S.). 
P. marmoreus, Leach.-Several localities (H.).

Portumnus latipes (Penn.).-Washed ashore, Irvine sands (R.).

\section{Fam. Corystidae.}

Corystes cassivelaunus, (Penn.).-Kames B., Cumbrae, sand below l. w. m. (R.) : small male at mouth of estuary, 15/6/99 (F. S. G.).

Atelecyclus septemdentatus (Mont.).-One from Alland Bank, Millport B. (R.).

Fam. Ocypodidae.

Gonoplax rhomboides (Lin.).-Ayrshire coast (G.\& M.) : nr. Ailsa Craig (trawled, F. S. G.) : shore, Ardeer (J. Smith).

\section{Fam. Pinnotheridae.}

Pinnotheres pisum (Lin.).-Not unc. in $1 \%$. modiolus, occasionally in C. edule (H.).

\section{Fam. Inachidae.}

Macropodia rostratus (Lin.).-Not unc. in lower Clyde.

M. longirostris (Fabr.).-Mod. c., gen. dist.; more c. than M. rostratus.

[Achaeus cranchii, Leach.-One, off Cumbrae by Mr. Kennedy (R.): U. L. Fyne, 10 f. (M.)].

Inachus dorsettensis (Penn.).-C. and gen. dist.

I. dorynchus, Leach.--Gen. dist., less c. than I. dorsettensis.

I. leptochirus, Leach.-F. of Clyde (A.M. N.): bet. Cumbrae and Bute, 20 f., r. (R.).

\section{Fam. Maiidae.}

[Maia squinado (Herb.).-Off Dumoon, 1878 (Flemyng): off Ardrossan (Maj. Martin): W. of Bute (Grieve) (See H.)].

Hyas araneus (Lin.).-C. and gen. dist., esp. inshore.

H. coarctatus, Leach.-C. and gen. dist., esp. in d. w.

\section{Fam. Parthenopidae.}

Eurynome aspera (Penn.).-Not c. ; 10-60 f. ; usually hard ground (H.) : off Fort Matilda 10 f. (S.).

\section{Fam. Leucosiidae.}

Ebalia tuberosa (Penn.).-Gen. dist. ; usually hard ground, 5-50 f. (H.) : off Fort Matilda (S.).

E. tumifacta (Mont.).-Lamlash B.(G. ; H.) : Alland Bank, Millport B. (R.): Kilbremnan Sd., 15 f. (Brook.).

E. cranchii, Leach.-Lamlash B. (L. : M.) : off Lion Rock Cumbrae (Alex. Patience)!

\section{Sub-Order Macrura.}

\section{Fam. Lithodidae.}

Lithodes maia (Lin.).-D. w. L. Fyne, and Clyde ; gen. dist. ; somewhat r. (H. ; F. S. G.).

\section{Fam. Paguridae.}

Eupagurus bernhardus (Lin).-Abund., more inshore than in d. w.

E. prideauxi (Leach).-Mod. c., more in d. w. than inshore.

E. cuanensis (Thomp.).-Skelmorlie Bank ; off Portincross ; Cumbrae ; Lamlash B.; not very c. (H.).

E. pubescens $(K r$.$) .-Mod. c. ; hard ground ; usually enveloped by Hymeni-$ acidon tuberea (H.).

Anapagurus hyndmanni (Thomp.).-F. of Clyde, 10-15 f. (A. M. N.) : off Cumbrae (R.) : E. L. Tarbert (S.). 
A. laevis (Thomp.).-Gen. dist., 10-105 f. (H.) : mod. freq. in Clyde and L. Fyne.

A. chiroacanthus (Lillj.).-Skelmorlie Bank; off Portincross ; Tan Buoy ; Lamlash B. (H.): E. L. Tarbert (S.).

\section{Fam. Porcellanidae.}

Porcellana platycheles (Penn.).-Under stones, nr. Cumbrae ; Lamlash B. (H.): Lunderston B. (S.).

P. longicornis (Lin.).-C. and gen. dist., more freq. inshore ; usually hard ground.

Fam. Galatheidae.

Galathea squamifera, Leach.-Under stones 1. w., Cumbrae ; Lamlash B. ; off Fairlie (H.) : U. L. Fyne (M.) : E. L. Tarbert ; Lunderston B.

G. nexa, Embleton.-L. Fyne, 20-40 f. ; Tan Buoy, 7-8 f. ; Lamlash B. ; Skelmorlie Bank ; etc. (H.) ; U. L. Fyne (M.).

G. dispersa, Bate.-Mod. c. and gen. dist.; usually hard ground.

G. intermedia, Lillj.-C. hard ground, 10-20 f. (H.): L. Fyne 10-20, f. (M.).

G. strigosa, Fabr.- Under stones at l. w. spring tides, Cumbrae ; young dredged off Roseneath Pt., 15 f., hard ground (H.) : Strachur B. (S.).

Munida rugosa ( $F a b r$.$) .-Gen. dist. and mod. c., usually d. w.$

\section{Fam. Thalassinidae.}

Jaxea nocturna, Nardo.-Adult fragments twice (1899) in fish stomachs nr. Ailsa Craig (F. G. Pearcey): Young at times freq. in bottom tow-net (F.S. G.).

\section{Fam. Thaumastochelidae.}

Calocaris macandreae, Bell.-L. Fyne, 40-105 f.; off Tarbert ; off Wemyss B., 40 f. ; off Brodick B., 93 f. (H.).

\section{Fam. Palinuridae.}

Palinurus vulgaris, Latr.-Off Campbeltown ; L. Fyne (H.) : r.

\section{Fam. Nephropsidae.}

Nephrops norvegicus (Lin.).-C., usually d. w.

Astacus gammarus (Lin.).--Rocky shores nr. mouth of Firth, c., (H.): E. L. Tarbert, etc.

\section{Fam. Crangonidae.}

Crangon vulgaris (Lin.).-Mod. c.; shall. w. inshore, on sandy, weedy bottom.

C. allmanni, Kinahan.-C. and gen. dist., mostly in d. w.

Egeon sculptus (Bell.).-Lamlash B., 5 f., two (A.M. N.) ; off Muggie Pt., L. Cumbrae, 20 f., one (H.).

Pontophilus spinosus, Leach.-Not c.; many localities as far up as Cloch L.H., usually soft ground 20-60 f. (H.).

Cheraphilus nanus ( $K r$.). - Off Cumbrae (R.) : Ballantrae Bank (F. S. G.).

C. echinulentus, M. Sars.-Off Skate I., L. Fyne, 105 f., one (H.) : not very r. at mouth of estuary (F.S. G.).

C. neglectus, G. O. Sars.-Occasionally in E. L. Tarbert and vicinity, 5-20 f. (S.).

\section{Fam. Nikidae.}

Nika edulis, Risso.-One off Skate I., 105 f. ; one off Brodick 93 f. (H.) : occasionally in shrimp-trawl in seaward part of estuary (F. S. G.).

\section{Fam. Hippolytidae.}

Caridion gordoni (Bate).-Lamlash B. (A. M. N.) : not c. throughout Firth ; d. w. (H.). 
Hippolyte varians, Leach.-C. ; rock pools 1. w., and lam. zone (H.) : c. E. L. Tarbert.

H. prideauxiana, Leach.-Shrimp trawl nr. mouth of estuary, 11/96 (F.S.G.).

[H. fascigera, Gosse.-E. L. Tarbert, amongst zostera, not r. Now considered to be a form of $H$. varians.]

Spirontocaris spinus (Sowerby), var. Hippolyte securifrons, Norm.-Is mod. c. Typical S. spinus at mouth of estuary, but r. (vide Stebbing).

S. cranchii (Leach).-L. Fyne ; off Cumbrae ; off Craigmore ; Hawk's Neb, Bute (H.) : E. L. Tarbert (S.).

S. pusiola $(K r$. $)$.-Off Cumbrae (R.) : L. Goil ; L. Long (H.).

S. gaimardii (M. Edw.).-Gen. dist., prob. not very r. (H.).

\section{Fam. Pandalidae.}

Pandalus montagui, Leach.-C. and gen. dist.; largest and most highly coloured from $d$. w.

P. bonnieri, Caullery.-L. Fyne ; L. Long (Calman).

P. propinquus, G. O. Sars.-I. L. Fyne ; L. Long, 40 f. (Calman).

Pandalina brevirostris, (Rathke).-C. and gen. dist. (H.)

Fam. Palaemonidae.

Leander squilla ( $\operatorname{Lin}$. .).-C. ; rock pools (H.).

Palaemonetes varians (Leach).-C'umbrae at l. w. (R.) : Inverkip (S.)

Fam. Pasiphaeidae.

Pasiphaea sivado (Risso).-Off Skate I. 105 f. (H.) : off Strachur 70 f. (M.) : mid-water tow-net, L. L. Fyne; not r. at mouth of estuary (F. S. G.).

\section{Sub-Order Schizopoda.}

Arraygement and Nomexclature Followed.

Rer. Canon A. M. Norman, F.R.S., D.C.L., "Revision of the Brit. Species of Schizopoda" (Ann. and Mag. N. H., Ser. 6, vol. ix., pp. 454-464, and Ser. 6, vol. x., pp. 143-166 : and pp. 241-263, 1892).

\section{Fam. Euphausiidae.}

Rhoda raschii (M. Sars) (= Boreophausia raschii).-Gen. dist., sometinies c. esp. in L. Fyne.

R. inermis $(K r$.$) .-Clyde (Brook ; Hoyle). Off Sanda I. 20-27$ f. (F. S. G., $15 / 12 / 98)$.

Nyctiphanes norvegica (M. Sars).-Gen. dist., usually more c. in L. Fyne than elsewhere.

Thysanoessa neglecta $(K r$.$) .- In bottom tow-net bet. Ailsa Craig and$ Sanda I. 20 f. (F. S. G., 16/1/99).

\section{Fam. Mysidae.}

Siriella clausii, G. O. Sars.-E. L. Tarbert ; L. Gilp ; r. (F. S. G.).

S. brooki, Norman.-E. L. Tarbert, 1886 (S.).

S. armata (M. Edw.).-Cumbrae, in surface tow-net, r. (R.) : E. L. Tarbert; L. Gilp (S.).

Gastrosaccus spinifer (Goës).-F. of Clyde (R.) ; nr. Sanda I.; nr. Ailsa Craig 20-30 f. ; S. of Davaar I. 7-10 f. (F. S. G.).

Anchialus agilis, $G$. O. Sars.-Nr. Sanda I. 20-27 f. (F. S. G., 15/12/98).

Heteromysis formosa, S. I. Smith.-Dredged, Tarbert Bank, L. L. Fyne (F. S. G., 1899) : r.

Erythrops elegans, G. O. Sars.-Gen. dist. from U. L. Fyne to seaward limits of estuary ; rarely captured except in bottom tow-net.

E. serratus, $G$. O. Sars.-Dist. somewhat similar to E. elegans. 
Mysidopsis didelphys (Norman).-Off Cloch L.H. 43 f. (H.) : dist. from U. L. Fyne to mouth of estuary.

M. gibbosa, G. O. Sars.-Gen. rlist. but not very c.

M. angusta, G. O. Sars.-L. Fyne and nr. Ailsa Craig; not c. (F. S. G.)

Leptomysis gracilis, G. O. Sars.-U. L. Fyne; nr. Ailsa Craig, etc.

I. lingvura, G. O. Sars.-Gen. dist., but not very c.

Hemimysis lamornae (Couch).-Port Glasgow ; L. Goil (R.) : E. L. Tarbert ; nr. Ailsa Craig; Davaar I. (F. S. G.).

Praunus flexuosus (Wüller).-More or less c. ; usually more so inshore than in d. w.

P. inermis (Rathke)-Cumbrae in Lam. zone (H.) : E. L. Tarbert, etc. (F. S. G.).

[P neglectus (G.O. Sars).-Mouth of L. Fyne 60 f. (H.): never met with by (S.)].

Schistomysis spiritus, Norman.-E. of Sanda I., surface tow-net 24/1/99 (F.S. G.).

S. ornata, $(G$. O. Sars).-Head of L. Fyne; bet. Ailsa Craig and Sanda I. ; scarce.

S. arenosa (G. O. Sars).-E. L. Tarbert ; shallow water, not r. ; Ettrick B., Bute (1887) (S., A. M. N.).

Neomysis vulgaris (.J. V. Thompson).-Dhu Loch, nr. Inveraray, not r.; in stomach of 15 spined stickleback nr. head of L. Fyne (S.). (Bell suggests this =Mysis integer recorded by Leach from L. Ranza.)

\section{ORDER EDRIOPHTHALMA.}

$$
\text { Sub-Order Sympoda. }{ }^{1}
$$

Arrangement and Nomenclature.

Prof. G. O. Sars, Crustacea of Norway, vol. iii.

\section{Authorities.}

(R.) = Dr. Robertson, F.G.S., "Thirteen Cumacea from the Firth of Clyde" (Nat. Hist. Soc. Glas. T'rans., vol. iii. (N. S.), p. 47, 1889).

(S.)=Thomas Scott, F.L.S., "Scottish Cumaceans" (Ann. Scot. N. H., Oct. 1900). Rev. T. R. R. Stebbing, A History of the Crustacea.

(A. M. N.) = Rev. Canon A. M. Norman, D.C.L., F.R.S, "On a Crangon, some Schizopoda and Cumacea, new or rare in the British Seas" (4th Ann. Rep. Fish. Bd. for Scot., 1886).

[' ${ }^{1}$ See Stebbing on change of "Cuma" and "Cumacea" to "Bodotria," and "Sympoda," in Memoir On Crustacea brought by Dr. Willey from the South Seas (Camb. Univ. Press) Dec. 1900].

\section{Fam. Bodotriidae.}

Bodotria arenosa, Goodsir.-Blackwaterfoot, Arran, 4-5 f. (R.).

B. scorpioides (Nont.).-Dredged, Ballantrae Bank, 6/9/98 (S.).

B. pulchella, G. O. Sars.-Dredged ur. Sanda I. (S.).

Iphinoë trispinosa (Goodsir).-Plentiful Kames B., Millport; L. Ranza (R.): U. L. Fyne ; Kilbremnan Sd. (S.).

I. serrata, Norman.-Kames B., Bute, 1887 ; off Ballantrae, 1899 (S.).

I. tenella, G. O. Sars.-Clyde (Stebhing).

Cumopsis edwardsii (Spence Bate) (=C. goodsiri), V. Ben.).-Shore pools Millport (S.).

C. longipes (Dohrn).-Shore pools Millport (R. ; S.)

Fam. Vaunthompsoniidae.

Vaunthompsonia cristata, $S p$. Bate.-E. L. Tarbert 1886 ; Ballantrae Bank, 15-20 f. 1899 (S.). 
Fam. Lampropidae.

Lamprops fasciata, G. O. Sars.-W. of Helensburgh Pier (R.) : E. L. Tarbert; Hunterston Sands (S.), freq.

Hemilamprops rosea (Norman).-U. L. Fyne ; Kilbrennan Sd. 1899, r. (S.) H. cristata, G. O. Sars.-F. of Clyde 1860 by Robertson (A. M. N.).

\section{Fam. Leuconidae.}

Leucon nasica, Kröyer:-U. L. Fyne ; off Arran, E. side 43 f. (S.).

Eudorella emarginata (Kröyer).-Rothesay B., 12 f. (R.) : d. w. bet. Arran and Ayrshire (S.).

E. truncatula (Sp. Bate).-L. Fyne ; nr. Ailsa Craig (S.).

Eudorellopsis deformis (Kröyer)._Nr. Ailsa Craig; off Sanda I. (S.).

Fam. Diastylidae.

Diastylis rathkii (Kroyer).-E. L. Tarbert, 1886-87 (S.), r.

D. rugosa, G. O. Sars.-L. Ranza, 5 f. ; Blackwaterfoot, Arran, 20 f. (R.): E. L. Tarbert, 1886 (S.).

D. lucifera (Kröyer).-Clyde district, mod. r. (S.).

D. rostrata (Goodsir). - Blackwaterfoot, 20 f. (R.): Kames B., Bute, 15 f. (S.).

D. tumida Lillj.-R., Blackwaterfoot, 20 f. (R.).

D. spinosa, Norman.-Dredged Blackwaterfoot; W. side of Helensburgh Pier l. w. (R.).

Diastyloides biplicata, G. O. Sars.-Blackwaterfoot, 20 f. (R.) : L. Fyne; off E. of Arran 40 f. ; nr. mouth of estuary 64 f. (S.).

Leptostylis villosa, G. O. Sars.-Bet. Arran and Ayrshire coast, $40 \mathrm{f}$. 1896 (S.).

Fam. Pseudocumidae.

Pseudocuma cercaria ( V. Ben.).-Kames B., Millport (R.): freq. and gen. dist.

P. similis, G. O. Sars.-D. w. nr. seaward limit of estuary, 12/1899 (S.).

\section{Fam. Nannastacidae.}

Nannastacus unguiculatus, Sp. Bate.-Kames B., Millport, m. c. (R.): L. Fyne; Kilbrennan Sd., \&c. (S.).

Cumella pygmaea, G. O. Sars._Cumbrae (R.) : L. Fyne ; Whiting B. ; Kilbrennan Sd., \&c. (S.).

\section{Fam. Campylaspidae.}

Campylaspis rubicunda (Lillj.).-U. L. Fyne, 30-40 f. ; E. of Arran, 40 f. ; E. of Sanda I., 30 f. (S.).

C. sulcata, G. O. Sars.-Single specimen off Cumbrae 20 f., 15/8/88 (A.M. N.).

C. costata, G. O. Sars.-U. L. Fyne 30-40 f.; Kames B., Bute, 15-20 f. (S.): off Cumbrae, 20 f. (A. M. N.).

\section{Sub-Order Isopoda.}

Arrangement and Nomenclatere.

Sars, Prof. G. O., Crustacea of Norvay, vol. ii.

\section{Aбthorities.}

$($ R. $)=$ Robertson, Dr. D., F.G.S., F.L.S., "Catalogue of the Amphipoda and Isopoda of the Clyde," Parts i. and ii. (N.H. Soc. Glas. Trans., vol. ii. iii. (N. S.).

Stebbing, Rev. T. R. R., History of the Crustacea.

(A.M.N.) $=$ Norman, Rev. Canon, A.M., D.C.L., F.R.S., "British Isopoda Chelifera" (Ann. and Mag. N. H., Ser. 7, vol. iii., 1899). 
(S.) = Scott, Thos., F.L.S., "Notes on some Scottish marine Isopods" (Ann. Scot. N. H., 1898).

Explanation of Abrreviations.

(R. I, 70)= reference to page 70, Part I. of Robertson's Catalogue.

(R. I, 24. 73, II, 15.) = recorded three times under different or corrected names. This formula used both in Isopoda and Amphipoda.

Fam. Apseudidae.

Apseudes talpa (Mont.)-Roots of Laminaria Tan, Cumbrae, 7 f. (R. II, 28).

\section{Fam. Tanaidae.}

Tanais cavolinii, M.-Edw. (T. vittatus, Bate and Westw.).-Farland Pt., Cumbrae (A. M. N.) : amongst barnacles at 1. w. E. L. Tarbert (S.): Cumbrae (R. I, 70).

Paratanais batei, G. O. Sars-Cumbrae (R. I, 70): L. L. Fyne ; Whiting B. (S.).

Leptognathia longiremis, (Lillj.).-L. Fyıe (S.).

L. rigida, (Bate \& Westw.).-Nr. Tan Buoy 7.8 f. (R. I, 70).

L. breviremis (Lillj.).-Bet. Arran and Ayrshire, 40 f.; Tarbert Bank; L. L. Fyne, 25 f. (S.).

L. brevimana (Lillj.).-Off Sanda I. 20-30 f. ; Ballantrae Bank, 14 f. (S.).

Tanaopsis laticaudata, G. O. Sars.-Nr. Cumbrae (A. M. N.: R. II, 29): L. Gair (L. Fyne), 2-3 f. ; Campbeltown L. 5 f. (S.).

Pseudotanais forcipatus (Lillj.).-Tarbert Bank; L. L. Fyne 25 f. (S.).

Fam. Gnathiidae.

Gnathia maxillaris (Mont.).-Gen. dist. ; female more c. than male. G. halidaii (Sp. Bate).-Kames B., Cumbrae (R. I, 71).

\section{Fam. Aegidae.}

Aega tridens, Leach.-Off S. end of Cumbrae; nr. Arran (R. I, 72) : Rothesay B. (S.) : parasitic on fishes.

[Ae. rosacea (Risso), (Ae. bicarinata, Leach).-L. Fyne 15 f. (R. I, 72).].

Fam. Cirolanidae.

Cirolana borealis (Lillj.), (C. spinipes, Bate and Westw.).-Cumbrae; L. Cumbrae, N. side, 27 f. ; mouth of L. Fyne 37 f. (R. I, 73) : not r. from d. w.

C. cranchii, Leach.-Farland Pt., Cumbrae, 14 f. r. (R. I, 72).

Conilera cylindracea (Mont.).-Bet. Bute and Cumbrae, 50 f. (R. I, 73) : F. of Clyde (A. M. N.).

Eurydice achata (Slabber), (E. pulchra, Leach.).-Fairly freq. shall. sandy bays (R. I, 74).

\section{Fam. Sphaeromidae.}

Sphaeroma serratum (Fabr.).--Taken on Ayr sands (R. I, 81).

S. curtum, Leach.-Off Portincross, Ayrshire, 6 f. (R. I, 82).

S. rugicauda, Leach.-Brackish pools; Hunterston (R. I, 82): Inverkip; Langbank, c. (S.).

S. hookeri, Leach.-Brackish pool, S. side of L. Cumbrae (R. II, 29).

Dynamene rubra, Mont.-Cumbrae (A. M. N. vide R. I, 82).

D. viridis, Leach. - Bet. t. m., Portloy, Cumbrae (R. II, 29).

Naesa bidentata (Adams).--With the last at Portloy (R. I, 84). [Note.For last three species and D. montague, Leach., vide Stebbing, p. 361.]

Fam. Limnoriidae.

Limnoria lignorum (Rathke).-C. on woodwork of piers and jetties (R. I, 77). 


\section{Fam. Idotheidae.}

Idothea baltica (Pallas), (I. tricuspidata, R.).-C. and gen. dist. (R. I, 79). I· pelagica, Leach.-Amongst weeds at l. w. Cumbrae (R. I, 79) : rocks nr. l. w., E. L. Tarbert (S.).

I. emarginata (Fabr.).--Amongst weeds at l. w., Cumbrae (R. I, 80).

I. linearis (Pennant).-In a sandy pool at l. w., Cumbrae (R. I, 80).

Zenobiana prismatica, Risso, (Idotea parallela, R.).-Dredged bet. Tan Buoy and Hawk's Neb, Bute, 50 f. (R. I, 80).

Stenosoma acuminata (Leach), (Idotea acuminata, $R$.).-Nr. l. w., Cumbrae; sandy pools, Kilchattan B. (R. I, 81).

\section{Fam. Astacillidae.}

Astacilla longicornis (Sowerby), (Arcturus longicornis, R.).-gen. dist. (R. I, 78).

[A. gracilis (Goodsir).-(R. I, 78), is the male of A. longicornis (Sars.)].

Arcturella dilatata, G. O. Sars. (Leacia dilatata, R.).-Off Blackwaterfoot, Arran, 20 f. (R. II, 28).

\section{Fam. Asellidae.}

Asellus aquaticus (Lin.).-C., in fresh-water ponds, canals, \&c. (R. I, 77)

Fam. Janiridae.

Janira maculosa, Leach.-L. w., Portloy, Cumbrae; mouth of L. Fyne 40-60 f. ; off Dunoon 13 f. (R. I, 76) : E. L. Tarbert ; Campbeltown L., \&c. (S.).

Jaera marina (Fabr.).-C. in shall. w., and under stones bet. t. m. (R. I, 74).

[J. nordmanni (Rathke).-(R. I, 75). Sars suggests that the form described by Spence Bate under this name may not be the true Rathkian species but the male of $I$. marina].

\section{Fam. Munnidae.}

Munna boeckii, $k r$. - Whiting B. (S.).

M. kroyeri, Goodsir.-Cumbrae, from nests of Lima hians (R. I, 76).

[M. Whiteana, Sp. Bate.-(R. I, 75), is the female of M. kroyeri (Sars).].

Paramunna bilobata, G. O. Sars.-F. of Clyde (A. M. N.): E. L. Tarbert ; Kilbrennan Sd., \&c. (S.).

[Leptaspidia brevipes (Sp. Bate).-Off Cumbrae (R. I, 76). Norman suggests this is a Pleurogonium].

Pleurogonium rubicundum, G. O. Sars.-F. of Clyde (A. M. N.). At mouth of estuary 64 f. Dec. 7 th, 1899 (F.S. G.).

P. inerme, G. O. Sars.-Off Farland Pt., Cumbrae, 23 f. (R. II, 29) : Kilbrennan Sd. ; Campbeltown L. (S.).

P. spinosissimum, G. O. Sars.-Off Farland Pt., Cumbrae (R. II, 29).

\section{Fam. Munnopsidae.}

Eurycope phallangium, G. O. Sars.-L. Fyne, r., 30-40 f. (S.).

Fam. Oniscidae.

Ligia oceanica ( $\operatorname{Lin}$.).-Under stones, \&c. ; more or less c. in various places. (Note:-This and the following eight species are land Isopods, and may be found under stones, old wood, \&c.)

\section{Fam. Trichoniscidae.}

Trichoniscus pusillus, Brandt.-Cumbrae (R. I, 86): Rothesay, nr. Aquarium (S.). Prob. not unc. if carefully sought for.

T. roseus, Koch.-E. Tarbert (S.) 


\section{Fam. Oniscidae.}

Oniscus asellus (Lin.).-Gen. dist. and mod. c.

Philoscia muscorum (Scopoli).-Widely dist. and not very unc. (R. I, 85). Porcellio scaber, Latr.-C. and gen. dist.

P. pictus, Brandt.-Cumbrae (R.): Ayrshire (Smith): nr. Campbeltown, 1896 (S.).

Cylisticus convexus (De Geer), (Porcellio armadilloides, $R$.).-Kilwinning (Smith, vide R. I, 88) : Lanarkshire ; Rothesay (S.).

Armadillidium vulgare (Latr.).-Mouth of Garnock (Smith, see R. I, 88).

\section{Fam. Bopyridae.}

Cryptothir balani (Sp. Bate).-One taken from a Balanus, on shore, E. L. Tarbert, 1886 (S.).

Pseudione affinis, G. O. Sars.-On a Pandalus montagui in shrimp trawl nr. Sanda I., $5 / 97$ (F. S. G.).

P. hyndmanni (Bute \& Westw.).-L. Fyne, 1886 ; and Clyde (S.).

P. crenulata, G. O. Sars.-From a small Munida rugosa in shrimp trawl, nr. Sanda I., $5 / 97$ (F. S. G.).

Pleurocrypta hendersonii, Giard \& Bonnier.-On Galathea dispersa. Clyde (Henderson, vide Stebbing).

Atheleges paguri (Rathke).-On Eupagurus bernhardus, L. Fyne; E. L. Tarbert.

Phryxus abdominalis ( $K r$.).-On Spirontocaris spinus in shrimp trawl, nr. Sanda I. (F.S. G.).

\section{Fam. Dajidae.}

Aspidophryxus peltatus, G. O. Sars.-On backs of Erythrops nr. Davaar I., \&c.

Note.-A recent monograph on the Bopyridae by M. Jules Bonvier gives the following Clyde records. Bonnier often differs from Sars as to what are distinct species.

Bopyroides sarsi, Bonnier.--Branchial cavity of a typical Spirontocaris spinus (Soverby), dredged nr. mouth of Clyde estuary (F. S. G., Aug. 30th, 1899). Distinct from B. hippolytes ( $K r$.).

Pseudione affinis, G. O. Sars.-Branchial cavity of Pandalus leptorhynchus, Kinahan. Firth of Clyde (Hoyle).

P. hoylei (Giard \& Bonnier).-Branchial cavity of Pandalus montagui, Leach. Firth of Clyde (Henderson; Hoyle ; F. S. G. ; Patience). According to Sars $P$. hoyle $i$ is identical with $P$. affinis.

P. hyndmanni (Bate \& Westwood).-Branchial cavity of Eupagurus bernhardus (Lin.). Clyde (Henderson and myself). See remarks by Prof. Sars and M. Bonnier.

P. insignis (Giard \& Bonnier) (=P. crenulata, G. O. Sars, of my list).According to M. Bonnier the Pseudione of Munida rugosa is a different sp. from P. crenulata, $G$. O. Sars, found on Munida tenuimana; Sars considers them the same species.

P. sp.-From the branchial cavity of Pandalina brevirostris (Rathke). Clyde (Henderson, as Bopyrus sp.).

(?) P. sp.-From the branchial cavity of Eupagurus prideauxi (Leach). Clyde (Henderson, as Bopyrus sp.).

Pleurocrypta hendersoni, Giard \& Bonnier (=P. marginata, G. O. Sars. Scott, in 18th Ann. Rept. Fishery Board for Scotland, Pt. III., p. 403). From branchial cavity of Galathea dispersa, Bate. F. of Clyde (Henderson; F.S. G. ; Patienee). According to M. Bonnier the P. marginata, G. O. Sars, from Norwegian specimens is different from that on English specimens of the same decapod. 
P. intermedia, Giard \& Bonnier (=P. microbranchiata, G. O. Sars).Branchial cavity of Galathea intermedia, Lillj., F. of Clyde (Henderson, as Bopyrus sp.).

Atheleges paguri (Rathke).-On abdomen of Eupagurus bernhardus (Lin.). F. of Clyde (Henderson (as Phryxus paguri); F. S. G.).

Phryxus abdominalis $(K r$.$) .--On abdomen of Spirontocaris spinus (Sowerby),$ S. securifrons, Norm., and Pandalus montagui, Leach. F. of Clyde (Henderson; F.S.G.; Patience). M. Bonnier doubts whether the Phryxus found on these species are identical with abdominalis, Kroyer, found on Spirontocaris gaimardi (M.-Edw.). Prof. G. O. Sars, on the other hand, regards them as belonging to that species.

P. cranchii, Giard \& Bonnier.-On abdomen of Hippolyte cranchii, Leach. F. of Clyde (Henderson as Phryxus sp.).

\section{Sub-Order Amphipoda.}

Arrangement Followed.

Prof. G. O. Sars, Crustacea of Norway, vol. i.

\section{Authorities.}

Robertson, Dr. D., F.G.S., F.L.S.- "Catalogue of the Amphipoda and Isopoda of the Clyde," (N. H. Soc. Glas. Trans., N.S.), vol. ii. p. 1, vol. iii. p. 199.

Norman, Rev. Canon A. M., D.C.L., F.R.S., "A Revision of the British Amphipoda," Ann. and Mag. I. $H$.

Stebbing, Rev. T. R. R., Papers on British Amphipoda.

Walker, A. O., Papers on British Amphipoda.

Fam. Hyperiidae.

Hyperia galba (Nont.).-In folds of Rhizostoma pulmo, Cumbrae (R. I, 64) : E. L. Tarbert (S.). F. of Clyde (A. M. N.).

Hyperoche tauriformis $\left(\dot{B} . \& W^{*}\right.$.).-Off Sanda; nr. Ailsa Craig; Kilbrennan Sd.; U. L. Fyne (S.).

Parathemisto oblivia $(K r$. ). - Nr. Sanda, in surface net (R. I, 65) : off Ailsa Craig (F.S. G.).

\section{Fam. Orchestiidae.}

Talitrus locusta (Pallas).--Sandy shores, abund. (R. I, 10). U. L. Fyne (S.). Orchestia littorea (Mont.).--Under stones $\mathrm{nr}$. and above h.w. m., freq. (R. I, 11).

O. mediterranea, Costa.-Cumbrae ; mouth of R. Garnock (R. I, 13): bet. Fairlie and Hunterston (S.). Inveraray (A. M. N.).

Hyale nilssoni (Rathke).-Kames B., Millport (R. I, 13).

H. lubbockiana (Bate).-Largs Pier; tide pools Cumbrae (R. I, 13-14): E. L. Tarbert ; Fintry B., Bute (S.).

\section{Fam. Lysianassidae.}

Normanion quadrimanus (B.\&W.).-Off Farland Pt., Cumbrae (R. II, 12): Nr. Davaar Is., 1898 ; Tarbert Bank, L. L. Fyne, 1901 (F.S. G.).

Acidostoma obesum (Bate).-Off Farland Pt., Cumbrae (R. I, 17).

Lysianax septentrionalis, Della Valle.-Cumbrae; off Skelmorlie Buoy; W. end of L. Cumbrae (R. I, 15-16): E. L. Tarbert; U. L. Fyne (F.S. G.).

L. ceratinus A. O. W.-F. of Clyde (A. M. N.).

L. atlanticus (M. Edw.).-Nr. Tan Buoy, Cumbrae (R. I, 17).

Socarnes vahli $(K r$.$) . - N. side of Clach Rock, Cumbrae, 6$ or 7 f. (R. II, 5).

S. erythrophthalmus, Robertson.-Tan, Cumbrae ; Castle-B., L. Cumbrae ; Rothesay ; Millport B. (R. II, 6). 
Sophrosyne robertsoni, Stebbing and Robertson-(Clyde R. II, 9) : U. L. Fyne (M.).

Perrierella audouiniana (Bate).-In a sponge, mouth of L. Fyne, 40-60 f. (R. I, 16 ; II, 7) : U. L. Fyne (M.) : Tarbert Bank; E. of Sanda, $30 \mathrm{f.}$ (F. S. G.).

Callisoma hopei, A. Costa [=Callisoma crenata (Bate)].-L. Fyne, 80 f. ; Kilchattan B., 30 f. (R. I, 19). Gen. dist.

Hippomedon denticulatus (Bate).-Nr. Tan Buoy; Castle-B., L. Cumbrae, \&c. (R. I, 18 ; II, 9). Gen. dist.

Orchomene humilis (A. Costa) (= Anonyx edwardsii, Bate and Westwood).--Tan Buoy ; L. Striven ; L. Goil ; L. Fyne (R. I, 17 ; II, 11); Whiting B. (S.).

Tryphosa pinguis (Boeck).-Dredged w. of Tan Buoy, 18 f. (R. II, 9).

T. nana $\left(K r_{\text {. }}\right)$. -W. of Tan Buoy, $14 \mathrm{f}$. (R. II, 10) : off Ballantrae, rather $\mathrm{r}$. (F. S. G.).

T. minuta ( $K r$. ).-Minard, U. L. Fyne (M.).

Tryphosella sarsi, Bonnier.-Off Farland Pt., Cumbrae, 23 f. (R. II, 11): off Largabruach ; off Inveraray, U. L. Fyne (F. S. G.).

T. höringii, (Boeck).-Cumbrae, on back of a codfish (R. I, 92).

T. nanoides (Lillj.).--Cumbrae, on back of a codfish (R. I, 92).

[T. pusilla, G. O. Sars.--Tan buoy 12 f. (R. II, 12).].

Tryphosites longipes (Bate).-Off N.E. corner of L. Cumbrae $14 \mathrm{f}$.; bet. Kilchattan and Cumbrae 66 f. $($ R. I, 18) : Kilbremnan Sd. ; E. L. Tarbert, \&c. (F. S. G.).

Hoplonyx cicada (Fabr.).-Bet. the Allans, Cumbrae, 2-4 f. (R. I, 18): Tarbert Bank, L. L. Fyne, 20-25 f. ; rather r. (F. S. G.).

H. similis, G. O. Sars.-Off Farland Pt., Cumbrae (R. Il, 12).

Lepidepecreum carinatum (Bate).-L. Ranza B. 5 f.; S. E. of Bute 10-12 f. (R. I, 91).

Euonyx chelatus, Norman.-Off Mull of Kintyre 49 f. (R. I, 90) : several dredged nr. mouth of estuary, 11/95 (F. S. G.).

\section{Fam. Pontoporeiidae.}

Bathyporeia pelagica, Bate.-Sandy shores bet. t. m., various places (R. I, 42): Cumbrae (A. M. N.).

B. norvegica, G. O. Sars.-Cumbrae (A. M. N.).

B. robertsoni, Bate.-Cumbrae (A. M. N.).

Haustorius arenarius (Slabber).-Sandy shores nr. 1. w. m., mod. c. (R. I, 23) : Cumbrae (A. M. N.).

Urothöe elegans, Bate.-Cumbrae (A. M. N.).

U. marinus, Bate.-Bet. t. m. Irvine and Fairlie ; Lanlash B. ; Kames B. ; Fintry B. ; Balloch B., Cumbrae (R. I, 29-30) : Barmore, L. L. Fyne (S.).

U. brevicornis, Bate. -F. of Clyde (R., vide A. M. N.).

Argissa hamatipes (Norman).-Kilchattan B., Bute, 8-9 f. (R. II, 12) : not unc. in seaward part of estuary.

\section{Fam. Phoxocephalidae.}

Phoxocephalus holbölli $(K r$.).-Dredged bet. the Allans, taken nr. l. w. m. Balloch B., Cumbrae (R. I, 24): Nillport B. bet. t. m. (A. M. N.).

P. fultoni, T. Scott.-Cumbrae, l. w. m. (R.) : L. Ryan (Fullerton) : F. of Clyde (A. M. N.).

P. simplex (Bate).-Tan Buoy 6 f. (R. I, 23).

P. oculatus, G. O. Sars.-(I think R. obtained this sp. in the Clyde).

Harpinia neglecta, $G$. O. Sars.-L. Ranza, 6-8 f. ; L. Fyne 80 f. (R. I, 24) : Clyde, gen. dist. (A.M. N.).

H. crenulata, G. O. Sars.-Campbeltown L. (S.) : off Farland Pt.; Cumbrae (A. M. N.): $r$. 


\section{Fam. Ampeliscidae.}

Ampelisca typica (Bate).-R. records this as A. gaimaidii (Spence Bate) from various places (R. I, 20): Cumbrae (A. M. N.).

A. tenuicornis, Lillj.-L. Fyne 80 f.; bet. Tan Buoy and Bute; L. Goil 12 f. (R. I, 21-22) : Campbeltown L. (A. M. N.).

A. assimilis, Boeck.-Row B., Gareloch, 10-12 f. (R. I, 22): off Sanda (F.S. G.).

A. brevicornis (A. Costa).--Off S. shore, Cumbrae; opposite Largs, 15 f.; off Fairlie 20 f. ; l. w. Crarae, L. Fyne, \&c. (R. I, 21) : nr. Ailsa Craig; off Sanda I. (F. S. G.).

A. macrocephala, Lillj._Off Brodick 80 f. (R. I, 22): Cumbrae (A. M. N.).

A. spinipes, Boeck.-Off Cumbrae L.H. 60 f.; off Holy I. 36 f. ; nr. Skate I. 80-100.f. (R. I, 91) : Cumbrae (A. M. N.).

Haploops tubicola, Lillj.-_Off L. Cumbrae 60 f.; L. Striven 35 f.; off Dunoon 15-25 f. ; off Fairlie 6.8 f. (R. I, 22,92): off Sanda I. (A. M. N.).

H. setosa, Boeck.-Off Skate I., L. Fyne, 100 f., two specimens (R. I, 23).

\section{Fam. Stegocephalidae.}

Stegocephaloides christianiensis (Boeck).-L. Fyne 40-70 f. (R. II, 20) : nr. head of L. Fyne (F.S. G.).

\section{Fam. Amphilochidae.}

Amphilochus manudens, Bate.-Off Tan Buoy 7-8 f. ; off Cumbrae L.H., 60 f. (R. I, 28).

A. tenuimanus, Boeck.-Off Farland Pt., Cumbrae, 17 f. (R. I, 28) : Ballantrae Bank (F. S. G.).

Amphilochoides serratipes (Norman).-Off Blackwaterfoot 20 f.; off Clach Rock, Cumbrae (R. II, 20-22) : off Sanda ; at Ballantrae Rk. ; off Ailsa Craig (F. S. G.).

Gitanopsis bispinosa (Boeck). - Off Blackwaterfoot 20 f. (R. II, 20).

Gitana sarsii, Boeck.-Kilchattan B. 5 f. (R. II, 2): Whiting B., Arran ; off Sanda I. 20 f. (F. S. G.).

Cyproidia damnoniensis, Stebbing.-Off Blackwaterfoot; off Farland Pt., Cumbrae (R. II, 21).

Stegoplax brevirostris (T. and A. Scott).-Tarbert Bank, L. Fyne, r. (S.).

\section{Fam. Stenothoidae.}

Stenothoe marina, Bate.-Cumbrae at l. w.; off Dunoon (R. I, 15): Whiting B. ; off Ailsa Craig (F. S. G.).

S. monoculoides (Montagu).--Various places about Cumbrae (R. I, 14): F. of Clyde (A. M. N.).

\section{Fam. Metopidae.}

Metopa alderi (Bate).-Bet. Cumbrae L. H. and Arran (R. I, 90).

M. borealis, G. O. Sars.-Off Farland Pt., Cumbrae, 20 f. (R. II, 21) : E. of Arran 30-40 f. (F. S. G.).

M. rubrovittata, G. O. Sars.-Off the N. side of L. Cumbrae, 10-15 f. (R. II, 21).

[M. affinis, Boeck.--W. of Tan Buoy ; Mull of Kintyre (R. I, 90).]

M. pusilla, G. O. Sars.-Off Farland Pt., Cumbrae, 20-24 f. (A. M. N.).

Metopella nasuta, (Boeck).-O Off Farland Pt., Cumbrae, 19 f. (R. II, 22).

\section{Fam. Cressidae.}

Cressa dubia, Bate.-W. of Tan Buoy, 7-8 f. (R. I, 15): Whiting B.; off Sanda I. (F. S. G.) : Cumbrae (A. M. N.). 


\section{Fam. Leucothoidae.}

Leucothoë spinicarpa (Abilgaard).--Nr. Tan Buoy, 5 f.; L. Fyne, 92 f. (R. I, 39): Whiting B. (F.S. G.).

[L. incisa, Robertson.-L. w. Balloch B.; Farland Pt., Cumbrae, 20 f. (R. II, 23) (?) : L. Gair (L. Fyne) (F. S. G.). Norman considers this only a form of the next species.]

L. lilljeborgii, Boeck.-L. Gair; head of U. L. Fyne ; r. (F. S. G.).

\section{Fam. Oediceridae.}

Monoculodes carinatus, Bate.--Several places about Cumbrae (R. I, 25.).

M. borealis, Boeck.-Off Blackwaterfoot, (R. II, 15).

M. tuberculatus, Boeck.-In d. w. E. of Arran, r. (F. S. G.).

M. packardi, Boeck--L. Striven, 40 f. (R. II, 14): L. Fyne, 30-60 f. ; E. of Arran, 40 f. ; not very r. (F.S. G).

Perioculodes longimanus (Bate).--Gen. dist., not unc. in d. w. (vide R. I, 26).

Pontocrates altamarinus (Bate).-Callum's Bay, Bute, 16 f. (R. I, 2ī): U. L. Fyne (S.).

P. norvegicus, Boeck.-Shall. w. in sandy bays freq. (R. I, 26).

Synchelidium brevicarpum (Bate).-Nr. Cumbrae; L. Fyne; Blackwaterfoot (R. I, 25; II, 16).

Halimedon parvimanus (Bate).-Various places (R. I, 24, 93 ; II, 15) : gen. dist.; not r. in d. w.

\section{Fam. Pleustidae.}

Paramphithoë bicuspis $(K r$.).-In surface tow-net after sunset, Cumbrae (R. I, 36).

P. monocuspis, G. O. Sars.-Off Sanda I., r. (F. S. G.).

P. assimilis, G. O. Sars.-Off Cumbrae, 15-20 f. (R. I, 94).

Stenopleustes nodifer, G.O. Sars.-Off N. side of L. Cumbrae, $20 \mathrm{f}$; off Fairlie Perch, 20 f. (R. II, 18).

\section{Fam. Epimeridae.}

Epimeria cornigera ( $F a b$. .).--Not unc. in d.w. (R. I, 32). Mouth of estuary, and in d. w. bet. Arran and Ayrshire coast (F. S. G.).

Fam. Iphimedidae.

Iphimedia obesa (Rathke).-Gen. dist.; not very r.

I. minuta, G. O. Sars.--Off Farland Pt., Cumbrae, 20 f. (R. II, 23).

I. elbanae, Bate.-Dredged nr. mouth of estuary (F. S. G.).

Odius carinatus (Bate).-Off Garnock Beacon, $5 \frac{1}{2}$ f. (R. II, 31).

Fam. Laphystiidae.

Laphystius sturionis ( $K r$.).-Kilbremnan Sd. (R. I, 93) : Rothesay B. (S.). Parasitic on Cod, Anglerfish, etc.

\section{Fam. Syrrhoidae.}

Syrrhoë fimbriatus, Stebbing and Robertson.-Clyde (R. II, 22).

Bruzelia typica, Boeck.-W. of Tan Buoy, 12-20 f. (R. II, 22).

Fam. Eusiridae.

Eusirus longipes, Boeck.-W. of Tan Buoy, 10 f. ; L. Goil, 12 f. (R. I, 38) : nr. Sanda I. ; head of L. Fyne, etc. (F. S. G.).

\section{Fam. Calliopiidae.}

Apherusa bispinosa (Bate).-C. in Clyde (R. II, 17) : Kilbrennan Sd.; off Ailsa Craig, etc. (F. S. G.).

A. jurinii (M. Edwo).-Bet. t. m., Farland Pt., Cumbrae (R. II, 17). 
Calliopius laevicusculus $(K r)$.-Mod. c., Kames B., Balloch B., Cumbrae (R. I, 37, 39, 94).

C. rathkei (Zaddoch).-Amongst weedy stones at l. w. Cumbrae (R. I, 38).

Fam. Atylidae.

Paratylus swammerdami ( $\left.M_{0}-E d w.\right)$. - C C. and gen. dist.

P. vedlomensis (Bate).-Not unc. in Clyde (R. I, 36).

P. uncinatus, G. O. Sars.-Kilbrennan Sd., 4/96 (F.S. G.)

\section{Fam. Dexaminidae.}

Dexamine spinosa (Mont.).-Mod. c. all round our shores (R. I, 32).

D. thea, Boeck.-Portloy, Cumbrae; Clach Rock, and off Hunterstone, opposite Millport (R. I, 33, 34) : head of L. Fyne (F. S. G.).

Tritaeta gibbosa (Bate).-Freq., by dip-net among seaweed, \&c. (R. I, 34) : nr. Davaar I. (F. S. G.).

Guernea coalita (Korm.).--Taken twice off Millport (R. II, 24): gen. dist. esp. in d. w., scarce (F. S. G.).

Fam. Melphidippidae, Stebbing (1899).

Melphidippa goesi, Stebbing.-On N. side of L. Cumbrae 20 f. (R. II, 19).

Melphidippella macera (Norm.).-N. side of L. Cumbrae (R. II, 19) : Kilbrennan Sd. ; off Ailsa Craig (F. S. G.).

\section{Fam. Gammaridae.}

Amathilla homari $(F a b r$.).--In surface-net after sunset, Cumbrae, and Sanda B. (R. I, 41, 92) : Bet. t. ms., E. L. Tarbert (S.).

Gammarus marinus, Leach.-C. under stones bet. t. ms., and in tidal pools (R. I, 50).

G. locusta (Lin.).--Bet. t. ms., and dredged nr. Cumbrae, 6-35 f. (R. I, 50, 94). Gen. dist.

G. duebeni (Lillj.).-Fresh water lochs nr. Campbeltown (S.).

G. pulex (de Geer).-C. in slow streams and ditches (R. I, 52).

Melita palmata (Mont.).-Clyde (A. M. N.) 1889.

M. obtusata (Mont.).-C. and gen. dist. (R. I, 47, 48).

M. gladiosa, Bate.-Taken bet. the Allans, Cumbrae, 4-5 f. (R. II, 18).

Eriopisa elongata (Bruzel). - Taken in Clyde by Norman (R. II, 25).

Maera othonis (M.-Edw.).--In various parts of Clyde and L. Fyne (R. II, 53) : nr. Davaar I. (F. S. G.).

M. semiserrata (Bate).-Dredged twice at Tan Buoy (R. I, 52).

M. loveni (Bruzel).--Off L.H., L. Cumbrae, 55-60 f. ; off Arran, 80 f. (R. I, 52).

Gammarella brevicaudata, (M.-Edv.).-Off Hunterstone (R. I, 47 ; II, 24). Megaluropus agilis, Norm.-Garrison B., and Kames B., nr. Millport (R. II, 25) : nr. Sanda I, 5/9/99 (F. S. G.).

Cheirocratus sundewalli (Rathke).--Various places (R. I, 45, 46) : nr. Largabruach, U. L. Fyne ; Tarbert Bank (F. S. G.).

C. intermedius, G. O. Sars.-E. L. Tarbert (S., 1886) : L. Gair, (L. Fyne); Tarbert Bank, 17-20 f. (F. S. G.).

C. assimilis, (Lillj.).-L. L. Fyne, 104 f. ; off Farland Pt., Cumbrae, 20 f. (R. II, 18): Tarbert Bank, 20-25 f. (F.S. G.).

\section{Fam. Lilljeborgiidae.}

Lilljeborgia pallida, Bate.-Off Farland Pt., Cumbrae, 20 f. (R. II, 23).

L. kinahani (Bate).-Nr. Tan Buoy, 7 f. (R. I, 46): Tarbert Bank, 20 f. (F. S. G.).

Fam. Aoridae.

[Phaedra antiqua (Bate).--In surface-net off the Allans, Millport B., after sunset (R. I, 94).] 
Microdeutopus anomalus (Rathke).-Off Tan Buoy, \&c., Cumbrae (R. I, 41). Whiting B. (S.).

M. versiculatus (Bate).-Dredged a little beyond l. w., Cumbrae (R. I, 42).

M. danmoniensis (Bate).--One S. of Tan Buoy (R. I, 40): on E. side and in centre of U. L. Fyne 10-17 f. (M.).

Aora gracilis (Bate).-Gen dist., but mod. r.

Autonoë websteri (Bate).- Under stones nr. 1. w., Portloy, Cumbrae, (R. I, 40)。

\section{Fam. Photidae.}

Leptocheirus hirsutimanus (Bate).-Clach Rock, nr. Tan Buoy; bet. Fairlie and Millport (R. I, 42): off Sanda I. (F. S. G.).

L. pilosus, Zaddach.-Castle B., L. Cumbrae, 2-3 f. (R. II, 2i) : Tarbert Bank, L. L. Fyne, 20-25 f. (F. S. G.).

Gammaropsis maculata, Johnstone.-Otter Spit, L. Fyne; nr. Cumbrae (R. I, 48). Gen dist.

G. palmata (Stebbing and Robertson).-Cumbrae; Clyde one (Steb. and Rob.): off Ballantrae, 24/9/98; Kilbrennan Sd. (F. S. G.).

Megamphopus cornutus, Norm.-Off Earland Pt. ; Castle B., Cumbrae ; off Blackwaterfoot (R. II, 24, 26).

Microprotopus maculatus, Norm.-Garrison B.; Kames B., Cumbrae (R. II, 26).

Photis longicaudata (Bate).-Millport B.; Clach Rock, Cumbrae; off S. end of Bute, 16 f. (R. I, 95) : Kilbrennan Sil. (F. S. G.).

Podoceropsis sophiae, Boeck.-Skelmorlie Bank, 10 f.; off Skelmorlie Pt., 39 f. ; S. of L. Cumbrae (R. I, 60, 61).

P. excavata (Bate).-Gen. dist. and mod. c. (R. I, 60).

\section{Fam. Amphithoidae.}

Amphithoë rubricata (Mont.).-Mod. c. : gen. dist. (R. I, 53, 54).

Pleonexes gammaroides, Bate.-Portloy and Kames B., Cumbrae; off L. Cumbrae 8 f. (R. I, 56 ; II, 27).

\section{Fam. Ischyroceridae.}

Ischyrocerus minutus, Lillj.-W. of Clach Rock; off Farland Pt.; on the Allans, Cumbrae (R. II, 28).

Jassa pusilla (G.O. Sars).-Amongst algae on Millport pier (R. II, 27). Off Sanda I. (F. S. G.).

J. falcata (Mont.).-Millport pier, amongst algae ; on Tan Buoy ; Portloy and bet. the Allans, Cumbrae ; off Dunoon 4 f. (R. I, 57).

J. dentex (Czerniavski) (= Podocerus herdmanni, A. O. Walker).-Off Sanda I. [A. O. Walker now thinks this is only a form of $J$. falcata.]

J. ocia (Bate).--N. of Tan Buoy 8 f.; off Clach Rock 6 f. (R. I, 58).

Microjassa cumbrensis (Stebbing and Robertson).-Off Farland Pt. 20 f. (R. II, 27).

Parajassa pelagica $($ Leach) [=Janassa capillata (Rathke)].-On Millport pier ; Kames B. ; Tan Buoy, Cumbrae ; off Dunoon (R. I, 57).

Erichthonius abditus (Templeton).-N. of Cloch L.H. 6 f. (R. I, 58) : Campbeltown L. ; nr. Ailsa Craig (F. S. G.).

E. difformis, M.-Edw.-L. w., Portloy; off Farland Pt. Cumbrae $17 \mathrm{f}$,, (R. I, 59).

\section{Fam. Corophiidae.}

Siphonoecetes colletti, Boeck.-W. of Cumbrae 10 f. (R. I, 59).

Corophium grossipes ( Lin. $_{\text {. }}$.- - Brackish water; Langbank; Roseneath ; Balloch B., Cumbrae ; mouth of Garnock (R. I, 61) : Inverkip, c. (S.).

C. crassicornis, Bruzel.-Balloch B., Cumbrae; shore pool, L. Cumbrae, c. (R. I, 62): Campbeltown L. (F. S. G.). 
C. bonelli, M.-Edw.-Gen. dist. (Whiting B. etc.).

C. affine, Bruzel.-Clyde (A. M. N.) : E. L. Tarbert (S.).

Unciola planipes, Norm.-Off Sanda I. (F. S. G., 1/9/98).

Fam. Cheluridae.

Chelura terebrans, Philippi.-All round coasts in submerged timbers of piers and jetties (R. I, 63).

\section{Fam. Dulichiidae.}

Dulichia porrecta, Bate.-Off Farland Pt., Cumbrae (R. II, 28).

D. monacantha, Metzger.-One found in stomach of haddock caught in Clyde (1897) (S.).

D. tuberculata, Boeck.-Dredged nr. Mull of Kintyre 49 f. (R. I, 95).

Fam. Caprellidae.

Phtisica marina, Slabber.-Gen. dist. (R. I, 65, 66) : freq. Tarbert Bank (F. S. G.).

Protella phasma (Mont.).-Gen. dist., and not very r. (R. I, 66) : Tarbert Bank freq. (F. S. G.).

Pariambus typicus (Kr.).-Gen. dist., not unc. on Asterias rubers (R. I, 69).

Caprella linearis ( $\operatorname{Lin}$.).-Cumbrae among weedy stones 1. w. ; off Garrochhead, Bute 15 f. (R. I, 67).

C. septentrionalis ( $K r$. $)$.-Cumbrae (R.).

C. acanthifera, Leach.-Cumbrae bet. the Allans amongst zostera, plentiful R. I, 68).

[C. tuberculata, Guerin.--Cumbrae, rare (R. I, 69).]

\section{Order Branchiopoda.}

Sub-Order Phyllocarida.

Fam. Nebaliadae.

Nebalia bipes (Fabr.).-Clyde ; L. Fyne, various places (S.).

Sub-order Cladoceru.

Arrangement Followed.

Prof. C. L. Herrick, Crustacea of Minnesota, 1884.

Authorities.

Baird, W., Monog. of the Brit. Entomostraca, 1849.

(A. M. N.) Norman, Rev. Canon A. M., and Prof. G. S. Brady, A Monograph of Brit. Entomostraca belonging to the Bosminidae, Macrothricidae, and Lynceidae, 1867.

Brady, Prof. G. S., on The Brit. species of Entomostraca belonging to the Daphnia and other allied species, 1898.

Scott, Thomas, F.L.S., "The Fauna of the inland waters of Scotland" (Ann. Reps. Fish. Bd. for Scotland).

\section{Fam. Sididae.}

Sida crystallina (Müller).-Bardowie L., nr. Glasgow ; L. Lomond ; Greenan L., Bute ; Park L., Campbeltown; L. Doon, Ayrshire.

Diaphanosoma brachyurum (Lievin).-Bardowie L.; Park L.

Fam. Holopedidae.

Holopedium gibberum, Zaddach.-L. Arklet; L. Doon, c. during summer. 


\section{Fam. Daphnidae.}

Ceriodaphnia reticulata (Jurine).-Possil Marsh.

C. quadrangula, Müller.--Bardowie L. ; St. Germains' L., Glasgow ; Dhu

Lochan, nr. L. Lomond ; Park L., nr. Campleltown.

C. laticaudata, Miiller.-Possil Marsh, rather r.

C. sp.-L. Lomond; L. Doon ; appears to be r.

Scapholeberis mucronata, Müller.-Bardowie L.; Dhu Lochan, not c.

Simocephalus vetulus, Müller.-Possil Marsh; L. Lomond; Greenan L. ; Park L. ; L. Doon.

Daphnia lacustris, G. O. Sars.-L. Lomond, with and without a vertex tooth.

var. aquilina, G. O. Sars.-L. Arklet, freq.

D. (?) longispina, Leydig.-L. Fad, Bute.

var. nasuta, G. O. Sars.-L. Doon, Ayrshire.

D. (?) jardinii, Baird.-St. Germains' L., Glasgow. A crested form which may belong either to this or to D. galeata, G. O. Sars.

Fam. Bosminidae.

Bosmina longirostris (Müller).-Gen. dist. esp. in smaller lochs and ponds. B. longispina, Leydig.-Not unc. in larger lochs, as L. Lomond and L. Doon.

\section{Fam. Macrothricidae.}

Lathonura rectirostris (Mfiller).-L. Doon-the shore on W. side.

Streblocercus minutus, $G$. O. Sars.-Dhu Lochan, nr. L. Lomond, r.

Drepanothrix dentata (Euren).-Cumbrae (R.) : L. Arklet ; L. nr. L'ranza; L. Doon, \&c., not unc.

Acantholeberis curvirostris (Müller).-Cumbrae (R.): L. Arklet; L. nr. L'ranza, not $\mathrm{r}$.

Ilyocryptus sordidus (Lieven).-Cumbrae (R.) : Possil Marsh ; L. Arklet ; L. Doon ; Park L., Campbeltown, not r.

\section{Fam. Lynceidae.}

Eurycercus lamellatus (Müller).-C. and gen. dist.

Acroperus harpae, Baird.-Gen. dist. and mod. c.

Camptocercus macrurus (Mrill.).-L. Lomond; L. Doon, freq. The Camptocercus found in Scotland is usually ascribed to C. macrurus, Müll., but seems to agree better with Schoedlers' C. rectirostris.

Alonopsis elongatus, G. O. Sars.-C. and gent. dist.

Ledigia quadrangularis (Leydig).-Pond nr. Rutherglen (J. Steel)! St. Germains' L., not c.

Graptoleberis testudinaria (Fischer).-L. Arklet; L. Doon ; freq.

Alona guttata, G. O. Sars.-Gen. dist., freq.

A. costata, G. O. Sars.-St. Germains' Loch ; L. Lomond (shore nr. Balmaha); not c.

A. quadrangularis (Müller).-Gen. dist., mod. c.

A. affinis (Leydig).-L. Lomond; L. Doon; L. behind L'ranza; Park L., Campbeltown \&c., freq.

A. intermedia, G. O. Sars (=A. neglecta, T. S.)-L. Arklet; L. Doon, not c.

A. rustica, T. Scott.-L. Arklet; L. Lomond ; L. Doon ; Park L.

A. rectangula, G. O. Sars.-Nr. E. Tarbert, L. Fyne ; Park L., Campbeltown. Alonella exigua (Lilljeborg).-C. and gen. dist.

A. nana, Baird.-L. Arklet ; L. Lomond ; L. Doon, \&c., not r., but being so small is easily overlooked.

Pleuroxus trigonellus (Mïller).-L. Lomond; I. Doon, not $\mathrm{r}$.

P. laevis, G. (). Sars.-Possil Marsh is the only station I know of. 
P. uncinatus, Baird.-Pond nr. Rutherglen (J. Steel): Possil Marsh; L. Lomond.

Harporhynchus falcatus, G. O. Sars.--L. Arklet; L. Lomond; L. Doon, not $r$.

Peracantha truncata (Müller).-L. Arklet; Dhu Lochan; Greenan L., Bute; L. Doon.

Chydorus sphaericus, Müller.-C. and gen. dist.

C. globosus, Baird.-Possil Marsh ; Bardowie L., nr.Glasgow ; L. Lomond ; Park L., nr. Campbeltown.

C, (?) latus, G. O. Sars.-Only observed in L. Arklet.

C. barbatus (G. S. Brady).--In most Lochs within Clyde area.

D. coelatus, Schoedler.-L. Arklet; L. Doon ; Park L., not c.

Anchistropus emarginatus, G. O. Sars.-Paisley Canal in 1863 (R.). Not observed since.

Monospilis tenuirostris (Fischer).-L. Lomond (shore bet. Balmaha and mouth of R. Endrick), rather $\mathrm{r}$.

\section{Fam. Polyphemidae.}

Polyphemus pediculus (Lin.).-Possil Marsh; L. Arklet; L. Lomond ; Park I.

Bythotrephes longimanus, Leydig.-L. Arklet: L. Lomond; L. Doon, not unc.

Podon polyphemoides, Leuckart.-F. of Clyde ; L. Fyne, sometimes pretty abund.

P. intermedius, Lilljeborg.--Dist. similar to preceding but much less c.

Evadne nordmanni, Loien.-Dist. similar to Podon; c., sometimes very abund.

\section{Fam. Leptodoridae.}

Leptodora hyalina, Lilljeborg.-L. Arklet; L. Lomond ; L. Doon, not unc., esp. during summer.

\section{Sub-Order Branchiura.}

Argulus foliaceus, Lin.-Plentiful a few years ago on the Greyling, Thymallus vulgaris in the upper waters of R. Clyde (Jas. Steel)!

\section{Order Ostracoda.}

\section{Arraygement and Nomenclature followed.}

(B. \& N.) = Prof. G. S. Brady and Rev. Canon A. M. Norman, "The marine and fresh water Ostracoda of the N. Atlantic and North-Western Europe (Roy. Soc. Dub. Sci. Truns., vol. iv. (S. ii.) Pt. il. and vol. v. (S. ii.) Pt. xii.).

R. = Robertson, Dr. D., F.G.S., F.L.S. Ostracoda in "Notes on the fauna and flora of the W. of Scotland," 1876.

"Fresh and Brackish water Ostracoda" (I. H. Soc. Gilas., vol. iv., 1879).

B. \& R. = Brady and Robertson.

B. C. \& R. = Brady, Crosskey, and Robertson.

\section{Fam. Cyprididae.}

Cypria exculpta (S. Fischer).--Somewhat local but not very r.; Possil Marsh (R.) : Cumbrae (B. \& N.): Dalrv (J. Smith) : L. Doon, \&c. (S.). C. ophthalmica (Jurine).-C. and gen. dist.

Cyclocypris laevis $(O . F$. Müller).-Mod. c. ; liable to be confounded with next species.

C. serena (Koch).--One of the most c. and gen. dist. 
C. globosa (G. O. Sars).-Nr. L. Ascog and L. Greenan, Bute (B. \& N.) : L. Lomond ; L. Arklet; L. Doon (S.).

Scottia browniana (Jones).-Marshy ground at side of L. Fad, Bute (B. \& N.) : Binend L. 1877 (J. Smith).

Cypris fuscata, Jurine.-Frankfield $\mathrm{I}_{\text {. }}$, nr. Glasgow ; brackish ponds, Cumbrae (R.) : Dalry (J. Smith) : L. Doon (S.).

C. incongruens, Ramdohr.--Pond nr. Paisley; brackish pool, Hunterston \&c. (R.) : sometimes very abund.

C. virens (Jurine).-Pond nr. Crosshill ; Frankfield L. ; Callum's Tarn, Bute (R.): Dalry (J. Smith) : Pools nr. Fort Matilda, Greenock ; L. Ascog, Bute, \&c.

C. reticulata, Zaddoch.-Possil Marsh ; side of Paisley Canal (R.).

C. obliqua, Brady.-Callum's Tarn, Bute ; Cragengower Tarn, Cumbrae (R.): Binend L. (J. Smith) : L. Lomond (S.).

C. prasina, Fischer.-Pond on shore at Hunterston; Pond nr. Ferry Ho., Cumbrae (R.): Brackish pools at Langbank (S.).

Herpetocypris reptans (Baird).-Mod. c. and gen. dist.

H. strigata (Müller).-Burnside L. nr. Glasgow ; ponds at Port Glasgow ; Cumbrae, \&c. (B. \& N.).

H. tumefacta (B. \& R.).-Cumbrae ; L. Greenan ; L. Fad ; L. Ascog, Bute ; Tarbert, \&c. (B. \& N.).

Ilyodromus robertsoni (B. \& N.).-Side of L. Fad (B. \& N.): L. Doon (S.). Cypridopsis villosa (Jurine).-L. Lomond ; Frankfield L. ; ponds, Cumbrae (R.): Dalry, \&c. (J. Smith) : L. Fad; L. Ascog, Bute (B. \& N.) : L. Doon.

C. newtoni (B. \& R.).-Little L. and Pilmuir Dam, Renfrewshire; Cumbrae; Bute (B. \& N.).

C. aculeata(Lilljeborg)._Brackish pools, S.W. end of Cumbrae (R.) : Tarbert; Langbank (S.).

Pionocypris vidua (Miiller).-Pond at Paisley ; L. Fad (R.): Kilwinning (J. Smith) : L. Lomond.

P. obesa (B.\& R.).-L. Lomond; old dam at Govan Colliery, Glasgow (R.): Kilwinning (J.Smith).

Potamocypris fulva, Brady.-Paisley Canal ; Cumbrae ; Kilwinning (R.): - Dalry; Pilmuir Dam; L. Goin (J.Smith): L. Fad, and Ascog, Bute ; Tarbert.

Paracypris polita, G. O. Sars.-Off Tarbert, 25 f. (B.\& N) : Tarbert Bank, 20 f. (S.).

Notodromus monacha (Mïller).-Cumbrae; L. Cumbrae (R.) : Kilwinning (J.Smith): Pools nr. L. Fad, Bute (S.).

Candona candida (Müller).-C. and gen. dist.

C. lactea, Baird.-Paisley Canal (R.): Pilmuir Dam (J.Smith): Park L. and Achy-Lochy, Campbeltown.

C. compressa (Koch).-Mod. c. ; more or less gen. dist.

C. rostrata $(B . \& N$. $)$.--Hairmyres, nr. E. Kilbride (B. \& N.) : Possil Marsh ; L. Doon (S.).

C. fabaeformis (Fischer).-Hairmyres ; Crosslea, nr. Paisley ; Cumbrae, etc. (B. \& N.): Dalry, Eaglesham Dams, etc. (J. Smith) : L. Lomond.

C. acuminata (Fischer).--Kilmuir Dam, Renfrewshire; Tarbert (B. \& N.) : Eaglesham Dam, Craigton Dam, Harelaw Dam (J. Smith): L. Lomond (S.).

C. euplectella, Robertson.-Tarn, L. Cumbrae ; Callum's Tarn, Bute (R.): Nockewart, Dalry (J.Smith): Pools nr. Pt. Glasgow; Mossclave Pond, nr. Greenock (S.).

C. hyalina (B.\& R.).-Frankfield L. ; Possil Marsh, etc. (R.) : Long Loch (J.Smith): Loch Lomond ; L. Arklet ; L. Doon (S.).

Candonopsis Kingsleii (B. \& R.).-Mod. c. and gen. dist. 
Ilyocypris biplicata (Koch).-Mod. c., but somewhat local.

Pontocypris mytiloides (Norman).-Gen. dist. throughout Estuary.

P. acupunctata, Brady.-Nr. Pt. Glasgow 1892, Campbeltown L. 1897 (S.).

P. trigonella, G. O. Sars.-Gen. dist., not $\mathrm{r}$.

Argilloecia cylindrica, G. O. Sars.--Inveraray ; Largs ; Campbeltown (R.) : off Greenock ; L. Long (B. \& N.) : off Tarbert (S.).

\section{Fam. Bairdiidae.}

Bairdia inflata, Norman.-Cumbrae ; Lamlash (R.): L. Fyne, off Tarbert ; Campbeltown L. (S.).

B. complanata, Brady.-L. Fyne (A. M. N.).

Fam. Darwinulidae.

Darwinula stevensoni (B.\&N.).-L. Lomond (shore S. of Balmaha) (S.).

\section{Fam. Cytheridae.}

Cythere lutea, Mïller:-C. and gen. dist.

C. pellucida, Baird.-Brackish water, freq. (Langbank ; Inverkip ; Hunterston shore, etc.).

C. confusa (B.\& N.).-Mod. c. and gen. dist.

C. porcellanea, Brady.-More or less gen. dist.

C. macallana $(B . \& K$. .).-Off Fairlie, 5 f. (A. M. N.) : off Cumbrae ; Roseneath (R.).

C. tenera, Brady.-C. (R.). Not very c. (S.).

C. (?) semipunctata, Brady-L. Fyne, off Tarbert; bet. the Cumbraes, 25 f. (A. M. N.): off Sanda I., mod. r.

C. badia, Norman.-Kames B. ; Cumbrae ; off Bute (R.).

C. crispata, Brady.-Freq. (R.) : L. Tarbert ; Campbeltown L., etc.

C. gibbosa $(B . \&$ R.). - Kames B., Cumbrae ; L. Gilp ; L. Tarbert (B.\& N.) : Brackish pools nr. Langbank (S.).

C. rubida, Brady.-Kames B., Cumbrae ; Clachland Pt., Arran (B. \& N.).

C. albomaculata, Baird.-Freq. (R.): mod. c. and gen. dist.

C. robertsoni, Brady.-Freq. (R.): Tarbert Bank; Campbeltown L., etc.

C. convexa, Baird.-Freq. and gen. dist.

C. marginata, Norman.-Off Tarbert, L. Fyne, 25 f. (A. M. N.) : Tarbert Bank ; rather r. (S.).

C. limicola, Norman.-Girvan (R.): Cumbrae ; L. Cumbrae (A. M. N.) : Campbeltown L. (S.).

C. cunieformis, Brady.-Freq. (R.).

C. navicula, Norman--Off Port Glasgow 1892 ; off Sanda I. 1897.

C. cluthae, B. C.\& R.-L. Fyne, 20 f. (B. \& N.).

C. villosa (G. O. Sars).-C. and gen. dist.

C. pulchella, Brady.-Kames B., Cumbrae; Kilchattan B. (B. \& N.).

C. quadridentata, Baird.-Off Cumbrae (R.) : Tarbert Bank, 25 f. ; not r.

C. emaciata, Jones.-Freq. (R.): Tarbert Bank, $25 \mathrm{f}$.

C. tuberculata (G. O. Sars).-Gen. dist., c.

C. emarginata (G.O.Sars).-O Off Inveraray (R.) : Tarbert Bank (prob. subfossil), not c. (S.).

C. finmarchica (G.O. Sars).-Off Inveraray (R.): Campbeltown L., 1897 (S.).

C. angulata $(G$. O. Sars).- Various places in F. of Clyde and L. Fyne (B. \& N.).

C. dunelmensis (Norman).-Mod. freq. and gen. dist.

C. antiquata Baird.-Various places in F. of Clyde (B. \& N.): Tarbert Bank; Campbeltown L.

C. whitei (Baird).--Kilchattan B.; Campbeltown L. (R) : Tarbert Bank.

C. jonesii (Baird).-Gen. dist. ; not r.

Limnicythere inopinata (Baird).- Not unc. in Fresh-water Lochs and ponds. 
L. sancti-patricii (B. \& R.).-L. Libo ; side of Bishop L. (R.).

Cytheridea elongata, Biady.-Freq. (R.) : nr. Fort Matilda; Campbeltown L., \&c.

C. papillosa, Bosquet.--C. (R.): off Greenock ; Roseneath; Rothesay (B. \& N.): L. Fyne.

C. punctillata, Brady.-C. (R.) : off Roseneath; Rothesay; Inveraray; Skipness; Tarbert (B. \& N.).

C. torosa (Jones).-Langbank; Pt. Glasgow ; Greenock (R.). A brackish water species.

C. lacustris (G. O. Sars).-Glasgow and Paisley Canal (W. of Pollokshields); Clyde, nr. Langbank (R.): Pilmuir Dam (J. Smith): L. Lomond (B. \& N.).

C. (?) subflavescens, Brady-L. Fyne; nr. Rothesay ; bet. the Cumbraes (B. \& N.).

Eucythere declivis (Norman).-Freq. and gen. dist.

Krithe bartonensis (T. R. Jones).-C. (R.). Clyde nr. Greenock; L. Fyne ; off Rothesay, \&c. (B. \& N.).

Loxoconcha impressa, Baird.-C. and gen. dist.

L. guttata (Norman).-Freq. and gen. dist. (B. \& N.).

L. viridis (Müller).-Brackish pools at Inverkip (1880); Campbeltown L. (1897) (S.). Irvine sands (J. Snith).

L. multifora (Norman).-C. (R.). L. Fyne (A. M. N.) : Cumbrae and Rothsay B. (B. \& N.) : Campbeltown L. (S.).

L. pusilla, B. \& R.-Greenock; Cumbrae (R.) : Campbeltown L. (S.).

L. tamarindus, (Jones).-C. and gen. dist.

L. fragilis, $G$. O. Sars.-Clyde nr. Greenock and Pt. Glasgow (R.): [probably fossil, not unc. in Artic shell beds bet. these two places].

Xestoleberis aurantia (Baird).-Kames B., Cumbrae (R.): Tarbert Bank ; E. L. Tarbert; Campbeltown L. ; not r.

X. depressa, G. O. Sars.-Gen. dist. throughout estuary.

Cytherura gibba (Müller).-Freq. (R.), but mostly in brackish water.

C. cornuta, Brady.-Gen. dist. and mod. c.

C. sella, G. O. Sars.-Gen. dist. and mod. c.

C. acuticostata, G. (). Sars.-Gen. dist. but scarcely so c. as the last.

C. striata, G. O. Sars.-Gen. dist. Freq. (R.).

C. angulata, Brady.-Rock-pools, Arran (A. M. N.): L. Fyne ; Campbeltown L. ; not so c. as some other Cytherurae (B. \& N.).

C. undata, $G$. O. Sars.-Gen. dist. freq. throughout estuary.

C. producta, Brady.-F. of Clyde (B. \& N.): L. Fyne, not c.

C. nigrescens (Baird).-Gen. dist. throughout estuary.

C. simplex, B. \& N.-St. Ninian's B., Bute ; off Fairlie (B. \& N.) : Campbeltown L. (S.).

C. concentrica, B., C., \& R.-Off Fairlie (A. M. N.). Appears to be r.

C. similis, G. U. Sars.-L. Fyne ; Rothesay B. ; off Fairlie (B. \& N.) : Campbeltown L. (F.S. G.).

C. fulva, B. \& K.-Off Greenock; L. Fyne ; F. of Clyde (B. \& N.) : Campbeltowil L. (F. S. G.).

C. clathrata, G. O. Sars.-Callum's B., Bute (R): Tarbert Bank, not c. (F. S. G.).

C. cellulosa, Norman.-Gen. dist. ; freq. (rery small).

C. bodotria, T. Scott.-Greenock Bank, off Pt. Glasgow, 1892 (S.).

Cytheropteron latissimum (Norman).-Gen. dist. throughout estuary.

C. nodosum, Brady.-F. of Clyde, freq. (R.): off Tarbert (A. M. N.): Campbeltown L. (F.S. G.).

C. inflatum, $B ., C$., \& R.-L. Fyne (A. M. N.).

C. punctatum, Brady.-Inverkip ; Cumbrae; L. Riddon ; off Girvan, r. (R.): off Tarbert, 25 f. (A. M. N.). 
C. alatum, G. O. Sais.-Off Tarbert, (A. M. N.) : Fintry B. ; Kilchattan B. ; Rothesay B. (B. \& N.) : off Sanda I. (F.S. G.).

C. angulatum, B. \& R.-Off Tarbert (A. M. N.) : Roseneath; Cumbrae ; Bute (R.) : off Sanda I. (F. S. G.).

C. depressum, B. \& $N$.-Campbeltown L. (189 $\left.{ }^{\top}\right)$ : r. in estuary (S.).

C. humile, $B . \& N$. - Off Fort Matilda, Greenock (B. \& N.): U. L. Fyne ; Kilbrennan Sd. (S.).

Bythocythere constricta, G. (). Sars.-Off Roseneath, etc.; L. Long; L. Frne (B. \& N.).

B. turgida, G. O. Sars.-Off Roseneath; Rothesay B. ; Kilchattan B. (B.\&N.): off Tarbert (S.).

B. simplex (Norman).-Gen. dist., but not very c.

Pseudocythere caudata, G. O. Sars.-Mod. freq. throughout estuary, and L. Fyne.

Selcrochilus contortus (Norman).-Gen. dist. throughout estuary.

Cytherideis subulata, Brady.-Cumbrae; Bute; Ardrossan, r. (R.): Campbeltown L. (F. S. G.).

Cytherois fischeri $(G$. O. Sars).-Gen. dist., but more freq. inshore amongst algae, Inverkip ; Campbeltown L. (F.S. G.).

\section{Fam. Paradoxostomatidae.}

Paradoxostoma variabile (Baird $)$.--C. and gen. dist.

P. ensiforme Brady.-Mod. c. ; but more so off shore than in shall.w.

P. abbreviatum, $G$. O. Sars.-Gen. dist., but not very plentiful.

P. obliquum, G. O. Sars._Cumbrae; Bute; Arran, r. (R.). Off Tarbert

(F.S. G.).

P. normani, Brady.-Campbeltown L., 1897 (S.). Somewhat r. in Clyde.

P. pulchellum, G. O. Sars.-L. Goil ; Cumbrae ; Arran ; Ardrossan, r. (R.) : L. Fyne, 1885 (S.).

P. hibernicum, Brady.-Cumbrae ; Bute ; Arran ; Campbeltown, r. (R.).

P. arcuatum, Brady.-Off Pt. Glasgow, r. (S.).

P. orcadense, B. \& R.-White B., Cumbrae ; off Glensannox, r. (R.).

P. hodgei, Brady.-Off Callum's Bar, Bute (R.) : off Tarbert, 25 f. (A. M. N.).

P. flexuosum, Brady.-Freq. in Clyde (R.): L. Fyne; Campbeltown L. (F.S. G.).

P. affine, T. Scott.-Off Inveraray, 25-40 f. (A. M. N.).

Machaerina tenuissima (Norman).-Off Skelmorlie; Eairlie ; nr. Cumbrae; Kilchattan B. (B. \& N.) : off Tarbert (F. S. G.).

\section{Fam. Asteropidae.}

Asterope mariae (Baird).-Off Tarbert (A. M. N.) : Cumbrae (R.) : U. L. Fyne ; East L. Tarbert.

A. teres (Norman).-Lamlash B. (A. M. N.): Cumbrae (R.) : E. L. Tarbert.

Fam. Cypridinidae.

Philomedes brenda (Baird).-Nr. Arran (E. side) 40 f. 1896 (S.).

P. interpuncta (Baird).-Gen. dist., in surface and bottom tow-nets, as well as dredge.

P. macandrei (Baird).-Nr. Cumbrae (R.).

\section{Fam. Polycopidae.}

Polycope orbicularis, G. O. Sars.-Gen. dist. throughout estuary.

P. punctata $G$. O. Sars.- "Some specimens dredged in L. Fyne are doubtfully referable to this species" (B. \& N.).

\section{Fam. Cytherellidae.}

Cytherella serrulata, Brady and Norman.-Nr. Sanda I., 1896 (S.). 


\section{Order Copepoda.}

Arrangement axd Nomenclature Followed.

Brady, Prof. G. S. (1) Monog. of the free and semi-parasitic Copepoda of the Brit. Islands (Ray Society, 1878-80).

(2) Revision of the Brit. species of the fiesh-water Cyclopidae and Calanidae. Nat. Hist. Trans., N.D. and N.C., vol. xi., Pt. 1 (1891).

Giesbrecht, Dr. W. (1) Die Pelagischen Copepoden des Golfes von Neapel.

(2) Die Asterocheriden des Golfes von Neapel.

Canu, Dr. Eugene, Les Copépodes du Boulonnais.

Schmeil, Dr. Otto, Deutschlands freilebende sïsswasser Copepoden.

List of species from Irish Sea (Brit. Assoc. Rep., Sect. D, Liverpool, 1896.

Drs. W. Giesbrecht and O. Schmeil, Copepoda Gymnoplea, Das Tierreich (6 Lieferung).

Dr. Basset Snith, A systematic description of the parasitic copepoda found on fishes (Proc. Zool. Soc. Lond., 1899).

Scott, T. \& A., Revis. of Brit. Copep. belonging to the Gen. Bradya and Ectinosoma (Tr. Lin. Soc., 2nd ser. ; Zool., vol. vi., Pt. 5 (1896)): papers in Ann. and Mag. Nat. Hist., and Ann. Scot. Nat. Hist. (1892-98).

Scott, T., papers in F.B. Reports, 1886-1900.

\section{Fam. Calanidae.}

Calanus finmarchicus (Gunn).--Throughout estuary, surface and bottom.

Paracalanus parvus, Claus.-Off Minard, U. L. Fyne; Kilbrennan Sd. ; Ayr B. ; off Sanda I. etc., not c.

Pseudocalanus elongatus, Boeck.-Gen. dist. and mod. c. (surface and bottom townets).

Stephus gyrans (G'iesbrecht).-L. Gair (U. L. Fyne), r., dredged.

S. minor, T. Scott.-Otter Spit (U. L. Fyne) ; off Sanda I., r., dredged.

S. fultoni, T. Scott.-Otter Spit (U. L. Fyne) ; Kilbrennan Sd., r., dredged.

Pseudocyclopia crassicornis, T. Scott.-Otter Spit (U. L. Fyne), r., dredged.

P. caudata, T. Scott.-Otter Spit; Ayr B. ; Ballantrae Bank, r., dredged.

Bradyidius armatus (Vanhöffen).-Gen. dist. throughout estuary.

Euchaeta norvegica, Boeck.-U. L. Fyne, very c.; much less so in seaward part of estuary ; chiefly in bottom townet.

Scolecithrix hibernica, A. Scott.-U. L. Fyne; d.w. E. of Arran; off Davaar I. ; nr. Ailsa Craig (in bottom townet).

S. pygmaea, T. Scott.--U. L. Fyne ; Kilbrennan Sd. ; Whiting B. ; nr. Ailsa Craig (in bottom townet), not c.

\section{Fam. Centropagidae.}

Centropages typicus, $k r$.-Gen. dist. and mod. freq.

C. hamatus (Lillj.).-Gen. dist., c.

Isias clavipes, Boeck.-Off Cumbrae ; off Portincross (Brady): Machrie B. (Brook) : off Ailsa Craig.

Diaptomus gracilis, G. O. Sars.-C. in fresh-water lochs, as L. Doon, Ayrshire ; L. Lomond, etc.

D. hircus, Brady.-Tangy L., nr. Campbeltown.

D. laciniatus, Lillj.-L. Doon, Ayrshire ; freq. during summer.

Temora longicornis (Müller).-Gen. dist. throughout estuary.

Eurytemora velox (Lillj.).-Cumbrae (Brady): pond at Rutherglen (J. Steel): Possil Marsh ; marshy ground at Langbank; brackish pools at Hunterstone.

Metridia lucens, Boeck.-E. L. Tarbert (Calderwood) : Largabruach, U. L. Fyne; nr. Ailsa Craig.

Paramisophria cluthae, T. Scott.-Largabruach, U. L. Fyne ; Tarbert Bank, L. L. Fyne, r. 
Fam. Candaciidae.

Candacia pectinata, Brady.-Whiting B.; mid.channel E. of Pladda I.; off Sanda I., not very c.

\section{Fam. Pontellidae.}

Labidocera wollastoni (Lubbock).-Machrie B. (Brook): nr. Ailsa Craig; off E. of Arran ; not c. ; 12-26 f.

Anomalocera patersoni (Temple).-Gen. dist. sometimes mod. c.

Parapontella brevicornis (Lubbock).-E. L. Tarbert (Calderwood) : Ayr B. ; Machrie B. ; off Davaar I. ; nr. Ailsa Craig.

Acartia clausii, Giesbrecht.-Gen. dist. and mod. c. throughout estuary.

\section{Fam. Misophriadae.}

Misophria pallida, Boeck.-Portincross (Brady): Largabruach, U. L. Fyne ; Otter Spit, r.

\section{Fam. Cyclopidae.}

Oithona helgolandica, Claus.-Gen. dist., mod. c.

Cyclopina littoralis, Brady.--Largabruach, and Head of U. L. Fyne; not c.

C. gracilis, Claus.-Loch Gair ; off Inveraray, Hunterstone ; not c.

Cyclops strenuus, Fischer.-C. in most fresh-water lochs.

C. leuckarti, Claus.-L. Lomond, not c.

C. dybowskii, Lande.-L. Lomond-shore S. of Balmaha.

C. bicuspidatus, Claus.-L. Lomond; L. Doon; Achy L. (nr. Campbeltown); Possil Marsh.

var. lubbockii, Brady.-Brackish pools at Langbank.

C. languidus, G. O. Sars.-L. Doon, Ayrshire ; not c.

C. vernalis, Fischer.-L. Lomond; L. Doon.

C. bisetosus, Rehberg.-L. Lonınd (shore); pools at Langbank ; Garry L., Ailsa Craig.

C. viridis (Jurine).-L. Lomond ; L. Fad ; L. Doon ; Park L., nr. Campbeltown; mod. c.

C. fuscus (Jurine).-L. Arklet; Park L.

C. albidus (Jurine).-L. Lomond; L. Doon; pond at Castlemilk; Possil Marsh.

C. serrulatus, Fischer.-C. and gen. dist. in lochs and ponds throughout the district.

C. macrurus, G. O. Sars.-L. Arklet.

C. affinis, G. O. Sars.-Achy L., nr. Campbeltown.

C. nanus, G. O. Sars.-Dhu Lochan, nr. L. Lomond ; L. Doon.

C. fimbriatus, Fischer.-Gen. dist. and mod. c.

C. phaleratus, Koch.-Bardowie L. ; not c.

C. aequoreus, Fischer.-Brackish pools at Langbank and Hunterstone.

Thorellia brunnea, Boeck.-Gen. dist. throughout estuary, freq.

\section{Fam. Ascidicolidae.}

Notodelphys allmani, Thorell.-E. L. Tarbert; Tarbert Bank (inside large Ascidians, as are most of the species in this family).

N. agilis, Thorell.-E. L. Tarbert; Tarbert Bank 20-25 f. (F. S. G.).

N. prasina, Thorell.-E. L. Tarbert; Tarbert Bank ; Kilbrennan Sd.

Doropygus porcicauda, Brady.-E. L. Tarbert; off Largabruach, U. L. Fyne ; Tarbert Bank (F. S. G.).

D. pulex, Thorell.-In ascidians, Tarbert Bank; 11 . Millport in Corella parallelogramma (Gray).

D. (?) gibbosa, Thorell.-In ascidians Tarbert Bank (F. S. G.).

Botachus cylindratus, Thorell.-Same localities as the last; Whiting B.

Notopterophorus papilio, Hesse.-In large Ascidians in E. L. Tarbert; not unc.; Kilbrennan Sd. 29/10/96 (F. S. G.). 
Ascidicola rosea, Thorell.-In large Ascidians dredged $\mathrm{nr}$. head of L. Fyne ; Tarbert Bank (F. S. G.).

Enterocola fulgens, van Beneden.-In the intestines of small Ascidians dredged at Tarbert Bank (F.S. G.).

Gunenotophorus globularis, Costa.-In material dredged nr. Sanda I. 12/98 (F.S. G.).

Botryllophilus (?) ruber, Hesse.-Associated with Botryllus sp., dredged Tarbert Bank, 1899 ; not very c. (F. S. G.).

Lamippi proteus, Clapurède.--Parasitic in Alcyonium digitatum in various parts of Clyde area.

\section{Fam. Harpacticidae.}

(Note.-The Copepods belonging to this family-both marine and freshwater-are for the most part found on or near the bottom.)

Longipedia coronata, Claus.-Freq. and gen. dist.

L. minor, T. \& A. Scott.-Largabruach, U. L. Fyne ; off Sanda I. (with ova). Canuella perplexa, $T$. \& A. Scott.-Ayr B.; Cumbrae, bet. tide marks; Inverkip, in shore pools.

Ectinosoma atlanticum (B. \& R.).-Geu. dist., sometimes abund. in tow-net.

E. sarsi, Boeck.-Gen. dist., and not unc.

E. melaniceps, Boeck.-Gen. dist., not r.

E. herdmani, T. \& A. Scott.-L. Gair and Largabruach, U. L. Fyne; shore at Hunterston.

E. curticorne, Boeck.-Dubh L., nr. Inveraray ; Largabruach; shore pools at Hunterston ; Ayr B.

E. normani, T. \& A. Scott.-Ayr B., r.

E. erythrops, G. S. Brady.-Otter spit, U. L. Fyne, not c.

E. gracile, T. \& A. Scott.--Shore pools at Inverkip; dredged nr. Sanda I., r.

F. pygmaeum, T. \& A. Scott.-Tarbert Bank 20 f., Kilbrennan Sd., r.

Bradya typica, Boeck.-Gen. dist., not very c.

B. minor, T. \& A. Scott.- Shore at Hunterston; Ayr B.

B. elegans, T. \& A. Scott.-L. Gair and Largabruach, U. L. Fyne.

B. hirsuta, T. \& A. Scott.-Ayr B., r.

B. similis, T. \& A. Scott.-Largabruach ; Kilbrennan Sd. ; Ayr B.

Zosima typica, Boeck.-Lowburn, and Largabruach, U. L. Fyne; Kilbremnan Sd., not r.

Tachidius brevicornis (G. F. Müll.).-Cumbrae, nr. Millport (Shore) ; Hunterston in brackish water pools.

T. littoralis, Poppe.-Shore pools, Dumbarton and Hunterston.

Robertsonia tenuis (B. \& R.).-Rothesay B.

Amymone sphaerica, Claus.-E. L. Tarbert ; Kilbrennan Sd. ; Whiting B. ; nr. Sanda I.

A. nigrans, T. \& A. Scott.-Otter Spit, L. Fyne 12/1/99.

Stenhelia hispida, Brady.-Off Portincross, Ayrshire 15 f. (Brady).

S. ima, Brady.-Off Callum's Hole, Bute; off Glen Sannox (Brady); E. L. Tarbert; off Inveraray.

S. intermedia, T. Scott. - Kilbrennan Sd.

S. hirsuta, I. C. Thompson.-Tarbert Bank; Campbeltown L.

Ameira longipes, Boeck.--Off Portineross, Ayrshire (Brady).

A. longicaudata, T. Scott.-U. L. Fyne; Kilbrennan Sd., off Sanda I.

A. exilis, $T$. \& A. Scott.-Shore pools at Hunterston.

A. exigua, T. Scott.-Kilbrennan Sd.

A. longiremis, T'. Scott.-L. Gair; Kilbrennan Sd.

Jonesiella spinulosa (B. \& R.).--Largabruach; Kilbrennan Sd. ; Campbeltown L.

J. fusiformis (B. \& R.).--Tarbert Bank 20 f. ; off Sanda I. 
Delavalia palustris, Brady--Brackish pools, Dumbarton; Hunterston.

D. reflexa, $B$. \& R.-Nr. Sanda I., rather r.

D. robusta, $B$. \& R.-Largabruach ; Kilbrennan Sd., nr. Sanda I.

D. mimica, T. S'cott.-L. Gair; Kilbrennan Sd., Ayr B.

D. aemula, T. Scott.-Ayr B. ; Campbeltown L., not c.

D. giesbrechti, T. \& A. Scott.-Ayr B. ; Campbeltown L. var ... ?-Brackish-water pools, Hunterston.

Pseudotachidius coronatus, T. Scott.-Off Lowburn, Hd. of L. Fyne ; off Skate I., 105 f. ; bet. Arran and Heads of Ayr, 40 f.

Cervinia bradyi, Norman.-D. w. E. of Arran, very r.

Canthocamptus staphylinus (Jurine).-C. in fresh water lochs, ponds, ditches, \&c.

C. palustris, G. S. Brady.-Brackish pools, Dumbarton; Langbank ; Hunterston ; Dubh L., nr. Inveraray.

C. parvus, T. \& A. Scott.-Brackish pools, Hunterston, not c.

C. minutus, Claus.-L. Lomond; L. Doon; Park L. and Achy-L., nr. Campbeltown.

C. inornatus, T. Scott.-L. Arklet; Park L., not c.

C. schmeilii, Mrazek.-L. Lomond; L. Doon; Park L.

C. hirticornis, T. Scott.-Brackish pools at Langbank.

C. cuspidatus, Schmeil.-L. Fad, Bute, r.

C. crassus, G. O. Sars.-Freq. in most fresh-water lochs and ponds.

C. pygmaeus, G. O. Sars.-More or less freq. in lochs, ponds, ditches.

C. zschokkei, Schmeil.-Dhu Lochan, nr. L. Lomond; L. Fad, Bute ; Black L. and Park L., nr. Campbeltown.

Moraria anderson-smithi, T. \& A. Scott.-L. Arklet; L. Lomond; L. Doon ; Garry L. (Ailsa Craig); Black L., nr. Campbeltown.

M. brevipes (G. O. Sars).-L. Doon, not c.

M. poppei (Mrazek).-L. Fad, Bute; Shore pools at Hunterston, r.

Maraenobiotus vejdovskei, Mrazek.-L. Doon, amongst shore vegetation.

Psyllocamptus fairliensis, T. Scott.-Shore pools bet. Fairlie and Hunterston.

Mesochra lilljeborgii, Boeck.-Brackish-water pools at Hunterston.

M. spinicauda, T. \& A. Scott.-Shore pools, nr. Millport.

Neobradya pectinifer, T. Scott.-Ballantrae Bank, r.

Tetragoniceps consimilis, T. Scott.-Ballantrae Bank; Otter Spit, L. Fyne.

T. incertus, T. Scott.--Dredged bet. Sanda and Bennan Hd. 1896.

T. macronyx, T. Scott.-Dredged, Ballantrae Bank, $18 \mathrm{f}$.

Diosaccus tenuicornis (Claus).-Cumbrae, surface net ; Portincross, dredged (Brady): E. L. Tarbert; Kilbrennan Sd.

Laophonte serrata (Claus).-E. L. Tarbert; Kilbrennan Sd. r.

L. horrida (Norman).-Off Cumbrae and Portincross (Brady): U. L. Fyne ; Kilbrennan Sd., not unc.

L. thoracica, Boeck.-Off Inveraray and Largabruach, U. L. Fyne.

L. similis (Claus).-E. L. Tarbert; L. Fyne (Calderwood). Shore pools, Hunterston.

I. curticauda, Boeck.-Amongst weeds at L. Cumbrae (Brady) : shore pools Hunterston.

I. longicaudata, Boeck.-Otter Spit; Kilbrenuan Sd.

I. lamellifera (Claus).-Portincross, Ayrshire; off Cumbrae and Bute (Brady) ; Otter Spit; Ayr B.

L. intermedia, T. Scott.-Shore pools Hunterston.

L. hispida (B. \& R.).-Off Glen Sannox ; off Cumbrae and Bute (Brady): Largabruach, U. L. Fyne ; Ayr B.

I. littorale, T. \& A. Scott.-Shore pools Hunterston.

L. mahommed, Richard.-Brackish pools Langbank.

L. depressa, T. Scott.-Tarbert Bank 25 f. not c. 
L. simulans, $T$. Scott.-Off Inveraray ; Kilbrennan Sd. ; freq. in crevices of decaying wood.

L. denticornis, T. Scott.--Machrie B. ; Kilbrennan Sd.

Pseudolaophonte spinosa (I. C. Thompson).-Dredged nr. Otter Spit 15-18f., Jany. 99.

Laophontodes typicus, T. Scott.-Nr. Otter Spit ; Carradale B.

L. bicornis, A. Scott.-Machrie B., not c.

Pontopolites typicus, T. Scott.-L. Gair ; Largabruach, U. L. Fyne ; Kilbrennan Sd.

Normanella dubia (B.\& R.).-L. Gair ; Largabruach ; Machrie B. ; Carradale B. ; Ayr B.

Cletodes limicola, Brady.-Kilbrennan Sd.

C. longicaudata, B. \& R.-Off Portincross, Ayrshire (Brady) : E. L. Tarbert ;

L. Gair ; Largabruach ; Kilbrennan Sd. ; Campbeltown L.

C. propinqua, $B$. \& R.-Shore pools Hunterston.

C. linearis (Claus).-r. ; E. L. Tarbert; bet. Sanda and Bennan Hd.

C. similis, T. Scott.-Otter Spit.

C. curvirostris, T'. Scott.-Carradale B. ; Campbeltown L.

C. lata, T. Scott.-Kilbrennan Sd. ; Campbeltown L. ; nr. Davaar I.

C. irrasa, T. Scott.-Kilbrennan Sd.

C. tenuipes, T. Scott.-r. ; Carradale B., off Sanda I.

C. hirsutipes, T. Scott.-Carradale B.

Itunella tenuiremis $(T$. Scott).-Nr. Lowburn and Largabruach, U. L. Fyne; shore pools Hunterston.

Leptopsyllus minor, T. Scott.--Shore pools, nr. Millport, not c.

L. herdmanni, I. C. Thompson \& A. Scott.-Shore pools, "ir. Millport, not c.

Enhydrosoma curvatum, B. \& R.-Off Portincross; Cumbrae; Bute (Brady): L. Gair ; Ayr B.

Pseudocletodes vararensis, T. \& A. Scott.-Nr. Sanda I. twice.

Nannopus palustris, Brady.-Brackish pools Inverkip and Hunterston.

Platychelipus littoralis, Brady.-Dumbarton; Ayr B.; Carradale B.; Hunterston, shore pools.

Huntemannia jadensis, S. A. Poppe.-Shore pools nr. Millport; Inverkip.

Heteropsyllus curticaudatus, T. Scott.-Carradale B., r.

Dactylopus pectinatus, T. Scott.-Nr. head of L. Fyne (18 f.).

D. tisboides, Claus.-Off L. Cumbrae, and Portincross (Brady) ; E. L. Tarbert; Kilbrennan Sd., etc.

D. similis, Claus.-Off Portincross (Brady); L. Fyne; Whiting B. ; Campbeltown L.

D. stromii (Baird).-Nr. Cumbrae (Brady); Ayr B.; Whiting B., etc.

D. flavus, Claus.-Off Callum's Hole, Bute (Brady); bead of L. Fyne ; Otter Spit; Ayr B.

D. brevicornis, Claus. - Whiting B. ; off Sanda I.

D. minutus, Claus. - E. L. Tarbert (16 f.); off Sanda I.

Thalestris mysis, Claus.-E. L. Tarbert; Machrie B.

T. helgolandica, Claus.-Clyde (A.M. N.); Whiting B. ; Kilbrennan Sd.

T. rufocincta, Norman.-Off Cumbrae, and Portincross (Brady); Otter Spit; Whiting B., freq.

T. harpactoides, Claus.--Shore pools Hunterston.

T. clausii, Norman.-L. Fyne (Calderwood); off Cumbrae (Brady): Machrie B. ; Ayr B.

T. violascens, Claus.-Nr. the 'Allans' Cumbrae (Brady), r.

T. hibernica, B. \& R.-Off Cumbrae (Brady), r.

T. longimana, Claus.-Off Portincross (Brady); Machrie B.

T. peltata $($ Boeck).-Otter Spit, rather r.

T. forficulus, Claus. - Off Inveraray, and Largabruach, U. L. Fyne; Machrie B. ; Shore pools Hunterston, not very r. 
Pseudothalestris pygmaea, T. \& A.Scott.-Machrie B. ; Ballantrae Bank, r. Westwoodia nobilis (Baird).-Off Portincross, 10-30 f. (Brady); E. L. Tarbert (Calderwood) ; shore at Hunterston.

Harpacticus chelifer (Miiller).-Gen. dist., freq.

H. fulvus, Fischer.-Brackish pools, Hunterston.

H. flexus, B. \& R.-.Kames B., Cumbrae, 1-2 f. (Brady); E. L. Tarbert; shore at Hunterston.

Zaus spinatus, Goodsir.-E. L. Tarbert; L. Fyne (Calderwood): Otter Spit; Machrie B., freq.

Z. goodsiri, Brady.- Off Portincross, $15 \mathrm{f}$. (Brady): Otter Spit; off Sanda I.

Alteutha bopyroides, Claus.-E. L. Tarbert; L. Fyne (Calderwood).

A. crenulata (Brady).-Off Sanda I. ; Ballantrae Bank.

Eupelta purpurocinctum (Norman).-E. L. Tarbert (Calderwood): Ayr B. ; N.-E. of Sanda I. Mod. freq. in Clyde.

Peltidium purpureum, Philippi.-E. L. Tarbert; off Largabruach; nr. Lowburn, L. Fyne, rather r.

Porcellidium fimbriatum, Claus.-Cumbrae; Portincross (Brady): E. L. Tarbert (Calderwood): Machrie B. Freq. on fronds of Laminaria.

P. viride (Philippi).-Cumbrae; Portincross (Brady).

P. subrotundum, Norman.-L. Fyne (M.); Portincross (Brady).

Idya furcata (Baird).-E. L. Tarbert (Calderwood): Cumbrae; Portincross (Brady); Machrie B.

I. gracilis, T. Scott.-L. Gair ; off Inveraray ; off Lowburn (U. L. Fyne); shore pools Hunterston.

I. longicornis, T.\&A. Scott.-E. L. Tarbert; Machrie B. ; Campbeltown L.

I. minor, T. \& A. Scott.-Largabruach, U. L. Fyne ; Machrie B.

I. cluthae, T. Scott.-Nr. head of L. Fyne ; off Ailsa Craig.

Scutelidium fasciatum, Boeck.-E. L. Tarbert (Calderwood).

Cylindropsyllus laevis, Brady.--E. L. Tarbert; Ballantrae Bank.

C. minor, T'. Scott.-Ballantrae Bank $18 \mathrm{f}$., not c.

C. fairliensis, T. Scott.-Brackish pools at Hunterston, rather r.

Leptocaris minutus, T. Scott.-Brackish pools at Hunterston, r.

\section{Fam. Monstrillidae.}

Monstrilla danae, Claparède.--U. L. Fyne, sometimes freq. ; Kilbrennan Sd.

Fam. Corycaeidae.

Corycaeus anglicus, Lubbock.-In surface net nr. Ailsa Craig, 29/5/99.

\section{Fam. Lichomolgidae.}

Modiolicola insignis, Aurivilius.-Commensal in shell of M. modiolus.

Lichomolgus albens, 7 horell.-Dredged nr. Otter Spit.

L. agilis, Leydig.-Kilbrennan Sd., on branchial plumes of Doris sp.

L. maximus, I.C. Thompson.-Freq. in Clyde ; conmensal with Pecten maximus and P. operculare.

L. fucicolus, Brady.-Nr. Largabruach, U. L. Fyne.

L. furcillatus, Thorell.-Off Inveraray, $\mathrm{x}$.

L. forficulus, Thorell.-E. L. Tarbert; Tarbert Bank, in branchial chamber of large Ascidians.

Sabelliphilus sarsi, Claparède.-Kilbrennan Sd. ; off Sauda I. ; on branchial plumes of Sabella sp.

Hermanella arenicola (Brady).-_Off Battery Pt., Cumbrae (Brady): Nr. Otter Spit, 8-15 f.; L. Gilp, 2-3 f. ; not c.

Pseudanthessius liber (B.\&R.).-S. of Bute, $16 \mathrm{f}$. (Brady): nr. Lowburn and Inveraray.

P. thorellii (B.\& $\dot{R}$.).-From various parts of estuary.

Clausia cluthae, T. \& A. Scott.-Tarbert Bank, 20-25 f. ; Ayr B. 


\section{Fam. Asterocheridae.}

Asterocheres lilljeborgi, Boeck.-Tarbert Bank, 20-25 f., r.

A. echinicola (Norman).-Gen. dist., freq. in water passages of Suberites.

A. simulans (T. Scott).-L. Fyne and Clyde, r.

A. violaceus (Claus).-Nr. Otter Spit; off Pladda ; r.

Dermatomyzon nigripes (B.\&R.).--E. L. Tarbert (Calderwood) : off Callum's Hole, Bute ; Portincross (Brady).

Rhynchomyzon purpurocinctum (T. Scott).-Otter Spit, 8-15 f., Jany./99.

Scottomyzon gibberum $(T . \& A$. Scott).-Nr. head of L. Fyne on Echinus esculentus.

Acontiophorus scutatus (B. \& R.).-Off Portincross (Brady): Otter Spit; Machrie B. ; off Sanda I.

Scottocheres elongatus ( T. \& $A$. Scott).-. Off Sanda I., r.

Neopontius angularis, T. Scott.--Otter Spit; Kilbrennan Sd., r.

Cribropontius normani (B. \& R.).-L. Gair, r.

Bradypontius magniceps (Brady).--Off Portincross (Brady) : E. L. Tarbert (Calderwood) : nr. Head of L. Fyne.

Dyspontius striatus, Thorell.-Whiting B., r.

Artotrogus orbicularis, Boeck.-Tarbert Bank, 20 f., very r.

Parartotrogus richardi, T. \& A. Scott.-Nr. Otter Spit, 15-18 f. (Jany. 99).

Eurynotopsyllus insolens, T. Scott (=Eurynotus insolens, T. Scott).-Kilbrenuan Sd., 86 (F.S. G.); very r.

Cancerina confusa, T. Scott.-Tarbert Bank, very r., 1899 (F. S. G.).

\section{COPEPODA PARASITA.}

Classification Adopted: Dr. Basset Smith, "Systematic description of parastic Copepoda found on fishes," (Proc. Zool Soc. London, April 1899).

\section{Fam. Ergasilidae.}

Bomolochus soleae, Claus.-Back of Solex vulgaris, captured in Clyde. (F.S. G.). Freq. in nostrils of Cod.

\section{Fam. Caligidae.}

Caligus curtus, O.F. Müll.-On various fishes, Cod, Saithe, etc., mod. c.

C. rapax, M.-Edw.-On various fishes, also in townet; c. and gen. dist.

C. diaphanus, Nordmann.-Chiefly in gill cavity of Gurnards, Trigla gurnardus; T. lineata, etc.

Lepeophtheirus pectoralis (O. F. Müll.).-Not unc, under pectoral fins of flat fishes, as the Plaice, Pleuronectes platess $a$, and Flounder, P. flesus.

L. thompsoni, Baird.-Freq. on the gills of Turbot, Bothus maximus, (F.S. G.).

L. stromi, Baird.-On Salmon nr. Girvan (Duthie, Fishery Officer).

L. (?) obscurus, Baird.-On gills of Brill, Bothus rhombus, Clyde (F. S. G.).

Trebius caudatus, $K r$.-On Raia batis and R. clavata, F. of Clyde; freq.

Fam. Dichelestiidae.

Clavella labracis, van Ben.-On gills of stripped wrasse Labrus mixtus, nr. Ayr, Jan. 1900.

Cycnus pallidus (van Ben.).--On gills of Conger, Conger niger, F. of Clyde ; not r. (F.S. G.)

Fam. Lernaeidae.

Lernaea branchialis, Lin.-Not gुunc. on gills of Haddocks, Whitings and other Gadoids (F. S. G.). 


\section{Fam. Chondracanthidae.}

Oralien asellinus ( $\mathrm{Lin}$.).-Not unc. on gills of Gurnards, flat fishes, ete,

Chondracanthus cornutus, $(O, F$. M Mill.$)$.-On gills of Plaice, Pleuronectes platessa; Clyde (F.S. G.).

C. clavatus, Basset Smith.-Mod. freq. on gills of Lemon Soles, Pleuronectes microcephalus, F. of Clyde (F. S. G.).

C. soleae, $\mathbf{K} r$.-On gills of Black Sole, Solea vulgaris, F. of Clyde (F. S. G.).

C. flurae, Kr:-On gills of Long Rough Dabs Drepanopsetta platessoides, F. of Clyde.

C. merluccii, Holten.-Clinging to roof and sides of mouth of Hake Merlucius merluccius, Clyde.

C. lophii, Johnston.-Inside gill pouches of Angler-fish, Lophius piscatorius, Clyde (F. S. G.).

C. zeus, De la Roche.-Occasionally on gills of John dory, Zeus faber, Clyde (F. S. G.).

C. limandae, $K r$.-On gills of common Dab, Pleuronectes limanda, Clyde (F. S. G.).

C. ornatus, T. Scott.-On gills of a Spotted dragonet, Cablionymus maculatus, Clyde 1899 (F. S. G.).

Fam. Lernaeopodidae.

Charopinus dubius, T. Scott.-On gills and gill-arches of Raia circularis, Clyde, Dec., 99 (F. S. G.).

Lerneopoda galei, $k r$.-Attached bet. ventral fins of Galeorhinus galeus (Duthie): also on Scylliorhinus caniculus (F. S. G.).

L. bidiscalis, W. F. de V. Kane.-Attached to end of claspers of Galeorkinus galeus, Clyde Jany. 1900 (Duthie).

L. cluthae, T. Scott.-On gills of Raia fullonica, Clyde, April 1897 (F. S. G.).

Brachiella insidiosa, Heller.-On gills of Hake, Merlucius merluccius, Clyde (F. S. G.).

B. triglae, Claus.--From gills of Trigla lineata, nr. Ailsa Craig 1897.

B. merluccii, Basset-Smith.-On gill-rakers of Merlucius merluccius, Clyde (F.S. G.).

Anchorella rugosa, $K r$.-On gills of Anarrhichus lupus, not unc. in Clyde (F. S. G.).

A. uncinata, O. F. Miill.-Not unc. on Whiting and other gadoids in Clyde (F. S. G.).

A. stellata, $K r$ :-On skin of Hake Nerlucius merluccius, Clyde, 18/12/99 (F. S. G $G_{n}$.

Fam. Choniostomatidae.

Aspidoecia normani, Giard and Bonnier.-Living upon Erythrops serrata, G. O. Sars, Clyde, rather r. (S.). (See Dr. H. J. Hansen's Monog. on the Choniostomatidae).

\section{Order Thoracica.}

Fam. Balanidae.

Balanus porcatus, Costa.-U. L. Fyne, on shells of Mytilus (M.). Gen. dist., freq.

B. crenatus, Brug.--U. L. Fyne (M.). Bet. Corswall and Mull of Kintyre (F. S. G.), freq.

B. balanoides (Lin.).-U. L. Fyne (M.). Gen. dist., freq.

B. hameri (Ascan.).- U. L. Fyne in 12-20 f., and also on the shore (M.). Occasionally by dredging. 


\section{Fam. Verrucidae.}

Verruca stromia (O. F. Müll.).-Freq. on stones and dead shells.

Fam. Lepadidae.

Scalpellum vulgare, Leach.-Attached to Zoophytes; not very r. in Clyde.

\section{ORDER RHIZOCEPHALA.}

\section{Fam. Sacculinae.}

(Note.-Several Sacculines have been obtained in the Clyde ; but without a knowledge of their development it would be unsafe to say whether they are distinct or not, and with one or two exceptions I am therefore unable to ascribe them to particular species).

Sacculina carcini (Thomp.).--On abdomen of shore crab, Carcinus maenas, not unc. in some parts of the Clyde.

S. sp.-On abdomen of Galathea dispersa, Clyde 1895-1896, r. (F. S. G.):

S. sp.-On abdomen of Munida rugosa (Fabr.). Clyde 1896-1897 (F. S. G.) : 1899 (Alex. Patience). Not very r. in seaward part of estuary.

S. sp.-On the abdomen of Inachus dorsettensis, dredged bet. Arran and Ayrshire, 20-43 f., 1897 (F. S. G.), apparently r.

S. sp.-On the abdomen of Stenorhynchus rostratus, in the trawl net E. of Arran in 20-43 f., 9/97 (F. S. G.).

Peltogaster paguri (Rathke).-On abdomen of Eupagurus bernhardus, E. L. Tarbert (1886), etc. (S.).

$$
\text { PYCNOGONIDAE. }
$$

By M. LaUrie.

Pycnogonum littorale, Fabi:-Mod. c.

Phoxichilidium sp.-Cumbrae, among sea weed, l. w. (R.).

Pallene brevirostris, Johnst.-L. w. Allans, Cumbrae (R.): Lamlash B. (H.). Nymphon gracile, Fabr.-L. Cumbrae, Lam Zone and l. w. (R.) : Lamlash B. (H.). 


\section{MARINE WORMS.}

By James F. Gemmill, M.A., M.D., The University, Glasgow.

References, Etc.

D. R. $+=$ Specimens sent to British Museum by the late David Robertson,

LL.D. ; v. Johnston, Catalogue of the Brit. Non-parasitical Worms, 186ว̃.

D. R. ${ }^{*}=$ Specimens sent by Dr. Robertson to Prof. M'Intosh, St. Andrews,

v. A Monograph of the British Annelids, vol. ii. (Ray. Soc.), 1873-74.

F. $=$ Edward Forbes, F.R.S., Brit. Assoc. Rep., 1850, p. 244.

H. $=$ Prof. W. A. Herdman, F.R.S., \&c., Trans. Roy. Phys. Soc. Edin., vol. v., p. 202.

Hoyle=W. E. Hoyle, M.A., F.R.S.E, Journ. Linn. Soc. (Zool.) xx. p. 442.

S.=Thomas Scott, F.L.S., 15th Ann. Rep. Scot. Fish. Board, Pt. iii., p. 157.

(The list of worms here given is mainly from MS. records of the S. Y.

"Medusa.")

$\mathbf{M}=$ "Medusa" records.

Rob. Mus. = Robertson Museum, Millport.

$\S=$ Specimens identified by M. I. Newbigin, D.Sc., \&c., Edin. School of Medicine for Women.

J. F. G. =J. F. Gemmill, M.A., M.D., The University, Glasgow.

(?) before a record indicates that no species authority was given in the source from which the particular record was taken.

\section{Polychaeta.}

The general arrangement adopted is that given by Malmgren, Annulata Polychaeta, Stockholm, 1867.

Aphrodite aculeata, Linn.-Widely dist. but not plentiful, 15-17 f.

Euphrosyne foliosa, Audouin and M. Edwards.-Millport. (D. R.t).

E. Robertsoni, M'Intosh.-Firth of Clyde (D. R.*) : nr. Ailsa 20 f. (J. F. G.).

Hermione hystrix, Savigny.-U. L. Fyne, 65-70 f. (S. : J. F. G.).

Laetmonice filicornis Kinberg, var. kinbergi.-U. L. Fyne $70 \mathrm{f}$ (S.).

Lepidonotus squamatus, Linn.-C. everywhere litt. zone and mod. depths. L. clava, Montagu.-Millport, litt. to 15 f. (J. F. G.).

Gattyana cirrosa, Pallas.-S.E. of Sanda, 23 f. (J. F. G.) : no doubt $=N y$ chia cirrosa (Pallas) recorded by $\mathrm{H}$. from Lamlash $\mathrm{B}$.

Eunoa nodosa Sars.-Specimen in Rob. Mus. identified by M'Intosh.

Lagisca floccosa, Sav.-Millport, shore and mod. depths (J. F. G.).

Acanthicolepis asperrima, Sars.-F. of Clyde (D. R.*) : S.E. of Sanda 23 f. (J. F. G.).

Evarne impar, Johnston.-Lamlash B. (H.).

Harmothoe imbricata, Linn.-Lamlash B. (H.); Millport shore and at mod. depths (J. F. G.).

H. lunulata, Delle Chiaje.-Millport 5-15 f. (J. F. G.). 
Halosydna gelatinosa, Sars.-U. L. Fyne (S.) : Millport shore and various depths (J. F. G.).

Panthalis oerstedi, Knbg.-L. Fyne 40 f. and over (F. G. Pearcey) : L. Fyne 50 f.; Bet. Arran and Cumbrae 70 (J. F. G.).

Scalisetosus communis, D. Ch.-Millport 5-15 f. (J. F. G.).

Sigalion Mathildae, Aud. and Edw.-Lamlash B. (H.).

S. Buskii, M'Int.-Dunoon Basin 8 f. (M.).

Sthenelais boa, Johnston.-Sand, Balloch B. (J. F. G.): possibly = Sigalion boa recorded in (M.) : from nr. Davaar 20 f., and nr. Pladda 15-35 f.

S. limicola, Ehlers,-Millport 15-20 f. ; nr. Davaar 20 f. (J. F. G.).

Pholoe inornata, Jnstn.-Millport (D. R. †).

Nephthys caeca (Fabricius.).-Gareloch (D. R.): v. Malmgren, p. 141). Millport sand (J. F. G.).

N. Hombergi (Aud. and Edw.).-E. side of U. L. Fyne (S.).

(?) N. ciliata.-U. L. Fyne 15-20 f. (S.) : may be N. ciliata (Müller).

N. longisetosa (Oersted.).-Lamlash B. (H.): Millport 10-15 f. (J. F. G.).

Phyllodoce lamelligera, Jnstn.-Under stones nr. l. w. Balloch: seems intermediate between $P$. lamelligera, Jnstn. and $P$. laminosa, Sav. Quatrefages (M. I. Newbigin, Millport Station "Communications," 1900).

P. maculata, (Müll.). \$-Millport 5-15 f. (J. F. G.).

P. groenlandica, Oerst. §-Campbeltown L. 20 f. (J. F. G.).

P. paretti, Blainville. $\$-M i l l p o r t ~ 10-15$ f. (J. F. G.).

Eulalia viridis, Müll.-Lamlash B. (H.) : off Sanda 19 f (M.).

E. obtecta, Ehlers. §-Campbeltown L. 20 f. ; off Whiting B. 20-30 f. ; bet. Fairlie and Cumbrae 15-20 f. (J. F. G.).

E. punctifera, Grube. $§-O f f$ S. End of Bute 15-20 f. (J.F. G.).

E. cordifolia, Jnstn. \$-Millport 10 f. (J. F. G.).

Eteone foliosa, $Q f g . \$-N r$. Ailsa 20 f. (J. F. G.).

E. depressa, Malmgren.-Millport 10-15 f. (J. F. G.).

Psamathe punctata (Jnstn.).-Millport l. w. m. to 10 f. (J. F. G.).

Syllis armillaris (Muill.).-Lamlash B. (H.): Millport 10 f. (J. F. G.).

Autolytus (prob.) longisetosus (Oerst.).-Millport bottom townet $10 \mathrm{f}$. (J. F. G.).

Nereis pelagica $(\operatorname{Linn}$.).--Very widely dist. on shore and in shall. waters.

N. Dumerilii, Aud. and Edw.-Lamlash B. (H.) : U. L. Fyne 10-15 f. (S.): Millport 5-15 f. (J. F. G.).

N. diversicolor, Müll.-Lamlash B. (H.): Ayrshire (P. W. M'Lagan): Cumbrae (D. R.t).

(?) N. virens.-Sanda 22 f. (M.), probably $=N$. virens, Sars.

(?) N. bilineata.-Dunoon basin shore (M.), probably $=N$. bitineata, Jfg., Qfg.

Nereilepas fucata (Sav.).-In shells tenanted by hermit crabs, many localities (J. F. G.).

Lumbrinereis fragilis, Müll.-Millport 10-20 f. (J. F. G.).

L. nardonis, Grube.-E. side of U. L. Fyne (S.).

Funice norvegica (Linn.).-E. side of U. L. Fyne (S.) : outside Davaar $19 \mathrm{f}$. (J. F. G.).

(?) E. sanguinea.-Off Pladda 30-35 f. (M.).

Hyalinoecia tubicola (Müll.).-Widely dist. 15-70 f., many records.

Northia tubicola (Jnstn.).--Synonymous with the foregoing.

N. conchylega (Sars.).-Firth of Clyde (D. R.t) : Dunoon Basin 5-10 f. (M.): Millport 12 f. (J. F. G.).

Goniada maculata, Oerst.-Millport 20 f.; bet. L. Cumbrae and Garroch Hd. 40 f. (J. F. G.).

G. (prob.) emerita,Aud. and Edw.-Millport 20 f. (J. F. G.).

Glycera tesselata, Grube. var. M'Intoshii.-U. L. Fyne 15-60 f. (S.).

G. capitata, Oerst.-C. litt. zone and mod. shall. water.

G. gigantea, Qfg.-Fairlie sand (M. I. Newbigin). 
Ammotrypane aulogaster, Rathke.-Widely dist. mud 10-25 f.

Ophelia limacina, Rtke.-Off Mull of Kintyre 55 f. (J. F. G.).

Travisia Forbesi, Jnstn.-Cumbrae (D. R. †).

Scalibregma inflatum, Rtke.-Millport (Kölliker): off Keppel 15 f.; bet. Bute and Cumbrae 20-50 f. ; U. L. Fyne 30 f., (J. F. G.).

Eumenia Jeffreysii, $M^{\prime} I n t$.- - In deeper waters all over Clyde area.

Arenicola marina (Linn.)-Very c. on shore wherever plenty of sand.

A. ecaudata, Jnstn.- Sand at Balloch (J. F. G.).

Ephesia gracilis, Rtke. [=Sphaerodorum peripatus (Jnstn.)].-Specimen in Rob. Mus. : Millport 5-10 f. (J. F. G.).

Trophonia plumosa (Müll.).-R. but widely dist., l. w. m. to $40 \mathrm{f}$.

T. glauca, Mgrn.-U. L. Fyne 15-20 f. (S.) : off Keppel 5-10 f. (M. I. Newbigin): bet. L. Cumbrae and Portincross 15 f. (J. F. G.).

Siphonostoma diplochaitos, Otto.-Many records.

Chaetopterus variopedatus, Ren. [=C. insignis (Baird)].-Widely dist. 10-47 f., many records.

Nerine foliosa, Sars. $[=\mathbf{N}$. coniocephala (Jnstn.)].-Sand at Balloch and Garrison B., Cumbrae (J.F. G.). Specimen in Rob. Mus., named Aonis vittata (Grube).

N. cirratulus, Clap. (D. Ch.).- Sand, Balloch and Garrison B., Cumbrae (J. E. G.).

Scolecolepis vulgaris (Jnstn.) Mgrn.-Foul sand at Lochgilphead (J. F. G.). Scoloplos armiger (Miill.).--Sand, Balloch; Lochgilphead, etc. (J. F. G.).

Cirratulus cirratus (Mïll.) Mgrn. [=C. borealis (Lam.)].-C. under stones (J. F. G.).

Chaetozone setosa, Mgrn.-Bet. L. Cumbrae and Portincross 15 f. (J. F. G.).

Notomastus latericeus, Sars.-Nr. Ailsa 23 f. ; bet. L. Cumbrae and Ayrshire 20 f. (J. F. G.). A Notonastus sp. (?) U. L. Fyne (S.).

Capitella capitata, Fabr.-Balloch, sand (J. F. G.).

Maldane biceps (Sars) Mgrn.-U. L. Fyne 60 f. (S.); off Cock of Arran 90 f. (J. F. G.).

Rhodine Lovéni, Mgrn.-L. Fyne 70 f. (S.): off Dippin 69 f. ; off Sheep I. 30 f. (J. F. G.).

Nicomache lumbricalis (Fabr.).-S. E. of Sanda 23 fms. (J.F.G.). Probably =Clymene borealis recorded by (H.) from Lamlash B. A Clymene lumbricalis (Aud. \& Edw.) found by D. R.t, from the description of the funnel seems to be Axiothea catenata, Mgrn.

Axiothea catenata, Mgrn.-See under preceding.

(?) Clymene amphistoma.-U. L. Fyne 15-20 f. (S.).

Praxilla gracilis (Sars).- Sand nr. Ailsa 29 f. (J.F. G.). Probably=the Clymene (Praxilla) gracilis, from U. L. Fyne 15-20 f. (S.).

P. praetermissa, Mgrn.-Millport 10-15 f. (J. F. G.).

Owenia filiformis, D. Ch.-Lamlash B. (H.): c. 10-20 f. nr. Millport (J. F. G.).

Sabellaria alveolata.-Clyde 15-20 f. (F.). Probably =S. alveolata, Linn. = S. anglica (Jnstn.).

Pectinaria belgica (Pall.).--Many records.

Amphictene auricoma ( $/$ iüll.).-Lamlash B. (H.) : Millport 10-15 f. (J.F.G.).

Lagis Koreni, Mgrn.-Millport. Rob's. specimen in Rob. Mus.

Petta pusilla.-Millport (Robertson).

Ampharete gracilis, Mgrn.-Fairlie Channel 15-20 f. (J. F. G.).

Amphicteis Gunneri (Sars).-E. of Davaar 23 f. ; off Sheep I. 20 f. (J.F.G.).

Amage auricula, Mgrn.-Bet. Turnberry and Pladda 30 f. (J. F. G.).

Sosane sulcata, Mgrn.-E. of Davaar 23 f. (J. F. G.).

Amphitrite cirrata, Müll.-Many records.

Terebella Danielsseni (Mgrn.).-Bet. Fairlie and Keppel 15-20 f. (J. F. G.). = Polymnia nesidensis, D. Ch., U. L. Fyne 15-20 f. (S.).

Lanice conchilega (Pall.).--Sand bet. tide marks, c. 
Nicolea venustula, Mont.-All round Cumbrae 10-20 f. (J. F. G.).

Thelepus circinnatus (Fabr.).-U. L. Fyne 10-20 f. (S.). All round Cumbrae 10-20 f. (J.F. G.).

Pista cristata (Mïll.).-Nr. Ailsa 20 f. ; S. E. of Davaar 23 f. ; bet. Bute and L. Cumbrae 40 f. (J. F.G.).

Trichobranchus glacialis, Mgrn.-Nr. Ailsa $20 \mathrm{f}$; S. E. of Sanda 20-25 f. (J. F. G.).

Terebellides Stroemi, Sars.-Widely dist. but nowhere plentiful, 15-40 f.

Polycirrus aurantiacus, Mgrn.-Centre of U. L. Fyne (S.).

P. haematodes (Clap.).-Fairlie Channel 15-20 f. (J. F. G.).

Sabella pavonina, Sav.-Widely dist., l. w. m. to 50 f. and over. $S$. penicillus (Linn.) also occurs frequently in (M.) and (H.). The two species seem however to be synonymous.

Potamilla reniformis (Miill.).-Boring in old shells, pieces of stone, ash, etc., various localities 8-30 f. (J. F. G.).

Dasychone bombyx, Dalyell. $\$-$ Rob. Mus. : mud, various localities 15-30 f. (J. F. G.). Probably = the D. argus, E. side of U. L. Fyne (S.).

Jasmineira elegans, St. Joseph.-Off Keppel Pier 10-15 f. (M. I. Newbigin.). Myxicola infundibulum, Renier.-Off Sheep I. 20-23 f. (J.F.G.). No doubt = Arippasa infundibulum, Cumbrae (D. R.†).

Chone Duneri, Mgrn.ई-Off Keppel Pier 10-20 f. (J. F. G.).

Euchone analis, Mgrn.\$-Millport 15-20 f. (J. F. G.).

Serpula vermicularis, Linn.-C., adherent to stones, shells, etc., 8 f. and downwards.

Protula tubularia, Mont.-Off Keppel (M. I. Newbigin).

Hydroides norvegica, Gunn, Mörch.\$-Millport 10-15 f. (J. F. G.).

Pomatocerus triqueter, Mörch.-Very c., adherent to stones, etc., $8 \mathrm{f}$. and downwards.

Filigrana implexa, Berkeley.-Many records $40 \mathrm{f}$. and downwards.

Protula protensa (Gr.).-Cumbrae (D. R. $\dagger$ ) : Lamlash B. (H.).

Tomopteris onisciformis (Escholtz).-Lamlash B. (H.) : L. Fyne (S.) : Millport in townet (J. F. G.).

Myzostomum cirriferum, Leuckart.-On crinoids dredged off L. Cumbrae 15-20 f. (J. F. G.).

Spirorbis borealis, Daudin.-C. everywhere encrusting stones, fucus, etc.

S. nautiloides (Lam.).-Lamlash B. (H.).

\section{Nemertinea.}

Lineus marinus, Montagu.-Many records from l. w. m. to mod. depths.

L. gesserensis, O. F. Mïller.-Under stones bet. tides Skelmorlie (N. M'Laren): Millport (Alex. Patience).

(?) L. sanguineus.-Gareloch, Rob. Mus.

Nemertes carcinophila, $K$ ölliker.-Millport (A. Patience ; J. F. G.).

N. neesii, Oersted. - Gareloch, Rob. Mus., Millport (A. Patience).

Amphiporus pulcher, Miill.-15-25 f. shelly ground Skelmorlie (N. M'Laren).

A. lactifloreus, Jnstn.-Under stones bet. tide marks (N. M'Laren).

Cerebratulus angulatus, Müll.-Fairlie Sands (J. F. G.).

Carinella annulata, Mont.- Several records, widely dist. but nowhere plentiful.

Micrura purpurea, Dalyell.-Millport 8 f. (J. F. G.).

Tetrastemma dorsalis, Abilgaard.-Among weeds l. w. m. (N. M'Laren).

Cephalothrix linearis, Rathke.-Under stones bet. tide marks (N. M'Laren).

? Polystemma alba.-Rob. Mus.

GEPHyREA.

Phascolosoma papillosum, Thompson.-Nr. Ailsa 20 f. (J. F. G.) (ident. by A. E. Shipley). 
P. vulgare, Blainville.-Tan buoy 12 f. and various other localities (J. F. G.) (ident. by A. E. Shipley, M. A.).

P. procerum, Mobius. -Nr. Ailsa 20 f. (J. F. G.) (ident. by A. E. Shipley).

(?) P. strombi, Mont.-L. Fyne 10-70 f. (S.).

(?) Sipunculus bernhardus.-Many records in (M.), etc.

\section{VARIOUS.}

Pontobdella muricata, Linn.-Many records.

Malacobdella grossa, $O$. F . Miiller.-Many records.

(?) Piscicola marina.-Loch Goil 24-40 f. (M.).

Priapulus caudatus, Lam.-Gareloch (M.).

Sagitta bipunctata, Quoy and Gainard.-All over L. Fyne (S.) : nr. Millport, many records.

Echinorhynchus acus, Rudolphi.-Intestine of cod and flounder (N. M'Laren).

E. lancea, Westrumb. - Intestine of Vanellus cristatus (N. M'Laren).

The Turbellaria have not been sufficiently well worked up to warrant the giving of a list. 


\section{ECHINODERMATA.}

By George Bell Todd, M.B., C.M., Prof. Zoology, Anderson's College, Medical School, Glasgow.

Arrajgenent : Bell, British Echinoderms.

Authorities :

$M=$ 'Medusa' M.S. Records of Sir John Murray.

Hoy $=$ Hoyle, W. E., "Deeper water fauna of the Clyde Sea Area" (Journ. Linn. Soc., vol. xx., 1890.)

\section{Asteroidea.}

Astropecten irregularis, Penn. [=Asterias aurantica (L.)].-Arran Bas. : Otterard and Carradale $18 \mathrm{f}$. ; Dumoon Basin (M.).

Luidia ciliaris (.Johnst.) [=fragilissima, Forbes].-R. : Arran Bas. ; Carradale 24 f. (M.).

Porania pulvillus (O. F.M.) [=Goniaster templetoni, Forbes].-L. Goil : Dunoon Bas. 18-20 f. : Arran Bas. 10-48 f.: U. L. Fyne 11-25 f. : The Plateau : Sanda to Ashinhoan, Sanda to Ailsa 19-24 f. (M.) : Kilbrennan Sd. 22-45 f. : Inchmarnock Bas. $37 \mathrm{f}$.

Asterina gibbosa, Penn.-Dunoon Bas. (M.).

Palmipes placenta (Penn). [=membranaceus (Retz)].-R.: L. Goil perch 5-8 f. : Dunoon Bas. lower end (M.).

Stichaster roseus [=Cribella rosea, $(O, F, M$.$) ]. -Gareloch : L. Goil :$ Dunoon Bas. 10-30 f. : Arran Bas. 30-35 f. : U. L. Fyne shore and 10-25 f. : Kilbrennan Sd. (M.).

Solaster papposus $(F a b r$.$) .-L. Goil: Gareloch: Dunoon Bas. 7-50 f.:$ Arran Bas. 18-28 f. : U. L. Fyne 10-30 f. : and shore: The Plateau 24 f. (M.): Inchmarnock Bas. 22 f. (Hoy).

S. endeca (L.).-Gareloch : L. Goil : Dunoon Bas. 6-20 f.: L. Striven 15-20 f.: Arran Bas. 16-26 f.: U. L. Fyne 10-25 f.: The Plateau : Davaar 24 f. (M.).

Henricia sanguinolenta, O. F. M. [= Cribella oculata (Penn.)].-Gareloch : L. Goil : Dunoon Bas. : L. Striven : U. L. Fyne: The Plateau 19-22 f. (M.) : Inchmarnock Bas. 80 f. (Hoy).

Asterias rubens $L$. C.

var. violacea (O. F.M.).-L. Goil 45 f. : Dunoon Bas. 30-40 f.: Arran Bas. 22 f. : U. L. Fyne shore and 15-20 f. : The Plateau-Sanda to Ashinhoan, Sanda to Ailsa 22-34 f. (M.): Kilbrennan Sd. 23 f. (Hoy).

A. glacialis $(O, F . M$.). - Arran B. 24 f. : U. L. Fyne 10-25 f.: The Plateau 24 f. (M.).

A. hispida, Penn.-L. Striven (M.). 


\section{OpHIUROIDFA.}

Ophiura ciliaris, L.-C. in Gareloch : L. Goil : Dunoon Bas. : U. L. Fyne, Minard, centre and near head 5-150 f. : the Plateau, Sanda to Ailsa 24 f. (M.), \&c.

O. albida (Forbes).-C.: Gareloch : L. Goil : L. Striven : Arran Bas. : Carradale 18-47 f. : U. L. Fyne, Minard 12-70 f. : the Plateau : Campbeltown L. 8-16 f. (M.).

O. affinis (Ltk.).-C. in Gareloch: L. Goil: U. L. Fyne, Minard, W. and E. side and centre 12-70 f. (M.): Kilbrennan Sd. 75-80 f.: Inchmarnock Bas. 104 f. (Hoy.).

Ophiocnida brachiata (Mont.).-Dunoon Bas. (M.).

Amphiura chiajii, Forbes.-C. Gareloch : L. Goil : Dunoon Bas. 5-50 f. : L. Striven 10-40 f. : Arran Bas. 22-92 f.: U. L. Fyne, centre and near head, 10-70 f. (M.): Kilbrennan Sd. 75-80 f. : Inchmarnock Bas. 37-109 f. (Hoy).

A. filiformis (O.F.M.).-C. Gareloch; L. Goil: Dunoon Bas., centre, 10-50 f. : L. Striven 10-40 f. : Arran Bas. 18-20 f. : U. L. Fyne 10-70 f. : The Plateau 22 f. (M.) : Brodick Bas. 50-90 f. : Kilbrennan Sd. 75-80 f. : Inchmarnock Bas. 100 f. (Hoy).

Ophiopholis aculeata (L.).-C.: Gareloch : L. Goil : Dunoon Bas.: L. Striven: Arran Bas.: U. L. Fyne: The Plateau Campbeltown L. 8-22 f. : Inchmarnock Bas. 37-104 f. (Hoy.).

Ophiocoma nigra (Abilg.) (= O. granulatus).-Gareloch : L. Goil : Dunoon Bas.: L. Striven : Arran Bas.: U. L. Fyne shore and 10-35 f.: The Plateau : Campbeltown L. 8-16 f. (M.).

O. minuta, (?) U. L. Fyne, Minard (M.).

O. neglecta (Robertson).-Dunoon Bas., S. end.

Ophiothrix fragilis (Abilg.).-C.: Gareloch: L. Goil: Dunoon Bas.: L. Striven: Arran Bas. : U. L. Fyne: The Plateau (M.).

\section{Echixoidea.}

Echinus esculentus, L.-C. all Clyde areas.

E. miliaris (Gmel.) - C. all Clyde areas (M.).

Echinocyamus pusillus (O.F.M.).-R.: Dunoon Bas., centre: Tan 5-20 f. (M.).

Spatangus purpureus (Leske).-C. all Clyde areas except Gareloch (M.).

Echinocardium cordatum, Penn. [=Amphidotus cordatus, Forbes].-C. all Clyde areas (M.).

Echinocardium flavescens (O.F. M.).-Comparatively r. L. Striven: Arran Bas.: The Plateau : Campbeltown L. 8-25 f. (M.): Dunoon Bas. $35 \mathrm{f}$. (Hoy.).

Brissopsis lyrifera (Forb.).-C. in all Clyde areas except Gareloch (M.).

\section{Holothuroidea.}

Synapta digitata (Mont.).-Comparatively r.; Gareloch: Dunoon Bas., W. side shore in muddy sand (M.).

S. inhaerens (O.F.M.).-R. Gareloch: Arran Bas., bet. Cumbrae and Arran 90 f. (M.).

S. buski, M'Int. [=tenera, Norm.].-R. Dunoon Bas., S. end (M.).

Cucumaria hyndmani (Thomps.).-Comparatively r. Dunoon Bas. : L. Striven, centre W. and E. side 16-22 f.: U. L. Fyne, E. side $20 \mathrm{f}$. (M.): Kilbrennan Sd. 75-80 f. (Hoy.).

C. pentactes, Mont.-Comparatively r. Gareloch: U. L. Fyne, E. side 30 f. (M.).

C. fucicola, $F$. and G.-Very r. L. Goil (M.). 
Thyone fusus (O.F.M.).-C. Gareloch : L. Goil : Dunoon Bas. : L. Striven, W. and E. side 10-20 f. : Arran Bas. : U. L. Fyne: The Plateau: Campbeltown L. 8-14 f. (M.). Kibrennan Sd. 75-80 f. (Hoy.).

T. raphanus, Düb. and Kor.-C. Dunoon Bas., centre 50 f.: L. Striven, W. side 20 f. : Arran Bas. : Pladda 30-35 f. : U. L. Fyne : E. L. Tarbert, S. side (M.).

Psolus phantapus (Strussenf).-C. Gareloch: L. Goil : L. Striven : Dunoon Bas.: U. L. Fyne: The Plateau : Campbeltown L. 8-14 f. (M.). Inchmarnock Bas. 40 f. (Hoy.).

Phyllophorus drummondi, Thomp.-R. L. Striven, W. side 20 f.: L. Goil (M.).

Holothuria intestinalis (Asc. and Rath.).-R. Kilbrennan Sd. 50 f. (Hoy.). Crinoidea.

Antedon bifida, Penn. [=rosacea, Auctt.].-Dunoon Bas.: Cumbrae to Wemyss B. 30-40 f., centre E. side : S. end Tan Buoy 5-30 f. (M.), (Hoy.): Castle B., L. Cumbrae, abund. 


\section{COELENTERA.}

ACTINOZOA.

By Malcolm Laurie, B.A., D.Sc., St. Mungo's College, Glasgow.

Arrangement and Nomenclature: Gosse, British Sea Anemones.

Contractions.

G. $=$ Gosse, loc. cit.

H. = Herdman, Proc. Roy. Phys. Soc. Edin., vol. v.

M. = MSS. records by S. Y. 'Medusa.'

R. = Dr. Robertson, for the most part his MS. notes.

\section{Zoantharia.}

Actinoloba dianthus (Ellis).-C., especially on wooden piers.

Sagartia bellis (Ellis).--Not c. ; tide pools Cumbrae (R.): Corrigills (G.) : Lamlash (H.).

S. miniata (Gosse).-C. ; rock pools.

S. rosea (Gosse).-L. Striven (M.).

S. venusta (Gosse).- - hather r.; holes at l.w. (R.).

S. nivea, Gosse.-Rather r. ; nr. l. w. Cumbrae; Cloch (R.).

S. troglodytes, Johnst.-Mod. c. var. prasinopicta. One, shell hole, Battery Pt., Cumbrae (R.).

S. viduata (Mïll.).-R. ; on stones Cumbrae (R.).

S. parasitica, Couch.-Not unc. deep water (R.).

S. cosenia-Tan buoy, 7 f. (M.) [? coccinea (Mïll.)].

Adamsia palliata (Bohad.).-C. Mostly with Eupagurus prideauxii.

Phellia pictà (Gosse).-R. on shells 20 f. Cumbrae (R.).

Anthea cereus (Ellis and Sol.).-Freq. on Zostera Cumbrae (R.): Lamlash (H.).

Actinia mesembryanthemum, Ellis and Sol.-C.

Bolocera tuediae (Johnst.).-U. L. Fyne 15-70 f. ; L. Striven ; L. Goil (M.): r. W. of Cumbrae (R.).

B. eques (Gosse).-Dunoon Bas. 20 f. ; L. Striven (M.) : L. Fyne c. deep water (R.).

Bunodes thallia (Gosse).-R. in a tide pool Cumbrae (R.).

B. coronata.

Tealia crassicornis (Müll.).-C. rocks and shingle.

Stomphia churchiae (Gosse).-Mod. c. ; $12-25$ f. Cumbrae (R.) : U. L. Fyne ; L. Striven \&c. (M.).

Peachia hastata (Gosse).-R. ; l.w.-2 f. betw. Alands; 8-10 f. Tan Buoy (R.): Dunoon Bas. (M.).

P. triphylla (Gosse).--R. muddy sand at extreme 1. w. Cumbrae (R.).

Edwardsia callimorpha (Gosse).-Mod. c. ; U. L. Fyne ; Dunonn Bas. (M.): Castle B. 6-25 f. ; nr. Callum's Hole (R.). 
E. carnea (Gosse).-Locally c., under stones; E. of Kames B.; Port Loy (R.).

Cerianthus lloydii (Gosse).-Rather r. at and below extreme 1. w. Garrison B. and betw. Alands, Cumbrae (R.): Dumoon Bas. (M.).

Cerianthus, Sp.-L. Goil (R.).

Corynactis viridis, Allman.-Locally c. ; rock pools Cumbrae (R.) : Lamlash (H.).

Caryophyllia smithii, Stokes.-R. ; L. Striven 20 f. (M.) : l. w. Cumbrae (R.).

Alcyonium digitatum, L.-C.

$$
\text { Alcyonaria. }
$$

Pennatula phosphorea, $L .-$ Not unc. deep water.

Sarcodictyon catenata. Pladda; Otterard 24-35 f. ; Sanda (M.) : Lamlash (H.).

Virgularia mirabilis, Lam.-U. L. Fyne 11-70 f.; Dunoon Bas. ; L. Striven ; L. Goil ; L. Ranza (M.).

$$
\text { SCY PHOMEDUSAE. }
$$

Lucernaria cyathiformis, Sars.-Arran, Landsborough.

L. Fascicularis, Fleming.-Ardrossan, Alder.

Aurelia aurita, Linn.-Common.

Cyanaea capillata (Baster). - Lamlash Bay, Herdm.

Rhizostoma pulmo. Common.

Many Ctenophors occur but there are no records. 


\section{HYDROIDA.}

By James Rankin, B.Sc., M.B., University, Glasgow.

Classification : Hincks' Classification followed.

References.

(C.) = Chopin, Manchester Micro. Soc. Trans., 1894.

(H.) = Herdman, Proc. Roy. Phys. Soc. Edin., vol. v.

$($ Hoy. $)=$ Hoyle, Jour. Linn. Soc. (Zool.), vol. xx., 1890.

(M.) = MSS. records of Sir John Murray's S. Y. 'Medusa.'

(R.) = Dr. Robertson, Collection in Robertson Museum, Millport.

(R. M. $=$ Specimens in Robertson Museum having no name attached.

Fam. Clavidae.

Clava multicornis, Forskal.-Lamlash B., litt. on Fucus, etc. (H.).

C. cornea, T. S. Wright.-Dunoon Basin, W. side, shore (M.) : L. Cum. brae (R.).

\section{Fam. Hydractiniidae.}

Hydractinia echinata, Flem.-Abund. and gen. dist.

\section{Fam. Corynidae.}

Coryne pusilla, Gaertner.-Lamlash B., litt. (H.).

C. vaginata, Hincks.-King's Cross, in rock pools (H.).

C. fruticosa, Hincks.-Cumbrae, nr. l. w. (R.).

C. Van Benedeni, Hincks.-L. Cumbrae, l. w. (R.).

Syncoryne eximia, Allm.-Cumbrae (C.).

S. Sarsi, Lovén.-King's Cross, litt. (H.).

S. pulchella, Allm.-Skelmorlie and Rothesay (Allm. Gym. Hyd.).

Zanclea implexa, Alder.-Off Skelmorlie, 10-15 f. (Maclaren).

\section{Fam. Eudendriidae.}

Eudendrium rameum, Pallas.-Sanda to Achahoan, 22 f. (M.) : Kilbrennan Sd. (M.) : U. L. Fyne (M.) : Millport B., 6 f. (M.): off Largs, 20 f. (M.): Lamlash B., 14-25 f. (H.).

E. ramosum. L.-Lamlash B., 5-25 f. (H.).

\section{Fam. Atractylidae.}

Perigonimus repens, Wright.-Kilbrennan Basin, 50 f. (Hoy.).

Dicoryne conferta, Alder.-Sanda to Achahoan, 19 f. (M.) : Dunoon Basin, $40 \mathrm{f}$. (Hoy.).

Bougainvillia ramosa, Van. Ben.-Lamlash B., 10-21 f. (Н.).

\section{Fam. Tubulariidae.}

Tubularia indivisa, L.-Not unc., gen. dist.

T. larynx, Ell. and. Sol.-L. Goil, Stuckbeg to head of loch, 40-24 f. (M.): Dunoon Basin, 30-40 f. (M.): Gareloch, from 21 f. to head of loch,

8 f. (M.) : Cumbrae (R.). 
T. coronata, Abildg.-Arran Basin, Saddell, 10-15 f. (M.): Dunoon Basin, $5-42$ f. (M.) : Gareloch, from 21 f. to head of loch, 8 f. (M.): Cumbrae (R.) : Lamlash B., 10-20 f. (H.).

T. simplex, Alder.-Lamlash B., 2-16 f. (H.).

T. humilis, Allm.-Keppel Pier, Cumbrae (R.).

Fam. Campanulariidae.

Clytia Johnstoni, Alder.-Off Keppel Pier, Cumbrae (R. M.) : Lamlash B., upper lam. (H.)

Obelia geniculata, L.-L. Striven, l.w. (M.) : Lamlash B., upper lam. (H.): Cumbrae (R.) : L. Goil, l. w. (R. M.).

0. gelatinosa, Pallas.-Cumbrae (C.).

O. dichotoma, L.-Lamlash B., litt. (H.).

O. flabellata, Hincks. - Lamlash B., litt. (H.) : Cumbrae (C.).

Campanularia volubilis, L.-L. Goil, Stuckbeg to head of loch, 40-24 f. (M.) : Kilbrennan Basin, 50-60 f. (Hoy.).

C. Hincksi, Alder.-Cumbrae (C.).

C. integra, Macgillivray.-Cumbrae (C.).

C. verticillata, L.-C.

C. flexuosa, Hincks.-Lamlash B. (H.): Cumbrae (R.).

C. angulata, Hincks.-L. Striven, 15-20 f. (M.): L. Goil, 40-24 f. (M.): Dunoon Basin 20 f. (M.): Kilbrennan Basin, 50-64 f. (Hoy.) : Cumbrae (C.).

C. (?) gigantea, Hincks.-Lamlash B. (Wyville Thomson, Br. Hyd., vol. i.).

Gonothyraea Lovéni, Allm.-Gareloch, Barrier $5 \mathrm{f}$., outside to $14 \mathrm{f}$., inside to $21 \mathrm{f}$. (M.).

G. (?) hyalina, Hincks.-Dunoon Basin, 15 f. (M.): Cumbrae (R. M.)

Lafoëa dumosa, Flem.-C.

\section{Fam. Lafoëidae.}

L. fruticosa, Sars.-Abund., gen. dist.

L. pocillum, Hincks.-Gareloch, on Sertularia abietina, 20 f. (M.) : off Keppel Pier (R.).

Calycella pygmaea, Alder (=Lafoëa pygmaea, Alder).-Gareloch, from

21 f. to head of loch, 8 f. (M.) : off Keppel Pier (R.).

C. syringa, L.-Cumbrae (C.).

C. fastigiata, Alder.-Cumbrae (C.) : Kilbrennan Basin 49 f. (Hoy.).

Filellum serpens, Hassall.-Lamlash B. (H.).

\section{Fam. Haleciidae.}

Halecium halecinum, L.-Abund., gen. dist.

H. muricatum, Ell. and Sol.--Sanda to Achahoan 19-22 f. (M.): U. L. Fyne, Minard, 15-20 f. (M.) : Kilbrennan Basin 49 f. (Hoy.).

H. Beani, Johns.--Sanda to Achahoan 22 f. (M.): Dunoon Basin 5-10 f. (M.): Lamlash B. (H.) : Kilbrennan Basin 80 f. (Hoy) : Cumbrae (C.) :

H. labrosum, Alder.--Cumbrae (C.).

H. tenellum, Hincks.-Off Keppel Pier 22 f. (R.).

H. plumosum, Hincks.-Cumbrae (C.).

\section{Fam. Sertulariidae.}

Sertularella polyzonias, L.-Dunoon Basin 10-15 f. (M.): Lamlash B. 3-25 f. (H.) : Cumbrae (R.).

S. Gayi, Lamouroux.-Off Davaar 20 f. (M.) : Arran Basin 18-47 f. (M.) : Dunoon Basin 16-20 f. (M.) : L. Bay, Lorn (R.) : Cumbrae (R.).

S. tricuspidata, Alder.-Cumbrae (R.).

S. rugosa, L.-U. L. Fyne, Minard, 12-20 f. (M.) : Kilbrennan Basin, $64 \mathrm{f}$. (Hoy.) : Lamlash B. (H.).

S. fusiformis, Hincks.-Off Pladda 30-35 f. (M.): Inchmarnock Basin $104 \mathrm{f}$. (Hoy.): U. L. Fyne 15 f. (M.). 
Diphasia rosacea, L.-Off Sanda 20 f. (R. M.) : Lamlash B. 14-21 f. (H.): Cumbrae (R.): Dunoon Basin 8-20 f. (M.).

D. attenuata, Hincks.-Dunoon Basin 8-42 f. (M.): Kilbrennan Basin 30-64 f. (Hoy.).

D. fallax, Johns.-Arran Basin, Saddell, 47 f. (M.) : Kilbrennan Basin 64 f. (Hoy): L. Fyne (A. M. N. Br. Hyd., vol i.).

D. pinaster, Ell. and Sol.-Kilbrennan Basin 64 f. (Hoy.): Lamlash B. 3-7 f. (H.) : off Keppel Pier 23 f. (R. M.).

D. tamarisca, L.-Kilbrennan Basin 64 f. (Hoy.) : Dunoon Basin 45 f. (M.) : Lamlash B. 10-21 f. (H.).

Sertularia pumila, L.-Abund.

S. gracilis, Hassall.-Cumbrae (C.).

S. operculata, L.-Cumbrae (R.).

S. filicula, Ell. and Sol.-L. Goil 9-20 f. (M.): Gareloch 5-21 f. (M.): U. L. Fyne, Minard, 11-25 f. (M.): off Keppel Pier (R.): Lamlash B. 10-25 f. (H.).

S. abietina, L.-C., from Sanda 19 f. to U. L. Fyne, Minard, 12-20 f.

S. argentea, Ell. and Sol.-C., gen. dist.

S. cupressina, L.-L. Goil 9-20 f. (M.) : Gareloch 5-21 f. (M.) : Cumbrae (R.). Hydrallmania falcata, $L_{\text {. }}-\mathrm{C}$.

Thuiaria articulata, Pallas.-Sanda to Achahoan 19-22 f. (M.) : Kilbrennan Sd. 17-20 f. (R. M.).

\section{Fam. Plumulariidae.}

Antennularia antennina, L.-C.

A. ramosa, Lamarck.-C.

Aglaophenia pluma, L.-Dunoon Basin 8-42 f. (M.) : Cumbrae (R. M.).

A. tubulifera, Hincks.-Kilbrennan Basin 30-64 f. (Hoy.): Dunoon Basin 16-20 f. (M.): Cumbrae (R.).

A. myriophyllum, L.-Kilbrennan Sd. (M.): Dunoon Basin, Warden Bank, 8 f. (M.): L. Fyne (A. M. N. Br. Hyd., vol. i.): off Keppel Pier 23 f. (R. M.).

A. pennatula (Ell. and Sol.).-Kilbrenuan Sd. (M.) : off Sánda (R. M.).

Plumularia pinnata, $L .-\mathrm{C}$.

P. setacea, Ellis.-Gareloch 5-21 f. (M.): off Keppel Pier 22 f. (R.) : Lamlash B. 10-13 f. (H.).

P. Catherina, .Johns.-Mod. c.

P. similis, Hincks.-Dunoon Basin (M.).

Fam. Hydridae.

Hydra viridis, L.-Possil Marsh : Cumbrae.

H. vulgaris,-Pallas.--Pond nr. Kennishead.

\section{HYDROMEDUSAE.}

\section{Anthomedusae.}

Bougainvillia Britannica, Forbes.-Kyles of Bute (Forbes).

Euphysa aurata, Forbes.-Lamlash Bay (H.).

Oceania octona, Forbes.-Lamlash Bay (H.).

Lizzia Claparedii, Haeckel (=Lizzia blondina, Forbes).-Arran, Claparède.

Sarsia pulchella, Forbes.--Skelmorlie, Rothesay ; (Allman).

\section{Leptomedusae.}

Stomobrachium octocostatum (Sars).-Bute (Forbes): Arran (Landsborough).

Thaumantias quadrata, Forbes.-L. Fyne (Forbes).

T. aeronautica, Forbes.-Lamlash Bay (H.).

T. octona, Forbes.-Tarbert, L. Fyne (Forbes) : Arran (Haeckel).

T. Thompsoni, Forbes.-Lamlash Bay (H.) 
PORIFERA.

By James Rankin, B.Sc., M.B., University, Glasgow.

Classification: Hanitsch's "Revision of the Generic Nomenclature and Classification in Bowerbank's British Spongiadae" (Liverpool Mar. Biol. C. Rep., vol. iv.).

The reference letters have the following significance :

(C.)= Chopin, Manchester Micro. Soc. Trans., 1894.

(R.) $=$ Dr. Robertson.

(H.) =Herdman ; P.R. Ph.S. E., vol. v.

(M.) = MS. Records of Sponges collected by Sir John Murray's S. Y.

'Medusa.'

\section{Class I. Calcarea.}

Leucosolenia botryoides, Ell. and Sol. (= Grantia botryoides, Flem.).-Cumbrae: Lamlash, litt. c. (M.).

L. coriacea, Flem. (=Ascetta coriacea, Flem.).--Arran Basin (M.) : Cumbrae (C.) : Lamlash B. (H.).

Sycon compressum, Auctt. (= Grantia compressa, Auctt.).-C.

S. coronatum, Ell. and Sol. (=Grantia ciliata, Flem.).-C.

Leucandra nivea, Grant (=Leuconia nivea, Grant).-L. Goil shore (M.): Cumbrae (C.).

\section{Class II. Silicea.}

Halisarca Dujardini, Johns.-U. L. Fyne, 55 f. on Inachus Dorsettensis (M.). Stelletta Collingsi, Bwk. (='Tethya Collingsi, Bwk.)-Off Sanda 12 f. (M.). Pachymatisma Johnstoni, Bwk.-Cumbrae (C.).

Pachychalina gracilenta, Buk.-Under stones, Cumbrae (R.): Mon. Br. Spong., vol. iv.

P. limbata, Mont. (=Chalina limbata, Bwk.).-L. Striven, l. w. (M.).

Halichondria albescens, Johns.-U. L. Fyne, E. and W. sides, and shore (M.).

H. fallaciosa, Bwk. (= Hymeniacidon fallaciosus, Bwk.).-Clyde district. Mon. Br. Spong., vol. iv.

H. panicea, Pallas.-C.

var. papillaris.-Upper L. Fyne, E. and W. sides and shore (M.).

H. reticulata, Buk. (= Hymeniacidon reticulatus, Bwk.).-Clyde district (Mon. Br. Spong., vol. iv.).

Reniera crassa, Bwk. (=Isodictya crassa, Bwk.).-Clyde district (Mon. Br. Spong., vol. iv.).

Esperiopsis sp.?-Off Skate I. 80-100 f. (M.).

Dendoryx incrustans, Esper. (= Halichondria incrustans, Esper.).-Clyde district (Mon. Br. Spong., vol. iv.).

D. Pattersoni, Bwk. (= Halichondria Pattersoni, Bwk.).--Clyde district (Mon. Br. Spong., vol. iv.). 
Acarnus stelliferus, $B w k$. (= Hymeraphia stellifera, $B w k$.).-Clyde district (Mon. Br. Spong., vol. iv.).

Clathria clavigera, Bwk. ( = Hymeniacidon clavigera, $B w k$.).-Clyde district (Mon. Br. Spong., vol. iv.).

Ophlitaspongia seriata, Grant (=Clathria seriata, Johns.)-Cumbrae (C.).

Phakellia ventilabrum, Johns.-Clyde district (Mon. Br. Spong., vol. iv.).

Tragosia infundibuliformis, Johns. (= Isodictya infundibuliformis, $B w k$.).Off Skate I., 80-100 f. (M.).

Suberites domuncula, Olivi. (= Suberites suberea, Gray).-C.

S. farinarius, Bwk.-(= Halichondria farinaria, Bwk.).-Clyde district (Mon. Br. Spong. vol. iv.).

S. ficus, Johns. (= Hymeniacidon ficus, Johns.)-Mod. abund.

Polymastia sp.? - Off Skate I. 80-100 f. (M.).

Cliona celata, $\operatorname{Grant}(=$ Hymeniacidon celata, $B w k$.).-Cumbrae (C.). Lamlash B. (H.).

Spongelia fragilis, Mont., var. irregularis (=Dysidea fragilis, Johns.).Lamlash B. (H.). 


\section{PROTOZOA.}

\section{INFUSORIA.}

By J. R. Thomson, 6 Vinicombe Street, Hillhead, Glasgow.

Arrangement Followed : W. Saville Kent, F.L.S., F.Z.S., F.R.M.S., Manual of the Infusoria, 1882.

Flagellata.

Actinophrys sol, Ehr.-C.

Dendromonas virgaria (Weisse).--Possil Marsh ; canal at Crookston.

Anthophysa socialis (From.).-Provan Mill.

Cephalothamnium cuneatum, $S$. K.-Provan Mill.

C. caespitosum, $S$. K.--Dougalston.

Petalomonas mediocanellata, S. K.-E. Kilbride.

P. abscissa, Duj.-E. Kilbride.

Menoidium pellucidum, Pty.-E. Kilbride.

Astasia trichophora, Ehr.-E. Kilbride.

Euglena acus, Ehr.-E. Kilbride ; Crookston.

E. spirogyra, Ehr.-Frankfield L.

E. viridis, Ehr.-Gen. dist.

Amblyophis viridis, $E h r$-C Crookston.

Phacus pleuronectes, $E h r$.-E. Kilbride.

Trachelomonas rugulosa, S. K.-St. Germains L.

Ascoglena vaginicola, St.-C. and gen. dist.

Eutreptia viridis, Pty.--St. Germains L.

Heteronema acus, Ehr.-Crookston.

Diplomastix caudata, Duj.-St. Germains L.

Anisonema truncatum, St.-Crookston and Dougalston.

A. grande, Ehr.-Provan Mill.

Mallomonas plosslii, Pty.-Possil Marsh ; Provan Mill.

Mitophora dubia, Pty.-E. Kilbride.

Ciliata.

Holotricha.

Paramaecium aurelia, Müll.-C. and gen. dist.

P. bursaria, Ehr.-Dougalston L.

P. putrinum, C. L.-Craigallian L.

Loxocephalus luridus, Ehr.-Bishop L., Crookston.

Conchophthirus anodontae, Ehr.-E. Kilbride.

Enchelyodon farctus, $C$. and $L$.-Crookston and Dougalston.

Coleps hirtus, Ehr.-St. Germains, and Provan Mill.

Enchelys arcuata, C. and L.-Crookston.

E. farcimen, Ehr.-Crookston.

Trachelocerca olor, Ehr.-Dougalston ; Bardowie L.

Amphileptus anser, Ehr.-St. Germains; Dougalston, L. 
Cyclotricha critreum, C. and L.-Frankfield, L.

Pleuronema chrysalis, Ehr.-Provan Mill.

\section{Heterotricha.}

Stentor polymorphus, Müll.-C. and gen. dist.

S. igneus, Ehr.-Crookston.

S. roeselli, Ehr.-E. Kilbride and Provan Mill.

Peritricha.

Halteria grandinella, Mïll.-Possil Marsh and Provan Mill.

Rhabdostyla longipes, S. K.-Dougalston L.

Vorticella nebulifera, Ehr.-Crookston and Dougalston L.

V. alba (From.).-Gen. dist.

V. campanula, Ehr.-Gen. dist.

V. citrina, Ehr.-Dougalston L.

V. cratera, S.K.-Dougalston L.

V. microstoma, Ehr.-Dougalston L.

V. putrinum. Gen. dist.

V. quadrangularis, S.K.-Possil Marsh ; Provan Mill.

V. spectabilis, S.K.-Dougalston L.

V. monilata, Tatem.-Dougalston L. ; Canal.

Carchesium polypinum, L.-Crookston; Possil Marsh.

C. epistylidis, C. and L.-E. Kilbride ; Crookston.

Zoothamnium arbuscula, Ehr.--Possil Marsh ; Crookston

Z. parasita, St.--Dongalston L.

Z. simplex, S. K.-Crookston; Provan Mill.

Z. affine, St.-Crookston; Provan Mill.

Epistylis galea, Ehr.-Crookston ; Possil Marsh.

E. anastatica, L.-Dougalston ; St. Germain's.

E. plicatilis, Ehr.-Dougalston.

E. flavicans, Ehr.-Crookston.

E. digitalis, Ehr.-Crookston.

Opercularia nutans, Ehr.-Provan Mill.

0 . berberina, L.-Crookston.

O. articulata, Ehr.-Possil Marsh.

O. microstoma, St.-Crookston.

Vaginicola crystallina, Ehr:-C.

Cothurnia imberbis, Ehr.-Craig Dam, Milngavie.

Ophrydium sessile, S. K.-Crookston.

0 . versatile, Müll.-Crookston.

O. eichornii, Ehr.-Crookston.

\section{Hypotricha.}

Urostyla grandis, Ehr.-Crookston.

Onychodromus grandis, Ehr.-Possil Marsh ; Crookston.

Gastrostyla steinii, Eng.-Provan Mill.

Opisthotricha parallela, Eng.-Provan Mill.

Oxytricha platystoma, Ehr.--Crookston; Provan Mill.

Histrio steinii, Miill.

Stylonychia mytilus, Ehr.-Provan Mill.

Aspidisca costata, Dij.-Crookston; Frankfield L.

\section{Tentaculifera.}

Rhyncheta cyclopum, Zenk.-Provan Mill.

Podophrya mollis, S. K.--Provan Mill.

P. quadripartita, C. and L.-Provan Mill.

P. cyclopum, C. and L.-Provan Mill.

Acineta stelata, S. K.-Provan Mill. 
FORAMINIFERA.

By Mrs. Robertson, Fernbank, Millport, Cumbrae.

\section{Classification.}

H. B. Brady, F.R.S., F.G.S., "A Synopsis of the British Recent Foraminifera" (Roy. Micros. Soc. Trans., 1897).

H. B. Brady, Report on the Scientific Results of the Voyage of H.M.S. Challenger," vol. ix., 1884.

\section{Abbreviations.}

H. = Herdman, Prof., W. A. : "Invertebrate fauna of Lamlash Bay" (Roy. Phys. Soc. Edinb., vol. v. and vi., 1880).

P. $=$ Fred. G. Pearcy, Naturalist on Fishery Board Steamer 'Garland.'

R.=The late Dr. David Robertson, Millport.

S. = Thomas Scott, F.L.S., Fishery Board for Scotland.

Fam. Miliolidae.

Sub.-fam. Nubecularinae.

Nubecularia lucifuga, Defrance.-Kilchattan B., 25 f., (R.).

Sub.-fam. Miliolinae.

Biloculina irregularis, d'Orb.-Mod. r. Kilbrennan Sd., 75-80 f.; off S. end of Bute, 40 f. ; L. Goil, 44 f. ; off Wemyss B. (R.).

B. ringens, Lamarck.-Gen. dist.

B. depressa, d'Orb.-C. everywhere.

B. elongata, d'Orb.-Gen. dist.

B. simplex, d'Orb.-Bet. Portincross and Ardrossan, 30 f. (R.).

B. bicarinata, d'Orb.-Kilbrennan Sd., 75-80 f. (R.).

Spiroloculina planulata, Lamk-L. Fyne, 25 f.; off Seamill, 30 f.; off Inverkip, 15 f.; Rothesay B., 10-12 f. ; off L. Cumbrae, 3-5 f.; off Girvan (R.).

S. limbata, d'Orb. - Widely dist.

S. canaliculata, d'Orb.-C., widely dist.

S. excavata, d'Orb.-Cumbrae :-Claugh, 6 f. ; off Figgetoch, 22 f. ; Port Loy, 10-12 f., and Tan : off Portincross, 15 f. ; Kilbrennan Sd., 75-80 f. ;

Lamlash B., 12-15 f. ; Rothesay B. (R.).

S. tenuis, Czjz.-Kilbrennan Sd., 75-80 f., r. (R.).

Miliolina trigonula, Lamk.-Gen. dist.

M. circularis, Borneman.-Off Corswall Pt., 60 f. (R.) ; off Ailsa Craig, 28 f.; bet. Mull of Kintyre and Corsewall L. H., 60 f. ; off Dumnighu Pt., 23.30 f. ; off Pigeon I., L. Fyne, 18 f. (P.). 
M. tricarinata, d'Orb.-C. everywhere.

M. oblonga, Mont.-Gen. dist.

M. seminulum, Linn.-C. everywhere.

M. venusta, K. Kar.-Kilbrennan Sd., 75-80 f., mod. r. ; off Callum's B., Bute; bet. Portincross and Ardrossan, 30 f. ; off Skate I., L. Fyne, $105 \mathrm{f}$. ; off Wemyss B. (R.) ; off Corsewall Pt., $60 \mathrm{f}$. (R.).

M. auberiana, d'Orb.-Tarbert Bank, 20-25 f. (S.); L. Fyne (R.).

M. contorta, d'Orb.-Tarbert, 20-25 f. (S.) ; Claugh, Cumbrae, 6 f. ; Lamlash B., 12-15 f.; White B., Cumbrae, 20 f. ; Port Loy, 10-12 f.; off Horse I., Ardrossan, 20 f. ; L. Fyne (R.).

M. labiosa, d'Orb.-L. Fyne; off Ailsa Craig, 25 f. ; off Corsewall Pt., $60 \mathrm{f.}$ (R.).

M. subrotunda, Mont.-C. everywhere.

M. candeiana, d'Orb.-Lamlash B., 12-15 f. (R.).

M. secans, d'Orb.-Widely dist.

M. tenuis, Czj.-Tarbert Bank, r. (S.) ; L. Gair, 18 f., mod. r. (R.) ; Gareloch (R.).

M. ferussacii, d'Orb.-E. L. Tarbert (B. \& S.) ; Lamlash B. (H.) ; off Inveraray (S.) ; Tan, Cumbrae ; St. Ninian's B., Bute ; 4 miles off Girvan ; off L. Cumbrae, 3-5 f. (R.).

M. bicornis, W. and J.-Gen. dist., mod. r.

M. boueana, d'Orb.-Tan, Cumbrae, 4-8 f. (R.), off Corsewall Pt., 60 f. (R.).

M. pulchella, d'Orb.-Lamlash B., 12-15 f. ; Tan ; Rothesay B. (R.).

M. fusca, Brady.-Tarbert Bank, L. Fyne, r. (S.); shore sands, Saltcoats to Troon (Smith) ; Clyde, off Langbank and Port-Glasgow, mod. r. (R.); L. Cumbrae, brackish (R.) ; brackish pool L. Fyne at Inveraray (R.).

M. agglutinans, d'Orb.-Gen. dist.

M. circularis, Born.--Kilbrennan Sd., 75-80 f., r. (R.).

\section{Sub-fam. Hauerininae.}

Articulina conico-articulata, Batsch.-Bet. Largs and Cumbrae, 20 f. (R.) ; off S. end of Bute, 40 f. (R.); one mile off Ailsa Craig, 25 (R.); L. Gair, $18 \mathrm{f}$. (R.) - all the specimens dead and not quite perfect.

Ophthalmidium inconstans, Brady.-Kilbrennan S., 75-80 f. (R.) ; off Corsewall Pt., 60 f. (R.); bet. Mull of Kintyre and Corsewall L.H. 60 f. (P.).

Planispirina contraria, d'Orb.-Wemyss B., 7-8 f., mod. r. (R.).

P. celata, Costa.-Off Dunnighu Pt., 23-30 f. (P.); off Ailsa Craig, 28 f. (P.).

\section{Sub-fam. Peneropladinae.}

Cornuspira foliacea, Phil.-E. L. Tarbert (B. \& S.) ; shore sands, Saltcoats to Troon (Smith); Lamlash B. (H.); bet. Portincross and Ardrossan, 30 f. (R.) ; Inverkip B., 15 f. (R.); off Ailsa Craig, 28 f. (P.).

C. involvens, Reuss.-Gen. dist.

\section{Fam. Astrorhizidae.}

\section{Sub-fam. Astrorhizinae.}

Astrorhiza limicola, Sand.-Tarbert Bank, L. Fyne, 20-25 f. (S.) ; Whiting B., 25 f. (H.); W. side of Bute, 60 f. (R.); Cumbrae, 12 f. (R.) ; not unc. in Clyde area from $12 \mathrm{f}$. upwards on muddy bottom.

Pelosina variabilis, Brady.-C., gen dist., lower reaches of Clyde basin.

Dendrophrya radiata, Str. Wright.-Port Loy, Cumbrae (R.); Ardlamont Pt. (P.); bet. Mull of Kintyre and Corsewall L. H., 60 f. (P.).

D. erecta, Str. Wright.-Port Loy, Cumbrae (R.): Ardlamont Pt. (P.). 
Storthospheara depressa, Pearcey.-Off Dunnighu Pt., 25-27 f. (P.); off Heads of A yr, 26-32 f. (P.) ; 4 miles N.W. of Ailsa Craig, 29-33 f. (P.) ; $6 \frac{1}{2}$ miles W. of Ailsa Craig, 26-35 f. (P.) ; off Shiprock Lt., Sanda I., 25.28 f. (P.); bet. Sanda and Bennan H., 30-38 f. (P.) ; off Dundraft Cas., Ayrshire coast, mid chamel 40 f. (P.); off Ballantrae, 25-28 f. (P.).

\section{Sub-fam. Pilulininae.}

Technitella legumen, Norman.-L. Fyne, 106 f. (R.) ; off Cumbrae, mod. r., 60-65 f. (R.) ; S. end of Bute, 40 f., r. (R.) ; off Ailsa Craig, 28 f. (P.).

Bathysiphon minuta, Pearcey.-Off Dundraft Cas., Ayrshire coast, midchannel, 40 f. (P.); off Ailsa Craig, 28 f. (P.).

\section{Sub-fam. Saccammininae.}

Psammosphaera fusca, Schulze.-Tan, Cumbrae, 60 f. (R.) ; bet. Bute and Cumbrae, 00 f. (R.) ; off Ailsa Craig, 28 f., v. r. (P.).

\section{Sub-fam. Rhabdammininae.}

Jaculella acuta, Brady.-Tan, Cumbrae, 50-60 f., mod. r. (R.).

Hyperammina elongata Brady.-L. Fyne, 105 f. (R.); Cumbrae 60 f. r. (R.) ; off Ailsa Craig, 28 f. (P.).

H. arborescens, Norman.-Abund. and gen. dist., 20-60 f. ; freq. on annelid tubes.

\section{Fam. Lituolidae.}

Sub-fam. Lituolinae.

Reophax difflugiformis, Brady.--Tarbert Bank, L. Fyne (S.) ; White B., Cumbrae (R.) ; L. Gair, 18 f. (R.) ; Kilbrennan Sd., 75-80 f. (R.) ; off Ferry Ho., Cumbrae, 6 f. (R.) ; bet. Mull of Kintyre and Corsewall L.H., 60 f. (P.) ; off Ailsa Craig, 28 f. (P.) ; off Pigeon I., L. Fyne, 18 f. (P.).

R. fusiformis, Will.-C., widely dist.

R. scorpiurus, Mont.-C., widely dist.

R. nodulosa, Brady [R, scottii, Chartres]-S. end of Bute, 40 f. (R.); E. L. Tarbert (S.) ; off Greenock and elsewhere ; Campbeltown L. ; L. Gair 18 f. (R.); bet. Mull of Kintyre and Corsewall L.H., 60 f., v. r. (P.).

R. findens, Parker.-Tarbert Bank (S.).

R. dentaliformis, Brady._-Off Dumnighu Pt., Kintyre Coast, 23-30 f. (P.).

Haplophragmium pseudospirale, Will.-C., gen. dist.

H. agglutinans, d'Orb. $\mathrm{S}$. end of Bute, 40 f. (R.).

H. canariense, d'Orb.-Widely dist.

H. globigeriniforme, P. and J.-L. Fyne, 105 f., mor. r. (R.).

H. glomeratum, Brady.-L. Fyne, 105 f., r. (R.); off Corsewall Pt., 60 f. (R.).

H. manum, Brady.--Off Dunnighu Pt., Kintyre Coast, 23-30 f.

Placopsilina cenomana, d'Orb.-Port Loy, Cumbrae, r. (R.).

P. vesicularis, Brady.-Cumbrae, 60 f. (R.).

\section{Sub-fam. Trochammininae.}

Thurammina papillata, Brady.-S. end of Bute, 40 f. (R.).

Hippocrepina oblonga, Pearcey.-Off Ailsa Craig, 23-28 f. (P.); off Corsewell Pt., 30-38 f. (P.).

Ammodiscus incertus, $d$ Orb.-R., gen. dist.

A. gordialis, J. and P.-Tarbert Bank, L. Fyne, 20-30 f. (S.) ; Kilbrennan Sd., $75-80$ f. (R.); Kilchattan B., 20-25 f. (R.); off S. end of Bute, 40 f. (R.).

A. charoides, J. and P.-Tarbert Bank, L. Fyne, 20-30 f. (S.) ; L. Fyne, 105 f. (R.) ; Kilbrennan Sd., 75-80 f., r. (R.); Campbeltown L., r. (R.); off Pigeon I., L. Fyne, 18 f., r. (P.).

A. shoneanus, Sidd.-Port Loy, Cumbrae (R.); L. Fyne (R.). 
Trochammina squamata, $P$. and J.-Tarbert Bank, L. Fyne, 20-30 f. (S.); Claugh, Cumbrae, 6 f. (R.); off Seamill, 30 f. (R.); Campbeltown L. (R.); off Lion Rock, Cumbrae (R.).

T. ochracea, Will.-Kilbrennan Sd., 75-80 f., r. (R.).

T. plicata, Terq. -Off E. L. Tarbert, r. (S.).

T. inflata, Mont. - Off Skate I., 105 f., v. r. (P.); off Inveraray, r. (R.); horse sands Saltcoats to Troon (Smith); off Dunnighu Pt., Kintyre coast, 23-30 f. (P.).

var. macrescens, Brady.-Brackish pool L. Fyne; off Inveraray, 15-20 f. (R.).

T. trullissata, Brady.-Off Skate I., L. Fyne, 105 f. (R.).

T. Bradyi, Robertson. [= T. Robertsoni, Brady].-Tarbert Bank, L. Fyne, (S.) ; L. Fyne, 105 f. (R.) ; Kilbrennan Sd., 75-80 f. (R.).

\section{Fam. Textularidae.}

Sub-fam. Textularinae.

Textularia sagittula, defr.-Gen. dist., mod. c.

T. trochus, d'Orb.-Tarbert Bank, L. Fyne, not c. (Scott) ; off Dunnighu, Kintyre, 23-30 f. (P.); bet. Mull of Kintyre and Corsewall L.H., 60 f. (P.); off Ailsa Craig, 28 f. (P.); off Pigeon I., L. Fyne, 18 f. (P.).

T. agglutinans, d'Orb.-Kilbrennan Sd., 75-80 f. (R.).

T. gramen, d'Orb.-Tarbert Bank, mod. c. (S.); Campbeltown L. (R.) ; off Ailsa Craig, 25 f. (R.).

T. variabilis, Will.-L. Striven, 26 f. (R.).

Gaudryina filiformis, Berth.-Cumbrae, 60 f. (R.); S. end of Bute, 40 f. (R.); White B., Cumbrae, 20 f. (R.).

Verneuilina polystropha, Reuss.-C., gen. dist.

Valvulina fusca, Will.-Off Inveraray (R.).

V. conica, $P$. and J.-L. Fyne, 15-20 f. (R.).

\section{Sub-fum. Bulimininae.}

Bulimina pupoides, d'Orb.-Gen. dist.

B. ovata, d'Orb. -Kilchattan B., $20-25$ f. (R.) ; L. Goil, 30 f. (R.) ; S. end of Bute, 40 f. (R.) ; L. Fyne, 105 f. (R.) ; L. Gair, 18 f. (R.) ; Kilbrennan Sd., $75-80$ f. (R.).

B. fusiformis, Will.-Gareloch, $7-16$ f. (R.).

B. pyrula, d'Orb.-Off Skate I., L. Fyne, 105 f. (R.) ; Gareloch, 7-16 f. (R.);

B. marginata, d'Orb.-C., widely dist.

B. aculeata, d'Orb.-Kilbrennan Sd., 75-80 f. (R.); S. end of Bute, 40 f. (R.); L. Fyne, 105 f. (R.); Lamlash B., 12-15 f. (R.); Campbeltown Loch (R.).

B. elegantissima, d'Orb.-Off Minard, L. Fyne, 28 f. (P.); off S. end of Bute, 4 () f. (R.).

B. inflata, Seg.-Off Ailsa Craig, 28 f. (P.).

Virgulina schreibersiana, $C z j$.-Gen. dist.

Bolivina punctata, d'Urb.-S. end of Bute, 40 f. (R.) ; Kilbrennan Sd., 75-80 f. (R.) ; off Inveraray (R.) ; off Inverkip (R.); off Girvan (R.); Port Loy, Cumbrae, 10-12 f. (R.); L. Gair (R.); Campbeltown L. 18 f. (R.); off Wemyss B. (R.); off Corsewall Pt., 60 f. (R.).

B. plicata, d'Orb.-Sparingly in many localities.

B. costata, d'Orb.-L. Fyne, 105 f. (R.); off Ardrossan, 30 f. (R.) ; off Lion Rock, Cumbrae (R.); off Claugh, Cumbrae (R.); L. Gair, 18 f. (R.).

B. difformis, Will.--Off S. end of Bute, 40 f. (R.).

B. dilatata, Reuss.-Tarbert Bank, L. Fyne (S.); Kilbrennan Sd., 75-80 f.

(R.); L. Goil, 30 f. (R.); Inverkip B. (R.); bet. Mull of Kintyre and Corsewall L.H., 60 f. (P.).

B. laevigata, Will.-Off Minard, L. Fyne, 28 f. (P.). 
B. aenariensis, Da Costa.-S. end of Bute, 40 f. (R.).

B. reticulata, Hantk.-Off Pigeon I., L. Fyne, 18 f. (P.).

Sub-fam. Cassidulininae.

Cassidulina laevigata, d'orb.-L. Fyne, 105 f. (R.); shore bet. Saltcoats and Troon (Smith); Kilbrennan Sd., 75-80 f. (R.); S. end of Bute, $40 \mathrm{f}$. (R.) ; off Ailsa Craig, 28 f. (P.).

C. crassa, d'Orb.-E. L. Tarbert (S.) ; off Skate I., L. Fyne, 105 f. (R.) ; Kilbrennan Sd. 75-80 f. (R.) ; S. end of Bute, 40 f. (R.) ; L. (Gair, 18 f. (R.).

\section{Fam. Lagenidae.}

Sub-fam. Lagenınae.

Lagena globosa, Mont.-Widely dist.

L. laevis, Mont.-Gen. dist.

L. clavata, d'Orb.-Widely dist.

L. gracillima, Seg.-Mod. c., widely dist.

L. hispida, Reuss.-Widely dist.

L. lineata, Will.-Off Minard, L. Fyne (P.) ; L. Fyne, 105 f. (R.) ; Fintry B., 22 f., c. (R.) ; Claugh, Cumbrae (R.); Rothesay B. (R.) ; Kilbrennan Sd., 75-80 f. (R.) ; off Figgetoch, Cumbrae (R.).

L. distoma, $P$. \& J.-L. Fyne, 105 f. (R.); shore sands Saltcoats to Troon (Smith) ; Kilchattan B. (R.) ; off S. end of Bute, 40 f. (R.) ; Kilbrennan Srl., 75-80 f. (R.) ; L. Gair, 18 f. (R.).

L. distoma-polita, P. and.J.-Bet. Portincross and Ardrossan 30 f., r. (R.).

L. curvilineata, B. and W.-L. Fyne (R.); off Figgetoch, Cumbrae (R.).

L. lyellii, Seg.-Off Ardrossan (Smith); shore sands Saltcoats to Troon (Smith); L. Fyne (R.) ; E. L. Tarbert (B. \& S.) ; Kilchattan B. (R.); Rothesay B. (R.); L. Gair, 18 f. (R.); off Portincross (R.).

I. sulcata, Walker and Jacob.-Gen. dist.

L. williamsonii, Alcock.-Widely dist.

L. costata, Will.--Tarbert Bank (S.) ; Tan, Cumbrae (R.) ; St. Ninian's B., Bute (R.) ; off Corsewall Pt., 60 f. (R.); Rothesay B. (R.).

I. striata, d'Orb.-Gen. dist.

L. gracilis, Will.-Off Skate I., L. Fyne, 105 f. (P.) ; L. Fyne (R.) ; off Dunnighu Pt., Kintyre, 23-30 f. (P.) ; otf Pigeon I., L. Fyne, 18 f. (P.).

L. semistriata, Will.-C., gen. dist.

L. striato-punctata, P. and J.-Off Skate I., L. Fyne, 105 f. (R.).

L. squamosa, Mont.-Gen. dist. var. montagui, Alcock.-Rothesay B. (R.) ; 4 miles off Girvan, 12-15 f. (R.).

L. hexagona, Will.-Widely dist.

L. melo, d'Orb.-L. Fyne (B.\&S.) ; Tan, Cumbrae, 6-8 f., r. (R.) ; between Portincross and Ärdrossan, 30 f., r. (R.); St. Ninian's B., Bute, r. (R.).

L. marginata, W. and B.-E. L. Tarbert (B. \& S.) ; Lamlash B. (H.); L. Gair, 18 f. ; off Ardrossan, 30 f. ; St. Ninian's B., Bute ; Kilbrennan Sd., 75-80 f. ; off Ardrishaig, 5-8 f. ; off Corsewall Pt., 60 f. (R.).

L. Iucida, Will.-Tarbert Bank (S.) ; L. Gair, 18 f. (R.) : off S. end of Bute, 40 f. (R.) ; Gareloch, 7-16 f. (R.) ; L. Fyne, 105 f. (R.) ; Kilbrennan Sd., 75-80 f. (R.) ; off Wemyss Bay (R.).

L. orbignyana, Seg.-Gen. dist.

L. pulchella, Brady.-Fintry B. (Brady); off Figgetoch, Cumbrae (R.).

L. lagenoides, Brady.-Oft Skate I., L. Fyne, 105 f. (P.) ; 4 miles off Girvan (R.).

L. acuticostata, Reuss.-Off Dunnighu Pt., Kintyre coast, 23-30 f. (P.).

L. quadrata, Will.-Off Dunnighu Pt., Kintyre coast, 23-30 f. (P.).

L. apiculata, Reuss.-Bet. Mull of Kintyre and Corsewall L.H., 60 f. (P.). 
L. quadricostulata, Reuss.-Bet. Mull of Kintyre and Corsewall L.H., 60 f. (P.).

Sub.fam. Nodosarinae.

Nodosaria laevigata, d'Orb.-Kilbrennan Sd., 75-80 f. (R.) ; C'umbrae, 3-5 f. (R.); off Corsewell Pt., 60 f. (P.).

N. rotundata, Reuss.-Kilbrennan Sd., 75-80 f. (R.).

N. pyrula, d'Orb.-C., gen. dist.

N. consobrina, d'Orb.-Off S. end of Bute, 40 f. (R.): Campbeltown L. (R.); Kilbrennan Sd., 75-80 f. (R.) : L. Goil, 30 f. (R.).

N. communis, d'Orb.-Gen. dist.

N. pauperata, d'Orb.-Off Ardrossan (Smith): Inverkip B. (R.) : White B., Cumbrae, 20 f. (R.) ; Kilbrennan Sound, 75-80 f. (R.); L. Goil, 30 f. (R.) ; L. Fyne, 15-20 f. (R.) ; off Inveraray, 75-80 f. (R.).

N. scalaris, Batsch.-Widely dist.

N. obliqua, Lin.-Tarbert Bank, L. Fyne (S.) ; Kilbrennan Sd., 75-80 f. (R.); Cumbrae, 30 f. (R.).

N. perversa, Schm.-Tarbert Bank, r. (S.).

Vaginulina legumen, Linn.--Tarbert Bank, r. (S.) ; Campbeltown L. (R.); off Figgetoch, Cumbrae, 22 f. (R.) : L. Striven, 26 f. (R.) : Kilchattan:B., $45-50$ f. mod. c. (R.).

V. linearis, Mont.--Off Figgetoch, Cumbrae (R.).

Marginulina glabra, d'Orb.-Tarbert Bank, r. (S.).

Cristellaria elongata, Will.-Kilbrennan Sd., 75-80 f. (R.).

C. crepidula, $F$. and $M$.-Widely dist.

C. rotulata, Lam.-Gen. dist.

C. cultrata, Mont.-Off Skate I., L. Fyne, 105 f. (R.): off S. end of Bute (R.) ; Kilbrennan Sd., 75-80 f. (R.); Kilchattan B., 2-25 f. (R.).

C. gibba, d'Orb.-Off Pigeon I., L. Fyne, 18 f., v. r. (P.).

\section{Sub-fam. Polymorphininae.}

Polymorphina lactea, $W$. and J.-C., widely dist.

var. oblonga, Will.-Tarbert Bank (S.) ; off Skate I., 105 f., v. r. (P.) ; off Pigeon I., L. Fyne, 18 f., v. r. (P.).

P. gibba, d'Orb.-Gen. dist.

P. problema, d'Orb.-Lamlash B. (H.) ; off Corsewall Pt., 60 f. (R.).

P. thouini, d'Orb.-Kilchattan B., 20-25 f. (R.).

P. lanceolata, Reuss.-L. Fyne (R.).

P. compressa, d'Orb.-Gen. dist.

P. sororia, Reuss.-L Fyne (R.) ; off E. L. Tarbert (S.). var. cuspidata.-L. Fyne (R.).

P. rotundata, Born.-Tarbert Bank, 20-25 f. (S.) ; L. Fyne, off Inveraray (R.) ; off Corsewell Pt., 60 f. (R.).

P. elegantissima, $P$. and J.-Off Dunnighu Pt., Kintyre, 23-30 f. (P.).

P. communis, d'Orb.-Off Pigeon I., L. Fy.re, 18 f. (P.).

Uvigerina pygmaea, d'Orb.-Off Skate I., L. Fyne, 105 f. (R.) ; Kilbrennan Sd., 75-80 f. (R.).

U. angulosa, Will.-Tarbert Bank, r. (S.).

Sagrina dimorpha, P. and J.-L.-w., Girvan (R.) ; Tarbert Bank, r. (S.).

\section{Fam. Globigerinidae.}

Globigerina bulloides, d'Orb.-Lamlash B. (H.); shore sands, Saltcoats to Troon (Smith); bet. Mull of Kintyre and Corsewall L.H., 60 f. ; off Dunnighu Pt., Kintyre, 23-30 f. ; off Ailsa Craig, 28 f. (P.): off Corsewall Pt., 60 f.; off Skate I., L. Fyne, 105 f. ; Rothesay B., 10-12 f.; Gareloch (R.). 
G. inflata, d'Orb.-Lamlash B. (H.).

G. pachyderma, Ehrmb.-Bet. Mull of Kintye, and Corsewall L.H., 60 f. (P.).

Orbulina universa, d'orb.-Gen. dist., often of a brown colour.

Pullenia quinqueloba, Reuss.--Kilbrennan Sd., 75-80 f. (R.).

Fam. Rotalidae.

Sub.-fam. Spirillininae.

Spirillina vivipara, Ehr.-Off Ailsa Craig, 28 f. (P.).

\section{Sub.-fam. Rotalinae.}

Patellina corrugata, Will.-Off Ailsa Craig, 28 f. (P.); L. Fyne (B. \& S.); shore sands Saltcoats to Troon (Smith); bet. Mull of Kintyre and Corsewall L.H., 60 f. (P.); Port Loy, on muddy stones at l. spring tides, c.; S. end of Bute, 40 f. ; Tan, Cumbrae ; 4 miles off Girvan ; Kilbrennan Sd., 75-80 f.; bet. Portincross and Ardrossan, 30 f. ; Claugh, Cumbrae ; St. Ninian's B., Bute ; off Corsewall Pt., 60 f. (R.).

Discorbina globularis, d'Orb.-Gen. dist.

D. rosacea, d'Orb. - Widely dist. but not so c. as D. rosacea.

D. orbicularis, Terq.-Off E. L. Tarbert, 20 f. (P.) ; off Dunnighu Pt., Kintyre coast, 23-30 f. (P.) ; bet. Mull of Kintyre and Corsewall L.H., 60 f., (P.); off Ailsa Craig, 28 f. (P.).

D. wrightii, Brady.-Kilbrennan Sd., 75-80 f. (R.).

D. rugosa, d'Ord.-Off Ailsa Craig, 28 f. (P.).

Planorbulina mediterraniensis, $d^{\prime} \mathrm{O} r b$.-Widely dist.

Truncatulina refulgens, Mont.-Kilbrennan Sd., 75-80 f. (R.).

T. lobatula, W. and J.-C. everywhere.

T. ungeriana, d'Orb.-E. L. Tarbert, r. (S.) ; Kilbrennan Sd., 75-80 f. (R.).

T. variabilis, d'Orb.-Off Dunnighu Pt., Kintyre, 23-30 f. ; off Ailsa Craig, 28 f. ; bet. Mull of Kintyre and Corsewall L.H., 60 f. (P.).

Pulvinulina auricula, $F$. and M.-Tarbert Bank, r. (S.); off skate I., L. Fyne, 105 f. (R.).

P. karsteni, Reuss.-Lamlash B. (Н.).

Rotalia beccarii, Linn.-Widely dist.

R. orbicularis, $d^{\prime} \mathrm{Orb}$.-Off Skate I., L. Fyne, 105 f. (R.).

R. nitida, Will.-E. L. Tarbert (B. \& S.) ; Kilbrennan Sd., 75-80 f. (R.) ; 4 miles off Girvan, $12-15$ f. (R.); off Skate I., L. Fyne, 75-80 f. (R.); Tan, Cumbrae (R.); off Corsewall Pt., 60 f. (R.).

\section{Sub.-fam. Tiniporinae.}

Gypsina vesicularis, $P$. and J.-Off Corsewall Pt., 60 f. (R.)

G. inhaerens, Schultze.-Gen. dist.

Fam. Nummulinidae.

Sub.-fam. Polystomellinae.

Nonionina depressula, W. and J.-C., gen. dist.

N. umbilicatula, Mont.-Off Skate I., L. Fyne, 75-80 f. (R.); Kilbrennan Sd., 75-80 f. (R.); L. Fyne, 25 f. (R.) ; off Callum's B., Bute (R.).

N. orbicularis, Brady.-Off Pigeon I., L. Fyne, 18 f. (P.); off Ailsa Craig, 28 f. (P.); off Dunnighu Pt., Kintyre coast, 25-30 f. (P.); off Skate I., L. Fyne, $75-80$ f. (R.) ; Kilbrennan Sd., 75-80 f. (R.); L. Fyne, 25 f. (R.) ; off Corsewall Pt., 60 f. (R.).

N. boueana, d'Orb. -Off Corsewall Pt., 60 f. (R.). 
N. scapha, $F$. and $M$.-Tarbert Bank, r. (S.) ; Kilbrennan Sd., 75-80 f. ; off Inveraray, 15-20 f. ; L. Goil, 30 f. ; off Largs, 20 f. (R.).

N. stelligera, d'Orb.-Off Figgetoch, Cumbrae (R.); Inverkip B., 15 f. (R.); off Corsewall Pt., 60 f. (R.).

Polystomella crispa, Linn.-C. everywhere.

P. striato-punctata, $F$. and $M$.-Gen. dist.

P. arctica, $P$. and .J.-Off Dunnighu Pt., Kintyre coast, $23-30$ f. (P.) ; bet. Portincross and Ardrossan (R.).

Sub-fam. Nummulitinae.

Operculina ammonoides, Gron.-Tarbert Bank, 20-25 f. (S.) ; off Ailsa Craig, 28 f. (P.) ; off Skate I., L. Fyne, 105 f. (R.) ; Campbeltown L. (R.); off Corsewall Pt., 60 f. (R.).

N. turgida, Will.-L. Fyne, 25 f. (R.) ; L. Goil, 30 f. (R.) ; L. Fyne, 105 f. (R.); Kilbrennan Sd., 75-80 f. (R.); bet. Mull of Kintyre and Corsewall L. H., 60 f. (P.). 



\title{
PHYSICAL CONDITIONS OF THE CLYDE SEA-AREA.
}

\author{
By Hugh Robert Mill, D.Sc., LL.D.
}

Position. The name Clyde Sea-area was introduced in order to group together the estuary of the Clyde and all the sea-lochs along that part of the coast of Scotland which is separated from the Atlantic by the protecting arm of the peninsula of Kintyre. It lies within a line drawn from the Mull of Kintyre to the Rinns of Galloway, and is included between the parallels of $55^{\circ} 5^{\prime}$ and $56^{\circ} 17^{\prime} \mathrm{N}$., and the meridians of $4^{\circ} 30^{\prime}$ and $5^{\circ} 40^{\prime} \mathrm{W}$., with a connected water area of 1140 square miles.

Configuration. The region consists of a lowland or seaward part, edged mainly by gentle landslopes, from the sea to the Island of Bute, and of a highland or landward part, in which the sea-water invades a series of long valleys, branching on the whole northwards with a tendency either towards the east or west. Two of these valleys, with an easterly and a westerly trend respectively, are connected, forming the Kyles of Bute, and others approach each other, such as Loch Goil and Loch Fyne or the Gareloch and Loch Long. A depression of 30 feet would admit seawater to Loch Eck and Loch Lomond (both of which are filled with fresh water) and would greatly lengthen all the sea-lochs by flooding the extensive Hats at their heads. An upheaval of 30 feet, on the other hand, would convert Loch Riddon, Loch Goil and the Gareloch into fresh water lakes, and separate the Kyles of Bute into two lochs of typical form.

In the infinite irregularity and variety of bare mountain slopes and deep valley trenches, the uniform level of the smooth surface of the sea-lochs and the broader reaches of the sea-area suggests a uniformity which does not really exist. Could one remove the veil of water, the hollows it covers would appear in their true character, scarcely less varied in outline than the land, forming ridges, hollows, mountainous islands and shoals sometimes of surprising steepness, and broad gently-sloping plains. The featureless monotony of the water is merely a mask, but it has caused names to be applied to different portions of the surface which do not correspond with the natural regions outlined by the hidden features whose influence on the régime of the water and its inhabitants is paramount. Hence for the purpose of scientific description some liberties must be taken with the names which appear upon ordinary maps, although we shall use these as far as possible. The types of submarine configuration to be considered may be restricted to the two simplest and most important-plateaux or shallows and basins or deeps; and of these the Clyde Sea-area is made up as follows :

Natural Divisions. The Great Plateau forms a broad shelf or counter across the mouth of the Area from the Mull of Kintyre to Ayrshire, a distance of 30 miles, separating the water of the North Channel and Irish Sea on the south (with depths over 80 fathoms) from the equally deep hollows of the Arran Basin to the north. The contour-lines of 30 fathoms depth inside and outside the Platean are about 12 miles apart, and the Island of 
Arran, Kintyre and Ayrshire are all comnected by a ridge, the water on which is nowhere more than 25 fathoms deep, and in many places considerably less. Numerous small islands, the most prominent of which is Ailsi Craig, rise from the Plateau. An upheaval of 150 feet would entirely exclude the sea and convert the Clyde Sea-area into one great fresh-water lake and half a dozen small ones.

The Aman Basin consists of two deep troughs closely embracing the west and east of Arran, which unite at the north of that island, and the single hollow runs straight up Lower Loch Fyne to Otter Spit, the whole having the form of the Greek letter $\lambda$. The western limb, 30 miles long, occupies Kilbrennan Sound, and has a maxinum depth of 84 fathoms. The eastern limb is in the region usually known as the Firth of Clyde, and it runs on continuously with the northern or central limb, the two being traversed for 50 miles by one depression, which, with a depth exceeding 50 fathoms, runs from off Pladda, in the south of Arran, to off Kilfinan, near the head of the Basin at Otter Spit. This depression lies near the Island of Arran and shoals gradually towards the great sweep of shallow water along the Ayrshire coast. The deepest area is a narrow trough continuously over 80 fathoms in depth, which runs for 27 miles from a line between Corrie in Arran and the south point of Bute to off Stonefield, north of Tarbert. In this trough the deepest depression in the Clyde Sea-area is found off Skate Island, where a hole only a few hundred yards in diameter has a depth of 107 fathoms. Two short branches of the Arran Basin project northeastward, one between Bute and the Cumbraes, the other up the western arm of the Kyles of Bute. The sea north of Arran where the eastern and western branches of the basin unite is known superficially as Inchmarnock Water, while the central branch running up to Otter Spit is popularly included in Loch Fyne, or is more accurately called Lower Loch Fyne.

Upper Loch Fyne, which is always meant in this notice when "Loch Fyne" is referred to without qualification, is barred off from the Arran Basin by the shoal at Otter, which rises to within 15 fathoms of the surface in mid-channel. The Otter Spit, curving out fron the Cowal shore, restricts the entrance of Upper Loch Fyne to a breadth of $\frac{3}{4}$ mile, except at high tide, when the spit is covered, and the breadth expands to $1 \frac{3}{4}$ miles. Inside Otter Spit there is a stretch of $7 \frac{1}{2}$ miles to Minard Narrows, with a mean depth along the axis of 31 fathoms and 35 fathoms as its maximum, which has been termed the Gortans Basin. At Minard a group of islands splits Loch Fyne into two narrow chamnels, which are 12 and 18 fathoms deep respectively. Beyond Minard the bed of Upper Loch Fyne deepens gradually to 40 fathoms off Furiace, and then abruptly to 60 fathoms, the greatest depth being 75 fathoms, off Pemnimore Point. ${ }^{1}$

The deep chamnel rums up Loch Fyne to beyond Dunderawe, the branch known as Loch shira being only a shallow bay. The distance from Minard to the head of Loch Fyne is $18 \frac{1}{2}$ miles, and the breadth of nearly a mile diminishes above Inveraray, the loch gradually narrowing towards the head, where it is less than $\frac{1}{4}$ mile wide, while the hills bordering it become higher and their slopes more steep.

The Dunoon Basin runs north-eastward from the Bute Plateau, which bars the short north-eastern branch of the Arran Basin, and pursues its way in a straight line up Lower Loch Long to the entrance of Loch Goil, a distance of 20 miles. The mountainous peninsula between the Dunoon Basin and Loch Fyne is known as Cowal, and is trenched by a series of inlets on its south-eastern side, all running nearly N.N.W. towards Loch Fyne, and most of them occupied by sea-lochs, which give to the Cowal shore of the

1 I have searched repeatedly and very carefully for the depth of 82 fathoms marked on the Admiralty Chart at this position, and am satisfied that $75 \frac{1}{2}$ fathoms is the greatest depth which actually exists. 
Dumoon Basin a complexity of outline in its large features, contrasting with the general smoothness of the shores of Loch Fyne and the Central Arran Basin. The Bute Plateau has a maximum depth of 20 fathoms on its shallowest line, and the Dunoon Basin deepens to 56 fathoms off Dunoon, and, after shallowing, deepens again at the head to 55 fathoms at Dog Rock, off the mouth of Loch Goil.

Upper Loch Long (to which the name "Loch Long" as used in this paper always refers) is simply the upper end of the Dunoon Basin, a stretch $8 \frac{1}{2}$ miles long, separated from the deep at Dog Rock by a bar rising to within 18 fathoms of the surface. It has a maximum depth of 35 fathoms; it is less than half a mile wide, and is walled by very steep mountain slopes.

Loch Goil opens into the head of the Dunoon Basin across a bar with only 7 fathoms of water on it. It is separated from Loch Long by the rugged peninsula rising into heights of 2000 feet and more, which is named in some freak of Highland humour "Argyll's Bowling Green." The loch penetrates for 5 miles amongst the steepest hillsides of the whole area and preserves a breadth of a little more than half a mile almost to its head. The maximum depth is 47 fathoms; and this depth, combined with the small area and shallow entrance, isolates the water of Loch Goil more completely than that in any other part of the area.

The Holy Loch is only a deep bay opening into the Dunoon Basin but it is of interest by occupying the mouth of the valley of the fresh Loch Eck, and receiving its extensive drainage.

Loch Striven and the eastern arm of the Kyles of Bute open to the north of the Bute Plateau between Rothesay and Toward Point. Loch Striven gradually tapers from its mouth to the head, unlike most of the lochs, and runs for 9 miles between steep and uniform hillsides. It maximum depth is 42 fathoms, and its main depression crosses the opening of the Kyles and cuts into the Bute Plateau.

Where the two branches of the Kyles of Bute unite the short but very picturesque Loch Riddon runs northward, forming the mouth of the long valley known as Glendaruel. It is much shallowed towards the head by the material brought down by the River Ruel.

The Estuary of the River Clyde runs due westward into the Dunoon Basin between Gourock and Kilcreggan. It is everywhere shallow; depths of 5 fathoms not extending further east than the line joining Greenock and Roseneath Point, and on account of the narrowness of the navigable channel and the great amount of traffic it has not been so minutely studied from the points of view of salinity and temperature as the deeper and quieter waters.

The Gareloch is entered from the estuary, and stretches in a straight line towards Loch Goil, a basin to which it presents several analogies and contrasts. It is five miles long, separated from the estuary by a bar with no more than 5 fathoms on it at Row Point, which is a spit resembling that at Otter. The loch is similar in outline, identical in orientation and nearly equal in area and depth on the bar to Loch Goil ; but it has only half the average depth of that loch and its deepest part is ouly 22 fathoms, while the land bordering it is comparatively low and has the gentlest slopes that surround any of the Clyde lochs.

Loch Lomond, which discharges into the estuary by the river Leven at Dumbarton, is filled with fresh water and its surface stands 24 feet above sea-level ; but its configuration is exactly similar to that of the sea-lochs of which, were it at sea level, it would be by far the deepest.

The relation of the depths along the axis of the deepest water from the Channel across the Great Platean, up the eastern branch of the Arran Basin to the head of Loch Fyne is shown in the accompanying section (Fig. 1), the slopes of which are enormously exaggerated as the scales show : 


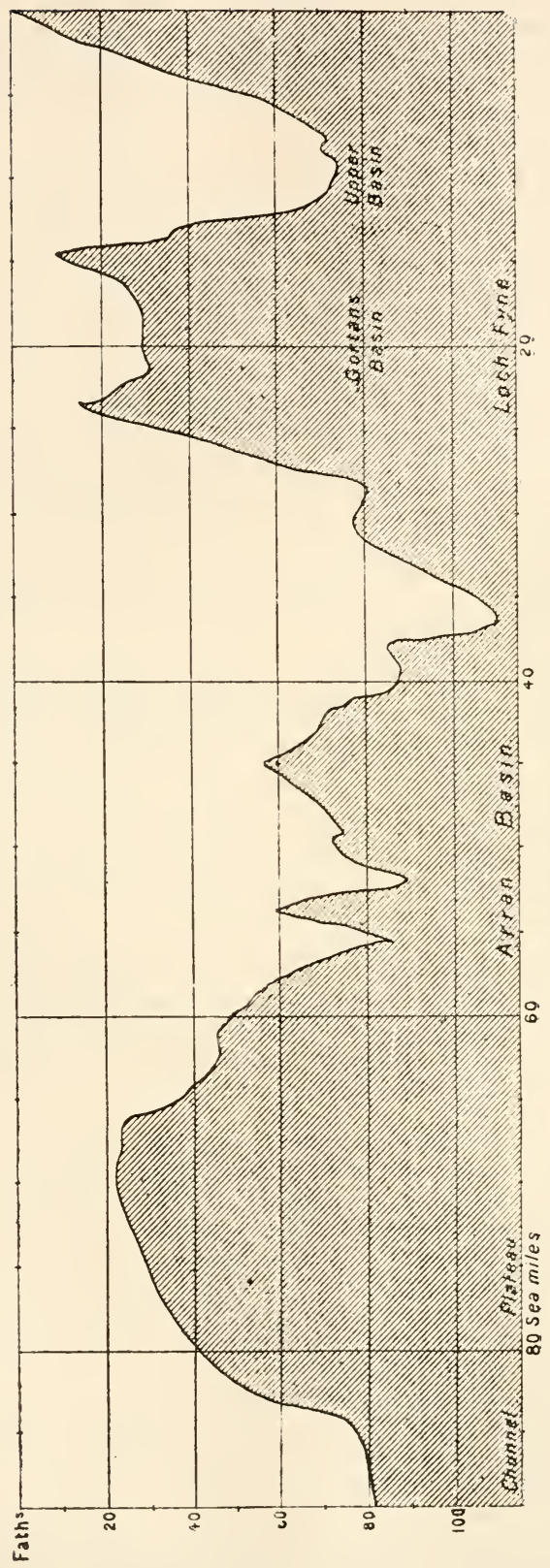




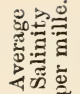

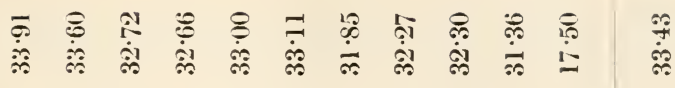

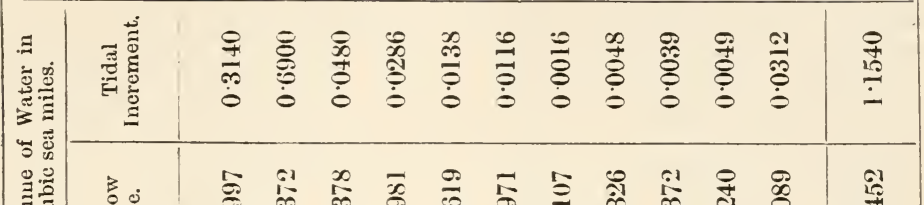

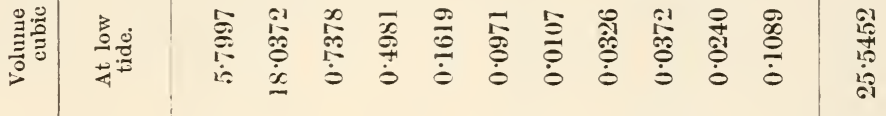

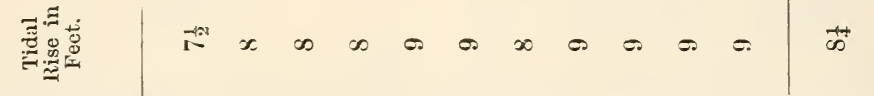

\begin{tabular}{|c|c|c|c|c|c|c|c|c|c|c|c|c|c|}
\hline \multirow{4}{*}{ 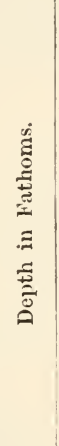 } & 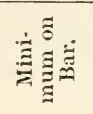 & 1 & $\bar{a}$ & ภิ & 12 & กิ & I & $i$ & $\stackrel{\infty}{\sim}$ & N & 10 & 1 & $\overline{\mathrm{N}}$ \\
\hline & 离蓄 & 1 & $\stackrel{t}{\varrho}$ & 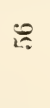 & 祝 & 군 & $\hat{\mathrm{o}} \mathrm{i}$ & 1 & 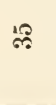 & 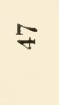 & 1 & 1 & 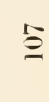 \\
\hline & 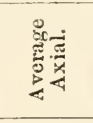 & 1 & $\cong$ & 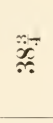 & $\stackrel{\oplus}{\varphi}$ & $\stackrel{-a}{a}$ & $\overline{3}$ & 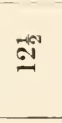 & ar & ఠ̊ & $\underline{x}$ & $\bullet$ & 1 \\
\hline & 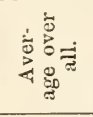 & $\vec{G}$ & $\vec{\because}$ & 고 & 今ે & 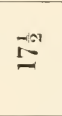 & 箅 & $\infty$ & $\cong$ & \pm & $\mathbb{A}^{-1}$ & 10 & 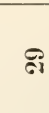 \\
\hline 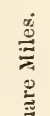 & 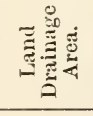 & $\begin{array}{l}\hat{\alpha} \\
\text { ôे }\end{array}$ & E & $\tilde{x}$ & $\stackrel{\infty}{\infty}$ & $\stackrel{0}{\circ}$ & 5 & $\dddot{i}$ & $\stackrel{3 i}{3}$ & $\vec{r}$ & $\ddot{\ddot{I}}$ & 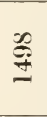 & 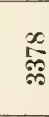 \\
\hline 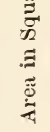 & 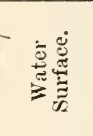 & $\ddot{m}$ & $\hat{y}$ & $\stackrel{x}{+}$ & 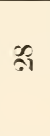 & $\stackrel{91}{2}$ & $\cong$ & $\dot{-}$ & + & $\ddot{\leftrightarrow}$ & + & 6 & $\ddot{\sim}$ \\
\hline
\end{tabular}


Tides. The crest of the tidal wave is almost simultaneous over the Clyde Sea-area, high water occurring at the heads of the remotest lochs within 17 minutes of the time of high water at Lamlash in Arran. In the river there is more retardation, about $1 \frac{1}{2}$ hours in the case of Glasgow. The tidal currents in the broad channels and at the heads of the lochs are rarely more rapid than 1 knot per hour; but in the narrow channels, and especially where the depth as well as the width is reduced, there are tidal races which give rise to a choppy sea, and mix the water thoroughly from surface to bottom. This is especially the case in the North Channel off the Mull of Cantyre and at the entrance to the Gareloch, at both of which the spring tides run at over 5 knots, while at Otter Spit at the entrance to Upper Loch Fyne the ordinary spring tide attains $3 \frac{1}{2}$ knots. These velocities are increased or diminished in a notable degree according as the wind conspires with or blows against the current.

Salinity. The saltness of the great body of the water in the Clyde SeaArea is remarkable; the deeper layers, even at the head of the remotest lochs, are nearly pure sea-water, while the brackish water on the surface only forms a thin skin. The average salinity of the water is subject to change by evaporation in dry weather, and by dilution in wet weather. The following table shows the average and the extreme range of the salinity of the whole mass of water in each division as observed in 1886-88:

\section{Table II.-Salinity of Water in the Clyde Sea-Area.}

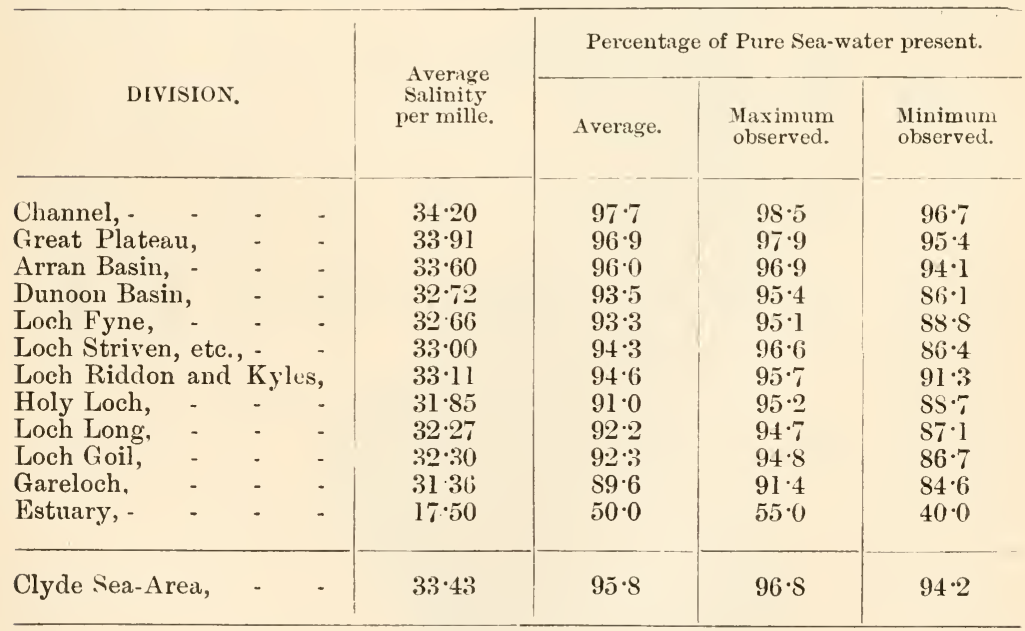

The "pure sea-water" of which the percentage present is given above is assumed to be of $35^{\circ} 00$ per nille salinity, or of specific gravity $\mathrm{S} \frac{15 \cdot 5}{4}=1.02600$. Although the salinities are calculated from specific gravities, the great diversity in the forms expressing the latter factor is a sufficient reason for using salinities for purposes of comparison either in the form of total salts or per cent. of pure sea-water. In order to show the difference between the salinity at surface and bottom and the slight influence exercised by the former on the salinity of the whole mass of water a few selected stations are compared in Table III. 
Table III.-Average Percentage of Pure Sea-Water.

\begin{tabular}{|c|c|c|c|c|}
\hline Division. & Station. & Surface. & Bottom. & Whole Depth. \\
\hline $\begin{array}{c}\text { Channel, } \\
\text { Plateau, } \\
\text { Arran Basin, - } \\
\text { Dunoon Basin, } \\
\text { Loch Goil, - } \\
\text { Gareloch, } \\
\text { Loch Fyne, - } \\
\text {,, } \\
\text {,, }\end{array}$ & $\begin{array}{l}\text { Mull of Kintyre, } \\
\text { Pladda, } \\
\text { Skate Island, } \\
\text { Dunoon, - } \\
\text { Dog Rock, - } \\
\text { Lochgoilhead, } \\
\text { Shandon, - } \\
\text { Otter, - } \\
\text { Furnace, - } \\
\text { Inveraray, - } \\
\text { Cuill, - - }\end{array}$ & $\begin{array}{l}97 \cdot 6 \\
95 \cdot 3 \\
94 \cdot 0 \\
86 \cdot 7 \\
84 \cdot 1 \\
82 \cdot 6 \\
86 \cdot 3 \\
93 \cdot 0 \\
91 \cdot 0 \\
83 \cdot 2 \\
56 \cdot 8\end{array}$ & $\begin{array}{l}97 \cdot 7 \\
96 \cdot \frac{7}{7} \\
96 \cdot 5 \\
95 \cdot 1 \\
94 \cdot 5 \\
93 \cdot 8 \\
90 \cdot 2 \\
95 \cdot 7 \\
94 \cdot 7 \\
94 \cdot 6 \\
93 \cdot 4\end{array}$ & $\begin{array}{l}97 \cdot 7 \\
96 \cdot 4 \\
96 \cdot 0 \\
93 \cdot 7 \\
92 \cdot 8 \\
91 \cdot 9 \\
89 \cdot 5 \\
95 \cdot 2 \\
94 \cdot 1 \\
92 \cdot 7 \\
87 \cdot 3\end{array}$ \\
\hline
\end{tabular}

The remarkable feature shown by this table is, that if the Gareloch be excepted, the amount of pure sea-water present in the bottom water at any point scarcely varies more than 2 per cent. from the average of the whole.

There are not sufficient observations to justify us in fixing the possible variations in salinity at any one point; but it seems probable that they are rarely more than correspond to an addition to the average of 5 per cent. more sea-water or of 10 per cent. more fresh water. An exception may occur at the head of lochs where the effect of wind in mixing the water is most felt.

The rainfall of the Clyde Sea-area is that typical of the west coast, heavy on the high ground, less so on the low ground, and everywhere showing a maximum in winter (December and January being the wettest months) and a minimum in early summer, the driest months being May and June. While it is impossible from the small number of rainfall stations to speak with any degree of certainty, it is probable that the average annual rainfall for the 20 years, 1866-1885, was about 56 inches on the landward portion of the Clyde Sea-area and about 43 inches on the seaward portion. During the investigation of salinity a clear relation was found between the degree of dilution of the water and the amount of rain in the preceding two months. There are fairly distinct indications that the normal salinity of the whole mass of the water is subject to an annual variation similar but inverse to the annual variation of rainfall. The rainfall minimum in May is followed by a maximum of salinity in July and August, and the rainfall maximum from October to January by a salinity minimum from December to March. The water as a whole seems to be freshest in February and saltest in July and August.

During a severe frost the surface of the narrow sea-lochs is frequently frozen over; but in the cases I have seen this is the result of the cooling during a cold night of the ice-cold surface film of fresh water poured in from the mountain slopes after a temporary thaw, and in no case was the ice formed from sea-water.

Chemistry of the Water. The chemistry of the water of the Clyde Seaarea has only been partially studied. I am not acquainted with any determinations of the dissolved gases in the water, and the only chemical analyses of high precision to which I can refer are those carried out by Mr. A. Dickie in the late Professor Dittmar's laboratory in Glasgow in 188\%, and those by Mr. H. N. Dickson in the Oxford University laboratory in 1896, the samples in both cases having been collected mainly by myself. Mr. Dickie determined Chlorine, Sulphuric Acid, and Alkalinity in 117 samples collected on six trips at intervals of about two months; Mr. Dickson determined Chlorine, Sulphuric Acid, and Density by direct pyknometer 
weighings in 30 samples collected on one trip. The results are not easily explained or accounted for. It is quite clear on expressing the amounts of sulphuric acid and alkalinity in terms of unit weight of chlorine (so as to eliminate differences due to mere variations in salinity) that the water of the Clyde Sea-area differs materially from that of the open ocean. By Professor Dittmar's analyses of 77 ocean-waters he found the average ratio of sulphuric acid $\left(\mathrm{SO}_{3}\right)$ to chlorine to be 0.1158 . Mr. Dickie found in the Clyde Seaarea an average of 0.1172 , and $\mathrm{Mr}$. Dickson 0.1189 . This indicates an excess of sulphates due either to the addition of river-salts or to impurities in the water, and the alkalinities, which are also greater than in ocean water, point in the same direction. Taking all the observations the averages according to vertical position are as follows:

$\begin{array}{llr}\text { Samples from } & \text { Dickie. } & \text { Dickson. } \\ \text { Surface, } & 0.1171 & 0.1185 \\ \text { Intermediate, } & 0.1173 & 0.1191 \\ \text { Bottom, } & 0.1172 & 0.1192\end{array}$

This shows some evidence of an increase of sulphates relative to chlorides: with depth, i.e. with salinity; in other words the less land-water the more sulphates - a paradoxical conclusion. No definite relations of the sulphates or alkalinity to position can be made out; the results of the chemical analyses showing a far greater change from time to time than from place to place. The averages for the different trips work out as follows :
Date, Nov. 1886.
Feb. 1887.
March 1887.
May 1887.
$\begin{array}{lr}\text { Surface, } & \text { (12) } 0.1174 \\ \text { Interm., } & \text { (3) } 0.1172 \\ \text { Bottom, } & \text { (14) } 0.1173\end{array}$
(6) $0 \cdot 1175$
(4) $0 \cdot 1175$
(3) 0.1175
(7) $0 \cdot 1176$
(6) $0 \cdot 1173$
(7) $0 \cdot 1177$
(8) $0 \cdot 1176$

$\begin{array}{llcr}\text { Date, } & \text { June 1887. } & \text { Sept. 1887. } & \text { April } 1896 . \\ \text { Surface, } & (8) 0.1177 & (14) 0.1161 & \text { (13) } 0.1185 \\ \text { Interm., } & -18 & - & (7) 0.1191 \\ \text { Bottom, } & \text { (8) } 0.1177 & \text { (14) } 0.1163 & \text { (9) } 0.1192\end{array}$

The figures in brackets are the number of samples of which the result is an average.

Deposits. The deposits on the bed of the Clyde Sea-area are mostly sands on the shallows and mud in the deep water. They have been studied to some extent by Mr. J. Y. Buchanan, who found evidence of the effect of the masses of chemical-works refuse which for many years have been discharged into the water of the Area. He found a very considerable proportion of sulphur, chiefly in the form of ferrous sulphide, in the muds of the deeper basins ; and at several points, especially in the Arran Basin and on the Bute Plateau, there were numbers of nodules mainly composed of oxides of manganese and iron, quite similar to those found in the red clay of the greatest ocean depths. The sulphur in the deposits may possibly account for the increased proportion of sulphates in the deep water.

Thermal Conditions. While there is a certain individuality in the thermal régime of each physical region due to its individual configuration, a general idea of the seasonal march of temperature in the water may be given by considering the North Channel, the Arran Basin, and the deep lochs, as a group represented by Loch Goil, which is a very good specimen of the type.

On account of the thorough tidal mixing of the water in the North Channel the temperature at any time is the same from surface to bottom, and all seasonal changes of temperature take place simultaneously throughout the whole depth. From the annual minimum of temperature in March, about $42^{\circ}$ or $44^{\circ}$, the water in the Chamnel warms up steadily and gradually to about $56^{\circ}$ in September, and cools again uniformly for the next six months (see curves in Fig. 2). All the water carried in to the Arran Basin by the 
tide is thus homothermic Channel water passed in sheets less than 25 fathoms thick across the flat counter of the Great Platean.

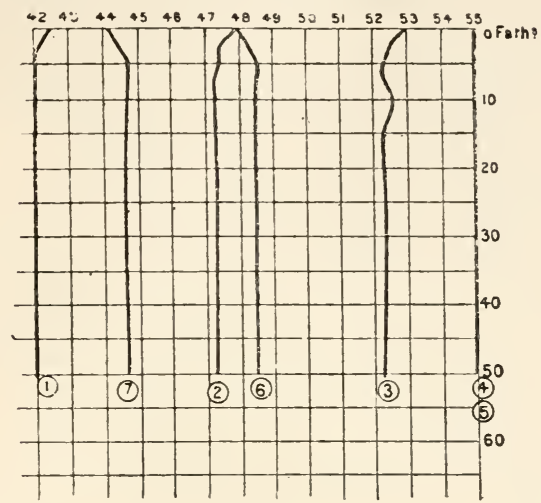

Fiє. 2.

At the annual minimum in March the Arran Basin throughout its whole depth is at the same temperature as the Channel and the Plateau; but as the process of warming goes on the superficial layers are most rapidly

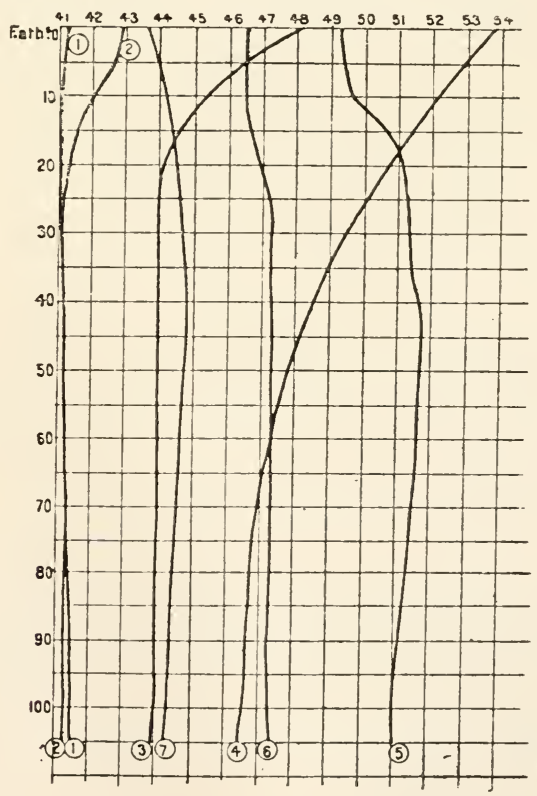

FIG. 3.

heated by the direct influence of the sun, and by the indirect inflnence of warm land-water which floats upon the surface of the salter mass. The result is that the surface water heats up more rapidly and to a higher degree than the deeper layers, which change their temperature-probably because 
of tidal mixture-almost homothermically, until at the period of annual maximum the surface reaches about $56^{\circ}$ in August, and the bottom about $51^{\circ}$ in October. When cooling commences it takes place almost simultaneously throughout the whole depth, so that although nearly nine months are required to raise the temperature at the bottom from the minimum to the maximum, only three months are necessary for reducing it from the maximum to the minimum. During the later months of cooling the surface water remains colder than that beneath (see curves in Fig. 3).

From the Arran Basin communication is had directly with Loch Fyne and the Dunoon Basin, the latter leading to Loch Goil.

Loch Goil, much more isolated than the Arran Basin from oceanic influence, shows all the characteristics which distinguish the Arran Basin from the Channel, but in an exaggerated degree. At the annual minimum in early spring the mass of water is homothermic, and practically at the same temperature as in all other parts of the Area, but the surface alone heats up rapidly as the season advances. The mass of water below the level of the bar heats very slowly, and only to a slight extent. It is probable that heat from the surface-layers is transmitted downwards mainly by the slow process of conduction, the maximum temperature at the bottom being reached late in winter nearly six months after the date of the surface maximum, and only a month or two before the minimum temperature reasserts itself from top to bottom. 'The vertical distribution of temperature is thus subject to remarkable changes. The curve of the minimum is homothermic as elsewhere, the curve of heating shows a great range of temperature, and when cooling sets in its upper part is reversed in direction. The cold of winter may have reduced the upper layers of water to $34^{\circ}$ or less, while the heat of the previous summer is still being conducted downwards, and the water remains warmest in the centre and colder both above and below.

The conditions of Loch Fyne have been more fully investigated than those of the other lochs. The shallow Gortans Basin, with its entrance and exit restricted by bars, serves as an intermediate chamber between the Arran Basin and the deep Upper Basin of Loch Fyne. The steep rise of the sea-berl off Otter causes the flood tide to produce an updraught of deep water from the Arran Basin, breaking the warm skin of surface water in summer and the cold skin of surface water in winter, and filling the Gortans Basin with nearly homothermic water of relatively high salinity. This water is passed on to the Upper Basin at Minard, and occupies the gently sloping bed of the loch as far as Eurnace; but there, where the Upper Basin drops abruptly, the incoming tidal water seems to intrude itself like a wedge horizontally into the mass of the water of the Upper Basin, not directly affecting the deeper layers, which thus remain nearly as isolated as those of Loch Goil, and present a similar thermal régime (see curves in Fig. 4).

In the deep lochs it will be noticed that the annual range of temperature becomes less as the depth is greater, and it would seem from a consideration of the temperature curves that if the depth of Upper Loch Fyne were increased to 150 fathoms, the temperature of the deepest water would retain the minimum temperature practically unchanged all the year round.

The three series of curves in Figs. 2-4 show the temperature at various depths in three typical regions as observed in 1886-87 during a complete cycle of heating and cooling. The numbers attached to the curves indicate their position in this cycle as follow: (1) Minimum, (2) Early heating, (3) Later heating, (4) Maximum of upper layers, (5) Maximum of mean temperature, (6) Early general cooling, and (7) Later cooling.

In April, 1886, the water of the whole area from a depth of 5 fathoms to the bottom had a temperature so nearly uniform that it did not vary more than $0 \cdot 2^{\circ}$ from $42^{\circ} 0 \mathrm{~F}$; ; at the corresponding date in 1887 it was within $1^{\circ}$ of $44^{\circ} \mathrm{F} . ;$ in 1888 within $1^{\circ}$ of $43^{\circ} \mathrm{F}$.; and from numerous though less 
complete observations in the first week of April, 1896, it was not more than $1^{\circ}$ from $44^{\circ} \cdot 8 \mathrm{~F}$. All these represent very nearly the period of annual minimum, and the upper layer of 5 fathoms was at no place more than, and rarely so much as, $1^{\circ}$ warmer than the average of the mass of the water

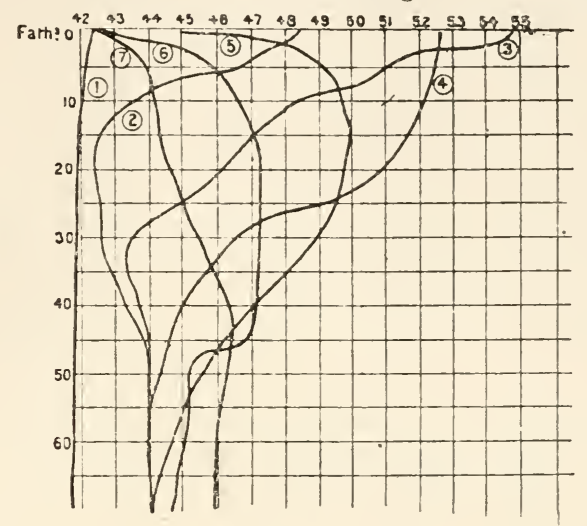

FIG. 4.

They amply justify the general statement that at the annual minimum the Clyde Sea-area is homothermic, i.e. is at the same temperature from surface to bottom throughout its whole extent.

The process of heating up brings into prominence the control that the con. figuration of the various divisions exercises on the march of temperature in the water, the greater the restriction of communication with the open sea the slower being the propagation of warmth downward, and the longer the period after the surface has begun to cool again before the seasonal maximum reaches the bottom. This is very clearly shown in the curves.

Taken as a whole the observations of 1886-88 showed that while the mean aunual temperature of the air was $47^{\circ}$, the mean annual temperature of the upper 5 fathoms of water was $48.5^{\circ}$, showing that the inflowing ocean water is on the average of the year warmth-bringing. For about 240 days the surface-water was warmer than the air, and the air was warmer than the surface-water for only 125 days in the year, i.e. for eight months out of the twelve the air is being warned by the water. As 1887 was a typical year and the various temperature trips were happily timed to catch the critical points in the curve of seasonal change the table on page 396 gives a fair idea of normal temperature changes.

The retardation of phase and restriction of range in deep water by isolation from the open sea is illustrated by the following table of temperatures at a lepth of 40 fathoms for various seasons in the year 1886 which started from the lowest minimum observed in the course of these researches.

Table IV.-Comparison of Temperature at 40 Fathoms.

\begin{tabular}{l|c|c|c|c} 
& Channel. & Arran Basin. & Loch Goil. & Loch Fsne. \\
\cline { 1 - 2 } Minimum, April 1886, - & $42 \cdot 0$ & $41 \cdot 2$ & $41 \cdot 5$ & $42 \cdot 0$ \\
Heating, June 1856, - & $47 \cdot 0$ & $44 \cdot 0$ & $42 \cdot 0$ & $44 \cdot 0$ \\
Maximum, Sep. 1856, - & $54 \cdot 7$ & $47 \cdot 4$ & $44 \cdot 2$ & $45 \cdot 0$ \\
Cooling, Dec. 18S6, - & $48 \cdot 6$ & $47 \cdot 6$ & $47 \cdot 6$ & $45 \cdot 0$ \\
\hline
\end{tabular}




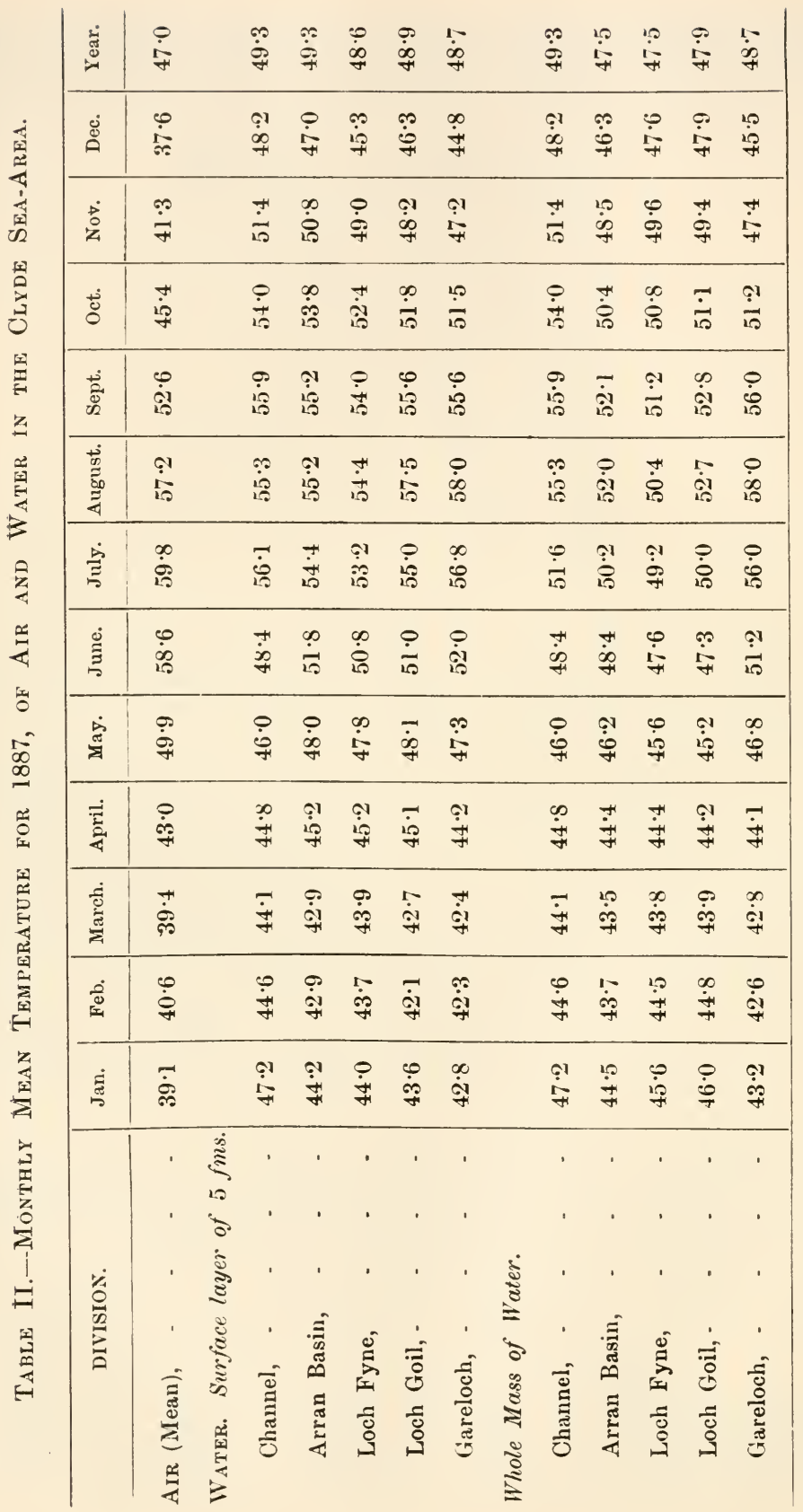


Influence of Wind. We have so far endeavoured to deduce from the observations actually made some approximation to the normal condition of things which would exist if the water were never subject to very strong winds, but it is necessary to refer to the great irregularities which a long continued strong wind produces. These effects are most strikingly shown in the narrow mountain-girdled sea-lochs, where the wind usually blows either up or down the valley. In the case of a strong continuous up-loch wind the flood-tide is accelerated and the ebb retarded ; but the fresher surface-water, which in summer is warmer and in winter colder than that beneath, is accumulated by a sort of skimming at the head of the loch, thus tending to raise the level and so forcing away the deeper salt layers. At the same time the reaction currents set up by the stream of water entering the loch cause an upwelling of the salter deep water on the bar at the mouth both from outside and inside; and if the wind were to last long enough the whole mass of water in the loch-basin would be thoroughly mixed and reduced throughout to a uniform temperature and a uniform salinity. It may be that the rapid fall of temperature to the spring minimum is partly due to the frequency of heavy gales in winter.

When a down-loch wind is blowing the conditions are reversed. Then the ebb-tide is accelerated and the flood retarded on the surface. At the same time the fresher surface-water is driven down, and perhaps out of the loch, and its place taken by the salter water drawn up from below. This accounts for the paradox that the saltest surface water in the whole Clyde Sea-area has been found at the head of the lochs where the largest rivers flow in, during a down-loch wind; while the freshest bottom water has been found in the same positions with an up-loch wind. Cross-loch winds produce similar effects, but these occur less frequently, and except when specially investigated have usually escaped attention, as the regular observations. designed to investigate the seasonal changes of temperature and salinity were usually made in mid-chaunel where the effect is at a mininum. 


\section{Bibliography.}

The observations and arguments on which the above brief statement is based will be found in-

Sir John Murray, "On the Temperature of the Salt and Fresh Water Lochs of the West of Scotland during the years 1887 and 1888." Proc. R.S.E., vol. xviii. (1891), pp. 139-228.

J. Y. Buchanan, "On the Occurrence of Sulphur in Marine Muds and Nodules." Proc. R. S. E., vol. xviii. (1890), 17-39.

H. R. Mill, "The Clyde Sea-Area," Part I., Physical Geography, Trans. R. S. E., vol. xxxvi. (1892) ; Part III., No. 23, pp. 641-663 ; Part II., Salinity and Chemical Composition of the Water; Ibid., pp. 664-729, Plates 1-12 ; Part III., Distribution of Temperature ; Ibid., vol. xxxviii. (1894); Part I., No. 1, pp. 1-161, Plates 1-32.

"Temperature Observations in the Clyde Sea-Area," Journ. Scot. Met. Soc., 3rd Ser., vol. vii. (1886), No. 3, 313-351 ; vol. viii. (1887), No. 4, pp. 47-110.

"Physical Conditions of the Water in the Clyde Sea-Area." Proc. Glasgow Phil. Soc., vol. xviii. (1887), pp. 332-356.

"Report on Physical Observations bearing on the Circulation of the Water in Loch Fyne in April and September, 1896." Fifteenth Annual Report of Fishery Board for Scotland, Part III., pp. 262-279.

A. Dickie, "On the Chemical Composition of the Water composing the Clyde Sea-Area." Proc. R. S. E., xiv. (1887), pp. 422-427, xv. (1888) 283-286. 


\title{
THE GEOLOGY AND PALAEONTOLOGY
}

OF THE

\section{CLYDE DRAINAGE AREA.}

\section{PREFATORY NOTE.}

\author{
By J. B. Ilurdoch, F.R.Ph.S.E.
}

The West of Scotland has for a long time been fortunate in possessing an active number of workers in Geological and Palaeontological science, and much of the outcome of their labours during the last fifty or sixty years has been made available to the public through the Transactions of the Natural History Society, and those of the Geological Society of Glasgow.

The first attempt to consolidate the many lists and papers on local geology resulted in the publication of "The Carboniferous Fossils of the West of Scotland, by (Dr.) John Young, with a General Catalogue of the Fossils by James Arnistrong," which was issued in 1871.1

This book again formed the nucleus of the more exhaustive "Catalogue of the Western Scottish Fossils," compiled by John Armstrong, John Young, F.G.S., and David Robertson, F.G.S., which was published as a local guidebook for the use of the members of the British Association, whose meeting was held in Glasgow in 1876. The editors were largely assisted in its articles by other workers in field and study work, and to such good purpose that the "Catalogue" has up to the present day served as a reliable guide to the Geology of the West of Scotland, and is by no means even yet superseded.

The following Geological portion of the "Handbook" for the British Association meeting of 1901 has been drawn up on somewhat similar lines to those of the former volumes, the various articles in it beginning with the lowest formation represented in the area and gradually ascending to the most recent. A glance at its pages will show that the contributors are worthy successors of the men who preceded them.

Preparations for the work were begun some years ago, and it is unfortunately the case that a number of those who promised to contribute died before they were able to carry out their intentions, or at least did not survive to revise and correct the articles in print, so that these have had either to be supplied by other hands, or at least have not had the benefit of the author's supervision.

Amongst these deceaser gentlemen may be mentioned Dr. John Young, F.G.S., to whose work and efforts the cause of Western Scottish geological

${ }^{1}$ Transactions of the Geological Socicty of Glasyow, vol. iii., supplement, 1871. 
investigation must ever owe a debt of gratitude; Dr. David Robertson, F.G.S., and Dr. Crosskey, F.G.S., his coadjutor in the investigation of the Clyde Post-tertiary beds; James Thomson, F.G.S., known generally as "Coral" Thomson, for his laborious work in connection with that group ; Robert C'raig, of Beith, an ardent worker in the Carboniferous Limestones of Ayrshire; Dugald Bell, F.G.S. an enthusiast in the study of geological glacial phenomena; James Bennie, of the Geological Survey, whose investigations, more especially in connection with "Surface Geology," have been of great importance; and Mr. James W. Kirkby, of Leven, Fifeshire, an authority upon all connected with the Carboniferous rocks, whose death occurred only within the last few weeks.

In conclusion it may be added that though the nomenclature of many of the genera and species will be found to be altered from that of the 1876 Catalogue there is much in that volume which has not been superseded in the present Handbook. The attention of students may therefore still be directed to it for much interesting matter. 


\title{
THE GEOLOGY OF THE CLYDE TERRITORY.
}

\author{
By J. HoRne, F.R.S.
}

THIs district embraces the natural drainage area of the River Clyde and of the sea-lochs that form extensions of its estuary. Northwards the boundary line is defined by the mountains round the head of Loch Fyne and Loch Lomond; eastwards by the watershed between the Clyde and the rivers flowing east to the German Ocean; and southwards by a line drawn from the Mull of Kintyre to the southern point of Ayrshire. It thus comprises a broad belt of crystalline schists extending from Loch Lomond to the Mull of Kintyre, a portion of the Silurian tableland of the Southern Uplands and a great development of Old Red Sandstone and Carboniferous strata occupying the western part of the Central Lowlands.

The southern limit of the crystalline schists of the southwest Highlands is defined, between Loch Lomond and Toward Point south of Dunoon, by powerful faults which let down the Old Red Sandstone on the southeast side. Immediately to the north of this fault, between Loch Lomond and Callander, there is a narrow belt of strata, provisionally correlated with the Arenig rocks of the south of Scotland, including hornblende-schists, chlorite-schists, cherts, black shales and grits. Similar strata have been recently identified by Mr. Gunn of the Geological Survey in North Glen Sannox, Arran, and they have been traced at intervals along the Highland border by Messrs. Barrow, Dakyns, and Clough, to Eorfarshire and Kincardineshire. In Arran the green rocks of igneous origin comprise lavas, volcanic agglomerates and intrusive masses which recall petrological types of the Arenig igneous rocks in Ayrshire. Both in Arran and in the Kelty Water near Callander these strata are considerably deformed; the igneous rocks have been rendered schistose, the black shales are cleaved, the cherts have been granulitised, and the grits show flaser structure. Though the black shales have yielded impressions which simulate the appearance of graptolites, it must be frankly stated that no fossils have been obtained from these rocks which prove their age. In Forfarshire, Radiolaria have been found in the cherts, and certain rounded bodies have been detected in the same rocks in the Callander region which may prove to be traces of these organisms. The relation of these presumably Silurian rocks to the schistose grits of the Highlands, both near Loch Lomond and in Arran, is still uncertain. In Forfarshire and Kincardineshire Mr. Barrow of the Geological Survey has drawn a reversed fault between the two, but no such line of displacement has yet been detected in the southwest Highlands. Indeed the boundary line must be regarded as a provisional one in the Callander district and in Arran.

To the north of the belt of strata just described there is an important development of altered sedimentary rocks forming the crystalline schists of the Eastern Highlands. The various subdivisions are arranged in a definite order, but it is uncertain whether it indicates the original sequence of 
deposition. In the Loch Lomond district and in the western part of Perthshire the groups are met with in apparent descending order as given below:

10. Blair Atholl limestone and black schists.

9. Quartzite.

8. Graphitic schist with thin lenticular bands of limestone, clay-slate, and calcareous sericite-schist.

7. Garnetiferous mica-schist.

6. Loch Tay limestone.

5. Mica-schists with sills of epidiorite.

4. Schistose epidotic grits (green beds).

3. Ben Ledi grits.

2. Aberfoyle slates, with subordinate bands of grit.

1. Leny and Aberfoyle grits.

In Cowal and the district round the head of Loch Fyne, further subdivisions of the crystalline schists have been introduced by the Geological Survey which need not here be given. It is sufficient to state that the groups met with in Perthshire have been identified and traced across the county of Argyll. For example, the Dunoon grits and phyllites are evidently the prolongations of the grits and slates at Aberfoyle; the Ben Ledi grit group is largely represented in Cowal and in Kintyre: the green beds (No. 4), micaschists (No. 5), and the Loch Tay limestone (No. 6) have been traced westwards from the head of Glen Fyne by Glendaruel to Loch Tarbert, and they reappear to the north of Campbeltown. The higher groups (Nos. 8, 9, 10) are evidently represented by the Ardrishaig phyllites and Loch Awe series, the latter comprising limestones, black slates, grits, and quartzites.

There can be little doubt that most of these rocks were originally sedimentary deposits, for in many instances the original clastic grains may still be recognised. Annelid tubes have been detected in the quartzites of Jura and Islay (No. 9); similar structures were detected by the late Duke of Argyll in quartzose-schists near Inveraray, and Mr. Macnair, of the Glasgow Geological Society, has detected what he believes to be worm-casts in certain schists apparently above the Loch Tay limestone. The geological age of these eastern Highland schists (the Dalradian series of Sir A. Geikie) still remains to be determined. These sedimentary rocks have been subjected to a regional metamorphism which cannot be attributed to any intrusion of igneous rocks now visible at the surface. Indeed Mr. Clough and Mr. Hill, of the Geological Survey, have been led to believe that in the Cowal area the metamorphism increases in intensity from the southeast and from the northwest towards a central anticline of foliation trending in a northeast and southwest direction.

These crystalline schists are pierced by igneous rocks belonging to different geological periods. One group, which is older than the regional metamorphism of the sedimentary rocks, comprises gabbro, epidiorite, and hornblendeschists ; the other set is later than this metamorphism, and is represented by various igneous masses, as, for example, the plutonic rocks of Garabal Hill near the head of Loch Lomond, and the numerous sheets and dykes of acid igneous materials (quartz-porphyries and porphyrites) in the neighbourhood of Loch Fyne, and in other districts.

The geological structure of the Silurian tableland of the Southern Uplands is extremely complicated, due partly to the non-fossiliferous character of many of the strata, partly to the inversion of the rocks over wide areas, and partly to the variation in the types of sedimentation ranging from oceanic to shallowwater and shore conditions. The true order of succession has been demonstrated by Professor Lapworth, who, by means of the vertical distribution of the graptolites, furnished a clue to unravel the stratigraphy of the whole region. As a result of the detailed examination of the tableland, it may be 
stated that the evidence points to continuous sedimentation from Arenig to Ludlow and Downtonian time, save in the northwest region where local unconformabilities occur.

The northwest portion of the Silurian tableland embraced in the Clyde territory furnishes striking proof of the lateral variation of the Silurian strata as the observer passes from the central Moffat region northwestwards to Leadhills and Girvan. The land from which the sediment was derived lay to the north, and hence there is a gradual increase in the thickness of several divisions of the Silurian system as we approach the Girvan area. One prominent rock-group preserves, with rare exceptions, its uniform lithological characters throughout the uplands. It consists of cherts and mudstones partly of Upper Arenig and partly of Lower Llandeilo age, which, where not deformed or altered by intrusive igneous masses, are richly charged with Radiolaria. The mudstones contain hingeless brachiopods and other organisms. The cherts, which have been formed from a true radiolarian ooze, and the mudstones, imply an oceanic phase of sedimentation. Their age is clearly defined, for throughout the uplands, where exposed on anticlinal folds, they are overlain by the Glenkiln shales with graptolites of Upper Llandeilo age; and they rest on volcanic rocks containing, in the Girvan area, cherty mudstones and graptolitic shales, yielding Middle Arenig graptolites (see general Table of Silurian strata, pp. 424, 425).

By far the greatest development of the Arenig volcanic rocks occurs near Ballantrae, where they consist of diabase and diabase-porphyrite lavas, agglomerates and tuffs, pierced by various plutonic masses, including serpentine, gabbro, dolerite, and granite. But they reappear on numerous anticlines between Abington and Leadhills in Upper Clydesdale, where they are overlain by the Radiolarian cherts and Glenkiln-Hartfell black shales.

The subdivisions of the Moffat series, established by Professor Lapworth in the central portion of the tableland: viz. Glenkiln shales (Upper Llandeilo), Hartfell shales (Caradoc), and Birkhill shales (Llandovery), imply conditions of deposition near the verge of sedimentation, for they consist of alternations of black shales, cherty bands and mudstones with rare intercalations of coarser sediment. The total thickness of these divisions of the Silurian system in the Moffat region does not exceed 300 feet, and when traced northwest to the limit of the tableland they are represented in the Girvan region by upwards of 5000 feet of strata (see general Table of Silurian rocks, pp. 424,425). These lateral variations may thus be briefly summarised. Northwards from the central Moffat area the Birkhill shales are gradually replaced by coarser sediments, till along the northern margin of the Taramon belt they are represented by grits, greywackes, and shales with thin carbonaceous seams yielding dwarfed representatives of Lower Birkhill graptolites. In like manner in the northern area, the Hartfell black shales undergo a similar change, and their characteristic graptolites appear, either in thin black seams interleaved in flaggy shales, or in dark sandy shales. The barren mudstones of the central Moffat region are represented in the Leadhills region by grey and blue micaceous shales (Lowther shales), greywackes and grits, with lenticular masses of limestone, which at Wrae and Glencotho are associated with volcanic rocks. Similarly the Glenkiln shales lose their normal lithological characters in the northern belt, and their characteristic graptolites are found in thin dark seams in sandy shales, interbedded with greywackes and shales.

In the Girvan region these lateral modifications of the strata are nore strongly marked, as shown by Professor Lapworth, for the Moffat series is there represented by a vast thickness of conglomerates, grits, greywackes, flagstones, shales, mudstones and limestones (Barr series, Ardmillan series, Newlands series of Lapworth, see p. 429). To the north of the valley of the 
Stinchar, in the Girvan and Ballantrae region, the foregoing divisions of the Silurian system rest unconformably on an eroded platform of Arenig volcanic rocks. South of the Stinchar valley this unconformability disappears, and the sequence resembles that found in the western part of the northern belt. In view of the fossil evidence it has been inferred that this break in the geological record north of the Stinchar valley took place in Upper Llandeilo time. The order of succession and subdivisions of the fossiliferous rocks of Girvan, ranging from the close of the Llandeilo period to Wenlock time, are given in the sequel (p. 429).

Along the southern margin of the tableland and beyond the limits of the Clyde territory the Tarannon rocks of the central belt pass conformably upwards into Wenlock and Ludlow strata.

North of the Silurian tableland and within the area occupied by the Old Red Sandstone, various inliers of Upper Silurian rocks are exposed, which have long been familiar to geologists from the discovery of eurypterids in the strata in Logan Water by the late Dr. Slimon of Lesmahagow. Recently fresh interest has been imparted to the study of these inliers by the remarkable fish-fauna obtained from the Ludlow and Downtonian strata. The Upper Ludlow rocks of the Lesmahagow inlier have yielded phyllocarid crustaceans and eurypterids in excellent preservation, together with the remains of a scorpion, a myriapod, two species of fishes (Thelodus), and other organisms.

Next in order there is a group of red and yellow sandstones, conglomerates, shales, and mudstones, forming passage-beds between the underlying Ludlow strata and the overlying Old Red Sandstone, resembling the Downton rocks of Shropshire. The shales and mudstones intercalated in this series have yielded an assemblage of organic remains, in some respects identical with that of the underlying Ludlow rocks, including ostracods, phyllocarid crustaceans, eurypterids, and fishes. The researches of Dr. Traquair have shown the great biological and palaeontological value of this fish-famna. The discovery of these organic remains in the passage-beds has. led to a change in the classification of these rocks by the Geological Survey. Though formerly grouped with the Old Red Sandstone, they are now regarded as forming the highest subdivision of the Silurian system in the south of Scotland. The band of greywacke-conglomerate which is traceable from the Pentland Hills into Ayrshire, save in certain parts of Lanarkshire, is now regarded as the base line of the Lower Old Red Sandstone. For it is not till we reach the horizon of this greywacke-conglomerate that evidence is found of the predominance of materials which have been derived from the Silurian tableland.

In the northwest part of the tableland the Silurian strata are pierced by various plutonic rocks, of which the largest is the granite mass stretching from Loch Doon to Loch Dee. According to Mr. Teall this mass includes various petrological types, as, for example, granitite, hornblende-granitite, quartz-augite-biotite-diorite, and quartz-biotite-hyperite.

Towards the close of Downtonian time the Silurian strata of the south of Scotland were elevated and subjected to prolonged denudation, for we find, both in Ayrshire and in the Pentland Hills, the basal conglomerates of the Lower Old Red Sandstone resting unconformably on the folded and eroded edges of the Silurian rocks. In Lanarkshire, however, there seems to be a passage from the one formation to the other. At that period also, the crystalline schists of the Highlands must have formed a prominent land barrier towards the north before the deposition of the Lower Old Red Sandstone sediments.

The various divisions of the Old Red Sandstone as developed in the Clyde territory are represented in the following table : 


\section{$\int$ Upper. $\left\{\begin{array}{l}\text { Band of cornstone near the top. } \\ \text { Red sandstones and conglomerates. }\end{array}\right.$ \\ Unconformability.}

3. Sandstones, grits, and conglomerates with pebbles of andesite.

2. Contemporaneous volcanic rocks (andesites and tuffs) with thin intercalations of sandstones and conglomerates near the top.

1, Chocolate-coloured sandstones with Cephalaspis Lyelli and conglomeratic bands, with greywacke-conglomerate at the base.

Lower Division. On the south side of the great midland valley, and along the margin of the Silurian tableland there is an important development of the lower division of the Old Red Sandstone. On the south side of the Girvan valley, the members of group 1 rest unconformably on an eroded platform of Silurian rocks, and on the north side of the same valley they reappear, and are largely developed near Maybole and Kirkoswald, passing northwards underneath the overlying volcanic series (group 2 in table) which extends north by Dunure Castle to near the Heads of Avr. In Lanarkshire the Lower Old Red Sandstone is let down against the Silurian strata by the great fault which skirts the tableland. The red sandstones and conglomerates (group 1 in the table) are well seen in the gorge of the River Clyde at Lanark, whence they stretch westwards by Lesmahagow to near Darvel in Ayrshire, where they pass underneath the overlying volcanic series (group 2). The volcanic group is also exposed on the slopes of Tinto, and can be traced westwards to near Douglas, reappearing in the Duneaton Water to the west of the Douglas coalfield. Along their southeast margin the lavas and tuffs pass upwards into the members of the overlying beds (group 3). Indeed between the Duneaton Water and the Clyde at Lamington the beds forming the highest division of the Lower Old Red Sandstone lie in a synclinal fold of the volcanic series (group 2). Grits and yellow sandstones occurring at the base pass upwards into massive conglomerates, and these are overlaid in turn by chocolate-coloured sandstones. These beds furnish evidence of the cessation of volcanic activity, for the sandstones are largely composed of volcanic detritus, and the pebbles in the massive conglomerates consist mainly of andesite.

The Lower Old Red Sandstone strata in Lanarkshire and Ayrshire are traversed by various basic and acid eruptive rocks. Near the head-waters of the Avon, southeast of Darvel in Ayrshire, a small mass of granite occurs, containing petrological types, which, according to Dr. Flett, resemble those met with in the Loch Doon granite, both masses being presumably of the same age. Numerous sills of acid material have been injected, mainly along the lines of bedding of the lower red sandstones, of which the massive sheet of quartz-felsite on the crest of Tinto are a conspicuous example.

On the north side of the midland valley the members of the Lower Old Red Sandstone can be traced from the Forth above Stirling, west by Drymen, to a point on the Firth of Clyde, near Cardross. In the eastern part of this area the strata are arranged in a great synclinal fold, the central axis of which coincides with a line drawn from Elanders Moss, in the valley of the Forth, to near Drymen. The strata forming this syncline belong to the highest division of the Lower Old Red Sandstone (group 3), for on the southeast side the volcanic series (group 2) rises from underneath these sandstones in the Ochil Hills, where the lavas, tuffs, and agglomerates reach their greatest development in Scotland. On the north side of this 
great syncline a representative of the volcanic series is found near Aberfoyle close to the great Highland fault. Here a band of andesite appears, overlaid by massive conglomerates and sandstones which are highly inclined or vertical. Southwards the angle of inclination decreases, and the strata have a gentle dip on both sides of the synclinal axis, where they consist of grey sandstones, which yielded to Mr. R. L. Jack plant-remains, regarded by Mr. Kidston as specimens of Arthrostigma (Dawson).

Representatives of the Lower Old Hed Sandstone likewise occur in Arran to the east and south of the granite area. In the latter district Mr. Gumn recently detected the volcanic zone in association with the sandstones. The Lower division is largely developed in the extreme southeast of Kintrre between Campbeltown and Southend, where the sandstones are accompanied by trappean conglomerates and pierced by necks of volcanic agglomerate.

Upper Division. At the close of the Lower Old Red Sandstone period important geographical changes again ensued, for everywhere there is a marked unconformability between the upper division of this system and older formations. The vast accumulation of deposits, both sedimentary and volcanic, of the lower division was elevated, folded, and subjected to prolonged denudation. Indeed, in some instances, the old Silurian tableland was trenched by narrow valleys, as in the far northeast in the Lammermuirs. Subsidence again ensued, but as yet the marine famma of the Carboniferous period was excluded from the area of sedimentation. Though the Upper Old Red Sandstone rests everywhere unconformably on older formations, it graduates upwards into the Carboniferous rocks. Indeed it was at one time regarded as forning a lower subdivision of the Calciferous Sandstone. Lithologically the red sandstones of the upper division resemble those of the lower, and they likewise yield land-plants and fishes. The fishfauna, however, is wholly different from that met with in the Caledonian or lower division, one of the most characteristic forms being Holoptychius nobilissimus.

In Upper Clydesdale the Upper Old Red Sandstone extends from Hyndford Bridge on the Clyde, east by Carnwath, to Dunsyre Hill, being a continuation of the Cairn Hill sandstones of the Pentland chain. In Ayrshire it is traceable from the shore at the Heads of Ayr, in a southeasterly direction,--lapping round the Lower Old Red volcanic rocks, and underlying red sandstones,- to Blairquhan in the Girvan Valley. There the cormstone near the top of this division is well seen in the Lamnielane quarries, south of Kilkerran Castle. Again to the north of the Campsie and Kilpatrick Hills a narrow belt of these red sandstones can be traced from Kippen, by Killearn, to the Firth of Clyde near Cardross. Here there is additional evidence of the marked unconformability between the two divisions of the system, for the upper red sandstones dip to the southeast, and the lower are inclined to the northwest. The cornstone near the top of this series has been traced at intervals along the north side of the Campsie Fells, and has been worked for lime between Balfron and Gargumnock. On the shores of the Firth of Clyde the Upper Old Red Saudstone is traceable from Wemyss Bay, southwards by Largs and Fairlie, to Ardrossan. On the promontory at Rosneath, at Toward Point, and again in the island of Bute, it is faulted against the crystalline schists of the Highlands. These red sandstones likewise occur in Arran, both to the east and south of the main granite mass, and likewise in Kintyre to the sonthwest of Campbeltown, and on the west coast near Cleongart.

The Carboniferous formation is largely developed in the West of Scotland where it occupies the greater part of the Central Lowlands, extending westwards to the shores of the Clyde, and southwards to Dalmellington in the County of Ayr. There is sufficient evidence for maintaining, however, that originally it must have covered a much wider area, for though the Silurian. 
tableland may have formed a land-barrier during the beginning of the period, yet as it advanced portions of the tableland were submerged and buried underneath these deposits.

The various divisions of the Carboniferous system as developed in the West of Scotland are given in the following table :

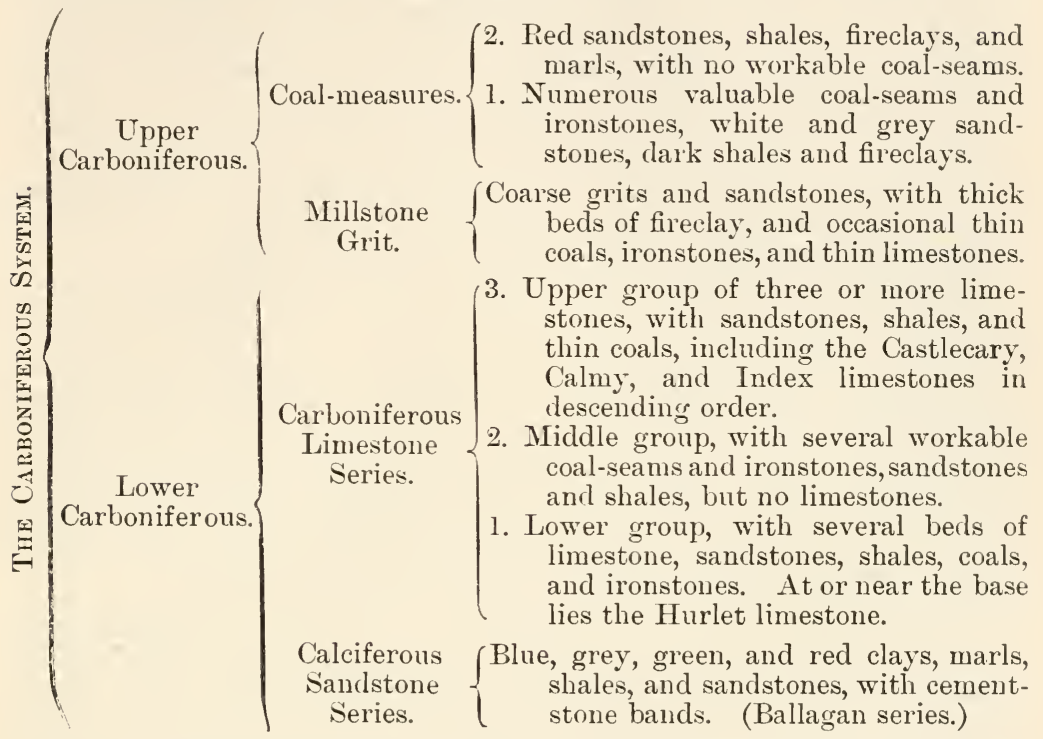

Reference has already been made to the gradual passage from the Upper Old Red Sandstone deposits to the Cement-stone group at the base of the Carboniferous system in the West of Scotland. But evidence will be adduced to show that in certain areas there is a strong overlap of the succeeding deposits, for the Calciferous Sandstones, Carboniferous Limestones, and even the Coal-measures, each in turn rest directly on older rocks.

The Cement-stone group in the West of Scotland presents uniform lithological characters ; the beds consisting of variegated clays, marls, shales, and sandstones, with cement-stone bands which are well exposed in Ballagan Glen near Strathblane. They are comparatively unfossiliferous, but they yield occasionally plant-remains, entomostraca, and fish-scales. Along the north and west sides of the Campsie Fells they are overlaid by white sandstones, and fine tuffs which herald the great outburst of volcanic activity during the Calciferous Sandstone period in Scotland. Indeed this development of volcanic energy rivals in importance the volcanic phase of the Lower division of the Old Red Sandstone. Sir A. Geikie in his recent work on "The Ancient Volcanoes of Britain" has depicted the extent of these plateaueruptions and described the various petrological types which they include. The lavas comprise olivine-basalts, andesites, and trachytes, which are associated with pyroclastic materials. A noteworthy feature is the number of necks or vents-now filled with agglomerates or massive igneous rocksfrom which the volcanic materials may have been discharged, as for example near Strathblane, Fintry, and in Renfrewshire. In the Clyde territory these plateau-eruptions give rise to striking features in the landscape. They form the Campsie Fells, where the terraced appearance of the lava-flows is well 
displayed, and stretch westwards by the Kilpatrick Hills to the Clyde at Bowling. On the south side of the estuary, they are traceable from Bishopton to the hills behind Gourock, thence they extend southeastwards for a distance of thirty miles to Strathavon, where they form a gentle anticlinal fold between the Carboniferous basins of Lanarkshire and Ayrshire. On the east side of the Firth of Clyde they stretch from Gourock by Largs to Ardrossan, they appear in Bute and the Cumbraes, they underlie the Hurlet limestone at Corrie in Arran, and they are well developed to the southwest of Campbeltown, where they rest directly on the sandstones and cornstones of the Upper Old Red Sandstone. Sir A. Geikie has called attention to the thickening and thinning of the lavas in different directions, which has been proved by the detailed mapping of the Geological Survey. For while the plateau-eruptions reach a thickness of 3000 feet in the Kilpatrick Hills they gradually thin away eastwards and disappear east of Stirling.

Though in the neighbourhood of the Campsie and Kilpatrick Hills, and again between Greenock and Ardrossan, the Lower Carboniferous volcanic rocks rest on the Cement-stone series, yet where the volcanoes remained active for a long course of time this subdivision is sparingly developed. Occasionally there are intercalations of sedimentry material, as, for instance, near Eaglesham, where Professor James Geikie mapped sandstones, shales, clay-ironstones, and impure linestones with Productus gigantens, which are intercalated in tuffs. Plant-remains are frequently entombed in the tuffs, as, for instance, on the east coast of Arran--a locality discovered by the late Mr. Wiinsch-and they sometimes form thin seams of coal in the volcanic series, as near Bowling, described by the late Dr. John Young.

Near the top of the volcanic series there is a gradual passage through fine tuffs, which contain much sedimentary material, into the basement beds of the Carboniferous Limestone series. This passage has been traced round the north portion of the Ayrshire field near Kilbirnie, and from Beith to Stewarton; again near Eaglesham in Renfrewshire, and at the foot of the Campsie Fells, west of Kilsyth. It is thus obvious that the Lower Carboni. ferous volcanoes, in certain portions of the Clyde area, must have remained active during the greater part of the Calciferous Sandstone period. Such prolonged volcanic activity accounts in great measure for the absence in the West of Scotland of the upper or oil-shale group of the Calciferous Sandstone series met with in the basin of the Forth. The latter possesses different lithological characters from those of the Cement-stone group, for they consist of oil-shales, blue and black shales, clay-ironstones, estuarine and marine limestones, yellow sandstones, and occasional seams of coal. Recently fine sections of the Cement-stone group have been exposed in artificial openings in the old part of Edinburgh, where they pass underneath the volcanic rocks of Arthur's Seat-the equivalents of the Renfrewshire volcanic series-these in turn being overlaid by the oil-shale group of the Lothians. The members of the latter group, so well developed in Midlothian and Linlithgowshire, are traceable southwestwards as far as Auchengray near the east boundary of Lanarkshire, but their occurrence has not been proved to the west of that locality.

The triple classification of the Carboniferous Limestones series (see Table, p. 407) is well represented in the Clyde territory. This division forms a belt of variable width surrounding the great Lanarkshire coal-field on the north, west, and south sides. Frequently the strata are faulted against the underlying volcanic series, as along the southern slope of the Campsie Fells. The Hurlet limestone is the lowest limestone of the series, and is one of the most persistent bands. In the Carluke district the lowest group contains from twelve to fifteen beds of limestone, but the two best known seams in it are the Hurlet and the Hosie limestones. The middle group contains several workable coal-seams, of which the Lesma- 
hagow gas-coal is one of the importantseams, and in the lower portion of this group there are valuable bands of ironstone. The upper group comprises three beds of limestone, the lowest being the Index-so named because it overlies the valuable coal-bearing subdivision of the Carboniferous Limestone, the middle being the Calmy, and the upper the Gair or Castlecary band. The same subdivisions are represented in the Ayrshire field, with this important modification, that the lowest or Hurlet limestone has an exceptional development near Beith, where it is about 100 feet thick, and is richly charged with marine organisms. In the northern parts of the same basin, at Dalry, evidence has been obtained of the existence of buried volcanoes, filled with tuff, which Sir A. Geikie assigns to the period of puy-eruptions that followed the volcanic phase of the Calciferous Sandstone period. He states that in one pit upwards of 115 fathoms of tuff were passed through before the position of the blackband ironstone in that portion of the field was reached by driving levels through the tuff into the adjoining strata. The tuff occurs in patches between which the blackband ironstone is workable. It is evident that volcanic cones must there have been locally developed during the deposition of the ironstone, and that these were eventually buried by higher deposits of the Carboniferous Limestone series.

The Carboniferous Limestone series with the group of workable coals, occurs in various small isolated basins, as, for instance, in the Douglas field in South Lanarkshire, at Dailly in Ayrshire, and to the west of Campbeltown in Kintyre. Representatives of this series, with its three subdivisions, are met with on the east coast of Arran between Brodick and the Cock of Arran, but the coal-seams there appear in an attenuated form and are not now worked.

The series of deposits just described points to a succession of marine conditions, to the existence of shallow lagoons and mud-flats, and of landsurfaces. It is evident that during the Carboniferous Limestone period the land was steadily subsiding with long intervals of repose, and this irregular subsidence of the land produced overlaps of the strata. For example, the Upper Old Red Sandstone of the Pentland Hills, when traced westwards, is overlapped by the Calciferous Sandstone, and still further west, near Lesmahagow, the Cement-stone group is in turn overlapped by the Carboniferous Limestone series, which there rests unconformably on the Lower Old Red Sandstone along the south margin of the Lanarkshire field. Similar evidence is obtained in the south part of the Douglas basin, where the Carboniferous Limestone transgresses the Cementstone group, and reposes on the Lower Old Red Sandstone. Further proof of the southward extension of the Carboniferous rocks and of overlap is found south of Tinto Hill in Lanarkshire, where, in a small outlier, the Calciferous Sandstone disappears, and the Hurlet limestone rests directly on the Lower Old Red Sandstone. A gain, between Dalmellington and New Cumnock conglomerates are associated with the Carboniferous Limestone in such a way as to point to an overlap of that series on to the Old Red Sandstone.

Throughout the Lanarkshire field the Carboniferous Limestone is overlaid by the Millstone Grit series, which consists of massive, white, yellow or red sandstones associated with thin coal-seams, thin limestones, ironstones, and valuable fireclays. In the south part of the basin, where it is of considerable thickness, it occurs to the northeast of Carluke and north of Auchenheath, while in the north part of the basin the fireclays are worked at Glenboig, Gartcosh, and Garnkirk. In the Ayrshire basin the Millstone Grit is absent, at least in some parts of the field, for the Coal-measures rest directly on the Carboniferous Limestone series. On this horizon, however, an interesting band of volcanic rocks has been traced round the east and north sides of the Coal-measures, which, according to Sir A. Geikie, seems 
to mark the latest Carboniferous volcanoes. Where most fully developed, these rocks consist of bedded basalts and tuffs, reaching a thickness of 600 feet. In the Geological Survey map (sheet 14) they form a conspicuous feature, intervening between the Carboniferous Limestone and the coalmeasures along the east side of the field near Kilmaurs, but they thin away and appear as a narrow band between Kilwinning and the shore section at Saltcoats. It is interesting to note that a band of fine tuff, occupying the same horizon at the base of the Coal-measures, has recently been detected by Mr. Gunn in Arran, and a similar band has been found in the strip of Carboniferous rocks on the west side of Loch Ryan. No contemporaneous volcanic rocks occur on this horizon in the Lanarkshire basin.

Though the massive sandstones of the Millstone Grit imply the accumulation of coarse sediment near the land, still the shales, ironstones, and impure limestones in this division have yielded plants, brachiopods, crustaceans, fishes and other organisms, pointing to the existence of marine conditions.

The Coal-measures overlying the Millstone Grit are divisible into two groups, a lower, containing numerous valuable coal-seams, ironstones, fireclays, bituminous shales, sandy shales, and sandstones, and an upper group of red sandstones, fireclays, marls, and thin coal-seams, resting, probably with a slight unconformability, on the lower. The vertical section of the Clyde coal-field, published by the Geological Survey, shows eleven coalseams and seven seams of ironstone in the lower group, in the central portion of the basin. ("Explanation" of sheet 23, one-inch Geological Survey Map, page 36.) Some of the seams rest on a bed of fireclay, representing the old land-surface, while others have no underclay; the latter may be due to the drifting of vegetable matter. The red sandstone. group overlying the valuable mineral field in Lanarkshire extends up the valley of the Clyde from Cambuslang by Bothwell to Hamilton, being admirably seen in the quarries near Uddingston. These two groups are represented in the Ayrshire field. Quite recently Mr. Gunn has detected representatives of the Coal-measures in Arran, in tributary branches of the Sliddery Water, which have yielded two species of Carbonicola, and several species of fishes appearing to be characteristic of the Upper Carboniferous formations in Scotland, together with specimens of Lepidodendron Veltheimianum, which, according to Mr. Kidston, has never yet been found above the Carboniferous Limestone. The shales, ironstones, and other sediments yielding these fossils are there associated with fine tuffs, coarse volcanic ash, and lavas, to which reference has already been made in connection with the volcanic zone at the base of the Coal-measures in Ayrshire. (Summary of Progress, Geological Survey, 1897, page 113.) Fron the constant succession of coal-seams, ironstones, sandstones, and shales throughout the Coal-measures it may be inferred that land conditions alternated with slight submergence during the accumulation of these deposits. 'That the irregular sinking of the Silurian tableland led to overlaps during the Coal-measure period is conclusively proved in the Sanqubar District, and near Loch Ryan. For in the former region both the Calciferous Sandstone and the Carboniferous Limestone are overlapped, and the Coal-measures rest unconformably on Silurian strata in the Sanquhar basin. Again, on the west shore of Loch Ryan the shales occurring in the strip of Carboniferous rocks, which there rest on the Silurian floor, have yielded plants characteristic of the Coal-measures.

Reference must be made to the researches of $\mathrm{Mr}$. Kidston, who, by means of the plants, has pointed out the existence of a great palaeontological break at the base of the Millstone Grit. A similar conclusion has been independently arrived at by Dr. Traquair from an examination of the fishes.

Numerous dykes and sills pierce the Carboniferous strata of the Clyde territory. The dykes, which may be referred to the period of the plateaueruptions of the Calciferous Sandstone period, consist mainly of trachyte or 
andesite, and others of diabase, basalt, or dolerite. The intrusive sheets of that epoch likewise consist mainly of andesite or trachyte. Mr. Gum has observed that in Bute and the Cumbraes the dykes of trachyte, basalt and dolerite sometimes pass into intrusive sheets. A prominent series of sills of a more basic character is largely developed along the northern belt of the Carboniferous Limestone series in the midland valley. These dolerite sills occur at Kilbarchan, Johnstone, and Paisley, and they extend at intervals from Milngavie by Kilsyth to Stirling, where one of these intrusive sheets forms a conspicuous feature in the Castle Rock. These basic sills are linked with the puy-eruptions of Carboniferous Limestone time by Sir A. Geikie.

In the Ayrshire basin of Carboniferous strata there is an oval-shaped area of volcanic and sedimentary rocks which have been referred to the Permian period. They rest on the upper or red sandstone group of the Coal-measures. The margin of this Permian basin consists of sheets of lava and volcanic tuffs, interstratified with brick-red sandstones, and these are overlaid by false-bedded red sandstones. The lavas are well seen in the course of the river Ayr above Ballochmyle, and the red sandstones in the large quarries near Mauchline. Outside the Permian basin, numerous necks or vents, filled with volcanic agglomerate, pierce the Coal-measures which have been referred to this period of volcanic activity. Since the discovery of Rhaetic and Liassic fossils in Arran, which has led to the grouping of the red sandstones in the south of Arran with the Triassic strata, it has been suggested that the Mauchline sandstones may be of the same age.

The part of Arran lying to the south of a line drawn from Brodick to Blackwaterfoot on the west coast is occupied by a great development of false-bedded red sandstones, conglomerates and marls, which are now regarded as of Triassic age. This correlation is based on the discovery of Rhaetic fossils characteristic of the Avicula contorta-zone, and Lower Liassic fossils in masses of shale, marl, limestone, and sandstones, which do not now occur in place on the island. These portions of sedimentary strata are associated with fragmental volcanic materials, and various intrusive igneous rocks which now fill a great volcanic vent. Its site is about halfway between Brodick Bay on the east and Machrie Bay on the sest, and to the south of the String Road which crosses the island from Brodick to Shiskine. This discovery was made by Messrs. Peach, Gunn, and Macconochie, in the course of the Geological Survey of that district. The occurrence of these sedimentary masses, one of which is acres in extent, points to the former existence in the Clyde area of Rhaetic and Lower Liassic strata which have now been swept away. The detailed mapping of the island by Mr. Gunn has conclusively proved that the Triassic sandstones rest partly on the Coal-measures, partly on the Carboniferous Limestone series, and partly on the Old Red Sandstone. Hence the apparent conformability is entirely deceptive. A patch of these rocks occurs in the north of the island at the Cock of Arran where the late Mr. James Thomson many years ago discovered pebbles with Carboniferous Limestone fossils in the Triassic conglomerate, though at the time he referred the conglomerate to the horizon of the Millstone Grit.

In addition to the Rhaetic and Liassic strata in the volcanic vent near Shiskine, fragments of limestone and chert were found associated with the agglomerate by the Geological Survey. The limestone has yielded fossils of Cretaceous age, including Globigerina, Textularia, Porosphaera globularis, and Inoceramus, thus pointing to the existence of Cretaceous strata in the Clyde area, which have been removed by denudation. It is obvious, therefore, that this vent is of post-Cretaceous age, and may with probability be referred to the age of the necks of Tertiary time in Skye. This discovery likewise furnishes valuable evidence in favour of referring the granite mass in the north of Arran, and most of the intrusive, acid and basic igneous rocks in that island to the Tertiary period. 
In connection with this development of Tertiary igneous rocks in the island, allusion must be made to the series of basalt and dolerite dykes so largely developed in the Clyde area. They traverse all the geological formations in the region and some pierce the Arran granite, facts which lend support to the view that they belong to the grand outburst of volcanic activity in Tertiary time in the West Highlands.

The phenomena comnected with the glacial period in the Clyde territory are of special interest, owing to the extent and variety of the deposits. There is evidence for maintaining that, during the period of maximum glaciation, this area experienced a conflict between the ice which radiated from the Highlands and from the Southern Uplands. The ice that radiated from the West Highlands moved partly down the Firth of Clyde and partly eastwards towards the Firth of Forth. The striae and the dispersal of the stones in the drift prove that part of the ice-stream from the Highlands invaded the Clyde basin and moved southeastwards to Hamilton, where it was met by the ice that descended from the higher grounds in Upper Clydesdale. These two opposing ice-sheets were deflected eastwards to the German Ocean and westwards across the Renfrewshire Hills towards the Firth of Clyde. The ice from the Highlands also overflowed the low grounds of Ayrshire and coalesced with the stream that moved northwards from the hills of Galloway. No less interesting is the evidence furnished by the glaciation of Kintyre. That peninsula was overridden by ice which moved from the Firth of Clyde in a westerly direction-such deflection being due probably to the influence of the ice that radiated from the north of Ireland.

A remarkable feature of the records of glacial time in the West of Scotland is the great thickness of the superficial accumulations, which in one place in the Clyde basin reaches 357 feet. The numerous natural sections reveal the existence of stratified deposits in association with Boulder-clay, which is confirmed by evidence from bores. The data prove the occurrence of more than one Bonlder-clay separated by sands, gravels, and silts. Professor James Geikie and the late Mr. Dugald Bell suggested that some of these interstratified deposits may have been lacustrine-the lake having been formed by the Loch Lomond glacier moving southwards across the Clyde at Bowling towards the Kilbarchan Hills, and the waters escaping by Lochwinnoch and Dalry to the Firth of Clyde. But apart from the evidence supplied by the great depth of the superficial accumulations, there is clear proof that the land must have stood relatively at a higher level in pre-glacial time than it does now. Dr. Croll contended that the thickness of stratified deposits found in the bores near New Kilpatrick in the valley of the Kelvin inclicated a pre-glacial channel of that river. If his suggestion be correct, then the buried river-course must have entered the Clyde about 200 feet below the present sea-level. This evidence is confirmed by the buried riverchannel that joins the Forth near Grangemouth about 260 feet below the sea. Mr. Cadell of Grange has recently obtained similar evidence in the case of the pre-glacial course of the river Almond, which must have entered the Forth about 100 feet below sea-level.

Underneath a thick mass of Boulder-clay in Ayrshire, both at Woodhill quarry near Kilmaurs, and at Drummuir near Dreghorn, stratified beds occur, that have yielded elephant tusks, antlers of reindeer, arctic ostracods, and foraminifera, together with several species of plants, including Ranunculus uquatilis and Potamogeton. Mr. John Smith has traced over a wide tract in Ayrshire and as far inland as the Guelh Water near Cumnock, a thick series of inter-glacial sands and gravels up to a height of 900 feet. These are associated with shelly pebbly clay, which he regards as of marine origin. Again, from samples of Boulder-clay near Glasgow Mr. Joseph Wright obtained a large number of foraminifera which were determined by him. Further on the west coast of Kintyre, at Cleongart, dark silt or clay with 
marine shells is overlain by 76 feet of Boulder-clay at a level of about 180 feet above the sea. In the basin of the Endrick draining into Loch Lomond, Mr. R. L. Jack mapped shelly Boulder-clay up to a level of 320 feet. He considered that the fragments of marine shells in the Boulder-clay had been derived from a pre-existing inter-glacial deposit, formed when the sea stood about 100 feet above its present level.

Among the most interesting records of glacial time in the West of Scotland are the Arctic shell-beds of the Firth of Clyde. They have been investigated and exhaustively described by Dr. Robertson, Dr. Crosskey, and Mr. James Bennie, whose researches have proved the Arctic character of the fauna found in the marine clays. These deposits belong to the period of the 100-feet beach, though owing to denudation they occur now at lower levels. The younger Raised Beaches at 50-feet and 25-feet levels are well developed in the basin of the Clyde. From the deposits of the 25-feet terrace canoes have been exhumed which point to the existence of neolithic man along the shores of the estuary in post-glacial time. 


\section{THE CRYSTALLINE SCHISTS OF THE HIGHLANDS.}

\section{By Peter Macnair.}

The area occupied by the metamorphic rocks about to be described may be defined as that lying immediately $\mathrm{N}$. of the great boundary fault which, crossing Scotland from shore to shore, with a N.E. and S.W. trend, divides the Highlands from the Lowlands geographically, and the Crystalline Schists from the Old Red Sandstone geologically. The position of this great line of demarcation has been more or less accurately fixed. It can be traced through Arran and Bute, thence from near Toward Castle to Innellau, and across the eastern point of Rosneath peninsula, and by Helensburgh across Loch Lomond northeastwards by way of Balmaha, Aberfoyle, Callander, and Comrie.

The valley of the Clyde proper after traversing the Silurian rocks of the Southern Úplands and the later palaeozoic rocks of the nidland valley eventually abuts against the great wall of crystalline schists forming the frontier Highlands near Helensburgh, where the Gareloch runs northwestwaras into them. Further on, Loch Long, Loch Goil, the Holy Loch, Loch Striven, Loch Fyne, and other sea-lochs trench deeply into the crystalline schists, exposing along their shores numerous sections of great value in unravelling the structure of this region.

Above Helensburgh the Clyde receives at Dumbarton the waters of Loch Lomond, which drains part of the Highland area, and is the most easterly drainage system falling into the Clyde valley from the crystalline schists of the Highlands. It will, however, be well here to include the ground further east as far as Loch Tay, as the rocks there still occupy their normal positions, whereas along the Firth of Clyde, owing to a succession of earthmovements, the original sequence has been obscured and their physical structure complicated.

As it is impossible to speak with certainty as to the physical structure, succession, or age, of the rocks forming the southern or marginal Highlands, it may be well to briefly sketch the history of opinion concerning them. In 1819 Macculloch ${ }^{1}$ pointed out for the first time the opposite directions of the dips in the schists of Cantyre, where the beds of micaceous schist on the eastern shore have an eastern dip, while those on the opposite side dip westwards. Murchison ${ }^{2}$ also at a later period refers to an anticlinal fold at Loch Eck. In 1860 . Jamieson ${ }^{3}$ described in more detail the anticlinal axis observed by Macculloch and Murchison, correlating the argillaceous series of Bute with that of Loch Fyne, which he states arches over into an anticlinal axis, the more arenaceous rocks of Cowal forming the core of the anticline at

I "Western Islands of Scotland," Nacculloch, 1819, vol. ii., p. 288.

${ }^{2}$ Quart. Journ. Geol. Soc, vol. vii., p. 169.

3 "The Geological Structure of the Southwest Highlands," Quart. Journ. Gcol. Soc., 1860, vol. xvii., p. 133 . 
Ben Capuill near Tighnabruaich. This he believed to be a true anticline of the bedding. The altered basic rocks he calls greenstones and points out their intrusive origin.

In 1861 Murchison and Geikie ${ }^{1}$ described certain sections along the margin of the southern Grampians with reference to the supposed succession of the rocks in northwest Sutherlandshire. They believed that the southern and central Highlands were overlaid by a great series of quartzites, limestones, and schists, the representatives of those in the northwest, and that they always bore the same relative position to one another, namely the quartzites at the base, followed by limestones, and the whole overlaid by the schists supposed to be of Silurian age. In another paper about the same date these authors maintained, in opposition to the views advanced by Sharpe, that the foliation of the Highland rocks generally coincided with or followed the original planes of sedimentary deposition. In the same year similar views to these were advanced by Harkness ${ }^{2}$ as to the rocks south of the Caledonian Canal.

In 1863 the next contribution to the study of these rocks appeared from the pen of James Nicol, ${ }^{3}$ and was, in many respects, as I have elsewhere pointed out, the most far-seeing paper which has ever been written on the subject. He entirely discarded the hypothetical views of Murchison, Geikie, and Harkness. Taking a series of sections across the Highland frontier he noted the occurrence in them all of a regular order of clay-slates, grits, greywackes, and quartzites. He also remarked the reversal of dip from S.E. to N.W. as he proceeded from west to east across the Highland frontier, and arrived at the conclusion that the slates along the Firth of Clyde were in their normal position overlying the schists of the interior, whereas these further east as in Perthshire, with a N.E. .dip and thus apparently underlying the schists of the interior, did not really do so, their position being really due to a reversal of the beds. This reading is, however, apparently incorrect, the Perthshire slates being really in their normal position, while they are reversed along the Firth of Clyde. Nicol also pointed out the existence of a highly contorted belt on both sides of Loch Long, and strenuously maintained that the central Highland quartzites belonged to a horizon higher than the schists further south, and did not underlie them as had been maintained by Murchison and Geikie.

In 1891, in a Presidential Address to the Geological Society, Sir A. Geikie ${ }^{4}$ gave a table of the Highland rocks, the work of the Geological Survey, and placed the Central Highland quartzite at the top, and the phyllites and greywackes of the Pass of Leny at the base of the series. Independently a similar succession was advocated the same year by Henry Coates and the author of this paper. In 1896 the author ${ }^{5}$ arranged the clastic rocks of the Highlands in descending order as follows:- Upper Arenaceous zone, Upper Argillaceous zone, Middle Arenaceous zone, Loch Tay Limestone zone, Lower Arenaceous zone, and Lower Argillaceous zone. The principal lithological features and geographical position of each zone was first given, then a series of sections illustrative of their succession and physical structure in Highland Perthshire, and it was pointed out that along the shores of the Firth of Clyde the zones forming the frontier Highlands have been bent into a deep synclinal fold with a reversal of dip.

In 1897, in a Memoir upon the Geology of Cowal, ${ }^{6}$ published by the Geological Survey, a series of schist-zones, beginning at the great boundary

1 "The Altered Rocks of the Western Islands of Scotland and the Northwestern and Central Highlands," Quart. Journ. Geol. Soc., 1861, vol. xvii., p. 171.

2 Quart. Journ. Geol. Soc., 1861, vol. xvii., p. 256.

3 Ibid., 1863, vol. xix., p. 180.

4 Ibid., 1891, vol. xlvii., p. 74 .

${ }^{5}$ Geological Magazine, 1896, vol. iii., p. 167 and p. 211.

6 "Geology of Cowal," Mem. Geol. Survey, 1897. 
fault and traversing that region in a northeast and southwest direction, are described. The existence of the anticline first noticed by Macculloch and Murchison and then in detail by Jamieson, as an anticline of the bedding, is recognised, with this important difference, that it is looked upon as a great arch of foliation, and not of bedding as maintained by the earlier geologists. From a comparison of the different schist-zones on each side of the anticline of foliation the conclusion is arrived at that it cannot be also an anticline of the bedding, but that probably it is an original syncline of bedding traversed by an anticline of foliation; a reversion to the view originally maintained by Sharpe--that the folds of the foliation in the Scottish Highlands were entirely independent of the bedding.

In 1897 the writer $^{1}$ further developed the views he had already published in the Geological Magazine. The Argillaceous zone along the Highland frontier is the oldest of the schist-zones, and is in its normal position in Perthshire. Westwards, however, towards the Clyde its position becomes steeper and steeper, till in the area of the Firth it becomes reversed, having been pushed backwards and inwards upon the main mass of the Central Highlands. In a series of papers lately contributed to the Geological Society of Glasgow, ${ }^{2}$ the writer has again more fully expressed his views regarding the structure and succession of the schists of the Southern Highlands as summarized in the following pages.

It has long been recognised that the metamorphic rocks of the Highlands traverse that area in bands or zones having a general N.E. and S.W. trend roughly parallel with the great boundary fault. The Lower Argillaceous zone abuts against the younger Old Red Sandstone rocks to the south, but separated from it by the boundary fault. Outcropping at the base of the schistseries of the southern Highlands it stretches across the frontier Highlands from sea to sea. In Perthshire it may be seen at Birnam, Logiealmond, Comrie, Callander, and Aberfoyle; in Dumbartonshire at Luss, Row, and Cove; and in Argyllshire at Kirn and Dunoon, crossing the Toward peninsula to Loch Striven, whence it can be traced through Bute from Kames Bay to Ettrick Bay.

The principal rocks of this zone are variously coloured phyllites, including black, blue, purple, grey, green, and buff, with intercalated bands of grit, greywacke, and thin limestones, and they frequently show a finely banded structure referable to their original bedding. Differences of texture may also be observed, more or less gritty bands being often inter-laminated with bands of extremely fine material. Some of these grit bands attain a considerable thickness, such as the Leny and Aberfoyle grits, and the Bull Rock greywacke. Towards the east, as at Birnam, Logiealmond, Comrie, and Callander, this zone of argillaceous rocks is not so highly metamorphosed as on the Firth of Clyde, having more the appearance of a clay-slate. In many instances, as in the quarries at Logiealmond, Aberuchill, and the foot of Loch Lubnaig, the bedding is distinctly folded, the folds being crossed by planes of cleavage. Rarely, however, can any folding or crumpling in the cleavageplanes themselves be detected so that the rocks might here be more fitly called clay-slates than phyllites. Towards the Firth of Clyde there is an increasing development of mica along the cleavage-planes, and at Dunoon there is evidence of more intense metamorphism, secondary foliation-planes being developed, while the cleavage is often violently twisted or folded and the folds crossed by ausweichung or strain-slip.

One of the most interesting features in the Lower Argillaceous zone is the evidence it affords of the behaviour of these beds during the process of plication and crushing. An examination of the arenaceous beds with which these

1 Trans. Perth. Soc. Nat. Science, vol. ii., 1897, p. 166.

2 Trans. Geol. Soc. of Glasgow, vol. xi., part 2, 1900, p. 273. 
phyllites have been interstratified, and of the Arenaceous zone which succeeds them to the north, generally reveals the planes of foliation and shear to be roughly coincident with the bedding, though there are numerous exceptions. In many places, such as in the Dunoon section, the foliation-planes in the phyliites have been themselves folded, and that oftener than ouce. This structure is only explicable on the supposition that the argillaceous beds must have been driven en masse between the more massive arenaceous beds with which they were interstratified, the latter having simply a rough foliation developed along their original bedding-planes, while the argillaceous beds were twisted into innumerable folds with a much more perfect foliation.

Immediately N.W. of this Lower Argillaceous zone another broad band of rocks, with a more or less developed foliation occurs. Because of the predominance in it of coarsely fragmental materials it is here termed the Lower Arenaceous zone, varying from exceedingly fine-grained light and dark greywackes to massive grits with pebbles often an inch in diameter. These pebbles generally consist of quartz or felspar set in a finely comminuted felspathic matrix.

Associated with these rocks occurs a group known as "the green beds" because of their marked greenish colour. They generally show a more or less well-developed schistose structure and are characterised by the presence of granular epidote, chlorite, and dark green or brown biotite. That they are of fragmental origin seems undoubted, but the conditions under which they were originally deposited are uncertain. When first mapped by the officers of the Survey they were supposed to be of pyroclastic origin, the green colouring matter being looked upon as similar to the fine dust of volearic tuff, but the complete absence of interbedded lava-flows, or of any pebbles referable to igneous rock, throws doubt upon such an origin. Like the phyllites they immediately succeed they exhibit a gradually increasing metamorphism from east to west, the grits and greywackes becoming more highly schistose.

Geographically this Lower Arenaceous zone may be traced from St. Fillans, in Perthshire, through Ben Vorlich, Ben Ledi, and Ben Venue, giving rise to the characteristic scenery of the Trossachs; thence along the shores of Loch Lomond below Rowardennan and Inverbeg into Cowal, where it may be seen at the head of the Gareloch, and along Loch Eck, where it gives rise to a peculiarly rugged type of scenery.

Above the group just described occurs one of the best marked zones of all the schists seen in the southern Highlands, that known as the Loch Tay limestone, the typical rock of which is a crystalline, black, grey, or mottled limestone, generally showing distinct crystals of calcite. With it are associated beds of calcareous mica-schist which often appear to split the limestone up into several bands. It is well exposed along the shores of Loch Tay, and can be traced westwards along Glen Dochart to near Crianlarich, and thence into Argyllshire at Ballimore, near Strachur, in Glendaruel, and near Kilfinan. Upon this horizon occur massive beds of sheared basic rocks which accompany the limestone in a remarkable manner from E. to W. across the whole of the southern Highlands.

Above this zone comes a band of mica-schists and quartz-schists characterised by the abundance of their garnets, sometimes in such quantities as to form the larger bulk of the rock. This group which has been named the garnetiferous schist-zone, forms a tolerably well-marked horizon immediately above the Loch Tay limestone, and can be traced along the mountains $N$. of Loch Tay into Glen Dochart, and thence into Argyllshire, where it accompanies the limestone which it apparently overlies.

A well-marked group of phyllites, schistose-quartzites, and graphiteschists, the Upper Argillaceous zone succeed this. Like those of the Lower Argillaceous zone, the rocks of this zone seem to have been driven between 
the more massive beds, and to have suffered intense metamorphism, the foliation-planes having been folded and twisted to an almost inconceivable extent. This is well seen in the mountains N. of Loch Tay and along Loch Fyne. Geographically this zone may be traced through the summits of Ben Lawers, Craig Na Calliach, and on to the high ground separating Glen Lochy and Glen Dochart. At Tyndrum it is faulted against the central Highland quartzites, whence it runs N.E. towards Loch Lyon, and it is also well exposed along both the E. and W. shores of Loch Fyne.

Succeeding the Upper Argillaceous zone and covering a great part of the central Highlands there is a group of quartzites and limestones here named the Upper Arenaceous zone, because of the predominance in it of the quartzites. It can be seen in the neighbourhood of Blair Atholl, the limestones being well exposed in Glen Tilt, whence they can be traced westwards through Schiehallion, Glen Lyon, the Black Mount, and Dalmally, to the shores of Loch Awe.

Associated with these different zones are other schists which have originally been intruded into the sedimentary schists as sills of igneous rock, prior to the general metamorphism of the region. These have suffered along with the clastic rocks, and are now known as epidiorites and hornblende schists. A remarkable development of them is to be found along the horizon of the Loch Tay limestone, and in the schists immediately above and below it. Though they now in many instances present a perfectly developed schistose structure, they have originally been igneous rocks of a basic character. Serpentines and chlorite-schists, both, probably, of igneous origin, occur here and there throughout the area.

The following table gives the principal schist-zones, with their characteristic rocks. For reasons to be afterwards shown it is probable that the order given in the table is a descending one, the newest rocks being placed at the top, the oldest at the bottom:

Table of the Metamorphic Rocks of the Southern Highlands.

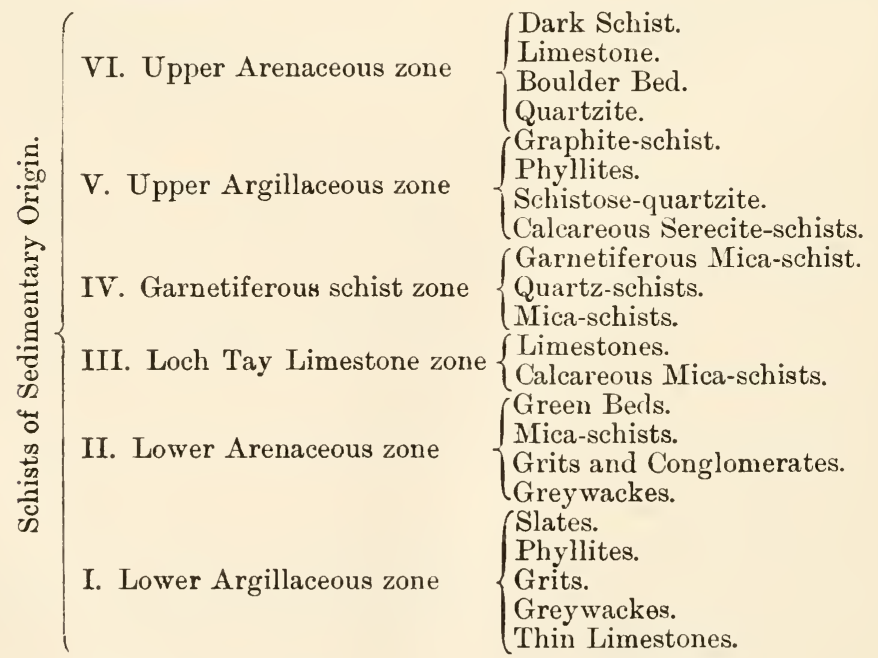

Hornblende-schists.

Epidiorites.

Serpentine.

Chlorite-schist. 
The two sections (page 420) will perhaps show more clearly the comparative physical structure of the area-the one in Perthshire typical of the structure of the eastern, and the other in Cowal of the western part. The eastern section runs from Comrie to Ben Lawers, and in the neighbourhood of Comrie the foliation-planes of the clay-slates, the representative rocks of the Lower Argillaceous zone, dip at high angles towards the northwest. These rocks are also well exposed on the eastern shore of Loch Lubnaig. Further west where the foliation has the same dip, the bedding-planes have at places undergone considerable folding, but generally dip in the same direction as the foliation. Above this zone, and succeeding it to the N.W., comes the Lower Arenaceous zone with its characteristic beds of grit and greywacke, which are all well exposed in the gorge of the Lednock N. of Comrie, and strike to the S.W. across the summits of Ben Vorlich and Ben Ledi. Tracing the section to the N. it will be found that these rocks continue up Glen Lednock with a gradually decreasing dip from the high angles along the Highland frontier, till near the watershed they become almost flat. On the summit of Meal Na Creige, a mountain overlooking Loch Tay, we find an outlier of the Loch Tay limestone zone, consisting of calcareous mica-schist with accompanying sills of epidiorite. To the W. of this the powerful Glen Ample fault truncates the schist, throwing down the Loch Tay limestone, and ushering in the shallow trough of limestones and schists stretching from Glen Beich westward across the Braes of Balquhidder towards the shores of Loch Katrine.

Descending Meal $\mathrm{Na}$ Creig to the other side of Loch Tay we find the Loch Tay limestone and its associated basic rocks dipping N.W. below Ben Lawers. Ascending the sides of the Ben these are succeeded by the garnetiferous schist-zone, and at about 2500 feet are in turn overlaid by the highly contorted phyllites, schistose quartzites, and black graphitic schists of the Upper Argillaceous zone. Down the northern side of the mountain towards Glen Lyon, the Loch Tay limestone with its associated epidiorites again rises to the surface, thus showing that the mountain has been carved out of a syncline of schists. At this point the quartzites of the Upper Argillaceous zone are seen to be cut off by a fault, but elsewhere the passage of the graphite-schists into the quartzite is clearly seen.

In the western portion of the area the section is taken across Cowal, from Dunoon to Inverary. At Dunoon on the Firth of Clyde the lower argillaceous zone is exposed along the shore from Hunter's Quay to Innellan, where the dip of the principal foliation is southeast at an angle of $53^{\circ}$. In many places, as already observed, the bedding shows evidence of being much folded. Up the Eoly Loch towards the north, the phyllites are succeeded by a group of green beds, mica-schists, schistose-grits, and greywackes, the representatives of the Lower Arenaceous zone, dipping southeast at about $53^{\circ}$.

From the head of the Holy Loch they begin to undulate, till at the foot of Loch Eck they give evidence of having been subjected to most violent twisting and contorting. This belt of highly contorted schists extends northwards towards the head of Loch Eck, when again the twisting liminishes and the dip is reversed, being now northwest at much gentler angles. At Ballimore the Loch Tay limestone, with its associated hornblendeschists, is exposed, dipping also northwest, and above it comes the garnetiferous schist-zone, seen in several of the stream-sections. On the shores of Loch Fyne the Upper Argillaceous zone is met with, with its characteristic phyllites and quartz-schists which cross to the north side of the loch and are well exposed near Inveraray. In Glen Aray these rocks are succeeded by the more massive quartzite beds, and limestones, so well developed along the shores of Loch Awe, which belong to the Upper Arenaceous zone, and below which the Loch Fyne phyllites pass in a shallow syncline or trough. 


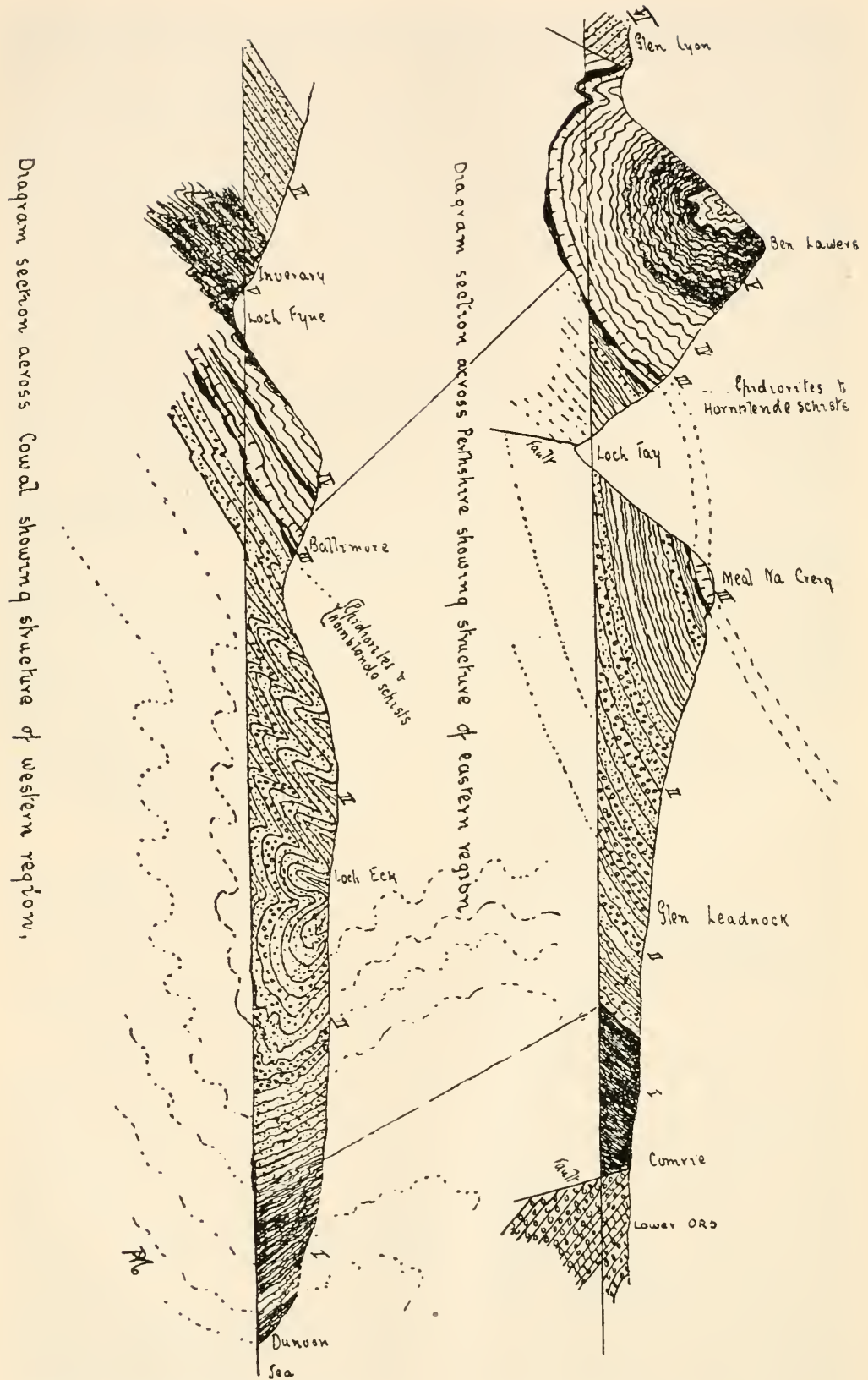

Note.-In the above sections of the Crystalline schists the lines represent foliationplanes, not necessarily bedding-planes. 
From a consideration of these two sections it would seem that in the eastern one across Perthshire we have the nearest approach to the normal order of the rocks. In the interior of Highland Perthshire they are comparatively flat, but as the Highland frontier is reached the dip rapidly increases to high angles, still, however, dipping beneath the rocks of the interior. Here there is a syncline, of which the northern limb is comparatively flat and composed of younger rocks, while the southern limb is exceedingly steep ushering in the lower and older beds. This simplicity may, however, be more apparent than real. One is at times inclined to suspect that the bedding has been folded into a series of isoclines, and that the foliation-planes crossing these parallel to the axes of the folds have made the structure appear more simple than it really is, and the thickness of the beds greater than they ought to be.

On the western side of the great fault which passes through Glen Beich the Loch Tay limestone zone seen on the summit of Meal $\mathrm{Na}$ Creige has been carried downwards by it, and the structure of the shallow syncline becomes more apparent, being well seen in Glen Ogle and the Kirkton Glen, where the limestones and epidiorites are exposed near the bottoms of the valleys and the overlying schists are seen on the higher grounds. This trough stretches towards the shores of Loch Katrine and the head of Loch Lomond, but in that direction the folding of the beds becomes more intense and the southern limb steeper, until it becomes inverted and pushed over towards the interior. The older rocks coming from beneath the syncline and seen along the frontier Highlands are also placed at high angles, and towards the shores of Loch Lomond they become reversed, dipping, also at high angles, to the southeast.

Traced into Cowal and along the shores of the Firth of Clyde the syncline becomes more and more acute, being now actually in a recumbent position with its axis heading towards the southeast at a low angle. The southern limb, consisting of the two lower zones, becomes flatter, the beds dipping southeast at $53^{\circ}$. The rocks, which formed a gentle trough in Perthshire with slightly undulating folds, become more violently contorted. But still their relationship to the eastern section seems to be quite clear, and the supposed anticline of the bedding described by the earlier geologists, and that of the foliation by the officers of the Survey, appear to be entirely deceptive.

Perhaps it may be somewhat misleading to use the term syncline as descriptive of the structure of this region. Strictly speaking it appears to be rather a series of isoclinal folds which traced from Loch Fyne across Cowal to the Firth of Clyde gradually usher in still lower beds. This structure will be better understood by a reference to the sectional diagrams (page 420).

Space does not permit of a detailed description of the minute structure of these schists. An early, and probably the first, foliation of this region took place along the lines of bedding, or parallel to the axes of the folds in the bedding, as is still well seen in the more arenaceous rocks. That this early foliation has been subjected to a series of later movements admits of no doubt, especially in the highly contorted belt which runs through Cowal, the structure of which has been minutely and carefully described by the officers of the Survey. In Cowal there is evidence that an early foliation has itself been folded and crossed by strain-slip, which has again been folded and crossed by still later movements, the process having been repeated oftener than once until all trace of the bedding or early foliation has become entirely obliterated. In the garnetiferous schist-zone and Upper Argillaceous zone of the central Highlands the original clastic rocks seem to have become so completely mineralized that it is almost hopeless to search for evidence of the original bedding, all their divisional planes being clearly of secondary origin, so that it must remain an open question as to the extent to which these secondary planes may be 
relied upon in determining the original succession of the rocks. Notwithstanding this, and the fact that the foliation-planes are themselves often so intensely folded as to make it difficult to determine even the apparent succession of these secondary planes, yet the relative positions of the principal zones given in this paper seem to be fairly well made out.

Where the foliation-planes have themselves been folded it is interesting to note that the axes of the folds generally head N.W., the overfolding facing S.E., the upper limbs being generally the longer limbs, and the under ones those which are most thimned. As regards the age of these rocks it seems impossible at present to give any definite answer. That they are older than the Lower Old Red Sandstone is evident, from the fact that pebbles of the schists are embedded in the conglomerates of that formation along the Highland frontier.

Along the Highland frontier and immediately $\mathrm{N}$. of the great line of fault the officers of the Survey have discovered a narrow belt of carbonaceous shales, schists and cherts, the latter containing forms resembling Radiolarian tests, which they consider may be of Arenig age. 'These appear to have been wedged in between the Highland schists and the Old Red Sandstones, and can be traced at intervals through Perthshire and Dumbartonshire into the Island of Arran.

The views expressed in this paper are here offered only as a tentative solution of a difficult problem, upon which it is as yet impossible to speak with assurance. 


\title{
THE SILURIAN ROCKS IN THE SOUTH OF SCOTLAND.
}

\author{
By B. N. Peach, F.R.S.; J. Horne, F.R.S.; and
}

A. MACCONOCHIE.

INTRODUCTION.

The broad tableland of the Southern Uplands, stretching from the great midland valley southwards to the Solway Firth and the Cheviot Hills is composed mainly of Silurian strata. Along its northern margin, the Silurian tableland is bounded by a powerful fault which lets down the Old Red Sandstone and Carboniferous rocks of the central lowlands; while on the southeast side, in the region extending from the Merse of Berwickshire to the Solway, the Old Red Sandstone and Carboniferous strata rest unconformably on the upturned and eroded Silurian rocks. The scenery of these pastoral uplands is remarkably uniform save where these older Palaeozoic rocks have been pierced by large granite masses, as for example between Criffel and Bengairn and between Loch Dee and Loch Doon. Over much of the tableland there is little variation in the lithological characters of the strata, as they consist mainly of grits, greywackes, flagstones and shales. There are, however, certain bands of black shales richly charged with graptolites, by means of which Professor Lapworth demonstrated the true order of succession of the strata. Everywhere the rocks have been thrown into innumerable folds-frequently inverted and traversed by normal and reversed faults - the axes of which run from southwest to northeast, that is, parallel to the long axis of the tableland.

Along the-sonthern margin of the tableland there is a strip of Wenlock and Ludlow rocks. In the central part of the chain, there is a belt-upwards of twenty miles in width-composed mainly of Llandovery and Tarannon rocks with inliers of the Moffat series of graptolite shales, and extending from the Mull of Galloway by Moffat to St. Abb's Head. In the northern portion, stretching from the northern slopes of the Lammermuir Hills southwest by the Leadhills to Loch Ryan and Portpatrick there is a great development of Arenig, Llandeilo, and Caradoc rocks. The Girvan region which embraces strata ranging from Arenig to Wenlock time is of special iuterest owing to the abundance of organic remains found on certain horizons. Beyond the northern limits of the Silurian tableland, and within the area occupied by the members of the Old Red Sandstone and Carboniferous systems in Lanarkshire and Ayrshire, there are various exposures of Upper Silurian rocks, of Wenlock, Ludlow and Downtonian age.

Though the portion of the Silurian tableland which falls to be described here is restricted to that embraced in the Clyde basin and adjoining the Firth of Clyde, the following table has been prepared to show the classification of the Silurian rocks throughout the Southern Uplands : 


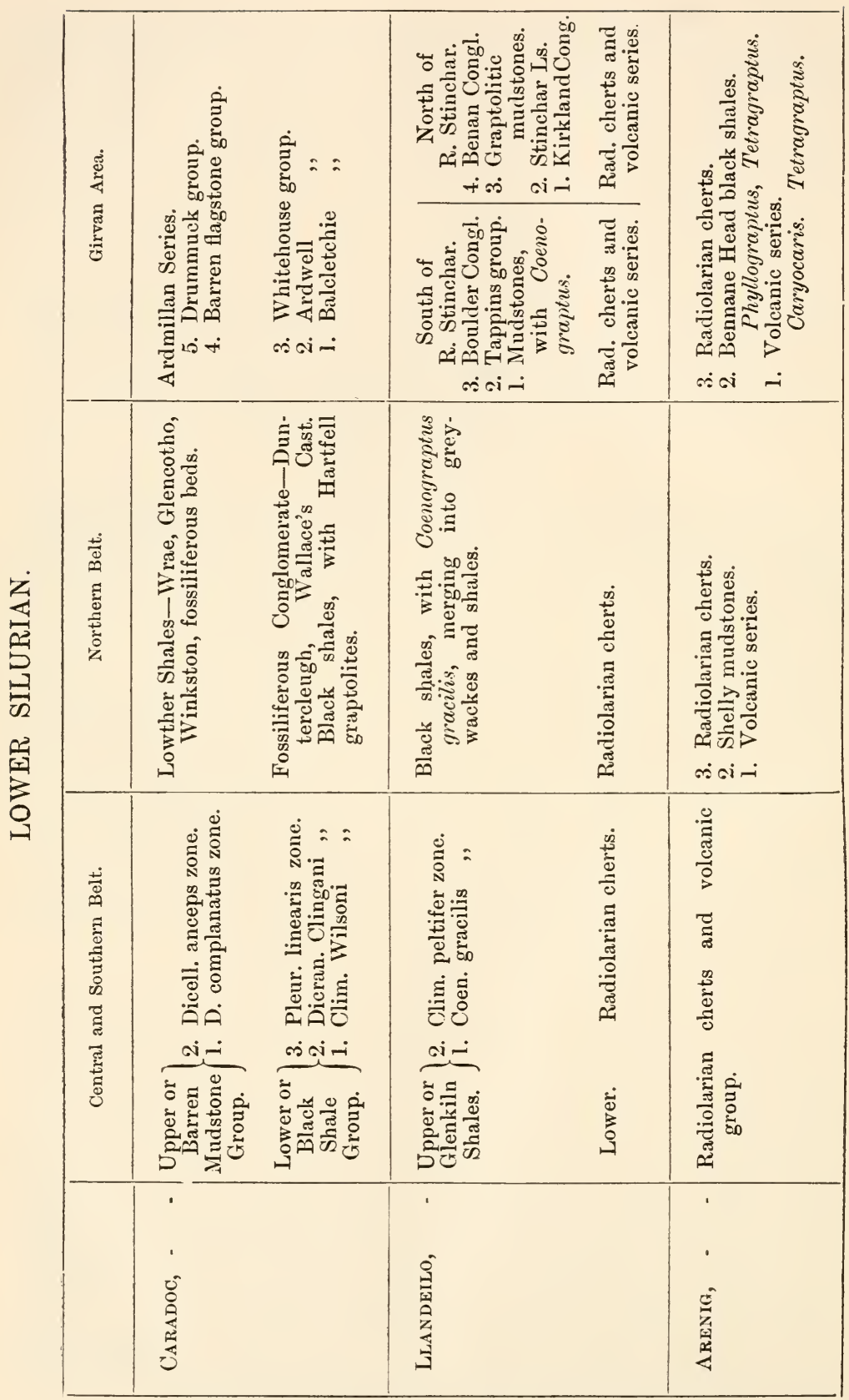




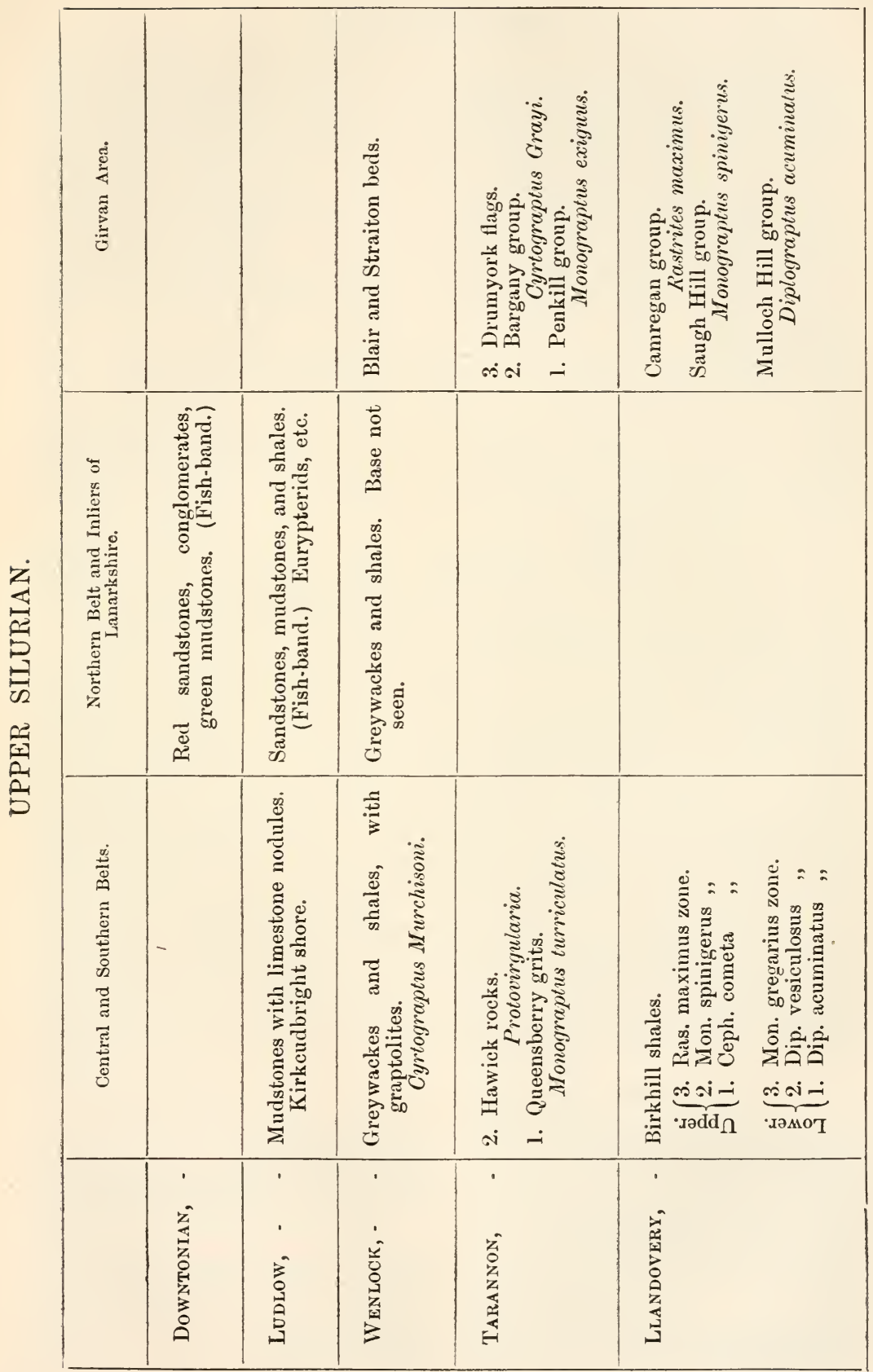




\section{LEADHILLS DISTRICT.}

As a prelude to the description of the Leadhills district, brief reference must be made to the geological structure of the classic region of Moffat which embraces the type-sections described by Professor Lapworth, in proof of the sequence and relations of the graptolite-shales of the central part of the tableland. The Moffat black shale series forms narrow boat-shaped areas, being brought to the surface along sharp anticlinal folds, in the midst of the younger Tarannon rocks. From the preceding table it will be seen that the members of the Moffat series have been grouped in three divisions: Glenkiln, Hartfell, and Birkhill ; corresponding to the Upper Llandeilo, Caradoc, and Llandovery rocks of Wales respectively, the whole sequence not exceeding 300 feet in thickness. Where denudation has proceeded far enough to expose strata underlying the Glenkilu shales, these consist of Radiolarian cherts and fine tuff's of Lower Llandeilo and Arenig age. The famous Dobb's Limn section at the head of Moffatdale, clearly shows the divisions and structural relations of the Moffat series. When the Moffat series is traced northwards on successive anticlines, towards the northern margin of the central belt of Tarannon rocks, the subdivisions of the Birkhill shales (Llandovery) disappear and are replaced by coarser sediments. Hence at certain localities it is not easy to trace with precision the northern limit of the Tarannon belt.

In the districts of Abington and Leadhills there is a remarkable development of Arenig, Llandeilo, and Caradoc rocks, of greater thickness than their representatives in the Moffat region. A remarkable feature of these northern districts is the occurrence of Arenig volcanic rocks, comprising lavas, agglomerates, and tuff's exposed in the cores of many anticlinal folds. They are immediately overlain by fine mudstones containing abundant hingeless brachiopods (see list), and these in turn by red, dark, and gray cherts charged with Radiolaria (see list). Next in order come the GleukilnHartfell shales yielding their characteristic graptolites of the Moffat region. This sequence is exposed in various folds in the districts of Abington, Leadhills, and Sanquhar. Part of the Lower Caradoc rocks of the northern districts is represented by greywackes, shales, and fossiliferous conglomerates. (Duntercleuch, Wallace's Cast, and Kilbucho, see list), while the Upper Caradoc rocks are represented mainly by the Lowther Shales which, to the east of the Clyde basin, include the fossiliferous limestones and conglomerates of Wrae, Glencotho, and Winkston. This change in the type of sedimentation of the Upper Caradoc rocks is also observable in that of the Lower Hartfell and Glenkiln black shales (Lower Caradoc and Upper Llandeilo) when the latter are traced northwards to the margin of the tableland. These in turn are replaced by coarse sediments and the graptolites of the Glenkiln group occur in thin dark seams, interleaved in greywackes and shales.

Fossils from Arenig Mudstones, Abington District.

Tetragraptus fruticosus, Hall. T. quadribrachiatus, Hall. Annelid jaws (?). Caryocaris Wrighti, Salt. Acrotreta Nicholsoni, Dav.

A. sp.

Acrothele granulata, Linnr.

A. sp.

Lingula, sp.

Lingulella lepis, Salt.

L. quebecensis, Bill.
Lingulella, sp.

Linnarssonia, sp.

Obolella like 0. Sabrinae, Callow.

Linnarssonia (Obolella) sagittalis, Salt.

L. $\mathrm{sp}$.

Kutorgina labradorica, ? Bill.

K. sp.

Discinoid shells.

InCERTAE SEDIS.

Rods, (Sponge ?) 
Radiolaria from Arenig-Lllandeilo Cherts, Abington District.

Acanthosphaera antiqua, Hinde.

Diploplegma cinctum, Hinde.

Dorydictum simplex, Hinde.

Doryplegma gracile, Hinde.

D. nasutum, Hinde.

Dorysphaera laxa, Hinde.

D. reticulata, Hinde.

Haliomma cornutum, Hinde.

H. vetustum, Hinde.

Spongoplegma priscum, Hinde.

Sphaerozoum patutum, Hinde.
Sphaerozoum priscum, Hinde.

Staurodorus gracilis, Hinde.

Stauroplegma brevispina, Hinde.

S. barbatum, Hinde.

S. compressum, Hinde.

S. diffusum, Hinde.

Styptosphaera antiqua, Hinde.

Triposphaera armata, Hinde.

T. densa, Hinde.

T. hastata, Hinde.

T. Peachi, Hinde.

Fossils from the Lower Caradoc Congloyerates of Duntercleugh, Wallace's Cast, axd Kilbucho, Abingtox District.

Cyclocrinus, sp.

Nidulites favus, Salt.

Alveolites, sp.

Favosites asper, $d 0 \cdot b$.

F. gothlandicus, Fougt.

F. $\mathrm{sp}$.

Heliolites, sp.

Lindstromia subduplicata, $\mathrm{M} / \mathrm{C}^{\prime} \mathrm{Coy}$.

L. subduplicata, var. crenulata, $\mathrm{H} \cdot \mathrm{CO} \%$.

Lyopora favosa, $\mathrm{H}^{\circ} \mathrm{C} 0 \%$.

Monticulipora lens, $I^{\circ} \mathrm{Coy}$.

Palaeocyclus, sp.

Petraia bina, Lonsd.

P. elongata, Phil.

P. uniserialis,.$/{ }^{\circ} \mathrm{Co} \%$.

P. zic-zac, $\mathrm{M} \cdot \mathrm{Coy}$.

Stenopora fibrosa, Goldf.

Tetradium, sp.

Crinoid stems.

Serpulites longissimus, Murch.

Calymene, sp.

Cheirurus clavifrons, Dalm.

Encrinurus punctatus, Brïnn.

Homalonotus, sp.

Illaenus latus (?) $\mathrm{I}^{\prime} \mathrm{Coy}$.

Ogygia, sp.

Phacops alifrons, Salt.

P. Brongniarti, Portl.

P. caudatus, (?) Briinn.

Remopleurides Colbii, Portl.

R. laterispinifer, Portl.

R. sp. nov.

Trinucleus fimbriatus, Nurch.

T. sp.

Ceriopora oculata, Goldf.

Fenestella, sp.

Ptilodictya dichotoma, Portl.

P. sp.

Retepora, sp.
Leptaena scissa, Dur.

L. sericea, Sow.

L. sericea, var. rhombica, $\mathrm{H} \cdot \mathrm{Coy}$.

$\mathrm{L}$. tenuicincta, $\mathrm{M} \cdot \mathrm{Coy}$.

L. transversalis, Wahl.

Orthis biforata, Sehl.

O. calligramma, Dalm.

O. crispa, $M^{\circ} \mathrm{Coy}$.

O. elegantula, Dalm.

O. flabellulum, Sour.

O. (Strophomena) kilbuchoensis, Dar.

0. polygramma, var. pentlandica, Dav.

o. testudinaria, Dulm.

O. vespertilio, Sow.

O. $\mathrm{sp}$.

Rhynchonella borealis, schl.

R. Jacki, Dav.

R. Stricklandi, Sow.

R. $\mathrm{sp}$.

Strophomena arenacea, Salt.

S. corrugatella, Dav.

S. deltoidea, var. rotundata, Conr.

S. deltoidea, var. expansa, Sou.

S. grandis, Sor:

S. rhomboidalis Witck:

S. sp.

Ctenodonta levata, Hull.

Cucullella, sp.

Modiolopsis orbicularis, Sow.

Bellerophon acutus, Sox.

B. dilatatus, Sow.

B. trilobatus, Sow.

Chelodes (Helminthochiton), sp.

Cyclonema, sp.

Ecculiomphalus, sp.

Euomphalus sculptus, Sow.

Holopella, sp.

Loxonema, sp. 
Maclurea macromphala, $M^{\prime} \mathrm{Coy}$.

Macrochilina, sp.

Murchisonia angulata, Sow.

M. gyrogonia, $M^{\circ} \mathrm{Coy}$.

Pleurotomaria alata, Wahl.

Pl. (Raphistoma) elliptica, His.

Pl. (R.) lenticularis, Sow.

Rhaphistoma sp.

Turbo, sp.

Conularia elongata, Portl.
Conularia sp.

Hyolithes, sp.

Pterotheca corrugata, Salt.

Cyrtoceras scoticum, Blake.

Endoceras, sp.

Lituites, sp.

Orthoceras arcuoliratum, Hall.

O. Avelini, Salt.

o. pendens, Blake.

\section{GIRVAN DISTRICT.}

This district embraces an area in the extreme northwest part of the tableland, extending along the shore from Girvan to the mouth of Glen App, and inland to the village of Barr in the valley of the Stinchar.

The geological structure of the area south of the Stinchar closely resembles that already described in the Sanquhar and Leadhills districts; for there we find a sequence from the Arenig volcanic rocks and overlying Radiolarian cherts and graptolitic mudstones with Glenkiln graptolites upwards to the greywackes, shales and conglomerates of Llandeilo-Caradoc age. (Portandea and Currarie north of Glen App.)

North of the Stinchar valley, however, the sequence is wholly different. One of the striking features of this northern area is the remarkable development of Arenig volcanic rocks near Ballantrae, comprising diabase and diabase porphyrite lavas, agglomerates and tuffs. The age of this volcanic series is clearly defined by the occurrence in it of black shales and cherty mudstones yielding graptolites of Lower or Middle Arenig age. North of the Stinchar valley they are overlain by a great development of Radiolarian cherts (Arenig and Lower Llandeilo) and other sediments. The lavas, tuffs and overlying sediments are pierced by various intrusive igneous rocks, including serpentine, gabbro, dolerite, diorite, and granite. Of special importance also is the marked unconformability that separates the rocks just described from the overlying sedimentary series of Girvan. For the massive conglomerates (Kirkland and Benan) at the base of the latter series not only rest on the eroded surfaces of the volcanic and plutonic rocks, but are mainly composed of materials derived from the underlying platform.

The general succession and subdivisions of the Girvan series, as worked out by Professor Lapworth, are given in the following table, from which it will be seen that there is a marked divergence in the lithological characters of the strata from those in the Central Moffat region. In most of the subdivisions there is a great development of coarse sediments consisting of conglomerates, grits, greywackes, flagstones, mudstones, and shales, implying deposition near land and in comparatively shallow water. As might be expected from the foregoing conditions the Girvan series yields organic remains in profusion, on certain horizons. Of special importance are the bands of graptolite shales, yielding many of the zonal forms of the Moffat region, which enabled Professor Lapworth to correlate the Silurian divisions of the Girvan and Moffat areas. (See general Table, pp. 424, 425.)

The list of fossils from the Girvan area, exclusive of the graptolites, has been compiled from all obtainable sources, and is, in large measure, based on the general list and on Mrs. Gray's list of fossils published in the Geological Survey Memoir on "The Silurian Rocks of Scotland." Special thanks are due to Mrs. Gray for supplying a note of recent additions to her list, which now appear for the first time. Want of space has prevented the insertion of more than one or two localities for each fossil. When two localities are given, they represent the lowest and highest horizons for each form.

In this list each division of the Silurian system is represented by a capital letter, each sub-division by a figure. 


\section{TABLE OF SILURIAN STRATA, GIRVAN.}

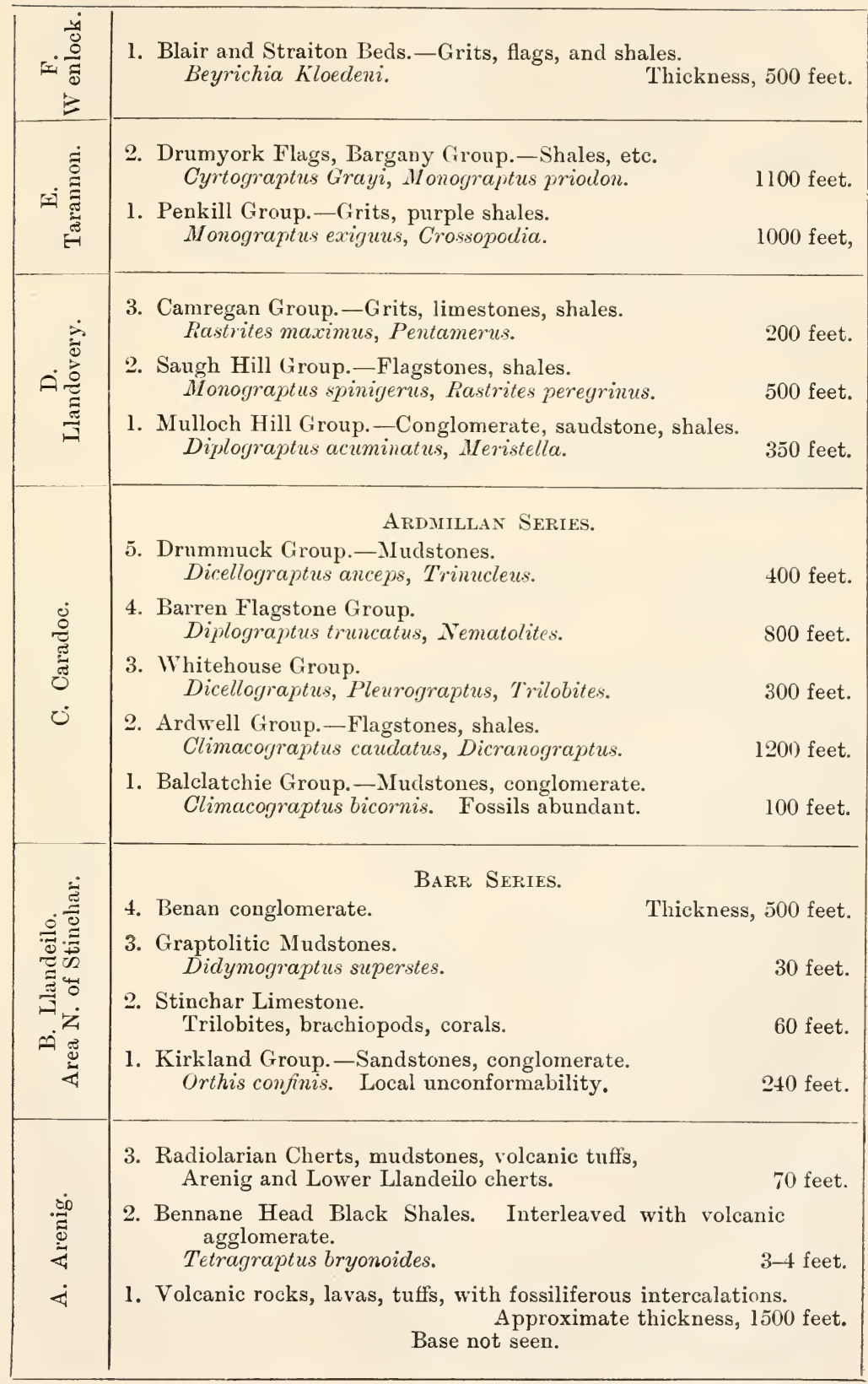


FOSSILS FROM THE SILURIAN ROCKS OF GIRVAN.

\section{Species. \\ Plantae (?).}

Chondrites verisimilis, Salt. Bargany Pond Burn.

Algae (?).

Girvanella problematica,

Nicholson te Etheridge.

Rhizopoda (?).

Nidulites favus, Salt.

Foraminifera.

Saccammina Carteri, Brady.

RADIOLARIA.

Radiolaria (abundant).

SpongidA.

Hyalostelia girvanense, $T$. \& $E$. Knockgerran.

Ischadites antiquus, Salt.

I. Koenigi, Murch.

Woodland Point ; Penkill.

Balclatchie.

Tramitchell.

B2.

Balclatchie; Mulloch Hill.

C1-D1

Craighead ; Tramitchell.

B2.

Bemnane Head ; Currarie.

A2.

C2

D 2-E1.

C1.

HydrozoA.

Clathrodictyon vesiculosum, $N$. and Ifurie.

Gorgonia regularis, Portl.

Woodland Point.

Woodland Point.

D2.

D2.

Coelenterata.

Aulacophyllum mitratum, His. Mulloch Hill.

Calostylis Lindströmi, $N$. and $E$.

Chaetetes, sp.

Favosites asper, d'Orb.

$F$. girvanensis, $N$. and $E$.

F. gothlandicus, Fougt.

F. mullochensis, $N$. and $E$.

Fistulipora favosa, $N$. and $E$.

F. pilula, $N$. and $E$.

Halysites catenulatus, $\operatorname{Linn}$.

Heliolites foliaceus, $N$. and $E$.

H. Grayi, Edw. and Haime.

H. interstinctus, $\operatorname{Linn}$.

$H$. parasiticus, $N$. and $E$.

H. tubulatus, Lonsd.

Labechia canadensis, $N$. \& Murie.

Lindströmia subduplicata, II'Coy.

Lyopora favosa, $\mathrm{M}^{\circ} \mathrm{Coy}$.

Monticulipora girvanensis, $\mathrm{Nich}$.

Palaeocyclus, sp.

Petraia bina, Lonsd.

P elongata, Phil.

Pinacopora Andersoni, $N$. and $E$.

P. Grayi, $N$. and $E$.

Plasmopora girvanensis, $N . \& E$.

Prasopora Grayae, $N$. and $E$.

Propora Edwardsi, $N$. and $E$.
Penkill.

Mulloch Hill.

Balclatchie; Rough Neuk.

Craighead.

Rough Neuk.

Mulloch Hill.

Balclatchie.

Craighear.

Craighead; Mulloch Hill.

Woodland Point.

Craighead.

Mulloch Hill ; Penkill.

Threave; Craigens.

Rough Neuk.

Aldons.

Craighead; Mulloch.

Craighead.

Craighead.

Rough Neuk.

Rough Neuk.

Rough Neuk.

Woodland Point.

Mulloch; Newlands.

Woodland Point.

Craighead.

Craighead.
D1.

D3.

D1.

C1-D1.

B2.

D1.

D1-D2.

C1.

B2.

B2-D1.

D2.

B2.

D1-E1.

C5-D1.

D1.

B2.

B2-D1.

B2.

B2.

D1.

D1.

D1.

D2.

D1-D2.

D2.

B2.

B2. 
Stenopora fibrosa, Goldf. Craighead.

B2.

Streptelasma aequisulcatum, II'Coy.

$\mathrm{S}$. aggregatum, $N$. and $E$.

Mulloch Hill.

D1.

S. Craigense, $\mathrm{M} / \mathrm{Coy}$.

Craighead.

B2.

S. europaeum, Röm.

Craighead.

B2.

Craighead. B2.

Stylarea occidentalis, $N . \& E$. Craighead. B2.

Tetradium Peachi, N. \& E. Craighead; Bougang. B2.

Thecostegites scoticus, $N$. and $E$. Craighead.

B2.

Asteroides.

Palaeaster, sp.

Dow Hill.

Tetraster Wyv-Thomsoni,E.\&.N. Threave, Starfish Bed.

C1.

C5.

Cystoidea.

Echinosphaerites granulatus,

$M^{\prime} \mathrm{Coy}$.

Pleurocystites sp.

\section{Crinoidea.}

Crinoid stems.

Myelodactylus sp.

Axvelida.

Cornulites sp.

Crossopodia scotica, $M^{\prime} \mathrm{C} O \mathrm{C}$.

Eione? sp.

Myrianites tenuis, $\mathrm{H}^{6} \mathrm{Coy}$.

Nemertites, sp.

Nereites cambrensis, Murch.

Olnencites sp. (jaws of).

Serpulites longissimus, Murch.

Tentaculites anglicus, Salt.

T. ornatus, Sow.

\section{Cirripedia.}

Turrilepas Peachi, $N$. and $E$.

T. scotica, $N$. and $E$.

T. Wrighti, Woodw.

\section{Ostracoda.}

Aparchites leperditioides, $J$.

A. subovatus, $J$.

Beyrichia comma, $J$.

B. impar, $J$.

B. impendens, Jones.

B. Kloedeni, $I^{\prime} \mathrm{Coy}$.

B. Kloedeni, var. infecta, $J$.

B. Kloedeni, var. scotica, $J$. and Holl.

Cythere aldensis, $M^{\circ} \mathrm{Coy}$.

C. aldensis, var. major, $J$.

C. Grayana, $J$.

C. Wrightiana, J. and Holl.

Cypridina Grayae, $J$.

Entomis globulosa, $J$.

Primitia Barrandiana, $J$.

P. elongata, var. nuda, $J$.
Trochrague Burn.

Threave.

B3.

C5.

Craighead ; Straiton.

Penkill.

B2-F1

D3.

Craighead.

Penwhapple Glen.

B2.

E1.

E1.

E1.

E1.

E1.

C1.

$\mathrm{B} 2-\mathrm{C} 5$.

(3-E1.

B2-D2.

C3.

Whitehouse Bay.

Balclatchie.

C1.

Whitehouse Bay.

C3.

Whitehouse Bay.

C3.

Threave.

Whitehouse Bay.

Straiton.

C5.

C3.

F1.

Threave; Straiton.

Whitehouse Bay.

C5-F1.

C3.

Bargany Pond Burn.

D3.

Aldons.

Aldons.

Aldons.

B2.

B2.

B2.

B2.

Aldons.

C3.

F1.

B2.

Straiton.

Aldons.

C3. 
Primitia girvanensis, $J$.

Whitehouse Bay.

C3.

P. Grayae, $J$.

Whitehouse Bay.

C:3.

P. Krausei, $J$.

Whitehouse Bay.

C3.

P. mundula, var. fimbriata, $J$. Whitehouse Bay.

C3.

P. mundula, var. Kloedeniana, $J$. Whitehouse Bay.

C3.

P. ulrichiana, $J$.

Whitehouse Bay.

C3.

Whitehouse Bay.

C.3.

Sulcuna praeurrens, Jones.

Ulrichia girvanensis, Jones.

U. Grayae, Jones.

Whitehouse Bay.

Whitehouse Bay.

C3.

C3.

\section{Phyllocarida.}

Caryocaris Wrighti, Salt.

Discinocaris gigas, Woodw.

Pinnocaris Lapworthi, Eth. Jnr.

Solenocaris solenoides, $Y$.

Balcreuchan Port.

Al.

Blackwood Head.

E1.

Balclatchie.

C1.

Threave.

C5.

\section{Trillobita.}

Acidaspis bispinosa, $M^{\circ} \mathrm{Coy}$.

A. Brighti, Murch.

A. Grayae, Eth. $J n r$.

A. hystrix, Wyv.-Thom.

A. Lalage, Wyv.-Thom.

Agnostus agnostiformis, $M \cdot C o y$.

A. perrugatus, Barr.

Ampyx Hornei, $E$. and $N$.

A. Maccallumi, Salt.

A. mammillatus, Sars.

A. nasutus, Dalm.

A. nudus, Murch.

A. rostratus, Sars.

Penkill.

D3.

Woodland Point. D2.

Balclatchie.

C1.

Balclatchie.

Balclatchie.

Cl.

C1.

Balclatchie; Threave.

Whitehouse Bay.

C1-C5.

C3.

Craighead ; Balclatchie.

Balclatchie.

Penwhapple Glen.

Penwhapple Glen.

Balclatchie.

Balclatchie; Threave.

Asaphus (Isotelus) gigas, Dekay. Minuntion ; Balclatchie.

A. marginatus, Portl.

A. rectifrons, Portl.

Threave.

Bougang; Balclatchie.

Barrandia sp.

Bohemilla sp.

Bronteopsis scotica, Salt.

Balclatchie.

Whitehouse Bay.

Balclatchie ; Ardmillan.

Bronteus Andersoni, $E$. and $N$.

B. hibernicus, Portl.

Calymene Blumenbachi, Brong.

C. tuberculosa, Salt.

Penkill.

Threave (?)

Craighead; Straiton.

Threave.

Cheirurus bimucronatus, Murch. Craighead; Penkill Burn.

C. clavifrons, Dalm.

C. gelasinosus, Portl.

C. Sedgwicki, $M^{\circ} \mathrm{Coy}$.

C. trispinosus, Young.

Cybele rugosa, Portl.

C. verrucosa, Dalm.

Cyclopyge armata, Barr.

C. rediviva, Barr.

Deiphon Forbesi, Barr.

Dindymene Cordai, $E$. and $N$.

Threave.

Craighead; Balclatchie.

Balclatchie.

Penkill.

B2-C1.

C1.

C.

C.

Cl.

C1-C5.

B2-C1.

C5.

$\mathrm{B} 2-\mathrm{C} 1$.

Cl.

C3.

Cl.

D3.

C5.

B2-F1.

C5.

B2-E1.

C5.

B2-C1.

C1.

D3.

Threave. C5,

Balclatchie; Dow Hill. C1.

Whitehouse Bay. C3.

Whitehouse Bay. C3.

Balclatchie. Cl.

Whitehouse; Drummuck. C3-C5.

Whitehouse; Threave. C3-C5.

Penkill ; Straiton.

Dionide Lapworthi, E. and $N$.

E. punctatus, var.arenaceus, Salt. Craighead ; Straiton.
E. punctatus, var. calcareus, Salt. Craighead ; Penkill.

D3-F1.

B2-F1.

B2-D3. 
Harpes sp.

Illaenus (Dysplanus) aemulus,

Salt.
I. (Bumastus) Barriensis, Murch.

Aldons; Bargany Pond Burn.

B2-D3.

I. (B.) Bowmani, Salt.

I. (B.) Maccallumi, Salt.

I. latus ? $M^{\circ} \mathrm{Coy}$.

I. Murchisoni, Salt.

I. nexilis, Salt.

I. Rosenbergi, Eichw.

I. Thomsoni, Salt.

I. $s p$.

Lichas ambiguus, Barr.

L. Barrandei, Flet.

L. Geikiei, $E$. and $N$.

L. Grayi, Flet.

L. hibernicus, Portl.

L. laxatus, $M^{\circ} \mathrm{Coy}$.

L. palmatus, Barr.

L. sp.

Phacops (Acaste) Brongniarti, Portl.

P. (A.) Downingiae, Murch.

P. (A.) Stokesi, M. Edw.

Phillipsia parabola, Barr.

Proetus girvanensis, E. and $N$.

P. latifrons, $M^{\prime} \mathrm{Coy}$.

P. procerus, $E$. and $N$.

P. Stokesi, Murch.

Remopleurides Barrandei, E.\& $N$.

R. Colbii, Portl.

R. dorsospinifer, Portl.

R. laterispinifer, Portl.

Salteria primaeva, Wyv.-Thom.

Sphaerexochus mirus, Beyr.

Penkill.

D3.

D2.

B2-C1.

Craighead; Balclatchie.

Drummuck.

Minuntion.

C5.

Penkill.

B2.

Drummuck ; Penkill.

Craighead; Penkill.

Mulloch; Woodland.

Shalloch Mill ; Camregan.

Mulloch Hill ; Newlands.

Mulloch Hill.

Threave.

Balclatchie.

Craighead; Balclatchie.

Threave.

Mulloch Hill.

Dow Hill ; Camregan.

D3.

C5-1D3.

B2-D3.

D1-D2.

C3-D3.

D1-D2.

D1.

C5.

C1.

B2-C1.

C5.

D1.

C1-D3.

Bougang; Threave.

Mulloch Hill; Straiton.

B2-C5.

Mulloch Hill; Straiton.

D1-F1.

D1-F1.

Threave Glen.

C5.

Balclatchie; Threave.

Threave.

C1-C5.

C5.

Threave.

Straiton.

C5.

F1.

C1.

Minuntion; Threave.

Ardmillan.

B2-C5.

C1.

Minuntion; Balclatchie. B2-C1.

Balclatchie.

Craighead; Balclatchie.

C1.

B2-C1.

C1-D2.

C1-C5.

S. unicus, Wyv.-Thom.

Stygina latifrons, Portl.

Balclatchie; Mulloch.

Ardmillan.

C1.

Drummuck.

C5.

Dow Hill.

Balclatchie.

C1.

Balclatchie.

C1.

Drummuck.

C1.

C5.

PolyzoA.

Fenestella assimilis, Lonsd.

F. Milleri, Lonsd.

F. patula, $M^{\prime} \mathrm{Coy}$.

F. subantiqua, d'Orb.

Glauconome disticha, Goldf.

Hippothoa inflata, Nich.

Ptilodictya costellata, $M^{\prime} \mathrm{Coy}$.

P. dichotoma, Portl.

P. lanceolata, Goldf.

Retepora sp.

Rhinopora verrucosa, Hall.
Woodland Point.

Woodland Point.

Woodland Point; Penkill.

Woodland Point; Penkill.

Woodland Point.

Woodland Point.

Mulloch Hill.

Balclatchie ; Penkill.

Woorlland ; Straiton.

Balclatchie; Rough Neuk.

Woodland Point.
D2.

D2.

D2-D3.

D2-D3.

D2.

D2.

D1.

C1-E1.

D2-F1.

C1-D1.

D2. 
BRACHIOPODA.

Acrothele granulata, Linnr. Acrotreta costata (?) Dav. A. Nicholsoni, Dav. Athyris sp.

Atrypa (Leptocoelia) hemispherica, Sow.

A. imbricata, Sow.

A. marginalis, Dalm.

A. reticularis, Linn.

A. scotica, $M^{\prime} \mathrm{Coy}$.

Crania llandoveriana, Dav.

C. siluriana, Dav.

Cyrtia exporrecta, Wahl.

Discina crassa, Hall.

D. oblongata, Portl.

D. perrugata, $M^{\prime} \mathrm{Coy}$.

D. rugata, Sow.

Glassia (Athyris) obovata, Sow.

Kutorgina sp.

Leptaena (Plectambonites) cornuta, Dav.

L. Etheridgei, Dav.

L. Grayi, Dav.

L. llandeiloensis, Dav.

L. (Plectambonites quinque costata, M'Coy.)

I. scissa, Salt.

L. segmentum, Angelin.

I. sericea, Sow.

I. sericea, var. rhombica, $M^{\prime} \mathrm{Coy}$.

L. (Christiania) tenuicincta, I'Coy.

L. (Plectambonites) transversalis, Wahl.

L. Youngiana, Dav.

Lingula attenuata, Sorv.

L. brevis, Portl.

I. canadensis, Bill.

I. granulata, Phil.

L. ovata, MrCoy.

L. quadrata, Eichw.

I. Ramsayi, Salt.

L. Symondsi, Salt.

Lingulella Davisi, M'Coy.

L. lepis, Salt.

Linnarssonia (Obolella) sagittalis (Salt.).

Merista cymbula, Dav.

Meristella angustifrons, $M^{6} \mathrm{Coy}$. M. (Whitfieldia) tumida, Dalm. Nucleospira pisum, sow.

Obolella sp.

Orbiculoidea Forbesi, Dav.

Orthis Actoniae, Sow.

o. alternata, Sow.
Dow Hill.

Balclatchie.

Craighead ; Balclatchie.

Whitehouse Bay.

Mulloch ; Camregan.

Threave; Penkill.

Penwhapple.

Mulloch; Straiton.

Mulloch Hill.

Newlands.

Mulloch ; Woodland Point.

Penkill.

Penwhapple; Straiton.

Balclatchie.

Craighead ; Threave.

Bargany Pond Burn.

Penkill.

Bennane Head.

C1.

C1.

$\mathrm{B} 2-\mathrm{C} 1$.

C3.

D1-D3.

C5-D3.

D.

D1-F1.

D1.

D2.

D1-D2.

D3.

E1-F1.

C1.

B2-C5.

D3.

D3.

A2.

Ardmillan.

Craighead.

Craighead.

Craighead; Ardmillan.

C1.

B2.

B2.

B2-C1.

Ardmillan : Woodland Point. C'1-D2.

Ardmillan; Woodland Point. C1-D2.

Shalloch Mill ; Cuddystone Glen. C3-D3.

Craighead; Penkill.

Craighead; Balclatchie.

B2-D3.

B2-C1.

Balclatchie; Shalloch Mill.

C1-C3.

Craighead ; Penkill.

Craighead; Balclatchie.

Balclatchie ; Drummuck.

Ardmillan ; Whitehouse.

Balclatchie.

Minuntion ; Ardmillan.

Craighead; Rough Neuk.

Craighead; Threave.

Craighead; Benan Burn.

Woodland; Straiton.

Auchensoul.

Portandea.

B2-D3.

B2-C1.

C1-C5.

C1-C3.

C1.

B2-C1.

B2-D1.

B2-C5.

B2-B3.

D2-F1.

B2.

B.

Balcreuchan Port.

A1.

Drummuck ; Threave.

C5.

D1.

D3.

Bargany Pond Burn.

B2-D3.

A2.

Bennane Head.

Mulloch ; Woodland Point.

Shalloch Mill; Threave.

C3-C5.

Benan Burn.

B1. 
Orthis (Platystrophia) biforata, Schl.

o. (Bilobites) biloba, Linn.

o. Bouchardi, Dav.

O. balcletchiensis, Dav.

0. calligramma, Dalm.

Craighead; Straiton.

$\mathrm{B} 2-\mathrm{F} 1$.

Shalloch Mill; Bargany Pond Burn. C3-D3.

Straiton.

F1.

Craighead; Balclatchie.

Craighead; Penwhapple.

B2-C1.

O. calligramma, var. plicata, Sow. Balclatchie; Woodlaud Point.

B2-E1.

o. calligramma, var. scotica, Dav. Craighead.

0. calligramma,var. virgata, Salt. Dularg; Balclatchie.

o. Carausii, Salt.

Ardmillan.

0 . confinis, salt.

Benan Burn; Minuntion.

0 . crispa, $\mathrm{M}^{\prime} \mathrm{Coy}$.

Ardmillau; Threave.

0. (Dalmanella) elegantula,Dalm. Craighead; Straiton.

0. (Dinorthis) flabellulum, Sow. Craighead; Straiton.

0 . girvanensis, Dav.

o. intercostata, Portl.

O. kilbuchoensis, Dav.

O. Lapworthi, Duv.

O. mullochiensis, Jai.

0. nina, Dai.

0. polygramma, Sow.

O. polygramma, var. pentlandica, Dan.

0. porcata, $M^{\circ} \mathrm{Coy}$.

o. protensa, Sow.

o. Rankini, Dar:

O. reversa, Salt.

0. rustica, Sow.

o. rustica, var. rigida, Dav.

0 . saggittifera, $M^{\circ} \mathrm{Coy}$.

O. Sowerbyana, Dav.

Craighead.

Aldons ; Trochrague.

A rdmillau.

Balclatchie; Shalloch Mill.

Threave; Mulloch.

Whitehouse Bay.

Camregan.

C1-D2.

B2.

B2.C1.

C1.

B1-B2.

C1-C5.

B2-F1.

$\mathrm{B} 2-\mathrm{F} 1$.

B2.

B2-B3.

C1.

C1-C3.

C5-D1.

C3.

D3-E1.

Balclatchie ; Penkill.

C1-D3.

Threave.

C5.

Benan Crag.

Ardmillan; Threave.

B2.

Penkill.

Mulloch ; Straiton.

Woodland ; Penkill.

Mulloch Hill.

Craighead; Threave.

C1-C5.

E1.

D1-F1.

D2-D3.

Dl.

B2-C5.

0. (Dalmanella) testudinaria, Dalm.

o. tricenaria, Cons.

0 . turgida, $\mathrm{J} / \mathrm{C}^{\prime} \mathrm{Coy}$.

0 . vespertilio, Sow.

Orthisina (Clitambonites)

Grayae, Dav.

Craighead; Shalloch Mill.

Piedmont Glen.

B2-C3.

Craighead ; Penkill.

Craighead; Shalloch Mill.

C2.

B2-E1.

B2-C3.

Shalloch Mill ; Threave.

C2-C5.

Bougang.

B2.

Paterula balcletchiensis, Dav.

Balclatchie; Threave.

Penkill.

C1-C5.

D3.

Penkill.

D3.

Newlands; Blackwood.

Penwhapple.

Penkill.

Shalloch Mill.

Nulloch; Penkill.

shalloch Mill ; Penkill.

Pholidops implicata, Sow.

Porambonites intercedens, Pand. Shalloch Mill.

Retzia Barrandei, Dav.

Rhynchonella aemula, Salt.

R. ardmillanensis, Dav.

R. balcletchiensis, Dav.

R. cuneata, Dalm.

R. cuneatella, Dav.

R: decemplicata, Sow.

Straiton.

Craighead.

Ardmillan.

D2-E1.

D3.

D3-E1.

C3.

D1-D3.

C3-D3.

C3.

F1.

B2.

C1.

Craighead; Balclatchie.

B2-C1.

Auldthorns; Camregan. C5-D3.

Balclatchie.

C1.

Mulloch Hill. D1.

R. girvanensis, Dav.

Balclatchie.

Cl. 
Rhynchonella Lapworthi, Dav. Craighead.

R. llandoveriana, Dav.

Camregan Wood.

B2.

R. micula, Sow.

Shalloch Mill.

D3.

R. nasuta, $M{ }^{\prime} \mathrm{Coy}$.

Craighead; Balclatchie.

Balclatchie : Shalloch Mill.

C3.

R. nucula, Sow.

R. Peachi, Dav.

R. (Hyattella)

Portlockiana, lov.

Craighead; Threave.

B2-C1.

C2-C3.

B2-C5.

R. Salteri, Dav.

Craighead; Balclatchie.

B2-C1.

Craighead ; Ardmillan.

Craighead.

R. scotica, Dav.

R. shallochiensis, Dav.

R. sub-borealis, Dav.

R. Thomsoni, Dav.

R. Thomsoni, var.?

R. Weaveri, Salt.

R. Wilsoni, Sow.

Shalloch Mill.

Craighead.

Craighead.

B2-C1.

B2.

C3.

B2.

B2.

Craighead.

Camregan Wood.

B2.

Siphonotreta anglica, Morris.

Barr ; Straiton.

S. micula, $\mathrm{H}^{6} \mathrm{Coy}$.

S. scotica, Dav.

Balclatchie.

Craighead ; Threave.

Skenidium Grayi, Dav.

S. Lewisi, Dav.

S. shallochiensis, Dav.

S. woodlandiensis, Dav.

Spirifera crispa, $H i$ is.

S. plicatella, Linn.

S. plicatella, var. radiata, Sow.

S. sulcata, His.

Threave.

Craighead ; Threave.

Shalloch Mill.

Woodland Point.

Bargany Pond Burn.

D3.

B2. F1.

C1.

B2-C5.

C5.

B2-C5.

C3.

D2.

D3.

Bargany Pond Burn. D3.

Bargany Pond Burn; Penkill. D3-E1.

Straiton.

Stricklandinia balcletchiensis, Balclatchie.

F1.

C1.

Mulloch ; Penwhapple.

D1-E1.

S. lirata, Sow.

Woodland Point.

D2.

Strophomena antiquata, Sow.

Mulloch ; Penkill.

D1-E1.

Newlands ; Penkill.

D2-E1.

Woodland Point; Camregan. D2-D3.

S. arenacea, Salt.

S. compressa, Sow.

S. corrugatella, Dav.

S. (Rafinesquina) deltoidea, Conr.

S. (R.) expansa, Sow.

S. Grayae, Dav.

S. grandis, Sow.

S. imbrex, Pand.

Ardmillan ; Camregan.

C1-D3.

Craighead; Woodland Point. B2- D2.

S. imbrex, var. semiglobosa, Dav.

S. insculpta, Hall.

S. llandeiloensis, Dav.

S. pecten, Linn.

S. retroflexa, Salt.

S. rhomboidalis, Wilck.

S. shallochiensis, Dav.

S. simulans, $11^{\circ} \mathrm{Coy}$.

S. undata, $M r^{\circ} \mathrm{Coy}$.

S. Walmstedti, Linds.

S. Waltoni, Dav.

Triplesia Grayae, Dav.

T. incerta, Dav.

T. Maccoyana, Dav.

T. monilifera, $M^{\prime} \mathrm{Coy}$.

T. spiriferoides, $\mathrm{M}^{\mathrm{C}} \mathrm{Co} y$.

Craighead; Woodland Point.

B2- D2.

Craighead ; Mulloch.

Craighead.

B2-D1.

B2.

C5.

C1.

Balclatchie.

B2-C1.

Cl.

Ardmillan.

B2-C1.

Craighead; Ardmillan.

$\begin{array}{ll}\text { Newlands; Woodland Point. } & \text { D2. } \\ \text { Craighead; Dow Hill.] } & \text { B2-C1. }\end{array}$

Craighead; Penkill.

B2-E1.

Shalloch Mill; Threave. C3-C5.

Shalloch Mill; Rough Neuk. C3-D1.

Dow Hill ; Bargany Pond Burn. C1-D3.

Cuddystone Glen.

D3.

Cuddystone Glen. D3.

Craighead. B2.

Penkill. D3.

Craighead. B2.

Woodland Point. D2.

Ardmillan ; Threave. C1-C5. 
LAMELLIBRANCHIATA.

Ambonychia amygdalina, Hall. Craighead; Woodland.

A. bellistriata, Hall.

Penkill.

B2- D2.

A. orbicularis, Conr.

Mulloch ; Woodland.

D3.

A. radiata, $E \mathrm{~mm}$.

Craighead; Shalloch Mill.

D1-D2.

Arca Edmondiaeformis, $M^{6} \mathrm{Coy}$.

Avicula Danbyi, M'Coy.

A. elliptica, Hall.

Cardiola fibrosa, Sow.

C. striata, Sow.

Cleidophorus sp.

Ctenodonta anglica, d'orb.

C. astartaeformis, Salt.

C. Eastnori, Wurch.

C. levata, Hall.

C. (Nucula) subacuta, $\mathrm{M}^{\circ} \mathrm{Coy}$.

C. varicosa, Salt.

Cucullella sp.

Ardmillan.

B2.C3.

Glenwells.

Woodland Point.

Penwhapple ; Straiton.

Penkill.

C1.

D1.

D2.

E1-F1.

Kirkdominae.

D3.

Balclatchie.

Ardmillan; Dow Hill.

Threave.

Balclatchie.

Balclatchie.

Ardmillan.

Straiton.

B3.

C1.

C1.

C5.

C1.

C1.

C1.

E1.

Goniophora cymbaeformis, Sow. Woodland Point; Penkill.

D2-D3.

Grammysia sp.

Straiton.

F1.

Lunulicardium elegans, Salt.

Modiolopsis modiolaris, Conr.

Penwhapple.

Ardnillan.

E1.

Shalloch Mill.

C1.

Mytilus gradatus, Salt.

M. mytilimeris, Conr.

M. semirugatus, Portl.

Orthonota contracta, Hall.

O. prora, Salt.

O. rigida, Sow.

O. semisulcata, Sow.

O. simplex, Portl.

O. truncata, Sow.

O. undata, Sow.

Palaearca modiolaris, Salt.

P. quadrata, Salt.

Pleurorhynchus (Conocardium) dipterus, Salt.

P. pristis, Salt.

Pterinea hyans, $M^{\circ} \mathrm{Coy}$.

P. pleuroptera, Conr.

P. Sowerbyana, $M^{\circ} \mathrm{Coy}$.

P. tenuistriata, $M^{\prime} \mathrm{Coy}$.

Woodland Point ; Penkill.

C.3.

Penkill.

D2-D3.

Craighead.

D3.

B2.

Threave, C5.

Camregan. D3.

Mulloch Hill. D1.

Mulloch Hill. DI.

Straiton. F1.

Mulloch; Newlands. D1-D2.

Mulloch Hill.

Mulloch Hill.

D1.

D1.

Craighead : Balclatclie.

B2-C1.

Mulloch Hill.

D1.

Rough Neuk. D1.

Straiton. F1.

Threave.

Camregan.

D3.

Gasteropoda.

Bellerophon acutus, Sow.

B. argo, Bill.

B. bilobatus, Sov.

B. carinatus, Sow.

B. dilatatus, Sow.

B. elongatus, Portl.

B. expansus, Sow.

B. fastigiatus, Linds.

B. perturbatus, Sow.

B. punctifrons, $E \mathrm{~mm}$.

B. sphaera, Linds.

B. squamosus, Linds.

B. subdecussatus, $M^{\circ} \mathrm{Coy}$.

Craighead; Ardmillan.

B2-C1.

Shalloch ; Threave.

C3-C5.

Ardmillan; Threave.

C1-C5.

Shalloch ; Threave.

C3-C5.

Mulloch; Woodland.

D1-D2.

Threave.

Ardmillan ; Penkill.

Bougang.

Drummuck.

C5.

C1-D3.

B2.

Craighead.

C5.

Woodland Point.

B2.

Threave; Mulloch Hill.

D2.

Drummuck; Mulloch.

C5-D1.

C5-D1. 
Bellerophon trilobatus, Sou.

B. Urei (?), Flem.

B. wenlockensis, Sou.

Bucania profunda, Hall.

Chelodes (Helminthochiton) Grayae, Woodw.

Cyclonema carinatum, sow.

C. crebristria, $M^{\circ} \mathrm{Coy}$.

Cyrtolites euryomphalus, Linds. N

C. orbiculus, Linds.

Ecculiomphalus Bucklandi, Portl.

E. laevis, Sow.

E. minor, Portl.

E. scoticus, $M^{\circ} \mathrm{Coy}$.

Euomphalus funatus, Sow.

E. granulatus, Portl.

Fusispira elongata, Hall.

Holopea lymnaeoides, Forbes.

H. paludiniformis, Hall.

Holopella obsoleta, Sow.

$\mathrm{H}$. tenuicincta, $\mathrm{M}^{\prime} \mathrm{Coy}$.

Loxonema elegans, $\mathrm{I}^{\circ} \mathrm{Co} \%$.

L. sinuosum, Sov.

Maclurea Logani, Salt.

M. Maccoyi, Salt.

M. (Ophileta) macromphala,

$$
M^{\prime} \cdot \mathrm{Coy} \text {. }
$$

M. magna, Lesu.

M. matutina, Hall.

Macrochilina elongata, Portl.

Metoptoma sp.

Murchisonia angulata, Phit.

M. cancellatula, $\mathrm{M}^{\circ} \mathrm{Coy}$.

M. elongata, P'ortl.

M. (Ectomaria?) exigua, Donald.

M. (E.) girvanensis, Donald.

M. gracilis, Hall.

M. (Hormotoma) Grayana, Don.

M. gyrogonia, $1 /{ }^{\prime} \mathrm{C}$ oy.

M. obscura, Portl.

M. pulchra, $M^{\circ} \mathrm{Coy}$.

M. simplex, $\mathrm{M}^{\circ} \mathrm{Coy}$.

M. (Pleurotomaria) turrita, Portl.

M. vitellia, Bill.

Ophileta compacta, Salt.

o. nerine, Bill.

0 . $\mathrm{sp}$.

Oriostoma angulatum, Linds.

0. discors, Sow.

Platyceras cornutum, His.

P. (Acroculia) haliotis, Sow.

Platyschisma (Trochus) helicites, Sow.

Pleurotomaria alata, Wahl.

P. aequilatera, Wahl.
Ardmillan; Threave.

Drummuck.

Mulloch Hill.

Craighead.

C5.

D1.

B2.

Threave Glen. $\quad$ C5.

Shalloch Mill. C:3.

Ardmillan. $\mathrm{Cl}$

D2.

(1.

Craighead; Shalloch Mill.

B2-C3.

Craighead; Shalloch Mill.

Ardmillan.

Ardmillan.

Shalloch Mill.

Mulloch.

Woodland Point.

Threave.

Craighead.

Threave; Mulloch.

Mulloch Hill.

Threave.

Drummuck.

Craighead; Bougang.

Minuntion.

B.2-C3.

C1.

C1.

(¿3.

D1.

12.

(5.)

B2.

C5-D1.

D1.

C5.

C.).

B2.

B2.

Craighead; Minnntion. B2.

Aldons; Minuntion. B2.

Balclatchie.

Mulloch Hill.

C1.

D1.

B2.

B2.

D1.

D1.

B2.

B2.

B2.

D2.

B2-C1.

C5.

C5.

C1.

(5.)

B2.

C1-( 5.

C3.

B.2.

1)1.

C3.

D2-D3.

C5.

C5.

C5-D2.

C5. 
Pleurotomaria claustrata, Linds. Mulloch Hill.

D1.

P. (Raphistoma) lenticularis. Minuntion.

$\mathrm{B} 2$.

P. Milleri Rogers $=$ P. bicincta, Hall.

Minuntion.

B2.

P. Moorei, Salt.

Mulloch Hill.

D1.

P.(Euomphalus)qualteriata, Schl. Minuntion; Newlands.

B2.D2.

P. scutulata, Linds.

Woodland Point.

D2.

P. trochiformis, Portl.

Ardmillan.

Raphistoma aequalis, Salt.

R. planistria, var. parva, Hall.

Tremanotus sp.

Trochus Moorei, M'Coy.

Trochonema sp.

Balclatchie.

C1.

Threave.

Threave.

Mulloch Hill.

Mulloch Hill.

C1.

C5.

C5.

D1.

D1.

\section{Pteropoda (?).}

Conularia aspersa, Linds.

C. bilineata, Linds.

C. elongata, Portl.

C. Sowerbyi, Def.

C. subtilis, Salt.

Hyolithes acutus, Eichw.

H. corrugatus, Salt.

H. elegans, Barr.

H. (Theca) operculatus, Salt.

H. reversus, Salt.

H. triangularis, Portl.

H. vaginulus, Salt.

Pterotheca corrugata, Salt.

P. transversa, Salt.

Woodland Point.

D2.

Threave; Mulloch.

Craighead; Dow Hill.

C5-D1.

Craighead.

B2-C1.

$\mathrm{B2}$.

Woodland Point. D2.

Balclatchie. C1.

Drummuck. C5.

Threave. C5.

Balclatchie. C1.

Balclatchie ; Threave. C1-C5.

Ardmillan; Threave. C1-C5.

Ardmillan; Threave. C1-C5.

Balclatchie. C1.

Ardmillan. $\mathrm{Cl}$.

Cephalopoda.

Cyrtoceras annulatum, Hall.

C. arcuatum, Hall.

C. compressum, Sow.

C. inaequiseptum, Portl.

C. multicameratum, Hall.

C. scoticum, Blake.

C. victor, Barr (?).

Mulloch Hill.

D1.

Woodland Point. D2.

Penkill. D3.

Minuntion. B2.

Bougang. B2.

Craighead. B2.

Threave. C5.

Endoceras strangulatum, Hall. Balclatchie; Threave. C1-C5.

E. trochleare, His.

Gomphoceras cinctum, Blake.

G. crater, Blake.

Ardwell.

Camregall.

C2.

Woorlland Point. D2.

Orthoceras angulatum, Wahl.

O. annulatum, Sow.

Threave; Penkill.

C5-E1.

Penwhapple Glen. E1.

Shalloch Mill. C3.

. arcuoliratum, Hall

O. argus, Barr.

O. Avelini, Salt.

O. bilineatum, Hall.

Drummuck.

C5.

Ardnillan.

C1.

Craighead; Shalloch Mill.

B2-C3.

O. bullatum, Sow.

O. calamiteum.

O. carinatum, Münst.

O. distans, Sow.

O. fimbriatum, Sox:.

O. fusiforme, Hall.

O. gracile, Portl.

O. Grayi, Blake.

O. Grindrodi, Blake.

Whitehouse Bay; Woodland Point. C3-D2.

Knockgerran.

Ardwell.

$\mathrm{C} 2$.

Woodland Point.

C2.

Bargany Pond Burn.

D3.

Penkill; Penwhapple.

D3-E1.

Shalloch Mill.

C.3.

Bargany Pond Burn.

D3.

Penkill.

D3-E1. 
Orthoceras ibex, Sow.

0. imbricatum, Wahl.

0. ludense, Sow.

0. MacLareni, Salt.

0. mocktreense, Sow.

o. multicinctum, Hall.

O. pendens, Blake.

O. politum, $\mathrm{M}^{\mathrm{C}} \mathrm{Coy}$.

o. primaevum, Forbes.

0. subundulatum, Portl.

o. tenuicinctum, Portl.

0. tracheale, Sow.

O. vagans, Salt.

O. vaginatum, $S$ chl.

Phragmoceras arcuatum, Sow.

Poterioceras sp.

Trochoceras aspersum, Barr. (?). Woodland Point.

T. (Lituites) cornuarietes, Sow. Mulloch Hill.

Trocholites planorbiformis, Conr. Craighead.
Ardmillan. Cl.

Threave; Penkill.

C5-D3.

C3-C5.

F1.

$\begin{array}{ll}\text { Woodland Point. } & \text { D2. } \\ \text { Penkill. } & \text { D3. }\end{array}$

Trochrague. B3.

Pinmore; Penwhapple. B2-C2.

Penkill.

D3.

C1-F1.

D1-D2.

D2.

C3-C5.

C2.

D1.

D1-D3.

D2.

D1.

B2.

\section{LESMAHAGOW DISTRICT.}

To the north of the margin of the Silurian tableland and within the area occupied by the Old Red Sandstone, there are several inliers of Upper Silurian strata, ranging from Wenlock to Downtonian time, which have been exposed at the surface by the folding and denudation of the younger Palaeozoic rocks. These may be grouped as follows :

1. The inlier near Lesmahagow ( $\mathrm{L}$ in fossil list).

2. The inlier of the Hagshaw Hills ( $\mathrm{H}$ in fossil list).

3. The inlier at Carmichael (C in fossil list).

4. The inlier south of Tinto.

Of the foregoing areas, by far the most important is that near Lesmahagow, where the strata are arranged in a gentle anticline, only the northern limb of which is preserved. The strata are admirably exposed in the Logan Water, Birkenhead Burn, and adjoining streams.

The passage-beds, comprising conglomerates and sandstones, with green and red mudstones, overlying comformably the Ludlow rocks, and formerly regarded as the base of the Old Red Sandstone, are now grouped with the Silurian strata. They have yielded a fauna consisting of ostracods, phyllocarid crustaceans, eurypterids, and fishes ; some of the fishes being identical with those in the underlying Ludlow rocks. The various subdivisions adopted by the Geological Survey are given in the following table ${ }^{1}$ :

I Memoir of the Geological Suvvey, "The Silurian Rocks of Scotland," p. 568. 


\section{SUB-DIVISION OF THE UPPER SILURIAN ROCKS.}

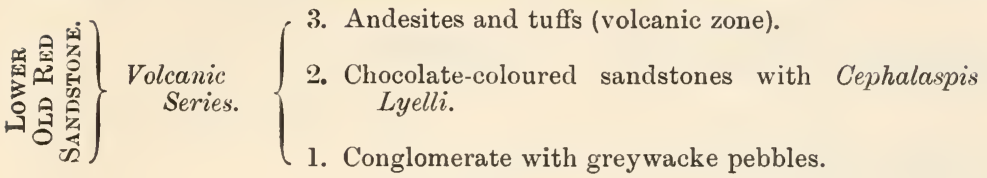

Unconformability in the Pentland Hills and in Ayrshire; apparent conformability in Lanarkshire.

\footnotetext{
$\left(\begin{array}{c}\text { 11. Chocolate-coloured sandstones-1200 feet in Lesma- } \\ \text { hagow inlier. } \\ \text { 10. Conglomerate with large pebbles of quartzite-100 }\end{array}\right.$ feet in Lesmahagow inlier.

9. Green and red mudstones, with bands of grey shale and greywacke, containing seams with fishes and crustaceans-100 feet in Lesmahagow inlier.

Downtonian.

8. Red and yellow false-bedder sandstones and red mudstones-1300 feet in Lesmahagow inlier.

7. Conglomerate of local occurrence, with small pebbles of Arenig volcanic rocks, radiolarian cherts, etc., resting conformably on Ludlow shales-S8 to 150 feet in the Hagshaw Hills anticline.

6. Green flaggy and sandy greywackes, with partings of grey and red mudstone-about 130 feet.

5. Blue, grey, and green shales with sandy mudstones and greywackes, occasionally weathering with a rusty colour-200 feet (Trochus beds).

4. Hard blue and grey flaggy shales and mudstones with occasional bands of calcareous nodules-350 feet (Pterygotu.s beds).

3. Hard grey flagstones and bands of hard greywacke, with bands and zones of dark fissile calcareous flaggy shales, weathering rusty brown -500 feet (Ceratiocaris beds and Ludlow fish-band).

2. Grey, blue, and olive shales, with occasional greywacke bands-300 feet. Wenlock. . $\left\{\begin{array}{c}\text { 1. Hard bands of greywacke in the shale partings-1300 } \\ \text { feet. }\end{array}\right.$
}

Two lists of fossils are appended, one from the Wenlock and Ludlow rocks and the second from the Downtonian strata. 
Fossils from the Wenlock-Ludlow Inliers of Lesmahagow, the Hagshaw Hills, and Carmichael Burn, Lanarkshire and Ayrshire HYDROZOA.

Monograptus vomerinus, Nich. M. sp.

Hagshaws.

Carmichael Burn.

Actinozon.

Alveolites repens, Fougt.

Favosites asper, d' $0, b$.

Lindströmia sp.

Hagshaws.

Hagshaws.

Crinoid stems.

Crinoldea.

Annelida.

Cornulites sp.

Spirorbis Lewisi, , tow.

S. sp.

Hagshaws.

Hagshaws.

Waterhead, L.

Logan Water, L.

Ostracoda.

Beyrichia (Entomis) impendens, J. Hagshaws.

B. Kloedeni, M'Coy.

B. Kloedeni, var. torosa, J.

B. (Entomis) tuberosa, $J$.

Entomis sp.

Logan Water, L., H., C.

Logan Water, L.

Hagshaws.

Hagshaws.

Phyllocarida.

Calyptocaris striata, Eth. Jnr.

Carınichael Burn.

Ceratiocaris angusta, .J. and Woodw. Logan Water, L.

C. laxa, J. and Woodw.

C. longa, Woodw. and Jones.

Shank's Castle, L.

C. Murchisoni, $\mathbb{I}^{6} \mathrm{Coy}$.

Shank's Castle, L.

C. papilio, Salt.

C. patula, Jones and Woodw.

Shank's Castle, L.

Logan Water, L., H.

Logan Water, L.

C. robusta, Salt.

C. stygia, Salt.

C. tyrannus, Salt.

C. sp.

Linn Burn, L.

Logan Water, L.

Logan Water, L.

Shank's Castle, L.

Trilobita.

Calymene Blumenbachi, Brong.

Encrinurus sp.

Illaenus sp.

Phacops sp.

Proetus Stokesi, Murch.

Hagshaws.

Hagshaws.

Hagshaws.

Hagshaws.

Hagshaws.

Xiphosura.

Neolimulus falcatus, Woodw. Dunside, L

Eurypterida.

Eurypterus lanceolatus, Salt.

E. obesus, Woodw.

E. scorpioides, Woodu.

Pterygotus bilobus, Salt.

Dunside, L.

Dunside, L.

Dunside, L.

Dunside, L.

P. bilobus, var. accidens, Woodw. Dunside, L.

P. bilobus, var. inornatus, Woodw. Dunside, L.

P. bilobus, var. perornatus, Salt. Dunside, L.

P. bilobus, var. raniceps, Woodw. Dunside, L. 
Slimonia acuminata, Salt. Stylonurus Logani, Woodx:

ARACH NIDA.

Palaeophonus caledonicus, Hunter: Logan House, L.

Mrriapoda.

Archidesmus loganensis, Peach. A. $\mathrm{sp}$.

Ceriopora sp.

Polyzod.

BRACHIOPODA.

Athyris (Glassia) compressa, Sou. Lingula cornea.

L. Lewisi.

L. minima, Sox.

Orthis Bouchardi, Iai.

O. (Dalmanella) elegantula, Dalm.

O. polygramma, Sou.

O. $\mathrm{sp}$.

Rhynchonella sp.

Strophomena (Leptaena) rhomboidalis, Wilck.

\section{LAMELLiBRANCHIATA.}

Anadontopsis bulla, $W^{\prime} C^{\prime} \circ y$.

A. lucina, salt.

Ctenodonta obesa, Sult.

C. sp.

Goniophora cymbaeformis, Sou.

Modiolopsis complanata, Sow.

M. Nilssoni, His.

Mytilus mytilimeris, Com:

Orthonota amygdalina, Sow.

O. impressa, Sou.

0. rotundata, Sor.

O. solenoides, Sorr.

O. sp.

Pterinea pleūroptera, Conr.

P. retroflexa, Wahl.

P. retroflexa, var. naviformis, Conr.

(iAsteropoda.

Holopella obsoleta, Sow.

Murchisonia sp.

Platyschisma (Trochus) helicites, Sorv.

Pteropoda (?).

Theca (Hyolithes) Forbesi, sharpe. Logan Water, L. T. sp.

\section{Cephalopoda.}

Orthoceras angulatum, Wahl.

O. dimidiatum, Sow.

O. gracile, Portl.

Waterhead, L.
Logan Water, L.H.

Dunside, L.

Logan House, L.

Shank's Castle, L.

Hagshaws.

Hagshaws.

Blackberry Burn, L.

Logan Water, L.

Logan Water, L.

Hagshaws.

Hagshaws.

Hagshaws.

Nutberry Hill, L.

Hagshaws.

Hagshaws.

Logan Water, L.

Logan Water, L.

Logan Water, L.

Hagshaws.

Waterhead, L.

Logan Water, Waterhead, L.

Logan Water, L.

Logan Water, L.

Logan Water, Waterhead, L.

Waterhead, L.

Logan Water, Waterhead, L.

Logan Water, L., H.

Logan Water, L.

Logan Water, L.

Logan Water, L.

Logan Water, L.

Nutberry Hill, L.

Logan Water, L.

Hagshaws.

Carmichael Burn.

Hagshaws. 
Orthoceras MacLareni, Salt.

0. sp.

\section{Pisces.}

Birkenia elegans, Traq.

Thelodus planus, Traq.

T. scoticus, Traq.

Fish remains indt.

Incertae sedis.

Dictyocaris Ramsayi, Salt.

D Slimoni, Salt.
Podowrin, H., L.

Hagshaws.

Shanks' Castle, L.

Logan House, L.

Shanks' Cas., Logan House, Linn Burn, L.

Logan House, L.

Shanks' Cas., Logan Water, L., H.

Blackberry Burn, L.

Fossils from the Downtonian Rocks of the Lesmahagow and Hagshaw Hills Areas.

Pachytheca sp.

Parka sp.

P. sp. nov.

Sponge.

\section{Spirorbis sp.}

Beyrichia sp.

Ceratiocaris laxa, Jones \& Woodw.

C. sp.

Eurypterus dolicoschelus, Lanirie.

E. sp.

E. small sp.

Pterygotus bilobus, Salt.

Slimonia acuminata, Salt.

Stylonurus ornatus, Laurie.

S. sp.

Scorpion, fragment.

Myriapod.

Glauconome disticha, Goldf.

Ateleaspis tessellata, Traq.

Birkenia elegans, Truq.

Lanarkia horrida, Truq.

L. spinosa, Traq.

L. spinulosa, Traq.

Lasanius armatus, Traq.

L. problematicus, Traq.

Thelodus scoticus, Traq.

Dictyocaris sp.

Incertae Sedis.

Chain of discs ( $=$ ? sponge).
Seggholm, Dippal, I. ; Smithy Burn, $\mathrm{H}$.

Dippal, L.

Dippal, L.

Seggholm, L.; Monk's Water, Smithy Burn, $\mathrm{H}$.

Smithy Burn, $\mathrm{H}$.

Birkenhead Burn, L.

Seggholm, L.

Birkenhead Burn, Dippal, L.

Seggholm, Dippal, L.; Smithy Burn, H.

Birkenhead Burn, L.

Monk's Water, $\mathrm{H}$.

Birkenhead Burn, L.

Birkenhead Burn, L.

Seggholm, L.

Birkenhead Burn, L.

Monk's Water, $\mathbf{H}$.

Seggholn, L.

Smithy Burn, $\mathrm{H}$.

Birkenhead Burn, Seggholm, L. ; Smithy Burn, $\mathrm{H}$.

Birkenhead Burn, Seggholm, Dippal, L. ; Monk's Water, H.

Birkenhead Burn, Seggholm, Dippal, L. ; Monk's Water, H.

Birkenhead Burn, Seggholm, Dippal, L. ; Monk's Water, $\mathrm{H}$.

Birkenhead Burn, Seggholm, Dippal, L. ; Monk's Water, H.

Seggholm, L.

Birkenhead Burn, Seggholm, Monk's Water, Smithy Burn, H.

Birkenhead Burn, Dippal, Seggholm, L. ; Monk's Water, H.

L., H., C.

L., H. 


\title{
THE TRILOBITES OF THE SILURIAN ROCKS OF SOUTHWEST SCOTLAND.
}

\author{
By B. N. Peach, F.R.S.
}

THE area under consideration is one in which there is an alnost unbroken succession of rocks recording contiunous deposition from Lower Arenig up to the close of Downtonian time-in fact nearly the whole of the Silurian period. During this prodigious lapse of time trilobites became the most prominent marine arthropods, they culminated in the Caradoc period, waned during Upper Silurian and Devonian time, while their last lingering remains finally disappeared within the Carboniferous period. As will be seen in the sequel the trilobite remains found in the Silurian rocks of the area, and more especially of the Girvan region, strongly bear out this conclusion.

\section{LOWER SILURIAN.}

During the deposition of the Arenig and Lower Llandeilo rocks of the area, which appear to have accumulated in an open sea free from land-borne sediment during pauses of volcanic activity, the conditions appear to have been so unfavourable to trilobite life that not a vestige of their remains has been recorded from rocks of these horizons. Towards the close of Upper Llandeilo time, however, when earth-movements had reared these pelagic strata above the surface over a great part of the area, trilohites appeared in profusion among the denizens of the shore, and their remains are numerous and wellpreserved in the rocks representing the finer sediments derived from the newly emerged land. In the Girvan district the chief horizons in which they occur, beginning at the lowest strata and working upwards, are as follows :

The Stinchar limestone, proved by graptolite evidence to be near the top of the Upper Llandeilo rocks, occurs between the massive Kirkland and Benan conglomerates, and, together with its associated mudstones probably representing a pause in the uplift, has yielded 18 species belonging to 14 genera, the forms being of Caradoc facies as shown by R. Etheridge, Jnr. ${ }^{1}$

The next horizon is that of the Balclatchie mudstones overlying the great Benan conglomerate. From the graptolites yielded by the associated beds, which are those of the intermediate zone between the Glenkiln and Hartfell subdivisions, these beds must lie somewhere near the base of the Caradoc rocks of the region. These fine green mudstones have been looked upon by some observers as volcanic tuffs, but, like the Benan conglomerate itself, theiare evidently only the ordinary detritus from the rocks of the ridged up Arenig volcanic group. They are exposed at Dow Hill and Ardmillan Braes

1 "A Monograph of the Silurian Fossils of the Girvan District in Ayrshire," vol. i. By H. A. Nicholson and R. Etheridge, Jur., 1880. 
to the south of Girvan as well as at the typical locality of Balclatchie. The mudstones have yielded the most abundant and best preserved remains of trilobites obtained from the Girvan region, belonging to 31 species falling under 18 genera, the facies being on the whole similar to that of the forms obtained from the Stinchar limestone.

A third horizon from which trilobites have been obtained is of Middle Caradoc age, the beds being found at Whitehouse Bay and Shalloch Mill on the coast south of Girvan, where they consist of calcareous shales. These have yielded a special group of forms among which are Agnostus perrugatus, Bohemilla sp., Cyclopyge armata, C. rediviva, Dindymene Cordai, and Dionide Lapworthi.

The next horizon lies at or near the top of the Caradoc subdivision and comprises the highest beds of the Lower Silurian series in Girvan. They are the well-known mudstones of Drummuck, almost identical in character with those of Balclatchie, and the prolitic "Starfish Bed" of Threave, both the localities being in the inlier of Silurian rocks north of the Girvan valley. From these beds 16 species belonging to 12 genera have been obtained. Among these occur Agnostus agnostiformis and Remopleurides Colbi⿱⺈, the last surviving remains of the two great Cambrian families of the Agnostidae and Olenidae respectively, no member of which is known to pass up into Upper Silurian rocks. The Lower Silurian family of Trinucleidae is represented by Trimucleus seticornis and its variety T. Bucklundi, typical Upper Bala forms, and Ampyx rostratus, and Dionide Lapworthi, being only known in the Girvan region from the Whitehouse horizon. This is also the last appearance of any member of the family.

The other genera which occur in the Lower Silurian rocks of Girvan and the southwest of Scotland, but which do not pass up into the Upper Silurian horizons, are as follows: Asaphus, Ogygia, Cyclopyge (Aeglina), Stygina, Brontenpsis, Barrandia, Salteria, Bohemilla, Deiphon, Sphaerexochus, Cybele, and Dindymene.

Outside the Girvan area the only other Lower Silurian rocks that have yielded trilobite remains are those of Duntercleugh and Snar Water near Leadhills, Wallace's Cast on the Wandel Water near Abington, and Culter Water and Kilbucho further to the east. The rocks in which they occur are all of similar type, conglomerates and coarse grits with calcareous nodules, associated with calcareous shales. That the rocks at the different localities are on one horizon is shown by the trilobite remains which they have yielded, numbering 11 species belonging to 8 genera, which are all of Lower Caradoc facies and very similar to those from the Balclatchie mudstones of Girvan. The horizon is proved to be probably that of the Dicranogiaptus Clingani sub-zone of the Hartfell group from the relation of the conglomerates to the black shales of the neighbourhood where they occur.

\section{UPPER SILURIAN.}

Returning to the Girvan area, the lowest members of the Llandovery rocks, viz., the shelly mudstones of Mulloch Hill and Rough Neuk, localities to the northeast of Girvan, have yielded the remains of 9 genera and 12 species of trilobites. The next horizon is found at Woodland Point, south of Girvan, in beds belonging to the Monograptus gregarius zone of the Birkhill group. These rocks have yielded 14 species belonging to 9 genera, many of the forms being common with those from the Mulloch Hill beds and the horizon next to be considered. The next horizon is that of the Rastrites maximus sub-zone, the highest of the Birkhill group and the top of the Llandovery rocks. The beds are exposed at Penkill and in the Bargany Pond Burn to the south of the Girvan Water between Girvan and Dailly. The beds there have yielded - 16 species belonging to 9 genera. A few trilobites have been obtained from a somewhat higher horizon, Tarannon, in Penkill Burn. 
From the rocks of Blair and Knockgardner between Girvan and Straiton, which represent a still higher horizon, either at the top of the Tarannons or the base of the Wenlock series, the following species have been obtained: Calymene Blumenbachi, Encrinurus punctatus and its variety E. arenaceus, Phacops Downingiae, P. Stokesi, and Proetus Stokesi.

The genera of trilobites found in the Upper Silurian rocks of Girvan, all of which made their appearance in Lower Silurian times and occur in those rocks at Girvan, are, Acidaspis, Bronteus, Calymene, Cheirums, Encrinumus, Harpes, Illaenus with its sub-genera Dysplanus and Bumastus, Lichas, Phacops, Proetus, and Staurocephalus. The genera Homalonotus and Phillipsia occur in the Lower Silurian rocks of the area, the former at Duntercleuch, and the latter represented by Phillipsia parabola at Threave. Though these genera are not represented in the Upper Silurian rocks of Girvan they pass up elsewhere, the former to the Deronian, and the latter as far as the Carboniferous. Beyond the Girvan area the only band of Upper Silurian rocks that has yielded trilobites is found among the Wenlock-Ludlow rocks of the Hagshaw Hill inlier of Lanarkshire. The locality is near High Broomerside on the Podowrin Burn, a tributary of the Douglas Water, and the strata consist of shales. These have yielded to Mr. Macconochie Calymene Blumenbachi, Encrinurus sp., Illaenus sp., Phacops sp., and Proetus Stokesi, a group almost identical with that from Blair and Straiton in the Girvan region.

It will be seen from the above that the distribution of the trilobite remains is similar to that which obtains elsewhere in Britain and Europe generally. The whole facies is European, even down to the forms that occur in the Stinchar limestone, though the corals of that zone were shown by Nicholson to be of American facies, ${ }^{1}$ and the peculiar American gasteropod genera Maclurea and Ophileta which occur in it have only been found elsewhere in Europe in the Durness limestone. The forms have a nearer affinity with those of Bohemia than those of Scandinavia and Russia, and it is evident that they belong to the same great geographical and biological province. The constant association of trilobite remains with mudstones and shales in the area under consideration seems to point to muddy sea-bottoms not far from shore having been their favourite habitat, a fortunate circumstance, since it favoured the preservation of their moults and their dead bodies for our study.

$$
1 \text { Op. cit., p. } 95 .
$$




\title{
THE CRUSTACEA OF THE SILURIAN ROCKS OF SOUTHWEST SCOTLAND.
}

\author{
By B. N. Peach, F.R.S.
}

PHYLLOCARIDA.

Tне phyllocarids are represented by Caryocaris Wrighti in the Arenig rocks of Balcreuchan Port and Bennane Head near Ballantrae, and of Ravensgill near Abington, the form being also found elsewhere in rocks of this horizon. The Caradoc rocks of Girvan have yielded two genera and species, viz. Pinnoraris Lapworthi, which occurs in the Balclatchie sandstones at their base, and Solenocaris solenoides in the Drummuck and Threave beds near their upper limit. In the Tarammon rocks of Blackwood Head, near Dailly, Discinocaris gigas has been found. This form occurs at Moffat in the Birkhill shales at a somewhat lower horizon along with $D$. browniana and Peltocaris aptychoides. These two latter forms have been recorded from the Birkhill shales, outcrops between Portpatrick and the Mull of Galloway, and reappear along with these shales in Ireland on the opposite shore of the Channel at Coalpit Bay, near Donaghadee. A form doubtfully referred to Peltocaris has been recorded by Mrs. Gray from Penkill in the Girvan area.

The genus Aptychopsis has not yet been recorded from the Girvan area, nor from the Wenlock rocks of the northwest margin of the southern uplands, but two species have been recorded from the Tarannon and Wenlock rocks of Burrow Head to the south of Wigtown. All the forms above enumerated seem to have associated with graptolites, as they are mostly found embedded in graptolite-shales, and seem like the graptolites to have flourished best at or near the limit of sedimentation.

The genus Ceratiocaris is the prevailing phyllocarid form in the WenlockLudlow rocks of Lesmahagow and the Hagshaw Hills, no fewer than nine species having been recorded from these beds. They occur in such numbers in certain bands that they have given the name to a very important sub-zone of the Ludlow rocks of the Lesmahagow inlier, viz. that from which the Ludlow fish- and scorpion-remains have been obtained. It is from these beds that the specimen showing abdominal appendages described by $R$. Etheridge, Jnr., ${ }^{1}$ and a considerable amount of the material which is figured by Jones and Wordward in their monograph ${ }^{2}$ was obtained.

The species of this genus seem to have frequented the muddy bottoms where slow deposition was going on, for their remains are most numerous in certain finely-laminated calcareous beds which are comparatively free from the remains of lamellibranchs and gasteropods which crowd many of the less finely-laminated beds of the Lesmahagow inlier. In the

${ }^{3}$ Memoirs Geol. Surv. Scot. "Explanation" of Sheet 23, p. 93.

"Palaeont. Soc. Monograph on "British Palaeozoic Phyllocarida," part i. 
Wenlock rocks of the southeast border of Scotland their remains are often found associated with such graptolites as Monograptus priodon, $M$. Flemingii, and Retiolites Geinitzianus, and with Orthoceratites, in thinlylaminated dark shales which weather into layers as fine as writing paper.

In their Monograph on the British Fossil Phyllocarida Professor Jones and Dr. Woodward make a new genus, Calyptocaris, ${ }^{1}$ to include the form recorded by R. Etheridge, Jur., as Dithyrocaris (?) striata, ${ }^{2}$ which was obtained by the Geological Survey from Carmichael Burn near Carmichael Manse, to the north of Tinto in Lanarkshire. In 1873, at the time of the publication of the "Explanation" of Sheet 23, these beds were considered by the Geological Survey to belong to the Lower Old Red Sandstone formation, ${ }^{3}$ but their subsequent work has shown them to be the uppermost zones of the Ludlow shales, which, together with the Downtonian rocks, make their appearance upon the back of a denuded isoclinal fold in the midst of Lower Old Red strata. ${ }^{4}$

\section{OSTRACODA.}

In the Girvan area ostracoda have been found on several horizons. The lowest horizon is that of the Stinchar limestone which at Aldons limeworks near Pinmore has yielded five species of the genus Cythere and one species of Primitic which Professor Rupert Jones considers to be of eminently Lower Silurian type.

From the Middle Caradoe shales of Whitehouse Bay Mrs. Gray has obtained the following forms-Aparchites leperditioides, A. subovatus, Beyrichia impar, Cypridina Grayae, Primitia elongata, var. nuda, P. girvanensis, P. Grayae, $P$. Krausei, $P$. mundula, var. fimbriata, $P$. mundula, var. Kloedeniana, $P$. ulrichiana, and Sulcuna praeurrens.

In the uppermost Caradoc rocks of Threave is the first appearance of the genus Beyrichia, represented by $B$. comma, and the common Upper Silurian form $B$. Kloedeni.

In the Upper Silurian rocks of Girvan and Straiton, in the Bargany Pond Burn, in shales at the top of the Llandovery Rocks, a variety of Beyrichia Kloedeni occurs, and the Wenlock rocks of Straiton have yielded the familiar forms Beyrichia Kloedeni, B.(Entomis) impendens, and Entomis globulosa. In the main it would appear that these early entomostraca seem to have frequented the same kind of sea-bottom as that sought out by the trilobites, as their remains are obtained from the same localities and the same beds.

In areas outside that of Girvan entomostraca swarm in some of the Wenlock-Ludlow beds of the Lesmahagow and Hagshaw inliers of Lanarkshire, but they are restricted to one or two species, Beyrichia Kloedeni and one of its varieties being the principal forms. A species of Entomis also. occurs. A species of Beyrichia is rare in the Downtonian fish-beds.

\section{CIRRIPEDIA.}

Two species of Turrilepas have been found in the Lower Silurian rocks of Girvan at Balclatchie, Whitehouse, and Drummuck, and an unnamed species. from the Newlands beds in the Llandovery rocks.

1 Palaeontolographical Soc., vol. liii., p. 183, pl. xviii., fig. 7, 1899.

2 Memoirs Geol. Surv. Scot. "Explanation" to Sheet 23, pp. 57 and 100.

3 Ibid., p. 14, par. 24.

${ }^{4}$ Mem. Geol. Surv. U.K., vol. i., pp. 5̃86-588. 


\title{
THE ARTHROPODA FROM THE SILURIAN ROCKS OF SOUTHWEST SCOTLAND.
}

\author{
By B. N. Peach, F.R.S.
}

Cirripedia.

Turrilepas Peachi, Nich. and Eth.-Caradoc: Girvan.

T. scotica, $N$. and E.-Caradoc: Girvan.

T. Wrighti, Woodw.-Caradoc : Girvan.

T. sp._Caradoc and Llandovery : Girvan.

T. sp.

Ostracoda.

Aparchites leperditioides, J.-Caradoc: Girvan.

A. subovatus, J.-Caradoc: Girvan.

Beyrichia comma, J.-Caradoc: Girvan.

B. impar, J.-Caradoc: Girvan.

B. (Entomis) impendens, $J$--Ludlow : Hagshaw Hills.

B. Kloedeni, $M^{\prime}$ Coy.-Caradoc to Ludlow : Girvan, Lesmahagow, Hagshaw Hills, Carmichael Burn.

B. Kloedeni, var. infecta, $J$.-Caradoc: Girvan.

B. Kloedeni, var. scotica, $J$. and Holl.-Llandovery: Girvan.

B. Kloedeni, var. torosa, J.-Ludlow : Lesmahagow.

B. (Entomis) tuberosa.-Ludlow : Hagshaw Hills.

B. sp.-Downtonian : Lesmahagow.

Cythere aldensis, $M^{*} \mathrm{Coy}$.-Llandeilo : Girvan.

C. aldensis, var. major, J.-Llandeilo : Girvan.

C. Grayana, J.-Llandeilo: Girvan.

C. Wrightiana, J. and Holl.-Llandeilo : Girvan.

C. sp.-Llandeilo and Llandovery : Girvan.

Cypridina Grayae, J.-Caradoc: Girvan.

Entomis globulosa, J.-Wenlock : Straiton.

E. sp.-Ludlow: Hagshaw Hills.

Primitia Barrandiana, J.-Caradoc: Girvan.

P. elongata, var. nuda, $J$-Caradoc: Girvan.

P. girvanensis, J.-Caradoc : Girvan.

P. Grayae, J.-Caradoc: Girvan.

P. Krausei, J.--Caradoc: Girvan.

P. mundula, var. fimbriata, J.-Caradoc: Girvan.

P. mundula, var. Kloedeniana, J.-Caradoc: Girvan.

P. ulrichiana, J.-Caradoc : Girvan.

Phyllocarida.

Caryocaris Wrighti, Salt.-Arenig: Girvan, Abington district. Ceratiocaris angusta, J. and Woodu.-Ludlow: Lesmahagow. 
Ceratiocaris laxa, J. and W.-Ludlow : Lesmahagow.

C. longa, IT. and J.-Ludlow : Lesmahagow.

C. Murchisoni, $M^{\prime}$ Coy.-Ludlow : Lesmahagow.

C. papilio, Salt.-Ludlow : Lesmahagow.

C. patula, J. and W.--Ludlow : Lesmahagow.

C. robusta, Salt.--Ludlow: Lesmahagow.

C. stygia, Salt.-Ludlow : Lesmahagow.

C. tyrannus, Salt.-Ludlow : Lesmahagow.

C. sp.-Ludlow : Lesmahagow.

Discinocaris gigas, W.-Tarannon: Girvan.

Calyptocaris striata, Eth. Ji:-Ludlow : Carmichael Burn, Lanarkshire.

Pinnocaris Lapworthi, Eth. Ji.-Caradoc: Girvan.

Solenocaris solenoides, Y.-Caradoc: Girvan.

\section{Trilobita.}

Acidaspis bispinosa, $I^{\circ}$ Coy.-Llandovery : Girvan.

A. Brighti, Murch.-Llandovery : Girvan.

A. Grayae, Eth. Jr.-Caradoc: Girvan.

A. hystrix, Eth. Jr.-Caradoc: Girvan.

A. Lalage, Wyv.-Thom.-Caradoc: Girvan.

A. sp.-Llandovery : Girvan.

Agnostus agnostiformis, $V^{\prime} \mathrm{Coy}$-Caradoc: Girvan.

A. perrugatus, Barr.-Caradoc: Girvan.

Ampyx Hornei, E. and N.-Llandeilo and Caradoc: Girvan.

A. Maccallumi, Salt.-Caradoc: Girvan.

A. mammillatus, Sars.-Caradoc: Girvan.

A. nasutus, Dalm.-Caradoc: Girvan.

A. nudus, Wurch.-Caradoc: Girvan.

A. rostratus, Sars.-Caradoc: Girvan.

Asaphus (Isotelus) gigas, De Kay.-Upper Llandeilo and Lower Caradoc: Girvan.

A. marginatus, Portl.-U. Caradoc: Girvan.

A. rectifrons, Portl.-U. Llandeilo and L. Caradoc: Girvan.

Barrandia sp.-L. Caradoc: Girvan.

Bohemilla sp.-U. Caradoc: Girvan.

Bronteopsis scotica, Salt.-L. Caradoc: Girvan.

Bronteus Andersoni, E. and $\mathrm{Y}$.-U. Llandeilo to Llandovery : Girvan.

B. hibernicus, Portl.-U. Caradoc: Girvan.

Calymene Blumenbachi, Brong.--U. Llandeilo to Wenlock: Girvan and Hagshaw Hills.

C. tuberculosa, Salt.--U. Caradoc: Girvan.

C. sp.-L. Caradoc: Abington district.

Cheirurus bimucronatus, Murch.-U. Llandeilo to Tarannon: Girvan.

C. clavifrons, Dalm.-L. and U. Caradoc: Girvan and Abington.

C. gelasinosus, Portl.-U. Llandeilo and L. Caradoc : Girvan.

C. Sedgwicki, $M^{\prime} \mathrm{Co} y$-LL. Caradoc: Girvan.

C. trispinosa, Young.-Llandovery : Girvan.

C. sp.-L. Caradoc: Girvan.

Cybele rugosa, Portl.-Caradoc: Girvan.

C. verrucosa, Dalm.-Caradoc: Girvan.

Cyclopyge armata, Barr.-Caradoc: Girvan.

C. rediviva, Barr.-Caradoc: Girvan.

Deiphon Forbesi, Barr.-L. Caradoc: Girvan.

Dindymene Cordai, $E$. and $N$.-Caradoc: Girvan.

Dionide Lapworthi, $E$. and $N$.-Caradoc : Girvan.

D. sp.-Caradoc : Girvan. 
Encrinurus punctatus, Brïn.-Llandovery to Wenlock : Girvan, Abington district, Straiton.

E. punctatus, var. arenosus, Salt.-U. Llandeilo to Wenlock: Girvan, Abington district, Straiton.

E. punctatus, var. calcareus, Salt.-U. Llandeilo to Llandovery : Girvan.

Harpes sp.-U. Llandeilo to Tarannon : Girvan.

Homalonotus sp.-L. Caradoc: Abington district.

Illaenus (Dysplanus) aemulus, Salt.-Llandovery : Abington district.

I. (Bumastus) Barriensis, Murch.-Llandovery : Abington district.

I. (B.) Bowmani, Salt.-U. Llandeilo to L. Caradoc : Abington district.

I. (B.) Maccallumi, Salt.-U. Caradoc : Girvan and Abington district.

I. latus (?), M'Coy.-U. Llandeilo and L. Caradoc: Girvan and Abington district.

I. Murchisoni, Salt.-Llandovery : Girvan and Abington district.

I. nexilis, Salt.-U. Caradoc to Llandovery : Girvan and Abington district.

I. Rosenbergi, Eichw.-Llandovery : Girvan.

I. Thomsoni, Salt.-Llandovery : Girvan.

I. sp.-Caradoc and Llandovery : Girvan.

Lichas ambiguus, Barr.-Llandovery : Girvan.

L. Barrandei, Flet.-Llandovery : Girvan.

L. Geikiei, E. and $N$.-U. Caradoc: Girvan.

L. Grayi, Flet.-L. Caradoc: Girvan.

L. hibernicus, Portl.-U. Llandeilo and L. Caradoc : Girvan.

L. laxatus, $M^{\prime}$ Coy.-U. Caradoc : Girvan.

L. palmatus, Barr:-Llandovery : Girvan.

L. sp.-L. Caradoc to Llandovery : Girvan.

Ogygia, sp.-Caradoc: Leadhills.

Phacops alifrons, Salt.-L. Caradoc : Abington district.

P. (Acaste) Brongniarti, Portl.-U. Llandeilo to U. Caradoc: Girvan and Abington.

P. Downingiae, Murch.-Llandovery to Wenlock : Girvan and Straiton.

P. Stokesi, M. Edw. -Wenlock : Hagshaw Hills.

P. sp.-L. Caradoc, Ludlow : Abington, Hagshaw Hills.

Phillipsia parabola, Barr.-U. Caradoc : Girvan.

Proetus girvanensis, E. and N.-L. and U. Caradoc : Girvan.

P. latifrons, $M^{\prime} \mathrm{Coy}$ - U. Caradoc: Girvan.

P. procerus, E. and N.-U. Caradoc : Girvan.

P. Stokesi, Murch.-Wenlock : Straiton.

Remopleurides Barrandei, E. and N.-L. Caradoc : Girvan.

R. Colbii, Portl.-U. Llandeilo and L. Caradoc: Girvan and Abington.

R. dorsospinifer, Portl.-L. Caradoc: Girvan.

R. laterispinifer, Portl.-U. Landeilo and L. Caradoc: Girvan and Abington.

Salteria primaeva, Wyv.-Thom.-L. Caradoc: Girvan.

Sphaerexochus mirus, Beyr.-U. Llandeilo to L. Caradoc : Girvan.

Staurocephalus globiceps, Portl.-L. Caradoc to Llandovery : Girvan.

S. unicus, Wyv.-Thom.-L. Caradoc to Llandovery : Girvan.

S. sp.-Llandovery : Girvan.

Stygina latifrons, Portl.-L. Caradoc : Girván.

Trinucleus concentricus, Eaton.-L. Caradoc: Girvan.

T. Macconochiei, E. and H.-L. Caradoc : Girvan.

T. ornatus, Stern.-L. Caradoc: Girvan.

T. seticornis, His.-U. Caradoc: Girvan.

T. seticornis, var. Bucklandi, Barr.-U. Caradoc : Girvan.

Xiphosura.

Neolimulus falcatus, Woodw.-Ludlow : Lesmahagow. 


\section{EURYPTERida.}

Eurypterus lanceolatus, Salt.-Ludlow : Lesmahagow.

E. obesus, Woodw.-Ludlow : Lesmahagow.

E. scorpioides, Woodw.-Ludlow : Lesmahagow.

E. dolicoschelus, Laurie.-Downtonian : Lesmahagow.

E. sp.-Hagshaw Hills.

Pterygotus bilobus, Salt.-Ludlow and Downtonian : Hagshaw Hills.

P. bilobus, var. accidens, Woodw.--Ludlow : Hagshaw Hills.

P. bilobus, var. inornatus, Woodw.-Ludlow : Hagshaw Hills.

P. bilobus, var. perornatus, Salt.-Ludlow : Hagshaw Hills.

P. raniceps, Woodw.-Ludlow : Hagshaw Hills.

Slimonia acuminata, Salt.-Ludlow and Downtonian: Hagshaw Hills. Stylonurus Logani, Woodw.-Ludlow : Hagshaw Hills.

S. ornatus, Laurie.--Downtonian: Hagshaw Hills.

Arachinida.

Palaeophonus caledonicus, Hunter.-Ludlow : Lesmahagow.

P. sp.-Downtonian: Hagshaw Hills.

\section{MYriaPoda.}

Archidesmus loganensis, Peach.-Ludlow : Lesmahagow.

A. sp.-Ludlow and Downtonian: Lesmahagow. 


\section{GRAPTOLITES.}

\section{By Professor C. Lapworth, F.R.S., Birmingham University.}

The Silurian strata of the Basin of the Firth of Clyde contain some of the richest graptolite-bearing deposits in the world, and the Graptolites which they afford include examples of all the known families of this group of fossils.

Researches carried on in the region of the Southern Uplands of Scotland (a portion of which lies within the limits of the Basin of the Clyde) first demonstrated the reliability of Graptolites as "zone fossils" for unravelling the sequence of the British Lower Palaeozoic deposits : and within the last thirty years these fossils have been keenly studied by foreign geologists and palaeontologists in Scandinavia, France, Bohemia, Belgium, Canada, the United States, etc. In these countries, as in Britain, their first-rate importance as aids in working out the geology of the older stratified rocks has long been admitted and utilized. Geologists owe it to the Graptolites that they are now able to divide the Ordovician and Silurian strata into successive chronological "life zones" corresponding with those demonstrated by means of the Ammonites for the Jurassic sediments more than half a century ago, and to parallel satisfactorily the strata containing them in Britain with the equivalent deposits in Europe and America.

The region of the Southern Uplands of Scotland--of which the basin of the Upper Clyde forms a part-is the type region for these fossils in Britain from the stratigraphical point of view. The recent Memoir of the Geological Survey ("The Silurian Rocks of Britain," vol. i., 1899) gives an admirable and detailed account of the distribution of Graptolites in the southwest of Scotland, and of the geology of the Southern Uplands. To this work the reader is referred.

Graptolites are especially abundant in the Silurian rocks of the basin of the Upper Clyde at the localities of Wanlockhead and the Leadhills. Here they constitute the predominant fossils of the district, and are practically confined to certain black shale bands which run through the country along the strike of the beds. They are also present, in less abundance, however, in the Silurian strata of the coastal district of Girvan; but here they are often associated with crowds of other fossils-Brachiopods, Trilobites, Cephalopods, etc., and are more generally distributed throughout the entire succession.

In the Guide Book issued for the members of the British Association at its last meeting in Glasgow in 1876 ("Catalogue of Western Scottish Fossils," J. Armstrong, J. Young, and D. Robertson) four plates by the writer of figures of the more characteristic Scottish Graptolites were included. Figures of the common Scottish forms have also been published elsewhere. See for example the Proceedings of the Belfast Naturalists' Field Club, Appendix, 1876-1877, and the plates in the Survey Memoir, 1899, cited above. 
The following Catalogue gives the names of the species of Graptolites hitherto recognised in the Silurian strata of the West of Scotland; and the appended Bibliography embraces the titles of those works and papers which deal with the description and illustration of these Scottish forms, or with their local or general geological distribution.

The localities for the various Graptolite species are arranged in the following order :

1. Girvan and Ballantrae district.

2. Currarie and Stinchar district.

3. Wanlockhead district of the Upper Clyde basin.

When the localities belong to different districts they are separated by a hyphen.

The letters $\mathbf{N}$. and S. in brackets ( ) refer to the northern and southern portions of the long section in Penwhapple Glen, Girvan district.

The geological range of each species is indicated by the initial letter of the formation in which it occurs being placed after the name in heavy type.
A. = Arenig :
L. = Lower Llandeilo :
G. = Glenkiln :
H. = Hartfell :
B. $=$ Birkhill : $\mathbf{T} .=$ Tarannon :
W. $=$ Wenlock

Fam. Monograptidae.

Rastrites distans, Lapw.-T. Penwhapple Glen (N.).

R. hybridus, Lapw.-B. Saugh Hill : Penwhapple Glen (N.).

R. maximus, Carr.-B. Penwhapple Glen (N.): Bargany Pond Burn.

R. peregrinus, Barr.-B. Baldrennan Burn: Penwhapple Glen (N.) : Saugh Hill.

Monograptus argutus, Lapv.--B. Baldrennan Burn.

M. attenuatus, Hopk-B. Penwhapple Glen (N.): Baldrennan Burn.

M. Becki, Barr.-T. Penwhapple Glen (N.).

M. concinnus, Lapv.--B. Penwhapple Glen (N.).

M. convolutus, His.-B. Penwhapple Glen (N.): Saugh Hill.

M. crassus, Lapw.-B. Penwhapple Glen (N.) : Bargany Poud Burn.

M. crenularis, Lapv.-B. Baldrennan Burn.

M. cyphus, Lapro.-B. Sangh Hill : Shalloch Forge: Woodland Point.

M. exiguus, Nich.-T. Penwhapple Glen (N.).

M. fimbriatus, Lapw.-B. Baldrennan Burn.

M. Flemingi, Salt.-W. Lady Burn : Blair Quarry.

M. galaensis, Lapw.-B., W. Penwhapple Glen (N.).

M. gregarius, Lapw.-B. Baldrennan Burn: Penwhapple Glen (N.): Saugh Hill : Woodland Point.

M. intermedius, Carr.-B. Penwhapple Glen (N.).

M. jaculum, Carr.-B. Penwhapple Glen (N.): Bargany Pond Burn.

M. leptotheca, Lapw.-B. Baldrennan Burn: Penwhapple Glen (N.): Woodland Point: Saugh Hill : Shalloch Forge.

M. lobiferus, $\boldsymbol{I}^{*} \mathrm{Coy}-\mathrm{B}$. Saugh Hill.

M. priodon, Broun.-T. W. Pen whapple Glen (N.).

M. riccartonensis, Lapw.-W. Blair Quarry.

M. runcinatus, Lapw.-B. Penwhapple Glen (N.).

M. Sedgwicki, Portlock.-B. Penwhapple Glen (N.): Saugh Hill.

M. tenuis, Portlock.-B. Glenwells Buru?: Baldrennan Burn: Penwhapple Glen (N.): Saugh Hill : Shalloch Forge: Woodland Point.

M. turriculatus, Barr.-T. Peuwhapple Glen (N.): Bargany Pond Burn.

M. vomerinus, Nich.--W. Blair Quarry : Lady Burn.

Cyrtograptus Grayi, Lapw.--T. Penwhapple Glen (N.). 
Fam. Leptograptidae.

Leptograptus flaccidus, Hall.-H. Shalloch Mill : Penwhapple Glen (S.) : Byne Burn :-Hortin Gill.

Amphigraptus radiatus, Lapw.-G., H. Castle Hill, Abington.

Pleurograptus linearis, Carr.-H. Shalloch Mill : Penwhapple Glen (S.) : Byne Burn.

Coenograptus explanatus, Lapw.-G. Wandel Water.

C. gracilis, Hall.-G. Rough Gill: Rein Gill: Wandel Water: Castle Hill : Gair Gill : Hortin Gill : Wanlock Water : Duntercleuch Burn.

C. pertenuis, Lapw.-G.-Portandea :-Rein Gill: Wandel Water: Gair Gill : Hortin Gill : Glengaber Burn : Duntercleuch Burn.

C. surcularis, Hall.-G. Gair Gill : Wanlock Water.

Fam. Dicranograptidae.

Dicellograptus anceps, Nich.-H. Ladv Burn.

D. complanatus, Lapw.-H. Shalloch Mill : Whitehouse Bay.

D. divaricatus, Hall.-G. Port Currarie :-Wandel Water: Key Gill : Gair Gill.

D. elegans, Carr.-G. Rein Gill : Castle Hill ?

D. Forchammeri, Geinitz.-H. Penwhapple Glen: Dalamford: Ardmillan Shore:-Castle Hill.

D. Forchammeri, var. flexuosus, Lapw.-G., H. Castle Hill.

D. intortus, Lapw.-G. Rein Gill : Wandel Water: Castle Hill.

D. moffatensis, Carr.-G., H. Portandea :-Ardmillan Braes: Penwhapple Glen (S.):- Rein Gill: Wandel Water: Laggan Gill: Hortin Gill : Duntercleuch Burn, \&c.

D. Morrisi, Hopk.-H. Whitehouse Bay: Shalloch Mill : Penwhapple Glen (S.): Byne Burn.

D. patulosus, Lapw.-G. Portandea :-Wandel Water: Laggan Gill : Hortin Gill: Wanlock Water: Glengaber Burn: Duntercleuch Burn, \&c.

D. sextans, Hall.-G. Benan Burn :-Portandea: Port Currarie:--Rein Gill: Wandel Water: Castle Hill: Laggan Gill : Glengaber Burn : Duntercleuch Burn, \&c.

Dicranograptus formosus, Hopk.-G. Rein Gill: Wandel Water : Castle Hill : Laggan Gill, \&c.

D. Nicholsoni, Hopk.-G., H. Pinmore:-Rough Gill: Rein Gill : Wandel Water : Glengonner Burn: Wanlock Water.

D. ramosus, Hall.-G., H. Craighead : Laggan Gill: Ardmillan Shore : Penwhapple Glen (S.) :-Rough Gill: Wandel Water: Glengonner

Burn : Wanlock Water: Duntercleuch Burn, \&c.

D. ramosus, var. spinosus, Lapw.-Pinmore :-Wandel Water.

D. rectus, hopk.-G. Glengonner Burn.

D. tardiusculus, Lapw.-G., H. Penwhapple Glen (S.) : Ardmillan Braes : Balclatchie.

D. zic-zac, Lapw.-G. Rein Gill : Wandel Water.

D. zic-zac, var. minimus, Lapw.-G. Castle Hill: Wanlock Water : Duntercleuch Burn, \&c.

Fam. Dichograptidae.

Didymograptus bifidus, Hall.-A. Bennane Head.

D. extensus, Hall.-A. Bennane Head.

D. serratulus, Hall.-G. Wandel Water: Birnock Burn.

D. superstes, Lapw.-G. Benan Burn :-Wandel Water: Wanlock Water : Glengaber Burn, \&c.

Tetragraptus Bigsbyi, Hall.-A. Bennane Head: Pinbain Burn. 
Tetragraptus bryonoides, Hall.-A. Bennane Head: Balcreuchan Port: Pinbain Burn.

T. fruticosus, Hall.-A. Bennane Head : Raven Gill.

T. Headi, Hall.-A. Balcreuchan Port.

T. quadribrachiatus, Hall.-A. Bennane Head: Pinbain Burn: Raven Gill.

Phyllograptus typus, Hall.-A. Bennane Head: Pinbain Burn.

Loganograptus Logani, Hall.-G. Hortin Gill.

Dichograptus multiplex, Nich.-A. Bennane Head.

D. octobrachiatus, Hall.-A. Bennane Head.

D. reticulatus, Nich.-A. Bennane Head.

\section{Fam. Diplograptidae.}

Diplograptus angustifolius, Hall, var. euglyphus, Lapw.-G. Benan Burn:-Rein Gill: Duntercleuch Burn: Wanlock Water, \&c.

D. foliaceus, Murch.-G., H. Portandea.

D. foliaceus, var. vulgatus, Lapw.-G. Craighead: Laggan Gill : Ardmillan Shore: Shalloch Mill: Penwhapple Glen (S.):-Wandel Burn: Glengaber Burn: Wanlock Water, \&c.

D. foliaceus, var. rugosus, Emm.-G., H. Benan Burn : Millenderdale: Craighead: Penwhapple Glen (S.): Laggan Gill: Ardmillan Shore: Dalamford.

D. modestus, Lapw.-B. Penwhapple Glen (N.): Saugh Hill : Shalloch Mill : Woodland Point.

D. perexcavatus, Lapw.-G. Rein Gill: Wandel Water: Coldchapel Burn: Castle Hill, \&c.

D. quadrimucronatus, Hall.-H. Whitehouse Bay: Shalloch Mill : Penwhapple Glen (S.): Byne Burn.

D. socialis, Lapw.-H. Whitehouse Bay.

D. tamariscus, Nich.-B. Baldremnan Burn: Penwhapple Glen (N.): Saugh Hill.

D. truncatus, Laprv.-H. Whitehouse Bay : Penwhapple Glen (S.): Lady Burn.

Climacograptus bicornis, Hall.-G., H. Benan Burn : Craighead : Laggan Gill: Ardmillan Shore: Penwhapple Glen (S.) :-Wandel Burn : Rein Gill : Wanlock Water: Glengaber Burn, \&c., \&c.

C. bicornis, var. peltifer, Lapw._-G. Rein Gill: Coldchapel Burn: Wanlock Water, \&c.

C. bicornis, var. tridentatus, Lapw.-G., H. Wandel Water: Glengomner Burn: Wanlock Water, \&c.

C. caudatus, Lapw.-G., H. Ardmillan Shore: Penwhapple Glen (S.) : Dalamford: Piedmont Glen: Duncan Gill : Castle Hill : Glengomner Burn, \&c.

C. coelatus, Lapw.-G., H. Penwhapple Glen(S.): Portandea : Currarie:Wandel Burn : Wanlock Water.

C. normalis, Lapw.-B. Glenwells Burn: Baldrennan Burn : Penwhapple Glen (N.): Saugh Hill : Shalloch Forge: Woodland Point.

C. rectangularis, $M^{\circ} \mathrm{Coy}-\mathrm{B}$. Woodland Point.

C. Scharenbergi, Lapw.--G., H. Benan Burn: Millenderdale : Craighead: Laggan Gill: Penwhapple Glen (S.) : Portandea:-Wanlock Water : G]engaber Burn, \&c.

C. tubuliferus, Lapw.-H. Shalloch Mill: Penwhapple Glen (S.) : Byne Burn.

Petalograptus folium, His.-B. Baldrennan Burn: Penwhapple Glen (N.).

P. palmaeus, Barr.-B. Penwhapple Glen (N.): Bargany Pond Burn : Saugh Hill. 
Cryptograptus tricornis, Carr.-G., H. Benan Burn : Millenderdale : Craighead: Pinmore: Penwhapple Glen (S.) :-Wandel Burn: Glengonner Burn: Wanlock Water, \&c.

Dimorphograptus acuminatus, Nich.-B. Glenwells Burn.

D. Swanstoni, Lapw.-B. Penwhapple Glen (N.).

Glossograptus Hincksi, Hopk.-G. Benan Burn :-Rein Gill : Wandel Water: Glengonner Burn, \&c.

Lasiograptus Harknessi, Nich._-G., H. Laggan Gill : Penwhapple Glen (S.) :- Rein Gill : Rough Gill : Castle Hill.

L. margaritatus, Lapw.-H. Penwhapple Glen(S.): Piedmont Glen :-Rein Gill : Wandel Water: Castle Hill.

Hallograptus bimucronatus, Nich.-G. Rough Gill: Wandel Burn : Rein Gill : Glengaber Burn, \&c.

Trigonograptus ensiformis, Hall.-A. Balcreuchan Port.

\section{Fam. Retiolitidae.}

Retiolites fibratus, Lapw.-H. Rough Gill ?: Grains Burn.

R. Geinitzianus, Barr.-T., W. Penwhapple Glen (N.) : Blair (quarry.

R. obesus, Lapw.-T. Penwhapple Glen (N.).

Clathrograptus cuneiformis, Lapw.-G. Benan Burn.

Corynoides calicularis, Nich.-G., H. Ardmillan Shore; Penwhapple Glen (S.) :-Wandel Burn: Glengonner Burn : Laggan Gill.

Thamnograptus typus, Hall.-G. Wandel Water.

Dictyonema venustum, Lapw.-B. Penwhapple Glen (N.).

D. delicatulum, Lapw.-B. Shalloch Forge.

Callograptus diffusus, Hall.-A. Bennane Head.

\section{BIBLIOGRAPHY OF SCOTTISH GRAPTOLITES.}

1839. Lyell, C., "On the occurrence of Graptolites in the Slate of Galloway." Proc. Geol. Soc., vol. iii., p. 28.

1840. Moore, J. C., "On the rocks which form the West Shore of the Bay of Loch Ryan," Proc. Geol. Soc., vol. iii., p. 277.

1841. Nicol, J., "Geology of Peebleshire," Trans. Highland Soc., 2nd series, vol. viai., p. 149.

1848. Nicol, J., "On the Geology of the Silurian rocks in the Valley of the Tweed," Q.J.G. S., vol. iv., p. 195.

1848. Moore, J. C., "On some fossiliferous beds in the Silurian rocks of Wigtonshire and Ayrshire," Q. J. G. S., vol. v., p. 7.

1849. Salter, J. W., "Notes on Fossils from the Limestone of the Stinchar River and from the Slates of Loch Ryan," Q. J. G. S., vol. v., p. 13.

1850. Harkness, R., "Description of Graptolites found in the Black Shales of Dumfriesshire," Q.J. G. S., p. 58.

1851. Salter, J. W., "List and description of the Silurian Fossils of Ayrshire,"Q.J. G.S., vol. vii., p. 170.

1851. M'Coy, F., "New Fossils from Southern Scotland," "Brit. Pal. Rocks and Fossils," pp. 3-9.

1852. Salter, J. W., "Description of some Graptolites from the South of Scotland," Q. J. G. S., vol. viii., p. 388.

1852. Harkness, R., "On the Silurian rocks of the South of Scotland and on the Gold districts of Wanlockhead and the Leadhills," Q. J. G. S., vol. viii., p. 393.

1855. Sedgwick, A., and M'Coy, F., "Synopsis of the classification of the British Palaeozoic Rocks, with a systematic description of the Fossils."

1855. Harkness, R., On the Anthracitic Schists and the Fucoidal remains occurring in the Lower Silurian rocks of the Sonth of Scotland, Q. .J. G. S., vol. xi., p. 468. 
1858. Carruthers, W., "Dumfriesshire Graptolites, with descriptions of three new species," Proc. Royal Physical Soc. Eclin., vol. i., p. 466.

1859. Carruthers, W., "On the Graptolites from the Silurian Shales of Dumfriesshire, with a description of three new species," Ann. and Mag. Nat. Hist., 3rd ser., vol. iii., p. 23.

1866. Nicholson, H. A., "On some Fossils from the Graptolitic Shales of Dumfriesshire," Geol. Mag., dec. 1., vol. iii., p. 488.

1867. Carruthers, W., "Graptolites, including Scottish species," Intellectual Observer, May, pp. 283-292, and June, pp. 365-374.

1867. Nicholson, H. A., "On a new genus of Graptolites, with notes on their Reproductive Bodies," Trans. Geol. Soc. Edin., vol. i., p. 57.

1867. Nicholson, H. A., and Carruthers, W., "Graptolites of the Moffat Shales," Geol. Mag., dec. 1, vol. iv., pp. 70, 108, and 135.

1868. Carruthers, W., "A Revision of the British Graptolites, with descriptions of the new species, and notes on their affinities," Geol. Mag., p. 64.

1869. Dairon, J., "On Graptolites from the Silurian Shales of the Moffat district," Proc. Nat. Hist. Soc. Glasgou, vol. i., p. 268.

1869. Nicholson, H. A., "New species of Graptolites," Ann. and Mag. Nat. Hist., 4th ser., vol. iv., p. 231.

1870. Nicholson, H. A., "On the genus Climacograptus, with notes on the British species of the genus," Ann. and Mag. Nat. Hist., 4th ser., vol. vi., p. 370 .

1870. Hopkinson, J., "On the structure and affinities of Dicranograptus, Geol. Mag., dec. 1, vol. vii., p. 353.

1871. Hopkinson, J., "On Dicellograptus, a new genus of Graptolites," Geol. Mag., dec. 1, vol. viii., p. 20.

1872. Lapworth, C., "On the Silurian rocks of the South of Scotland," Trans. Geol. Soc. Glasgow, vol. iv., p. 164.

1872. Hopkinson, J., "On some new species of Graptolites from the South of Scotland," Geol. Mag., dec. 1, vol. ix., p. 501.

1872. Young, J., "On Graptolites from the Silurian strata of Girvan," Proc. Wat. Hist. Soc. Glasgow, vol. ii., p. 179.

1872. Nicholson, H. A., "Monograph of the British Graptolitidae," part 1, Edin.

1873. Lapworth, C., "An improved classification of the Rhabdophora," Geol. Mag., dec. 1, vol. x., pp. 500 and 555.

1876. Lapworth, C., "On Scottish Monograptidae," Geol. Mag., dec. ii., vol. iii., pp. 308, 350, 499, 544 .

1876. "Notes on Graptolites from Girvan collected by Mrs. Gray," Proe. Nat. Hist. Soc. Glasgow, vol. ii., pt. ii., p. 182.

1876. Young, J., "Notes on a series of Fossils from the Silurian rocks of the Girvan Valley," Proc. Nat. Hist. Soc. Glasgow, vol. ii., pt. ii., p. 166.

1876. Armstrong, J., J. Young, D. Robertson, and C. Lapworth. "Catalogue of the Western Scottish Fossils."

1877. Lapworth, C., "On the Graptolites of County Down," Proc. Belfast Nat. Field Club, 1876-1877, Appendix, pp. 125-144, plates v., vi., vii.

1878. Lapworth, C., "The Moffat Series," Q. J. G. S., vol. xxxiv., pp. 240-346.

1878. Etheridge, R., and Newton, E. T., "A Catalogue of the Cambrian and Silurian Fossils in the Museum of Practical Geology."

1879. Lapworth, C., "On the Geological Distribution of the Rhabdophora," Ann. and Mag. Nat. Hist., 5 ser., vol. iii., pp. 245 and 449 ; vol iv., pp. 333 and 423.

1879. Dairon, J., "On the Rocks and Graptolitic Shales of the Moffat district," Trans. Geol. Soc. Glasgou, vol. vi., p. 178.

1879. Dairon, J., "Note on the Reproduction and Development of Graptolites," Trans. Geol. Soc. Glasgow, rol. vi., p. 206. 
1880. Lapworth, C., "On Graptolites," Trans. Geol. Soc. Glasgow, vol. vi., pp. 260 and 303.

1880. Lapworth, C., "On new British Graptolites," Ann. and Mag. Nat. Hist., Feb., 1880, pp. 149-177.

1880. Dairon, J., "Notes on several new forms of Graptolites from the Silurian Shales of Dumfriesshire," Trans. Geol. Soc. Glasgow, vol. vii., p. 43.

1882. Lapworth, C., "The Girvan Succession," Q.J. G. S., vol. xxxviii., pp. 537-666.

1884. Macconnochie, A., "Review of the Southern Silurian question," Trans. Geol. Soc. Glasgow, vol. vii., pp. 370 and 431.

1884. Forsyth, D., "The Silurian rocks of the Girvan district," Trans. Geol. Soc. Glasgow, vol. vii., p. 558.

1889. Lapworth, C., "On the Ballantrae rocks of the South of Scotland and their place in the Upland Sequence," Geol. Mag., dec. iii., vol. vi., pp. 20 and 59.

1898. Elles, Miss G. L., "The Graptolite Fauna of the Skiddaw Slates," Q.J. G. S., vol. liv., p. 463.

1899. Peach, B. N., and Horne, J., "The Silurian rocks of Britain, vol. i., Scotland." Memoir of the Geol. Survey of the U.K. 


\title{
THE OLD RED SANDSTONE OF THE CLYDE AREA.
}

\author{
By J. G. Goodchild, F.G.S.
}

THe rocks usually classed under the general name of the Old Red Sandstone in Scotland consist of four separate formations, three of which are well represented within the basin of the Clyde. These three are widely separated from each other in time, and are linked together chiefly because they collectively occupy a geological position intermediate between that of the Silurian rocks below them and the Carboniferous rocks above. In addition to that they may be said to have had a common origin, seeing that they present various types of rocks formed under continental conditions ; in which respect they differ from the strata of marine origin which occur above and below them.

The key to their common characteristics is to be found in the fact that they were all deposited during a period of prolonged terrestrial disturbances during which movements of upheaval predominated, and maintained for long periods at a time climatal conditions of exceptional aridity.

Of the three subdivisions occurring in the basin of the Clyde the lowest has lately been classed as a member of the Silurian rocks. Under the name of the Lower Old Red Sandstone its geological position was accurately described by Murchison and Geikie. But when the fact came to be known that a newer Old Red lay unconformably upon it and was in turn unconformably succeeded by the true Upper Old Red, it became evident that some more distinctive name was needed for the lowest strata of the group, and this was more especially the case when palaeontological evidence rendered it clear that the Orcadian rocks were the true Middle Old Red. I therefore proposed to call these oldest rocks the Lanarkian rocks, with reference to the county in which they are typically represented. When, however, the officers of the Geological Survey re-examined these rocks, and it was found that they appeared to graduate downward into the Silurian rocks, and that they were linked on to them further by containing an ichthyic fauna having the same facies as that found in the associated strata of Silurian age, the name Downtonian was proposed instead, and is now coming into use.

The Downtonian rocks consist of alternating beds of sandstone and mudstone, characterised by reddish and greenish-grey colours, with which are associated one or more bands of fine conglomerate, whose predominant constituents are small pebbles of quartzite, with little or no intermixture of pebbles of greywacke. These strata are interstratified with others of the petrographical types prevalent in the underlying Ludlow rocks. No traces of any volcanic rocks have yet been found in them.

The entire aspect of the group is exactly what might be expected in the case of strata formed under transitional conditions when the area in which they occur was gradually passing from an area of subsidence to one of 
elevation. The reader will find this subject, and others comnected with the origin of the Old Red rocks in general, discussed at some length in the P'roceedings of the Royal Physical Society, vol. xiii., pp. 291-299.

Considerable interest attaches to this Lanarkian Old Red now that an abumdant and varied ichthyic fauna has been discovered in them, which has formed the subject of an important memoir by Dr. Traquair. ${ }^{1}$

I am inclined to think that the Lanarkian rocks were originally of considerable thickness, and that, while the terrestrial oscillations to which they are due were in progress, a band of marine limestone sinilar to the Plymouth limestone was formed in connection with them. But upon this point there is still some difference of opinion.

This, however, is certain; whatever strata may at one time have been formed in connection with these rocks they soon afterwards underwent considerable disturbance and denudation, which ended in the removal of nearly the whole of the Lanarkian rocks, as well as a considerable thicknessmany thousand of feet in all probability - of the older Silurian and Ordovician rocks. Hence it has happened that only a few fragmentary patches of the strata originally formed have been left, and of these a still smaller part has been exposed by later demudation. As a consequence, the Lanarkian rocks are now only to be seen within limited areas. One of these lies in the heart of the Pentland Hills, near the head-waters of the rivers Lyne and North Esk. Another occurs on the flanks of Tinto. The third, and perhaps the most important, occurs in connection with the Silurian outlier of the Logan Water, near Lesmahagow, and near Muirkirk.

The second division of the Old Red, in chronological order, is that great group of strata which forms the Pentland Hills, the Cheviots, the Uchils, the Sidlaws, etc. For this the name Lower Old Red Sandstone is still employed by many geologists ; but having regard to the confusion likely to arise from such a use of the term many others consider that it is as well to adopt some more distinctive term, and they therefore refer to these rocks as the Caledonian Old Red, seeing that it may be justly regarded as par excellence mHe Old Red of Scotland.

This formation, in the area under notice, lies upon an exceptionally uneven surface, which is shaped out of every rock older than the Caledonian old Red. In other words, there is an extensive and wide-spread unconformity, the base of the Caledonian Old Red overstepping all the rocks older than itself, from the highest surviving member of the Lanarkian Old Red down to the lowest Ordovician rocks occurring in the district. Further, its middle, or even its higher, subdivisions may overlap any one of the lower.

Usually the basement beds consist of purplish- and chocolate-coloured sandstones, which are well seen at the Falls of Clyde, and the area a few miles to the south. Uccasionally these are more or less conglomeratic, and very commonly there is at the base a well-marked band of conglomerate which is readily distinguished from the older conglomerate found in connection with the Lanarkian rocks by containing, amongst many other rocks, a large percentage of greywacke pebbles, derived from the waste of the ancient uplands of Silurian and Ordovician strata which formerly occupied the area to the south. This greywacke-conglomerate has been found to be a very useful datum by the officers of the Geological Survey who lately re-mapped the district.

As above renarked, the base of this formation is extremely variable as a consequence, chiefly, of the unevenness of the old land-surface upon which it accumulated. The irregularity is further increased by the fact that important volcanic outbreaks commenced at an early period in the history of the formation, and were continued throughout a period of great length.

${ }^{1}$ Trans. R. S. E., vol. xxxix., part 3. 
Quite commonly one of the ancient lava-streams may be found to end off suddenly, and sandstones, or even conglomerates, may be found side by side with it. This fact has to be borne in mind in considering the geology of the country around Tinto, and also many other areas in the Pentland Hills and elsewhere. On the southeastern flank of Tinto the Caledonian Old Red is represented by a series of andesitic lavas which overstep the various members of the Lanarkian rocks in a manner which impresses one very much with the importance of the chronological break between the two formations. On the opposite side of Tinto we find the basement beds to be simply conglomerates and sandstones, with not a trace of any volcanic rocks amongst them. It is the same elsewhere.

The general character of the Caledonian Old Red is that of a formation accumulated under continental conditions, when a certain degree of aridity characterised the climate. The torrential deposits from the ancient hills to the south were spread out on the lowlands and in the shallow waters of inland lakes, liable to be periodically dried up, wholly or in part. A chain of volcanos contributed occasional streams of lava, mostly of andesitic composition, and now and then explosive eruptions took place, from which beds of tuff, usually of no great thickness, were spread out far and wide over the adjacent land. The volcanos must have attained to considerable dimensions if one may judge by the magnitude of the remnants left. During the active phases of volcanic action some considerable masses of intrusive rock were left at different levels below the surface; while, at great depths below the rolcano, the slow cooling, under enormous pressure, of the last of the volcanic magmas gave rise to several interesting masses of granite, whose dominant petrographical varieties may be termed diorite-granites, but which, as might be expected, locally graduated into more basic, or more acid, varieties. Considerable thermometamorphism arose in connection with these intrusions, as may be seen in many places in the southwestern parts of the basin of the Clyde.

It is difficult, from the very fragmentary and disconnected nature of the existing remnants of the Caledonian Old Red, to form any reliable estimate of what its full thickness may have been. It is certain, however, that the maximum in any part of the basin of the Clyde must have been considerably less than has usually been considered to be the case.

As regards the life of the period when the Caledonian Old Red was being formed the evidence is scanty, and has to be sought chiefly outside the area. It is recorded, however, that the late Mr. Brown of Lanfine once found a specimen of Cephalaspis Lyelli in the sandstones near that place. Most of the other fossils recorded from these rocks have been obtained from areas beyond the linit of that specially under notice.

Remains of the Caledonian Old Red occur at several places within the basin of the Clyde. They appear in force near the foot of Loch Lomond, where they form the western end of the great tract constituting the Sidlaws, the Ochils, and Strathmore. Discontinuous patches are exposed at several localities between Lanark and Girvan, and others more extensive are, doubtless, concealed beneath the unconformable covering formed by the newer rocks. A third exposure is to be found in the northern half of the Island of Arran.

The andesitic lavas of these rocks form some of the chief repositories of the Agates or "Scotch Pebbles," for which the land has so long been famous.

The highest group of strata classed under the general name of the Old Red Sandstone is the Upper Old Red. It consists almost entirely of sandstones and conglomerates, which latter occur chiefly in its lower portion. It is characterised, on the whole, by a much brighter-red coloration than either of the others. In its upper part calcareous concretions or "cornstones" occur. These mark the passage-beds into the Carbonifcrous rocks. They 
are due (as the writer suggested some years ago) to the reducing action of organic matter upon aqueous solutions of sulphate of lime, and mark a transition-period from the extremely arid climatical conditions which prevailed during the earlier part of the period to the humid conditious which characterised the succeeding Carboniferous times. Everywhere the Upper Old Red lies with a strongly-marked unconformity upon the rocks below, including the granites which are contemporaneous with the Caledonian Old Red volcanic rocks.

The Upper Old Red Sandstone includes no volcanic rocks. It has yielded fossils at a few localities within the basin of the Clyde, chiefly at the Heads of Ayr.

There is some reason to believe that part of the rocks within the Clyde area which have been referred to the Upper Old Red Sandstone may really belong to the Bunter division of the New Red rocks. 


\title{
THE CARBONIFEROUS ROCKS OF THE CLYDE DRAINAGE AREA.
}

\author{
By Johy SHITH.
}

The Carboniferous strata of the Clyde drainage area, including the contemporaneous volcanic rocks and the later intrusive sills, reach a total thickness of several thousand feet. Following the divisions adopted by the officers of the Geological Survey the arrangement of the different series may be given as follows:

1. Upper Coal and Ironstone Series.

a. Red Sandstone, etc.

b. Coals, Ironstones, Fireclays, Shales, Oil-shales, White and Grey Sandstones.

2. Millstone Grit Series.

3. Upper Limestone Series.

4. Lower Coal and Ironstone Series.

5. Lower Limestone Series.

6. Calciferous Sandstone Series.

a. Cement Shales, and Grey Sandstones.

b. Red or Grey Sandstones with Cornstones.

Taking these divisions in ascending order we have first the

\section{Calciferods Sandstone Series.}

The strata of this group rest either on Silurian rocks, as at Lady Glen, Kilkerran, or on Old Red Sandstone, as near Sorn. The red or grey sandstones of the division contain few fossils-Lepidodendron, Calamites, etc. - and the Cornstone beds, once extensively worked near Galston, New Cumnock, Kirkmichael, Dailly, Ayr, Ardrossan, etc., both in opencast quarries and in mines, are now entirely abandoned. They are remarkable deposits, sometimes with layers of chert, containing, amongst the limey material, abundance of sand-grains, pebbles of agate, jasper, quartz, etc., but they are entirely unfossiliferous. In the red sandstones near West Kilbride occur footprints, probably reptilian, worm-trails, rain-prints, ripple-marks and sun-cracks. The cement-shales in the upper part of the series occasionally yield ostracods, fish-remains, and plants, as on the shore between the mouth of the River Doon and the Heads of Ayr, and in the district between Galston and Sorn they contain thin layers, some crowded with Spirorbis and others with small bivalves. No truly marine remains have been found in the Calciferous rocks of this area.

\section{Lower Limestone Series.}

This series may rest on the cement-beds, but where best developed in the Beith and Dalry districts it rests on a great thickness of volcanic debris 
which forms the upper part of the Dalry and Kilbirnie Hills. At Wildshaw near Douglas, however, it lies almost directly on the Old Red Sandstone. It contains a large proportion of the marine fauna of the Carboniferous rocks of Scotland. Near Campsie, Paisley, and Beith, it contains a bed with freshwater ostrocoda, and on the top of a thin coal below the lowest limestone in the Beith and Dalry districts a band with Naiadites crassa. Above the second limestone in the same localities and also at Kilwinning there is a "fish-bed" in which volcanic debris mixed with the limestone is penetrated by roots and rootlets of Stigmaria. Some of the beds of this series were at one time very exteusively worked for industrial purposes, but the workings are now confined to a few opencast workings near Beith and some pits near. Lesmahagow.

\section{Lower Coals and Ironstone Series.}

This series occurs in a succession of strata between the Lower and Upper Limestone series, and its economic bands of ironstone generally occupy the lower part. The coals range from three or four workable seams at Dalry and Kilbirnie to seven or eight at Dalquharran and Muirkirk where the series attains its greatest importance. One of the seams near New Cumnock was 40 feet thick, and the Johnstone coal is said to have been even thicker. There are but few indications of marine conditions having obtained during the deposition of the beds of this series, but many of freshwater ones. Above one of the coal-seams near Giffen there is a thick band crowded with Naiadites, and in the lower strata there are occasionally thin layers containing some of the smaller species of Carbonicola. In the shales associated with one of the ironstones huge spines of Gyracanthus are sparingly got, also Rhizodus Hibberti, and sometimes reptilian remains.

\section{Upper Limestone Series.}

Like the Lower Limestones these strata attain their full development near Dalry (the very thickest bed in the latter lies to the east of Beith), but they are also well represented near Muirkirk and Barrhead. At the last-named place one of the thicker beds has long been worked as a "cementstone." They, as a rule, contain more clay than the Lower Limestones, and so have seldom been burned for lime, but some of them yield good hard material for roads. One of the lower beds, known as the "Index limestone" is a "calm lime," that is, a limestone with almost no fossils large enough to be visible to the naked eye, and breaking with a conchoidal fracture. It has been largely used in iron-smelting, building, and agriculture. Chert sometimes occurs in these beds as well as in the Lower Limestones. Marine fossils are occasionally abundant in certain limestone bands and in their under and overlying shales. Under the chief bed of cement-stone at Dalry and at Thornliebank there is a hard shale with Estheria and some crustacean remains, and the last of the trilobites occurs in abundance at Bowertrapping. Corals are but feebly represented in this series. Some thick and good white and grey sandstones occur in it. Nearly all the limestone beds rest, as in the Lower Linestones, with very little intervening shale, ou thin coal-seams with under clays. A few of these coals swell out in places to a considerable thickness. I have come to the conclusion that the Scottish Carboniferous limestones, as well as those in the north of England, are sedimentary deposits, the finer limey material of which they are largely composed having been brought by marine currents from the sea-bed during shallow depressions of the areas over which they extend. Plenty of evidence can be produced in favour of this view, but it is too extensive a subject to be entered upon here. 


\section{Millstone Grit Series.}

The officers of the Geological Survey have introduced this series into their maps and memoirs, and have for this purpose drawn the base of the Upper Coal and Ironstone series at the slatyband ironstone, and they seem to have come to the conclusion that there is no Millstone Grit in the Kilwinning area. But the slatyband ironstone does occur there with several argument from the Survey point of view that there is no occurrence of the of the principal coals of the Upper series under it. If this represents the Millstone Grit it will include all the Upper Limestones and the sandstones immediately above and below the Lower and Upper beds.

\section{Upper Coal and Ironstone Series.}

The strata of this series occupy a very large area in Ayrshire and Lanarkshire, and are associated with the usual clays, shales, and white and grey sandstones of the division. Economically, where at its best, it contains about a dozen workable coals and several iroustones. The fossils generally belong to the genera Anthracomya and Carbonicola, which indicates freshwater or estuarine conclitions. C. robusta often extends in great "scalps" over large areas. In only one locality-near Coatbridge-do truly marine forms occur in the series, and Lingula is got in one or two places in Ayrshire. Spirorbis is found attached to plants and shells, S. helicteris occurring crowded into thin bands much in the same way as it is in the cementstone (Calciferous) group. Plant-remains occur scattered throughout all the series, or sparingly collected into thin bands known as "fern beds." Several oil-shales occur, and generally yield disjointed remains of fishes and sometimes reptiles. Gyracanthus is got, generally in the roof-shales of some of the coal-beds, ostracoda occur in some of the shales and ironstones, and Belinurus Prestwichia, Euphoberia, Xylobius, etc., have been obtained sparingly near Kilmaurs. At its upper part this series generally contains thick beds of reddish or purplish sandstones, shales of the same colours, and thin yellow sandstones. In the shale a thin limestone band with Spirorbis minutus occurs, and also burrows filled with shale, as is well seen at Ballochmyle Scar near Catrine. Other bands of limestone are apparently unfossiliferous. [This Spirorbis limestone also is found at the top of the Lower Coal series of England, near Manchester, there being twelve bands of it, and what have long been known as "The Upper Coal-measures" of Scotland are now considered to be the equivalents of the English Lower Coal-measures.]

The coal-seams of the Clyde drainage area number in their entirety about seventy, and they are all interesting from a geological point of view. The thin brownish layer-the old land- or swamp-surface-under them often contains a great variety of beautiful microscopic objects-Triletes and microspores-with remains of scorpions and eurypterids. These fossils are also got in the coals themselves, the hard layers (when not caused by clay) being often masses of their remains. These layers are called "splint."

The Permian rocks rest unconformably on the Upper Coal and Ironstone series, though sometimes, as in the Suar Valley, on the Silurians. 


\title{
THE CARBONIFEROUS FOSSIL PLANTS OF THE CLYDE BASIN.
}

\author{
By Robert Kinston, F.R.S.E., F.G.S.
}

Is Britain the Carboniferous formation is divisible into: ${ }^{1}$
Upper Carboniferous.
I. Upper Coal-measures.
II. Middle Coal-neasures.
III. Lower Coal-measures.
IV. Millstone Grit Series.
Lower Carboniferous. $\left\{\begin{array}{r}\text { V. Carboniferous Limestone Series. } \\ \text { VI. Calciferous Sandstone Series. }\end{array}\right.$

Of these only Nos. III., IV., V., and VI. occur in the Clyde area.

Locally the Lower Coal-measures are referred to as the "Upper CoaIs and Ironstones," and the coals of the Carboniferous Limestone series as the "Lower Coals and Ironstones," but as these terms are very misleading I have adopted a nomenclature which is applicable to the Carboniferous formation in its entirety in Britain.

One most interesting circumstance in regard to the vertical distribution of the Carboniferous flora is that, as far as observations have yet shown, not a single species (with the exception of Stigmaria) passes from the Lower Carboniferous into the Upper Carboniferous.

I am specially indelted for the Lanarkshire Coal-plants to Mr. R. Dunlop and Mr. P. Jack. For the Renfrewshire fossils I have received much assistance from Mr. Peter Macnair, and for the Ayrshire records I am very specially indebted to the Rev. Ur. Landsborough; also to Messrs. A. Sinclair, J. Rorrison, D. Beveridge, J. Stevenson, R. Linton, and others. Mr. J. Snith has submitted to me specimens from the Kilwinning district, and to the same geologist I owe the majority of the records from the Calciferous Sandstone series. To the Director of the Geological Survey of Scotland I owe my thanks for permission to include in the list the plants collected in Arran by Mr. A. Macconochie and Mr. D. Tait, but it is to Dr. W. Ivison Macarlam, F.P.S.E., that we owe our first knowledge of the Lower Carboniferous plants of Lochrin Burn. From the late Dr. John Young, the late Mr. A. Yaton, and the late Mr. James Bemie, $\mathrm{I}$ also received much assistance.

The list is divided into Lower Coal-neasures, Carboniferous Limestone series, and Calciferous Saudstone series. In mentioning the horizons of the Coal-measure plants, I merely give the name of the seam, but the fossils have. been derived in almost all cases from the shale forming the roof of the coal.

The following list of the various localities may be of assistance in finding. them :

${ }^{1}$ See Kidston, Proc. Rэy. Phys. Soc. Edin., vol. xii., 1894, pp. 183-258. 
Laxarkshire. Auchenheath, Lesmahagow; Bartonshill Pit, Bargeddie, $1 \mathrm{~m}$. W. of Coatbridge; Bent Coll., $1 \frac{1}{2} \mathrm{~m}$. E. of Bothwell ; Bellsdyke Pit, Mains, Airdrie; Brownieside Pit, Mains, Airdrie ; Brownrigg Pit, Longriggend, Airdrie ; Calderbank, Airdrie ; Dunsiston, Gartness, Airdrie ; Ellismuir, Baillieston ; Gartness, Airdrie ; Greengairs, Airdrie ; Howlit Glen, Crossford, Lesnahagow; Howlitness, Airdrie; Inkerman Pit, Airdrie: Lochwoorl, Easterhouse; Longriggend, Airdrie ; Souterhouse, Coatbridge ; Springhill Pit, Baillieston ; Stanrigg, Airdrie; Whiterigg, Airdrie.

Arrshire. Annandale Colliery, Kilmarnock; Ardeer, Stevenston ; Bonnington Pit, Kilmarnock ; Busbie, Kilnıarnock ; Bruntswood Mains, Galston ; Glenmuir Water; Dalblair, Old Cumnock; Grange Colliery, Kilmarnock; Hillhead, Kilmarnock; Springhill Colliery, Crosshouse ; Springside, Dreghorı; Windyedge, Crosshouse ; Woodhill Quarry and Colliery, Kilmaurs.

Resfrewshire. Braidwood Quarry, Giffnock.

Bute. Cock of Arran; Lochrin Burn, Corrie, Arran.

Horizons are printed in italics throughout the list.

\section{UPPER CARBONIFEROÚS.}

Lower Coal-measures.

Filicaceae.

Sphenopterideae.

Sphenopteris obtusiloba, Brongt.-Lanark. Sourmilk Coal,-Ry. cutting, Airrlrie: Ell Coal,-Carluke: Kiltongue Coal,-Mt. Vernon: Howlitness: Foxley : Bent Col.: Lochwood Col.: Blaes betu. Kiltongue and Dinmgray Coals, - Whiterigg: Drumgray Coal,_Castlehill, Carluke : (Hor. ?)-Bothwell: Springhill Pit. Ayr. Small seam 13 fms. abore 1/. Waught Coal,-Grange Col. : Stranger Coal,-Grange Col. : Major. Coal,-3 Pit, Springhill: (Hor. ?)-Galston.

S. nummularia, Gutbier.-Lanark. Kiltongue Coal,-Howlitness.

S. Schillingsii, Andrae-Lanark. (Hor. ?)-Airdrie.

S. latifolia, Brongt.-Lanark. Kiltongue Coal,-Carluke: Mt. Vernon: (Hor:?)-Springhill Pit: Auchenheath : Howlit Glen. Ayr. Stranger Coal,-Grange Col. : $18 \mathrm{ft}$. aboie Durroch Coal,-Woodhill Quarry: Turf Coal,-Ardeer: (Hor.?)-Galston.

? S. rotundifolia, Andrae.-Lanark. Shale betw. Kiltongue and Drumgray Coals,-Whiterigg.

S. rutaefolia, Gutbier.-Lanark. Kiltongue Coal,-Lochwood Col.

S. germanica, Potonié.-Lanark. Kiltongue Coal,-Ellismuir.

? S. spinosa, Göpp.-Ayr. Stranger Coal,-Grange Col.

S. furcata, Brongt.-Lanark. Sourmilk Coal,-Py. cutting, Airdrie : Main Coal,-Souterhouse: Kiltongue Coal,-Calderbank: Foxley : Souterhouse : Lochwood Col. : Dirumgray Coal,-Black Pit, Longriggend. Ayr. Major Coal,-3 Pit, Springhill Col. : $18 \mathrm{ft}$. above Durroch Coal,-Woodhill Quarry: Whistler Seam,-Bounington Pit.

S. Walteri, Stur.-Lanark. (Hor. ?)-River Avon, near Hamilton.

S. Sternbergii, Ett.-Lanark. Kiltongue Coal,-Brownrigg Pit. Ayr. 2 fins. below Ell Coal,-Busbie Pit, Kilmaurs.

Eremopteris artemisiaefolia, Stemb., sp.-Lanark. Kiltongue Coal,Souterhouse : (Hor. ?)-Howlit Glen : Farme Col., Rutherglen (type of Sphenopteris stricta, Brongt.): Bothwell: Carluke. Ayr. Stranger Coal,Grange Col.

Renaultia Footneri, Marrat., sp.-Lanark. Kiltongue Coal,-Lochwood Col.: Calder Ironworks: Ellismuir Col. : Mt. Vernon: Calderbank: Foxley. Ayr. Pavement under Tourha' Coal,-3 Pit, Springhill : Major Coal,-3 Pit, Springhill. 
Renaultia Schatzlarensis, Stur., sp.--Lanark. Kiltongue Coal,-Cal. Ry. Bridge, Calderbank.

Urnatopteris tenella, Brongt., sp.--Lanark. Kiltongue Coal,-Baillieston : Calderbank : Ellismuir : Cairnhill, Airdrie : Howlitness : Rawyards Pit, Airdrie: L. Drumgray Coal,--Howlitness: (Hor.?)-Scrawhill Col., Airdrie: Bartonshill Pit, Bargeddie. Ayr. Stranger Coal,--Grange Col. Cyclocheta biseriata, Kiidston.-Lanark. Kiltongue Coal,-Baillieston.

\section{Pecopterideae.}

Mariopteris muricata, Schl., sp.-Lanark. Kiltongue Coal,--Bent Col. : Calderbank: Greengairs: (Hor.?)-Auchenheath: Tollcross: Chapelhall, Airdrie : Blaes betw. Kiltongue and U. Drumgray Coals,-Whiterigg Col. Ayr. Major Coal,-3 Pit, Springhill : Stranger Coal,-Grange Col.: 18 ft. above Durroch Coal,--Woodhill Quarry: Whistler Coul,-Bonnington Pit: Kilwinning Main Coul,-Borough Pit, Irvine: Main Coal,-10 Pit, Springside Col. : Amandule Main Coal,--Windyedge Pit: (Hor. ?)-Hillhead Pit: Gauchallan Pit, Galston : Lucknow Pit, Stevenston. Bute. 15 yds. above junct. with Never Red Rocks,-Corrie : $20 y d s$. S. of junct. with Never Red Rocks,-Shore, Cock of Arran.

M. muricata, var. nervasa, Brongt. sp.-Lanark. Kiltongue Coal,-Bent Col. : Mt. Vernon : Calderbank : U. Drumgray Coal.-Pit near Calder Ironworks : (Hor.?)—Chapelhall, Airdrie: Howlit Glen. Ayr. Stranger Coal,-Grange Col.: $18 \mathrm{ft}$. above Durroch Coal,--Woodhill Quarry : (Hor. ?)-Lucknow Pit, Stevenston.

\section{Alethopterideae.}

Alethopteris lonchitica, Schl., sp.-Lanark. Main Coal,-Newmains, Cambusnethan: Kiltongue Coal,-Foxley: Mt. Vernon: Carluke: Souterhouse : Brownrigg Pit : Bent Col. : Calderbank : Lochwood Col. : Ellismuir Col.: Blaes betw. Kiltongue and U. Drumgray Coals,--Whiterigg Col.: (Hor. ?)-Holytown: Springhill Pit: Howlit Glen. Ayr. $18 \mathrm{ft}$. above Durroch Coal,-Woodhill Quarry : Whistler Seam,-Bonnington Pit: 2 fms. below Ell Coal,-Busbie Pit: Splint Coal,-16 Pit, Woodhill Col.

A. decurrens, Artis., sp.-Lanark. Kiltongue Coal,-Foxley: Lochwood Col. : L. Drumgray Coal,-Bellsdyke Pit: (Hor.?)-Near Holytown. Ayr. Bed betw. Major and Main Coals,-10 Pit, Springside: Amandale Main Coal,-10 Pit, Springside: 18 ft. above Durroch Coal,-Woodhill Quarry : Lin Bed,--Springhill Col.

Lonchopteris Eschweileriana, Andiae-Lanark. Kiltongue Coal,-Ellismuir.

\section{Neuropterideae.}

Neuropteris heterophylla, Brongt._Lanark. Sourmilk Coal,-Ry. cutting, Airdrie: Kiltongue Coal,--Mit. Vernon: Bent Col.: Foxley: Calderbank: Loch wood Col. : Ellismuir: Betw. Kiltongue and Drumgray Coals, - Whiterigg: U. Drumgray Coal,-Pit near Calder Ironworks: L. Drumgray Coal, -Pit near Coatbridge: (Hor. ?)-Howlit Glen. Ayr. M/'Naught Coal, -3 Pit, Springhill: $18 \mathrm{ft}$. above Durroch Coal,-Woodhill Quarry: Whistler Seam,-Bonnington Pit: Major Coal,-3 Pit, Springhill: Betw. Major and Main Coals,-10 Pit, Springside: Five-quarter Coal,-Stevenston: Splint Coal,-16 Pit, Woodhill Col. : Lin Bed,--9 Pit, Annandale Col.: (Hor. ?)-Ardeer : Goatfoot Pit, Galston. Bute. About 15 yds. above junct. with Never Red Rocks,-Lochrin Burn: (Hor.?)-Sliddery Water-head, Arran.

N. obliqua, Brongt., sp.-Lanark. Kiltongue Coal,-Mt. Vernon : Ellismuir : Brownrigg : Lochwood Col. 
Neuropteris gigantea, Sternb.-Lanark. Kiltongue Coal,-Dit at Ry. Sta., Baillieston: Lochwood Col.: Foxley : Greengairs: Bent Col. : Coatbridge. Ayr. About $18 \mathrm{ft}$.above Durroch Coal,-Woodhill Quarry: Main Coal,Wellington Pit, Hurlford: 10 Pit, Springhill Col.: Whistler Seam,Bonnington Pit: Lin Bed,-9 Pit, Annandale Col. (Hor.?)-Hillhead Pit: Goatfoot Pit, Galston. Bute. Above Limestone, Maoldon, north face, Corrie : :20 yds. S. of junct. with Never Red Rocks,-Shore, Cock of Arran.

N. acuminata, Schl. sp.-Lanark. Filtongue Coal,-Ellismuir: Lochwood Col. : Blaes betw. Kiltongue and Drumgray Couls,-Whiterigg Pit.

N. crenata, Brongt.-Ayr. About $18 \mathrm{ft}$. above Durroch Coal,-Woodhill Quarry.

N. Blissii, Lesqx.--Ayr. Whistler Seam,-Bonnington Pit.

Filicaceae. Incertae Sedis.

Rhacophyllum (?) anomalum, Brongt.-Lanark. Kiltongue Coal,-Ellismuir.

\section{Calamarieae.}

Group I. Calamitina.

Calamites varians, Sternb.-Lanark. $\quad U$. Drumgray Coal,-Airdrie. Bute. 20 yds. S. of junct. with Newer Red Rocks,-Shore, Cock of Arran.

C. varians, var. insignis, Weiss.-Ayr. About $18 \mathrm{ft}$. above Durroch Coal,Woodhill Quarry.

C. approximatus, Brongt. (in part).-Ayr. About $18 \mathrm{ft}$. above Durroch Coal, -Woodhill Quarry : Five-quarter Coal,-Stevenston : (Hor. ?)-Ardeer : Bruntwood Mains.

C. verticillata, L. and H.-Ayr. Major Coal,-3 Pit, Springhill.

C. Gopperti, Ett.-Ayr. Major Coal,-3 Pit, Springhill.

C. undulata, Sternb.-Lanark. Filtongue Coal.-Foxley. Ayr. Stranger Coal,-Grange Pit: Whistler Seam,-Bonnington Pit : Splint Coal,-16 Pit, Woodhill.

\section{Group II. Euculamites.}

C. ramosus, Artis.-Lanark. Filtongue Coal,-Foxley: Bent Col. : Mt. Vernon : Calderbank: Bellsdyke Pit: Blaes betw. Kiltongue and Drumgray Coals,-Whiterigg: U. Drumgray Coal,-Inkerman Pit : L. Drumgray Coal,-Pits, Airdrie : Shale a short distance above Millstone Grit,Dennistoun, Glasgow. Ayr. Major Coal,-3 Pit, Springhill : $18 \mathrm{ft}$. above Durroch Coal,-Woodhill Quarry: Whistler Seam,-Bonnington Pit: Irvine Water, near Kilmarnock: Lin Bed,-3 Pit, Springhill: (Hor.?)-Galston. Bute. Above Limestones,-Maoldon, north face, Corrie : 20 yds. S. of junct. with Newer Red Rocks,-,Shore, Cock of Arran.

\section{Group III. Stylocalamites.}

C. Suckowii, Brongt.-Lanark. Kiltongue Coal,-Ellismuir : Bent Col. : Calderbank: Foxley : Bartonshill Pit, Baillieston : Mt. Vermon : Lochwood Col. : U. Drumgray Coal,-Inkerman Pit: Pit near Calder Ironworks : L. Drumgray Coal,-Pits near Airdrie ; Drumgray Coal,-Gartness. Ayr. About $18 \mathrm{ft}$. above Durroch Coal,-Woodhill Quarry: Major Coal,3 Pit, Springhill : Whistler Seam,-Bomnington Pit: Dean, Kilmarnock Water: Turf Coal,-Redburn, Kilwinning: Splint Coal,-10 Pit, Annandale Col.: Shale near Annandale Main Coal,-Windyedge: (Hor?)-Hurlford, Kilmarnock : Stevenston : Bruntswood Mains.

C. Cistii, Brongt.-Lanark. Kiltongue Coal,-Lochwood Col. : L. Drumgray Coal,-Pit near Calder Ironworks: (Hor.?)-Auchenheath. Ayr. (Hor. ?)—Streethead Pit, Galston. 
Calamocladus equisetiformis, Schl., sp.-Lanark. Kiltongue Coal,-Bent Col. : Calderbank : Howlitness : Rawyards, Airdrie : Foxley : Ellismuir : Blaes betw. Kiltongue and Drumgray Coals,-Whiterigg: Virtuewell Coal,-Bellsdyke Pit: Shale a short distance above Millstone Grit,Deunistoun, Glasgow. Ayr. Major Coal,-3 Pit, Springhill : M'Naught Coal,-3 Pit, Springhill : About $18 \mathrm{ft}$. above Durroch Coal,-Woodhill Quarry: Whistler Seam,-Dean Water, Kilmarnock : 2 fms. below Ell Coal,-Busbie Pit : Lin Bed,-Cauldhame Pit, Springhill Col. : (Hor. ?) -Thornton Quarry, Crosshouse.

C. longifolius, Sternb., sp.-Lanark. (Hor. ?)-Howlit Glen : Kiltongue Coal,_Calderbank (sp. ?): 10 yds. below U. Drumgray Coal,-Longriggend (sp. ?).

C. grandis, Sternb., sp.-Lanark. Kiltongue Coal,-Bent Col. : Calderbank.

C. lycopodioides, Zeiller, sp.-Lanark. Kiltongue Coal,-Foxley.

Calamostachys typica, Schimper (in part).-Lanark. Kiltongue Coal,Foxley. Ayr. Stranger Coal,-Grange Col.

? C. longifolia, Weiss.-Lanark. Kiltongue Coal,-Pit beside Ry. Sta., Baillieston.

? C. nana, Weiss.-Lanark. Kiltongue Coal,-Pit beside Ry. Sta., Baillieston.

Palaeostachya pedunculata, Will.-Lanark. Main Coal,-Craigneuk, Motherwell.

P. gracillima, Weiss.-Lanark. Kiltongue Coal,-Calderbank : Foxley.

Stachannularia northumbriana, Kidston.-Ayr. Whistler Seam,-Bonnington Pit.

Annularia radiata, Brongt.-Lanark. Kiltongue Coal,-Baillieston: Carluke: Longriggend: Howlitness : Calderbank : Foxley : Lochwood Col. : Greengairs: Main Coal,-Holytown : Drumgray Coal,--Longriggend : L. Drumgray Coal,-Pit near Airdrie : Virtuewell Coal,-Bellsdyke Pit : (Hor. ?)-Howlit Glen: Auchenheath. Ayr. Major Coal,-3 Pit, Springhill : About $18 \mathrm{ft}$. above Durroch Coal,-Woodhill Quarry : Whistler Seam,-Bonnington Pit: (Hor. ?)-Prince Pit, Stevenston : Galston.

A. galioides, L. \& H., sp.-Ayr. Major Coal,-3 Pit, Springhill.

\section{Sphenophylleae.}

Sphenophyllum cuneifolium, Sternb. (including forma saxifragaefolium, Sternb.).-Lanark. Kiltongue Coal,-Mt. Vernon : Foxley : Bent Col. : Calderbank: Lochwood Col.: Blaes betw. Kiltongue and Drumgray Coals,-Whiterigg: L. Drumgray Coal,-Pit, Airdrie. Ayr. Major Coal,-3 Pit, Springhill : M'Naught Coal,-3 Pit, Springhill : About 18 ft. above Durroch Coal,-Woodhill Quarry : Whistler Seam,-Bonnington Pit: Lin Bed,-3 Pit, Springhill.

S. myriophyllum, Crépin.-Bute. 20 yds. S. of junct. with Newer Red Rocks, -Shore, Cock of Arran.

\section{LYCOPODIACEAE.}

Lepidodendron ophiurus, Brongt.-Lanark. Kiltongue Coal-Bent Col.: Cairnhill, Airdrie : Howlitness : Sourmilk Coal,-Ry. cutting, Airdrie : L. Drumgray Coal,-Pit, Airdrie : Brownieside Pit: Drumgray Coal,Dunsiston: Tirtuewell Coal,-Gartlea, Airdrie: Main Coal,--Stanrigg : Oil shale,-Airdrie: (Hor. ?)-Pit, Gartuess. Ayr. About $18 \mathrm{ft}$. above Durroch Coal,-Woodhill Quarry: Whistler Seam,-Bonnington Pit: Main Coal,-Kilwinning: Shale betw. Splint Coal and Blackband Ironstone,-Alnwick Lodge, Irvine: Hurlford Main Coal,-New Mill Pit, Kilmarnock: 2 fms. below Ell Coal,-Busbie Pits: (Hor. ?)Brututswood Mains.

L. lycopodioides, Sternb.-Lanark. Drumgray Coal,-Greengairs. 
Lepidodendron Landsburgii, Kidston.-Lanark. Drumgray Coal,--Dunsiston. Ayr. Whistler Seam,-Bonnington Pit.

L. aculeatum, Sternb.-Lanark. Humph Coal,-Airdrie : Kiltongue Coal, -Whiterigg: Brownrigg: (Hor. ?)-Bellsdyke. Ayr. Stranger Coal, -Grange Col. : Whistler Seam,-Bomnington Pit: Near Stevenston : Hurlford Main Coal,-Wellington Pit, Hurlford: (Hor. ?)-Bruntswood Mains.

L. aculeatum, forma modulatum, Lesq. . Ayr. Whistler Seam,-Bonnington Pit.

L. Jaraczewski, Zeiller.-Lanark. Kiltongue Coal,-Ellismuir : Gartness Col. : Mt. Vernon.

L. Gaudryi, Renault.-Lanark. Kiltongue Coal,-Lochwood Col. : Brownrigg.

L. obovatum, Sternb.-Lanark. Kiltongue Coal,-Mt. Vernon : Foxley: Blackband Ironstone,-Stanrigg: Oil Shales,-Airdrie : (Hor. ?)-Bellsdyke : Coal Burn, Lesmahagow. Ayr. Whistler Seam,-Bonnington Pit: Splint Coal,-9 Pit, Ammandale Col.: Tourha' Coal,-Cauldhame Pit, Kilmaurs.

L. serpentigerum, König.-Lanark. Immediately above Millstone Grit,Stanrigg Pit. Ayr. Stranger Coal,-Grange Col.

L. rimosum, Sternb.-Lanark. Drumgray Coal,--Greengairs.

L. fusiforme, Corda.-Ayr. Shale over roof of Durroch Coal,-Woodhill Pit.

Lepidostrobus variabilis, $L$. and H.-Lanark. Kiltongue Coal,-Bent Col.: Mt. Vernon: U. Drumgray Coal,--Pit near Calder Ironworks: Drumgray Coal,-Dunsiston: Blackband Ironstone, Airdrie: Shale a short distance above Millstone Grit,-Dennistoun, Glasgow. Ayr. About $18 \mathrm{ft}$. above Durroch Coal,-Woodhill Quarry: Major Coal,-3 Pit, Springhill: Whistler Seam,-Bonnington Pit: 2 fms. below Ell Coal,Busbie.

L. spinosus, Kidston.-Ayr. Whistler Seam,-Bonnington Pit.

L. squarrosus, Kidston.-Ayr. Whistler Seam,-Bonnington Pit.

L. Geinitzii, Schimper.-Lanark. (Hor. ?)-Airdrie : Pit, Calder Ironworks. Ayr. Blackband Ironstone,-Dalmellington : 2 fims. below Ell Coal,-Busbie Pits: Ironstone Bed betu. Raise Road Coal and Calm Limestone,-Rankinston.

Lepidophyllum lanceolatum, L. and H.-Lanark. Kiltongue Coal,-Bent Col.: Calderbank : Lochwood Col. : L. Drumgray Coal,-Pit, Airdrie. Ayr. $18 \mathrm{ft}$. above Durroch Coal,-Woodhill Quarry.

L. intermedium, L. and H.-Lanark. Kiltongue Coal,-Calderbank.

Lepidophloios acerosus, L. and H., sp.-Lanark. Filtongue Coal,-Foxley : Calderbank: Lochwood Col. : Greengairs: Brownrigg : L. Drumgray Coal,-Pit near Coatbridge. Ayr. Durroch Coal,-Woodhill Old Pit: Whistler Seam,-Bonnington Pit.

Halonia, L. and H.-(Decorticated fruiting branch of Lepidophloios.)

H. regularis, L. and H.-Ayr. $18 \mathrm{ft}$. above Durroch Coal,-Woodhill Quarry: Whistler Seam,-Bonnington Pit : Blackband Ironstone,-Dalmellington : (?) Ardeer Quarry.

Bothrodendron punctatum, L. and H.-Ayr. Major Coal,-3 Pit, Springhill: Whistler Seam,-Bonnington Pit.

B. minutifolium, Boulay-Lanark. Kiltongue Coal,-Calderbank: Ellismuir: Lochwood Col. : Blaes betw. Kiltongue and Dirungray Coals,-Whiterigg. Ayr. Whistler Seum,-Bonnington Pit.

Sigillaria discophora, König.-Lanark. Kiltongue Coal,-,Shettleston : Howlitness : Drumgray Coal,-Dunsiston : L. Drumgray Coal,--Toad Pit, Airdrie: Humph Coal,-Airdrie: (Hor. ?)--Shotts Ironworks. Ayr. Whistler Seam,-Bonnington Pit: Borland Water, Kilmarnock: 2 fms. belor Ell Coal,-Busbie Pits : Parrot Coal,-10 Pit, Springside Col.: 
Blackband Ironstone,--Dalmellington: Ironstone Bed betw. Raise Road Coal and Calm Limestone,-Rankinston.

Sigillaria camptotaenia, Wood, sp.-Ayr. Major Coal,-3 Pit, Springhill.

S. tessellata, Brongt.-Ayr. Tourha' Coal,-Bomnington Pit.

S. scutellata, Brongt.-Lanark. Kiltongue Coal,-Bent Col. : Bed betw. Pyotshaw and Main Coals,-Whiterigg: Main Coal,-Stamrigg. Ayr.

Whistler Seam,-Bomington Pit.

S. Walchii, Sauveur.-Ayr. Turf Coal,-Kilwinning.

S. Arzinensis, Corda.-Ayr. Main Coal,-Annandale Col.

S. orbicularis, Brongt.-Ayr. Whistler Seam,-Bonnington Pit.

S. laevigata, Brongt., var.-Lanark. Kiltongue Coal,--Mt. Vernon.

Sigillariostrobus, sp.-Ayr. Major Coal,-3 Pit, Springhill.

Stigmaria ficoides, Sternb., sp.-Lanark. Common. Ayr. Common.

S. reticulata, Göpp.-Lanark. Betw. Pyotshaw and Main Coals,-Airdrie.

Ayr. Major Coal,-3 Pit, Springhill : M'Naught Coal,-4 Pit, Springhill : Splint Coal,--Annandale Pit.

\section{Cordaiteae.}

Cordaites principalis, Germar., sp.-Lanark. Kiltongue Coal,-Bent Col. : U. Drumgray Coal,-Pit near Calder Ironworks: L. Drumgray Coal,Brownieside Pit. Ayr. Stranger Coal,-Grange Pit: Major Coal,-3 Pit, Springhill: Whistler Seam,-Bonnington Pit. Bute. 72 yds. from junct. with Newer Red Rocks: 20 yds. S. of junct. with Newer Red Rocks,-Shore, Cock of Arran.

Cordaianthus Pitcairniae, L. and $H$., sp. (including Cardiocarpus acutus, L. and H.).-Lanark. Kiltongue Coal,-Brownrigg: Bent Col. : Foxley: Greengairs : U. Drumgray Coul,-Longriggend. Ayr. Stranger Coal,Grange Col. : Major Coal,-3 Pit, Springhill ; Whistler Seam,-Bonning. ton Pit: (Hor. ?)--Borough Pit, Irvine.

Cardiocarpus crassus, Lesqx.-Lanark. Kiltongue Coal,-Greengairs : Ellismuir.

C. orbicularis, Ett.-Ayr. Major Coal,-3 Pit, Springhill.

Carpolithus perpusillus, Lesq.x.-Lanark. Kiltongue Coal,--Rawyards, Airdrie: Howlitness; Bredisholm, Baillieston. Ayr. Small Coal, 13 fms. above M'Naught Coal,--Grange Col.: Whistler Seam,-Bonnington Pit.

Trigonocarpus Parkinsoni, Brongt.-Lanark. Kiltongue Coal,-Foxley: Souterhouse : Pit near Coatbridge : Mt. Vernon : Lochwood Col. : Shale a short distance above Millstone Grit,-Dennistoun, Glasgow. Ayr. Whistler Seam,-Bonnington Pit: Sandstone-Conglomerate roof of Fivequarter Coal,--Ardeer Quarry.

T. Parkinsoni, forma alata, L. and H., sp.-Ayr. Whistler Seam,-Bonnington Pit.

Rhabdocarpus elongatus, Kidston.-Lanark. Kiltongue Coal,-Mt. Vernon: Calderbank: Greengairs: Foxley. Ayr. Major Coal,-3 Pit, Springhill.

Artisia approximata, Brongt.-Lanark. Kiltongue Coal,-Brownrigg. Ayr. Whistler Coal,-Bonnington Pit: Five-quarter Coal,-Ardeer.

Pinnularia capillacea, L. and H.-Lanark. Kiltongue Coal,-Foxley : Lochwood Col.: (Hor.?)—Airdrie: Castlehill, Carluke. Ayr. Whistler Seam,-Bonnington Pit: Major Coal,-3 Pit, Springhill : Bed betw. Major and Main Coals,-3 Pit, Springhill.

Incertae Sedis.

Psitotites unilateralis, Kidston, sp.-Lanark. (Hor. ?)-Baillieston. 


\section{LOWER CARBONIFEROUS.}

Carboniferous Limestone Series.

Algate.

Spirophyton cauda-galli, ranuxem, sp.-Stirling. Corrieburn, Campsie : Spouthead Burn, Miltou of Campsie. Ayr. Den, Dalry.

\section{Filicaceae.}

\section{Sphenopterideae.}

Sphenopteris Ettingshauseni, Feistm.-Lanark. Calderwood Group,E. Kilbride.

S. Haueri, Stur.-Lanark. Calderwood Group,-E. Kilbride.

S. elegans, Brongt.-Renfrew. Immediately under Orchard Limestone,-New Braidbar Quarry.

S. moravica, Ett.-Renfrew. Immediately under Orchard Limestone,-New Braidbar Quarry.

S. subtrifida, Stur.-Renfrew. Immediately under Orchard Limestone,New Braidbar Quarry.

S. Gersdorfii, Göpp, sp.-Lanark. Calderuood Group,-E. Kilbride.

Sphenopteridium dissectum, Göpp, sp.-Lanark. Calderuood Group,E. Kilbride. Bute. Shale over U. Limestone,-Waterfall, Lochrin Burn. Rhacopteris inaequilatera, Göpp, sp.-(Adiomtites Lindseaeformis, Bunbury.) Lanark. Calderwood Group,-Kirktonholm, and Burnbrae Old Quarry E. Kilbride: (Hor. ?)--Braidwood.

R. transitionis, Stur.-Lanark. Calderwood Group,-E. Kilbride.

? R petiolata, Göpp, sp.-Lanark. Calderwood Group,-E. Kilbride.

Adiantites Machaneki, Stur.-Lanark. Calderwood Group,-E. Kilbride.

A. bellidulus, Heer--Bute. Sliddery Water-head, Arran.

Archaeopteris Tschermaki. Stur.-Lanark. Calderwood Group,-E. Kil. bride.

Plumatopteris elegans, Kidston.-Lanark. Calderwood Group,-E. Kilbride.

Calymmatotheca Stangeri, Stur:-Renfrew. Immediately under Orchard Limestone,-New Braidbar Quarry.

\section{Pecopterideae.}

Dactylotheca aspera, Brongt., sp.-Renfrew. Immediately under Orchard Limestone,-New Braidbar Quarry.

\section{Neuropterideae.}

Neuropteris antecedens, Stur.-Lanark. Calderwood Group,-E. Kilbride. Cardiopteris nana, Eichwald, sp.-Lanark. Calderwood Group,-E. Kilbride. Bute. 130 yds. N. of Hurlet Limestone,--Shore, N. of Laggan, Arran.

\section{Callamarieae.}

Asterocalamites scrobiculatus, Schl., sp.-Lanark. Calderwood Group,E. Kilbride. Renfrew. Immediately under Oichard Limestone,--New Braidbar Quarry. Bute. Shale over U. Limestone,-Waterfall, Lochrin Burn. In Tuff,-Sliddery Water-head, Arran.

Volkmannia Morrisii, Hooker--Lanark. Ironstone miduay betw. Cannel Coal and Main Limestone,-Carluke.

\section{SPHENophyLLEAE.}

Sphenophyllum tenerrimum, Ett.-Lanark. Possil Ironstone series, horizon of Robroyston Limestone,--Robroyston. 
LYCOPODIACEAE.

Lepidodendron Veltheimianum, Sternb.-Lanark. Possil Ironstone series,Victoria Park, Whiteinch : Possil : Keppoch Hill : Calderwood Group,Limekilns, E. Kilbride: (Hor. ?)-Carluke. Ayr. Clayband Ironstone,-Dalry. Renfrew. Immediately under Orcliard Limestone,New Braidbar Quarry. Bute. Shale over $U$. Limestone,-Waterfall, Lochrin Burn: In Tuff,-Sliddery Water-head, Arran.

L. spetsbergense, Nathorst.-Renfrew. Immediately under Orchard Limestone,-New Braidbar Quarry.

L. Rhodeanum, Sternb.-Lanark. Calderwood Group,-E. Kilbride. Renfrew. Immediately under Oichard Limestone,-New Braidbar Quarry. Bute. Shale over U. Limestone,-Waterfall, Lochrin Burn.

Lepidophloios Wunschianus, Will.-Bute. Volcanic Ash,--Laggan Buru, Arran.

Sigillaria Taylori, Carr:-Renfrew. Immediately under Orchard Limestone, - New Braidbar Quarry.

S. Youngiana, Kidston.-Lanark. Possil lionstone series,-Robroyston.

Stigmaria ficoides, Sternb., sp.-Common.

S. stellata, Göpp.-Bute. Shale over U. Limestone,-Waterfall, Lochrin Burn. Ayr. Loose in Boulder-clay,-Bent, Galston : Bruntswood Mains : Townhead, Riccarton: (Hor.?)-Stream near Darvel.

\section{Cordaitean.}

Carpolithus sulcatus, L. and H.-Bute. Shale over Upper Limestone,Waterfall, Lochrin Burn.

Trigonocarpum Gloagianum, J. Young.-Lanark. Calderwood Group,-E. Kilbride.

\section{Calciferous Sandstone Series.}

Filicaceae.

\section{Sphenophterideae.}

Sphenopteris elegans, Brongt.-Ayr. Glenmuir Water.

S. moravica, Ett.-Ayr. Glenmuir Water.

Sphenophylleae.

Sphenophyllum tenerrimum; Ett.-Ayr. Glenmuir Water.

\section{Lycopodiaceae.}

Stigmaria ficoides, Sternb.--Dumbarton. Glenarbuck, Bowling.

Cordaiteae.

Araucarioxylon fasciculare, Scott-Dumbarton. L. Humphrey Burn, Kilpatrick Hills. 


\title{
THE CARBONIFEROUS FORAMINIFERA OF THE CLYDE DRAINAGE AREA.
}

\author{
By (the late) John Young, LL.D., F.G.S.
}

The Carboniferous Foraminifera of the West of Scotland are found in nearly atl the fossiliferous Marine Limestones and their.accompanying shales, though certain forms are often restricted to particular horizons and localities. During the earliest years of. research specimens were almost entirely obtained from the weathered and rotted limestones and shales, which, on being carefully washed and examined, yielded a considerable number of species, but more recently, through the use of transparent.sections ground down from the harder strata, many interesting species have been added to the lists.

When the late Dr. H. B. Brady began his well-known Monograph on "The British Carboniferous Foraminifera," issued by the Palaeontographical Society in 1876 , nearly all the genera and species of foraminifera submitted for his determination were sent as single specimens detached from the rock-matrix, and he had to section many of them to transparency, often with considerable difficulty, in order to obtain a knowledge of their shell-walls and internal structure. Had the same work now to be gone through Dr. Brady would have been spared much labour by the aid of the many microscopic sections which would have been at his disposal.

- Further particulars of the West of Scotland foraminifera will be found in a paper by the late Dr. Young, which he read before the Geological Society of Glasgow in $1891 .{ }^{1}$

The divisions of the Carboniferous rocks which yield the foraminifera are indicated in the following list by heary letters-U. L. S., Upper Limestone Series ; L. I. S., Lower Limestone Series.

Lituola Bennieana, Brady.-U.L.S. Linn, Dalry.

Saccammina Carteri, Brady.-L.L.S. Braid wood, Carluke, Campsie, Beith, (Main Limestone).

Climacammina antiqua, Brady-L.L.S.S. Muirkirk.

Trochammina incerta (d'Orb.).-L.L.S., U.L.S. Nuirkirk, Robroyston, Dalry.

T. centrifuga, Brady.-L.L.S., U.L.S. Muirkirk, Robroyston, Dalry.

T. annularis, Brady.- L.I.S. Capelrig, Kilbride.

T. gordialis, $P$. and J.-L.L.S. South Shields, Kilbride, Dalry.

T. pusilla (Geinitz).-L.L.S., U.L.S. Trearne, Beith, Gare, Carluke.

1 "Notes on a small group of Carboniferous Foraminifera found in the Lower Limestone Shales of the MLuirkirk district in Ayrshire, with a list of the Genera and Species found in the Coal-fields of Western Scotland." By John Young, F.G.S., V.P. Trans. Geol. Soc. of Glasgow, vol. ix., part 2, 1893, p. 313. 
Trochammina anceps, Brady.-L.L.S. Capelrig.

T. Robertsoni, Brady.-U.L.S. Gare, Carluke.

Valvulina palaeotrochus, Ehrenb.-L.L.S., U.L.S. Robroyston, Brockley, Beith, Muirkirk, Dalry.

V. palaeotrochus, var. compressa, Brady.-L.L.S., U.L.S. Gare, Carluke, Brockley, Muirkirk.

V. Youngi, Brady.-L.L.S. Brockley, Trearne, Dalry, Muirkirk, Campsie.

V. Youngi, var. contraria, Brady.-L.L.S. Brockley, Trearne, Beith.

V. bulloides, Brady.-L.L.S. Brockley.

V. decurrens, Brady.-L.L.S., U.L.S. Gare, Carluke, Brockley, Muirkirk, Dalry.

V. plicata, Brady.-L.L.S. Calderside, Blantyre, Hairmyres.

V. rudis, Brady.-L.L.S. Headsmuir, Carluke.

Endothyra Bowmanni, Phill.-L.L.S., U.L.S. Calderside, Trearne, Dalry Muirkirk.

E. ammonoides, Brady.-L.L S., U.L.S. Gare, Gillfoot, Carluke, Dalry, Muirkirk.

E. globolus (Eichw.).-L.L.S., U.L.S. Gillfoot, Braidwood, Muirkirk.

E. crassa, Brady.-L.L.S., U.L.S. Brockley, Muirkirk, Beith.

E. radiata, Brady.-L.L.S., U.L.S. Robroyston, Gillfoot, Brockley, Muirkirk.

E. macella, Brudy.-L.L.S. Brockley, Muirkirk.

E. ornata, Brady.-L.L.S. Brockley, Muirkirk.

E. ornata, var. tenuis, Brady-U.L.S. Robroyston, Barmulloch.

E. subtilissima, Brady.-L.L.S. Brockley.

Stacheia marginulinoides, Brady.-L.L.S. Brockley.

S. fusiformis, Brady.-L L.S. Belston Burn, Brockley.

S. pupoides, Brady.-L.L.S. Brockley, Hairmyres.

S. acervalis, Brady.-L.L.S. Hairmyres, Gare, Carluke.

S. congesta, Brady.-L.L.S., U.L.S. Belston Burn, Carluke, Limekilns.

S. polytrematoides, Brady.-L.L.S., U.L.S. Gare, Braidwood, Hairmyres, Muirkirk.

Lagena Parkeriana, Brady.-U.L.S. Belston Burn, Carluke.

I. Howchiniana, Brady.-U.L.S. Belston Burn, Carluke, Muirkirk, Gillfoot.

Nodosinella concinna, Brady.-U.L.S. Belston Burn, Carluke, Muirkirk. * N. digitata, Brady.-U.L.S. Muirkirk.

N. cylindrica, Brady.-U.L.S. Muirkirk.

* Nodosaria radicula, Linné.-U.L.S. Clonbeith, Kilwinning ; Stacklawhill, Stewarton.

Textularia gibbosa (d'Orb.).-L.L.S. Brockley, Muirkirk, Dalry.

T. eximia (Eichw.).-L.L.S. Brockley, Muirkirk.

T. sp., undetermined.--L.L.S. Muirkirk.

Bigenerina patula, Brady.-L.L.S. Headsmuir, Carluke.

Archaediscus Karreri, Brady.-L.L.S., U.L.S. Craigenglen, Brockley, Muirkirk, Belston Burn, Beith.

Girvanella sp. (Nich. and Ether.).-L.L.S. Muirkirk, Law Quarry, Dalry.

Haplophragmium rectum (?) Brady.-L.L.S. Hillhead Quarry, Beith.

Globigerina sp.-L.L.S. Beith, Campsie, Dalry, Muirkirk.

Pulvinulina Broeckiana, Brady.-L.L.S. Craigie.

Those marked * are Permian species not hitherto recorded fron the Carboniferous rocks. Nodosinella is new to Scotland, but recorded for England and Wales. Pulvinulina Broeckiana is a Belgian species new to Britain. Lituola Bennieana was hitherto doubtfully recorded from Levenseat.-J. S. 


\section{THE CARBONIFEROUS SPONGES OF THE CLYDE DRAINAGE AREA.}

\section{Bx John SuIth.}

Ix 1876 I discovered remains of Sponges in the Carboniferous Limestone strata-both the Lower and Upper divisions. These were described by Prof. John Young and Dr. John Young, F.G.S., in the "Catalogue of Western Scottish Fossils," 1876, and in the Annals and Magazine of Natural History, 1877. They have since been more exhaustively treated by Dr. G. J. Hinde in his Monograph on "Fossil Sponges" issued by the Palaeontographical Society, and in his " (atalogue of Fossil Sponges in the British Museum."

With perhaps the exception of Acanthactinella Benniei, which may have been a sponge with calcareous spicules, all those found in the Carboniferous rocks of the Clyde drainage area appear to have been furnished with siliceous spiculae, and a peculiarity is the immense size of the spicules compared with those of recent sponges.

They occur in both the Lower and Upper Limestones, but most abundantly in the upper divisions of the Lower Limestones, and though generally in the limestone strata, only occasionally in the shales.

The divisions are indicated in the following list in heavy letters placed before the localities-U.L.S., Upper Limestone Series; L. L.S., Lower Limestone Series.

Hyalostelia (Hyalonema) Smithi, Young and Young.-L. L. S., CunninghamBaidland, Law ; Birkhearl and Auchenskeith, Dalry ; Dykes, Kilbirnie.

Hyalonema parallela, $\boldsymbol{K}^{\prime} \mathrm{Coy} .-\mathrm{L}$. L.S., Auchenskeith : Dockra, Gateside, Beith ; Brockley near Lesmahagow.

Tholiasterella Youngi, Hindle.-L. L. S., Law and Thirdpart, Dalry ; Dykes ; U. L. S., Glencart, Dalry.

T. gracilis, Hinde.-L. L. S., Law ; Dykes ; Cunningham-Baidland ; U. L. S., Stacklawhill, Stewarton.

T. compacta, Hinde.-L. L. S., Cunningham-Baidland ; Law.

T. crassa, Hinde.-L. L. S., Crawfield, Kilbirnie ; Law.

Holasterella conferta, Carter.-L. L. S., Dalry.

Asteractinella tumida, Hinde.-L. L. S., Law.

A. expansa, Hinde. - L. L. S., Blackstone, Dalry ; U. L. S., Stacklawhill.

Geodites deformis, Hinde.-L. L. S., Law.

G. antiquus, Hinde.--L. L. S., Cumningham-Baidland ; U. L. S., Glencart.

Haplistion Armstrongi, $Y$. and $Y$.- L. L. S., Law; Cumningliam-Baidland.

H. vermiculatum, Carter.-L. L. S., Law.

Acanthactinella Benniei, Hinde.-L. L. S., Law ; Cumningham-Baidland.

Dorydemia dalryense, Hinde.-U. L. S., Monkcastle, Kilwinning.

Axinella vetusta, Hinde.-L. L. S., Law ; U. L. S., Glencart.

Pachastrella vetusta, Hinde.-I. I. S., Law. 


\title{
THE CARBONIFEROUS CORALS OF THE CLYDE DRAINAGE AREA.
}

\author{
By (the late) James Thomson, F.G.S.
}

This list of the Carboniferous Corals of the Clyde drainage area was drawn up by Mr. Thomson only shortly before his death in 1899, and therefore has not had the benefit of his revision in print. So far as possible it has been compared with an exhaustive paper on the Scottish Carboniferous Corals, which Mr. Thomson read before the Philosophical Society of Glasgow in 1883, and which was published at length in its Transactions, accompanied by 14 plates with numerous figures. ${ }^{1}$

Aulopora campanulata ( $\left.M^{`} \mathrm{Coy}\right)$.-Wistown, Lanarkshire.

A. gracilis (Thomson).-Broadstone, Beith.

Cladochonus crassus $\left(H^{\circ} \mathrm{Coy}\right)$.-Brockley, Lesmahagow.

C. bacillarius $\left(M^{\circ} \mathrm{CO}\right)$ ).-Auchenskeith, Dalry.

C. antiquus $\left(M^{\circ} \mathrm{Coy}\right)$.-Auchenskeith, Dalry.

C. Michelini (Edv. and Huime).--Howood, near Paisley; Auchenskeith, Dalry.

C. minutus (Thom.).-Auchenskeith, Dalry.

Pyrgia Labechei (Edwards and Haime).-Cunningham-Baidland, Dalry.

Protocyatohphyllum quadrophyllum (Thom.).-Cumningham-Baidland, Dalry.

P. plicatum (Thomson).-Cunningham-Baidland, Dalry.

P. spinulosum (Thom.).-

P. elegans (Thom.).--

P. Verilliense (Thom.).-

P. dalryense (Thom.).-

P. pachytheca (Thom.).

P. quadrophyllum (Thom.).-Cumningham-Baidlan"d, Dalry.

Chaetetes tumidus (Phillips).-Brockley, Lesmahagow, and in almost every bed of limestone in the series.

Monticulipora alveolites $\left(d^{\prime}()_{i} \cdot b\right.$.).--(Lanark).

M. depressa (Edw. and Haime).-Garsewater and Asheyburn, near Muirkirk. M. Etheridgei (T\%om.).-Asheyburn, near Muirkirk.

Michelinia tenuisepta (Edw. and Haime).-Broadstone, Beith.

Favosites parasitica (Phill.).-Brockley, Lesmahagow.

Fistulipora sp. nov.-Brockley, Lesmahagow.

Alveolites depressa (Edv. and Haime).-Garsewater and Asheyburn.

A. Etheridgei (Thom.).-Asheyburn.

1 "On the Development and Generic Relation of the Corals of the Carboniferous System of Scotland." By James Thomson, F.G.S. Proc. Phil. Soc. of Glasgow, vol. xiv., 1883, pp. 296-502, plates i. to xiv. 
Amplexus Sowerbyi (Phill.).-Brockley, Lesmahagow.

A. serpuloides (de Kon.).-Brockley, Lesmahagow.
A. modulosus (Phill.).-.-
A. spinosus (de Kon.).-
A. coralloides (Sow.).-Broadstone, Beith.

A. Haimeanus (de Kon.).-Brockley, Lesmahagow.

A. Henslowi (Ed. and Haime).-Broadstone, Beith.

A. cornuformis (Ludwig).--Brockley, Lesmahagow.

Calophyllum Danai (Thom.).-Roughwood, Beith.

C. spinosum (Thom.).-Auchenskeith, Dalry.

C. tuberculatum (Thom.).--Brockley, Lesmahagow.

C. irregularum (Thom.).-Auchenskeith, Dalry.

C. honiana (de Kon.). -

C. cuspidum (Thom.).-Brockley, Lesmahagow.

C. nodosum (Thom.).-

C. angularum (Thom.).-Auchenskeith, Dalry.

C. denticulatum (Thom.).-Brockley, Lesmahagow.

C. robustum (Thom.).-Roughwood, Beith.

C. approximatum (Thom.).--Roughwood, Beith.

Zaphrentis Edwardsiana (de Kon.).-Boghead, Hamilton.

Z. Phillipsi (Ed. and Haime).-Auchenskeith, Dalry.

Z. curvulina (Thom.).-Brockley, Lanarkshire.

Z. tuberculatus (Thom.).-,

Z. granulatus (Thom.).-

Z. spinulosa (Ed. and Haime).-Brockley, Lesmahagow

Z. bicentrica (Thom.). -

Z. centralis (Ed. and Haime).-Broad"stone, Beith.

Z. clavatus (Thom.).-Brockley, Lesmahagow.

Z. Konincki (Ed. and Haime).-Auchenskeith, Dalry.

Z. amphitheca (Thom.).-Brockley, Lesmahagow.

Z. vermicularis (de Kon.).

Z. intermedia (de Kon.).-Gare, Carluke.

Z. Smithi (Thom.).-Auchenskeith, Dalry.

Z. patula (Vichelin).-Beith, Ayrshire.

Z. Guerangeri (Ed. and Haime).-Auchenskeith, Dalry.

Z. Bowerbanki (Ed. and Haime).--Shields, E. Kilbride.

Z. Cliffordiana (Ed. and Haime).-Boghead, Hamilton.

Z. Enniskilleni (Ed. and Haime).-Roughwood, Beith.

Heterophyllia Sedgwicki (Duncan).-Brockley, Lesmahagow.

H. I'Coyi (Duncan).-Brockley, Lesmalıagow.

H. Lyelli (Durcan).-Craigenglen, Campsie.

H. mirabilis (Duncan)._- , , ,

Densyphyllum granulatum" (Thom.).-Broskley, Lesmahagow.

D. minutum (Thom.).-Nethernewton, Loudon, Ayrshire.

Lophophyllum parvulum (Nich. and Thom.).-Shields, E. Kilbride.

L. reticulatum ( T $^{\mathrm{i}} \mathrm{ch}$. and Thom.).-Shields, E. Kilbride.

L. scoticum (Wich. and Thom.).-Brockley, Lesmahagow.

L. eruca ( $K^{\circ}$ Coy).-Auchenskeith, Dalry.

L. intermedium (Thom.). -Shields, E. Kilbride.

Campophyllum Murchisoni (Ed. and Haime).-Brockley, Lesmahagow.

C. brockleyensis (Thom.).-Brockley, Lesmahagow.

C. simplicum (Thom.).-

C. recurvatum (Thom.).-

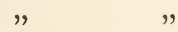

C. breviseptum (Thom.).-Nettlehirst, Beith.

C. laxicum (Thom.).-Brockley, Lesmahagow.

C. dissimilis (Thom.).- heteroseptum (Thom.)."-Brockley, Lesmahagow. 
Campophyllum turcatum (Thom.).-Cunningham-Baidland, Dalry.

C. rectangularum (Thom.).-Brockley, Lesmahagow.

C. dendriformum (Thom.).-- ", ",

C. subclaviformis (Thom.).- " " "

C. turbinatum (Thom.).- ", ",

C. concavum (Thom.).-Broadstone, Beith.

C. marginatum (Thom.).-Brockley, Lesmahagow.

C. interruptum (Thom. and Nich.).-Brockley, Lesmahagow.

C. parricida (M.Coy).-Brockley, Lesmahagow; Broadstone, Beith, and Asheyburn, Muirkirk.

C. echinatum (Thom.).-Brockley, Lesmahagow.

C. asheyburnense (Thom.).-Asheyburn, Muirkirk.

C. radiolarium (Thom.).-

C. dendriformum (Thom.).-Howrat, Dalry.

C. eleganteum (Thom.).-Corrieburn, Campsie.

C. Agassizi (Thom.).-Asheyburn, Muirkirk.

C. domiformum (Thom.).-Brockley, Lesmahagow.

C. tuberculatum (Thom.).-Asheyburn, Muirkirk.

C. Taylori (Thom.).-Brockley, Lesmahagow.

C. intercellulosum (Thom.).-Broadstone, Beith.

C. subclavatum (Thom.).-Howrat, Dalry.

C. crumlatum (Thom.).-Asheyburn, Muirkirk.

C. clavatum (Thom.).-Brockley, Lesmahagow.

C. fasiculatum (Thom.).- ,

Cyathaxonia profunda (Thom.).-Cunningham-Baidland, Dalry.

C. tortuosa (Münster).-Cumningham-Baidland, Dalry.

C. domiformis (Thom.).- , ", , ,

C. Dybowskii (Thom.). - — " ", ", ",

C. elegans (Thom.).- $\quad$ ", , , ",

C. compressa (Thom.).- " ", ", ",

C. expansa (Thom.).- $\quad$, , , ", ",

C. cornua (de Kon.).-- ", ", ",

C. mammillata (Thom.)._- ", ", ",

C. Konincki (Ed. and Haime).- , , ", ", ", ", ", ", "

C. Newburyi (Thom.).— " " ", ",

C. robusta (Thom.).-— " " " ",

C. prolifera (M'Chesney).- " " ., ",

C. Armstrongi (Thom.).— ", ", ",

C. $\operatorname{ejecta}($ Thom.).- $\quad, \quad, \quad$, ,

C. granulata (Thom.).- " ", ",

C. cyathominuta (Thom.).- ", ", ",

C. spiralis (Thom.).- ", ", ",

C. reticulata (Thom.).- " ", ",

Axophyllum sp. ?-Brockley, "Lesmahagow.

A. sp. ?-Cunningham-Baidland, Dalry.

Koninckophyllum interruptum (Nich. and Thom.).-Brockley, Lesmahagow.

K. Lindströmi (Nich. and Thom.).-Brockley, Lesmahagow.

K. retiforme (Nich. and Thom.).-

K. sp. ?-Brockley, Lesmahagow.

Lithostrotion Portlocki (Bron.).-Corrieburn, Wiston, Lanarkshire.

L. junceum (Ure).--Brockley ; Braidwood; Wiston.

L. junceum, var. intermedium (Thom.).-Asheyburn, Muirkirk.

L. simplex (Thom.).-Cunningham-Baidland, Dalry ; Brockley, Lesmahagow.

Fasciculophyllum magnificum (Thom.).-Nettlehirst, Beith.

F. sp. ? (Thom.).-Auchenskeith, Dalry.

Diphyphyllum Argylli (Thom.).-In a boulder, associated with Arran granite. 
Diphyphyllum concinnum (Lons.).-Boghead, Lesmahagow.

D. concinnum ? var. turcatum (Thom.).-Corrieburn, Campsie.

D. Blackwoodi (Thom.).-Kilmarnock Water, near Fenwick.

D. cylindricum (Thom.).--Boghead, Lesmahagow, and Roughwood, Beith.

D. latiseptum (M/Coy).-Corrieburn, Campsie; and Fenwick, Ayrshire.

D. gracile $\left(\mathrm{M}^{\circ} \mathrm{Co} y\right)$.--Brockley, Lesmahagow, and Roughwood.

D. giganteum (Thom.).-Corrieburn, Campsie.

D. interruptum (Thom.).-Boghead, Lesmahagow.

Lonsdaleia rugosa ( $\left.1 r^{\circ} \mathrm{Coy}\right)$.-Boghead, Lesmahagow.

L. duplicata (Iartin).-Garsewater, Muirkirk.

L. floriformis (Fleming).-Garsewater, Muirkirk.

Clisiophyllum Keyserlingi ( $\left.\mathrm{I}^{*} \mathrm{Coy}\right)$.-Auchenskeith, Dalry.

C. bipartitum ( $\left.\boldsymbol{K}^{\circ} \mathrm{Coy}\right)$.-Broadstone, Beith.

C. conoseptum (Keys.).-Langside, Beith.

C. oblongum (Thom.).-Roughwood, Beith.

C. M·Coyianum (Thom.).-Gateside, Beith.

C. Bowerbanki (Ed. and Haime).-Langside, Beith.

C. grandicum (Thom.).-Langside, Beith.

C. broadstoneianum (Thom.).-Broadstone, Beith.

C. Geinitzianum (Thom.). - Broadstone, Beith.

C. elegante (Thom.).-

C. abruptum (Thom.).-Gateside, Beith.

C. turbinatum $(M \cdot C o y)$--Brockley, Lesmahagow.

C. vesicularum (Thom.).-Langside, Beith.

C. intermedium (Thom.).-Auchenskeith, Dalry.

C. subimbricatum (Thom.).-Broadstone, Beith.

C. irregulare (Thom.).-Broadstone, Beith.

C. subplicatum (Thom.).-

C. centrocellulosum (Thom.).-Gateside, Beith.

Aspidiophyllum Huxleyanum (Thom.).-Thirdpart, Beith.

A. Konincki (Thom.).-Thirdpart, Beith.

A. cruciforme (Thom.).- , , ,

A. Hennedyi (Thom.).- ", ",

A. elegans (Thom.).- ", "

Dibunophyllum splendens (Nich. and" Thom.).-Gateside, Beith.

D. Muirheadi (Nich. and Thom.).-Brockley, Lesmahagow.

D. M'Chesneyi ( Nich. and Thom.).- "

D. sp. ?-Brockley, Lesmahagow.

D. sp. ?- ", "

D. sp. ?-Langside, Beith.

Rhodophyllum Slimonianum (Thom.).-Brockley, Lesmahagow.

R. Phillipsianum (Thom.).-Trearne, Beith.

R. Craigianum (Thom.).-

R. simplex (Thom.).-Brockley, 'Lesmahagow.

R. sp. ?-Langside, Beith.

R. Romeri (Thom.).-Langside, Beith.

R. reticulatum (Thom.).-Langside, Beith.

R. simplex (Thom.).-Brockley, Lesmahagow.

Cymatophyllum Harknessi (Thom.).-Thirdpart, Beith.

C. concentricum (Thom.).-Langside, Beith.

C. Haimeanum (Thom.).- , , ,

C. octolamellum (Thom.). — " ",

C. Etheridgei (Thom.).- ", ",

C. Davidsoni (Thom.). - , , ,

Asymmetrilamellum Lintoni ("Thom.)."Kilmarnock Water.

A. asheyburnense (Thom.).-Asheyburn, Muirkirk.

Histiophyllum Ramsayi (Thom.).-Brockley, Lesmahagow, 
Histiophyllum beithianum (Thom.).-Thirdpart, Beith.

H. fasiculatum (Thom.).-Brockley, Lesmahagow.

H. flexuosum (Thom.).-Nettlehirst, Beith.

H. ellipticum (Thom.).-Trearne, Beith.

H. Milleri (Thom.).-Langside, Beith.

* Centrolamellum subcentricum (Thom.).-Thirdpart, Beith.

C. bicentricum (Thom.).--Thirdpart, Beith.

C. hexalamellum (Thom.).-Brockley, Lesmahagow.

C. granulatum (Thom.).-Thirdpart, Beith.

C. cylindricum (Thom.).-Gateside, Beith.

C. quadralamellum (Thom.).-Langside, Beith.

C. pentalamellum (Thom.).-

C. Mystii (Thom.).-Bowertrapping, Dalry,"

Albertia Victoria-Regia (Thom.).-Langside, Beith.

A. Argylli (Thom.).-Langside,Beith.

A. Lindströmi (Thom.).--" "

A. vesiculata (Thom.). - , ",

A. irregularis (Thom.). - , ",

A. depressa (Thom.).- $"$,

A. intermedium (Thom.). "Langside, Beith.

A. Oweni (Thom.).-

A. subconicum (Thom.).-

A. Edwardsianum (Dun. and Thom.).-Brockley, Lesmahagow.

A. Haimeanum (Thom.).-Brockley, Lesmahagow.

A. Wünschianum (Thom.).-,

Cyclophyllum fungites (Ure).--Shields, E. Kilbride.

C. Bowerbanki (Ed. and Haime).-Gameshill, Dunlop.

C. biacuminatum (Thom.).-Brockley, Lesmahagow.

C. obovatum (Thom.).--Trearne, Beith.

C. pachyendothecum (Thom.).-Brockley, Lesmahagow.

C. Scoulerianum (Thom.).-

C. Duncanianum (Thom.).-

C. ellipticum (Thom.).--Roughwood,"Beith.

C. orbiculum (Thom.).-Trearne, Beith.

C. Carpenterianum (Thom.).-Brockley, Lesmahagow.

C. Bennieianum (Thom,).-Shields, E. Kilbride.

C. concentricum (Thom.).-Gameshill, Dunlop.

C. paradoxicum (Thom.).-Brockley, Lesmahagow.

C. intermedium (Thom.).-Nettlehirst, Beith.

C. Moseleyianum (Thom.).-Trearne, Beith.

The above list includes all forms of the Scottish Carboniferous Corals which have been figured and described. Some genera of the group may require to be divided or even sub-divided, and some of the species placed as varieties. More cannot be said until our knowledge of it is greater.

J. T.

* This genus was at first named Centrophyllum, but I have since altered it to Centrolamellum, as descriptive of the fact that the lamellae only extend inwards from the inner ends of the septa to the centre of the central area. 


\title{
THE CARBONIFEROUS ANNELIDA OF THE CLYDE DRAINAGE AREA.
}

\author{
By (The Late) John Young, LL.D., F.G.S.
}

CASTS and tracks of these organisms are to be met with in both the Lower and Upper divisions of the Carboniferous rocks of the Clyde area.

Many traces of the smaller Annelids are found in the debris of the weathered limestone shales. A most interesting exposure of saudstone beds, containing abundance of the tubes or burrows of Arenicolites, afterwards filled with dark clay, is to be seen at Burnfield Quarry, near Thornliebank. After a period of possession the inhabitants seem to have died out, their remains having been covered up by a barren layer of shale, and this alternation has occurred some 12 or 14 times with the utmost regularity.

Arenicola, Lamarck, sp.

Ortonia carbonaria, J. Young.

Serpulites carbonarius, $\mathrm{M} / \mathrm{CO} \%$.

S. compressus, Gow.

S. membranaceus, $M^{\circ} \mathrm{Coy}$.

Spirorbis caperatus, $H \cdot C \cdot$ oy . S. carbonarius, Murch., sp.

S. helicteres, Salter.

S. spinosus, de Kon. Vermilia minuta, Brown.
Burnfield Quarry, Thornliebank.

Orchard, Boghead, Calderside, Brockley, Craigenglen.

Sculliongour, Langside, Beith.

Trearne (common).

Gare, High Blantyre (common).

Craigenglen (very rare).

Brockley, Gare, on shells, crinoids, etc.

Upper Coal-measures, on shells and plants.

Newton, Cambuslang.

Hairmyres, Roughwood.

Gare, Robroyston, Highfield, Dalry, Capelrig, East Kilbride. 


\title{
THE CARBONIFEROUS POLYZOA OF THE CLYDE DRAINAGE AREA.
}

\author{
By (the late) John Young, LL.D., F.G.S.
}

The Polyzoa of the Clyde drainage area are represented by numerous genera and species which are distributed over the Lower and Upper Limestone series, and chiefly in the shales associated with the limestones proper. They may be obtained plentifully from the weathered shales in most of the localities mentioned in the following list, which has been compiled with the assistance of Dr. Young's MS. notes.

Actinostoma fenestratum, $Y$. and $Y$. Hairmyres, High Blantyre.

Archaeopora nexilis, de Kon.

Carinella cellulifera, Eth. $J t$.

Ceriopora interporosa, Phill.

C. similis, Phill.

Diastopora megastoma, $M^{\prime} \mathrm{Coy}$.

Fenestella bicellulata, Eth. $J r$.

? F. carinata, $M^{\prime} \mathrm{Coy}$.

? F. crassa, $M{ }^{\prime} \mathrm{Coy}$.

F. ejuncida, $M^{\circ} \mathrm{Coy}$.

F. flabellata, Phill.

? F. formosa, $M^{`} \mathrm{Coy}$.

F. frutex, $M I^{\circ} \mathrm{Coy}$.

? F. hemispherica, $M^{\prime} \mathrm{Coy}$.

? F. membranacea, Phill.

F. Morrisi, $M^{\prime} \mathrm{Coy}$.

F. multiporata, $M^{`} \mathrm{Coy}$.

F. nodulosa, Phill.

F. plebeia, $M^{\prime} \mathrm{Coy}$.

? F. quadridecimalis, $M^{\prime} \mathrm{Coy}$.

F. tenuifila, Phill.

Fenestella tuberculo-carinata, Eth.Jr. High Blantyre.

F undulata, Phill.

G lauconome aspera, $Y$. and $Y$.

G' elegans, $Y$. and $Y$.

G- flexicarinata, $Y$. and $Y$.

G. laxa, $Y$. and $Y$.

G. marginalis, $Y$. and $Y$.

G. retroflexa, $Y$. and $Y$.

G. stellipora, $Y$. and $Y$.

G. stellipora, var. spinosa, $Y$. and $Y$. Hairmyres, Gare.

G. robusta, $Y$. and $Y$.
High Blantyre, Gillfoot.

Gare, Robroyston, Orchard.

Gare, Brockley, High Blantyre.

Capelrig, Gare, Corrieburn.

Gare, High Blantyre, Hairmyres.

Boghead, Hamilton.

High Blantyre, Hairmyres.

Beith Quarries.

Newfield, Blantyre.

Corrieburn, Beith Quarries.

First Calmy Limestone, Carluke, Corrieburn.

Corrieburn, Gillfoot.

Roughwood.

Craigenglen, High Blantyre.

Howrat, Corrieburn.

Roughwood, Corrieburn.

Corrieburn, Beith Quarries.

High Blantyre, Hairmyres.

Gillfoot, Gare.

Gare, High Blantyre.

Gillfoot.

Hairmyres.

Hairmyres.

High Blantyre, Gillfoot.

Hairmyres.

Hairmyres, Gillfoot.

Beith Quarries.

Hairmyres, Gare. 
Gonocladia cellulifera, Eth. Jr. ? Gorgonia Lonsdaliana, $M^{*} \mathrm{Coy}$. Hemitrypa hibernica, $\boldsymbol{M}^{\circ} \mathrm{Coy}$. Hyphasmopora Buski, Eth. Jr. Polypora dendroidës, $M^{\circ} \mathrm{Coy}$.

? P. papillata, $M^{\circ} \mathrm{Coy}$.

P. tuberculata, Prout.

Ptylopora pluma, $\mathrm{M}^{\circ} \mathrm{Coy}$.

Rhabdomeson gracile, Phill.

R. rhombiferum, Phill.

Sulcoretepora parallela, Phill.

S. raricosta, $M^{\circ} \mathrm{Coy}$.

S. Robertsoni, $Y$. and $Y$.

S. sp. nov., J. Young.

Synocladia carbonaria, Eth. $J r$.

S. Scotica, $Y$. and $Y$.

Thamniscus Rankini, $Y$. and $Y$. T. sp.

Vincularia Binniei, Eth. $J r$.

V. dichotoma, $\mathrm{M}^{\circ} \mathrm{CO} y$.
Gare, Carluke.

Auchenskeith.

Highfield Quarry.

High Blantyre.

Corrieburn, Beith Quarries.

Auchenskeith, First Calmy Limestone, Carluke.

Hairmyres, Beith Quarries.

Corrieburn.

Hairmyres, Trearne.

Hairmyres, Capelrig, East Kilbride.

Gare, Hairmyres, Beith.

Corrieburn, Brockley.

Trearne.

Gillfoot (Robertson Collection).

High Blantyre, Gillfoot.

Gillfoot, Carluke.

Gillfoot, Gare.

High Blantyre.

Mouse Water, Wilsontown.

Corrieburn. 


\title{
THE CARBONIFEROUS OSTRACODA OF THE CLYDE DRAINAGE AREA.
}

\author{
By Prof. T. Rupert Jones, F.R.S., and (the late) \\ JAMES W. KIRKBY.
}

THE Ostracoda found in the Carboniferous strata of Western Scotland are obtained from certain fossiliferous beds in each of its chief divisions, viz. the Calciferous Sandstone series, the Lower Limestone series, the Middle Coal and Ironstone series, the Upper Limestone series, and the Upper Coal and Ironstone series. The division, however, which has yielded the greatest number of genera and species is the Lower Limestone and its accompanying shales, chiefly of marine origin. In the strata, believed to be of lacustrine or freshwater origin from their fossil evidence, and from the absence of characteristic marine remains, as in the case of those strata which compose the Lower and Upper divisions of the Coal and Ironstone series, there are found certain forms of a small group of Ostracoda highly characteristic of these so-termed lacustrine conditions, and some of the species of which are found to range in time from the lower to the higher beds. The Ostracoda, wherever they appear, have evidently been very abundant in the waters in which these strata were being deposited, as their minute shells are often seen to have largely contributed to the formation of the beds. As a general rule they are hardly ever found mingling with the characteristic marine forms, which shows that the conditions under which the two groups lived were different.

The species of the group have been, so far as discovered, very fully determmed, described, and figured, thanks to the long-continued labours of Prof. T. Rupert Jones, F.B.S., and Mr. James W. Kirkby, ${ }^{1}$ who have made its study one of their chief specialities, culminating in the publication of their Monograph on the Carboniferous Ostracoda issued by the Palaeontographical Society in 1874 and 1884. Extracted from a paper by the late Dr. John Young, F.G.S., read before the Geological Society of Glasgow in 1891.2

Other important memoirs by Prof. Jones and Mr. Kirkby with figures and descriptions of the same subject have been published in the following:

Annals and Magazine of Natural History, 1865, 1866, 1875, 1879, 1885, 1886,1892 , and 1895 .

Transactions of the Geological Society of Glasgow, 1869.

Quarterly Journal of the Geological Society, 1879.

${ }^{1} \mathrm{~A}$ few weeks before this article was put in type the regretted death of $\mathrm{Mr}$. Kirkby occurred. Consequently the list has not had the benefit of his supervision.

2 "Notes on the group of Carboniferous Ostracoda found in the strata of Western Scotland, with a revised list of Genera and Species." By John Young, F.G.S., V.P. Trans. Geol. Soc. of Glasgow, vol. ix., part 2, 1893, p. 301. 
Proceedings of the Geologists' Association, 1886.

Geological Magazine, 1886.

Transactions of the Manchester Geological Society, 1890.

Transactions of the Royal Dublin Society, 1896.

Canadian Record of Science, 1897.

Transactions of the Edinburgh Geological Society, 1899.

Cypridina brevimentum, Jones and Kirkby.-(Fide J. Young.)

C. Hunteriana, $J$. and $K$.-Braidwood.

C. oblonga, $J$. and $K$.-Trearne.

C. Phillipsiana, Jones.-Braidwood, Glencartholm.

C. primaeva $\left(M^{\prime} \mathrm{Coy}\right)$.-Brockley.

C. radiata, $J$. and $K$.-Airdrie.

C. scoriacea, $J$. and $K$.-Gare.

C. Grossartiana, $J$. and $K$.-Bathgate.

C. Thomsoniana, $J$. and $K$.-Gare.

C. Youngiana, $J$. and $K$.-Gare.

Cypridella Edwardsiana, de Kon.-Bathgate.

C. Edwardsiana, var. septentrionalis, $J$. and $K$.-Trearne.

C. Koninckiana, Jones.-(Robertson Collection.)

C. obsoleta, $J$. and $K$.-(Robertson Coll.).

C. Wrighti, $J$. and $K$.-(Robertson Coll.).

Cypridinella Cummingi, $J$. and $K$.- Trearne.

C. superciliosa, $J$. and $K$.-Trearne, Bathgate, Beith.

C. vomer, J. and K.-(Fide J. Young.)

Cypridellina intermedia, $J$. and $K$.-Bathgate.

C. Burrovi, J. and $K$.-Near Beith (Robertson Coll.).

Cyprella annulata, de Kon.-Bathgate.

C. chrysalidea, de Kon., var. subannulata, J. and K.-Bathgate.

Bradycinctus Rankinianus, $J$. and $K$.-Gare.

Entomoconchus Scouleri, M.Coy.-(Small.) Beith (Robertson Coll.).

E. globosus, J. and $K$.-Broadstone.

Polycope simplex, $J$. and $K$.-Braidwood.

P. Youngiana, J. and $K$.-South Hill, Campsie.

Entomis biconcentrica, Jones.-Carluke.

Cytherella attenuata? $J$. and $K$.-Glencartholm.

C. Benniei,. . and $K$.-Williamwood.

C. brevis, Jones.-Campsie, Carluke.

C. concinna, $J ., K$. and Brady.-East Kilbride.

C. elongata? $J$. and $K$.-Bathgate.

C. aequalis,$J ., K$. and $B$.-Gare.

C. inflata (Münster).-Campsie.

C. obesa, $J ., K$. and B.-West Broadstone.

C. obliquata, J., $K$. and B.-C'raigenglen, Capelrig Quarry, E. Kilbride.

C. recta, J., $K$. and B.-Gare, Auchenbeg.

C. reticulosa, $J$. and $K$.--Robroyston.

C. rotundata, $J$. and $K$.-Burnbank, Carluke (Robertson Coll.).

C. scrobiculata.-Williamwood, Orchard.

C. simplex, J. and $K$.-Raes Gill, Carluke.

C. valida,. and K.-Glencartholm, Gilnockie Tower.

Leperditia acuta, $J$. and $K$.-Craigie.

L. Armstrongiana, $J$. and $K$.-Brockley, Howrat.

L. Bosquetiana, J. and K.-Tirfergus Glen.

L. compressa,. . and $K$.-Craigenglen.

L. Lovicensis, .J. and $K$.-Braehead, Craigie.

L. oblonga, $J$. and $K$.-East Kilbride.

L. Okeni (Mün.).-Brockley, Williamwood, Thornton. 
Leperditia parallela ? J. and K.-Glencartholm.

L. scotoburdigalensis (Hibbert). - Glencartholm.

L. suborbiculata (M̈̈̈n.).-Craigie, Thornton.

L. subrecta (Portlock).-Glencartholm.

L. Youngiana, J. and K.-Dalry.

Beyrichia arcuata (Bean).--Shotts, Carluke.

B. bicaesa, $J$. and K.-Woodhill.

B. Bradyana, J. and $K$.-Boghead, High Blantyre.

B. cratigera, Brady.-Glencartholm, Calderside.

B. fastigiata,. . and $K$.-Craigenglen, Bathgate.

B. fodicata, $J$. and $K$.-Linlithgow Bridge.

B. gigantea, J. and K.-Glencartholm, Carluke.

B. intermedia, Jones and Holl.-Dernshaw.

B. multiloba, Jones--Boghead, Craigenglen.

B. radiata, $J$ and $K$.-Orchard, Robroyston.

Beyrichiella Youngiana, J. and K. (MS.).-Glencartholm.

B. reticosa, J. and K.-Glencartholm, Whitebaulks.

B. ventricornis, J. and K.-Brockley, Gair.

Beyrichiopsis cornuta, J. and K.-Linlithgow Bridge.

B. fimbriata, $J$. and $K$.-Glencartholm.

B. fortis, $J$. and $K$.-Glencartholm.

Ulrichia bituberculata, $J$. and $K$.-Orchard, East Kilbride.

U. tuberculospinosa, $J$. and $K$.-Williamwood, Stacklawhall.

Kirkbya costata $\left(M^{\prime} \mathrm{Coy}\right)$.- Gilnockie Tower, Glencartholm.

$\mathrm{K}$. oblonga, $J$. and $K$.-Brockley, Williamwood.

$\mathrm{K}$. permiana, Jones.--Orchard, Robroyston.

K. plicata, J. and $K$.-Campbeltown.

$\mathrm{K}$. rigida, $J$. and $K$.-Orchard, Williamwood.

$\mathrm{K}$. Robertsoniana, $J$. and $K$. (MS.).-Dernshaw.

K. scotica, $J$. and. $K$.-Campbeltown, Linlithgow Bridge.

$\mathrm{K}$. spinosa, $J$ and $K$.-Craigenglen, Capelrig, East Kilbride.

$\mathrm{K}$. spiralis, $J$. and $K$.-Glencartholm, Oakbank.

$\mathrm{K}$. tricollina ? J. and $K$.-Orchard.

K. umbonata (Eichw.).-Brockley, Hairmyres.

$\mathrm{K}$. Urei, Jones.-Craigenglen, Brockley.

Synaphe annectens, $J$. and $K$.-Craigenglen, Orchard.

Carbonia Bairdioides, $J$. and $K$.-Craigenglen.

C. fabulina, J. and $K$. - Whifflet, Shotts Ironworks, Thornton.

C. pungens, $J$. and $K$.-Provanhall, Carluke.

C. Rankiniana, J. and $K$.-Provanhall, Airdrie.

C. secans,. . and $K$.-Craigenglen.

C. subula, $J$. and $K$.-Craigenglen.

Bythocypris bilobata (Miin.).--Broadstone, Braidwood.

B. cuneola, $J$. and $K$.-Robroyston, Orchard.

B. cornigera, $J$. and $K$.-Robroyston, Gare.

B. Phillipsiana, Jones and Holl, var. carbonica.-East Kilbride.

$B$. Robertsoniana, $J$. and $K$. (MS.).-Braehead.

B. sublunata, J. and K.-Glencartholm.

B. pyrula,. . and $K$.-Braehead.

Argilloecia aequalis, $J$. and $K$.-Glencartholm, Heads of Ayr.

Aglaia cypridiformis, $J$. and K.-Glencartholm.

Macrocypris Jonesiana, Kirkby.-Craigenglen.

M. carbonica, Brady.-Campsie.

Bairdia ampla, Reuss.-Hairmyres, Stacklawhall.

B. amputata, Kirkby.-Brockley, Gilnockie Tower.

$B$. brevis, $J$. and $K$.-Brockley, Craigenglen.

B. curta, $M^{\prime} C o y$.-Kennox Water, Braidwood. 
Bairdia grandis, $J$. and $K$.-Carluke.

B. Hisingeri (M /ïn.).--Brockley, Stacklawhall.

B. legumen ? J. and $K$.-Craigenglen.

$B$. siliquoides, $J$. and $K$.-Kennox Water, Glencartholm.

B. subelongata, J. and K.-Brockley, Craigenglen.

B. subcylindrica (Mün.).-Carluke, Gillfoot.

B. submucronata, J. and K.-Gare, Carluke, Orchard.

B. plebeia, Reuss.-Orchard, Craigenglen.

Cythere? superba, $J$. and $K$.-Heads of Ayr.

C. intermedia, $J$. and $K$.-Carluke.

Bythocythere Youngiana, J. and K.-Brockley, Craigenglen.

Youngiella rectidorsalis, $J$. and $K$.-Dernshaw, Orchard.

Y. sp. nov. ? Williamwood, Westerhouse.

Xestoleberis subcarbuloides ? $J$. and K.-Shields.

Darwinula? Berniciana? Jones.--Robroyston, East Kilbride.

Phyllopoda.

Estheria striata (Mün.).-Lanarkshire.

E. tenella, Jordan.-Airdrie, Carluke, Lanarkshire.

E. Youngi, Jones.-Arden, Thornliebank.

E. tessellata, Jones.-Airdrie?

E. tegulata, Jones.-Airdrie?

\section{Phyllocarida.}

Dithyrocaris glabra, Woodw. and Ether.-Ardrossan, East Kilbride.

D. granulata, W. and E.-East Kilbride.

$D$. insignis, $J$. and W.-East Kilbride.

D. Neilsoni, $J$. and $W$.-East Kilbride.

D. ovalis, $W$. and E.-East Kilbride.

D. testudinea, Scouler.-Paisley, Ardrossan, East Kilbride, Carluke.

D. tricornis, Scouler:-Paisley, East Kilbride.

Calyptocaris striata, Woodw.-Carmichael Burn, Lanarkshire.

Chaenocaris Youngi, $J$. and $W$.-Robroyston.

Lebescontia occulta, $J$. and $W$.-Dalry. 


\title{
THE CARBONIFEROUS BRACHIOPODA OF THE CLYDE DRAINAGE AREA.
}

\author{
By James Neilson.
}

THE important group of Brachiopods is well represented in the marine beds of the Upper and Lower Limestone series of the Clyde drainage area, especially in the Lower Limestones, and the most finely preserved examples are found in the associated shale-beds, showing in many cases the interior structure and muscular impressions. The minute organisms have been obtained in great abundance from the rotted limestone of the upper part of the Lower Limestones near Beith in Ayrshire.

The Middle Coal and Ironstone series, which lies between the abovementioned marine beds, and is chiefly of freshwater origin, is not known to contain any brachiopods except a few specimens of Lingula mytiloides and L. squamiformis, which occur in the alternating brackish-water beds.

The Calciferous Sandstone series of the Clyde drainage area does not yield any brachiopods, several species previously recorded from Arran being now found to belong to the Upper and Lower Limestones.

The boundaries of the Millstone Grit series are not as yet well-defined, and the fossils recorded from it appear so low down in the beds, abutting on the Upper Limestones, that it has been thought best to include them in the list from that series.

The remains of brachiopods, chiefly as casts, are found in a bed of hard, white sandstone, exposed in a cutting on the North British Railway just south of Garngad Station, Glasgow, and this is, so far as we know, the only instance of the remains of marine mollusca having been met with in sandstone belonging to the Western Scottish coal-field.

One or two forms of brachiopods, e.g. Lingula, range upwards into the lower strata of the Upper Carboniferous series, but are confined to thin bands which do not contain any of its more characteristic forms.

In 1865 a thin bed containing two species of brachiopods and some other marine forms was discovered in the sinking of a coal-pit at Drumpark, about 200 fathoms above the Millstone Grit, but no similar occurrence has since been noted. ${ }^{1}$

The arrangement adopted in the following list is that of the late Dr. Thomas Davidson in his Monograph of "The British Carboniferous Brachiopoda "issued by the Palaeontographical Society. The divisions of the rocks in which the fossils occur are given before the localities in heavy letters.

I Trans. Geol. Soc. of Glasgow, vol. ii., 1865, p. 52. 


\section{Tretenterata.}

Lingula mytiloides, Sovv-U.C.S. Alexandra Parade, near Craigpark Street: Drumbeg, Annbank. Slatyband Ironstone. Benhar: and Shotts. U. L. S. Gare: Robroyston: Orchard: Thornliebank. M. I. S. Possil : Cadder : Beith: Dalry. L. L. S. Calderwood series: Kilbride: High Blantyre: Boghead : Craigenglen: Beith.

L. squamiformis, Phill.-Not in U.C.S. but generally in same locs. as above.

L. scotica, Dav.-(very rare). U. L. S. Gare : Robroyston : Limekilnburu : Gillfoot, Carluke. M. I. S. Hall Hill, Lesmahagow. L. L. S. Boghead, Hamilton.

L. (?) Thomsoni, $D a v$-_(very rare). L. L. S Tirfergus Glen, Campbeltown. Discina nitida, Phill.-U. C. S. Drumpark Pit. Baillieston (Skipsey). Shotts. Slatyband Ironstone. U. L. S. Same beds as L. mytiloides. L. L. S. Same beds as L. mytiloides. Appears to be absent in M. I. S.

D. Craigi, Dav.-U. L. S. N.B. Ry. cutting S. of Garngad Road, Glasgow. L. L. S. Trearne, Beith.

Crania quadrata, $\mathbf{Y}^{\prime} \mathrm{Coy}-\mathrm{U}$. L. S. Gare: Orchard: Thoruliebank. L. L. S. Calderside limestone shale (common and fine), E. Kilbride : High Blantyre: Boghead.

\section{Clistenterata.}

Dielasma (Terebratula) sacculus, Martin.-L. L. S. Beith : Dalry : Corrieburn: Braidwood.

D. (T.) sacculus, var. hastata, Sow.-Found along with above.

D. (T.) sacculus, var. vesicularis, de Kon.-U. L. S. Bowertrapping: Arden: Linn Spout. L. L. S. Braidwood: Beith.

D. (T.) sacculus, var. Gillingensis, Dav--L. L. S. Craigenglen: Corrieburn: Cumningham-Baidland, Dalry.

Spirifera duplicicosta, Phill.--(rare). L. L. S. Beith Quarries: Brockley: Braidwood: Balgrochan Burn, and Main Limestone, Campsie.

S. triangularis ? Martin.-L. L. S. Carluke (Rankin).

S. trigonalis, Martin (and var. bisulcata, Sow).-U. L. S. Orchard : Williamwood : Thornliebank : Arden : Bowertrapping: Saltpans, Arran. L. L. S. Bathgate: High Blantyre : East Kilbride : Craigenglen, and Main Limestone, Campsie: Corrieburn: Beith and Dalry : Gameshill, Dunlop : Corrie.

S. ovalis, Phill.-L. L. S. Brockley : Corrieburn: Beith.

S. triradialis, Phill.-L. L. S. Dockra, and Waterland, Beith: Cunningham-Baidland, Dalry : Brockley.

Martinia (Spirifera) glabra, Martin.-U. L. S. Orchard: Arden : Thornliebank. L. L. S. Beith and Dalry Quarries: Corrieburn: Main Limestone, Campsie: Thornton.

M. Urei, Fleming.-U. L. S. Orchard: Bowertrapping: Gare. L. L. S. South Hill, Craigenglen: Main Limestone, Campsie: Thornton: Brockley: Braidwood: Dockra, Beith.

M. carlukensis, Dav--U. L. S. Gillfoot. L. L.S. Brockley : Dockra and Trearne, Beith.

Reticularia (Spirifera) lineata, Martin.-U. L. S. Arden : Thornliebank Orchard: Gare: Robroyston. L. L. S. Beith Quarries: Braidwood: Lesmahagow : Corrieburn: Main Limestone, Campsie: High Blantyre : E. Kilbride.

Spiriferina cristata, var. octoplicata, Sowo.--U. L. S. Gare: Orchard. L. L. S. Boghead : High Blantyre: E. Kilbride: Carluke: Trearne and Dockra, Beith: Corrieburn. 
Spiriferina insculpta, Phill.-(very rare). U. L.S. Gare: Gillfoot: Muirkirk: Saltpans, Arran.

S. laminosa, M'Coy-(very rare). U. L. S. Gillfoot, near Carluke: Saltpans, Arran (common). L. L. S. Auchenskeith: Brockley.

Athyris ambigua, Sow.-U. L. S. Gare : Orchard: Arden: Hillerhirst : Saltpans, Arran. L. L. S. Braidwood : Corrieburn : Craigenglen : Beith : Netherwood, Strathavon.

A. plano-sulcata, Phill.-L. L. S. Brockley : Braidwood : Corrieburn : Beith and Dalry.

A. Royssi, Leveillé.-L. L. S. Braidwood : Corrieburn : Beith and Dalry.

A. pisum, Dav.-(very rare). L. L. S. Brockley.

Retzia radialis, Phill.-(rare). U. L. S. Gare: Limekilnburn. L. L. S. Brockley: Dockra and Trearne, Beith : Braidwood : Corrieburn : Laggan, Arran.

Rhynchonella pugnus, Martin.-U. L. S. Gare: Robroyston : Castlecary : Arden : Bowertrapping. L. L. S. Corrieburn : High Blantyre : E. Kilbride: Braidwood : Beith.

R. pleurodon, Phill.-L. L. S. Corrieburn : Craigenglen : High Blantyre : E. Kilbride: Braidwood: Beith : Corrie and Laggan, Arran.

S. brockleyensis, Dav.-(very rare). L. L. S. Brockley.

Rhynchopora Youngi, Dav.-(very rare). U. I. S. Bowertrapping; Dalry.

Camarophoria crumena, Martin.-(very rare). L. L. S. Main Limestone, Campsie.

C. globulina, Phill.-(very rare). L. L. S. Brockley : Braidwood : Auchenskeith : Broadstone, Beith.

Strophomena rhomboidalis, Phill., var. analoga, Phill.-(very rare). L. L. S. Corrieburn : Main Limestone, Campsie : Langside, Beith.

S. rhomboidalis, var. distorta. U. L. S. Gare : Limekilnburn : Browntod : Bowertrapping.

Streptorhynchus crenistria, Phill. (and var. radialis). U. L. S. Gare : Orchard: Thornliebank: Limn Spout, Dalry: Garngad Rd., Glasgow. L. L. S. Corrieburn: Main Limestone, Campsie : Braidwood: Beith : Auchenskeith : Laggan, Arran.

S. crenistria, var. senilis, Phill.-(very rare). U. L. S. Bowertrapping.

S. crenistria, var. cylindrica (robusta), $M^{\prime} \mathrm{Coy}$. U. L. S. Tirfergus Glen, Campbeltown : Garngad Road, Glasgow : Muirkirk.

Orthis Michelini, Leveillé.-L. L. S. Beith Quarries: Braidwood: Corrieburn: Main Limestone, Campsie.

O. resupinata, Martin.-U. L. S. Gare : Robroyston : Castlecary : Thornliebank: Orchard : Garngad Road. L. L.S. Corrieburn : Craigenglen : Carluke : Beith : Laggan, Arran.

Chonetes Laguessiana, de Kon.-U. L. S. Gare : Orchard: Thoruliebank. L. L. S. E. Kilbride : High Blantyre: Boghead: Thornton: Beith : Campsie.

C. Laguessiana, var. gibberula, $M^{\prime} \mathrm{Coy}-$-(very rare). L. L. S. Corrieburn : Dockra, Beith.

C. Buchiana, de Kon.-(very rare). U. L. S. Gare: Swindridge, Beith. L. L. S. Millburn, Campsie : Braidwood.

C. polita.-U. L. S. Gillfoot, Braidwood. L. L. S. Craigenglen: Thornton: Braidwood.

Productus giganteus, Martin.-U. L. S. Bowertrapping: Arden: Orchard. L. L. S. Braidwood: Muirkirk : Shields, E. Kilbride: Thornton: Lesmahagow (largest specimens): Corrieburn and Millburn, Campsie : Corrie, Laggan, Maoldon, etc., Arran.

P. latissimus, Sow.-U. L. S. Bowertrapping. Muirkirk : Auldhouse, E. Kilbride : Saltpans, Arran. L. L. S. Craigenglen. 
P. cora, d'Orb.-U. L. S. Arden: Bowertrapping. Hamilton: Braidwood: Campsie : Dockra, Beith.

L. L. S. Boghead,

Productus semireticulatus, Martin (and vars. P. Martini, Sow, P. concinnus, Sow, and P. scoticus, Sow).-Generally distributed through Marine Limestones and Shales of U. L. S. and L. L. S.

P. costatus, Sow.-U. L. S. Orchard: Thornliebank. L. L. S. Braidwood: Main Limestone, Campsie: Gameshill, Dunlop.

P. costatus, var. muricatus, Phill.-U. L. S. Ry. cutting, Garngad Rd., in Sandstone : Thornliebank. L. L.S. Corrieburn : Beith Quarries.

P. scabriculus, Martin.-U.C.S. Drumpark Colliery. U. L. S. Garngad Rd.: Garnkirk: Castlecary : Arden. L. L. S. Carluke: Brockley : Beith : Craigenglen: Corrieburn.

P. pustulosus (?) Phill.-L. L. S. Braehead, Busby : Langside, Beith : Braidwood.

P. carbonarius, de Kon.-U. L. S. Shale over Cement, Garngad Rd., N.B.Ry. Station.

P. longispinus, Sow.-Generally distributed through the marine Isimestones and Shales of U. L. S. and L. L. S.

P. Griffithianus, de Kon.-L. L. S. Brockley: Dockra, Beith.

P. sinuatus, de Kon.-U. L. S. Garngad Rd. : George Square, Glasgow : Arden : Bowertrapping. L. L. S. Braidwood.

P. fimbriatus, Sow.-L. L. S. Beith Quarries: E. Kilbride: Main Limestone, Campsie.

P. aculeatus, Mart.-L. L. S. Cunningham-Baidland : Braidwood : Brockley: Main Limestone, Campsie.

P. Youngianus, Dav.-U. L. S. Orchard (very rare). L. L. S. Corrieburn : Beith : Cunningham-Baidland : E. Kilbride : Laggan, Arran.

P. punctatus, Mart. (and var. elegans), $M^{\circ} \mathrm{Coy}$ - - U. L. S. Castlecary : Arden : Bowertrapping. L. L. S. Craigenglen : Corrieburn : Beith : Dalry : Braidwood.

P. undatus, Def.-(very rare). U. L. S. Castlecary : Gare: Arden. L. L. S. Millburn and Glorat, Campsie: Carluke: Braidwood.

P. mesolobus, Phill.-(very rare). U. L. S. Arden. L. L. S. Main Limestone, Campsie: Braidwood.

P. spinulosus, Sow.-L. L. S. Brockley: Beith : Cunningham-Baidland: Corrieburn.

P. Deshayesianus, de Kon.-L. L. S. Main Limestone, Braidwood. 


\title{
THE CARBONIFEROUS LAMELLIBRANCHIATA OF THE CLYDE DRAINAGE AREA.
}

\author{
By James Neilson.
}

This class of the mollusca ranges throughont the several divisions of the Carboniferous rocks, the marine species being met with in the greatest numbers in the shales and clay-ironstones alternating with the limestones, in which latter, however, comparatively few specimens are found.

The freshwater, or brackish-water group, represented by the Carbonicola, Anthracomya, and Naiadites, are confined chiefly to the musselband ironstones and shales of the Upper Carboniferous series, a few species being got in similar strata in the Middle Coal and Ironstone series, while oneNaiadites crass -is found in shale under the lowest limestone in the Beith district, associated with marine fossils. None of this group are to be met with in any of the beds yielding the characteristic marine organisms of the system, while, on the other hand, none of the latter are found in the Middle Coals and Ironstones. In several instances where Carbonicola is said to have been got along with marine organisms it may probably have been derived from some earlier deposit, or drifted seawards from its own proper habitat, or even more probably, it may have been picked up on a shale-heap amongst marine fossils, having really been derived from quite a different stratum, as recently happened in the case of other fossils at Alexaudra Parade, Glasgow. It is evident that these freshwater or brackish-water forms have lived in the Scottish coal-field under quite different conditions from the marine ones found in the Limestone series.

In the following list the names of the freshwater group are those given in Dr. Wheelton Hind's Monograph on Carbonicola, Anthracomya, and Naiadites, and those of the marine Dimyaria in his Monograph on the Carboniferous Lamellibranchiata, both issued by the Palaeontographical Society, 1894 to 1900. Unfortunately Dr. Hind has not yet worked out the Monomyaria, though it is to be hoped he will soon do so, as at present the group is in a most unsatisfactory condition. When this is done we are under the impression that the number of species will be very much reduced.

Many of the generic and specific names in this list will be found to differ from those in the 1876 Catalogue $^{1}$ owing to various causes, such as the sub-division of genera, the former names being synonyms of previouslyexisting species, or former faulty identification of the species. For facility of reference to the existing literature on the subject the old names have been. given in italics, and within brackets ( ).

\section{MONOMYARIA.}

Leiopteria lunulata, Phill.-(rare). U. L. S. Gare: Thornliebank. L. L. S. Howrat, Dalry.

L. squamosa. U. L. S. Thornliebank : Garpel Water, Muirkirk.

${ }^{1}$ Catalogue of the Western Scottish Fossils, Glasgow, 1876. 
Avicula? concinna, $M^{\prime} C o y .-U$. L. S. Shale over Linn Limestone, Dalry.

A. ? decussata, $M^{\prime} \mathrm{Coy}$ - - U. L. S. Along with above.

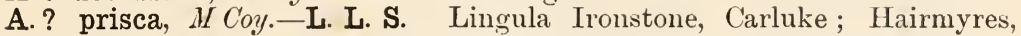
E. Kilbride.

A. subanisotus, R. Ether. jun.-L. L. S. Glenwhapple Burn, near Craigenglen.

Aviculopecten arenosus, Phill.-L. L. S. Carluke ; Campsie (Main Limestone), High Blantyre; Thornton.

A. caelatus, MCCoy.-U. L. S. Orchard; Linu, Dalry; Garngad Road. L. L. S. Beith Quarries.

A. clathratus, $M^{*} \mathrm{Coy}--$ L. L. S. Boghead, Hamilton.

A. cognatus, $M^{\prime} C o y$ - (Rare). L. L. S. Main Limestone, Braidwood.

A. concavus, $\Gamma^{\prime}$ Coy--L. L. S. Boghead, Lesmahagow.

A. concentricostriatus, $M^{\prime} \mathrm{Coy}$--(Rare). L. L. S. Corrieburn.

A. consimilis, $\mathbf{I}^{\prime} \mathrm{Coy}-\mathrm{-}$ (Rare). U. L. S. Bowertrapping. L. L. S. Craigenglen.

A dissimilis, Flem.-(Rare). L. L. S. Boghead, Hamilton; Main Limestone, Carluke.

A. docens, M'Coy.-(Very Rare). L. L. S. East Kilbride.

A. Dumontianus, de Kon.-U. L. S. Garngad Road; Bowertrapping. L. L. S. Trearne ; Main Limestone, Braidwood.

A. duplicicosta, $M^{\prime}$ Coy--(Rare). L. L. S. Boghead, Hamilton; Lingula Ironstone, Carluke.

A. elongatus, $M^{\prime} C o y$. L. L. S. Roughwood, Beith.

A. fallax, $M^{\prime} \mathrm{Coy}$ - - L. L. S. Lingula Ironstone, Carluke.

A. fimbriatus, $M^{\prime} \mathrm{Coy}$-- (Common). L. L. S. Newfield ; Boghead, Hamilton ; Brockley; Carluke; Corrieburn ; Beith ; Cunningham-Baidland.

A. flexuosus, $M$ Coy-L. L. S. Hillhead, Beith.

A. granosus, Sow.-U. L. S. Garugad Road. L. L. S. Corrieburn.

A. incrassatus, $M^{6} \mathrm{Coy}-\mathrm{L}$. L. S. Auchenskeith.

A. interstitialis, Phill.-U. L.S. Gare; Bowertrapping. L. L.S. C'raigenlen ; Corrieburn.

A. Knockonniensis, $M \cdot C o \%$ - L. L. S. Brockley : Boghead, Hamilton.

A. macropteris, $M^{\prime} C^{\prime} 0 \%-$ - L. L. S. First Calmy Limestone, Carluke.

A. ornatus, K. Ether., jun.-L. L. S. Calderwood Cement Shales; Main Limestone, Carluke.

A. oryza, R. Ether., jun.-L. L. S. Second Kingshaw Limestone, Carluke.

A. ovatus, $M$ Coy.-U. L. S. Linn Limestone, Dalry.

A. papyraceus, Goldf.-M. I. S. Inkerman, Paisley. L. I. S. Shale over Cement, E. Kilbride. (In England this shell is considered characteristic of Upper Carboniferous strata.)

A. planoradiatus, $M \cdot C o y-$ - L. L. S. Boghead ; Lesmahagow.

A. plicatus, Sow.-(Rare). U. L. S. Gare. L. L. S. Main Limestone, Carluke : Clay Ironstone, Craigenglen.

A. scalaris, Sow.-(Very Rare). U. L.S. Gare.

A. sclerotis, Mr'Coy.-(Very Rare). L. L. S. Boghead, Hamilton ; Craigenglen ; Main Limestone, Braidwood.

A. semicircularis, $M^{\prime} \mathrm{Coy}$.- L. L. S. Roughwood; Thornton, in Shale under Main Limestone.

A. semistriatus, $M^{\prime} \mathrm{Co} \%$-L. L. S. East Burn, Stewarton.

A. serratus, $M^{\prime}$ Coy.-L. L. S. Newfield; Howrat.

A. simplex, de Kon.-U. L.S. Gare; Orchard. L. L. S. Boghead, Hamilton ; Capelrig ; Cunningham-Baidland.

A. subelongatus, $\mathbf{I}^{\prime} \mathrm{Coy}$-U. L. S. Bowertrapping. L. L.S. Craigenglen.

A. stellaris, Phill.-L. L. S. Corrieburn; Main Limestone, Braidwood.

A. tessellatus, Phill.-U. L. S. Gare. L. L. S. Lingula Ironstone, Carluke. 
Entolium (Pecten) Sowerbyi, M/Coy-_L. L. S. High Blantyre; Boghead, Hamilton; Thornton, in Shale under Main Limestone.

Pinna flabelliformis, Mart. (including $P$. flexicostata.)-U. L. S. Bishop,briggs ; Arden. L. L. S. Beith ; Craigie ; Brockley.

P. mutica, $Y^{\circ} \mathrm{Coy}-(P$. Ivanskiana and $P$. spatula). L. L. S. Inkerman Paisley ; Lingula Ironstone, Carluke ; High Blantyre; Craigenglen.

Pteronites latus, M'Coy.-(Very Rare). L. L. S. Corrieburn; Cunningham-Baidland.

Actinopteria (Pteronites) fluctuosa, $M^{*} \mathrm{C} o y .-$ L. L. S. Abundant in thin band of Shale. Craigenglen.

A. persulcatus, $M^{\prime} \mathrm{Coy}-$ U. L.S. Linn Spout. L. L.S. Craigenglen ; Corrieburn; Kilbride; Waterland ; Beith.

Posidonomya? (Anomia) corrugata, R. Ether. jun.-U. L. S. Lim Spout. L. L. S. Boghead ; East Kilbride (in Cement-shales); Thornton (under Main Limestone); Craigie.

P. ? (Estheria) punctatella, Jones.-U. L. S. Limn Spont; Arden.

\section{DIMYARIA. \\ (Freshwater Shells.)}

Unless where marked otherwise these localities are all Upper (arboniferous.

Carbonicola (Anthracosia) robusta, Sow.-(Note.-This species is not found higher than the roof of the Drumgray coal). U. C.-Carluke; Shotts; Slamamnan; Dalmellington; Alexandra Parade, Glasgow. M. I. S. Dalry.

C. acuta, Sow.-Shales of the Drumgray coal and upwards. Kilmarnock; Shotts ; Airdrie; Shettleston; Carluke. Slatyband Ironstone, Stonehouse and Douglas (Survey). L. L. S. Raes Gill Ironstone, Carluke (Geol. Survey, sheet 23).

C. ovalis, Martin.-Virtuewell coal, Shotts; Airdrie, Blackland Ironstone. Bellside Ironstone, Carluke, Carmyle and Kenmuir.

C. polmontensis, Brown.-Coal shale, Polmont, nr. Falkirk; Springhill Colliery, nr. Kilmarnock ; Kirkwood Colliery, Old Monkland ; Ell Coal, Kilwimning.

C. turgida, Brown.-Dalmellington; Lugar ; Wishaw ; Cambuslang ; Shettleston.

C. aquilina, Sow.-(Unio or Anthracosia (rei, Flem.). Ell to Splint Coal. Rutherglen; Cambuslang; Shettleston; Motherwell; Fullarton, Ayrshire. Alexandra Parade, Glasgow. Slatyband Ironstone, Douglas. Enters largely into the composition of Musselband Ironstone.

C. similis, Brown.-Lugar : Springburn Colliery, Ayrshire.

Anthracomya modiolaris, Sow.-Ell to Drumgray coal, Airdrie ; Motherwell ; Shettleston ; Carluke ; Kilmarnock ; Old Cumnock.

A. Williamsoni, Brown.-Eastfield, Rutherglen.

A. minima, Ludwig.-M. I. S. Possil, Glasgow.

A. Phillipsi, Williamson.-Palacecraig Ironstone, Airdrie.

A. Wardi, Salter.-M. I. S. Possil Lower Ironstone.

Naiadites (Anthracoptera) modiolaris, Sow.-Kilwimning: Splint Coal, Shettleston to Rutherglen, Shotts, from Kiltongue to Gas Coal.

N. triangularis, Sow.--Shotts.

N. carinata, Sow.-Shettleston ; Carmyle; Old Monkland ; Shotts.

N. quadrata, Sow.-Splint Coal, Shotts.

N. (Myalina) crassa, Flem.-L. L. S. Lugton Water, nr. Dunlop; Roughwood and Lyonshields, Beith.

(NotE.-This species is found associated with marine forms.) 
Naiadites magna, Hird.-Middle Ironstone and Coal Series. Blackband Ironstone, Bankend, Lesmahagow.

\section{(Wuine Shells.)}

Modiola megaloba, $M / C o \%-$ L. L. S. Craigenglen. (Note.-Dr. Hind now believes this to be a young or dwarfed condition of Taiadites crassa.)

? M. (Lithodomus) Jenkinsoni, $V^{*} \mathrm{Coy}$-Lingula Ironstone, Carluke.

Lithodomus lingualis, Phill.-(Very Rare.) L. L. S. Craigenglen; Broadstone, Beith; E. Kilbride ; Lingula Ironstone, Carluke.

L. lithodomoides, R. Ether., jun.-L. L. S. Shale under Lower Limestone, Beith; Glen Lora and Lochwinnoch, Renfrewshire ; Colrieburn ; Craigie, near Kilmarnock. (I'ery local and giegarious.)

Posidoniella vetusta, Sov.-U. L. S. Castlecary; Burn Anne (opposite Cessnock (astle); Galston.

Myalina Flemingi, $\boldsymbol{V} \cdot \mathrm{Coy}-\mathbf{U}$. L. S. shale and sandstone in ry. cutting, Garngad Road. L. L. S. Thin band of Ironstone on shore S. of landingplace, Corrie, Arran.

M. Verneuili, M'Coy.--U. L. S.-Garngad Road (as above), Anchenbeg and Bankend, Lesmahagow. M. I. S. Inkerman, Paisley. L. L. S. Corrie, (as above) Lingula Ironstone, and first Kingshaw Limestone, Carluke ; Campsie ; E. Kilbricle.

Parallelodon(Arca) reticulatus, $\boldsymbol{H}^{\circ} \mathrm{C}^{\prime} \mathrm{y} .-\mathrm{U}$. L. S. Gare; Orehard. L. L.S. Craigenglen.

P. semicostatus, $\|^{*} C_{0 y}-$ U. L. S. Limn spout, Dalry ; Orchard. L. L. S. Craigenglen.

P. Geinitzi, de Kon.-U. L. S. Linn spont, Dalry. L. L. S. Craigenglen.

Nucula gibbosa, Flem.-(Conmon.) U. L.S. Gare; Robroyston; George Square, Glasgow; Orchard ; Waukmill Glen; Thornliebank; Swindridge and Linn spout, Dalry. M. I. S. Bishoplriggs and Cadder; Robroyston. L. L.S. Hosie Limestone, Campsie and Thornton: Carluke ; E. Kilbride ; Craigenglen ; Dalry ; Kilwinning.

N. luciniformis, Phill.-U. L. S. Gare; Robroyston: Orchard; Wankmill Glen. M. I. S. Cadder ; Bishopbriggs ; Robroyston. L. L. S. Lingula Ironstone, Carluke : Campsie and Thornton, over Hosie Limestone.

N. oblonga, $\boldsymbol{V}^{\prime}$ Coy.-(Very Rare.) U. L.S. Orchard; Waukmill Glen ; Thornliebank.

N. aequalis, Sou. (I.lineata.)-U.L.S. Gare ; Robroyston ; George Square; Orchard. L. L. S. Shale above Hosie Limestone, Campsie; Thornton and Rae's Gill, Carluke; Craigenglen.

N. Scotica, Hind.-L. L. S. Craigenglen.

Nuculana (Leda) attenuata, Flem.-(Common) nearly always associated with Vucula gibbosa. U. L.S. Gare; Robroyston; George Square, Glasgow ; Orchard; Waulkmill Glen : Thornliebank; Swindridge, and Linn Spout, Dalry. L. L. S. Shale above Hosie Limestone, Campsie and Thornton; Carluke; E. Kilbride; Craigenglen.

N. Sharmani, R. Ether.jun.-(Rare). U. L. S. Garngarl Road, in shale over Cement.

N. stilla, $M \cdot C o \%-($ Very Rare.) U. L.S. George Square, Glasgow; (iu shale over Robroyston Limestone).

N. brevirostris, Phill. (Leda longirostris, Leda Youngi).-(Rare.) U. L.S. Gare; Orchard; Garngad Road. L. L.S. Carluke; Campsie and Thornton, in shale above Hosie Limestone.

N. laevistriata, Meek and IVorth.-U. L.S. Orehard: Muirfoot Burn, New Cumnock; Den, Dalry. L. L. S. Craigengleı; Brockley, Lesmahagow

Ctenodonta (Leda) undulata, Phill. - L. L. S. Craigenglen.

C. levirostrum, Portlock (Leda clavate).-U. L. S. Linn Spout, Dalry : Orchard ; Waukmill Glen. L. L.S. Lickprivick, East Kilbride. 
Schizodus axiniformis, Phill.-U. L.S. Railway cutting, Garngad Road, Glasgow (in sandstone).

Protoschizodus axiniformis, Portl.-U. L. S. Gare : Garngad Road. L.L.S. Lingula Ironstone, Calmy and Main Limestone, Carluke; Craigenglen: E. Kilbride : Beith.

P. impressus, de Kon.-U. L. S. Orchard. L.L.S. E. Kilbride.

P. obliquus, MrCoy-L. L. S. Shale below Main Limestone, Beith.

P. triangularis, Hind.-L. L. S. Shale below Main Limestone, Beith.

P. aequilateralis, $M \cdot C o y$ - L. L. S. Calderwood Cement-stone, E. Kilbride : Burn Anue, Galston.

Cardiomorpha oblonga, Sow.-L. L. S. Gameshill, Stewarton.

C. orbicularis, $M^{\prime} \mathrm{Coy},-$ L. L.S. Newfield, High Blantyre ; Gameshill, Stewarton.

C. limosa, Flem. (C. oblonga of 1876 Catalogue). U. L. S. Gare ; George Square and Garngad Road, Glasgow ; Thornliebank ; Orchard. M. I. S. Bishopbriggs ; Cadder ; Robroyston. L. L. S. Beith ; Craigenglen.

C. parva, Hind.--U. L. S. Orchard; Clonbeith, Kilwinning. L. L. S. Waterland, Dunlop ; Gateside, Beith.

Sedgwickia scotica, Hind.-L.L.S. M'Donald Limestone, Muirkirk ; Shale under Main Limestone, Beith ; Craigenglen.

Edmondia unioniformis, Phill.-U.L.S. Shale over Arden Limestone, Barrhead. L. L. S. Shale under Main Limestone, Beith ; Hindog Glen, Dalry.

E. Josepha. U.L.S. Garngad Road; Browntod, near Quarter Road Station. L. L.S. Trearne, Dockra, and under Main Limestone, Langside, Beith.

E. Lowickensis, Hind.-U.L.S. Thornliebank; Girtle Quarry; Dalry ; Index Limestone, Hillerhirst.

E. oblonga, Portlock.-L. L. S. Shale below Main Limestone, Beith.

E. Lyelli, Hind.-- L. L. S. Newfield, High Blantyre ; Craigenglen ; Swinlees and Auchenskeith, Dalry ; Broadstone, Beith; M'Donald Limestone, Muirkirk.

E. rudis, M/Coy.-L. L.S. Newfield, High Blantyre ; Craigenglen ; Shale below Main Limestone, Beith ; Hindog Glen, Dalry.

E. primaeva, Portlock.-L. L.S. Corrieburn (in Pecten Shale), Langside, Beith.

E. transversa, Hind.-U. L. S. Garugad Road. L. L. S. Beith ; Auchenskeith, Dalry.

E. sulcata, Phill.-L. L. S. Bathgate; Howood; Beith ; Carluke.

E. M'Coyi, Hind.-L. L.S. Trearne and Dockra, Beith; Aucheuskeith, Dalry.

Scaldia fragilis, de Kon.-L. L.S. Calderwood Cement-stone, Kirktonholm, E. Kilbride.

Cypricardella concentrica, Hind.-(Rare.) (= Venus elliptica of 1876 (atalogue.) U. L. S. Linn Spout, Dalry; Gare, Carluke; L. L. S. Law, Dalry ; Craigenglen.

C. crebricostata, Armstrong.-(Very Rare.) U. L.S. Gare and Westerhouse, Carluke ; Arden.

C. Selysiana, de Kon.-U. L. S. Gare; Robroyston. L. L.S. Craigenglen ; Law, Dalry.

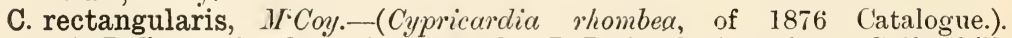
U. L. S. Orchard; Williamwood. L. L.S. Craigenglen ; Gallowhill, Strathavon.

C. acuticarinata, Armstrong.-(Rare.) U. L.S. Gare ; Robroyston ; Orchard; Williamwood; Linn Spout. L. L. S. Law, Dalry.

Sanguinolites angustatus, Phill.-L. L. S. Kersland Glen, Beith; Craigenglen. 
Sanguinolites Omalianus, de Kon.-L. L.S. Newfield, High Blantyre.

S. (Leptodomus) costellatus, $\mathbb{K}^{6} \mathrm{Coy}$-L.L.S. Boghead; E. Kilbride ; Craigie, near Kilmarnock. Railway cutting, Gurdy near Beith, Horizon of Hurlet Limestone.

S. plicatus, Portl.-(S. iridinoides.) U.L.S. Orchard; Garpel Water, Muirkirk; 10 fathoms below Lim Spout limestone. L. L. S. Kirktonholm, E. Kilbride.

S. striatogranulatus, Hind.-(S. tricostatus.) U.L.S. Linn Spout. L. L. S. Boghead ; Craigenılen; Beith Quarries; Hindog Glen, Dalry.

S. striato-lamellosus, de Kon.-U. L.S. Linn Spout; Craigie, Kilmarnock. L. L. S. Hindog Glen, Dalry:

S. Abdenensis, R. Ether., jun.-- L. L. S. Corrieburn ; near Cairn Bog, Kilsyth. Allorisma sulcata, Flem.-U. L. S. Garngad Road. L. L. S. Shale under Main Limestone, Beith.

A. variabilis, $\boldsymbol{I}^{6} \mathrm{Coy}$-L. L.S. Calderwood Linestone, Kirktonholm, E. Kilbride. Dockra, Beith.

A. Ansticei. Sow.-L. L.S. Auchenmarle, Ayrshire.

Tellinomorpha cuneiformis, de Kon.-U.L.S. Garngad Road. L. L. S. Thornton ; Hindog Glen, and Auchenskeith, Dalry.

Solenomya primaeva, U. L.S. Thornliebank. L. L.S. Hairmyres, E. Kilbride ; Bathgate.

Conocardium rostratum, Martin.-(Very Pare.) L. L. S. Langside, Beith ; Auchenmade, and Law Quarry, Dalry.

C. aliforme, Sou:-(Very Rare.) 'L. L. S. Corrieburn, Kilsyth.

C. decussatum, R. Ether:, jun.-(Tery Rare.) U. L. S. George Square, Glasgow. L. L.S. Law, and Glencart. Dalry. Cement-shale, F. Kilbride.

C. alatum, de Kon.-(Very Rare.) L. L.S. Law, Dalry ; Lesmahagow. 


\title{
CARBONIFEROUS CEPHALOPODA.
}

\author{
BY Jantes NeILSON.
}

The Carboniferous Cephalopods are represented by a considerable number of genera and species, which range from the Lower to the Upper Limestones, the greater number both of species and of individuals being found in the latter. A small species of Goniatites has been found abundantly in a thin marine band in the Upper Carboniferous series at Alexandra Parade, Glasgow, Remains of large examples of Nautilus, Actinoceras, Orthoceras, and Poteriorercts occur in the limestone chiefly in the form of casts, but the good - pecimens which are got in the shales generally have the outer shell well preservel, some of the (1)thoceratites still showing the remains of chevronshaped colour-bands.

Actinoceras giganteum, Sov.-U. L. S. Orchard; Gare; Castlecary.

L. L. S. Calderwood Cement-shale; Thornton.

A. sp. (with siphuncle larger and more compressed vertically than the above species).-U. L. S. Thornliebank.

Cyrtoceras Gesneri, Mart.-(Very Rare). U. L. S. Gare ; Robroyston ; Arden Limestone, Barrhead. L. L. S. Craigenglen.

C. rugosum, Flem.-(Rare). U. L.S. Orehard; Thornliebank. L. L. S. Calderwood Cement-shale, East Kilbride; Hairmrres ; Craigenglen.

C. unguis, Phill.-(Common). U. L.S. Gare; Thornliebank; Orchard. L. L. S. Calderwood Cement-shale, E. Kilbride: Thornton ; Craigenglen.

Orthoceras attenuatum, Flem.-(Common). U. L.S. Gare; Thornliebank; Orchard. L. L. S. Craigenglen; Calderwood Cement-shale : Thornton ; Carluke.

O. cylindraceum, Flem. U.L.S. Gare: Robroyston: Thornliebank. L. L. S. Carluke; Thornton; ('raigenglen (with colour-bands).

0. dentaloideum, Phill.-(Very Rare). L. L.S. Shale over Hosie Limestone, Campsie ; Calderwood Cement-shale, E. Kilbride.

O.dilatatum, de Kon.-U. L. S. Gare. L. L. S. Corrieburn.

O. Goldfussianum, de Kon.-U. L. S. Gare. L. L.S. Raes Gill, Carluke; South Hill, Campsie ; Thornton.

O. laterale, Plill.-U. L.S. Orchard. L. L.S. Craigenglen ; Braidwood.

O. laeve, Flem.-L. L. S. Calderwood Cement-shales; Boghead : Newfield; E. Kilbride.

O. lineale, de Kon.--L. L.S. Netherfield, Strathavon ; Balgrochan Glen, Campsie.

0. ovale, Phill.-U.L.S. Orchard ; Gare.

O. Munsterianum, de Kon.-L. L. S. Shale above Hosie Limestone, Campsie.

O. pygmaeum, de Kon.--U. L. S. Shale above Hosie Limestone, Canpsie, and Thornton. 
Orthoceras subcentrale? de Kon.-U. L. S. Orchard; Gare; Barrhead; Bishopbriggs. L. L. S. Calderwood Cement-shales, Kilbride.

O. sulcatum (undatum), Flem.-Common. U. L. S. Gare; Robroyston ; Orchard ; Thornliebank; George Square. L. L.S. Hosie Limestoneshale, Thornton and Campsie. Craigenglen ; Kirktonbolm.

Poterioceras cordiforme, Sow.-(Very Rare). L. L. S. Craigie; Waterland ; Calderside : Loudon Hill.

P. fusiforme, Sow.-(Very Rare). L. L.S. Calderwood Cement-limestone.

P. ventricosum, $M \cdot C o \%$ - (Very Rare). L. L. S. Calderwood Cement-shale, E. Kilbride ; Calderwood Limestone, Newfield ; Carluke.

Discites Leveilleanus, de Kon.-L. L.S. Calderwood Limestone series. High Blantyre, and E. Kilbride ; Main Limestone, Carluke.

Stoboceras (Nautilus) sulcatus, Flem. (S. quadratus, Flem.).-U. L. S. Orchard; Thornliebank; Barrhead; Garngad Road. L. L. S. East Kilbricle; Thornton (shale over Hosie Limestone).

Acanthonautilus bispinosus, Foord.-U. L.S. Cock of Arran (Geol. Survey).

Nautilus biangulatus, Sou.-U. L. S. Gare; Arden; Thornliebank. L. L.S. East Kilbride; Corrieburn; Shale over Hosie Limestone, Thornton, and South Hill, Campsie.

N. bifrons, de Kon.-L.I.S. Lugton; (type in the Thomson collection, Kilmarnock).

N. cariniferus, Sow.-L. L. S. Braidwood; Bankend, Lesmahagow.

N. dorsalis, Phill. (Tery Rare).-U. L. S. Castlecary.

N. excavatus, de Kon.-U. L.S. Castlecary.

N. globatus, Sox.-U. I. S. Gare; Orchard; Cock of Arran.

N. ingens, Mart.-U. L. S. Arden; Castlecary ; Muirkirk. L. L. S. Thornton; Braidwood; Campsie--in Main Limestone.

Pleuro-nautilus dorso-cariniferus, Romer, (Nautilus nodiferus, Armstiong).-U.L.S. Arden; Barrhead; Garngad Road ; Gare. L. L. S. E. Kilbride in Cement Limestone shale.

Solenocheilus pentagonus, Sow.-U. L.S. Castlecary.

Temnocheilus coronatus, $M^{\circ} \mathrm{Co} \% \quad$ (Nautilus tuberosus.)-U.L.S. Arden Limestone, Barrhead; Orchard; Castlecary; Auchenbeg. L. L.S. E. Kilbride.

Dimorphoceras (Goniatites) Gilbertsoni, Phill.-L. L. S. Shale over Hosie Limestone at Thornton, Braidwood, and South Hill, Campsie.

D. Looncyi, Phill.-L.L.S. Boghead; Raes Gill, Carluke; Thornton, in Shale over Hosie Limestone.

Glyphioceras (Goniatites) diadema._Goldf. U. L. S. Orchard; Thornliebank. IM. I. S. Blackband Ironstone-shale, Dalry. L.I.S. Craigenglen.

G. excavatum, Phill.-U.I.S. Orchard; Gare; Thornliebank. L.L.S. Thorntōn?

G. implicatus, Phill.-U. L. S. Gare; Robroyston.

G. micronotum, Phill.-U. L.S. Orchard; Garngad Road. L. L. S. Shale over Hosie limestone at Campsie and Thornton.

G. mutabilis, Phill.-U.L.S. Gare; Robroyston.

G. paucilobus, Phill.-U. L. S. Gare ; Robroyston.

G. Phillipsi, Foord and Cick.-U. I. S. Thornliebank.

G. reticulatum, Phill. (this species includes $(Y$. Gibsoni).-U.L.S. Gare.

G. sphericum, Ifart.-U. L. S. Gare. L. L.S. Corrieburn.

G. stenobolum, Phill.-M.I.S. Robroyston; Bishopbriggs ; Cadder.

G. striatus, Sou.-U.L.S. Gare. L. L.S. Shale above Hosie Limestone, Campsie ; Main Limestone, Carluke.

G. striolatum, Phill.-U.L.S. Gare ; Robroyston ; Orchard; Anchenbeg. M. I. S. Robroyston.

G. vesica, Phill.--U. L. S. Bowertrapping; Gare ; Robroyston ; Auchenbeg. L. L. S. E. Kilbride; Thornton. 


\section{GENERAL NOTES.}

\section{By James Neilson.}

Is concluding my lists of the larger groups of the Carboniferous mollusca some interesting points regarding their distribution may be mentioned.

On certain horizons of both the Lower and Upper Limestone Series an associated group of shells always appears in some of the shales and the clay ironstones, and sometimes in the calmy or cement limestones. The following are its most characteristic genera :-Nucula, Nuculana, Ctenodonta, Parallelodon, and Cypricardia, amongst the bivalves ; Pleurotomaria, Murchisonia, Euomphalus, Macrocheilus, Naticopsis, Loxonema, Dentalium, and Bellerophon, amongst the univalves; and Nautilus, Cyrtoceras, Orthoceras, and Goniatites, amongst the chambered shells.

From these same strata Corals, Crinoids, Polyzoa, and most of the Brachiopods, are absent, or at least rarely present; but, on the other hand, in the strata where these latter groups do occur abundantly, the above-mentioned group of mollusca rarely appears. It may also be stated that the above genera of mollusca are generally absent from the purer limestones, or are sparely represented by different species which do not appear in the shales. $\dot{A}$ cursory examination of any collection of Western Scottish fossils will show that all the genera named are chiefly derived from the Lower and Upper Limestone shales.

This grouping of the molluscan and other marine faunas of the Scottish Carboniferous sea-botton has in all probability depended greatly upon the depth of water, the temperature, and the nature of the sediments which were then being deposited. The reappearance at wide intervals, and at several horizons, of strata containing such varying groups of molluscan life shows clearly that certain conditions of the sea-floor were requisite for their growth and development, and also, on the other hand, that the same conditions were not favourable to the growth of Corals, Crinoids, Polyzoa, and many of the Brachiopods. 


\section{THE CARBONIFEROUS GASTEROPODA OF THE CLYDE DRAINAGE AREA.}

BY J. G. Goodchild, F.G.S.

The following list of the Carboniferous Gasteropoda occurring in the Basin of the Clyde has been compiled from various sources, chiefly by Mr. A. Macconochie, Assistant Curator of the Scottish Geological Survey Collections.

The nomenclature of this section of the mollusca remains in a very unsatisfactory state, except as regards the species which have been revised by Miss Donald.

Aclisina aciculata, Donald.

A. attenuata, Donald.
A. costulata, Donald.

A. costulata, var. dubia, Donald.

A. elongata, Fleming.

A. eiongata, var. cingulata, Donald.

A. elongata, var. varians, Donald.

A. elongata, var. parvula.

A. pulchra, var. intermedia.

A. pulchra, var. tenuis, de Kon.

A. pusilla.

A. quadrata, Donald.

A. quadrata, var.striatissima, Donald. Law.

A. similis, Donald.

A. terebra, Donald.

Bellerophon apertus, Soverby.

B. cornu-arietis, Sow.

B. (Bucania) decussatus, Fleming.

B. (B.) decussatus, var. striatus, $F$

B. (Tropidocyclus) Duchastelli, Léveillé.

B. (Waagenella)Dumonti, d'orbigny.

B. hiulcus, Sow.

B. Larcomi, Portlock.

B. (Waagenella) Leveilleanus, de Kon.

B. (Tropidocyclus) Oldhami, Portl.

B. tangentialis, Phill.

B. tenuifascia, Sow.
Gillfoot; Capelrig ; East Kilbricle; Craigenglen.

Gare ; Glencart ; Capelrig.

Law ; Glencart ; High Blantyre; Craigenglen.

Craigenglen ; Cunningham-Baidland.

Glencart ; Capelrig.

Law ; Crawfield.

Capelrig ; Craigenglen.

Law ; Crawfield.

Law Quarry, Dalry.

Robroyston; Swindridge.

Law ; Glencart.

Law.

Law ; Glencart.

Crawfield Quarry, Beith.

Howrat.

Main Limestone, Carluke.

Gare; Robroyston; Swindridge.

Gare; Robroyston.

Boghead ; Hamilton.

Bowertrapping: Craigenglen.

Pandearon Burn, Kilbirnie.

Hairmyres.

Orchard ; Gare.

South Hill, Campsie.

Gare.

Gare; Woorhead, Galston. 
Bellerophon (Euphemus)Urei, Flem. (iare; Orchard ; Craigenglen.

Chiton Armstrongianus, Eth. jui. Willianwood; Orchard.

C. burrovianus, Kirkby.

C. cordatus, kirkby.

C. dalryensis, Eth. jun.

C. Geikiei, Eth. jun.

C. gemmatus, de Kon.

C. humilis, Kirlby.

C. Loftusianus, King.

C. soleaformis, Eth. jun.

Chitonellus Bennieanus, Eth. jun.

C. Kirkbyanus, Eth. jun.

C. patelliformis, Eth. jun.

C. subquadratus Kirkby.

C. Youngianus, Kirkby.

Dentalium (Entalis) dalryense, Young.

D. (E.) ingens, de Kon.

D. (E.) inornatum, $\mathrm{I}^{\prime} \mathrm{Coy}$.

D. (E.) priscum, Goldfuss.

D. (E.) scoticum, Young.

Elenchus antiquus, $\boldsymbol{W}^{\circ} \mathrm{C} \% \%$.

E. subulatus, $M \cdot C o y$.

Eulima (Polyphemopsis) Phillipsiana, de lion.

Euomphalus, Sow.

E. acutus, Sow.

E. calyx, Phill.

E. (Schizotoma) carbonarius, Sov.

E. Dionysii, Goldt:

E. marginatus, $\dot{I}^{\circ} \mathrm{Coy}$.

E. (Straparollus) pentangulatus, Sow.

E. pileopsideus, Phill.

E. pugilis, Phill.

E. (Raphistoma) radians, de Ron.

E. serpula, de Kon.

E. tabulatus, $\mathrm{H} \cdot \mathrm{Coy}$.

E. (Omphalotrochus) tuberculatus, Flem.

Lacuna antiqua, $1 \%^{\circ} \mathrm{Coy}$.

Loxonema brevis, $/ / C \mathrm{C}$ y.

Williamwood.

Law Quarry, Dalry.

Law Quarry, Dalry.

Law Quarry, Dalry.

Gallowhill, Strathavon.

Robroyston.

Williamwood ; Orchard.

Law Quarry, Dalry.

Law Quarry, Dalry.

Law Quarry, Dalry.

Law Quarry, Dalry.

Law Quarry ; Craigenglen.

('raigenglen; Cunningham-Baidland.

Swindridge.

First Calmy Limestone, Carluke.

Swindridge ; Orchard.

Gare; Orchard ; Craigenglen.

Dockra ; Kerrsland Glen.

Robroyston.

Robroyston.

Orchard ; Gare; Craigenglen.

Bowertrapping; Craigenglen.

Burtonhead, Stewarton.

Orchard; Thorton.

Bowertrapping ; High Blantyre.

Limn Spout.

Arden : Bowertrapping.

William wood.

('armel Water, Kilmaurs.

Gare; Craigenglen.

Glencart.

Limu Spout.

Craigenglen.

Law (Quarry, Dalry.

Gare.

L. clathratvila, Joung and Aimstiong. Robroyston; Gare.

L. constricta, Mart.

L. curvilinea, Phill.

L. Lefebvrei, Lée.

L. (Orthonema) polygyra, $\mathrm{H}^{\circ} \mathrm{C} \% \mathrm{y}$.

L. rugifera, Phill.

L. scalaroidea, Phill.

L. sulcatula, $M^{\prime} \mathrm{Coy}$.

L. Urei, Flem.

Macrocheilus (Macrochilina)acutus, Sor:

Capelrig.

(xare; Robroyston ; Gurdy.

Beith Quarries; Main Limestone, Carluke.

Cumningham-Baidland; Gillfoot.

Craigenglen ; Hairmyres.

Gare; Robroyston; Hairmyres; Craigenglen.

Bowertrapping.

Capelrig; Boghead ; Hairmyres.

Gare; Hairmyres; Craigenglen.

M. (Polyphemopsis) fusiformis, Sow. Gare; Robroyston ; Swindlidge.

M. (Macrochilina) imbricatus, Sow. Orchard ; Gare ; Craigenglen. 
Macrocheilus Michotianus, de Kon. Robroyston ; Gare; Boghead, Hamil-

M. rectilineus, Phill.

M. (Macrochilina) semistriatus, Foung and Armst.

M. tricinctus, $\mathrm{M}^{\circ} \mathrm{Co} \%$.

Murchisonia angulata, Phill.

M. cincta, Donald. ton.

Gare.

Urchard ; Robroyston.

Gare.

Craigenglen.

Law ; Glencart.

M. (Stegocoelia) compacta, Donald. Glencart.

M. (Hypergonia) conula, var. convexa, Jonald.

M. dalryensis, Donald.

Craigenglen.

Dalry.

M. (Hypergonia) deplanata, Donald. Law; Glencart.

M. elongata, Portl.

M. (Glyphodeta) fimbricarinata, Young and Armst.

M. M'Coyi.

M. (Hypergonia) pentonensis, I)onald.

M. (H.) plana, Donald.

M. (H.) quadricarinata, $\mathrm{M} / \mathrm{C}$ o $y$.

M. quinquecarinata, de Kon.

M. quinquecarinata, var. pulchella,

Donold.
M. (Stegocoelia) Smithiana, Donald. Law.

M. (Aclisoides) striatula, de Kon.

M. (A.) striatula, var. Armstrongiana, Donald.

II. subsulcata, de hon.

MI. (Goniostropha) subtilistriata.

M. Thomsoni, Donald.

Gillfoot.

Robroyston.

Law.

Law ; Craigenglen.

Law ; Craigenglen.

Craigenglen.

Robroyston; Craigenglen.

Law.

Orchard; Robroyston; Swindridge ; Craigenglen.

Law ; Craigenglen.

Craigenglen.

Glencart.

Craigenglen.

M. (Goniostropha) turriculata, var. scotica, Donald.

Dalry Upper Limestone series.

II. Stegocoelia) variabilis, Donuld. Law, Dalry ; Crawfield, Beith.

M. Youngiana, Domald.

Naticopsis canaliculata, $M^{\prime} \mathrm{Coy}$.

N. elliptica, Plitl.

N. elongata, Phill.

N. lirata, Plilll.

Law ; Glencart.

Main Limestone, Campsie; Boghead, Hamilton.

Craigenglen ; below Main Limestone, Carluke.

High Blantyre; Craigenglen.

Arden ; Bowertrapping.

N. (Tychonia) Omaliana, de Kon.

N. plicistra, Phill.

Swindridge; Lingula Ironstone, ('arluke.

Gare; Hairmyres; Gillfoot.

N. robroystonensis, Young and A 'mst. Robroyston ; Gare; Orchard.

N. tabulatus, Phill.

N. variata, Phill.

Niso Smithiana, Young.

Orthonema pygmaeum, Doncle.

Platyceras (Capsulus) angustus, Phill.

P. (C.) carinatus, $\mu^{\circ} \mathrm{Co} \%$.

P. (C.) neritoides, Phill.

P. (C.) vetustus, Sow.

Porcellia armata, De Teineuil.

Glencart, Dalry.

Bowertrapping; Hairmyres ; Craigengleu.

Glencart.

Glencart, Dahry.

Gare.

Craigenglen.

Orchard; High Blantyre.

Gare; Bowertrapping; Limekilnburn.

Orchard ; Craigenglen ; Craigie. 
Porcellia (Leveilleia) puzosi, Lév. Pleurotomaria acuta, Phill.

P. altavittata, $\mathrm{M}^{\circ} \mathrm{Co} \%$.

P. benediana, de fion.

P. carinata, Sow.

P. (Mourlonia) conica, Phill.

P. (Agnesia) contraria, de Kon.

P. (Mourlonia) expansa, Phill.

P. frenoyana, de Kon.

P. (Ptychomphalus) galleottiana, de Kon.

P. granulata, de Kon.

P. interstrialis, Phill.

P. (Ptychomphalus) monilifera, Phill. (iare; Orchard; Craigenglen.

P. multicarinata, $M^{\prime} \mathrm{Coy}$.

P. ovoidea, Phill.

P. striata, Sowv.

P. undulata, Phill.

P. Youngiana, Armst.

P. (Baylea) Yvani, Lév.

Rabdospira Selkirki.

Siliquaria (?) carbonaria, Young.

Trochus (Microdoma) biserratus, Phill.

T. coniformis, de kon.

T. (Turbonellina) lepidus, de hon.

Turbo (Turbonitella)biserialis, Phill. Broadstone.

T. spiratus, $\mathrm{M}^{\circ} \mathrm{Coy}$.

Roughwood.

Craigenglen.

Gilencart, Dalry.

Bowertrapping; Main Limestone, Carluke.

Robroyston ; Gare.

Robroyston.

Gare; Gillfoot; South Hill, Campsie.

Capelrig; Boghead, Hamilton ; Hairmyres.

Gare; Craigenglen ; Beith Quarries.

Gare; Orchard.

Craigenglen ; Hairmyres.

Inkerman Pits, Paisley.

Glencart.

Main Limestone, Braidwood.

Main Limestone, Carluke.

Robroyston ; Gare ; Germiston.

Gare.

Craigenglen.

Orchard ; Boghead, Hamilton ; ('raigenglen.

Swindridge; Craigenglen.

Arden.

Craigenglen ; Main Limestone, Braidwood.

Ixcertae Sedis.

Conularia quadrisulcata, Sow.

Gare; Robroyston ; Boghead, Hamilton ; Thornliebank. 


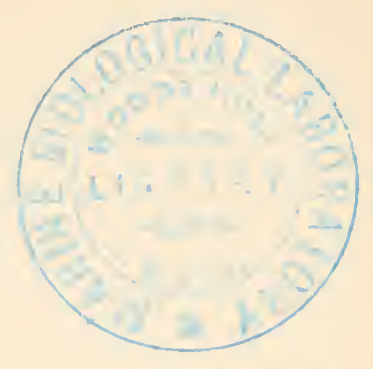

\title{
THE CARBONIFEROUS ECHINODERIIATA OF THE CLYDE DRAINAGE AREA.
}

\author{
By John Suith.
}

I A s much indebted to Dr. F. A. Bather of the British Museum for kindly undertaking the revision of the nomenclature of the following list of the Echinoderms of the Clyde drainage area. It may be added that I solely an responsible for the identification of the species included in it.

Archaeocidaris Munsteriana, de Kon.-- L. L. S. Beith and Dalry; very rare. A. scotica, J. Young.-Craigenglen, Campsie; very rare.

A. Urei, Flem.-U.L. S., L. L. S. ; abundant.

Melonechinus Youngi, Keeping, sp.-L. L.S. Beith, Dalry, Muirkirk: abundant, but local.

Palaechinus sphericus, $M^{\prime} \mathrm{Coy}$ - - L. L.S. East Burn, N.E. of Stewarton : very rare.

Allagecrinus Austini, Eth. and Carp.-L.L.S. Dalry and Howood; common at Howood.

Platycrinus laevis, Mill.--L. L. S. Kilsyth, Dahry, Beith.

P. trigintidactylus, Austin.-L. L. S. Dalry, Beith, Muirkirk.

Megistocrinus globosus, Mill., sp.-Carluke; first calmy limestone; rare.

Parisocrinus quinquangularis, Hill.-U. L. S., L. L. S. Muirkirk, Dalry. Beith, Kilwinning.

Scaphiocrinus conicus, Phill., sp.-L. L. S. Dalry, Beith.

Poteriocrinus crassus, Mill.-U. L. S., L. L. S. Dalry, Carluke, Thornliebank ; frequent.

P. opissus, de Kon. and Le Hon--Capelrig, Newton-Mearns; very rare.

Zeacrinus M'Coyanus, de Kon. and Le Hon., sp.-L. L. S. Beith, Dalry. Howood; scarce.

Hydreionocrinus calyx, $M^{\prime} \mathrm{Coy}, \mathrm{sp} .-\mathrm{L} . \mathrm{L}$. S. Dalry ; rare.

H. scoticus, de Kon.-L. L. S. Boghead, Hamilton; High Blantyre.

Scytalecrinus tenuis, Mill., sp.-U. U. S., L. L. S. Beith, Gare; scarce.

Ulocrinus globularis, de Kon., sp.-L.L.S. Beith, Dalry, Campsie : frequent.

Rhodocrinus uniarticulatus, de Kon. and Le Hon.-Beith ; rare.

Chiridota Robertsoni, Eth. Jr.-Orchard; rare.

C. primaeva, Eth. Jr.-Orchard.

C. Traquairi, Eth.Jr:--(An Elpidiid, notot near Chividota), U. L. S. Muirkirk. - L. L. S. Orchard.

Ancistrum Nicholsoni, Eth. Jr.-Orchard, Robroyston. 


\section{THE CONODONTS OF THE CARBONIFEROUS ROCKS OF THE CLYDE DRAINAGE AREA.}

\section{Br John Suith.}

IT has long been a subject of dispute as to the order of animal life to which Conodonts belonged. Dr. Panrler was the first to discover their remains, in 1856, and I found them in Scottish Carboniferous strata in 1876. I did not, however, publish my observations till 1899, so that I have had ample time to make a fairly exhaustive search for them in the rocks of the West of Scotland. ${ }^{1}$ Being minute and very tender these organisms require to be searcherl for in the most careful manner. They are found chiefly in the powder of rotted limestone, and, but very rarely, in shale, belonging to the Upper and Lower Limestone series. These are indicated in the foliowing list by letters in heavy type, U.L.S. and L.L.S. :

Polygnathus dubius, Hinde.-L.L.S., Birkhead, Dalry; U.L.S., Stacklawhill, Stewarton ; Robroyston, Glasgow.

P. (Gnathodus) mosquensis, Pander:-L.L.S., Cunningham-Baidland; Law and Birkhead, Dalry; Glenbuck, Muirkirk; U.L.S., Glencart, Dalry : Limn Spout, Dalry ; Monkcastle, Kilwiming; Stacklawhill, Stewarton : Robroyston, Glasgow.

P. navicula, Hinde.--L.L.S., Poneil, Donglas.

P. (Centrodus) connexus, Pander-L.L.S., Law and Auchenskeith. Dalry ; U.L.S., Glencart ; Monkcastle.

P. situlus, Hinde--U.L.S., Lim Spont; Monkcastle ; Glencart ; Orchard : Hillhead, Chryston ; Limekilns, E. Kilbride.

Centrodus duplicatus, Pander.-L.L.S., Law ; Birkhead ; U.L.S., Glencart : Monkcastle.

C. lineatus, Pander.-U.L.S., Linn Spont ; Glencart; Monkcastle ; Orchard. Prioniodus tulensis, Pander.-[Skateraw, Dumbar ;] L.L.S., Glenbuck: Law ; U.L.S., Glencart.

P. angulatus, Hinde.-L.L.S., Birkhead ; U.L.S., Glencart; Monkcastle.

P. spicatus, Hinde.-L.L.S., Birkhead.

P. peracutus, Hinde.-L.L.S., Law and Low Baidland, Dalry ; U.L.S., Glencart; Robroyston; Monkcastle ; Stacklawhill ; Limekilns.

P. complex, Hinde.-U.L.S., Glencart; Linn Spout.

P. genunus, Hinde.-U.L.S., Glencart ; Limn spout.

P. porcatus, Hinde.-U.L.S., Monkcastle.

Ctenognathus obliquus, Pander.-L.L.S., Law ; Birkhead.

1 Trans. Nut. Hist. Soc. of Glasgow, 1898-1899. 


\section{INCERTAE SEDIS. \\ Micro-Fossils in Middletonite in the \\ Clyde Drainage Area. \\ By JoHN SiIth, \\ Order Confervoldae.-Smith. 1}

Sphaironema curta, Smith.-Annandale, Kilmarnock.

S. plana, S.-Annandale.

S. miskensis, S.--Misk, Stevenston.

S. ayrshirensis, S.-Misk.

S. clavata, S.-Annandale.

S. tenuis, S-Annandale.

S. (?) spinulosa, S-Misk.

S. monilifera, S.-Annandale.

S. filiformis, S.-Annandale.

Nemaplana filiforme, S.-Amnandale.

Nemaclada alternata, S.-Annandale.

N. dichotoma, S.-Annandale.

N. pulvifera, S.-Amnandale.

N. contorta, S.-Annandale.

N. Beveridgei, S.-Misk.

\section{Orders Uxcertais.}

Peronosporoides carbonifera, S.-Amandale.

Leptonema tenuis, S.-Annandale.

Carbonacarpa annandalensis, S.--Annandale.

The following may belong to Crustacea or Annelida :

Corophioides polyupsilon, Smith.-('rawfordland, Kilnarnock; Gowkha', Kilwinning. ${ }^{2}$

${ }^{1}$ Trans. Geol. Soc. of Glasgow, vol. x., 1900, p. 318, plate vii.

2 Ilid., vol. ix., 1893, p. 289, plate x. 


\title{
THE CARBONIFEROUS FISHES OF THE IVEST OF SCOTLAND.
}

\author{
By R. H. Traquair M.D., LL.D., F.R.S., F.G.S.
}

The Carboniferous rocks of the West of Scotland are rich in fish-remains, although entire specimens of fishes are not of such frequent occurrence as in Midlothian or North Staffordshire. I have not myself collected in the district, but I have carefully examined the Carboniferous fish-remains in the principal collections of Western Scottish Fossils, viz. :

1. The James Thomson collection now in the new Kilmarnock Museum.

2. The Hunter-Selkirk collection, in the same institution.

3. The collection contained in the Hunterian Museum, of the University of Glasgow, which includes the fish-remains collected by the late

Dr. Rankine of Carluke.

4. The collection formed by the late Mr. Robert Craig, Beith.

5. The collection of Mr. John Smith, Monkredding, Kilwimning.

6. The collection of Mr. James Neilson, Glasgow.

7. The collection of Mr. Robert Dunlop, formerly of Stanrigg, Airdrie, and now in New Zealand.

8. The collection of Mr. Daviıl Sinclair, Kilmarnock.

Besides the fish-remains in these collections (to the possessors and guardians of which I must return my best thanks for facilities of inspection), I have noted those in the Edinburgh Museum of Science and Art, which, a good nany years ago acquired the collection of the late Mr. James Armstrong of Glasgow, and that of Dr. Grossart of Salsburgh, Carluke.

The result of my recent examination is to confirm the conclusion at which I arrived a good nany years ago, after studying the fossil fishes of Fife and the Lothians, - that so far as fish-life is concerned there are only two great life-zones-Upper and Lower-in the C'arboniferous system of Great Britain. In Scotland the Upper division includes the true Coal-measures with the underlying Millstone Grit, while in the lower one may be reckoned, in down ward succession, the Upper Limestone series; the Edge Coal series of Edinburgh geologists, or the "Lower Coal" series of those who dwell in the west; the Lower Limestone series; and the Calciferous Sandstone series.

The difference between the fish-famna of these two great divisions is not, however, quite so instructively brought out in the West of scotland as in the East, the reason being that the fish-remains from the Lower Carboniferous rocks of the West are principally from the marine limestones, while those of the Upper division or true "Coal-measures" are wholly estuarine, and in setting up "life-zones" we must, of course, compare the organisms which lived under similar conditions. This we are enabled to do better in the East of Scotland owing to the great richness in fossil fishes of the Lower Carboniferous estuarine berds there, thongh the list from the entire formation is not 
so great as that from the West, owing to the smaller extent of the Coalmeasures, and the consequently smaller number of the workings. The fishremains which have, however, occurred in the Coal-measures (Upper Carboniferous) of Fife and the Lothians belong to the same fauna as those of the West of Scotland, and of the North and West of England.

In the following list of species I have, therefore, only indicated two great horizons, the Lower and Upper Carboniferous, which are distinguished by the letters L.C. and U.C. respectively, in heavy type.

\section{Elasmobranchii.}

Diplodus gibbosus, Agassiz.

Pleuracanthus laevissimus, Agass.

P. cylindricus (Agass).

P. robustus, Davis.

P. alatus, Davis.

P. denticulatus, Davis.

P. Thomsoni, Davis.

P. tenuis, Davis.

Cladodus mirabilis, Agass.

C. striatus, Agass.

C. Neilsoni, Traq.

Dicrenodus dentatus $\left(M^{\circ} \mathrm{Coy}\right)$.

Janassa clavata $\left(\mathrm{M}^{\circ} \mathrm{Coy}\right)$.

$\mathrm{J}$. linguaeformis, Atthey.

\section{J. Wisei, Traq.}

\section{Petalorhynchus psittacenus} ( $\mathrm{M} /{ }^{\circ} \mathrm{CO} \mathrm{Cy}$ ).

Petalodus acuminatus (Agass).

Ctenoptychius apicalis, Agass.

C. serratus (Owen).

C. lobatus (R. Eth. jun.).

C. tripartitus, Davis.

Callopristodus pectinatus (Agass).

Polyrhizodus magnus, Agass.

Pristodus Benniei, R. Eth.jun.

Copodus cornutus, Davis.

C. prototypus (Davis).

C. spatulatus, Davis.

Psammodus rugosus, Agass.

Helodus simplex, Agass.

H. serratus (Davis).

Pleuroplax Rankinei (Agass).

P. Attheyi, Barkas.

P. falcatus, Traq.

Psephodus magnus $\left(\mathrm{M}^{\prime} \mathrm{Coy}\right)$.
U.C. Carluke; Newarthill.

U.C. Carluke; Newarthill; Annick Lodge; Motherwell; Airdrie.

U.C. Annick Lodge; Motherwell ; Airdrie.

U.C. Kilmarnock Water; Newarthill.

U.C. Lugton Water.

U.C. Kilmarnock Water.

U.C. Quarter.

U.C. Shotts.

L.C. Waterland ; Beith.

L.C. Bowertrapping; Beith.

L.C. East Kilbride.

L.C. Overton, Beith.

L.C. Overton and Broadstone, Beith.

U.C. Newarthill, Dykehead, Kilwinning.

L.C. East Kilbride.

L.C. Beith; Auchenskeith.

L.C. E. Kilbride ; Trearne, Beith ; Boghead ; Lesmahagow ; Stewarton.

U.C. Carluke.

L.C. Broadstone, Beith; Auchenskeith.

L.C. Brockley ; Cunningham-Baidland; Gameshill ; Gateside, Beith; Corrieburn, Campsie.

L.C. Beith.

U.C. Carnbroe.

L.C. Auckenskeith; Trearne, Beith.

L.C. Orchard; Dockra ; Auchenskeith.

L.C. Beith ; Lugton.

L.C. Broadstone, Beith.

L.C. Beith ; Lugton.

L.C. Beith ; E. Kilbride; Waterland; Lugton.

U.C. Thornton; Fergushill ; Carluke.

L.C. Waterland ; Lugton; Beith.

U.C. Carluke; Carnbroe; Quarter; Kilmarnock; Wellwood; Muirkirk.

U.C. Carluke; Thornton.

L.C. Overton, Beith.

L.C. E. Kilbride; Broadstone, Beith ; Auchenskeith ; Brockley, Lesmahagow. 
Sandalodus Morrisi (Davis).

Xystrodus striatus $\left(M^{\circ} \mathrm{Coy}\right)$.

Poecilodus Jonesi ( $\left.M^{\prime} \mathrm{Coy}\right)$.

P. obliquus $\left(M^{\circ} \mathrm{C} / \mathrm{y}\right)$.

Cochliodus contortus, Agass. Streblodus oblongus, (Portlock).

S. Colei, Davis.

Deltoptychius acutus, $M^{\prime} \mathrm{Coy}$.

Orodus sp.

Sphenacanthus serrulatus, Agass.

S. hybodoides (Egerton).

Tristychius arcuatus, Agass.

Euphyacanthus semistriatus, Traq.

Ctenacanthus major, Agass.

C. denticulatus, $M^{\bullet} \mathrm{Coy}$.

Acondylacanthus Jenkinsoni $\left(M^{\circ} \mathrm{Coy}\right)$.

Asteroptychius ornatus, $M^{\circ} \mathrm{Coy}$.

Harpacanthus major, Traq.

Perissacanthus Craigi, Traq.

Cosmacanthus carnatus, Davis.

Physonemus arcuatus, $M^{\circ} \mathrm{Coy}$.

Erisonacanthus Jonesii, M'Coy.

Oracanthus Milleri, Agass.

0 . armigerus, Traq.

Euctonius unilateralis (Barkas).

Lepracanthus Colei, Owen.

Gyracanthus formosus, Agass.

G. Youngi, Traq .

Aganacanthus striatulus, Traq.

Bertacanthus striatus, Traq.

B. tuberculatus, Traq.

Acanthodes Wardi, Egerton.

Acanthodopsis Wardi (Hancock and Atthey).

L.C. Barkip, Dalry.

L.C. Trearne, Beith.

L.C. Craigbank ; Lesmahagow.

L.C. Bowertrapping; Linnspout, Dalry; Broadstone, Beith.

L.C. Howrat. This is considered by Dr. Smith Woodward to be the lower dental plate of P. Jonesi.

L.C. Broadstone, Beith.

L.C. Broadstone and Dockra, Beith.

L.C. Overton, Beith.

L.C. Roughwood, Beith; Auchenskeith.

L.C. Beith.

L.C. Barkip, Dalry.

U.C. Shettleston ; Quarter ; Larkhali ; Newarthill ; Annick Lodge; Fergushill, \&c.

L.C. Lugton ; Blackstone ; Greenside ; Barkip, Dalry ; Possil.

L.C. Dairy ; Waterland ; Lugton.

L.C. Gameshill ; Stewarton; Beith.

L.C. Barkip, Dalry.

L.C. Broadstone and Overton, Beith ; Loudon Hill.

L.C. Trearne, Beith.

L.C. Beith.

L.C. Overton, Beith.

L.C. Overton, Beith.

L.C. Broadstone, Beith.

L.C. Dockra, Beith.

L.C. Ringwood, Beith.

L.C. Muirkirk ; Beith.

U.C. Newarthill ; Quarter; Fergushill. U.C. Carluke.

U.C. Shettleston ; Larkhall ; Quarter ; Cambuslang; Newarthill; Kirkwood; Annick Lodge; Motherwell ; Wishaw.

L.C. Beith.

U.C. Motherwell.

U.C. Crosshouse ; Kilmarnock.

U.C. Airdrie ; Carluke ; Kilmarnock ; Lugton Water.

U.C. Carluke.

Teleostomi.

Crossopterygii.

Megalichthys Hibberti, Agass. U.C. Newarthill ; Airdrie ; Carnbroe; Carluke; Quarter ; Busbie HeadPit; Kilmarnock Water; Annick Lodge ; Fergushill.

M. coccolepis, Young. U.C. Quarter. 
Megalichthys intermedius, $A$. $S$.

Woodward.

M. pygmaeus, Traq.

M. sp.

Rhizodopsis sauroides (Williamson).

Rhizodus Hibberti (Agass.).

R. ornatus, Traq.

Strepsodus sauroides (Bininey).

S. sulcidens (Atthey).

S. striatulus, Traq.

Coelacanthus elegans, Newb.

Coelacanthus abdenensis, Traq.
U.C. Carluke; Airdrie; Carnbroe.

U.C. Castlehill, Carluke ; Bartonholm.

L.C. Howrat.

U.C. Newarthill ; Castlehill, Carluke ; Kilmarnock Water; Lugton Water; Bartonholm.

L.C. Possil ; Dalry ; E. Kilbride.

L.C. Thorntonhall ; E. Kilbride.

U.C. Carnbroe; Newarthill ; Motherwell ; Fergushill ; Bogend.

U.C. Annick Lodge ; Fergushill.

L.C. E. Kilbride ; Overton, Beith.

U.C. Newarthill ; Castlehill, Carluke ; Motherwell ; Kilmarnock Water; Fauldhouse ; Lugton Water; Fergushill ; Bartonholm ; Stevenston.

L.C. Overton, Beith.

\section{Dipnoi.}

Ctenodus cristatus, Agass.

Sagenodus inequalis, Owen.
U.C. Larkhall ; Quarter ; Carnbroe ; Kilmarnock Water; Fergushill ; Crosshouse.

U.C. Newarthill ; Busbie ; Airdrie ; Fergushill ; Crosshouse, Kilmarnock.

Actinopterygii.

Gonatodus parvidens, Traq. Elonichthys Robisoni (Hibbert).

E. Egertoni (Egert.).

E. A.itkeni, Traq.

E. pectinatus, Traq.

E. multistriatus, Traq.

Acrolepis Hopkinsi, $\mathrm{M}^{\prime} \mathrm{Coy}$.

A. Hopkinsi, $M^{\prime} \mathrm{Coy}$.

Rhadinichthys ornatissimus (Agass).

R. Grossarti, Traq.

R. monensis (Egert.).

Nematoptychius greenocki (Agass).

Eurynotus crenatus, Agass. Cheirodus granulosus (Young).

C. crassus, Traq.

\section{Mesolepis sp.}

Platysomus parvulus, Young.

P. Forsteri (Hancock and Atthey).
L.C. Possil.

L.C. E. Kilbride.

L.C. Carluke.

U.C. Carluke; Crosshouse.

L.C. E. Kilbride.

L.C. Broadstone, Beith.

L.C. Braidwood; E. Kilbride.

U.C. Kilmarnock Water.

L.C. E. Kilbride.

U.C. Shotts ; Crosshouse.

U.C. Stevenston.

L.C. Possil.

L.C. Possil ; Crawford, Beith.

U.C. Lugton Water; Fergushill; Cauldhame.

L.C. Overton and Langside, Beith ; Auchenskeith.

U.C. Carluke.

U.C. Carluke; Cauldhame.

U.C. Newarthill.

It will be observed that of the 99 species contained in the above list 58 have been obtained exclusively from the Lower, and 39 exclusively from the Upper division of the Carboniferous formation, while one only (Acrolepis Hopkinsi) has occurred in both. 
It is true that a large proportion of the fishes of the Lower Carboniferous rocks of this region are marine, while those of the true Coal-measures are entirely estuarine, but in the East of Scotland, where those of the Lower division are likewise mostly estuarine, almost as marked a difference obtains. as regards species, though there is of course a greater similarity in general facies. Consequently as we can there compare estuarine with estuarine forms, the break in the Carboniferous fish-fauna which occurs at the top of the Upper Limestone series is, as I have already remarked, brought home to us with all the greater force. 


\title{
THE AMPHIBIA OF THE CARBONIFEROUS ROCKS OF THE CLYDE DRAINAGE AREA.
}

\author{
By the late Dr. John Young.
}

ONLY a few genera and species of Amphibians have been found in the freshwater or brackish-water strata from Lower Limestones to the higher beds of the Upper Coal-measures, and usually in a fragmentary state.

\section{Labyrinthodontia.}

Anthracosaurus Russelli, Huxley. Blackband Ironstone, Airdrie and Quarter.

Loxomma Allmanni, Hux.

Shale, Drumgray Coal, Carluke; Palacecraig Blackband, Carnbroe.

Megalerpeton plicidens, Young and

Thomson.

M. simplex, $Y$. and $T$.

Pholaderpeton, sp.

Pteroplax cornuta, Hancock and Athey.
Blackband, Quarter.

Blackband, Quarter.

Blackband, Quarter ; Blackband, Palacecraig.

Blackband, Quarter; Ironstone, Raes Gill. 


\title{
THE PERMIAN ROCKS OF THE CLYDE DRAINAGE
} AREA.

\author{
By Jợn Sмiтн.
}

As observed by Sedgwick, Binney, Harkness, and Goodchild, the Permian rocks of England are unconformable to the underlying strata, and the patches of this formation in the Clyde drainage area occupy a similar position.

\section{Ballantrae District.}

Just north of Ballantrae harbour and on the shore, there is a narrow patch of Permian rocks. It consists of $(a)$ a subangular conglomerate of a reddish tinge at parts bound together with calcite, the contained pebbles being evidently derived from the local Silurian rocks, greywacke, and trap, and having suffered very little tear and wear, generally no more than their angles having been removed. (b) From a short way N. of the harbour and on to near Bennane Head there is an exposure of fine-grained red sandstone closely resembling that of Mauchline. The beds dip gently, and are frequently cross-bedded and ripple-marked. It is so soft that the recent mollusc Pholas crispata bores freely iuto it.

These beds have been bored for coal, and fresh water issues from a borehole under high-tide mark. They terminate abruptly a short distance inland, and may be faulted against the Silurians. A few narrow trap dykes cut through them.

\section{Mauchline District.}

The Permian rocks of this district occupy a "pear-shaped" area, 9 miles by 6 at its widest part. The lower beds consist of a series of "porphyrites, melaphyres and tuffs, the product of volcanic vents which were active during the earlier part of the Permian period." ("Explanation" sheet 14, Geol. Survey.) They form a ring with an average width of less than a mile, and doubtless extend under the red sandstones, which at parts are seen to rest on them. There is, however, no definite line of junction, the tuff dovetailing into the sandstone lying above it.

The Permian sandstone is well exposed on the Water of Ayr at Ballochmyle and Barskimming; on the Lugar Water, near Auchinleck; and in several large quarries near Mauchline. It resenbles that of the Ballantrae district, and probably is largely a subaerial formation, although some of it as exposed in the railway cutting between Mauchline station and the Mossgiel tunnel has evidently been laid down in water. The thickness of this patch is not known, but is at least several hundreds of feet. Towards its upper part, bombs of the characteristic Permian volcanic, steatitic, and tender amygdaloidal rock occur in the sandstone, showing that towards 
the close of its formation (so far as seen here) volcanic activity had again set in. A volcanic vent is seen at the north end of the Mossgiel tunnel. Carboniferous Coal-measure rocks extend all round this Permian area, and doubtless under it.

\section{Arran.}

The geological position of the red sandstone strata of Arran had long been a matter of dispute till the discovery on the N.E. shore of a conglomeratic underlying sandstone which closely resembles that of Mauchline, proved at least that they were of post-Carboniferous limestone date and were in all likelihood of Permian age. (Truns. Geol. Soc. of Glasgow, vol. xi., 1898, p. 29.) The sandstones closely resemble those already described, but the conglomerate is entirely different from that of Ballantrae, and that of the Snar Valley to be presently mentioned. It contains pebbles of limestone with at least 29 species of Carboniferous fossils; the other pebbles consisting of quartz, varieties of trap, and fragments of sandstone.

The patches of red sandstone near Corrie and at Maoldon may be of Permian age, and have evidently been influenced, as to their dip, by the granitic nucleus of the island.

\section{Srar Valley.*}

In the Snar Valley, between Crawfordjohn and Leadhills, there is a suboval area of two miles by one mile, its long axis running N.N.W. and S.S.E. With the exception of a few feet of sandstone it is entirely coniposed of conglomerate with pebbles of greywacke and radiolarian chert. It dips towards Glendowran Hill (1543 feet) and Brown Hill (1603 feet), at about $20^{\circ}$ on an average. Close to the east boundary, on these hills, the dip becomes reversed and increases to as much as $60^{\circ}$, which apparently indicates that since the Permian strata were deposited they have been let down or the hills have been elevated. They rise from 850 to 1350 feet above sea-level. The conglomerate has a considerable resemblance to that of Ballantrae, and like it is occasionally cemented by calcite, the greywacke pebbles being stained (generally to their centres) of a reddish colour, and occasionally reaching a diameter of two feet. (Trans. Geol. Soc. Glas. vol. xi.) It is seen at one part to rest on the upturned edges of Silurian strata, also stained to some depth by the red colouring matter of the conglomerate.

At Bothwell the Clyde cuts through red rocks, but they are probably just the upper part of the Coal-measure strata, although some of the beds closely resemble the sandstone of Ballochmyle.

No fossils having been found in the Permian patches of the Clyde area, it is entirely on lithological and stratigraphical evidence that these remnants of an evidently once more extensive formation have been relegated to the Permian period.

*For a detailed description of this deposit see the author's paper, Trans. Geol. Soc. of Glasgow, vol. xi., part 2, 1900, page 250. 


\section{THE DRIFT OR GLACIAL FORMATION OF THE CLYDE DRAINAGE AREA. Bу Јонм Sмiтн.}

\section{The Drift below Sea-Level.}

The Clyde Drift-deposits extend to at least 230 feet below sea-level, ${ }^{1}$ and to 1750 feet above it. ${ }^{2}$ In a bore at Millichin, near Garscadden, 355 feet of drift-beds were passed through, the bottom being 221 feet below the present sea-level. These contained probably six Boulder-clays of varying shades of colour. ${ }^{3}$ In another bore at Drumry the bottom of the drift was 230 feet below sea-level.

It has been shown by Messrs. Croll and Bennie that a deep drift-filled gutter extends between the Clyde and the Forth in the hollow at present occupied by parts of the River Kelvin and the River Carron. As far as borings give the information the highest part of that hollow cannot be far, geographically, from the present watershed at Kilsyth, the bottom of the trough there being 15 to 20 fathoms below the level of the canal. The hollow E. of that deepens even more-at least 252 feet below sea-level-than that yet proved on the Clyde side. Several Boulder-clays have been passed through in the bores (as on the Clyde end of the hollow), but in the shallow portion near Kilsyth "only sand and gravel has been found." Shells of mollusca and foraminifera have been occasionally recorded from these beds, but no attempt was made to "work" them systematically for organic remains when the borings were made. At a little below and above sea-level a series of beds with Arctic shells, etc., is found, but as they are evidently of more recent date than the drift-beds higher up country I shall take the latter as first in order.

\section{The Drift above Sea-Level.}

The drift is only occasionally seen on the shore-level, as at Ardneil Bay, where the surface is composed of a tough reddish Boulder-clay; on the Garnock Water and the Water of Irvine; on several parts of the coast between Gourock and Skelmorlie; and in some of the sea-lochs. This paucity of drift on the sea-margin is owing to the immense time that the waves must have acted both on it and the adjoining rocks during the Raised Beach period, and also the recent one when it was cut off from that below sea-level. The last Raised Beach epoch is represented in the Clyde by a platform or terrace about 10 feet above high-tide mark, and that it was of great duration is shown by the present line of cliffs on its landward side.

1 J. Bennie, Trans. Geol. Soc. of Glasgow, vol. iii., part 1, 1868, p. 139.

2 The author, Ibid., vol. xi., supplement, 1898 , p. 83.

3 J. Bennie, Ibid., vol. iii., part 1, 1868, p. 139. 
At present it is the fashion to regard the close of the glacial period as of comparatively recent date- 8000 years even having been suggested. North of Portincross there is a Raised Beach cliff a mile long, composed of reddish sandstone and pink trap, rising to a vertical height of 300 feet, west of which, during the Raised Beach period, a quantity of rock of probably at least $9,000,000$ of tons must have been weathered from the face of the retiring cliff, ground into sand and mud, and carried off by the waves and currents. The talus of this cliff amounts to more than 100,000 tons. Where the rock is composed of sandstone and conglomerate the talus is a reddish clayey sand with pebbles and large masses of sandstone, but where the sandstone is capped by trap, 150 feet thick, the talus has also large blocks and shivers of trap. Some of the blocks from this cliff rest on Raised Beach shelly beds which they have protected from decay.

Adrocates of the theory of a short period of time since the close of the glacial period must bear in mind that there are no extinct shells in the Raised Beach beds of the Clyde, nor any boulders, and that little or no alteration in sea-level has taken place since Roman times, and very little since Iverian ones.

Above sea-level, the drift rises to at least 1750 feet, as already stated, and like that below it contains several beds of Boulder-clay-sometimes four. On some parts of the coast-line there are high ind old "scars" of drift, as N. of Girvan and N. of Ballantrae. An exposure 3 miles N. of the latter shows:

Boulder-clay, with a few shelly fragments, .

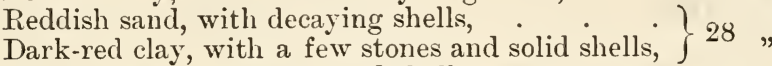

98 feet.

Gravel and sand, with rotted shells, . . . 21 ,

Boulder-clay, only occasionally seen, . . . 5 ,

The base of this section, not seen, is probably about sea-level.

The drift-beds as we ascend in altitude generally become thinner, and at about 1100 feet, in Ayrshire at least, no intercalated beds have been recorded -only Boulder-clay. In a recent investigation of the deposits cut through by the new railway from Elvanfoot to Wanlockhead in Lanarkshire I observed that there is no Boulder-clay above 1000 feet, and that all the drift is well-stratified, sometimes containing large foreign blocks.

In no part of Scotland are the drift-deposits better seen, perhaps, than in Ayrshire, the strata in many of the sections lying almost horizontal, or dipping with the valleys. There is clear evidence of extensive deformation having taken place, sometimes during their deposition, but occasionally after it, and there is an almost continuous exposure of the shelly-drift from sea-level to a height of 1061 feet above it. ${ }^{1}$ The shells are generally preserved in the Boulder-clay or in stoney clay, though sometines in sand or gravel, or in clay layers in the sandy beds and in laminated clay.

In Lanarkshire shelly-drift occurs on the Douglas Water at 1060 feet, and for two miles down stream. Recently I have obtained marine fossils at even a higher level on the Powbrane Burn. In other parts of the Clyde area shells have been found in the drift from near to over 1100 feet above sea-level.

\section{Shells in the Boulder-clay.}

It must have been noticed by most observers that shells in the Boulderclay exist almost always as fragments or as single valves, though these are often in such a fine state of preservation that it is impossible to suppose they have been transported any distance. The fine teeth of the most delicate Leda are in the most perfect preservation, and the epidermis is often

${ }^{1}$ Trans. Geol. Soc. of Glasgow, vol. xi., supplement, 1898, p. 113. 
retained. True, some of the shells are scratched, and in such cases must have been dragged a little. But how the valves have been so generally disjoined it is not easy to explain.

That the Boulder-clays are marine deposits does not, I think, admit of doubt; they are frequently stratitied, they often contain passage-beds between them and their associated sand and gravel beds, and they shade into laminated clays interbedded with them. These, taken with the fact that they often contain an abundance of marine fossil remains, afford strong proofs that Boulder-clays have been deposited in the sea.

The coast of Ayrshire lies well open to the Atlantic, and it is difficult to see how its drift could be a deposit from land-ice carrying " ground-moraine" uphill, as some geologists maintain. It is generally admitted that before the glacial period the land stood much higher than it does at present, but this only increases the difficulty of understanding how marine remains could have been transported uphill by land-ice. ${ }^{1}$

But how are the drift-shells so uniformly single-valved? It may be suggested that after the large ligaments have decayed or been eaten by microzoa the valves would easily fall asunder by agitation of the water caused by the falling of stones from floating ice, and probably a large proportion of the shells were smashed by the same agency.

\section{Drift Peculiarities.}

The Original Ground-Moraine is a thin layer on top of the rock which differs from any of the drift above it, and is, I believe, the only deposit of the kind ever formed by land-ice. Where the drift has been dragged $(a)$ by the stranding of icebergs, $(b)$ by glaciers pushing into the sea amongst deposits, or (c) by subsequent land-ice dragging the beds, it has been converted into what may be called secondary gromd-moraine.

Boulder-clay is seen sometimes resting on rock entirely different in colour from itself even at the point of contact, and it is often difficult to know, on the one hand, where the Boulder-clay ends and the gravel or laminated clay begins. On the other hand, it is puzzling to decide as to whether a bed is simply clay or Boulder-clay, as sand, gravel, and clay often contain large blocks, and gravel is sometimes very clayey, as may at present be seen at Blackhall, near Paisley, where it also contains boulders, is stratified, and lies under true Boulder-clay.

Unscratched Angular Stones, well-scratched stones, and unworn and unscratched shells, are often got lying near each other in Boulder-clay.

Boulders versus Stones. The latter are found often in the drift, whereas boulders are the exception, though they are conspicuous from their size.

Lines of Boulder's are frequently seen in sections in the Boulder-clay, but. the arrangement is only noticeable when they extend over a considerable space.

Ripple-marked Sand is occasionally seen interbedded in the drift, as in sections on the Guelt Water.

Manganese Gravel. Black gravelly beds stained by the binoxide of manganese are sometimes seen in the drift.

Drift on steep Hill-sides seen in sections on the burns is always very stoney and sometimes stratified.

Crumpled Mud is occasionally met with in the drift under normal beds.

Vertical Burrows in Sand are found in thick Boulder-clay at Newmilns. ${ }^{2}$

Sand-dykes in Boulder Clay are rare, but in Crawfordland Burn eight are

1 The Norwegian expedition to Greenland of 1876, 1878 found remains of a littoral fauna down to 6000 feet below sea-level.

2 Trans. Geol. Soc. of Glasgow, vol. xi., supplement, 1898, p. 31, fig. 10. 
exposed within a few yards, at abuut 380 feet above sea-level, and dip with the valley at about $80^{\circ} .1$

Passage-beds from Boulder-clay to Sand are well seen on Changue Burn, in Galston parish, 700 feet above sea-level.

Peat and Vegetable Matter in Drift are found:-under a sand-bed in Boulderclay at Gamesloup, 70 feet $^{2}$; at Burnhead, near Airdrie ${ }^{3}$; in sand under thick Boulder-clay on Guelt Water, at 860 feet above sea-level ${ }^{4}$; on Patrick Burn, Muirkirk, in Boulder-clay and resting on a rotted surface of the same material, at about 1000 feet above sea-level; on Afton Water, but doubtfully if in situ, at 1350 feet above sea-level.

Shore-lines and Gravel Terraces. Near the "Windy Wizzen," E. of Darvel, the officers of the Survey have shown on the 1 inch map No. 22, "an old seabeach about 700 feet above sea-level." Lately, I saw that, where exposed, large blocks of trap from the great scar on the south face of Loudon Hill had at one time rolled down on the top of this sand and gravel deposit, so that this cliff may have been the work of the waves helped by floating-ice. Terraces of sand and gravel occur near Eaglesham 535 to 900 feet above sealevel, ${ }^{5}$ and among the Moorfoot Hills at 1050 to 1100 feet. ${ }^{6}$ Where Boulderclay has been denuded away, sand and gravel are often exposed on the surface over small areas, as on the Annick Water at 620 feet above sea-level, where they may be seen going under Boulder-clay.

Hill-Benches backed by Cliffs or Banks are occasionally seen at Loudon Hill ; Glen, near New Cumnock about 900 feet above sea-level; Ponesk Valley, Muirkirk, at about 1300 feet $^{7}$; and in many places to much higher altitudes on the hills near the higher tributaries of the Clyde.

old Drift-filled Glens are frequent, the rivers having at many places left their old glens and cut new ones, often out of solid rock. ${ }^{8}$

Post-Glacial Glens cut in Rock. Examples of these are :-the Mouse Water, Lanark ; Craignethan ; Ness Glen, Loch Doon ; Boreland Glen, near Patna ; Hindog Glen and Cleaves Glen, Dalry ; and the gorge in the Permian rocks near Barskimming.

Old Land-Surfaces have been found in the drift 300 to 400 feet above sealevel, near Beith, with roots of oak, hazel, and other trees, between Boulderclays. $^{9}$

Angular Blocks.-In the moraine of the Ford of Moak, Loch Doon, there is a great assemblage of angular blocks, which to all appearance have never been rubbed, and were probably carried on the surface of a glacier.

Dry River Channels occur near Muirkirk, New Cumnock and Ballantrae, and are cut out both of rock and drift. They have probably been formed by streams diverted from their normal courses by ice-dams. ${ }^{10}$

\section{Boulders.}

According to the late Mr. Allport there is not a boulder in Arran foreign to the island, and although it is a strong statement I know of no contradictory evidence. The principal carriage of the granite blocks has been S. and towards the Atlantic, very few having, apparently, come E. Across the Firth of

1 Ibid., p. 38, fig. 15.

2 Ibid., p. 12, fig. 2.

3 Ibid., vol. viii., part 2,1888 , p. 312.

${ }^{4}$ Ibid., vol. xi., supplement, p. 73 .

5 James Geikie, Great Ice Age, 3rd ed., 1894, p. 175, fig. 46.

6 Ibid., p. 177 .

${ }^{7}$ Trans. Geol. Soc. of Glasgow, vol. xi., supplement (referred to in Index).

8 See paper by the author on "The Buried or Drift-filled Glens and Channels; and the Post-glacial Glens of Ayrshire," Annals of the Andersonian Naturalists' Society, vol. ii., pp. 51-66.

${ }^{9}$ R. Craig, Trans. Geol. Soc. of Glasgow, vol. iv., part 2, 1873, p. 138.

${ }^{10}$ Trans. Geol. Soc. of Glasgow, vol. x., part 2, 1896, p. 331. 
Clyde in Ayrshire I have seen no Arran granite above the 100 feet contour, and very little below it, indeed not more that might have been introduced by human agency. In the island itself many large granite blocks have come east. A few north Highland schistose rocks are abundant in the northern part of the Clyde area, and extend as far S. as Muirkirk (perhaps to Wanlock Water). They have been long known to the country folk as "Heelan Whin." Boulders of mackled granite, possibly from Ben Cruachan, but more probably from the patch of similar granite which lies E. of the head of Loch Fyne at Loch Garabal, ${ }^{1}$ diorite from Glen Falloch, and actinolite (hornblende) probably from near Loch Tay, are occasionally got. Knype granite from New Cumnock is found towards the head-waters of the Clyde, more especially in the district between the Lowthers and the Crawick Water.

Spango granite is frequent about Muirkirk, Douglas Water, and the headwaters of Glenmore Water and Crawick Water. On a recent investigation I found that the Spango granite boulders extended for several miles all round the outside of the granitic area. Watstone Hill granite is frequent in the upper part of the Irvine valley, but less so about Strathavon, an occasional block having found its way as far to the N.N.W. as Kilwinning and as far E. as the Nethan Water. The granite to the south of Loch Doon and Loch Bradan is found in immense quantities in the valleys of the Doon and the Girvan, and along the Carrick shore, and has come N. as far as Portincross, and S. to Leadhills as seen in recent railway cuttings, and also some way West. Boulders are sometimes seen lying with their long axes in the same direction as the rock-striae, but they are also found lying across them, in fact in all ways, and sometimes even standing perpendicularly in the drift.

\section{ROCK-STriae.}

Perhaps these should have been partly treated of first of all, but it is extremely difficult to discriminate between the first formed striae and the later ones. Those on rock-faces are often taken as indexes to the direction from which the drift was carried along and deposited by land-ice, but I believe the striae have nothing to do with the drift-beds above them. It is evident that glacier-ice was in motion long ages before they were deposited, the old rotted rocks having in many parts been previously removed; and the condition of the majority of the stones and boulders in the drift shows that they were derived from solid rock and not from the rotted surface-rock. At the present day, for instance, solid serpentine cannot be got from the ontcrops, except on the sea-shore or from underdrift, but it can be obtained in firstrate condition from the Boulder-clays of Lendalfoot, etc. Where the bottom beds of drift are composed of gravel there are no striae on the rock-faces under it. In the higher reaches of the Clyde area some of the rotted greywacke and Spango granite may date from pre-glacial times.

The directions of the rock-striae in the Clyde area are briefly :-On the Ayrshire coast, S. of, or parallel to, the coast-line; in the lower part of the Doon valley, N.W., or with the valley ; at Loch Doon, nearly N., or with the valley and loch ; in N.E. Ayrshire, S.W., or with the valleys; in the upper hilly part of the Garnock valley, S.E., or with the valley; on the head waters of the Irvine, W., or with the valley; at Fairlie, S., or with the shore (or Clyde valley); at Little Cumbrae, the same; in Renfrewshire, from Greenock to Paisley, E.S.E. ; on Loch Lomond, S.S.E., or in the direction of the loch ; at Airdrie, E. ; at Lanark and Caruwath, E.N.E. ; in Bute, S.S.E., the direction of the Firth of Clyde valley; on the upper part of Loch Fyne, S.S.W., or with the loch ; in the lower part of Kintyre, both across and with the long axis of the peninsula.

It will be seen from this that the direction of the striae generally follows the slope of the ground (though sometimes they are at right angles within

${ }^{1}$ Hopkins, Q. J. G. S., 1850. 
short distances, or even on the same rock-surface) so that the bulk of the evidence is in favour of their having been produced by the action of land-ice, before the drift-beds were deposited, but some of them may have been caused by icebergs during a depression of the land. Striae occasionally ascend on rock-surfaces, as in Bute, at Ashgrove near Stevenston, in Dunnach Burn, Ballantrae, ${ }^{1}$ in Loch Doon, and in the Afton valley.

\section{Rock-Drums.}

In the low grounds rock-drums often occur, probably under drift, and near the coast examples are sometimes laid bare, as at Bennane Head, N. of Ballantrae. In the valleys hemmed in by steep-sided hills-especially where the rocks are of unequal hardness ${ }^{2}$ - they are very numerous. Perhaps the finest display of them in the Clycle area is on the hill-slopes in the lower eastern part of Noddsdale, and in the upper part of the Girvan valley. On the moors they are abundant, and permanently wet rock-faces often have them very well preserved. The long axes of rock-drums are usually with the striae.

\section{Drift-Droms.}

The 60-feet and 40-feet Raised Beaches occasionally rest on Boulder-clay drums. Up to 800 feet above sea-level there are immense numbers of driftdrums, their long axes being generally with the valleys, but sometimes across them. Above that height clusters of small drift-drums occasionally occur in the narrow valleys and usually at the junction of a side valley with a larger one. $^{3}$ It is quite evident that many at least of the drift-drums have been carved out of stratified deposits by glacier-ice. ${ }^{4}$ A drift-drum is sometimes found resting on top of a rock-drum. The waves during the last Raised Beach period truncated the large drift-drums N. of Girvan and Ballantrae, ${ }^{5}$ and drift has in many places, like beds of rock, been entirely carried away by glacier-ice.

\section{Moraines.}

These remains of ice-action are singularly scanty. Some of the fishing "banks" in the Clyde estuary may be the upper surfaces of either moraines. or drift-drums. At low levels near the moutlıs of some of the Highland glens a few occur, like the remarkable one near Row ; on Loch Lomond-side N. of Balmaha ; and in Arran. The fine example in Glen Fruin has a gromnd plan of nearly semicircular outline, with a length of about 4 miles, and climbs the hills on either side to a height of several hundred feet. ${ }^{6}$ There are also the Colmonell moraine ${ }^{7}$; the Cuffhill moraine; the Penwhapple, Polreoch, and Avon moraines, about 750 feet above sea-level. ${ }^{8}$

\section{KAMES.}

Carnwath is the great centre for the peculiar accumulations of stratified sand and gravel which are known as kames. There they present the appearance of a "tumbled sea ... the ground now swelling... into beautiful peaks and cones, and anon curving up in sharp ridges that often wheel suddenly round so as to enclose a lakelet of bright, clear water." 9 Somewhat similar surface-features are to be found near Maybole. Some kame-like hillocks of drift are probably due to recent river-denudation, as near Skelmorlie; in the angle between the Avon Water and the Glengavil Water; and near

1 Trans. Geol. Soc. of Glasgow, vol. xi., supplement, p. 68.

3 Ibid., pp. 45, 101, $102 . \quad 4$ Ibid., p. 16, fig. 4.

${ }^{6}$ Renwick, Trans. Geol. Soc. of Glasgow, vol. x., 1895, p. 96.

2 Ibid., p. 104, fig. 42.

${ }^{5}$ Ibid., p. 118, fig. 49.

7 Ibid., vol. xi., supplement, p. 19.

${ }^{9}$ J. Geikie, Great Ice Age, 3rd ed., 1894, p. 181. 
Muirkirk. From a recent investigation of the Carnwath and Carstairs kames I have come to the conclusion that they are the result of river and ordinary denudation acting on a large delta of drift.

Localities of Marine Fossiliferous Boulder-clays.

These may be defined as :- (a) Beds below sea-level, in the hollow between the Clyde and the Forth; (b) Beds at or near sea-level, at Drumuir, near Dreghorn, in sand, with remains of Elephas primigenius, under 76 feet of Boulderclay; and $(c)$ Beds above sea-level.

The following list gives the latter with their respective heights in feet:-

12. Warwickhill, near Dreghorn, Ayrshire.

30-60. Bennane Head, near Ballantrae.

40. Annick Water, near Dreghorn.

90. Cundry, near Lendalfoot.

94. Woodhill, near Kilmaurs (the Mammoth bed).

100. Currarie Glen, S. of Ballantrae ; Croftamie, near Drymen.

130. Tangy Glen, near Campbeltown.

140. Water of Ayr.

180. The River Doon, below Cassillis.

200. The Water of Ayr at Gadgirth ; Sevenacres nr. Kilwinning.

200-460. Crawfordland Burn near Kilmarnock.

230. The Water of Ayr.

240. Byne Hill Burn near Girvan.

260. The Water of Ayr, Barskimming.

260. Score Burn, Newmilns.

290-380. Lugar Water below and above Ochiltree.

300. Water of Ayr, opposite Stair House.

310. Broomhouse near Auchinleck.

320. Near Lag in Arran.

340. Barturk near Ochiltree.

350. Airdrie.

360. Near Ochiltree Sawmill, a wooded bank.

370. Coyle Water opposite Drongan Mains.

380. "Timmer Brig," Water of Ayr, near Sorn.

400-430. Burnock Water near Ochiltree.

400. Crawfordland House.

425-550. Annick Water.

428. Water of Ayr, below High Holehouse.

430-690. Polbaith Burn, N. and N.E. of Galston.

447-560. Water of Ayr at Nether Heiler.

450. Water of Ayr near High Holehouse.

450-560. Glen Water, above Darvel.

500. Lugar Water near Longhouse.

510. Chapelhall near Airdrie.

520-550. Merkland Burn, E. of Sorn.

560-580. Hareshawmuir Burn, N. of Galston.

570-600. Airds Moss ; and Water of Ayr.

580. Annick Water, at Blacklaw.

600. Westown Burn, Merkland Burn near Sorn; Annick Water at

Blacklaw; Glen Water at Laigh Braidlie.

620. Whitehaugh Water, between Muirkirk and Sorn.

650-670. Greenock Water, near Muirkirk.

660-680. Merkland Burn, near Sorn.

680. Glenmore Water at Dornal.

700. Changue Burn, at Score Tulloch, Galston ; Glenmore ; Merkland Burn. 
720.740. Hole Burn, E. of Sorn.

750. Dunton Water, in puddle trench, N.E. of Fenwick.

780. Muirfoot Burn, New Cumnock.

800. Greenock Water ; Guelt Water.

880-900. Guelt Water, N.E. of New Cumnock.

920. Coyle Water above Rankinston.

1000 (above). Patrick Burn, near Muirkirk.

1060. Douglas Water, and 2 miles down stream.

1061. Dippel Burn, between Muirkirk and Lesmahagow, and for $\frac{1}{4}$ mile down stream.

Since the above was drawn up I have found remains of marine fauna in drift on Pockmuir Burn, about 1000 feet; on Nethan Water, over 1000 feet; and Powbrone Burn, over 1100 feet above sea-level.

Fossils in Drift or Boulder-clay.

None of the localities mentioned in the preceding list have been systematically "worked" for fossils, but I have got from them the following molluscan remains. Mr. Joseph Wright, F.G.S., has recorded 42 species of Foraminifera obtained from them, these organisms having been extremely abundant in some of the Boulder-clays. As many as 3000 specimens were obtained from less than 10 lbs. weight of clay taken from high levels.

Ostracoda, 11 species.

Crisia eburnia, L.

Verruca strömia, Mull.

Balanus crenatus, Brug.

B. porcatus, Da Costa.

* Pecten islandicus, Mull.

** P. groenlandicus, Lane.

* Leda pernula, Mull.

L. pygmaea, Munst.

L. pygmaea, var. Gouldi.

Nucula tenuis, Mont.

Cyprina islandica, L.

Cardium sp.

* Astarte borealis, Chem.

A. sulcata, Da Costa.

A. compressa, Mont.

Tellina balthica, L.

** T. calcarea, Chem.

Montecuta elevata, Stimp.

Mactra, sp.

Venus ovata, Penn.

Saxicava rugosa, L.

Mya truncata, L.

Corbula gibba, Olivi.

Trochus, sp.

Littorina littorea, L., worn specimens.

Turritella terebra, L.

Natica groenlandica, Beck.

$N$. affinis, ( $N$. clausa), Gmel.

A porrhais pes-pelecani, $\mathrm{L}$.

Buccinum (or Fusus).

Eurrows of boring Sponges.

Burrows in sand under Boulder-clay.

Borings of Gasteropods in shells.

Many Plant-remains, not identified.

Note.-Those species marked ** are now extinct in British seas. 


\section{THE POST-DRIFT FOSSILS OF THE CLYDE DRAINAGE AREA AT LOW LEVELS.}

\section{By John Smith, Thomas Scott, F.L.S., and James Steel.}

A short distance below and above the present sea-level in the Clyde area there occur a series of beds containing Arctic shells, many of which are now extinct in the Clyde estuary and in British seas. These beds sometimes rest on rock or Boulder-clay, but often on a very fine-grained laminated clay which contains no organic remains except a few foraminifera.

The deposits passed through in sinking coalpits at Bogside, Lucknow, and Misk, on the Ayrshire coast, may have belonged to the same period. In the latter pit they reached a depth of 42 feet below sea-level. Large scratched boulders, covered with polyzoa, etc., were found in them, along with Arctic shells.

The Raised-Beach beds are clearly distinguished from the glacial or Postdrift deposits above mentioned, $(a)$ by the absence of boulders, $(b)$ by the absence of extinct shells of boreal habit, and $(c)$ by the presence of remains of the recent Clyde estuarine fauna. Only the youngest Raised-Beach (which lies at about 10 feet above present high-tide mark) and the 40 -feet one possess distinctive features and show fairly continuous lines, but the others occur in patches, up to a height of 120 feet above sea-level. As these beaches principally consist of sandy deposits, the organic remains have now either wholly disappeared from many of them or are only represented by decayed fragments. To this there is one notable exception : this is the 40 -feet Beach at Shewalton near Irvine, which still contains quantities of shells, and these are exposed after floods in the river.

The lower Raised-Beaches contain at least two beds of peat in situ as they were laid down, which are covered by shelly deposits, bearing evidence to changes of level during their deposition. At present the shores along the Ayrshire coast are sinking.

The Post-drift, or as they were formerly known, the Post-tertiary, deposits of the West of Scotland were first investigated largely by the late James Smith of Jordanhill, whose numerous papers on the subject to the Wernerian Society and other bodies were begun in 1836. After his time the work was carried on by Dr. David Robertson and Rev. Dr. Crosskey amongst others, which resulted in the full account of the beds and their fossil remains published in the "Catalogue of the Western Scottish Fossils" in 1876, where a detailed description of many of the localities will also be found.

Since that time considerable additions have been made through the exhaustive work carried on at Garvel Park Dock, Greenock, and elsewhere in the area, with the result that the present may be taken as a fairly complete list of the organisms found in the low-level Post-drift beds of the Clyde area. 
The Arctic shells and the recent species are distinguished as follows :-

* Arctic shells still living in British seas.

** Arctic shells now extinct in British seas.

+ Recent mollusca of the Firth of Clyde and its sea-lochs.

(No localities are given for living species.)

(R-B.) Raised-Beach beds.

\section{AlgaE.}

Sphacelaria cirrhosa, Ro.-Gourock; Garvel Park.

Dictyosyphon foeniculaceus, Grev.-Gourock; Garvel Park.

Desmarestia aculeata, Leyr:x.-Gourock ; Garvel Park.

Melobesia polymorpha, L.-Paisley; Garvel Park; Gourock; Misk ; (R-B., Shewalton).

Corallina officinalis, L.-Paisley ; Garvel Park (R-B., Shewalton).

C. rubens, L.-Paisley.

Dictyota dichotoma, Huds.-Garvel Park.

Peyssonuelia Dubyi, Cronan.-Garvel Park.

\section{Musci.}

Gymnostomum.-

Garvel Park.

Dichodontium pellucidum, Schimp.

Dicranum scoparium, Hedw.-

Cynodontium virens, var. compactum, Schimp.-

Distichium inclinatum, Schimp.-

Trichostomum.-

Barbula fragilis, Schimp.-

B. tortuosa, Web. Mohr.-

B. aciphylla.-

Racomitrium lanuginosum, Hedw.-

Webera albicana, Wahl.-

Bryum pseudotriquetrum, Hedw.-

B. palens, Swartz.-

Mnium subglobosum, B.\&S.-

M. affine, Bland.-

Paludella squarrosa, Brid.-

Aulocomnium palustre, Schw.-

Philonotis fontana, Brid.-

Polytrichum juniperinum, Willd.-

P. strictum, Banks.-

Pogonatum curtipendula.-

Antitrichia curtipendula, Hook \& Taylor.-

Climacium dendroides, Lin.-

Thuidium tamariscinum, Hedw.-

T. decipens, De Not.-

Brachythecium rivulare, $B . \&$ S.-

B. reflexum, Web.-

B. populeum, Hedw.-

B. salebrosum, Hoffm.--

B. albicans, Neck.-

Camptothecium nitens, Schreb.-

C. lutescens, Huds.-

Eurhynchium piliferum, Schreb.-

Plagiothecum denticulatum, Linn.-

Amblystegium.-

Hypnum elodes, Spruce.-

H. stellatum, Schreb.-

H. giganteum, Schreb.- 
Hypnum sarmentosum, Wahl.-Gravel Park.

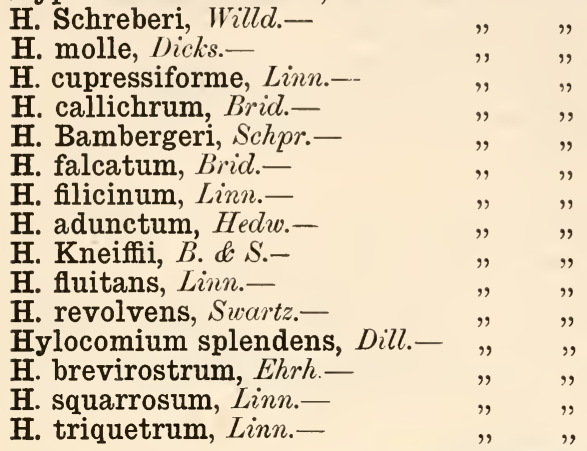

Flowering Plants.

Potentilla tormentilla, Sib.-

Taraxacum officinale, Mig.-.

Thymus serpyllum, Linn.-

Rumex, sp.-

Atriplex patula, Linn.-

Potamogeton, sp.-

Carex dioica? Linn.-

Anthoxanthum odoratum, Linn.-

Poa trivialis, Linn.-

Greenock.

,
,
,
,
,
,
,

Foraminifera.

Cornuspira foliacea, Phill.-Garvel Park; Garnock Water ; E. Tarbert ; Misk; Lochgilp; Tangy Glen.

C. involvens, Reuss.-Garvel Park.

Trochamina inflata, Mont.-(R-B., Shewalton).

T. macrescens, Brady.-Garvel Park.

T. squamata, P. and J.-Garvel Park.

Vertebralina striata. Garvel Park.

Biloculina ringens, Lam.-Garvel Park ; Jordanhill ; Old Mains ; Paisley ; Kilchattan; Dipple ; Misk ; Lochgilp; Tangy Glen ; (R-B., Cumbrae).

B. affinis, d'Orb.-Misk.

B. depressa, d'Orb.-Jordanhill; Garnock Water; Kyles of Bute; (R-B., Cumbrae).

B. simplex, d'Orb.-Garvel Park.

B. elongata, d'Orb.-Jordanhill ; Dalmuir ; Tangy Glen ; Misk.

B. carinata, d'Orb.-Misk.

Miliolina trigonula, Lam.-Garnock Water; (R-B., Cumbrae).

M. oblonga, Mont.-Garvel Park; Garnock Water; Kyles of Bute; Lochgilp.

M. tricarinata, d'Orb.-Misk ; Garvel Park.

M. Brongniarti, d'Orb.-Garnock Water; Misk.

M. Auberiana, d'Orb.-(R-B., shewalton').

M. contorta, d'Orb.-(R-B., Shewalton ; Largs).

M. pulchella (R-B., Largs).

M. seminulum, L.-Frequent in the glacial beds ; (R-B., Cumbrae).

M. secans, d'Orb.-Misk ; Garvel Park ; (R-B., Cumbrae).

M. Gaulteriana, d'Orb.-Paisley Canal.

M. subrotunda, Mont.-Frequent in the glacial beds ; (R-B., Cumbrae).

M. bicornis, W. and J.-Garnock Water; (R-B., Cumbrae). 
Miliolina agglutinans, d'Orb.-Paisley ; Garvel Park; Kyles of Bute ; Misk. M. Ferussacii, d'Orb.-Misk.

Spiroloculina planulata, Lam.-Dalmuir ; (R-B., Cumbrae).

S. excavata, d'Orb.-Garvel Park.

S. limbata, d'Orb.-(R-B., Shewalton).

Haueriana compressa, d'Orb.-Garvel Park.

Lituola scorpiurus, Montf.-Paisley ; Kilchattan.

Haplophragmium canariensis, d'Orb.-Misk.

Lagena sulcata, W. and J.-Garvel Park; Garnock Water; Kyles of Bute; Misk ; E. Tarbert ; Lochgilp ; Tangy Glen.

L. laevis, Mont.-Paisley; Garvel Park; Cumbrae Coll. ; Kyles of Bute ; Misk; Kilchattan; Tangy Glen.

L. gracillima, Seq.-Garvel Park; Tangy Glen.

L. costata, Will.-Garvel Park.

L. globosa, Mont.-Jordanhill; Dalmuir; Paisley; Garvel Park; Kil. chattan; Misk; Cumbrae Coll.; Kyles of Bute; E. Tarbert; Tangy Glen.

L. Haidingeri, Czj.-Garvel Park.

L. hexagona, Will.-Garvel Park ; (R-B., Largs).

L. melo, d'Orb.-Garvel Park.

L. laevigata, Reuss.-Garvel Park; (R-B., Shewalton).

L. Williamsoni, Alcock.-(R-B., Shewalton).

L. clavula, d'Orb.-(R-B., Shewalton).

L. striata, d'Orb.-Paisley; Garvel Park; Kyles of Bute; Kilchattan ; Misk; Lochgilp.

L. semistriata, Will.-Kyles of Bute ; Garvel Park ; Lochgilp ; Misk.

L. apiculata, Reuss.--Kyles of Bute ; Misk ; Garvel Park.

L. distoma, $P$. and J.-Paisley ; Garvel Park; Kyles of Bute; Kilchattan ; Lochgilp; Misk.

L. caudata, d'Orb.-Garnock Water ; Garvel Park ; Misk.

L. marginata, Mont.-Paisley ; Garvel Park; Garnock Water ; Cumbrae Coll : Kilchattan ; Tangy Glen ; Misk.

L. ornata, Will.-Lochgilp ; Garvel Park.

L. squamosa, Mont.-Misk; Dipple; Kyles of Bute ; Garvel Park ; Lochgilp; Taugy Glen; (R-B., Shewalton).

L. hispida, Reuss.-E. Tarbert ; Tangy Glen.

Glandulina laevigata, d'Orb.-Garvel Park.

Nodosaria raphanistrum, L.-Garvel Park.

N. scalaris, Lamk.-Garvel Park.

Dentalina consobrina, d'Orb.-Misk ; Garvel Park.

D. communis, d'Orb.-Garvel Park; Cumbrae; Kyles of Bute ; Kilchattan.

D. pauperata, d'Orb.-Garvel Park.

Astrorhiza cornuta, Brady.-Garvel Park.

Cristellaria rotulata, Lam.-Misk; Garvel Park; Kyles of Bute; Kilchattan; (R. B., Shewalton).

C. crispidula, $F$. and $M$.-Garvel Park.

Sorosphaera confusa, Brady.-Garvel Park.

Polymorphina lactea, W. and J.-Dalmuir; Garvel Park; Garnock Water; Kyles of Bute; Kilchattan; Lochgilp; Tangy Glen; (R-B., Shewalton).

P. lactea, var. communis, d'Orb.-C'umbrae.

P. compressa, d'Orb.-Dalmuir; Paisley; Garvel Park; E. Tarbert; Tangy ; Misk.

P. compressa, var. tubulosa, d'Orb.-(R-B., Cumbrae).

P. oblonga, Brown.-Garnock Water; Kyles of Bute; E. Tarbert; Misk ; Garvel Park.

P. gibba, d Orb.-Misk ; Kyles of Bute ; E. Tarbert ; Garvel Park; (R-B,, Shewalton ; Cumbrae). 
Polymorphina acuminata, Will.-Garvel Park.

P. lanceolata.-(R-B., Shewalton).

Reophax fusiformis, Will.-Garvel Park ; Greenock.

Spirilina vivipara, Ehr.-Garvel Park.

Ưvigerina pygmaea, d'Orb.-Kilchattan ; Tangy Glen ; Garvel Park.

Orbulina universa, d'Orb.-Jordanhill ; Garnock Water ; Garvel Park.

Globigerina bulloides, d'Orb.-Garvel Park ; Jordanhill ; Garnock Water ; Tangy Glen; Misk.

Textularia sagittula, Defr.-Misk ; Jordanhill ; Dalmuir ; (R-B., Cumbrae).

T. variabilis, Will.-Misk.

Verneuilina polystropha, Reuss.-Garvel Park ; Kilchattan ; Misk.

Pulvinulina canariensis, d'Orb.-Garvel Park.

Bulimina pupoides, d'Orb.-Kilchattan ; Misk ; (R-B., Largs).

B. marginata, d'Orb.-Misk ; Garvel Park ; (R-B., Shewalton).

B. elegantissima, d'Orb.-Garvel Park.

B. elegans, d'Orb.-(R-B., Shewalton).

B. ovata, d'Orb.-Misk ; Garvel Park.

Bolivina punctata, d'Orb.-Garnock Water ; Misk ; Garvel Park.

B. costata, d'Orb.-Garvel Park.

Cassidulina laevigata, d'Orb.-Kilchattan; Lochgilp ; Tangy Glen.

C. crassa, d'Orb.-Cumbrae Coll : Lochgilp; Garvel Park.

Virgulina squamosa, d'Orb.-Misk.

V. Schreibersiana, Czizak.-(R.B., Largs).

Discorbina rosacea, d'Orb.-Paisley ; Garnock Water ; Lochgilp; (R-B., Shewalton).

D. globularis, d'Orb.-Misk ; Dipple ; Tangy Glen ; Garvel Park ; (R-B., Shewalton).

D. Wrighti, Brady.-Garvel Park.

Planorbulina mediterranensis, d'Orb.-Misk; Garnock Water; Garvel Park ; (R-B., Shewalton).

Truncatulina lobatula, Walker.-Dalmuir ; Paisley ; Garvel Park; Lochgilp ; Misk ; Kilchattan; Garnock Water : Tangy Glen ; (R-B., Shewalton.)

Rotalia Beccari, L.-Paisley ; Misk; Garvel Park; Garnock Water; Kyles of Bute ; Kilchattan ; Tangy Glen; (R-B., Shewalton).

R. nitida, Will.-Garvel Park.

R. orbicularis, d'Orb.--Lochgilp.

Gypsina inhaerans, Shultze.-(R-B., Shewalton).

Patellina corrugata, Will.-Paisley; Garvel Park.

Polystomella crispa, L.-Frequent in the glacial and Raised-Beach beds.

P. striato-punctata, $F$. \& M.-Frequent in the glacial and Raised-Beach beds.

P. arctica, $J . \& P$.-Kyles of Bute.

Nonionina asterizans, F.\& M.-Tangy Glen; Garvel Park ; Garnock Water; Cumbrae Coll : Kyles of Bute; Misk.

N. turgida, Will.-Kyles of Bute; Kilchattan ; Lochgilp ; Garvel Park.

N. depressula, $W . \& J$. Frequent in the glacial and Raised-Beach beds.

N. scapha, L.-Garvel Park.

N. stelligera, d'Orb.-Garvel Park.

\section{Porifera.}

Cliona celata, Grant.-Misk; Gourock; Garvel Park; Lochgilp ; Old Mains ; Paisley ; (R-B., Cumbrae).

C. gorgonoides (R-B., Shewalton).

Spongia, spicules (R-B., Largs).

C'OELENTERATA.

Tubularia larnyx, Ellis \& Sol.-Garvel Park.

Sphenotrochus Wrighti, Gosse.-Old Mains. 
Eudendrium ramosum, Ehr.-Arklieston.

Paracyathus taxilianus ; (R-B., Largs).

Sertularia pumila, Doody.-Garvel Park.

S. filicula, Huds.-Garvel Park.

\section{Echinodermata.}

Ophiopholis aculeata, L.-Dalmuir ; Paisley ; Garvel Park.

Ophiura albida, Forbes.-Duntroon; Garvel Park; Kilchattan.

Strongylocentrotus dröbachiensis, Mull.-Frequent in the glacial beds.

Echinus esculentus, Lin.-Lochgilp; Garvel Park; Kilchattan ; Gourock ; (R-B., Shewalton ; Cumbrae).

Echinocyamus pusillus, Müll.-(R-B., Largs).

Echinocardium cordatum, Forbes.-(R-B., Shewalton ; Largs)

Psolus phantapus, L.-Houston; Bute ; Garvel Park.

\section{Vermes.}

Sipunculus Bernhardus, ? Forbes.-Dalmuir.

Filograna implexa, Berk.-Garvel Park.

Serpula triquetra, Mart.-Dalmuir ; Garvel Park ; Stevenston ; Lochgilp.

S. Alderi, Robertson.-Garvel Park.

S. vermicularis, Ellis.-Troon; Dalmuir ; Lochgilp; Garvel Park ; Gourock ;

Misk; Kilchattan ; Jordanhill : Garnock Water; (R-B., Cumbrae).

Spirorbis carinatus, Flem.-Paisley.

S. communis, Flem.-Garvel Park ; (R-B., Shewalton ; Cumbrae).

S. nautiloides, Lam.-Dalmuir ; Stevenston.

S. corrugatus, Mont.-Bute.

S. spirillum, L.-E. Tarbert: Duntroon; Paisley ; Garvel Park; Arran; Gourock ; Jordanhill ; Misk.

S. Wattianus, Scott.-Garvel Park.

Crustacea.

Cyclocypris globosa, Gr. O.S.-(R-B., Shewalton).

Potamocypris fulva, Brady.-Garvel Park; Dalmuir ; (R-B., Shewalton).

Argilloecia cylindrica, G. O. S.-Garvel Park; Paisley; Garnock Water; Misk; Kilchattan.

Pontocypris mytiloides, Nor.-Garvel Park ; Paisley; (R-B., Shewalton ; Cumbrae).

P. trigonella, G. O.S.-Garvel Park ; Paisley ; Lochgilp.

Aglaia complanata, Baird.-(R-B., Largs).

Bairdia inflata, Nor.-(R-B., Largs).

Cythere confusa, Baird.-Frequent in the glacial beds; (R-B., Shewalton).

C. pellucida, Baird.-Frequent in the glacial beds.

C. porcellanea, Brady.-Dalmuir; Garvel Park; Garnock Water; Misk; Cumbrae Coll : Lochgilp; Kilchattan.

C. Macallana, B. \& R.-Cumbrae Coll : Kilchattan ; (R-B., Shewalton).

C. tenera, Brady.-Garnock Water; (R-B., Shewalton ; Cumbrae).

C. deflexa, B. C. \& R.-Jordanhill.

C. crispata, Brady.-Paisley (R-B., Shewalton ; Largs).

C. lutea, Mïll.-Frequent in the glacial and Raised-Beach beds.

C. albo-maculata, Baird.-Cumbrae Coll. ; (R-B., Shewalton; Largs ; Cumbrae).

C. convexa, Baird.-Paisley; Cumbrae Coll.; Lochgilp; (R-B., Shewalton ; Cumbrae).

C. clutha, B. C. \& R.-Garvel Park ; Kilchattan.

C. finmarchica, G. O. S.-Lochgilp.

C. Iimicola, Nor.-Garvel Park; Cumbrae Coll. : Kyles of Bute; Tangy Glen ; Misk ; Kilchattan. 
Cythere globulifera, Brady.-Jordanhill; Paisley; Tangy Glen.

C. cuneiformis, Brady.-(H-B., Shewalton.)

C. pulchella, Brady.-Jordanhill; Garnock Water; Cumbrae Coll. : Kilchattan ; Lochgilp; (R-B., Shewalton) ; Cumbrae ; Largs.

C. confusa, B. and N.-Garvel Park (R-B., Shewalton).

C. badia, Nor.-(R-B., Shewalton).

C. emaciata, Brady--(R-B., Shewalton).

C. Jonesi, Baird.-(R-B., Shewalton).

C. villosa, G. O. S.-Frequent in the glacial and Raised-Beach beds.

C. concinna, Jones.-Frequent in the glacial beds.

C. quadridentata, Baird.--Lochgilp.

C. angulata, $G$. O. S.-Frequent in the glacial (and R-B.) beds.

C. tuberculata, G. O. S.-Frequent in the glacial berls.

C. emarginata, G. O. S.-Lag ; Garvel Park ; E. Tarbert ; Misk (R-B., Shewalton).

C. costata, Brady.-Paisley.

C. mirabilis, Brady.-Lochgilp?

C. Dunelmensis, Nor.-Frequent in the glacial beds.

C. Robertsoni, Brady.-Lochgilp.

C. gibbosa, B. \& R.-Garnock Water.

Cytheridea papillosa, Bosq.-Frequent in the glacial beds; (R-B., Cumbrae).

C. elongata, Brady.-(R-B., Shewalton ; Largs).

C. punctillata, Brady.-Frequent in the glacial beds.

C. Sorbyana, Jones.-Tangy Glen; Garvel Park; Misk.

Eucy there declivis, $N^{r}$ or.-Frequent in the glacial beds; (R-B., Shewalton).

Krithe Bartonensis, Jones.-Duntroon.

K. glacialis, B. C. and R.-Garvel Park.

Loxoconcha impressa, Baird.-Misk; Garvel Park; Jordanhill ; (R.B., Shewalton; Cumbrae).

L. tamarindus, Jones.-Frequent in the glacial beds.

L. fragilis, G. O. S.-Paisley ; Garvel Park.

L. viridis, Mïll.-Govan; (R-B., Shewalton).

Xestoleberis depressa, G. O. S.--Jordanhill; Paisley ; Lochgilp (R-B., Shewalton).

X. aurantia, Baird.--Lochgilp ; Garvel Park (R-B., Cumbrae).

Cytherura nigrescens, Baird.-Frequent in the glacial beds; (R-B., Shewalton ; Cumbrae).

C. similis, G. O. S.-Dalmuir : Garvel Park; Cumbrae Coll. : Kyles of Bute, Kilchattan; E. Tarbert; (R. B., Shewalton).

C. pumila, B. C. and R.-Dalmuir ; Garvel Park ; Cumbrae Coll.

C. concentrica, B. C. and R.--Paisley.

C. undata, G. O. S.-Frequent in the glacial beds; (R-B., Largs ; Shewalton).

C. striata, G. O. S.-Garvel Park; Garnock Water; Cumbrae Coll. : Kyles of Bute; Misk; Kilchattan ; (R-B., Shewalton).

C. gibba, Müll.-Lochgilp; Jordanhill; Kilchattan; (R-B., Shewalton).

C. cellulosa, Nor.-Jordanhill ; R-B., Shewalton ; Cumbrae).

C. clathrata, G. O. S.-Frequent in the glacial beds.

C. sella, G. O. S.-Garvel Park; Kyles of Bute; (R-B., Shewalton ; Largs ; Cumbrae).

C. acuticostata, G. O. S.-(R-B., Shewalton ; Cumbrae ; Largs).

C. producta, Brady.-(R-B., Largs).

C. angulata, Brady.-Misk; (R-B., Shewalton ; Cumbrae ; Largs).

C. fulva, $B$. and $R$.-(R-B., Shewalton ; Largs).

C. cornuta, Brady.-Garnock Water ; (R-B., Shewalton ; Largs).

C. simplex, Baird.-(R-B., Largs).

Cytheropteron latissimum, Nor.-Jordanhill; Dalmuir; Old Mains ; Paisley ; E. Tarbert; Tangy Glen. 
Cytheropteron arcuatum, B. C. and R.-Tangy Glen Garvel Park.

C. nodosum, Brady.-Jordanhill ; Dalmuir; Garvel Park ; Cumbrae Coll. ; (R-B., Stewalton).

C. Montrosiense, B. C. and R.-Tangy Glen; Misk.

C. angulatum, B. and R.-Dalmuir ; Garvel Park ; Cumbrae Coll.; Kyles of Bute; (R-B., Largs).

C. inflatum, Brady.-Garvel Park.

Cytherois Fischeri, G. O. S.-(R-B., Shewalton).

Bythocythere simplex, Nor.-Jordanhill ; Dalmuir ; Paisley ; Garvel Park ; Misk.

B. constricta, G. O. S.-Tangy Glen; Misk.

B. elongata, $B$. C. and R.-Govan.

Pseudocythere caudata, G. O .S.-Dalmuir ; E. Tarbert.

Sclerochilus contortus, Nor.-Frequent in the glacial beds.

Paradoxostoma variable, Baird.-Frequent in the glacial beds.

P. abbreviatum, G. O.S.-Lochgilp.

P. ensiforme, Brady.-Garnock Water; Kyles of Bute (R-B., Shewalton ; Cumbrae).

P. Fischeri, G. O. S.-Garvel Park; Garnock Water.

P. flexuosum, Brady.-Lochgilp ; Misk ; (R-B., Shewalton).

P. tenerum, B. C. and R.-Dalmuir ; Garvel Park.

P. obliquum, G. O. S.-(R-B., Shewalton).

Asterope teres, $N o r$-Jordanhill.

Polycope orbicularis, G. O.S.-Dalmuir ; Old Mains ; Paisley ; Garvel Park; Misk.

Bosquetia robusta, B. C. and R.-Paisley.

Hyas araneus, Fabr.-Garvel Park ; (R-B., Cumbrae).

Cancer pagurus.-Garvel Park.

Eupagurus sp.-Garvel Park.

Galathea sp.-Garvel Park.

Balanus balanoides, L.-Paisley ; Garvel Park; Windmilleroft ; Dalmuir ; Jordanhill ; Misk ; (R-B., Cumbrae).

B. crenatus, Brug.-Frequent in the glacial beds ; (R-B., Cumbrae).

B. Hameri, Ascanius, Lochgilp ; Old Mains ; Garvel Park.

B. porcatus, Da Costa.-Frequent in the glacial beds ; (R-B., Cumbrae).

B. porcatus, var elongata ?--Garvel Park.

B. cariosus, Darwin.-Kyles of Bute.

Verruca strömia, Mull.-Frequent in the glacial beds ; (R-B., Shewalton).

\section{Polyzoa.}

Menipea tērnata, Ellis and Sol.-Garvel Park; Misk.

Cellularia Peachi, Busk:-Garvel Park.

C. reptans, L.-Duntroon ; Paisley ; Misk.

Scrupocellaria scruposa, L.-Garvel Park.

S. reptans, L.-Garvel Park.

S. scabra, var. elongata, Smith.-Garvel Park; (R-B., Shewalton).

Hippothoa catenularia, Iam.-Dalmuir ; Duntroon.

Caberea Ellisi, Flem.-Garvel Park.

Bugula avicularia, Pallas-Duntroon.

Membranipora Flemingi, Busk.-Garvel Park ; Lochgilp.

M. lineata, L.-Garvel Park.

M. tuberculata, Busk.-Garvel Park.

M. unicornis, Blain.-Garvel Park ; Paisley ; Dalmuir ; Duntroon.

M. craticula, Alder.-Paisley ; Misk.

Lepralia Peachi, Johnston.-Garvel Park ; Cumbrae Coll. ; Misk.

L. concinna, Busk.-Garvel Park; Lochgilp.

L. annulata, Fabr.-Garvel Park. 
Lepralia hyalina, L.-Garvel Park.

L. verrucosa, Esper.-Dalmuir ; Duntroon; Garvel Park.

L. crystallina, Nor.-Garvel Park.

L. spinifera, Johnston.-Dalmuir.

L. cruenta, Nor.-Garvel Park.

Porina tubulosa, Nor.-Garvel Park ; Misk.

Schizoporella sinuosa, Busk.-Garvel Park.

Eschara patens, Smitt.-Garvel Park.

E. struma, Nor.-Garvel Park.

Smittia Landsborovi, Johns.-Garvel Park.

Escharoides Sarsi, Smitt.-Garvel Park.

Crisia eburnea, L.-Frequent in the glacial beds ; (R-B., Shewalton).

Idmonea atlantica, Forbes.-Garvel Park.

Tubulipora flabellaris, Fabr.-Dalmuir.

T. phalangea, Conch.-Dalmuir ; Duntroon ; Garvel Park.

T. serpens, L.-Dalnuuir ; Garvel Park.

Diastopora obelia, Flem.-Garvel Park.

Discoporella hispida, Flem.--Paisley.

D. grignoniensis, Busk.-Dalmuir ; Duntroon ; Misk.

D. flosculus, Hincks.-Garvel Park.

D. radiata, Busk.-Garvel Park.

\section{Mollusca.}

Rhynchonella psittacea, Chem.-Ayrshire.

† Terebratula caput-serpentis, L.--Ayrshire.

+ Crania anomala, Miill.

† Anomia ephippium, L.-Frequent in the glacial beds ; R-B., Shewalton).

A. ephippium, var. aculeata, L.-Frequent in the glacial beds; (R-B., Shewalton).

A. ephippium, var. squamula, L.-Garvel Park ; Paisley ; Lochgilp.

A. patelliformis, L.-Stevenston.

+ Ostrea edulis, L.-(R-B., Shewalton ; Cumbrae).

* * Pecten islandicus, Muill.-Common in the glacial beds.

** P. groenlandicus, Lam.-(R-B., Shewalton).

† P. maximus, L.-Garvel Park ; Troon; (R-B., Shewalton ; Cumbrae).

$+\mathrm{P}$. striatus, Müll.

+ P. opercularis, L-Lucknow ; Kyles of Bute ; Arran ; (R-B., Shewalton ; Largs ; Cumbrae).

+ P. pusio, L.-Dalnuir.

† P. septemradiatus, Mïll.-Loch Lomond; R-B., Shewalton).

$+\mathrm{P}$. varius, L.-Dalmuir.

+ P. similis, Lask.-Tarbert.

† P. tigrinus, Müll.-Loch Lomond.

† P. striatus, Müll.

† Lima hians, Gmel.-(R-B., Cumbrae ; Largs).

† L. elliptica, Jeff.

+ L. subauriculata, Mont.

† L. Loscombi, G.B. Sow.

* + Mytilis edulis, L.-Frequent in the glacial and Raised-Beach beds.

* + M. modiolus, L.-Frequent in the glacial and Raised-Beach beds.

+ M. phaseolinus, Phill.

+ Modiolaria discors, L.-Paisley.

M. laevigata, Gray.-Dalmuir ; Garvel Park.

M. nigra, Gray.--Garvel Park; Kyles of Bute.

+ M. marmorata, Forbes.

+ Crenella decussata, Mont.

Dacrydium vitreum, For.-Garvel Park. 
+ Nucula nitida, G.B. Sow.-Paisley ; Garvel Park ; (R-B., Largs).

$+\mathrm{N}$. tenuis Mont.-Frequent in the glacial beds.

N. tenuis, var. expansa, Reeve.-Cumbrae College.

N. tenuis, var. inflata, Mörch.-Paisley; Garvel Park.

N. nucleus, L.-Paisley ; Lochgilp.

N. nucleus, var. tumidula, Malm.-Paisley.

N. nucleus, var. radiata, $F$. and $H$.-Garvel Park.

* * Leda pernula, Miill.-Common in the glacial beds.

L. pernula, var. mucilenta, Steenst.-Troon ; Garvel Park ; Paisley ; Kilchattan; Gourock.

* L. pygmaea, Münst.-Frequent in the glacial beds.

L. pygmaea, var. gibbosa, Smith.-Cumbrae College.

L. pygmaea, var. lenticulata, Mïll.-Garvel Park; Paisley ; Kilchattan.

* * L. arctica, Gray.-Lucknow ; Troon; Garvel Park.

L. limata, Say.-Garvel Park.

* + L. minuta, Mïll.-Bute.

+ L. frigida, Torell.-Garvel Park.

* Pectunculus glycymeris, L.-(R-B., Shewalton).

+ Lepton nitidum, Turt.-Garvel Park; Lochgilp; (R-B., Shewalton ; Largs).

+ Montacuta bidentata, Mont.--Garvel Park ; Gourock ; Dalmuir ; (R-B., Shewalton).

+ M. elevata, Stimp.-Lochgilp ; Tangy Glen.

+ M. ferruginosa, Mont.-Kilchattan ; (R-B., Shewalton).

+ M. substriata, Mont.

+ Lucina borealis, L.-Troon; Garvel Park; (R-B., Shewalton ; Largs ; Cumbrae).

L. spinifera, Mont.-(R-B., Shewalton).

† Axinus flexuosus, Mont.-Frequent in the glacial beds; (R-B., Largs ; Shewalton).

A. flexuosus, var. Gouldii, Phill.-Paisley ; Lochgilp ; Garvel Park ; Kyles of Bute; Kilchattan.

† A. ferruginosa, Forbes.

+ Cyamium minutum, Fabr.-Garvel Park ; (R-B., Shewalton ; Largs).

+Cardium norvegicum, Speng.-Stevenston; Garvel Park; Lucknow ; Cumbrae College; (R-B., Shewalton; Cumbrae).

C. fasciatum, Mont.-Frequent in the glacial beds ; (R-B., Shewalton).

+C. exiguum, Gmelin.-Dalmuir; Garvel Park; Bute; (R-B., Shewalton).

+C. nodosum, Turt.--(R-B., Shewalton).

$*+C$. edule, L.-Frequent in the glacial beds ; (R-B., Shewalton).

+C. echinatum, L.-Frequent in the glacial beds.

†C. aculeatum, L.-Stevenston.

†C. minimum, Phill.

+ Isocardia cor, $L$.

Axinopsis orbiculata, G. O. S.-Garvel Park.

* +Cyprina islandica, L.-Common in the glacial beds ; (R-B., Shewalton).

* +Astarte sulcata, Da Costa.-Garvel Park; Old Mains ; Paisley ; Loch gilp; Kyles of Bute ; Troon.

A. triangularis, Mont.-Garvel Park.

* +A. elliptica, Brown.-Garvel Park; Dalmuir ; Lochgilp ; Croftamie Troon; Misk.

* + A. compressa, Mont.-Common in the glacial beds.

A. compressa, var. globosa, Mull.-Garvel Park; Paisley.

A. compressa, var. striata, Mull.-Paisley ; Garvel Park.

**A. borealis, Chem.-Frequent in the glacial beds.

A. crebricostata, Forbes.-Dalmuir; Bute ; Garvel Park.

+Circe minima, Mont.--(R-B., Largs). 
+Venus ovata, Penn.-Tangy Glen; (R-B., Cumbrae).

+V. exoleta, L.-Lucknow ; (R-B., Shewalton ; Largs ; Cumbrae).

+V. casina, L.-Garvel Park; (R-B., Shewalton ; Largs).

+V. fasciata, Da Costa.-Lucknow ; (R-B., Shewalton ; Largs ; Cumbrae).

+V. gallina, L.-(R-B., Shewalton ; Cumbrae ; Largs).

+V. lincta, Pult.-Dalmuir ; (R-B., Shewalton).

$+\mathrm{V}$. verrucosa, $L$.

+Tapes virgineus, L.-Garnock Water; Kyles of Bute ; (R-B., Shewalton; Largs).

+T. pullastra, Mont.-(R-B., Shewalton ; Cumbrae).

†T. decussatus, L.-(R-B., Shewalton; Cumbrae).

†T. aureus, Gmel.-(R-B., Cumbrae).

+Lucinopsis undata, Penn.-Garvel Park.

* * Tellina calcarea, Chemn.-Common in the glacial beds.

*+T. balthica, L.-Garvel Park ; Dalmuir ; Old Mains ; Paisley ; Girvan ; (R-B., Shewalton; Cumbrae).

+T. donacina, L.-(R-B., Shewalton).

†T. crassa, Gmel.-(R-B., Shewalton ; Cumbrae).

+T. fabula, Grön.--Garvel Park ; Lochgilp; (R-B., Shewalton).

T. squalida, Pult.-Dalmuir; Kyles of Bute; (R-B., Shewalton).

T. groenlandica, Beck.-Bute.

$+\mathrm{T}$. tenuis, Da Costa.-Kyles of Bute ; (R-B., Shewalton).

+Psammobia tellinella, Lam.-(R-B., Shewalton).

+ P. costulata, Turt.

+P. ferroensis, Chemn.-Garvel Park; Kyles of Bute.

+P. vespertina, Chemn.-(R-B., Shewalton).

+Donax vittatus, Da Costa.-Ayr ; (R-B., Shewalton).

Mactra solida, L.-Garvel Park; Kyles of Bute ; Stevenston.

†M. solida, var. elliptica, Brown.-Duntroon.

+M. subtruncata, Da Costa.-Cumbrae College ; Kilchattan ; Troon ; (R-B., Shewalton ; Cumbrae).

M. subtruncata, var. striata, Brown.-Dalmuir ; (R-B., Shewalton).

+ M. stultorum, L.-(R-B., Shewalton).

+Lutraria elliptica, Lam.-Kyles of Bute ; Lucknow ; (R-B., Shewalton).

+Scrobicularia alba, Wood.-Dalmuir ; Loc. gilp ; Garvel Park ; Gourock ; Garnock Water.

+S. prismatica, Mont.-Lochgilp ; Kilchattan ; Troon ; Misk ; Garvel Park

+S. piperata, Bellon.-(R-B., Shewalton).

+Solen ensis, L.-Garvel Park ; (R-B., Shewalton ; Cumbrae).

+ S. siliqua, L.-(R-B., Shewalton ; Cumbrae ; Largs).

+S. pellucidus, Penn.

†Lyonsia arenosa, Móll.-Garvel Park.

+L. norvegica, Chemn.

+Thracia myopsis, Beck.-Greenock.

+T. distorta, Mont.

†T. papyracea, Poli.-Garvel Park; Kyles of Bute; Lochgilp; (R-B., Shewalton).

T. truncata, Brown.-Garvel Park.

†T. praetenuis, Pult.-Garvel Park.

+ T. pubescens, Pult.

+ T. convexa, Wood.

+ T. septentrionalis, Jeff.-Garvel Park.

†Corbula gibba, Olivi.-Garvel Park ; E. Tarbert ; Tangy Glen.

Neaera subtorta, G. O. S.-Garvel Park.

+ N. abbreviata, Fort.

+ N. costellata, Desh.

+ N. cuspidata, Olivi. 
* + Mya truncata, L.-Common in the glacial beds.

* * M. truncata, var. uddevallensis-Dalmuir ; Lochgilp ; Kyles of Bute.

+ M. arenaria, L.-Garvel Park; Lochgilp ; Bute.

Saxicava (Panopoea) norvegica, Speng.-Kyles of Bute; Fairlie; Langbank ; Garvel Park; Gourock.

* +S. rugosa, L.—Frequent in the glacial beds ; (R-B., Shewalton).

S. rugosa, var. arctica, L.-Jordanhill; Garvel Park; Kyles of Bute; Dalmuir ; Lochgilp ; E. Tarbert.

S. rugosa, var. praecisa, Mont.-Lochgilp.

S. rugosa, var. sulcata, Smith.-Paisley ; Rothesay ; Kyles of Bute.

S. pholades, Jeff.-Garvel Park.

+ Panopoea plicata, M. de la Groge.

+ Pholas crispata, L.-Cumbrae; Garvel Park; Kilchattan ; Stevenston ; (R-B., Shewalton ; Cumbrae).

P. dactylus, L.-Stevenston ; (R-B., Shewalton).

† P. candida, L.-(R-B., Shewalton).

+ Xylophaga dorsalis, Tur.-(R-B., Shewalton).

+ Teredo norvegica, Speng.-(R-B., Shewalton).

+ T. megotara, Han.

* + Dentalium entalis, $L$.

\section{Gasteropoda.}

+Chiton marmoreus, Fabr.-Garvel Park ; Dalmuir ; Old Mains ; Lochgilp ; Misk; Garnock Water.

†C. ruber, L.-Garvel Park ; Dalmuir ; Lochgilp.

+C. cinereus, L.-Garvel Park ; Lochgilp.

+ C. fasicularis, $L$.

+C. marginatus, Penn.

+C. laevis, Fab.

† Patella vulgata, L.-Lucknow ; (R-B., Shewalton ; Cumbrae).

+ Helcion pellucidum, L.-Garnock Water ; Garvel Park; Lochgilp ; Dalmuir; (R-B., Shewalton; Cumbrae).

+ H. pellucidum, var. laevis, Penn.-Dalmuir.

+ Tectura virginea, Mull.-Garvel Park; Dalmuir; Old Mains ; Paisley ; Garnock Water; Kyles of Bute; Kilchattan; Lochgilp; Gourock; Misk.

+ T. testudinalis, Miill.

+ T. fulva, Müll.

+ Puncturella Noachina, L.-Frequent in the glacial beds.

+ Propilidium ancyloides, $F$. \& $H$.

† Fissurella graeca, L.-Clyde beds.

+ Emarginula fissura, L.-(R-B., Cumbrae).

E. crassa, J. Sow.

+ Capulus hungaricus. $L$.

Cyclostrema costulata, Möll.-Paisley.

+ Trochus helicinus, Fabr.-Frequent in the glacial beds ; (R-B., Shewalton).

$+\mathrm{T}$. groenlandicus, Chemn.-Frequent in the glacial beds.

T. lineatus, Da Costa.-(R.B., Cumbrae). [Shell-mound, Ardrossan.]

†T. tumidus, Mont.-Frequent in the glacial beds; (R-B., Shewalton; Largs).

T. Vahlii, Möll.-Paisley ; Garvel Park.

T. cinereus, Couth.-Clyde Beds :- glacial.

† T. cinerarius, L.-Lochgilp; Garvel Park ; Kilchattan ; Garnock Water ; Lucknow ; (R-B., Shewalton ; Cumbrae ; Largs).

+ T. millegranus, Phill.-Clyde Beds.

+ T. magus, L.-Clyde Beds ; (R.B., Shewalton; Cumbrae ; Largs).

+ T. umbilicatus, Brod. \& Sov.-Garvel Park; (R-B., Shewalton). 
Trochus nitens, Phill.

+ T. Montacuta, W. Wood.

+ T. zizyphinus, $L$.

Molleria costulata, Möll.-Misk ; Garvel Park ; (R-B., Shewalton).

Margarita cinerea, Couth.-Bute; Rothesav.

M. olivacea, Brown.-Clyde Beds.

+ Lacuna divaricata, Fabr.-Frequent in the glacial beds ; (R-B., Shewalton ; Cumbrae ; Largs).

L. divaricata, var. quadrifasciata, Moulf.-Dalmuir.

L. puteolus, Turt.-Dalmuir : Paisley ; Garvel Park ; Cumbrae Coll. ; (R-B., Shewalton).

L. pallidula, Da Costa._Lochgilp ; Dalmuir ; (R-B., Cumbrae). var. neritoidea, Gould.--Dalmuir.

+ Littorina littorea, L.-Common in the glacial and Raised-Beach beds.

$+\mathrm{L}$. rudis, Maton.-Common in the glacial (and R-B.) beds.

†L. rudis, var. saxatilis, John.-Garvel Park; (R-B., Shewalton).

+ L. rudis, var. patula, Jeff.-Dalmuir ; Bute ; Troon.

† L. obtusata, L.--Frequent in the glacial beds ; (R-B., Cumbrae).

L. obtusata, var. neritiformis, Brown.-E. Tarbert.

L. limata, Lovén.-Jordanhill; Garvel Park; Dalmuir ; E. Tarbert ; Misk ; Paisley ; Lochgilp.

L. squalida, Brod. and Sow.-Paisley.

† I. neritoides, L.-

† Rissoa violacea, Desw.-Lochgilp; (R-B., Shewalton; Cumbrae).

R. violacea, var. ecostata, Jeff.-(R-B., Shewalton).

+ R. striata, Adams.--Frequent in the glacial (and R-B.) beds.

R. striata, var. arctica, Loven.-Garvel Park ; Paisley.

R. lactea, Mich.-(R-B., Shewalton).

+ R. parva, Da Costa.-Garvel Park ; Duntroon ; Paisley ; (R-B., Shewalton ; Cumbiae).

R. parva, var. interrupta, Adams.-Frequent in the glacial beds ; (R-B., Shewalton).

+ R. abyssicola, Forbes.-(R-B., Shewalton).

+ R. soluta, Phill.--Paisley; (R-B., Shewalton).

R. inconspicua, Alder.-Jordanhill; (R-B., Shewalton).

R. inconspicua, var. ventrosa, Mont.-Dalmuir.

+ R. cingillus, Mont.-Dalmuir ; (R-B., Largs).

† R. membranacea, Adams.-Bute; (R-B., Shewalton ; Largs).

R. membranacea, var. minor, Jeff--(R-B., Shewalton).

** $\mathbf{R}$. arenaria, $M$. and $A$.-Garvel Park.

+ R. reticulata, INont.-Lochgilp; Paisley; Garvel Park; (R-B., Shewalton: Cumbrae).

+ R. cancellata, Da Costa. - Lochgilp.

+ R. striatula, Mont.-Lochgilp; (R-B., Shewalton; Largs).

R. costata, Adams.-Garvel Park ; Largs; (R-B., Shewalton ; Cumbrae).

+ R. punctura, Mont.-(R-B., Shewalton).

+ R. calathus, $F$. and $H$.

+ R. vitrea, Mont.-(R-B., Largs).

+ R. fulgida, Adams.-

$+\mathrm{R}$. zetlandica, Mont.-

+ Barleeia rubra, Mont.

Menestho albula, Fabr.-Paisley.

+ Hydrobia ulvae, Penn.--Dalmuir; Garvel Park; Paisley ; (R-B., Shewalton; Cumbrae).

+ Jeffreysia opalina, Jeff:

$+\mathrm{J}$. diaphana, Jeff.

+Skenea planorbis, Fabr.-Frequent in the glacial (and R-B.) beds. 
+ Homalogyra atomus, Phill.-Frequent in the glacial beds (R-B., Largs ; Shewalton).

$+\mathrm{H}$. rota, T. and H.-(R-B., Shewalton).

+ Turritella terebra, L.-(R-B., Shewalton; Cumbrae).

+ Caecum trachea, Mont.-(R-B., Shewalton ; Cumbrae).

+ C. glabrum, Mont.-(R-B., Shewalton ; Cumbrae ; Largs).

+ Scalaria communis, Lam.-(R-B., Shewalton ; Cumbrae).

S. groenlandica, Chemn.-Fairlie.

+ S. Turtonae, Turt.

+ Cioniscus (alcis) unicus, Mont.-(R-B., Shewalton).

Odostomia unidentata, Mont.-Lochgilp; Garvel Park; Kilchattan ; Misk.

† O. rissoides, Han.-(R-B., Shewalton).

† O. turrita, Hanley-Lochgilp; (R-B., Shewalton).

O. plicata, Mont.-(R-B., Shewalton).

† O. spiralis, Mont.-Lochgilp; Dalmuir ; Garvel Park ; (R-B., Shewalton ; Cumbrae).

0. lukisi, Jeff.-Garvel Park.

+ O. decussata, Mont.-(R-B., Shewalton ; Largs).

† O. conoidea, Brocchi.-Lochgilp.

† O. pallida, Mont.-Lochgilp.

o. pusilla, Phill.-(R-B., Shewalton).

O. nitida, Ald.-(R-B., Shewalton).

† 0. scalaris, Phill.

+ 0. excavata, Phill.-(R-B., Largs).

+ 0. rufa, Phill.-.

+0. acicula, Phill.-

+O. nivosa, Mont.-

† 0 . conspicua, Alder.-

+0 . insculpta, Mont.-

† O. obliqua, Alder.-

+0 . indistincta, Mont. -

† O. interstincta, Mont.-

† O. nitidissima, Mont.-

† Eulima distorta, Desh.-Misk ; (R-B., Largs).

+ E. polita, $L$.

+ E. bilineata, Alder.-(R-B., Largs).

+ Natica affinis, (clausa) Gmelin.-Frequent in the glacial beds.

+ N. catena, Da Costa.-Dalmuir ; (R-B., Shewalton ; Cumbrae).

+ N. groenlandica, Bick.-Frequent in the glacial beds.

+ N. pallida, Brod. and Sow.-Dalmuir; Paisley ; Kilchattan.

+ N. Alderi, Forbes.-(R-B., Shewalton; Cumbrae).

+ N. Montacuta, Forbes, Clyde Beds ; (R-B., Shewalton).

+ N. Smithi, Brown, Ardencaple.

+ N. sordida, Phill.-Troon.

+ Adeorbis subcarinata, Mont.

+ Velutina laevigata, Penn.-Garvel Park ; Dalmuir; Kilchattan.

** V. undata, Smith-Garvel Park ; Dalmuir ; Old Mains ; Paisley ; Garnock Water ; Girvan.

† Lamellaria perspicua, $L$.

+ Trichotropis borealis, Brod. and Sow.-Garvel Park ; Kyles of Bute.

+ Aporrhais pes-pelicani, L.-Garvel Park ; Kilchattan ; Gourock ; (R-B., Shewalton; Cumbrae).

+Cerithium reticulatum, Da Costa.-Garvel Park; Cumbrae Coll : Lochgilp; Duntroon ; Garnock Water ; (R-B., Shewalton ; Cumbrae).

† Triforis perversa, L.-Garvel Park ; (R-B., Shewalton ; Cumbrae ; Largs).

+ Cerithiopsis tuberculata, Mont. 
*+ Purpura lapillis, L.--Frequent in the glacial ; (and R-B.) beds.

Buccinum groenlandicum, Chem.--Old Mains; Paisley; Gourock Water ; Gravel Park.

* + B. undatum, L.-Common in the glacial ; (and R-B.,) beds.

B. ciliatum, Forbes.-Bute.

Murex erinaceus, L.-Dalnuir.

** Trophon clathratus, L.-Frequent in the glacial beds.

T. clathratus, var. Gunneri, Lovén.-Frequent in glacial beds.

† T. truncatus, Ströin.-Frequent in the glacial beds.

* Fusus antiquus, L.-Frequent in the glacial beds.

† F. gracilis, Da Costa.-Dalmuir ; Girvan; (R-B., Cumbrae).

F. propinquus, Alder.-Lochgilp.

F. despectus, L.-Dalmuir.

F. barvicensis, John.-Garvel Park.

+ Nassa incrassata, Ström.-Kyles of Bute; Lochgilp; Troon; (R-B., Cumbrae).

+ N. reticulata, L.-(R-B., Shewalton ; Cumbrae).

$+\mathrm{N}$ pygmaea, Lam.

† Defrancia linearis, Mont.-Garvel Park.

†D. purpurea, Mont.-(R-B., Shewalton).

+D. teres, Forb.

†D. gracilis, Mont.

+ D. Leufroyi, Michand.

Pleurotoma pyramidalis, Ström.-Frequent in the glacial beds.

P. rufa, Mont.-(R-B., Cumbrae).

*+ P. turricula, Vont. - Frequent in the glacial beds.

P. violacea, Migh. and Ad.-Frequent in the glacial beds.

P. costata, Don.-(R-B., Cumbrae).

+ P. septangularis, Mont.-(R-B., Cumbrae).

+ P. nebula, Mont.-(R-B., Shewalton).

† P. striolata, Phill.-(R-B., Cumbrae).

P. Trevelyana, Turt.-Kilchattan; Garvel Park; Garnock Water; (R-B., Cumbrae).

+Cypraea europaea, Mont.-Garvel Park; (R-B., Shewalton; Cumbrae ; Largs).

Cylichna alba, Brown.-Dalmuir ; Lochgilp ; Duntroon ; Paisley ; Kyles of Bute; Garnock Water; Garvel Park.

+C cylindracea, Penn.-Paisley; Garvel Park.

C. obstricta, Gould.-Dalmuir; Lochgilp.

†C. umbilicata, Mont.

† C. nitidula, Lovén.

Utriculus hyalinus, Turt.-Dalmuir ; Cumbrae Coll ; Duntroon ; Paisley ; Garvel Park ; Kilchattan.

† U. obtusus, Mont.-Frequent in the glacial beds ; (R-B., Shewalton). var. turrita, Möll.-Garvel Park.

+ V. truncatulus, Brug.-Garvel Park; Duntroon ; (R-B., Shewalton, Largs).

† U. mammillatus, Phill.-Garvel Park; Dalmuir; Arklieston ; (R-B., Shewalton).

+ Bulla utriculus, Brocchi.-Garvel Park.

+ Actaeon tornatilis, $L$.

+ Scaphander lignarius, L.-Greenock.

+ Philine scabra, Möll.-Garvel Park.

+ P. lima, Brown.-Garvel Park.

P. nitida, Jeff.-Garvel Park.

$+\mathbf{P}$. aperta, L.-Garvel Park.

$+\mathrm{P}$. catena, Mont. 
+ Philine punctata, Clark.

+ P. pruinosa, Clark.

+ Aplysia punctata, Cuvier.

+ Pleurobranchus plumula, Mont.

+ Runcina Hancocki, Forbes.

+ Melampus bidentatus, De Mont.

+ Otina otis, Turt.

Helix rotundata, Mull.-(R-B., Shewaltou).

Vertigo edentula, Drap.-Garvel Park.

Cochlicopa lubrica, O.F. Mïll.-Garvel Park.

C. tridens.-Misk; (R-B., Shewalton).

Pupa marginata, Drap.-Garvel Park ; (R-B., Cumbrae).

Carychium minimum, Müll.--(R-B., Largs).

\section{Pteropoda.}

Spirialis retroversus, Flem.-(R-B., Largs.)

\section{Pisces.}

Vertebrae and otolites.-Old Mains; Garvel Park ; Lochgilp ; Gourock ; (R-B., Largs).

Aves.

Bones.-Paisley ; Dalmuir ; Garvel Park.

Mammalia.

(a) Under Boulder-clay.

Cervus tarandus, L.-Woodhill near Kilmaurs; Croftamie, Dumbartonshire (Proc. Roy. Phys. Soc. Edin., vol. i., 18-, p. 247).

Elephas primigenius, Blum.-Chapelhall, in stratified sand 350 feet above sea-level. Woodhill; Drummuir near Dreghorn, under 76 feet of Boulder-clay.

(b) In Boulder-clay.

Cervus tarandus, L.--Raes Gill, Carluke.

Elephas primigenius, Blum.-Bishopbriggs. (A molar was got in a 45 feet sand-bed, 33 feet from the surface, at Baillieston. This bed rested on Coal-measure strata.)

(c) Above Boulder-clay.

Bos primigenius, Bojanus.-In the Clyde at Jordanhill, in clay ; Rothesay Bay ; Cowdenglen, in peat; Greendyke Street, Glasgow, in silt.

B. longifrons, Owen.-Rutherglen Loan, Glasgow, in sand and gravel.

Cervus tarandus, L.- In the Clyde at Jordanhill.

Megaceros Hibernicus, Owen.-Cowdenglen in peat 15 feet from surface; Maybole, in peat.

Equus caballus, L.-Cowdenglen ; (R-B., Shewalton).

Whale, a number of bones and two skulls got near the base of the 40 feet Raised-Beach bed at Shewalton. 
Vertebrata from Caves and Shell Mounds, which may have been contemporaneous with the last Raised-Beach beds.

Excavations made in the Shell-mound, Ardrossan, and at Cleaves Cove, Dalry, resulted in the discovery of the remains of the following animals. For further information on the subject see papers by the author in the Transactions of the Geological Society of Glasgow, vol. vii., p. 284 ; vol. ix., p. 355 ; and his "Prehistoric Man in Ayrshire."

$\begin{array}{lll}\text { Homo sapiens, broken bones.* } & \text { Hare.* } & \text { Oyster Catcher. } \\ \text { Long-faced Ox.* } & \text { Fox. } & \text { Red Grouse. } \\ \text { Goat.* } & \text { Horse. } & \text { Herring Gull. } \\ \text { Dog or Wolf.* } & \text { Otter. } & \text { Razorbill. } \\ \text { Slender-legged Sheep.* } & \text { Cat. } & \text { Puffin. } \\ \text { Red Deer.* } & \text { Beaver.* } & \text { Guillemot. } \\ \text { Pig.* } & \text { Weasel. } & \text { Conger. } \\ \text { Badger.* } & \text { Seal. } & \text { Cod. } \\ \text { Rabbit. } & \text { ? Cetacean.* } & \\ \text { Roebuck. } & \text { Goose.* } & \end{array}$

* Found at Cleaves Cove as well as Ardrossan.

Localities of Post-Drift Fossils ${ }^{1}$ in the Clyde Drainage Area.

Adamton, near Monkton.

Ardencaple, near Helensburgh.

Ardmarnock, Loch Fyne, in sandy, grey clay.

Arkleston, near Paisley, railway cutting.

Baillieston, near Glasgow.

Balnakaile Bay, Bute.

Bogside, near Irvine, in pit, muddy sand.

Bute, Island of, Balnakaile Bay, Kilchattan, Rothesay, etc.

Campbeltown, Tangy Glen, near.

Carluke, Raes Gill, near.

Cartsdyke, Greenock, in laminated clay.

Cleaves Cove, near Dalry, cave deposit.

Colintraive, Kyles of Bute, shore sections.

College, Great Cumbrae, in sand.

Cowdenglen, near Neilston.

Crinan Canal, in clay.

Cumbrae, Island of Great, at the College.

Dalmuir, burn section in sandy clay, or Boulder-clay.

Dipple Tilework, near Girvan, in clay.

Drummuir, near Dreghorn.

Dumbarton, in clay.

Duntroon, Loch Gilp, in clay or Boulder-clay.

East Tarbert, in clay.

Ettrick Bay, Bute.

Fairfield, see Govan.

Fairlie, Largs, shore sections, in sand and clay.

Garvel Park Dock, Greenock section, in clay.

Girvan Harbour, section in brownish-red clay ; Dipple tilework.

Glasgow, Baillieston ; Govan ; Jordanhill ; Stobcross.

Govan, near Glasgow, at Fairfield, in sand and clay.

Greenock, Cartsdyke, in laminated clay; Garvel Park, Dock section.

Gourock. 
Helensburgh, Ardencaple, near.

Irvine, Bogside ; Kennox; Shewalton.

Jordanhill, near Glasgow, in clay.

Kames Bay, Bute, shore section.

Kennox, near Irvine, river section in sandy mud.

Kilchattan Tilework, Bute, section in sandy mud.

Kilmaurs, Woodhill Quarry near.

Kilwinning, Town of, in sandy mud.

Kyles of Bute, Ettrick Bay.

Loch Fyne, near Strachur, in clay ; Ardmarnock.

Lucknow, near Stevenston, in pit sinking.

Misk, near Stevenston, in pit-sinking, in sand and sandy mud, or laminated clay.

Monkton, Adamton near.

Old Mains, Renfrew, in sand and "earth."

Neilston, Cowdenglen near.

Paisley Tileworks, in opencast pits ; Arkleston railway cutting.

Paisley Canal, in giey clay.

Raes Gill, near Carluke.

Renfrew, Old Mains near.

Rothesay, Island of Bute.

Shewalton, vear Irvine, river section, in sand and sandy mud.

Stobcross Dock, Glasgow, in laminated clay.

Stevenston, Lucknow ; Misk, in blue clay.

Strachur, Loch Fyne, in clay.

Tangy Glen, near Campbeltown.

Tarbert, East, in clay.

Troon Gaswork, excavations in sandy clay and sand.

Woodhill Quarry near Kilmaurs. 


\title{
THE ROCKS OF THE CLYDE DRAINAGE AREA.
}

\author{
By Joseph Sommerville and G. R. Thompson.
}

THE Rocks of the district are given in a tabulated form, and are chiefly compiled from Sir Archd. Geikie's "Ancient Volcanoes of Britain," the Memoirs of the Geological Survey of Scotland, and the Transactions of the Geological Society of Glasyow.

\section{IGNEous Rocks.}

The Igneous Rocks have been classified from their chemical and mineralogical composition. For their positions in geological chronology, see "The Ancient Volcanoes of Britain." They are divided into four groups as follows :-

Acid group. - Those containing over 65 per cent. of silica.

Granite-Arran : Loch Doon : Spango.

Micro-Granite, Eurite or Granulite-Ailsa Craig.

Graphic Granite or Pegmatite-Cowal District.

Felsite-Quartz-porphyry and Feldspar-porphyry or Porphyrite--Tinto: Lochfyne: Ballantrae.

Pitchstone-Arran.

Intermediate group. - Those containing 55 to 65 per cent. of silica.

Lamprophyre, including Kersantite, Camptonite, Vogesite, etc.-Cowal District.

Diorite-Girvan and Cowal districts.

Trachyte-in dykes in the Cowal district.

Andesite-largely represented in the district and often amygdaloidal. Dumbarton, Ayr, Renfrew, and Lanark shires.

Basic group.-Those containing 45 to 55 per cent. of silica.

Gabbro: Hornblend gabbro and Hyperite-Girvan : Cowal.

Basalt-common in the district in intrusive sheets and dykes, often columnar.

Tachylyte - a basalt glass forming selvages of basalt dykes-Whiteinch : Lendalfoot. Mr. Clough has found it in the centre as well as on the selvages of dykes; see Survey Memoir: "The Geology of Cowal."

Dolerite-commou all over the district in dykes and intrusive sheets. Where it has been erupted or intruded amongst carbonaceous strata its usual dark colour has been changed into grey and white.

Diabase and Diabase porphyrite, showing pillow structure-Girvan district: Dumgoyn.

Ultra-Basic group.- Those containing generally less than 45 per cent. of silica. Serpentine-Lendalfoot: Innellan.

In this group may also be noted Olivine-enstatite rock and Hornblend-picrite-Girvan district.

Volcanic Fragmental Rocks.

Volcanic agglomerate-Dumbuck: Campsie Hills: Renfrewshire and Ayrshire. 


\section{Volcanic Conglomerate and Brecia-Ayrshire.}

" Tuff-This is found associated with the agglomerate. A very fine variety known as Water-of-Ayr-stone was recently exposed in a fine section at Troon.

\section{Metamorphic Rocks.}

A group of these rocks are well exposed in Argyllshire, passing into Bute and forming a rim around the granite area in Arran. These are more fully described by Mr. Peter Macnair, p. 414. Their geological age has not yet been ascertained, but probably they are not younger than Silurian.

They consist of altered igneous rocks, forming Epidiorites, Hornblende, and Chlorite-schists and Serpentines.

The rocks of sedimentary origin are altered to Gneissose-grits, Schistosegrits, S'chistose-greywackes, Albite-schists, Graphite-schists, Mica-schists, Schistose-limestones, Phyllites, and Chlorite-epidote-schists. See the Green beds of the Geology of Cowal.

\section{Aqueous or Sedimentary Rocks.}

(The Aqueous or Sedimentary Rocks are given in ascending geological order.)

\section{Silurian.}

Sandstones, Greywackes, Grits, Breccias, Conglomerates (Haggis rock). Mudstones, Radiolarian Cherts, Limestones, etc.-Ayrshire and Lanarkshire.

\section{Old Red Sandstone.}

Red Sandstones, Breccias and Conglomerates, Cornstones and Magnesianlimestones-Ayr, Lanark, Dumbarton, and Argyle shires.

\section{Carboniferous Rocks.}

The rocks of this formation are largely developed in the counties of Lanark and Ayr, and consist of thick-bedded Limestones and Sandstones, Grits, Conglomerates, Shales, Fireclays, Blackband Ironstones, and numerous seams of Coal.

\section{Permian (?) or New Red Sandstone.}

Red Sandstones-Ayrshire.

\section{Pleistocene or Glacial Beds.}

Boulder-clay, Stratified clays, Sands and Gravels, Moraines, and Kames, Erratic blocks, etc.

These rocks are abundant all over the district. See "The Great Ice Age," by Prof. James Geikie ; "The Drift or Glacial Deposits of Ayrshire," by Mr. John Smith ; and the Transactions of the Geological Society of Glasgow.

\section{Recent Becls.}

Alluvium in the river valleys.

Blown sand-along the shore from Ardrossan to Ayr: near Ardlamont Point, Argyllshire.

Raised-Beaches-along the shores of the river and firth of Clyde.

Peat-extensive tracts occur on many parts of the district, chiefly in Lanark and Ayr shires, as at Shotts, Aird's Moss, ete.

Soil-Boulder-clay deposits being extensive in the district, a great part of the soil is the weathered surface of that clay. There is also fine soil produced by the disintegration of some of the volcanic rocks.

Talus-This is found at the base of cliffs and steep slopes. 


\title{
THE MINERALS OF THE CLYDE DRAINAGE AREA.
}

\author{
By Joseph Sommerville and G. R. Thompson.
}

THIS list of minerals has been compiled from various sources, amongst which may be mentioned The Mineralogical Magazine; The Transactions of the Royal Society of Edinburgh; The "Memoirs of the Geological Survey of Scotland"; The Transactions of the Edinburgh Geological Society; and The Transactions of the Geological Society of Glasgow. The classification with the chemical formulae are based upon Dana's "System of Mineralogy," 1892. A few of the more important local varieties are given, but synonyms have been avoided as far as possible. A number of the better known ones are, however, given in the alphabetical index with a reference number to the species to which they belong.

\section{Native Elements.}

1. Diamond ? C

2. Graphite, C

3. Gold, Au

4. Silver, Ag

5. Copper, $\mathrm{Cu}$

6. Iron (Meteoric) Fe
Craigman.

Craigman : Shotts: Hurlford.

Leadhills: Wanlockhead: Ailsa Craig : M'Phun's Cairn.

Campsie Hills: Corrie Glen: Enterkin : M'Phun's Cairn.

Barrhend: Mauchline : Corrie Glen.

Fell at Possil, near Glasgow, 5th April, 1804.

\section{Sulphides.}

7. Stibnite, $\mathrm{Sb}_{2} \mathrm{~S}_{3}$

Hare Hill : New Cumnock.

8. Galena or Galenite, $\mathrm{PbS}$

9. Chalcocite, $\mathrm{Cu}_{2} \mathrm{~S}$

Leadhills : Corrie Glen: Dockra.

Ayrshire.

Wanlockhead: Strontian.

10. Sphalerite or Blende, ZnS

11. Pentlandite, (Fe. Ni)S

12. Greenockite, CdS

13. Millerite, Nis

14. Niccolite, NiAs

15. Pyrrhotite, $\mathrm{Fe}_{11} \mathrm{~S}_{12}$

16. Inverarite of Heddle.

\section{Sulphide of Iron and Nickel.*}

17. Chalcopyrite, CuS. $\mathrm{Co}_{2} \mathrm{~S}_{3}$

18. Pyrite, $\mathrm{FeS}_{2}$

19. Smaltite, $\mathrm{CoAs}_{2}$

20. Marcasite, $\mathrm{FeS}_{2}$

21. Kermesite, $\mathrm{Sb}_{2} \mathrm{~S}_{2} \mathrm{O}$
Inveraray.

Bishopton: Barrhead: Kilpatrick Hills.

Dockra: Broadstone.

Inveraray : Wanlockhead : Leadhills.

Loch Long : Appin.

Near Inveraray.

Wanlockhead.

Common in volcanic and derivative rocks Dunoon : Leadhills.

Inveraray.

Lanarkshire and A yrshire coal-fields, common. Hare Hill : New Cumnock.

* Same as Pyrrhotite. 


\section{Chlorides and Fluorides.}

22. Halite (common salt), $\mathrm{NaCl}$ Only obtained in the district by the evapor-

23. Fluorite, $\mathrm{CaF}_{2}$ ation of sea-water.

Gourock: Broadstone: Wanlockhead: in clear crystals at Waterland, Lugton.

\section{Oxides.}

24. Quartz (Rock Crystal), $\mathrm{SiO}_{2}$ In fine crystals at Leadhills : Campsie Hills : Gourock: Cathkin: and other localities. In minute double-terminated crystals in sooty coal at Kilwinning, and in microscopic crystals from Carbonite (columnar coil) from Paisley, Provanhall, and other places where a coal-seam has been altered by intrusive Dolerite.

The following varieties and localities may also be noted: AmethystineCarrickshore : Leadhills : Langbank : Galston : Dalry Hills : Cathcart Castle. Milky-Galston. Ferruginous-Bute : Stockie Muir. Calcedouy - Galston. Cornelian - Cantyre. Agate - Galston. Agate-Jasper-Dunglass: Galston. Plasma-Kilwinning. Jasper -Burn Ann : Galston: Spout of Ballagan : Lendalfoot: Dunglass. Flint-Beith : Dunoon. Heliotrope-Cantyre. Smoky-Arran. Quartzyte-Campsie: Black Craig: Argyllshire.

25. Opal, $\mathrm{SiO}_{2}$ with water

26. Valentinite, $\mathrm{Sb}_{2} \mathrm{O}_{3}$

27. Cervantite, $\mathrm{Sb}_{2} \mathrm{O}_{4}$

28. Water, $\mathrm{H}_{2} \mathrm{O}$ in the district and in the crystalline form as Snow and Ice in winter.

29. Cuprite, $\mathrm{Cu}_{2} \mathrm{O}$

30. Tenorite or Melaconite, $\mathrm{CuO}$ Leadhills.

31. Haematite, $\mathrm{Fe}_{2} \mathrm{O}_{3}$

32. Reddle, $\mathrm{Fe}_{2} \mathrm{O}_{3}$ a variety of Haematite

33. Ilmenite or Menaccanite, $\mathrm{FeTiO}_{3}$ Holy Loch: Glen Massan : Bute : Cantyre : Loch Long.

34. Picotite-Chrome Spinel, $(\mathrm{Mg} . \mathrm{Fe}) \mathrm{O}(\mathrm{AlCr})_{2} \mathrm{O}_{3}$ as a constituent of some volcanic rocks.

35. Magnetite, $\mathrm{FeO} \cdot \mathrm{Fe}_{2} \mathrm{O}_{3}$

36. Minium, $\mathrm{Pb}_{3} \mathrm{O}_{4}$

37. Rutile, $\mathrm{TiO}_{2}$

38. Plattnerite, $\mathrm{PbO}_{2}$

39. Octahedrite, $\mathrm{TiO}_{2}$

40. Pyrolusite, $\mathrm{MuO}_{2}$

41. Göthite, $\mathrm{Fe}_{2} \mathrm{O}_{3} \mathrm{H}_{2} \mathrm{O}$

42. Limonite, $2 \mathrm{Fe}_{2} \mathrm{O}_{3} 3 \mathrm{H}_{2} \mathrm{O}$

43. Psilomelane, $\mathrm{H}_{4} \mathrm{MnO}_{5}$

44. Wad-Bog-Manganese.

Taumesition variable but chiefly an oxide uf Burrmill.

45. Asbolite. A variety of Wad containing Oxide of Cobalt. Tyndrum.

\section{OXYGEN-Saltis-CaRbonates.}

46. Calcite, $\mathrm{CaO}_{3}$

In many crystalline forms; the ordinary rhombic ; Dog-tooth and Nail-head, at Dockra : Gourock : Campsie Hills : Dalry: Waterland : Leadhills : Barrhead : and as Limestone at Beith : Campsie Hills : Nitshill : as Rock-Milk at Cleaves Cove, Dalry : Pink crystals occur at Gourock. 
47. Dolomite, $(\mathrm{CaMg}) \mathrm{CO}_{3}$

48. Magnesite, $\mathrm{MgCO}_{3}$

49. Siderite, $\mathrm{FeCO}_{3}$
Gourock : Wanlockhead: Toward : Cantyre. Inch Moran, Loch Lomond.

Lanarkshire and Ayrshire coal-fields as blackband, clayband and musselband ironstone, a variety having a cone-in-cone structure at Temple : Possil : Rutherglen : Stewarton: lugton.

50. Smithsonite (Calamine), $\mathrm{ZnCO}_{3}$ Leadhills: Wanlockhead.

51. Aragonite, $\mathrm{C}^{\mathrm{aCO}} \mathrm{CO}_{3}$

52. Bromlite, (BaCa) $\mathrm{CO}_{3}$

53. Witherite, $\mathrm{BaCO}_{3}$

54. Strontianite, Sr. $\mathrm{CO}_{3}$

55. Cerusite, $\mathrm{PbCO}_{3}$

56. Berytocalcite, 3 acO

57. Malachite, 2CuO. $\mathrm{CO}_{2} \cdot \mathrm{H}_{2} \mathrm{O}$ Leadhills : Barrhead : Cowal : Aberfoyle.

58. Azurite or Chessylite, $3 \mathrm{CuO}_{2} 2 \mathrm{CO}_{2} \mathrm{H}_{2} \mathrm{O}$ Leadhills: Wanlockhead.

\section{Oxygen-Salts--Silicates.}

59. Orthoclase-Potash Feldspar, $\mathrm{KAlSi}_{3} \mathrm{O}_{8}$ Arran: Bute: Kilpatrick: Cowal: Corriegills, Arran.

60. Erythrite, a flesh-red variety of Orthoclase. Kilpatrick Hills.

61. Weissegite, a variety of Orthoclase. Campsie Hills: Kilpatrick: Hartfield Moss.

62. Murchisonite, a variety of Orthoclase. Arran.

62A. Plagioclase Series. Albite to Anorthite.

63. Albite, $\mathrm{NaAlSi}_{3} \mathrm{O}_{8}$

64. Oligoclase?

65. Labradorite,

66. Bytownite?

67. Anorthite, $\mathrm{CaAl}_{2} \mathrm{Si}_{2} \mathrm{O}_{8}$ Lendalfoot in dolerite.

Cowal district.

Cowal district.

Ballantrae: and in the basaltic dykes of the district.

In the basalt dykes of Cowal.

69. Enstatite, $\mathrm{MgSiO}_{3} \quad$ Lendalfoot.

70. Bronzite, $\mathrm{IgSiO}_{3}$ with Iron Lendalfoot.

71. Bastite or Schiller-Spar, an altered Enstatite or Bronzite. Balhamie Hill.

72. Hypersthene? (FeMg) $\mathrm{SiO}_{3}$ Strachur : Inveraray.

72A. Pyroxene Group. Composition variou*.

73. Angite, CaMgSi $\mathrm{O}_{6}$ witl alumina Arran : Fairlie : Cowal.

74. Diallage,

Lendalfoot.

75. Pectolite, $\mathrm{HNaCo}_{2}\left(\mathrm{Si}_{2} \mathrm{O}_{3}\right)_{3}$.

Kilsyth : Girvan : Lendalfoot : Knockdolian Hill.

75A. Amphibole Group.

76. Anthophyllite, $(\mathrm{MgFe}) \mathrm{SiO}_{3}$ Girvan.

77. Asbestos, comp. various Lochfineside: Girvan.

78. Hormblende, comp. various Dunoon.

79. Tremolite, $\mathrm{CaMg}_{3} \mathrm{Si}_{4} \mathrm{O}_{12}$ Inveraray.

80. Actinolite? $\mathrm{Ca}(\mathrm{MgFe})_{3} \mathrm{Si}_{4} \mathrm{O}_{12}$ Cowal district.

81. Momntain Leather,

82. Uralite,

Leadhills : Strontian.

83. Riebeckite, $2 \mathrm{NaFe}\left(\mathrm{SiO}_{3}\right)_{2} \mathrm{FeSiO}_{3}$ Ailsa Craig.

84. Iolite or Corlierite, $\mathrm{H}_{2}(\mathrm{MgFe})_{4} \mathrm{Al}_{8} \mathrm{Si}_{10}()_{37}$ Glenfine : Cowal.

85. Garnet, composition various Glenbucket: Strontian.

86. Crysolite, $(\mathrm{MgFe})_{2} \mathrm{SiO}_{4}$ Kilpatrick and Renfrewshire Hills: Cowal district.

87. Ferrite, an altered Chrysolite Gleniffer: Boylstone: Cowal district.

88. Willemite, $\mathrm{Zn}_{2} \mathrm{SiO}_{4}$ Wanlockhead. 
89. Vesurianite or Idocrase, a basic calcium-aluminium silicate. Cowal district.

90. Zircon, $\mathrm{ZrSiO}_{4} \quad$ Strontian.

91. Sillimanite or Fibrolite, $\mathrm{Al}_{2} \mathrm{SiO}_{5}$ Glen Fyne : Cowal.

92. Datholite or Datolite, $\mathrm{HCaBSiO}_{5}$ Kilpatrick: Bishopton : Barrhead.

93. Zoisite? $\mathrm{HCa}_{2} \mathrm{Al}_{3} \mathrm{Si}_{3} \mathrm{O}_{13}$ Cowal district.

94. Epidote, $\mathrm{HCa}_{2}(\mathrm{AlFe})_{3} \mathrm{Si}_{3} \mathrm{O}_{13}$ Bute: Arran.

95. Prehnite, $\mathrm{H}_{2} \mathrm{Ca}_{2} \mathrm{Al}_{2} \mathrm{Si}_{3} \mathrm{O}_{12}$ Bowling: Barrhead: Bishopton.

96. Calamine, $\mathrm{HZn}_{2} \mathrm{SiO}_{5} \quad$ Leadhills.

97. Tourmaline, a complex silicate of boron and aluminium. Cowal district.

98. Okenite, $2 \mathrm{H}_{2} \mathrm{OCaO} 2 \mathrm{SiO}_{2}$ Carleton Castle.

99. Apoply yllite, $\mathrm{K}_{2} \mathrm{O} .8 \mathrm{CaO} \cdot 16 \mathrm{Si}_{2} \mathrm{O} \cdot 16 \mathrm{H}_{2} \mathrm{O}$ Kilpatrick Hills : Strontian.

99A. Zeolites.

100. Heulandite, $\mathrm{H}_{4} \mathrm{CaAl}_{2} \mathrm{Si}_{6} \mathrm{O}_{18}+3 \mathrm{H}_{2} \mathrm{O}$ Kilpatrick Hills : Little Cumbrae.

101. Brewsterite, $\mathrm{H}_{4}(\mathrm{SrBaCa}) \mathrm{Al}_{2} \mathrm{Si}_{6} \mathrm{O}_{18}+3 \mathrm{H}_{2} \mathrm{O}$ Strontian.

102. Harmotome, $\mathrm{H}_{2}\left(\mathrm{~K}_{2} \mathrm{Ba}\right) \mathrm{Al}_{2} \mathrm{Si}_{5} \mathrm{O}_{15}+4 \mathrm{H}_{2} \mathrm{O}$ Strontiın: Campsie Hills : Kilpatrick Hills.

103. Stilbite, $\mathrm{H}_{4}\left(\mathrm{Na}_{2} \mathrm{Ca}\right) \mathrm{Al}_{2} \mathrm{Si}_{6} \mathrm{O}_{18}+4 \mathrm{H}_{2} \mathrm{O}$ Cochno : Campsie Hills : Arran : Little Cumbrae.

104. Laumontite, $\mathrm{H}_{4} \mathrm{CaAl}_{2} \mathrm{Si}_{4} \mathrm{O}_{14}+2 \mathrm{H}_{2} \mathrm{O}$ Kilpatriek, Campsie Hills : Renfrewshire Hills.

105. Chabazite, $\left(\mathrm{CaNa}_{2}\right) \mathrm{Al}_{2} \mathrm{Si}_{4}+6 \mathrm{H}_{2} \mathrm{O}$ Kilpatrick Hills : Kilmalcolm : Dalry.

106. Levynite, $\mathrm{CuAl}_{2} \mathrm{Si}_{3} \mathrm{O}_{10}+5 \mathrm{H}_{2} \mathrm{O}$ Hartfield Moss.

107. Analcite, NaAlsi. $\mathrm{O}_{6}+\mathrm{H}_{2} \mathrm{O}$ Barrhead : Port-Glasgow : Inverkip : Kilpatrick Hills: Strontian.

108. Cluthalite, var. of Analcite with flesh-red crystals. Bowling: Little Cumbrae: Fergusbill Ha', Kilwinning.

109. Edingtonite, $\mathrm{BaAl} \mathrm{S}_{2} \mathrm{Si}_{3} \mathrm{O}_{10}+3 \mathrm{H}_{2} \mathrm{O}$ Kilpatrick Hills.

110. Glottalite, var. of Edingtonite Port-Glasgow.

111. Natrolite, $\mathrm{Na}_{2} \mathrm{Al}_{2} \mathrm{Si}_{3} \mathrm{O}_{10}+2 \mathrm{H}_{2} \mathrm{O}$. Kilmalcolm : Port-Glasgow : Campsie Hills: Kilpatrick Hills: Cuwal : Cloch.

112. Galacite, var. of Natrolite Berry Glen, Ayrshire.

113. Scolecite, $\mathrm{CaAl}_{2} \mathrm{Si}_{3} \mathrm{O}_{10}+3 \mathrm{H}_{2} \mathrm{O}$ Kilpatrick Hills.

114. Mesolite, Composition between Natrolite and Scolecite. Kilpatrick Hills : Hartfield Moss.

115. Thomsonite $\left(\mathrm{Na}_{2} \mathrm{Ca}\right) \mathrm{Al}_{2} \mathrm{Si}_{2} \mathrm{O}_{8}+\mathrm{H}_{2} \mathrm{O}$ Bowling : Kilmalcolm : Port-Glasgow.

116. Doliauite, a doubtful Zeolite Knock Station, Ayrshire.

116A. Mica Division.

117. Muscorite, $\mathrm{H}_{2} \mathrm{KAl}_{3}\left(\mathrm{~S}_{2} \mathrm{O}_{4}\right)_{3} \quad \mathrm{In}$ granites and sandstones.

118. Sericite, a variety of Muscovite In schists of the Cowal district.

119. Agalmatolite? an amorphous mineral with a composition near muscovite Cowal district.

120. Paragonite, sodium mica Cowal district.

121. Lepidolite, Lithium Mica Argyleshire.

122. Biotite, Magnesium-iron Mica Dalry : Cowal.

123. Haughtonite (Hedıle), same as Biotite.

124. Clinochlore, $\mathrm{H}_{8}(\mathrm{MgFe})_{5} \mathrm{Al}_{2} \mathrm{Si}_{3} \mathrm{O}_{18}$ Inveraray.

125. Prochlorite or Chlorite, $\mathrm{H}_{40}(\mathrm{Fe} I \mathrm{Ig})_{23} \mathrm{Al}_{14} \mathrm{Si}_{13} \mathrm{O}_{90}$ Cowal district.

126. Delessite, $\mathrm{H}_{10}(\mathrm{MgFe})_{4}(\mathrm{AlEe})_{4} \mathrm{Si}_{4} \mathrm{O}_{22}$ Bowling: Dumbuck : Long Craigs.

127. Chlorophaeite of Macculloch, a chloritic mineral. Loch Fyne: Strachur.

127A. Serpentine and Tulc Division.

128. Serpentine, $\mathrm{H}_{4} \mathrm{Mg}_{3} \mathrm{Si}_{2} \mathrm{O}_{9}$ Lendalfoot : Colmonell : Innellan.

129. Antigorite, a variety of Serpentine Toward.

130. Chrysotile, a fibrous variety of Serpentine Lendalfoot: Games Loup.

131. Talc or Steatite, $\mathrm{H}_{2} \mathrm{Mg}_{3} \mathrm{Si}_{4} \mathrm{O}_{12}$ Toward: Bute. 
132. Saponite, a hydrous silicate of magnesium and aluminium, composition variable. The three following are local varieties.

133. Bowlingite

134. Cathkinite

135. Prasilite

Bowling: Auchenharvie.

Cathkin.

136. Celadonite, a silicate of iron, magnesium and potassium G'alston.

137. Glauconite, a hydrous silicate of iron and potassium Old Kilpatrick : Little Cumbrae.

138. Kaolinite? composition not determined. Troon.

139. Chrysocolla, $\mathrm{CuSiO}_{3}+2 \mathrm{H}_{2} \mathrm{O}$ Leadhills.

140 Chonicrite, a hydrous silicate. Colmonell : Lendalfoot: Dalry.

141. Pilolite,

142. Titanite, CaTiS̈iO
Leadhills.

River Fyne near Newton Hill : Strontian.

Oxygen Salts-Phosphates, Etc.

143. Apatite, $(\mathrm{CaF}) \mathrm{Ca}_{4}\left(\mathrm{PO}_{4}\right)_{3}$ or $(\mathrm{CaCl}) \mathrm{Ca}_{4}\left(\mathrm{PO}_{4}\right)_{3}$ In igneous rocks and schists of the Cowal district.

144. Coprolites, amorphous phosphates In shales of the carboniferous system of the district.

145. Pyromorphite, $(\mathrm{PbCl}) \mathrm{Pb}_{4} \mathrm{P}_{3} \mathrm{O}_{12}$ Leadhills.

146. Mimetite, $(\mathrm{PbCl}) \mathrm{Pb}_{4} \mathrm{As}_{2} \mathrm{O}_{12}$ Leadhills: Wanlockhead.

147. Vanadinite, $(\mathrm{PbCl}) \mathrm{Pb}_{4} \mathrm{~V}_{3} \mathrm{O}_{12} \quad$ Wanlockhead.

148. Olivenite, $\mathrm{Cu}_{2}(\mathrm{OH}) \mathrm{AsO}_{4}$

149. Dechenite, $\mathrm{PbV}_{2} \mathrm{O}_{6}$

150. Erinite, $\mathrm{Cu}_{5}(\mathrm{OH})_{4} \mathrm{P}_{2} \mathrm{O}_{8}$

151. Vivianite, $\mathrm{Fe}_{3} \mathrm{P}_{2} \mathrm{O}_{8}+8 \mathrm{H}_{2} \mathrm{O}$

Leadhills : Wanlockhead.

Leadhills.

Leadhills.

Leadhills.

152. Annabergite, $\mathrm{NiAs}_{2} \mathrm{O}_{8}+8 \mathrm{H}_{2} \mathrm{O}$ Wanlockhead.

153. Uraninite, a uranate of uranyl, Lead formula uncertain. Wanlockhead.

\section{Oxygen Salts-Sulphates, Chromates, Etc.}

154. Barite, $\mathrm{BaSO}_{4}$ Aberfoyle : Gourock: Leadhills : Corrieburn : Queenside Hill : Arran.

155. Calcareobarite, a variety of Barite containing Lime. Strontian.

156. Celestite, $\mathrm{SrSO}_{4}$

157. Anglesite, $\mathrm{PbSO}_{4}$ Aucheureoch Glen.

158. Vauquelinite, a phospho-chromate of Lead Leadhills : Wanlockhead.

159. Leadhillite, $4 \mathrm{PbOSO}_{3} 2 \mathrm{CO}_{2} \mathrm{H}_{2} \mathrm{O}$ Leadhills.

160. Susannite, a sulphate-tricarbonate of Lead Leadhills.

161. Lanarkite, $\mathrm{Pb}_{2} \mathrm{SO}_{5}$ Leadhills.

162. Caledonite, $(\mathrm{PbCu}) \mathrm{SO}_{4}(\mathrm{PbCu}) \mathrm{OH}_{2}$ Leadhills.

163. Linarite, ( $\mathrm{PbCu}) \mathrm{SO}_{4}(\mathrm{PbCu}) \mathrm{OH}_{2}$ Leadhills.

164. Mirabilite, $\mathrm{Na}_{2} \mathrm{SO}_{4}+2 \mathrm{H}_{2} \mathrm{O}$ Hurlet.

165. Gypsum, $\mathrm{CaSO}_{4}+2 \mathrm{H}_{2} \mathrm{O}$ Spout of Ballagan : Hamilton : Ayr : Auchenreoch Glen.

166. Epsomite? $\mathrm{MgSO}_{4}+7 \mathrm{H}_{2} \mathrm{O}$ Giffuock.

167. Melanterite, $\mathrm{FeSO}_{4}+7 \mathrm{H}_{2} \mathrm{O}$ Hurlet : Kilpatrick.

168. Chalcanthite, $\mathrm{CuSO}_{4}+5 \mathrm{H}_{2} \mathrm{O}$ Wanlockhead.

169. Kalinite, $\mathrm{K}_{2} \mathrm{SO}_{4} \cdot \mathrm{Al}_{2}\left(\mathrm{SO}_{4}\right)_{3}+24 \mathrm{H}_{2} \mathrm{O}$ Campsie : Hurlet.

170. Halotrichite, $\mathrm{FeSO} \mathrm{Al}_{2}\left(\mathrm{SO}_{4}\right)_{3}+24 \mathrm{H}_{2} \mathrm{O}$ Giffnock: Auchenskeith : Hurlet: Campsie.

171. Albertite

172. Urpethite

173. Anthracite

174. Middletonite

\section{Hydrocarbon Compounds.}

Nitshill.

Dalry.

Rankinston: Hurlford: Provanhall.

Stevenston: Hurlford : Kilmarnock. 
175. Ozokerite

176. Carbonite, native coke 177. Elaterite 178. Hatchittite, Mountain tallow.

179. Chrismatite

180. Asphaltum

181. Mineral Charcoal
Dalry : Airdrie.

Paisley : Provanhall : Kilwinning.

Dalry: Airdrie.

ow. Lochfyne.

Lugar in blackband ironstone.

Hurlet: Bishopbriggs.

Between layers of nearly all coals. 


\section{INDEX TO THE MINERALS.}

\section{WITH REFERENCE NUMBERS.}

A.

Actinolite, 80 .

Agalmatolite, 119.

Agate; see Quartz, 24.

Agate - jasper ; see Quartz, 24.

Albertite, 171 .

Albite, 63 .

Alstonite ; see Bromlite, 52.

Alum, Native ; see Kalinite, 169.

Alum, Iron ; see Halotrichite, 170 .

Alum, Feather ; see Halotrichite, 170.

Amethystine Quartz; see Quartz, 24.

Amianthus ; see Amphibole, $75 \mathrm{~A}$.

Amphibole Group, 75.

Analcime, 107.

Analcite, 107 .

Anatase ; see Octahedrite, 39.

Andreolite ; see Harmotome, 102.

Anglesite, 157.

Annabergite, 15․

Anorthite, 67.

Anthophyllite, 76.

Anthracite, 173.

Antigorite, 129.

Antimonite; see Stibnite, 7 .

Apatite, 143.

Apophyllite, 99.

Aragonite, 51.

Asbestos, 77 .

Asbolite, 45.
Asphaltum, 180.

Augite, 73.

Azurite, 58.

Barite, 154.

Barytes; see Barite, 154.

Barytocalcite, 56.

Bastite, 71.

Biotite, 122.

Bitumen; see Asphaltum, 180.

Blackband Ironstone ; see Siderite, 49.

Blackjack; see Blende, 10.

Blacklead ; see Graphite, 2.

Blende, 10.

Bog - Manganese ; see IVad, 44.

Bostonite ; see Chrysotile, 130 .

Bowlingite, 133.

Brewsterite, 101.

Bromlite, 52.

Bronzite, 70.

Bysolite; see Amphibole, 75.

Bytownite, 66 .

\section{C.}

Calamine, 96.

Calcareobarite, 155.

Calcite, 46.

Caledonite, 162.

Capillary Prrites ; see Millerite, i3, and Marcasite, 20.
Carbonite, 176.

Carnelian; see Quartz, 24.

Cathkinite, 134.

Celadonite, 136.

Celestite or Celestine, 156.

Cerusite, 55.

Cervantite, 27.

Chabazite, 105.

Chalcanthite, 168.

Chalcedony ; see Quartz, 24.

Chalcocite, 9.

Chalcoprrite, 17.

Chalybite; see Siderite, 49.

Charcoal; see Mineral Charcoal, 181.

Chert ; see Quartz, 24.

Chessylite ; see Azurite, 58.

Chlorite; see Prochlorite, 125 .

Chlorophaeite, 127.

Chonicrite, 140.

Chrismatite or Chrismatine, 179.

Christianite, 68.

Chronı-spinel ; see Picotite, 34.

Chrysocolla, 139.

Chrysolite, 86 .

Chrysotile, 130.

Clinochlore, 124.

Cluthalite, 108.

Cobalt-earthy; see Asbolite, 45 .

Common Salt ; see Halite, 22. 
Cone in Cone ; see Siderite, 49.

Copper, 5.

Copper-Glance; see Chalcocite, 9.

Copper Pyrites ; see Chalcopyrite, 17.

Copper Sulphate; see Chalcanthite, 168.

Coprolites, 144.

Cordierite ; see Iolite, 84.

Crispite; see Rutile, 37.

Cuprite, 29.9.

\section{D.}

Datholite or Datolite, 92.

Dachanite, 149.

Delessite, 126.

Delphinite ; see Epidote, 94.

Diagonite; see Brewsterite, 101.

Diallage, 74 .

Diamond, 1.

Dillenburgite; seec'hrysocolla, 139.

Dioxylite; see Lanarkite, 161 .

Dog-tooth Spar; see Calcite, 46.

Dolianite, 116 .

Dolomite, $4 \pi$.

\section{E.}

Edingtonite, 109.

Elaterite, 177.

Enstatite, 69.

Epldote, 94.

Epsonite, 166.

Erinite, 150.

Erythrite, 60.

\section{F.}

Faröelite; see Thomsonite, 115.

Felspar (Potash), 59.

Ferrite, 87.

Ferruginous Quartz; see Quartz, 24.

Fibrolite ; see Sillimanite, 91 .

Flint; see Quartz, 24.

Fluor Spar; see Fluorite, 23.

Fluorite, 23.
G.

Galactite, 112.

Galena or Galenite, 8.

Garnet, 85.

Glauconite, 137.

Glottalite, 110.

Gold, 3.

Göthite, 41.

Graphite, 2.

Greenockite, 12.

Gypsum, 165.

H.

Haematite or Hematite, 31.

Halite, 22.

Halotrichite, 170.

Harmotome, 102.

Hatchettite, 178.

Haughtonite, 123.

Heary Spar ; see Barite. 154.

Heliotrope ; see (quartz, 24 .

Heulandite, 100.

Hornblende, 78 .

Humboldtite; see Datholite, 92.

Hypersthene, 72.

\section{I.}

Jce ; see Water, 28.

Idocrase, see Tesuvianite, 8.9.

Ilmenite, 33 .

Inverarite, 16.

Iolite, 84.

Iron 6.

Iron Alum; see Halotrichite, 170 .

Iron Carbonate ; see siderite, 49.

Iron Magnetic Oxide; see Magnetite, 35.

Iron Prrites; see Prrite, 18.

Iserine; see Ilmenite, 33.

\section{J.}

.Tasper ; see Quartz, 24.

K.

Kalinite, 169.

Kaolinite, 138.

Kermesite, 21.

L.

Labradorite, 65.

Lanarkite, 161.
Latrobite, 68.

Laumontite, 104.

Lead Phosphate; see Pyromorphite, 145.

Lead Sulphate; see Anglesite, 157 .

Lead Sulphide ; see Galena, 8.

Leadhillite, 159.

Lepidolite, 121.

Leuchtenbergite ; see Clinochlore, 124.

Levynite, 106.

Limonite, 42.

Linarite, 163.

Lincolnite ; see Heu landite, 100.

Lithia Mica; see Lepidolite, 121.

\section{II.}

Magnesian Limestone; see Dolomite, 47.

Magnesite, 48.

Magnetic Pyrites; see Prrrhotite, 15.

Magnetite, 35.

Malachite, 57.

Malacotite; see Augite, 73.

Manganese, Bog-; see Warl, 44.

Marble; see Calcite, 46.

Marcasite, 20.

Melaconite: see Tenorite, 30.

Melanterite, 167.

Menaccanite; see Ilmenite, 33.

Mesole; see Thomsonite, 11 J.

Mesolite, 114.

Mesotype; see Mesolite, 114 ; Natrolite, 111 ; scolecite, 113 and Thomsonite, 115.

Meteoric Iron; see Iron, 6.

Mica Division, 116 A

Middletonite, 174 .

Milky Quartz; see Quartz, 24.

Millerite, 13.

Mimetite, 146.

Mineral Charcoal, 181.

Minium, 36.

Mirabilite, 164. 
Mornite; see Labrador. ite, 65 .

Morvenite ; see Harmotome, 102 .

Mountain Leather, 81.

Murchisonite, 62.

Muscovite, 117.

Musselband Ironstone ; see Siderite, 49.

\section{N.}

Natrolite, 111.

Needle Spar ; see Aragonite, 51

Niccolite, 14.

\section{O.}

Octahedrite, 39 .

Okenite, 98.

Oligoclase, 64.

Olivenite, 148.

Olivine ; see Chrysolite, 86.

Opal, 25.

Orthochase, 59.

Ozokerite or Ozocerite, 175.

P.

Paragonite, 120.

Pectolite, 75.

Pentlandite, 11.

Peridot; see Chrysolite, 86.

Picotite, 34.

Pilolite, 141.

Pitchblend; see Uraninite, 153.

Pitchstone ; see Felspar, 59.

Plagioclase Series, 62A.

Plasma; see Quartz, 24.

Plattnerite, 38.

Plumbocalcite ; see Calcite, 46.

Poonahlite; see Scolecite, 113.
Potash Feldspar; see

Orthoclase, 59.

Prasilite, 135.

Prehnite, 95.

Prochlorite, 125.

Psilomelane, 43.

Pyrite, 18.

Pyrolusite, 40.

Pyromorphite, 145.

Pyroxene Group, 72A.

Pyrrhosiderite ; see

Göthite, 41.

Pyrrhotite, 15.

Q.

Quartz, 24.

\section{R.}

Ratholite ; see Pectolite, 75 .

Reddle, 32.

Riebeckite, 83.

Ripidolite ; see Clinochlore, 124.

Rock Crystal ; see Quartz, 24.

Rock Milk ; see Calcite, 46.

Rutile, 37.

$\mathrm{S}$.

Sagenite; see Rutile, 37.

Saponite, 132.

Satin Spar ; see Aragonite, 51.

Schiller Spar; see Bastite, 71.

Schorl ; see Tourmaline, 97.

Scolecite, 113.

Sericite, 118.

Serpentine and Division, $127 \mathrm{~A}$.

Serpentine, 128.

Siderite, 49.

Sillimanite, 91.

Silver, 4.
Smaltite, 19.

Smithsonite, 50.

Smoky Quartz; see Quartz, 24.

Specular Iron; see Haematite, 31 .

Sphalerite, 10.

Sphene; see Titanite, 142.

Steatite; see Talc, 131.

Stibnite, 7.

Stilbite, 103.

Strontianite, 54.

Susannite, 160.

$\mathrm{T}$.

Talc, 131.

Tenorite, 30.

Thomsonite, 115.

Titanite, 142.

Tourmaline, 97 .

Tremolite, 79.

Troostite; see Willemite, 88 .

U.

Uralite, 82.

Uraninite, 153.

Urpethite, 172.

$\mathrm{V}$.

Valentinite, 26.

Vanadinite, 147.

Vauquelinite, 158.

Vesuvianite, 89.

Vivianite, 151.

W.

Wad, 44.

Water, 28.

Weissegite, 61 .

Willemite, 88.

Talc Witherite, 53.

\section{Z.}

Zeolites, 99A.

Zircon, 90.

Zoisite, 93. 


\section{LOCALITIES FOR OLD RED SANDSTONE AND CARBONIFEROUS FOSSILS IN THE CLYDE DRAINAGE AREA.}

\section{By John Sirth.}

The following list of localities in the Clyde area where Carboniferous and Old Red Sandstone fossils have been or may be obtained, has been drawn up for the use of geological observers. The distances given are those from the nearest railway stations. The formations and their various divisions are indicated by letters as follows :
(C.) = Carboniferous.
(O.R.S.) = Old Ped Sandstone.
(P.) $=$ Permian.
U.C.S. = Upper Coal Series (Scotland).
U.I.S. = Upper Ironstone Series.
U.L.S. = Upper Limestone Series.
L.C.S. = Lower Coal Series.
L.I.S. = Lower Ironstone Series.
L.L.S. = Lower Limestone Series.
C.S. $=$ Calciferous Sandstone Series.

Airdrie (C.) ; pits in U.C.S. ; Cypridina, fish, plants, etc.

Alton Burn, $1 \frac{1}{2}$ m. N. of Galston (C.) ; Serpulites, etc.

Annbank, pits near (C.) ; Lingula, Carbonicola, etc., in U.C.S.

Annicklodge, $1 \frac{1}{2}$ m. E.S.E. of Montgreenan (C.) ; in oil-shale in U.C.S.; Anthracosaurus, and fish-remains.

Annick Water, 2 m. N.E. of Stewarton (C.) ; L.L.S.

Arden, near Thornliebank (C.) ; U.L.S. ; cement-limestone workings ; Estheria, Athyris with spiral arms, etc.

Ardrossau, S. shore-section (C.) ; L.I.S.

Arran, near the Cock (P.); derivative fossils in conglomerate.

" Cock; on shore (C.); Mariopteris, etc.

$"$ Corrie (C.); shore-section with marine fossils.

" , (C.) ; quarry ; P. giganteus, etc., in L.L.S.

" Fallen Rocks ; Calamites.

$" \quad$ Glen Shurig (O.R.S.) ; Psilophyton.

" Maol Dom, N. side (C.) ; Calamites, etc.

" Merkland Burn, $1 \frac{3}{4}$ m. N. of Brodick (C.) ; Carbonicola, etc.

" Millstone Point; Calamites.

" Salt Pans (C.); shore-sections, fossils common in U.L.S.

" Salt Pans, N.E. shore (C.) ; fine Anthracite coal-field extending under the sea in L.C.S.

Sliddery Water-head (C.); Carbonicola, Lepidostrobus, Megalichthys, etc. Arthurlie, $\frac{1}{2}$ m. S. of Barrhead (C.) ; burn section. 
Auchenbeg, near Coalburn (C.); U.L.S.; Dithyrocaris, Leda, Mytilus, Solenopsis, etc.

Anchencloich, $2 \frac{1}{2} \mathrm{~m}$. W. of Kilbirnie (C.); L.L.S.

Auchengree, $\frac{1}{2}$ m. S.E. of Kilbirnie, G. \& S.-W.Ry. (C.) ; L.I.S. ; Sphenopteris, etc.

Auchenharvie, W. of Stevenston, pits (C.); U.C.S.; Prestwichia, Carbonicola, etc.

Auchenreoch Glen, N.E. of Dumbarton (C.) ; C. S.; Ballagan limestone group.

Auchenskeith, $2 \frac{1}{2}$ m. S.E. of Dalry (C.); L.L.S ; Cladochonus, Fistulopora, Polyihizodus, etc.

Auchentorlie Glen, Bowling (C.); plants with structure in C.S.

Auchenmade, near the Station (C.); L.L.S.

Auchenheath (C.) old shale heaps of "Lesmahagow" gas-coals, L.I.S.

Auchinleck, pits near (C.) ; U.C.S.

Auchmeden, $2 \frac{1}{2}$ m. E. of Lesmahagow (C.) ; L.L.S.

Auchreen, $1 \frac{1}{2}$ m. E. of Lesmahagow (C.) ; L.L.S.

Auchter Water, $3 \mathrm{~m}$. E. of Wishaw (C.) ; curly ironstone shale-heaps.

Auldhouseburn, $\frac{3}{4}$ n. E. of Muirkirk (C.) ; L.L.S.

Avon Water, near Hamilton (C.); Sphenopteris, etc., in U.C.S.

Ayr Water, $1 \frac{1}{2}$ m. S. of Tarbolton (C.); U.C.S. ; hone (snakestone) mine and quarry, occasional ferns in the honestone.

Baillieston (C.) ; Palaeophalangium, Psilotites, Pecopteris, etc., in U.C.S.

Baldernock Limn, near Lennoxtown (C.) ; estuarine or freshwater limestone in L.L.S.

Balglass Burn, near Lenuoxtown (C.) ; L.L.S.

Balgrochan Burn, near Lennoxtown (C.) ; L.L.S.

Ballagan Burn, near Strathblane (C.); C.S. ; Ballagan limestone group.

Ballochmyle, 2 m. E. of Mauchline (C.) ; Spirorbis limestone on N. bank of Ayr Water in U.C.S.

Bank, 2 m. S.E. of New Cumnock (C.) ; U.C.S.

Banton, near Kilsyth (C.) U.L.S.; and L.I.S.; Lepidodendron, fish-remains, etc.

Bargeddie near Shettleston (C.) ; U.C.S. ; Anthracoptera, etc.

Barkip, 3 m. E. of Dalry (C.) ; pits in L.C. and I.S.

Barmulloch, $2 \frac{1}{2}$ m. W. of Steps Road (C.); U.L.S. ; Loxonema, Polyzoa, etc.

Bashaw, 2 m. N.E. of Carluke (C.) ; U.L.S.; shale-heaps from the Gare and Main limestones.

Beith (C.) ; L.L.S. ; Clodendron, Psammodus, Cyathophyllum, etc.

Bello Water, $1 \mathrm{~m}$. E. of Lugar (C.) ; Carbonicola, etc., in U.C.S.

Bellshill (C.); pits in U.C.S.

Belston Place Burn, $1 \frac{1}{4}$ to $1 \frac{1}{2} \mathrm{~m}$. N. of Carluke (C.) ; U.L.S.

Benhar, 2 m. N. of Fauldhouse (C.); crustaceans, etc. ; in slatyband ironstone.

Benston, between Old and New Cummock (C.); U L.S.; corals, etc.

Birkhead, on Caaf Water, $2 \frac{3}{4} \mathrm{~m}$. E. of Dalry (C.); conodonts, sponge-spicules, etc., in L.L.S.

Birkwood Burn, $1 \frac{1}{2}$ m. N. by W. of Lesmahagow (C.); L.L.S.

Birkwood Quarry, 2 m. N. of Lesmahagow (C.) ; L.L.s.

Bishopbent, $2 \frac{3}{4}$ m. S.E. of Carluke (C.); opencast working of Raes Gill ironstone in L.L.S.

Bishopbriggs (C.) ; shale-heaps and railway sections in L.C. and I.S.

Blackcraig, 1 13 11. E. of E. Kilbride (C.); Lingula shales.

Blackhall, 1 m. S.E. of Paisley (C.) ; marine and freshwater ostracoda limestones in L.L.S.

Blackstone, 2 m. N.W. of Paisley (C.) ; pits in L.I. and L.S.

Blackstone, $2 \frac{1}{2}$ m. west of Dalry (C.) ; L.L.S.

Blantyre (C:); pits in U.C.S.

Boghead, 3 n. N.W. of Lesmahagow (C.); corals, etc., in L.L.S. ; Lonsdaleia, etc. 
Boghead Burn, $2 \frac{1}{2}$ m. N.E. of Cronberry (C.) ; limestone, etc.

Boghead, 2 m. W. of Quarter Road (C.); Calderwood limestone ; once a good locality.

Bombo Burn, at waterfall, $1 \mathrm{~m}$. E. of Dalry (C.) ; rich fossiliferous shale in U.L.S. ; Serpulites, etc.

Bourrock, $1 \frac{1}{4} \mathrm{~m}$. N. of Dunlop railway section (C.) ; outlier of L.L.S.

Bowertrapping, 3 m. N.E. of Dalry (C.) ; trilobites, etc.; a good locality in U.L.S. ; Streptorhynchus, Strophomena, Iaticopsis, etc.

Braehead, mile N. of Eaglesham Road (C.); labyrinthodont-remains in a quarry in L.L.S.

Braidwood (C.) ; main linestone ; Saccammina, Textularia, etc.

Braidwood Gill, 2 n.. S. of Carluke (C.) ; U.L.S. and L.L.S.

Brankumhall, I m. N.E. of E. Kilbride (C.) ; Ure's locality of "Laurieston."

Broadlie, $1 \frac{1}{2}$ m. N.W. of Dalry (C.) ; U.L.S. ; Kirkbya, Dentalizum, etc., on side of old railway.

Brockley, $1 \frac{3}{4}$ m. N.W. of Douglas (C.) ; banks of Ponniel Water, a good locality ; ostracoda and foraminifera abundant in shale in L.L.S.

Brock's Hole, 1 m. E. of Carluke (C.) ; U.L.S.'

Broadlie Glen, $1 \frac{1}{2}$ m. N.W. of Dalry (C.); U.L.S.; rich fossiliferous shale.

Browntod, 1 m. S.W. of Quarter Road (C.); U.L.S.; Acrolepis, Pleurotomaria, etc.

Bullerholes, $4 \mathrm{~m}$. N.E. of Kilwinning (C.); U.L.S.; fine section of Index limestone.

Burn Ann, 1 m. S.E. of Galston (C.); U.C. and L.S.; Posidonomya, Pteronites, etc., $1 \frac{3}{4} \mathrm{~m}$. S. of Newmills, Carbonicola, etc., in L.L.S.

Burnbrae, near Milton of Campsie (C.); U.L.S.

Burntongues Burn, 2 m. N.W. of Dalry (C.); Lingula shale, ironstone, and limestone in L.I. and L.S.

Byrehill, $1 \frac{1}{4} \mathrm{~m}$. S. of Stewarton (C.); L.L.S.

Caaf Water, above Giffartland (C.); U.L.S.; volcanic debris with derivative fossils.

Caaf Water, $\frac{3}{4} \mathrm{~m}$. S.W. of Dalry (C.); middle beds of U.L.S., with a bel of Productus latissimus, Beyrichia, etc.

Caaf Water, 150 yards above Giffartland Mill, $2 \frac{3}{4}$ m. S.W. of Dalry (C.); shale with fish-remains above shale and limestone.

Caaf Water, at Drumcastle Mill, and Holms of Caaf, $1 \frac{3}{4}$ m. S.W. and W.S.W. of Dalry (C.); U.L.S.

Caaf Water at Giffartland, 2 m. W.S.IW. of Dalry (C.); U.L.S.; limestone and shale.

Cairn Table Hill, N.W. foot of (C.); old quarries in L.L.S.

Caiderbank, 2 m. S. of Airdrie (C.); Airculopecten papyraceous, Oithoceras, etc.; between Kiltongue and Virtuewell coals in U.C.S.

Calderside, near High Blantyre (C.); Janassa, Trigonocarpum, etc., in cementshales.

Calder Water, 1 $\frac{1}{2}$ m. E. of E. Kilbride (C.); limestone and shale.

Calderwood Glen, 2 m. E.N.E. of E. Kilbride (C.); limestone and shale.

Campsie (C.); main limestone ; Camarophora, etc.

Capelrig, 1 m. N.E. of E. Kilbride (C.); limestone and shale.

Caprington, 2 m. S.W. of Kilmarnock (C.); pits in U.C.S.

Carluke (C.); Cyclus in first calmy limestone; fish-remains, etc., in roof of Drumgray coal.

Carmyle (C.); shale-heaps of U.C.S.

Carubrae (C.); shale-heaps of U.C.S.

Carrick Coast, 5 m. S. of Ayr (O.R.S.).

Cartleburn, $1 \frac{1}{2}$ m. N. of Kilwinning (C.); L.L.S.

Castlecary (C.) lime, and ganister pits in U.L.S., Nautilus, ete.

Castlehill, $1 \mathrm{~m} . \mathrm{N}$. of Carluke (C.); shale heaps of U.C.S. 
Cessnock Water, 4 n. S.E. of Galston (C.); Spirorbis in C.S.

Chapel, 2 m. S. of Carluke (C.); "maggy" ironstone in U.L.S.

Chapel Farmhouse, $2 \frac{1}{4}$ m. S. of Carluke (C.); sections on Fiddler's Burn in L.L.S.

Cleaves Glen, 2 m. S.E. of Dalry (C.); L.L.S.

Cleckhimin, $3 \frac{1}{2}$ m. S.E. of Carluke (C.); shale heaps of L.L.S.

Cleland (C.); pits in U.C.S.

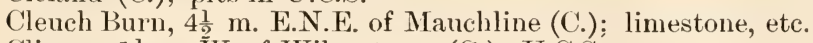

Climpy, $1 \frac{1}{2}$ m. W. of Wilsontown (C.); U.C.S.

Cloch, near Gourock (C.); fossiliferous shale in C.S.

Clonbeith, $3 \mathrm{~m}$. N.E. of Kilwimning (C.); U.L.S.; Bairdia, Platyceras, Nucula, Bellerophon, etc.

Coalburn (C.); pits in L.C.S.

Coldgreen Glen, 3 m. S.W. of Kilbirnie (C.); limestone and shale on Parluff Burn in L.L.S.

Coltpark (C.); quarries in U.L.S.

Corbie Craigs, $1 \frac{1}{2}$ m. N.E. of Waterside (C.); pits, Carbonicola in living position in U.I.S.

Cot Castle, Stonehouse (C.); Sphenopteris, etc.

Corrieburu, $1 \frac{1}{2} \mathrm{~m}$. N. of Twechar (C.); limestone, shale, and ironstone in L.I. and L.S.; Cauda-galli, ete.; a good locality.

Cowdon Burn, between Neilston and Barrhead (C.); L.L.S.

Coylton (C.); pits, and stream sections, Carbonicola, ferns, etc., in U.C.S.

Craigburn, $2 \frac{1}{2}$ m. N.N.E. of Douglas (C.); U.L.S.

Craigenglen, $1 \frac{1}{2} \mathrm{~m}$. S. of Lennoxtown (C.); shale-heaps and buru-section in L.L.S.; Archaeodiscus, Polyzoa, Gastropods, Lamellibranchs, etc.

Craighall, 3 m. S.W. of E. Kilbride (C.); L.L.S.

Craigie, 3 m. S. of Kilmarnock (C.); L.L.S.; Poterioceras, Entomostraca, etc.

Craigmaddie Moor, $2 \frac{1}{2}$ m. N.E. of Milngavie (C.); L.L.S.

Craignethan Glen, near Tillietudlem (C.).

Crawfield, $\frac{3}{4}$ m. E.N.E. of Kilbirnie, G. \& S.-W. Ry. (C.); L.L.S.

Crawfordland Burn, near Crawfordland Castle, $2 \frac{1}{2}$ m. N.E. of Kilmarnock

(C.); U.L.S.; the only open section for Corophioides polyupsilon, Smith.

Crofthead, near Fauldhouse (C.); shale-heaps.

Crookedstone Muir, 3 m. N. of Strathavon (C.); U.L.S.

Crossflat, near Muirkirk (C.); foraminifera abundant in L.L.S.

Crossford, 2 m. S. of Braidwood (C.); L.L.S. Sphenopteris, etc.

Crosshouse, $2 \frac{1}{2}$ m. S.W. of E. Kilbride (C.); L.L.S.

Crosshouse, near the station (C.); shale-heaps of U.C. and I.S.; Carbonicola, fish-remains, etc.

Croy, pits near (C.); L.I S.

Cubs Glen, 1 m. S.E. of Lugar (C.); U.L.S.; a great whin sill.

Cunningham-Baidland, 2 m. N.W. of Dalry (C.); sponge-remains abundant in the upper bed of the L.L.S.; Conocardium, Gastropods, etc.

Dailly, pits near the station (C.); L.C.S.

Daleagles (Daleccles), 3 m. S.W. of New Cumnock (C.); burn-section.

Dalmellington, pits and burn-sections near, (C.); U.C.S.

Dalquharran, near Dailly (C.); pits in L.C.S.

Dalry (C.); abundance of blaze bings mostly from L.I.S.; Lepidodendron, Nautilus, Sigillaria, Dadoxylon, Anthracoptera, etc.

Dalserf Burn, near Ayr Road (C̈.); U.C.S.; fish-remains, etc.

Dalzell (C.); pits in U.C.S.

Darnconnar, $1 \frac{1}{2}$ m. N.W. of Lngar (C.); pits in U.C. and I.S.

Darnley, 1 m. S.W. of Kennishead (C.); U.L.S.

Daviland, near Thornliebank (C.); U.L.S.

Dean, 1 m. N.N.E. of Kilmarnock (C.); sections on Crawfordland and Fenwick burns in U.C. and I.S.; Beyrichia, fish-remains, etc. 
Den, 3 m. N. of Lesmahagow (C.); L.L.S.

Den, $2 \frac{1}{2}$ m. N.E. of Dalry (C.); pits in L.I.S.; Gyracanthus, Rhizodus, Entomostraca, etc.

Dennistoun, Glasgow (C.); fossiliferous shale in street cutting, Goniatites, etc.

Dernshaw, $3 \frac{1}{2}$ m. W.S.W. of Stewarton (C.); U.L.S.; Nautilus, Pleurotomaria, Bellerophon, etc.

Diddup, $2 \mathrm{~m}$. N. of Stevenston (C.); thick bed of Arden Cement-limestone in U.L.S

Dinnans, 2 m. S.E. of Stewarton (C.); U.L.S.

Dockra, $\frac{1}{2}$ m. N. of Barnill (C.); L.L.S.; Ulocrinus, Psammodus, Poecilodus, etc.

Douglas, pits near, in U.C.S.

Doura, $1 \frac{1}{2}$ m. S.E. of Montgreenan (C.); pits in U.C.S.

Draffen, near Stewarton (C.); L.L.S.

Dreghorn, pits near, (C.); Spirorbis ironstone, freshwater limestone, etc., in U.C.S.

Drongan (C.); pits near, U.C.S.

Drumbuie (C.); railway section $\frac{1}{2} \mathrm{~m}$. W. of Giffen in U.L.S.

Drumclog, 5 m. E. of Darvel (C.); L.L.S.

Drumpellier at Drumpark, $1 \frac{1}{2}$ m. W.S. W. of Coatbridge (C.); marine fossils in U.C.S.

Dubs, 1 m. S.E. of Barrhead (C.); Goniatites, Cyrtoceras, etc.

Duniflat Burn, 1 m. N.E. of Lugton (C.); L.L.S.

Duntocher, $1 \mathrm{~m}$. N.E. of Dalmuir (C.); L.L.S.

Dykehead, near High Blantyre(C.); cement-shale heaps, polyzoa, crinoids, etc.

Dykes, $1 \frac{1}{2}$ m. N.W. of Kilbirnie, Cal. railway (C.); sponge-spicules abundant in the limestone of L.I.S.

East Burn, N.E. of Stewarton (C.); Palaechinus, Aviculopecten, etc.

East Drumloch, 3 m. S.E. of E. Kilbride (C.); L.L.S.

East Kilbride,(C.); cenent-limestone, Anthrapalaemon, Eoscorpius, Palaemysis, Odontopteris, etc.

Ellismuir, near Baillieston (C.); Cyclotheca, Urnatopteris, etc., in U.C.S.

Faifley, $1 \frac{1}{2}$ m. N.E. of Dalmuir (C.); L.L.S.

Fergushill, S. of Montgreenan (C.); pits in U.C.S.

Ferniegair, near the Ry. Station (C.); pits in U.C.S.

Fiddler's Burn, Headsmuir, $1 \frac{1}{4}$ m. E.S.E. of Carluke; Shales of L.L.S.

Gabrochill, 3 m. N.E. of Dunlop (C.); outlier of L.L.S.

Gallowhill, $1 \frac{1}{2} \mathrm{~m}$. E. of Strathavon (C.); Chiton, bivalves, etc.

Gameshill, $1 \frac{1}{2}$ m. N.W. of Stewarton (C.); L.L.S.; corals, Spirifera, Heterophyllia, Cardiomorpha, etc.

Gare, 2 m. N.E. of Carluke (C.) ; a good locality in U.L.S., but heaps grassed over ; foraminifera, bivalves, univalves, etc.

Garngad Road, and S. of, Glasgow (C.); U.L.S.

Garnkirk (C.); marine limestone and shale.

Garple Water, $1 \mathrm{~m}$. W. of Muirkirk (C.); U.L.S. and L.L.S. in stream ; sandstone with marine fossils; Ortonia, Retzia, crinoids, ostracoda, etc.

Garrion Gill, $2 \frac{1}{2}$ m. N.N.W. of Carluke (C.); shale heaps of Belside ironstone from U.C.S.S.

Garscube (C.); pits in L.I.S.

Gas Water, 2 m. E. of Cronberry (C.); L.L.S.

Gatesicle, Beith (C.); old quarries in L.L.S.; Clisiophyllum, Columnaria, Michelinia, and Carcharopsis.

Gateside, 2 m. E.S.E. of Carluke (C.); Raes Gill ironstone and shales in L.L.S.

Giffartland Burn, $2 \frac{1}{4}$ m. W.S.W. of Dalry (C.); outcrop of Dalry clayband ironstone in L.I.S.

Giffen pit, 1 m. S.W. of Giffen (C.); Naidites berl above a coal-seam in L.C.S.

Giffnock, $1 \frac{1}{2} \mathrm{~m}$. S.W. of ry. station, (C.); section of Orchard cement-limestone on $\mathrm{L}$. and $\mathrm{A}$. railway. 
Giffnock, Sandstone quarries near, (C.); Knorria, Arenicolites, ferns, etc.

Gill Burn, 3 m. W.S.W. of E. Kilbride (C.); Calderwood cement-limestone.

Gillfoot, $2 \frac{1}{2}$ m. S.S.W. of Carluke (C.); Belston Burn limestone and shale; a good locality on burn in U.L.S.; Eoscorpius, Thamniscus, Synocladia, etc.

Gillhead Bridge, $2 \frac{1}{4}$ m. N.N.W. of Carluke (C); Kiltongue musselband in burn in U.C.S.

Girthill, $2 \frac{1}{2}$ m. S.W. of Dalry (C.); ostracoda abundant in shale of U.L.S.; bivalves, etc.

Glebe Quarry, E. Kilbride (C.); plants, Dithyrocaris, Sphenopteris, etc., Calderwood cement-limestone.

Glenboig, $2 \mathrm{~m}$. E. of Garnkirk (C.); cement-limestone in U.L.S.

Glenbuck (C.); old shale-heaps and limestone quarries of L.I. and L.S.

Glencart, $1 \frac{1}{2}$ m. E. of Dalry (C.); conodonts, sponge-spicules, gasteropods, bivalves, etc., in cavities in the limestone of U.L.S.

Glenlogan, $4 \frac{1}{2}$ m. E.S.E. of Mauchline (C.); U.C.S. and U.L.S.

Glenmore Water, $4 \frac{1}{2}$ m. E.S.E. of Cronberry (C.); Cockstail sandstone, etc.

Glenmuir, 3 m. S.E. of Lugar (C.); L.L.S.

Glentagart, $5 \frac{1}{2}$ m. S.S.W. of Douglas (C.).

Glespin, $3 \frac{1}{2}$ m. S.S.W. of Douglas (C.); U.C.S.

Golderaig, 2 m. N.E. of Kilwinning (C.); U.L.S.

Goodock Hill, 2 m. N.E. of Omoa (C); pits in U.C.S.

Govan (C.); pits in L.I.S., with Lepidodendron, etc.

Gowanlee, 2 m. N.W. of Dalry (C.); sponge-remains, etc., in L.L.S.

Gowkha' Quarry, $1 \frac{1}{2}$ m. S.S.W. of Auchenmade (C.); U.L.S.

Gowkhouse Burn, $2 \mathrm{~m}$. W. of Kilbirnie(C.); outcrop of Dalry clayband ironstone, etc., in L.I. and L.S.

Greenhill, $1 \frac{1}{2}$ m. N.E. of Omoa (C.); U.C.S.

Greenhill, $\frac{1}{2}$ m. E. of Crosshouse (C.); Palaeoxyris, Pygocephalus, Prestwichia, Euphoberia, Xylobius, etc., in U.C.S.

Gryfe Water, 1 to $1 \frac{1}{2}$ m. E. of Bridge of Weir (C.); L.L.S.

Guelt Water, 5 m. S.E. of Lugar (C.); L.L.S.

Gurdy, Ry. cutting, $1 \mathrm{~m}$. E. of Glengarnock (C.); impure marine limestone and shale, and bed of freshwater ostracoda in L.L.S.

Hag Burn, $1 \frac{1}{2}$ m. N.E. of Galston (C.); L.L.S.; Aviculopecten, etc.,

Hagshaw Burn, 2 m. S.S. W. of Coalburn (C.); limestone, etc.

Hairmyres, near the station (C); L.L.S.; polyzoa, foraminifera, entomostraca, etc.

Hall Hill, $3 \frac{1}{2}$ m. N.E. of Lesmahagow (C.); Lingula, etc., in L.C. and I.S.

Halleraig Bridge, $1 \frac{1}{2} \mathrm{~m}$. W. of Carluke (C.); Lingula limestone in L.L.S.

Harderaft, 2 m. N.W. of Dalry (C.); burn-section in U.L.S.

Hareshaw, 2 m. N.E. of Omoa (C.); U.C.S.

Headsmuir, $1 \frac{1}{2}$ m. S.E. of Carluke (C.) ; first calmy limestone in L.L.S.

Heads of Ayr (C.); volcanic debris with blocks of limestone containing fishremains in C.S.

High Dalblair, $4 \frac{1}{2}$ m. S.E. of Cronberry (C.) ; outlier of L.L.S.

Highfield, 2 m. N.E. of Dalry (C.) ; U.L.S.; old quarry in Highfield Index limestone.

High Polwhirter, $1 \frac{1}{2}$ m. S.E. of New Cumnock (C.); Alveolites, etc., in U.L.S.

High Smithstone, $2 \frac{1}{2}$ m. N.W. of Kilwinning (C.); sponge-spicules, bivalves, univalves, etc.; good locality in U.L.S.

Hill, 1 m. S. of Lesmahagow (C.); L.L.S.

Hillhead, 1 m. E. of Carluke (C.); Raes Gill ironstone, and Hosie limestone, in L.L.S.

Hillhead, 3 m. N.E. of Steps (C.); U.L.S.

Hindog Glen, 2 m. N.W. of Dalry; L.I. and L.S.; Stacheia, Valvulina, Orthis, Platychisma, etc.

Hole Burn, 6 m. E. of Mauchline (C.); limestone, etc. 
Horse Island, off Ardrossan (C.); occasional plants with structure in volaanic debris in C.S. ?

Howood, $\frac{1}{2}$ m. N.E. of (C.); Allagecrinus, Syringopora, etc., in L.L.S.

Howrat, $3 \mathrm{~m}$. N.W. of Dalry (C.) ; volcanic debris, with fish-remains and Stigmaria on top of limestone in L.L.S.; Solenomya, etc.

Hullerhirst, $1 \frac{1}{4}$ m. S.W. of Kilwinning (C.) ; Index limestone, U.L.S. ; Rhynchonella, Productus, Edmondia, Murchisonia, etc.

Hurlford, pits (C.) ; U.C.S.

Inkerman, $1 \frac{1}{2}$ m. W. of Paisley (C.) ; pits in L.I.S.

Irvine, pits E. of (C.) ; U.C.S.

Isle Port, shore section near, $4 \mathrm{~m}$. N.W. of Maybole; conglomerate in (O.R.S.) with derivative fossils in limestone pebbles.

Itlington, 3 m. S.W. of Dalry (C.) ; U.L.S.

Jerviston, $1 \frac{1}{2} \mathrm{~m}$. S. of Holyton (C.); U.C.S.

Johnstone, pits N.W. of, (C.); L.I.S.

Jordanhill, $2 \frac{\mathrm{I}}{2} \mathrm{~m}$. W. of Glasgow (C.) ; shale-heaps of L.I.S.

Keirshill, $1 \mathrm{~m}$. S. of Waterside (C.) ; old limestone quarry.

Kennox Water, 4 m. S. of Douglas (C.); Gill limestone in U.L.S.; Cordaites.

Kerelaw (C.), $1 \frac{1}{4}$ m. N. of Stevenston, Index limestone, etc., in U.L.S.

Kerse Glen, $1 \frac{1}{2}$ m. N. of Lesmahagow (C.); L.L.S.

Kersland Glen, 1 m. E. of Kilbirnie, G. \& S.-W. Ry. (C.); limestone and shale with Sanguinolites costellatus, etc., in L.L.S.

Kilbride, $2 \mathrm{~m}$. W. of Stewarton (C); thick seam of Dalry clayband ironstone; outcrops in L.I.S.

Kilcadzow, 3 m. E. of Carluke (C.) ; L.L.S. ; Raes Gill ironstone ; second calmy and main limestones.

Killoch Burn, $3 \frac{1}{2}$ m. S.E. of Galston (C.); mollusea, etc., in C.S.

Kilmaurs, burn section, above village (C.) ; Nautilus, Euomphalus, etc., in U.L.S.

Kilsyth (C.) ; pits in L.C. and I.S.; fish-remains, etc.

Kilwinning, pits south of (C.) ; U.C.S. ; Sigillaria, Carbonicola ; abundant fish-remains above Lady Ha' coal.

Kingshaw, 1 m. N.E. of Carluke (C.); second Kingshaw limestone in L.L.S.

Kirktouholm, E. Kilbride (C.); Calderwood cement-limestone and shale, Adiantes, etc.

Knightswood, $2 \frac{1}{2} \mathrm{~m}$. W. of Glasgow (C.); L.C. and I.S.

Laigh Baidland, 2 m. N.W. of Dalry; fish-remains in L.L.S.; Cochliodus, etc.

Langhill Point, $2 \frac{1}{2}$ m. S.W. of Ayr (C.); fish-remains, entomostraca, plants, etc., shore-section in C.S.

Langshaw, 1 m. S.E. of Carluke (C.); Raes Gill ironstone ; second Kingshaw limestone, in L.L.S.

Langshaw Burn, 1 m. S.E. of Carluke (C.); Lingula limestone in L.L.S.

Langside, Beith (the late Robert Craig's quarry); L.L.S.

Larkhall (C.); pits in U.C.S.

Law, 2 m. S. W. of Carluke (C.); shale-heaps of U.C.S.

Law, at Cubside, $2 \frac{1}{2} \mathrm{~m}$. N.W. of Dalry (C.); sponge-spicules, chiton plates, conodonts, gasteropods, bivalves, etc., in L.L.S.

Lee Muir, I $\frac{3}{4}$ m. S.E. of Carluke (C.); Raes Gill ironstone in L.L.S.

Levenseat, $1 \mathrm{~m}$. from Fauldhouse (C.) ; limestone and shale.

Lickprivick, 2 m. S.W. of E. Kilbride (C); Calderwood cement-limestone and shale.

Limekilnburn, 1 m. W. of Quarter Road (C.); U.L.S.

Limekilns, near E. Kilbride (C); old shale-heaps.

Linn Spout, 1 m. S.W. of Dalry (C.); a thick bed of Arden cement-limestone, with rich fossiliferous shale under it, and below that a bed with Estheria, Anomia, Avicula, crustaceans, etc., in U.L.S. 
Lissens, railway cutting, $1 \mathrm{~m}$. S.W. of Auchenmade (C.) ; occasional plantremains showing structure, in volcanic debris in L.C.S.

Little Auchinback, 1 m. S.E. of Barrhead (C.); cement-limestone and shale.

Loans, $1 \mathrm{~m}$. E. of Dalry (C.); thick bed of Arden cement-limestone in U.L.S.

Longlands, $2 \frac{1}{2}$ m.S. of E. Kilbride (C.); Calderwood cement-limestone and shale.

Low Dykehead, $2 \frac{1}{2}$ m. S. W. of Dalry (C.); U.L.S.

Lucknow, $1 \frac{1}{4}$ m. S.E. of Stevenston (C.) ; pit-heap, with drifted vegetation in sandstone, Trigonocarpum, etc., in U.C.S.

Lugar, pits (C.); a bed of Lingula in U.C.s., Crustaceans, Carbonicola, etc.

Lugton Water from Auchentiber to near G. \& S.-W. Ry. (C.) L.C.S. ; U.L.S., and U.C.S.

Lyelston, $3 \frac{1}{2} \mathrm{~m}$. N.E. of Kilwimning (C.); U.I.S.

Maich Burn, $\frac{1}{2}$ to $1 \frac{1}{2}$ m. N.W. of Beith, G. \& S.-W. Ry. (C.) ; L.C.S., L.I.S., and part of L.L.S., with Carbonicola, Lingula, Sunguinolites, etc.

Mansfield Burn, 1 $\frac{1}{2}$ m. S.S.E. of New Cumnock (C.); U.L.S. with bed of Productus latissimus, ete.

Marsh, 3 m. N.E. of Dalry (C.); once a good locality ; Index limestone in U.L.S.

Mayfield, 1 m. S.E. of Carluke (C.); shale-heaps of L.L.S.

Mavisbank, 4 m. N.E. of Kilwinning (C.); U.L.S.; abundant crinoid-remains in shale, Archaeocidaris, etc.

Meadowfoot, 3 m. E. of Darvel (C.); L.L.S.

Meikle Busbie, 3 m. N. of Ardrossan (C.): plants in C.S.

Middleholm, 2 m. S. W. of Lesmahagow (C.) ; L.L.S.

Mill Burn, $\frac{1}{2}$ m. N.E. of Lennoxtown (C.); marine and freshwater limestones in L.L.S.

Milton Lockhart, $\frac{3}{4}$ m. S. W. of Carluke (C.); shale-heaps of L.L.S.

Misk, $1 \frac{1}{2}$ m. S.E. of Stevenston (C.); microscopic plants in middletonite in U.C.S. (Trans. Geol. Soc. Glas. vol. x. 169 pl.).

Monkcastle Glen, $2 \frac{1}{2}$ m. N.W. of Kilwinning (C.); Arden cement-limestone with conodonts, sponge-spicules, etc., in U.L.S.; rich fossiliferous shale under limestone.

Moncur, $1 \frac{1}{4}$ m. E. of Kilwinning (C.) ; U.C.S. with freshwater entomostraca, and fish-remains.

Morningside (C.); U.C.S.

Mossfoot, $1 \frac{1}{2}$ m. N. of Auchinleck (C.) ; U.C.S.

Motherwell, pits round (C.); U.C.S.

Mount Vernon (C.); Glyptoscorpius, etc., in U.C.S.

Mouse Water, 1 to $1 \frac{1}{2}$ m. N.N.E. of Wilsontown (C.); L.L.S.; Tincularia, Palaeocoryne, etc.

Muirburn, $1 \frac{1}{2} \mathrm{~m}$. S. W. of Stonehouse (C.); L.L.S.

Muirfoot Burn, 1 m. E. of New Cumnock (C.); estuarine shales, etc., in U.L.S.

Muirkirk (C.); pits in L.C.S.

Nellfield Burn, 2 m. S.E. of Carluke (C.) ; L.L.S.

Nethan Water, at Auchenheath (C.) ; old shale-heaps of L.L.S.

Nethercraigs, 2 m. S.S.W. of Paisley (C.) ; L.L.S.

Netherfield, 1 m. E. of Strathavon (C.) ; L.L.S. ; Zaphrentis, etc.

Netherhouses, $1 \mathrm{~m}$. S. of Caldwell (C.) ; shale-heaps from L.I.S.

Netherton, near Caldwell (C.); shale-bings from L.I.S.

Nettlehirst, near Giffen (C.); large entomostraca in upper bed of L.L.S.; lower bed worked in a quarry; corals, etc.

Newarthill (C.) ; shale-heaps of U.C.S.

Newfield, 1 m. S.W. of High Blantyre (C.); old shale-heaps from cementlimestone quarry and mine; polyzoa abundant; Hydreionocrinus, ? Edmondia, Pecten, etc.

Newhouse, 1 m. N.W. of Dalry (C.) ; L.L.S.

Newmains (C.); coal-pits in U.C.S. 
Newton (C.) ; conl-pits in U.C.S.

North Brae, 1 m. S.E. of Barrhead (C.) ; U.L.S.

Ochiltree, Burnock Water; Spirorlis limestone in the drift.

Old Cumnock (C.); pits and river-sections near ry. station, in U.C.S. ; Anthracomya, etc.

Old Mill, $1 \frac{1}{2}$ m. N.W. of Lugton (C.) ; L.L.S.

Orchard (C.); old shale-heaps with holothurian-remains, Platycrinus, Univalves, Bivalves, etc., in U.L.S.

Paduff Burn, 2 m. W. of Kilbirnie (C.) ; L.L.S.; Productus giganteus in living position, etc.

Palace Craig (C.); shale-heaps of U.C.S. ; Estheria.

Patna, pits near (C.); L.C.S.

Penbreck, $5 \frac{1}{2}$ m. S.S.E. of Muirkirk (C.) ; outlier of U.L.S. and L.L.S., the former with rich fossiliferous shale.

Penyvenie Burn, $1 \frac{1}{2}$ m. N.E. of Dalmellington (C.); U.C.S. capped by trap.

Pitcon Burn, 2 m. S.W. of Kilbirnie (C.); shales, limestones and ironstones, in L.L. and I.S.

Plan, near Crosshouse (C.) ; heaps from coal and ironstone workings in U.C.S.

Polbaith Burn, $2 \frac{1}{2}$ m. N. of Galston (C.); L.L. and I.S.; Posidonella, Lingula, etc.

Polquheys, $1 \frac{1}{2} \mathrm{~m}$. N. of New Cumnock (C.); U.L.S.; corals, etc.

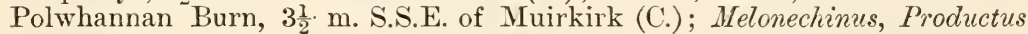
giganteus (small var.), holothurian-remains, etc., in outlier of L.L.S.

Possil, N. side of Glasgow (C.); old shale-heaps of L.C. and I.S.; Rihizodus, Lepidodendron, Lingula, etc.

Powmillan Burn, $\frac{1}{4}$ m. E. of Strathavon (C.) ; rich fossiliferous shale.

Provanhall, $3 \mathrm{~m}$. N.E. of Glasgow (C.) ; pits in U.C.S.

Pundeavon Burn, $1 \frac{1}{4} \mathrm{~m}$. N.W. of Kilbirnie (C.) ; onterop of Dalry clayband ironstone, Lingula shale, and limestone in L.I. and L.S.

Quarter, 1 m. from Quarter Road (C.); old shale-bings of U.I.S.; Anthracoptera, Callopristodus, Eyracanthus, Harpacodus, Amphicentrum, etc.

Raes Gill, 2 m. W. of Carluke(C.); Tolkmania, Pteroplax, Palaeoniscus, Deltodus, Lingula limestone ; first calmy limestone, Raes Gill ironstone, and Hosie limestone, in L.L.S.

Rankinston (C.); Carbonicola, plants, etc., in U.I.S.

Rankinston Glen, E. of ry. station (C.); Anthracite and free coals in U.C.S. ; great trap sill.

Robroyston, 2 m. E.S.E. of Bishopbriggs (C.); old shale-heaps of U.L.S.

Roughwood, 1 m. S. of Beith, Cal. Ry. (C.); bed with Laidites, Cyclophyllum, Rhodocrinus, Spirorbis, Amplexus. etc., in L.L.S.

Rutherglen (C.); pits in U.C.S.; Cyclopteris, Sphenophyllum.

Rye Water, S. slope of Hindog glen (C.); shale and limestone of U.L.S.

Rye Water, escarpment on N. side, $1 \frac{1}{2}$ m. N.N.W. of Dalry (C.) ; foraminifera abundant in shale in U.L.S.

Rye Water, a little further down than last, and nearly opposite Ryefield; fossils in bed of stream in U.L.S.

Saltcoats (C.) ; U.L.S. and U.C.S. on the shore; bed of Productus lutissimus in the former.

Sculliongour, $1 \mathrm{~m}$. N. of Lennoxtown (C.) ; shale-heaps.

Shettleston (C.); pits in U.C.S.

Shielburn, near Benthall (C.) ; L.L.S. ; $2 \frac{1}{2} \mathrm{~m}$. S. of E. Kilbride.

Shotts (C.) ; pits in U.C.S.; Pinularia, Carbonicola, Favularia, Sigillaria, ete.

Skaterigg, $2 \frac{1}{2} \mathrm{~m}$. W. of Glasgow (C.); L.C. and I.S.

Skitridge Gill, $2 \mathrm{~m}$. S. of Carluke (C.); "maggy" ironstone in U.L.S.

Sorn, $4 \mathrm{~m}$. E. of Mauchline (C.); old shale-heaps and river-sections on Ayr Water in U.L.S.

South Biggart, 1 m. W. of Lugton ; L.L.S.; Saccammina, etc. 
South Hill, 1 m. S.W. of Lennoxtown (C.) ; shale-heap of L.I.S.

South Shields, 2 m. S.W. of E. Kilbride (C.) ; L.L.S. ; Vincularia, Petalorhynchus, etc.

Springhill, (C.); shale-heaps of U.C.S.

Stacklawhill, $3 \frac{1}{2}$ m.S. W. of Stewarton (C.) ; U.L.S. ; Murchisonia, Nodosaria, bivalves, ostracoda, etc.

Stanrigg, Airdrie (C.); U.C.S.; Palaeostachya, Renaultia, Urnatopteris, etc.

Stevenston (C.) ; pits, Prestwichia, Carbonicola, Halonia, Lyginodendron, Trigonocarpum, etc., in U.C.S.

Stewarton, sections on Annick Water, (C.) ; L.L.S.

Swansie Burn, $2 \frac{1}{2}$ m. N.E. of Stewarton (C.); L.L.S.

Swindridgemuir, 3 m. N.E. of Dalry (C.); Dentalium, Naticopsis, Euomphalus, Loxonema, Murchisonia, Macrocheilus, etc.

Swinhill, $1 \frac{1}{4} \mathrm{~m}$. N. by E. of Stonehouse (C.); U.C.S.; with Cardiocarpon, Megalichthys, etc.

Swinlees, old quarry, $3 \mathrm{~m}$. N.W. of Dalry (C.) ; foraminifera and Melonechinus plates abundant in the shale; L.L.S.; Fuvosites, Heterophyllia.

Swinlees Glen, 3 m. N.N.W. of Dalry (C.); L.I.S.

Teiglam Burn, 1 m. N. by W. of Lesmahagow (C.): L.L.S. ; Aviculopecten.

Thirdpart, $2 \frac{1}{2} \mathrm{~m}$. N.W. of Dalry (C.) ; L.L.S.

Thorn, 1 m. N.E. of Carluke (C.); Archaeocidaris in disjointed masses in nodules in L.L.S.

Thornliebank (excavations now closed), rich in fossils, Conularia, Goniatites, etc., (C.)

Thornton, quarry near Eaglesham Road (C.) ; limestone, oolitic nodules, oilshale, volcanic ash-bed, etc. ; reptilian remains, etc. ; Leda in L.L.S.

Tibby's House (ruin) $1 \mathrm{~m}$. W. of Muirkirk; rich shale, Fenestella, etc.

Tillietudlem, pit heaps near (C.); shales from "Lesmahagow" gas-coals in L.I.S.

Tirfergus Glen, near Campbeltown (C.) ; L.L.S.

Torrance Glen, near E. Kilbride (C.); L.L.S.

Torry Glen, Chapelhall (C.); shale with fish-remains in U.C.S.

Troon, S. side of peninsula (C.); Water-of-Ayr hone-stone bed, with occasional plants, in U.C.S.

Tulloch, 2 m. S.E. of Darvel, (O.R.S.), with Cephalaspis.

Twechar, pits near (C.) ; L.C. and I.S.

Wallaceton, $1 \mathrm{~m}$. N.E. of Dailly (C.); railway section, shales, coals, and limestone, in U.L. and L.C.S.

Warwickhill (C.) ; pits near Springside in U.C.S.

Waterland, near Lugton (C.) ; quarry-and burn-section in L.L.S.; volcanic ash on top of limestone, with fish-remains and Stigmaria roots ; Cardiomorpha and Poterioceras.

Watston, 1 m. S.E. of Stonehouse (C.) ; U.C.S.; Sphenopteris, fish-remains, etc.

Waukmill, $1 \frac{1}{2}$ m. E. of Strathavon (C.); sections on Avon Water in L.L.S.

Waukmill Glen, $1 \frac{1}{2}$ m. E.S.E of Barrhead (C.); Cyrtoceras, Nucula, Leda, etc.

Waygateshaw, $1 \frac{1}{4}$ m. S.S.W. of Carluke (C.); first calmy limestone and Raes Gill ironstone in L.L.S.

Wemyss Bay (C.); Helminthites tracks (?) in sandstone in C.S.

Westerhouse, 3 m. N.N.E. of Carluke (C.) ; Gare limestone; once a good locality, but heaps now grassed over, U.L.S.

West George Street, Glasgow (C.); in founds for houses, etc. ; U.L.S.

West Kilbride, railway section (C.); footprints, etc., on sandstone in C.S.

Whatriggs, $2 \mathrm{~m}$. N. of Galston (C.); L.L.S.

Whitecleuch, 7 m. N.N.E. of Sanquhar (C.) ; outlier of L.L.S.

Whiteinch, W. of Glasgow (C.) ; fossil trees in Victoria Park.

Whitehill, near Airdrie (C); Megalichthys pygmaeus, etc., in oil-shale in U.C.S. 
Whiteshaw Bridge, $1 \mathrm{~m}$. W. of Carluke (C.) ; burn-section in U.L.S.

Whitespot, railway section between Giffen and Glengarnock (C.); Naidites bed above a coal-seam in L.C.S.

Wildshaw, 5 m. S.E. of Douglas (C.); outlier of L.L.S.

Wilton, 1 m. S. of Carluke (C.) ; shale-heaps from Raes Gill ironstone in L.L.S.

Wishaw (C.) ; Sigillaria, etc., in U.C.S.

Woodhill, $\frac{1}{2}$ m. E. of Crosshouse (C.) ; U.C.S.; Prestuichia, Belinurus, etc. (Mammoth remains were got in the "bare" of the quarry.)

Woodside Pits, W. of Glasgow, 1837 (C.) ; Tristychius.

Yuildshiels, 2 m. E. of Carluke (C.); burn-section in L.L.S. 


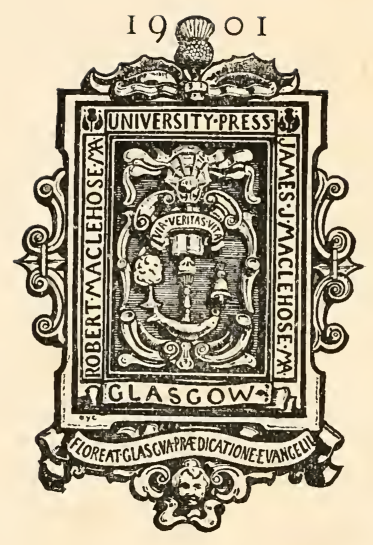



$+$ 

